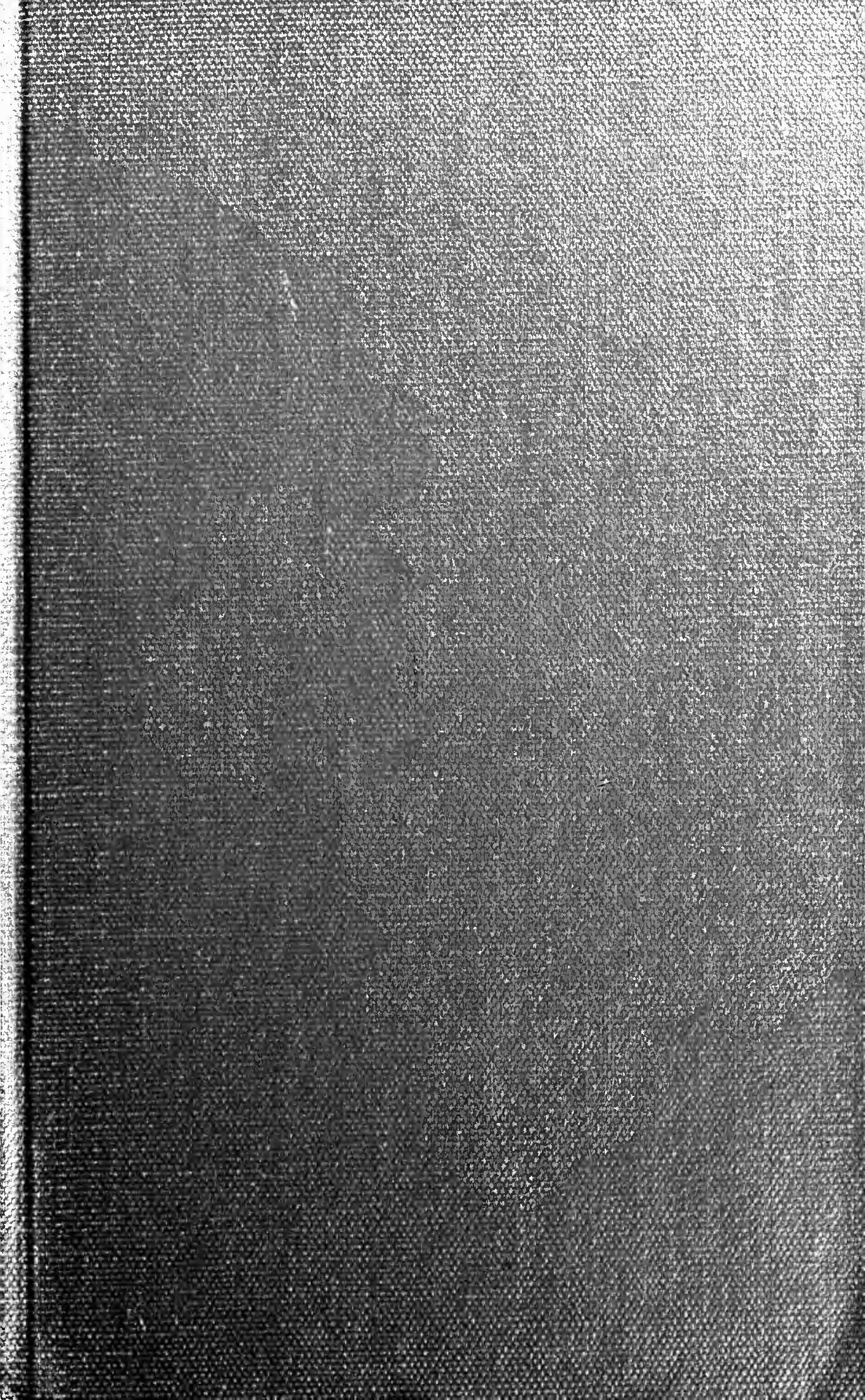




\section{LIBRARY}

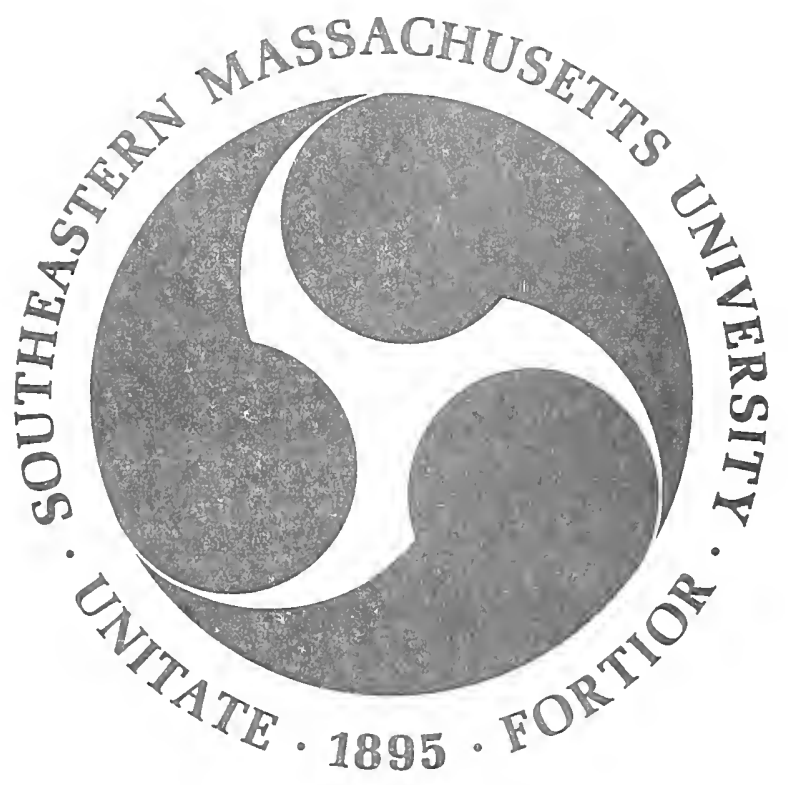






DEPARTMENT OF THE INTERIOR

HUBERT WORK, Secretary

United States Geological Survey George Otis Smith, Director

\section{Bulletin 738}

\section{THE COMMERCIAL GRANITES OF NEW ENGLAND}

$\mathrm{BY}$

T. NELSON DALE

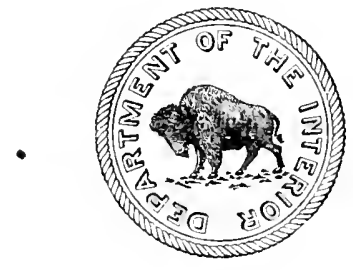

WASHINGTON

GOVERNMENT PRINTING OFFICE 
ADDITIONAL COPIES

OF THIS PUBLICATION MAY BE PROCURED FROM THE SUPERINTENDENT OF DOCUMENTS GOVERNMENT PRINTING OFFICE WASHINGTON, D. C. AT

50 CENTS A COPY

PURCHASER AGREES NOT TO RESELL OR DISTRIBUTE THIS COPY FOR PROFIT.-PUB. RES. 57, APPROVED MAY 11, 1922 


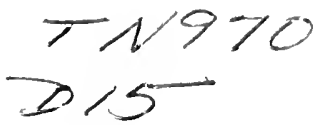

\section{CONTHNTS'}

Introduction

Part I. Scientific discussion _. 3

Granite proper.__-

General features_._. 3

Definition _._. 3

Origin_..._.

Mineral composition

Chemical composition. 7

Texture

Definition___-_n_- 9

Character and grade____... 9

Forms of minerals_______- 9

Arrangement of minerals____._._._._. 10

Porphyitic texture

Color

Physical properties.___. 10

Weight______n 10

Cohesiveness_____n_. 11

Elasticity___ 11

Flexibility__. 11

Hardness_._. 12

Expansibility____ 12

Porosity__-_- 12

Vitreousness___n_- 12

Classification

Scientific classification____- 13

Economic classification___- 13

General structure._. 14

Flow structure

Rift and grain._. 15

Definition__. 15

Previous descriptions____._. 15

Relation of rift and grain to fluidal cavities_._._._- 17

General examples___. 17

Fluidal cavities in granite gneiss____._._. 21

Fluidal cavities in small dikes or veins__....... 22

Are some fluidal cavities secondary?_........_ 22

Summary on rift and grain... 24

Sheet structure

Double-sheet structure

Joints_-_-_- 37

Headings_._- 38

Faults_-_-___- 38

Shear zones__._. 38

"Shake" structure______ 39 
l'AkT I. Scientific discussion-Continued.

firanite limper-continumes.

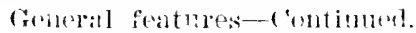

fonelal structure-continuerl.

Subjoints

Contemporary fractures_._.

Modifications of gran te Dikes

Aridic dikes.

Granite.

Aplite

I'egmatite

Lermatitic quaptz-10

Basic dikes

Pasic schistose dikes

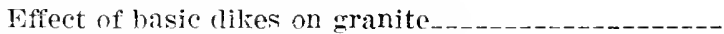

Sorrregations ("knots")

Basic segregations

Acidic segregations

Orbicular granite

Geodes

Inclusions.

Gueissic structure

Rusty stain and its causes

Pecomposition

General features

Ovoidal weathering

Special features

Pegmatite dikes in gromps_._-_._._-

Muscovite veins

Zeolite reins

Mineral veins

Felrispars.

Original and secondary colors

Cut surfaces

Granitic quartz.

Texture

Colors

Olive-green granite

Minerals on joint faces

Contact phenomena

Petrographic relations

Bethel, Vt

Barre, vt

Woodbury, Vt

Conclusions

Structural relations

Waterford, Conn _-_-__-_-_-

Waldoboro, Maine.

Milford, N. H

Westerly and Charlestown, R. I

Conclusions. 
Pant I. Scientific discussion-Continuerl.

Page.

"Black granites"

Classification

Grigin

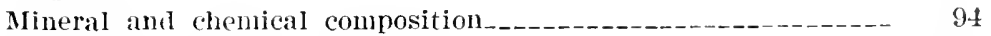

Texture

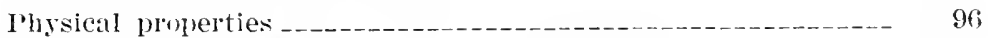

Textbook references on granite and "black granites " _._._._._. 97

PAIRT II. Economic discussion_- 99

General features_._. 99

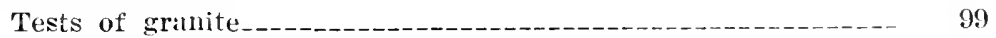

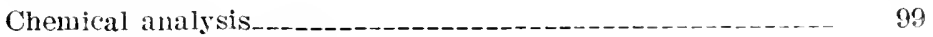

Determination of $\mathrm{CaCO}_{3}$

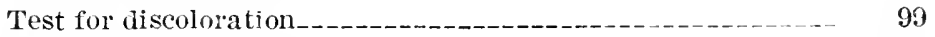

Mineral composition__-_._-_._- 99

I'roportions of minerals

Polish _... 100

llariness___ _._._. 100

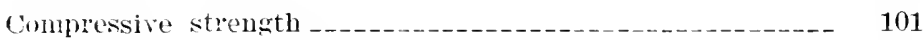

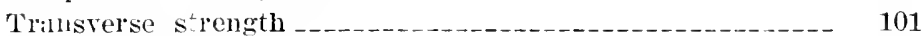

Teusile strength _ _ _

I'orosity _...

Absorption _._. 102

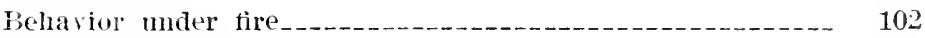

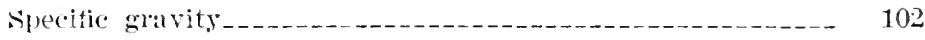

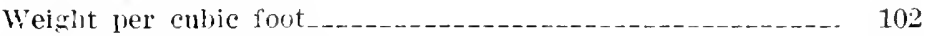

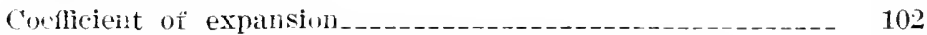

fieographic distribution of New Lngland granite quarries...... 103

Pherintions of the quaries, granites, and product____._. 103

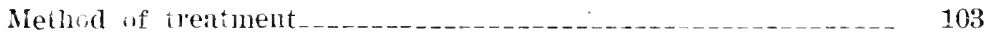

Vermont _._. 104

Distribution of the granites and quarrying centers._._._... 101

Geologic relitions of Vermont granjtes___________-_ 105

Outline of earlier history of Vermont granites_________... 107

The grinite railroads______._. 168

The quarries, their granite and finished product__..._._._. 108

Caledonia County._._._. 108

Hardwick _._. 108

Kirby

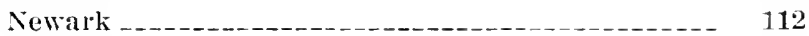

Ryegate____ 113

Topography _._._._._. 113

General geologs' _......... 113

"Iryegate grimite" -

Geolugy of Rregate quarries______... 114

Quaries _._._. 114

I iroton__._.

Orange Connty _-

'Toms bat!1 _..._- 118

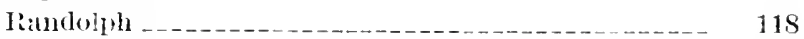

()rleans County -

Derby -

Barton__._. 121 
PArT II. Economic discussion-Continuerl.

Deseriptions of the quarries. granites. and product-Continued.

vermont-Continued.

The quarries, thoir wrinite and finished product-Continued.

Washingt on County

Barre and Williamstown_._.

Topography

General ceology

Barre granite

Geology of Barre quarries

Quarries

Topography _-_._._-_-_-

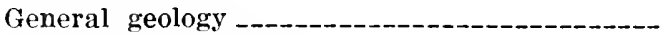

"Woodbury grimites"

Geology of Woodbury quarries._.

Quarries

Windham County _......

Dummerston

Topography and general geology

"Bethel granite"

Quarries _..._-_._._. 158

Rochester - _-_-_ 159

Plymouth _.

Windsor.

Tolngraplyy and general geology___-__-_-_-_- 161

"Windsor granite"

Guarries _... 163

New Hampshire

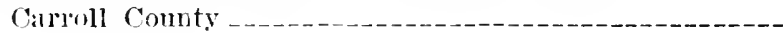

Gonway

Topography - -

Geolngy of the quarries

Quarries _.

Mardison_____._- 170

(heshire County _._._- 171

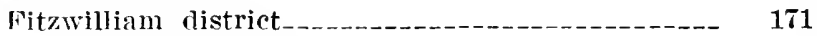

Geologic relations_._._._._._. 171

Quarries _............ 171

(joos County

Kilkenny__.

Stark

Grafton County

Canaan _._- 177

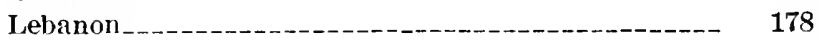

Haverhill__-_._- 179 
Part II. Economic discussion-Continued.

Descriptions of the quarries, granites, and product-Continued.

New Hampshire-Continued.

The quarries, their granite and finished product-Continued.

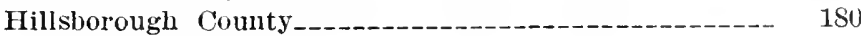

Milford district_____-_ 180

Topography _..._-_._- 180

Geology of quarries_...-_-_-_-_-_-_-_- 180

“Milford granite"-_-_-_-_-_-_-_-_-_-_-_- 182

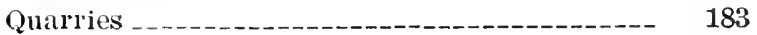

Brookline - _...-_-_- 191

Nashua _- 193

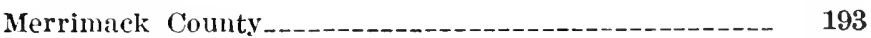

Allenstown _._._- 193

Hooksett _-_-_-_-_ 194

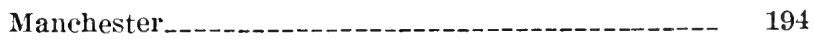

Concord._-_._-_._- 195

Topography _......-_._- 195

Geology of the quarries_._._._._._._._._._. 195

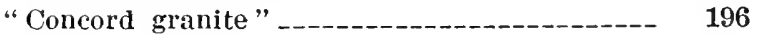

Quarries _._-_-_-_._- 197

Rockingham County

Auburn

Strafford County

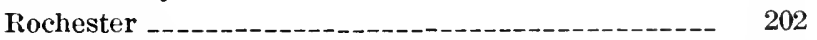

Sullivan County

Sunapee -

Maine -

The occurrence of granite in Maine, by George Otis Smith __ 205

Geographic distribution _-_._- 205

Geologic relations__-_-_._-_._- 207

Distribution of granite quarries

Quarries of granite proper

Quarries of "black granite"

The quarries, their granite and finished product_________- 210

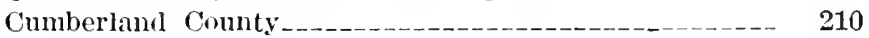

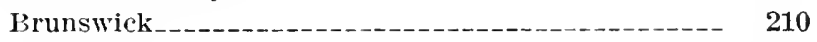

Freeport_____-_-_-_-_-_ 211

Pownal_-_-_-_-_-_-_._- 211

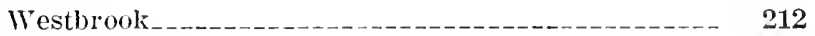

Franklin County-__n__._. 212

Jay __. 212

Hancock County -_._-_._- 214

Bluehill _._. 214

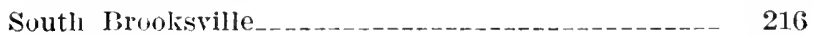

Dedham____ 217

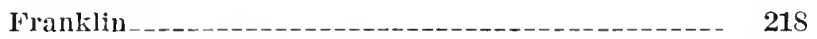

Long Island (Black Island) -

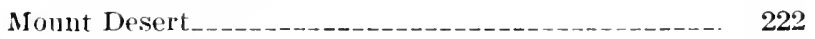

Stonington district

Nistribution and geology of the quarries_..._. 224

Quarries___._._. 224 
l'ART II. Fconomic discussion-Continued.

Descriptions of the quarries, granites, and product-Continued.

Maine-Continued.

The quarries. their granite and finished product-Continued.

Hancock County-Continued.

sullivan

Kennebec County

Hallowell__........

knox County__.

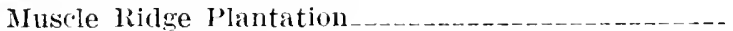

South Thomaston

St. Grorge

Vinalharen and Hurricane islands

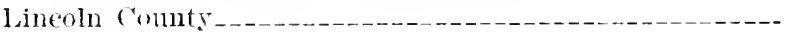

Bristol

Traldolıro

IV'hitefield _..._.

( Xxford County _..........

Fryeburg-_._-

Oxford__-__-

Woodstock

253

Penobscot County

Hermon

Piscataquis County____. 255

Guilford

Somerset County

Hartland_________. 255

Norridgewock______._._. 255

Waldo Counts_____n 25

Frankfort__ 257

Lincoln___ 260

Sear'sport___

Swanville__._._-_-_-_._- 261

Washington County

Addison_._._-_._- 262

Baileyville_._. 263

Calais_._. 264

Jonesboro_______. 267

Jonesport___.

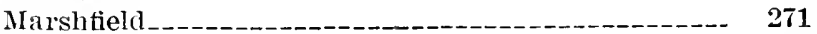

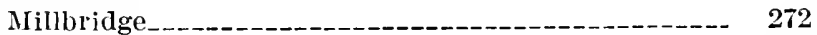

York County _..._._. 272

Alfred

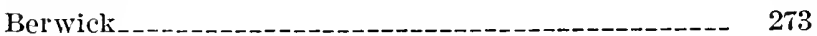

Biddeford___-_-_-_ 274

Hollis__.

Kennebunkport__-_- 276

Wells._. 
Part II. Economic discussion-Continued.

Descriptions of the quarries, granites. and product-Continued. Page.

Massachusetts._.

Distribution of granite-quarrying centers___._._._.... 2is

The quarries, their granite and finished product_.......... $27 \mathrm{~S}$

Berkshire County ......._._._._._._._............ 278

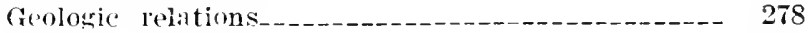

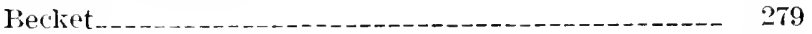

Otis

Iiristol County _._._._.

Geologic relations._.

Fan River.

New Bedford

Dartmouth__._._._._. 286

Essex County

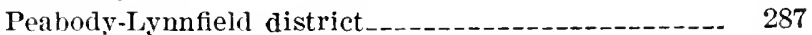

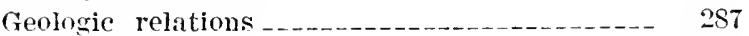

Quarries_._._._._._. 287

Rockport ..._.

Topography__........ 291

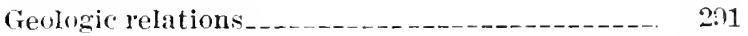

"Rockport granite"

Geology of Rockport quarries_._.......... 293

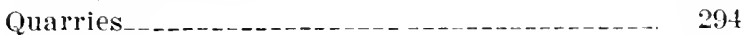

Hampden County _... 303

Monson

Hampshire County _._. 305

Pelham _... 305

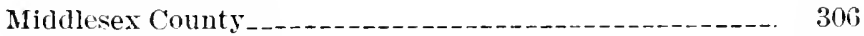

Geologic relations_._._._._._. 306

Acton_._.

Groton _......_. 308

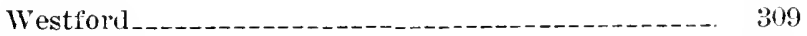

Townsend_._._._._._._. 313

Norfolk County

Wrentham__..___._. 314

Stoughton _... 315

Cohasset____._. $31 \mathrm{~J}$

Quincy, Milton, and Braintree____._._-_._- 315

Topography _._._._. 315

Geologic relations

Quincy granite _-_._-_._._-_._- 316

Geology of Quincy quarries_._._.______._. 319

Quarries_..._._._..._. 321

Plymouth County - 33.

Brockton

Hingham_...

Sutfolk Comty

Revere

L.ynn _... 340

Worcester County

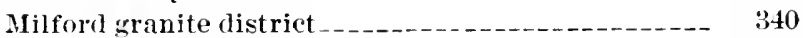

'Topography _._._._._._._._. 340

Geologic relations_._._. 340 
Part II. Economic discussion-Continued.

Descriptions of the quarrirs, granites, and product-continued.

Massachusetts-Continued.

'The quarries, their grinite and finished product-Continued.

Worcester County-Continued.

Milford granite district-Continued.

"Milford granite"

Geolory of Milford qun rries

Quarries_-_-_-

Uxbridge

343

344

I.eominster

Fitchburg

353

355

Connecticut.

Geologic relations, by $\mathrm{H}$. E. Gregory

355

355

Outline of geologic history of Connecticut...............

Distribution of granites and gneisses in Connecticut_----

Nature and age of the granitic intrusions of Connecticut

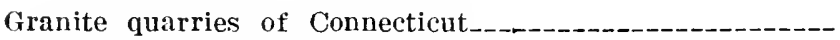

Fairfield County

Bridgeport

Danbury

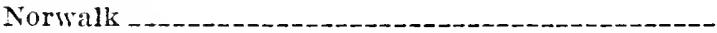

359

36 I

361

361

362

362

364

Hartford County _.

365

Bristol

365

Glastonbury

366

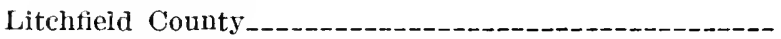

Cornwall

369

Litchfield

369

370

Noriolk

Roxbury -_.

Thomaston_-_-_-_-

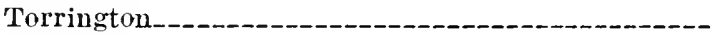

Warren_...-

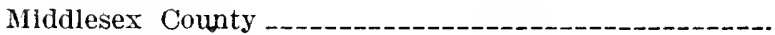

Middletown _...

New Haven County-_-_-_-_-_-_-_-_-_-_-_-_-_- 376

Ansonia

Branford

Guilford

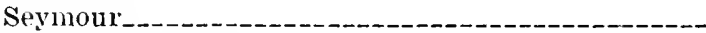

New London County

Groton

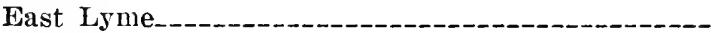

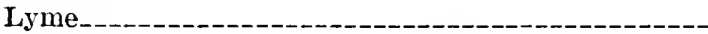

Old Lyme

Stonington -..-.--

Waterford _...-_-

Tolland County -

Bolton_. 399

385

388

389

390

392

394

399

Windham County_-_-_-_-___-_ 400

Sterling _..._- 400

Windham _..._. 402 
Part II. Ecomomic discussion-Continued.

Descriptions of the quarries. granites, and product-Continued. Page.

Rhode Island _._.

Washington County--_-_-_-

Westerly and Charlestown

Topographs

Geologic relations.

Geology of Westerly and Charlestown quarries

"Westerly granites"

Quarries

Adaptability of New England granites

Economic classification of New England granites___-_-_-_-_-_-_-_._-

Geologic fictors in granite quarrying

The production of granite in the New England States, by A. T. Coons.

\section{ILLUSTRATIONS.}

Plate I. Map of Vermont and New Hampshire showing location of granite quarries.

II. Map of Barre, Vt., showing location of granite quarries_

III. A, Orbicular granite from Bethel, Vt.; $B$, Schist injected with granite, Barre and Ryegate, $\mathrm{Vt}_{\text {-........-. }}$

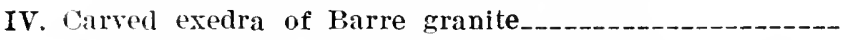

V. $A$, Statue of Barre granite; $B$, Carved panel of granite from Woodbury, Vt

VI. $A$, Effect of compressive strain on granite, West Dummerston, Vt.; $B$, Double sheet structure, Robeson Mountain, Woodbury, Vt

VII. A, Carving of Bethel white granite from Vermont; $B$, Polished and cut syenite from Mount Ascutney, Vt..-

VIII. A. Contart of granite and granite gneiss. Milford, N. H.; $B$, Diorite with pegmatite dike cut by diabase like, Round Pond, Maine

IX. Map showing distribution of granitic rocks and quarries in Maine

X. A, Joint strurture on Heron Neck, Green Island, Maine; $B$, Sheet. dome, and joint structure, Crotch Island. Maine

XI. d, Sheet structure. Ryan-Parker quarry, Crotch Island, Maine; $B$. Sheet and dome structure, Mosquito Mountain, Frankfort, Maine

XII. A, Hurricane Island quarry, Maine, showing a 60 -foot sheet; $B$, Sheet and joint structure, Stinchfield quarry, Maine 
Plath XIII. Sheet structure, Crabtree \& Havey quarry. Sullivan, Maine: $A$, South side; $B$, Wast wall_

XIY. A, Sheet ancl joilit structure, Sands quarly. Vinalhaven. Maine; ?, sheets and curved joint, White duary, Fluehill, Mains

XV. A. Sheets nindre complessile strain, IRels clatpel Hill. Ga.; $B$, Schist inchusion at Freeport quarry, Maine--

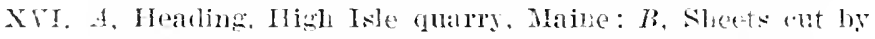
diabase dike, Allen quarry. Mount Desert. Maine....-

xir. A, Granite and schist contact, Waldobore gharry, Maine; $B$, Interseeting headings and wenthering, Longfellow quarry, Hallowell, Maine _................

XVIII. A, A tirlewater quary, Vinalhaven, Maine: $B, A$ oneman paving-block quarry, Vinalhaven, Maine

256

256

XIX. A, Carving in coals granite from Sands quary. Vinalhaven, Mane; ls, Grante column in lathe, Palmer quary, Vinalhaven, Maine

$\mathrm{XX}$. Fine carving of granite from Stinchfield quarry, Hallowell, Matine

XXI. Statue of granite from Stinchfield quarry. Hallowell,

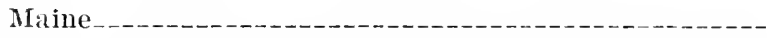

XXII. A, Monnuent of guarty diorite, Round Fourl quarry. Maine: $B$, Monment with die of olivine-norite, Heal quarly, Lincoln, Maine

xxIlI. Mrap of Massachusetts showing location of granite quarries.

XXIV. Mar, of Guing, Mass., sinwing location of glanile qualries

XXY. A. Dell Hitcheock gullily, Quincy, Máss.; B. Monument of porphyry from liockport. Mass.

XXVr. Ball of polished Quiney granite

XXir. A, l'igeon Hill [uner quarry, Rockport, Mass.; $B$. Deep Pit quarry, Rockport, Mass

XXVIII. foologic mal of Connerticht showing location of glanite quarries.

XXIX. $A$, Granite gneiss, Leete Island quarry, Conn.; $B$, Oroidal weathering in rery fine quartz monzonite from Westerly, R. I

XXX. A, Polished slab of pegmatitic biotite granite gneiss, Nurcross quarry, Stouly Creek. Conn.; $B$, Obelisk of lammered permatilie biotite granite gneiss. Noreross

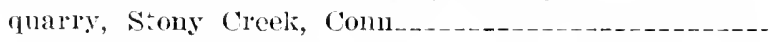

Xxxi. A, Coarse porphyritic granite gneiss, Hoadly Point, Branford, Conn.; B, Porphyritic granite gneiss. Derby, Conn

Xxxil. Monument of line quartz monzonite from Waterford, Conn

XXXII. A, Bas relief of fine quartz monzonite from Waterford, Conn.; B. Momument of tine quartz monzonite from Groton, Conn.

XXXIV. A. Contact of granite and granite gneiss, Klondike quary, Charlestown, Ii. I.; $B$, Carving in fine quartz monzonite from Westerly, R. I 
GIGtiRe 1. Rift aml glain in thin section of gran te from liedstone (Con-

Page. way), N. H

$\because$. Bumeter aplite dike in diorite, leavitt quary, Leominster, Matsis

3. Horizontal section of dialase dike in Deep Pit quarry, Rockport, Mass.

15

$4 . \overline{7}$

$5+1$

17

High lsle, Maine

6. Limonitic stain from a crystal of allauite in olive-green orruite from Redstone, conway, N. H

9. Thin section of granite and schist contact, bethel, $\mathrm{Vt}_{\text {- }}$

10. Strutual relations of gramite and schist, Anderson quary. Isarele, Yt

11. Details at contact of srimite and mical slate, Anderson quarry, Balre, It

12. Mica slate with dikes of pegmatite and lenses of apatitic franite from the granite-slate contact, Anderson quarry, Barre, rt

13. Section of Waterford quarly, Connecticut quarry, Comnecticut

15. Discordint sheet structure in granite and granite gneiss, south wall of Waterford quarry, Comecticut.

Maine

17. Gianite and granite gneiss contaret at Pease quarry, Milford. N. H

18. Gramite and glanite meiss contact at Catto quarry. Westerly. I. I

19. Plicated hiotite granite gneiss, Foadly I'oint, Branford, Conn

20. Map of Woolbmry and Hardwick, Vt., with quarry locations and granite railroad

21. Map of Kirby, Burke, and Newark. Vt., with quary locations.

22. Map of Regeate, Groton, and Tupsham, Vt., with quarry locations

23. Structure at Benzie quarry, Groton, Vt

24. General topographic section through granite mass at Barre, $\mathrm{Vt}$

25. Structure at Boutwell quarry, Barre, Vt

26. Structure on vest wall of Empire dark quarry, Barre, Vt

27. Structure at Stephen \& Gerrard quarry, Barre, Yt-one,

28. Structure, north wall of Stephen \& Gerrard quarry, Barre, Vt

29. Structure at Jones Light (main) quarry, Barre, Vt_-_-_....

30. Structure at Smith Upper. Smith Lower, and Duffee quarries, Barre, Vt

31. Structure at Consolidated quarry, Barre, Vt

32. Structure at Milne quarry, Barre, Vt

33. Structure at Pirie quarry, Williamstown, $\mathrm{Vt}$

34. Structure at Woodbury Granite Co.'s quarries, on Robeson Mountain, Woodbury, Vt 
Figure 35. Mal of Bethel, Randolph, and Rochester, Vt

36. Structure at Ellis and Woodloury quarries, Bethel, Vt

37. Matp showing location of quarries at Conway, $X$. H........

38. Mal, showing location of quarries at Milford, $>H_{-}$

39. Structure at Young quarry, Milford, N. H_____._._._._._._.

40. Structure at Fox quarry, Concord, N. H

41. Structure at Maine \& New Hampshire Granite Co.'s quarry, North Jay, Maine

42. Structure at White quary, Bhuchill. Maine

43. Structules at Brown quarry, Dedham, Maine.

44. Structure at Robertson quary, Franklin, Maine_..._-_._....

t5. Structure at T. M. Blaisdell quarry, East Franklin, Maine_--

46. Structure at W. B. Blaisclell quarry, East Franklin, Maine_--

47. Structure at McMullen quarry, Mount Desert, Maine

48. Milp showing location of quarries about Stonington, Maine -

49. Structure at Ryan-Parker quarry, Crotch Island, Maine

50. Structure at Goss quarry, Crotch Island, Maine.

51. Structure at Sherwood Lower quary, Crotch Island, Maine

52. Structure at Settlement quarry, Deer Isle, Stonington, Maine

53. Structure at Stinchfield and Longfellow quarries, Hallowell, Iraine

54. Structure at Tayntor quarry, Hallowell, Maine_

55. Structure at High Isle quarry, Maine.

56. Structure at Sprucehead quarry, South Thomaston, Maine_--

57. Structure at Long Cove quarry, St. George, Maine-_-_._-_-

55. Map showing location of quarries on Vinalhaven and adjacent islands, Maine_.

59. Structure at Sands quarry, Vinalhaven, Maine

60. Structure at Hurricane Isle quarry, Maine

61. Structure at Round Pond diorite quarry, Bristol, Maine_..--

62. Structure at Waldoboro quarry, Maine

63. Structure at Eagle Gray quarry, Fryeburg, Maine.

64. Flow and sheet structure at Dodlin quarry, Norridgewock, Maine

65. Structure at Mosquito Mountain quarry, Frankfort, Maine_--

66. Structure at Mount Waldo quarry, Frankfort, Maine

67. Structure at Beaver Lake diorite quarry, Calais, Maine.

68. Structure at Bodwell quarry, Jonesboro, Maine-

69. Structure at Gowan Emmons quarry, Biddeford, Maine

70. Structure at Ross boulder quarry, Kennebunkport, Maine

71. Structure at Beattie \& Wilcox quarry, Fall River, Mass

72. Structure at Beattie quarry, Fall River, Mass

73. Map of part of Cape Ann, Mass., showing location of quarries-

74. Structure at lower Pigeon Hill quarry, Rockport, Mass_-_-_--

75. Structure at upper Pigeon Hill quarry, Rockport, Mass_--_--

76. Structure at Blood Ledge quarry, Rockport, Mass_-_-_-_-_-_--

77. Structure at Deep Pit quarry, Rockport, Mass_-_-_-_-_-_-_--

78. Structure at Reinhalter quarry, West Quincy, Mass_-_-_.-_--

79. Structure at Swingle quarry, West Quincy, Mass__-_-_-_-_-_--

80. Structure at Granite Railway quarry, West Quincy, Mass_-_-

81. Map showing location of quarries about Milford, Mass.....--

82. Structure at Cutting quarry, Milford, Mass 
Figure S3. Structure at East quarry, Miliord, Mass-

84. Structure at Blanchard quarries, Uxbridge, Mass

S6. Map of Glastonbury, Conn., showing location of curbing quarries.

S7. Map of Branford and Guilford, Comn., showing location of quarries

SS. Structure at Holbrook quarry, Seymour, Comn

395

89. Map of Waterford, Conn., showing location of quarries

90. Details at Millstone quarry, Waterford, Conn

92. Map showing location of quarries in Westerly and in Charlestown, R. I

93. Structure at Klondike quarry, Charlestown, R. I
94. Granite produced in New Enclanr. 1896-1921, and in the United States, 1916-1921

95. Value of granite produced in New England and in the United States, 1896-1921

96. Granite of different classes produced in New England, 18961921 



\title{
THE COMMERCIAL GRANITES OF NEW ENGLAND.
}

\author{
By T. Nelson Date.
}

\section{INTRODUCTION.}

This work is a revised and abridged edition of the writer's four bulletins and two supplementary papers on the commercial granites of the States of New England. ${ }^{1}$ The exhaustion of the edition of some of these bulletins and the duplication of the general treatment of granite involved in any reprint of the originals make such a combination and revision advisable. The revision has also permitted greater systematization in the introductory part, as well as the correction of some errors in both parts. The descriptions of quarry plants, which change from year to year, have been omitted; also the purely technologic details, which belong properly to the province of the Bureau of Mines.

A small area of white granite in Plymouth, Vt., not mentioned in Bulletin 404, has been visited, and its granite is here described. The granites of quarries opened in Woodbury, Vt., and Milford, Otis, Stoughton, Cohasset, and Braintree, Mass., since the publication of Bulletins 404 and 354 are described.

As in the original bulletins, the general aim of this one is to present the subject in both its economic and its general scientific aspects and to make the scientific part intelligible to the general reader. The economic part includes a chapter on the adlaptations of New England granites and another on the economic geologic factors in granite quarrying, with some practical suggestions.

A number of abandoned quarries are described with the active ones, either because of the scientific interest of their granite or their rock structure or because of their latent economic possibilities.

${ }^{2}$ Dale, T. N., The granites of Maine, with an introduction by George otis Smith: U. S. Geol. Survey Bull. 313, 1907; The chief commercial granites of Massachusetts, New Hampshire, and Rhode Island: U. S. Geol. Survey Bull. 354, 1908; The granites of Vermont: U. S. Geol. Survey Bull. 404, 1909; Supplementary note on the granites of New Hampshire. U. S. Geol. Survey Bull. 430, pp. 346-372, 1910 ; Supplementary note on the granites of Massachusetts: U. S. Geol. Survey Bull. 470, pp. 240-288, 1911. Dale, T. N., and Gregory, H. E., The granites of Connectlcut: U. S. Geol. Survey Bull. 484, 1911. 
The word "granite" in the title is used in its commercial sense and thus includes, besides true granites, quartz monzonite, granite gneiss, diorite, diorite gneiss, gabbro, diabase, and norite. The scientific name is always given.

The specimens described from active quarries were always selected by the foreman or operator of the quarry. The number of each specimen described, to which that of the thin section or sections corresponds, is given, so that the description can be verified by consulting the collections at the National Museum.

The word "coarse," applied to the texture of granite, includes that with feldspars over 0.4 inch in diameter; "medium," with feldspars under 0.4 inch and orer 0.2 inch; "fine," with feldspars under 0.2 inch.

All the granites described are classified according to their characteristics of texture, color, and uses on pages 419-435, with their commercial and scientific names. A bibliography of the economic geology of granite is given on pages 464-467. It includes several works of a general character besides papers on physical tests and geometric analyses of granite, and on the statistics of granite production in the United States. A short list of more or less elementary text books on mineralogy and igneous rocks will be found on page 97 , and a glossary of such scientific terms as have been unavoidably used and of quarry terms on pages 467-471. Miss Altha T. Coons, of this Survey, contributes the statistics of production.

The section by George Otis Smith on the occurrence of granite in Maine, including its geographic distribution and its geologic relations, formed his introduction to Bulletin 313. The passages on the geologic history of Connecticut, the distribution of granite and gneiss in that State, and on the nature of its granitic intrusions have been taken entire from Herbert E. Gregory's contribution to Bulletin 484. Similar but shorter quotations from other geologists as to other States are duly credited.

The writer's obligation to Albert Johannsen for the critical revision of the more difficult microscopic mineral determinations is renewed here. Chemical determinations by W. T. Schaller and George Steiger of this Survey, by E. C. Sullivan, and by George P. Merrill, of the United States National Museum, and a complete mineral analysis by Wirt Tassin, also of the National Museum, are credited in their place. The Rosiwal method of estimating mineral percentages in rocks has been applied as far as practicable to all the types of granite described. 


\section{PART I.-SCIENTIFIC DISCUSSIUN.}

\section{GRANITE PROPER.}

\section{GENERAL FEATURES.}

DEFINITION.

(rranite, in a general sense, is essentially an entirely crystalline igneous rock, consisting mainly of quartz, potash feldspar, and a feldspar containing both soda and lime, in some granites microscopically combined, and containing also a small amount of either white or black mica or both, and in places of amplibole (hornblende, riebeckite), more rarely of pyroxene (augite, aegirite), or both. Where granite has, subsequent to or during its crystallization, been subjected to pressure sufficient to produce a parallelism in the arrangement of its minerals-that is, a schistosity-it is called gneiss or granite gneiss; but as some sedimentary rocks in becoming crystalline also possess this parallelism and closely resemble a granite grneiss they are rlistinguished by the term "serlimentary gneiss."

ORIGIN.

Granite is now regarded as the product of the slow cooling and crystallization of molten glasslike matter at a lull-red heat-matter which contained -uperheated water and was intruded from below into an overlying mass of rock of sufficient thickness not only to prerent the rapid cooling and general extrusion of the molten matter at the surface but also to resist the pressure of the intrusive by its cohesion and powerfully to compress the molten matter by its rravity. As carbonic acirl can be liquefied only under pressure, its presence in liquid form within some of the microscopic cavities in the quartz of granite is alone evidence that the rock was formed under pressure. That the temperature at which granite solidified was comparatively low has been inferred from the fact that it contains minerals which lose their physical properties at temperatures higher than dull-red heat. The relations of the mineral constituents of granite to one another show the order in which they must have crystallized. This order differs from that in which they would crystallize if molten in a dry state, but laboratory experiments have shown that the presence of even a small quantity of water suffices to change that order of crystallization. 'The presence of superheated water in the formation of granite, inferrel from the arrangement of its minerals, shows that the conditions requisite to its formation included not only the pressure of an overlying mass of rock but also expansive pressure from below. Had this molten matter been extrucled at the surface it would have cooled so rapidly that but few of its constituent mole- 
cules would have had time to arrange themselves in geometric order. The process of crystallization would have been arrested by the sudden passage of the material into the solid state, and the proluct rould have been a volcanic glass somewhat resembling that which forms cliffs in Yellowstone National Park. In granite, however, the mass has cooled slowly enough to permit the complete crystallization of the originally molten glasslike matter, and no unarranged molecules remain. The production of a glass by the rapid cooling of the surface of a granitic intrusion in consequence of its contact with a schist mass is seen at Bethel. Vt., and shown in thin section in figure 9 .

From observations in Norway. Colorado, Utah, Arizona, and Montana geologists conclude that the thickness of the rock overlying this molten matter may have been only a few hundred yards. the essential conditions for the production of granite being slow cooling and the confinement of the vapor of water escaping during crystallization to the adjacent rocks. ${ }^{2}$

Lacroix, in his studies of Mount Pelée, found that quartz may crystallize in a superficial volcanic dome, even under a thin solidified crust, as soon as this forms a closed ressel. ${ }^{3}$

The overlying rock mass which furnished a part of the pressure required to form granite has at many places been removed from it by erosive processes that operated through great stretches of time. Indeed, it is only by the removal of this mass that granite is anywhere naturally exposed. Although this mass may have measured hundreds of feet in thickness, its former presence is at some places attested only by a thin capping on the granite or by fragments which the lacerating action of the intruding granite has incorporated into itself.

The lacerating effect of an intrusion and the subsequent erosion of some of the overlying strata have been reproduced experimentally."

${ }^{2}$ Brögger, W. C., Dle geologischen Verhältnisse der Pegmatitgänge des Christlaniagebietes: Zeitschl. Krystall. (Groth), Leipzig, p. 225, 1890. Cross, Whitman, The laccolitic mountain groups of Colorado, Utah, and Arizona: U. S. Geol. Survey, Fourteenth Ann. Rept., pt. 2, pp. 230, 238, 1894. See also Barrell. Joseph, Geology of the Marysille mining district, Mont., a study of igneous intrusions and contact metamorphism: U. S. Geol. Survey Prof. Paper 57, 1907.

${ }^{3}$ Lacroix, Alfred, La Montagne Pelée et ses êruptions, p. 517, Paris, 1904.

- IIowe, Ernest, U. S. Geol. Survey Twenty-first Ann. Rept., pt. 3, pp. 294-296, pl. 43, 1901. Reyer, of the Austrian Geological Survey, has illustrated a granite intrusion by this simple experiment: Upon a table a frame of clay, say 2 inches thick, is constructed about a square piece of board 1 inch thick. After removing the board a mixture of medium-thick plaster and red coloring matter is poured into the inclosure. The surface of the red plaster is then sprinkled with a layer of white plaster powder. After making a lens-shaped perforation in the center of the board it is again fltted into the frame and pressed against the red and white layers until the white plaster exudes through the opening, and afterward the red intrudes the white. The materials are allowed to harden and are then sawn to show the structure. See Reyer, Ed., Tektonik der Granit Erguisse von Neudeek und Carlsbad, etc.: K.-k. geol. Reichsanstalt Jahrb., vol. 29, pp. 432-433, fig. 6,1879 . 
Granite itself las been converted in the laburatory into a material which upon cooling under ordinary conditions has proved to be a glass, and the chief mineral constituents of granite have heen artificially crystallized at ligh temperatures in the presence of water vapor under high pressure. but the conditions requisite for the production of a granitic rock from its chemical constituents lave not yet been successfully imitated.

Some granite shows locally a certain alinement of its mica plates and feldspars. due to the fiow of the mass while it was in a plastic state-a structure which was probably controlled by the pressure and form of the bordering rock. "This "flow structure" should not be confounded with the schistosity, which is the to later pressure, involves mineral changes, and is usually regional rather than local in extent, and which is called "gneissic structure."

The great differences in the grade of texture in granites-the mineral particles ranging from an average diameter of 0.02 inch (0.5 millimeters), and even 0.0069 inch (0.175 millimeter), to over 0.5 inch-is attributed to differences in the rate of cooling. The portions at the margins of large masses, or in small masses such as dikes, which cooled rather quickly, crystallized in very small crystals; the central portions, which cooled more gradually, became coarsely crystalline.

\section{MIINERAL COMPOSITION.}

Feldspar is the most conspicuous and generally the most abundant mineral in granite. By its color or colors it usually determines to a large extent the general color of the rock, and by the light which it reflects it gives brilliancy. It is easily distinguished from the other constituents by its smooth cleavage surfaces and milky, bluish-white or opalescent, reddish, brownish, or greenish color. Granite usually contains two kinds of feldspar, the more abundant of which is generally potash feldspar, a silicate of alumina and potash. This occurs in one or both of two crystal forms, orthoclase or microcline, which, however, can be distinguished only by means of the microscope. The other variety of feldspar (plagioclase), containing either soda or soda and lime, although it may be of the same color as the potash feldspar, can in some granites be distinguished by the very fine parallel lines on its surface. Usually it differs greatly in color from the potash feldspar, which may be reddish, brownish, or lavender-colored; the plagioclase may be white, gray, or greenish. Under the microscope the soda-lime feldspar can be readily distinguished from the potash feldspar by its behavior in polarized light, which brings out its crystalline structure and indicates its particular variety and approximate chemical composition. A granitic rock that. 
contains the two feldspars in equal proportions is distinguished by a special technical name.

Quartz (silica), the next most abundant constituent, is readily recognized by its glassy luster, uneren fracture, and brittleness. It may be clear, milky, bluish, opalescent or amethystine, or smoky. The quartz determines in some measure the shade of the rock. The vitreouness of the quartz greatly affects the granite.

The next most abundant constituent of granite is mica. which is present in two forms-the white (muscovite, or potash mica), essentially a silicate of alumina with potash and minor amounts of soda and ferrous oxide. and the black (biotite. or magnesia mica), essentially a silicate of alumina with potash, magnesia, and both ferric and ferrous oxide. Granite may contain one or both of these micas. The dimensions and number of the scales of black mica largely determine the shade of many granites.

Amphibole, a constituent of many granites. although greenish (rarely bluish in minute or very thin crystals). may in crystals of ordinary size appear as dark as the black mica, but. unlike that mineral. it does not split into scales. Amphibole and prroxene resemble each other so closely when in small particles that they can be distinguished only by means of the microscope. Both may occur in granite.

In addition to these more abundant minerals, others are usually present in minute or microscopic quantities. Some of these including kaolin. sericite (a potash mica or muscorite), chlorite, epidote, zoisite, and calcite, as well as paragonite (soda mica), which may possibly be present, are the result of chemical changes in the feldspars or the biotite or amphibole and are therefore called "secondary." Others, like zircon, apatite, titanite, rutile, tourmaline, fluorite, garnet, magnetite, molybdenite, ilmenite, pyrite, and allanite, are regarded as original "accessory constituents." Calcite also occurs in microscopic quantity as an original mineral of some granites. ${ }^{5}$ Of these minor accessories, pyrite (iron disulphide) and calcite (lime carbonate) alone have economic significance, for these may discolor or weaken the stone when dissolved or oxidized on an exposed surface.

The chemists of this Survey have treated 10 granites from Maine, 23 from Massachusetts, New Hampshire, and Rhode Island, and 10 from Vermont, with hot dilute acetic acid and find that they contain from 0.05 to 2.46 per cent of $\mathrm{CaCO}_{3}$ (lime carbonate).

The following accessory minerals have been detected in the New England granites: Garnet, tourmaline, zircon, titanite, magnetite,

\footnotetext{
5 Sce Zirkel, F., Petrographie, vol. 2, p. 13, and Weinschenk, E., K. Bayer. Akad., Math.-phys. Classe, Ahh., vol. 18, p. 730, pl. 5.
} 
IImenite (?), pyrite, ${ }^{8}$ molybdenite, fluorite, apatite, biotite, allanite, and rutile; also the secondary minerals hematite, limonite, calcite, kaolin, muscovite, paragonite (probably), quartz, hornblende, riebeckite, chlorite, epidote, and zoisite. The number of minerals occurring in the pegmatite dikes within the same granites is very much larger. (See pp. 46,47 .)

The arrangement of the chief minerals in the stone is described under the heading "Texture" (p. 10).

The percentages of the mineral constituents differ within wide limits in granites from different localities. The percentages of muscovite and of the ferromagnesian minerals (biotite, amphibole, pyroxene) are always small; those of the feldspar and quartz are large. There is considerable variation in the relative amounts of feldspar and quartz and still more in the amounts of each of the feldspars.

\section{CHEMICAL COMPOSITION.}

The chemical composition of granite is of less scientific and economic significance than its mineral composition, for, although chemical analysis shows the percentages of the constituent elements, the process by which these are determined necessarily mingles the elements of several minerals whose proportions vary and whose contributions to the physical properties of the rock differ greatly. When, however, a combination of elements occurs only in one or two of the minerals the chemical analysis serves to corroborate the evidence obtained by microscopic analysis.

Many analyses of granite have been published, but it will suffice here to give the extremes of the percentages shown by some of the more authoritative of these and to refer the reader to works containing complete analyses. ${ }^{7}$ Four analyses of granites from Scotland, Ireland, Italy, and Sweden show the following ranges: ${ }^{8}$

\footnotetext{
${ }^{B}$ As to the question whether marcasite (white iron pyrites) occurs in granite, Allen, Crenshaw, and Johnston, in an important paper on "The mineral sulphides of iron" (Am. Jour. Sci., 4th ser., vol. 33, pp. 169-236, 1912), state on page 216 that " the fact that marcasite never occurs as a primary constituent of magmas, while pyrite sometimes does, is explained by the fact that marcasite can not exist above $450^{\circ} . "$ On p. 190 they add: "Paramorphs of pyrite after marcasite are certainly possible, but paramorphs of marcasite after pyrite are evidently impossible." J. D. Dana, in the fourth edition of his system of mineralogy $(1858$, p. 61), stated that "At Warwick, N. Y., marcasite occurs in simple and compound crystals in granite witb zircon." This passage is repeated verbatim in the sixth edition, 1911, p. 95.

'See Washington, H. S., U. S. Geol. Survey Prof. Paper 99, 1917; also Clarke, F. W., U. S. Geol. Survey Bull. 419, 1910.

${ }^{8}$ Geikie, Archibald, Textbook of geology, 4th ed., vol. 1, p. 207, London, 1903.
} 
Analyses of Europcan granites.

Silica $\left(\mathrm{SiO}_{2}\right)$ $70.60-74.82$

Alumina $\left(\mathrm{Al}_{2} \mathrm{O}_{3}\right)$ 14. $86-16.40$

Ferric oxide $\left(\mathrm{Fe}_{2} \mathrm{O}_{3}\right)$ $.10-1.63$

Felpous oxide (FeO)

Mignesia ( $\operatorname{MgO})$

Magnesia $(\mathrm{MgO})$

$42-3.20$

$.14-2.23$

$.23-1.00$

Lime $(\mathrm{CaO})$

$.89-2.47$

Soda $\left(\mathrm{Na}_{2} \mathrm{O}\right)$

$3.51-6.12$

Potash $\left(\mathrm{K}_{2} \mathrm{O}\right)$

$3.55-5.10$

Twelve analyses, made at the laboratory of the United States Geological Survey, of granites from California (2), Colorado (1), Maryland (3), Michigan (1). Minnesota (1), and Montana (4) show the following ranges: ${ }^{\circ}$

Analyses of American granites.

Silica $\left(\mathrm{SiO}_{2}\right)$ 63. $87-76.10$

Alumina $\left(\mathrm{Al}_{2} \mathrm{O}_{3}\right)$ 12. 95-19. 13

Felric oxide $\left(\mathrm{Fe}_{2} \mathrm{O}_{3}\right)$

$.00-1.80$

Ferrous oxide ( $\mathrm{FeO})$

Magnesia ( $\mathrm{MgO})$

Lime ( $\mathrm{CaO})$

$.42-3.20$

$.14-2.23$

Sorta $\left(\mathrm{Na}_{2} \mathrm{O}\right)$

$.12-4.30$

Potash $\left(\mathrm{K}_{2} \mathrm{O}\right)$

2. $36-4.53$

Titanium dioxide $\left(\mathrm{T}_{1} \mathrm{O}_{2}\right)$

1. $87-7.99$

Phosphoric acid $\left(\mathrm{P}_{2} \mathrm{O}_{5}\right)$

$.07-0.65$

Trace- 0.30

The average of 21 analyses of even-grained Georgia granites made by Watson ${ }^{10}$ yields the following percentages:

Analyses of Georgia granites.

Silica $\left(\mathrm{SiO}_{2}\right)$ (extremes 68.38, 72.56).

69.97

Alumina $\left(\mathrm{Al}_{2} \mathrm{O}_{3}\right)$

16. 63

Ferric oxide $\left(\mathrm{Fe}_{2} \mathrm{O}_{3}\right)$

1. 28

Lime $(\mathrm{CaO})$

2.13

Magnesia $(\mathrm{MgO})$

.55

Soda $\left(\mathrm{Na}_{2} \mathrm{O}\right)$

4. 73

Potash $\left(\mathrm{K}_{2} \mathrm{O}\right)$

4. 71

Holmquist ${ }^{11}$ gives 137 analyses of Swedish granites arranged in a continuous table.

In all these analyses most of the lime is to be attributed to the lime-soda feldspar and nearly all the rest of it to apatite (lime phosphate), or to amphibole and pyroxene, if these are present.

- See U. S. Geol. Survey Bull. 419, p. 33, analyses C, D, E; p. 46, analysis A; p. 52 , analysis $D$; p. 77 , analyses $D, E$, F ; p. 86 , analysis $C ;$ p. 99 , analysis $\mathrm{E}$; p. 151, analysis A ; p. 157, analysis E.

${ }_{10}$ Watson, T. L., Georgia Geol. Survey Bull. 9-A, p. 241, 1902.

11 Holmquist, P. J., Studien tiber die Granite von Schweden : Upsala Univ. Geol, Inst. Bull., vol. 7, Nos. 13 and 14, pp. 77-269, 1906. 
It is of interest to note in this connection that certain seotch and Irish qranites contain from 1.6 to 2.5 rolumes of pas per rohme of rock. This gas is inclosed in mieroseopie carities within the minerals, and in the Scoteh granite it consists of carbon. oxygen, hydrogen. and nitrogen in the following combinations and proportions: $\mathrm{CO}, 23.60 ; \mathrm{CO}, 6.45 ; \mathrm{CII}_{4}, 3.02 ; \mathrm{N}_{2}, 5.13 ; \mathrm{II}_{2}, 61.6812$

R. T. Chamberlin ${ }^{13}$ found in a gray granite from Quincy, Mass.. 1.60 volumes of gas per rolume of rock and made up as follows: $\mathrm{CO}_{2}$, $0.39 ; \mathrm{CO}, 0.09 ; \mathrm{CH}_{4}, 0.06 ; \mathrm{H}_{2}, 1.04 ; \mathrm{X}_{2}, 0.02$. Areraring 19 analyses of granites and granite gneisses ( $17 \mathrm{by}$ himself and 2 by Gautier) he obtained the following rolumes of each gas per volume of roe': $\mathrm{CO}_{2}$, 1.47 ; $\mathrm{CO}, 0.22: \mathrm{CH}_{4}, 0.05 ; \mathrm{II}_{2}, 1.36 ; \mathrm{N}_{2}, 0.09$--total, 3.19.

\section{TEXTERE.}

Definition.-The texture of a rock signifies the size, the forms, and the mutual relations of its minerals as seen without or with a microscope.

Character and grade.-The most charaeteristic external feature of granite is the character of its grain. Some granites are eren grained: others contain more or less thinly disseminated and complete crystals of feldspar in a mass of finer, eren-grained material-that is. they show what is ealled porphyritic texture. (See p. 10.) The next most striking feature is the relative coarseness or fineness of grain in an even-grained granite. Three rrades of texture of this sort may be distinguished-(1) coarse, in which the feldspars generally measure orer 1 centimeter, or 0.4 inch; (2) medium, in which they measure under 1 centimeter $(0.4$ inch) and over 0.5 centimeter $(0.2$ inch); (3) fine, in which they measure under 0.5 centimeter $(0.2$ inch). In some coarse-grained granites the felfspars measure one or sereral inches, and in some fine-grained ones all the particles range from 0.25 to 1 millimeter $(0.04$ ineh) in diameter, and some average as low as 0.5 millimeter or (0.02 inch). Extremely fine ones average 0.175 millimeter or about 0.007 inch.

Forms of minerals.-Eren without the aid of the microscope it will be noticed that, except in granites of porphyritic texture, the minerals rarely attain their complete crystalline form. They have interfered with one another's growth. It will also be noticed that some of the crystals of feldspar in some granites are surrounded by a border of a different feldspar. Thus a red feldspar may be bordered by a white or greenish one, or vice versa. Either of these may be the potash feldspar and the other a soda-lime feldspar. It will also be noticed that many of the feldspars are not simple incomplete or complete

12 Tilden, W. H., Roy. Soc. London Proc., vol. 60, pp. 454, 455, 1897.

${ }_{13}$ Chamberlin, R. T., The gases in rocks: Carnegie Inst. Washington Pub. 106, p. 23, 1916. 
crystals, but "twins." having the eleavage planes in one half at a different angle from those in the other half. so that when held in the sunlight only one half will reflect the light in one position.

Arrangement of minerals.--A polished surface of any medium or coarse grained granite shows that the quartz fills up the spaces between the feldspars-that is. it was formed after them-also that both feldspars and quartz inclose particles of mica, etc., which must therefore have crystallized before them. Under the microscope the arrangement of the minerals is found to be such that they must usually have crystallized in the following order: Magnetite, pyrite, apatite, zircon, titanite, amphibole and pyroxene, biotite, muscovite. the feldspars, and, last of all, the quartz. It should be noted, however, that many of the feldspar crystals eontain intergrown quartz, so that some of the quartz must therefore have crystallized at the same time as the feldspar. The structure of the potash feldspar in some granites is very intricate, as it contains microscopic intergrowths of a lime-soda feldspar, both having evidently crystallized at the same time or in close alternation. Also, as stated above, the potash feldspar may be rimmed with soda-lime feldspar, or vice versa.

Porphyritic texture.-In some granites some of the minerals, generally the feldspars, occur as large, isolated, more or less complete crystals in a mass (groundmass) of finer, eren-grained granite. This is known as the porphyritic texture. (See Pl. XXXI, B.) The conditions under which a porphyritic granite was formed are not yet perfectly understood. The large crystals were, of course, formed before the completion of the groundmass. If a porphyritic granite passes into a gneiss, the large crystals become elongated and lens-shaped and the rock is called a porphyritic or "angen" (eyes) gneiss. (See Pl. XXXI, 1.) The secondary structure known as gneissic is described on page 65 .

COLOR.

The color of a granite is almost entirely governed by that of its dominant feldspar, and its shade is largely determined by that of its quartz and its mica. These physical qualities of granitic feldspar and quartz are described on pages $75-79,80,81$.

I HYSICAL PROPERTIES.

Granite derives its physical properties from its mineralogic constitution, particularly from its large content of feldspar and quartz, and from its texture. Among these physical properties the most important are weight, cohesiveness, elasticity, flexibility, hardness, expansibility, porosity, and vitreousness.

Weight.-In order to establish a fixed standard the weight of a certain volume of a rock is compared to that of an equal volume of 
distilled water. The weight thus determined is called the specitic gravity of the rock. The specific gravity of granite ranges from 2.593 to 2.731 . The arerage of these extremes is 2.662 , which is equivalent to 2 long tons, or 4,480 pounds, to the cubic yard, or about 165 pounds to the cubic foot- Geikie ${ }^{14}$ calls attention to the change in the weight of granite when immersed in sea water, as given by Stevenson. ${ }^{15}$ A red granite having a specific gravity in air of 2.51 , or 13.2 cubic feet to the ton, will in sea water of a specific gravity of 1.028 measure 21.3 cubic feet to the ton.

Cohesiveness.-The cohesiveness of a rock is ascertained by determining it crushing strength-that is, the weight in pomels required to crush it or to destroy its cohesion. The ultimate compressive strength of granite ranges from about 15,000 to 43,973 pounds per square inch, ${ }^{16}$ but the usual range is from 18,000 to 34,000 pounds. Herrmann ${ }^{17}$ gives the crushing strength of European granites as ranging from 1,100 to over 3,000 kilograms per square centimeter. Recent tests by the Bureau of Standards on five granites from Maine, Naryland, and North Carolina show their compressive strengths ranging from 17,132 to 41,772 pounds per square inch. ${ }^{18}$

Elasticity.-Tests made at the United States Arsenal at Watertown, Mass., to determine the compressive elasticity of specimens of granite from Arkansas, Connecticut, Maine, Minnesota, and New Hampshire, show that the specimens, in a gaged length of 20 inches and a diameter of 5.5 inches at the middle, when placed under a load of 5,000 pounds to the square inch, suffered compression ranging from 0.0108 to 0.0245 inch. resulting in a lateral expansion ranging from 0.005 to 0.007 inch, and giving ratios of lateral expansion to longitudinal compression ranging from $1: 8$ to $1: 47 .^{19}$

The results of some experiments on the elasticity of granites from Westerly, R. I.. are given by Adams and Coker. ${ }^{20}$

Flexibility.-Although granite contains a large amount of brittle material (estimated at 30 to 60 per cent) and the interlocking of its various particles gives to it great cohesion and rigidity, yet in sheets of sufficient thinness and areal extent it is flexible. Sheets half an inch thick and 4 feet long may be bent, as noted in the description

14 Textbook of geology, 4th ed., p. 568 .

15 Sterenson, T.. Harbours. p. 107.

18 These extremes are from Wisconsin granites. See Buckley, E. B., On the building and ornamental stones of Wisconsin: Wisconsin Geol. and Nat. Hist. Survey Bull. 4, pp. 361,390 .

${ }^{17}$ Hermann, O., Steinbruchindustrie und Steinbruchgeologie, p. 43.

${ }^{18}$ Figures from the Director, Oct. 11, 1916.

${ }^{13}$ Report of the tests of metals, etc., made with the United States testing machine at Watertown Arsenal, Mass. (1S95), pp. 339-34s, 1896.

20 Adams, F. D., and Coker, E. G., An investigation into the elastic constants of rocks, more especially with reference to cubic compressibility: Carnegie Inst., Washington Pub. 46, 1906. For another reference to the compressibility of Westerly granite see Adams, F. D., An experimental contribution to the question of the deptl of the zone of flow in the earth's crust: Jour. Geology, vol. 20, pp. 112-115, 1912. 
of the Lawton quarry, at Norrictgewock, Maine (p. 256). Whether flexibility in this granite was conditioned upon a slight loosening of the grains by chemical and physical change is uncertain.

Hardness.-As will be seen by reference to the tests for hardness described on page 100, granites differ greatly in hardness. This difference is due not merely to differences in the percentage of quartz but also to variations in the character of the feldspars.

Expunsibility.-The expansibility of granite has been variously tested. Bartlett ${ }^{21}$ found that a piece of granite coping s feet long, subjected to a winter temperature of $0^{\circ} \mathrm{F}$. and a summer temperature of $96^{\circ} \mathrm{F}$., expanded 0.027792 inch, or 0.000004825 inch per inch of length for each degree of increase in temperature. The Ordnance Department at the Watertown Arsenal, ${ }^{22}$ tested the granites referred to under the heading "Elasticity" and found that slabs of gaged lengths of 20 inches in passing from a cold-water bath at $32^{\circ}$ F. through a hot-water bath at $212^{\circ} \mathrm{F}$. and back again to cold water at $32^{\circ} \mathrm{F}$. expanded from 0.0017 to $0.0059 \mathrm{inch}$, a veraging $0.0040 \mathrm{inch}$.

Porosity.-.Granite contains and absorbs water, which is held in microscopic spaces both within and between its constituent minerals. Ansted ${ }^{23}$ states that granite generally contains about 0.8 per cent of water and is capable of absorbing about 0.2 per cent more. In other words, a cubic yard of granite weighing 2 tons contains in its ordinary state about $3 \frac{1}{2}$ gallons of water and can absorb nearly a gallon more on being placed in pure water for a short period. Buckley ${ }^{24}$ found that the pore space or porosity in fourteen Wisconsin granites ranges from 0.17 to 0.392 per cent, and that the ratio of absorption (percentage of weight of absorbed water to the average dry weight of the sample) of the same granites ranges from 0.17 to 0.50 . The Bureau of Standards finds that this percentage in a North Carolina and a Maryland granite ranges from 0.15 to $0.43 .^{25}$ Merrill ${ }^{26}$ has shown that certain Maryland granites absorb from 0.196 to 0.258 per cent of water after drying 24 hours at $212^{\circ} \mathrm{F}$. and then being immersed for 24 hours.

Vitreousness.--The vitreousness of granite is due to that of its contained quartz. Under extreme changes of temperature, as in a city fire, where water is thrown on the stone, granite exfoliates badly. This exfoliation or shelling is attributable to the unequal expansion or contraction of the outer and the inner portions of the rock under sudden changes of temperature. It is also probably connected

${ }^{21}$ Bartlett, W. C., Experiments on the expansion and contraction of building stones by variation of temperature: Am. Jour. Sci., 1st ser., vol. 22, pp. 136-140, 1832.

22 Op. cit., p. 322 .

23 Ansted, D. T., quoted by Edward Hull, in A treatise on building and ornamental stones of Great Britaiu and foreign countries, p. 30, 1872.

24 Buckley, E. B., Op. cit., p. 400.

${ }_{25}$ Figures from the Director, Oct. 11, 1916.

${ }^{26}$ Merrill, G. P., Maryland Geol. Survey, vol. 2, pp. 94, 95. 
with the vitreousness of the quartz. The unequal expansive ratios of the different constituent minerals would result in general disintegration. not in exfoliation. (Nee further under "Fire test," p. 102.)

Buckley ${ }^{27}$ subjected 2 -inch cubes of five Wisconsin granites to hightemperature tests and found that they were all destroyed at $1,500^{\circ} \mathrm{F}$. One of them cracker at $1,000^{\circ}$; two others began to disintegrate at $1,200^{\circ}$. The most notable change was that "when struck with a hammer or scratched with a knife they emitted the sound peculiar to a burnt brick." Cutting. ${ }^{2 s}$ applied a fire test to granites from eighteen quarries in Maine, Maryland, Massachusetts, Minnesota, New Hampshire, Vermont, and Virginia, with the result that after saturation they all stood a temperature of $500^{\circ} \mathrm{F}$. without clamage but showed the first appearance of injury at $700^{\circ}-800^{\circ}$ and were rendered worthless at $900^{\circ}-1.090^{\circ}$. 'Twenty-three sandstones subjected to the same tests showed the first appearance of injury at $800^{\circ}-900^{\circ}$ and became worthless at $950^{\circ}-1,200^{\circ}$. His general results agree with those of experience as to the relative fire endurance of granite and sandstone. ${ }^{29}$ The beharior of granite under rery high temperature is not attributable to any one physical property. The physical properties of granite are further discussed in Part II, under the heading "Tests of granite" (pp. 99-103).

CLASSIFICATION.

The rarieties of granite are so numerous that for either scientific or economic purposes they need to be classified.

Scientific classificution.-For scientific purposes granites may be classified according to their less essential mineral constituentsmica, hornblende, and augite. Thus a granite containing white mica is termed a muscovite granite; one containing black mica, a biotite granite; one containing both, a muscovite-biotite granite. A granite containing black mica and hornblende is called a biotite-hornblende granite. Granites may also be classified according to both their mineral and their chemical composition. These two form the basis of an elaborate classification of igneous rocks, which is too complex to be outlined here. ${ }^{30}$

Economic rlassification.-For economic purposes granites may be classified first as to texture-as even grained, or porphyritic, or as coarse, medium. or fine, according to the scale given on page 9. Those of extra coarse or extra fine texture can be distinguished by the prefix "very." This scale gires five grades of textures. Gran-

27 Op. cit., p. 411.

${ }^{29}$ Cutting, H. A.. Vermont Aor. Sixth Rept., pp. 4i-54, 1890 ; Durability of building stone: An. Jour. Sci.. 3d sør., vol. 21, p. $410,1 S S 1$.

20 Merrill, G. I'. Stones for building and decoration, p. 435.

so See Cross, Whitman, Iddings, J. P., Pirsson. L. V., and Washington, II. S., Quantitative classification of inneous rocks based on chemical and mineral characters, wlth a systematic nomenclature, Chicago, 1903; also Jour. Geology, vol, 10, pp. 555 et seq., 1902. 
ites should also be classified as to general color and shade-as pinkish, reddish. lavender, or gray or warm gray (that is, a gray showing the presence of a slight reddish, reddish-purplish, or yellowish tinge), and as dark, medium. or light; and the terms "dark gray" and "light gray" may be modified by prefixing the word "very." The word "shade" here is used throughout to denote degree of blackness apart from color. In very many granites this is due directly to the relative smokiness of the quartz or the amount of black mica or other very dark silicate. They may be further classified and designated by the colors of their most conspicuous minerals, the feldspars, quartz. and mica. A stone may thus be called a coarse even-grained warm-gray granite, with lavender and white feldspars, smoky quartz, and black mica: or another may be called a fine evengrained, very light gray granite, with white feldspar, clear quartz, and both white and black mica. Lastly, they may be clissified by their uses-as constructional, monumental, inscriptional, polish, or statuary granites. All the commercial granites of New England will be found classified according to their uses. colors. and shades on pages 419-135. The outline of an exhanstive technical description of any granite can be constructer from the tesis enunerated on pages $99-103$.

\section{GENERAL STRUCTURE.}

The term "structure" embraces all the divisional planes that traverse the rock. These occur at intervals ranging from a microscopio distance to one measured by scores of feet and either cross or, very rarely, are parallel to the texture resulting from crystallization.

\section{FLOW STRUCTURE.}

Where two varieties of granite lie in contact. as at Redstone, N. H. (p. 165), and at Norridgewock, Maine (fig. 64), the dividing line between them indicates the direction of their flow, for the same reason that the direction of the flow of a stream would be shown by the demarcation between its water and that of a muddy tributary a little below their junction. In some places this direction is also indicated by streaks or sheets of mica scales parallel to the line between the granites. Such streaks, therefore, where alone, are regarded as indicating flow structure. They may be inclined at all angles or be in horizontal undulations with axes pitching $10^{\circ}$ to $40^{\circ}$. In some Massachusetts and New Hampshire quarries the structure is parallel to the surface of the granite at its contact with overlying rocks or surrounds in parallel bands the surface of large inclusions. (See pp. 90, 281, and fig. 17.) Flow structure also is conspicuous in the granite of Milford, Mass., and in some of the quarries of Milford, N. H. (See pp. 185, 343.) At the Millstone quarry in Water- 
ford, Conn., flow structure doubles over on itself. (See fig. 90 and p. 396.) The very local character of such structural features indicates that they are not due to pressure affecting the entire region, but that they originated while the granite masses were still plastic. A granite that exhibits flow structure is caller by some writers a How gneiss.

\section{RIFT AND GRAIN.}

DEFINITION.

The rift in granite is a feature of considerable scientific interest and of much economic importance. It is an obscure microscopic foliation-cither vertical. or very nearly so, or horizontal-along which the granite splits more easily than in any other direction. The grain (see glossary) is a foliation in a direction at right angles to this, along which the rock splits with a facility second only to that of the fracture along the rift. After a little experience an observer san detect the rift with the mnaided eye, where it is marked.

\section{PREVIOUS DESCRIPTIONS.}

The earliest mention of rift in geologic literature appears to be that made in 1778 by J. F. W. Charpentier, ${ }^{31}$ who noticed that granite millstones which were cut with their largest diameter parallel to the rift were much more readily worn than those cut at right angles to it-that is, parallel to the "hard way." He attributed this property to a parallel arrangement of the mineral particles. The next reference was made in 1803 by Pötsch, ${ }^{32}$ who described the rift in the granites of Lausitz, in Saxony. In 1833 it was referred to by Enys and $\mathrm{Fox}^{33}$ as characterizing the granites of Penrhyn, and in 1834 it was mentioned by De la Beche; ${ }^{34}$ also in 1855 by Adam Sedgwick, ${ }^{35}$ who attributed it to crystalline action at the time of consolidation. In 1860 C. F. Naumann ${ }^{36}$ ascribed it either to local differences of cohesion or to an inner strain possibly related to the direction of original consolidation. In $1864 \mathrm{G}$. vom Rath ${ }^{37}$ described a diorite from Monte Adamello, in the Tyrol, without dominant rift, and observed that the rift course was, on the contrary, uniform in the granite of Monte Motterone (Baveno). In 1876 James D. Dana ${ }^{38}$ stated that "granite often has a directon of easiest fracture due to the fact

\footnotetext{
${ }^{31}$ Mineralogische Geographiv des chursächsischen Lande, 17TS, See also his Beobachfungen über die Lagerstätte der Erze, 1779.

32 Bemerkungen und Beobachtungen Hber das Vorkommen des Granits in geschichtete ijagen, p. 140, 1803.

${ }^{33}$ London and Edinburgh Philos. Mag., 3d ser., vol. 2, pp. 321-327, 1833.

34 Researches in theoretical geology, and Report on the geology of Cornwall, 1834 .

25 Geol. Soc. London Trans., 2d ser., vol. 3, pt. 3, p. 483, 1855.

${ }^{30}$ Lehrbuch der Geognosie, 2d ed., vol. 2, pp. 191-192, Leipsig, 1860.

${ }^{37}$ Beiträge zur Kenntniss der eruptiren Gesteine der Alpen: Deutsch. geol. Gesell Zeitschr., vol. 16, pp, 249-260, 1864.

Manual of geology, 2d ed., p. 628, 1876 .
} 
that the feldspar crystals have approximately a uniform position in the rock, bringing the cleavage planes into parallelism." This is true in those places where the directions of flow structure and rift chance to coincide, and in some porphyritic granites the porphyritic crystals are arranged with reference to the rift, but that this arrangement is not the cause of rift is shown by the fact that the feldspar cleavages usually inter'ect the rift face at all angles. In 1879 Reyer ${ }^{39}$ attributed rift to an original arrangement of particles by flowage. As rift in places crosses flow structure this explanation is also inadequate. In 1893 Carl C. Riiber, in a work on the granite industry of Norway ${ }^{40}$ described an augite syenite with inferior rift and grain, in which the clearage planes of the individual feldspar crystals were parallel to the two cleavages, rift and grain, of the rock. In 1894 F. Zirkel, ${ }^{41}$ after reviewing the opinions of his predecessors, tentatively suggested that rift might be the result of conditions of strain brought about by pressure from one side only, which failed to find adequate relief in jointing. In 1913 Eduard Suess ${ }^{42}$ expressed the opinion that horizontal rift or grain structure is the primary effect of compressive strain upon granite and that vertical rift or grain, as well as vertical joints, are secondary effects of the same strain. In 1916 John Oxaal," State geologist of Norway, found that "rift is a primary phenomenon determined by the congealing of the rock and by the crystallization of the mineral constituents." This was the view of Adam Sedgwick (1855). Oxaal states further:

There is a well-defined conformity to law as regards the orientation of the separate constituents of the rock. In labrador or larvikite the feldspars are nearly parallel to each other, and the beautiful blue opalescence in the direction $(\overline{8} 01)$ in feldspars appears consequently only along one direction in the rock, while in the other directions little or no play of color appears. The clearages of the rock (rift and grain) are parallel to the cleavages of the feldspar constituents.

Two American geologists ${ }^{44}$ have described rift minutely: Tarr presents four figures reproduced from drawings made from enlarged views of thin sections showing the rift in Cape Amn hornblendebiotite granite. These figures and his descriptions indicate microscopic faults, most of which meander across feldspar and quartz alike, although some go around the quartz particles rather than through them. In the feldspars they usually follow the cleavage.

${ }^{30}$ Reyer, Ed., Tektonil der Granit Ergüsse von Neudeck and Carlsbad, etc. : K.-k. geol. Reichsanstalt .Tahrb., rol. 29, p. 415, 1879.

${ }^{40}$ Norges Granit Industri : Norges geol. Undersogelse Aarbog for 1893, No. 12, p. 45.

41 Lehrbuch der l'etrographic, 2d ed., vol. .2, p. 52-53, 1994.

42 Über Zerlegung der gebirgsfaldenden Irraft: Geol. Gesell. Wien Mitt., rol. 6, pp. $13-60,1913$.

${ }^{43}$ Norsk Granit: Norges geol. Undersökelse No. 76, pp. 210, 211, 1916.

4 Tarr, R. S., The phenomena of rifting in sranite: Am. Tour. Sci., ad ser., rol. 41, pp. 267-272, figs. 1-4, 1891 ; Economic geology of the United States, p. 124, 1895 . Whittle, C. L., Rifting and grain in granite: Eng. and M1n. Jour., vol. 70, p. 161, figs. 1, 2, 1900. 
These minute faults are lined with microscopic fragments of the rimeral they traverse and some of them send off short, minute diagonal fractures on either side. I fter comparing this deseription with that given by the writer on page is of certain micrescopic fractures in the granite at its contart with a basic dike in the Flat Leslge quarry at Rockport, and also with the writer"s descriptions of rift and grain cracks it may he questioned whether the microscopic fanlts described by Tarr were not produced by a dike and therefore can not be rift.

Whittle gives two sketches made from polished surfaces of a wellknown granite quarried by the Maine \& New Hampshire Granite Co., at Redstone. N. H. One of these sketehes, marle from a surface running at right angles to the rift. shows quartz and feldspar grains traversed by a generally parallel set of lines corresponding to the rift planes. The lines are more numerous in the feldspar than in the quartz grains. The other sketch, male from another specimen. shows besides the rift lines another less pronounced set intersecting these at right angles. This second set corresponds to the grain. I visit made by the writer in 1906 to the quarry at Redstone. X. H.. corroborated Whittle's observations.

RELATION OF RIFT AXD GRALN TO FLUIDAL CAVITIES.

General examples.-During the writer's visit to Redstone a specimen of the pink granite was obtained, with a face $t_{4}^{3}$ by 4 inches cut and polished parallel to the "hard way"-that is, at right angles to both rift and grain: also a specimen of the green granite from the adjoining western quarry. 5 by 4 inches, cut and polished in the same way. Material for a thin section of the pink granite was also obtained, and a section $1 \frac{1}{2}$ by 1 inch in area was cut at right angles to both rift and grain. The direction of the rift at the quarries was found to be horizontal, crossing the shects, which curve in anticlinal attitude across the axis of the hill with a dip of $15^{\circ}$ both to the east and the west, while the grain is vertical with an east-west course and corresponds with the most prominent set of joints.

A careful examination of these specimens shows rift cracks in both the feldspar and quartz of the pink granite, though they are more conspicuous in the quartz, partly because of the darkness of its shade. Grain cracks are less abundant. The green granite shows both rift and grain cracks, if anything more abundant. though not as easily seen as in the yuartz of the pink granite.

The large thin section shows 12 prominent rift eracks in the quartz areas in a space of 1.2 inches measured along the grain-that is, with an arerage distance apart of 0.1 inch. The grain cracks are far less numeroms and less continuous. Some of the rift and grain cracks are filled with secondlary $105709-23-3$ 
filnous miar. The gnaltz areals alko show two intersecting sets of lines, really sheets of planes of gis or lirquid inchusions, the latter with vacuoles. Many of these cavities are very integular in ontline. some having sereral ramifications. They all range in diameter irom less than 0.002s5 to 0.063 millimeter. The strike of these two sets of sherts corresponis respectively to that of the rift and grain. Sume of the rift al srain araks apreat to have followed the sheets of cavities, for they coine ind with them. Iortions of this section are slown in figure 1.

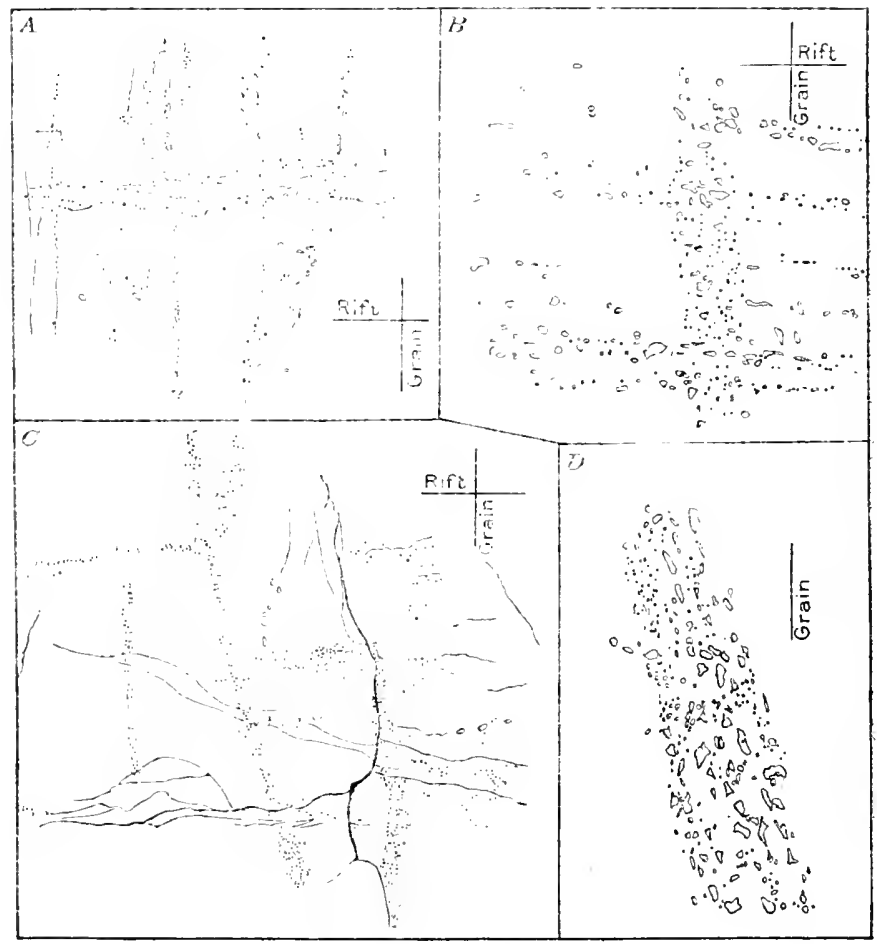

Figcre 1.-Camera lucida drawings of quartz areas in an enlarged thin section of biotite granite fiom the Redstone quary in Conway, N. H., cut prallel to the "hard way." $A$, enlarged 62.2 diameters. shows sheets of cavities and incipient cracks in both rift and grain directions. $B$, from a different quartz area, enlarged 175 diameters, shows the variation in the size of the cavities and their arrangements in both rift and grain directions. $C$, from still another quartz area, enlarged $23 \frac{1}{2}$ diameters, shows conspicuous rift and grain cracks, filled with fibrous white mica, coinciding here and there with the sheets of cavities, also two parallel exceptional fractures crossing the rift and grain directions diagonally. $D$ shows part of one of the grain sheets of cavities of $C$, enlarged 175 diameter's in order to show the sbapes of the cavities. As most of these sheets of cavities in the section appear to undulate in the direction of the line of vision when placed under the microscope the outlines of all the carities become visible only by altering the focus.

Emerson ${ }^{45}$ in describing the granite of Becket, Mass., uses these words: "The quartz grains were full of sheets of cavities, with large moving bubbles." Washington refers to streaks of inclusions in the

${ }^{45}$ Emerson, B. K., The geology of eastern Berkshire County, Mass. : U. S. Geol. Survey Eull. 159 , p. $73,1899$. 
greeni-h granite of Bay View. on Cape Ann: "Gas and liquici inchusions. the latter carring a movable hubble, are quite abmont though smatl and occul in streaks." ${ }^{*}$ "Tho morements of the vacuoles in these fluidal cavities are probably related to the Brownian morement discovered by Jean Perrin. If so, they represent the molecular motion either of the "matter" within the varmole or of the linuid without it. "Tarr and Newman ${ }^{48}$ report from their study of Missouri granites: "The study with the binocular microscope showed that the inclusions were really in planes."

At the Redstone quarry of Westerly, R. I., the quartz has "arities in sheets with rift cracks parallel to them. Sheets of carities intersecting one another at right angles and with rift and grain cracks parallel to them were also obserred in granite sections from the quarry at Becket, Mass. (p. 279) : and in several other Massildmsetts and New Hampshire granites the cavities are arranged in rectangnlar sheets. This has also been found to be true in many sections of Vermont granites. One of these from Cobble Hill, near Barre, shows quartz containing sheets of cavities with conspicuous rift cracks parallel to or coinciding with them. Some of the rift eracks polarize brightly and extend into the feldspars, where they are clearly filled with fibrous muscovite; but in other sections, cut without reference to rift or grain directions, the sheets of cavities intersect at all angles or the eavities have no apparent arrangement. Many such irregularities thus result simply from the haphazard direction of the section. For this reason probably Rosenbusch refers to their occurrence in apparently irregular groups or courses only.

In the thin section of granite from Redstone, N. H., described on page 17 some of the sheets of carities pass uninterruptedly and without deflection from one quartz particle to another, and the rest do not appear to terminate abruptly at the edge of the particle. The passage of sheets of cavities from particle to particle without interruption or deflection can be observed also in a section (109, specimen 36 . b) from the adjoining green granite of Redstone, also in one (150, specimen 38, a) from the White Mountain quarry, near North Conway, N. H. This is also the case in several sections of Quincy granite $(234$, specimen $79, \mathrm{f}$, from the Hardwick quarry, and 206 , specimen 85, a, from the Mount Pleasant quarry, Milton) and in some $(221,228$, specimen $91, \mathrm{f})$ from the quarry at Becket (Chester), Mass. There is also in all these sections a general parallelism in the sheets, which lie either in the rift or the grain direction or between

¿6 Washington. H. S.. The petlograplical province of Essex County, Mass., I : Jour. Gitology. rol. 6. p. 790, 1 s.98.

s: Perrin. Jean, The Brownian movement and molecular rality (translation by F. Soddy), London, 1910.

"Tarr, W. A., and Newman, L. MI., A sturly of the effects of heat on Missouri granites: Missouri Univ. Bull., vol. 15, No. 27, p. 55. 1914. 


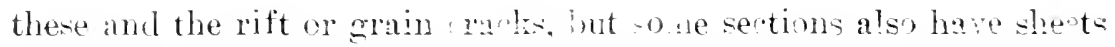
of carities diagonal to those directions. Fren sections cut parallel to rift or gram or at right angles oo both usually show carities, nore or less almndant, which are without any apparent arrangement.

These facts point to the probability of an intinate relation between the arangement of the inchusions and the rift and grain structure. If the carities, containing water or liquid carbonie acid, or aither of these in a gascous form, in the quartz of granite, are correctly re. garded as haring originated at the time of the crystallization of the material of the granite, then the rift and grain structure would seem to be either original also or, if secondary, to have had its directions generally determined by those of the sheets of inclusions.

That these fluidal cavities in the quartz of granite are not the only factor in the origin of rift ant grain structure is evident from the parallelism which exists between the arrangement of the mica scales and the rift of many granites. At the abandoned Hayden quarry in Milford, N. H., large porphyritic crystals of biotite have their charage parallel to the rift. The detection of this arrangement of the mica is the primcipal means of determining the course of the rift hefore actual experiment. Similarly the course of the " hard way" in a quarried block is ascertained by the greater roughness of the particles to the touch on the "hard way " side than on either of the others.

The observations of Riber and Oxaal in Norway on the relation of the arrangement of the feldpars in porphyritic granite to the rift fall in with the facts as to the arrangement of the mica (see p. 16), and so also does the statement of the Cornish granite quarryman ${ }^{* 9}$ as to the granite quarried at Colcerrow, in Cornwall, having its large feldspars ( 2 by 0.5 inch) with their long axes parallel to the rift and the short ones to the "hard way." The porphyritic feldspars in the granite of Woodbury, Vt., show a parallelism in their arrangement in the groundmass (p. 146).

That any alinement of the mica scales in the direction of the sheets of Huiclal cavities and the rift cracks is not necessarily identical with their arrangement or that of the feldspar by flow structure is shown by the following observations in New England granite quarries: At Mount Waldo, Frankfort, Maine, flow structure strikes N. $20^{\circ} \mathrm{W}$., rift is horizontal, and grain vertical with $\mathrm{N} .85^{\circ} \mathrm{W}$. course. At the Tayntor quarry, Hallowell. Maine, flow strikes N. $35^{\circ} \mathrm{WV}$., rift is horizontal, and grain is vertical with $\mathrm{N} .70^{\circ} \mathrm{W}$. course. At North Jay, Maine, flow is horizontal in undulations 20 feet wide and rift is horizontal without grain. At Dodlin Hill, Norridgewock, Maine, rift is horizontal, flow and grain are both vertical with $\mathrm{N}$. $60^{\mathrm{c}} \mathrm{E}$.

40 See U. S. Geol. Survery Bull. 484, p. 46, 1911. 
comse. The norite at the Irall quarry, near Baileyrille, Maine, has horizontal sheet, flow, and rift structure.

At Milford, N. H. (p. 343), flow varies greatly (N.. N. 15).21, ido. $70^{\circ} \mathrm{E}$. and $\mathrm{X} .75^{\circ}-80^{\circ} \mathrm{W}$.) , rift is horizontal or nearly so, and ganin is about rertical with $\mathrm{N} .60^{\circ}-90^{\circ} \mathrm{W}$. and $80^{\circ} \mathrm{E}$. comse. At the Kilondike quarry. in Charlestown near Bradford station. R. I. flow is $N$.

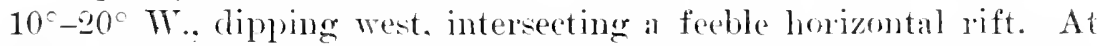
Milford. Mass. there is a wide range in both strike and dije of flow. but rift is everylere reported as horizontal and orain as relieal with $\mathrm{X} .40^{\circ}-90^{\circ} \mathrm{E}$. conlses. In places fiow and ritt ale parallel (p. 311).

Fluidal revities in gramite gme iss. The following observations were made in sturlying the Vew England granites: In angite diorite gneis- with a rertical foliation werlying an intrusive guarty nomzonite at Milforl. X. II. (see Pi. VIII. 1). has sherets of fluidal cavities intersceting each other at right angles. An inchusion of granite guejes in the quarty monzonite of Blue Mominain, in Fonth Ryegate. Yt.. has paralled heots of fluidal cavities parsing from one givartz arain to another at right angles to the foliation of the gneiss. A timely banded gneiss at Old Lyme. Comn. cont by dikes of comse leermatite. has its quartz laminac arossel by sheets of cavities. With rift cracks parallel to them and to the gneissic foliation. coossed at right angles by a sparser and finer set of cracks. Sheets of fluidal ravities and rift cracks parallel to or roinciding with them were observed in the mica diorite aneiss of Greenwich and Torrington. Comn. also in the granite gneiss of Norwalk. Ansonia. Roximry: Benrenue. Stony Creek. Hoadly Point. Leete Island, Sachem Head, Waterford. and Bolton. Comn. Rift in these Connecticut ancisses was always found parallel to the foliation. lunt in the gneiss of Felden Teck. in Iyme, which has hiotite lenses with their longer axes transrorec to the gneissic foliation, the rift is parallel to the lone axes of the lenses and at right angles to the foliation: also in the lander anej-s of the MeIntosh quarry. near froton. Mass, the rift is transverse to the foliation. loth rift and grain fractmes leing smonther than thase along the bandiug.

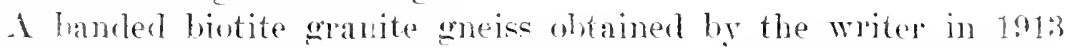
form a conspicuons hill in the sontheast corner of Peru, in Benningtom County. Tt., consists of bands of feldspar grains altermating with bands of strained quatz grains whose longel axes are alout at right angles to the hands. The feld-par bands carry liotite scales with their longer axes parallel to the bands. Sheets of fluidal ravities and rift cracks cross the quartz bands at right angles mafferted by the straining, but stop at the feldspar bands.

The question arises whether the sheets of fluidal carities coussing the gneisic foliation were formed before or during the alteration 
of the granite to gneiss. If the quartz individuals of the granite were greatly elongated the transverse sheets of cavities could not well have retained their original parallelism, and in such gneisses the arrangement of the cavities nay be ascribed to the period of metamorphism.

Fluidal cavitiss in small dikes or veins.-In a veinlet of quartz and feldspar at the Calder \& Carnie quarry at Westerly, R. I., the quartz particles are crowder with cavities in sheets parallel to the sille of the rein and also in line with streaks of kaolinization in the feldspars. I smoky quartz vein averaging 0.35 inch thick, of pegmatitic origin, in the A. Milne quarry at Barre, Vt., shows many roughly parallel diagonal fractures. In thin section it has a largely feldspathic border, 0.2 inch thick, which is partly micacized, and inside of it the quartz is in places granulated. Discontinuous sheets of cavities with racuoles extend both in the direction of the rein and at right angles to it, and some cracks with granular quartz zigzag along these directions. In places the carities are abundant but without apparent arrangement. A section of a little pegmatite dike cutting the schist that overlies the granite at the Bailey quarry in Barre, Vt. shows sheets of cavities and rift cracks transwerse to the dike and the foliation of the schist. Small pegmatite dikes proceeding from the granite surface into the overlying mica slate at the Anderson quary in the same town hip also show two transver-e sets of sleets of cavities, one parallel to the dike and another across it.

Are some fludal cavities secondary? - Van Hise ${ }^{50}$ points ont that in a certain quartzite of the Black liills rows of minute gas-filled or liquid-filled inclusions rumning in parallel lines across the entire section. transiere to the longer axes of tho ynartz grains, with rows of black forrite and secondary quartz similarly oriented, are of secondary origin. He regards them as probably due to the fracture of the grains by mechanical action and the introduction of liquid along the cracks, with the later deposition of secondary quartz. which has retained the liquid as inclusions.

Some vitreous Cambrian quartzite collected by the writer near Fort Ann, Washington County, N. Y., in 1899, shows in thin section enlargement of the original quartz grains by secondary interstitial quartz and also sheets of liquid inclusions intersecting one another at various angles within the quartz grains. As these sheets of cavities stop abruptly at the edge of the original quartz grains, and the courses of the sheets in different grains are not parallel but quite discordant with one another, it is evident that these liquid inclusions antedate the

so Van 1lise, C. li., l're-Cambrian of the Black Hills: Geol. Soc. America Bull., vol. 1, pp. :16-219, fir. 4, $1590 ;$ A treatise on metamorphism: U. S. Geol. Survey MIon. 47, p. $620,190-1$. 
metamorphisn which produced the quartzite. ${ }^{51}$ I thin section of a calcareous sandstone from the same vicinity shows similar sheets of cavities in its quartz grains, but their directions are such that they can have had no relation whatever to the bedding planes of the sandstone or to any secondary fractures in it. but their origin must date back to the granite or gneiss from which they came.

The inference to be lrawn from the quartzites of the Black Hills and Fort Inn is that lines or sheets of fluidal cavities within the quartz grains of a quartzite may be secondary or primary-that is, they may have originated in the process of the formation of the quartzite or they may have been associated with that of the parent granite or gneiss itself. The thin sections themselves will indicate in most cases the mode of origin.

C. W. Cross ${ }^{52}$ in 1881 described a gneissoid plagioclase-pyroxene rock from Roquedas, near Vannes, in Brittany, which bears on the origin of fluidal carities. A summary follows:

The onterop is between tirle levels, and its feldspars are therefore much weathered, the orthoclase passing into muscovite and the plagioclase into wollastonite. The weathered feldspar shows rows of fluidal carities with racuoles, and some of the carities have negative crystal bonndaries. These rows of cavities, however. form the continuation of acicular crystals of wollastonite, which occur at the begimning of the zone of weathering and radiate into the fresh feldspar. Delicate lines corresponding to the sides of the crystal and extending beyond them into the feldspar commect the rows of carities. These rows disappear in the more altered parts of the feldspar. The fluidal cavities are regarled as clearly secondary and as precursors of the wollastonite. Where the feldspars are much altered similar rows of fuidal cavities berin to extend into the pyroxene from the wollastonite crystals. The same rock has streaks crossing differently oriented quartz partieles. One such streak crosses 14 particles of quartz, 5 of plagioclise, 5 of titanite, and 4 of pyroxene-that is, 28 different crystal indiviluals. In a titanite the streak is represented only by a crack, but as it reaches the quartz or the plagioclase it contains fluidal cavities.

These rows of fluidal cavities associated with the marine weathering of a gneiss and the alteration of its plagioclase into wollastonite are of very different origin from the fluidal cavities common in quartz crystals. They also differ from the sheets of cavities in the fresh parts of granite, which do not extend into the feldspars. Only one of the many sections of New England granites examined by the writer showed cavities bounded by crystal faces. That one was a section of the hornblende-augite granite of Mount Ascutney, in Vermont (p. 162.)

52 see also Merrill, G. P., Fluidal cavities in quartz grains of sandstones: Scipnce, vol. 1, p. 221, 1S83. He calls attention to the same saurlstone or quarizite nenr Fort Ann, and to the rapid movement of the racuoles within the fluidal carities.

${ }^{52}$ Cross, C. W.. Studien iiber bretonische Gesteine: Mín. pet. Mitt., $Y$. F., rol. 3 , pp. $373-376$, pl. 7 , figs. 1, 2, $18 s 1$. 
E. S. Bastin, ${ }^{53}$ in studying the pegmatites of Maine, found that some of the sheets of fluidal carities in the quartz of pegmatite pass without deflection from an area of unstrained quartz into a strained and a recrystallized zone of it, as clearly shown in his photomicrograph. The writel finds in his granite sections one from the Marr \& Corclon quarry in Barre. I't., in which sheets of fluidal cavities cross strained quartz without deflection, as they do also in the granite gneiss from Peru, It., described on page 21. But such examples do not prove that the carities were formed or arranged after the straining. for changes in the orientation of the guartz molecules and even their recrystallization in place would not necessarily alter the courses of the sheets of cavities. nor is the passage of sheets of carities without deflection from one crystal of quartz to another evidence that the cavities were formed or arrunged after the crystallization of the cuartz. The arrangement of the earities and the crrstallization of the quartz, the first governed by crustal strains and the second by crystalline cohesion. may have been synchronous processes.

No such rows of fluidal cavities as Rosenbusch ${ }^{54}$ describes as connected by fine cylindrical canals and as occurring especially in granites containing quartz with crush borders have been detected in the New England granites studied by the writer. Rosenbusch regards these as possibly of secondary origin or else caused by crustal compression.

SLMMART ON RIFT AND GRAIN.

1. Rift and grain structure consists of minute cracks from 0.09 to 1.3 millimeters apart crossing the quartz particles and extending into the feldspars. These cracks produce a rough fissility in two rectangular directions, that of the rift being more pronounced.

2. One of these sets of fractures is always horizontal, or nearly so, and the other is rertical, or nearly so.

3. Proth sets are independent of flow structure.

4. Both sets are independent of sheet structure, intersecting granite domes, except where one of them chances to coincide with the sheets in part of their course.

5 . Rift is usually parallel to the mica plates and in many porphyritic granites to the longer axes of the phenocrysts (isolated large feldspars).

6. Rift and grain are not pronomeed in all granites. Either or both may be rery feeble or both may be absent.

53 Origin of the pegmatites of Maine: Jour. Geology, vol. 18, p. 308, 1910; Geology of the pegmatites and associated rocks of Siaine, in luding feldspar, quartz, mica, and gem deposits: U. S. Geol. Survey Bull. 445, pp. 19-21, pl. 6, fig. 4, 1911.

Mikroskopische Physiographie, 4th ed., vol. 2, pp. 41, 42, 1907. 
7. Rift and grain fractures are abont parallel to or coincide with sheets of fluidal cavities in the quartz particles. In some places the fracture extends from the end of the sheet into the quartz omly: in others it continues into the fehlspars. These eavities measure from less than 0.0025 to 0.03 millimeter in cliameter. The sheets cross one another at right angles. but those in the grain direction are less abundant.

8. These sheets of fluidal eavities with vacuoles pass without interuption or deflection from one crystal particle of quarty to the adjacent one or from an area of unstrained quartz into an area of strained and recrystallized quartz.

9. Some sheets of cavities are diagonal to rift and grain directions, and some cavities appear to be without arrangement.

10. The sheets of cavities in granitic quartz stop abruptly at its contact with the guartz of any inclusion or rock intruded by the granite. Thus at an inclusion of schist on Blue Mountain, in Ryegate, Vt., also at the schist mass in the Marr \& Gordon quarry in Barre, Vt., where. although the two rocks are firmly welded together and the quartz of the schist has sheets of cavities. those of the quartz of the granite stop at the quartz of the schist.

11. Rift and sheets of fluidal cavities occur also in granite gneiss, usually parallel to its foliation but in places at right angles to it.

12. Small quartz veins, presumably of pegmatitic origin, and small granitic and pegmatitic dikes cutting granite or schist also have sheets of carities and rift cracks. Some of these are parallel to the sides of the dike, and some dikes have a second set at right angles to the first.

13. Secondary minerals (sericite. riebeckite, himonite) form within the rift or grain cracks.

14. Rift and grain are affected ly temperature. Firanite splits. more rearlily along the rift in winter.

15. Rift appears to be slightly deflected by gravity. A detached block of granite plits at one angle from the top but at another from the side.

16. Rift is also affected ly present compressive crustal strain, an undetached block having a horizontal rift when split from one point of the compass but acquiring a slightly inclined rift when split from a point of the compass removed $90^{\circ}$ or $180^{\circ}$ from the first point. (Data obtained from experienced granite workmen at Concord, N. H., and Quincy, Mass.)

The facts arduced support the following interpretation of the orter of events in the formation of rift and grain structure:

(a) During the consoliclation of granite, when the quart\%, the last constitnent to consolidate, was crystallizing, the fluidal carities were formed and. in obedience to crustal strain, were largely alined, some 
in approximately horizontal sheets and others in vertical sheets. Under the same strain the mica plates in most granites and the large feldspars in many porphyritic granites became alined with their long axes in the rift direction. ${ }^{55}$

(b) After complete consolidation, as crustal strain continued, rift and grain cracks ensued, following more or less continuously the planes of diminished cohesion afforded by the sheets of carities; and these fractures were extended from the quartz into the feldspars.

(c) Under later metamorphism and deep-seated weathering secondary minerals were deposited in the rift and grain cracks. and kaolinization took place along the feldspar fissures.

(d) Wherever a granite with fluidal cavities passed under metamorphism into a gneiss and the quartz was simply recrystallized in place, the sheets of cavities persisted, but where under more intense metamorphism the minerals were rearranged as well as recrystallized the fluidal cavities in the quartz under the new compression became realined, some of the sheets of cavities and the later ensuing cracks being parallel to the gneiss foliation and others running across it.

Rift and grain structure has been the chief economic factor in granite quarrying from the time of the ancient Egyptian quarrymen to the present. Although the rift cracks do not greatly weaken the stone they diminish its compressive strength. The average difference (loss) of compressive strength shown by two tests made by the Tnired States Ordnance Department on granite from Mount Waldo, Maine, and Concord, N. H., one with the pressure applied at right angles to the rift and the other in the same direction as the rift, was 11.8 per cent.

\section{SHEET STRUCTURE.}

The division of granite into "sheets" or "beils" by jointlike fractures whish are variously curvel or nearly horizontal, being generally parallel with the granite surface, attracted the attention of geologists long ayo. In $179-$ De Dolomien and shorty beiore that De Saussure ${ }^{56}$ describer granite sheet structure.

In 180:3 Pötsch ${ }^{57}$ published a paper on the subject. In 18+! Edward Hitchcocks ${ }^{58}$ described what he termed the "psendostratification of granite," near Worcester and Fitchburg, Mass., as a con. centric, onionlike structure generally conforming to the rock surface.

5s The orientation by crustal compression of mica scaies, feldspar crystals, and fluidal cavities in glanite during its consolidation is somewhat anilogous to the process in one of the early experiments made to illustrate slaty cleavige, where unaranged metallic scales in a mass of plastic clay became oriented with reference to the pressure brought to bear upon the mass.

${ }^{56}$ Jour. des nines, vol. 7 , No. 43 , p. 426,1797

st Bemerkungen und Leobachtungen ïber das Yorkommen des franits in geschicbtete lagen, p. 140, 1803 .

be linal report on the seology of Massachusetts. p. 693, 1841. 
In 1860 C. F. Xamuann ${ }^{59}$ dealt with the subject.

In $1863 \mathrm{~F}$. ron Adrian ${ }^{60}$ described the structure in Bohemia and regarded it as the result of rooling.

In 1859 Reyer ${ }^{61}$ described it as formd in another part of Bo. hemia; and in 1894 Zirkel $^{62}$ also treated the subject.

Although this is the most striking feature in every granite quarry and next to the rift and grain is of the greatest importance to the granite industry, there is much diversity of opinion as to its cause. Whitney ${ }^{63}$ writes:

The curves are arranged strictly with reference to the surface of the masses of rock, showing clearly that they must have been produced by the contraction of the material while cooling or solidifying and also giving very strongly the impresson that in many liaces we see something of the original shape of the surface as it was when the granitic mass assumed its present position.

Shaler, a few years later, ${ }^{64}$ attributed the sheet structure to expansion due to solar heat.

C. H. Hitchcock ${ }^{65}$ notices in New Hampshire granite " numerous joints, the planes of which correspond very nearly with the slope of the hill," but does not undertake to explain them.

Vogt ${ }^{66}$ states that the sheets in granites of southeastern Norway meastire from 6 inches to 6 feet in thickness and dip from $8^{\circ}$ to $33^{\prime \prime}$ on the sides of the monntains, toward the valleys, but that they are horizontal on top and approximately parallel to the surface. He shows that they are of preglarial wrigin, attributes them to the same (arse that is postulated by Whitney for those in California, and regards them as parallel to the original surface of the granite masses.

Harris ${ }^{67}$ referring to the English granite quarries, writes: "In every quary we risited we found that the direction of the 'beds' approximately corresponded with the outline of the hill on which it was situated." He offers no explanation of the phenomenon, however.

J. J. Crawford ${ }^{68}$ describes the sheet structure at granite quarries in Madera and Tulare conties, Calif., as consisting of "concentric

so lelirbuch dri Geognosie, 2d ed., vol. 2, p. 191. Luipzig, 1sfon.

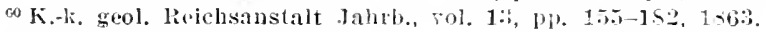

в: Irlem, vol. 2!), p. 405, 1879.

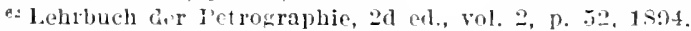

as Wlitney, .J. 1), (ieolosy of lalifornia, vol. 1, reology, p. :37: also pp. 227, 417 figs. $49-54,1.865$.

shaler, N. S., Not:s on the concentric structure of granitic rocks: Boston Soc. Nat. llist. l'roc., vol. 12, pl). $289-292,1869$.

of (ivology of New IIampshire, vol. 2, pl). 511-512, plate opposite p. 15s, showing shent structure at the "Flume," 1877.

Wost. J. H. L., Sheets of eranite and syenite in thejr rolation to the present surface: Geol. Fïzen. Fïrlı. No. 56, vol. 4, No. 1t, 1879; also Nosie, Pemacrkningur on Granj : Christiania Videnskabsselsk. Wörh., No. 9, 1S.S1.

orllaris, r. F., Granites and our granite industries, fondon, $19 S$.

California Stale Minelalouist Twelfth Rept., pp. 3S1-3ST, 3 IMlates, 1994. 
layers conforming in a general way to the contour of the hills," but suggests no cause for them.

Herrmamn.: who made a special economic study of the granites of Saxouy, wites:

Cpon closer inslection it appear's that the granite sheets are elougated

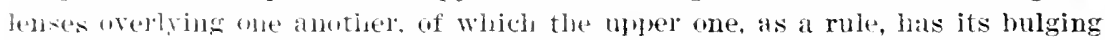
frat lying in the denression formen by the two underlying lenses where they ronte togenthe's.

Bramner describes the exfoliation of the granitoid gneisees in Brazil. which he attributes only in part to changes of temperature. He calls attention to the fart that the linear expansion of a mass of gneiss 300 feet long at a repth of 1 in feet from the surface under a surfice temperature of $108 \mathrm{~F}$. wonld amount to only 0.072 inch; and he quotes the results of Forbes, Quetelet, and others to show that the amnual change of temperature can penetrate rock only to a depth of $t(1)$ feet in temperate regions and still less in the Tropies.

Menill "is describes tone Wountain, in (reorgia as a boss of granite 2 miles long hy $1 \frac{1}{2}$ miles wirle and 650 feet high, which owes its form wholly to exfoliation parallel to prexisting lines of weakness. The mass anpear's to be marle up of imbricated sheets of granite which he regurds as the result of torsional strains. The bosslike form is incidental and consequent. Intermittent expansion and contraction from changes of temperature have so affected the sheets that bound the mass at the sides that they have found relief in expansion in an upward direction. These ruptured sheets are rarely more than 10 inches thick. lut are 10 or 20 feet in diameter. ${ }^{2}$

Herrmann is sums up his conclusions on the subject substantially as follows: The so-called sheets are thin near the rock surface, generaliy only a few centineters thick. but hecome wradually thicker with increasing depth. This downward increase in the thickness of the sheets is generally more rapid where the terture of the stone is coarser. The course of the sheets is not. as Voct claims. parallel to the ond ginal surface of the consolidating rock. It is not gorerned by internal strains. The attitude of the sheets corresponds to the form of the present rock smiface. The sheet structure is to be looked upon as the effect of the beginning and progress of weathering from the sur-

69 Ifermaun, O., 'lechuische Verwerthung der Lausitzer Granite: Zoitschr. prakt. Geologir. $189 . \div$, ก. 435 .

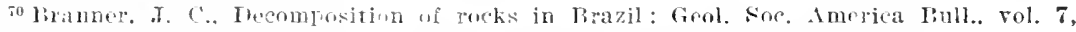

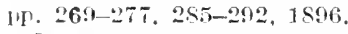

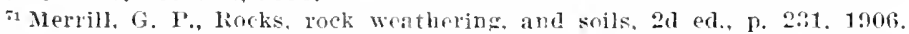

¿2 lor description and representations of slone Monntain sce Merill, G. F., op. cit., pl. 1; l'mington, C. W.. Geological and topographical features of the region about Atlanta. Ga.: Am. Geologist, vol. 14, pp. 105-10S, pl. 4, 1s.4: also Watson, T. L., Georgia Geol. Survey Bull. 9-A, p. 11:, pls. 1-S. 1902. See also description of anotler granite dome-Ston Nountain, in North Caro!ina-by Watson and Laney, in North Carolina Geol. Surrey Bull. No. 2, p1. 25. 1906.

73 Ilerrmann, O., Steinbruchindustrie und Steinbruchgeologie, pp. 109-111, 1899. 
face inwark. These weathering aracks are determined ly the form of the rock surface instear of that being determined by them.

Turnerit ealls attention to the sheet structure and exfoliation of Fairview dome, in the Yosemite.

Gilbert ${ }^{75}$ shows that sheet structure oceurs in synclinal as well as in anticlinal attitude-in other words, is parallel to hollows as well as to hills-which he considers unfaromable to the theory that it is an original structure. He suggests that sheet structure may posibly be due to expansive stress consequent upon ralief from compressire stress brotight about ly the remoral of the mass into which the granite was intruded. Subordinately he notes that in the sierra. at least, the dome structure and the parallel joint strueture to not occur in the same place and that the former has resisted genera! erosion more snccessfully than the latter.

G. F. Becker, in a conversation with the writer, stated that he had found the aranites and gneisses at the bottom of the Colorado Canyon both vertically and horizontally jointed. If these are trum granites and are still in contart with the rocks into which they were intruded and show genuine sheet structure the phenomenon would conclusively prove that such structure may occur indepent. ently of solar heat and load.

S. F. Emmons similarly stated that in the Mosquito (Park) Rangre, in Colorado, the pre-Cambrian granite and schist are ent by horizontal joints to a lepth of 50 feet below their contact with the overlying Cambrian, and that the joints diminish in number downward. The original load upon the granite here consisted of at least 10.000 feet of Paleozoic rocks and between 5,000 and 6,000 feet of Cretaceous rocks. As the granite, howerer, was not intruded into Cambrian sediments it must have been exposed to atmospheric erosion hefore they were deposited. These horizontal joints may therefore have been related to solar temperature.

G. K. Gilbert studied the granite domes of freorgia and attributed their sheet structure to compressive strains. He found that the irranite in these domes ${ }^{i s}$ is not naturally divided into p'ates, but that the outer parts of the granite-the parts nearest the surfaceare in a condition of compressive strain, which results in slow exfoliation and which enables quarrymen. by means of carefully regulated blasts. to develop joints that run approximately parallel to the surface. so that the granite is detacherl in sheets. Is these

\footnotetext{
74 Turner, H. W. The Pleistocene geology of the soutl-eentral sierra Bovala, with especial reference to the origin of the Yosemite Valley: California Acall. Sei. I'roc., 3A ser., Geology, vol. 1. No. 9, Formation of doms, pp. 312-314, pl. $87,1900$.

is Gilbert, G. K., Domes and dome structure of the high Sierras: Giol. Sor. Ameriea liull., vol. 15, pp. 29-36, pl. $8,1904$.

${ }^{76}$ I.etters to writer dated May 4 and June 11,1906
} 
sheets are dirided into blocks in the process of guarrying. the blocks expand horizontally as they are released from the general mass. In these granitic domes parting planes also dere'op naturally within a few inches of the surface. and the expansive force is there so great as to inchuce compicuous buckling in the thin sheets thus formed. This buckling is illustrated in Plate XY, A, from a photograph taken by Gilbert. The jar of blasting precipitates this sheeting action, so that several of the domes at which quarrying is in progress show long lines of fresh'y formed disrupted arches. Gilbert found that the horizontal elongation, or rather the elongation approximately coincident with the contour of the dome surface, amounted, by one measurement, to 0.55 inch in a length of 40 feet.

The effects of compressive strain on granite were observed by the writer in 1907 at a qualy at the west foot of Black Mountain, a domelike mass in West Dimmerston, near Brattleboro, Tt, and are illustrated in Piate TI, A. Few thin sheets have thus been formed and one of the sheet fractures opened $3 \frac{1}{2}$ inches.

The owner of a large granite quarry in Westford, Mass. (p. 310) finds that the sheets are under a compressive strain which relieves itself by an expansion amounting to an inch in 100 feet, or 0.0083 .

The artificial production of sheets in granite, as practiced at Bangalore, in southern India, shows similar phenomena. It is described by H. Warth it in substance as follows: At the surface there is a horizontal sheet of rather weathered rock 4 feet thick; below this lies a sheet of fresh rock 3 feet thick, but below this lies fresh rock without split. These sheets "are probably due to the variations of temperature, daily and seasonal." By means of wood fires plates 60 by 40 feet by 6 inches in thicliness are detached in one piece. A line of fire $\tau$ feet long is gradually elongated and moved orer the granite. The effect of the fire is tested by hammering the granite in front of it. and then the fire is moved forward. The maximum length of the are of fire is 25 feet. The burning lasts eight hours: the line of fire is advanced 6 feet an hour. The area passed orer by the line of fire is 460 square feet. The amount of wood used is 15 hundredweight. The average thickness of stone is 5 inches, and its specific gravity is 2.62 . These data show that 1 pound of wood suffices to quarry 30 pounds of stone. Some plates are taken out in inclined position. The action of fire is independent of the original surface of rock, also of the direction of lamination (the granite is gneissose) and of veins. The uniformity in the thickness of the sheets is attributed to the regulating influence of preexisting cracks.

77 The quarrying of granite in India: Nature, rol. 51, p. 272, 1895. 
Van Mise ${ }^{-5}$ is inclinerl to attrihnte shect structure to solar temperature.

Oxal "9 comnects sheet and rift structure. "In the con ing of the granite mass a strain or tension is canser which is relieved natmally in the formation of cracks in the line of least resistance, nanely. parallel with the rift.

Before these theories are discuscol sheet structures as exposed at a few of the lareer quarries in Maine will be alescriberl.

Dome forin and sineet structure are most finely exhibiterl at Crotch Island, near Stomington, and at Mosquito Mountain, nar Frankfort. Plate $\mathrm{X}, B$, sinows the structure in the southern half of Crotch Island. at 'Thurlow Mearl. The dome is oblate, measuring about 1,500 feet from north to south and 110 feet in lieight.

Plate XI. A, from a photograph of the Ryan-Parker quary, at the southern edge of the clome, shows that the sheets rapilly increase in thickness downward-from 1 to 2.; feet in a depth of 75 fect-and that they dip $20^{\circ}-2.5^{\circ} \mathrm{S}$. At the next qualy north, the Goss quary (see p. 226), the excaration has exposed the center of the lome mass. Here the sheets dip both north and sonth, measure from 1 to 30 feet in thickness, and extend to a depth of fully 140 feet from the surface. At both of these quarries the rift is rertical and thus intersects the bome sheet struture.

Mosquito Momntain, 2 miles south of Frankfort, in Waldo County, Is an oval granite dome its feet high, with a north-south axis about 1 mile long and measuring alout half a mile across. It has a steep east face, the sheet structure of which is shown in Plate XI, $B$. On the top of this mountain. Where the quarry is situated. the sleets bip gently north, west, and east, tapering ont on the sides, and are 6 to 1.5 feet thick. The dome sheet structure is intersected by horizontal rift and vertical grain.

At the Mount Waldo quary, $1 \frac{1}{4}$ miles north-northrest of the top of Mosquito Mountain, the sheets dip $10^{\circ}$ and are 8 inches to 8 feet thick, and the excavation averages about 20 feet in depth, about 300 feet from north to south, and 400 feet from east to west. 'The granite here is evidently under compressive strain, for the progress of quarrying resulted in a rertical fissure, rumning north-northrest by south-southeast for the entire width of the quar'y and across the rift, which is horizontal. The formation of the fissure was accompanied by a clull explosive noise. At several other quarries in the State foremen report a partial closing of vertical drill holes by expansion or compressive strain of the rock. (See pp. 236, 251.)

\footnotetext{
is Van Hise, C. R., A treatise on metamorphism: U. S. Geol. Survey Mon. 47, pp. 434-439, 1904.

Oxaal, John, Norsk Granit: Norges geol. Undersükelse No. 76, p. $211,1916$.
} 
It the White quary, in Phohill, tho ganite horaks with explosive sound when split in large sheets along a vertical rift that extends N. $50^{\circ} \mathrm{W}$. The grarlual increase in the thickness of sheets downward is well shown at the Stinchfield quarry. near Hallowell (Pl. XII, B). Their evenness and curvature aro shown at the sands quarry, at Vinalharen (Pl. XIV, A). It the Hurricane Island quarry (P1. XII, A) the excavation is 105 feet deep. The upper sheets measure from 3 to 20 feet in thickness, lut the lowest sheet is fully 60 feet thick. I good cross-section of granite sheets is seen at the Crabtree \& Havey quarry, in Sullivan. shown in Plate XIII. B, which brings ont their lenticular form and arrangement. The tapering end of one lens lies letween the thickest parts of two others. This accounts for the apparent irremlarity in the thickness of the sheets in some longitudinal sections, notwithstanding their progressive thickening downward. (Compare Pl. XIII. A, taken at the same quarry, with $\mathrm{Pl}$. XIII, B.)

theet structure as exposed in the other New England quarries is described on pages 297 and 320 aml is illustrated in Plates XXV, A, and XXVII, 1; its relation to overlying rocks is shown in Plates 1111. A, XVII, 1, and XXXIV, 1, and figures 14, 15, 17, 18, 93.

The observations as to sheet structure made at over 100 of these quarries are here summarized:

1. There is a general paralleliom between the sheets and the rock surface, resulting in a wavelike joint structure and surface over large areas.

2. The sheets increase in thickness nore or less gradually downward.

3. The sheets are generally lenses, though in some places their form is obscure. Their thick and thin parts alternate rertically with one another. The joints that separate these superposer lenses therefore undulate in such a way that only every other set is parallel.

4. On Crotch Island, Maine, the sheet structure extends to a depth of at least 140 feet from the surface, and at (anincy, Mass., to 250 feet.

5. Sheet structure, with rare exceptions, intersects the rift.

6. There are indications here and there that the granite is under compressive strain, which tends to form vertical fissures or to expand the sheets horizontally so as to fill up small artifical openings or to extend the sheet partings horizontally. (See pl). 15., 198, 236, 251.)

The observations made in Europe and in this eountry, taken in connect on with the inferences geologists have drawn from them, indicate that sheet or "onion" structure in granite rocks is due to the following possible causes:

1. To expansion caused by solar heat after the exposure of the granite by erosion. 
2. 'To contraction in the cooling of the granite while it was still under its load of beds, the sheets being therefore approximately parallel to the original contact surface of the intrusive.

3. To tensional strain in the cooling of the granite finding relief in the direction of the rift.

4. To expansive stress or tensile train brought about by the diminution of the compressive stress in consequence of the removal of the overlying material.

5. To concentric weathering due to original texture or mineral composition. This action would be chiefly chemical and would be aided by vertical joints and by any superficial cracks due to expansion and contraction under changes of tenperature.

6. To compressive strain akin to that which has operated in the folding of sedimentary beds.

7. To the cause named under 1 at the surface, but to the cause named under 6 lower down.

These propositions will be considered in the order given :

1. Solar heat may produce a certain amount of exfoliation in thin sheets at the surface, as is proved experimentally in the fire method of granite quarrying in India (p. 30 ), but as it penetrates only to a depth of 40 feet and as sheet structure is known to occur on Crotch Island, Maine, at a depth of 140 feet and at Quincy, Mass., at a depth of 175 feet. it is quite inadequate to account for sheets that are 20 to 30 feet thick and 100 to 175 feet below the surface. In Quincy at a depth of 175 feet the next sheet is over 50 feet thick.

2. In view of the load under which granite was probably formed ${ }^{80}$ and the gradual rate at which. therefore, it probably cooled, which is also indicated by the generil coarseness of its texture, it is improbable that the temperature at its contact surface and the temperature at depths 100 or 200 feet helow could have so greatly differed as to bring about such a system of joints by contraction.

3. As the sheets in very many New England granite quarries and notably in the domes of Crotch Island and Mosquito Momtain, Maine, cross the rift the explanation that postulates relief from tensional strain in the direction of the rift will not answer. Wher-

\footnotetext{
S See p. 4. Sorby thought that this load could be estinated by calculating the contraction of the liquid in the carities of tise qualtz. Sorbs. H, C., On the microseopic structure of crystals, indicating the origin of minerals and rocks. Geol. Soc. Tonrlon Quart. Jour., vol. 14, pp. 453 et seq., 185. W. Ward, J. C., On the granitic. granitoid, and associated metamorphic locks of the Lake district. Idem, vol, 31, pp. 568-602, 1875. Rosenbusch claims that the great rariation in the relative dimensions (amount) of the liquid and the vacuoles in the cavitis of granitic utartz shows conclusively that the vacuole was not due to the contraction of the liufuid. Mikroskopische Physiorraphie der Mineralien und Gesteine, 4 th fd., vol. 2, pp. 41, 42. For further discussion of this ques tion see Chamberlin, R. T., op. cit., pp. 64-66. For drawings of these cavities and vacuoles see Judd, J. W., Volcanoes, figs. 8, 9, 1Ss1; also Bastin, E. S., U. S. Geol. Survey Bull. 445, fig. 4, 1911.
} 
ever the sheets are parallel to the rift it is a coincidence, not an effect. Sheets also occur in granite gneiss (see figs. 14, 15, 17, and Pls. VIII, A, XXXIV , A) and in places intersect its rift. The same sheets even traverse a granite and the overlying granite gneiss intruded by it. (See Pl. XXXIV, A, and fig. 17.) At the lower Sherwood quarry, on Crotch Island, Maine, sheet structure crosses the contact of a coarse and a rery fine granite-that is, the direction of the flow structure-at $90^{\circ}$ (see fig. 51) and a rertical rift at $75^{\circ}$. Its origin was therefore subsequent to consolidation and to rift and imrelated to flow and rift.

4. As (iilbert states, in suggesting the theory of fracture by relief of tensile strain through the erosion of overlying masses, we have no distinct knowledge of it. It is a possible explanation.

5. Careful inspection of the rock on both sides of the sheet joints fails to show any difference in texture or mineral composition. The shect structure trarerses both rift and flow structure, and it would be possible to procure specimens showing a sheet joint traversing a single crystal of feldspar. Whatever chemical action has taken place along the sheet joints is of secondary character. Acid waters may hin re gained access to the joint but have not caused it. (See matter under heading "Finsty stain ("say')," p. 66.)

6. The condition of strain described by Merrill and Gilbert as existing in the granite domes of Georgia and by Niles and Emerson in the gneiss at Monson. Mass.. ${ }^{s}$ and by the writer at West Dummerston. Vt. (p. 153 and Pl. VI. 1), and occuring to a lesser extent in some Maine quarries (p. 236), shows that granite and gneiss are in places still under compressive strain. Another instance occurs at the quarry of the New England Granite IVorks, at Concord, N.H. (p. 198). The foreman at this quarry was in the habit of calling certain sheets marked by the absence of rusty stain "strain sheets," to distinguish them from the others. At one place a northwest-southeast compressive strain had actually extended the strain sheet about 5 feet and also caused a vertical fracture that extended over 15 feet diagonally from the north-south worling face to a point on a vertical east-west channel 5 feet back of the face, closing up the channel to half its original width. Evidences of compressive strain were also noted at Quincy (p. 320) and Rockport. Mass. (p. 294), and at Westerly, R. I. (p. 406), and have been observed by the writer in some of the quatries at Barre and Woodbury, Vt. (pp. 12s, 147). The practicalility of developing sheet structure by the use of explosives and compressed air, as is done in some of the North Carolina granite

Ex Niles, W. II., Some interesting phenomeva observed in quarrying: Boston Soc. Nat. Hist. Proc., vol. 14, pp. 80-87, 1872, vol. 16, pp. 41-43, 1874. Emerson, B. K., Geology of Old Hampshire County, Mass.: U. S. (ieol. Survey Mon. 39, pp. 63-65, 1898. 
quarries. show that the rock is nnier a compressive strain there. ${ }^{82}$ Recent effects of compressive strain have been noticed in the granite unarries of Quenast, in Belgrinm. ${ }^{83}$

All these observations bring this theory within the domain of influctire science. If sheet structure is due to compressive strain, it is due to such a strain as would produce a series of undulating fracture- extending entirely across a granite mass several miles in diameter and to a depth, as la as observet. of 250 feet from the rock surface.

7. In view of the undoubted sheeting effect of expansion under solar heat within a short distance of the surface ${ }^{s 4}$ and of the fact that some of the sheets near the surface measure but a few inches in thickness. it is quite possible that very thin surface sheets have originated in this way; but in view of what was stated moler heading 6 it seems probable that compressive strain is the main factur in producing massive sheets. At the surface both canses may have eooperater. The progressive thickness of the sheets downward inticates that the operation of this strain is evidently also dependent upon tistance either from the present surface or from a former surface or contact.

Accorting to this riew sheet structure may be sain to exert a controlling influence mpon surface forms. yet it seems quite possible that granite domes as conspicuons as Stone Mountain, in Creorgia, and Fairvew Dome, in California. notwithstanding all the exfoliation that has taken place on them or the erosion they may have suffered. may still retain some degree of parallelism between their present form and the original contone of the granitic intrusions of which they are parts. This may be true also of the granite hills of Mount Desert.

The probability being admitted that the general parallelism between. the present surfice and the sheet structure is the result of erosion that followed the sheeting. the question still remains. What has determined the form and location of the domes? These may possibly be referred to major arches (anticlines) in the fuldson the stratified rocks that originally overlay the cranite. The crustal movement that poduced these folch may also have brought about the intrusion of the material that formen the domes beneath them.

Althomgh the sheet structure and the rock surface are very grenerally parallel. they are not universally so.

\footnotetext{
\&2 Watson. T. L., and Laney, F. F.. The budding and ornamental stomes of North Carolina: North calolina (ieol. Surver I'nil. 2- 11), 15i-160, 1906.

8s Hankar-Crban. A., Note sur des molvements spontanés des roches dans les car-

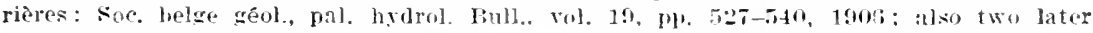
papers in vols. 21, 190 t, and :3, 1!os.

\& See refence to Walther's observation of the exfoliation of granite undur suldr labt in Egtpt, on p. 71 .
} 
Sheet structure in granite so much resembles the structure of folded stratified rocks that underground water circulates in practically the same way along the fracture planes of one and the bedfing planes of the other. The exudation of water along sheet joints on rertical rock faces is seen in many of the Maine quarries ( $P$ l. XIV, $;$ ). and also in Massachusetts (Pl. XXVII, l) and Rhode Island (Pl. XXXIV, A).

\section{DOUBLE-SHEET STRUCTURE.}

Robeson Momntain, in Woolbury. Yt., is a narrow granite ridge, attaining an elevation of about 1,100 feet above Hardwick station and some 930 feet above Woolbury (Sabin) Pond. It is from 300 to for) feet above the hollows on either side of it. Its axis trents from $\mathrm{N} .80^{\circ} \mathrm{E}$. to $\mathrm{S}$. $70^{\circ} \mathrm{W}$., deseribing a slight curve. Near its west-southwest end the Fletcher quarry cuts the ridge in a northeastsouthwest direction. and in 1907 had reached a depth of to feet. The sheets exposed here are from 1 to 5 feet thick, horizontal at the top of the ridge but curving over on the sontheast with a dip of $15^{\circ}$ to $30^{\circ}$. as shown in Plate VI. P', and determining the slope of the ridge on that side. These sheets are, however. intersecterl by another set from 5 to 9 feet thick, dipping $50^{\circ}-10^{\circ} \mathrm{s} .70^{\circ} \mathrm{W}$. in the direction of the axis of the ridge. In the Woolbury Granite ('o.'s puaries, roughly alout 1,750 feet N. $80^{\circ}$ E. of the Fleteher quary, the sheets at the top of the rirlge turn, dipping to the northern horizon. Jower lown on the sontheast side of the ridge they

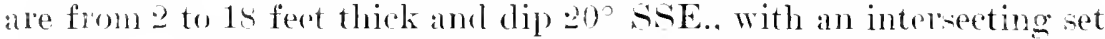
which is horizontal and evidently corresponds to the second set of the Fletroher qualry.

At one of the Oak Iill granite yluaries, 6 miles west of Lowell,

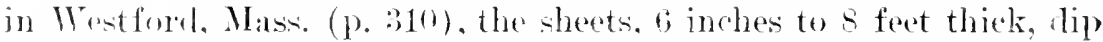
16 XIs. but are intersectel by secomblar sheets. 10 to 20 feet thirk, dipling $20 \mathrm{~N} .45 \mathrm{E}$.

But of the f25 granite quarries visitel by the writer in New Eng. lame, these are the only ones in which recontary sheet structure was oliserierl.

The only explanation offered for this double-sheet structure is the "xistence at some time of a secomdary compressive strain operatimg differently from that which probluced the primary sheet strueture and wiring rise to a nearly horizontal set of joints or sheet partings. There is now a marked compressive strain in the Fleteher quarry. operating from northeast to southwest, parting the sheets and giving rise even in the upper part of the quary to horizontal strain fractures. Its existence lends support to such an explanation. 
JOINTS.

Hermann sa divides joints into two groups-joints formod by lateral compression. whose distances from one another are related to the coarsmess of the rock texture. and joints che to axpansion some of which are parted and filled with calcite. quart\%. pewmatite. or volcanic rock. That many joints are the to compressive or torsional strain. and that every such strain resolves itself into two components. resulting in two sets of joints that intersect at an angle of abont $90^{\circ}$. each forming an angle of abont $45^{\circ}$ with the direction of the strain, are facts now generally recognized. Crosby ${ }^{46}$ has maggested that torsional strains may have been supplemented hy vinatory strains in causing joints. Becker ${ }^{\mathrm{s}}$ shows that four or even more than four systems of joint may be due to a single force. He also shows that subsequent strain on a region thus jointerl wonkd tend to produce motion along the previously formerl joints rather than a new system of jointing. It is conceirable that if a region hat been jointed and afterward subjected to a tensile strain. some of its joints might be parted, and if they were rery deep the openings might become filled with rolcanic matter from below, or. if not. with matter from alove, infiltrated from overlying rocks. That motion has occurred along some of the joints in the quarries is evident from the polished and striated surfaces of the joints as well as from the faulting of the sheets.

Toints are exceptionally as curved "as the side of a ship." (Fee Pl. XIV. B.)

Possibly related to such curved joints are what some New England quarrymen term "toe nails." These joints strike with the sheets but extend only from one sheet surface to the next and have a eurve which sharply intersects that of the sheet structure. Such joints seem to be due to a strain different from that which produced the sheets. They may be due to an incipient secondary sheet structure. They were noted at Quincy, Mass., Westerly, R. I., and Milford, X. H.

The spacing of the joints varies considerably, ranging from 1 foot to 500 feet, but usually from 10 to 50 feet.

In some localities the jointing is rery irregular. The granite is broken up into various polygons, which at the surface, where weathering has made inroads. resemble boulders. Quarries opened in such places are called boulder quarries. Another sort of irregularity in joints consists in their discontinuity or intermittence, their strike and dip for the short spaces in which they occur being uniform. Joint

\footnotetext{
se Hermann. O.. Steinbruchindustrie und steinbruchgeolngie. p. 103. 18:9.

so ( rosby, W. O. The origin of parallel and intersecting joints: Am. Geologist, vol. 12, pp. 368-375, 1893.

si Recker, G. F., Simultaneous joints: Washington Acad. Sci. Proc., vol. 7, pp. 267-275, pl. 13,1905 .
} 
courses at the quarries referred to in this work are given under the quarry descriptions in Part II, and many of them are there shown in diagrams.

HEADINGS.

In some places joints ocenr within intervals so short as to break up the rock into useless blocks. For a space of 5 to 50 feet the joints may be from 6 inches to 3 feet apart. A group of close joints is called by quilrymen a "healing." possibly because, when practicable, such a mass is left as the head or wall of the quarry. (See Pls. XVI, 1; XVII, li.) Headings afford ample ingress for surface water, and consequently the granite within a heading is generally badly stained, if not decomposed. This will be referred to more fully under the hearling "Decomposition" (p. 70).

An interesting feature of both headings and joints shown in some of the leeper quarries at Quincy, Mass. (p. 320), is their vertical discontinuity. A heading occurring at the surface may disappear below, or a heading may abruptly appear a hundred feet below the surface and continue downward.

The hornblende granite of High Rock, in Wrentham, Mass. (Curry quarry, p. 314), besides the usual sheet and joint strueture, has steep headings at irregular intervals in its upper part. These are only 5 to 10 feet deep and several feet wide, differing from ordinary headings in the eloseness of their joints, which are only 1 to 2 inches apart.

Headings are not easily accounted for. They may be produced by vibratory strains recurring at intervals of time. If they are so caused, the character of the fractures in some headings indicates that the strains are very complex. (See under Concord, N. H., p. 196.)

\section{FAULTS.}

The polished and grooved faces ("slickensides") observed on many of the joints at the quarries show that faulting has oceurred along them. The discontinuity of the sheets at some of the joints, causing, where the joints are slightly inclined, what quarrymen call "toeing in," may probally be attributed to faulting. This supposition assumes, of course, that the sheet structure was formed prior to the jointing. Faulting occurs also along sheets, displacing vertical flow structure, or vertical dikes. (See Pl. XVI, B.) It may occur along one of two intersecting dikes, displacing the other, as at the Deep Pit on Cape Ann, Mass! (See Pl. XXVII, B.)

SHEAR ZONES.

Zones along which numerous microscopic parallel meandering fractures have been made and shearing has occurred, giving rise to sccondary minerals and plicating the lamellae of plagioclase, were 
olserved at one of the quarries at Fall River, Mass. (See p. 283.) This is incipient gneissic foliation.

\section{"SHAKE" STRUCTURE.}

In quarries where rift structure and sheet structure happen to coincide the granite in proximity to steep joints and near the surface acquires a marked foliation parallel to rift and sheets. This is known by quarrymen as "shake." It occurs at the top and bottom of sheets through a thickness of 6 inches and is coextensive with the rusty stain. Under the microscope it proves to consist of minute nearly parallel fissures of no great continuity, traversing the mineral grains and conspicuous in the quartz and mica. The spacing of the fissures ranges from 0.004 to 0.02 inch.

The structure is attributed to the action of frost upon the rift, surface water having reached sheets and rift through steep joints. It is uncertain whether the fine horizontal fissures at right angles to the gneiss foliation but parallel to the sheets, and spaced 0.5 to 6 inches, at the Sachem Head quarry, in Guilford, Conn. (p. 354), are also to be so explained or constitute a miniature sheet structure.

\section{SUBJOINTS.}

Careful inspection shows that the joint structure in granites does not everywhere consist of a simple fracture but is at many places complex. Minute fractures branch off from the joint at an acute or right angle and penetrate the rock a few inches, or the rock for a few inches on either side of the joint is traversed by microscopic fissures that are roughly parallel to it. All such structural features may properly be called subjoints.

The following observations were made in the Maine granites and quarries:

A thin section of North Jay granite across a joint face shows two diverging subjoints that form an acute angle with each other and with the main joint and are filled with limonite and sericite (?). Single subjoints are, however, rarely found, five or six fine parallel fissures generally occurring together. In one of the quarries at Franklin (quarry of W. B. Blaisdell \& Co., p. 220), the subjoints are parallel to the main joint and steeply inclined, and as both main and subjoints are filled with calcium carbonate the granite near the joint weathers out vertically in small slablike pieces from half an inch to 2 inches thick. As these usually contain one or more subjoints filled with calcite or aragonite they consist of alternating bands of calcium carbonate and granite. Under the microscope one of these subjoints, measuring 0.74 millimeters across, is seen to be filled with long slivers of quartz and feldspar and scales of biotite, forming a breccia. Another, 0.07 millimeter wide, is filled with secondary 
quartz. At the T. M. Blaisdell qarry in East Franklin, Hancock County (1) 219). a northeast-molthwest rertieal joint has on one side numerous suljoints that meander off at right angles to it and traverse a cubical miss whose sicles measure 10 to 1 . feet. It the Shattuck Momntain quarry. in Calais (p. 206(i), a joint striking $\mathrm{N}$. 25 E. has subjoints striking $\mathrm{N} .40^{\circ} \mathrm{E} ., \mathrm{N} .60^{\circ} \mathrm{E}$, and N. $50^{\circ} \mathrm{W}$.

Woodworth so has sturlied analogons and related structures in rarious rocks and describer them as "joint fringe" and "feather fractures.

The termi subjoint is liere extemded to include also series of minor parallel joints traversing quartz reins.

Sich jointed reins occur in several quarries at Ruincy. Mass. on the North Commons. They are male conspicnous by a zone of light riscoloration in the granite on either side of the rein. At the

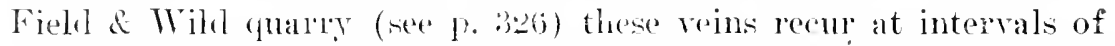
2 to 25 feet, with a north and northwest strike. They are crossed every inch or two by subjoints about 1 foot long. which strike about I. $1.5^{\circ} \mathrm{W}$. and dip east like the chief joints of that quarry. At the (ialvin quarry (see p. 325) similar quartz reins, striking N. $25^{\circ}$ IT.. are crossed by vertical subjoints an inch apart and a toot long. with a northerly strike like that of the major joints. Wrorkmen report that the granite near such reins is harder than elsewhere.

These subjoints may be accounted for by the greater rigidity and vitreousness of the reins and the adjacent granite, thus causing them to fracture more readily than the surrounding rock under the jointforming movements. Although parallel to the major joints, such subjoints may laave been formed at a different time.

\section{CONTEMPORART FRACTURES.}

The geologic structural features termed contemporary fractures, formed by processes that are still going on, have been described muler the subject of sheet structure on payes 29-30 and are illustrated in Pls. VI. A, and XV. A. The effect of compressive strain has also been noted at the Tayntor quarry, Hallowell, Maine (p. 236), the 11 ooper \& Havey quarry, North Sullivan, Maine (p. 231), also at these quarries in Vermont: Woodbury quarry, Bethel, strain east to west; Boutwell quarry, Barre, strain north to south; Bruce quarry, Barre, strain north to south; Wells-Lamson quarry, Barre, strain north to sontlı; Canton quarry. Barre, strain east to west; Fletcher quarry, Woodbury, strain northeast to southwest; Benzie quarry, Groton. strain general; Tupper quarry, Blue Mountain, Ryegate, strain east to west; Lyons quarry, Black Mountain, Dummerston, strain $\mathrm{N} .10^{\circ}$ E. to $\mathrm{S} .10^{\circ} \mathrm{W}$.

\& Woodworth, J. P.. On the fracture ssstem of joints. with remarks on certain great fractures: Boston Soc. Nat. IIist. l'roc.. rol. 27, pp. 169-173, pls. 1, 2. 1896. 
The usual effect of such strains is the closing of channels and the crishing of " cores" (rock intervals) between rertical trill hoies.

\section{MODIFICATIONS OF GRANITE.}

Cuder the above heading are gromed all those variations from typical granite that are dne to injection. segregation. inclusion. steam carities. compression. infiltration, and decomposition.

DIKES.

Dikes in granite are fissures filled from below by the injection of matter in a heated and more or less plastic to fluid condition. The injected material or dike rock may be acidic or basic-that is, it may be very siliceous. like granite. or it may contain more of the basic elements. like basalt.

\section{ACIDIC DIKES.}

The ardic dikes in the quarries are of three kinds-fine or medium grained granite; extremely fine grained aplite, and very coarse grained pegmatite. The courses of these dikes at each quarry are given in the diagram: or descriptions in Part II. In thickness they range from a fraction of an inch to over 20 feet but usually from 2 inches to 2 feet.

Gramite.-The following observations were made in the Maine quarries: At the Settlement quarry, near Stonington (see p. 229), the coarse granite is traversed by a dike, 4 to 12 inches thick, of light pinkish-gray granite, in which the feldspars attain a size of 0.1 inch (2.5 millimeters). This rock consists of a pinkish potash feldspar (microcline), a white soda-lime foldspar (oligoclase-andesiue), smoky quartz. and black mica (biotite). At the Mosquito Mountain quary (1). 2.s ), near Frankfort, there is a 10 -foot dike of medium-grained gray granite (quartz monzonite), with feldspars up to 0.3 inch. The potash feldspar (microchine) is about eyual in amount to the sola-lime feldspar (oligoclase), the quartz is smoky. and the mica is black. At the Mount Waldo quarry (1). 259) there is a dike 200 feet wide of fine biotite granite, with coarse biotite granite on both siles of it. The feldspars of this dike measure np to 0.15 inch, but range ordinarily from 0.36 to 1.45 millimeters. 'The fine-grained biotite-muscovite granites quarried at the Sherwood quary, on Crotch Island (specimen 25. a, described on p. 227). at East Bluehill (specimen 39, a, p. 216), and at a small opening on Dodlin Hill, near Norrilgewock (specimen 117, a. p. 257), all soem to belong to similar dikes that are not many feet thick. At an old quarry near Bluehill there is an 18-inch dike of fine-grained musovite-biotite granite, in which the feldspars are much interorown wh quartz. 
At Milford, Mass., the medium-coarse, even-grained, slightly gneissoid biotite granite is cut by a $t$-foot dike of fine to medium grained porphyritic biotite aranite. (Nee further p. 346. .) The same wranite at the West quary (p. 3ts) is cut by dikes of tine quartz monzonite.

In Rhode Island the fine Westerly granites appear in dikelike masses from 50 to 150 feet thick, striking $\mathrm{N}$. $75^{\circ}-90^{\circ} \mathrm{W}$. and dipping $30^{\circ}-45^{\circ}$. At the Smith quarry they are underlain by a parallel mass of aplitic granite of similar character, currying also inclusions of finely banded biotite gneiss. At the Klondike quarry the granite has a flow structure striking $\mathrm{N} .10^{\circ}-20^{\circ} \mathrm{W}$., intersecting the course of the apparent dike. It is uncertain whether these are granite dikes or protuberances from a broad intrusive mass which have become exposed by the erosion of the thinner parts of the overlying gneiss.

The fine quartz monzonites of connecticut, like thome of Rhote Island, occur as dikes, or apparent dikes, in various gneisses. At the Waterford quarry there are two such parallel dikes with an intervening strip of gneiss. The relations are shown in figures 13 and 14. The thickness of the dikes measured at a right angle to their inclination ranges from 12 to 40 feet, but at the Millstone quarry the relations are not clear. The granite is exposed for a depth of 50 to 125 feet and a width of 50 to 300 feet, and is capped here and there by 25 feet of gneiss, but no underlying gneiss is yet exposed, although the abundance of inclusions at the bottom of the quarry may indicate its proximity. If the width of the granite at right angles to the flow, which appears to dip $35^{\circ} \mathrm{SW}$. is taken as 200 feet, the thickness of the granite would be about $11 t$ feet. It is possible that a part of this quarry overlies the vertical portion of a granite dike. (See pp. 396, 397.) At the Torrington Borough quarry (p. 379) a finely banded biotite granite gneiss associatei with pyritiferous quartz-mica diorite gneiss is crosset by a network of dikes-the largest 6 inches thick-of bluish-gray quartz monzonite, which has acquired a gneissic texture.

In Dummerston, Vt., on the west side of Black River (Bailey prospect, p. 155), the granite is eut by a dike of fine granite, 30 feet wide, with a $\mathrm{N} .10^{\circ} \mathrm{W}$. course and dip of $50^{\circ} \mathrm{W}$. It is of medium bluish-gray color and of very fine, even-grained texture, with feldspar and mica up to 0.05 inch. In thin section its particles range from 0.074 to 1.1 millimeters in diameter. It is a quartz monzonite of similar composition to that of West Dummerston. Its mica is chiefly biotite. Feldspar and quartz are intergrown and have crush borders.

Aplite--Aplite differs from ordinary granite by the greater fineness of its texture and its scant content of mica. It is known by quarrymen as "salt horse" or "white hor'se." 
Aplite dikes are supposed to have originated in the same deepseated molten mass as the granite they traverse, but they represent at later stage of igneous a tivity. The fissures they fill were the result of various tensional strains or antractions. posibly consequent upon the cooling of the granite.

In color these dikes range fom white, huish or brownish gray to light pinkish gray, cream eolor, and tark reshlish. The textme of some aplites is so fine that the mineral particles can not he distinmished with the maided eye; that of others is so coarse that the feldspar and mica may be thus detected. Tnder the microscope the dimensions of the particles range from 0.05 to 0.75 millimeter, the average being abont 0.16 millimeter for the finer ones and 0.50 millimeter for the coarser ones. Some aplites have a porphyritic texture.

Most aplites contain a slightly higher percentage of silica than granite. Five analyses of aplites from the far West marle at the laboratory of the Tnited States Geological Survey show a range of silica from $7+.21$ to 76.03 pere cent and an average of 75.18 , which is near the maximum of silica for granites generally.

The minerals of aplite dikes are so firmly attached to the granite on either side that a split can he readily made across both granite and aplite. Tnrler the micros ope the minerals of the dike appear to be welded, so to speak, to those of the granite. In construction the blocks containing such dikes shomld not, therefore, necessarily be regarderl as places of weakness, but in a quarry at Franklin. Hancock County, Maine, the granite is close jointed for a space of a foot on either side of an aplite dike, the joints being parallel to the dike.

Two typical aplites will be descrihel in detail. One, from the Goss gurry on Moose Island, near Stonington, Maine, is from a dike 15 inches witle and over 200 feet long, consists largely of quartz, potash feldspar (microcline), and a soda-lime feluspar (oligoclase) in particles ranging from 0.047 to 0.141 millimeter in diameter, a few thinly disceminated particles of the same minerals measuring from 0.55 to 1.45 millimeters and a few scales of black mica measmring up to 0.47 millimeter. Another aplite, from the Sands quarry at rinalhaven. Iaine, consists mostly of quartz but contains some potash feldspar (orthoclase and microcline), still less soda-lime fellopar (oligoclases), amr a few scales of black mica. The particles range from 0.047 to 0.3 millimeter in diameter.

Dikes of aplite were observed at the quarries in Roxbury, Benvenue, Bolton, Greenwich, and Sterling, Conn. Aplite is also associated with pegmatite at several other quarries.

At Roxbury some of the aplite is ross colored, and the larger dikes are 4 feet thick. Its particles are all under 0.1 inch and consist of olixockase-andesine, smoky amethystine quartz, microcline, rare muscovite, ancl microscolvic galnets. The feldspars have crush borders, the dikes having heen exposed to the same pressure that made a gneiss of the inclosing cranite. A white aplite from the same quarry has oligoclase-albite as its chief feldspar.

๑ U. S. Geol. Survey Bull. 419, pp. 64, 86, 92, 148, 157, 1910. 


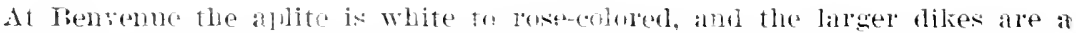

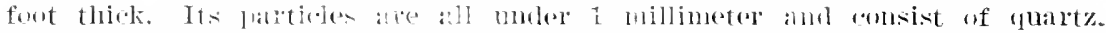

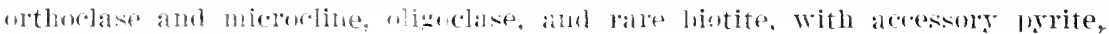
titanite, allatnite.

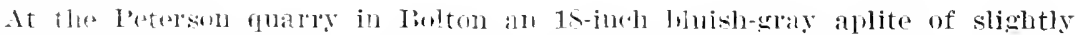

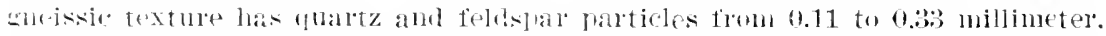

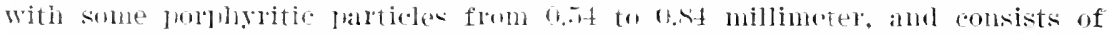

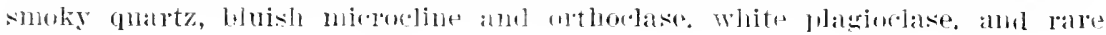
biritite.

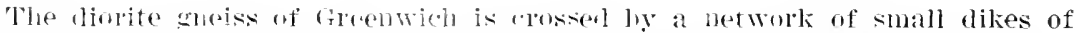
aplite of bluish-glay ablus. W.th faltides umler 0.76 and mustly moler 0.57 nillimeter and comsisting of fuartz with arities in sheets, microcline and

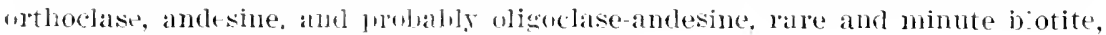
with arcessury lyrite. alatite. titanite. zircon.

At the quarlies near onew. in Sterling. the larer aplite dikes are a font thick and the aplite is cream-colored. with particles ranging in dianeter from 0.0.5 to 1.11 millimeters. It comsists of clear colorless quartz with cavities, microline and ortlurbse, rare anl minute hiotite, and accessory imenite. samet, and almtite. A small dike contains a central band of imenite.

At the Bodwell Cranite ('o.'s quarry (see p. 268), 2 miles east of Jonesboro, Washington County, Maine, the reddish granite is traversed by a 6 -foot dike of rather coarse dark-reddish aplite, in which the higher power of the microscope shows that the source of the color lies in exceerlingly minute dots of hematite. The aplite contains also muscovite. biotite. and accessory pyrite. This dike crosses the quarry in a $\mathrm{N} .201^{\circ} \mathrm{W}$. direction. A similar dike, having a like course. but only 4 feet wide. occurs at the east end of the quarry. A third dike. 8 to 6 inches wide, has a $\mathrm{X}$. $\pi^{\circ} \mathrm{E}$. course, and a fourth, of fine-grained material. 0.5 to 1 inch wide. crosses the others with a course $\mathrm{N} .60^{\circ} \mathrm{W}$. and can be traced for 200 to 300 feet. This is evilently of later date than the others.

The gneissoid biotite granite of the Savoie quarry, in Fall River, Mass. (p. 284), is crossed by two aplite dikes.

one (specimen $\Gamma, X_{X X}$ 118. a), 10 feet wide, is of light pinkish-gray color and fine, even-grained texture. Its second feldspar is athite (soda feldspar), sompwhat micacized and epidotized. Its biotite is chloritized. The other (sperimen D. XXX, 118. h), up to 2 feet thick. is of dark brownish-gray color and semiporphyritic texture, its smaller particles generally aranged about the larger. Its serond fellspar is also allite.

The biotite granite gneiss of the Blanchard quarry, in Uxbridge, Mass. (p. 353). has aplite dikes up to 3 feet thick.

The muscovite-biotite granite gneiss of the Merrill quarry. in Westford, Mass. (p. 310), has whitish aplite dikes with longitudinal bands of black toumaline 0.2 inch wide.

A very unusual dike of aplite crosses the mica diorite of the Lea vitt quarry, in Leominster, Mass. (p. 353). (See fig. 2.) It is of light-gray and bluish-gray color. Its broadest part consists of over 150 meandering paraliel bands of these alternating shades 
(specimens D, XXX, 110, b, c), many of them bopleres with micro. scopic prisms of black tommaline with their main axis aross the band. The meanderings of these bamals resemble the plications of a metamorphic stratified rock. The aplite contans here and there clear felispars up to an inch long.

In thin section it resembles a quartz monzonite. its comstituents, in descending orter of abundance, heing oligoclaserabite, quatz. microcline, and black tourmaline in minute prisms. The accessory minerals are apatite in needles and particles (abmolant). lyrite, garnet, and takes of muscovite (rare). The yellowish tingt of some of the hands is probably due to the oxidation of the pyrite. A few of the banls are fowmatite without toumaline but with biotite, a little muscorite, and ilmenite (?) surrounded by lencoxene.

'The hatuling of this aplite like may be ascriber to a grarlual enlargenent of the fissure ant the (leposition of aplite on either sifle. as in bander mineral veins. The meandering or phication of the bamms and the transverse orientation of the tonrmaline jrisms are possibly due to one cause. Other smaller dikes of aplite are parallel to this one, and some of aplite and of pegmatite intersect the main dike.

The considerable area of pyritiferous aplite quarrier in Iingham, Mass. (p. 336). is of light, slightly greenishgray color and searcely dereloperl sheet structure, but with

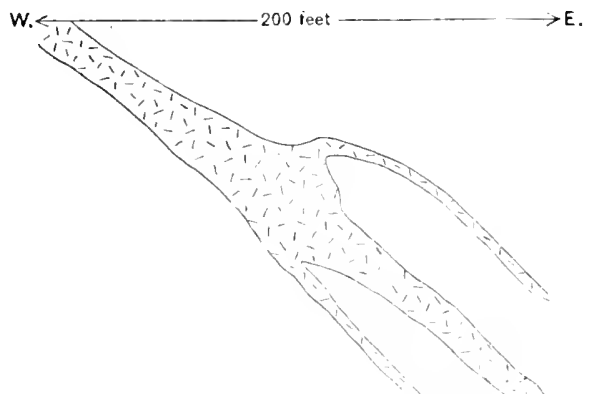
many hearlings showing rusty faces from the limonitization of the pyrite.

This rock also resembles a quartz monzonite, with these constituents in descenting order of ahmounce: Olicoclase-alhite. quartz, mirrocline, and very littr. biotite mostly diloritizerl and associated with epilote. The accessory minerals are lyrite am magnetite. As the stone is extremely hard, its percentige of quartz must be high.

In ('aledonia Comnty. Yt. (Grout rilarry, Kirby Township, p. 111). three aplite dikes strike $X$. $80^{\circ} \mathrm{E}$. and are 6 feet 6 inches, 6 feet. and 1 foot thick.

This allite (swomen D, XXIX, if, b) is lark oray and of very fine porphyritic texture. bint few particles can be distinguished; feldspar 0.1 incli, nica 0.0.5 inch. It effervesces slightly with muriatic acid test. In thin section the partinles of grommanss lange from 0.037 to 0.149 millimeter and censist, in

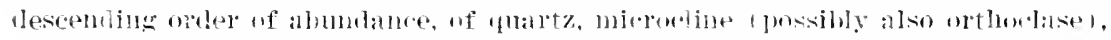
rare smiltine feldspar. minute biotite sales. muscovite or bleached biotite. anu serunlary zoisite. The porphyritic particles and crystals are quartz. sodalime feldspar, orthoclase and botite. One of the former feldspars has curverl twinning planes. another is fanlted across them and has much secondary quartz abont it. all indirating motion after crystallization. Cilleite is present. 
Other aplite dikes in New England are referred to on pages $12 \pi$, 167.265 , and 415 .

Pegmatite.-Pegmatite lies at the other extreme. Its mineral constituents range generally from 6 inches to 1 foot or eren several feet in diameter. It is reported that the crystals in some pegmatite dikes measure from 10 to 30 feet in length by 1 to 3 feet in width. The chief minerals in pegnatite dikes are the same as in granite, but they occur in different though varying proportions. With these minerals are commonly associated tourmaline, garnet, beryl, etc. Chemically these dikes generally contain more silica than the granite. Dikes of pegmatite are, as a rule, more irregular in width than those of aplite. They generally range in thickness from 1 inch to 10 feet.

The origin of pegmatite has been much discussed both in Europe and in this country. ${ }^{90}$ Bastin in the bulletin cited states that the " distinguishing feature of pegmatites is not coarseness of grain but extreme irregularity of grain." Gregory ${ }^{91}$ in showing the bearing of the phenomena in the granite quarries of Connecticut upon the origin of pegmatite states:

The contact hetween the regmatites and the gneiss ar other rock into which they have been intruded is clearly detined, showing no gradation between the pegmatite and the gness. In the feldspar quaries of Glastonlmry. where the contact may be clearly traced, the gneiss immediately adjoining the pegmatite retains all the minute structures of foliation and differs in no way from the main body of sranite gneiss. * * * The proportions of the chief minerals in peguatites vary greatly. Some dikes or veins contain quart\%, feluspar, and mica in about the same proplortions as those found in normal granites. In other dikes feldspar and quartz make up practically the entire mass. and in some localities culartz alone constitutes probably 90 per cent of the cutire rock.

Peguatite may be regarded as a form of granitic intrusive that or.ginated in parts of the isneous mass which were abmulantly supplied with water vapor. Most masces of pegmatite were formed in a manner somewhat different from that in which ordinary granito was formerl. and their composition raries with their distance from the granite mass. For instance, in the Collinsville granite gneiss area the pesmatities that are closely associnted with the granite mass, such as those at Canton. are of essentially the same minelal content as the granite. The pegmatite farther alwy. which cuts the schist orerlying the granite, is composed dhiefly of quartz and feldspar. and that which lies still more distant is formed entirely of quart\%.

Referring to the minerals occurring in pegmatite. Gregory states:

The pegmatite reins along connectirnt River have rielded sphalerite, gahnite, manetite, chrysoheryi, hismutite, orthorlase (crystals). alhite, oligoclase,

20 The prineipal American writings on the subject are those by Williams, $r_{\text {. }}$ H., The genelal relation of the granitic rocks in the middle Atlantic Piedmont Plateau: I. S. Gicol. Survey Fiftecnth Ann. Rept., pp. 675-654, 1895; Crosby. W. O., and Fuller, M. L., Origin of pegmatite: Tech. Quart., vol. 9, pp. 326-356, 1896: Am. Geologist, vol. 19, pp. 14t-180, 1897; Van Hise. C. R.. A treatise on motamorphism: T. S. Geol. Survey Mon. 47. pp. 720-728, 1904; Bastin. F. S., Geology of the pegmatites and assoeiated rocks of Maine, including feldspar. quartz, miea, and gem deposits: U. S. Geol. Survey Pull. 445, 1911. An important European work on the subject is that of Brögger. W. C., I ie Syenitpenmatit-giinge der stidnorwegischen Augit- und Nephelinsycnite: Zeitsehr. Iiryst., vol. 16. 1890 .

${ }^{81}$ Gfregory, H. E., U. S. Geol. Surrey Bull. 484, pp. 18, 19, 1911. 
beryl, iolite, garnet, ejidote, tourmaline, muscovite (crystals), lenilolite, biotite, columbite. samarskite, monazite. triplite. turbernite, autunite, and maninite. From a single pegmatite mass at Branchville twenty-seven minerals were collected. Single crystals taken from this mass weighed $1(\mu)$ to 200 pounds.

Bastin ${ }^{92}$ nanes 20 minerals from the Maine permatites, exclusive of the quartz, feldspar, and mica of the dikes and the secondary minerals.

The writer's notes on the pegmatites of the Connecticut granite quarries follow:

Pegmatite in lenses or small dikes occurs at nearly all the quarries. There is a 20 -foot dike with large gneiss inclusions at the Torrington Borough quarry (p. 375), and pegmatite oecurs near or about such inclusions at the Nillstone quarry (p. 396. fig. 90, b, ll) and also at short intervals intersecting one another.

The permeation of the Stony Creek granite gneiss with pegmatite differentiates it from many granites and partly accounts for its very irregular texture. (See p. 378 and Pl. XXX, i.) The biotite granite of the Maccurdy quarry, at Lyme, is really a pegmatite occurring as dikes. 15 to 22 feet thick, cutting a mass of fincly banded granite gneiss. (See p. 391.) At the Slater quarry, in Glastonbury (p. 369), a 12 -inch pegmatite dike in fine porphyritic biotite granite gneiss contains museovite crystals. the largest 5 inches across and 4 inches thick. At the Center Groton quarry the quartz monzonite on either side of a 4-foot pegmatite dike has been darkened. Dikes from 6 inches to 2 feet thick abound in the Holbrook quarry at Seymonr. (See p. 385 and fiğ. 88.) At the Benvenne quarry, in Middletown, small pegrmatite dikes are bordered with bands of feldspar and hornblende and the granite gneiss itself also contains hornblende.

Generally pegmatite dikes contain the same minerals as the granite they penetrate, but in larger particles. In the very fine granites such dikes afford a ready means of observing in the field the ehief constituents of the granite they penetrate.

The pegmatite of Lyme village contains apatite, that of the Oneco quarry fluorite and epiclote, that of Pawcatuck allanite, that of the Mascetti quarry, in East Litchfield, and the Potter quarry, in Ansonia, black tourmaline, and that of several other quarries garnets, all in small particles or crystals.

The pegmatite of the Collins quarry, in Danbury, owing to crustal motion, has all its quartz granulated like that of the gneissoid granite of Milford, Mass., and its feldspar's bordered with crushed feldspar.

The courses of many of the pegmatite dilies and their relations to the structure of the granite in the New England quarries are shown in figures $4,32,33,39,41,53,54.57,61,62,63,64,72$, and 88 . 
The following observations were made in the Maine quarries: A pegmatite dike crosses the diorite at Round Pond, in Lincoln County. (See p. 24?, also PI. X. B. of C. S. Geol. Surrey Bull. 313.) At the Hallowell Granite Works quarry (P. 2034) there is a 2 -foot dike consisting of milk-white soda-lime and potash feldspars (oligoclase and microcline). smoky quartz, biotite and muscovite (black and white mica), and garnet. The feldspars. quartz. and mieas attain a length of several inches. At the North Jay quarry (p. 214) the pegmatite dikes, which are as much as 2 feet 6 inches in width, consist of a milk-white potash feldspar, smoky quartz, biotite, and muscovite, the constituents measuring several inches in diameter. At the Clark Island (Rodgers) quarry (p. 2t1) there are two interesting pegmatite dikes with similar material of similar dimensions, together with black tourmaline and garnet. The granite at Fryeburg, near the New Hampshire line, abounds in pegmatite. At the Eagle gray granite quarry (p. 252 and fig. 63) two dikes, one 5 feet and the other 10 feet thick, alternate with granite 25 and 60 feet thick. The feldspar masses and crystals attain a length of 12 inches, and the biotite and muscovite crystals and the quartz masses a length of 6 inches. Small garnets are abundant. Mingled with the pegmatite is some fine-grained aplitic material. There is also considerable pegmatite at the Waldoboro quarry. in Lineoln Comty. (See p. 250 and fig. 16.) At the Willard Point quarry there is a 12-inch pegmatite dike of feldspar, quart\%. muscovite, and black tourmaline, which has a banded structure. It is crossed by another dike half as thick with a difference in strike of $20^{\circ}$.

The following observations were made in New Hampshire:

At a quarry in Milford (1. 189: Pl. VIII, A) large dikes of pegmatite appear to proceed from the surface of a mass of quartz nonzonite into an overlying granite gneiss. The pegmatite dikes at the Bailey quarry, in Allenstown, Merrimack County, contain black toumaline and beryl. A thick dike of coarse garnetiferous pegmatite in the center of the Marlboro quarry. in Cheshire County, has a border made up largely of beryl and its biotite is in blades 1 foot long and 1 inch wide. This dike is reported to have vielderl a garnet crystal orer 6 inches in rliameter and beryls of the same length. The pegmatite dikes of the Perry Sunapee quirry contain the usual black tourmaline and garnets.

The following observations were made in Rhorle Island:

It the Klondike quarry, in Charlestown (Pl. XXXIV, A), large dikes of pegmatite appear to proceed from the surface of an intrusive quartz monzonite into an overlying granite gneiss. At the Redstone quarry, near Westerly, a pegmatite dike 5 to 10 feet thick runs the whole length of the quarry, 850 feet, with a dip of $10^{\circ}$. and consists of alternating rerldish aplite and coarse pegma- 
tite made up of reddish feldspar, smoky quartz, and biotite. Some of its surfaces are coated with drusy hematite. This dike overlies a fine-grained quartz monzonite and underlies a medium-grained biotite granite of earlier date than the monzonite. At the Chapman quarry, also near Westerly, the fine-grained quartz monzonite is cut by a pegmatite dike of very low dip, and 20 to 30 feet below it is a small aplite dike with like dip.

The following observations were made in the Vermont quarries:

At the Pirie quarry, near Barre, the biotite granite is cut by a pegmatite dike $3 \frac{1}{2}$ feet thick, consisting almost entirely of light bluish-gray feldspars having a 6 -inch biotitic border on each side, with the axes of the biotite crystals at right angles to the course of the dike. At the Anderson quarry, near Barre, a 1-foot pegmatite dike intervenes between the granite and the slate capping, which is also injected with minute dikes of pegmatite as much as 4 feet in length. (See further p. 85 and figs. 11, 12.) At the Barney quarry, in Barre, a pegmatite dike follows the contact of cranite and schist, and the granite, for a thickness of 15 feet from the schist, appears to be pegmatized in alternating bands. At the Bailey quarry, in Barre, pegmatite dikes. large and minute, penetrate the schist capping and a large schist inclusion and are associated with aplite. Some of the pegmatite dikelets, only 0.3 to 0.4 inch thick, run across the bedding foliation and then subdivide to pass at right angles within one of the little beds. The adjacent schist is unaltered. On Robeson Mountain, in Woodbury (p. 88), minute pegmatite dikes also proceed from the granite surface and penetrate the schist capping.

A very exceptional cylindrical dike of pegmatite penetrates the riebeckite-aegirite granite at the Ballon quarry, in Quincy, Mass., and a similar one was discovered abont five years afterward in the Fallon quarry, about 600 feet south. (See map, Pl. XXIV.) These pegmatites and their minerals have been exhaustively studied by Palache and Warren and are described in three papers. ${ }^{93}$ The dike at the Ballou quarry is vertical. roughly cylindrical, and about 2 feet in diameter. A horizontal section of it has for many years been exposed at the gradually deepening bottom of the quarry, which in 1906 had reached a depth of 150 feet. A block containing an entire cross section of this dike was shown to the writer in the yard

9s Warren, C. H. Note on the occurrence of an interesting permatite in the granite of Quincy, Mass.: Am. Jour. Sci.. 4th ser.. rol. 28, pp. 449-452, 1909. Palache, Charles, and Warren, C. H., The chemical composition and crystallization of parisite and a new occurrence of it in the granite-pegmatites at Quincy, Mass, U. S. A., with notes on microcline, rlebeckite, aegirite, ilmenite, octahedrite, fluorite, and wulfenite from the same locality : Am. Jour. Sci., 4th ser., vol. 31, pp. 533-557, 1911. Warren, C. H., and Palache. Charles, The pegmatites of the riebeckite-aegirite granite of Quincs, Mass., U. S. A.: their structure, minerals, and origin: Am. Acad. Arts and Sci. Proc., vol. 47. pp. 125-168, Boston, 1911.

$$
105709-23-5
$$


of the Quincy Granite Co. It has an outer rim with abundant blueblack riebeckite crystals slightly larger than those of the surrounding granite. Within this is an intermediate zone (specimen D. XXIX, 80, b) of light greenish-gray feldspar and slightly milky quartz (particles up to 0.8 inch in diameter), containing bright grassgreen crystals of aegirite in sizes up to 1 by 0.5 inch, with some purple furorite and rusty metallic spots. The center consists mainly of quartz, with coarse feldspar outside of it.

Under the microscove the feldspars prove to be orthoclase with a finely intergrown plagioclase, also particles of abbite and probably oligoclase-albite. Both feldspars have the minute crystals of riebeckite and minute grains and prisms of aegirite typical of guincy granite. The quart has many fluidal cavities. There are slender aegirite crystals in feldsplar and quartz. The riebeckite, is intergrown with aegirite, and ilmenite is somewhat plentiful. The feldspars are somewhat kiolinizet. and there is some hematite and limonite stain. The brownish metallic areas of the middle zone consist of ilmenite, titanite, zircon in double pyramids. allanite, fluorite. aegirite, anı quartz.

This eylindrical dike is this a riebeckite-aegirite granite-that is. a granite containing rarieties of amphibole and pyroxene rich in soda and ferric oxide but poor in alumina, magnesia, and line-and therefore resembles the surrounding granite, but its particles are much coarser and radially arranged; some of its accessory minerals are exceptional, and the others are more abundant. A polished complete section of the Balion dike is in the collection of Harvard University.

The minerals identified by Palache and Warren in the pegmatite dikes of the Ballou and Fallon quarries include quartz in crystals. aegirite, riebeckite, crocidolite, zircon, fluorite, ilmenite, octahedrite. parisite, ${ }^{94}$ beckelite, ${ }^{94}$ wulfenite, molybdenite, chalcopyrite, galenite, sphalerite, hematite, secondary calcite, and ferruginous stain.

Pegmatitic quartz.-Besides these dikes of normal pegmatite there are dikes consisting largely of quartz of pegmatitic origin. At the old Bodwell Co.'s quarry on Cook's Mountain, near Redbeach, Maine. the red granite is traversed by a banded grayish quartz rein, abont 18 inches thick, with a N. $25^{\circ} \mathrm{W}$. course and vertical dip. It comprises three or in places four bands, which differ mainly in texture and are separated by more or less pyrite in fine particles. In places this rein divides into three smaller veins, each of which is from 3 to 4 inches thick. The quartz contains some purple fluorite (lime fluoride), as determined by W. T. Schaller, of this Survey, and a variable amount of a foliaceous lemon-colored mineral which Wirt Tassin, of the Tnited States National Museum, has analyzed and determined as a new variety of sericite, resulting possibly from the alteration of a feldspar, and which is accompanied by another mineral. regarded by him as probably talc. Mr. Tassin's analysis and note follow :

o Parisite and beckelite contain the rare elements cerium, lanthanum, and didrmium. 
Analysis of yellow foliated mineral (speeimen D, XTFT, 105a. 190.51.

Silica $\left(\mathrm{SiO}_{2}\right) \ldots$

Alumina $\left(\mathrm{Al}_{2} \mathrm{O}_{3}\right)$ 23. 06

Ferric oxide $\left(\mathrm{Fe}_{2}\left(\mathrm{O}_{3}\right)\right.$ .10

Ferrous oxide (Feu)

Magnesia $(\mathrm{MgO})$

4.09

Soda $\left(\mathrm{Na}_{2} \mathrm{O}\right)$

Potash $\left(\mathrm{K}_{2} \mathrm{O}\right)$

8.90

Water $\left(\mathrm{H}_{2} \mathrm{O}\right)$

6. 00

The mineral is secontary mica. probably derived from feldspar (although this is merely a conjecture), and will approximate sericite in composition. It accurs in fine scales, occasionally compacted and then resembling serpentine. Luster. pearly : color, greenish yellow; hardness. 2.5 ; specific gravity, 2.79 at $20^{\circ} \mathrm{C}$. It is associated in the rein with quartz, pyrite, purple flucrite, and another mineral which has a greasy luster and contains magnesia but which it was impossible to separate in a state of sufficient purity for analysis. This last mineral I believe to be talc.

It the (ialvin quarry, in Quiney, Mass. (p. 325), the granite is cut at intervals of 2 to 10 feet by quartz veins up to 1 inch thick, each of which occupies the center of a belt of light granite 10 inches wide. Similar veins occur at intervals of 2 to 25 feet at the Field \& Wild quarry (p. 326).

It the Blanchark quary. in Txhricge, Mass. (p. 352), the granite gneiss is crossed by veins of medium smoky quartz banded lengthwise with feldspar (specimen D, XXX. 114.c) and measuring up to 3 feet in thickness. The feldspar bands are 0.2 to 0.5 inch wide and the quartz $(1.5$ to 1.5 inches.

At the Milne quarry, at Barre, Vt., veins of smoky quartz with diagonal fractures occur at intervals of 3 feet. The granite for 0.2 inch next to the veins is largely feldspar. Along the edge of the vein there are bands of fibrous muscovite and in places streaks of granulated quartz.

RASIC DIKES.

Dikes of dark-greenish hard, dense rock (diabase, rarely basalt) are of very rommon occurrence in the granite quarries of Maine and Massachusetts. The courses of some of these dikes and their relations to the joints are shown in figures $4,23,44,61,63,67,71,74,75,76$, 77. 84. Some of them are represented in Plates VIII. $B, X V I, B$. and XXVII, $A, B$.

The following observations were made on the Maine dikes:

The dikes are vertical or nearly so and range in width from 1 inch to 7 feet or more, cutting the granite sheets with mathematical definiteness. Plate XVI, $B$, shows one of these dikes on Mount Desert, which has a course $\mathrm{N} .15^{\circ} \mathrm{W}$. and has been faulted from east to west, or west to east, along a gently inclined sheet with a displacement of 16 inches. A few feet beyond this point the same dike has been 
faulted along a northeasterly vertical joint, with a displacement of 5 feet. Although it might seem that this dike was injected into the granite before the sheet structure was formed, it is quite possible that the sheet structure preceded the dike and that later faulting affected both the sheets and the dike, cracking the dike along the sheets where it did not actually fault the dike.

Most of these dikes are so firmly welded to the granite that hand specimens one-half granite and one-half diabase are readily obtained. Thin sections of the glassy rims of dikes at Bryant Pond and Fryeburg show that the dike sent out microscopic branches for short distances into the granite, in places surrounding some of its quartz particles. A dike at the Dunbar Bros.' quarry, near Sullivan (p. 231), 16 to 18 inches wide, has a 0.25 -inch border of light-green epidote, derived from the alteration of its glassy rim. These glassy borders are due to the rapid cooling of the material at its contact with the cold granite. A few typical thin sections of these dikes will be described in detail.

The center of a 7 -foot dike at the Mosquito Mountain quarry, near Frankfort (p. 258). shows a network of minnte lath-shaped crystals of lime-soda feldspar (labratorite) partly alterel to a white mica, in the meshes of which is a green hornblende; also some masnetite in fine particles, and prrite, with accessory titanite, apatite, and secondary epidote.

A 4-inch dike at the Havey (Whaleback) quarry, in North Sullivan, shows a groundmass of fine hornblende and feldspar (plagioclase), in incomplete crystais, with magnetite and thinly disseminated larger crystals of hornblende and lime-soda feldspar (labradorite), some large quartz particles, and a little pyrite. One feldspar crystal is almost completely altered to a white mica.

A $2 \frac{1}{2}$-foot dike at the Campbell \& Macomber quarry, on the west side of Somes Sound, on Mount Desert (p. 223), shows a groundmass of fine hornblende and feldspar (plagioclase) in inconılete crystals, with magnetite (?), pyrite partly altered to limonite, and lime-soda feldspar (labradorite). Some of the particles of the feldspar measure 0.1 inch in length by 0.02 inch in width and are largely altered to kaolin and a white mica. The hormblende in all these dikes is regarded as a product of the alteration of augite.

The geologic age of these dikes has not been precisely determined. They are considerably more recent than the granite they traverse or the dikes of aplite and pegmatite which cut the granite. In Plate VIII. $B$, is shown one of these diabase dikes crossing both a vein of pegmatite and a mass of diorite ("black granite"), at Round Pond, in Lincoln County, Maine. ${ }^{95}$ (See p. 249.)

The following observations were made in the granite quarries of Massachusetts:

At the Granite Railway quarry, in West Quincy, there is a 15-foot diabase dike striking about $\mathrm{N}$. $75^{\circ} \mathrm{W}$. in which the feldspar is altered

95 Some of the dikes of that part of the coast have been described by $F$. Bascom: On some dikes in the vicinity of Johns Bay, Maine: Am. Geologist, vol. 23, pp. 275-280, pls. 9-11, 1897. See also Keeley, F. J., Notes on some igneous rocks at Ogunquit, Maine, and Pigeon Cove, Mass. : Acad. Nat. Sci. Philadelphia Proc., vol. 66, pt. 1, pp. 3-8. 1914. 
to a white mica. It has a greenish rim. in which the augite is all chloritized. At the Merry Mount quarry on the North Commons, a 5 -foot dike, striking about north, appear's to be a garnetiferous biotite lamprophyre.

The conspicuous feature of the Rockport quarries on Cape $\operatorname{Inn}$ is the large number of basic dikes that traverse them. The geology of Cape Ann has been interestingly described by Shaler and Tarr. ${ }^{96}$ The entire Cape is represented on Shaler's map (Pl. IXXVII) as of granite but traversed at very frequent intervals by diabase dikes and at a few points by quartz porphyry dikes. The basic dikes may be Triassic. They range from 0.25 inch to 40 feet in width. Of 361 observed by Shaler and Tarr 266 lie in the northrest quadrant and more than half in the $45^{\circ}$ between north and northwest. Those writers conchude from numerous observations of dike and joint courses that the number of dikes does not appear to have been determined by the number of incipient fissures afforded by the joints-in other words, "that the conditions which guided the direction of the dikes were probably due to some feature or condition not inherent in the joints themselves." Some of these dikes are shown in Plate XXVII, $A$ and $B$. Their courses are given in the cuarry descriptions. One attains a thickness of 18 feet. They are mostly diabase (soda-lime feldspar, angite more or less altered to hornblende, magnetite, and biotite). One was found to contain both augite and homblende but no mica. The dike matter was erupted through deeply parted joints. Contemporaneous with them was the irregular-shaped injection described beyond and shown in Plate XXVIT, $B$.

The Pigeon Cove diabase porphyry quarry is on a dike of altered diabase porphyry, 18 feet wide, which was represented by Shaler ${ }^{97}$ and Tarr as exposed for half a mile on the hillock west of Pigeon Cove, with a N. $21^{\circ} \mathrm{W}$. course, also as reappearing in Rockport 0.75 mile west of Gap Head with a N. $9^{\circ} \mathrm{W}$. course. Washington ${ }^{98}$ refers to this dike as cutting the quarry pit at Pigeon Cove and describes it microscopically as a labradorite porphyry.

Plate XXV, $B$, from a photograph of a polished ball 2 feet 7 inches in diameter, quarried and finished by Fuller, Foley \& Co., of West Quincy, shows its general character.

This diabase porphyry (specimens D, XXIX, 89, a. b) has a rery dark green or black fine-grained groundmass, with porphyritic feldspars of medium greenish-gray color, measuring from 0.2 to 4.42 inches in length by about 0.78 inch in width. Many of the crystals are from 1 to 2 inches long. Their striation shows plainly.

\footnotetext{
to See Shaler. N. S., The geology of Cape Ann, Mass.: U. S. Geol. Survey Nintl Ann. Rept., pp. 529-611, 1899.

s Op. cit., p. 609 , pl. 7 i.

1s Washington. H. S., The petrographical prorince of Essex County, Nass. J Jour. Geology, vol. T, p. 290, 1899.
} 
The groundmass consists of the following minerals, in descending order of abundance: Iime-soda feldspar (andesine-labradorite) bartly micacized, augite latrely alteres to a green hornblemb ant chlorite, biotite (black mica), magnotitr, and apatite; rarely a little secomdary calcite.

A like of unusual form, composed of fine-grained black hornbende diabase, is exposed at the bottom of the Rockport Granite Co.'s "Deep Pit," near Bay View, on Cape Ann, 195 feet below the surface, as shown in Plate XXVII, $B$, and in more detail in figure 3. It dips north. Its original upper surface, 30 feet above its present surface, is reported as not over 8 ieet in diameter. As shown in Plate XXVII, $B$, the quarry is traversed by two intersecting basic rikes. The one nearest to this mass, 10 feet west of it, is not a hornhencle diabase (ophitic texture with hornblende and biotite), but a lamprophyre without biotite (porphyritic texture with augite). The large like on the east side, which from its dip must traverse the

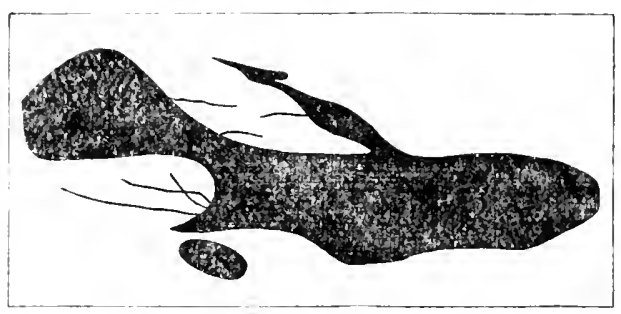

Frguke 3.--Diagrammatic sketch of horizontal cross section of injection of hornblende diabase at Deep Pit granite quarry, near Bay View, on Cape Aun, Mass. Length, nortl to south, 25 feet, and east to west $S$ feet. The fine ramificatious are 3 fper ly 1 incl in greatest size. granite about 80 feet east of the mass, proves to be also a hornblende diabase. The connection of the central mass will, therefore, if excavations proceed deep enough, very probably be found to be with the dike on the east, not with that on the west.

Thin sections of the finegrained rim of one of the dikelets protruding from this mass and of the granite next to it bring out interesting facts. The rim sends out branclies 0.125-0.25 nillimeter long into the granite. In places both rocks are dovetailed into each other. The rim consists of ninute roundish particles of hornblende and incipient crystals of feldspar and fine particles of magnetite. There are crowds of apatite crystals along the contact and a little secondary calcite. In one place the hornblende and magnetite of the dike are thickly disseminated in the sranite; in another both rocks are merger in one containing the minerals of both.

This diabase mass appears to have been injected at the time of the intrusion of the other diabase dikes of the Cape and to owe its shape to an irregular east-west fissure with a northern inclination. That the intrusion probably took place under considerable pressure and heat is shown ly the commingling of the minerals of both rocks along their conticet.

Some interesting dikes were found in the quarries of Uxbridge, New Bedford. Fall River, and Hingham. The elongated porphyritic biotite granite gneiss of the Blanchard quarry in Uxbridge (p. 353) is cut by an amphibolite dike up to 18 inches thick, the schistosity of 
which strikes at an angle of $33^{\circ}$ with that of the inclosing gneiss. This dike consists of feather-rimmed crystals of amphibole up to 1 inch in length in a matrix of biotite with interspersed quartz grains and minute slender crystals or strings of lenses of zoisite. In places, however, along the edgres the matrix is of quartz, biotite, epidote. and oligoclase-andesine. The dike was orignally a porphyritic mica diorite. It cuts dikes of pegmatite and of aplite.

At the sullivan quaries, near New Bedford (p. 285), is an interesting complex of dikes of varions sorts and ages whose courses are shown in figure 4 . The rock is a slightly gneissoid biotite-muscovite granite of light pinkish-gray color.

The rentral rlike A, with northeist course and up to a foot thick, is a darkgreenish chlorite schist (sperimen l) XXX, 121, () consisting of chlorite, mobably after homblende, in parallel arrangement, micacized plagioclase, quartz, and microcline. Its aressory minerals are pyrite, magnetite, purple fluorite, apatite. and biotite, and its secondary minerals epidote, carboirate, and hematite from the maguetite. This dike was evidently originaly a diorite. Itike B. on the south wall, with at $\mathrm{N}$. $70^{\circ} \mathrm{E}$. course and a tip of $60^{\circ} \mathrm{N} .20^{\circ} \mathrm{W}$, orer 2 feet thick, is a lark-grayish mica diorite schist (specinen 121, a), consisting, in descending order of abundance, of andesine, biotite. epidote, and muscovite. This was originally a mica diorite. bike $C$, on the north wall,

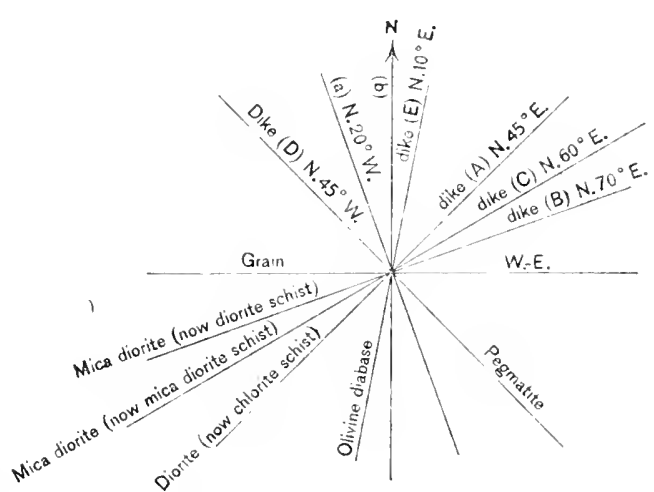

Figere 4.-Structure and dikes at Sullivan quarries, New Bedford, Mass. with a N. $60^{\circ}$ E. comrse and vertical dip, up to 3 feet thick, is a black finesrained mical diorite schist (specimen 121, f), consisting, in descending order of abundance, of biotite, oligoclase, microcline, quartz, and epidote. This aiso was originally a micu (iiorite. It differs from dike $B$ in being more micaceous and in containing no muscorite. The edge of this dike (specimen 121, g), for a thickness of a few inches, consists of brecciated grayish feldspars up to 0.3 inch in diameter in a matrix of hiotite. At the extreme edge this breccia passes into a mass of the same feldspar with a little quartz and still less biotite. The more glassy rim of the dike resisted the pressure which brecciated its inner border and converted its central part into a schist. Dike D, near the west wall, with a northmest course and steep dip, 3 inches thick, is pegmatite. It intersects the central chlorite schist (diorite) dike. Finally, dike E, on the west wall, with a N. $10^{\circ} \mathrm{E}$. course, up to 2 feet thick, is a diabase (specimen 121. e) with ophitic texture, consisting, in descending order of abundance, of andesine, pyroxene, serpentine (probably after olivine), and magnetite or ilmenite with a little carbonate and biotite. This was presumably an olivine diabase.

The evidence from these dikes shows that the granite was injected with dikes of diorite and mica diorite. Later both the granite and 
the dikes were crossed by pegmatite. After dynamic metamorphism had altered the diorites to schists they were traversed by a diabase dike in which the only change has been the serpentinization of the olivine and the micacization of the andesine.

Another basic dike in these quarries is an altered but not metamorphosed lamprophyre, in the gneissoid biotite granite of the Beattie \& Wilcox quarry, at Fall River (p. 283), which Whitman Cross, of this Survey, determines as rogesite. It has much augite and brown hornblende, biotite, and magnetite in a feldspathic base, probably of orthoclase, also a few porphyritic crystals of olivine altered to serpentine.

There is also a slightly altered diabase dike crossing the aplite of the Miller quarry, in Hingham (p. 338).

The reddish biotite granite of the Redstone quarry, at Westerly, R. I., is cut by a 6-inch dike of porphyritic olivine diabase, probably of Triassic age. Near by in the same granite is a vertical meandering mass of coarse biotite schist with krolinized feldspar which is either a basic segregation elongated in the direction of the flow or else a very ancient metamorphosed dike.

BASIC SCHISTOSE DIKES.

The dikes ordinarily occurring in granite are either acidic, including pegmatite, aplite, and granite proper, or basic. If a granite after the intrusion of such dikes is itself subjected to metamorphism so as to become schistose-that is, a gneiss-then these various dikes will also become more or less schistose. In the granite of Milford, Mass., however, there are schistose basic dikes without an equally gneissic or a parallel gneissic structure in the granite.

At the Cutting quarry (fig. 82) the west wall is formed by a vertical dikelike mass of biotite schist 2 feet thick striking N. $25^{\circ} \mathrm{W}$. The east wall is formed by a heading of almost identical strike, $\mathrm{N}$. $20^{\circ} \mathrm{W}$., but dipping $70^{\circ} \mathrm{E}$. As shown in the figure, neither of the flow directions nor the trend of rift or grain corresponds to the strike of the schist dike. The only corresponding structure is that of the heading and the inclosing walls of the dike. At the West quarry, $1 \frac{1}{2}$ miles south-southwest of the Cutting quarry, there are two dikes of similar schist, one striking N. $67^{\circ} \mathrm{W}$. and dipping $65^{\circ} \mathrm{NNE}$., the other striking about $N .45^{\circ} \mathrm{W}$. with nearly rertical dip. The nearest parallel structure is a joint striking N. $60^{\circ} \mathrm{W}$. and dipping $47^{\circ} \mathrm{SSW}$. At the Massachusetts Pink quarry 0.6 mile southwest of the Cutting quarry, there is another schist dike, 2 feet thick, striking N. $3^{\circ} \mathrm{W}$. and dipping $55^{\circ} \mathrm{E}$., without other corresponding kinds of structure. The general schistosity of all these dikes is parallel to the joint faces which inclose them, and no merging between granite and schist was observed. Emerson and Perry (p. 340) note the rudely parallel films 
of biotite in the granite, which give it a gneissoid look but which seem to be partly due to flow structure, and they note the undulatory extinction of the fractured quartz particles as showing a state of strain. The granular structure of the quartz areas is very noticeable on a polished face, and this very possibly resulted from the pressure which converted the dilies into schist.

In thin section the fine-grained dark greenish-grily schist of the Cutting quarry dike is seen to consist of biotite, quartz, epidote in roundish grains from the alteration of feldspar, and a little pyrite. The slightly more greenish schist of the dike at the West quarry consists of hornblende, quartz, biotite, epicote, and zoisite from alteration of feldspar, a brownish chudy mineral (leucoxene?), and prite altered to limonite. Both are evidently altered dikes of mica diorite-that is, diorite schist.

Emerson and Perry regard these dikes as a "basic differentiate of the Milford granite" (p. 3i0, footnote 51).

At the Sullivan quarry, in New Bedford, Mass. (p. 285, fig. 4), a very slightly gneissoid biotite-muscovite granite is cut by a mica diorite schist dike, the schistosity of which was evidently also due to the pressure of the dike walls. In these places the dike material was intruded between parted joints in the granite. It is evident that the change of the eruptive into schist and the alinement of its particles with reference to the inclosing walls were brought about chiefly by compression which, although sufficient to metamorphose the dikes, affected the granite but slightly; nor was the vertical pressure sufficient to plicate the dike or its inclosing walls.

Thus a basic dike traversing a mass of granite in a highly inclined position may under lateral compression become schistose without the inclosing granite acquiring a corresponding schistosity.

Soon after the first publication of the above description Clough, Crampton, and Fleet, of the British Geological Survey, found similar dikes in Scotland which they define as foliated by dynamic metamorphism under the pressure of the inclosing granite. ${ }^{99}$

EFFECT OF BASIC DIKES ON GRANITE.

Generally these dikes produced little or no effect upon the granite into which they were injected, but in some places the heat of the dike material developed minute cracks in the quartz and feldspar, in which secondary minerals were formed, darkening the granite, or minute particles of hematite were disseminated in the feldspars, reddening the stone. In other places the granite on either side of the dike became closely fissured in a direction parallel to it.

Thus at the Robertson quarry, in Franklin, Maine, the granite for a space of 10 feet on each side of a vertical 3-foot diabase dike is

90 See Clough, C. I.. Crampton, C. B., and Flcet, J. S., The augen gneiss and Moine sediments of Ross-shire: Geol. Mag., new ser., decade 5, vol. 7, pp. 337-345, 1910. 
altered from medium to dark gray and the rock is filled with close joints dipping at low angles. In thin section the quartz particles and some of the feldspars are crossed by roughly parallel cracks $0.25-1.25$ millimeters apart.

At the Flat Ledge quarry, in Rockport, Mass., the granite on either side of a diabase dike is darkened. A thin section of the darkened rock shows it to be crossed by minute parallel or converging fractures, 0.004-0.04 inch apart. The intervening space is crowded with angular slivers. the walls of the fractures are coated with chlorite, and the adjacent feldspars are altered to mica.

At the Tonella (King) quarry, in Milford, N. H., the granite is cut by a 2-foot 6 -inch dike of augite camptonite. For 8 feet on one sicle of the dike the granite has a marked pinkish tint due to minute specks of hematite in the feldspar. At the Pease quarry, in the same town, the granite has been reddened and darkened for a thickness of $x$ f feet, apparently by basic dikes. (See p. 185.)

The light-gray granite at the Bailey quarry, in Allenstown, N.H. (p. 193), is cut by a hornblende diabase dike 3 to 4 feet thick, and the granite for 14 feet on one side and 2 feet on the other has become greenish gray owing to the slight chloritization of its plagioclase feldspars.

The granite for a foot on each side of a basic dike in Ryegate, Vt., has elose joints parallel to the dike. C. H. Richardson has published a photograph of a zone of laminated (close-jointed) granite adjacent to a basaìt dike exposed in a newly opened quarry in Woodbury, Vt. ${ }^{1}$

\section{SEGREGATIONS ("KNOTS").}

BASIC SEGREGATIONS.

Quarrymen know too well that granite is commonly disfigured by gray or black "knots" of circular or oval outline, ranging in diameter from 0.5 inch to 3 feet and exceptionally even 10 feet. These were studied by geologists long ago. They are finer grained than the granite in which they occur, contain nearly 10 per cent less silica, much more black mica or hornblende (which accounts for their darkness), and a little more soda-lime feldspar, and their specific gravity is about 0.09 per cent higher. ${ }^{2}$

In none of the knots is there a definite boundary separating them from the granite, except such as is caused by the change in the pro-

${ }^{1}$ See Vermont State Geologist Ninth Rept., pl. 67, a, 1914; also p. 151 of this bulletin.

2 Phlllips, J. A., On concretionary patches and fragments of other rocks contained in granite: Geol. Soc. London Quart. Jour., vol. 36, pp. 1-22, pl. 1, 1880. Merrill, G. P., On the black nodules or so-called inclusions in the Maine granite: U. S. Nat. Mus. Proc., vol. 6, pp. 137-141, 1883. Grimsley, G. P., Basic segregations: The granites of Cecil County in northeastern Maryland: Am. Soc. Nat. Hist. Jour., April and July, 1894. Daly, R. A., Basic segregations: The geology of Ascutney Mountain, Vt.: U. S. Geol. Survey Bull. 209, p 164, 1903. 
portionate abundance of the darker minerals. The cause of knots is not perfectly understood. They are collections (segregations) generally of the darker, heavier iron-magnesia minerals that were formed before the rock passed into a crystalline state.

Plate XIII, A, shows 12 knots in the vertical cuts at Crabtree Havey's quarry, in Sullivan. Me. As the strength and durability of the stone are in no wise affected by the "knots," the blocks containing them are used for curbing, crossings, or other constructions where color is not taken into consideration.

A thin section of at riy lark waly hot from thes quary shows a much greater abundance of biotite than the granite. The feldspar and the biotite particles in the knot measure up to 0.5 millineter $(0.02$ inch $)$, whereas in the granite the feldspar measures up to 2.25 millimeters and the biotite up to 0.75 millimeter.

A serreation from the Palmer quary, on Vinalhaven, Maine, is of mediumgray shade, with a very fine grained grounimass inclosing porplyritic bufipinkish feldspars and smoky quartz particles up to about 0.25 inch in diameter. The groundmass consists of quartz, potash feldspar (miteocline), sodalime feldspar, black mica, and holnblende in proticks ranging in size from 0.075 to 0.5 millimeter. The porphyritic particles are of quartz, potash feldspar, or sola-linle feldspar, and hornblende, and measure from 0.75 milli meter up.

A very dark, almost black knot from the Sands quarry, also on Vinalhaven, innsists of crowled particles of hornblende and biotite, which compose onelaif the knot, the rest being mostly soda-lime feldspar and quartz. A spherical knot at the same quarry was $2 \frac{1}{2}$ feet in diameter; a similar one, at the Webster quary, niso in Vinalbaven, was 5 feet in diameter. One at the Nount Waldo quarry, 6 by 3 feet, consists of a medium-gray groundmass with porphyritic feldspars up to $0.75 \mathrm{inch}$ and biotite scales up to 0.05 inch. One at the Andrews quarries, near Biddeford (1). 275), is 10 feet long. At another Fibleford quarry the knots are egg-shaped and occur in clusters. It the Tayntor quarry, in Hallowell, there is a belt 5 to 25 feet wille, with a course N. $10^{\circ}$ F... in which knots are abmudant. This crosses the flow strncture, which strikes Y. $35^{\circ} \mathrm{WT}$.

The segregations in the granite exposect in the quarries at Quincy, Nass., are of three kinds:

One is very fine grained, aplitic, dark bluish grav, with a matrix of potash feldspar, quartz, and more or less soda-lime feldspar (albite to oligoclase albite), with particles from 0.025 to 0.3 millimeter, containing porphyritic crystals of aegirite (with some riebeckite) up to 0.84 by 0.09 millimeter, which appear as if corroded. Zircon, magnetite or ilmenite, and abundant apatite wecur as accessories. There are also minute crystals of riebeckite and titanite, with secondary limonite and carbonate. The two other linds belong in the acidic group described beyond.

The dimensions of the large knots given in the quarry descriptions were obtained from the foremen. It is assumed that the knots are segregations, not inclusions. The dimensions range from 0.5 inch to 2 feet by 1 foot 6 inches, 2 feet 6 inches by 2 feet 6 inches, 3 feet by 4 inches, and 6 feet by 2 feet. The knots are usually small and roundish or elliptical. 
ACIDIC SEGREGATIONS.

Segregations in granite consist generally of the darker. more ferruginous minerals, but some are lighter or of the same shade as the surrounding granite. Among these are two varieties in the Quincy granite.

Those of one variety are medium grained and medium gras, lighter or of the same shade as the inclosing sranite. These are identical with the granite, but the orthoclase tends to complete its crystals. One such knot contains a complete section of an aegirite crystal in the center of a quartz area many times its size. Another has secondary orange fibrous hornblende growing on aegirite. Zircon and fluorite are accessory. The other variety comprises some muddy yellow to greenish lnots consisting of potash feldspar (orthoclase) minutely intergrown with soda-lime feldspar, in twins from 0.2 to 1 millimeter long, and guitz with aegirite and riebeckite, which usually appear to fill spaces bewwen the other minerals. The soda silicates art mure or less altered to fibrous muscorite and carbonate; the feldspars are also streiked with white mica and contain secondary epidote. The usual magnetite, apatite, and riebeckite are present.

Segregations are not uncommon in the granite of Rockport, Mass., but at Halibut Point, the extreme north end of Cape Ann, in the Babson Farm quarry, there is one of unusual character. It is 8 by 1 by $2 \frac{1}{2}$ feet and consists mainly of feldspar and quartz. The feldspar is a somewhat kaolinized light-grayish potash feldspar (microcline) minutely intergrown with soda-lime feldspar (oligoclase-albite) and containing a fer particles of quartz. The clearage of the feldspar has in places a marked curvature. The quartz is amethystine smoky, in particles up to 2 feet across, and has cavities from 0.00285 to 0.0285 millimeter in diameter. In the center of this knot is a mass. 6 by 2 inches, of a yellow-brownish mineral of the augite group. which .Johannsen determines as bronzite, a silicate of magnesia with 60 per cent of silica and 40 per cent of magnesia.

\section{ORBICULAR GRANITE.}

The white quartz (muscorite-biotite) monzonite of Bethel, Vt., is crossed on the east side of the Ellis quarry (see p. 158 and fig. 36) by a belt a few feet thick which has a marked flow structure consisting of rertical micaceous bands 0.5 inch or less wide, a foot or more apart. and with a northerly strike. The micas in these bands tend to arrange themselves about the quartz and feldspar particles and are roughly parallel. Near the granite surface there is a branching mass of wrinkled bronze-colored micaceous material a foot thick lying in the plane of flowage. Biotite appears to be the chief constituent in this mass. In thin section it consists of coarse stringers of an olive-greenish biotite, more or less completely surrounding particles of quartz and soda-lime feldspar. There are also small 
scales of muscovite penetrating the quartz and feldspar particles. In this same flowage belt there are crowds of elliptical discoid nodules of bronze-colored mica from 0.5 to 2 by 1.5 inches and about 0.2 inch thick. The surfaces of these disks are either longitudinally or concentrically corrugated. Most of these nodules are discoid. but some of the smaller ones are nut shaped, resembling those in the well-known butternut granite of Craftsbury and Northfield. Vt." Aside from their discoid form, the noticeable features of the Bethel nodules are that they lie in sheets parallel to the flow structure and that the major axes of the disks are parallel to the micaceous flowage bands. Plate III, $A$, is made from a photograph of a hand specimen containing one of the larger disks. The white quartz monzonite of Plymouth, Vt. (p. 161), also contains a few of these discoirl nodnles.

The attention of geologists was first called to the nodular granite of Craftsbury ("Craftsbury pudding granite") by Hitchcock and Hager in 1861 . It was next described by Hawes in $1878^{*}$ and in greater detail by Chrusthoy in $1885,{ }^{5}$ and again by the same geologist in an elaborate monograph in $1894 .{ }^{6}$ He found that the nodules contained orer twice as much calcite as the granite. As both the granite and the nodules of Craftsbury differ from those of Bethel, his inferences do not exactly apply to the Bethel nodules. But a conchusion of Frosterus from the study of a nodular granite in Finland applies well to that of Bethel and shows the real significance of its nodules. It is that the nodules are basic segregations lying in a more basic part of the granite, indicating that the orbicular structure is simply a basic flowage band ("Schliere") and that the nodules themselves lie in this as still more basic segregations."

The nodules in orbicular granite vary greatly in composition, size, and structure. Orbicular granites have been described from Bohemia, California, Corsica, Finland, France, Germany, Greece, Ireland, North Carolina, Norway, Ontario, Portugal, Rhode Island, Sardinia. Scotland, and Sweden. The literature of the subject is already large, embracing 47 papers and probably more. ${ }^{8}$

\footnotetext{
${ }^{3}$ See Hitchcock, Edward, and others, Report on the grology of Vermont, vol. 2, pp. 563, 564, 721, 1861 ; also Dale, T. N., U. S. Geol. Surrey Bull. 275, p. 90, 1906 ; l'elkins, G. H., Vermont State Geologist Fifth Rept., p. 108, pl. 32, fig. 2, 1906.

4 Hawes, G., Geology of New Hampshire (by C. H. Hitcheock), vol. 3, pt. 4, p. 203, pl. 11 , fig. 4,1878 .

$\Xi$ Chrusthor, K. D., Note sur le granite variolitique de Craftsburs en Imérique: Sor. min. France Bull., vol. 8 , pp. 132-141, 1885 .

- Ueber holokrystalline makrovariolitische Gesteine: Acad. imp. sci. St.-Pétersbourg Jém., ser. 7, vol. 42, No. 3, Pudding granit vou Craftsbury, Vt., pp. 132-146, pl. 2. fig. 5 , and pl. 3, fig. 20,1894 .

7 Frosterus, Benjamin, leber ein nolles forkmnnis ron kuengranit unferu Wirvik bei Borga in Finland, nebst Bemerkungen über älinliche Bildungen: Min. pet. Mitt., vol. 13, pt. 3 , p. $18 \pi, 1893$.

s See Zirkel, F., Lehrbuch der Petroglipbie, 2d ed., vol. 2, Kugelbildung, pp. 50, 51, 1894 ; also Rosenbuseh, H., Mikroskopische Plysiographle der Mineralien uud Gesteine, 4th ed., rol. 2, Kugelstruktur, pp. S5-94, $190 \overline{\text { T. }}$
} 
GEODES.

Small cavities lined with crystals occur in granite. They are uncommon in the New England quarries, but at the Bodwell Granite Co.s quarry, near Jonesboro, Maine (p. 268), there are several abont a foot in diameter, lined with quartz crystals and epidote. The center of some of these is filled with calcite in very obtuse rhombohedra halt an inch across. The large aplite vein at the same quarry has many irregular openings lined with crystals of feldspar and muscovite. It the Machias Granite Co.'s quarry, near Marshfield, Maine (1. 271), there are several geodes up to 6 inches in liameter, lined with crystals of feldspar and amethyst, with the central space filled with chlorite. epidote, fluorite, and calcite.

At the Redstone quarry, Conway, N. H. (p. 168), there are lenticular geodes, mainly of intergrown quartz and feldspar surrounded by a half-inch band of aplite. These geodes are lined with crystals of smoky amethystine quartz and orthoclase incrusted with chlorite and calcite. Some obtuse rhombs of calcite are 0.5 inch wide.

Such cavities are attributed to bubbles of steam or gas that were in the rock while it was molten and that gave room for the growth of crystals of the minerals of the granite and its accompanying fluorite and later became filled with secondary chlorite, epidote, and calcite.

INCLUSIONS.

Not to be confounded with "knots," although some of them are equally dark and occur near by, are irregular or angular particles of various rocks generally schistose, which the granite incorporated into itself during its intrusion. They can usually be distinguished from the knots by their different microscopic texture.

Inclusions are important, for they are specimens of the rocks that originally overlay the granite and they indicate the relative age of the intrusion. The process of the formation of an inclusion of mica slate is shown in figure 11.

In Connecticut, at the Stony Creek quarries, the inclusions consist of diorite gneiss and mica diorite gneiss. At the Hoadly Point east quarry an inclusion of mica diorite gneiss appears to have been elongated in the direction of the flow structure. Inclusions abound at the Millstone quarry (p. 396). One of banded biotite gneiss, 20 by $8 \frac{1}{2}$ inches, is shown in figure $84, b$. Another of the same gneiss, 20 by 20 feet, has a very iregular outline, with small outlying fragments and adjoins a 6 by 3 foot mass of pegmatite with particles as much as 5 inches across. This mass and a smaller inclusion are shown in figure $90, d$. The granite is somewhat banded about the large inclusion Another, near the northwest end and bottom of the quarry, measures 35 by 25 feet. It is a black diorite gneiss (specimen $\mathrm{D}, \mathrm{XXX}, 6, h$ ) 
consisting of oligoclase-andesine, hornblende, quartz, and biotite, witl accessory titanite. It is crossed by quartz veins, some of which start at the granite, others within the granite. A rertical pegmatite dike, 3 to 5 feet wide, in the upper granite mass referred to, contains an inclusion of biotite gneiss about 5 feet by 6 inches, with its long axis in rertical position. (See fig. 90, a.)

In the Maine quarries the inclusions range from an inch to 40 feet in length. Part of the jagged lower edge of an inclusion in granite at 1 reeport (p. 211) is shown in Plate $X Y, B$. It is a mass of hinte schist between 30 and 40 feet long and 3 feet thick, striking north and dipping $35^{\circ} \mathrm{E}$. In quarrying, this mass has been cut from east to west. Under the microscope this is a coarse biotite-quartz-feldspar (oligoclase) schist, probably of sedimentary origin.

The following inclusions were noticed in the Massachusetts granite gneiss and granite quaries:

The muscovite-biotite granite gneiss of the Rafferty quarry, in Groton (p. 308), contains several inclusions, the largest of which. triangular in outline, measures 30 feet on one side and 8 feet on another. This rock (specimen D. XXX, 100, a) is a dark-gray biotite granite gneiss with porphyritic feldspars up to 0.6 inch. Its quartz is granulated like that of the inclosing gneiss. Both gneisses are crossed by pegmatite dike, and aplite occurs also in both.

The muscovite-biotite-quartz monzonite gneiss of the Palmer quarry, in Testford (p. 312), has a lenticular inclusion, 3 feet by 3 inches, of very fine grained, evenly foliated quartz-biotite schist with some cloudy particles (much kaolinized feldspar?) also a little muscovite and zoisite. This rock may be of sedimentary origin. The gneiss at the Merrill quarry, in the same town (p. 310), also contains small dark finely banded inclusions.

The quartz monzonite of Barker Hill, in West Townsend (p. 314), has inclusions up to 4 feet across of a fine-grained biotite gneiss, probably a quartz-mica diorite gneiss like those in the quartz monzonite of the O'Rourke quarry, in Brookline, N. H., about 5 miles to the northeast (p. 192).

'The fine-grained muscovite-biotite granite of Becket (p. 281) contains an 8 by 10 foot inclusion of a coarse muscovite-biotite granite gneiss.

The following inclusions occur in the New Hampshire granite quarries: At Concord, in the center of the now abandoned Crowley quarry is an inclusion of dark banded biotite-muscovite-oligoclase gneiss of slight purplish hue. It was originally 30 feet high and pointed at the top. It measures 30 feet in diameter at the base, which is nearly round on one side but rectangular on the other. A 2-inch pegmatite dike crosses the schistosity of the gneiss but ends abruptly at the granite contact. Another part of this inclusion consists of por- 
phyritic granite with feldspars an inch long. At Milford, in the Daniels quarry, a roughly diamond-shaped inclusion of gneiss, over 3 feet in diameter, has a flow structure about it parallel to its surface, showing that while the plastic material was adjusting itself to the foreign body a zonal rearrangement of the mineral constituents of the granite took place.

Among the notable features of Vermont granite quarries are the schist inclusions. Those at Barre have been briefly referred to by Finlay. ${ }^{9}$ Eighteen schist inchusions were noticed by the writer in the Barre quarries. There are three at quarry 32 (Pl. II); one of these, 25 by 10 by 10 feet, has a foliation striking N. $30^{\circ} \mathrm{W}$. and dip. ping $60^{\circ} \mathrm{E}$.; another is 20 by 8 by 5 feet. The granite is slightly darker for a space of 7 feet from these inclusions. At quarry 25 several measure up to 8 by 2 feet. At quarry 8 two are 10 by 6 by 2 to 3 feet. One at quarry 6 is 20 by 5 feet. One at quarry 10 is 30 by 3 feet, tapering. The largest was at the Boutwell quarry, No. 1, measuring 57 by 10 by over 6 feet, with a foliation striking N. $10^{\circ} \mathrm{E}$. and dipping $55^{\circ} \mathrm{W}$. Another, 10 by 8 feet, has a foliation striking north and dipping west. Some of these do not seem to have suffered much horizontal displacement, for their foliation nearly agrees with that of the schist capping. In others it differs greatly.

The Iarger Bontwell quarry inclusion was examined in detail. Parts of it are lustrous dark-gray muscorite-biotite-quartz schist spangled with biotite flakes 0.15 inch long and witl garnets measuring about 0.05 inch. Parts of it consist of small beds of medium greenish-gray fine-grained quartzite (grains up to 0.2 inch) alternating with dark beds of quartz-biotite schist. The quartzite bands contain plates of green hornblende (up to 0.75 by 0.37 millimeter) and larger garnets which inclose the quartz grains of the rock. The schist bands contain similar plates of biotite lying transverse to the bedding and the foliation. Both kinds of bands contain lenses of carbonate (up to 0.37 millimeter) and irregular particles and crystals of zoisite and epidote. As the schists of Barre away from the granite are spangled with various minerals (see p. 123) it is hardly possible to determine which if any of the isolated minerals in this mass was formed at the time of the granitic intrusion. The hornblende and garnet may have been. A few inches of the under side of this inclusion consist of interbanded sranite and schist, the schist having evidently at the time of the intrusion been broken into slivers along its schistosity, and the semiliquid granite having been forced in between them. The specimen in Plate III $B$, at the left, is from this point. It shows two minute dikes of granite, 0.5 to 1.2 inches wide, penetrating the schist and ramifying. The main dikes follow the foliation, but the minor branches form very acute angles with it and taper out. A thin section made across one of these little dikes and the inclosing schist shows the former to be the typical biotite granite of Barre and the latter a quartz-muscovite-biotite schist spangled with biotite plates (up to 0.1 inch). The quartz of the granite shows marked strain effects. The demarcation between granite and schist is sharp, and no effect of granite npon schist appears.

? Finlay, G. I., The granite area of Barre, Vt.: Vermont State Geologist Third Rept.. p. 51,1902 . 
At the Bailey quarry (No. 6, Pl. II) an inclusion lies very near the schist capping. As the bedding of the inclusion strikes nearly east and that of the capping $\mathrm{N} .200^{\circ}-60^{\circ} \mathrm{E}$., the inclusion has been revolved. Both capping and indusion have been shattered and injected with aplite and pegmatite.

At the Morrison quary, on Blue Momntain, in Ryegalte, two schist inchusions were noticed measuring $8 \mathrm{by}+$ feet and : feet by 1 foot. The edge of the larger one is injected with granite, which fills lenticular spaces, as shown in Plate III. B. at the right. In another specinen the schist has sharp plications. of inches high, with lenses of smoky quartz parallel to them. but the noarest escge of the inalusion is nearly a plane surface.

A thin section, 1.6 hy o.t inchl, aldoss the edge of this inchsion shows at little graute dike. the quartz monzonite of the quarry, 0.3 to 0.6 inch thick, with schist on both sitles. The schist is a quartz-micorochene-biotite solhist with

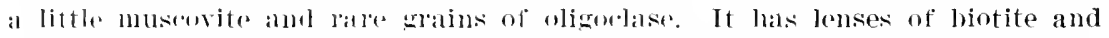

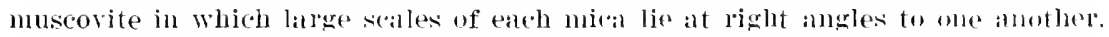
The sheets of arities in the guartz of the grable ale aloout palallel to the comrse of the dikelet and the foliation of the schist. 'Two other sections of the schist show much apatite in minute crystals ant rare particles of allanite The sheets of cavities in the quartz particles of the schist are at right angles to its foliation and do not lenetrate the quartz of the granite.

Although not connerted with any quarry certain granite boulders on a shoulder of Miles Momntain, in Concord. in northeastern Vermont." are of interest because of their inclusions of sedimentary schist still preserving hedding planes and cleavage foliation.

The greneral inferences from atl these observations of inclusions are as follows:

Inclusions in granite rock may consist of any igneons or seelimentary rock intruderl by the granite.

The ragged edges of schistose inclusions and the interbanding of granite with slivers of schist afford evidence of the lacerating effect of the intrusion upon such rorks.

The effect of heat upon the minerals of inchrled metamorphic rocks was very slight incleed.

Inclusions in granite are likely to be associated with pegmatite ant aplite.

The plastic granite in arlapting itself to rigid inclusions of lower temperature usually rearranged its mineral constituents in zones abont the inclusions, as in flow structure.

GNEISSIC STRUCTURE.

Gneissic structure consists of an alinement of the constituents of : granite in more or less parallel planes, giring to the rock a schis-

${ }^{10}$ See Dale, T. X., U. S. Geol. Survey Rull. 589, p. 54, 1915.

$105709-23-6$ 
tosity, as shown in Plate XXIX, $A$, so that it can be split into irregular, slablike pieces of minute or larger dimensions.

According to Gregory, ${ }^{11}$ the sheets may be all of the same material or may be of different materials; for instance, sheets consisting largely of biotite and feldspar may alternate with sheets that are prevailingly quartz. Granite gneisses have been formed from granites, the change being chiefly a rearrangement of the mineral particles. The micas and other minerals are drawn out along well-marked planes, and new micas, both muscovite and biotite, have been produced. Gneiss may also contain tourmaline, garnet, and other minerals that are not generally fonnd in granite. The lifference in appearance between the granite and the gneiss will depend on the amount of metamorphism-chemical and crystalline action under moisture, heat, and compression--the rock has undergone. Occasionally the two types will appear in the same quarry. as in the Stony Creek region [Commect:cut].

The general cause of gneissic structure is crustal compression.

\section{RUSTY STAIN AND ITS CAUSES.}

Rusty (limonite) staining ("sap") along the upper and lower parts of the sheets and also along the joints and headings is common in granite quarries, althongh some quarries are almost entirely free from it. The concentric inward growth of "sap" from the close joints of a heading is well shown in Plate XVII, $B$. The zone of stain along the sheets is from half an inch to 12 inches, exceptionally even 24 inches, wile on each side of the sheet parting. Its width, however, decreases gradually from the surface sheets downward. In places the "sap" consists of two parts-an outer dark brownish zone from 0.75 to 1.5 inches wide, and an inner more yellowish zone from 0.25 to 0.5 inch wide Generally, howerer, the stain diminishes gradually from without inward.

When the stone is intended for faring or trimming buildings the presence of "sap" is a serious matter, as the stained edge of each block must be split off, which adds somewhat to the cost of production. This stain has been supposed to be always due to the oxidation of the ferruginous minerals of the granite, biotite, hornblende, magnetite, and pyrite, but some thin sections do not bear out this theory.

Thus one from the Tayntor quarry, near Hallowell, Maine, shows that the stain has insimuted itself into the clearage planes and cracks of the feidsiar and muscovite and in the cracks of the quartz, forming minute deposits of limonite therein, but the biotite scales and magnetite particles are generally un related to the stain. A section, taken from the "top" of the Hopewell quarry, in Sullivan, Maine, where the fresh rock has a bluish tinge and the "sap " a general buff color, shows that the staining extenks along the clearages and fissures and in the spaces between the minerals, but that it does not appear in connection with the biotite scales, although it is increased by the magnetite particles. A section from the upper part of High Isle, sonth of Rockland, Maine, where the dark "sap" is 1 inch wide and an innor lighter part is 0.2 inch

${ }^{11}$ Gregory, H. E., U. S. Geol. Survey Bull. 4S4, pl. 16-17, 1911. 
wide, shows a series of roughly parallel cracks crossing the "sap" verticalls, with subsidiary transverse cracks. These cracks ant the cleavages of the feldspar and the spaces between the minerals are stained, but the staining has no'connection with the biotite, and some large particles of mannetite are scarcely touched by it. (See fig. 5.)

Limonitic stain is rery abundant in the quarries at Rockport, Mass., where its hrightness has led to the architectural nse of the stone showing it. Thin sections of the Rockport "sap" show the stain along the bomclaries of particles and in all cleavage and rift cracks as well as in streaks across them. It is conspicuous about hornblende and magnetite particles. The stain has also proceeded from the cracks inwarl into the intervening areas. The zonal arrangement of the stain is also noticeable. The medium gray of the fresh granite becomes at first greenish toward the surface: this is followed by a zone of deep yellowbrown; and that in turn by a much lighter yellowhrown. The greenish zone is that of adrancing limonitization. the next of maximum stain, and the outside is that of delimonitization, or deoxidation due to organic acids, and made still lighter by the greater kaolinization of the feldspars of the surface. In

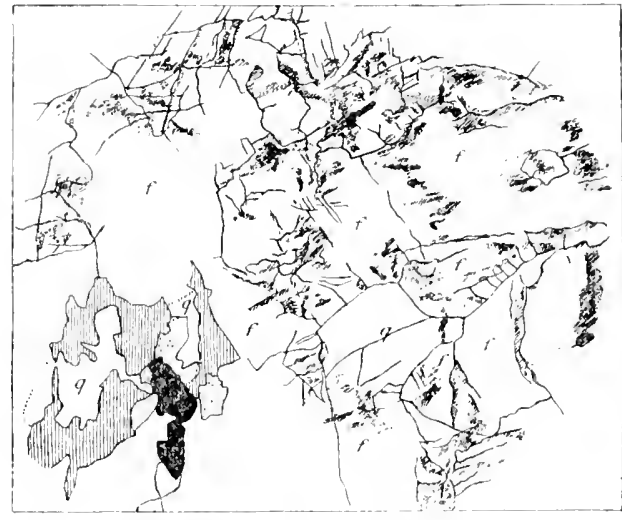

Figure 5.-Minerals in thin section (3.76 by 4.23 millimetels $=0.15$ by 0.17 inch) of biotite granite from lligh Isle in Kuox County, Maine, showing "sap." The ramifications of "sap" (limonite stain) across and around feldspar and quartz particles (marked $f$ and $q$ ) are independent of the biotite and magnetite particles. Fine-lined parts are biotite; fine-dotted areas are titanite; large hlack masses are magnetite. Some of the vordrrs of quartz particles are shown by dotted lines. some Rockport specimens this outer paler zone is corered by an extremely thin crust of bright yellow-brown, as if a secondary infiltration of limonite had taken place after the deoxidation. Although in the granite of Rockport the ferruginous minerals have furnished some of the stain, it is donbtful whether they conld have supplied enough to color so many sheet and joint surfaces so intensely.

A specimen of granite from the Dell Hitchcock quarry, Quincy, Mass., has a rim of "sap" from 1 to 1.5 inches wide, of which the inner tenth to three-tenths is dark brown and the rest light brown. The inner boundary is very uneven, the rusty part having encroached upon the granite in roundish protuberances. Some of the limonite streaks start from aegirite particles. In a piece from the Wigwam quarry the stain proceeds from magnetite particles and not from the 
black silicates, but some of the magnetite particles are within crystals of riebeckite. In a specimen from the pea-green granite of the Lepage quarry. out of a rusty band 1.5 to 2 inches thick. an inner 0.2 inch is deep brown, but the fresh granite next to it is dark-greenish. The rest, or onter part, ranges from a rery light brown to cream-colored at the surface. The stain proceeds from the black silicates and from the vicinity of zircon crystals, many of which are associated with iron in some form. In aegirite crystal is one-half hematite. The central parts of others are altered to limonite before the onter. A thin section of discolored granite from Westerly, R. I.. also show: the rust stain arising from biotite and magnetite particles (1). +13).

In one of the fine-grained granites of Milford, N. H. (Hayden (quary, now abandoned), there are scattered porphyritic crystals of black mica up to 1 inch long, 0.5 inch wide. and very thin, around which. after exposure. a circle of slight limonitic stain 20 inches in diameter appears on the rift surface. The biotite probably contains, as usual. small particles of magnetite.

Another kind of limonitic staining. exen more serious in its consequences, appears on fresh faces of granite. either in the quarry or after its removal. This consists of sporadic rusty stains from 0.5 to 1 inch in diameter, arising from the oxidation of minute particles of some undetermined ferruginous mineral, possibly al. lanite. Such stains generally, however, arise from pyrite.

Daly ${ }^{12}$ describes a bluish-gray syenite from Windsor, Vt. (feldspar, quartz, hornblende, augite, biotite), that after 24 hours' exposure assumes a greenish tinge, which eventually becomes more or less brownish. He has demonstrated by experiment with oxygen that this change is clue to the oxidation of minute blackish granules of ferrous oxide within the feldspar, giving a yellow which, in combination with the original bluish tint of the feldspar, produces a green. The large columns of the library of Columbia University. in New York, are made of this rock. The quartz diorite of Alfred, Maine (1). 272) becomes Ereenish a fter one or two years' exposure; and the gray hornblende granite of the Blood Ledge quarry, in Rockport. Mass. (p. 300), becomes olive-green in three or four hours after wetting.

fome of the green granites, as shown on page 76 . owe much of their color to limonite stain proceeding from minute allanite crystals. (See fig. 6.)

Rusty discoloration in granite is thus of five kinds-that due to the infiltration of ferruginous water; that due to the oxidation of the generally disseminated ferruginous minerals (biotite, hornblende,

${ }^{12}$ Daly, R. A., The geology of Ascutney Mountain, Vermont: U. S. Geol. Survey Bull. 209 , pp. 51-53, 1903. 
aegirite. magnetite, and pyite ${ }^{13}$ by nonfermuginom- water : that due to the oxidation of sporadic ferruginous minerals; that due to the oxidation of ferrons oxide within the feldspars: and finally that due to limonite from the alteration of the iron compommls in mimute crystals of allanite. ()f comse, some ruty stain may hava arisen fron several of these somres combined.

The water that produces the rust-colored bands reaches the sheet partings thromeh the intersecting joint partings and then travels between the sheets and permeates the lower surface of the overlying sheet and the upper surface of the underlying sheet by appillary attraction.

General cirant's tomb in New Tork is an unfortunate example of the discoloration of granite after its exposure to the weather. Neither the chemical analysis of the stone nor its appearance in the quarry or muler the microscope affords any explanation of this change. (Nee under North Jay, Maine, pp. 212-214.) 'That the discoloration followed certain structural planes in the look is evident. because the zones of stain are parallel to the axes of some of the columns but at right angles to those of others. It is also evident that some of the columns were cut parallel to the structure and others at right angles to it, a difference which makes the discoloration still more conspicuous. The only two structures are the rift. which is horizontal, and the flow structure. which is in gently inclined monulations. It may be surmised that in that portion of the quarry which furnished the stone for the tomb there was more iron in the form of pyrite or magnetite than there was in the samples of the stone the chenical, microscopic, and geologic sturly of which is here reported: and that upon continned exposme the oxidation of these iron compomels produced enomgh limonitic stain to discolor buth walls and columns. This stain followerl the arrangement of the prrite and magnetic urains. Which was probably in the direction of the flow structure.

Limonitic stain along the sheet surfaces may be remorell by natural causes. It the Frazer quarry. on Blue ifountain, in Ryegate. Tt. (p. 115), there is a band of rusty stain along the lisise of a sheet 12 feet thick dipping $25^{\circ}$ down the hill. The hand. which is an inch wide. is separated from the lower surface of the sheet br 1 or 2 inches of clear granite. I careful examination of the specimen shows that all the minerals in the rusty band are stained a medimm

\footnotetext{
13 The rust-stained joint faces of aplite at Hingham, Mass. (p. 32s), are prohably due to the oxidation and hydration of its abundant pyrite as well as of its magnetite. Allen J. Howe (freology of building stunes, 1) 360, fondon, 1970), stites that "well-crystallized pyrite in a frosli sranite is not a source of much danger, but it, like all ofluel iron compounds. may produce, by oxidation and hydration, either local spets or a uniform tinge of iron stain. in aceordance with its distribution in isolated crystals or in unlformly scattered iranules."
} 
brown. and that the space below it, although of the same color a; that above it, yet has dots 0.1 inch wide of very dark brown. A thin section of this part shows limonite proceeding from biotite and allanite crystals. A thin section of the clear granite above the band shows no limonite whatever about a crystal of allanite. There seens, therefore, to have been a partial delimonitization of the lower part of the zone of "sap," which may be attributed to organic acids in the water circulating between the sheets after that which produced the stain.

It the oll Crabtree quarry, east of Minturn, on Swans Island, in Maine, the limonitic band. abont an inch thick, is 2 inches above the bottom of the sheet. owing to such delimonitization.

\section{DECOMPOSITION.}

GENERAL FEATURES.

Notwithstanding the strength and durability of granite, it is liable. under certain conditions and in the course of long time, to decompose into a clayey sand. This is the result of its physical mineralogical. and chemical constitution and properties. One of the most striking illustrations of decomposition is the occurrence in some of the Maine quarries of "beds" of sand or decomposed granite within the fresh granite, either between the sheets away from head nus or within the headings and along or across the sheets. Thus at the Palmer quarry, in Tinalhaven, 20 feet below the surface in the face of the quarry, there is a bed of granite sand 18 inches thick between two sheets, which at that point dip about $10^{\circ}$ into the hill. On the southeast side of the Longfellow quarry. near Hallowell, some of the sheets within a wide heading include granite sand beds about 10 inches thick. It the Shattuck Monntain quarry, near Red Beach, a 6 -foot heading includes a vertical layer of granite sand 8 inches thick. Specimens taken from these various sand beds show that the disintegration begins with microscopic fractures, or in some places the enlarged rift cracks, producing the "shake" structure describerl on page 39, and is followed by more or less kaolinization of the feldspars. This process consists in the loss of alkali and the taking up of water, resulting in the passing of the feldspar into a white clay (kaolin).

The joint and sheet structure affords ingress to surface water, which contains its usual percentage of carbonic acid, and the "rift" structure facilitates the kaolinization of the feldspar on either side of the sheet parting by this water. As the feldspars pass into clay the rock crumbles into sand consisting of quartz, mica, and kaolin and of feldspar in various stages of kaolinization. In some places within the range and depth of frost a large part of this work may 
have been done by frost. The sand would there be mainly the product of the "shake" structure.

Along the Maine coast the surface of granite ledges bear in protected places an inch or so of granite sand, which represents surface disintegration since the postglacial submergence.

In regions that have not been swept by a continental glacier any granite mass would be covered with the products of the decomposition of its own surface. In the Tropies the abundant rainfall and the organic acids from a luxuriant vegetation materially hasten the decomposition, and granitic rocks in such regions are for these reasons often covered with many feet of sand and soil. ${ }^{14}$

Walther, ${ }^{15}$ in an interesting work on erosion in the Egyptian desert, describes the effect of the weathering of a certain gray granite in the sinaitic peninsula as the excaration of a series of circular holes, 1 to 8 inches in liameter and 4 to 2 inches deep, in the sides of the sheets. He attributes these holes to chemical action upon the feldspars in shady depressions where rain. dew, and rock moisture are less easily dried up. aided by the wind-blown sand of the desert. He also (p. 363) attributes exfoliation of granite in the desert, in which the folia measure $0.2-0.6$ inch in thickness, to differences in temperature causing unequal expansion of the outer surface cooled at night and the inner one still preserving the heat of the previous day.

The incipient stage of weathering may be observed in any longexposed granite ledge in the milky whiteness of the feldspars. This change usually attacks the soda-lime feldspars first. The black mica, owing to its content of iron oxide, is also liable to early decomposition. The process of weathering, as it affects the rock as a whole. involves the following chemical changes: A loss of lime, magnesia, potash, and soda; a gain of water, and a relative gain of silica, alumina. and iron oxide-that is. relative to the reduced weight of the weathered rock. The subject of weathering of granite is fully treated in the writings of Merrill. ${ }^{16}$ Keyes. ${ }^{17}$ and Watson. ${ }^{18}$

The changes in granite after it has entered into buildings or other structures are less marked than those in the natural rock, because the blocks are not then traversed by anything analogous to sheet and

\footnotetext{
" Branner, J. C., Decomposition of rocks in Brazil: Geol. Soc. America Bull., vol. 7, p. 31, 1s96.

15 Walther, Johannes, Die Denijdation in der Wiste und ihre geologische Bedeutung: k. sichs. (iesell. Wiss., Math.-phys. Classe, Abh., vol, 16. pp. 367, 368, Leipzig, 1 s91.

${ }^{10}$ Merrill. G. P.. Disintegration of the granite rocks of the District of Columbia: Geol. Sroc. America Bull. vol. 6, p. 321. 189.; : ilso A trentise on rocks, rock-weathering. and soils, pr. 206-214, 226, 244, 245, 25i. New York, 1897.

17 Keșes. C. R., The origin and relations of central Maryland granites: U. S. Geol Survey Fifteenth Ann. Rept., p. 725 , pls. 42-45, 1595. See also Iowa Acad. Sci. I'roc. vol. 1, J.t. 5 , pp. 22-24, rol. 2, pp. 27-31, p!s. 2-4, 1895.

14 Watson. 'T. L., A preliminary report on a part of the wrinites and gucisses of Georgia, pp. $299,300,308,329,331,333,1902$.
} 
joint structure. and also because the years of historic time are few compared to those of geologic time. Much has been written on the decay of granite in monmments and buildings. ${ }^{19}$ Such decay is mainly attributable to microscopic fissures produced by the unequal and repeated expansion and contraction of the different minerals of the granite under changes of solar temperature. In countries where the winter temperature is very low the action of frost within such fissures powerfully assists the process of disintegration. Thus the obelisk now in Sew York suffered more from three rears exposure to our climate than it had during over 3,400 vears in Egypt. although the fissures along which frost operated were started long before it reacher this comtry. I minor factor in decay is the chemical action of water along fissures. ${ }^{20}$

The results of some recent studies on the weathering of ancient granite monuments in Egypt ${ }^{21}$ show the durability of this stone in terms of years in that rlimate. It was found that in sonthern Egypt obelisks dating from 588 to 2100 B. C., or from 2.504 to 4.016 years old, showed no perceptible disintegration or even incipient exfoliation on southern exposures, but that farther nortl. at Luxor. 'Thebes. and Gizeh, and in the Museum at ('airo the granite (chiefly that of syene) of prramirls, statues, and temples. lating fom 318 to 2850 B. C., or from $2.23+$ to 4.766 year's old, showed an average rate of disintegration and exfoliation ranging from nearly 0.04 to 0.08 inch per 1,000 years. The maximum rate in the temple at Karnak was about 0.2 inch per 1,000 years, and the minimum rate so slow as to be imperceptible in 3,000 years.

All the canses of decary referred to operate more effectively in coarse granites than in fine ones. Merrill points out that the reason for the greater resistance to weathering offered by sawn or polished surfaces than by cut or hammered surfaces is that the latter are full of minute fractures parallel to the surface. produced by tool impact. and that these fractures facilitate scaling.

WOIHAL WEATHIINI.

Shaler ${ }^{22}$ called attention to spheroidal weathering in the granite of Rockport. and gave a plate showing "decomposition boulders," which are the result of the progress of deeay working inward from

19 Julien, A. A., The durability of building stones in New York City: Tenth (ensus, vol. 10, Granite, pp. 370-371. 1sst. Merrill, Geo. l'., Physical, chemical, and economic properties of building stones: Maryland Gool. Survey, rol. 2, Granite, pp. 02-94, 1898 . Also Ierrill's Nitone's for building and docoration. 3d ad., Weathering of granite, pp. $434,495,1903$.

2o Julien, A. A., A study of the New York obelisk as a decayed bonlder: New York Acad. Sici. Aunals, vol. 8, pp. 93-166, 1893.

${ }^{21}$ Barton, D. C. The disintegration of granite in Esypt: Jour. Geology, vol. 24, pp. $386-391,1916$.

"s Shaler, N. S., The geology oi Cape Ann, Mass.: U. S. Geol. Surres Ninth Ann. Rept., 1) $567, \mathrm{pl}, 51,1859$. 
both sheet and joint surfaces. This is not unusual in inranite regions. A fine illustration of the concentric surface weathering of granite in the Sierra Nevada was given by Turner. ${ }^{23}$ This decay is mainly due to the chemical processes describer under "Decomposition" (p. 70). Spheroidal weathering in granite may. howerer. le party of different origin. The writer many years ago malle some colored sketches of a concentric cylindrical structure in granite at a railroad cut at Inter Brambach, in Saxony. in which the surfaces an inch or two apart were coated with limonite stain. 'The cylindrical forms, although brought out by weathering, were apparently due to internal structure. Of like structural origin are also the concentric shelly spheroids of erranite about an inner concretion of mica, a foot in diameter, in central Bohemia described by .Jokély. ${ }^{24}$ P. A. Wagner attributes spheroidal weathering in a Sonth African granite to spheroidal contraction during cooling.

Plate XXIX, B, represents an ovoid mass of extremely fine quartz monzonite ( 45 by $33 \frac{1}{2}$ by 25 inches) from the Redstone quarry, near Westerly. R. I. $(p,+13)$. This mass came from a point 30 feet below the surface within a heading 40 feet wide at the north end of the quarry, where much decomposition had taken place. Is there are no indications at any of the Westerly quarries of an original spheroidal structure, this mass must be classed with those of (ape Ann, but the decomposition. instead of working on five sides of an exposed mass, has operated on the sides of a block formed by intersecting joints and sheets considerably below the greneral surface. and the egg shape is due to the unequal spacingr of these partings.

\section{SPECIAL FEATURES.}

The following ten sections include certain geologic and petrosraphic features of granite which, although of scientific interest, hardly come under any of the previous headings.

\section{PEGMATITE DIKES IN GROUPS.}

The granite of Milford, N. H., is crossed by the usual pegmatite dikes, but at several quarries instead of being single or ramifying the dikes occur in parallel sets of 3 to 12.2 and have sinnons comses. This grouping is exceptional in the New England quarries. It the old Field quary, near the village, the individual dikes measure 0.25 to 1 inch in width and number up to 10 in a set. and the sets recur at inter-

${ }_{23}$ Turner, H. W., Rocks of the Sierra Nevada: U. S. Gesol. Surver Fourternth Inn. Rept., pt. 2, 1. 491. 11. 5:3. 1894.

24 Jokély, Johann, Geognostische Verhältuisse in einem l'heile des mittlarn Höhmen: K.-k. geol. IReichsanstalt Jahrb., vol, 6, p. 27.5 and figure, 1s.i.n.

${ }^{25}$ Wagner, P. A., Negative spheroidal woathering and jointing in a granite of southern Rhodesia: Ciecl. Soc. South Ifrica Trans., vol, 15, pp. 155-144, pls. 18-21, 1913. 
vals of 15 to 20 feet. At the abandoned Hayden quarry, a mile south, such dikes 0.25 to 1 inch wide and up to 12 in a group, recur at intervals of 20 to 30 feet. At the Young quarry, midway between these localities, the sets consist of 3 to 8 dikes up to 3 inches thick and recur at intervals of 20 feet. The dikes here meander and unite in the most intricate manner, occupying bands of granite 5 to 10 feet thick, which in quarrying have to be discarded. Somewhat similar dikes were noted in a small quarry 3 miles northeast of Lewiston, Maine, where a fine-grained biotite gneiss is traversed in a space of 30 feet by 27 pegmatite dikes, 1 inch to 2 feet thick, all dipping $80^{\circ}$.

It is difficult to explain the grouping and spacing of these dikes without supposing some periodicity in the application of the tension that made openings for them. The sinuosity of the courses of such dikes has been regarded as eridence that the openings were the result of tensile rather than of compressive or other strain.

MUSCOVITE VEINS.

At some of the quarries in Concord, N. H., the muscovite-biotite glanite is traversed here and there by what quarrymen term "sand streaks" or "sand seams." These are reins of white mica, 0.1 to 0.4 inch wide, with a border of quartz and feldspar about 0.1 inch wide on each side. The mica plates measure up to 0.07 inch in diameter. Some of these reins, however, consist almost entirely of mica plates without any regular arrangement, attain a thickness of $1 \frac{1}{2}$ inches, and have mica plates up to 0.2 inch.

Veins of kindred but not identical character were observed at Milford, N. H. At the disused Field quarry muscovite veins 0.5 inch wide, with a central parting, recur at intervals of 15 to 20 feet. They strike like the pegmatite dikes referred to on page 73 and are discontinuous, not exceeding 6 feet at a stretch and being in places but a few inches. It the neighboring quarries of the Milford Granite ( o. there is a heading striking N. $30^{\circ} \mathrm{E}$, the joints of which inclose segregation veins of muscovite and quartz, the quartz in the center. These are from 0.1 to 0.5 inch wide and the granite is discolored bright reddish up to 0.5 inch on each side. The biotite is also chloritized.

It will be noticed that these Concord and Milford veins differ in that the former usually have muscovite in the center and the latter quartz. Both kinds of veins may be attributed to the percolation of mineral solutions along fissures. In either kind the outer mineral was deposited first. The proximity and parallelism of many of these veins to pegmatite dikes suggest that although deposited from solutions they were probably intimately related to the pegmatite dikes and were formed at the same time. In that case the heading referrel to at Milford antedates the sheet structure. 
ZEOLITE VE1NS.

At the McGaughey quarry, in Mystic village, in Groton. Com. (p. 388), the quartz monzonite has two zeolites. A rertical "blinl seam," striking N. $60^{\circ}$ E., proves to be a veinlet, 1 millimeter wide, of a fibrous light-brownish zeolite (natrolite?), with a more minute parallel branch, 0.5 millimeter away, of another zeolite near stilbite. This mineral has replaced some of the adjoining oligoclase-andesine and also sends microscopic reinlets across quartz particles. The granite is discolored for 0.5 inch on either side of the veinlet. I rertical pegmatite dike strikes $\mathrm{N} .30^{\circ} \mathrm{W}$.

\section{MINERAL VEINS.}

The presence of mineral veins in sranite has no special significance in a work on granite, but in the one case noted the course of the vein was governed by that of a group of joints ("heading").

At the Roxbury quarry, (Conn. (p. 372), owing to the proximits of a vein of silerite which was formerly mined, three reins, each not orer 8 inches thick. consisting of siderite. pyrite. chalcoprrite. galena, and secondary quartz coating crystals of siderite. ocm within and parallel to three rertical headings.

\section{FELDSPARS.}

ORIGINAL AND SECONDARY COLORS.

Although the shade of a cranite is largely determined by that of its quartz particles and the relative abundance and size of its black mica scales. its general color is almost invariably determined by that of its feldspars. The colors of feldspars in commercial granite are sn varied as to be an object of interest not only to the greologist but to the quarryman and the architect.

The New England granites described in this bulletin have feldspars of 11 colors-bluish, greenish, olive-green. pea-green. cream color. lavender. buff. pinkish buff. reddish, and greenish brown. Some are colorless and transparent or milk-white. others are dark or light gray, and the colored ones may be either transparent. translucent. or opaque. The relative oparity is determined mainly by degree of kaolinization and micacization.

In some granites the origin of the color is unt easily determinab?e. Thus the feldspar of the granite of Concord. N. H.. is transhucent. with a slight bluish tinge. but the se tions show no mineral which would produce such a tinge. In other granites, however. the results of microscopic examination are more satisfactory. Thus one of the granites of Rockport. Mass. (p. 299). owes its greenish tinge to chlorite scales and limonite stain. The granites of Milford. Mars. 
(p. :34). Thave a delicate pink orthorlase and a rellow-greenish plagioclase. The greenish tint is due to innumerable minute crystals of epidote and a few scales of chlorite. The smallest of these epirlote rrvstals measure about 0.001 millimeter. The orthoclase is much kaolinizerl, and the anse of the pinkish tinge is not apparent but is supposed to be due to the presenre of infinitesimal particles of reddish hematite $\left(\mathrm{Fe}_{2} \mathrm{O}_{3}\right)$.

The reddish biotite granite of the Redstone quarry at Westerly. R. I. (p. 412), contains a pinkish potash feldspar and a cream-colored plagioclase, both transhucent and more or less micacized. Ther are both stained redelish here and there by hematite $\left(\mathrm{Fe}_{2} \mathrm{O}_{3}\right)$ proreerling from the oxidation of magnetite particles (Fo, $\left.)_{4}\right)$. This shows how the reddish aolor may be brought abont. A similar reddening of the feldspar along the joint faces at Rerkstone, N. H.. is due to hematite plainly proceeding from magnetite particles (1). $1($ is) .

The olive-green granite of Rockport (1). 293) contains a grayish olive-green orthoelase which appears crowded with opaque particles, the largest of which measure from 0.0028 to 0.014 millimeter. There is yellow limonitic $\left(\mathrm{Fe}_{4} \mathrm{O}_{4} \mathrm{H}_{6}\right)$ staining both along the rift cracks and about the opacue particles. some of which may be ferrous irom (FeO) and other's kaolin. This limonite stain. in connection with an original bluish tinge marcomted for, produces the olive-green. This granite contains also biotite and allanite. The similar olive-green granite from Rerlstone, N. H. (p. 168), owes its areen tinge more to the color of the quartz than to that of the feldspar. The feldspar is a medimm bluish gray with an occasional rellow-stained clearage or rift crack. The limonite stain here rearly proceeds from the alteration of somewhat abundant particles and crytals of allanite. ${ }^{2 ;}$ as shown in figme 6 , and also from particles of hornblencle.

Daly ${ }^{27}$ has shown experimentally that the erren color which appears soon after exposme in the cranite of Windsor. Vt.. is dne to the oxidization of extremely minute blackish granules of ferrous oxide in the feldspars and to the combination of the rellowish-brown color from the limonite thus produced with the bluish gray of the maltered fellspar.

The bluish and greenish tints of the medium to dalk gray feldspar of (Quiney granite (p. 317) are due to finely disseminated crystals of hluish riebeckite, measuring from abont 0.001 to 0.1 milli-

26 Sef glosiary (p. 467), also Iddings, J. P., and Cross, Whitman, On the widespread occurrence of allanite as an accessory constituent of many rocks: Am. .Jour. Scl., 3d ser., rol. 30, 1'p. 10s-111, 1885.

${ }_{27}$ Daly, R. A., The geology of Ascutrey Mountain, Vt.: U. S. Geol. Survey Bull. 209, 1903. 
meter in length by about 0.001 millimeter in wilth, and to inmunerable still more minute particles of grass-green aegirite.

This bluish-greenish gray feldspar of Quincy granite assmues very lifferent colors as the result of varions alterations. In some places it becomes crean-colored. in other's a delicate pea-green. or pink to pinkish gray or dark greenish-brownish gray, in other's a light olive-gray, and in still others it becomes spotted with a deep red. The mode of these occmrences. the appentance of the changed fellspars in thin section. and prol. able causes of the changes are set forth below.

At the Galvin quarry. in Quiney (p. 325), the granite on either sicle of the quartz reins. which contain a little ilmenite and carbonate. is changed for 4 inches from its usual bluish gray to cream-color. At the Fireld is Wild quarry, also in Quincy (p. 326), these veins are bordered by 3-inch zones of greenish, pinkish. or light-grayish discoloration. The cream and light gray seem to be due not so much to thes kaolinization of the feldspars and to limonite stain from the ilmenite of the rein as to a diminution of certain minute black particles which abound

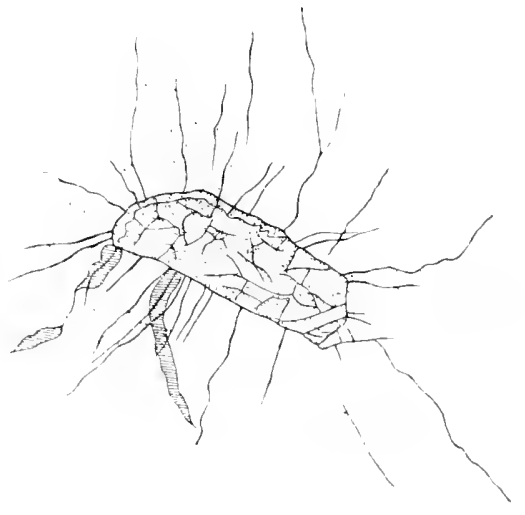

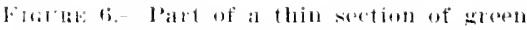
biotite-hornblende granite from Reilstone, Conway, X. Hl., rnlarrorel : $: 1_{3}^{*}$ diameters, showing a rrstal of allanite with radiating cracks, which ale filled with yellowish limonite stail, also hambs of such stain apart from these cracks. The dotted areas alte quartz, the rest feldspar. Such elystals in jart aceoumt for the color of the rouk.

in the unaltered feldspar. The pinkish color is due to hemaltite and the greenish to aegirite and the removal of the riebeckite. The reduction of the black particles and any kaolinization of the feldspars along these veins must be attributed to carbonic acid waters, and these must either have come from below with the silica of the vein or from above by infiltration along the rein courses. $^{2 s}$

At the Cashman quarry, in West Quincy (p. 331). the granite at both the north and the south ends, to a depth of orer $i_{0}$ feet from the rock surface, has delicate pea-green feldspars, but normal gray granite occupies the center of the quarry. Similar pea-green felispar occurs on the south side of the Lepage quarry (p.330), in West Quincy, to a depth of 30 to to feet, and at one of the Winquist

sa Van llise, C. R., A treatise on metamorphism: I. S. Feol. Survey Mon. 47, pp. $720-728,1904$. 
quarries on the North Commons (p. 324), to a depth of 125 feet from the rock surface. This pea-green tint seems to be due mainly to the presence of minute particles and crystals of light-green aegirite, and secondarily to the absence or removal of the minute riebeckite crystals. There is also here and there a secondary light yellowishbrown hornblende in minute prismatic crystals. This granite has the appearance of having undergone alteration of one or two kinds. - Come structural feature seems necessary to account for the separation of two vertical belts of light-green granite by a normal gray one at the Cashman quarry.

1 pink granite occupies one-half of the savo quarry (1).331). in West Quincy, to a depth of 30 feet, and the pea-green granite the other half. The feldspars of the pink stone have been kaolinized and made pink. The larger riebeckite and aegirite particles have passed into masses (pseudomorphs) of quartz. magnetite. and carbonate, with some epidote and chlorite. Magnetite crystals are conspicuous in them. The minute crystals of riebeckite have disappeared. These changes in the feldspar and the ferro-soda silicates could be explained by access of carbonated surface waters and metamorphic action. The color of the feldspar must be attributed either to the reduction of limonite particles or to the oxidation of magnetite.

At the Sartori quarry, in (2uincy (p. 335), the feldspar has become largely kaolinized and micacized and also somewhat stained with hematite. It has lost its translucence and acquired a dull greenishbrown hue. The black silicates have passed largely into an aggregate of biotite, magnetite, carbonate. and quartz, and there are no minute riebeckite crystals in the feldspars.

It the Rogers quarry, in West Quincy (p. 333), the feldspars at the south end and west side become a light olive-gray after exposure. In thin section faint yellowish limonite stain appears along the rift and grain and along clearage and irregular cracks. The yellow of the stain combined with the bluish green of the riebeckite yields an olive-gray. In one section bright limonite stain is seen to ramify from the large particles of intergrown riebeckite and aegirite.

At several Quincy quarries some of the granite is spotted with deep cherry-red and muddy olive-colored stains up to an inch in diameter. These stains surround the larger riebeckite and aegirite particles, from which they penetrate the adjacent feldspars. In thin section many of the feldspars are seen to be permeated by bright red hematite stain. ramifying within them from the cleavage and rift cracks, as shown in figure 7 . This stain is also accompanied here and there by yellowish limonite stain probably of later date; and there are long, slender greenish particles up to 0.33 by 0.0002 millimeter, which are all parallel in the same feldspar crystal. 
Radiating needle-like and fibrous felty crystals of secondary yellowish or muddy green hornblende are attached to the riebeckite and aegirite particles. Some of the aegirite crystals are completely altered to chlorite, magnetite. and quartz. The immediate cause of the staining of the feldspar and of the formation of the fibrous hornblende is thus the alteration of the riebeckite-aegirite particles. but the cause of that alteration is not so apparent. Their alteration to magnetite, alone. implies metamorphism. At the Cashman quarry, already referred to, some of this altered aegirite and feldspar was found next to a steep heading, and at the Hardwick quarry the granite within a heading has a hematitic color. These occurrences suggest that the change in the llack silicates may have been brought about by access of surface water along joint planes, hydrating and oxidizing the iron of the silicates, and that the granite thus stained by limonite has become reddish as the limonite under metamorphism became reduced to hematite. It is also possible that, the black silicates having under. metamorphism passed partly into magnetite, this may by oxidation have yielded hematitc.

This reddening of the feldspar also characterizes the gray granite of two of the

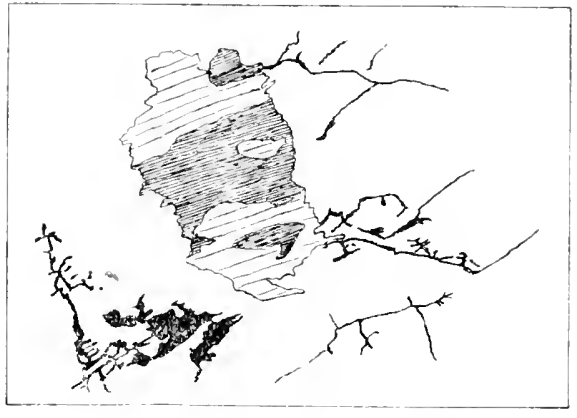

I ICLkE 7.-Thin section of altered Quincy granite, enlarged 621 diameters, showing liematite stain in the feldspar. The large particle from which streams of stain proceed is aegirite. Its altered parts are shaded.

quarries at Milford. N. H. (pp. 185, 18i), for a thickness of 10 to 50 feet from its contact with basic dikes. The change takes place chiefly in the soda-lime feldspar, which is also much kaolinized. The source of this hematite is probably the magnetite particles.

CUT SURFACES.

In studying the "black granites" it was found that if one of two of identical shade is a diorite-that is, a granite with only a sodalime feldspar-and the other a normal biotite granite-that is, a granite with very little soda-lime feldspar and considerable potash feldspar-the cut surface of the diorite will be very much lighter than that of the normal granite, and this was attributed to some optical property of the soda-lime feldspar. (See Pl. XXII, A.)

It has also been found that the pinkish and grayish quartz monzonites of Westerly. R. I., Milford, N. H., and Waterford and Groton. Conn.. in which the soda-lime feldspar is in excess of the potash 
feldspar, cut lighter than normal granites even of lighter tint. The very dark gabbros, syenites, diabases, and norites also (cut light, as shown in Plates XXII, $B$, and VII, $B$. Dr. (r. P. Merrill suggests that the optical property involverl here is the multiple twinning of the soda-lime feldspar. which must greatly facilitate its breaking up under the hammer and thus increase the diffusion of light. As the dark purplish porphyritic rhyolite ("granite") of Montello, Wis., in which potash feldspar makes up half the rock and which has no other feldspar, hammers quite as light as the Westerly qualtz monzonite, this shows that the same effect may be prorluced in some other way. ${ }^{29}$

MRANITIC QTARTZ.

TEXTURE.

The observations here bought together show that granitic quartz is far from possessing the homogeneous texture popularly attribnted to that mineral. Not only is the quartz likely to contain cavities with or withont vacuoles, as was shown on page 18 . in intersecting sheets relaterl to rift and grain cracks, but it also contains minute opaque particles, particularly abundant in smoky quartz. Some of it abounds in hairlike crystals, probably of rutile. The quartz of some granites shows by its behavior in polarized light that the arrangement of its molecules has been disturbed by mechanical strain. In three Massachusetts granites, Milford, Fall River, and Quincy Goldleaf quarry. and in that of Lebanon. N. H.. this strain has been carried far enough to granulate the quartz. The granules generally measure under 1 millimeter in diameter.

COLORS.

The quartz of the granites described in this bulletin ranges from colorless, transparent or milky, to blue, amethystine smoky or milky, greenish smoky, rose-colored, and smoky of various shades. At Redstone, N. H. (p. 168), an amethystine smoky quartz has become greenish by the coating of its rift and grain cracks with limonite. Colorless quartz has the fewest cavities or particles. The smokiness appears to be due to minute black particles. but the microscope fails to show the "ause of the blue, rose, and amethystine tints. ${ }^{30}$

The results of recent investigations by Watson and Beard ${ }^{31}$ and those of previous writers quoted by them show that the amethyst

s see Buckley, E. R., On the building and ornamental stones of Wisconsin: Wisconsin Geol. and Nat. Hist. Survey Bull. 4, p. 94, pl. 5, 1898.

${ }^{20}$ Ioseubusch, 1l.. Mikroskopische l'lysiographie der Mineralien und Gesteine, 4 th ed. rol. 1, pt. 2, Granit Quarz, pp. 93, 94, 1905.

si Watson, T. I., and Beard, R. E., The color of amethyst, rose, and blue varieties of quartz: U. S. Nat. Mus. Proc., vol. 5i, pp. 553-563, 1917. 
tint is due to manganese oxide, the rose tint to some organic substance, and the blue may be due to the reflection of blue light wares from abundant minute colorless prisms of rutile (titanium dioxide), whose width is a fraction of the length of light wares.

OLIVE-GREEN GRANITL.

The peculiar olive-green of the green granites of New England is due to changes both in the feldspar and the quartz as explained on page 76 . The following description of a thin section of the green granite of Redstone, N. H. (p. 168). is typicil of most of them.

There is a faint yellowish limonitic stain along the rift and grain cracks of the quartz, along these and the cleavage planes of the feldspar, and along borders of all particles. 'This stain is deeper in the quartz because there are more cracks in it, and this, in combination with its original slight?y amethystine hue. gives the quartz a greenish tint; and this yellow stain also, in connection with the original slightly bluish gray of the feldspars, gives them in places a greenish color.

Olive-green granites occur also at Rockport (p. 293), Peabody (p. 2S6), and Lynnfield (p. 2SS), Mass.; at Killenny, N. II. (p. 176); and on Mount Ascutney, in Windsor, Vt. (p. 162). That of Rockport is a hornblende granite, that of Redstone a biotite-hornblende granite, that of Kilkenny an augite-biotite granite, and that of Windsor a hornblende-angite granite. The green granite of Peabody and Lynnfield (pp. 2S7-289) is also a holnblende-augite granite but contains less quartz and more dark silicates. It is analogous to the riebeckiteaegirite granite of Quincy, but its black silicates contain very little or no soda.

Washington ${ }^{32}$ refers to this green granite in these words:

The rocks belonging to this class were first noticerl by Wardsworth in 1885 and were later described more in detail hy Sears. Rosenbusch has expressed the opinion that these are related to the akerite type of syenites, a keen observation which my study of the rocks fully confirms. These rocks are found chiefly in the eastern part of Essex County, in Essex, Beverly, Manchester, Gloncester, and on Cape Ann. * * * The color even of the freshest specimens is greenish, which varies in shade from a dark greenish black to a light shade of greenish gray.

In common with the green granites of Rockport and Redstone, that of Peabody and Lynnfield contains considerable allanite, to the oxidation of which the green color is partly due.

MINERALS ON JOINT FACES.

Many granite joint faces are coated with secondary mineralshematite, pyrite, limonite, calcite, epidote, chlorite, stilbite, quartz,

22 Washington, H. S., The petrographical province of Essex County, Mass. : Jour. Geology, rol. 6, p. 787, 1898. See also Sears, J. 1I., The physical geography, geology, mineralogy, and paleontology of Essex County, Mass., pp. 178, 190, Salem, Mass., 1905. 
and muscovite. All these may owe their origin to alteration of the minerals of the granite, but where calcite occurs in consiclerable quantity, as in the unusual and interesting granite found at the WV. B. Blaisdell quarry, in Franklin, Maine, described under "Subjoints," on page 39 , it very probably came from originally overlying calcareous rocks. But these may not have been those intruded by the granite.

Some of the joint and even sheet faces in the quarries at Quincy, Mass., are coated with a blue-black mineral with a peculiar sheen due to fibrous structure parallel to the face and with a bluish-gray streak. Such black faces can be seen at the Dell Hitchcock, Field \& Wild, Granite Railway, and Rogers quarries and at the Mount Pleasant quarry in Milton. (See Pl. XXIV.) On one side of the Mount Pleasant quarry both sheet and joint faces are thus coated, and at the Rogers quarry such black joint faces, spaced from 6 inches to 4 feet, make up a heading. These black joints are commonly intermittent. however, extending only a few yards or even inches at a stretch.

A thin section cut diagonally to one of these joints and its parallel subjoints shows six meandering or intersecting cracks, 0.125 to 1.25 millimeters apart, filled with crystals of riebeckite (a dark-blue soda hornblende), the smallest of which are 0.02 and the largest 0.1 millimeter long, together with ribrous white mica, limonite, and very little carbonate. The granite between these fissures is broken up here and there into minute angular framents and the feldspar is granulated. The cement of this microscopic breccia is also riebeckite, the crystals of which lie with their axes either paraliel to the fracture or across them or even projecting into the feldspar fragments. Some of the feldspars next to the joint are unusually crowded with riebeckite crystals, which probably originated in the same manner and at the same time as those within the joints. ${ }^{33}$

The secondary and relatively recent origin of this riebeckite is evident, and its formation by segregation from the ferro-soda silicates of the granite scems also quite probal,le.

James P. Smith ${ }^{34}$ has explained the alteration of al certain California arkose (decomposed granite or diorite) and a sandstone, with varying proportions of impure clay, into schists consisting largely of glaucophane (a soda hornblende closely related to riebeckite) as due to a process of recrystallization under heat and pressure.

At the Linehan quarry, in Peabody, Mass., the hornblende-augite rianite has joints coated with hornblende and calcite.

In the riebeckite-coated joints and sheets of Quincy and the hornblende-coated joints of Peabody some transfer of material into the joint spaces must also have taken plare. The presence of these minerals shows that the granite was subjected to a certain amount

${ }^{23}$ This and the occurrence of secondary riebeckite in rift and grain cracks, mentioned on p. 317, partly confirm the suspicion expressed by A. Sauer as to the origin of this mineral. See Deutsch. geol. Gesell. Zeitschr., vol. 40, p. 145, 1858.

* Smlth, J. P., Paragenesis of the minerals in the glaucophane-bearing rocks of Califorvia: Am. l'hilos. Soc. I'roc., vol. 45, p. 183, 1906. See also summary, idem, pp. $238,240,1906$. 
of metamorphism after the development of its sheet and joint structure.

Some joint faces at Milford and Becket, Mass., and Concord and Redstone, N. H., present different features. At the East quarry, Milford (p. 347), the parted joint which forms the west wall is filled with a fine-grained greenish, brownish, and cream-colored mass with transverse and longitudinal slickensided cracks. In thin section this proves to be a brecciated granite cemented with calcite, chlorite, fibrous muscovite, and limonite. The amount of calcite in this mass is so considerable that it seems improbable that the granite alone could have supplied it.

At the quarry of the Hudson \& Chester Granite Co., in Becket (p. 280), some of the joint faces of the bluish-gray muscovite-biotite granite are dark greenish for 0.12 inch from the face. The granite in this zone has been altered by the formation of fibrous mica with limonite stain along cracks transverse to the face and along feldspar cleavages and by the formation of mica in the feldspars and of calcite both in the lime-soda feldspars and between the particles. These secondary minerals added to the original ones make these suall rims rery complex.

At the Upper or Granite Railway qualry of John Swenson, at Concord, N. H. (p. 200), joints with a N. $65^{\circ} \mathrm{W}$. course and short farallel subjoints are coated with minute quartz crystals and obtuse calcite rhombs standing edgewise on the joint face, and also here and there with the beginnings of 2 -inch cubes of deep purple and white fluorite. Similar fluorite occurs exceptionally within the granite near the face.

At Redstone, N. H. (p. 168), the light-pink granite for an inch back of one of the major joints is a yellowish pink with patches of grass-green, while the face itself is pale brick-red, rust-colored, hluish, and grass-green. Thin sections show the feldspars much altered to white micas and crossed by veinlets of them. They are also kaolinized and stained pink by hematite from the magnetite larticles. There is some carbonate, limonite, chlorite, and cpidote.

At the Sands quarry, in Vinalhaven, Maine, one of the joint faces bears very minute crystals of stilbite, a hydrous silicate of alumina, lime, and soda, ${ }^{35}$ also hematite.

While nearly all the secondary minerals in these joint coatings (chlorite, epidote, muscovite, hematite, limonite, calcite, stilbite, and quartz) may be accounted for by processes of "deep-seated weathering"-that is, by the alteration, largely chemical, of the minerals of the granite itself-the fluorite was probably brought from the same source as the granite itself but at a later time, and the calcite from once overlying calcareous sedimentary beds.

* Determination by W. T. Schaller; of the United States Geological Survey. 
Large areas of the joint faces in the Longfellow quarry, at Hallowell, Maine, are coated with dendrites (frostlike crystals) of iron wides and probably maganese oxides from surface infiltration.

\section{CONTACT PHENOMENA.}

In the 425 granite quarries of New England contacts of the granite with the rock intruded by it were observed in the following townships and are mentioned in the quarry descriptions on the pages given: In Connecticut. in (iroton (p.386), East Lyme (p.389), Mystic (p. 388), Seymour (p.384), Stonington (p.392), Thomaston (p. 373), and Waterford (Millstone and Waterford quarries, pp. 396, 398); in Maine, in Bristol (Round Pond, p. 249), Freeport (p. 211), and IValdoboro (p. 250, fig. 57); in Massachusetts. in Recket (p. 280) and North Aeton (p. 30s): in New Hampshire, in Manchester (p. 195) and

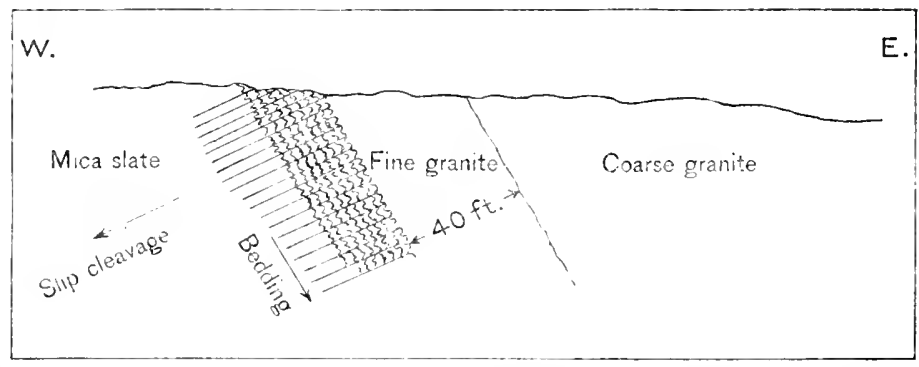

FIfUen 8.-Contact of quartz monzonite on the wrst side of Ellis quarry, Christian Hlill, Bethel, rt., showing relations of zone of fine granite to coarse granite and to bedding and clearage of schist.

Milfork (p. 180); in Rhode Island, in Charlestown (p. 415) and Westerly (p. 411); in Termont, in Barre (p. 132), Bethel (p. 159), Hardwick (p. 120), and Plymouth (p. 160).

Out of all these contacts a few are of special petrographic or structural interest, and these will be described in some detail.

\section{PETROGRAPHIC RELATIONS.}

Bethel, Vt.-The white granite at Bethel, Vt. (p. 156), appears to be encircled by a zone of finer-grained light buff-gray granite, which is about 40 feet thick. Both rocks are quartz monzonites, but the finel contains more biotite scales than the coarser, and the scales are mostly very minute and evenly distributed. On the west side of the Ellis quarry the plane of contact between the coarse and the fine granite strikes N. $15^{\circ} \mathrm{W}$. and dips $60^{\circ} \mathrm{E}$. The fine-grained granite is in contact on the west with a finely plicated, very fine grained quartz-muscovite-biotite schist, and this granite is finer grained at its contact with the schist than it is 20 feet away. The plane of contact strikes and dips about like that between the two granites, 
and the plications of the schist run parallel to this plane but are crossed by a slip cleavage striking $\mathrm{N}$. $70^{\circ} \mathrm{W}$. and dipping $25^{\circ} \mathrm{WNW}$. The relations are shown in figure 8 . Figure 9 shows bow the granite has been molded by the minute wrinkles in the schist. The schist contains a few small garnets and plates of magnetite. In the glassy zone the particles range from 0.009 to 0.03 millimeter. In the next the porphyritic feldspars mealsure as high as 0.92 by 0.5 millimeter. There are thus four grades of texture in the granite-the glas.y. 1 to 2 millimeters thick; the very fine (porphyritic, at least toward the

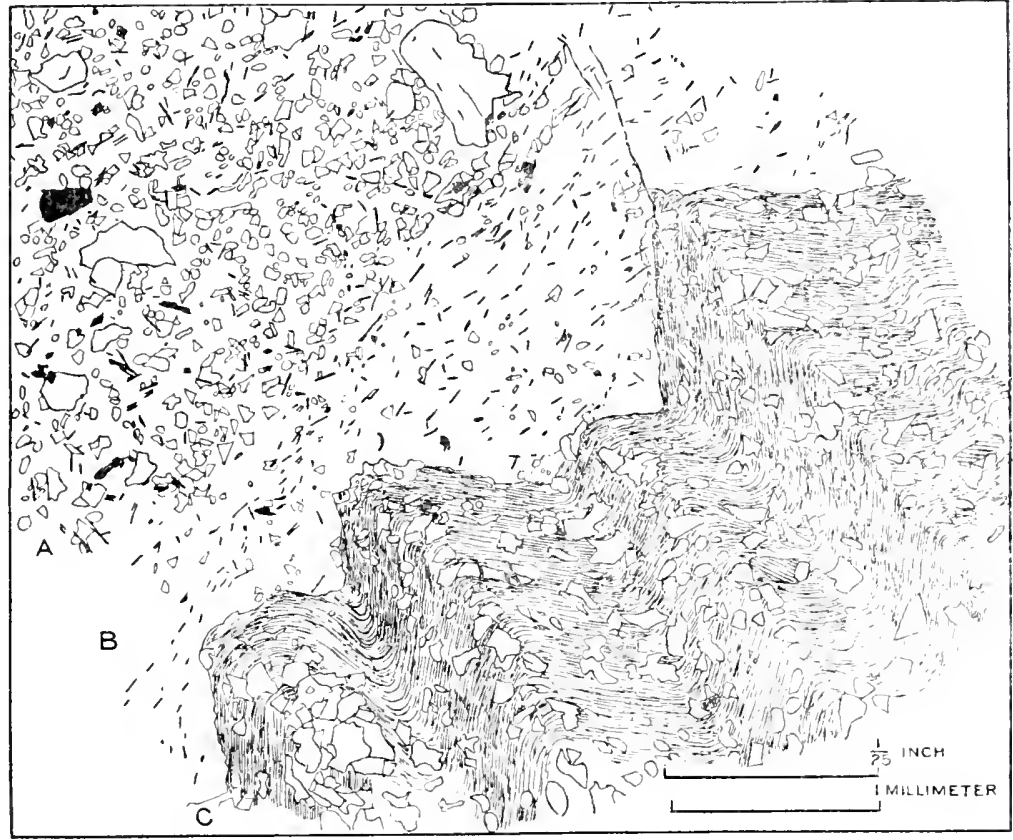

Figere 9.-Camera lucida drawing of enlarged thin section aeross contact of sehist and granite at Bethel, Vt., shown in diagram in figure $s$. A, Fine granite with some larger porphyritic feldspar and botite seales. The finc undistinguishablo particles of matrix are not shown. B. Zone. 1 to 2 millimeters wide, of glassy material with lout few quartz and feldspar partichs and biotite scales (in black): most of the latter with their long axis parallel to the general contact surface; a few at right angles to it. A fracture with limonite stain crosses this zone. C, sharply plicated sehist of fibrous muscovite with a little biotite and much quartz (unshaded particles). The two shaded particles are nonmetallic opaque mineral.

glassy), about 20 feet wide; the fine. with feldspar and mica not over 1 millimeter, about 20 feet wide: and the coarse. with feldspars up to 0.4 and 0.5 inch and mica to 0.9 , over 200 feet wide.

Barre, It.-At the Anderson quarry, Barre, Vt. (No. 8, Pl. II, also p. 132), the granite contact with schist and slate is finely exposed. The under surface of the schist is coarsely serrate, forming as it were a series of folds, which, however, are not structural. The granite is 
larker for a space of 25 feet from the schist, and a pegmatite dike, 1 foot thick. borlers one of the schist tongues. (See fig. 10.)

In the sonthern corner of this quarry pieces of the mica slate have scalet off from the mass and becn earried a few inches into the

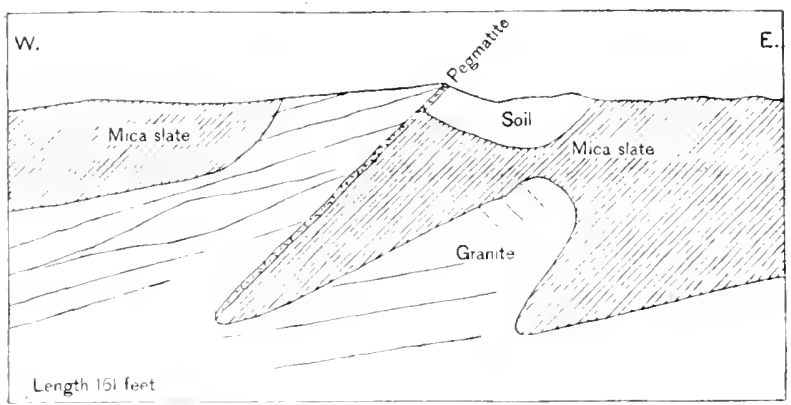

Froure 10.-Diagrammatic sketch showing relations of granite and mica schist and slate at Inderson quarry, birre. Vt. granite. (Sies fig. 11.) It this point the sehist is a purplish-gray, very quartzose mica slate of quartz - feldspar biotite, in places with muscorite also, in others without feldspar. Generally the rock resembles the mica slates used for whetstones. The slate has little dikes, of pegmatite which start from the granite surface with a thickness of 0.5 inch and taper out at a distance of $t$ feet. The course of these dikes has no reference to the cleavage of the slate, and their thickness is very irregular. The pegmatite consists, in descending ordor of abundince, of quartz, orthoclase, microcline, oligoclase-albite, and liotite. The quartz has carities in sheets, some parallel to the dike, others across it. Minme particles of slate are here and there inclurles in the pegmatite. The slate within a few inches of the granite is marked by rery fine grained wal greenish-white spots, 0.1 to 0.5 inch and rarely + by 2 inches. These lerses lie with one of their major axes in the plane of the slaty clearage. In some the biotite is zonally arranged. or the leas has a flange of biotite extenting considerably bevond it and parallel to the slaty cleavage.

small lenses (0.1.i to 2.2 by 0.1 to 1 millimeter) were found in thin section to con-

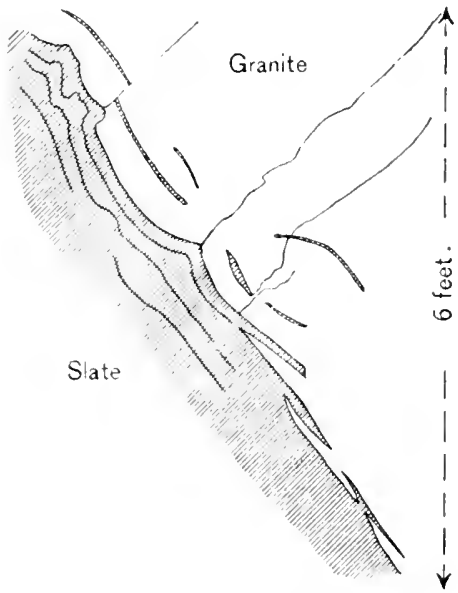

Fitrie 11.--Detilis at contact of mica slate and wranite at south cortuer of Anderson quarry, Barre, Vt., as viewed along the strike of cleavage.

sist of mranitic quartz with biotite and muscovite scales transverse or diag. cnal to the longer axis of the leis, and to he sulroundod by a zone, $0.11 \mathrm{mill}$ meter wide, of apatite particles. One has a little pyrite; another has apatite disseminated throughont it; another a little carbonate. The schist for a little space about the lens is finer grained than it is farther away. The little dikes do not. show apatite except in rare, very minute prisms. Such dikes and lenses are shown in figure 12. 
These lenses have usually been regarded as the result of vaporous impregnation from the granite along the cleavage foliation. ${ }^{36}$ The slate about the lenses shows dark intersecting streaks which are due to more or less complete fractures lined with chlorite with a wide border of very minute undeterminable black particles.

At the Bailey quarry (No.6, Pl. II) the contact is somewhat obscured by an inchusion which lies very near the schist capping. 'The schist, which is like that of the large inclusion at the Bontwell quarry, described on page $6 t$. consists of little beds of whit ish quartzite dotted with greenish hornblende and a few garnets, alternating

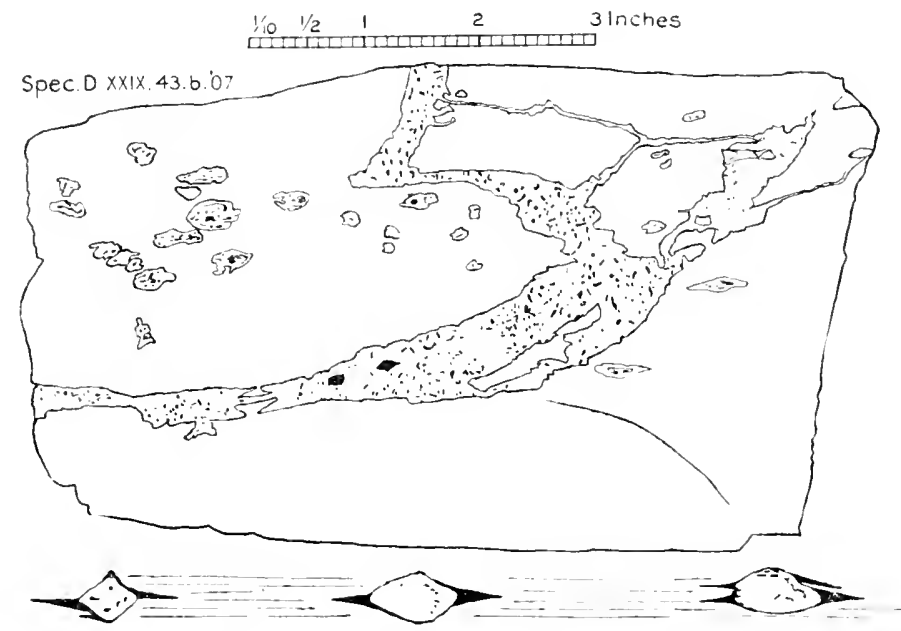

FIgURe 12.- Specimen of purplish-gray mica slate with minute dikes of pegmatite and lenses of apatitic granite, obtained near contact witl granite at Anderson quarry, Barre, Vt. Cleavage parallel to length of block. At bottom several lenses (enlarged one half) from other side of same specimen, slowing biotite flanges and relation to cleavage.

with little beds of quartz-biotite schist spangled with biotite scales. These beds are crossed by large and minute dikes of pegmatite. Some of them, only 0.3 to 0.4 inch wide, run transverse to the bedding for a space and then subdivide to pass at right angles within one of the little beds. Small hand specimens combining both transverse and longitudinal dike courses can be obtained here. The aplite here has a matrix of quartz, oligoclase-albite, microcline, in particles measur-

se Vogt regards apatite in veins as having been formed by pneumatolytic ageneies. Vogt, J. H. L., Ueber die durch pneumatolitische Processe an Granitgebundenen Mineralneubildungen : Zeitsehr. prakt. Geologie, 1894, p. 458; Die Apatit-Ganggruppe: Idem, 1895, pp. $367,444,465$. Barrell deseribes the oceurrence of apatite in a banded hornstone at contact with granite. IIe attributes this apatitization to pneumatolytic im. pregnation. See Barrell, Joseph, Geology of the Marysville mining district, Mont.: U. S. Geol. Survey Prof. Paper 57, pp. 128, 130, 1907. For the formation of apatite at contact of diabase and granite, see p. 54 of this bulletin. 
ing 0.25 to 0.1 millimeter. with porphyritic feldspar and quartz measuring from 0.25 to 1 millimeter.

Woodlury, Tt.-The contact of granite and schist is finely exposed on the northwest side of Robeson Mountain. Woodbury, Vt., along the granite railroad. The axes of the schist folds strike $\mathrm{N}$. $70^{\circ} \mathrm{W}$. and pitch $30^{\circ} \mathrm{S}$. ; the axis of the hill runs about $\mathrm{N} .70^{\circ} \mathrm{E}$. 'The plane of contact appears to be abont parallel to the strike. The schist is of two sorts. One is a dark, rather coarse biotite-muscovitequartz schist with minute black particles and speckled with lenticular biotite plates (up to 0.75 by 0.25 millimeter) lying across the schistosity of the rock. Some plates have a nucleus of magnetite. There are also a few lenses of pyrite. The other sort, a thin bed of which touches the granite, is a dark bluish-gray calcareous muscovitic quartzite with abundant slender flattish sixsided prisms (up to 2 by 0.34 millimeters) of a light-colored amphibole. These are evidently the product of contact metamorphism. The granite sends little pegmatitic dikes into the schist. At the Webber quarry, north of the mountain, the capping is similarly injected.

Conclusions.- - All these contact phenomena lead to the following general inferences:

The 40-foot zone of fine-grained granite, with its three grades of texture, which intervenes between the coarse granite and the schist at Bethel, shows the effect of more rapid cooling upon texture. The material nearest the schist is glassy, but that farthest a way is coarsely crystalline. The semiliquid condition of the granite when it met the schist is shown by its having been molded by the delicate plications of the schist.

That the granite intrusion at Barre was accomplished under great pressure is indicated by the intrusion of minute granitic dikes into such narrow transverse and longitudinal fissures in the schist and slate.

That the granitic intrusion at Barre was also attended by sufficient heat and moisture to inject quartz, feldspar, biotite, pyrite, and apatite (constituents of granite) in vaporous condition into the cleavage foliation of the slate is shown by the position and character of the lenses described. The formation of these lenses also affected the texture of the slate.

At Woodbury the same causes sufficed to produce minute amphibole prisms within a calcareous quartzite along the granite contact.

The phenomena at these contacts of granite with slate and schist, although on so small a scale, are scientifically related to the famous Sea Point locality in South Africa, about which at least 10 geologists 
have written from 1813 to $1914 .^{37}$ The granite there not only sends out large and small.dikes of both coarse and fine granite into the slate, but the slate has become impregnated with feldspar forming crystals up to 2 inches in length. In places the slate has been meta. morphosed into a gneiss; both small and large pieces of slate have also been incorporated in the granite; and in places the rock is a complete mixture of slate and granite.

\section{STRUCTURAL RELATIONS.}

Waterford, Conn.-At the Millstone quarry, Waterford, Conn. (p. 396), the granite is capped on the northeast wall by several masses of gneiss up to 25 feet thick with a foliation striking N. $70^{\circ} \mathrm{W}$. and dipping $25^{\circ} \mathrm{N} .20^{\circ} \mathrm{E}$. At the shore south of the quarry the same gneiss strikes N. $85^{\circ}$ E. and dips steeply north, with pegmatite dikes 2 to 3 feet thick. The plane of contact between the granite and the gneiss remnants is in some places vertical, in others horizontal or gently inclined, the original complete outline of that plane having evidently been very irregillar. In the central embayment, 15 to 20 feet of granite overlies a saguging

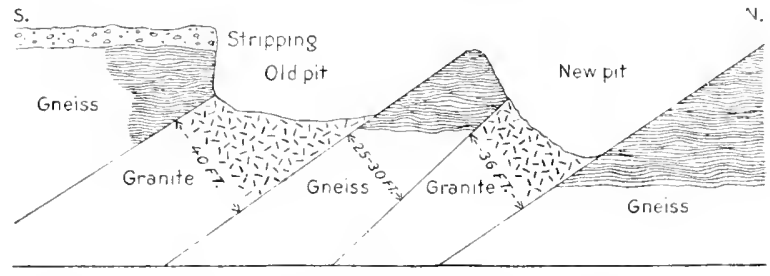

Figure 13. - Section of Waterford quarry, Waterford, Conn. Total length, 265 feet. strip of the gneiss

5 to 10 feet thick. Large dikes of pegmatite, starting at the contact, penetrate the gneiss, and in places the gneiss is cut up by an intricate network of pegmatite and aplite dikes. One of these pegmatite dikes contains a fragment of the gneiss 5 feet long, in vertical position. (Sce fig. 90.)

At the Waterford quarry (p. 398) the granite occurs in two dikelike masses, 30 and 40 feet thick, alternating with three masses of granite gneiss, the central one of which is 20 to 30 feet thick. all strilking N. $80^{\circ} \mathrm{E}$. and dipping $30^{\circ}-45^{\circ} \mathrm{S} .10^{\circ} \mathrm{E}$. The relations are shown in figure 13 . The gneiss foliation strikes N. $45^{\circ}-60^{\circ} \mathrm{W}$. and dips about $40^{\circ} \mathrm{NE}$. but in places is nearly horizontal. The two granite masses are apparently connected in the center of the quarry by a small dike of the granite crossing the gneiss mass, as shown in figure

\footnotetext{
${ }^{27}$ Some of the more important of these papers are:

Darwin, Charles, Obserrations on the voleanic islands visited during the voyage of H. M. S. Beagle, together with some brief notices on the geology of Australia and the Cape of Good Hope, pp. 148-152, London, 1844.

Cohen, E., Geognostische-petrographische Skizzen aus Sid Africa: Neues Jahrb., 1874, pp. $477-502$.

Hatch, F. I1., and Corstorphine, G. S., Geology of South Africa, pp. 36-41, London, 1905.

Schwarz, E. H. L., The Sea Point granite-slate contact : Geol. Soc. South Africa Trans., vol. 16 , pp. $33-38,1914$.
} 
14. This gneiss (specimen D, XXX, 5, c, Mamacoke gneiss, No. 36 of the State preliminary geologic map) is a black and white banded fine-grained quartz monzonite gneiss, consisting. in descending order

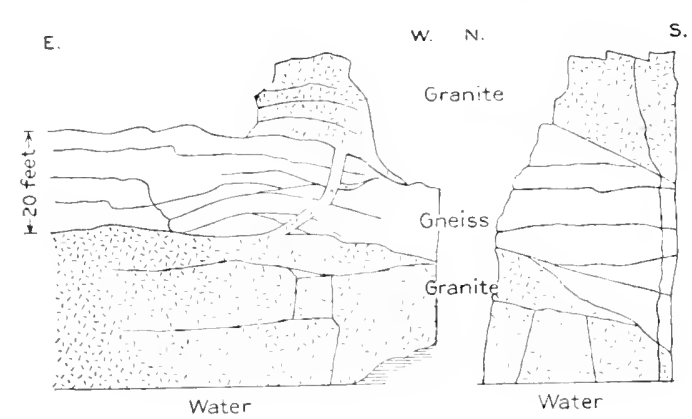

Futre 14.- Relations of granite and granite gneiss

in center of Waterford quarry, Waterford, Conn.

s of ahmulance. of light smoky quartz. milkwhite oligoclase, very little microcline. and biotite. The grinite sheets, 1 to 9 feet thick, are lenticular, irregular, dipping south and southeast at $15^{\circ}-22^{\circ}$. The sheet structure of the gneiss is not continuous with that of the granite, as shown in figures 14 and 15 , evidently having been set up before the intrusion of the granite.

Waldoboro, Maine.-At the Waldoboro quarry, Waldoboro, Maine, the original contact of the upper part of the granite mass with the lower part of the remmant of the schist mass, which once overlay that region and into which the granite was intruded, is exposed. (See Pl. XIII, A, and p. 250.) This schist is an amphibole-biotite-quartz schist containing some andesine feldspar, also accessory titanite and zircon. It is a metamorphosed rock, probably of sedimentary origin. At the opposite or southwest end of the quarry (see fig. 16) the relations between the schist and granite are very complex, and in places a considerable mass of pegmatite intervenes. The granite sends small dikes into the schist and also contains inclusions of it. The granite was erupted after or during the folding of the schist, otherwise it would have become a gneiss.

Milford, N.II.At the sonthwest corner of the Pease quarry, at Milford, N. H. (p. 185), mica diorite gneiss, about 6 feet thick, overlies the fine-grained

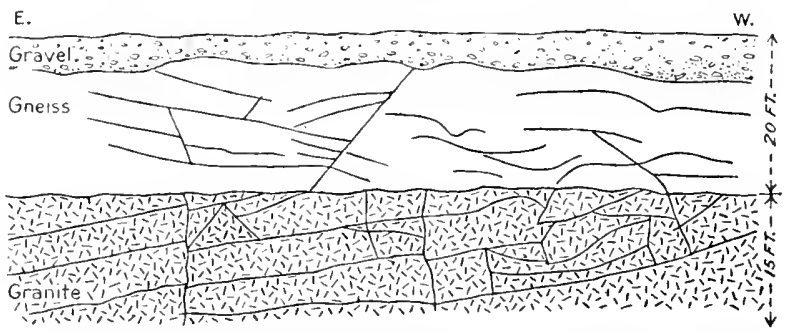

FIgURe 15.-Discordant sheet structure in granite and granite gneiss on south wall of Waterford quarry, Waterford, Conn.

quartz monzonite, as shown in figure 17 , with a foliation striking N. $75^{\circ} \mathrm{W}$. and a dip of $20^{\circ} \mathrm{S}$. The granite has a flow structure about parallel to the contact surface, but sheet structure crosses both gneiss and granite and flow structure and postdates them all. 
At the quarries of the Milford Granite Co., now idle (p. 1s9), there is a working face on the west about 1,000 feet long. It its south and north ends granite and gneiss contacts are finely exposed. The finegrained quart\% mo: zonite is orerlain by about 15 feet of gneis. with a foliation strik$\operatorname{ling}$ N. $7 . \pi^{\circ} W^{2}$ and lipping i.t sill. Plate VIII. A, shows the (0)11tart at the north cari of the rout. The sheet strueture is lentirular horizontal but does not continue into the aneis:. which seems to hase an indepentent and tiscontinuous theet structure of its own. The gueiss varies greatly in texture, composition.

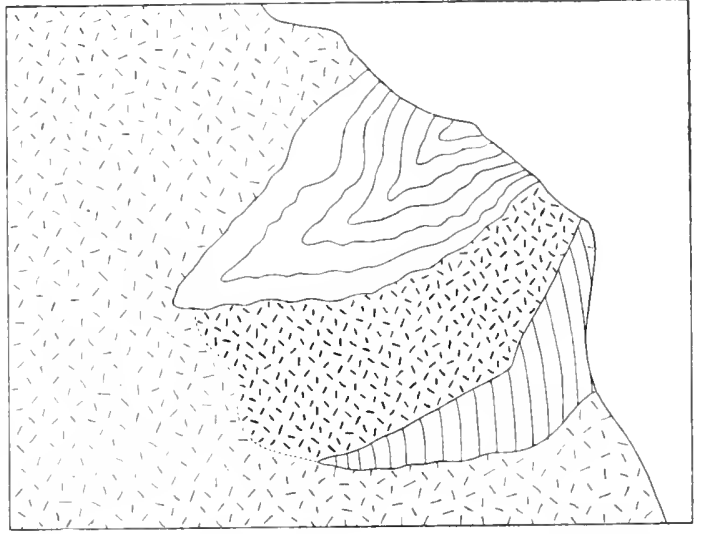

Figure 16.- Schist at southwest end of Waldoboro quarry, Waldoboro, Maine. Total heigltt, 45 feet. The coarse material, between the two inclusions, is pegmatite. The finer is muscovite-biotite granite.

and color. In some places it is coarse, black, biotitic, and hornblendic; in others medium grained, gray or white. and more fuartzose and feldspathic. It appears to be a quartz-mica diorite gneiss but contains streaks of a finely banded light-greenish fine-grained rock, which in thin section shows quartz, soda-lime feldspar (oligoclaseandesine), angite. hornblende, and biotite and thus appears to be il quartz-augite diorite gneiss. There are also dikes of pegmatite starting from the surface of the granite and tapering out in the gneiss.

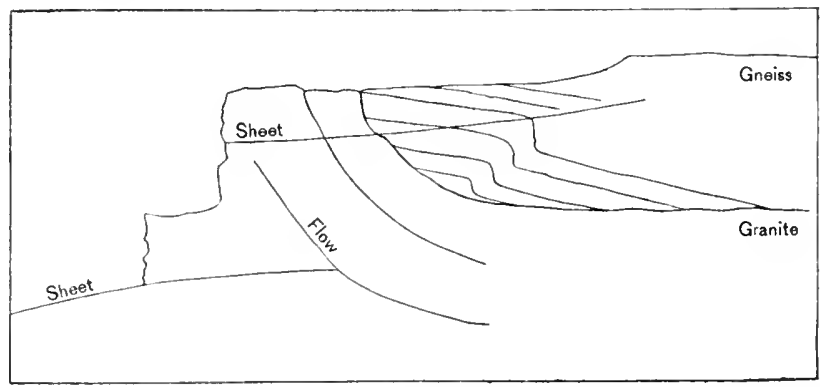

Figure 17.- Section showing relations of granite and gneiss at the l'ease quarry, near Milford, N. 11.; height, 10 feet. The flow structure is parallel to the contict surface, and sheet structure traverses both rocks.

Westerly and Charlestown, R. I.-At the Catto quarry in Westerly, R. I. (p. 412), the granite is a quartz monzonite. The sheets, from 6 inches to 10 feet thick, dip north at low angle. The east face of the quarry shows the relations of the granite to overlying granite 
gneiss. (See fig. 18.) This strip of gneiss extends the entire width of the quarry, with a foliation striking $\mathrm{N} .65^{\circ} \mathrm{W}$. and dipping $65^{\circ} \mathrm{NNW}$. As the granite crops out in places above the gneiss, this may be a very large inclusion. but it probably came from immediately under the original capping. The gneiss is so broken up here that hand specimens, half granite and half gneiss. with granite eutting the gneiss foliation, can be readily obtained. The gneiss is rather fine grained and consists of dark-gray very biotitic bands, 0.1 to 0.3 inch wide, alternating with light-gray bands that contain little biotite and with very light bands in which biotite is altogether lacking.

At the Klondike quarry (p. 415), in Charlestown. near Bradford Station, R. I., the fine-glained quartz monzonite is overlain on the

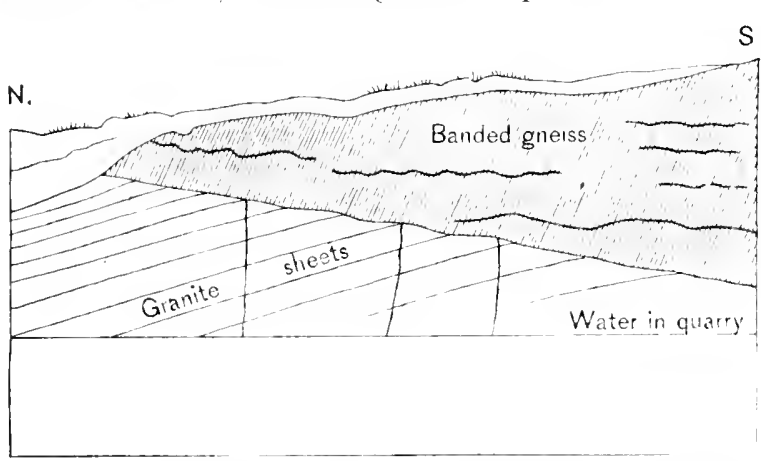

F1GURE 18.-Diagram of east face of Catto quarry, Westerly, I. I., showing granite overlain by a mass of biotite granite gneiss, each with its own sheet structure, also rertical joints in the granite. Length, 65 feet; leight above quarry water, 50 feet.

XXXIV, A, the contact between the granite and gneiss dips somewhat steeply, and sheet structure crosses both granite and gneiss at a lesser angle. There are also dikes of pegmatite beginning at the contact and tapering upward in the gneiss. On the east side the same gneiss underlies the granite, the granite intrusion liaving apparently reached the present surface in a dikelike mass. the sides of which dipped about $30^{\circ} \mathrm{S}$. and cut a mass of porphyritic biotite granite gneiss. The granite mass is about 75 feet thick, measured at right angles to its inclination. The foliation of the gneiss is not far from horizontal. On the south side the sheet structure extends into the gneiss, as shown in Plate XXXIV, $A$, and figure 93 (p. 416). Fifteen feet below the gneiss the granite contains one or more angular inclusions of finely banded biotite gneiss. Three years after the writer's visit the excavation showed the quartz monzonite dike narrowing downward, so that the figure requires some modification. 
Conclusions.- These structural contact phenomena lead to the following inferences:

Flow structure in places is parallel to the under surface of the intruded rock.

Sheet structure is quite independent of flow structure.

In some places sheet strueture was set up in the granite gneiss of the eapping prior to the granitic intrusion, but in others (Pease quarry, Milford, N. I.; Klondike quarry, Charlestown, R. I.) the sheet structure of the granite passes into the intruded gneiss and is of later date than the intrusion itself.

The contact surface in places is rudely serrate or otherwise irregular from the ruptures camed by the intrusion, and large fragments of the intruded rock evidently dropped into the plastic granite.

The intrusion of a granite gneiss by a gneissoid granite indicates two periods of intrusion and two of metamorphism at the same locality.

The thinness of the schist or gneiss (in places only 2i feet) now capping the granite indicates the erosion of at least several humdred feet of the capping since the intrusion took place. (See p. 4.)

Pegmatite and aplite dikes usually originate at the surface of the fntruding granite and penetrate the intruded mass. Pegmatite also collects along the intruded surface and about the inclusions.

\section{PLICATED GNEISSIC TEXTURE.}

Under metamorphism a granite passes into a granite gneiss (p. 65) that is, from a massive crystalline to a schistose condition. If this schistose granite is subjected to lateral compression its foliation will become plicated, and if the pressure continues the plications may even be faulted. An interesting example of this is seen at the West quarry, on Hoadly Neck, in Branford, Conn. (p. 381), and is shown in figure 19. The original granite was very coarsely porphyritic, and the feldspars have become lenses up to 3 inches in length. The little folds are up to 10 inches in width and are faulted.

\section{"BLACK GRANITES."}

\section{CLASSIFICATION.}

The term "black granites," although sufficiently descriptive for general commercial purposes, includes a variety of rocks of different character, origin, and appearance-gabbros, diorites, diabase, etc. They have, howerer, three mineralogic features in common-they contain comparatively little or no quartz, their feldspar belongs entirely or almost entirely to the series which contains both soda and lime, and they contain a considerable amount of one of the pyroxenes, or hornblende or biotite, and magnetite, which accounts for the general darkness of their shade or their greenish color. 


\section{ORIGIN.}

The gabbros and diorites are more or less granitic in texture, as they crystallized under conditions resembling those which attended the formation of granite. But the diabase was in part erupted through narrow fissures, forming dikes or sheets. and at many places reached the surface, always crystallizing with comparative rapidity.

Diabase, however, occurs in Vinalhaven, Maine, as stated by George Otis Smith, "in large bodies which have the form of neither dikes
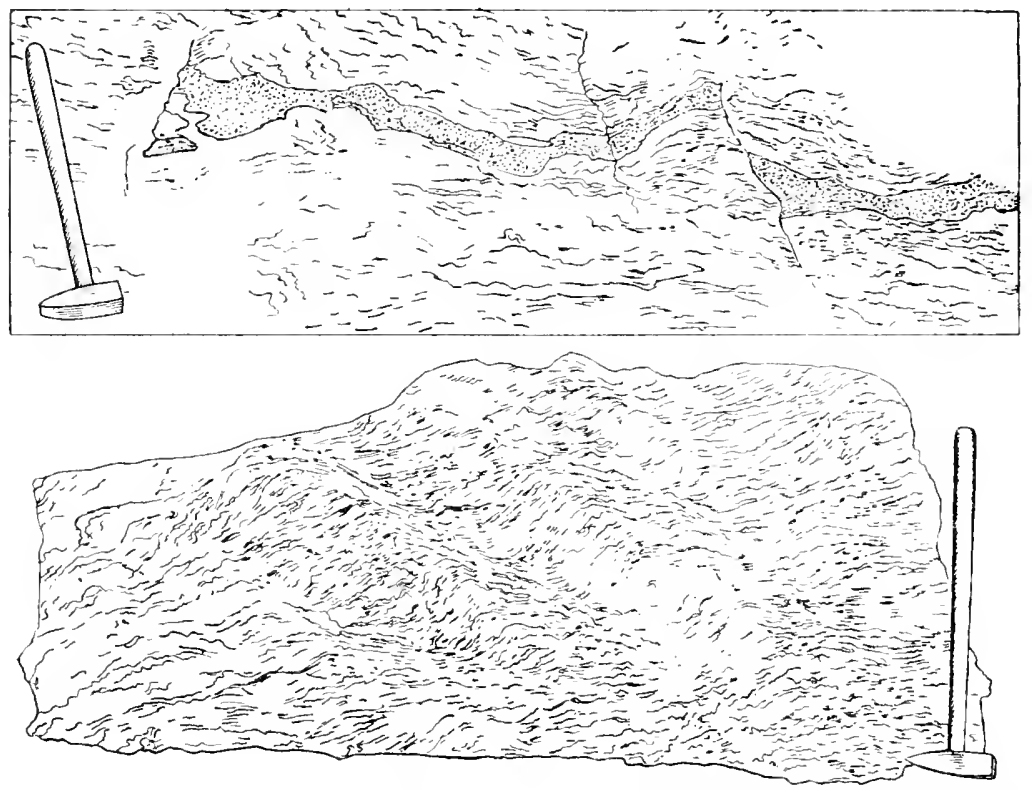

Figure 19.-Lower: Block of plicated blotite granite gnelss from West quarry, Hoadiy Point, Branford, Conn. Upper: Plicated and faulted band of fine biotite granite gneiss within the coarser gneiss of same quarry. Hammers 20 inches long. (From photo. graphs.)

nor sheets, being, in fact, part of the same masses as the diorites and gabbros."

\section{MINERAL AND CHEMICAL COMPOSITION.}

Gabbro consists essentially of a lime-soda feldspar and one or both of the varieties of pyroxene known as diallage and hypersthene. Diallage is a foliated silicate of iron and lime with about 12 per cent of magnesia; hypersthene is a silicate of iron with about 24 per cent of magnesia. Each of these minerals crystallizes differently. Rock that contains hypersthene is called a norite; rock that contains both hypersthene and diallage is a hypersthene gabbro. If the mineral olivine (a greenish silicate of iron with 50 per cent of mag- 
nesia) is present also the name olivine may be prefixed to the rock name. The accessory minerals in gabbros are ilmenite (a titanate of iron), magnetite, pyrite, apatite, biotite, garnet, and rarely quartz and metallic iron. The secomdary minerals-that is, those derived from the alteration of the primary ones-are hornblende, chlorite, epidote, zoisite, analcite, serpentine, a white mica, and calcite. The percentage of silica in gabbros varies a little on each side of 50 . Iron oxides and lime average 9 per cent each; magnesia, 6 per cent.

Diorite consists essentially of feldspar (of the series containing lime and soda) and hornblende with biotite, or biotite alone. Quartz, augite, and potash feldspar may or may not be present. The accessory minerals are magnetite, pyrite, titanite, zircon, apatite, garnet, and allanite. The secondary minerals are epidote, chlorite, a white mica, and calcite. If quartz is present the rock is called a quartz diorite. If black mica or augite are the preponderating iron-magnesium silicates the rock is a mica diorite or an augite diorite. In diorites the silica ranges from about 49 to 63 per cent, but in quartz diorite it rises to about 69 per cent. which is the minimum in granite. The iron oxides range from 0.52 to 9.70 per cent, the nlagnesia from less than 1 to more than 11 per cent, but usually from 2 to 7 per cent.

Diabase consists essentially of a feldspar of the series containing lime, or soda and lime, together with a pyroxene (usually angite, a silicate of alumina, lime, magnesia, and iron), which, however, is frequently altered to hornblende or other secondary minerals; also magnetite or ilmenite, or both. Olivine may or may not be present, and some spccimens contain a little quartz. The accessory minerals are orthoclase, biotite, pyrite, hypersthene, and apatite. The secondary minerals are hornblende, a white mica, chlorite, epidote, serpentine, and calcite. The percentage of silica in diabase ranges from about 45 to nearly 5 , of iron oxides from about 9 to 14 , and of magnesia from 3 to 9 .

These "black granites," as will be seen by the foregoing descriptions, are distinguished chemically from the ordinary granites by their low percentage of silica (45) to 67 per cent), their high maxima of iron oxides (9 to 14 per cent) and of magnesia (9 to 11 per cent), and mineralogically by their dominant feldspar not being a potash felilspar, and generally also by their considerable content of the darker iron-magnesia minerals.

TEXTURE.

The general texture of the "black granites" corresponds in grade to that of the fine and medium granites. In the diorites the arrangement and order of crystallization of the minerals always correspond to those of the granites described on page 10. In some of the gabbros 
this is also true, but in others and in diabase the arrangement greatly differs. The feldspars are in needle-like crystals, between which the pyroxene has afterward crystallized (ophitic texture).

PIIYICAI, IROPERTIES.

Aside from their great tonghness, the diorites and the granitic gablores probably differ but little in physicil properties from granites of the sime grade of texture. By reason both of their peculiar texture and their mineral composition, the cliabases and gabbros with ophitic texture should differ considerably in physical properties from the granites. As these stones are rarely used in large buildings, owing to the difficulty of quarrying them either in blocks of sufficient size or at low enongh cost, data as to their compressive strength and wher useful physical properties are not available.

The specific gravity of gabbro ranges from 2.66 to about 3 , that of diabase from 2.7 to 2.95, and that of diorite averages 2.95. In these rocks it thus usually exceeds that of granite.

As the "black granites" are used chiefly for monumental purposes, and particularly for inscriptions, their color, susceptibilty to polish, and the amount of contrist between their cut or hammered and their polished surfaces are the physical properties of chief economic importance.

Merrill as explains the cause of these contrasts very satisfactorily:

The impart of the hammer hreaks un the granules on the immediate surface, so that the light falling upon it is reflected insteald of absurbed, and the resultant effect upon the eye is that of whiteness. The darker rolor of a polished surface is due merely to the fact that, through eareful grinting, all these irregulatities and reflecting surfaces are removel, the light penetrating the stone is absorbed, and the effect upon the cye is that of a more or less complete absence of light, or larkness. Obviously, then, the more transparent the feldspars and the greater the abundance of dark minerals, the greater will be the contrast between hammered and polished surfaces. This is a matte: worthy of consideration in cases where it is wished, as in a momment, to have a polished die surrounded by a margin of hammered work to give contrast.

The ordinary granites, while taking a high polish, do not afford such strong contrasts between hammered and polished surfaces as the "black granites." In some black granites this seems clearly to be due to their larger percentage of the black minerals, but in others, as some of the quartz diorites, in which the black minerals do not exceed those in some gray granites, the cause of this marked contrast must be sought in some optical property of the soda-lime feldspar and in its relative abundance.

${ }^{28}$ Merrill, G. P., The physical, chemical, and economic properties of building stones: Maryland Geol. Survey, vol. 2, p. 61, 1898. 


\section{TEXT-BOOK REFERENCES ON GRANITE AND “BLACK} GR A N ITES."

As the matter contained in the foregoing pagres may not fully provide answers to all questions arising in the minds of persons interested in tracing the phenomena in granite quarries to their causes, the names of a few reliable general works in English on the subjects considered are here given.

Dana, J. D., Mantal of mineralogy, 13th ed., by W. E. Ford. New York, 1912. Dana, E. S., Texthook of mineralogy (with treatise on crystallography.

Genile, Ancrimald, Texthook of geology, thl ed., London, 1903.

Granite, etc. Pp. 89. 90. 203-209, 402-115, 715-809; gabbro, np. 231, 3:2, 256 ; diorite, p. 223 ; diabase, p. 233 ; basalt, p. 234.

Harker, Alfred, Petroglaphy for students; an introduction to the study of rocks under the microscope, 4th ed., Cambridge, England, 1908.

Granites, pp. 27-41; gabbros. pp. 67-S3; diorite, pl. 54-66; basalts, pp. 188-203.

Натсн, F. H., The petrology of the igneous rocks, thl ed., Ionion, 1915.

Jomannsen, Ambert, Essentials for the microscopical determination of rockforming minerals and rocks, Chicago, 1922.

Kemp, J. F., A handbook of locks for use without the microscope, 3d ell.. New York, 1904.

The granites, pp. 33-38; gabbros, pp. $72-74$; diorites, Ip. 60-62; diabases, pp. $70-72$.

Luquer, L. M., Minerals in rock sections. revised ed., New York. 1908.

Mfrrill, G. P., A treatise on rocks, rock weathering, and soils, $2 \mathrm{~d}$ ed., New York, 1906.

Igneous rocks, pN. 52-60; granites. p). 61-64; diorites, pp. 76-77; diabases, pp. 82 , 85 ; basalts, pp. 86.87 ; weathering, pp. 150-273.

Pirsson, L. V., Rocks and rock minerals : a manual of the elements of petrology without the use of the microscope, New York, 1908.

$105709-23-S$ 



\section{PART II--ECONOMIC DISCUSSION.}

\section{GENERAI FEATURES.}

The practical side of the granite industry will now be considered. $A$ list of the more important works on granite quarries and quarrying and other matters of conomic character will be found at the end, together with a glossary of both scientific and quarry terms.

\section{TESTS OF GRANITE.}

The testing of granite is a subject of considerable importance, as may be seen by its literature given on pages 464-467. As pointed out by Merrill, there is danger of attaching undue importance to tests of compressive strength alone, the results of which almost invariably far exceed the generous margin allowed by architects beyond that required by the weightiest structures. On the other hand, there is danger of losing siglit of several other qualities which ought to be carefully tested and upon which the economic value of granite in part depends. The following tests include all the kinds made at European testing institutions or recommended by American authorities, as well as some suggested by the writer's investigation of New England granites:

Chemical analysis.-Chemical analysis is made in order to determine the amount of iron and lime or to detect anything abnormal in the composition.

Determination of $\mathrm{CaCO}_{3}$.-Tests are made to determine the presence of lime not combined with silicates in order to ascertain the percentage of $\mathrm{CaCO}_{3}$ (lime carbonate) present. This is done by powdering and treatment with warm dilute acetic acid.

Test for discoloration.-The method applied by Daly ${ }^{1}$ seems to be well adapted for the test for discoloration. A piece of fresh rock is immersed in a stream of carbon dioxide gas for 20 minutes and then kept in an atmosphere of that gas for 24 hours. Inother piece of fresh rock is placed in an atmosphere of purified oxygen overnight and then exposed for 30 minutes to a temperature of $151^{\circ}$ C. $\left(302^{\circ}\right.$ F.). Any discoloration due to the carbonization or oxidation of the minutest particles of any mineral would be sure to show itself under these tests.

Mineral composition.-The mineral composition is determined by the microscopic examination of a considerable number of typical

\footnotetext{
${ }^{1}$ U. S. Geol. Surrey Bull. 209, p. 52, 1903.
} 
thin sections. All the mineral constituents are noterl, and for the fine-textured granites the average size of the mineral particles is estimated. Any peculiarities of texture, rift, etc., can also be noted.

Proportions of minerals. - The method devised by Rosiwal, ${ }^{39}$ of the Austrian Geological Survey, by which the approximate proportions of the chief minerals (feldspar, quartz, mica, hornblende) and their arerage size can be determiner, consists in tracing a network of lines intersecting one another at right angles upon a polished granite surface, at intervals so great that no two parallel lines will traverse the ame mineral particle. The total length of the lines is measured, then the diameters of all the particles of each kind of mineral are added separately and their proportion to the total length of the lines obtained. The arerage size of the particles of each mineral can be also calculated from the same measurements. Although this method was designed primarily for application to the coarse and medium granites, it can be extended also to the finer ones by drawing the lines upon amera-lucida drawings made from thin sections of such granites under polarized light. Certain microscope attachments have made this work less laborious. As the quartz is the source of the vitreousness of the rock the determination of its amount is important.

Polish.-Besides the manifest object of the test for polish it also facilitates exact descriptions of color and comparisons between dif. ferent granites. The size of the mica plates determines the brilliancy and durability of the polish more than their number doesthat is, a considerable number of rery minute mica plates is not objectionable.

Hardness.-As pointed ont by Hawes, ${ }^{40}$ the hardness of rertain granites is not due entirely to the quartz, which is always equally hard and brittle and which the tools do not cut but crush, but to the feldspar, which is of variable hardness and, it might be added, has different clearages, and the proportion of which in relation to quart $z$ also varies. Rosiwal.41 adopting a principle establisher by Toula, takes a piece of smooth unpolished granite of about 2 grams weight and rubs it with emery (of 0.2 millimeter diameter of particle) upon a glass or metal plate for six or eight minutes until the emery loses its effectiveness. The granite is then weighed again and its loss of volume calculated. He found, assigning to emery an arbitrary value of 1,000 as representing its average hardness, that granite

39 See Rosiwal, August, Teber geometrische Gesteinsinalysen; pin pinfaeler Weg zur ziffermässigen Feststellung des Quantititsverhältuisses d'r Mineralbestandtheile gemengter Gesteine: K.-k. geol. Reiehsanstalt Verh., vol. 32, pp. 143-175, 1898.

${ }^{40}$ Hawes, G. W. (edited by Merrill), Granite; Building stones of the United States and statisties of the quarry industry: Tenth Census, vol. 10, pp. 16-18, 1858.

"Neue Untersuchungsergebnisse über die Härte von Mineralien und Gestcinen: K.-k. geol. Reichsanstalt Verh., 1896, p. 488. 
from nine localities showed the following degrees of hardness: 31.7, $38.1,41.7,44.8,48.4,50.7,52.9,56.6$, and $6 \pi .1$. The extremes of these figures show that some granites have a general hardness more than twice as great as others.

J. F. Williams ${ }^{42}$ proponed to determine the relative hardness of granites by noting the rate of penetration of a drill of a given cliameter. or by measuring the distance to which such a drill will penetrate without being sharpened, or the amount of surface of rongh-pointed granite which can be reduced to a bush-hammered surface per hour. since the introduction of pneumatic drills and surfaces these methods (an be easily applied.

The United States Bureau of Standards expects to devise a maehine for the satisfactory letermination of the relative hardness of building stones.

C'ompressive strength.-Whe methods of testing the strength of building stones have grown in precision. The first requisite is that the cubes to be tested should be salved by diamond saws and not hammered out. The next is that the direction of both rift and grain should be indieated thereon. and that three culses shombl be testerl. one with pressure applied parallel to the direction of the rift. one with pressure applied parallel to that of the grain. and the third with pressure applicd at right angles to rift and grain. Where the rift and grain are pronomced the three results will differ. ('ompressive strength is now tested by the United States Burean of Standards, both dry and wet, after two weeks immersion in water. and, also after 10 to 30 freezings and thawings.

Trunsverse strength.-The transverse strength shoulh be tested both across the rift and with it, these directions being indieatid on the lock by the quarry foreman. The length of the span, the breadth and depth of the piece. and the weight of the loak are taken into account in arriving at the modulus of rupture, given in pounds per square inch.

Tensile strength.-The test for tensile strength is useful in some building stones, particularly those designed for delicate carving. Small blocks are sawn ont shaped somewhat like the figmre 8 and pulled apart. The results are given in pounds per square inch. Of course, in a granite the results would differ if tension were applied with the rift or the grain or diagonal to both.

Porosity-Buckley ${ }^{43}$ points ont that the danger from frost depends not upon the amount of absorption but upon the size of the pore space. Rocks with large pore spaces stand frost better than those

42 lgneous rorks of Arkansas: Arkansas linol. Surveg Ann. Rept. for 1891, rol. 1. p. 41, 1.91 .

43 See lucklry. E. R., Building and ornamontal slones of Wisconsin, pp. 6S. 69, 372-376, $400,41: 3,1 \mathrm{~s}, \mathrm{~s}$. 
with small ones, because they do not retain the water that they absorb. Tests of porosity are therefore important. Buckley used the dry and saturated weights obtained for the samples used in computing the specific gravity.

'The difference in these weights was multiplied by the specific grarity of the rock. This amount was added to the dry weight, giving the sum. The difference of the dry and saturated weights multiplied by the specific gravity of the rock was then divided by the sum. This last result is the actual percentage of pore slace compared with the volume of the sample tested.

Absorption.-The Bureau of Standards gives the results of tests of water absorption in percentage by weight. Buckley ${ }^{44}$ describes a method of testing absorption.

Behavior under fire.-The test for behavior under fire is best applied to saturated specimens, which are then exposed in a laboratory furnace to a temperature up to $1,500^{\circ} \mathrm{F}$. and the effect noted. Some of them can be allowed to cool gradually, but other's should be immersed quickly in cold water; or they may be exposed to high temperature while unler compression and then cooled slowly or quickly. ${ }^{45}$

Recent studies of the cause of the disintegration of granite under fire by Sosman ${ }^{46}$ and Tarr ${ }^{47}$ show this cause to be twofold-(1) the wedging and straining consequent on the different coefficients of thermal expansion of the constituent minerals: (22) a like effect due to the "rapid rolume increase of quartz as its $575^{\circ}$ inversion point is approached and by its final sudden increase in volume at $5.55^{\circ} . "$

Sprecific grarity-The specific gravity is the weight of the stone at $16^{\circ}$ C. compared with that of the same rolume of distilled water at $4^{\circ} \mathrm{C}$. All ail should first be removed from the piece to be tested by boiling in distilled water. The specific grarity is also required for the test of porosity.

Weight per cubic foot.- The weight of the dry stone per cubic foot is obtained by multiplying its specific gravity by the weight of a cubic foot of water, but from this there should be deducted "the weight of a quantity of stone of the same specific gravity equal in volume to the percentage of the pore space in the stone." 48 This gives the actual weight of the stone free from interstitial water.

Coefficient of expansion.-Finally, it may be desirable to obtain the coefficient of expansion of a granite intended for some particular construction. The expansion of certain granites was determined at

44 ldem, pp. 396-398.

45 dem, np. $73,411$.

40 Day, A. L., Sosman, R. B., and Hostetter, J. C., The determination of mineral and rock densities at high temperatures: Am. Jour. Sci., 4th ser., vol. 37, pp. 1-39, 1914. Sosman, R. B., A study of some heating tests: Econ. Geology, vol. 11, pp. 86, 87, 1916.

47 Tarr, W. A., A study of some heating tests, and the light they throw on the cause of the disaggregation of granite: Econ. Geology, vol. 10, pp. 345-367, 1915; vol. 12, p. $280,1917$.

4 Buckley, E. R., op. cit., p. 70. 
the Watertown Arsenal by hot and cold water baths. 'The stones thus tested were afterward subjected to the test of transverse strength, when it was found that they had lost 16.93 per cent of their original strength. ${ }^{49}$

A list of the varions tests applied to building stones by German testing institutions is given by Herrmann. ${ }^{50}$

\section{GEOGRAPHIC DISTRIBUTION OF NEW ENGLAND GRANITE QUARRIES.}

In Termont the granite quarries lie all in the eastern half of the State and from the Canada line to Brattleboro. In New Hampshire they are on the northwest and southeast sides of the White Momtains, also about Concord and near the Vermont, Maine, and Massachusetts lines. In Maine the quarries are scattered along the coast and on its islands from the New Mampshire to the New Brunswick line: a very few are 40 to 55 miles inland. In Massachusetts, with unimportant exceptions. they all lie in the eastern half of the State, from New Bedford to Cape Ann. In Connecticut the quarries are mostly along the Sound, with a few in the western part of the State, along Connecticut River and the Rhode Island border. In Rhode Island they are almost entirely near Block Island Somd and the Connecticut line.

\section{DESCRIPTIONS OF THE QUARRIES, GRANITES, AND} PRODUCT.

\section{METHOD OF TREATMENT.}

The States will be taken up in the following geographic order: Vermont, New Hampshire, Maine, Massachusetts, Connecticut, and Rhode Island. The quarries will be taken up by counties in alphabetic order and by townships. The particulars of each quarry will be given in the following order:

1. Name and location of quarry : name and oflice addless of operator.

2. The granite (specimen No.), its trade and technical names; its color, texture, minerals, estimater mineral percentages; its chemical composition and physical qualities, as shown by any arailable analyses or tests.

3. The quarry, date of opening, and approximate dimensions.

4. Rock structure, comprising sheets, joints, headings, their strike, dip, and spacings; courses of rift, grain, flow structure, dikes, and veins; dimensions of "knots," width of discoloration. Where the structure is complex, a diagram of the courses is given.

5. Transportation, method, and distance to dock or railroad.

6. The product. its uses, and the names and location of a few specimen buildings and monuments.

49 Report of the tests of metal, etc. made with the United States testing machine at Watertown Arsenal, Mass., p. 320, (1895)-1896.

50 Herrmann, A., Steinbruchindustrie und Steiubruchgeologie, pp. in st seq.. Berlin, 1899. 
The quary descriptions for each state are preceded by a section on the geographic distribution of its quarrying centers, accompanied for sereral of the States by a map and followed by a chapter on the zeologic relations of the granites. In some cases. however, instead of a state map. a map showing the location of the curarries in each important quarrying center precedes the description of its quarries, and the geologic relations of the granite of that renter are also considered separately.

An economic classification of all the granites of New England appears at the end of the clescriptions in tabular form (pp. 41!-435). In one table the trade name. general color and tint, shade, grade of texture, and scientific name of each granite are given in separate columns, and also page references to the detailed descriptions. In another table most of the granites are classified by color and shade.

\section{VERMIONT.}

\section{DISTRIBUTION OF THE GRANITES AND QUARRYING CENTERS.}

Not until a contour map of the momtainous portions and of the easterin half of Termont is completed and a careful geologic survey based upon such a map is male will the geographic distribution and extent of the granite areas of the state be accurately known. According to the geolugic map of Vermont traced and compiled by the authors of the State report of $1861^{51}$ and also according to the greologic: map of Orange and parts of Washington and IVindsor comnties by C. H. Richardson, ${ }^{52}$ a series of granite areas, rarying greatly in size but mostly small, extend in a north-northeasterly direction between the central (ireen Mountain axis on the west and connecticut River on the east for almost the entire length of the state.

The distribution by counties of all the granite-quarrying centers and prospects of Vermont described in this bulletin is shown in Plate I. At the extreme north end of the state, in Orleans County, franite is curried in Derby, east of Lake Memphremagog. Near. the northeast corner of Caledonia County, the next rounty south, there is a cranite quary in Newark: and there are several quarries in Kirby, abont 14 miles sonth of Newark. There are also several quarries near the western corner of this county, 20 to 23 miles west of Kirby, in Hardwick; and the quarries of Ryegate and Groton lie near its southern edge. In Washington County, the southern half

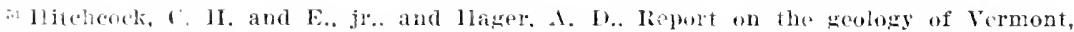
vol. 2. pl. 1. 1\$61. This man, valuable as it is. can to-flay hardly be rewarded as more than a reconnaissance map. Some of its granite areas are wrongly located, and granite las been found where the map does not show any.

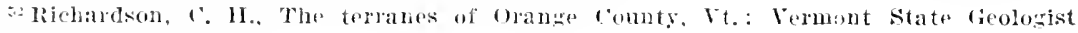
liest., 1902, pls. !), sa. 
of which adjoins Caledonia on the west. there are three groups of quarries. the Woolbury quarries, at the north. and east of them a quarry in Cabot: sonth of Woolbury the quarries in Calais: and 20 miles sonthwest of Woolbury and s miles sontheast of Montpelier, the quarries of Barre, which is the chief granite-producing renter of the state. I few of the Barre district quarries lie south of the Orange Comnty hine. Abont 20 miles sonthwest of Barre is the granite prospect of Randolph, in Orange County. In the northern part of Windsor County is the small but important white granite area of Bethel; 10 miles southwest of it is a quarry in Rochester; $21 \frac{1}{2}$ miles nearly south-sonthwest of Bethel is another but very small white granite area in Plymouth, and 33 miles sontheast of Bethel and near the Comnecticut is the green syenite of Mount Ascutney, in Windsor and West Windsor. Finally, in Wintham County, towarl the southern border of the State. 37 miles southsouthwest of Ascutney, near Brattleboro and the Commecticut, are the light-glanite quarries of Dummerston.

\section{GEOLOGIC REIATIONS OF VERMONT GRANITES.}

The contact of the granites of Bethel, Barre, and Woodbury with schist or slate and the inclusions of these rocks in the wranites of Barre and Ryegate have already been lestribed (pp. 84, 88, 64). The granite of Bethel contains inclusions of very fine black biotiteortho-lase-oligoclase schist quite unrelated to the schist and slate surrounding that granite (pp. 155. 158). As is shown on page 160, the granite of Plymonth is surrounded by and in conta th with schist. On Buffalo IFill, in Hardwick. the granite is in contact with a biotiteyuartz schist.

The general inference from these contacts and inclusions is that the gray biotite granite of Barre, Calais, and Woodhury, the white quartz monzonite of Bethel and Plymonth. the gray biotite errmite of Ryegate, and the light and dark gray guartz monzonites of Derly and Hardwick were intruded into certain mica schist: and mica slates which are metamorphosed clayey and sandy sediments. Whether the intrusion of granites as riverse in character as those of Barre. Bethel, and Hardwick took place at the same time can not ret he determined. The green syenite (hormblende-augite granite) of Mount Ascutner, in Wind-or. is in contact with a mass of schist which crops out along the base of the mountain a little below the Noreross quarry and has been carefully traced by Daly ${ }^{53}$ on three sides of the svenite mass and mountain. He has also described the thanges brought about in the schist by the intrusion of the syenite ${ }^{5+}$

s Dals. k. A., The geology of Ancutney Mountain, Vt.: C. S. Geol. Surrey Buli. 20l9, ก. T. 1903.

Idem, pp. 33,34 . 
and shows a biotite granite intmsive in the syenite on the eastern flank of the mountain.

In view of the certain amount of pressure needlul for the slow cooling and crystallization of granite the schist masses intrided by these various granites must have been thicker than they now are. The exposmre of the present granite surfaces has been brought about by the erosion of the schist masses.

Views have changerl as to the age of these schists. On Hitcheock and Hager's map the granite areas are represented as surrounder by "alciferous miea schist" which was regarded as not later than Deronian.5. Iichardson ${ }^{55}$ in his papers and map subdivided the "calciferons mica schist" belt of Hitcheock and Hager into a cal"areous formation (in places a marble but containing schist phases) which he finally designated Waits River limestone. and an overlying noncalcareons schist. the Tershire schist. Iie associates the latter formation with a certain belt of slate that flanks the central Green Mountain axis on the east. extends from Take Memphremagog sonth to Barnard, and includes the roofing slate of Northfield and Montpelier. This slate he finally designated the Memphremagog slate. Abont 3 miles west of the head of Lake Memphrenugog, at Willards Mill, Casilebrook, Nagog, Province of Quebec, this slate bears abmdant graptolites of lower Trenton age.

In 1912 Richardson ${ }^{5 \tau}$ announced the discovery in Irasburg of a basal Ordorician conglomerate. and in a more recent paper, ${ }^{58}$ in referring to the same locality, he reports pre-Ordovician granites intruding Cambrian sedimentary rocks, and also announces the discovery of Ordovician graptolites, with determinations by R. Rnedemann. in the calcareons or noncalcareons sedimentary rocks of Newport, Irasburg, Craftsbury, Hardwick, Woodbury, Calais, Mont velier, and Northfield, estrblishing the Ordovician age of the slate belt from Lake Nemphremagog to Northfield and Barnard. He also found Ordovician graptolites in the slates of Barre. The conclusion is thus reached that the mica schists and mica slates intruded by the granites of Newport. Hardwick, Woodbury, Calais, Barre, and Bethel are very prohably all of Ordovician age. Richardson is careful to state, however, that althongh the intruded rocks are Ordorician the intrusion may not have taken place until

${ }^{55}$ Op. cit., vol. 1, p. 470.

so Richardson, C. II., The Washington limestone in Vermont: Am. Assoc. Adv. Sci. Proc., vol. 47, pp. 295-296, 1S98; The terranes of Orange County, Vt.: Vermont State Geologist Third Rept., pp. 84, 97, 98, pl. 9, 1902 ; The areal and economic geology of northeastern Vermont : Vermont State Geologist Fifth Rept., pp. 86, 90, 1906; The geology of Newport, Troy, and Coventry: Vermont State Geologist Sixth Rrpt., pp. 274-279, 1908.

s7 Richardson, C. H., The terranes of Iraslurg, Vt.: Vermont State Geologist Eighth Rept., p. 151, 1912.

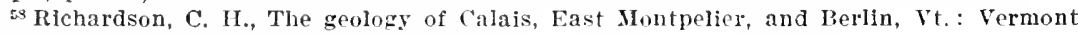
state Geologist Tenth Rept., pp. 112-145, 1916. 
post-Devonian time-that is, during the second crustal movement and metamorphism after the deposition of the Ordovician sediments.

Daly, ${ }^{59}$ basing his opinions on Richardson's results and inferences, regards the schist of Mount Ascutney as of Trenton or pre-Trenton age and the intrusion of the syenite as "of latel date than the last great period of rock folding which has aflected the Ascutney region." and says that "the bakan e of probability makes it of post-Carboniferous and pre-Cretaceons age."

Evidences are not wanting in the composition and microscopic structure of the granites and in their larger stuctures as exposed at the quarries that since their intrusion they have been subjected to one and possibly several crustal movements. (See pp. 127, 128, 153.)

The basic dikes that traverse the granite or their inclosing schists at Barre, Groton, and Mount Asentney are of later, possibly 'Triassie, date.

\section{OUTLINE OF EARIIER HISTORY OF VERIMONT GRANITES.}

The general earlier history of the granites and associated rocks of eastern Vermont may be tentatively put in the following simple for'm :

1. In Algonkian time there was a period of selimentation followed by the intrusion of granitic loks into the sedimentary beds. These granities are the present gneisses of the Green Momntain range.

2. It the end of Algonkian time a crustal morement metamorphosed the Algonkian sediments into schists and quartzite and the granites into gneisses. This movenent was accompanied by folding and elevation. The earlier mountin system of the State was thus formed.

3. In early Paleozoic time a large area of Algonkian rocks was submerged and received sediments resulting from the erosion of Algonkian land masses, together with calcareous sediments largely of organic origin.

4. At the end of Lower Cambrian time a minor crustal movement took place, subjecting the Lower Cambrian beds to erosion, followed by a resubmergence at the beginning of Ordovician time. Evirlence of this morement is obscured in many places by the effect of the cristal movement noted below (5).

5. At the end of Ordovician time a crustal movement took place, metamorphosing the Cambrian and Ordovician sediments into schist, quartzite, slate, and marble, and powerfully folding and also elevating them. The later mountain system of the State was then formed. Some of these schists and slates are those which now surround the granite areas.

op. cit., pp. $20,21$. 
6. After a long interval. probably at the end of Devonian or Carboniferous time, another crustal morement occurred, accompanied by the intrusion of the Ordorician schist mass by granitic material in a state of fusion with superheated water. The intrusion produced in places further changes in the schist and also injected it with dikes of pegmatite. Fragments of the schist became inchuded in the granite.

i. No long after the erystallization of the granite it was trarersed loy granite dikes (pegmanite and aplite).

8. Mount Ascutury shows two intrusions. one of the Ordovician shist by the syenite, and a later one of the syenite by a biotite granite. The age of the last is quite mucertain.

9. The schist and granite masses were travereed, possibly in Triasi- time, by basir dikes (diabase, etr.).

10. Atmo spherir erosion of the Paleozrie rdhists and slates, begun at the close of Ordorician time. has firally remored those parts of the schist nuas which arered the erranite lomes. This process of rosion has been aceelerated by suressive uplifts.

\section{THE GRANITE RAIIROADS.}

The wanite inchistry of Vermont owes no -mall part of its present prosperat to "granite railromls." which connect not only groups of quan ries but every gnarry in ea horomp with the main line, although these quarries are situated at considerable elevations and are inconreniently related to c ne anothor. I'late II shows the intricate cinararter" of the granite railroal about Millstone Hill near Barre: figure 20 eives a coneral idea of that comnecting Roheson Mountain in Wrodhury wh Indwi: k, and figme 3.5 that leading from Christian Hill to Bethel.

\section{THE QUARPIES, THEIR GRANITE AND FINISHED PRODUCT.}

('ALEDUNA (O) ITY.

\section{HARDWICI.}

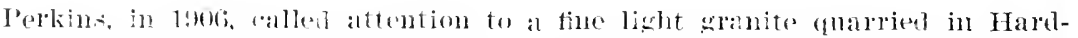

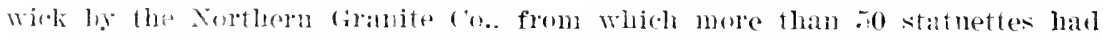

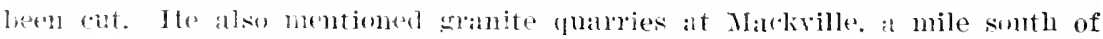
II rowing villaw, as then operater ly the same company. As these quaries were not in ofuration in $190 \mathrm{~s}$ they were not vis ted by the witer.

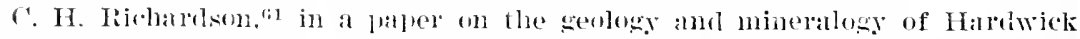
and Woollomy, aives a geologiv mat of IIardwick slowing three grante areas. one worth of the village ( West If ll ame Tuclierville areal), one south of it Markville areal) amd one west-soutluwest of it which inclurles Puffalo Hill and the Matele quarries.

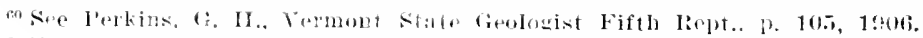

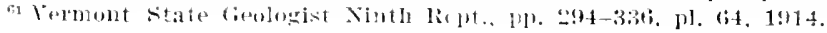




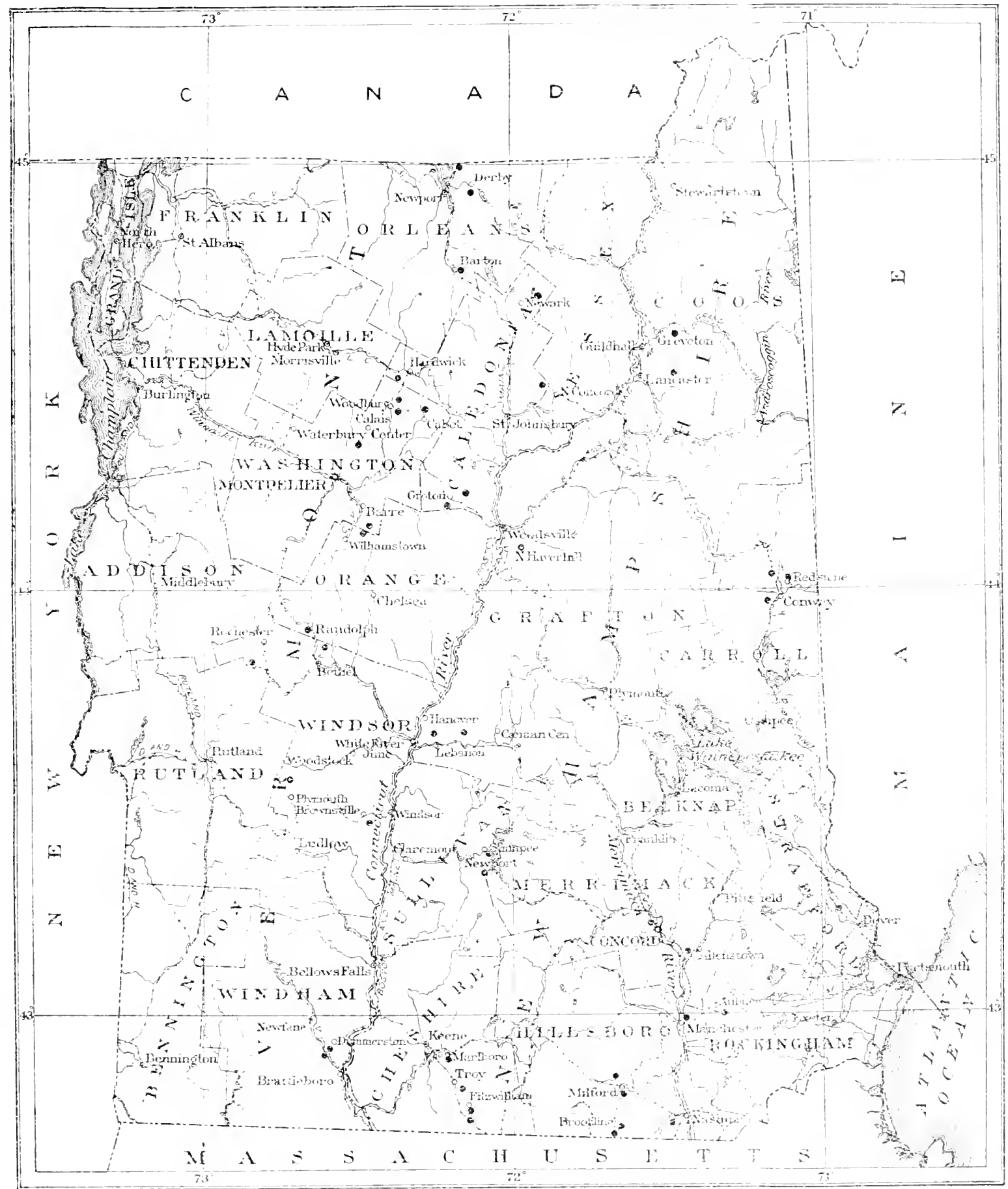





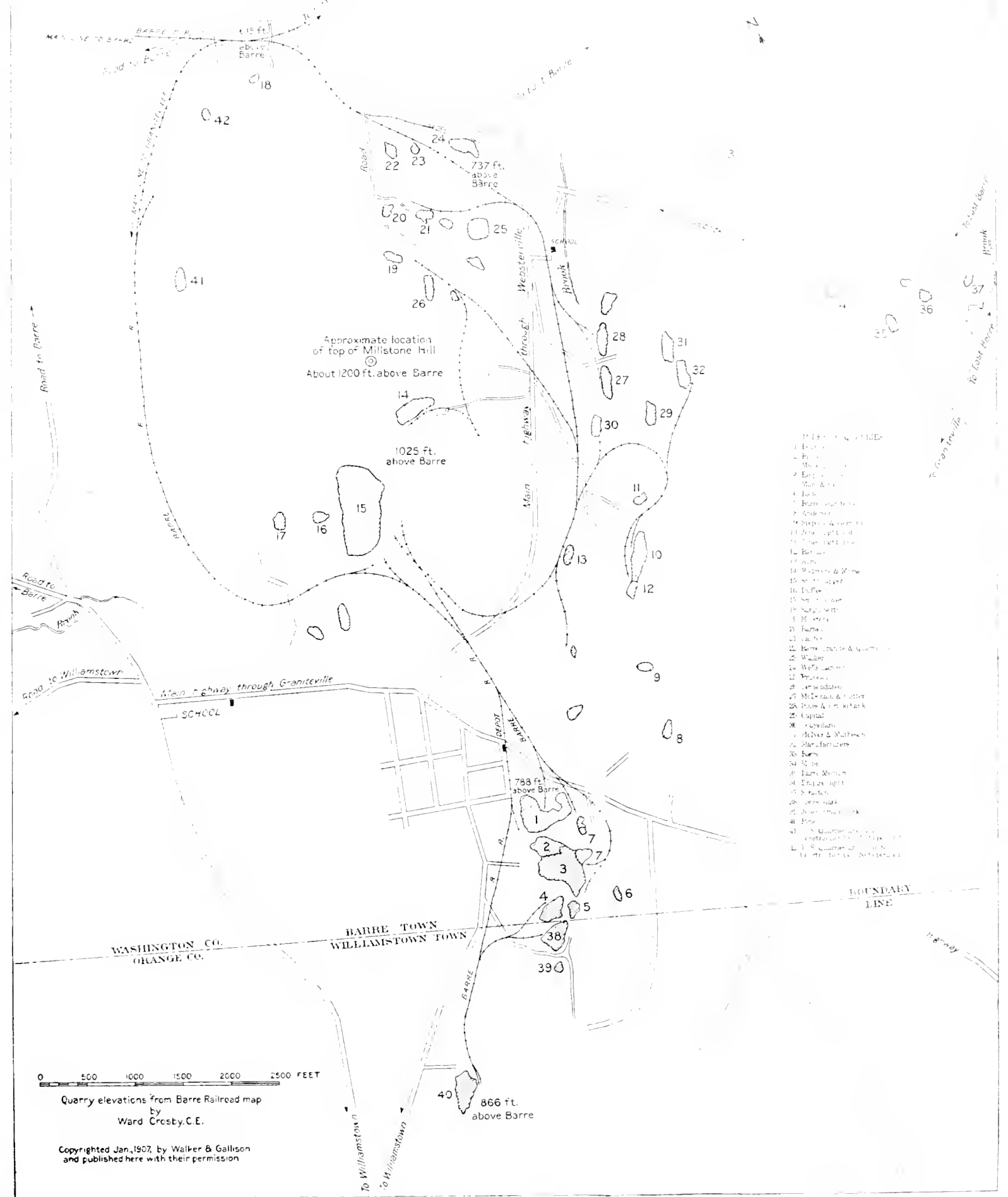



In 1915 the Northern Granite Co., 168 (ollege street, burtingtom, operated

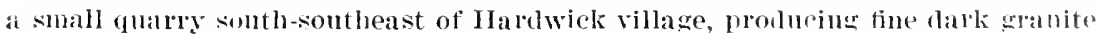
on its south sire and fine light eranite on jts north sirle. 'Thu stome is usel for monuments. The quarry las heen idle since 191.

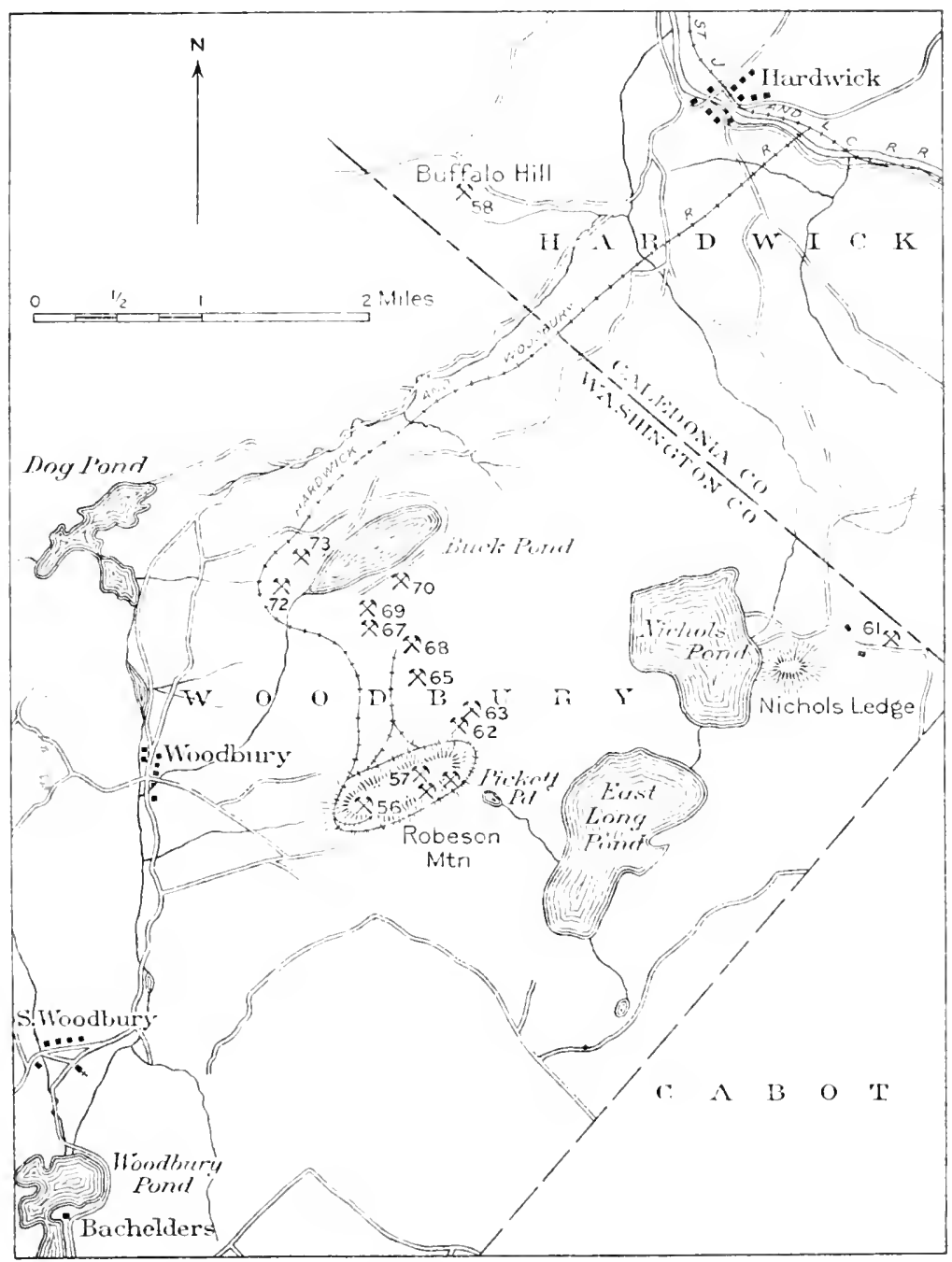

Flgtre 20.-Map compiled from various sources showing approximate focations of granite quarries in Woodbury, Washington County. Vt, Quaries: 56, Fletcher; 57, Woodbury Granite Co. ; 61, Carter ; 62, Carson ; 63, Alnsworth ; 65, Vermont White; 67, Webber, new ; 68, Webber, main; 69, Imperial Blue; 70, Old Quarry ; 72, Leach; 73, Chase.

The Buffalo Hill quarry is on Buffalo Hill, about $2 \frac{1}{2}$ miles S. $60^{\circ}$ W. from Hartwick village and about 500 feet above it. (See map, fir. 20.) Operator, Hardwick Granite Co., Hardwick. Idle since 1917.

The granite (specimen D, XXIX, 58, a and $d$ ), "dark-blue Hardwick," is a quartz monzonite of dark-gray shade, a little darker than "dark Barre" and a trifle lighter than "dark Quincy." Its texture is medium, with feldspars up to 
0.3 inch and mica to 0.2 inch, generally even grained but with sparse clear porphyritic feldspars up to 0.4 inch, inclosing the feldspars, quartz, and miea. Its constituents, in descending order of abundance, are smoky quartz with hairlike crystals of rutile, with cavities $1 \mathrm{n}$ sheets parallel to rift cracks and with another shorter and rarer set at right angles to the first; milk-white soda-lime feldspar (oligoclase to oligoclase-andesine), much kaolinized, somewhat micacizeil and epidotized, and containing calcite; in ahont equal amount with this feldspar a clear to bluish-white potash feldspar (microcline with a little orthoclase), some of it kaolinized, some inclosing particles of all the other constituents; olive-colored biotite (black mica), with a little muscovite or bleached biotite. Accessury: Pyrite, magnetite, apatite, zircon (crystals), and allanite. Secondary : Kablin, a white mita, elidote, and calcite. The sola-lime feldspar is radially intergrown with qualtz.

The stone efforvesces alinhtly with muriatic-ileid test.

An estimate of the mineral percentages ly the Rosiwal method gives these results with a mesh of 0.4 inch and a total linear length of 38.8 inches: Feldspar, 62.05; quartz, 21.75; mica (biotite), 16.20.

The average diameter of all the particles by the same calculation is 0.093 inch: that of feldspar. 0.106 inch; of quartz, 0.122 inch ; and of mica, 0.052 inch.

This is a bright stone with strong contrast between the white feldspar and black mica. It takes a fair polish and hammers light with marked contrast to the polished face, which shows some pyrite and less magnetite.

The quary, opened about 1887, was in 1907 a small irregular opening 20 to 30 feet deep. It is a "bonlder quarry" without sheets.

liock structure: Joint systems-(a), strike N. $30^{\circ} \mathrm{W}$.. dip $35^{\circ} \mathrm{W}$., spaced about 10 feet; (b), strike $N .45^{\circ}$ E., dip $40^{\circ}$ NW., spaced about 10 feet; (c), strike N. $25^{\circ} \mathrm{W}$., dip $50^{\circ}$ to $75^{\circ}$ NE., spacing irregular. The rift is reported as vertical with $\mathrm{N} .50^{\circ} \mathrm{E}$. conrse, and the grain as about like joints (a), but neither is marked. There are some white. probably fellspathic, and black hiotitic "streaks," really veins, with curving course. Rusty stain up to 6 inches thick appears on joint faces.

Transportation, by cart, $2 \frac{1}{2}$ miles, to Hardwick.

The molnct is usen for monuments. particularly for polished and rock-faced work.

\section{ISIR BY,}

The quaries in Kirby are all on Kirby Mountain, in the eastern part of the townslip, about 9 miles northeast of St. Johnsbury. (See map, fig. 21.)

The Grout quarry is on the south side of Kirly Mountain, $2 \frac{1}{2}$ to 3 miles N. $20^{\circ}$ W. of North Concord and about 450 feet above the station there. (See fig. 21.) Operator, A. Rossi, North Concord.

Gront quary gray granite (specimen $D$. XXIX, 76, a) is a biotite granite of light to medium, slightly bluish-gray color and of medium inclining to fine, even-grained texture with feldspars up to 0.25 inch and mica to 0.1 inch. Its constituents, in descending order of abundance, are clear to translucent potash feldspar (microctine, with inclusions of the other constituents, and also orthoclase), light smoky quartz with cavities in sheets witl a set of cracks parallel to them. milli-white soda-lime feldspar (albite to oligoclase-albite) much kaolinized and with some white mica, biotite (black mica), and a little muscovite or bleached biotite. Zircon is an accessory mineral. Neither magnetite nor pyrite was detected. Secondary minerals, kaolin and a white mica. No effervescence with niuriatic-acid test.

This is a bright stone, but the fineness of its mica and the light shade of its quartz preclude strong contrasts. 
The quarry, opened about 1899 , consisted in 1907 of two openings. the northern and upper one 40 by 25 feet and 10 feet deep; the lower one 70 feet square and 3 to 5 feet deep.

linck structure: The sheets. 6 inclues to 4 feet thick, but ohselure in the uper opening, strike $\mathrm{N}$. $55^{\circ}$ E. and dip $25^{\circ} \mathrm{SE}$. Joints (a), rertical. strike x. $25^{\circ} \mathrm{W}$., spaced 1 foot to 2 feet 6 inches to 50 feet; (b) strike N. $85^{\circ}$ F., (ip) $55^{\circ} \mathrm{N}$. forming the south wall, spacerl o to 8 feet; (c) strike $\mathrm{N}$. $S 0^{\circ} \mathrm{W}$.. dip $40^{\circ}$ N. $20^{\circ}$ E., spacel 9 feet. The rift is reported as vertical, with $\mathrm{N} .70^{\circ} \mathrm{E}$. course, and grain as horizontal. The flow structure, consisting of streaks of biotite, is farallel to the rift. There are some biotitic knots. Rusty stain is confined to the surface and the thimnest sheets next to it.

Three aplite dikes, 1 foot to 6 feet 6 inches thick, strike N. $80^{\circ}$ E. This aplite is described on page 45.

Transportation, by cart. 5 to 6 miles, to rail at Concord.

The product was userl for momments. Quarry operated in 1915 but re. ported alandoned in 1916.

The Burke quarry is on the west foot of Kirly Mountain, about 1,000 feet N. $60^{\circ}$ E. from the Kearney Hill quarey and $2 \frac{1}{5}$ miles roughly N. $50^{\circ} \mathrm{W}$. from Nortl Concord. (see figr. 21.) Operator, Kirloy Granite Co. (W. J. Chanman), East Burke. Iole since 1916.

The granite (specimen D, XXIX, $\overline{78}$, a) is a quartz monzonite of light to me-

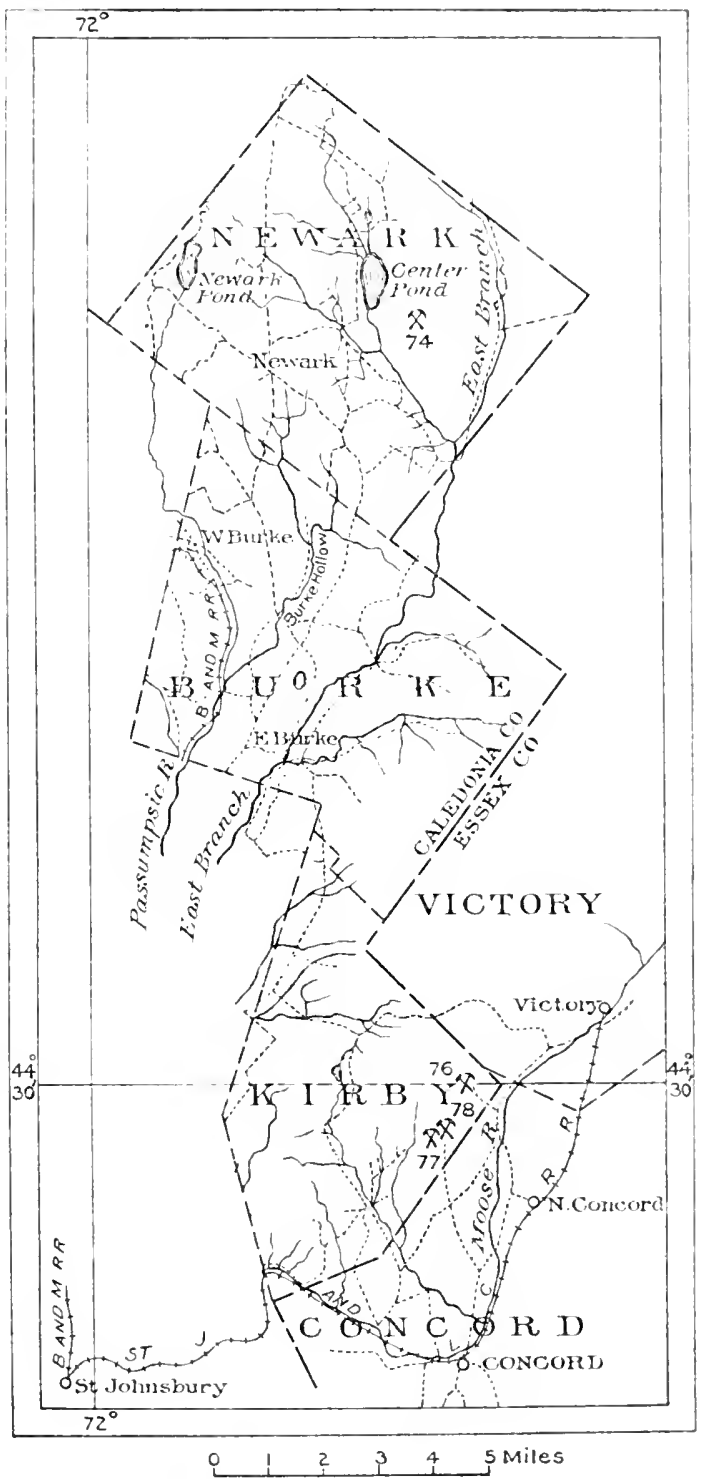

Figcre 21.-Map of Kirby, Burke, and Newark, Vt. From Beers's Atlas. Quarrles: 74, Packer ; 76, Grout ; 77, Kearney Hill; 78, Kirby Granite Co.

dium gray color, and of medium inclining to fine, even-grained texture, with feldspars up to 0.25 inch and mica to 0.1 inch. Its constituents, in descending order of abundance, are light smoky quartz with hairlike crystals of rutile, and sheets of cavities with cracks parallel to them; milk-white soda-lime feld- 


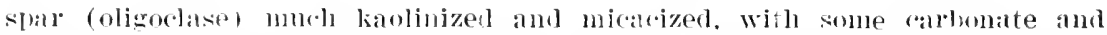
epidote, and in places intergrown with quartz in vermicular structure; clear to scalreety bhish potash feldsplar omirrorline with inclusions of oligoclase. quartz and mica, also orthoclase micacized); biotite (black mica) some of it (luloritized; and muscovite (white mica). Accessory: Very little magnetite, apatite, zincon, and rutile. Secoudary: Kanolin, a white mica, spidote, zoisite, carbonate. and chlorite. No effervescenee with muriatic-acid test.

This stone closely resembles that of the Grout quary in its color and weakness of contrasts.

The glam in 1907 measured abont 17.5 by 100 feet and from 10 to 20 feet in clepth.

Rock structure: Between this and the abandoned Kearney Hill quarry there is an outcrop of schist, either an inclusion or the original schist capping, which strikes N. $15^{\circ} \mathrm{E}$. The sheets, from 1 to 5 feet thick, dip $10^{\circ} \mathrm{S}$. There are thres sets of joints-(a), strike $\mathrm{N}$. $25^{\circ}$ to $30^{\circ} \mathrm{W}$. dip $30^{\circ} \mathrm{W}$., forms the east wall, recurs 100 fert west, ant has some parallel subjoints; (b), dis-

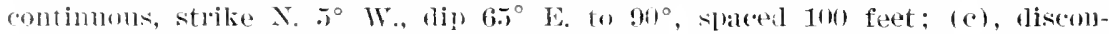
tinuous, strike N. $75^{\circ}$ E., vertical, spaced 2 to 50 feet. The rift is reporterl as horizontal and marked, and the grain as rertical with $\mathrm{X}$. $70^{\circ} \mathrm{F}$. course Biotitic knots up to 2 inches across. There is little or no rusty stain below the top sheet.

'Transportation. by cart $5 \frac{1}{2}$ miles to rail at Concorr.

The product is used for rongh and cut monuments.

\section{NEWARK.}

The Packer quary is in the eastern part of Newirk, on the west side of a ridge between Center or Island Pond on the west and the East Branch of the Passumpsic on the east. This ridge lies north of Burke Mountain and southeast of Ball Hill. There is a marked east-west sag in the ridge. The opening is a little north of the sag on a gently sloping bench below the steeper part of the ridge and 363 feet above Center Pond, about east-southeast from its south end. (See map, fig. 21.)

The quary, idle since 1915, has heen operated by the Newark Granite Co. (auldress H. D. Packer), West Burke.

The granite (sperimen 1) XX1X, $74, \mathrm{~b})$, "Newirk pink," is a hiotite granite of light finkish-griy color and of ralse, even-glained texture, with feldspars up to 0.8 inch and mica to 0.15 inch. Its constituents, in descending order of ahundance, are light pinkish-gray potasl feldspar (orthoclase and microcline), some of it intergrown with soda-lime feldspur or with inclusions of it, slightly kanolinized; medium smoky quartz with cavities in sheets; cream-co'ored, in places slightly greenish-gray striaterl soda-lime feldspar (alb te to oligoclase, albite), much kablinized, and with some white mical and carbonate; biotite (black mica), some of it chlorit zed. Accessory : Magnetite, lyite, titanite, and alanite. Secondary: Katolin, a white mica, epidote, and calcite.

An estimate of the mineral percentages hy the Rosival method, with a mesh of 0.6 inch and total linear length of 46 inches, yields these results: Feldspar, 64.80 ; quart $\%, 30.30$; micat, 4.64; malgnetite, 0.26 . The average diameters of the particles obtained from the same calculation are: Feldspars (adding 20 per cent to the number as an estimate of the uncounted soda-lime partic'es), 0.162 inch; quartz, 0.106 inch; mica, 0.0406 inch. Average llimeter of all particles, 0.123 inch.

The rock effervesces slightly with muriatic-acid test. W. T. Schaller, chemist of this Survey, finds that it contains $0.23 \mathrm{per}$ cent of CaO (lime) soluble in 
warm dilute acetic aeid ( 10 per cent), which indicates a content of 0.4 per cent of $\mathrm{CaCO}_{3}$ (calcium carbonate, calcite), the presence of which is also shown by the microscope.

The contrasts in this granite are chiefly between the smoky quartz and the combined feldspars. It has very sparse porphyritic feldspars up to 1.5 by 0.5 inch, but these are hardly numerous enough to impart to it a technieally porphyritic texture. The polished face shows magnetite in nimute particles and very few of pyrite. The polish is fairly grod, the mica particles, although somewhat large, not being very abumlant.

Rock structure: The sheets on the sterper, higher part of the ridge, 110 fuet above the bench carrying the outcrop sampled, are from 3 to 6 feet thick and not far from horizontal. Joints (a) strike N. $30^{\circ}$ E., dip $70^{\circ} \mathrm{W}$.; (b) strike N. $5^{\circ}$.W., vertical. The rift is possibly east-west and rertical. The granite for a thickness of 110 feet and presumably to the top of the ridge is the same as that described, but recent prospecting, it is claimed, indieates the presence of finer-grained granite between the opening sampled and the pond.

The nearest railroad is $S$ miles away.

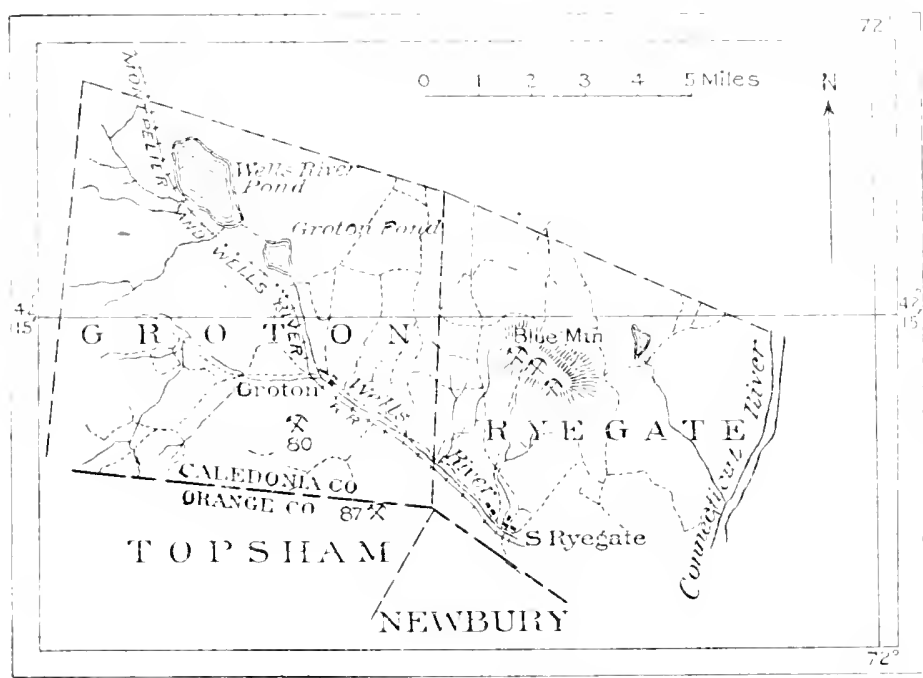

Figurf 22,-Map of Ryegate, Groton, and part of Topsham, Vt. From Beers's Atlas. Quarries: 80, Benzie; 87, Ricker.

\section{RYEGATE.}

TOPOGRAPHY.

The Ryegate quarries are on the southwest and northeast sides of Blue Mountain, a northwest-southeast ridge about 5 miles west of Connecticut River, in the east-central part of the town. (See maps. Pl. I anr fig. 22.)

GENERAL GEOLOGY.

A miea schist crops out in the village of South Ryegate with a very steep dip and appears to continue 3 miles north onto a benclı on the southwest side of Blue Mountain and $\mathbf{7 7 0}$ to 800 feet above the village. The granite extends 
from the back or northeastern part of the bench to the top of the ridge. At a point about 770 feet above the village the foliation and bedding of the schist strike N. $50^{\circ}$ W. and dip $55^{\circ}$ NE. In places the schist is coarse and speckled, but with it is interbedded a very quartzoze mica slate (quartz-biotite-muscovite-epidote).

\section{" RYEgAtE GRANite."}

The granites of Blue Mountain are quartz monzonites and biotite granites of light and medium, more or less bluish gray color and of medium, very rarely fine to medium, even-grained texture, and are used chiefly for rough or hammered monuments. All the quartz monzonites of Ryegate ought to cut light.

\section{GEOLOGY OF RYEGATE QUARRIES.}

The inclusions of schist in "Ryegate granite" have already been described on page 65 and shown in Plate III, $B$, at the right. The sheets, from 6 inches to 12 feet thick, are in some places horizontal and in others dip from $5^{\circ}$ to $25^{\circ}$ S. $25^{\circ}, 45^{\circ}, 60^{\circ} \mathrm{W}$., also gently south and S. $45^{\circ}$ E., on the southwest side of the mountain. Their relation to that slope of the mountain is apparent at the Frazer quarry and on the ridge northeast of the Italian quarry for some 300 feet above it; but at the Rosa quarry, on the other side of the axis of the ridge, the sheets range from horizontal to $10^{\circ} \mathrm{E}$., thus indicating a broad anticlinal sheet structure. There are four sets of joints, or two sets each with its complementary one. The strikes are $\mathrm{N} .70^{\circ}-90^{\circ} \mathrm{W} ., \mathrm{N} .5^{\circ} \mathrm{E} ., \mathrm{N}$. $50^{\circ} \mathrm{W}$., and N. $30^{\circ} \mathrm{E}$. The flow structure, shown by biotitic streaks, strikes N. $70^{\circ} \mathrm{W}$. and $\operatorname{dips} 20^{\circ}-25^{\circ}$ N. $20^{\circ}$ E. The rift is reported as vertical with north-south or N. $55^{\circ}$ E. course, and the grain as horizontal. A 22-inch basic dike closses the granite on the northeast side with a N. $65^{\circ} \mathrm{W}$. course. The granite for a foot on either side of it has subjoints 0.5 to 3 inches apart parallel to the dike. Small pegmatite dikes hare N. $50^{\circ}$ W. and N. $15^{\circ} \mathrm{E}$. courses.

\section{QUARRIES.}

The Gibson quarry is on the southwest sicle of Blue Mountain. 940 feet above the village of South Ryegate. Operator, Ryegate Granite Works Co., South Ryegate.

The granite (specimen D, XXIX, $\overline{81}$, a, from upper sheets), "Ryegate," is a quartz monzonite of light to medium gray shade and medium, even-grained texture with feldspars up to 0.4 inch and mica to 0.1 inch. Its constituents, in descending order of abundance, are very light smoky quartz with fluidal and other cavities in sheets and a set of cracks parallel thereto, also with traces of another set of sheets at right angles to these; milk-white sodalime feldspar (oligoclase) slightly kaolinized with a little white mica and epidote, some of it intergrown with quartz in vermicular structure; bluish potash feldspar (microcline, also orthoclase) similarly intergrown; biotite (black mica) and a little muscovite or bleached biotite. Accessory: Titanite, zircon crystals, apatite, and pyrite. Secondary: Epidote, kaolin, and white mica.

The rock does not efferresce with cold dilute muriatic acid. Its contrasts are weak.

The quarry, opened in 1906, was about 200 feet square and from 2 to 4 feet deep in 1907.

Rock structure: The sheets, 6 inches to 4 feet thick, dip $15^{\circ} \mathrm{S}$. $25^{\circ} \mathrm{W}$. aud are normal. There is but one set of joints, strike east, vertical, at irregular 
intervals, and discontinuous. The rift is reported as vertical north-south and the grain as horizontal. Flow structure (biotitic streaks) strikes N. $70^{\circ} \mathrm{W}$. and dips $20^{\circ} \mathrm{N} .20^{\circ} \mathrm{E}$. A schist inclusion measures 12 by 8 inches. Small vertical pegmatite dikes strike N. $15^{\circ} \mathrm{E}$.

Transportation, by cart, 3 miles, to cutting sheds at Sonth Ryegate, 340 feet lowel. The product is used for monuments and bases, and to some extent for building.

The Morrison quarry is on the southwest side of Blue Miountain, in Ryegate, about 940 feet above the village of South Ryegate and about 700 feet southeast of the Gibson quarry. Last operator, D. A. Morrison. Quarry abandoned in 1915.

The granite (specimen D, XXIX, $\overline{82}$, b) is a quartz monzonite of medium gray color and medium, even-grained texture, with feldspars up to 0.4 inch and inica to 0.2 inch.

This stone is identical with that of the Gibson quarry, but its contrasts are a little sharper.

The quarry, opened in 1300 , measured about 400 by 200 feet, with an average depth of 20 feet in 1907 .

Roek structure: The sheets, 1 to $\overline{5}$ feet thick, dip very gently south and southeast. There are two sets of joints-(a), strike N. $85^{\circ}$ E., dip $70^{\circ} \mathrm{S}$., forms a heading on the north side; (b), strike N. $30^{\circ}$ E., dip $75^{\circ} \mathrm{N} .30^{\circ} \mathrm{W}$., is discontinuous and spaced very irregularly. The rift is reported as rertical north-south, and the grain as horizontal. Schist inclusions, 3 feet by 1 foot and 8 by 4 feet, are described on pages 21 and 65. (See also Pl. III, $B$, at the right.) Small pegmatite reins, "tight sets." are bordered with large biotitic spots and muscovite flakes.

Transportation, by cart 3 miles to South Ryegate, 940 feet lower.

The product was used for bases and hammered monuments.

The Italian quarry is on the southwest side of Blue Iountain, 940 feet above the village of South Ryegate and about 400 feet N. $60^{\circ} \mathrm{W}$. from the Gibson quarry. Operator, Rinaldo Tonelli, South Ryegate.

The granite is a quartz monzonite of light to medium gray shade and medium, even-grained texture, identical with that of the Morrison and Gibson quarries.

The quarry opened in May, 1907, measured in August about 250 by 100 feet and about 5 feet in depth.

Rock structure: The sheets, 10 inches to 5 feet thick, dip $20^{\circ} \mathrm{W}$. Only one set of joints, strike N. $50^{\circ} \mathrm{W}$., dip $30^{\circ}$ E., spacing 50 feet. The rift is reported as vertical with $\mathrm{N} .55^{\circ} \mathrm{E}$. course and the grain as horizontal, and both as equal.

The product is carted 3 miles to South kyegate and used for bases and hammered monuments.

The Frazer quarry (formerly known as Hall's) is on the southwest side of the southeast spur of Blue Mountain, about 950 feet above South Ryegate. It is no longer operated.

The granite (specimen D, XXIX, $85, b$ ) is a quartz monzonite of light to medium gray shade and of medium inchining to coarse, even-grained texture, with feldspars up to $0.4 \mathrm{inch}$ and mica to $0.2 \mathrm{inch}$.

While the general shade of this stone differs but little from that of the Morrison and Gibson quarries, the contrasts between its minerals are much more marked.

The quarry measures about 300 feet square and from 5 to 20 feet in depth.

Rock structure: The sheets are normal, 1 to 12 feet thick, flipping $25^{\circ} \mathrm{SW}$. There is but one joint, strike N. $70^{\circ} \mathrm{W}$, dip $35^{\circ} \mathrm{N} .20^{\circ} \mathrm{E}$. A flow structure of biotitic streaks and sheets strikes N. $70^{\circ} \mathrm{W}$. and dips $45^{\circ} \mathrm{N} .20^{\circ} \mathrm{E}$. In the west 
half of the quarry this is so prominent as probably to detract from the value of the stone. Rusty stain along the shert surfaces is up to 3 inches thick. (See on the natural removal of this stain by organic and carbonic acids, p. 69.)

The product had to be carted $3 \frac{1}{2}$ miles to South Ryegate.

The Rosa quarry is on the northeast side of a southeast spur of Blue Mountain, about 300 feet below its top and in line with its main axis. This quarry is about one-third of a mile by road from the Frazer quarry and about 1,100 feet above South Ryegate. Operator, Rosa Bros., South Ryegate.

The granite is of two kinls. The first, "fine gray" (specimen D. XXIX, $\overline{79}$, a), is a biotite granite of medium-gray shade and of fine, inclining to medium, even-grained texture, with feldspars mp to 0.2 inch and mica to 0.1 inch. Its general shade is a trifle darker than that of the quartz monzonite of the Gibson quarry. Its constituents, in descending order of abunfance, are translncent to very light bluish-gray potash felispar (orthoclase and microcline); light smoky quartz with hairlike crystals of rutile, and fluidal and other cavitics in sheets with craclis parallel thereto; whitish sola-lime feldspar (oligoclase), slightly kaolinized, micacized, and epidotized, in places intergrown with quartz in rermicular structure; biotite (black mica); and a little nuscovite or bleached biotite. Accessory: Apatite, zircon crystals, titanite. Secondary: Kaolin, a white mica, epirtote, limonte.

W. T. Schaller, a chemist of this Survey, finds that this stone contains $\mathbf{0 . 0 3}$ per cent of CaO (lime) soluble in warm dilute (10 per cent) acetic acid, which indicates the presence of 0.05 ner cent of $\mathrm{CaCO}_{3}$ (calcium carbonate). No carbonate wis detected in thin section, nor any effervescence with muriatic-acid test.

The fineness of the texture of this stone precludes mineral contrasts.

The other granite (specimen D, XXIX, 79, b), "coarse gray," is a biotite granite of medium bluish gray color, and medium, even-grained texture, with feldspars up to 0.3 inch and mica to 0.15 inch. This is also a trifle darker than that of the Gibson quarry. Its constituents are like those of the fine gray, with the addition of calcite and more biotite. The stone efferresces with muriatic-acid test.

Its contrasts are stronger than those of the quartz monzonites of the Morrison and Gibson quarries.

The quarry, opened in 1906, measured in 1907 about 150 by 75 feet and from 10 to 25 feet in depth.

Rock structure: The sheets, 1 to 10 feet thick, are horizontal or dip to $10^{\circ} \mathrm{E}$. There are three sets of joints-(a), strike east. dip $65^{\circ} \mathrm{S}$., forms a 3-foot-wide heading on the north; (b), strike N. $70^{\circ}-80^{\circ} \mathrm{W}$, dip $40^{\circ} \mathrm{N} .10^{\circ}-20^{\circ}$ E., spaced 1 to 25 feet, coated with epidote and slickensided; (c), strike N. $5^{\circ}$ E., vertical, oue only. The lift is reported as vertical with N. $60^{\circ} \mathrm{E}$. course, and the grain as horizontal. The fine sranite (specimen 79 , a) occuls only north of heading (a). On the south edge of the quarry a vertical basic dike, 22 inches thick, strikes N. $65^{\circ}$ E. (See p. 114.) Rusty stain measures 1 to 2 inches.

The product is carted nearly 4 miles to the cutting shed at South Ryegate and is used for hammered and rock-faced monuments and bases.

\section{GROTON.}

The Benzie quarry is in Groton about a mile S. $25^{\circ} \mathrm{W}$. from the Wells River Bridge at Groton and 300 feet above it, and about $4 \frac{1}{2}$ miles S. $85^{\circ} \mathrm{W}$. irom Blue Mountain, is Ryegate. (See fig. 22.) Operator, Bonazzi Quarry Co. (Inc.), Montpelier. 
The grasitu (specinen D. XXIX, $\overline{S 0}$, a), "Vormont blue," is a quart\% monzonite of medium, very bluish gray color. and even-grained melinm inclining to fine texture. Its constituents, in descending order of abund:unce, are clear colorless to rejy light smolsy or very light bluish quartz, with few cavities and brightly polarizing rift and grain cracks; translucent light-bluish sodalime feldspar (oligoclase), somewhat kaolinized and with white fibrous mica, also a white mica in small scales, and some calcite; a little clear potash feldspar (microcline, also orthoclase), with inclusions of oligoclase, quartz, and biotite; biotite (black mica); and a little muscovite or bleached biotite. Some of the feldspars are minutely intergrown with quartz in vermicular structure. Accessory : Titanite, pyrite, zircon crystals, apatite, allanite. Secondary : Kalin. : white mica, citlcite, lencoxene. Eflervesces with muriaticalcid test.

This stone is brilliant and mirkelly bluish, but its mineral contrasts ade feeble.

The quary, opened in 1896 , measured in 1907 about $200 \mathrm{by}$ 16 feet am from 40 to in feet in deptl.

Rock strurture: The sluets are normal, 1 to 10 feet thick, and lange from the horizontal to a very low dip north and also east. The structure is shown in figure 23 .

There are three sets of joints(A), strike $Y .55^{\circ}$ E., vertical, spraced 15 to no feet, forms a

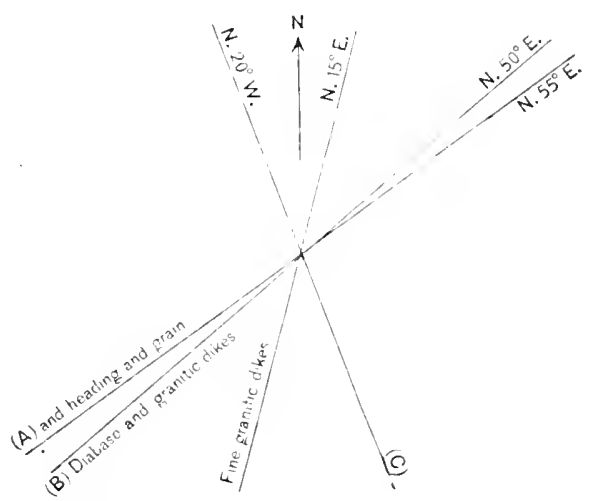

Figure 23.-Structure at Benzie quarry. Groton, it.

rusty heading on the west wall, with short verticai subjoints at right angles to it; (B), strike N. $50^{\circ}$ E. (diagonal to quarry), dip $6,0^{\circ} \mathrm{S} .50^{\circ}$ E. discontinnous and at irregular intervals: (C), strike N. $20^{\circ} \mathrm{W}$, and rertical, discontinuons and rare. The rift is reported as horizontal, and the grain as rertical, with $\mathrm{N}$. $55^{\circ}$ E. course. There is a coarse "shake" structure in bands up to a foot thick parallel to the sheets, at points 25,40 , and 60 feet below the surface. (see p. 39.) There are biotitic masses on the west sile parillel to joints $(A)$, the cours of which is also that of the grain, and thus also that of the flow. On the west wall is a dike of quarty monzonite (specimen D, XXIX, S0, b) 5 feet thick, of medium bluish-gray rolor and very fue, event-ratined texture, with feldsiars up to 0.1 ant mical mostly under 0.5 , exceptionally 0.1 inch. Its constituents are the sane as those of the main granite. There are two dikes of similar quartz monzonite, but of dark, slightly bluish-gray color and extremely fine textme, with feldspars up to 0.06 (exceptionally 0.1 ) ant mica to 0.04 inch. These dikes are 6 and 2 inches thick, strike N. $5^{\circ}$ and $20^{\circ}$ E., and dip $70^{\circ}$ E. and $90^{\circ}$. Sereral pegmatite dikes, 1 to 6 incies thick, cross the entire quarry. cutting the first granite dike, some striking $\mathrm{N} .17^{\circ} \mathrm{W}$. others in valious directions. There is also a 3 -inch diabase dike on the west wall. It contains porphyritic angite crystals, some of which have been replaced by quartz or calcite or chlorite. A compressive strain is reported here as from all directions. Rusty stain is only an inch thick on sheets 10 feet below the surface.

The product was carted $1 \frac{1}{2}$ miles to the cutting shed at Groton. It was used for monuments and buldings. The fine stone of the granite dike was used 
for special orders and carved work. Examples are the Davison monument at Woodsville, N. H., and the Dr. S. N. Eastman monument at Groton, Vt.

\section{ORANGE COUNTY.}

The quarries of Orange County are chiefly in Williamstown, but as these closely arljoin those of Barre, as shown on the map, they will be considered in connection with the Barre quarries. (See p. 141.) A quarry in Topsham and a prospect in Randolph properly belong here.

\section{TOPSHAM.}

Granite was formerly quarried at two points in Topsham. One was very near the village of South Ryegate, the other on Pine Mountain about southsouthcast of Groton. ${ }^{62}$ Hitcheock and Hager's geologic map represents a granite area extending from Groton into Topsham, but it seems too far west.

The Ricker quarry is in Topsham at the west foot of Pine Mountain, roughly about $5 \frac{1}{2}$ miles west-southwest of Blue Mountain, $2 \frac{1}{4}$ miles sontheast of the Benzie quarry, and $2 \frac{3}{4}$ miles south-southeast of Groton and 490 feet above it. (Sce fig. 22.) Quarry abandoned.

The granite (specimen D. XXIX, si, a), "Pine Mountain," is a quartz monzonite of medimm bluish-mray color and medium, somewhat even-grained texture with feldspar up to 0.4 inch and mica to 0.1 inch, but with sparse clear porphyritic feldspars inchuling all the other chief constituents. The stone is not quite so bluish as that of the Benzie quarry, in Groton, nor do its feldspars seem to he as evenly distributer. Its constituents are similar. Effervesces with muriatic-acid test.

The porphyritic clear feldspars enhance the brilliancy of the rough surface. Its contrasts are greater than those of the Benzie quarry stone, but there are minute rust spots on the long-exposed hlocks about the quary, the cause of which was not manifest.

The quarry is about 40 by 32 feet. and the working face on the east is 20 feet high from the road and quarry level.

Rock structure: The sheets, 5 to 12 foet thick at their widest parts, are normal and horizontal or inclined $10^{\circ} \mathrm{X} .45^{\circ} \mathrm{W}$. There are two sets of joints-(a), strike $X$. $70^{\circ}$ E., rertical, forms the north wall, and a 25 -foot heading north of it with joints 2 to 4 feet apart, and another on the south wall; (b), strike N. $40^{\circ} \mathrm{E}$, dip $55^{\circ}$ N. $50^{\circ} \mathrm{W}$., forms the east wall and recurs 10 feet cast. The flow structure has a $N .35^{\circ}$ E. course. Vertical pegmatite dikes up to 1.5 inches thick strike $X .255^{\circ} \mathrm{W}$. Aplite dikes up to 1 inch thick. strike N. $45^{\circ}$ and $55^{\circ} \mathrm{E}$.

The product was carted about 3 miles to rail at Groton, 490 feet lower.

\section{RANDOLPH.}

Beedle's prospect is in the west corner of the town of Randolph between the Bethel line and the west branch of White River, in school district 11, three-fourths of a mile west and southwest of the Vermont Central Railroad, which here describes a curve. It is on the farm of A. H. Beelle, of Randolph. (See fig. 35.) The foregoing particulars were obtained by G. H. Perkins, State geologist.

62 The quarry on Pine Mountain, here described, is probably the one referred to by the State Geologist in 1900 as operated then by the Pine Mountain Franite Co. (See Perkins, G. H., Mineral resources of Vermont, for 1899-1900, p. 75.) 
According to the State geologic map of 1861 this granite should be on the west side of the western belt of "clay slate," but no granite is shown on the map in this town.

The granite (specimen D, XXIX, 100, a, and b), fine white granite, is a quartz monzonite of etxremely light gxay shade without any mica spots. It is lighter than "Dummerston white" but not as white as that of Bethel when the rough faces are compared, and its slight grayness has a tinge of green in it. Its texture is even grained and fine, with feldspars nearly all under 0.1 inch and none over 0.15 inch. Its constituents, in descending order of abundance, are milkwhite striated soda-lime feldspar (albite to oligoclase-albite), some of it intergrown with potash feldspar (microcline), the latter forming, however, but a small portion of the particle (the soda-lime feldspar is more or less kaolinized and micacized); clear colorless quartz with fluidal and other cavities, rarely with hairlike crystals of rutile; very little separate potash feldspar (micro. cline) in minor particles; and muscovite (white mica) in scales up to 0.37 millimeter. The accessory minerals are zircon, apatite, and rutile. No masnetite or pyrite was detected. Secondary minerals, kaolin, a white mica, rather abundant epidote, and zoisite in irregular particles up to 0.5 millimeter, exceptionally 0.75 millimeter, accounting fol the greenish tinge (this is really the fifth mineral in order of abundance); a little calcite and rare chlorite scales up to 0.22 , exceptionally 0.75 millimeter, reinforeing the greenish tinge.

An estimate of the mineral percentages made by applying the Rosiwal method to a camera lucida drawing of a thin section enlarged 40 diameters yields these results with a mesh of 1 inch and a total linear lengtl of 34 inches: Feldspar, 76.5; quartz, 21.2; mica, 2.3. The arerage diameter of the particles obtained from the same calculation is 0.0049 inch; that of the feldspar, 0.0083 inch; of the quartz, 0.0032 inch; and of the mica, 0.0024 inch.

The stone efferresces slightly with muriatic-acid test. W. T. Schaller, a chemist of this Survey, finds that it contains 0.37 per cent of CaO (lime) soluble in warm dilute (10 per cent) acetic acid, which indicates a content of 0.66 per cent of $\mathrm{CaCO}_{3}$ (calcium carbonate, calcite), and this mineral also appears in thin section.

The stone takes a high polish, owing to the absence of all but very minute mica plates. Being a quartz monzonite and also free from mica spots, it will probably hammer quite as white as the quartz monzonite from Bethel. The hand specimens show traces of rift or flow structure.

There are no data as to size of outcrop or as to structure. The principal opening is 60 by 30 feet. There was no quarrying in 1916.

\section{ORLEANS COUNTY.}

\section{DERBY.}

The Lacasse quarry, formerly owned by the Newport Granite Co., is near the center of the town of Derby and about 4 miles roughly east of the city of Newport, on Lake Memphremagog. (See map, Pl. I.) Operator, A. C. Lacasse Granite Co., Newport.

The granite (specimen D, XXIX, 75 a), "Derby gray," is a quartz monzonite, with both biotite and muscovite, of light bluish-gray color and even-grained, medium inclined to fine texture, with feldspars up to 0.25 and 0.3 inch and mica to $0.15 \mathrm{inch}$. Its constituents, in descending order of abundance, are light smoky quartz with hairlike crystals of rutile, fluidal and other cavities in sheets with cracks parallel to and in places coinciding with them; clear to bluish milk-white striated soda-line feldspar (oligoclase), mostly much kaolinized and somewhat micacized, also intergrown in places with quartz in 
vernicular structure; clear to translucent bluish potash feldspar (microcline and orthoclase), slightly kaolinized; biotite (black mica); and muscovite (white mica). Accessory: Apatite, titanite, allanite, rutile. No magnetite or pyrite was detected. Secondary: Kaolin, a white mica, and calcite from chemical test.

There is no effervescence with dilute muriatic-acid test, but W. T. Schaller, a chemist of this Survey, finds that it contains 0.05 per cent of CaO (lime) soluble in warm dilute (10 per cent) acetic acid, which indicates the presence of nearly 0.09 per cent of $\mathrm{CaCO}_{3}$ (calcium carbonate, calcite). which is slight indeed.

The shade of this stone is between that of "light Barre" and of the granite of Hallowell, Maine. It has more black mica than "light Barre" and stronger contrasts. This stone should hanmer lighter than a biotite-muscovite granite. ${ }^{63}$

The qual'ry, opened about 1880, measured in 1907 about 300 feet N. $45^{\circ} \mathrm{W}$. by 250 feet $N .55^{\circ}$ E. and averaged 20 feet in depth.

Rock structure: The sheets, 3 to 18 feet thick, din $20^{\circ} \mathrm{S} .55^{\circ} \mathrm{W}$. They " grow together" - that is, sheet structure is undeveloped in the western part of the quarry-making masses 22 to 25 feet thick. One set of vertical joints, discontinuous, strikes $\mathrm{N} .55^{\circ} \mathrm{W}$., is spaced 10 , 30, and 100 feet, and forms a heading on the north wall. At the northeast corner there is a trace of a transverse set. The rift is reported as horizontal, and the grain as vertical with $\mathrm{N}$. $55^{\circ}$ E. course. Both are marked. Flow structure, consisting of muscovitic and biotitic bands, is vertical with $N$. $50^{\circ}$ E. course. The muscovite scales in these bands measure up to $0.25 \mathrm{inch}$. There are very irregular biotitic surfaces in the eastern part of the quarry, resembling tree roots in form. Associated with them are nommicaceous lighter tortuous bands. These are presumably irregularities in the flow structure: A "shake structure" up to 5 inches thick oecurs on some sheet surfaces. and the rock there is passing into sand. The contact here has been alluded to on page 105. A north-south compressive strain was reporter by the foreman. There is no stain on the sheet surfaces.

The product is carted 4 miles to the railroad at Newport. It is used for monuments and buildings. Specimen: The prison-ship martyr's' monument in Fort Greene l'ark, Brooklyn. N. Y. Height, 150 feet, shaft 18 feet in diameter at base and 14 feet at top.

The Parmenter quary is in Derby Township, near Reebe Plain, close to the Canada line and about a mile east of Lake Memphremagog. (See Pl. I.) Owner, W. H. Parmenter, North Derby. Abandoned in 1920.

The granite (specimen $\mathrm{D}, \mathrm{XXX}, 72$, a), a light granite, not examined microscopically, is either a biotite granite or a biotite-quartz monzonite of very light gray color and even-grained medium texture, with feldspars up to 0.3 inch and micas to 0.2 inch. Its constituents are slightly bluish milkwhite feldsuars, light swoky quartz, anl biotite (black mica). It effervesces slightly with acid test.

In general shade this granite is lighter than that of North Jay and darker than that of Bethel, or nearly the same as "West Dummerston white" but with more conspicuous black micas.

The quarry in 1909 was 40 by 25 feet in area and 10 feet deep.

Rock structure: The sheets, 2 to 5 feet thick, are insufficiently exposed but appear to undulate horizontalls. Joints (a) strike N. $50^{\circ} \mathrm{W}$., dip $60^{\circ} \mathrm{SW}$., spaced 10 to over 20 feet; (b) strike N. $30^{\circ}$ E., dip $80^{\circ}$ S. $60^{\circ}$ E., one only. The rift is reported as horizontal, and the grain vertical with N. $50^{\circ} \mathrm{E}$. course.

63 See a reference to this stone and quarry in Richardson, C. H., The geology of Newport, Troy, aud Coventry: Vermont State Geologist Sixth Rept., p. 280, pl, 58, 1908. 
In a larger quarry on the Canadian side, a few hundred feet from the other", formerly worked by the same operator, granite of the samm mass and character laas sheets 10 feet thick and a tlow structure with N. $60^{\circ} \mathrm{W}$. course.

The product is carted half a mile to a siding on the Canadian Pacitic Railway at North leerby and is used for hammered momments or bases. The quarry was idle in 1916.

\section{BARTON.}

In 1913 a specimen was received by this Survey from Milo J. Owen, of Barton, as occurring within that township.

The granite (specimen D, XXXV, 109, a) is a medium to dark-gray aplite (p. 42) with a groundmass of fine particles ranging from 0.05 to 0.17 miliimeter in diameter and inclosing porphyritic feldspars (milky oligoclase to oligoclase-andesine) from 0.37 to 1.25 millineters, quartz (smoky?) up to 0.87 millimeter, and biotite (black mica) up to 0.75 millimeter.

As aplites occur in dikes and are a little harder than granite the economic value of this aplite will depend upon the width of the dike, the relative cost of cutting it, and also, of course, the spacing of the joints and sheets.

The Barnard quary is in the township of Birton. Operator, John M. Barnard, R. D. 1, Barton. Quarry idle.

The granite (specimen D, XXXVIII, 26, a), "Barton," is a biotite granite of medium gray shade and of medium texture, with feldspars up to a trifle over 0.2 inch and biotite (black mica) to 0.05 inch.

It does not effervesce with muriatic-acid test. It is a bright granite without marked contrasts.

Its constituents, in descending order of abundance, are clear colorless potash feidspar (microcline), pale smoky quartz with carities in sheets, clear to milky soda-lime feldspar (oligoclase-albite), somewhat kaolinized, biotite, and very little muscovite. Accessory : Apatite, zircon. Secondary: Kaolin, chlorite, calcite.

The quarry is 300 by 100 feet and up to 9 feet deep.

The product is used for monumental work.

\section{WASHINGTON COUNTY.}

\section{BARRE AND WILLIAMSTOWN.}

The quarres of Williamstown, in Orange County, will be described in connection with those of Barre, as they belong to the same group and their granite is continuous and identical.

\section{TOPOGRAPHY.}

The city of Barre lies abont 5 miles southeast of Montpelier (see I'l. I), and the Barre quarries are 3 miles farther southeast, near the southeast corner of the township of Barre, and a few of them are in Williamstown, in Orange County, which adjoins Barre on the sontls. The city of Barre lies on Stephens Brook, a tributary of the Winooski, which empties into Lake Champlain. About half a mile southeast of Barre this brook receives a tributary from the southeast, known as Jail River. Some $2 \frac{1}{2}$ miles southeast of the city this river flows through a canyon-like gorge between flat-topjed masses of sand, clay, and boulders over 200 feet thick. A little north of Jail River at this point a roundish granite mass, known as Cobble Hill, rises to a height of 1.000 feet (by aneroid) above the city, and 2 miles about southwest of this hill and a little south of the river another granite mass, known as Millstone Hill, rises to a 
height of 1,200 feet above the city. In 190756 quarries were grouped about these two granite masses, and of these 52 were about Millstone Hill. The section (fig. 24) will serve to convey a general idea of the surface features described. The locations and designations of the Millstone Hill quarries are given in Plate II.

GENERAL GEOLOGY.

The geology of the granite area of Barre was last treated by George I. Finlay. ${ }^{64}$

His map shows that he regarls the two granite hills as parts of one granite area, with a north-northeast trend, orer 4 miles long by $1 \frac{1}{2}$ miles wide, surrounded by slate and schist. Its representation on the State geologic map of 1861 is not far different. The writer's time was too short to enable him to trace the boundaries of the granite and schist, nor was a map suitable for such purpose available. Finlay represents a schist tongue crossing Millstone Hill diagonally from northwest to southeast and Cobble Hill as all granite, but the writer found schist on the north side of the top of the Cobble, without, however, determining its northern limit. The schist capping also crops out at Jones Bros.' and Barclay's quarries, also near the Marr \& Gordon quarry (Nos. 10, 12, 26 in Pl. II), and in Websterville. Some of these schist

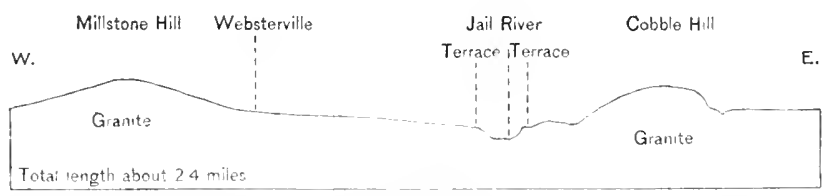

Figure 24.-Gencral topographic section through granite mass of Barre, Vt. Scale, about 400 fect to 0.1 inch.

masses are probably lesser hands still lying on the granite, which Finlay stites wre too small to enter on his small-scale map. The strike of the foliation of the schist about the quarries varies from north to $\mathrm{N}$. $60^{\circ} \mathbf{E}$., and the dip is steep west or $90^{\circ}$. In a group of quarries south-southeast of Millstone Hill it strikes uniformly N. $30^{\circ}-35^{\circ} \mathrm{E}$.

'These are the chief geologic features of the Barre district. Four formations are represented-(1) the schist, a metamorphosed marine argillaceous and ealcareous sediment of unknown thickness, underlying the city and surlounding the granite area; (2) the granite, of igneous origin, intruded in the schist and forming two clomes, 2 miles apart, with an intervening depression, which in consequence of the erosion of the schist now project through it; (3) certain dark basie dikes of later date eutting the granite and the schist also; (4) finally, masses of sand, clay, and boulders, over 200 feet thick in the hollow between the domes, of glacial origin, overlying the sehist and part of the granite.

The geologic age of schist and granite have been discussed on page 106, and their probable history was slietehed on page 107.

As many as seven different sets of surface forms have existed here(1) the original surface of the sediments of clay and sand before their emergence from the sea; (2) the surface of those sediments after their metamorphism into schist and before the granitic intrusion; (3) the surface of the schist mass as modified by the granitic intrusion; (4) the surface of

o4 The granite area of Barre, Vt.: Vermont State Geologist Third Rept., pp. 46-59, pl. 4. 1902 . 
the schist and granite masses which resulted from the long period of preglaciul erosion; (5) the original surface of the superimposed glacial deposits; (6) the surface of the glacial deposits as modified hy glacial-lake levels; ( 7 ) the surfaces produced in both unnodified and modified glacial deposits by postglacial streams. It is assumed in this ontline that any modifications of the eroded rock surface by the glacier were unimportant, and the surface of the ice shect itself has not been considered.

The present surface is evidently of complex origin. Parts of it were formed under (4), (5), (6), and (7). Wherever no glacial deposits were formed or wherever they were afterward removed we have the surface (4). In the gorge between Millstone and Cobble Hills, as slıwn in figure 24, the coarse and fine glacial deposits have a nearly level surface, which is probably due to terracing by a clacial lake (6). These opposite terraces may have been continuous, but the gorge itself is partly or entirely the result of the cutting of the terraced glacial deposits $(\boldsymbol{T})$. In places the processes of $(\boldsymbol{T})$ have exposed the sclist surface formed by (5) and made small inroads upon it.

The schist of Barre varies much in character. A few observations were made and specimens collected. In many places it contains lenses and beds of calcareous quartzose rock. On Brook Avenue, in the northwestern part of the city, a mass of this rock dips $30^{\circ}$ to $40^{\circ}$ about southwest, but with traces of plicated bedding in the opposite direction. It is a very dark gray fine-grained quartzose crystalline limestone. The sections show quartz particles up to 0.24 millimeter in a cement of calcite plates with rare muscovite scales and many minute black (carbonaceous?) particles. At the other end of the city, near the covered bridge over Jail River, it is a very fine black roofing slate with minute secondary llications and spangled with black tabular crystals up to 0.1 inch across, probably of ilmenite. The microscope shows it to be a muscovite-quartz slate with a little biotite and chlorite. Part of the outcrop is a muscovite schist with quartz and calcite and spangled with biotite scales lying across the schistosity; also with rhombic plates of chlorite and ilmenite up to 0.2 inch. Near quarry No. 26 (Pl. II) a granitic dike 3 feet thick crosses the schist. This proves to be a light-gray fine-textured porphyritic biotite granite differing from Barre granite mainly in texture. There are here and there within the grimite area strips of schist which are parts of the original capping left by erosion. There are also blocks of schist within the granite (inclusions) which probably dropped into the rising semiliquid granite from the underside of the fractured capping. These are described more fully on pages $6 t-65$.

The pegmatite and aplite dikes which traverse the granite belong to a later stage of the period of intrusion, after the consolidation of the granite. The basic dikes described on page $12 S$ and referred to by Finlay ${ }^{\text {es }}$ belong to al still later date. He describes as camptonite a 5 -foot dike which crosses the schist just south of Barre on the road to South Barre, and he illustrates its spheroidal weathering.

B.AREE GRANITE.

Barre granite is known commercially as "dark Barre," "medlum Barre," and "light Barre," with some exceptional "very dark Barre" and "white Barre." It appears to be everywhere a biotite granite in which the orthoclase is considerably kaolinized and micacized, but the microcline is fresh. The dark stone of the Milne \& Wylie quarry and of the Jones quarry shows so great a contrast between its hammered and polished faces as to indicate that the amount of sorla-lime feldspar in it is larger than it is in the other grantes of 
Barre or in biotite granites generally, and the thin sections show considerable plagioclase altered like the orthoclase. But Whitman Cross, ${ }^{66}$ of this Survey. found a specimen of " lark Barre" quarried by Wells, Lamson \& Co. to be a typical biotite-muscovite granite in which the amount of plagioclase (soda-lime feldspar) was so small as to place it among the accessory constituents. (See p. 138.)

The various shade and color designations of this granite are due in part to the different degree of kalinization and micacization of its orthoclase feldspar, causing it to range from a translucent bluish wray to milk-white. and in part also to the varying content of black mica. Technically its colors are here defined as (1) very light gray (Wheaton quarry, abandoned), equivalent to that of North Jay, Maine; (2) light inclining to medium, slightly bluish gray (Jones light quarry), between that of North Jay and of Hallowell, Maine; (3) light medium bluish gray (Smith upper quarry), between that of Hallowell, Maine, and Concord. N. H.; (4) medium bluish gray (Duffee quarry), a trifle darker than "Concord sranite"; (b) dark inclining to medium bluish gray (Bruce quarry); (6) dark bluish gray (Marr \& Gordon quarry) ; ( 7 ) very dark bluish gray (Marr \& Gordon quarry knots), equivalent to "dark Quincy." The chief product consists of (3), (4), and (5). The dark shades occm near the Williamstown line, the light near the top of Millstone Hill on its south and southwest sides, and also about three-fifths of a mile south-sonthwest of the top. The cause of this distribution is not evident.

Its texture ranges from fine to medinn-that is, with feldspars up to 0.2 and 0.4 inch, generally. however, not exceeding 0.2 inch, few reaching 0.3 inchso that it may be generally designated fine inclining to medium or medium inclining to fine. But the light granites of the Millstone quarry, on Millstone Hill, and of the Wheaton quarry, on Cobble Hill, are of medium texture, with feldspars to $0.4 \mathrm{inch}$. Its mica particles range up to 0.1 and $0.2 \mathrm{inch}$, but in the "very dark" to 0.3 inch.

Its constituents, in descending order of abundance, are (a) clear colorless or bluish to translucent and milk-white potash feldspar (orthoclase. kaolinized. and nicacized, and less of (lear microcline) rarely interorowin with a little soda-lime feldspar; (b) light smoky quartz, showing optical effects of strain, rarely with rutile needles, generally with fluidal and other ravities in sheets, and with rift cracks parallel te or coinciding with them, and in some sections with another set of fewer and shorter sheets of such carities at right angles to the other and with grain cracks parallel to them (in one place the rift cracks extend into the feldspar and are there tilled with fibrous muscovite) $;^{\theta 7}$ (c) translucent to milk-white soda-line feldspar (oligoclase-abite to oligo-

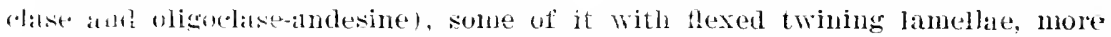
or less kaolinized and micacized. and in places with calcite; $(d)$ biotite (black mica), some of it chloritized; (e) a little muscovite or bleached biotite. Accessory minerals, pyrite, magnetite, titanite. allanite, apatite, zircon, rutile. Secondary, calcite (abundant within the orthoclase), one or two white micas, epidote, and chlorite. Minute veinlets of quartz, of calcite, and of epidote occur exceptionally.

An estimate of the mineral percentages made by the Rosiwal method on a piece of "dark" yielded these results: Feldspar, 65.522; quartz, 26.578; mica, 7.900 .

${ }^{00}$ See U. S. Geol. Survey Nineteenth Ann. Rept., pt. 6, continued, p. 224, 1898.

c7 Finlay (op. cit., p. 54) describes these rift cracks as crossing from one quartz crystal particle to another without interruption and as containing arborescent crystalline growths, possibly of manganese aloxide. 
All the Barre granites effervesce with muriatic-acid test. W. T. Schaller, chemist, of this Survey, finds that the "light Barre" contains 0.49 per cent of CaO (lime), soluble in warm dilute ( 10 per cent) acetic acid, and the dark 0.63 per cent, indicating a content of 0.87 and 1.12 per cent of $\mathrm{CaCO}_{3}$ (calcium carbonate, calcite), respectively; the presence of this mineral is also shown by the microscope.

Finlay's analysis of the darker granite from the area south of Millstone Hill is given here for reference. ${ }^{68}$

Analysis of "darl Barre" granite.

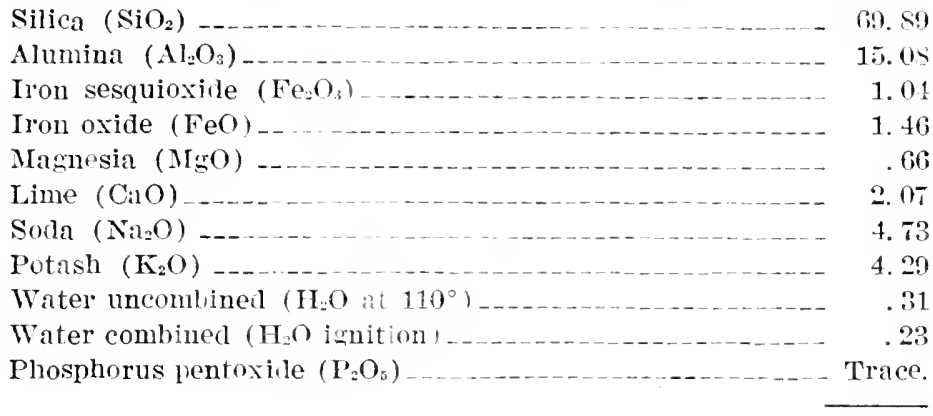

9.7. 76

W. C. Day found the specific gravity of "dark Barre" and "metlium Barre" to be 2.662 to 2.672 , and its crushing strength to range from 14,968 to 19,957 pounds to the square inch. (See p. 139.) L. P. Finnicutt in 1908 foum that 100 pounds of Barre granite absorbs 0.294 pound of water. (See p. 157.)

Barre granite is mostly monmental, but some is building granite. The lisht, medium, and dark monumental stone, although blilliant in the rough, has weak mineral contrasts, but these are stronger on the polished face of the dark. The white of the more kaolinized and micacized orthoclase feldspars and the black of the mica, and the combined bluish gray of some of the feldspar and smoke color of the quartz form three distinct shades, but owing to the fineness of the texture these merge a few feet away, and the white alone shows against a darkgray ground. "Light Barre" granite is nerer polished but is hammered, because of the feeble contrast between the polished and cut surface. but the dark is often used for polished work. Its polish is fair, and the contrast between the polished and cut face is more marked along the hard way than in the rift or grain directions. In the stone from the Milne \& Wylie and Jones dark quarries this contrast is so marked as to imply the presence of considerable soda-lime feldspar, for the contrast is almost as great as in a quartz monzonite. The polished face slows pyrite and a little magnetite.

\section{GEOLOGY OF R.ARRE QUARRIES.}

The granite was observel in contact with the selnst at six quarries (Pl. II. Nos. $6,8,9,10,12,20$ ). The results of a study of the contact phenomena at two of these quarries are given on pages s5-SS.

The schist inclusions have already heen dwelt upon (pp. 61-65). At two quarries (I'l. II, Nos. 6, 32) these inclusions and the schist capping have been penetrated by minute dikes of granite and pegmatite proceeding from the granite. At one of these quarries the granite is darkened for a space of 7 feet from the inclusion. 
The sheet structure of Millstone Hill appears to form a more or less unsymmetrical flattish dome. The central part of this dome is exposed at the Wetmore \& Morse quarry (Pl. II, No. 14), where the sheets dip from the horizontal both eastward and westward $10^{\circ}$. West-southwest of that point and lower down, at the Smith upper quarry (1'I. II. No. 15), they dip $10^{\circ}-15^{\circ}$ SW., and so also in the Duffee quarry : still further down, at the Snith lower quarry (Pl. II, No. 17). they dip $20^{\circ}-30^{\circ} \mathrm{SW}$. On the northeast side at the Bond \& Whitcomb quarry (Pl. II, No. 19). the sheets dip low to the northeast, and at the next (puarly (Pl. II. No. 26) $15^{\circ}$ E. : at the Canton quarry (No. 21) $10^{\circ} \mathrm{N}$., but at the Barney quarry (No. 20) $10^{\circ} \mathrm{NE}$. and NIV. At the Walker quarry (No. 23) low east and northeast. An east-northeast to west-northwest section of the hill passing through the quarries named would thus give a general low anticlinal. The sheets of Cobble Hill also form a dome, for at the Wheaton quarry, north-northwest of the top, they dip $10^{\circ} \mathrm{NW}$. and NNE., but on the southwest side of the hill, at the Wildbur quarry, they dip $60^{\circ} \mathrm{S} .75^{\circ} \mathrm{W}$., and at the Bianchi quarry, farther south, $35^{\circ} \mathrm{S} .50^{\circ} \mathrm{W}$. But the sheet structure half a mile southeast of Millstone Hill (Jones and Consolidated quarries) and toward the Williamstown line is too complex to unravel. The sheets are lenticular and normal at only 21 out of the 41 quarries visited. These 21 quarries include, besiles those named above, the small group of quarries in the northwest corner of the area mapped (Pl. II), also the Milne \& Wylie, Anderson, and Wells-Lamson quarries, and the Pirie. in Wiltianstown. In the remaining 20 quarries the sheets are more or less irrosular or ahsent. In some places the lenses are very short and thick; in others, as in the large Jones Bros. quarry, there are only traces of sheets. In several quarries, as the Manufacturers and Anderson quarries, the sheets " grow on "- that is, the sheet partings stop laterally, leaving the center or half of the quary without sheets. Figure 27 shows close joints without sheets in one part of the quarry, and sheets without joints in the adjoining part. In several quarries sheet structure stops vertically at depths of 20, 25, or 35 reet from the rock surface-for example, at the Barclay, Capital, and Milne quarries. At the Smith lower quarry there is a mass 58 feet thick without sheets; at the Bruce. one such of 48 feet; at another, of 40 feet; and at the Marr \& Gordon, of 80 feet. At one of the Boutwell quarries there is a lens ("boulder") about 33 feet thick estimated to contain about 500,000 cubic feet. At some quarries there is no trace of sheet structure. This incomplete development of sheet structure is the chief difficulty in quarrying at Barre. Wherever low-dipping joints occur these are utilized as sheets, but where such joints are wanting horizontal chauneling has to be resorted to, which is expensive. The sheets range from 6 inches to 30 feet in thickness. At the Wells-Lamson quarry the "toe-nail" structure intersects the sheets. At one quarry a sheet surface is slickensided.

During the last 10 years the depth of some of the quarries has greatly increased. The bottom of some of the Boutwell, Milne \& Varnum Co.'s quarries is 200 feet below the rock surface. In some places the limit of sheet structure seems to have been almost reached.

There are ten sets of joints-(a). strike N. $5^{\circ}$ W. to N. $10^{\circ}$ E.; (b) N. $15^{\circ}-20^{\circ}$ E.; (c) N. $30^{\circ}-40^{\circ}$ E.; (d) N. $45^{\circ}-55^{\circ}$ E.; (e) N. $60^{\circ}-70^{\circ}$ E.; (f) N. $75^{\circ}-90^{\circ}$ E.; (g) N. $60^{\circ}-80^{\circ}$ W.; (h) N. $45^{\circ}-50^{\circ}$ W.; (i) N. $30^{\circ}-40^{\circ} \mathrm{W}$, ; (j) N. $10^{\circ}-25^{\circ}$ W. Of these (c) occurs at 21 and (f) at 18 quarries. The next most frequent are (e) and (i), each at 10 quarries, and (j) at 8 . These Joints divide themselves into five complementary sets-that is, sets at right angles to one another and presumably due to the same strain. These sets consist of (a) and (f), (b) and (g), (c) and (h), (d) and (j), and (e) and $(j)$. The spacing of the joints ranges from 1 to 200 feet. In 26 quarries 
the spacing ranges from a minimum of 1 to $S$ feet to a maximum of 20 to 50 feet; in 18 quarries from a minimum of 10 to a maximum of 100 to 200 feet. Many of the joints are intermittent or discontinuous. Abnormal relations of joints and sheets are shown in figure 28 . In some quarries joints of the same strike incline in opposite directions, as shown in figure 26 .

Some joints are coated with limonite and calcite; others with a greenish. usually slickensided film of muscovite, secondary quartz, and chlorite. Back of it the feldspars are microscopically brecciated and cemented with fibrous muscovite, also minutely veined with calcite and quartz. These veins run at right angles to the face. Some joint faces are very uneven, and their minor protuberances are slickensided. Other joint faces are coated whth somewhat large muscovite scales. The slickensides of joints usually have their furrows pointing in the direction of the dip of the joint, indicating motion up or down along the dip.

Headings are numerous and usually rusty. On the northwest wall of the Marr \& Gordon quarry the central part (25 feet) of a heading striking $N$. $35^{\circ} \mathrm{E}$. branches off to the northwest; and at another quarry (p. 143) a heading undulates back and forth laterally.

Flow structure is rarely observable. At the Wells-Lamson quarry (Pl. II, No. 24) a 12-inch band of darker granite shows the flow to have been $\mathrm{N}$. $70^{\circ}$ E., with an inclination of $60^{\circ} \mathrm{N}$. $20^{\circ}$ W. On Cobble Hill (Bianchi quarry) it is about north and vertical. At the Barney quarry for a space of 15 feet from the contact with schist the granite is coarse and fine ln alternating bands.

Segregations are uncommon. At the Sanguinetti quarry (Pl. II, No. 1S) the granite is concentrically banded in a pear-shaped mass, 1 and 2 feet in its diameters. Biotitic knots are rare and small. One 1.5 by 0.5 inch was noted. Possibly the darker, more biotitic, irregular roundish portions of the granite near the schist contacts at the Marr \& Gordon and Jones dark quaries (pp. 130, 141) are of the nature of the segregations.

The rift as reported by foremen is everywhere vertical, and the grain in all but two quarries is horizontal. The course of the rift about Millstone Hill and in Williamstown appears to range from N. $30^{\circ}$ E. to N. $60^{\circ}$ E., and on Cobble Hill from N. $50^{\circ}$ E. to N. $75^{\circ} \mathrm{E}$. In the group of quarries about the Boutwell and Bruce quarries and the adjoining ones in Williamstown the rift is $\mathrm{N} .50^{\circ}-60^{\circ}$ E., but near the top of Millstone Hill (Duffee, Millstone) it is N. $30^{\circ}-40^{\circ}$ E. At the Capital and Barre quarries (PI. II, Nos. 29, 33) it is reported as varying in different blocks. At the Anderson quarry (No. 8 ) it is reported as $\mathrm{N} .60^{\circ} \mathrm{E}$., and the grain, here better than rift, as dipping $20^{\circ} \mathrm{N}$.; but at the Jones light quarry, only 1,500 feet away, the rift is reported as $\mathrm{N}$. $35^{\circ} \mathrm{E}$. and the grain as horizontal. At the Pirie quarry the grain is reported as dipping $35^{\circ} \mathrm{N}$.

Pegmatite dikes are not abundant. One at the Pirie quarry is lescribed on page 49 ; those at the Anderson quarry on page 85 (fig. 10), aud those at the Bailey quarry on page 49 .

Aplite occurs in irregular veinlike masses in contact with schist inclusions at two quarries. Specimen D, XXIX, 14, a, from the Jones dark quarry, is of light medium bluish to greenish gray color and of very fine texture, with mica up to 0.05 inch, its other minerals not distinguishable. In thin section it consists of microcline, kaolinized albite to oligoclase-abite, and quartz with a little biotite, some of it chloritized, and still less muscovite or bleached biotite. It contains allanite and carbonate. Specimen 44, c, from the Bailey quarry, is of light medium purplish gray color and of porphyritic texture. It 
consists of light purplish-gray to milk-white feldspar, elear quartz, and black mica. The particles of the matrix are from 0.025 to 0.1 millimeter in diameter. The porphyritic crystals (mostly oligoclase-albite, some with zonally arranged quartz, rarely microcline) measure from 0.25 to 1 by 0.5 millimeter. Pyrite is a ceessory.

Quartz veins from 0.05 to 2 inches wide of pegmatitic origin are more abundant. One at the Milne quarry is described on page 51.

Basie dikes were noted at seren quarries. At three (Jones light, Capital, and MeIver \& Matheson) the exposures may all belong to one dike, which would thus be half a mile long; and as two others (Barney and Walker quarries) are clearly the same dike, thus S00 feet long, only four dikes were actually observer. The long one is from 2 feet 6 inches to 9 feet thick, with a N. $40^{\circ}-45^{\circ}$ E. comse and vertical. The other, from 1 to 2 feet thick, has a N. $35^{\circ}-40^{\circ}$ E. conrse. One at the Millstone quarry, up to 2 feet thick, has a $\mathrm{N}$. $25^{\circ}$ W. course and weathers siheroidally. One at the Bianchi quarry, on Cobble Hill, is 6 inches thick, with a N. $55^{\circ}$ E. course. Two of these dikes were exanined in thin section. The dike rock of the Jones light quarry is a darkgreenish diabase of very fine texture (labradorite, augite, magnetite, apatite needles, secondary calcite). Its angite is altered to a chlorite-like mineral giving the greenish eolor. The Millstone dike rock appears to be an altered camptonite of very dark gray color and porphyritic texture, with very fine matrix (plagioclase, micacized, kalinized, and with calcite, magnetite in erystals, and skeleton erystals). The porphyritic crystals or masses appear to be hornblende more or less altered to chlorite and calcite: one is replaced by quartz.

At three quarries the granite within 1 to 2 feet of these dikes is crossed by vertical subjoints 1 to 6 inches apart parallel to the dike wall; and the granite scilles off along them. These subjoints are to be regarded as the effect either of the heat of the dike or of the strain which accompanied its intrusion.

A north-sonth compressive strain is reported at the Bruce and Wells-Lamson quarries, and an east-west one at the Canton quarry.

Rusty stain along sheet surfaces varies creatly in amount. In many quarries it loes not exceed 6 inches in thickness: in others it reaches 12.16, and 18 , and in one place 24 inches, hut that was confined to the upper sheets. Generally it is confined to the lower surfaces of sheets. On joint faces it is from 6 to 21 inches and abounds on headings.

In concluding this part of the subject attention is recalled to the evidence of minor mineral and structural changes brought out in this and the previous section. The rift and grain eracks in the quartz, the straining of the quartz as shown by its optical behavior, the bending of the twinning lamellae of the soda-lime feldspars, the formation of minute veins of secondary quartz, calcite, and epidote, the brecciation of feldspars and the formation of fibrous muscovite and of chlorite and of little veins of quartz and calcite in consequence of motion along joint planes, the formation of subjoints near basic dikes-all these facts point to crustal morements of different dates, some probably preceding the sheet and joint structure, others subsequent to it.

\section{QUARRIES.}

The Boutwell quarry is about south of the top of Millstone Hill, in Barre. (See Pl. II, No. 1.) Operator, Boutwell, Milne \& Varnum Co., Montpelier.

The granite, chiefly "dark Barre" (but also some "dark medium" and "medium"), is a biotite granite of dark inclining to medium bluish-gray color and of fine, even-grained texture, with feldspars up to 0.2 inch and mica to 0.1 inch. Its color, texture, constituents, and qualities correspond to those of the "dark" of the Bruce quarry, deseribed on page 131. 
The quarry, opened about 1856 , is somewhat $\mathbf{T}$-shaped, measuring about 600 feet in a N. $80^{\circ}$ I. direction by 60 feet north and sonth at the east end and 120 feet at the west end, with a 150 -foot square extension on the north side, but only 150 feet from the west end. Its depth in 1907 was from 50 to 100 feet.

Rock structure: The sheets are irregular, 4 to 30 feet thick, striking $\mathrm{N} .30^{\circ}$ E. and also east-west and dipping $10^{\circ}, 20^{\circ}$, and $35^{\circ} \mathrm{N} .30^{\circ} \mathrm{W}$, and north. Joint, rift, and dike courses are given in figure 25.

Joints (A) dip $55^{\circ}-70^{\circ} \mathrm{S} .10^{\circ} \mathrm{W}$, are spaced 5 to 50 feet, and form the north and south walls of the main part. They are mostly limonitic or slickensided with a lustrous greenish coating, described on lage 127 . Joints (B) are vertical, discontinuous, only a few feet long, form small headings, and are coated with calcite and limonite to 0.25 inch. One at the southeast corner dips $60^{\circ} \mathrm{N}$. $40^{\circ} \mathrm{W}$. (C) dips $10^{\circ} \mathrm{S}$., exceptional, only a few feet long, with lustrous coating, as under (A). The rift is reported as vertical, and the grain as horizontal. Three large schist inclusions measure respectively 55 by 10 by over 6 feet, 20 by 4 by 3 feet, and 10 by $\&$ feet. The first has been described on page 64 . A minute vein (a) of muscovite and quartz dips $50^{\circ}$ E. The granite parts along it. Vein (b) is scarcely 0.05 inch wide, but has a border of dark bluish green (chloritic) or brown (limonitic), 0.25 inch wide on either side. (See further p. 74.) The "sap" is from 8 to 12 inches thick on the lower surfaces of sheets and is conspicuous in the headings.

Product: As the stone is sold by the company in rough blocks, there are no records of the monuments made of its blocks. The monolithic Smith obelisk at Sharon, Vt., canie from this quarry.

The Milue \& Wylie quary adjuins the Bruce quarry on the south and lies about south of the top of Millstone Hill, in Barre. (See Pl. II, No. 3.) Operator, Boutwell, Milne \& Varnum Co., Montpelier.

The granite (specimens D, XXIX, 11, a, b, c), "dark Barre," is a biotite granite of dark bluish-gray color, a trifle darker than that of the Bruce quarry, and of even-grained fine inclining to medium texture, with felispars up to 0.3 inch and mica to $0.12 \mathrm{inch}$. Its constituents are the same as those of the Bruce and Marr \& Gordon quarry stone described on pages 130,131 , but it contains considerable soda-lime feldsnar, more or less kaolinized and micacized and with calcite. Its strong contrasts of shade between cut and polished faces also indicate the presence of an unusual amount of soda-lime feldspar for a biotite granite. It effervesces with muriatic-acid test.

An estimate of the mineral percentages by the Rosiwal method yields the following results with a mesh of 0.2 inch and a total linear length of 66.6 inches: Feldspar, 65.522; quartz, 26.578; mica, 7.900. The average size of all the particles obtained from the same measurements, adding 50 per cent to the

$$
105709-23-10
$$


number of feldspar particles for the unseparated second feldspar, proves to be 0.069 inch, that of the feldspar $0.074 \mathrm{inch}$, the quartz $0.079 \mathrm{inch}$, and the mica 0.033 inch.

The polished face shows a little pyrite and less magnetite. The cut or hammered hard-way face is as light as the cut face of the Jones "light Barre," thus affording a very marked contrast with the polished face. The mineral conirists are weak in the rough stone, but stronger on the polished face, white, black, bluish-grily, and smoke color being easily distinguished in it within a distance of 2 feet. The polish is fair.

The quarry, opened about 1887 , was in 1907 about 400 feet from east to west by 200 feet across, but with a mass 100 by 50 feet projecting into the quarry from the east wall.

Rock structure: The sheets, 3 to 30 feet thick, dip $20^{\circ}-30^{\circ}$ NW. Joints, one set only, strike neariy east, dip $60^{\circ}-70^{\circ} \mathrm{S}$., form the north and south walls and a heading which constitutes the projecting mass on the east wall. These joints, being spaced 3 to 20 feet, cut up the sheets.

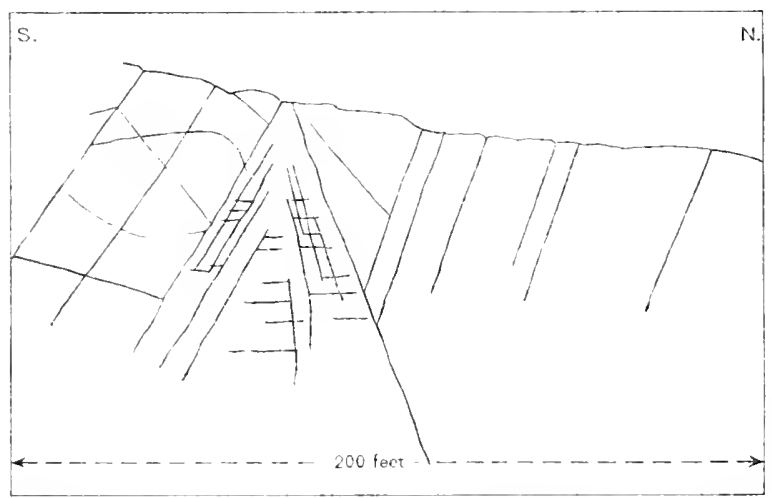

Figure 26.-Structure on west wall of Empire dark quarry, Barre, vt.

The Empire dark quarry is southwest of the Milne \& Wylie quarry and about south-southwest of the top of Millstone Hill, in Barre, just north of the Williamstown I i ne. (See Pl. II, No. 4.) Operator, Boutwell, Milne \& Varnum Co., Iontpelier.

The granite is like that from the Bruce quarry, described on page 131 .

The quarry, opened about $18 S S$, is about 375 feet in a N. $75^{\circ}$ E. direction by 200 feet across and in 1907 was from 75 to 120 feet in depth.

Rock structure: The sheets, 3 to 18 feet thick, are somewhat irregular, dip. ping low, rarely $40^{\circ}-45^{\circ} \mathrm{N}$. There are two sets of joints-(a), strike N. $65^{\circ}-70^{\circ}$ E., dip $65^{\circ}-70^{\circ} \mathrm{S} .15^{\circ} \mathrm{E}$., spaced 4 to 25 feet, forms a heading on the north wall, a 10 -foot one on the south wall, and a 25 -foot one in the middle. This set exceptionally dips $65^{\circ}-70^{\circ} \mathrm{N} .15^{\circ} \mathrm{W}$., forming with the rest a $\mathrm{V}$-shaped heading in the center of the quarry, as shown in figure 26. The faces of (a) are coated with limonite and bordered with its stain. The other set (b) is exceptional, strike $\mathrm{N}$. $15^{\circ} \mathrm{W}$, vertical. The rift and grain are as at adjoining quarries. There are three schist inclusions on the east wall, the largest 20 by 10 feet.

The Marr \& Gordon quarry is east-soutleast of the Empire quarry and about south-southwest of the top of Millstone Hill, in Barre, just north of the Williamstown line. (See Pl. II, No. 5.) Operator, Boutwell, Milne \& Varnum Co., Montpelier.

The granite (specimens D, XXIX, $8, b, b b, d$ ), “dark Barre" (derrick 9), is a biotite granite of dark bluish-gray color and of even-grained fine texture, with feldspars up to 0.2 inch and mica to 0.1 inch. Its constituents, in descending order of abundance, are clear bluish to translucent and milk-white potash feldspar (orthoclase, kaolinized and nicacized, with a little clear microcline), some of it with minutely intergrown soda-lime feldspar; light smoky quartz, witn 
cavities in sheets and showing marked ontical effects of strain; translucent to milk-white soda-lime feldspar (oligoclase to oligoclase-andesine) rarely with curved twimning lamella, more or less altered: biotite (black mica), larely chloritimed : very little muscorite or bluached biotite. Accessory : l'yrite, magnetite, zircon, titanite, apatite. Secondary: (Calcite (in orthoclase), kaolin, one or two white micas, and cinlorite.

The stome effervesces with muriatic-acid test. W. 'T. Schaller, a chemist of this Survey, finds that it contains 0.63 per cent of CaO (lime) soluble in warm dilute (10 per cent) acetic acid, which indicates a content of 1.12 ler cent of $\mathrm{CaCO}_{3}$ (calcium carbonate, (alcite); the presence of this mineral is also shown ly the microscoje.

This granite is regarded by the firm as harder and darker than the "dark" from its other quarries. It resembles that of the Milne \& Wylie quarry (1. 129) but when polished shows somewhit higher mineral contrasts. It takes a fair polish. The polished face shows some pyrite and magnetite.

At the west end of the quarry, near the contact of granite and schist, is a mass (so-called knot) of still darker granite of sufficient si\%e for commercial use. This "very dark Barre" (slecimen D. XXIX, 8, a) is a biotite granite of very dark bluish-gray color. much darker than the "dark" and as dark as "dark Quincy" (1. 3:1) ant of fine indining to merlinm. even-grined texture, with feldspars up to 0.2 inch and nica to 0.3 inch. Its constituents are the same as those of "dark Barre," specimen 8 , b. etc., but the liotite is much more abundant. The second feldspar is oligoclase-albite. The stone effervesces with muriatic-acid test.

Rock structure: In the main opening the sheets are unusually irregular. At the east eud they are 18 to 20 feet thick, but in the northwestern liart for a depth of 80 feet there are none. In the small wiening the sheets are mole regnlar and from 4 to 14 feet thick. There is hint one set of joints, strike N. $35^{\circ}$ E. and vertical. forming a 20 to 25 foot heading on the northwest wall. also the northwest wall of the smaller opening, where it recurs at intervals of 3 to 10 feet. The heading in the main quarly branches off tiagonally to the northwest, forming a bind 20 to 30 feet wille. about halfway down the quarry. This musual structure indicates complex strains. At the top of the west end the granite is in contact with a quartz-biotite schist spangled with biotite scales. The two rocks are firmly welded together in places across the foliation of the schist. Near this schist the granite is much darker from more abumdant and larger biotite scales. (Ste 1) 25.) The outline of the darker stone is irregular. The rift is reported as vertical, with N. $55^{\circ}$ E. course, and the grain as horizontal.

The Bruce quarry adjoins the Boutwell on the southwest and lies about south of the top of Millstone Hill, in Barre. (See Pl. II. No. 2). Operator, Boutwell, Milne \& Varnum Co., Montpelier.

The granite (specimen D, XXIX, 12. a). "lark Barre." is a biotite granite of dark inclining to metium bluish-gray color. ant of even-grained fine texture, with feldspar up to 0.2 inch and mica to 0.1 inch. Its constituents, in descending orler of abundance. are transhucent bluish-gray to milk-white potash feldspar (orthoclase. kaolinizer and nicacizerl. and a litte clear microcline, one such orthoclase inclosing a fresh microcline) ; light smoky (juart\%. with cavities in sheets and with cracks parallel to them (the quartz shows optical effects of strain); milk-white soda-lime feldspar (oligoclase-albite), more or less altered, rarely with bent twinning planes; biotite (black mica); and a little muscovite or bleached biotite. Accessory: Titanite, magnetite, pyrite. Secondary: Not a little calcite within the orthoclase, kaolin, one or two white micas. The stone effervesces slightly with muriatic-acid test. 
Its mineral contrasts are feele owing to fineness. of texture and the lightness of quartz. The is some contrast between the polished and cut faces along the hard way.

The quarry. opened in 1890, measured in 1907 about 250 feet in a N. $80^{\circ}$ E. direction hy 125 feet arross and 60 to 100 feet in depth.

Inck structure: The sheets, 4 to 10 feet thick, dip $5^{\circ}-10^{\circ} \mathrm{N}$. At the bottom is a mass $4 \mathrm{~S}$ feet thick without sheets. There are three sets of joints-(a), strike $\mathrm{N}$. $80^{\circ}$ L., with rarying rip. forms the soutl wall and an 8 -foot heading on the north wall, spacing 10-20 feet, but makes werlge-shaped masses owing to varying dip; (b), diagonal, "slide," strike N. $40^{\circ}$ E., vertical, at northwest corner, with uneven slickensided face; (c), strike N. $20^{\circ}$ W., dip $70^{\circ}$ N. $70^{\circ}$ $\mathrm{E}$, one in center. The rift and grain are as at Boutwell quarry. A heavy north-sonth compressive strain is reported.

The Bailey quarry is southeast of the Mine \& Wylie quarry and about south of the top of Millstone Hill, in Barre. (See Pl. II, No. 6.) Idle but owned by the Boutwell Co.

The granite, "dark Parre," is a biotite granite of dark color and fine eren-grained texture, similar to that of the Bruce and Milne \& Wylie quarries.

The quarry in 1907 was about 135 by 75 feet and from 10 to 35 feet in depth.

Rock structure: The sheets are imperfectly developed. There are two sets of joints-(a), strike N. $20^{\circ}$ W., dip $70^{\circ}$ N. $70^{\circ}$ E., spacel 3 to 20 feet; (b), strike N. $60^{\circ}$ E., dip $75^{\circ}$ S. $30^{\circ}$ E., spaced 2 to 6 feet, riccurs on the west sile only. There the granite is in contact with schist which las a foliation strike of N. $60^{\circ}$ E, dip of $35^{\circ} \mathrm{N}$. $30^{\circ} \mathrm{W}$; also one of $\mathrm{N} .20^{\circ} \mathrm{E}$., with vertical dip. At the nortlimest corner is a schist inclusion 26 by 5 feet. with a foliation striking N. $85^{\circ}$ W. and a lip of $55^{\circ} \mathrm{N}$. Dikes large and minute of pegmatite and aplite penetrate the schist capping and the inclusion renlering the relations in. tricate. Somes of the details are given on page 87 .

The Anderson quarry is about $S .10^{\circ}$ E. of the top of Millstone Hill, in Barre, 1,800 feet northeast of the Williamstown line. (See Pl. II, No. 8.) Abandoned but described on account of its great geologic interest.

The granite is a biotite granite of gray shade ant fine even-grained texture.

The quarry, opened about 1S92, measured in 1907 about 200 feet in a $\mathrm{N}$. $45^{\circ} \mathrm{W}$. direction by 150 feet across and from 50 to 75 feet in lepth.

Rock structure: The granite on the southeast an! northeast sides and on the west of the south corner is capper by schist and slate up to 15 feet thick, with a cleavage and schistosity strikiug N. $30^{\circ}$ E. and lipping $55^{\circ} \mathrm{N} .40^{\circ} \mathrm{W}$. The relations of granite and slate are shown in Figures 10 and 11, and the contact phenomena have been given on page 85 . The sheets, 1 to 15 feet thick, dip $20^{\circ} \mathrm{NW}$. There are three sets of joints(a), strike N. $50^{\circ} \mathrm{W}$., din $75^{\circ} \mathrm{N} .50^{\circ}$ F., occul's on the sonthwest side only; (b), strike N. $5^{\circ}$ E., dip $70^{\circ}$ E., spaced 6 to 15 feet; (c), strike N. $69^{\circ}$ L., dip $75^{\circ}$, spaced 3,15 , and over 25 feet. The rift is reported as vertical, with $\mathrm{N} .60^{\circ}$ E. course; the grain as dipping with the sheets $20^{\circ} \mathrm{NW}$., and as easier than the rift. A 1-font pegmatite rike borders one of the schist masses, as shown in figure 10. Af the enst ill there are two schist inclusions, measuring 10 by 2 to 3 feet and 6 by 2 feet, respectively, besides minor fragments.

The Stephen \& Gerard quarry is 600 feet north of the Anderson quarry and south to south-southeast of the top of Millstone Hill, in Barre. (See Pl. II, No. 9.) Operator, Standard Granite Co., Barre.

The granite, reported by the firm as "medium Barre," is a biotite granite of gray shade and of even-grained, fine texture. For descriptions of "medium 
Hallowell, Maine, which is light, inclining to medilum. Its texture is even grained, fine inclining to medium, with feldspar up to $0.2 \mathrm{inch}$, rarely $0.3 \mathrm{inch}$, and mica to 0.1 inch. Its constituents, in descending order of abundance, are clear colorless to bluish translucent and milk-white potash feldspar (orthoclase, kaolinized and micacizerl, with fresh microcline); very light smoky quartz with sheets of carities with brightly polarizing rift or grain cracks parallel to or coincicling with them; translucent to milk-white soda-lime feldspar (oligoclase-albite, more or less altered), mrely with bent twinning planes; biotite (black mica), some of it chloritized; very little muscovite or bleached biotite. Accessory : Magnetite (very little) and zircon. Secondary: Calcite, usually in the orthoclase, kaolin, one or two white micas, and chlorite.

The stone effervesces with nuriatic-acid test. W. T. Schaller, chemist, of this Surrey, finds that it contains 0.49 per cent of CaO (lime) soluble in warm dilute (10 per cent) acetic acid, which indicates a content of 0.87 per cent of $\mathrm{CaCO}_{3}$ (calcium carbonate, calcite), the presence of which is also shown in thin section.

The mineral contrists are feeble, and so are those between cut and polished faces. The stone is used for rough, hammered, and carved monumental work.

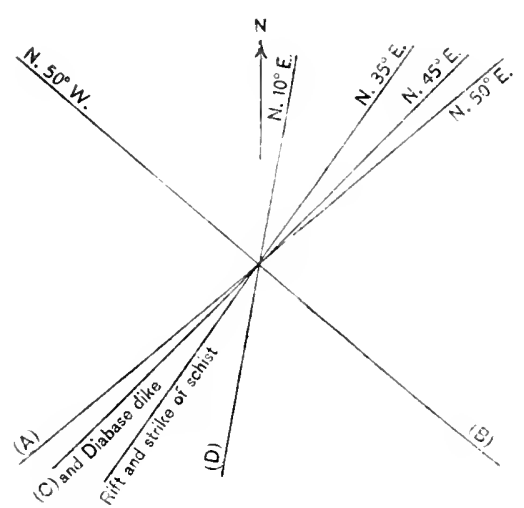

Figcre 29.-Structure at Jones Light quarry, Barre, vt.

The quarry consists of two openings. The main and older one in $\mathbf{1 9 0 7}$ neasured over 550 feet in a N. $35^{\circ} \mathrm{E}$. airertion by 60 to 200 feet across, and in 1918 was 125 fcet deep. A later one, 300 feet N. $30^{\circ}$ E. from the north end of the other, was about 200 feet square and 50 feet deep.

Rock structure: Joint, rift, and dike courses are shown in figure 2 ?. Sheet structure is hardly develoned or very irlegular. Traces of sheets dip $10^{\circ} \mathrm{W}$. On account of this much horizontal channeling has to be done. There are six sets of joints-(A), diagonal and vertical; $(B)$, also vertical, spaced 20 to 30 , 50 feet and over; (C), dip $45^{\circ}$ S. $45^{\circ}$ E., discontinuous, occurs here and there in north part of quarry; (D), dip $45^{\circ}$ W., undulating, occurs with (C) ; (E), in new opening, dip $45^{\circ} \mathrm{N}$. $65^{\circ}$ E., spaced 3 to 50 feet, forms a heading at northwest corner; ( F), in new opening, dip stecply N. $58^{\circ} \mathrm{E}$. There is a schist capping on the west wall of the main opening 10 to 20 feet and more thick, and on part of east wall, and also forming the east wall of new opening. Its foliation strikes N. $35^{\circ}$ E. and dips steeply to $90^{\circ}$. The schist is said to continue indefinitely on the east and also to be at least 150 feet wide on the west. Rift is vertical and good, the grain horizontal. A vertical diabase dike, 8 feet thick, crosses the north half of the main quarry diagonally, and also the schist (apping. (See, further, p. 128.) Thirty feet below the granite surface is a schist inclusion 30 feet long and up to 3 feet thick, tapering.

The product is used for rough and hammered face and carved monuments. The following specimen monuments combine the product of this quarry with that of the firm's dark quarry described on page 141: Soldiers and sailors' monuw'ent. Angola, Ind.; Ohio and Iowa State soldiers' monuments, Chattanooga, 'Tenu.; Governor Curtin monument, Bellefonte, Pa.; State soldier's' monument, York. Pa.; Hearn monument, with monolithic spire 53 by 4 by 4 feet, Woodlawn. N. Y.; Rouse mausoleum, Winchester, Va.; Krueger mausoleum, Newark, 
N. J.; Gary mausoleum, with roof stones of the "light," 35 by 9 feet 6 inches by 1 foot 6 inches each, Wheaton, Ill.; Goodall monument, Sanford, Maine.

The Wetmole \& Morse quarry, 1,007 feet above the city, lies in al sadde about south-southeast of the top of Millstone Hill and about 200 feet below it. (See Pl. II, No. 14.) Olerator, Wetmore \& Morse Granite Co., Montpelier.

The granite (specimen D, XXIX, 19, b), "light Barre," is a biotite granite of light, medium, slightly bluish-gray color (darker than that of the Jones Light quarry and that of Hallowell, Maine, but lighter than "Concord granite") and of even-grained fine inclining to medium texture, with feldspar up to 0.3 inch and mica not over 0.1 inch. Its constituents, qualities, etc., are identical with those of specimen 18, a, from the Smith Upper quarry described beyond. The quarry yields also some "medium."

The stone effervesces with muriatic-acid test. W. T. Schaller, chemist, of this Survey, finds that it contains 0.49 per cent of CaO (lime) soluble in warm dilute (10 per cent) acetic acid, indicating a content of 0.87 per cent of $\mathrm{CaCO}_{3}$ (caleium carbonate, calcite); the presence of this mineral is also slowi in thin section.

The quarry, opened about 1875. measured in 1907 about 610 feet in a N. 60 E. direction by 100 to 200 feet across and in 1917 had reached a depth of 150 feet in some places and 100 feet in others.

Rock structure: The sheets are from 1 to 28 feet thick. 'The quarry cuts the axis of the hill so as to show the arching of the sheets on the northnorthwest wall. They are horizontal in the center at the top and dip $10^{\circ} \mathrm{E}$. and W., but in the center at the bottom they dip $15^{\circ}$ SSW., showing the dome structure of the hill. There are four sets of joints-(a), strike N. $60^{\circ}$ E., rertical and steep S. $22^{\circ}$ E., forms part of the south-southeast wall; (b), strike N. $82^{\circ}$ E., dip almost $90^{\circ}$, forms part of the north-northwest wall; (c), strike N. $35^{\circ} \mathrm{W}$., vertical, occurring only in the north half of the quarry, coated with chlorite and sericite; (d), strike N. $30^{\circ}$ E., dip $45^{\circ}$ N. $60^{\circ}$ W., greenish, slickensided. The rift is reported as vertical with northeasterly course, and the grain as horizontal. Rusty stain is up to 2 feet thick on upper sheets, but disappears entirely below.

The stone of this company's quarries has gone into the following monuments: That to Admiral Schley in Arlington Cemetery, Washington; that to Andrew J. Frame at Waukesha, Wis.; and the Everitt mausoleum at Bennington, $\mathrm{Vt}$.

The Snith Upper quarry, southwest of and below the last, is S. $32^{\circ} \mathrm{W}$. of the top of Millstone Hill, in Barre. (See Pl. II, No. 15.) Operators, E. L. Smith \& Co., Barre.

The granite (specimen D, XIX, 1S, a), "light Barre," is a biotite granite of light, medium, slightly bluish-gruy color (darker than the "light." of the Jones quarry and that of Hallowell, Maine, which are light inclining to medium gray, but lighter than that of Corcord, N. H., which is medium gray) and of evengrained fine inclining to medium texture, with feldspar up to 0.3 inch and mica not over 0.1 incli. Its constituents, in descending orler of abundance, are (lear colorless to translucent bluish and milk-white potash feldspar (orthoclase, kaolinized and micacized, with a little fresh microcline) ; light smoky quartz with carities in sheets with cracks parallel to or coinciding with them; translucent to milk-white soda-lime feldspar (oligoclase-albite more or less altered), rarely with Hexed twimning planes; biotite (black mica), some of it chloritized and with epidote; a little muscovite or bleached biotite. Accessory: Pyrite, magnetite, titanite, apatite, zircon. Secondary : Caleite, generally in the orthorease, kaolin, me or two white micas, chlorite, and epidote. It efferresces slightly with muriatic-icid test. 
The mineral contrasts are feeble.

The quarry is rery irregular in outline, measuring about 400 feet in a $\mathrm{N} .30^{\circ}$ F. direction by 200 feet across and about 50 feet in depth.

liock structure: The sheets, 1 to 10 , rarely 20 feet thick, are horizontal at the liorth end but elsewhere bend over to the southwest $10^{\circ}$ to $15^{\circ}$. Joint and rift courses of this and Duffee and Smith Lower quarries are combined in figure 30 . There are two sets of joints-(A), vertical, forming headings on the northwest and southeast walls; (B), dip $75^{\circ}$ SW., spaced 10 to 30 feet and over. The rift is reported as vertical and grain as horizontal. Rusty stain 1 to 18 inches thick, but little of it on the upper surfaces of sheets.

The product is monumental stone. Specimens from all the quarries of $\mathbf{E}$. $\mathrm{L}$. Smith \& Co. are: Tuxbury exedra at Saco, Maine (see Pl. IV); pedestal of equestrian statue of St. Louis (erected by W. R. Hodges) and Lemp mausoleum, St. Louis, Mo.; Cluett obelisk, with 44-foot shaft, Hegeman mausoleum, Woodlawn Cemetery, Troy, N. Y.; Fleischmann mausoleum, Cincinnati; Kaufman mausoleum, Marquette, Mich.

This comprany also furnished the stone for the Barre post office.

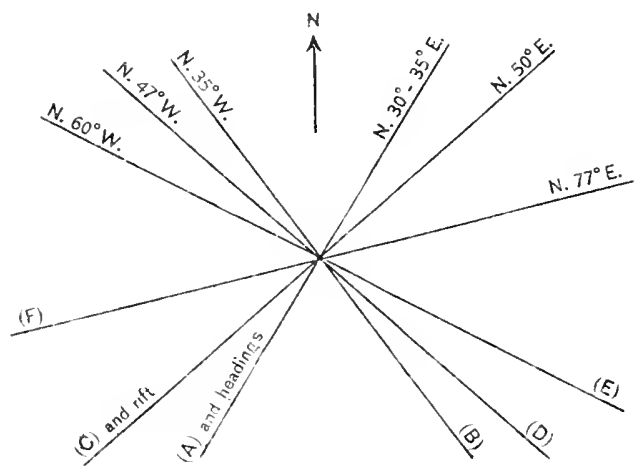

Figure 30.- Structure at Smith Upper, Smith Lower, and Duffee quarries, Barre, V't.

The Duffee quarry is westnorthwest of and lower than the Smith Upper quarry and soutbwest of the top of Millstone Hill, in Barre. (See Pl. II, No. 16.) Operators, E. L. Smith \& Co., Barre.

The granite (specimen $D$, XxIx, 17, a), "medi u m Barre," is a biotite granite of medium bluish-gray color (a trifle darker than "Concord granite") and of evengrained fine texture with feldsnars up to 0.2 inch and mica rarely to 0.1 inch. Its constituents, in descending order of abunclance, are translucent bluish to milk-white potash feldspar (orthoclase, kadinized and micicized, with a little fresh microcline); light smoky quartz with cavities in sheets and with cracks parallel to them, also showing optical effects of strain; translucent to milk-white soda-lime feldspar (oligoclasealbite, more or less altered), some of it with curving twining planes; biotite (black mica), some of it chloritized: a little muscovite or bleached biotite. 'There are microscopic veins of epidote, of quartz, and of calcite. Accessory: Allanite, zircon, probably also magnetite and pyrite, although not in section. Secondary: Calcite, usually in orthoclase, kaolin, one or two white micas, epidote, quartz, chlorite. The stone effervesces slightly with muriatic-acid test. The quarry produces some "dark" also.

The mineral contrasts are weaker than in the "dark" or in the "light" of the Jones or Smith Upper quarries, because of greater fineness of mica and more bluish cast of feldspar.

The quarry is estimated as about 400 feet east to rest on one side and 300 on the other by 200 feet across and about 75 feet in depth.

Rock structure: The sheets, 2 to 12 feet thick, are somewhat regular, dipping $15^{\circ} \mathrm{SW}$., witli the rock surface. There are four sets of joints (see fig. 30)(A), dip $75^{\circ} \mathrm{S} .60^{\circ} \mathrm{E}$, forms a 15 -foot head through the center of the quarry and is spaced 10 to 100 feet; (B) dip $60^{\circ} \mathrm{N} .55^{\circ} \mathrm{E}$., one only in 
southwest part; (C) dip $60^{\circ}$ S. $40^{\circ}$ E., one on south wail; (D) (lip S. $43^{\circ} \mathrm{W}$., one on southeast wall. The rift is reported as vertical and the grain as horizontal.

The Smith Lower quarry is west northwest of the Duffee quarry near the foot of Millstone Hill and $\mathrm{S}$. $60^{\circ} \mathrm{W}$. from its top, in Barre. (See l'l. II, No. 17.) Operators. E. L. Smith \& Co., Barre.

The granite, " medium Barre," is identical with that of the adjoining Inffee quarry described above. The quarry also yields some "dark."

The quarry is estimited as about 250 feet east to west hy 200 leet across, and 150 feet in depth.

Rock structure: The sheets. 1 to 15 feet thick. dip $20^{\circ}-30^{\circ} \mathrm{SW}$., but in the lower part is a mass 58 feet thick without sheets. Joint and rift courses are shown in figure $30-(\mathrm{A})$, dip $80^{\circ} \mathrm{S} .60^{\circ} \mathrm{E}$., forms the east wall and a heading on the southwest wall, and recurs 20 feet sotith of the north wall; (B), (lip) $50^{\circ} \mathrm{NNW}$. (two of this set, 8 feet apart, are in the sontheast coner); (c), dip $40^{\circ}$ N. $55^{\circ}$ E.. one only, discontinuous, on northeast wall. Iift and grain as at atijacent quarries.

The Millstone quarry is $\mathrm{N} .40^{\circ} \mathrm{E}$. from the tol of Millstone Hill and 200) feet below it, or 1,000 feet above the city, in Salre. (See P. II, No. 19.) Operators, E. L. Smith \& Co., Barre.

The granite (specimen D, XXIX, 26. a). "coarse light Barre." is a biotite granite of light-gray shade, owing to more biotite a trifle darker than the "light" of Jones quarry, and of even-grained medium texture with feldspars up to 0.3 inch, exceptionally 0.4 inch, anc mica to 0.2 inch. Its constituents, in descending order of abundance, are clear colorless to milk-white potash feldspar (orthoclase, kaolinized and micacized, with a little fresh microcline, rarely inclosed by the orthoclase); light smoky quartz with cavities in sheets, with rift cracks parallel to them, also showing optical effects of strain; whitish soda-lime feldspar (oligoclase to oligoclase-andesine) more or less altered; biotite (black mica), some of it chloritized; a little muscovite or bleached biotite. Accessory : Titanite. Seconclary: Calcite, generally within the orthoclase, kaolin, one or two micas, chlorite. The stone effervesces with cold muriatic-acid test.

This is a light constructional granite.

In another opening a little north of the main one the stone (specimen D, XXIX, 26, b) " medium Barre," is a biotite granite of medium gray color and fine texture, with feldspars up to 0.2 inch, rarely 0.3 inch, and mica not over 0.1 inch. Its constituents are the same as in the coarser granite, except that the soda-lime feldspar is oligoclase and some of the orthoclase is fresh. The stone effervesces slightly with muriatic-acid test.

This is a monumental granite.

The main quarry, opened in 1902, measured in 1907 about 200 feet in a $\mathrm{N}$. $35^{\circ}$ E. direction by 150 feet N. $25^{\circ} \mathrm{W}$., and in 1917 was abont 50 feet deep.

Rock structure: The sheets are regular, 6 inches to 7 feet thick, and dip gently northeast. There are two sets of joints-(a), strike N. $25^{\circ} \mathrm{WV}$, vertical, forms the northeast wall and a healing 75 fcet from the southwest wall; (b), strike N. $35^{\circ}$ E., vertical and steep N. $55^{\circ}$ W.. one only, forming the north wall. Some of the joint faces are coated with muscovite scales. The rift is reported as vertical with $N .35^{\circ}-40^{\circ} \mathrm{E}$. course, and the grain as horizontal. For spaces 1 to 2 inches wide the granite has very little biotite, and the average size of feldspars is there greater. A basic dike, described on page 12S, rums parallel to the north wall and a little back of it. It is 2 feet thick but taper's out at heading (a). Rusty stain does not exceel $1 \frac{1}{2}$ inches on sheet surfaces. 
The Barclay quarry is the S. $35^{\circ} \mathrm{W}$. continuation of the large Jones Light quarry, as slown on Plate II, No. 12. Operator, Standard Granite Co., Barre.

The granite, "light Barre," is a biotite granite of light, slightly bluish-gray color and even-grained fine inclining to medium texture, identical in every respect with that of the Jones light quarry described on page 133, but the lower part of the quarry is said to lave yielded " medium Barre" granite.

The quarry in 1907,220 by 100 feet, was about 75 feet deep.

Rock structure: The sheets, 6 inches to 12 feet and over in thickness, dip $20^{\circ} \mathrm{N} . \mathrm{W}$, but sheet structure terminates at a depth of 35 feet. Joints and rift are the same as in the Jones Light quarry. The granite is capped by schist on the northwest side. The schist is spangled with minute crystals of biotite and with a few garnets.

The product is used for monuments and memorial chapels. Specimens are the Robert Burns statue and pedestal, Barre, shown in Plate V, A; First North Dakota soldiers' memorial, St. Paul, Minn.; Indian massacre memorial, Serena, Ill.; Wade memorial chapel, Cleveland, Ohio; Hancock (canopy) memorial, San Francisco, Calif.; Doctor Kimball memorial, Concord, N. H.; General Thomas (shaft) memorial, Springfield, Ohio; Senator Dillon shaft, Davenport, Iowa.

The Sunnyside quarry is in line with the Barclay. It is operated by the Sunnysicle Granite Co., Barre.

The Wells-Lamson quarry is 640 feet above the city and about northeast of the top of Millstone Hill. (See Pl. II, No. 24.) Operator, Wells-Lamson Quariy Co., Barre.

The granite, "light and medium Barre," is a biotite granite of light medium, slightly bluish-gray, or of medium hluish-gray color, and of even-grained fine inclining to medium or fine texture. It is reported as identical in quality with the "light" and "medium" of the Smith Upper and Duffee quarries described on pages 135, 136 . The following result of a microscopic examination of "dark" granite from this quarry, made by Whitman Cross, of this Survey, was published in $1898:{ }^{\text {"日 }}$

“Messrs. Wells, Lamson \& Co.'s dai'k granite is a fine, even-grained, typical granite containing two micas (biotite, muscorite), sometimes called granite proper. The constituents of importance are quartz, orthoclase, microcline, biotite, and muscovite. The first tbree occur in wholly irregular grains interlocking in a very complex manner. The micas are in small leaves between and penetrating the other minerals to some extent. Muscovite apparently occurs in two forms, one corresponding to the biotite, as seemingly primary, and the other in small flakes in the orthoclase, and clearly a secondary mineral. Accessory constituents are oligoclase, albite(?), titanite (sphene), and apatite. There is an almost total absence of magnetite or other iron ore. Biotite is slightly changed to green and probably yields chlorite in some samples. The orthoclase gives way to an aggregate of ine muscovite leaves, also varying much in different samples, no doubt. Both quartz and biotite show that the rock has endured considerable pressure, the former by the 'undulatory extinction' it exhibits, and the biotite by the curved and bent lamellae. The pressure did not extend to a crushing of the grains or any banded structure. In the feldspars is some calcite filling small cracks. On the basis of this examination I should estimate it at quartz 30 to 35 per cent, orthoclase 30 jer cent, microcline 20 to 25 per cent. Iuch of the iron is present in the ferrous or unoxidized condition."

$\omega$ See U. S. Geol. Survey Nineteenth Ann. Rept., pt. 6, continued, p. 224, 1898. 
A chemical analysis of the "dark" from this quarry made by William C. Day at Swarthmore College, Pennsylvania, published in the same place, is repeated here for reference.

Analysis of "dark Barre" granite.

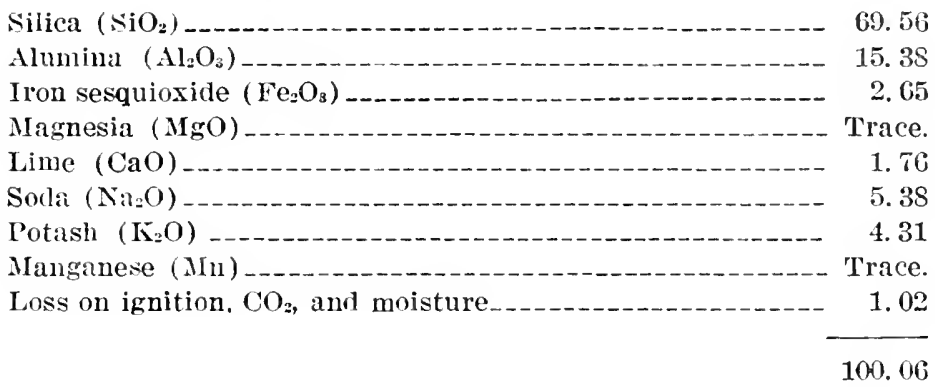

Day also made the following physical determinations of "lark" and "medium" from this quarry : ${ }^{\text {io }}$ Specific gravity, dark, 2.672; medium, 2.662; water absorbed, dark, 0.121 per cent ; medium, 0.129 per cent; crushing strength, dark, 16.719 to 19,957 pounds ; medium, 14,968 to 17,856 pounds.

The quarrs, opened about 1855, was estimated in 1907 as measuring about 400 feet in a $N \cdot 25^{\circ} \mathrm{W}$. direction by 300 feet across and from 50 to 60 feet in ileptl.

Rock structure: The sheets, 6 inches to 15 feet thick, dip gently southeast and $\mathrm{N} .65^{\circ} \mathrm{E}$. On the west side the lenses are very short. There is one sharply curving "toenail" 10 feet high, intersecting the sheet structure. There are three sets of joints-(a), strike N. $65^{\circ}-70^{\circ}$ E., dip $40^{\circ}-60^{\circ} \mathrm{N} .27^{\circ} \mathrm{W}$, spaced 25, 50, and 200 feet; (b), strike N. $30^{\circ}$ E., vertical, forms a small heading on south edge only; (c), strike $N$. $45^{\circ}$ E., vertical, forms a heading on the north wall and is spaced 200 feet and over. The rift is reported as vertical (probably N. $30^{\circ}$ E.), and the grain as horizontal. A 12-inch band of darker granite strikes N. $70^{\circ} \mathrm{E}$. and $\mathrm{dips} 60^{\circ} \mathrm{N} \cdot 20^{\circ} \mathrm{W}$, marking the direction of the flow. Schist crops out close to the south wall and continues in that direction. A north-south compressive strain is reported.

The product is used for monuments and buildings.

The Consolidated quarry is 860 feet above the city and $\mathrm{N}$. $75^{\circ}$ E. from the top of Millstone Hill, in Barre. (See Pl. II, No. 26.) Operator, Wetmore \& Morse Granite Co., Montpelier. Idle since 1920.

The granite, "light Barre," is a biotite granite of light medium, slightly bluish color like that of the Wetmore \& Morse and Smith Upper quarries, and of even-grained fine inclining to medium texture. (See p. 135.)

The quarry was estimated in 1907 as measuriug about 300 feet from north to south by as much across and in 1917 was from 75 to 100 feet deep.

Rock structure: The sheets, 1 to $\mathbf{1 5}$ feet thick, the thicker ones generally $\mathbf{5}$ to 10 feet, in places irregular. dip $15^{\circ} \mathrm{E}$. There are four sets of joints, as shown in figure $31-(\mathrm{A})$. rip $35^{\circ} \mathrm{N} .40^{\circ} \mathrm{W}$., one on the west wall, and a hersing at the southeast corner; (B), dip $75^{\circ} \mathrm{W}$.. one at the southeast corner; (C), $\operatorname{dip} 50^{\circ}-80^{\circ} \mathrm{N} .20^{\circ} \mathrm{W}$. forms north and south walls and small heading 30 feet west of the south wall; (D), dip $75^{\circ} \mathrm{N} .60^{\circ}$ E., one crosses the quarry from the northeast corner. The rift is reporterl as vertical and the grain as horizontal.

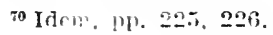


The Empire Light Granite quarry is about soo feet rast-southeast of the Milne quarry, on the nortl side of the southern road from Websterville to East Barre. (Sce Pl. II, No. 36.) Owners. E. L. Smith \& Co., Barre.

The granite, "light and medium Barre," is a biotite granite of light medium and medimn, slightly bluish-gray color. and of eren-grainet fine inclining to melium texture. (See p. 124.)

The quarry, opened about 1889, was estimated in 1907 as alout 375 by 200 feet and 1rom 10 to 50 feet deep. It was not operated in 1917.

Rock structure: The sheets are normal, 1 to 16 feet thick, dipping $10^{\circ} \mathrm{SE}$. There are two sets of joints--(a), strike N. $70^{\circ}$ E., dip $53^{\circ}$ S. $20^{\circ}$ E. spaced 10 to 50 feet and over; (b), strike northwest, dip $75^{\circ} \mathrm{SW}$., discontinuous, spaced 100 feet and over. The rift is reported as vertical with $\mathrm{N} .35^{\circ} \mathrm{E}$. course, and the grain as horizontal.

The Milne quarry is on the south side of the southern road from Websterville to East Barre and 0.9 mile east-sontheast of the top of Millstone Hill,

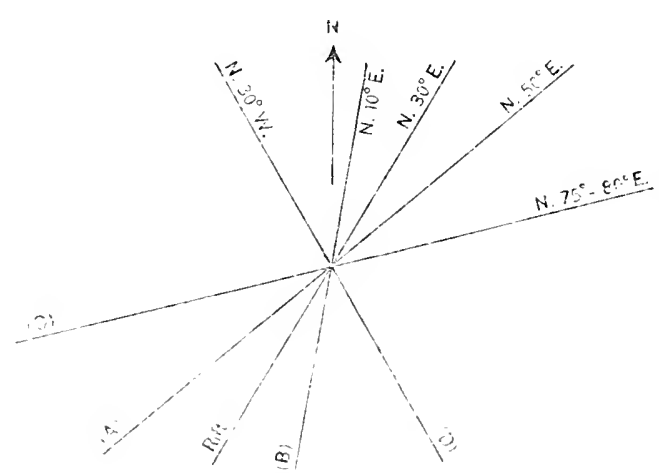

Figure 31.--Structure at Consolidated quarry, Barre, Vt.

in Barre. (See Pl. II, No. 34.) Operator, Boutwell, Milne \& Varnum Co., Montpelier.

The granite, "light and medium Barre," is a biotite granite of light medium and medium bluish-gray color, and of even-glained fine inclining to medium texture. (See pp. 135-136.)

The quarry was estimated in 1907 as measuring about 250 feet in a north-northwest direction by 250 feet across and from 55 to 70 feet in depth.

Rock structure: The sheets, 1 to 6 feet thick, are about horizontal or dip $20^{\circ}$ E., but disappear 25 feet below the rock surface, where low-dipping joints are used by the quarrymen instead. There are four sets of joints, as shown in figure $32-(\mathrm{A})$, vertical, dip $20^{\circ}$ and $40^{\circ} \mathrm{N} .60^{\circ} \mathrm{W}$., forms the east-southeast wall, spaced 3 to 150 feet, coated with coarse scales of muscovite; (B), dip $40^{\circ} \mathrm{NW}$., discontinuous, spaced 15 to $150 \mathrm{feet}$; (C), dip $70^{\circ} \mathrm{S} .15^{\circ}$ E., spaced 2 to 20 feet and over, but stop 20 feet down; (D), dip $75^{\circ}$ S., one only, at the south corner. The rift is reported as vertical with $\mathrm{N}$. $35^{\circ} \mathrm{E}$. course, and the grain as horizontal. There are reins of smoky quartz up to 2 inches thick, at intervals of about 3 feet, dipping $60^{\circ}$. Some with another strike are part pegmatite. The microscopic structure of this quartz has been described on page 51.

The Straiton quarry is about $1 \frac{1}{1}$ miles east-southeast of the tol of Millstone Hill, in Barre. (See Pl. II, No. 37.) Operator, George Straiton Quarry Co., Barre.

The granite, "light and medium Barre," is a biotite granite of light medium and medium gray shade and of even-grained fine inclining to medium texture like that previously described.

The quarry, opened in 1905 , measured in 1907 about 100 feet square and averaged 10 feet in depth. 
Roek structure: The sheets, 1 to $\bar{x}$ feet thick, vary from horizontal to a dip of $10^{\circ}$ abnut south. There is but one set of joints; strike N. $65^{\circ}$ L., dip $55^{\circ}$ S. 2.5 li., spacing 1 to 20 feet. The stain is un to 6 inches thick.

The product is used for buldings and monuments.

The Jones Dark quary is iu Williamstown (Orunge County) lut adjoing the Empire quarry in Barr. (See Pl. II. No. 38.) Operator. Jones Bros. Co., Pare, Vt., amu Poston. Mass.

The granite rspecimen D. XXIX. 13, a), "dark Barre," is a biotite granite of dark bluish-gray color, a trifle darker than that of the Bruce quarry, and of eren-grained fine inclining to medium texture, with feldspars up to 0.3 inch and mica to 0.1 inch. Its constituents are identical with those of the Milne \& Wylie quarry stone desclihed on page 129. It effervesces with muriatic acid test.

The polished face shows pyite and a little manetite. The polish is fair. Its cut hard-way face is as light as that of the "light Parre." and thus in marked contrist to its polished face. Its mineral contrasts and rualities are identical with thuse of the Milne \& Wylie quarry stone (p. 129), but its texture, particularly its mica, appears to be il little finer.

The quarry, opened about 18s6, was estimated in 1907 as neasuring about 300 feet in a $\mathrm{N} .80^{\circ} \mathrm{F}$. direction bs 250 feet across and in 1917 was 125 feet diep.

Rock structure: The sheets, 2 to 20 fect thick, are irregular and mdulating. There

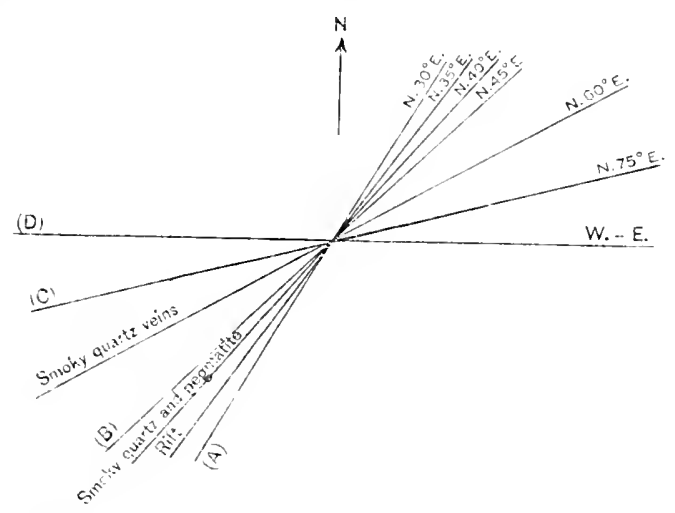

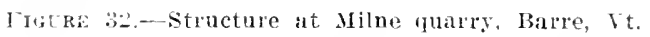
is one mass $2 S$ feet thick. There are four sets of joints-(a). strike N. $80^{\circ}$ E. vertiral, forms healiugs on north and south walls, is spaced 5 to 30 feet, and has rusty faces; (b), strike N. $15^{\circ} \mathrm{W}$., vertical, usually discontinuons reltically, spaced 10, 20 , 30, and 200 feet; (c), strike east, dip $55^{\circ}$ S., discontinuous. one only in southern part; (d), strike N. $55^{\circ}-55^{\circ}$ E., dip $37^{\circ} \mathrm{S}, 37^{\circ} \mathrm{E}$., forms a small head:ner north of the south wall. The rift is reported as vertical, with course of about $X .5 .5^{\circ} \mathrm{l}$, and the grain as horizontal. A schist inclusion in the west wall is 30 fect long with a foliation striking N. $50^{\circ}$ E. There are also masses of darker granite of roundish outline up to 3 feet in diameter, like those in the Mary \& fiomlon fuarry (p. 131). Rusty stain is up to 6 inches thick on sheet surfaces.

The Pirie quarry is in Williamstown (Orange County), nearly $1 \frac{1}{2}$ miles south-southwest of the top of Millstone Hill. (See Pl. II, No. 40.) Operator, Janes K. Pirie estate, Barre.

The granite, "dark Pare," is a biotite granite of dark, slightly bluish-gray color and of even-grained fine inclining to medium texture like that of the Barre quarries described on page 124 .

The quarry, opened in 1882, was estimated in 1907 as meisuring 350 feet in a northeasterly direction by 100 and 250 feet across, and from 30 to 100 fort in repth. 
Rock structure: The sheets are normal, 1 to 12 feet thick, and dip $10^{\circ}-30^{\circ}$ NNW. Joint, rift, and dike courses are shown in figure 33. Joint set (A), dip $60^{\circ} \mathrm{s} .27^{\circ}$ E., forms part of the west wall and a rusty heating across the center of quarry; (I), dip $55^{\circ}$ S. $55^{\circ}$ E., forms the east wall, spaced 1 to 20 and over 50 feet, also very rusty; (C), dip $55^{\circ}$ E., only three, spaced 10 feet; (D), about vertical, discontinuous. spuced 30 feet. The rift is reported as rertical, and the grain as dipping about $35^{\circ} \mathrm{N}$. $30^{\circ}$ W. A 3 -foot 6 -inch pegmatite dike dipping $65^{\circ} \mathrm{S} .25^{\circ}$ E. closses the center of the quarry and sends out tapering branches up to a foot in length. (See, further, p. 49.) Stain up to a foot thick is mostly confined to the undersile of sheets.

The Wildbur quary is on the west sitle of Cobble Hill, G00 feet above the city and N. $35^{\circ}$ E. from the top of Millstone Hill, in Balle. Uperators, Wildbur Bros. \& Bessey, Barre. Idle since 1900.

The granite (specimen D, XXIX, 31, a), "light fiare," is a biotite granite of light medium gray shade (like Jones "licht Barre") and of even-grained

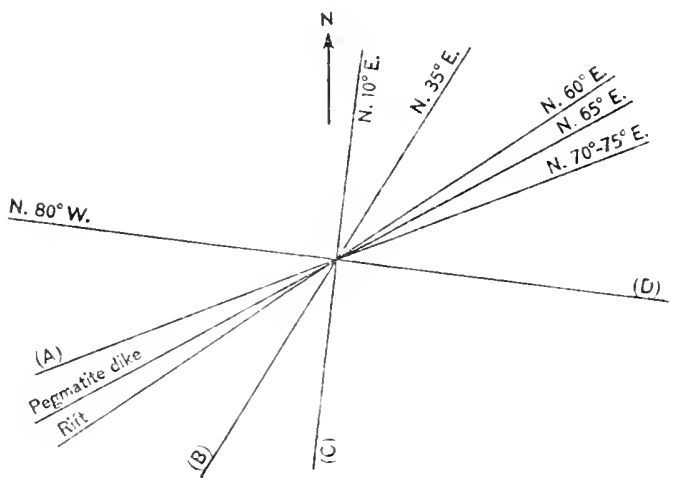

Figure 33.- Structure at Pirie quarry, Williamstown, near Barre, Vt. fine inclining to medium texture, with feldspars up to 0.2 inch and mica to 0.1 inch. The mica is finer and more abundant than in the stone of Wheaton quarry. Its constituents are identical with those of Jones "light Barre" described on page 133 . A clear microcline incloses an a 1 tered orthoclase. The quartz shows effects of strain and conspicuous rift cracks parallel to or coinciding with sheets of cavities. Some of these cracks polarize brightly and continue into the feldspars, where they are clearly filled with fibrous muscovite. The stome efferresces with muriatic-acid test.

The quarry was estimated in 1907 as measuring 100 feet east and west by 75 feet across. It had a working face 80 feet high on the east.

Rock structure: The sheets, 1 to $S$ feet thick, beconing thickel eastward, appear to belong to the outside of an arch or dome striking here $\mathrm{N}$. $10^{\circ}-20^{\circ}$ W. and dipping $60^{\circ}$ S. $75^{\circ} \mathrm{W}$. One set of joints only--strike N. $75^{\circ} \mathrm{E}$., dip $70^{\circ} \mathrm{S} .15^{\circ} \mathrm{E}$., spaced 8 to 30 feet and over. The rift is reported as rertical with N. $75^{\circ} \mathrm{E}$. course, and the grain as horizontal.

The product is used for monuments and buildings.

This quarry was idle in 1916.

The Barre Medium quary is about 500 feet southeast of the Milne quarry. (See Pl. II, No. 35.) Operator, Barre Medium Granite Co., Barre. Idle in 1922. The granite, "medium and light Barre," is a biotite granite of medium and light medium bluish-gray color and even-grained fine inclining to medium texture like that described on pages 135-136.

The quarry, opened in 1906, wis estimated in 1907 as measuring 200 feet from north to south by 150 feet across and from 10 to 25 feet in depth.

Rock structure: Sheets 6 inches to 5 feet thick, increasing in thickness downward, dip low southeast. No joints had been found. The ritt is reported as vertical with $\mathrm{N} .60^{\circ} \mathrm{E}$. course, and the grain as horizontal. 
The McDonald \& Cutter quarry is east-northeast of the top of Millstone Hill, east of the main street of Websterville, in Barre. (See Pl. II, No. 27). Operator, Wetmore \& Morse Granite Co., Barre.

The granite is mostly "light Barre" with some "medium." It is a biotite granite of light medium or medium, slightly bluish-gray color and of evengrained fine incliniug to merimm texture, like those described on fatges 135-136.

The quarry was estimated in 1907 as measuring about $2\left(60\right.$ feet in a N. $20^{\circ}$ W. direction by 175 feet across and fom 65 to 110 feet deep.

Rock structure: The sheets, in places imperfectly developed, from 3 to 30 feet thick, undulate horizontally. There are masses 40 feet thick without sheets. There are three sets of joints-(a), strike N. 10-15. W., vertical, forms the east and west walls, spaced 10 to 30 feet; (b), strike N. $40^{\circ}-45^{\circ} \mathrm{E}$, vertical, spaced 1 to 30 feet; (c) forms an irregular rusty heading at the northeast end, strike N. $15^{\circ}$ E. and dip $70^{\circ}$ E., but undulating along the strike. "Stain" is up to 14 inches thick.

The Capital quarry is 750 feet south-southeast of the McDonald \& Cutter quarry and southeast of Millstone Hill, in Barre. (See Pl. II, No. 29.) Operator, Consolidated Quarry Co., Barre. Idle in 1921 and 1922.

For the granite, see under foregoing quarry.

The quarry was estimated in 1907 as measuring 150 feet in a northeast direction by 100 feet across and 50 feet in depth.

Rock structure: This is a "boulder" quarry. The sheets, 6 inches to 4 feet thick but extending to a depth of only 20 feet, dip about $10^{\circ} \mathrm{SE}$. There are three sets of joints-(a), strike N. $65^{\circ}$ E., dip $55^{\circ}$ S. $25^{\circ}$ E., spaced 3 to 10 feet, on south side only; (b), strike N. $35^{\circ}$ E., dip steep N. $55^{\circ} \mathrm{W}$., discontiuuous; (c), strike northwest, dip $70^{\circ}$ NE. spaced 5 to 20 feet. A basic vertical dike, 2 to 6 feet thick, with northeast course, forms the northwest wall. It weathers spheroidally. The rift is rejorted as varying in different blocks.

The Canton quarry is about 450 feet east-northeast of the Millstone quarry and northeast of the top of Millstone Hill, in Barre. (See Pl. II, No. 21.) Operators, E. I. Smith \& Co., Barre.

The granite, "medium and light Barre," is a biotite of medium and light bluish-gray color, like those already described.

The quarry was estimated in 1907 as measuring about 300 feet in a northeasterly direction by 200 feet across and from 35 to 60 feet in depth.

Rock structure: The sheets, 1 to 14 feet thick, are normal and dip $10^{\circ} \mathrm{N}$. There are two sets of joints-(a), strike N. $37^{\circ} \mathrm{W}$., dip $80^{\circ} \mathrm{N} .53^{\circ} \mathrm{E}$, forms the east wall and a heading on the west wall, spaced 5 to 50 feet; (b), strike N. $35^{\circ}$ E., dip $55^{\circ}$ S. $55^{\circ}$ E., spaced 10 to 25 and 200 feet, slickensided in the direction of dip. The rift is reported as vertical with N. $42^{\circ}$ E. course, and the grain as horiontal. A marked east-west compressive strain is shown in the faulting of channel cores.

САВОT.

The town of Cabot adjoins Woodbury on the southeast and Walden on the northeast.

Lambert's prospect is in the northern corner of the township, on the east side of a north-south ridge, roughly about 4 miles east of Robeson Mountain in Woodbury and about 700 feet above Woodbury Pond. (See fig. 20.) It is on the farm of Myron Goodnough, near the Walden line, on the South Walden road which leads from Cabot to Hardins. Operator, Cabot Granite Co. (Joseph Lam. bert), Hardwick.

The granite (speclmen D, XXIX, 59, a). " dark gray," is a quartz monzonite of dark bluish-gray color (as dark as "dark Barre") and of even-grained fine 
texture with fehdspars and mica up to 0.2 inch, the latter rarely 0.3 inch. Its constituents, in descenling orler of abundance, are clear quartz with fluidal and other arities in sheets and with rift cracks parallel to them filled with fibrous muscovite and extending into the feldspars; bluish-gray to milk-white sodaline feldspar (oligoclase, but little kaolinized, micacized, and with calcite); bluish-iray potash feldspal (orthoclise, kaolinized and micacized, with microcline) ; Greenish biotite (black mica); and a little muscovite or bleached biotite. Accessory: Irrite, titanite, apatite, and allanite (a crystal 0.33 by 0.09 millimeter rimmed with epidote). Secondary: Calcite, epidote, kaolin, and one or two white micas. Effervesces slighly with muitic-acial test.

This stone is a little finer textured than some of the "dark Barre" and more micaceous. Its mineral contrasts are more marked owing to its feldspars being whiter and less bluish and its quartz not smoky. It ought to hammer light.

The quarry was opened in 1904. A little work was done in 1907 and more later, but onerations were suspended in 1915.

The sheets in 1907 were not yet sufficiently exposed to show their thickness. There are five sets of joints-(a), strike N. $85^{\circ}$ E., dip $75^{\circ}$ N.; (b), strike N. $55^{\circ} \mathrm{W}$., dip $55^{\circ} \mathrm{S} .35^{\circ} \mathrm{W}$.; (c), strike N. $65^{\circ}$ E., dip $25^{\circ}$ NNW.; (d), strike N. $5^{\circ}$ E., vertical ; (e), strike N. $60^{\circ}$ E., dip $75^{\circ}$ S. $30^{\circ} \mathrm{E}$.

\section{CALAIS.}

The town of Calais adjoins Woodbury on the southwest. The quarries are at Adanant (formerly known as Sodom), in the west corner of the town and 6 miles north-northeast of Montpelier. ${ }^{71}$ (See Pl. I.) The quarries lie along a N. $30^{\circ} \mathrm{F}$. line on the southeast side of a granite ridge. The granite is a biotite granite of medium and light-gray shate and fine texture. Of geologic interest is the absence of sleet structure and the occurrence of graphite in connection with the quartz veins. Schist crops out below the quarries at the village, with a foliation striking N. $20^{\circ}$ E. and dipping $55^{\circ} \mathrm{W}$.

The Patch quarry is within half a mile of Adamant, in Calais. Operator, Inches Granite \& Quary Co., Montpelier.

The granite (specinen D, XXIX. 52, a) "medium gray," is a biotite granite of medium, slightly bluish-gray color and of even-grained medium texture, with feldspars up to 0.3 inch, rarely $0.4 \mathrm{inch}$, and mica up to 0.1 inch. The larger feldspars are crystallized about the quartz and mica up to 0.1 inch. The larger feldspars are crystallized about the quartz and mica and give the stone a somewhat porphyritic texture. Its constituents, in descending order of abundance, are clear cololless potash feldspar (orthoclase, somewhat kaolinized and wicacized, with microcline) with inclusions of the other constituents; clear, colorless quartz with but few cavities; bluish to milk-white soda-lime feldspar (oligoclase-albite more or less altered); biotite (black mica); and a little muscorite or bleached biotite. Accessory: Apatite and zircon. Secondary: Kaolin, calcite, and white mica. It effervesces slightly with muriatic acid test.

This granite is of the same shade as "medium Barre" but of less bluish and more greenish tinge. Its mineral contrasts are stronger and its texture a little courser. Its large clear feldspars give brilliancy to its rough surface.

The quarry, opened about 1893, was estimated in 1907 as measuring 250 feet from north to south by 150 feet across and from 20 to 50 feet in depth.

7 See U. S. Grol. Survey Full. 5S9, pl. 1 (map of Vermont with township lines), 1915 ; also Vermont State Goologist Tenth Rept., pl. 38 (geologic sketch map of Calais, by C. H. Richardson), 1916 . 
Rock structure: Sheet structure is absent. There are two sets of jolnts(a), utilized as sheets in quarrying, strike N. $85^{\circ}$ E., dip $50^{\circ}$ S., spaced 2 to 17 feet and slickensided in a southwest direction; (b), strike like (a), dip $40^{\circ} \mathrm{N}$. to $90^{\circ}$, spaced 20 to 75 feet. in places discontinuous. The rift is reported as striking N. $30^{\circ} \mathrm{E}$. and dipping $50^{\circ} \mathrm{N}$. $60^{\circ} \mathrm{WV}$, and the grain as striking and dipping as joints (a). The "sap" is 4 inches thick on joint faces. A small vein of smoky quartz parallel to joints (a) contains large limonite particles from the alteration of some iron mineral. The slickensided face of this vein is graphitic.

Transportation, by cart, 7 miles to Montpeller.

The product is used for monuments and finds a market chiefly in the Middle West.

The Lake Shore quarry is about 1.200 feet S. $32^{\circ} \mathrm{W}$. from the Pateh quarry, near Adamant, in Calais. It was abandoned before 1915.

The granite (specimen D, XXIX, 53, a) is a biotite granite of light inclining to medium gray shade and of even-grained fine texture, with feldspars up to 0.2 inch and mica to 0.1 incl, rarely 0.2 inch. The larger feldspars are crystallized about the cuartz and mica, giving the stone a somewhat porplyritic texture. Its constituents are identical with those of the Patch quarry stone, except that it contains secondary epidote in particles up to 0.5 millimeter. It eftervesces slightly with cold dilute muriatic acid.

This stone is a trifle darker than "light Barre" and a trifle lighter than "medium Barre." Its shade corresponds to that of the granite of Hallowell, Maine, but its contrasts are stronger. Its other qualities are identical with those of the Patch quarry stone.

The quary in 1907 was about 300 feet long in a $\mathrm{N} .60^{\circ} \mathrm{W}$. direction by 250 feet across and from 20 to $40^{\prime}$ feet deep.

Rock structure: Sheet structure is undereloped. There are three sets of joints-(a), utilized as sheets in quarrying, strike N. $80^{\circ}$ E. dip $80^{\circ}$ S., spaced 1 to 18 feet; (b). strike $\mathrm{N}$. $75^{\circ}$ E.. dip $30^{\circ} \mathrm{N} .15^{\circ} \mathrm{W}$., only two on south wall: (c). strike $\mathrm{N}$. $20^{\circ} \mathrm{E}$. dip $30^{\circ} \mathrm{W}$., discontimuous, at intervals of 20 feet and over. The rift was reported as having a N. $20^{\circ}$ E. course and dipping $70^{\circ} \mathrm{N} .20^{\circ} \mathrm{W}$.

\section{WOODBURY.}

TOPOGRAPIIY.

The township of Woodhury lies northeast of Calais, northwest of Cabot, and southwest of Hardwick. Its principal quarries are on the southeast ilank of Robeson Mountain. about a mile east of Woodbury Center and 3 miles north-nortleast of Woolbury (Salbins) Pond. (See majs, I'l. I and fig. 20.) Robeson Momutain is a rifge about a mile long with an axis curving from $\mathrm{N} .80^{\circ}$ E. to S. $70^{\circ} \mathrm{W}$. Its top is $300^{\circ}$ to 400 feet above the hollows on either side amd 930 feet above Wondmury Poms and about 1.100 feet above the railroad at Hardwick. Granite has also heen quarried on the ridges on thr. nortluest and sontheast sides of Buck Pond and on the rising ground at the head of the hollow on the north side of liobeson Mountain. This mass is continuous with the rilge sontheast of Buck Pond. Granite has also heen quirried on the north and northeast foot of Nichols Ledge, a bold cliff about 3 miles $x$. $70^{\circ} \mathrm{F}$. from Robeson Mountain and 740 feet above Woodbury Pont. in the east corner of the town east of Nidhols Pond. The granite masses referred to ale all within an area of about $3 \frac{1}{2}$ miles square, occupying the northeastern part of the town.

$10.709-23-11$ 
GENERAI, GEOLOGY.

In the Vermont report of 1861 all the central and eastern part of the town aplear's as "calciferous mica schist." A belt of "chay slate" is represented as crossing the western part of the town in a north-northeastern direction.

In Richardson's sketch map of the geulogy of Woodbury's the granite mass in the northeastem part of the town is represented as bordered on three sides by Ordovician limestone, although the granite is in contact with schist at several points. This is explained on page 314 of his parper in these words: "On Robeson Mountain in Woodbury the original capping of the granite mass contained both calcareous and noncalcareous beds of sediments. The calcareous outcrops now predominate, and therefore no phyllites appear in this area on the areal map."

Schist crops out on the northwest side of liobeson Mountain with a bedding strike of $\mathrm{N} .70^{\circ} \mathrm{W}$. and rertical dip and north pitch; also on the westsouthwest side with a N. $67^{\circ}$ E. strike and a dip of $55^{\circ} \mathrm{N} .23^{\circ} \mathrm{W}$. This would indicate a syuclinal structure for the schist of this mountain. Schist also crops ont near the quarries on the rising land north of the mountain, and appears also to cap the ridge east of the north end of Buck Pond. This is a muscovite-quartz-biotite schist with interbedded calcareous quartzite. The contact of schist and granite on Robeson Mountain has been described on page SS. The mountain appears to be an oblong dome in structure with an eastnortheast to west-southwest axis, the sheets of which, horizontal at the top, bend over to $15^{\circ}$ to $20^{\circ}$ on the northwest and southeast sides, although in places still corered by schist. Nichols Ledge is another conspicous eminence in the same granite mass. The granite of the top is coarsely porphyritic, with feldspars an inch long, but at its north and northeast foot there is a granite of fine texture, possibly a dike in the coarser. The foliation of a schist mass back of the Webber quarry, between Buck Pond and Robeson Mountain, strikes N. $20^{\circ} \mathrm{E}$.

\section{" WOODBURY GRANITES."}

The "Woodbury granites" are all biotite granites either of more or less bluish-gray color, ranging flom dark to light, or else of a cream-tinted light gray, and ranging in texture from very ine to medium. They fall into four kinds, but, taking acconnt of minor differences, into nine varieties. Most of them possess in large masses one general characteristic: They carry sparse more or less incomplete crystals up to an inch across of clear potash feldspar formed about the other minerals. There is some parallelism between these crystals, for seen at a certain angle the cleavage planes of adjoining crystals reflect the light alike.

The granites of Robeson Mountain range from light to medium gray in shade and from medium to fine, inclining to medium, porphyritic in texture. Their constituents, in descending order of abundance, are clear to translucent bluish potash feldspar (orthoclase and microcline), rarely somewhat kaolinized, its large particles with inclusions of biotite, quartz, and soda-lime feldspar; light to medium smoky quartz with hairlike crystals of rutile and fluidal and other cavities in sheets in two rectangular sets parallel to rift and grain cracks, respectively (some of the rift cracks extend into the feldspars and are filled with fibrous muscorite) ; milk-white soda-lime feldspar (oligoclase to oligoclasealbite), more or less kaolinized, micacized, and with calcite and in places epidote; hiotite (black mica), some of it chloritized; a little muscovite or

72 Vermont State Geologist Ninth Rept., pl. 53, 1914. 
bleached biotite. Accessory : Pyrite, titanite, zircon, apatite, rutile. Secondary : Kaolin, a white mica, epidote, zoisite, calcite, limonite. Some of the feldsuars are minutely intergrown with quartz in vermicular structure.

Two estimates of mineral percentages by the Rosiwal method average as follows: Feldspar, Gi.35; quartz, 29.15; nica, 6.48.

One chenical test (p. 14S) shows it to contain 0.16 per cent of Gal (line). soluble in warm dilute (10 per cent) acetic acid, indicating a content of 0.28 per cent of $\mathrm{CaCO}_{3}$ (lime carbonate, calcite).

The general differences between the three varieties of granite on Robeson Mountain are these: In the stone from the Fletcher quary the feldspar and quartz areas are rather large and well defined by differences of shade. In the stone from the Woodbury Lower quarry the quartz areas are finer, fewer, and less smoky. In the "Bashaw" the texture is finer and contrasts weaker than in either of the others.

The dark gray of the Drenan $(65$, a) and Webber $(67$, a) openings is of dark bluish-gray color and fine texture, with feldspars to 0.2 inch and mica to 0.1 inch. Its composition is identical with that of the granite of Robeson Mountain, but its quartz is clear and its feldspar is albite to oligoclase-albite. Its general shade is like that of "dark Barre," hut its texture is finer.

The stone from the Nichols Ledge quarry is of light inclining to medium bluish-gray color and of very fine to fine texture, with feldspar to 0.15 and mica to 0.1 inch, with a few larger porphyritic clear feldspars. This is lighter and finer than the last. Its quartz is clear with apatite needles, and its second feldspar is oligoclase to oligoclase-andesine.

The stone of the Imperial Blue quarry (specimen 69, a, of 1907) is of medium to dark bluish-gray color and of fine to medium texture.

Finally, there is the very light, slightly cream-colored constructional granite of the Vermont White quarry, very near locality 65 (specimen 66, a, of 1907), which is of medium texture and speckled with black mica. Its quartz is smoky.

The minor differences in these granites appear in the descriptions of the stone of each quarry.

\section{GEOLOOY OF WOODBURY QUARRIES.}

The usual range in thickness of sheets is from 2 to 8 or 20 feet; the extremes are 1 to 40 feet. The double sheet structure at the Fletcher quarry las already been described on page 36 and is shown in Plate VI, $B$. The secondary, nearly horizontal set is from 5 to 9 feet thick. It recurs in the lower part of the nuain quarry of the Woodbury Granite Co. There is a northeast to southwest compressive strain at the Fletcher quarry near the axis of the mountain, parting and extending the upper sheets.

The joints divide themselves into six sets-(a), strike north to $\mathrm{N} .10^{\circ} \mathrm{E}$., with its complementary set (b). N. $85^{\circ}-90^{\circ}$ E.; (c), strike N. $20^{\circ}-30^{\circ}$ E., with its complementary set (d). N. $50^{\circ}-65^{\circ}$ W.; (e), strike N. $20^{\circ}-30^{\circ}$ W., with its complementary set (f), N. $60^{\circ}-65^{\circ}$ E. The spacing of these joints ranges from 2 to 200 feet but is mostly from 10 to 40 feet. Headings, 3 to 30 feet wirle. of set (a) are spaced 30 to 50 feet on Robeson Mountain. The rift is reported as vertical with courses of $\mathrm{N} .15^{\circ}, 26^{\circ}, 35^{\circ}$, and $60^{\circ} \mathrm{E}$., and the grain as uniformly horizontal. At one quarry the rift has to be followed closely in winter. but the rock is reporterl as splitting with equal facility in any direction in summer.

Flow structure appears with a dip of $50^{\circ} \mathrm{SW}$. There is an irregulir banding at one of the Drenan openings caused by unequal distribution of biotite. 
The schist capping is exposed at another of the Drenan openings, and the 100-foot mass of schist at the back of the Webber quarry is either part of the same or a very large inclusion. The schist inclusions on Robeson Mountain, 25 anil \& feet long, are referred to on page 150. A small light-greenish calcarrous inclusion at the Ainsworth quarry proves to be chiefly crystalline ealcite with quartz particles under 0.1 millimeter, together with apatite and secondary epidote and zoisite, and has veinlets of epidote, quartz, and calcite. This appears to have originally been a quartzose marble, and its interest lies in its evidence of the presence of calcareous rocks here prior to the granite intrusion.

There are biotitic segregations up to 2 feet in diameter. Small pegmatite dikes at the Chase quarries, near Buck Pond, strike about north, and a 4-inch quartz rein on the northwest side of Robeson Mountain strikes N. $35^{\circ}-40^{\circ} \mathrm{E}$.

QUARRIES.

The Fletcher quarry is on Robeson Mountain near its west-southwest end and on its southeast side, in Woodbury. (See fig. 20.) Operator, E. R. Fletcher, Woodbury.

The granite (specimens D, XXIX, 56, a. c), "Woodbury gray," is a biotite granite of light-gray shade (between "light Barre" and the granite of Hallowell. Maine, and of medium texture, with feldspars up to 0.3 inch and mica to $0.1 \mathrm{inch}$. Its constituents, in descending order of abundance, are clear to transhucent bluish potash feldspar (orthoclase, some of it minutely intergrown with plaginelase, also microcline), the linger particles with inclusions of biotite and sola-lime f'eldspar' medium smoky quartz with hairlike crystals of rutile and cavities in two sets of rectangular sheets, with rift and grain cracks parallel to them; milk-white sorla-lime feldspar (oligoclase-albite) much kaolinized, somewhat micacized and epirotizerl, and with calcite; biotite (black mica) some of it chloritized; and a little muscovite or bleached biotite. Accessory: I’rite, titanite, zircon. alutite, rutile. Secondary: Kilolin, a white mica, epirlote, zoisite calcite. limonite.

An evtimate of the mineral percentages by the Rosiwal method yields these result: with a mesh of 0.5 inch aml a total linear length of 46.5 inches: Feldspar, fir.11; quartz, 31.22; mica, 5.67. The average diameters of the particles ny the silme calculation are, feldspars (adding 20 per cent to number for plagiorlase), 0.103 inch; quartz, 0.1 inch; mica, 0.029 inch.

The stome efferresces rery slightly with muriatic-acid test. W. T. Schaller, chemist. of this survey, finds that it contains 0.16 per cent of CaO (lime)

- soluhlr in warm dilute (10 per cent) acetic acid, which indicates a content of 0.25 fer (ent of $\mathrm{CaCO}_{3}$ (calcium carbonate, calcite); the presence of this mineral is also shown by the microscope.

This is a brilliant granite with marked mineral contrasts. The quartz and feldspar areas are rather large and well defined. The polish is poor owing to the burge size of the mieas. The polished face shows some pyrite.

The quarrs. opened about 1857 , was estimated in 1907 as measuring 300 feet in a northwesterly direction, or across the rilge, by 300 feet along it, and from 20 to 40 feet in depth. It was really the beginning of a cross section of the ridge and dome and this fact has greatly facilitited quarrying oporations.

Rurk strurture: The complex sheet structure here has already been de(a) rilusl (1).36) and is shown in Plate VI, $B$. The primary sheets, 1 to 5

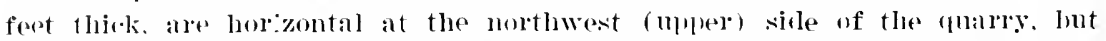
aramally bend oxer and al $20^{\circ}-30^{\circ}$ s. at the southeast (lower) side. The 
muscovite; milk-white soda-lime feldspar (oligoclase), much micacized, with epirlote and ralcite. also intergrown with quartz in vermicular structure; biotite (black mica), some of it chloritized; a little muscovite or bleached biotite. Accessory: Pyrite, zircon crystals, apatite. Secondary: A white nica. epidote, ralrite, chlorite. The stone offervesces slightly with muriaticacid test.

This is a nenumental granite. Its mineral contrasts are not as marken either in the rough or the polish as in the "Woodbury gray." This is due to the feldspars boing less kalinized and thus less white. Its texture is tiner and it polishes better. The polished face shows a little pyrite.

Three compression tests of the "Woodbury gray" made for the firm at the United States Arsenal at Watertown, Mass. (test No. 13261), yielded these

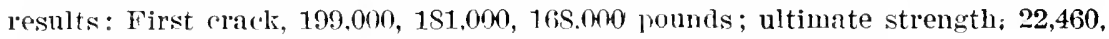
19,850, 20,110 ponnds; average, 20.806 punds per square inch.

The quarries consist of four openings. Their dimensions were estimated in 1907. The main and western one, made in 1880 , beginning at the south foot of the ridge, extends about 500 feet along it and 400 feet northward up its side, with an average depth of 50 feet. The " upper quarry," above and north

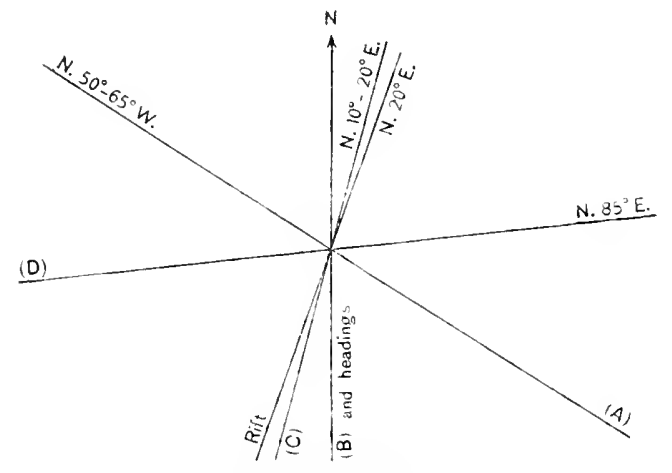

FigLue 34.-Structure at Toodbury Granite Co.'s quarries, on Roheson Mountain, Woodbury, Vt. of the milin onc, is abont $\mathbf{2 0 0}$ feret sopuine. and its north sicle is at the top of the liill nearly 300 feet higher than the lower enge of the main fllary.y. The thirol opening, about son feet east of the main one. made in 1906 , is about 125 by 70 feet ind f?om 10 to 30 feet deep. This produces the finer monumental sxanite, "Wondbury Hiislaw." rescriber un page 149. The fourth is a small onening mate in 1907. about 200 feet northwest of the thiril.

Rock structure: The sheets at the top of the upper quirry and of the ridge are horizontal. In the third opening they are from 2 to 13 feet thick, ill defined, and about horizontal. In the main quarry they range from 2 to 18 feet, exceptionally 23 feet and even 40 feet, curving over from the horizontal to din $20^{\circ} \mathrm{S}$. They are intersected by a horizontal set. (See pp. 36, 148.) The joint courses (shown in fig. 34) are four-(A), dip $60^{\circ}-65^{\circ}$ N. $35^{\circ}$ E. (some vertical, discontinuons), spraced 20 to 40 and 200 feet; (B), vertical or dip $75^{\circ} \mathrm{W}$., discontinuous along the dip, in third opening spaced 10 to 30 feet, but in main quarry mostly headings, five in all, 3 to 30 feet wide and 30 to 50 feet apart; (C), vertical, discontinuous, and much more open than (A) or (B) ; (D) is spaced 2 and 10 to 40 feet. The rift is reported as vertical, and the grain as horizontal but not marked. The rift has to be followed closely in winter, but in summer the rock splits almost any way. There are two schist inclusions in the main quarry, 25 by 10 feet and 8 feet by (?), also some sinaller ones. Rusty stain is 1 to 18 inches thick on sheet surfaces.

The product is used both for buildings and monuments. Specimen buildings : Pennsylvania capitol, Harrisburg; Cook County courthouse, Chicago; base course and 36 interior polished columns of Kentucky capitol, Frankfort; City hall, Cleveland, Ohio; Hotel Pontchartrain, Detroit, Mich.; Mercantile Trust 
Co. Building, St. Louis, Mo.: main entrance. State eapitol, Boise, Idaho; Mandell residence, Boston; post office, New Bedford, Mass. Specimen monuments: Navy memorial (obelisk), national military park, Vicksburg, Miss.; soldiers and sailors' monument, Bloomington, Ill.: memorial archway, lort Huron, Micl., clock on the Green. Waterbury, Conn.

The adaptability of this granite for carving is shown in Plate V. B. representing a nanel on the Cook County courthouse.

The Imperial Blue quarry is on the southeast side of Buck Poncl, in Woodbury Township. (See map, fig. 20. p. 109. quarry 69.) Gperator, Wondbury Granite Co., Hardwick.

The granite (specimen D, XXXVIII, 21, a, b). "Imperial blue." is a biotite granite of medium to lark bluish-gray color and of fine to medium texture, with feldspars up to 0.2 inch (a few porphyritic ones to 0.4 inch) and mica to 0.1 inch.

Its constituent minerals. in descending order of abundance, are elear colorless potash feldspar (microcline). with inclusions of plaqioclase and hiotite; slightly hluish quartz; slightly milky sorla-lime feldspar (oligoclase-anrlesine), somewhat kaolinized, with oriented inclusions of muscovite; hiotite; museovite. Secondary: Kaolin, earhonate. Slight effervescence with muriatic-aeid test.

This is a monumental granite of bluish-gray tint. It takes a fair polish.

The quarry, reopened since 1907. has a working face about 100 by 150 feet.

Rock structure: The sheets. 5 to 8 feet thiek, dip low to the south. One set of joints strikes about east; another about north.

The stone is used entirely for monuments and thus far for tomlsstones and small memorials.

The Vermont White quarry lies about midway between Robeson Mountain and Buck Pond (see map, fig. 20, locality 65), in Wondbury Township. Operator. Wnodhury Granite Co., Hardwick.

The granite (specimen D, XXXVII, 22, a, b). "Vernont white." is a biotite granite of general very light cream color and of medium-coarse texture. with feldspars up to 0.3 , exceptionally 0.5 inch and sparse black mica to 0.15 inch. Its quartz is pale smoky and felispars clear to milk-white and light cream color. The mica on near view is in strong contrast to the other minerals. The granite is a brilliant rock in the rough; its polished face is noticeably darker.

Its constituents, in descending order of abundance, are clear colorless potash feldspar (microcline and orthoclase), pale smoky quartz with cavities in sheets; milk-white to eream-colored lime-soda feldspar (oligoelase), generally kaolinized, some of it altered to a white mica, some with oriented inclusions of muscovite; biotite; muscovite. Secondary: Kaolin, carbonate, a white mica. Some effervescence with muriatic-acid test.

Rock structure: The quarry face is about 500 by 200 feet. Richarclson is mentions inclusions of limestone and schist up to $30 \mathrm{by} 15 \mathrm{feet}$, also a dike of anygdaloidal basalt with a zone of closely cleft granite beside it, the structure lraving probably resulted from the intrusion. (See further p. 58.)

The product is used chiefly for buildings. Speeimens: Nortbwestern Mutual Life Insurance Builring, Milwakee, Wis.; Museum of Fine Arts, Minneapolis, Minn.; soldiers and sailors' memorial, Wiehita. Kans.; Bridgeport Trust Building, Bridgeport. Conn.

The Ainsworth quarry is on the northeast foot of Robeson Mountain, in Woodbury, about 1,000 feet northeast of the railroad. (See fig. 20.) Operator. Andrew A. Ainsworth, Hardwick. Quarry abandoned.

${ }^{73}$ Vermont State Gevlogist Ninth Rept., pp. 323, 324, pl. 67, A, 1914.

${ }^{7 \star}$ This edlfice has 10 Corinthian columns of this granite, five stories high. 
The granite is a biotite granite similar to that of the main quary of the Woodbury Ganite (o. (1). 149).

Rock structure: The sheets are from 15 to 20 feet thick. There are very lark gray knots up to 2 feet by 1 foot, with half-inch porphyritic feldspars, mueh fine biotite, and not a little prite. A small inclusion of fine-grained yllartzose mitrble was noticed on page 148.

The Drenan fuardes arr in Wondlumy, on the rising land north of the east end of Robeson Mountain. abont 150 feet above the north spur of the Hardwick \& Woolbury kailroal. (Seer tig. 20.) They are not in operation.

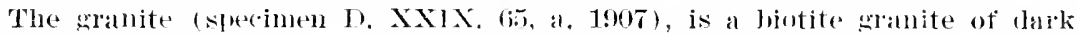
bluish-gray color and fine texture, with feldspar up to 0.2 inch and mica to 0.1 inch, but with some large clear siarse porphyritic feldspars formed about the other minerals. As many of these have their cleavage parallel, the rough rock face seen at a fertain ankle has a hrillint sheen. Its constituents. in descending order of abundance, are clear colorless to transheent bluish potash feldspar (microcline and orthoclase), slightly kaolinized, with inchusions of biotite, quatz, and sofla-lime fellsprar; clear colorless quartz with cavities in sheets; l,hish milk-white sorla-lime feldspar (albite to oligoclase-albite), kaolinized and micacized. also with calcite; biotite (black mica); and a little muscovite or bleached biotite. Accessory : Pyrite, apatite, zircon. Secondary: Kaolin, a white mica. calcite, zoisite. Eliervesces with muliatic-acid test.

This is a monumental granite of the same color" as " dark Barre" but of finer texture. It is darker than any of the granites of Robeson Mountain.

The Webber quarries are in Woodbury, still farther north of Robeson Momntain, on a mass continuous with that on the sontheast side of Buck Pond. (See fig. 20.) They are not in operation.

The granite of the main opening (specimen D, XXIX, 68, a, 1907) is a biotite granite of light bluish-gray color and of medium inclining to fine texture, with feldspars up to 0.3 inch and mica to 0.15 inch. It is slightly more bluish and finer textured than the gray of the main quarry of the Woodbury Granite Co. and lighter in shade than their "Bashaw" and a trifle darker than "light Barre." Its constituents, in descending order of abundance, are clear to translucent bluish potash fehlspar (microcline and orthoclase), slightly kaolinized, with inclusions of biotite, quartz, and soda-lime feldspar; light smoky quartz with hairlike crystals of rutile and cavities in sheets; milk-white soda-lima feldspar (oligoclase-albite), kaolinized and nicacized and with calcite, with rims radially intergrown with quartz; biotite (black mica), some of it chloritized; a little muscovite or bleached biotite. Accessory, magnetite, rutile. Secondary, kaolin. a white mica, calcite, chlorite, epidote. Scarcely any effervescence with muriatic-acid test.

The stone of an opening made in 1907 (specimen D. XXIX, 67, a) is a biotite granite of dark hhuish-ray folor and of fine texture, with feldspar up to 0.2 inch and mica to $0.1 \mathrm{inch}$, and with sparse clear porphyritic feldspars up to 0.3 inch, with inclusions of quatrty and mica. This granite, as to its constituents, is identical with that of the Drenan quary (specimen 65, a) described above, and it has the same peculiar sheen. Its sola-lime feldspar is oligoclase-albite. It effervesces with muriatic-acid test.

The Nichols Ledge Carter quary, no longer operater. is at the northwest foot of Nichols Ledge in the east corner of the town of Woodbury. (See fig. 20.)

The granite (specimen $\mathrm{D}, \mathrm{XIX}, 61, \mathrm{~b}$ ) is a biotite granite of light inclining to medium bluish-gray color and of fine to very fine texture, with feldspars up to 0.2 inch and mica to 0.1 inch, also with larger porphyritic clear feldspars formed alout the other minerals. It is finer textured than the stone of the new 
per (ent of ('aCO $\mathrm{O}_{3}$ (calcium (arlonate, alcite); the presence of this mineral is also shown by the microscope.

A comprossion test, made on a t-incl cube at the United States Arsenal at Watertown. Mass., in 1905. showed the first crack at 308.000 pounds, and an ultimate compressive strength of 27.810 pounds to the square inch.

This is a building granite of medium grain and very light shade, between that of Norih fay, Maine, and that of Bethel, Vt., in whiteness.

The other granite (specimen D, XXIX, 90, a). "dark blue," is a quartz monzonite of light inclining to medium blush-gray color and of even-grained fine inclining to medium texture. with ieldspars up to 0.2 inch and mica to 0.1 inclu. Its comstituents are identical with those of the "white" (specimen 90 , b), but its oligoclase-albite is bluish and less altered, and its mica is nearly all muscovite. It shows less calcite in thin section and does not effervesce with muriatic-acid test.

This is a monumental granite of light bluish-gray tint and without mineral contrasts.

The qualy, opened about 1S7t. Was estimated in 1907 as measuring about 1,200 feet in a $N .20^{\circ} \mathrm{W}$. direction along the hase of the mountain, by 200 freet across and from 15 to 50 feet deep. It was reopened in $\mathbf{1 9 2 1 .}$

Rock structure: The sheets for a thickness of 25 to 35 feet above the road level ann for a length of 100 feet are 6 inches to 2 feet thick and horizontal or slightly inclined west. Bolow the rad level they measure up to 14 feet in thickness an! dip $20^{\circ} \mathrm{W}$., although horizontal for short spaces. Above this thin-sheeted mass they dip $30^{\circ}-40^{\circ} \mathrm{W}$. and are considerably thiclier. At the north end of the duarry compressive strin forms new thin sheets and parts them. (See 1. 30.) There are two sets of joints-(a), strike N. 15\% E., vertical, spaced 7 to 30 feet; (b), strike N. $20^{\circ} \mathrm{Wr}$. dip $80^{\circ} \mathrm{N}$. $70^{\circ}$ F., only one, at the south end. Flow strueture strikes $\mathrm{N}$. $22^{\circ}$ F. and dips $80^{\circ}$ N. $68^{\circ} \mathrm{W}$. The rift is reported as rertical with $\mathrm{N} .15^{\circ} \mathrm{F}$. course and the grain as horizontal. Both are gook. The gneissic structure is parallel to the "hard way." Pegmatite dikes from 0.25 to 3 inches thick. with large light bluish-gray unstriated feldspars, strike N. $10^{\circ}$ E. The light-bluish granite occupies 350 feet of the north ent of the quary, the rest of it being "white." Knots are rare and up to 6 inches across. Rusty stain. up to 3 inches wide on the upper sheets, is generally absent from the lower ones.

The product is used for buillings, monuments and street work. Specimens: Post oflice at Troy. N. Y.; Diamond Rank, Pittshmrgh, Pa.; McFadrlen Building, ('hicago, Ill.; Royal Balking Powter Iuilding and Plaza Hotel, New York City.

The Clark quarries are east of West Dummerston village, on the northwest sille of Black Momntain. Operators, James Clark \& Son. West Dmmiuerston. Ille in 1921 and 1922.

The granite (specimen D, XXIX, 91, a) from the lower quary is a quartz monzonite of very light gray shade, witl conspicuous black mica, and of evengrained medium inclining to fine texture, with feldspars up to 0.25 and 0.3 inch and mica to 0.15 inch. Its constituents, in descending order of abuudance, are light smoky quartz showing effect of strain, and with some cavities in sheets; milk-white soda-lime feldspar (oligoclase-albite), kaolinized, micacized, and with calcite, also intergrown with quartz in vermicular structure; clear colorless potasl feldspar (microcline and othoclase), with inclusions of the other feldspar and mica; biotite (black mica) ; muscovite or blenched biotite.

This differs from the "white" of the Black Mountain quarry in that the biotite is more prominent and the fibrous muscovite is absent.

The stone from the upper quarry appears to be exactly like the "white" of the Black Motmtain quarry (p. 153). 
The lower opening is about 150 feet above the river bank, aud the uprel albont 330 feet. Both are small.

Rock structure: The sheets of the upper onening are from 6 inches to "2 feet 6 inches thick; those of the lower 10 to 12 leet. They strike $\times 150^{\circ}$ L. and dij $30^{\circ} \times 30^{\circ} \mathrm{W}$.

The Bailey prospects are on the west side of West liver about a nile south-southwest of the Black Nountain qu:lry, in Inumnerston. Gwner, ['avie .J. Bailey, R. D., Brattleboro. Iolle in 1921.

The sranite from an opening about 200 feet above the roald to bratteboro is a quatiz monzonite of light-gray shade and medium inchining to tine erent grained texture, with feldspars up to 0.25 inch ame mica mostly maler 0.0. in in and more thickly disseminated than in the "white" of the likak Mountain quarry. Its conslituents are the sane as in that stone, but the quart\% is more smoky, the mica mostly biotite. The tibrous museovite and crush forders ane lacking.

This stone is of slightly finer texture and, owing to the smokiness of its quartz and the distribution and anount of its biotite, of slightly darker shade than the "white." It is lighter than "light Barre."

The opening represented loy this specimen measured in $190 \mathrm{t} 200$ by 15 feet. with a working face of 10 feet.

Rock structure: The sheets, up to $S$ feet thick, dip $20^{\circ}-25^{\circ} \mathrm{N} .35^{\circ} \mathrm{W}$. A granite ledge a little north-northwest of this quary is crossed by a dilie of fine sranite, 30 feet wide, with a $\times 10^{\circ} \mathrm{W}$. course and dip of $50^{\circ} \mathrm{W}$. It is of medium bluish-gray color and of very fine even-grained texture, with feldspar and mica up to 0.05 inch. In thin section its particles range from 0.074 to 1.1 millimeters in diameter. It is a quartz monzonite of similar composition to that of West Dunmerston. Its mica is chiefly biotite. Feldspar and quartz are intergrown and have crush borders. The soda-lime feldspar is bluish gray and scarcely altered.

This fine granite, althougl probably harder than ordinary granites, may be found of economic value.

\section{WINDSOR COUNTY.}

BETHEI.

TOPOGRAPHY AND GENERAL GEOLOGY.

The State map of 1861 represented a small granite area in the east corner of the town of Bethel, surrounded by "calciferous nica schist." with a northsouth belt of "clay slate" a little west of it. This granite is on Christian Hill, an elongated mass rising about 350 feet above the adjacent hollows, about 2 miles north of Bethel village and east of White River. Its general position is shown on the map (fig. 35 ).

The granite exposure is reported as at leist half a mile long from north to soutb. Its wiuth at the quarries is : lbout 550 feet, witl a borler of finer less whitish granite on either side ahout 40 feet wide. The entire width between the schist on the east and west is not far from 625 feet, but there is said to be another narrower belt of granite several hundred feet east of the main one protruding through the schist. The mica schist immediately west of the granite strikes N. $10^{\circ} \mathrm{W}$. and $\operatorname{dips} 57^{\circ}$ E. ; that east of the granite (a garnetiferous mica slate), with 12-inch calcareous beds, strikes north to N. $5^{\circ} \mathrm{E}$. and is vertical. The mica schist, in places chloritic, north of and near Bethel, strikes $\therefore 10^{\circ}-15^{\circ} \mathrm{W}$. and is vertimal. While the min sranite mass. from its lateral zones of finer granite, would appear to be a truncated arch or dome, its sheet structure all dips east, from $15^{\circ}$ to $45^{\circ}$ on the east and $30^{\circ}$ on the west. The 
vertical north-south flow structure with its alined discoid nodules of muscovite

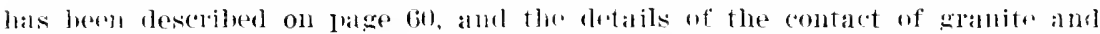
schist are given on page st and shown in figures 8 and a.

\section{"BETHEL GRANITE."}

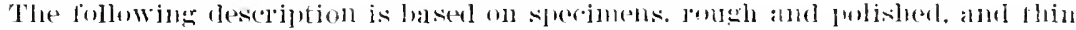
sections from both the Woodhury and Ellis quarries. which are but a few feet apart in one mass of contemporaneons origin and of inentical composition and texture.

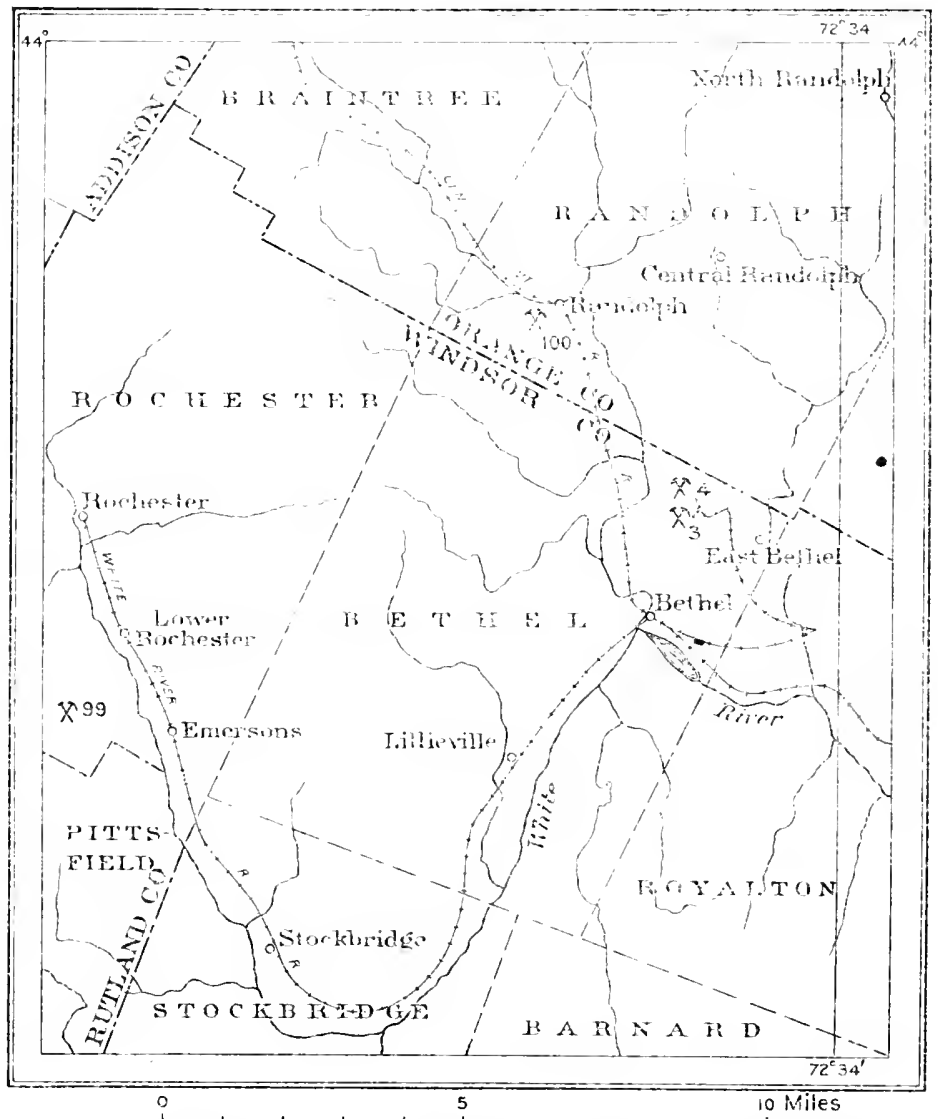

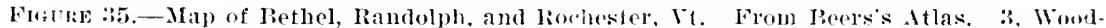
bury quarry : 4, I:llis quarly ; 9!), Ljberty lIill quarry; 100, Reedles prosprect.

The granite of Bethel (specimens D. XXIX, 3, 11, p, and 4, a. b), "Bethel White," is a quartz monzonite of slightly bluish milk-white color, with grayish spots up to 0.3 inch, and of conrse inclining to medium texture, with feldspars up to 0.4 and 0.5 inch and mica to 0.3 inch. Its constituents, in descending order of abundance, are clear colorless or rarely bluish quartz, with hairlike crystals of rutile, and with fluidal and other cavities in sheets, witl rift cracks parallel thereto; bluish nilk-white soda-lime feldspar (oligoclase), slightly kaolinized and micacized; clear potash feldspar (orthoclase, slightly kaolinized, with very little microcline); muscovite (white mica); and very little biotite (black mica). Accessory: Apatite, titanite, zircon, and rutile. 
No magnetite or pyrite was detected. Secondary: Kalolin, a white mira, epidote, zoisite in some abundance, and very little calcite.

The stone does not effervesce with muriatic-acid test. W. T. Schaller, chemist, of this Surver. finds that it contains 0.07 per cent of $\mathrm{CaO}$ (lime) soluble in dilute (10 per cent) aretic acid, which indicates a content of 0.125 ler cent of $\mathrm{CaCO}_{3}$ (calcium carbonate), which is rery slight.

A chemical analysis made for the former owners of the Ellis quarry by Charles F. McKenna, of New York, in 1903, is given here for reference.

\section{Analysis of "Bethel granite."}

Silical ( $\mathrm{SiO}_{2}$ )

77.52

Alumina $\left(\mathrm{Al}_{2} \mathrm{O}_{3}\right)$.

16. 78

Iron oxide $(\mathrm{FeO})$

.84

Magnesia (MgO)

.32

Lime $(\mathrm{CaO})$

2. 56

Soda $\left(\mathrm{Na}_{2} \mathrm{O}\right)$

1. 21

Potash $\left(\mathrm{K}_{2} \mathrm{O}\right)$

.62

Loss on ignition

100. 18

Three compression tests (No. 13261) made at the United States arscnal at Watertown, Mass., yielded these results (direction of rift in blocks not stated: First craek, 287,000, 301,000, 272,000 pounds; ultimate strength, 33,120, 34,350, 31,990 ; arerage, 33,153 pounds per square inch.

The stone is regarded as relatively hard by workmen. Its grade of whiteness is shown by these comparisons: The "white" of North Jay Maine, is, technically, very light gray. The "white" of West Dummerston is a trifle lighter, that of Randolph (P. 118) lighter sot. and that of Bethel still lighter, strictly white mottled with gray. Its white is more blue than that of ordinary Vermont white marble but is closely allied to its blue variety, though not its bluish gray. Owing probably to the abundance of its sola-lime feldspar, its hammered face is considerably whiter than its rough face, and the lammering also diminishes the prominence of the gray micaceous spots. It takes a high polish, but the effect is to make the mica spots more conspicuous than they are even on the rough face. The polished specimens handled by the writer do not show any pyrite or magnetite. Plate VII, A. representing a carved eagle. shows how the whiteness of the stone has overcome the effect of the coarseness of its texture. Although this granite is remarkably free from iron, its recent use in lalge alifices shows that extreme care should be exercised in handling it to prevent its absorbing lusty water. cement water, or other discoloring liquids.

Leonarll I'. Kinnientt. of the Worester Polytechnic Institute, in December, 16xs, male the following leterminations of absorption in "Betluel and other granites. by W. F. Hillebramls methofl, for Norcross Bros. Co. of Worcester, Mass.:

Heter absorlod by 100 pounds of rarions granites.

Poumi.

0. $47(1)$

" Bethel sranite"

$\begin{array}{ll}\text { "Yew Westerly," Milford. X. H } \mathrm{H} \ldots & .420 \\ \text { Hallowell, Maine_. }\end{array}$

Concoln. X. H

I'esterly, R. I $I+340$

Milford, Mass

Barre, Vt 
QTHRHES.

The Enis quarry is on the east side of Christian Hill. about 2 miles north of Ibothel village, in Bethel Towmship. (See fix. 35.) Operator, Woodbury Ganite (o., Hardwick. Idle in 1922.

the yranite has heen deseribed above.

'the quatry, permanthtly opened in 190: but in a small way many years earlier and abandoned, was estimated in 1907 as being about 1,000 feet loug from north to south, and for the southern three-fifths of its length 150 feet wirle, but for the remainler 400 feet wide. Its depth was 5 to 40 feet, averaging about 15 feet. Its west edge is about 80 feet higher than its east edge.

linck structure: The sheets. 6 inches to 12 feet thick but mostly 1 to 2 feet, strike N. $10^{\circ} \mathrm{W}$. and on the west side of the north end dip $30^{\circ} \mathrm{E}$. but on the east side $15^{\circ} \mathrm{F}$. For some not apparent reason the sheets thicken more rapidly at the east side and south ent than in any other part of this or the adjoining quilry. Joint, griin, and flow courses of this and the Woodbury quarry are shown in figure 36. Joint set (A) is vertical, forms a heading at north end, recurs at two intervils of $S 0$ fect: $(B)$ is diagonal to the quarry and rertical, one

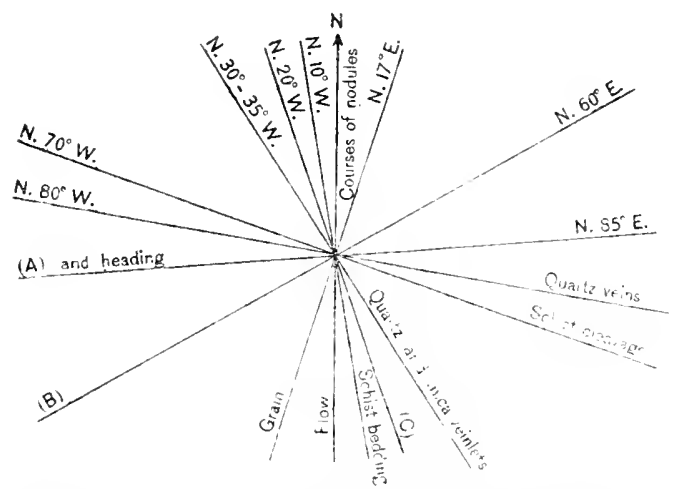

Figrif: 36.-Structure at Ellis and Woodbury quarries, Bethel, Vt. only, ahout the middle of the sille, but discontinuous. Compressive strain affects east-rest channels more than now th-sonth ones. Flow structure, malked at the east side nui south end, consists of m i c a ceous (muscovite) streaks up to 0.5 inch wide iind sheets of discoid nodules uf $\mathrm{muscovite}$, also of a wanching mass, 12 inches thick, largely mica, and is vertical with north course. (For details see p. 60 and Pl. 1II. A.) The rift is reported as horizontat and the grain as

vertical, with $\mathrm{N} .17^{\circ} \mathrm{E}$. course, thus intersecting the flow structure at an acute angle. A few pegmatite dikes. up to 5 inches thick, have an east-west course. A quartz vein up to 1.5 inches wide strikes $\mathrm{N}$. $80^{\circ} \mathrm{W}$. and dips $65^{\circ} \mathrm{S} .10^{\circ} \mathrm{W}$. Some minute museovite and quartz veins strike N. $30^{\circ}-35^{\circ} \mathrm{W}$. and dip $60^{\circ} \mathrm{S}$. $55^{\circ} \mathrm{W}$. There is one light-gray lnot 10 by 8 by 2 inches; also an inclusion, $21 \mathrm{by} 12 \mathrm{by} 5$ inches, of fine-grained syenite gneiss consisting of orthoclase. hotite, epidote. and a little oligoclase, with titanite and lencoxene but with little or no quartz. There is no rusty stain on sheet surfaces. The relations of the coarse white granite to the fine light buff-gray granite aud the contact of the later with the srlhist have been described on lage $S 4$ and shown in figures Si and 9 .

The Woodbury quarry is 50 feet not th of the Ellis quarry. on the east side and top of Christian Hill, about 2 miles north of Bethel village, in Bethel Township. (See fig. 35.) Operator, Woodbury Granite Co., Harlwick. Idle in 1022.

The granite has been described on page 156 .

The quarry, opened in 1902, was estimated in 1907 as measuring about 500 feet from north to south by 200 feet arross and from 5 to 30 feet in depth.

Rock structure: The sheets, 6 inches to 8 feet thick, are normal, dipping ahout $15^{\circ}$ F. At a small opening about 300 feet north of the main one and 
on the east sile of the highest part of' the hill the sheets dill $45^{\circ}$ W. 'There are two sets of joints (courses shown in fig. 34 )- $(1)$. vertial. forms a 10 foot heading on the south wall hetween this and the Ellis quarry; (IB), also veltical, is discontinuons and spated 10 to 40 foet. An east-west compressive strain is reported by the foreman. The rift is reported as dipping less than $15^{\circ} \mathrm{E}$, and the grain as rerticul, with nearly east-west course. Very few of the discoin micacens nombes lefermed to on page 60 aecur. Abont to feet of fine buff-gray granite with schist firther east correspond to the same rocks on the west side of Ellis quarry. There is no rusty stain on sheet surfaces except near the heading.

The product of both quarries is used for buildings and monuments. Specimens: Capitol of Wisconsin at Madison; American Bank Note Building. New Fork (Pl. VII, $A$, replesents a curving of this granite over the entrance); Theodore N. Vail residence. Morristown, N. J.; Mary Ann Brown Memorial Library, Providence. R. I.; State library and city hall, Hartford, Conn.; the post office, Union Station. and first and second stories New National Museum, Washington, D. C.; Franklin Savings Bank, Greenfield, Mass.; Congdon residence, Duluth, Minn.: Eddy Memorial. Mount Auburn Cemetery, Cambridge, Mass.; Swope Memorial, Swope Park. Kansas City. Mo.

\section{ROCHESTER.}

The Liberty Hill quary is 3 miles south of Rochester village (the west terminal of the White River Valley Railroad). on the Rochester-Pittsfield town line. The outcrop extends into the town of Pittsfield, in Rutland County. (See fig. 35.) Operator, Liberty Hill Granite Corporation, Rochester. Quarry abandoned.

The granite (specimens D, XXIX, 99, a. b) is a quartz monzonite of slightly greenish-white color with conspicuous brilliant muscovite spots up to 0.5 inch across and of coarse texture, with feldspars up to 0.5 inch. These mica spots, being collections of mica scales, have a peculiar sheen. As they are not over 0.04 inch thick and lie with their flat sides roughly parallel, the rock has a somewhat gneissoid textme. Its constituents, in descending order of abundance, are milk-white to slightly greenish soda-lime feldspar (alhite to oligoclasealbite), somewhat kaolinized and with thickly disseminated white mica scales up to 0.15 millimeter long and not a few plates of calcite; clear colorless to pale-bluish quartz, rarely with hairlike crystals of rutile, and with fluidal and other carities in two rectangular sets of shcets, one set with many more cavities than the other; muscovite (white mica) in large flakes and aggregates. Orthoclase may be present in small amount but was not detected. There is no microcline.

An estimate of the mineral percentages by the Rosiwal method rields these results with a mesh of 0.5 inch, total linear length of 35.5 inches, and on face at right angles to gneissoid structure: Feldspar, 62.1: quartz. 20.6; muscorite, 8.3. The arerage diameter of all the particles obtainel from the same measurements proves to be 0.34 inch; that of feldspar, 0.194 inch; quartz, 0.106 inch; and mica, 0.538 inch.

The stone effervesces with muriatic-aciu test. W. T. Schaller, chemist, of this Survey, finds that it contains 1.38 per cent of CaO (lime) soluble in warm dilute (10 per cent) acetic acid, which indicates a content of 2.46 per cent of $\mathrm{CaCO}_{3}$ (calcium carbonate. calcite); the fresence of this mineral is also shown in thin section.

This is a building granite of extremely light greenish-gray color, with striking contrasts produced by large mica spots, the brilliancy of which on the fresh rift face is almost metallic. Whether its somewhat gneissoid texture 
and its content af nearly 2..5 per eent of line allonate are serious obstacles to its use for building can be determined only by compression tests and by continued exposmre to the weather.

In 1909 the corporation was filling a contract for the base course for the gymnasium of Dartmouth College at Hanover, $\mathbf{N}$. H.

Although the outcrop is $\mathbf{3}$ miles from Rochester station, its distance from the nearest point on the railroad is only about a mile, and a siding is reported to have been constructed.

\section{PLYMOUTH.}

The State geologic map of 1861 shows a smatl granite area in the township of Plymouth. (See Pl. 1). Alhert D. Hager ${ }^{75}$ foum the locality by tracing glacial boulders, and described its geologic relations in these words:

"We have seen but one case in the State where granite is found in the talcose schist formation, and it is a small outcrop about 60 rods [990 feet] in length and in the widest part not more than 10 rods [165 feet] in width, situated in the northern part of Plymouth. *** The outerop is evidently a protruded mass forced up through the schist rock. The strata of the schist are partel, and the intervening space filled with granite. At the south end of the outcrop the exact limit of the granite can he scen, the slate being parted and appearing above and below the granite. The strike of the schist over the granite is $\mathrm{N} .10^{\circ} \mathrm{W}$. with a dip from $40^{\circ}$ to $50^{\circ} \mathrm{E}$. The dip of the schist below the granite is a little less than that above. * * * Frag. ments of schist occur in the granite. These framents are the same as the rock in which the granite is found. The edges and comers of the fragments are not worn, but appear to have become embedaled in the matrix of granite when the latter was in a plastic state; but from this mass there are several offshoots or spurs rmning off at right angles across the strata of schist, as shown in the dikes in the cut and filling fissures that appear to have been made at the time the grinite was erupted. These sinurs, some five or six in number, vary in thickness from 1 to 10 inches."

The writer made a brief visit to this locality in .June, 1916. It is about 2 miles $N$. $7^{\circ}$ E. of Plymouth (Chmrch), betwcen the 1,500 and 1,600 foot levels as shown on the Uniterl States Geologial Survey's topographic map of the Woodstock quadrangle, on the south side of Morrison Hill. It is reached by a small road rmming northwestwald from the Pinney Hollow road

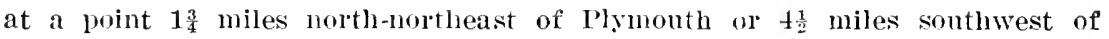
Bridgewater. The outerop is five-eighths of a mile from the min roar.

The hillside has become thickly wooded since Hager's visit, and a talus hides part of the outcrop, so that only approximate measurements were practicable in the time at the writer's disposal. The length of the granite lens from northwest to sontheast is not less than 450 feet, its width is 150 to 200 feet, and the height exposed on the hillside about 40 feet. The sheets, 3 to 5 and even 10 feet thick, strike N. $25^{\circ} \mathrm{W}$. and dip $50^{\circ} \mathrm{S}$. $65^{\circ} \mathrm{W}$. Sericite schist, abounding in quartz lenses and presmunhly of Cambrian age, crops out northeast of and above the granite with a strike of $\mathrm{N}$. $50^{\circ} \mathrm{W}$. and a tip of $50^{\circ} \mathrm{N} .40^{\prime}$ W. Southeast of th" granite the schist strikes $\mathrm{N} .40^{\circ} \mathrm{W}$.

${ }^{75}$ Hitchcock, C. II. and E. jr., and 11 ager, . I. Il.. Report on the geology of Vermont, vol. 2 , p). $740,741,18(; 1$.

io The strike of $\mathrm{N} .10^{\circ} \mathrm{W}$. given by llaw represents the normal westrily axtreme of the strike of the Cambrian scluist of the renion. 

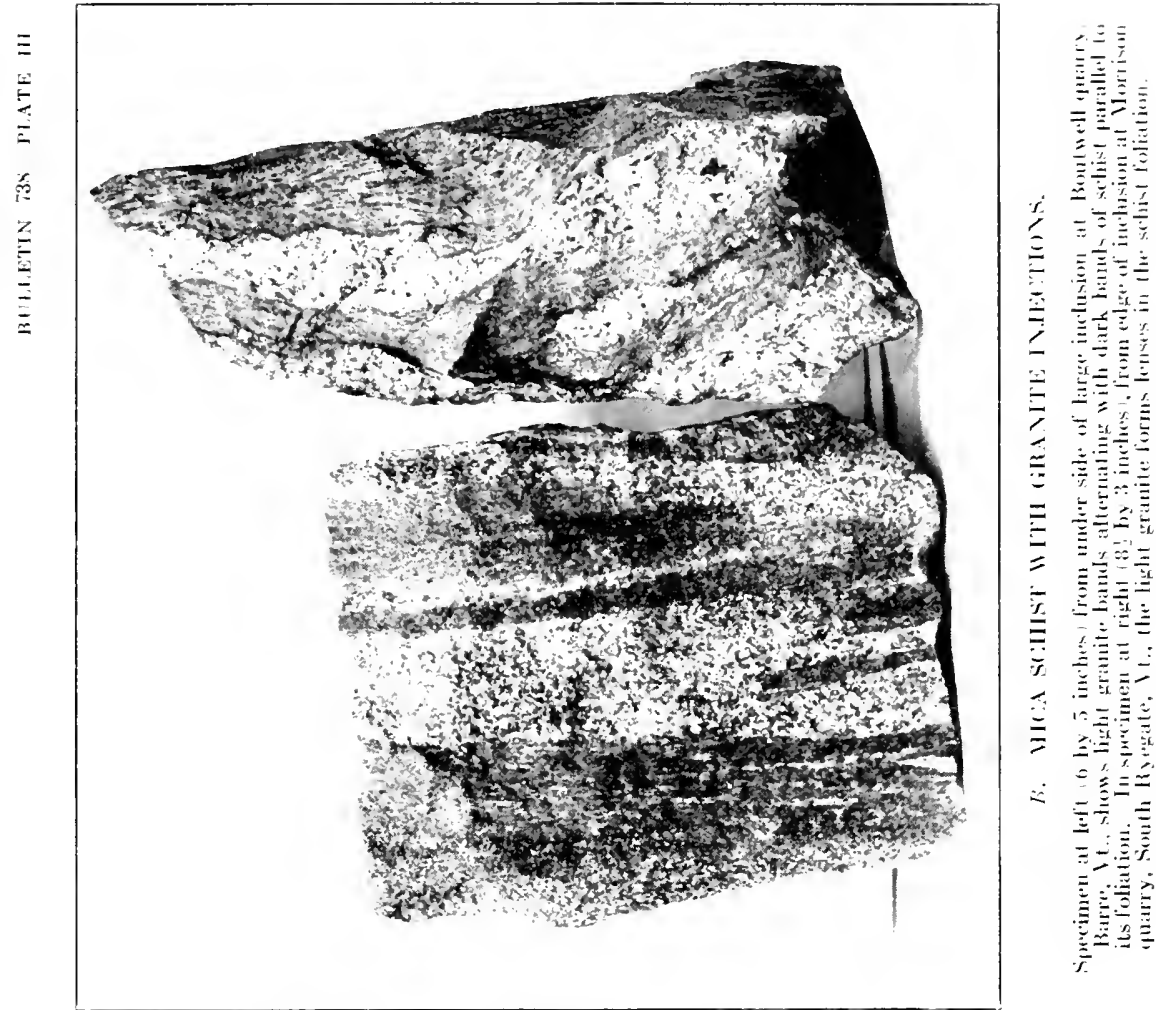

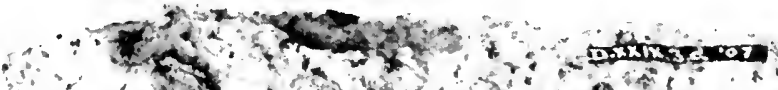
4 


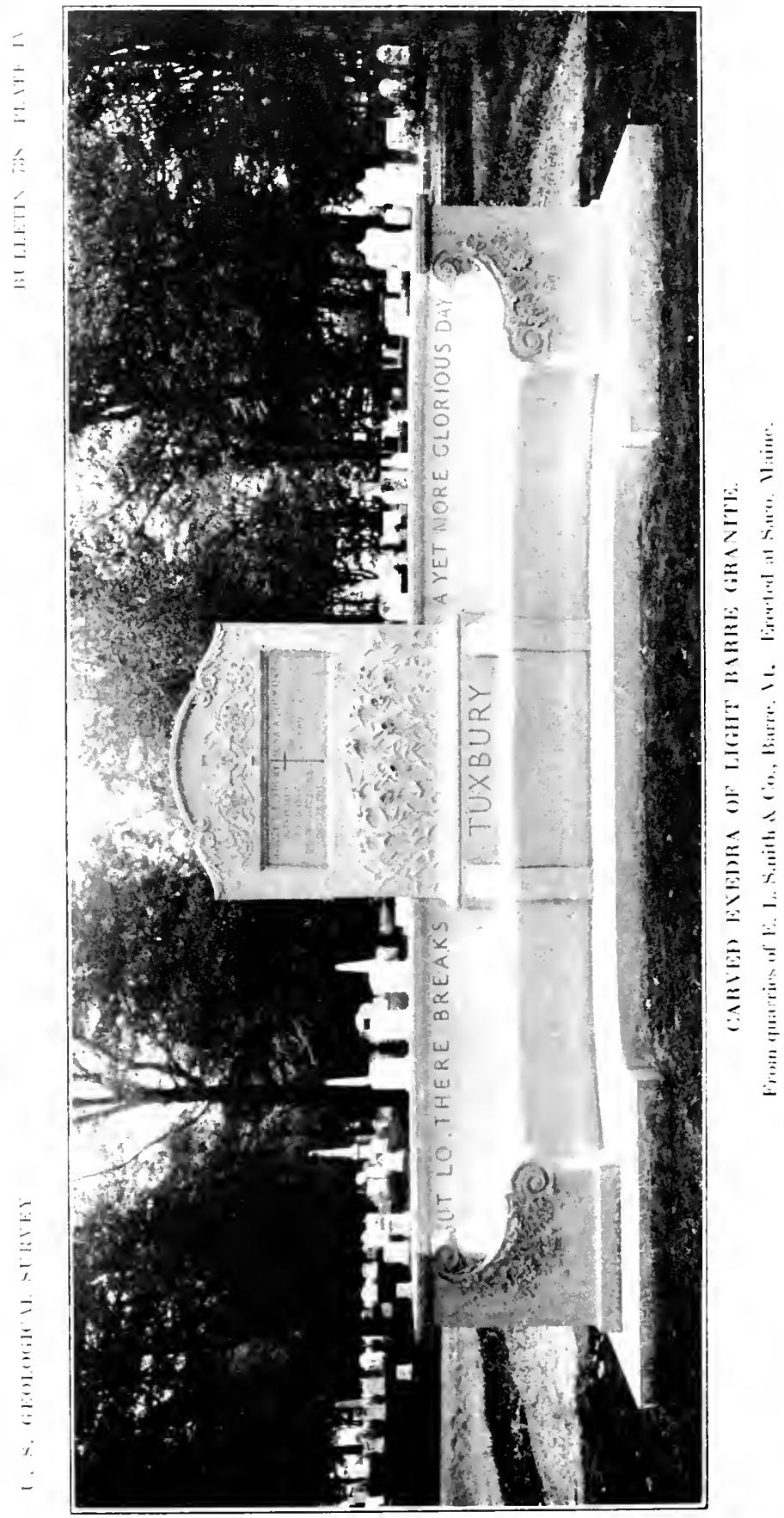




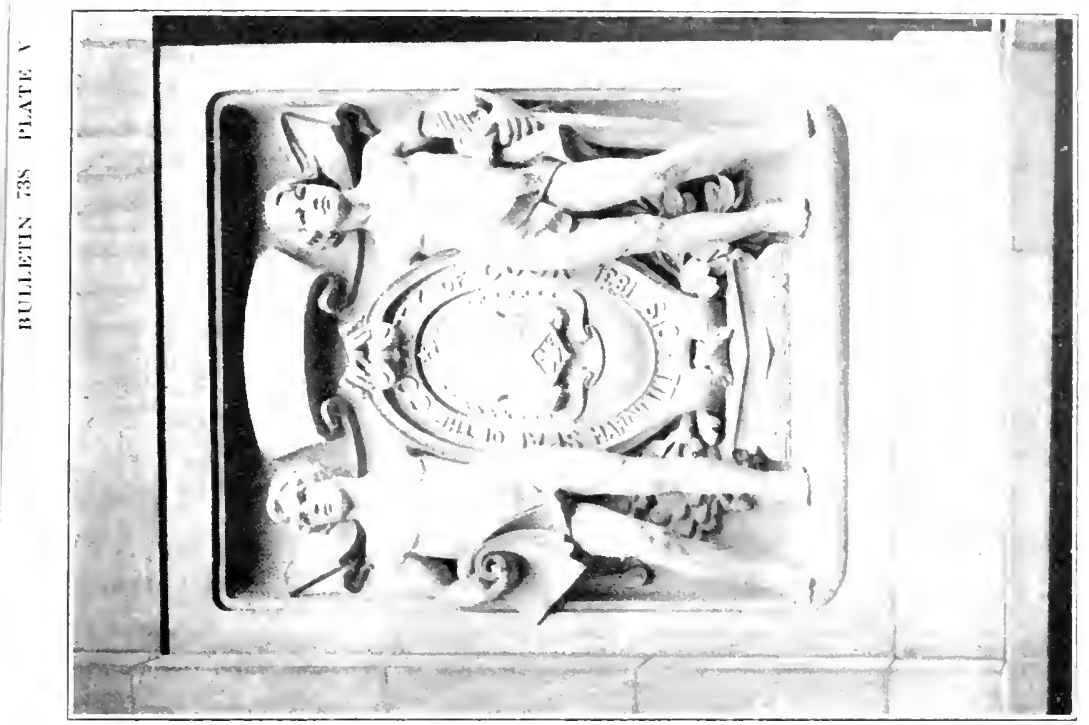

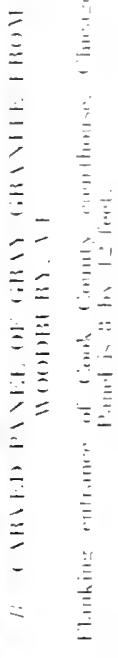

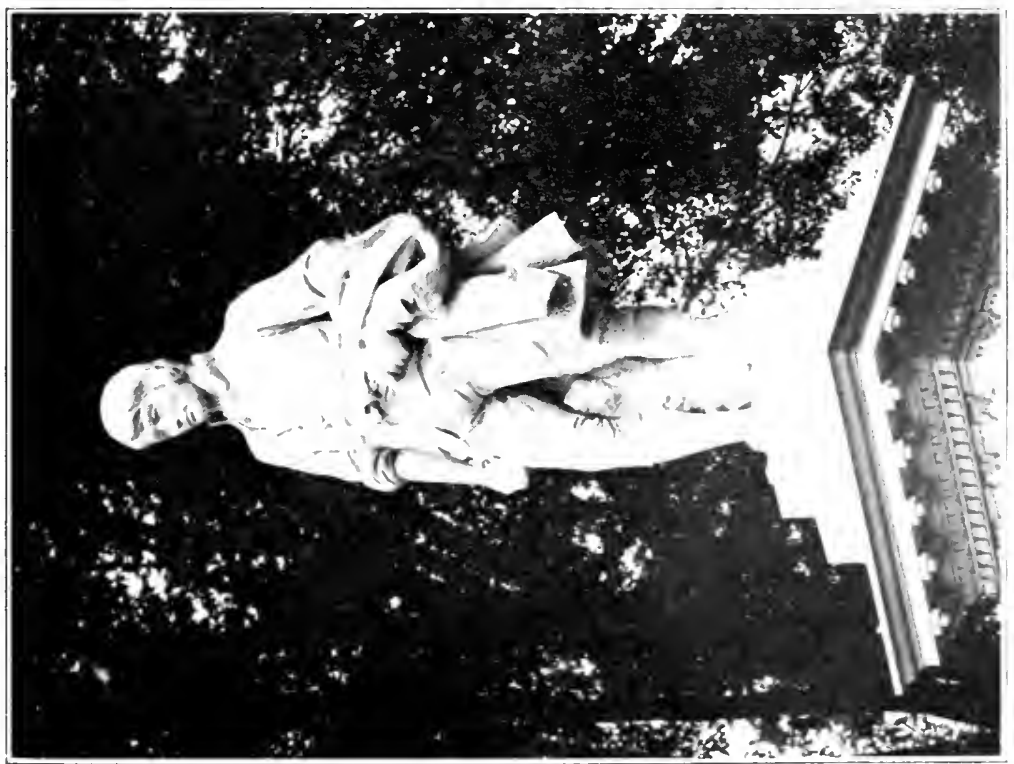




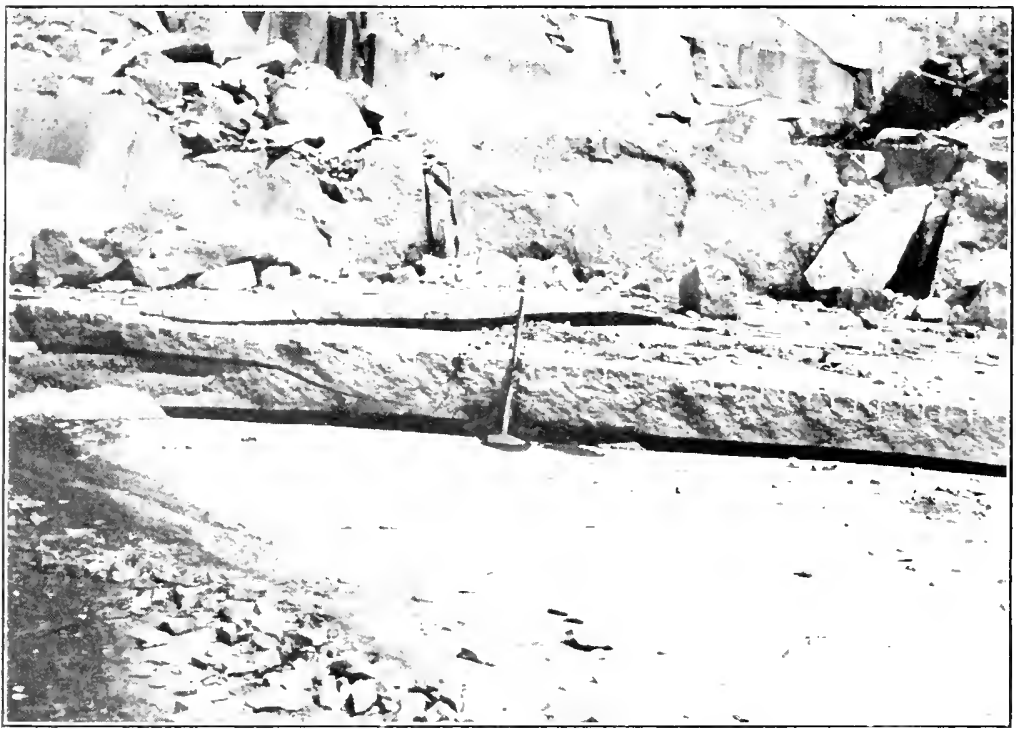

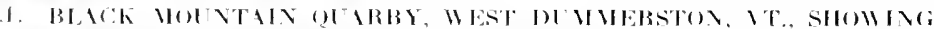

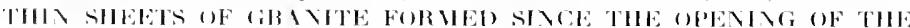

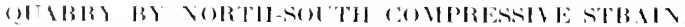

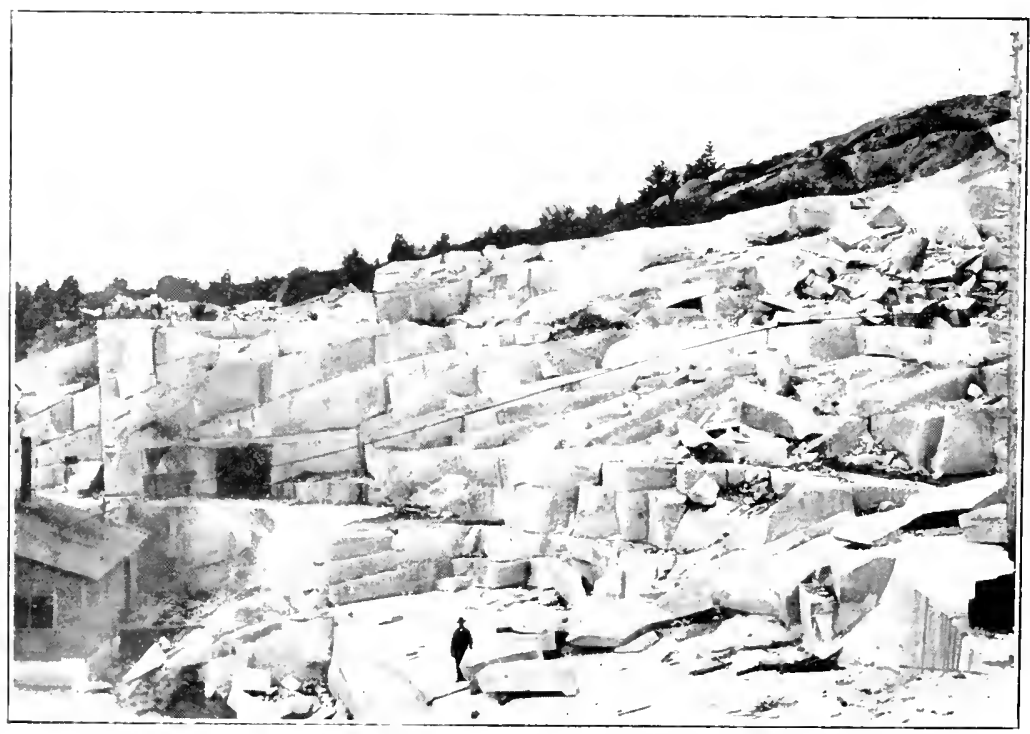

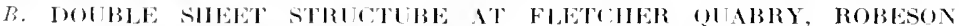

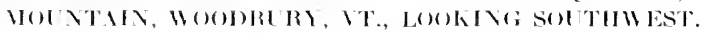

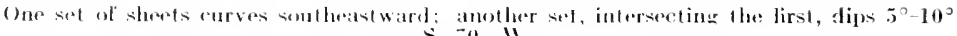
S. 7111 . 


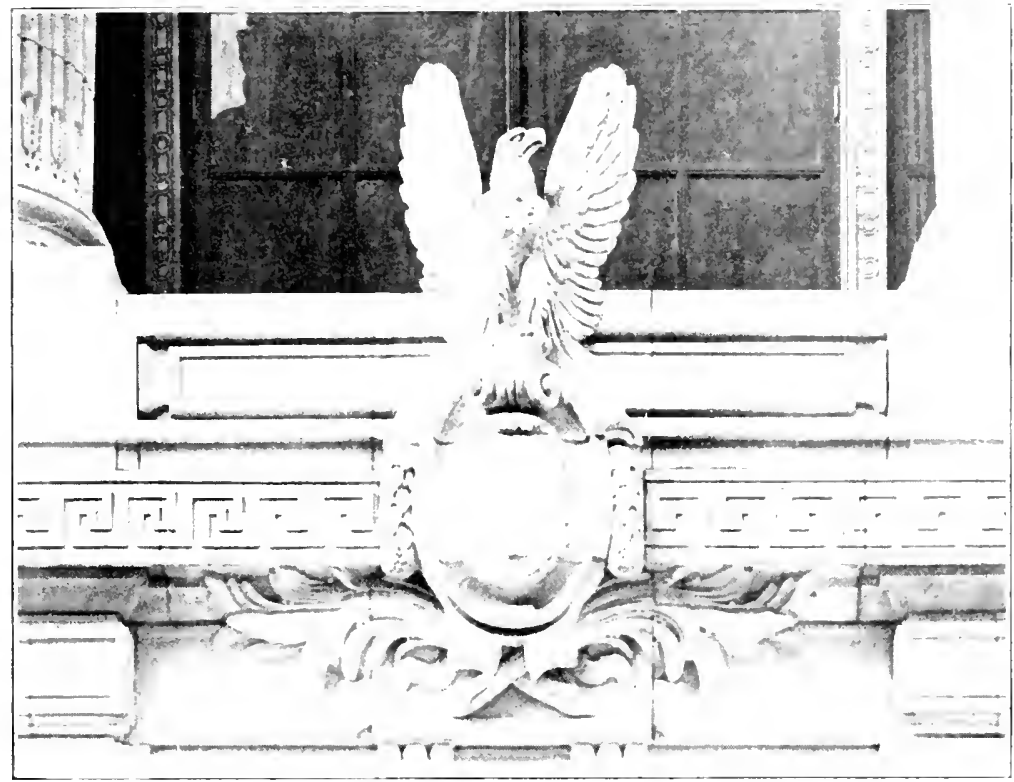

A. GARITNG OF COMRSE WHTE QLARTZ WOIZONITE FROM BETHEL, IT.

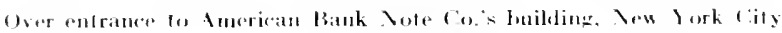

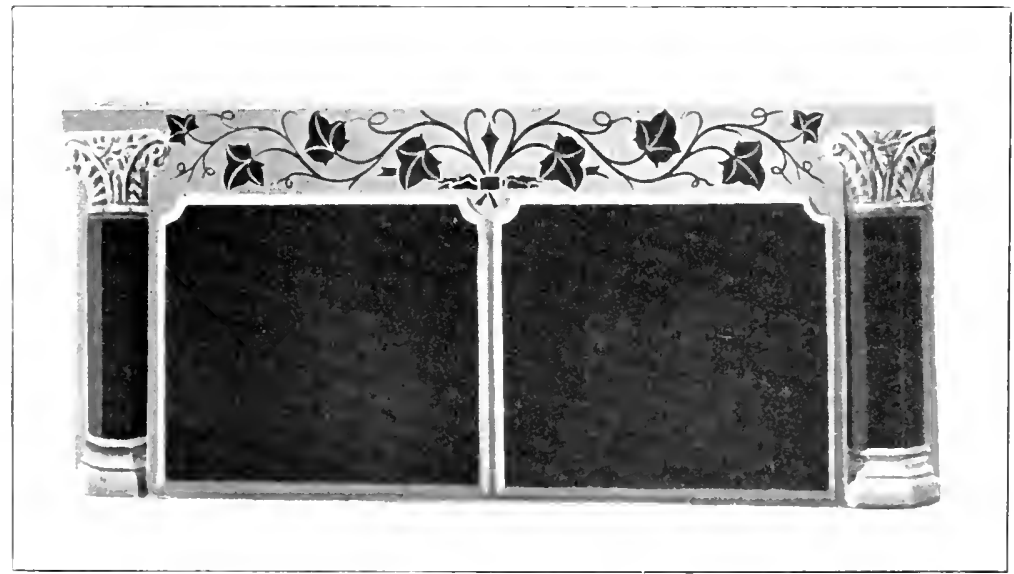

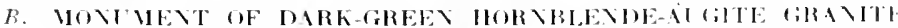

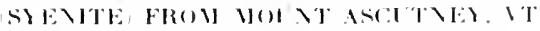

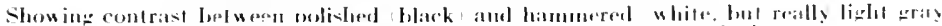

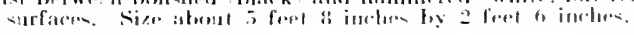




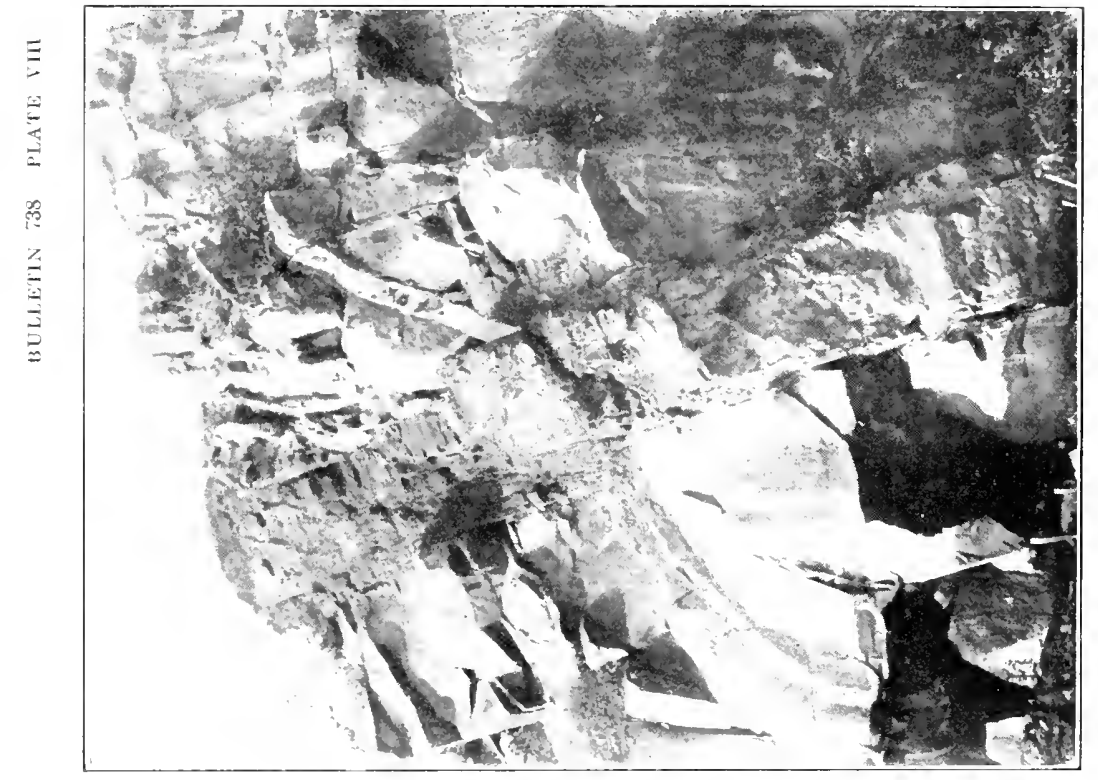

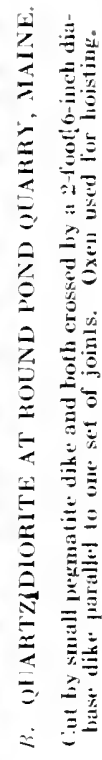

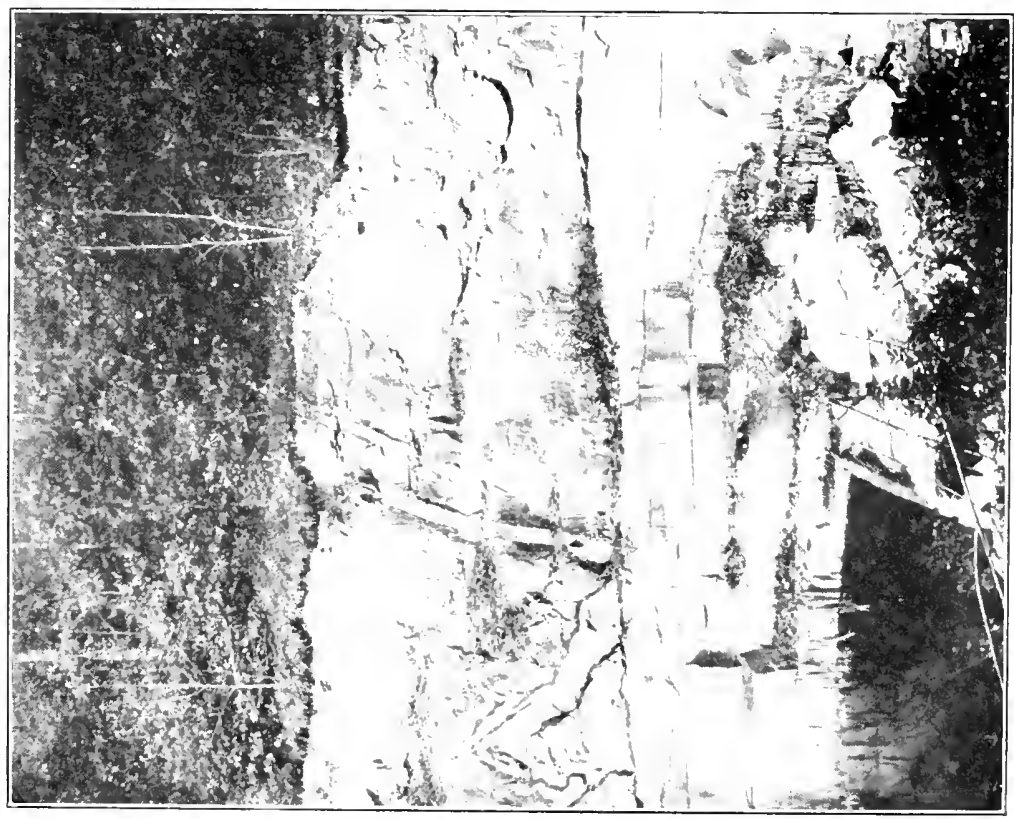

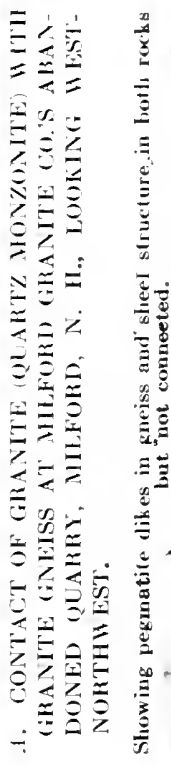


and dips $40^{\circ} \mathrm{X}$. $50^{\circ}$ E. On the northeast the granite is in contart with the overlying schist and a small dike of fine-grained granite (probably aplite) projects from the granite into the schist a few feet. The lower southwestern contact is covered by talus in which some quarrying has been done.

The granite (specimens D, XXXVII, 145, a-d), "Plymouth white," is a quartz monzonite of fine granitic texture (grade 3) with felispars under 0.5 centimeter ( 0.2 inch). The feldspars are milk-white, exceptionally remotely pinkish, and become more white on continued exposure. The quartz is very faintly smoke-colored, and the mica mostly very light. There are some discoid nodules of mica up to 0.75 inch in diameter, the granite being thus in places slightly orbicular like that of Bethel. (See 1. 60.)

Its constituents, in descending orler of abundance, are soda-lime feldspar (oligoclase-albite), somewhat kaolinized and micacized (many of the mica scales, being oriented, are presumably interpositions), with some epidote and calcite; quartz with rutile needles and fluidal cavities with vacuoles; potash feldspar, generally clear (microcline and orthoclase, some of the latter minutely intergrown with plagioclase) ; muscovite; and epidote. Some of the grains of oligoclase-albite are intergrown with microcline. Accessory, apatite and rutile. Secondary, kaolin, epidote, a white mica, and calcite.

In 1895 a small Episcopal chapel of this granite was erected in the Ottaquechee Valley, in Sherburne Township. The blocks were not squared. After 20 years of exposure the stone showed no signs of discoloration and at a little distance appeared like white marble.

Although the areal exposure of this granite is small its depth is, of course, unlimited, but its workable thickness below should be tested. Core-drilling through the schist 100 feet back from its boundary with the granite would also determine whether the schist covering may not at some points be sufficiently thin to warrant quarrying through it, and the available granite area may thus be really larger than the exposed surface of the lens.

The distance of the "Plymouth granite" to the nearest railroad, which is at Woodstock, is 13 miles by road, and the drop is to the 700 -foot level, or about 850 feet.

The economic possibilities of this granite lie mainly on the very great rarity of really white granite in the United States.

\section{WINDSOR.}

TOPOGRAPHY AND GENERAL GEOLOGY.

The State map of 1861 shows a granite area in the southern parts of Windsor and West Windsor and the northern part of Weathersfield. The geology of this area has been made known by $\mathrm{R}$. A. Daly ${ }^{77}$ in an elaborate report already cited. His map (Pl. VII) shows that Mount Ascutney, which lies about 5 miles southwest of Windsor village and rises 2,800 feet above the Connecticut and 3,100 feet above sea level, consists mainly of a mass, about $2 \frac{1}{2}$ miles square, of greenish hornblende-augite granite (syenite) intrusive in schists, which crop out along its base, and also containing inclusions of the schist. But adjoining this syenite on the west is an area of still older gneisses, which are intruded by a mass of gabbro and diorite about 2 by $1 \frac{1}{2}$ miles in area. That this intrusion is older than that of the syenite is shown by the fact that dikes of the syenite penetrate it. The syenite of Mount Ascutuey was itself in turn intruded by a

7 U. S. Geol. Survey Bull. 209, 1903.

$105709-23-12$ 
very irregular mass of biotite granite characterized by abundant dark segregations (knots) and covering about a square mile. This granite was formerly quarried, and monuments of it can be seen in the Windsor cemetery.

\section{" WINDSOR GRANITE."}

"Windsor glanite," “Ascutney green" (syenite, nordmarkite phase of Daly, specimens D, XXIX, 88, a, 89, a-d) is a hornblende-augite granite which when first quarried is of dark bluish-gray color but after very brief exposure becomes dark olive-green. Its texture is medium to coarse, with feldspars up to 0.3 and 0.5 inch and black silicates to 0.2 inch. Its constituents, in descending order of abundance, as made out from the study of four thin sections, two from each quarry, are dark olive-green potash feldspar (orthoclase), minutely or obscurely intergrown with soda-lime feldspar (certainly oligoclase in two of the slides), with cleavage planes stained with limonite; dark smoky quartz with cavities (apparently without vacuoles, some of them of quartz crystal form) in streaks and sheets and crossed by intersecting cracks filled with limonite stain; green hornblende; augite, associated with or inclosed by the hornblende; biotite in very small quantity, in three slides none. Accessory: Titanite, magnetite or ilmenite, zircon, apatite, and allanite. Secondary: Limonite and white mica in the feldspar.

The cause of the change in the color of the feldspar and thus of the granite upon exposure lias already been referred to (p. 76). It does not effervesce with muriatic-acid test. It is very hard and has a metallic ring under the hammer. It is brilliant in the rough from the cleavage faces of the large feldspars. Their shade is so dark that the black silicates appear only on close inspection. Owing to its extremely small content of mica it takes a very high polish. quite as high as that of the granite of Quincy. Its polished face is much darker than its rough face, but the hammered or cut face, being of medium greenish gray, is much lighter than either, so that lettering or carving stands out boldly on the polished face. (See Pl. VII, B.) It is best adapted for Internal decorative use.

The following analysis ${ }^{78}$ was made by W. F. Hillebrand :

Analysis of "Windsor" hornblende-(nugite granite (syenite).

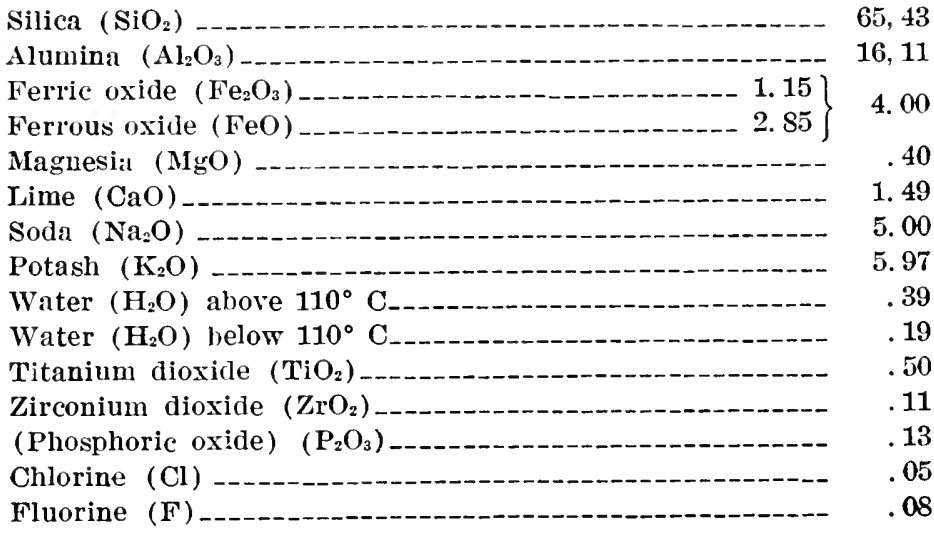

${ }^{78}$ U. S. Geol. Surrey Bull. 209, p. 59, 1903. 


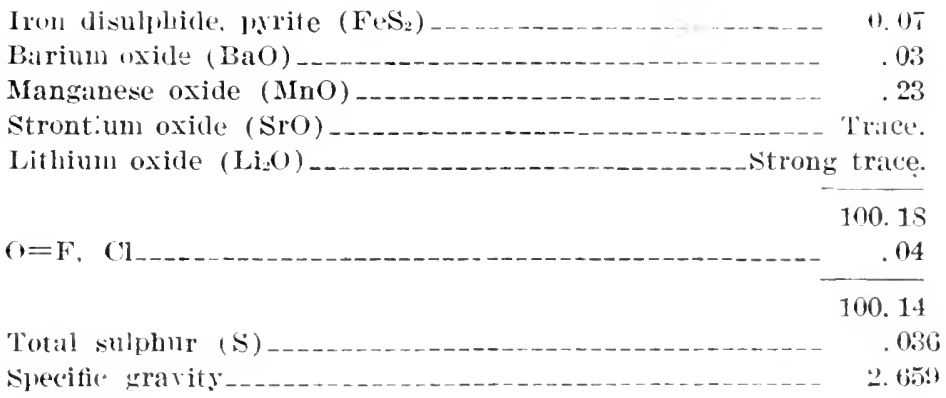

QUARRIES.

The Mower quarry is on the west side of Mount Ascutney noilly $1 \frac{1}{x^{\prime}}$ miles south of Rrownsville and 580 feet ahove it, in West Windsor. (see map, Pl. I.) Operator. Asrutney Mountain Granite Co., Windsor. Quarry abandoned.

The granite, atready descrihed. has received the trade name of "hronze vein green."

The opening. matle in 1906. was in 1907 about 50 feet sfuare and arelatided 10 feet in depth.

Rock structure: The sheets, 10 feet thick, are horizontal or dil so $\mathrm{W}^{\circ}$. There are three sets of joints-(a), strike N. $85^{\circ}$ E., rertical, spacel 2 to 18 feet; (b), strike N. $30^{\circ}$ E., dip $75^{\circ}$ S. $60^{\circ} \mathrm{W}$., one forming the east wall; (c). strike N. $55^{\circ} \mathrm{W.}$ dip $65^{\circ}$ N. $35^{\circ}$ E., one forming the sonth wall. The rift is reported as vertical with N. $85^{\circ}$ E. course, and the grain as horizontal. There is a black bronzy streak dipping $45^{\circ}$ E., possibly of the black silicate, and showing the direction of flow. Light rusty-brown and cream-colored discoloration is 0.5 inch thick on the joint faces. In thin section some of the limonite stain of this rim proceeds clearly from particles of magnetite (or ilmenite), angite, and allanite.

The product is used mainly for dies, wainscoting, and indoor columns. Specimens: Tlie two monolithic sarcophagi in the Mckinley mansoleum at Canton, Ohio. When finished these measured 8 feet 10 inches by 4 feet 4 inches by 2 feet $6 \frac{3}{4}$ inches. The covers measured 9 feet $4 \frac{1}{2}$ inches by 4 feet $8 \frac{3}{4}$ inches by 1 foot $3 \frac{3}{4}$ inches. The monument (Pl. VII, $B$ ) shows the contrast between cut and polished faces, the black representing what is a dark olive-green and the white what is a medium greenish gray.

The Norcross quarry is on the north side of Mount Ascutney on the 1,350foot level. about 950 feet above Windsor village, a little orer a mile east-southeast of Brownsville, in Windsor. (See Pl. I.) Operator, Norcross Bros. Co., Worcester, Mass. This quarry has been operated only occasionally and is now abandoned.

The granite has been described on page 162 .

The quarry is about 200 feet from east to west by 40 feet across and has a working face 60 feet high on the south, with a rugged cliff above it, making a total face of $S 0$ to 90 feet above the quarry bottom and road.

Rock structure: The sheets, 2 to 10 feet thick, are horizontal or dip $10^{\circ} \mathrm{N}$. There are two sets of joints-(a), strike N. $75^{\circ}$ to $80^{\circ} \mathrm{E}$., vertlcal, spaced 2 to 10 feet: (b). strike N. $5^{\circ}$ W., vertical, spaced 5 to 30 feet, with a heading 10 feet wide through the center of the quarry. The splitting has been done in the direction of (a). which is the rift direction at the Mower quarry and presumably here also. There are many dark streaks. A 4-foot dike crosses the quarry parallel to and within heading (b). This appears to be also a horn- 
b]ende-biotite granite. It is of medium greenish-gray color and of medium inclining to fine texture, with feldspars mostly under 0.2 incb, rarely 0.4 inch, and black silicates mostly under 0.1 inch. Its constituents, in descending order of abunclance, are greenish nedium-gray potash feldspar with obscurely intergrown sorla-lime feldspar. kaolinized; smoky quartz, more of it than in the adjacent sranite; finely striated soda-lime feldspar (oligoclase-albite); hornblende; a little biotite. Accessory: Magnetite or ilmenite, titanite, and allanite. Seconclary : Kaolin.

The sheet surfaces, chiefly owing to the kaolinization of the feldspar, are discolored to a medium, slightly greenish gray, and the joint faces are similarly discolored but have a limonitic border. The discoloration is from 1 to $\mathbf{1 . 5}$ inches thick.

Transportation by cart to rail at Windsor.

The lirumct has been used for monmmental and decorative purposes. Specimens: Sixteen polished columns ( 24 feet $9 \frac{1}{2}$ inches by 3 feet 7 inches) in Columlia Lniversity Library, New York; monument to General Gómez in Cuba; it die in the Bemnington monument; 34 large columns in the Bank of Montreal; columms and die of W. C. T. U. fountain, Orange, Mass.

\section{NEW HAMPSHIRE.}

\section{DISTRIBUTION OF GRANITE-QUARRYING CENTERS.}

Plate I shows the location of the granite-quarrying centers and of the isolated quarries in New Hampshire.

\section{GEOLOGIC RELATIONS OF NEW HAMPSHIRE GRANITES.}

In view of the transition from the older views as to the origin of granite to the more matured views of to-day and also the substitution of more exhaustive methods of geologic exploration for the necessarily more cursory methōds of the past, it does not seem advisable to undertake to transcribe here an outline of the complex and uncertain geologic relations of New Hampshire granites from geologic literature. Instead of that, a summary of the geologic observations made at all the quarries of each quarrying center or district will be given. These facts will ultimately fit into the final geologic mapping and history of the State, whatever these may prove to be.

THE QUARRIES, THEIR GRANITE AND FINISHED PRODUCT.

\section{CARROLL COUNTY.}

CONWAY.

TOPOGRAPHY.

The Conway quarries are near North Conway, some of them on the east and west sides of the Saco Valley. The Redstone quarries, on the east, are at the south foot of a series of summits ranging from 1,550 to 2,375 feet above sea level (Black Cap, Middle Mountain, and Rattlesnake Mountain), known collectively as the Green Hills; and the White Mountain quarry on the west, is on a 765-foot lenticular granite mass lying about 2 miles $\mathrm{S}$. $25^{\circ}-\mathbf{4 5}^{\circ}$ 
li. of the granite dowes known as White Horse and Catherlual ledges.s. Also belonging to this group of quarries is the Fletcher quarry, in the town of Madison, which adjoins Conway on the south. This quarry lies southeist of Moat Mountain and about $2 \frac{1}{2}$ mlles southwest of Conway Cornels. (See fig. 37.)

GEOLOGY OF THE QUARTILS.

The geologic feature of general interest in Conwily granites is their market rift and grain and the manifest relation of these to the sheets of mirros(copic cavities, as shown in figure 1 and described on page 17 . The rift is repulpol

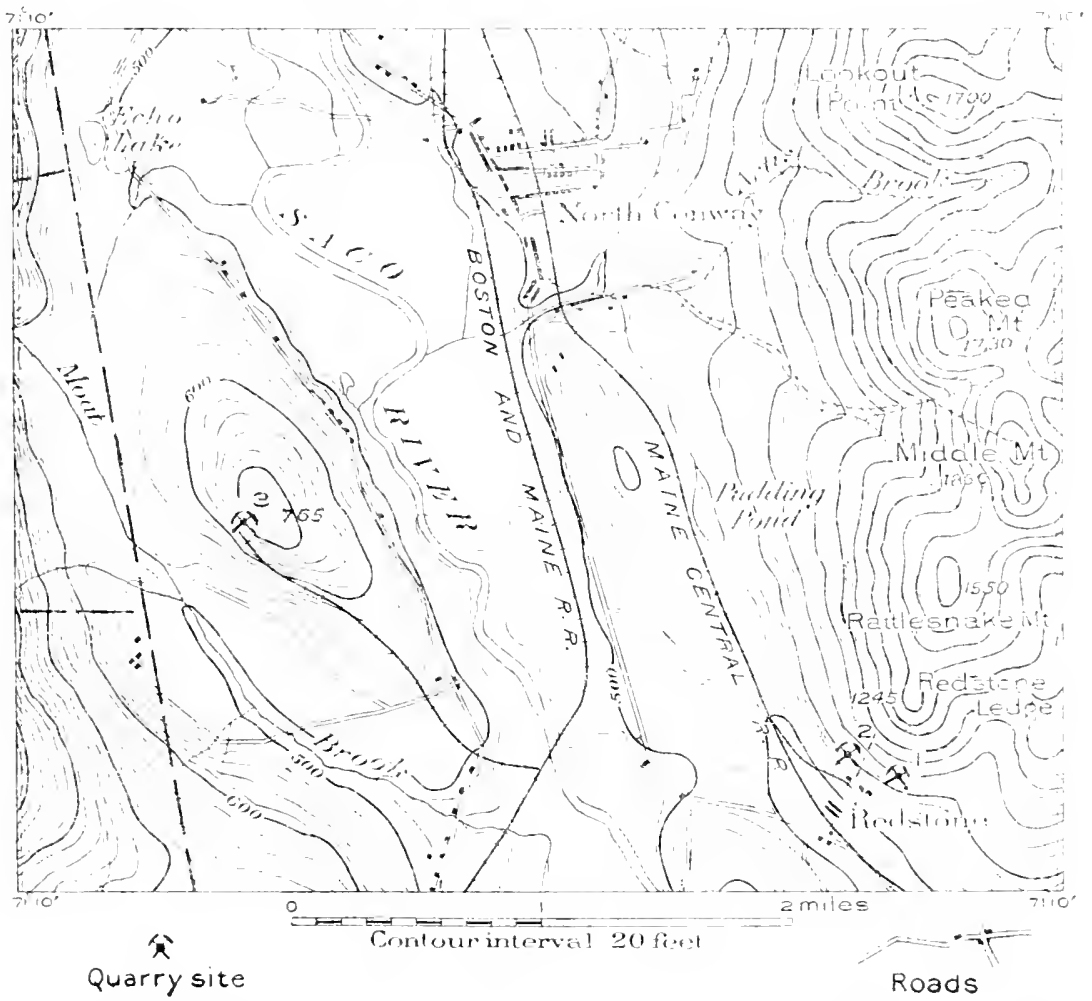

Fifure 37.-Map of part of Conwar, $\mathrm{N}$. H, showing location of granite quarris. 1, Redstone red granite quarry; 2, Redstone green granite quarry ; 3, White Mountain quarry. The boundary between pink and green granite is shown by dotted line.

as uviformly horizontal, and the grain as vertical with $\mathrm{N}$. $80^{\circ}-90^{\circ} \mathrm{W}$. course. Another feature is the contiguity of a yellowish-green biotite-hornblende granite to the pink biotite granitc at Redstone. (See fig. 37.) Petween the 500 and 500 foot levels the boundary has a $\mathrm{N} .23^{\circ} \mathrm{E}$. course and is sait to continue in that direction toward Rattlesnake Mountain. Although the feldspars of both these granites are equally kaolinized, their original color's probably differed as greatly as their present ones. The feldspar of the green stone seems to have been a bluish gray and that of the pink probably clear and colorless or slightly pinkish. Their present colors are due to the formation of limonite in the green and hematite in the pink. This limonite is 
largely tractable to somewhat abundant allanite and to the hornblende; the hematite may he attributed to the oxilation of magnetite or of ferrite in infinitesimal particles in the feldspars. These two granites side by side represent originally different materials, and the line of their contact indicates the direction of their flow. A 20 by 30 foot segregation or dike of porphyritic biotite-hornblende granite, and geodes, coated internally with calcite rhombs and chlorite, should also be noted as occurring at the red quarry. The joint systems at the four quarries have courses of N. $70^{\circ}-90^{\circ} \mathrm{W}$., N. $35^{\circ}$ W., N. $15^{\circ}$ E., and $\mathrm{N} .30^{\circ} \mathrm{F}$. The sheets dip gently east and west from the axis of the ridge.

\section{QUARRIES.}

The Redstone pink quarry is in the town of Conway, about 3 miles $\mathbf{S}$. $35^{\circ} \mathrm{E}$. of North Conway, on the base of Redstone Ledge, one-third of a mile N. $50^{\circ}$ E. of Redstone station on the Maine Central Railroad, and 180 feet above it. (See North Conway topographic map, U. S. Geol. Survey; also fig. 37.) Operator, Maine \& New Hampshire Granite Corporation, North Jay, Maine.

The granite (specimens D, XXVIII, 35, a, b, j, k), “Conway pink," is a biotite granite of light pinkish-gray color with large dark-gray and small black spots. Its texture is even grained, coarse, and with feldspars up to 0.75 inch, exceptionally 1.25 , and black mica up to 0.3 inch. Its constituents, in descending order of abundance, are a light pink, nearly opaque potash feldspar (orthoclase, mostly twinned), minutely intergrown with soda-lime feldspar; smoky amethystine quartz with cavities up to 0.012 millimeter, in sheets, intersecting at right angles and parallel to rift and grain cracks (see fig. 1 and p. 1T); translucent very light gray to milk-white striated sodalime feldspar (oligoclase-albite); and biotite (black mica), but little of which is chloritized. The orthoclase is mucl kaolinized; the oligoclase less so. The orthoclase in places surrounds oligoclase; in one specimen a small crystal of orthoclase is inclosed by oligoclase, and that has a zone of orthoclase about it. Accessory: Magnetite (ilmenite?), pyrite, apatite, fluorite, and zircon. Secondary : Kaolin, chlorite, titanite (leucoxene), calcite, and hematite stain mostly combined with the kaolin and only visible under incident light.

Estimates of the mineral percentages by the Rosiwal method yield the following results:

Estimated mineral percentages in "red granite" of Redstone, N. H.

\begin{tabular}{|c|c|c|c|}
\hline$\theta^{-}$ & 1 & 2 & 3 \\
\hline $\begin{array}{l}\text { Feldspar } \\
\text { Quartz } \\
\text { Mica (hotite }\end{array}$ & $\begin{array}{r}62.60 \\
31.00 \\
6.40\end{array}$ & $\begin{array}{r}68.00 \\
26.30 \\
5.70\end{array}$ & $\begin{array}{r}65.30 \\
28.65 \\
5.55\end{array}$ \\
\hline & 100.00 & 100.00 & \\
\hline
\end{tabular}

1. Specimen cut at right angles to both rift and grain; mesh 0.8 inch, total linear length 39.2 inches.

2 . Specimen cut parallel to rift showing larger feldspars; mesh 1.2 inch, total linear length 28.8 inches.

3. Average of both estimates.

An analysis of this granite, made for the firm in 1898 by Franklin C. Robinson. State assayer of Maine, is here given merely for reference. 
Analysis of "red granite" from Redstone, N. H.

Silica $\left(\mathrm{SiO}_{2}\right)$

71.44

Alumina $\left(\mathrm{Al}_{2} \mathrm{O}_{3}\right)$

14. 72

Iron stequioxide $\left(\mathrm{Fe}_{2} \mathrm{O}_{8}\right)$

2. 39

Iron oxide ( $\mathrm{FeO})$

(Total iron oxides, 2.85.)

Magnesia ( $\mathrm{IgO})$

Suda $(\mathrm{Na} 2 \mathrm{O})$

Rare elements, mostly titanium and zirconium dioxides

$\left(\mathrm{TiO}_{2}\right.$ and $\left.\mathrm{ZrO}_{2}\right)$

Manganese, sulphur, calcium, phosphites Traces.

Loss at red heat (mostly water)

.61

99. 91

Specific gravity, 2.635.

W. T. Schaller, a chemist of this Survey, finds that this granite contains 0.16 per cent of $\mathrm{CaO}$ (lime), soluble in hot dilute acetic acid, which indicates a content of 0.267 per cent of $\mathrm{CaCO}_{3}$ (calcium carbonate); the presence of this carbonate is also shown by the microscope.

A test made at the United States arsenal at Watertown, Mass., in 1887, gives this granite a compressive strength of 22.370 pounds to the square inclu.

The stone takes a high polish, but the large size of its mica scales is not favorable to the durability of the polish under long-continued outloor exnosure. Polished faces show some magnetite. As the relative amount of gray to pink feldspar is small, the contrast is mostly between the pink feldspar and the smoky amethystine quartz, which is very pleasing. The minor spots of black mica give it still more character. This is a constructional granite hut is also, by its polish and contrasts, adapted to internal decorative uses.

The quarry, opened about 1887, measured in 1906 about 500 feet from east to west by 300 feet across and from 30 to $\$ 0$ feet deep, with a working face so feet high on the north.

Rock structure: The sheets, 4 to 30 feet thick, are normal and arch across the axis of the hill, dipping $15^{\circ} \mathrm{E}$. in this quarry. There are three sets of joints-(a). strike east, rertical, slaced 5 to 40 feet, not everywhere continuous; (b). strike N. $35^{\circ} \mathrm{W}$, dip $80^{\circ} \mathrm{S}$, forms a heading in the west part but does not recur: (c), strilit $\mathrm{N}$. $15^{\circ} \mathrm{F}$, vertical, recurs at 160 feet. The rift is reported as horizontal, and the grain as vertical with east-west course. Both are marked and appear as delicate cracks in the quartz particles on polished surfaces parallel to the "hard way." This interesting textural feature is fully discussel on bige 17 and is illustrated in figure 1. There are snall llikes of (leep pinkislı aplite (fine texturel, particles $0.185-0.555$ millimeter) consisting of pinkish orthockase. clear quartz, (lear oligoclase, and very little biotite, with secondaly muscovite and hematite stain. In the castern palt of quary is a mass about 30 feet from north to south by 20 feet from east to west and with an exposed depth of 10 feet, which may be a very large knot or possibly the upper part of a dike oval in cross section. Streaks of black mica 10 feet long radiate from its upper surface, also irregular pegmatitic bands with small dark-gray knots. Its matrix (particles 0.074 to 0.59 inillimeter) is of medium purplish-gray color and incloses porphyritic light pinkish feldspars up to 0.7 inch, light smoky quartz to 0.03 inch, and black silicate to 0.2 inch. The matrix itself consists of orthoclase, quartz, oligoclase-albite, 
hornblende, and biotite, with accessory magnetite, apatite, fluorite, titanite, and zircon. The large feldspars are orthoclase with intergrown oligoclase and quartz.

There are elliptical and spherical knots from 0.5 inch to 14 inches in diameter of exceedingly fine, very dark gray, large biotitic material with sparse porplyritic feldsiars. Lenses of pegmatite up to 2 feet by 6 inches also occur, and lenticular geodes, mainly of intergrown quartz and feldspar surrounles ly a half-inch band of aplite. These geodes are lined with crystals of smoky amethystine quartz and orthoclase incrusted with chlorite and calcite. Some obtuse rhombs of calcite are 0.5 inch wide. Joint (c) is coated with epidote and chlorite, and the granite for 0.5 inch back of it is much altered to kaolin aud mica and stained by hematite and limonite. (see p. 83.) Rusty stain is an inch thick along sheet surfaces, but up to 4 inches along the joints.

The product is used mainly for buildings. Specimens: First National Bank, Chicago; First Nationál Bank and Hamilton County courthouse, Cincinnati; Wisconsin Telephone Co.'s building, Milwaukee. Wis.; Franklin Savings Bank and McAlpin Hotel, New York; Temple Bar Building, Brooklyn ; Union Station, Plttsburgh; city hall, Lowell, Mass.; base of Longfellow monument, Portland, Me.; State library, Concord, N. H. (the pilasters and trimmings of "Concord granite," the columns at entrance of polished green granite from the next quarry, and the rest of "Conway pink").

The Redstone green quarry, operated by the same company, is about 800 feet west-northwest of the pink quarry, described above, and about 140 feet above Redstone station. (See fig. 37.)

The granite (specimens D, XXVIII, 36, a. b, c), "Redstone green granite," is a biotite-hornblende granite of dark-yellow greenish color with black spots. Its texture is even grained, coarse, with feldspars up to 0.8 inch and mica to 0.3 inch. Its constituents, in descending order of abundance, are mediumgray potash feldspar (orthoclase) with some yellow-green stained cleavage faces (this feldspar is always minutely intergrown with lime-soda feldspar, oligoclase-albite, some of it is twinned, and it is all much kaolinized) ; dark yellow-green smoky quartz with cavities in two or three sets of intersecting sheets with rift and grain cracks parallel to two of them and in places coinciding with them (see p. 17) ; very little separate soda-lime feldspar (oligoclasealbite), slightly micacized; biotite (black mica) and hornblende, some of it corroded. Accessory: Magnetite (ilmenite?), fluorite, allanite (mostly in biotite), and zircon. Secondary: Kaolin, a white mica, calcite, epidote in veinlets, chlorite, and limonite.

An estimate of the mineral percentages, obtained by the Rosiwal method, yields the following results with 0.5 -inch mesh and total llnear length of 71 inches: Feldspar, 54.79 ; quartz, 38.26 ; mica (biotite), 6.95 .

An analysis made for the firm by Franklin C. Robinson, State assayer of Maine, in 1899, is given here merely for reference:

Analysis of "green granite" from Redstone, N. H.

Silica $\left(\mathrm{SiO}_{2}\right)$

Alumina $\left(\mathrm{Al}_{2} \mathrm{O}_{8}\right)$

14.64

Iron sesquioxide $\left(\mathrm{Fe}_{2} \mathrm{O}_{3}\right)$

1. 54

Iron oxide $(\mathrm{FeO})$

(Total iron oxides, 3.88.)

Magnesia (MgO) 
hare dements, mostly fitanimm ant zireonimm diuxides (Tio, and $/ \mathrm{r}_{0}$ )

Manganese, sulphur, calcium, and phosphates_....... Trars.

Ioss at red lieat, mostly water. . . (i1

99.74

Specific gravity, 2.634.

It will be noticed, on comparing the amounts of irom oxides in this and the red granite (1). 167), that this exceeds the other by 1 per cent, which is attrilutable to its larger content of horublende and allanite and of the limonite proceeding therefrom.

When first quarried this stone is more greenish than after a few yaurs' exposure, when its feldspars become more grayish, but its general color is even then still markedly greenish. The cause of this change is not apparent, for organic acids do not reach the quarried blocks. It takes a high polish, but its large mica plates furnish vulnerable points of attack by the weather under prolonged exposure. The polished face shows a little magnetite. The contrasts are weaker than in the red granite, owing to the darker shade of its feldspar. Whether in the rough or polisher, its color is striking. Thongh not unsuitable for purposes of construction, it is a coarse decorative granite well adapted for sheltered positions.

The quary, opened about 18si. measured in 1906 abont 150 feet north to south by 100 feet across and up to 50 feet in depth, which is the height of the working face on the north. It is worked at intervals only.

The sheets, 11 inches to 14 feet thick, dip about $15^{\circ} \mathrm{W}$. Joint sets, rift, and grain are the same as in the red quarry.

The product is used for buildings and polished columus. Specimens: Union Arcade Building, Pittsburgh, Pa.; front of the first three stories of Fidelity Mutual Life Insurance Building, lhiladelphia; interior columns, post office, Washington, D. C.; exterior columns, Dime Savings Bank, Detroit, Mich.; interior columns, Missouri capitol, Jefterson City, Mo.; exterior columns, First National Bank, Bridgeport, Conn.; also in Baxter Building, l'ortland, Maine.

The White Mountain quarry is in the town of Conway, 13 miles southwest of North Conway, on the west sirle of a hill between Saco River and Moat Brook, southeast of White Horse Ledge. (See fig. 37.) Owner, Henry A. Hitner's Sons Co., Pennsylvania Building, Philadelphia.

The granite (specimens D, XXVIII, 38, a, b) is a biotite granite of medium pinkish buff-rray color with black spots. Its texture is even grained, coarse, with feldspars up to 0.5 inch and mica to 0.3 inch. Its constituents, in descending order of abundance, are pinkish-buff potash feldspar (orthoclase) in twins and minutely intergrown with soda-lime feldspar (oligoclase-albite), also intergrown with quartz and kaolinized; amethystine quartz with cavities in sheets intersecting at right angles, those in the rift direction being very close together; slightly greenish gray sola-lime feldspar (oligoclase), also interwown with quartz, kaolinized, ond partly micacized, in places inclosed in orthoclase; biotite (black mica). some of it chloritized. Accessory: Fluorite, allanite, zircon. Secondary: Kaolin, a white mica, chlorite, and limonite and hematite stain.

This is a coarse constructional granite with good rift.

The quarry, not operated since December 1. 1903, lies between the 645 and 735 foot levels, measures about 400 feet $\mathrm{N}$. $75^{\circ} \mathrm{W}$. by 250 feet across and from 
35 to 90 feet in leptl, The top of the working face is 30 feet below the top of the hill.

Rock structure: The sheets, from 3 to 30 feet thick, are horizontal or dip low north and also south. Joints (a) strike N. $30^{\circ}$ E., dip $60^{\circ}$ N. and $90^{\circ}$, spaced 20 to 70 feet. Joints (b) strike $\mathrm{N}$. $70^{\circ}-80^{\circ} \mathrm{W}$., vertical, spaced 2 to 50 feet.

Iiusty stain is from 1 to $S$ inches thick en the sheets and up to 2 feet along the joints.

Transportation by private siding, 13 miles long, from main line of Boston \& Maine Railroad. (See fig. 37.)

This quary was opened by the contractors for the Boston dry dock at the Charlestown Nary Yard, in which the stone was used.

\section{MADISON.}

The Fletcher quarry is in the town of Madison, about $2 \frac{1}{2}$ miles southwest of Conway and 1 mile about west of the main line of the Boston \& Maine Railroad. (See Pl. I.)

The granite (specimens D, XXVIII, 37, b, d)--the more pinkish variety-is a biotite granite of light pinkish-gray color, mottled with dark purplish gray and with small black spots. Its texture is even grained, coarse, with feldspars up to 0.7 inch and nica to 0.2 inch. Its constituents, in descending order of abundance, are a light pinkish-gray potash feldspar (orthoclase, mostly twinned), minutely intergrown with soda-lime feldspare (oligoclasealbite) and considerably kaolinized; dark amethystine smoky quartz with cavities; translucent slightly greenisl-white striated soda-lime feldspar (oligoclase), partly micacized; and biotite (black mica), some of it chloritized. Accessory: Magnetite ancl allanite. Secondary: Kaolin, a white mica, and chlorite.

An estimate of the mineral percentages. by the Rosiwal method yields the following results with mesh of 0.5 inch and total linear length of 20 inches: Feldspars, 67.20; quartz, 2S.60; mica (biotite), 4.20.

E. C. Sullivan, a chemist of this Surver, finds that this granite contains 0.25 per cent of $\mathrm{CaO}$ (lime) soluble in hot dilute acetic acid, which indicates a content of 0.44 per cent of $\mathrm{CaCO}_{3}$ (lime carbonate).

This is a coarse-textured constructional granite of warm tint, possessing marked contrasts of color, which come out strongly on the polished face (delicate pink, mottled with purplish smoke and dotted with black). The somewhat large mica scales are not favorable to the durability of the polish under long-continued outdoor exposure.

The less pinkish variety (specimen $37, a$ ) is like the other except in that the orthoclase is more nearly cream-colored. Apatite and zircon appear among its accessory minerals. Its contrasts are, if auything. a trifle more marked than those of the other.

The quarry, opened between 1SSS and 1891, abandoned before 1917, is at the east foot of a granite bluff 200 feet high. which also has a steep sonth sicle. It is about 500 feet square, with an extension on the bluff where there is a working face 100 feet high. Its depth is from 15 to 50 feet.

Rock structure: The sheets, 2 to 20 feet thick, are horizontal but dip $10^{\circ}$ E. to ENE. There are two sets of joints--(a), strike N. $80^{\circ}$ W., vertical spaced 5 to 100 feet, forms a 10-foot hearling in the north half of quarry and another at the north wall; (b), strike $\mathrm{N}$. $15^{\circ}$ E., vertical, spaced 5 to 100 feet, forms a heading on the east side. The rift is reported as horizontal and the grain as vertical, with $N$. $80^{\circ} \mathrm{W}$. eourse. The pinkish variety oc- 
curs on the south side, and the lighter variety on the north. Rare granitic dikes. 1 to 6 inches wide, eonsist of a groundmass of medium-gray shade and fine to medium textmre (orthoclase, microchine, oligoclase-all,ite, fllartz, and biotite), spangled with biotite and with porphyritic pinkish fellspars up to 0.4 inch. Rusty stain is from 1 to 4 inches thick on upper sheets, lecreasing below. Joint faces are coated with epidote.

Transportation, by a siding 1 mile to main line of boston \& Maine Raiboatl.

In 1906 the stone was used for celtain piers on the lioston \& Maine Prison Point Street Bridge, at East Cambridge, Mass., and also for a bridge at south Acton, Mass. Specimen monument: Dudley Porter memorial fountain, Haverhill. Mass.

CHESHIRE COUNTY.

FITZWILIIAM DISTRICT.

GEOLOGIC REIATIONS.

The granite of the Fitzwilliam district, Cheshire County, occurs in an area extending a little into the State of Massachusetts, designated by Emerson ${ }^{70}$ on the geologic map of that State "Fitzwilliam granite (white muscovite-biotite granite)," and regarded by him as of late Carboniferous or post-Carboniferous ase.

QUARRILS.

The Webb Fitzwilliam quarry is half a mile south of Fit\%william Depot, in ritzw:lliam Township. (See Monadnock topographic map, U. S. Geol. Survey.) Orerator, Webh Granite \& Construction Co., 40 Crescent Street, Worcester, Mass.

The granite (specimen D. XXX, 66, a), "Fitzwilliam Webb," is a muscovitehiotite granite of light, very biuish gray color and of even-grained fine texture, with feldspars and micas under 0.2 inch. Its constituents, in descending order of abundance, ale clear, colorless to translucent bluish potash feldspar (micro(line and orthoclase), slightly kaolinized; clear colorless quartz with cavities amt hairlike crystals of rutile; clear to milk-white soda-lime feldspar (oligo(lase), some of it slightly kaolinized and micacized; muscovite (white mica) in lalde scales; and biotite (black mica) in more abundant and much smaller sales. Accessory: Magnetite (very little), apatite, rutile. Secondary: Kaolin. ¿ white mica. No effervescence with muriatic-acid test.

The quarry, opened before 1829 , measured in 1909 about 1,300 feet in a $\mathbf{N}$. $50^{\circ} \mathrm{E}$. direction by 200 feet in width for half of its length and by 250 feet for the rest. and from 6 to 35 feet in depth.

lorek structure: The slects are 6 inches thick at the tor and 3 feet at the botton, the greater part, howerer, being thin ones. They dip $15^{\circ} \mathrm{NW}$. at the northwest side but turn, dipping northeast on the northeast side of the hill. The general structure of the hill is thus that of either a dome or an anticline. There are only five joints-set (a), of four joints, near the northeast end of the quarry, strike N. $20^{\circ}$ W., dip $90^{\circ}$ or steep, spaced 5, 20, and 100 feet; (b), near the southwest end of the quarry, strike N. $40^{\circ} \mathrm{E}$. dip $70^{\circ} \mathrm{N} .50^{\circ} \mathrm{W}$. The rift is reported as striking N. $55^{\circ} \mathrm{E}$. and dipping $35^{\circ}-40^{\circ} \mathrm{N} .35^{\circ} \mathrm{W}$., and the griain as dipping $80^{\circ} \mathrm{S} .35^{\circ} \mathrm{E}$. In working the rock is split along the grain. Many dikes of garnetiferous pegmatite, from an inch to 2 feet thick, strike north or north-northwest and dip $90^{\circ}$ or $20^{\circ} \mathrm{E}$. In places the pegmatite is associated with

${ }^{7}$ Emerson, B. K., Geology of Massachusetts and Rhode Island : U. S. Geol. Survey Bull. Б97. pl. 10 , p. 238,1917 . 
aplite. Small apite dikes, 1 to 2 feet apart, strike east. All these dikes throw (onsiderible stone into the second class. No rusty stain nor segregations wer? (n)

Thanspoltation, by a z,000-foot silling to Fitzwillam Delwt. besicles 1.jog foot of subsidiary siding in the quarry.

The probuct was used mainly for huildings and nomments. Specimens: Gity hall, Newark, N. J.; alploaches and base of First Church of Chr:st. Scientist, Boston. The smaller sheets were used for paving.

This quarry was abandoned before 1917 .

The Victoria White (formerly Silver White) quarry is a quarter of a mile northeast of Fitzwilliam Depot, in Fitzwilliam Township. (See Monadnock topographic map, U. S. Geol. Survey.) Operator, Milford Pink-Victoria White Granite Co., Milford, Mass.

The granite (specimens D, XXX, 6S, a, b), "Victoria white," is a biotitemuscovite granite of light bluish-gray color and of even-grained, very fine texture, with feldspars under 0.1 inch and micas to about 0.05 inch. Its constituents, in descending orler of abundance, are clear colorless to traus. lucent bluish potash feldspar (orthoclase and microcline); very light smoky quartz with cavities and hairlike crystals of rutile; clear to milk-white sodalime feldspar (oligoclase), very little kaolinized. some small mica crystals; biotite (black mica); muscovite (white mica). Accessory: Rutile. Secondary: Kaolin, alcite. Effervesces slightly with muriatic-acid test. Polished face shows neither pyrite nor magnetite.

An estimate of the mineral percentages by the application of the Rosiwal method to a camera lucida drawing of a thin section enlarged 40 diameters yields these results with a mesh of 1.8 and a total linear length of 43.2 inches:

Estimated mineral percentages in Fitzwilliam granite from Victoria White quarry.

Quartz

43. 66

Potash feldspar (microcline and orthoclase)

32. 22

Soda-lime feldspar (oligoclase)

13. 52 \}

45. 74

Black mica (biotite)

$5.88\}$

White nica (muscovite)

4. 72

100.00

The average diameter of the particles, obtained from the same calculation. is 0.00668 inch.

Prof. Leonard P. Kinnicutt, of the Worcester Polytechnic Institute, by a test made December 11, 1908, for the Norcross Bros. Co. in Worcester, found that 100 pounds of Fitzwilliam granite quarried at this or the Snow Flake quarry absorbed 0.382 pound of water.

This is a delicate bluish-gray fine-grainet stone. well adapted for fine work. Its particles are so fine and its minerals so evenly distributed that aside from a fine mottling, visible only near by, its color is uniform. It takes a good, polish.

The quarry, opened about 1904, was in 1909 about 300 feet square and 40 feet leep.

IRock stlucture: The sheets consist of short lenses at the surface but are not well marked below. The quarly is probably near the lower limit of 'sheet structure. There are no joints, but here and there a fracture crosses one sheet only. One such fracture strikes N. $40^{\circ} \mathrm{E}$. and $\operatorname{dips} 60^{\circ} \mathrm{N}$. $50^{\circ} \mathrm{W}$. The 
rift is reported as horizontal and the grain as vertical, with a neally east-west course. Pegmatite dikes up to 1 foot thick strike N. $30^{\circ} \mathrm{W}$. and N. $60^{\circ} \mathrm{W}$., with steep dips. Biotitic segregations are rare and up to $t$ inches alcross. There is little or no rusty stain on sheet surfaces.

The product is used for monuments. Specimens: Pylon monuments and approach to Manhattan Briclge, Brooklyn Plaza; Katherine Sefton l'age Memorial, Auburn, N. Y.; L. C. Smith mausoleum, Syracuse, N. Y.; industrial monument by Zolnay, New Bedford, Mass.; C. IV. Post mausoleum, Oak Hill Cemetery, Battle Creek, Mich.; Lilly exedra, Anđerson, Inc.

The Snow Flake quarry is two-fifths of a mile northeast of Fit\%william Depot and three-fourths of a mile south of Fitzwilliam village, in Fitzwilliam Township. (See Monalnock topographic map. U. S. Geol. Survey.) Owner, Victoria White Granite Co., Keene, N. H.

The glanite (specimen D. XXX, 67. a), "Snow Flake," is a biotite-musenvite granite of light inclining to medium gray shade and of porphyritic texture, with fine matrix (micas under 0.1 inch) and feldspars to 0.5 inch. Its constituents, in descending order of abundance, are faintly greenish clear potash feldspar (microcline in twins with crush borders, also orthoclase), some of the microcline intergrown with quartz, some slightly kaolinized; light smoky quartz with cavitles, generally in sheets, and hairlike crystals of rutile; clear to milk-white soda-lime feldspar (oligoclase-albite), some of it minutely intergrown with quartz (vermicular structure), some of it a little kiolinized; blotite (black mica); and muscovite (white mica). Accessory: Apatite, zircon, rutile. Secondary: Kaolin, limonite from liotite. No efforvescence with muriatic-acid test.

The fineness of the mica deprives the stone of strong contrasts, and the porphyritic texture is discernible only on close inspection.

The quarry, opened between 1885 and 1887, was in 1909 about 300 feet square and 40 to 70 feet deep.

Rock structure: The sheets, 10 to 20 feet thick, are about horizontal but irregular. There is but one joint. The rift is reported as horizontal and the grain as vertical, with about east-west course.

Transportation, by siding to Fitzwilliam Depot.

The product has been used for buildings.

The following are specimens of the combined product of this and the Victoria White quarry: Art Museum, Toledo, Ohio; law building of University of Iowa. Iowa City; post offices at Muskegon, Mich., Chippewa Falls, Wis., Grand Island, Nebr., Decatur, Ill., Bedford. Ind., Mayfield, Ky., Devils Lake, N. Dak., Allentown, Pa., and Ithaca, N. X.; and Wysong residence, corner Serenty-sixth Street and Serenth Avenue, New York City.

This quarry has not been operated since it passed into the hands of its present owners.

The Emerson quarry is 2 miles northeast of Fitzwilliam Depot, in Fitzwillam Townclip. Operator, Paul Drewes, Fitzwilliam Depot. Idle in 1922.

(See Monadnock topographic map, U. S. Geol. Survey.)

The granite is a muscovite-biotite granite, a trifle highter and conser textured than the "Victoria white" (11. 172).

The quarry measures about 1,000 feet square and 50 to 70 feet in depth.

The Yon quarry is about $1 \frac{1}{4}$ miles south-southeast of Fitzwilliam Depot and half a mile east of South Pond (Laurel Lake), in Fitzwilliam Township. (See Winchendon topographic map, U. S. Geol. Survey.) Operator, Edward Yon \& Son, Fitzwilliam Depot.

The granite, "white," resembles the other light bluisl-gray muscovite-biotite granites of thls township. 
The quarry, opened about 1897, has been regularly operated since 1908 .

The product is used mainly for buildings and monuments, also for curbing.

The Thompson quarry is about 2 miles northeast of Fitzwilliam Depot, in Fitzwillim 'Townshi]. (see Monalnock topographie map, U. s. Geol. Surrey.) Operator, E. M. Thompson, Fitzwilliam Depot.

The quarry was opened in 1900 .

The granite is a muscorite-biotite granite of medium grayish shade and fine even-grained texture with fellspars up to 0.2 inch. muscovite and biotite to 0.1 inch.

Its constituents, in descending order of abundince, are clear colorless potasl feldspar (orthoclase and microcline), with inclusions of plagioclase and intergrown with quartz; pale smoky quartz with rutile needles; clear to milk-white soda-lime feldspar (probably oligoclase); muscovite and biotite. No effervescence with muriatic-acid test.

The Webb Marlboro quary is $1 \frac{1}{4}$ miles north-northeast of Webb station (Marlboro depot), in Marlboro Township. (See Monadnock topographic map, I. s. Genl. Survey.) Operator, Hildreth Granite Co., Boston, Mass.

The grimite (specimen D, XXX, 69, a), "Marlboro." is a biotite-muscovite granite of light inclining to medium, very bluish gray color and of evengrained tine texture, with feldspars and mitas up to 0.2 inch. Its constituents, in descending order of abundance, are clear colorless to translucent bluish potash feldspar (microcline), intergrown with quartz, circular in cross section and slightly kaolinized; clear colorless quartz with cavities in sheets and hairlike crystals of rutile; milk-white soda-lime felclspar (oligoclase), somewhat kiolinized and with small plates of muscovite; biotite (black mica) ; muscovite (white mica). Accessory: Apatite, zircon, rutile. Secondary: Kaolin, calcite. Effervesces with muriatic-acid test.

The quarry, opened before 1849 , was originally about 950 feet long by about 700 feet wide but in 1909 measured about 750 feet in a north-northeasterly direction by 200 feet across and average 50 feet in depth.

Rock structure: The sheets, 6 inches to 6 feet thick, but not orer 2 feet in the upper half of the quarry. are normal and horizontal, but dip low northnortheast at the north end of the quarry and turn to dip low south-southwest at the south end. The thinness of the sheets and the compressive strain prerent channeling, so dynamite is used. Two vertical joints near the north end, with N. $60^{\circ}$ E. strike, extend off and on for 50 feet. On the extreme east side a joint striking $\mathrm{N}$. $50^{\circ}$ E. and lipping $50^{\circ} \mathrm{NW}$. extends only 100 feet. Flow structure is very marked on sheet surfaces at the west side. It consists of alternately more or less biotitic planes striking N. $30^{\circ}$ E. but also curving, varying much in width and resembling a gneiss foliation. On the east side flow structure lias a N. $35^{\circ} \mathrm{N}$. course. There is an inclusion or an irregular biotitic flowage band, $4 \frac{1}{2}$ feet long, 1 foot wide, and oval in cross section. The rift is reported as horizontal and the grain as vertical, with N. $22^{\circ}$ E. course. A thick pegmatite dike crosses the center of the quarry with N. $55^{\circ} \mathrm{W}$. course. There are smaller pegmatite dikes and streaks of like course in the northern half of the quarry. There is no rusty stitin on sheet surfaces.

Transportation, by 4 miles of siding from Webb station.

The product is used mainly for buildings, curbing, and paving. Specimens : The lower seven stories of the Marshall Field Building, Chicago; First Congregational Church, Nashua, N. H.; Soldiers' monument, Fitzwilliam village, $\mathrm{N}$. $\mathrm{H}$. 
The Troy quary is three-fourths of a mile east-southeast of Troy station, in Troy Township. (see Monalnock topographic map, U. S. Geol. Survey.) Quarry abandoned.

The granite (swecimen D, XXX, 70, al), "Troy white." is a museovite-biotite granite of light inclining to medium bhish-gray color and of eren-graned line texture. with feldspars under 0.2 inch and mica to 0.1 inch. Its constituents, in descending order of ahundance, are clear bluish polash feldspar (microcline, generally in twins, intergrown witl quartz, circular in cross section, also orthoclase) ; clear colorless quartz with hairlike crystals of rutile and calvities in sheets; milk-white soda-lime feldspar (oligoclase-albite), some of it minutely intergrown with quart\%, generally kaolinized and a little micacized, and with calcite; muscovite (white mica); biotite (black nica), some of it chloritized, Accessory: Magnetite (very little). write, apatite, rutile. Secondary : Calcite, a white mica, chlorite.

An estimate of the mineral percentages by the application of the Rosiwal method to a cameral lucida drawing of a thin section, enlarged 25 diameters, yields these results with a mesh of 1 inch and a total linear length of 59 inches, from which, however. areas of mixed particles too fine for measurement and having a total linear length of 1S.2S inches hat to be deducted, leaving as the total length of measured particles 40.72 inches:

\section{Estimated mineral percentages in "Troy aranite."}

Quartz

Potash feldspar (microcline and orthoclase)

Soda-lime feldspar (oligoclase-albite)

White mica (muscovite)

Black mica (biotite)
44. 94

44. 29

13. 06$\}$

8. 22

2. 55$\}$

100. 00

The following analysis, made for the Troy White Granite Co.. the last operators. by Prof. I. P. Kinnicutt, of the Worcester Polytechnic Institute. in 1891, is given here for reference:

\section{Analysis of "Troy white aranite."}

Silica $\left(\mathrm{SiO}_{2}\right)$

Alumina $\left(\mathrm{Al}_{2} \mathrm{O}_{3}\right)$

Lime $(\mathrm{CaO})$

Magnesia ( $\mathrm{MgO})$

Potash $\left(\mathrm{K}_{2} \mathrm{O}\right)$

Soda $\left(\mathrm{Na}_{2} \mathrm{O}\right)$

Loss and undetermined
73. 15

17. 04

.81

.30

574

2. 05

.91

100.00

Prof. Kinnicutt, by a test made December 11. 1908, found that 100 pounds of this granite absorbs 0.269 pound of water, as compared with 0.371 pound for the same weight of "Concord granite" and 0.420 pound for 100 pounds of quartz monzonite from the New Westerly quarry at Milford, N. H. (p. 188).

The following compression test on a 6 -inch cube was made at the United States arsenal at Watertown, Mass., April 15, 1891 (No. 7419) : First crack at 525,000 pounds. total 630,100 pounds: ultimate strength per square inch, 17,950 pounds.

This stone is harder than many other granites. It lends itself well to fine carving, as is shown by the garland of roses so finely executed by Joseph Cara- 
belli, of New York, on the Hawgood momument at Lake View Cemetery, Clevelant. (hin).

The quarry, opened about 1859 , measured in 1909 about 300 feet in a N. $15^{\circ} \mathrm{E}$. direction by 180 feet across and from 50 to 70 feet in rlepth.

Rock structure: The sheets, 6 inches to 15 feet thick, dip $10^{\circ}-15^{\circ} \mathrm{W}$. There are two sets of joints-(a), strike N. $77^{\circ} \mathrm{W}$., dip $65^{\circ} \mathrm{S} .13^{\circ} \mathrm{W}$.; (b), strike about nortin, one only, on the east wall. The rift is reported as horizontal, and the grain as vertical, with N. $15^{\circ}$ E. course. There are biotitic segregations up to '2 nches in diameter. Rusty stain is generally alssent, but one sheet surface showed 6 inches of it. An east-west compressive strain is noticeable.

Tramsportation by an electric siling, 4,230 feet long, operated by a 40-horsepower gasoline engine.

The product is used about equally for buillings and monuments. Specimens: Worcester County Institution for Savings, Worcester, Mass.; Bank of Pittsburg, Pittshurgh, Pa.; Howard Savings Institution, Newark, N. J.; Metropolitan Savings Bank, Paltimore; steps and approaches to Library of Congress, Washinston; steps and approaches to New York Library; Hawgood monument and Mark Hanna mausoleum. Lake View Cemetery, Cleveland, Ohio; James Lister monument, Swan Point Cemetery, Provilence, R. I. ; Albert Wyckoff mausoleum, Woodlawn Cemetery, New York.

\section{CONS COUNTT.}

\section{KILIENNY.}

The Kilkenny quarry is in Kilkenny Township, about 19 miles N. $28^{\circ} \mathrm{W}$. from the top of Mount Washington and about 5 miles N. $79^{\circ}$ E. from Lancaster station and 940 feet above it, on the southwest side of a ridge. (See Pl. I.) The quarry has been idle for a number of years.

The granite (specimen D, $\mathrm{XXX}, 73, \mathrm{~b}$ ), is an augite-biotite granite of dark olive-green color, a little lighter than the green granite of Mount Ascutney, Vt., and considerably dalker than the green granite of Redstone, N. H., and Iroxliport. Mass. (pp. 168, 293). It becomes ligliter-that is, more yellowish lrown-on continuet exposure. The polished face is a dark olive-smoke color. Its texture is even-grained medium, with feldspars up to 0.3 inch and black sili"ate to $0.1 \mathrm{jnch}$. Its constituents, in descending order of abundance, are medium olive-greenish potash feldspar (orthoclase), intergrown with soda-lime feldspar (probably albite) in alternating bands (microperthite), the feldspar sections almost all nearly rectangular; black (in thin section green) augite; biotite (black mica); greenish hornblende; rare grains of quartz with sheets of cavities; very little separate soda-lime feldspar (probably albite). Accessory: Magnetite, titanite, apatite. Secondary: Limonite from magnetite and biotite following the banding of feldspars. This is conspicuons in long-exposed specimens. No efferrescence with muriatie acid test.

The olive tint, as in other green granites, is probably due to the combination of limonite with the originally bluish color of the feldspar. The stone takes a high polish, but some blocks are streaked either from flow structure or from veinlets.

The quarry (the upper and more recent of two openings) is about 50 feet square and 10 feet deep.

Rock structure: 'The sleets, 1 to 5 feet thick, dip $30^{\circ} \mathrm{SW}$. Joints (a), strike N. $45^{\circ} \mathrm{W}$, vertical, spaced 6 to 30 feet; (b), strike N. $65^{\circ}$ E., vertical or steep southwest, one only on northwest side, slickensided. Minute veins run parallel to joints (b), spaced 6 inches to 3 feet and more, and disfigure that 
part of the rock. An aplite dike, 2 inches wide, strikes east. Rusty stain on sheet surfaces is not over an inch thick.

The quarry road to the highway at the foot of the ridge is over half a mile long. There is a disused lumber-railroad bed from the Boston \& Maine Railroad at Lancaster, within a mile of the quarry.

Some steps on the south side of the Lancaster House in Lancaster are made of the granite.

STARK.

The Dawson quarry is in Stark Township, 3 to 4 miles due east of Groveton station, on a north-south rilge about $S 00$ feet above the station. (See Pl. I.) Operators, Cushing \& Frizzell, Groveton. Quary abandoned.

The granite (specimens D. XXX, 74, a, e), "Stark," is a biotite granite of medium pinkish-gray color (a trifle darker than "Concord granite") and of even-grained medium texture, with feldspars nnder 0.4 inch and micas to 0.2 inch, exceptionally 0.3 inch. Its constituents, in lescending order of abundance, are pinkish potash feldspar (orthoclase), obscurely intergrown with plagioclase (probably oligoclase-albite) and much kaolinized; medium smoky quartz with cavities in sheets, a few in a set at right angles to the others; pinkish sodalime feldspar (oligoclase-albite); biotite (black mica), some of it chloritized; and rarely a scale of bleached biotite or muscovite. Accessory: Magnetite, allanite, apatite. Secondary : Kaolin, a white mica, limonite, epidote, chlorite. No effervescence with muriatic-acid test.

An estimate of the mineral percentages by the Rosiwal method yields these results with a mesh of 0.3 inch and a total linear length of 66.4 inches: Feldspar, 70.14 ; quartz, 27.15 ; mica, 2.71.

This is a constructional granite of dull pinkish color and feeble contrast, which. however, may become stronger as the quarry deepens.

The quarry, opened before 1897, measured in 1909 about 50 by 30 feet and 8 to 20 feet in depth.

Rock structure: The sheets, 6 inches to 3 feet thick, are horizontal. One set of rertical joints strikes $\mathrm{N}$. $80^{\circ} \mathrm{W}$. and is spaced 20 feet. There are traces of a north-south set. A few discontinuous ones strike N. $50^{\circ}$ E. There are fine-grained light-gray and also black segregations, some of the latter with biotite and quartz inclosed in whitish lenses.

The quarry is operated only in winter, on account of the economy of sledding the stone to Groveton rather than carting it over bad roads.

The product is used for trimmings. Specimens: Trimmings of courthouse, Berlin, N. H., and of several buildings in Lancaster, and a monument in the cemetery at Groveton, N. H.

The firm also opened another quarry in the same stone about a mile north, in Stark. It is near the Grand Trunk Railway and thus has better shipping facilities.

\section{GRAFTON COUNTY.}

\section{CANAAN.}

The Mascoma quarry is on the top of a knoll $1 \frac{1}{2}$ miles north-northeast of Enfield station, in Canaan Township. (See Hanover topographic map, U. S. Geol. Survey, also geologic map of Hanover and Lebanon, N. H., by C. H. Hitchcock, Vermont State Geologist Eighth Rept., pl. 46, 1912.) Operator, Norcross Bros. Co., Worcester, Mass. Quarry abandoned.

The granite (specimens D. XXX, $7 \pi$, a, b. e), "Mascoma," is a biotite granite gneiss of lisht buff-glay color speckled with black, and of even-grained. 
somewhat gneissoid coarse texture, with feldspars up to 0.7 inch and mica aggregates to 0.4 inch. Its constituents, in descending order of abundance, are very light hufi-glay (almost cram-colored) potash feldspar (microcline and orthoclase), slightly kaolinized; light smoky quartz, coarsely granulated, with carities in sheets and cracks jarallel thereto; milk-white soda-lime feldspar (oligoclase), much intergrown with quartz minutely circular in cross-section, generally kaolinized and micacizel; biotite (black mica), some of it chloritized; and very little muscovite or hleached biotite. Accessory : Magnetite, titanite, apatite, zircon. Secondary: Kaolin, a white mica, chlorite, calcite, rare limonite stain, and probably hematite. It effervesces with muriatic-acid test.

This is a constructional granite, in some respects resembling that of Milford, Mass. (p. 342). It takes a fail polisin, and the polished face shows some magnetite. The contrasts are chiefly between the black mica and the other minerals.

The quarry, opened in 1907 , measured in 1909 about 147 by 70 feet and 5 to 25 feet in depth.

Rock structure: The sheets, 6 inches to 3 feet thick and over, are about horizontal, forming short lenses. There are three sets of joints: (a), strike N. $50^{\circ}$ E., dip $70^{\circ}$ N. $40^{\circ}$ W., spaced 2 to 25 feet, forms a heading at the northwest corner; (b), strike N. $80^{\circ}$ W., dip S. $10^{\circ}$ W., spaced 2 to 25 feet; (c), strike N. $65^{\circ}$ E., dip $60^{\circ}$ N. $25^{\circ}$ W.. spaced 4 to $S$ feet and more. Flow structure strikes porth. In the center of the quarry is a flowage band with more pinkish feldspars. The rift is reported as horizontal and the grain as rertical, with $N$. $32^{\circ}$ W. course. A pegmatite dilie (smoky quartz and feldspar) up to 5 inches thick strikes northeast. There are lenses or veins of smoky quartz up to 4 inches thick. Biotitic knots measure up to 6 inches across. There is hardly any rusty stain along the surfaces of lower sheets, and on joint faces it is not over 2 inclies thick.

Transportation, by cart 2 miles to Enfield station.

The product is used mainly for buildings. Specimens: Tercentennial commemorative monument, Jamestown, Va.; lower stories of Slater Building, Worcester, Mass.; Plain Dealer Building, Cleveland, Ohio; Carnegie Institute, Pittsburgh, Pa.; Royal Bank of Canada, Winnipeg, Manitoba.

\section{LEBANON.}

The Lebanon quary is at the east foot of Quarry Hill, on the west side of and close to the Hanover-Lebanon road, $1 \frac{1}{4}$ miles north of Lebanon village, in Lebanon Township. (See Hanover topographic map, U. S. Geol. Survey; also geologic map of Hanover and Lebanon, N. H., by C. H. Hitchcock, Vermont State Geologist Eighth Rept., pl. 46, 1912.) There are some now disused quarries of the same glanite higher up on Quarly Hill. Owner. Rockport Granite Co. Fockport, Mass. Quarry idle.

The granite (specimens D, XXX, 70. a, b), "Lebanon pink," is an epidotic biotite granite gneiss of light, faintly pinkish and greenish gray color, speckled with greenish black, and of gneissoid coarse texture, with feldspars up to 0.7 inch and mica aggregates to 0.4 inch. Its constituents, in descending order of abundance. are light-pinkish potasli feldspar (microcline and orthoclase, some minutely intergrown with plagioclase), more or less kaolinized; clear colorless quartz, with carities and few hairlike crystals of rutile. finely granulated; a little greenish soda-lime feldspar (oligoclase-albite to albite), much kaolinized and epidotized; biotite (black mica), usually associated with epidote and some of it cllloritized; and a little muscovite (white mica). Accessory: Magnetite, pyrite, titanite. Secondary: Epidote, kaolin, calcite, a white mica, 
chlorite. Epidote is fifth in order of abunlance. In places the foldspars are surrounded by crushed feldspars and epilote. Eftervesces with muriatic-acil test. $^{\text {so }}$

This is a constructional granite of mixed greenish and pinkish tint and gneissoid texture, resembling in some respects the granite of Milford, Mass., and also that of the Mascoma quarry. The polish is poor, owing to the presence of large mica aggregates. The polished face shows nagnetite and pyrite.

The present quarry was hardly fully opened in 1909 . The opening measured then 150 by 50 feet and up to 10 feet in depth.

Rock structure: The sheets, 5 to 10 feet thick, are about horizontal. There are four sets of joints-(a), strike N. $43 \mathrm{~W}$., vertical or steep northeast, also $35^{\circ} \mathrm{NE}$., spaced 10 to 20 feet; (b), strike N. $25^{\circ}$ E., (lip $70^{\circ}$ S. $65^{\circ}$ E.; (c), strike N. $15^{\circ} \mathrm{W}$.. dip $55^{\circ}$ S. $75^{\circ} \mathrm{W}$., spaced 10 feet and more; (d), strike N. $80^{\circ}$ E., dip $40^{\circ}$ N. $10^{\circ}$ W., faced with secondary muscovite, spaced 9 feet and more. The rift is probably horizontal. Dikes of light-pinkish aplite up to $3 \frac{1}{2}$ inches thick range from the horizontal to a dip of $30^{\circ} \mathrm{W}$. Light and dark segregations are up to 4 inches across. Rusty stain on sheet surfaces is not over 2 inches thick.

Transportation, by cart 11 miles to rail at Lebanon.

The product is used for buildings. Specimens of the same granite but largely from now disused openings are the following: India Building. Boston; two storles (polished) of the New York Mutual Life Insurance Building, on Chestnut Street, Philadelphia; two stories of the Borden Building. Hudson Street, New York. The stone has also been used to some extent in the chapel, hospital and Butterfield Memorial buildings of Dartmouth College, at Hanover, N. H.

\section{HAVERHILI.}

The Pond Ledge quarries are on the southeast side of the domelike granite mass known as Briar Hill, about a mile from Haverhill Center and about 3 miles east of Black Mount station (North Haverhill), in Haverhill Township. (See Pl. I.) Briar Hill lies about N. $60^{\circ}$ W. of Black Mountain. Operator (1909), Jessman Granite Co., North Haverhill. Quarries abandoned.

The granite from the southwestern quarry (specimen $D, \operatorname{XxX}, 75, a$ ), " Pond Ledge gray," is a biotite-muscovite granite of light inclining to medium gray shade, and of even-grained fine texture, but with sparse porphyritic clear feldspars up to 0.4 Inch and mica under 0.1 inch. Its constituents, in descending order of abundance, are clear colorless potash feldspar (microcline and orthoclase) ; clear colorless quartz with cavities and hairlike crystals of rutile and granulated; milk-white soda-lime feldspar (oligoclase-albite), kaolinized, nicacized, and with calcite; biotite (black mica), some of it chloritized; muscovite (white mica). Accessory: Magnetite, titanite, apatite, zircon, allanite, rutile. Secondary: Kaolin, a white mica, calcite, epidote, chlorite. Efferresces with muriatic-acid test.

The granite from the northeastern quarry (specimens $\mathrm{D}, \mathrm{XXX}, 75, \mathrm{~b}, \mathrm{c}$ ), "Pond Ledge pink," is a biotite-muscovite granite of light pinkish-gray color and even-grained fine texture, but with sparse porphyritic feldspar up to 0.3 inch and micas to $0.1 \mathrm{inch}$, rarely 0.2 inch. Its constituents are identical with those of the gray (specimen 75 , a), but the secondary minerals include some hematite, which produces the pinkish tint.

so A full microscopic description of this granite was giren by J. $r$. Iddings in U. S. Geol. Surrey Bull. 150, p. 353, 1898. He regards the epidote as mostly primary. (See in this connection Butler, B. S., Pyrogenetic epidote: Am. Jour. Sci., 4th ser., vol. 28, pp. 27-32, 1909.) 
This stone takes a good polish. It is said to lose some of its pinkish tint on continued exposure.

These "quarries" merely utilize the talus of Briar Hill-that is, material already quarried by glaciers, frost, etc. The blocks are attacked at two points about 1,000 feet apart.

Rock structure: The structure above the talus is not clear. The sheets on top of the bill are said to be horizontal and to range from 6 inches to 10 feet in thickness. On the side above the talus some steep joints or sheets strike nearly with the face of the cliff and are spaced 20 feet and more. There are also gently northwestward-dipping planes, possibly headings. The two granites are reported as merging into each other, the rift as dipping gently northwest, and the "head grain" as forming an angle of $75^{\circ}$ to $80^{\circ}$ to it. Knots are 2 inches across. Rusty stain is an inch thick on sheets, rarely 6 to 8 inches.

Transportation, by cart 3 miles to rail.

The product is used for monuments at Bath, Lisbon, Haverhill, and Haverliill Center cemeteries.

HILLSBOROUGH COUNTY.

\section{MILFORD DISTRICT.}

TOPOGRAPHY.

The Milford quarries lie within a radius of 4 miles northwest, southwest, and south of Milford Village. The region about Milford, as shown on the Milford topographic map published by the United States Geological Survey, is marked by hills and short ridges, from 440 to 760 feet above sea level, trending north or north-northeast. The highest of these hills are Burns Hill (720 feet) and Badger Hill (760 feet), southwest of the village, and Federal Hill (700 feet), southeast of it. This hilly surface is, however, bisected east and west by the valley of Souhegan River, which hereabouts flows between the 206 and 240 foot levels. The locations of the quarries are shown on the map (fig. 38). None of them are above the 400 -foot level, or 130 feet above the bench mark at Milford Village.

\section{GEOLOGY OF QUARRIES.}

The most interesting geologic features of the Milford granite quarries are the contact phenomena and inclusions. The former have been fully described on page 90 and are illustrated in figure 17 and Plate VIII, $A$. At these places remnants of the gneisses which once probably overlay the granite mass of the entire region are preserved. As these gneisses are evidently themselves granitic rocks which under powerful compression have undergone chemical and textural changes and become schistose, we are led to conclude that the Milford region has been the scene of two intrusions of rock material in molten condition, with an intervening period of metamorphism. The gneiss now capping the granite at the quarries of the Milford Grinite Co. (p. 91) represents the earlier granitic rock metamorphosed, the presence of which supplied part of the pressure that made possible as granite the stone now quarried. The strike of the gneiss foliation, N. $75^{\circ} \mathrm{W}$., furnishes a clue to the direction from which came the compression that metanorphosed the earlier granite. It is assumed, of course, that these few feet of gneiss are but the shreds of a mass which originally measured lundreds of feet in thickness but which was eroded mainly in preglacial tlme. The pegmatite dikes, which, apparently starting at the contact, run up into the 
gneiss. were probably formed ar the time of the intrusion of the underlying granite. This original gneiss of the region is also exposed at the 'Tonella quarries. (See pn. 1S6-187.) At two quatries fragments of coarse hiotite gneiss occur as inclusions in the granite. (See pp. 64, 1ST.) These probably formed part of the same overlying gneiss, which, indeed, they closely resemble. This was fractured $h y$ the vertical and lateral strain accompanying the intrusion, and

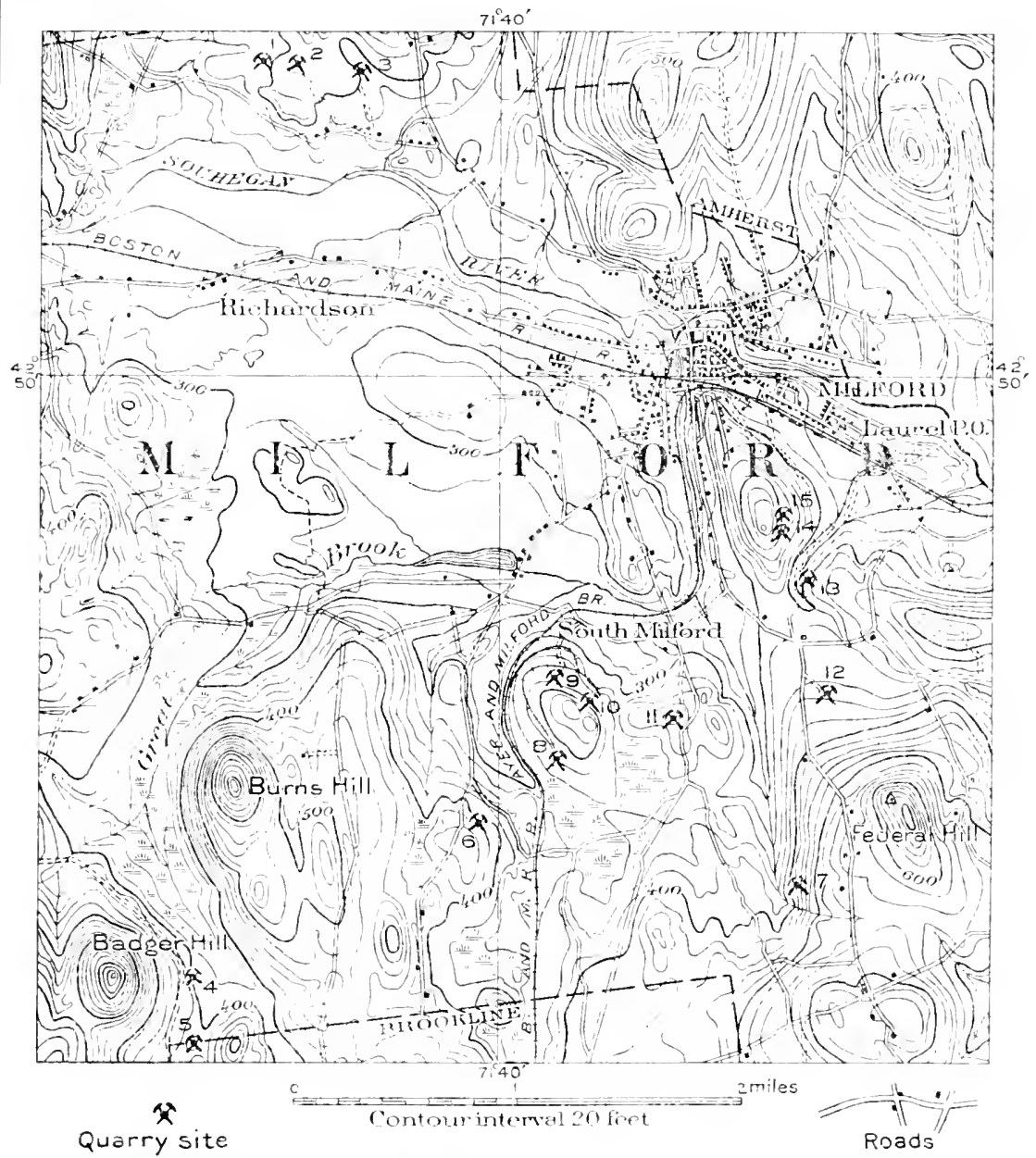

Figure 3S.-Map of vicinity of Milford, N. H., showing location of granite quarries. 1. New Westerly ; 2 , Carlton ; 3 , Bishop ; 4, Comolli ; 5 , Paradise ; 6 , Tonella ; 7 , Souhegan ; 8 , Lorejoy ; 9, Pease ; 10, Kittredge ; 11, Tonella Old; 12, Hayden; 13, Young ; 14, Milford Granlte Co., south opening; 15, Milford Grantte Co., north opening.

fragments fell into the rising semiliquid fused mass. There is also at several quarries a marked banding in the granite, with courses of north, N. $15^{\circ}, 20^{\circ}$, $50^{\circ}, 70^{\circ} \mathrm{E} .$. and $\mathrm{N} .75^{\circ}-80^{\circ} \mathrm{W}$., which must hare been caused by the grinite current (flow structure).

Flow structure about an inclusion at the Daniels quarry has been described on page 64 and the occurrence of pegmatite dikes in groups on page 73 . The 
courses of pegmatite dikes at the quarries are $\mathrm{N} .20^{\circ}, 25^{\circ}, 30^{\circ}, 75^{\circ} \mathrm{E}$. and $\mathrm{N}$. $20^{\circ}, 25^{\circ}, 50^{\circ}, 65^{\circ} \mathrm{W}$. These must be attributed to a seconlary intrusion in the grante in openings lussibly due to contraction. The pegmatites thus represent a third access of heated matter to this portion of the crust. Finally, the basic dikes, noted on pages $184,185,187$. represent a fourth and probably much later injection of rock material in molten condition. The effect, direct or indirect, of these dikes in reublening the adjacent granite is rery noticeable (see 1P. 1S5, 1S7) and appears to be due to the hematitization of the feldspars either by the oxidation of magnetite by water or by the deoxidation of limonite by heat. The most abundant set of joints strikes $\mathrm{N} .70^{\circ}-85^{\circ} \mathrm{W}$., its complementary set striking $\mathrm{N} .10^{\circ}-30^{\circ}$ E. Others strike north, N. $35^{\circ}-10^{\circ}, 45^{\circ}-50^{\circ}, 60^{\circ}$ D., and N. $30^{\circ}, 50^{\circ}, 60^{\circ} \mathrm{W}$. The rift is reported at all the quarries as either horizontal or inclined at a very low angle south or $\mathrm{S}$. $70^{\circ} \mathrm{W}$. or west. The grain is reportes as vertical or dipping $70^{\circ} \mathrm{N}$. with a course of $\mathrm{N} .60^{\circ}-90^{\circ} \mathrm{W}$., in one llace $\mathrm{X}$. $50^{\circ} \mathrm{F}$. The sheets are from 3 inches to 30 feet thick.

\section{" MILTORD GRANITE."}

The following combines all the more detailed descriptions of specimens and thin sections given on pages $183-190$.

The granites of Milford, N. H., are quartz monzonites of light, medium and dark-gray shade, in places of a slight bluish. pinkish, or buff tinge, and always spangled with black mica. The texture of all except one is even grained and very fine to fine, with feldspars and mica in the very fine up to $0.1 \mathrm{inch}$ and in the fine to 0.2 inch. The constituents of these monzonites, in descending order of abundance, are clear to slightly smoky quartz with cavities (in sheets) up to $0.00 \mathrm{~S}, 0.017,0.03$ millimeter, and in some quarries with hairlike crystals, prohably of rutile; clear colorless to milk-white, bluish, greenish, or pinkish soda-line feldspar (oligoclase), somewhat kaolinized and micacized; clear colorless to milk-white, bluish, greenish, pinkish, or cream-colored potash feldspar (microcline with or without orthoclase), in places slightly kaolinized and micacized; black nuica (biotite), some of it chloritized or bleached. Both feldspars are intergrown with quartz circular in cross section. Accessory : Magnetite, nyrite, apatite, zircon, allanite, and rutile. Secondary: Chlorite, two white micas, carbonate, liaolin, limonite, and hematite.

Estimates of the mineral percentages by the application of the Rosiwal method to camera lucida drawings of three thin sections of the very fine Milford granite from three widely separated quarries (1pp. 1S6, 1SS, 190) yield the following results:

\section{Average estimates of mineral percentages in monumental granite of} Milford, N. H.

Quartz

27.09

Soda-lime feldspar (oligoclase)

34.03

Potash feldspars (microcline 14.15 ; orthoclase 15.57)

29. 72

Black mica

8. 58

Magnetite

Minor accessories

As the percentages of quartz, sodil-lime feldspar, and mica varied considerably in the separate estimates, the averages for these minerals are more trustrortiny. 
The arerage dianeter of the particles in these three granites, as determined by the same methol. is 0.0095 inch, which is about the sime as the average of three "blue granites" of Westerly, R. I., given on page 407 as 0.0099 inch.

Messrs. Sullivan, Schaller, and Steiger, chemists, of this Survey, found that granite from five Nilford quarries contained from 0.11 to 0.26 per cent of CaO (lime) soluble in lot dilute acetic acid, or an average of 0.16 per cent, which indicates a content of 0.19 to 0.46 per cent, or an average of 0.29 per cent, of $\mathrm{CaCO}_{3}$ (calcium carbonate). The rresence of this carbonate is also shown by the microscope and by effervescence with muriatic acid test.

The finer "Milford" granites, which are properly monumental granites, take a high polish. to which the fineness of the mica contributes. The hammered face of these quartz monzonites offers a consideralle contrast to the polished face, owing to their large percentage of soda-lime feldspar. The particles are so fine that the only contrast, that between the mica and the other particles. is visible only at a short distance. In the coarser "Milford" granites, in which the mica measures 0.2 inch in two of its diameters. this contrast is more marked. The chief characteristics of all these finer granites are the uniformity and delicacy of their shade or tint, the varjety of tints obtainable at the different quarries, and the adaptability of the stone for fine carving. The coarser "Milford" granites are entirely constructional.

\section{QUATRIES.}

The Lorejoy quarry is in Milford, about 2 miles S. $25^{\circ} \mathrm{W}$. of Milford village, on the 380 -foot lerel, on the sonthwest side of an oblong hill 440 feet high. (See fig. 3S.) Operator, Lorejoy Granite Co., Milford.

The granite (specimen D, XXVII, 51, b), "Milford, N. H.," is a quartz monzonite of light-gray shade spangled with black mica. Its texture is eren grained, fine, inclining to medium, with feldspars and mica up to 0.2 inch. It consists, in descending order of abundance, of a milk-white potash feldspar (microcline and orthoclase); in almost equal amount a clear to milk-white sola-lime feldspar (oligoclase), partly kaolinized and micacized; light smoky quartz; biotite (black mica). some of it chloritized. Accessory: Allanite, zircon. apatite. Secondary: Chlorite, two white micas, kaolin, carbonate, and hematite.

George Steiger finds that this granite contains $0.1 \pm$ per cent of CaO (lime) soluble in hot dilute acetic acid, which indicates the content of 0.25 per cent of $\mathrm{CaCO}_{3}$ (calcium carbonate); the microscope also shows the presence of a carbonate. Effervesces slightly with muriatic-acid test.

The quarry, opened about 1886, measured in 1906477 feet $\mathrm{N} .35^{\circ} \mathrm{E}$. by 150 feet across and from! 5 to 20 feet in depth.

Rock structure: The sheets, from 3 inches to 10 feet thick, but mostly up to 5 feet 6 inches, dip $5^{\circ}-10^{\circ} \mathrm{E}$. or SE. There is but one set of joints, vertical, strike N. $85^{\circ} \mathrm{W}$, recurs at intervals of 40,100 , and 330 feet, and forms a 4 to 10 foot heading 140 feet from the north end. The rift is reported as horizontal but tending to incline with the sheets, the grain as vertical with east to west course. In summer the rock splits without reference to rift and grain. A flow structure, shown by more micaceous bands alternating with some 2 -inch white bands, strikes $\mathrm{N} .40^{\circ} \mathrm{W}$. and dips $25^{\circ} \mathrm{NE}$. Pegmatite dikes, up to 2 inches thick, strike N. $65^{\circ} \mathrm{W}$, exceptionally $\mathrm{N} .25^{\circ} \mathrm{E}$. They consist of half-inch particles of clear to milky striated soda-lime feldspar (oligoclase). light smoky quartz, and black mica with magnetite and pyrite. There are no knots. Rusty stain is light and up to 6 and 18 inches thick, but is not present on all sheets. 
Transportation, as shown on the map) (fig. 38), by siding from the Boston \& Maine Railroad.

Specimen structures: Pier 4 of Haverhill Bridge, Essex County, Mass.; piers 4 and 6 of the railroad bridge at the same place; trimmings of Majestic Theater, Chicago; and Ferguson mausoleum at Kensico Cemetery, New York.

The Kittredge quary is in Milford, about $1 \frac{1}{2}$ miles S. $15^{\circ} \mathrm{W}$. of Milford village, on the 360-foot level of the same hill as the Lovejoy quarry but on the onmesite side. (See fig. 38.) Operator, Edward L. Kittredge, Milford.

The granite (specimen D, XXVIII, 50, b) is a quartz monzonite of light-gray shade, with very slight bluish tinge apparent when the stone is in large masses, spangled with black mica. Its texture is even grained, fine, inclining to medium, with feldspars up to 0.2 and mica to 0.1 inch. In four thin sections the particles do not exceed 2.96 millimeters, or $0.012 \mathrm{inch}$, and most of them are not 2.2 milineters, or 0.08 inch. At very rare intervals porphyritic feldspars occur up to 12 inches in diameter. Its constituents, in descending ordel of abundance, are very slightly bluish milk-white potash feldspar (microcline intergrown with quartz, and orthoclase); in almost if not quite equal amount clear colorless to milk-white soda-lime feldspar (oligoclase), partly micacized and kaolinized; light smoky quartz with sheets of cavities and rift or grain cracks parallel to them; and biotite (black mica), some of it chloritized. Accessory : Magnetite, allanite, zircon, and apatite. Seconlary: Kaolin, chlorite, white mica, and limonite. In the upper sheets the stone is of light cream color owing to limonite proceeding from magnetite and allanite particles.

This is a constructional granite closely resembling that of the Lovejoy quarry, on the other side of the hill, but with slightly finer mica scales and a more bluish tinge. It effervesces very slightly with muriatic-acid test.

A very fine monumental granite (specimen D, XXVIII, 50, a), forming a band 20 feet wide at the south end of the quarry, is also a quartz monzonite of light-gray shade with very slight bluish tinge and spangled with fine black mica. Its texture is very fine, with feldspars measuring up to 1.85 millimeters and the mica 0.74 millimeter. The constituents are like those of the coarser stone, but the potash feldspars appear to predominate.

The quarry, opened about 1890, measured in 1906 s00 feet from north to south by 200 feet across and from 5 to 40 feet in depth. The working face is on the southwest.

Rock structure: The sheets are lenticular, from 4 inches to 2 feet 10 inches thick, and dip at a low angle north and east. There are three sets of joints(a), strike N. $22^{\circ}$ E., vertical, forms a heading 5 to 7 feet wide on each side of a basic dike; (b), strike N. $70^{\circ}$ W., vertical, spaced 200 feet; (c), strike N. $45^{\circ}$ E., dip $55^{\circ}$ N. $45^{\circ}$ W., exceptional. The rift is reported as horizontal, and the grain as vertical with a N. $80^{\circ}$ E. course. A flow structure marked by parallel bands of black mica strikes N. $20^{\circ}$ E., also N. $50^{\circ}$ E. with a dip of $20^{\circ}$ NNW. and NW. A basic dike, a foot thick, striking N. $22^{\circ}$ E. and vertical, forms the east wall. This is related to joint system (a). Pegmatite dikes, 11 to 3 inches thick, strike N. $20^{\circ}$ and $50^{\circ} \mathrm{W}$., forming in one place a network with meshes 15 feet square.

Transportation, by siding from Boston \& Maine Railroad (fig. 38). Seveneighths of the product consisted of paring, curbing, flagging, and crossings; the rest is dimension stone and bases for monuments.

The Pease quarry is in South Milford, about $1 \frac{1}{2}$ miles S. $25^{\circ} \mathrm{W}$. of Milford village, on the 350-foot level, on the same hill as the Lovejoy and Kittredge quarries. (See fig. 3S.) Operator, Pease Co., Nashua.

The granite in the east half of the quarly is a quartz monzonite of light-gray shade with very slight bluish tinge apparent only in large masses of the 
stone, and spangled with black mica. Its texture is fine inclining to medium, with feldspar and mica up to 0.2 inch. Its constituents are identical with those of specimen 50 , b, from the Kittredge quarry (p. 1S4).

The granite from the west lialf of the quarry (specimen D, XXVII, 64, a) is a quartz monzonite of light buff-gray color spangled with black mica. Its texture is even grainet, fine inclining to medium, with fellspar and mica up to 0.2 inch. Its constituents, in descending order of abundance, are light smoky quartz with cavities in sheets, many parallel; clear colorless to milkwhite soda-lime feldspar (oligoclase); light buff-gray potash fellspar (microcline); both feldspars somewhat kaolinized and micacized ; and biotite (black mica), some of it chloritized. Accessory: Magnetite, apatite, and zircon. Secondary: Kaolin, white micas, chlorite, and carbonate. It eiferresces sliuntly with muriatic-acid test.

This is a constructional granite of warm tint with conspicuous small black micas.

The quary. opened in 1886, measured in 1906 about 600 leet east-west by 400 and 300 feet from north to south, and from 35 to 60 feet in depth.

Rock structure: The sheets are lenticular, from 2 to 22 feet thick, and have a slight northerly dip. There are two sets of joints-(a) strike N. $15^{\circ}$ E., vertical, spaced 50 to 200 feet. forms headings on west wall and 200 feet east of it next to the dikes; (b) strike N. $80^{\circ} \mathrm{W}$., dip $75^{\circ} \mathrm{S}$., spaced 5 to 50 feet, accurs on north and south walls. The rift is reported as horizontal, and the grain as vertical with $\mathrm{N}$. $65^{\circ} \mathrm{W}$. course. A flow structure. shown by biotitic bands, alternating with more feldspathic and quartzose ones, strikes N. $70^{\circ}-75^{\prime}$ W. and dips $25^{\circ} \mathrm{S}$. This is conspicuous on the sontl side, but at the southwest corner, where the granite is overlain by a gneiss, as shown in fig. 17 (p. 191), the flow structure has a N. $70^{\circ}-75^{\circ} \mathrm{E}$. course and dips $20^{\circ}-25^{\circ} \mathrm{s}$. The strike of the gneiss is N. $75^{\circ} \mathrm{W}$. and the dip $20^{\circ} \mathrm{S}$. This gneiss consists of light-gray to milk-white soda-lime feldspar (oligoclase), smoky quartz, biotite, with magnetite, apatite, and zircon. It is thus a mica diorite gneiss. There are two basic dikes striking N. $15^{\circ} \mathrm{E}$. and vertical; one, 4 feet thick, makes the west wall; the other, 12 to 18 inches thick, forms a jog 200 feet east of it. Within 50 feet of the thicker dike the granite passes from a light buff gray to a medium pinkish-gray, "Milford pink," owing to the darkening of the feldspars and to hematitic stain. These dikes are also the probable cause of the difference between the color of the granite in the western and eastern halves of the quarry, the amount of hematitic stain increasing with the nearness of the dikes. (See pp. 184-185.) A 4-inch pegmatite dike strikes N. $65^{\circ} \mathrm{W}$. and consists of quartz, white feldspar, and biotite, the particles being up to 2 inches in diameter. Rusty stain up to 2 inches thick occurs on some sheets only.

Transportation, by siding from Boston \& Maine Railload.

The product is used for bridges and buildings and the waste for paving. Specimen building of "pink stock"; Thayer Memorial Library, Franklin, Mass.; railroad bridge, Neponset, Mass.; and Piers 12, 25, 26, and 32 on the Prison loint Street Pridge (Boston \& Maine Railroad). East Cambridge, Mass.; and east side coping of Atlantic Avenue Bridge, Boston.

The Tonella old quarry is in Milford, 1르 miles south of Milford village. (See fig. 38.) Quarry no longer operatel.।

The granite (specimens D, XXVIII, 54, a. b) is a quartz monzonite of lightgray shade (witbout either bluish or greenish tinge), witl very minute black spangles. Its texture is fine, even grained, with feldspars up to 0.15 inch, and black mica in slender scales but exceptionally over 0.1 inch. Its constituents, in descending order of abundance, are very light smoky quartz with hairlike crystals, probably of rutile, and cavities in sheets; clear colorless to 
milk-white soda-lime feldspar (oligoclase) slightly kaolinized and micacized; very light gray potash feldspar (microcline and orthoclase), mostly intergrown with quartz, circular in cross section, and some of it very slightly kaolinized; and biotite (black mica), some of it chloritized. Accessory : Magnetite, zircon, allanite, apatite, and rutile. No pyrite detected. Secondary: Kaolin, chlorite, and two white micas.

An estimate of the mineral percentages, made by applying the Rosiwal method to a camera lucida drawing of a thin section enlarged 40 diameters, rields the following results with a mesh of 1.7 inches and a total linear length of 42 inches: Quartz, 36.76; soda-lime feldspar (oligoclase), 29.16; potash feldspars (microcline 14.00, orthoclase 13.58), 27.58; black mica, 6.50. The average diameter of the particles obtined by the same method is 0.011 inch.

This is a fine-grained monumental granite, in shade a trifle lighter than the granite of Hallowell, Majne, but not as light as that of North Jay, Maine. It takes a high polish. The only contrast, visible but a few feet off, is between the black mica and the combined quartz and feldspars. The polished face shows many minute particles of magnetite.

The quarry, opened in 1900, measured in 1906 abont 300 feet north anit south by 100 feet across and is now 75 feet deep.

Rock structure: The sheets, 2 to 14 feet thick, are lenticular, horizontal, and regular. There are two sets of joints-(a), strike N. $85^{\circ}$ W., vertical or steep south. spaced 20 to 50 feet, forms a heading 3 feet wide, 125 feet from the south end; (b), strike N. $35-40^{\circ}$ E., vertical, intermittent and confined to upper sheets, forms a heading on the east wall, and recurs 30 feet from west wall. From the large blocks of gneiss attached to granite lying on the dumps and from the occurrence of this gneiss in a much weathered condition in or under the drift on the edge of the quarry it is evident that the rock surface originally included a mass of gneiss which either capped the granite or formed a large inclusion in its upper part. This gneiss is coarse, biotitic, with lenses of pinkish potash feldspar (microcline) bordered with clear to milk-white soda-lime feldspar (oligoclase). Its quartz is smoky. Accessory: Pyrite, magnetite, allanite, and zircon. The rift is reported as horizontal and the grain as vertical, with N. $85^{\circ}$ W. course. There are no dikes, veins, or knots. Rusty stain occurs only along the headings, where it is 6 inches thick. This quarry is remarkably free from the common structural difficulties.

Transportation, by cart, half a mile to railroad for rough stock, but 2 miles to cutting shed for blocks to be tinished.

The product was used principally for monuments, and the waste for paving. The firm made a specialty of fine carved work. Specimens: the Morgenthaler monument, Greenwood Cemetery, Hamilton, Ohio. This is a 5-ton block, 6 feet high, with a delicately carved branching ivy vine entwined about a cross, all in high relief on a roughly chipped face. The carring, having been done with hand instearl of pneumatic tools, is sharp.

The Tonella King quarry is $2 \frac{1}{4}$ miles 5 . $25^{\circ} \mathrm{W}$. of Milford rillage. (See fig. 38.) Operators. Tonella \& Sons, Milford.

The granite (specimen D, XXVIII, 55, a) is a quartz monzonite of medium buff-gray color spangled with fine black mica. Its texture is generally evengrained and fine, with feldspar up to 0.2 inch and mica to 0.1 inch, but with rare porphyritic light-pinkish feldspars an inch in diameter. Its constituents, in descending order of abundance, are light amethystine to pale smoky quartz; clear colorless to milk-white soda-lime feldspar (oligoclase), partly kaolinized and micacized; light-buff to cream-colored potash feldspar (microcline, much intergrown with quartz, circular in cross section); and black mica, some of it chloritizerl. Accessory: Magnetite, allanite, apatite, and zircon. 
Secondary: Kaolin, a white mica, chlorite, hematite from magnetite, and limonite from allanite.

In general color this rock resembles specimen 64, a, of the Pease quarry (p. 1St), but its mica scales are tiner.

A finer granite (specimen D, XXVIII, 55, c) from the upper part of the quarry is also a quartz monzonite of medium buff-gray color, spangled with extremely fine mica. Its texture is ren grained, very fine, with feldspars up to 0.1 inch and mica rarely over 0.05 inch. Its constituents are the same as those of the other.

A pinkish granite (specimen D, XXYIII, 55, d) $S$ feet thick, on the south side of the dike described beyond, is of pinkish medium-gray color, liki that adjoining the dike in the Pease quarry (p. 185). It is the same wamite as 5.5, a, described above, but its oligoclase contains hematite, and its potash feldspars are also pinkish, owing to the dike.

The quarry, opened in 1905, measured. in 1906, 100 feet north and south by 80 feet across, and is now 75 feet deep.

Rock structure: The sheets, 18 inches to 6 feet thick, are lenticular aud horizontal or dip as high as $20^{\circ} \mathrm{E}$. Only one set of joints, strike N. $30^{\circ} \mathrm{W}$, dip $35^{\circ} \mathrm{W}$., spaced 5 to 20 feet. The granite is canped on the east and west sides by about 5 feet of coarse biotite gneiss, but on the west this is overlapped by 2 to 3 feet of granite, and so the gneiss may be merely a large inclusion. This gneiss (specimen D, XXYIII, 55, b) consists of pinkish potash feldspar (microcline) and milk-white soda-lime feldspar, both intergrown with quartz; smoky quartz with cavities in sheets; and biotite. The foliation of the gncis: strikes about $\mathrm{N} .45^{\circ} \mathrm{W}$. The rift is reported as horizontal, and the grain as vertical. with $\mathrm{N}$. $\mathrm{S}^{\circ} \mathrm{W}$. course. A flow structure shown by more biotitic streaks and planes strikes north and dips $20^{\circ} \mathrm{W}$. The baud of fine-grained granite, 2 feet thick at the top (specimen $55, \mathrm{c})$, lies in the flow direction. On the south side a vertical dike of ancite campronite 2 feet 6 inches thick strikes $X$. $10^{\circ} \mathrm{E}$. This consists of sola-lime feldspar (andesine). augite, brown hornblende, magnetite in octahodra and skcleton crystals, apatite in slender prisms all through the feldspar, and prite, together with secondary chlorite and carlonate from alteration of augite. Specimens of product: Hudson Monument, Lakewood Cemeters, Minneapolis, Minn., and Gareiss Monument, Chicago.

The Souhegan quarry is $2 \frac{1}{2}$ miles S. $12^{\circ}$ E. from Milford village and threefifths of a mile southwest of Federal Hill. (See fig. 38.) Operator, SmalleySoulegan Granite Co., Milford.

The granite (specimens D, XXVIII, 53, a, b, c) is a quartz monzonite of clark-gray shade with very slight pinkish tinge and very fine scales of black mica. Its texture is even grained and fine. with feldspar and mica not over 0.1 inch. Its constituents, in descending orler of abundance, are light smoky quartz with few cavities, some in sheets; milk-white soda-lime feldspar (oligoclase), shightly liaolinized and nicacized; colorless to dull greenishgray potash feldspar (microcline), intergrown with quartz, circular in cross section; and biotite (black mica), some of it chloritized. Accessory: Magnetite, pyrite, apatite, allanite, and zircon. Secondary: Kaolin, a white mica, chlorite, carbonate, and some irregularly disseminated hematite stain which gives the pinkish hue.

George Steiger, of this Survey, finds that this granite contains 0.26 per cent of CaO (lime) soluble in hot dilute acetic acisl, which indicates a content of 0.46 per cent of $\mathrm{CaCO}_{3}$ (calcium carbonate): the presence of this carbonate is also shown by the microscope and by muriatic-acid test.

The stone takes a high polish and ofters a notabie contrast of sharle hetween its hammered and polished faces. The polished surface shows rare 
particles of pyrite along with the usual abundance of magnetite particles. The only contrast between its minerals, that between the black mica and the general color of quartz and feldspar, is visible but a few feet off.

The quarry, opened in 1896, measured in 1906, 150 by 50 feet and 10 to 25 feet in depth.

Rock structure: The sheets, generally normal and from 6 inches to 5 feet thick, dip low west and south, but are intersected by sharply curved planes, "toe nails." There are two sets of joints-(a), strike N. $80^{\circ} \mathrm{W}$, vertical, occurs only in the southern part; $(b)$, strike $\mathrm{X}$. $22^{\circ} \mathrm{E}$, rertical, forms headings on the east and west walls and recurs discontinnously at intervals of 10 feet. There is a rhomb-shapel inclusion at the south end, about 3 feet 6 inches across, of very coarse biotite gneiss, consisting of milk-white soda-lime feldspar (oligoclase-andesine), swoky quartz, and biotite, with a little copper pyrite. There is some banding in the granite parallel to the surface of the inclusion. (See p. 64.) The rift is reported as in places horizontal but generally dipfing south at a very low angle, and the grain as vertical with $\mathrm{N}$. $70^{\circ} \mathrm{W}$. course. A pegnatite dike, up to 2 inches thick, with a little magnetite, strikes $\mathbf{N} .30^{\circ} \mathrm{E}$ Rusty stain on the sheet surfaces is up to 6 inches thick.

Transportation, by cart 3 miles to cutting shed on siding of Boston \& Maine Railroad.

The product is usen for monuments.

The New Westerly quarry is $2 \frac{1}{4}$ miles northwest of Milford village. (See fig. 38.) Operator, New Westerly Granite Co., Milford.

The granite (specimens D, XXVIII, 60, a, b), "New Westerly blue," is a quartz monzonite of medium slightly bluish-gray color, spangled with fine black mica. Its texture is even-grained, fine, inclining to medium, with feldspar and mica up to 0.2 inch and a marked parallelism in the mica scales. Its constituents, in descending order of abundance, are light smoky quartz with cavities up to 0.008 millimeter in sheets; slightly greenish-blue soda-lime feldspar (oligoclase). parily kaolinized and micacized; slightly pinkish-gray potash feldspar (microcline, some twinned); biotite, (black mica), some of it chloritized. Both feldspars ale intergrown with quartz. Accessory: Magnetite, pyrite, allanite, apatite, and zircon. Secondary: Kaolin, two whie micas, chlorite, hematite, and carbonate.

An estimate of the mineral percentages, obtained by applying the Rosiwal method to a camera lucida drawing of part of a thin section, enlarged 40 diameters, yields the following results with a mesh of 1.5 inches and a total linear length of 34.5 iuches: Quartz, 17.10; solla-lime feldspar (oligoclase), 45.22 ; potash feldspars (microcline 15.59; orthoclase 15.71), 31.30; black mica (biotite), 5.74; magnetite, 0.64. The average diameter of all the particles, obtained by the same method is 0.009 inch.

George Steiger, chemist, of this Survey, finds that this granite contains 0.12 per cent of CaO (lime) soluble in hot dilute acetic acid, which indicates a content of 0.21 per cent of $\mathrm{CaCO}_{3}$ (calcium carbonate) ; the presence of this carbonate is shown by the microscope and by muriatic acid test.

The stone takes a high polish, which brings out the greenish and reddish tints and darkens the general color so that it becomes a medium greenish gray. The polished face shows a few grains of magnetite and rare ones of pyrite.

The quarry, opened in 1876 , measured in 1906 about 150 feet from east to west by 100 feet across and from 15 to 65 feet in depth.

Rock structure: The sheets, 6 inches to 30 feet thick, increasing in thickness downward, dip south at a low angle. There are two sets of joints-(a), strike N. $10^{\circ}$ E., dip $60^{\circ}$ E. and $90^{\circ}$, spaced 3 to 50 feet, forms a heading on east side; (b), strike N. $75^{\circ}-80^{\circ}$ i., vertical. spracer 30 to 40 feet, forms a heading on 
the south side. The rift is reported as horizontal, and the grain as vertical with a $\mathrm{N} .80^{\circ} \mathrm{W}$. conrse, but it is so feeble that the stone can be split almost as well across it.

Transportation, by cart about 23 miles to cutting shed ani railroad at Milford.

The product is used for monuments.

The Milford Granite Co.'s quarries are a mile southeast of Milford village and 130 feet abore it, on the east side of a hill. (See fig. 3S.) The quarries are abandoned.

The prinite generally is like that of the Young quarry, described on page 190.

The quarries comprise two openings, along a N. $20^{\circ}$ Is. line. The southern opening is about 120 feet $\mathrm{N}$. $20^{\circ}$ E. hy 60 feet across and is 40 feet deep. The northern opening, separated from the other by an interval of 150 feet, is about 900 feet $\mathrm{N} .20^{\circ} \mathrm{E}$. by 50 to 75 feet across and from 10 to 30 feet deep.

Rock structure: The sheets, 1 to 5 feet thick, are lenticular and horizontal. Joints, strike $\mathrm{N} .10^{\circ}-30^{\circ} \mathrm{E}$, vertical, spacerl 1 to 5 feet, form beadings on the east and west walls of both quarries and in center of southern one. Some of the joints of these headings are "sand seams," or veins ul to half an inch thick of a central bancl of quartz erystals with borders of muscovite. (See p. 74.) The granite of the west wall of both quarries is overlain by a mass of manycolored banded gneiss. 12 to 16 feet thick, with a foliation striking about $\mathrm{N}$. $75^{\circ} \mathrm{W}$. and dipping $75^{\circ} \mathrm{S}$. with injections of pegmatite starting at the contact and tapering nut within the gneiss. (See Pl. VIII, $A$, and p. 91.) There is much variety in the composition and texture of the gneiss. The quartz of the finer augite ciorite gneiss has cavities, up to 0.047 millimeter, in sheets intersecting at right angles. The granite on either side of the muscovite reins in the beading is much reddened for llalf an inch; the biotite is mostly chloritized, the oligoclase is wuch kaolinized and micacized, and much limonite and hematite stain proceeds from particles of magnetite and pyrite.

The Carlton quarry is 2 miles northwest of Milford village. (See fig. 38.) Operator, C. V. Carlton, Milford. Idle since 1913.

The granite (specimen D, XXVIII, 61, a) appears to be also a quartz monzonite, but probably with more of the potash fellspar. Its color is medium pinkish gray, spangled with black. Its texture is porphyritic; the groundmass is fine, with feldspar and mica up to 0.1 inch and the isolated feldspar's up to 0.4 and exceptionally 1 inch. Its constituents, in descending order of abundance, are light smoky quartz with hairlike erystals, probably of rutile, and cavities in sheets, with rift cracks parallel to then; light pinkish-grav potash feldspar (microcline), intergrown with quartz, circular in cross section, inclosing particles of soda-lime feldspar, and somewhat kaolinized and micacized, making up part of the groundmass and also the porphyritic crystals; in almost equal amount a milk-white soda-lime feldspar (oligoclase), somewhat kao. linized, micacized, and intergrown with quartz; and biotite (black mica), some of it chloritized. Accessory: Magnetite, apatite, allanite, and rutile. Secondary: Kaolin, two white micas, chlorite, and hematite.

At the north corner of the quarry there is a band of quartz monzonite of medium slightly bluish-gray color, with fine black mica, like the stone of the Ney Westrily quarry described on page 185 .

The chief product of this quarry differs from all the other granites of Mil. ford, $\mathbf{N}$. H., by its marked porphyritic texture. It is a constructional granite.

The quarry, opened in 1S81, was in 1906 about 110 by 100 feet and areraged 30 feet in depth.

Rock structure: The sheets, 1 to 16 feet thick, dip west at a low angle. There are two sets of joints-(a). strike $\mathrm{N} .50^{\circ} \mathrm{W}$., about vertical, spaced 20 to 60 
feet, forms a heading on the west side and the east wall; (b), diagonal, strike north, dip $75^{\circ}$ E., one joint only. The rift is reported as slightly inclined to the west. and the grain as dipping $70^{\circ} \mathrm{X}$. Flow structure, shown by streaks of black mica, also by the band of fine granite, strikes N. $70^{\circ} \mathrm{E}$. and dips $40^{\circ}-50^{\circ} \mathrm{N} .20^{\circ} \mathrm{W}$. Rnsty stain is up to 8 inches thick.

Transportation, by cart, 2 miles to Milford.

The probuct is used mostly for street work in Boston and Cambridge.

The Young quarry is $1 \frac{1}{4}$ miles southeast of Milford village and three-fourths mile sumthrest of East Milforl, or Lamel post office. (See fig. 3S.) Operators, Yomug's Sons \& Co., Milford.

The granite (specimens D, XXVIII, 52, aa, c), "dark-blue New Westerly," is a quartz monzonite of general dark-gray shade (neither bluish, greenish, nor pinkish but smoky), with very fine black spangles. Its texture is even-grained and fine, with feldspar up to 0.1 , rarely $0.15 \mathrm{inch}$, and mica to 0.1 inch. Its constituents, in descending order of abundance, are very light smoky quartz, with cavities; slightly greenish-gray soda-lime feldspar (oligoclase), somewhat kaolinized and micacized; clear, colorless to grayish potash feldspar (microcline and orthoclase), very slightly kaolinized; and black mica, some of it chloritized. Accessory: Magnetite, pyrite, apatite, allanite, and zircon. Secondary: White mica, kaolin, chlorite, carbonate, and a little hematite and limonite stain, the latter about the allanite.

An estimate of the mineral percentages obtained bs applying the Rosiwal method to a camera lucida drawing of part of a thin section enlarged 40 diameters yields these results with a mesh of 2 inches and a total linear length of 34 inches:

Estimated mineral percentages in granite from the Young quarry, Milford, $N . H$.

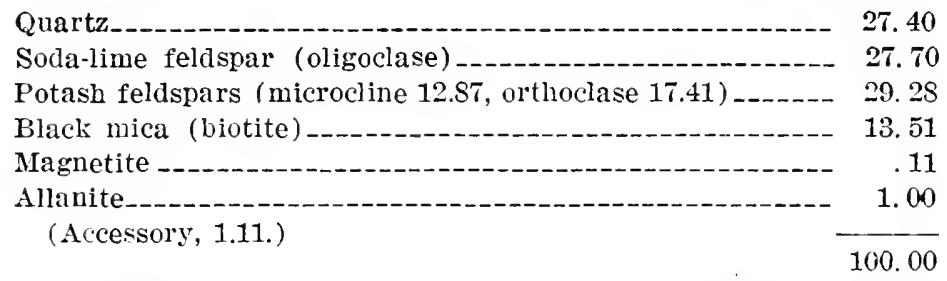

The percentages of magnetite and allanite are not perfectiy reliable, for a slight shifting of the mesh would have changed the figures for one or both, but as representing together the accessories they are not far from the truth. The average diameter of all the particles, by the same method, is 0.0084 inch.

W. T. Schaller, a chemist of this Survey, finds that this granite contains $0.1 \mathrm{~S}$ per cent of $\mathrm{CaO}$ (lime) soluble in hot dilute acetic acid, which indicates a content of 0.32 per cent of $\mathrm{CaCO}_{3}$ (calcium carbonate); the presence of this carbonate is also shown by the microscope and by muriatic-acid test.

A crushing test, made for the firm by Prof. Ricketts, of the Rensselaer Polytechnic Institute, at Troy, N. Y., is reported as showing an ultimate crushing strength of 24.950 pounds to the square inch.

The stone takes a fine polish. The polished face shows some magnetite and a little pyrite. There is much contrast of shade between the hammered and the rough or polished face, the hammered face being light, slightly bluish gray. The contrast betreen the minerals, not visible at a distance, is between the black mica and the general color of the others. 
The quarry, opened in 18s6, a plan of which is shown in figure 39. hat in 1906 a length of 370 feet, a width of 75 to 100 feet. and an average depth of 50 feet. Only the northwest bend was being worked in 19 ra.

Rock structure: The sheets, 2 to 10 feet thick, are lenticular and generally horizontal. Joint courses are giren in tigure 39 . (A), rertical, forms a heading at the west enu, and recurs 70 feet tast only; (B). dil $40^{\circ} \mathrm{N}$., spaced 5 to 10 feet, and occurs only at the northwest corner. The rift is reported as horizontal, but with a slight inclination. There is no perceptible srain. Flow structure, shown by biotitic streaks, strikes $X .15^{\circ}$ E. and dips $45^{\circ} \mathrm{W}$. The marked featme of this quarry is the recurrence, at intervals of 20 feet, of dikes of pegmatite and aplite, already described on page 73 . These dikes are from 0.25 to 3 inches thick, occur in sets of three to eight, with a $\mathrm{X} .25^{\circ}$ W. course and a rertical dip. A few strike N. $25^{\circ}$ E. and dip $40^{\circ}$ ESE. They consist of cream-colored oligoclase. smoky quartz, cream-colored or pink microcline, and biotite, with manetite. allanite, and zircon. The biotite crystals measure up to 2 inches in length. Iinsty stain is up to $S$ inclues wille on sheet surfaces. Joints A are coated with prite, which has mostly passed into limonite.

Translortation, by cart threefonrths mile to cutting shed, on the Boston \& Maine Railroad, with siding to quarry.

The rroduct is used for monuments, the stained and reined parts and small sheets for paring. Specimens: Mrs. R. J.

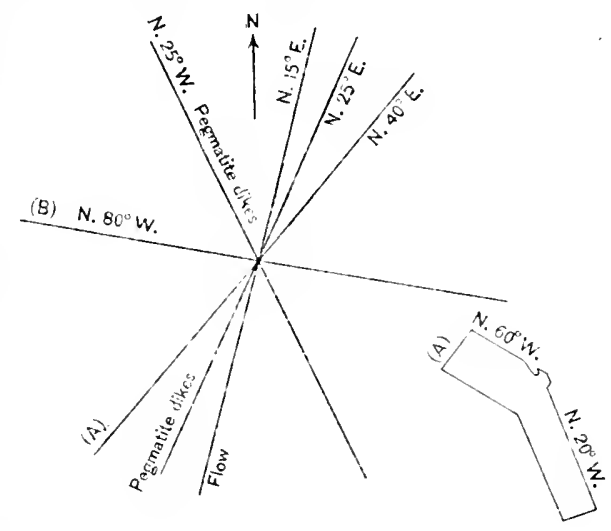

Figcre 39.-Structure and plan of Young quarr, Milford, N. H.

Stark monument, Oakwood Cemetery, Tror, X. Y.; Mrs. J. Crais monment, Rural Cemetery, Albany, N. Y.

\section{BROOKLINE.}

The O'Rourke quarry is at the enst end of Brookline village. in Brookline Township. (See topographic man of Groton quadrangle, U. S. Geol. Survey.) Operator, O'Rourke \& Magner Quarrying Co., Brookline, N. H.. also 73 North street, Salem. Mass. Quary abandoned.

The grauite (specimen D, XXX, 87 a). "Brooliline." is a quartz monzonite of medium buff-gray color and of even-grained fine texture, with feldspars and micas under 0.2 inch. Its constituents, in descending order of abmunce, are light smoky quartz with cavities; cream-colored soda-lime feldspar (oligoclase), kaolinized and micacized; clear to translucent whitish potash feldspar (microcline and orthoclase), intergrown with quartz, circular in cross section; biotite (black mica), some of it chloritized; and a little muscovite or bleached biotite. Accessors: Magnetite, apatite, zircon. Secondarr: Kaolin, a white mica, calcite, chlorite. No effervescence with muriatic-acid test.

This is a fine-grained monumental granite closely related to that of Milford, in the same county. It cuts light.

The quarry, opened in 1909 , is on a bare ledge measuring 200 feet in a $\mathrm{N} .20^{\circ}$ E. direction by 100 feet across. 
Rock structure: The sheets, 1 to 8 feet thick, dip mostly east at low angles. There are two sets of joints-(a), strike N. $20^{\circ}$ E., vertical, spaced 6 to 12 feet, forms a small heading on the west side; (h), strike $\mathrm{N}$. $80^{\circ} \mathrm{W}$, vertical, spaced 25 feet and more. The rift is reported as horizontal, and the grain as vertical. Inclusions of gneiss up to 6 by 3 feet occur. (See p. 63.) Rusty stain is 2 inches thick on surface sleets, but very little on the lower ones.

Transportation, by cart three-fourths of a mile to the railroad.

The product is used for momments and trimmings. Specimens: Simon Cottan and Philip Sheridan monuments, St. Mary's Cemetery, Salem, Mass. The quarry was not operated in 1916.

The Fessenden quary is one-eighth of a mile west of South Brookline station, in Brookline Township. (See Groton topographic map, U. S. Geol. survey.) Operator, John R. Richards, Lrookline.

The granite (specimens D, XXX. 8S, a, b), "Brookline," is a quartz monzonite of medium, faintly pinkish-gras color and of even-grained fine texture, with feldspars up to 0.15 inch and micas to 0.1 inch. Its constituents, in descending order of abundance, are very light smoky quartz with cavities and hairlike crystals of rutile; milk-white soda-lime feldspar (oligoclase), kaolinized and micacized; slightly pinkish potash feldspar (microcline and presumably orthoclase); biotite (black mica), some of it chloritized; and a little muscovite or bleached biotite. Accessory: Magnetite, apatite, zircon, allauite. Secondary: Kaolin, white micas (one in veinlets), hematite and limonite stain, chlorite, calcite. Very slight effervescence with muriatic-acid test.

An estimate of the mineral percentages, made by applying the Rosiwal method .0 a camera lucida drawing of a thin section enlarged 40 diameters, yields these results with a mesh of 2 inches and a total linear length of 48 inches:

Estimated mineral percentages in "Brookline" quartz monzonite from Fessenden quarry.

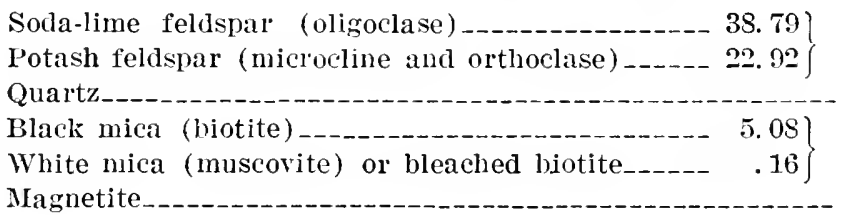

61. 71

32. 20

5. 24

100.00

The average diameter of the particles calculated from the same measurements proves to be 0.0097 inch.

This is a fine-grained monumental granite, related to that of Milford, in the same county. Its color is warmer than that of the rock from the O'Rourke quarry, but the granites are the same. It takes a high polish and like other quartz monzonites cuts light.

The quarry, opened in 1909 , was about 80 by 50 feet and up to 8 feet deep.

Rock structure: The sheets, 2 to 3 feet thick, range from the horizontal to a gentle easterly dip. There are two sets of joints-(a) strike N. $30^{\circ}$ E., vertical, one only in center; (b), strike N. $75^{\circ} \mathrm{W}$., vertical or steep, spaced 10 to 20 feet. The rift is reported as horizontal, and the grain as vertical, with $\mathrm{N} .20^{\circ} \mathrm{E}$. course. There are inclusions of coarse gneiss and granite up to 21 inches in diameter. (See P. 63.) Rusty stain on top sheets is not orer 2 inches thick. 
The quarry, opened about 1874 , is on the northwest side of a low granite dome and measures about 500 feet in a northeasterly direction by 250 feet across and from 20 to 60 feet in depth.

Rock structure: The sheets, 6 inches to 6 feet thick, dip gently northeast and northwest. There are two sets of joints-(a), strike N. $60^{\circ}$ E., vertical, rare; (b), strike N. $60^{\circ} \mathrm{W}$., vertical, forms a heading 40 feet widle within 200 feet of the northeast end of the quarry. The rift is reported as horizontal, and the grain as vertical, with $\mathrm{N}, 60^{\circ} \mathrm{E}$. course. A hornblende diabase dike 3 to 4 feet wide crosses the quarry lengthwise within 75 feet of the working face, with a $\mathrm{N} .60^{\circ}$ E. strike and rertical or steep dip. The granite is darker for 14 feet on one side of the dike and 2 feet on the other. (See p. 58.) Three pegmatite dikes, 14 inches to 5 feet thick, strike about N. $60^{\circ} \mathrm{W}$. and dip $45^{\circ} \mathrm{N} .30^{\circ} \mathrm{E}$. to $90^{\circ}$. Some of the granite near the heading of set (b) is porphyritic and has large micas. A flow structure appears also in places. Biotitic linots measure to 5 inclies.

Transportation, by siding a mile to Suncook Valley branch of the Boston \& Maine Railroad.

The product is used partly for trimmings but mainly for curbing, paving, foundations, and crushed stone for concrete. Specimens: Weston Observatory, foundation and trimmings of Coolidge mill and New Manchester mill of Amoskeag Manufacturing Co., Manchester.

\section{HOOKSETT.}

The Shirley quarry is near Merrimack River in Hooksett, 6 miles north of Amoskeag, Manchester. Operator, George H. Shirley, 255 Front Street, Manchester.

The granite (specimen $\mathrm{D}, \mathrm{XXX}, 80, \mathrm{a}$ ) is a muscovite-biotite granite of very light gray shade and medium texture, with feldspars and micas up to 0.3 inch, the white mica in rhombic crystals. Its constituents, in descending order of abundance, are milky potash feldspar (microcline), slightly kaolinized; clear colorless quartz with cavities; milk-white soda-lime feldspar (oligoclase-albite), much kaolinized and somewhat micacized; muscovite (white mica), mostly in rhombic crystals; biotite (black mica). Accessory : Magnetite, apatite. Secondary: Kaolin, a white mica, calcite. The stone efferresces with muriaticacid test.

The quarry, opened in 1891, was not visited by the writer.

The stone is brought down Merrimack River 6 miles in a steam tug to the cutting yard at Amoskeag and carted to its destination.

The product is used for curbing, steps, trimmings, and underpinning. Specimens: Trimmings on Amoskeag School and on Manchester Street Railway car barn.

\section{MANCHESTER.}

The Bodwell quarry is about $2 \frac{1}{2}$ miles east-northeast of the city hall in Manchester. Operator, John McCarthy, near R. D. 9, Manchester.

The granite (specimen D, XXX, S3, a) is a biotite granite of light inclining to medium gray shade and of even-grained nedium texture, with feldspars up to 0.3 inch, exceptionally 0.5 or $0.7 \mathrm{inch}$. Its constituents, in descending order of abundance, are clear colorless to translucent potash feldspar (microcline), intergrown with quartz, circular in cross section, slightly kaolinized and micacized; light smoky quartz with cavities in slieets; milk-white soda-lime feldspar (oligoclase-andesine), some of it much kaolinized and micacized; biotite (black mica), some of it chloritized. Accessory : Magnetite, allanite. Secondary : Kaolin. white micas, calcite, chlorite. Much effervescence with muriatic-acid test. 
The quarry, opened about 1879 , measured in 1909 about 350 feet in a N. $70^{\circ} \mathrm{E}$. direction by 65 feet across and 20 to 40 feet in depth.

Rock structure: The sheets, 2 to 6 feet thick, dip $5^{\circ} \mathrm{S}$. There is one set of Joints only, strike N. $35^{\circ} \mathrm{W}$., vertical, spaced irregularly. The rift is reported as horizontal and the grain as rertical, with $\mathrm{N} .57^{\circ}$ E. course. The quarry is walled on its longer sides by banded quartz-mica diorite gneiss of varying texture and pegmatite lenses. The gneiss foliation strikes N. $45^{\circ}$ E. There are tongues and inclusions of this gneiss in the granite. Rusty stain is 2 to 3 inches thick on sheet surfaces.

The product is used locally for foundations and curbing. The quarry has not been operated for several years.

The Iiennard Ledge quarry is $1 \frac{1}{2}$ miles about northeast of the city lall in Manchester. Operator, Evariste Dionne, 368 Lake Arenue, Manchester. Quarry idle.

The granite (specimen D, XXX, 8: a) is a biotite granite of medium bufgray color and of eren-grained medinm texture, with feldspars up to 0.3 inch, rarely 0.4 inch, and micas under 0.2 inch. The mica scales lie parallel to the rift. Its constituents, in descending order of abundance, are greenish-gray potash feldspar (microcline), slightly kaolinized; medium smoky quartz with cavities in sheets: huft-gray soda-lime feldspar (oligoelase-andesine), some of it much kaolinized and micacized; biotite (black mica), some of it chloritized; and a little muscovite or bleached biotite. Accessory: Pyrite, magnetite, allanite, apatite, zircon. Secondary: Kaolin, a white mica, chlorite, calcite. There is no efferreseence with the muriatic-acid test.

The quarry, opened about 1879 , measured in 1909 about 300 feet from east to west by 150 feet across and 60 feet in depth.

Rock structure: The sheets, 6 inches to 9 feet thick, dip low north on the north side and low south on the south side. There is but one set of joints, strike $\mathrm{N}$. $17^{\circ} \mathrm{W}$., vertical, spaced 14 to 22 feet, forming a heading 20 feet wide on the south side. The rift is reported as horizontal, and the grain as vertical, with east to west course, hoth marked. The north wall of the quar'y is gneiss with thick dikes and lenses of pegmatite. The foliation strikes $\mathrm{N} . \mathrm{S} 0^{\circ} \mathrm{E}$. The south wall is of like gneiss. The granite thus appears to be a dike 150 feet wide with north to south strike, cutting a granite gneiss with a nearly east to west foliation. Stain is up to 8 inches thick on sheet surfaces.

The product is used locally for trimmings. curbing, and foundations, for which its marked rift and grain well adapt it.

\section{CONCORD.}

TOPOGRAPHY.

The Concord quarries are on the east side and top of a north-sonth ridge known as Rattlesnake Hill, which is said to attain an elevation of 580 feet above the high-water mark of Merrimack River; and they lie within a radius of $1 \frac{1}{2}$ to 2 miles from about N. $25^{\circ} \mathrm{W}$. to $\mathrm{N}$. $50^{\circ} \mathrm{W}$. of the statehouse. Some of them are at the foot of the ridge on North State Street at about the lerel of the city; others are from 70 to 360 feet above it.

\section{GEOLOGY OF THE QUAPRIES.}

The salient geologic feature is the occurrence here and there within the granite of inclusions of coarse and fine banded gneisses from a few inches to 30 feet in diameter. The largest of these (see p. 63) is a bright, dark biotitemuscovite gneiss with fine bands of rarying shades. according to the proportions of the micas or of the quartz and feldspar. Its feldspar is a soda-lime 
(olisgolase-all,ite to olignclase), and the accessory minerals are girnet, zircon, apatite, etc. others are biotite gneisses and consist of alternating bands of very light feldspathic quartzose rock and of dark, coarse, and very fine micaceous schist, the particles of the schist not exceeding 0.02 inch. The geologic age of these gneisses is uncertain. The pegmatite dike that traverses this large inclusion seems, from its relation to the granite, to have been formed before the block was surrounded by granite. Of general interest is also the occurrence of fluorite on joint fices, referred to on lage 63, which implies deepseated origrin of the solutims out of which it arystallized and raises the question whether the assuciated calcite and quartz may not lave come from the same source.

Joint planes at the Concord quarries may be divided into eight sets. of which

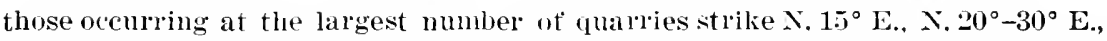
N. $60^{\circ}-65^{\circ}$ E., and N. $60^{\circ}-75^{\circ} \mathrm{W}$. Of less frequent orcurrence are those stribing N. $10^{\circ} \mathrm{W} . . \times 15^{\circ} \mathrm{W} ., \times .80^{\circ}$ E., and east. The number and variety of fractures within one of the headings at the Granite Railway cuary indicate the localization and sharpness of the strain which produced the heading.

Flow structure mpear:s at only one quary, where it is vertical with a N. $60^{\circ} \mathrm{W}$. rourse. The ritt is reported as either horizontal or inclined $5^{\circ}-15^{\circ}$ N. $65^{\circ}-75^{\circ} \mathrm{W}$. or $\mathbf{S} .45^{\circ} \mathrm{W}$.. and the wrain as vertical, with east-west course, but exceptionally $N .45^{\circ}$ E.. $\times 70^{\circ}$ E.. or $\times 50^{\circ} \mathrm{W}$. The effect of heat and cold on the quality of rift and grain is recognized, and also the fact that the degree of dip of rift is affected by the direction in which the sheet is split. If the splitting is done from the north or south. the rift will prove horizontal, but if from the west it will be incherl. Whether the east-west compressive strain that affects Rattlesnake Hill has anything to do with this deflection is uncertain.

There are pegmatite dikes with courses of $\mathrm{x.} 30^{\circ}$ E., $\mathrm{x} .45^{\circ}$ E., $\mathrm{x} .45^{\circ} \mathrm{W}$., and $x .8 .^{\circ} W^{\circ}$, and segregations of vely fine porphryitic granite. (see p. 201.)

\section{"CONCORD GRANITE." ,}

The following combines all the more detailed descriptions of romgh and polisher specinens :nd thin sections wiven on lages 197, 199.

"Concord granite" is a muscorite-biotite granite of medium bluish-gray color. The significance of the term "medium gray" becomes apparent upon comparing the terms applied to the princilal light granites of New England. The granite of Hallowell, Maile, is light gray; the "white granite" of North Jay, Maine, is very light gray ; and the granite of Bethel, Vt., is white mottled with gray. The general shades of these light or whitish granites form a lescending series in which "Concorcl granite" stants fourth, the granite of Bethel, Vt., being white with a mottling of shate. 'The texture of "Concord granite" is fine to medimm, somewhat porphyritic, with sparse slender, isolated feldspars up to 0.5 inch. Although the micas occur in very minute particles, especially the biotite, they measure up to 0.2 inch and exceptionally 0.4 inch. Its constituents, in descending order of abmulance, are slightly bluish translucent potash feldspar (microcline, usually in longish twins. and some ortho(clase), inclosing particles of quartz and of sorla-lime feldspar (in some specimens these minerals with biotite are zonally arranged within a crystal of feldspar); clear to pale anethystine quartz with hairlike crystals. probably of rutile, and with cavities in sheets which in some sections are parallel; milk-white striated soula-lime feldspar (olignclase-albite), more or less kaolinized and centrally micacized ; white potash nica (nuscovite); and black mica (biotite), some of it chloritizerl, generally in smaller scales than the muscovite. 
In some specimens the mica plates have their flat sides parallel to the rift direction; in some the biotite appears to predominate over the muscovite, possibly owing to the different alinement of its scales, Accessury: Magnetite, apatite, zircon (some in donbly terminated slender prisms), and rutile. purple and white fluorite occurs here and there on and near joint planes. Calcite and quartz are associated with it on these joints. Secondary: Kaolin, museorite in veinlets, a white mica withont potash, chlorite, and calcite. ${ }^{81}$

But one chemical analysis of "Concord granite" is available. That is giren on page 199. The specific gravity of the stone was determined by Crosby as 2.64 and 2.65. averaging 2.65, or $\mathbf{1 5 5 . 6}$ pounds per cubic foot.

George stejger and W. T. Schaller, chemists, of this Survey, find as the result of two tests that "Concord granite" contains from 0.15 to 0.17 per cent of CaO (lime) soluble in hot dilute acetic acid, which indicates a content of 0.26 to 0.30 per cent of $\mathrm{CaCO}_{3}$ (calcium carbonate), and the microscope also shows the presence of carbonate.

Two tests of compressive streng.h, male at the United States arsenal at Watertown, Mass., show a compressive strength of 30,830 pounds to the square inch with pressure applied at right angles to the rift, and of 23,860 pounds with Iressure applied parallel to the rift. There is thus a loss of $\mathbf{1 2 . 5}$ per cent of compressive strength in the rift direciom. A more recent test made at the same flare gave th:s stone a compressive strength of 23.670 pounds, direction of rift and grain not stated.

The polish of "Concord granite" is fair, but the abundant mica plates and the size of some of them do not favor the durability of the polish under longcontinued outdoor exposure. The muscovite appears much darker when polished. No pyrite was detected in the polished specimens or thin sections, althongl the chemical analysis inclicates its probable presence. There is considerable contrast between the rough and hammered faces. The general bluish cast of the granite is marked, particularly on the polished face, but the rongh face becomes lighter on continuel exposure. There is some variation in the amount of mica apparent on the lifferent faces of a block, as well as a clifference in the actual amount of black mica and in the sparseness of the large felkspars in the stone from different quarries. Only on close inspection do strong contrasts appear between the bright muscovite plates, the fine black biotite scales, and the glassy feldspar.

\section{QUARRIES.}

The New England Granite Works quarry is in the upper part of Rattlesnake Hill, roughly northwest of Concord. Operator, New Englanil Granite Works, 20 Ferry Street, Concord.

The granite (specimens D, XXVIII, 39, a, b, f, g), "Concord granite," Is a muscovite-biotite granite of medium bluish-gray color and fine to medium, somewhat porphyritic texture, with sparsely disseminated larger feldspars up to 0.4 inch (exceptionalls 0.5 inch) and micus from rery minute size up to 0.2 inch (exceptionally 0.4 inch). It consists, in descending order of abundance, of a slightly bluish translucent potash feldspar (microcline. mostly in lon twins, less orthoclase), inclosing quartz and soda-lime feldspar particles: clear to faintly amethystine quartz with abundant hairlike crystals, probably of rutile. also with sheets of cavities; milk-white more or less kaolinized and micacized soda-lime feldspar (oligoclase-ahite) containing rare particles of

${ }^{81}$ A microscopic description of Concord granite by $G$. $W$. Ifawes will be found in his Mineralogy and lithology of New Hampsbire, which forms rol. 3, pt. 4, of C. H. Hitchcock's Geology of New Hampshire, 1878. 
carbonate, probably calcite; white potash mica (muscovite); and black mica (biotite), nostly in smaller scales than the muscovite or with their flat sides at right angles to the muscovite scales. Accessory: Magnetite (some within biotite), apatite, zircon, and rutile. Secondary: Kaolin, muscovite in reinlets, white mica without potash, and calcite.

George Steiger, a chemist of this Surves, finds that this granite contains 0.15 per cent of $\mathrm{CaO}$ (lime) soluble in hot dilute acetic acid, which indicates a content of 0.26 per cent of $\mathrm{CaCO}_{3}$ (calcium carbonate); the presence of this carbonate is also indicated by the microscope.

A test of the compressive strength of this granite, made at the United States arsenal at Watertown, Mass., in 1907, gave the following results: A cube of approximately 2 -inch edge showed the first crack at 86,000 pounds and was crushed at 94.200 pounds, thus having an ultimate compressive strength of 23,670 pounds to the square inch. It does not appear whether the pressure was applied in the rift or grain direction.

The granite of this quarry appears to be more biotitic and to have its larger feldspars more sparse than the stone of the other Concord quarries.

The quarry, opened in 1812, was in 1906 about 350 feet from northeast to southwest, by 300 feet across, and had a working face on the southwest 130 feet in height.

Rock structure: The sheets, from 6 inches thick in the upper 30 feet of the working face to 40 feet at the bottom, dip $10^{\circ}-15^{\circ} \mathrm{SE}$. Some of the sheets, owing to their freedom from rusty discoloration, are regarded by the foremen as of recent origin and are called "strain sheets;" and even now a northwestsoutheast compressive strain occasionally extends these sheets. (See p. 32.)

There are two sets of joints-(a), strike N. $62^{\circ}$ E., vertical, forms headings on the northwest and southeast sides and recurs in the middle, but is apt to be discontinuous; (b), strike N. $45^{\circ}$ W., dip $35^{\circ}$ NE., represented by only two on the northwest wall 5 feet apart. The rift is reported as horizontal, and the grain as rertical and exactly east-west. Two 6-inch pegmatite dikes, 20 feet apart, and several an inch thick traverse the quarry vertically with a N. $30^{\circ} \mathrm{E}$. course. The thick ones are banded, consisting of a central $1 \frac{1}{2}$ to 2 inch band of aplitic material with a half-inch border on one or both sides made up of coarse pegmatite, milk-white oligoclase and microcline, and smoky quartz. Very fine garnets occur throughout these dikes, some in bands, and here and there a small beryl. There are also half-inch muscovitic veins, "sand streaks" (p. 74), striking N. $45^{\circ} \mathrm{W}$. and consisting of a central band of muscovite and quartz, with borders of quartz and feldspar. Gray and black knots of the micas measure up to 6 by 5 inches. Light rusty stain measures from 6 inches to 2 feet on the sheet surfaces, but for 100 feet vertically in the center of the quarry the sheets have little or none of it.

Transportation, by track five-eighths mile to siding of Boston \& Maine Railroad.

The product consists mainly of building stone. Thin sheets and waste furnish about 100,000 paving blocks annually as a by-product. Specimen structures: The four outer walls and the covered driveway of the Congressional Library and the outside and inner court walls of the basement of the United States Senate Office Building, Washington ; Blackstone Library, Chicago ; Bankers Trust Co., Wall Street, and Christian Science Church, New York; Camden County courthouse, Camden, N. J.; city and county building, Pittsburgl, Pa.; Adelphia Hotel, Philadelphia; Assabet River bridge, Northboro, Mass.; Early Settler's monument, Galveston, Tex.; receiving tomb, Greenwood Cemetery, Wheeling, W. Va.; Stassforth mausoleum, Evergreen Cemetery, Los Angeles, Calif.; New Hampshire Historical Society Building, Concord, N. H. 
The Granite Railway or Upper Swenson quarry ${ }^{82}$ (of Concord) is on Rattlesnake Hill, about $N .40^{\circ} \mathrm{W}$. from the statehonse at Concord and 200 feet above it. Operator, John Swenson Granite Co., Concord.

The granite (specimens D, XXVIII, 40 c, e), "Concord granite," is a muscovite-biotite granite of medium bluish-gray color and fine to medium, somewhat porphyritic texture, with feldspars up to 0.5 inch and mica plates to 0.2 inch. Feldspar appears to be relatively more abundant and biotite less so than in the stone of the New England Granite Works quarry. In other respects the two granites are identical. A section cut at right angles to the rift shows that the mica plates, both black and white, lie with their flat sides parallel to the rift.

The following analysis of this granite was made by Sherman \& Edwards, chemists, from a "thoronghly composite sample carefully selected" by W. O. Crosby, of the Massachusetts Institute of Technology. This analysis form $\mathrm{S}$ part of a report made by him for the firm in 1907, and is published here merely for reference.

\section{Analysis of "Concord granite" from Swenson quarries.}

Silica $\left(\mathrm{SiO}_{2}\right)$

Alumina $\left(\mathrm{Al}_{2} \mathrm{O}_{3}\right)$

Iron sesquioxide $\left(\mathrm{Fe}_{2} \mathrm{O}_{3}\right)$

Iron oxide ( $\mathrm{FeO})$

Magnesia $(\mathrm{MgO})$

Lime $(\mathrm{CaO})$

Soda $\left(\mathrm{Na}_{2} \mathrm{O}\right)$

Potash $\left(\mathrm{K}_{2} \mathrm{O}\right)$

Sulphur (S)

Carbonic dioxide $\left(\mathrm{CO}_{2}\right)$

Water not combined $\left(\mathrm{H}_{2} \mathrm{O}\right)$

Water combined $\left(\mathrm{H}_{2} \mathrm{O}\right)$
74. 47

14. 15

1. 16

1. 21

.63

1. 70

1. 97

4. 14

.27

.25

.06

.20

100. 21

Crosby, in the same report, gives two determinations of specific gravity as 2.64 and 2.66, arerage 2.65, which is equiralent to 155.6 pounds to the cubic foot.

W. T. Schaller, a chemist of this survey, finds that this granite contains 0.17 per cent of $\mathrm{CaO}$ (lime) soluble in hot dilute acetic acid, which indicates the presence of 0.30 per cent of $\mathrm{CaCO}_{3}$ (calcium carbonate).

Compression tests made at the United States arsenal at Watertown, Mass., in 1906 show it to have an ultimate compressive strength of 30,830 pounds to the square inch with pressure applied at right angles to the rift, but of 23,860 pounds with pressure applied in the direction of the rift, the rift thus weakening the stone 12.5 per cent when pressure is applied parallel to it.

The quarry, opened in 1863, measured in 1906 abont 500 feet in a northnortheasterly direction by 400 and 200 feet in width and from 10 to 100 feet in depth.

Rock structure: The sheets are irregular, lenticular, 4 inches to 14 feet thick, but mostly from 2 to 7 feet, and dip northwest at a low angle. There are two sets of joints-(a), strike N. $20^{\circ}$ E., dip $70^{\circ}-75^{\circ}$ E., spaced 10 to 100 feet, forms the west wall and a heading 50 feet wide on the east side; (b),

82 This quarry owes its first name to the fact that it was originally operated by the Granite Railway Co., of Quines, Mass., referred to on p. 320. 
strike $\mathrm{X} .0^{\circ} \mathrm{W}$, vertical or dip $75^{\circ} \mathrm{s}$., suaced 10 to 300 feet, forms the north wall and a heading 6 to 15 feet wide on that side. The ritt is reported as dipping $15^{\circ} \mathrm{W}$., with a strike of $\times .5^{\circ}-10^{\circ} \mathrm{E}$, and the grain as rertical eastwest. In summer time it is not necessary to follow the grain closely in splitting. There are pegmatite dikes up to $1 \frac{1}{2}$ inches wide. Segregations of the micas are said to he rery rare and to measure only $t$ inches. Rusty stain is up to $S$ inches wide, but confined to the proximity of headings. A little east-west compressive strain is reported. The joint faces of headings (b) are dull greenish, owing to chloritization of biotite and the formation of fibrous muscovite in the feldspar and between the particles. The soda-lime feldspars also contain chlorite and carbonate. Other joint fidces of the same set carry secondary quartz and calcite crystals and apparently also fluorite, deep purple and white. (See p. s3.)

Transportation, by cart one-third mile to cutting sheds on siding of Boston \& Maine Railruat.

The product is used for huihlings and monuments. Specimens: Institute of Arts and sciences, Manchester, X. H.; city hall and Christian science Chureh, Boston; Northampton County Sarings Bank, Easton, Pa.; Lehigh County courthouse. Allentown, Pa.; Medico-Chirugical Hospital, Eighteenth and Cherry streets. Philadelphia; post oflices at Dayton, Ohio, Lincoln, Nebr., Adrian, Mich., and Hammond, Ind.; pedestal of the Monaghan monument, spokane, Wash.; New Hampshire soldiers' monmment, Vicksburg, Miss.; pedestal and exedra of IcKinley memorial, McKinley Park, Chicago: and electric station of New York Edison Co., East Thirty-ninth Street, New York.

The Lower Swenson or Hollis quary is about 600 feet northeast of the last and 70 feet below it. It is operated by the same company.

The granite is identical with that of the upper quary, just described. The quarry, opened about 1S6t, measured in 1906 about 450 feet north and south by 300 feet across and from 40 to 50 feet in depth.

Rock structure: The sheets, 6 inches to 35 feet thick, are irregular, lenticular, and horizontal or dip $15^{\circ} \mathrm{W}$. There are two sets of joints-(a), strike $\mathrm{N}$. $25^{\circ} \mathrm{E}$., dil $65^{\circ}-70^{\circ}$ E., spaced 10 to 50 feet, forms headings on the west and east sides and another 50 feet of the west wall; (b), strike N. $65^{\circ} \mathrm{W}$. to east-west, about rertical, spaced 20 to 75 feet, forms the northeast wall. There are several inclusions of bander gneiss; one 3 feet 6 inches by 2 feet; another, originally much harger, now measures 4 feet 6 inches in liameter and is roughly quadrangular. Part of this is pegmatitic and part a biotite gneiss, with soda-lime feldspar (oligoclase-andesine) and garnets. In the finer parts the particles do not exceed 0.3 i millimeter in diameter. The rift and grain are reported as the same as at the upper quarry. One-inch pegmatite dikes cross the quarry diagonally, Rusty stain on the upper sheets is up to 8 inches thick. The granite along heading (a) on the west wall is much kaolinized and in places very limonitic. The surfaces have frostlike crystallizations (dendrites), probably of limonite also.

The product of this quarry has been combined with that of the Upper Swenson quary.

The Fox quarry is on Rattlesnake Hill, 110 feet above North State Street. $\mathrm{N} .43^{\circ} \mathrm{W}$. from the statehouse, and about half a mile $\mathrm{N} .40^{\circ} \mathrm{E}$. from the New England Granite Works quarry. Operator, Thomas Fox, 272 North State Street, Concord. Idle in 1921.

The granite, "Concord granite," is a muscovite-biotite granite of medium bluish-gray color and fine to medium, somewhat porphyritic texture, resembling that of the Upper Swenson quarry more than that of the New England Granite Works quarry. (See p. 199.) 
The quarry, opened in 18St S.5. a plan of which is given in figure 41), moasured in 1906 about 200 feet and 300 feet hy 17.5 feet alcross and from 40 to 70 feet deep.

Rock structme: The sheets, 2 to 20 feet thick, are, for this region, exceptionally regular. and $\mathrm{di}_{\mathrm{p}}, 10^{\circ} \mathrm{SW}$. There are three sets of joints. (See fig. 40.) A, rertical to steep, east-southeast. spaced 3 to 30 feet, forms east and west walls and the headings on the east side and center. B, rertical to steep, east, spaced 10 feet and over. C. splaced 10 to 70 feet, apt to be discontinuous. The rift is reported as dipping $5^{\circ}-7^{\circ} \leqslant W^{\circ}$ and the grain as rertical, with a $\times 70^{\circ} \mathrm{E}$. course. The stone splits more easily along the rift in winter than in summer. In the northern fart a 10-foot band of sranite. without the bluish tint of the rest, strikes $X .60^{\circ} \mathrm{W}^{\circ}$. and dips $90^{\circ}$. The cause of the difference is not clear, unless it is the nicacization of the potash feldspar. This band contains zonally arranged particles of quartz and oligoclase. Its course presumably indicates the flow direction of the sranite. On one or both sides of it is an inch vein of muscovite. Pegmatite alikes are $u 1$ to $1 \frac{1}{2}$ inches thick. There are spheroinal segregations. from dinches to 3 feet by 2 feet 6 inches, of a porphyritic granite of bluish-gray color, darker than any "Concord granite." The matrix is fine-textured (particles 0.18 to 0.74 millimeter) : the felltspars measure up to 0.4 inch and the mica to 0.2 inch. The crinstituents are the same as those of "Concord granite." The sheet surfaces are mostly free from rusty stain, and it is said nerer. to exceed 4 inches in thickness. One of the joint faces carries chlorite, calcite, and pyrite.

Transportation, by cart onefourth mile to siding of Boston \& Maine Railroad. or three-fourths mile to cutting shed.

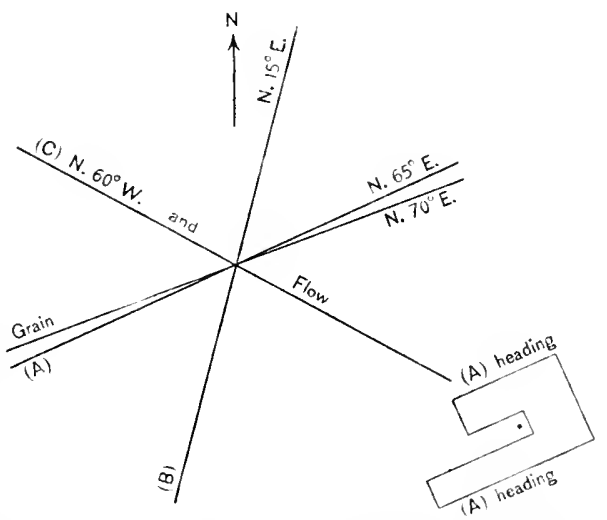

Figle 40.-Structure and plan of Fox quarry, Concord, X. H.

The product is used for buildings and monuments. Specimens: Church of Christ, Scientist. Sheldon Library, St. Paul's School. Concord; soldiers' monument, Warner, X. H. ; Carpenter tomb, Manchester, N. H.; entrance to Forest Lawn Cemetery, Buffalo, N. Y.

The Perry quary is on Rattlesnake 11ill. $X .50^{\circ} \mathrm{W}$. from the statehouse and 360 feet above North State Street. This is the most southerly of the Concord quarries. Operators, Perry Bros., Concord.

The granite, "Concord granite," is a medium bluish-gray muscovite-biotite granite of fine to medium, somewhat porphyritic texture, closely resembling that of the New England Granite Works quary described on page 197.

The quarry, opened in 1873 , measured in 1906250 feet $N$. $75^{\circ} \mathrm{W}$. by 125 to 250 feet $\times 10^{\circ}$ E., and from 60 to 100 feet in deuth.

Rock structure: The sheets, 1 to 18 feet thick, are about horizontal. There are four sets of joints-(a), strike $\mathrm{N}$. $10^{\circ} \mathrm{E}$. . dip steep east, spaced 5 to 20 feet; (b), strike N. $75^{\circ}$ W., vertical, spaced 18 to 35 feet; (c), strike N. $30^{\circ}$ E., dip $50^{\circ}$ E., spaced 200 feet; (d), strilie N. $45^{\circ} \mathrm{W}$., dip $75^{\circ} \mathrm{S} .45^{\circ} \mathrm{W}$., occurs only at the northeast corner. The rift is reported as horizontal. and the grain as vertical, with N. $80^{\circ}$ W. course. A 4 to 5 inch pegmatite dike has a $\mathrm{N} .85^{\circ}$ 
IV. course and vertical dip. Rusty staln does not exceed 4 inches and is absent rrom some sheets.

Transportation, by cart 3 miles to eutting shed on Boston \& Maine Railroad.

The product is used mostly for monuments. Specimen: George Fogg monument, Blossom Hill Cemetery, Concord.

The Henneberry quarry is on Rattlesnake Hill, one-fourth mile west of North State Street and $\mathbf{7 0}$ feet above it, at a point one-fourth mile north of the State prison. Operator, Thomas Fox, 272 North State Street, Concord. Inle in 1921 .

The granite (specimens D, XXVIII, 49, a, c), "Concord granite," is a muscovite-biotite granite of medium bluish-gray color and fine to medium, somewhat porphyritic texture, with feldspars up to 0.5 inch and white mica scales up to 0.2 inch. This stone resembles more closely that of the New England Granite Works quarry than that of the Swenson quarries, being more micaceous and less feldspathic than the latter, but the black mica scales are generally finer thau in the former, so that it has a larger number of fine particles. The constituents are the same as in the sections described on pages 197, 199.

The quarry, opened in 1900, was in 1906 about 200 feet N. $25^{\circ}$ E. by 100 feet across and from 50 to 65 feet deep.

Rock structure: The sheets, 2 to 15 feet thick, are somewhat irregular and horizontal or dip $17^{\circ}-30^{\circ} \mathrm{NE}$. There are two sets of joints-(a), discontinuous, strike N. $25^{\circ}$ E., spaced 3 to 15 feet, forms a heading at the northeast end; (b), strike about northeast, diagonal, spaced 12 to 25 feet. The rift is reported as horizontal or nearly so, and the grain as vertical with a northeast strike. Three garnetiferous pegmatite dikes, 1 to 4 inches thick, in a space of $2 \frac{1}{2}$ feet, strike about N. $45^{\circ}$ W. and dip $60^{\circ}$ SE. Rusty stain is about 4 inclies thick on sheet surfaces.

Transportation, by cart, one-eighth mile to Boston \& Maine Rallroad.

The product is used entirely for monuments. Specimens: Fay sarcophagus, Dewitt, Iowa; Sielaff sarcophagus, Milwaukee, Wis.; Raines sarcophagus, Memphis, Tenn.; McElwee sarcophagus, Homer, Ill.; Alten cross, Elyria, Ohio ; Crippen sarcophagus (elaborately carved), Blossom Hill Cemetery, Concord.

\section{ROCKINGHANI COUNTY.}

AUBURN.

The Auburn quarry is 7 miles east of Manchester, in the township of Auburn. Operators, Perry Bros., Concord.

The granite (specimens, D, XXVIII, 46, a, b), "deep-pink Auburn," is a quartz monzonite of medium pink-buff color with very fine black clots. Its texture is fine, with feldspar and mica up to 0.1 inch. Its constituents, in descending order of abundance, are slightly pinkish potash feldspar (orthoclase and microcline); alnost if not quite as abundant, clear to milk-white soda-lime feldspar (oligoclase), some of it kaolinized and micacized; smoly quartz; and biotite (black mica), some of it chloritized and bleached. Accessory: Mag. netite, apatite, and zircon. Secondary: Kaolin, a white mica, chlorite, and hematite stain.

The stone takes a fair polish, and the hammered face by its lightness offers not a little contrast to the rough and polished faces. It is used for monumental work.

STRAFFORD COUNTY.

ROCHESTER.

The Langmaid quarry, in Rochester Township, 5 miles northwest of Dover, is no longer operated. 
The granite (specimen $\mathrm{D}, \mathrm{XXX}, 8 t$, a) is a biotite granite of very light gray shade, with close lark specks, and of even-grained medium texture, with feldspar up to $0.3 \mathrm{inch}$ and micas to $0.2 \mathrm{inch}$. Its constituents, in descending order of abundance, are clear to translucent potash feldspar (uicrocline and orthoclase); medium smoky quartz with cavities in sheets and hairlike crystals of rutile; milk-white sola-lime feldspar (oligochase-albite), most of it kablinized and micacized; biotite (black mica), some of it chloritized; and a little muscovite or bleached biotite. Accessory: Magnetite, rutile. Secondary: Kaolin, a white mici, chlorite, calcite. It effervesces slightly with muriatic acid test.

This is a constructional granite with marked contrast of shade between its smoky quartz and milk-white feldspar.

The quarry, opened before 1879 , measured in 1909 about 300 by 90 feet and . from 12 to 15 feet deep.

Rock structure: The sheets, 1 to 8 feet thick, are horizontal. There are three sets of joints-a longitulinal, a transverse, and a diagonal set-spaced generally 10 to 20 feet. The rift is reported as horizontal, and the grain as vertical, with north-south course. There are several pegmatite dikes about a foot thick. Rusty stain is 1 to 3 inches but in places 8 inches thick on sheet surfaces.

Transportation, by cart 5 miles to Dover or Rochester.

The product was used for bases, trimmings, and faces. Specimen: Some of of the trimmings of the courthouse at Dover, N. H.

\section{SULLIVAN COUNTY.}

SUNAPEE.

The Spectacle Pond quarry is at the southeast corner of Sunapee Township, about a quarter of a mile south of Spectacle Pond and the same distance southwest of Edgemont (formerly Mount Sunapee) station. (See Sunapee topographic map, U. S. Geol. Survey.)

The granite (specimen $\mathrm{D}, \mathrm{XXX}, 78$, a) is a biotite-muscovite granite of light buff-gray color and of even-grained fine texture, with feldspars up to 0.2 inch, rarely $0.25 \mathrm{inch}$, and micas under 0.1 inch. Its constituents, in descending order of abundance, are clear colorless potash feldspar (microcline and orthoclase); light smoky quartz with hairlike crystals of rutile and with cavities in sheets and cracks parallel thereto ; crean-colored soda-lime feldspar (oligoclase-albite), more or less kaolinized and micacized; biotite (black mica); muscovite (white mica). Accessory: Garnet, apatite, rutile. Secondary: Kaolin, a white mica. No effervescence with muriatic-acid test.

This is a fine-grained monumental granite. Its color may be less buff and even bluish farther below the surface.

The quarry, when opened in 1909 , was 75 feet square and 3 to $S$ feet deep.

Rock structure: The sheets, 1 to 5 feet thick, dip $15^{\circ}$ about northeast. There are three sets of joints-(a), strike N. $10^{\circ}$ E., dip $80^{\circ} \mathrm{W}$., spaced 5 to 10 feet, forms a heading on the east side; (b), strike northeast, dip $65^{\circ} \mathrm{NW}$., spaced 10 to 25 feet, forms a heading at the southwest corner; (c), strike N. $30^{\circ}$ E., dip $70^{\circ} \mathrm{N}$. $60^{\circ} \mathrm{W}$., forms a heading 10 feet wide through the mirlde of the quarry. The rift is reported as horizontal, and the grain as vertical, with nearly east-west course. A quartz vein up to 5 inches thick crosses the midale of the quarry, with $\mathrm{N}$. $70^{\circ}$ E. strike. Rusty stain is up to 4 inches thick on sheet surfaces. The quarry is no longer operated. 
The Perry Sumapee quarry is on the top of a 200 -font knoll half a mile west of Bmrkelaven, on Lake sunapee, and three-fourths of a mile south-southeast of smapee village, in sunapee Township. (see Smapee topographic map, U. S. (Geol. surrey.) Operators, Perry Bros.. Concuri.

The granite (specimens. I. XXVIII, 47, a. b). "light sunapee," is a biotitemuscovite granite of a light-gray. slightly bluish color and very tine to fine texture, with feldspars $u p$ to 0.15 inch ani mica to 0.1 inch. Its constituents, in descending order of abundance, are clear colorkess potash feldspar (microchine and orthoclase, the latter with hairlike crystals, probably of rutile, both being intergrown with (ulartz circular in (ross section) : clear colorless quartz, also with rutile needles; translucent to milk-white soda-lime feldspar (oligoclasealbite), somewhat kaolinized and intergrown with quartz; biotite (black mica); and muscovite (white mica). Acressory : Magnetite, garnet, zircon, and rutile. Secontary: Kaolin and carbonate.

This, as will be seen by rompring the descriptions, is finer grained than "Concord granite." It lends itself well to fine carving. Its particles are too fine to afford contrasts. It takes a fair polish.

The "black granite" (specimen I, XXVIII, 48, a, b), "black pearl" or "dark Sumapee," is a quartz diorite of rery dark bluish-gray color and fine, inclining to melium texture. with feldspars up to 0.2 inch. Its constituents, in descending orler of abundance, are clear colorless to milk-white soda-lime feldspar (oligoclase-andesine to andesine), but little kaolinized, rarely intergrown with quartz; biotite (black mica); clear colorless quartz (possibly equal in amount to feldspar); and titanite. There is so much of this molasses-colored mineral present that it is easily seen witb a loop. Accessory: Magnetite (ilmenite?), prrite, allanite, and zircom. Secondary: Laolin, epidote (about allanite), calcite, and hematite. It effervesces slightly with muriatic acid test.

When polished the rock appears black mottled with white. The polish is poor owing to the large size and abundance of mica. It shows magnetite and a little pyrite. The hammered face is light gray and thus is in marked contrast to both rough and polisher faces. The stone is used for monuments and is suitable for inscriptions.

The quarry, opened in 1S69, measured in 1900 abont 150 by 100 foet and from 15 to 30 fect in depth.

Rock structure: The sheets, 6 inches to 3 feet thick, are undulating. There are no joints. The rift is probably horizontal. and the grain vertical, with $\mathrm{N} .80^{\circ}$ W. course. A pegmatite dike up to 30 inches thick. strike N. $30^{\circ}$ L., vertical or steep, forms part of the east wall. A 3-foot dike striking about east forms the morth wall. Other pegmatite dikes up to 6 inches thick, strike N. $50^{\circ}-70^{\circ} \mathrm{K}$.. recur at intervals of 5 to 20 feet. A vertical porphyritic wranite mass, also striking N. $30^{\circ} \mathrm{F}$. forms the west wall. Two large inclusions of quartz-mica diorite gneiss ocenr near the sonth end of the east wall, apparently in a coarser granite. The larger, 10 feet long and of very irregular outline. is crossed by meanlering quart\% veins. These inclusions apnear to lie not within the fine granite of the quarry but within a coarser granitic rock adjoining or crossing it. The diorite consists of andesine, biotite, quartz, and titanite. The other inclusion back of the northeast corner of the qualry is of similar rock but contains hormblende. These diorites resemble that of specimens $4 S$, a, b, described above. A disused quarly of that rock occurs a little north of the Perry light-granite quarry. A coarse porphyritic granite occurs also on the same hillock. A little rest of Sumapee on the road to Newport a coalse pornhyritic granite, a finegrained granite. and a dark schistose rock all occur in a single outcrop. The relations of the diorite gneiss to the fine and the coarse granite were not further investigated. 
Transportation, by cart more than 3 miles to Sumpe station, on Claremont branch of Boston \& Iraine Railroal.

The product is used for momments, which a re finished at the firm's cutting shed at Concord. The quarry is oprerated only oceasionally.

\section{MAINE. \\ THE OCCURRENCE OF GRANITE IN MAINE.}

By (ieorge Otis Simth.

\section{GEOGRAPIIE DISTRIBLTION.}

Areally. granite is perhaps the most abundant rock in Maine. Slates, schists, sandstones. and limestones of various types occur in the different sections of the state. but the mountains and hills of the interior and the islands and heallands of the coast for the most part all exhibit slopes and cliffs of massive granite. Even where the exposures are of other rock varieties the notable abundance of gran: ite dikes and quartz reins indicates the presence of granite at no great distance. Not only is this rock most conspicuous, but its importance in both the geology and the industry of the state can hardly be overestimated.

The areal distribution of the granite is somewhat irregular, as may be noted on the map accompanying this report (PI. IX). Three general granitic regions may be distingnished for convenience of description-that of the western tier of comnties, that of the castern part of the state. and the Mount Katahdin area. in the north-central part of the State. In addition to these larger regions there should also be mentioned three small areas in Lincoln. Kennebec, and Somerset counties, which are intermediate in position between the three main regions.

The granite areas of the western region are not widely separated, and the largest of these areas as outlined on the map is not all granite, although, as will be explained in a later paragraph. the intrusive granite forms the larger part of the rock exposed within these limits. The northermmost of these manite masses is exposed in the elevated comntry that forms the divide between the Chandiere drainage basin on the Canadian side of the international boundary and the headraters of Androscoggin and Dead rivers in the northern part of Franklin County. Sonth of this is a much larger area of granite. extending from the western part of Somerset County across Franklin into Oxford Connty and including prominent pealss, like Mount Bigelow and Saddleback Mountain, as well as the rugged country south of the Rangeley Lakes. South of this is a large, irregular-shaped area of metamorphic rocks-gmeisses and schistsmore or less thoroughly impregnated with granite, which extends 
southward and eastward through seven counties, reaching the coast at Casco Bay on the west and Penobscot Bay on the east. Southwest of this area is a mass of granite, which constitutes the eastern extension of the White Mountain massif of New Hampshire and reaches the coast at Casco Bay, Cape Porpoise, and York Cliffs.

The Mount Katahdin area of granite lies wholly within the forested region of northern Maine, and therefore its exact boundaries are unknown. At the northeast end of the area is the highest elevation in the State. Katahdin, 5,268 feet above the sea, a typical granite mountain. To the sonthwest, possibly connected with this area, is the granite near Lake Onawa, where the rock is well exposed in a deep cut of the Canadian Pacific Railway.

In the eastern counties three extensive granitic areas may be distinguished. Of these the northernmost extends southwestward from New Brunswick across the northern portions of Washington and Hancock counties into Penobscot and is almost wholly forested country. Southeast of this is the horseshoe-shaped granitic area of Hancock County, which crosses into Washington County near Cherryfield. On the west the outlying Mount Waldo mass may represent an extension of the same granite, although connecting exposures along Penobscot River below Bucksport have not yet been observed. In the Hancock County area the granite can be traced from the shore of Eggemoggin Reach northward along a line of prominent hills, which are best seen from the Maine Central Railroad near Green Lake. North of Aurora these granite hills have less relief, but east of that place the belt extends southward with increasing ruggedness of topography, Tunk Mountain, near the Washington County Railroad, being characteristic of this southern portion. The other area of granite in eastern Maine is the belt extending from New Brunswick across the St. Croix, thence southwestward to the coast at Addison, and thence along the coast to Penobscot Bay. Within this belt are included several large islands-Swans, Deer, and Vinalhaven-and the mountains of Mount Desert owe their topographic prominence to the massive character of the granite composing them.

Of the smaller areas of granite not included within the three groups described above, that in Lincoln County comprises the town of Waldoboro and islands at the head of Muscongus Bay. The HallowellAugusta area in Kennebec County, the North Jay and Phillips area in Franklin County, and the Hartland and Norridgewock areas in Somerset County represent the larger of many small intrusive masses of granite in central Maine. With these should be mentioned the granite occurring in Aroostook County, about 12 miles west of Houlton.

In the preparation of the map (Pl. IX) showing the distribution of the granite, as described above, the data used have been largely the 


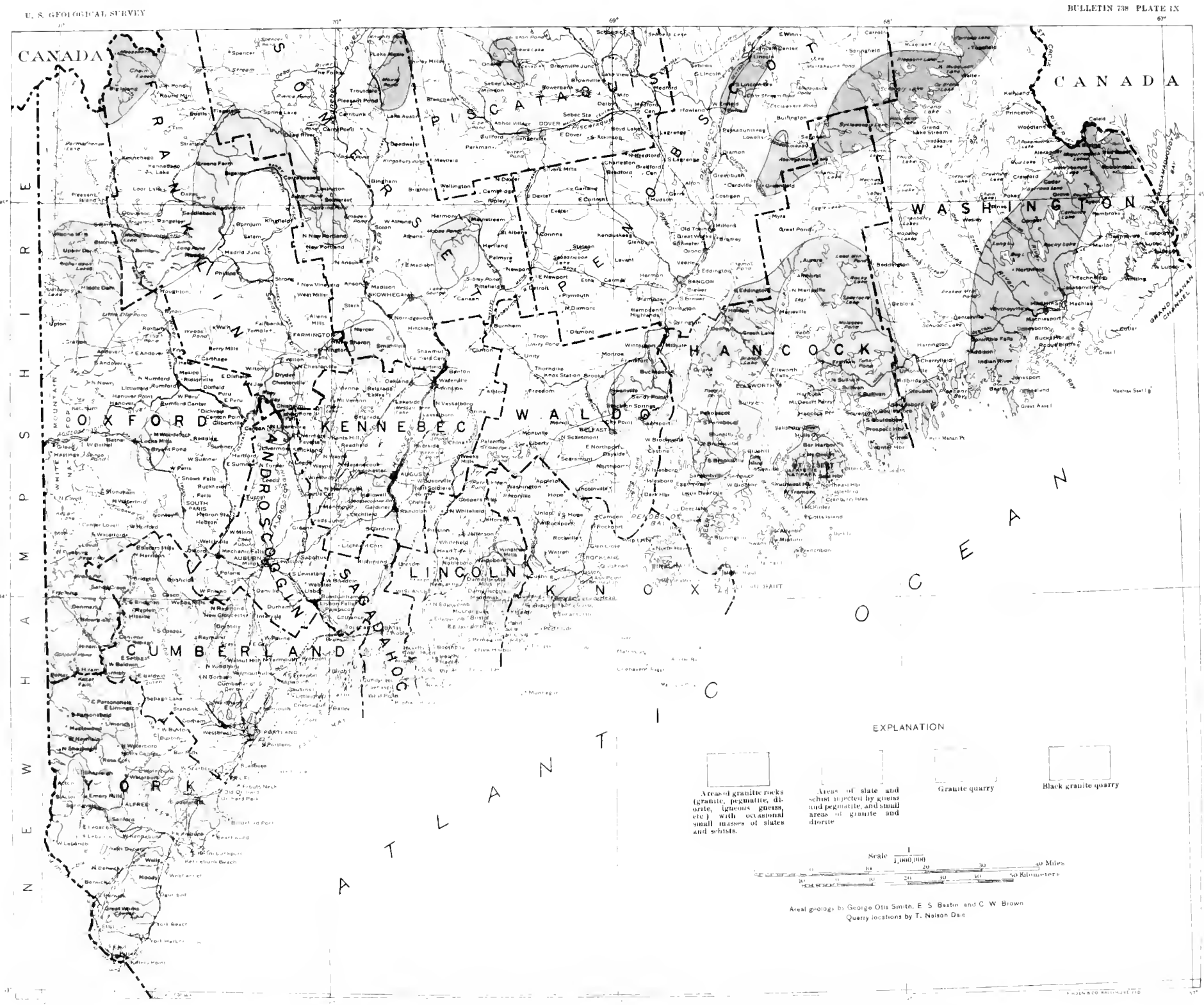



results of areal mapping for folio publication by E. S. Bastin, C. W. Brown, and the writer, and of general recommaissance by the writer, assisted by Mr. Bastin. In the more northern areas the work by H. E. Gregory and the earlier mapping by C. T. Jackson and C. H. Hitchcock have been utilized to supplement this recent work. Mr. Brown also contributed the results of recent observations in the vicinity of Mount Katahdin.

\section{GEOLOGIC RELATIONS.}

Wherever the granites of Maine have been studied in any degree of detail. their relations are plainly those of intrusion into part, at least. of the adjacent formations. Evidence that the granite is the younger rock is found in the tendency shown by some of the granite areas (see Pl. IX) toward elongation in a northeast-southrest direction, parallel to the general trend of the main structural features of the region, but more conclusive evidence is found in the fact that the granite actually cuts across the bedding of the sedimentary rocks and has in some localities produced in them a rery considerable amount of alteration. Bordering the granite in Franklin County. for example. and in some other parts of the State are andalusite schists which plainly represent sedimentary strata metamorphosed by the granite. In many regions, as will be described later, the granite masses are bordered by gneisses which were formed by the injection of granitic material along the foliation planes of sedimentary schists. Thus the general relations throughout the State suggest that the granites are relatively the younger rocks.

The feature which is perhaps the most significant in the geologic relations of the granites to the other rocks of the State is the great contrast between the sharpness of certain granite borders and the indefinite character of others. In the vicinity of Bluehill and Brooksville, in Hancock County, for example. the contact is absolutely sharp, pure granite being succeeded within a foot by schists unmixed with granite. Along such sharp borders, too. the granite usually preserves its normal texture up to the very contact, and the surrounding rocks show almost no effects of contact metamorphism. In striking contrast to this are the broar contact zones which characterize most of the granite masses lying farther west. In the Rockland region, for example, the Sprucehead-Clark Island granite area is bordered on the northwest by a zone 3 to 4 miles in width in which sedimentary slates and schists are intimately associated with injection gneisses, basic granites, fine-grained granite, pegmatite, diorite, gabbro, and diabase. These igneous rocks were plainly derived from the granitic magma and are most abundant in those portions of the contact zone which lie nearest to the areas of pure 
granite. A granite area near south Penobscot. in Hancock County, is almost completely surrounderl by a border zone from one-fourth mile to $1 \frac{1}{2}$ miles in width in which the rocks are largely diorite and gabbro with small amounts of igneous gneiss and fine-grained granite.

Some hint as to the cause of this contrast in the character of granite borders in different regions is obtained from a study of the rocks in the sonthwestern part of the State, especially in Sagadahoc. Cumberland. and ()xford counties and the sonthern part of Kennebec County. Here, as indicated on the map (Pl. IX), there are considerable areas which contain no large continuons masses of normal granite but in which the prevailing sedimentary schists have been invaded in the most intimate manner by dikelike or irregular masses of pegmatite and fine-grained granite and in many places have been given a gneissic texture by the injection of granitic material. The areas of intrusion and injection pass gradually into the larger areas of nearly pure normal-textured granite shown on the map. To explain such intimate injection and intrusion in areas far removed from any outcropping masses of pure normal granite it seems necesary to assmue that a granite mass underlies these rocks at no great distance below the present surface and that such invaded areas constitute in reality portions of the "roof" of great granite batholiths.

It seems almost certain that the escape of gases and water vapor and the differentiation of basic rocks from the granitic magma would proceed much more rapidly from the upper surface of a buried magma than from its sides. It is to be expected. therefore, that portions of the "roof" of such granite masses should be particularly characterized by the abundance of pegmatites, diorite, gabbro, etc., and by notable contact metamorphism of the sedimentary rocks through which these forced their way. The sharpness of other granite contacts is readily explained by supposing that they represent the side contacts of the granite batholiths, where the gases and water vapor escaped from the magma laterally in much less volume and where the accompanying metamorphic effects were very much less than at the upper surface.

The geologic history of the great granite intrusions of Maine may therefore be summarized as follows:

All the granite masses now exposed solidified below the surface as it existed at the time when they were intruded. The depth at which they solidified varied in different places. Erosion gradually removed the rocks covering some of the masses and has in some places even revealed their deeper portions, so as to show the sharp lateral contacts. In other places all or a part of the "roof" of the 
granite masses still remains. The present land surface therefore truncates the various granite batholiths at different horizons. It is highly probable that a further erosion of 500 to 1,000 feet would expose much larger areas of grinite than now appear.

All the granites of Maine were formerly supposed to have been intruded during a single great period of igneous activity and to be of the same general geologic age. This conclusion was based on their general lithologic similarity and on the presumed continuity, at no great depth below the surface, with the granite of neighboring areas, as stated above. There is little loubt, for example, of the contemporaneity of the granite of the Perry Basin. on the eastern border of the State, with that of Vinalhaven, as a belt of granite extends with slight interruptions from one of those localities to the other. It was thonght, therefore, that the greater part of the State is underlain by a huge granite batholith with an irregular upper surface, exposed by erosion in many areas but elsewhere covered by uneroded portions of the "roof."

The age of the belt of granite just mentioned is approximately known, as the Silurian strata of the Perry Basin district contain no pebbles of granite, but such pebbles, plainly derived from the neighboring granite masses, are abundant in the conglomerate at the base of the Perry formation, which is of late Devonian age. The granite is therefore late Silurian or early Devonian, and this conclusion is strengthened by the evidence in the Vinalhaven district, where the granite is intruded into surface volcanic rocks of Niagaran age.

In southwestern Maine, however, the rocks into which most of the granites are intruded are now believed to be Carboniferous, because of their strong lithologic similarity to the Carboniferous strata of central Massachusetts and their virtual continuity with those strata across southeastern New Hampshire. Hence most of the granites of that part of the State are much younger than those of the eastern part. At present, therefore, although all the granites of Maine are regarded as of Paleozoic age, they are thought to be separated into at least two eruptive groups, one middle Paleozoic and the other probably late Paleozoic.

\section{DISTRIBUTION OF GRANITE QUARRIES.}

The map (Pl. IX) shows the location of the principal quarries and groups of quarries and prospects, which include 115 separate openings, and also the relation of these to the rock areas described above by Doctor Smith. A number of unimportant paving-block and underpinning quarries have been overlooked or intentionally omitted. A typical one-man paving-block quarry which from its changing location is called in Maine "a motion" is shown in Plate XVIII, $B$. 
Quarries of granite proper.- With the exception of the important quarries at Hallowell, Kennebee County, and North Jay, Franklin County, and the minor ones at Fryeburg and Bryant Pond, Oxford County, Pownal, Cumberland County, Norridgewock and Hartland, Somerset County. Oak Hill and Lincolnville, Waldo County, and Dedham, Hancock County, all the granite quarries of Maine are along the seaboard. either on islands or on bays or navigable rivers, or within 4 miles of them. The inland quarries are all on railroads or within a short distance of them. The distance to rail from a few quarries is 3 miles, from one 5 miles, but as the product of these quarries is used entirely for monumental work the cartage is a matter of less moment. The Maine granite industry may be said to have its center in Penobscot and Bluehill bays and the islands about them. A line drawn from Clark Island, sonth of Rockland, north-northeast to Frankfort, thence about east to Franklin, in Hancoek County, thence sonthwestward through Bar Harbor, and thence around the islands southwestward back to Clark Island, would embrace an area of about 1.200 square miles, which would include the bulk of the granite industry.

Quarries of "black granite."--Of the total number of quarries, 18 are of "black granite," although a few obscure ones may have been overlooked. Their location is shown by a separate symbol on the map. They are in York, Lincoln, Waldo, Penobscot, and Washington counties. Of these only the Addison (Washington County), Vinalhaven (Knox County), and Round Pond (Lincoln County) quarries are at tidewater, but as the "black granites" are used only in small quantities for expensive work the cost of transportation is a minor consideration.

\section{THE QUARRIES, THEIR GRANITE AND FINISHED PRODUCT.}

\section{CUMBERLAND COUNTY.}

\section{BRUNSWICK.}

The Grant quarry is in the town of Brunswick, 3 miles west of Brunswick village, on the south side of the Maine Central Railroad, on the Merriman farm. It has not heen operated for many years.

The granite (specimen D, XXVI, 110, a) is a biotite granite of medium-gray sharle and fine, eren-grained texture, in which the particles of quartz measure up to about 0.4 inch and those of feldspar and mica up to 0.15 inch. Its minerals, in descending older of abundauce, are potash feldspar (both microcline and orthoclase), quartz, a feldspar with both lime and sola (oligoclase-albite), and biotite, with rarely a scale of muscovite. The orthoclase has inclusions of quartz, circular in cross section, and the second feldspar is greatly altered. Accessory: Zircon.

The opening measures about 75 by 50 feet by 5 feet in depth.

Rock structure: The sheets, 2 to 12 inches thick, dip not higher than $5^{\circ}$. The joints strike N. $55^{\circ}$ W. and N. $60^{\circ}$ E. A marked flow structure is indicated 
by alteruating light and dark hands. due fo varying amounts of blak mica, und also by the parallelism of the longer axes of the larger feldspar erystals null biotite plintes. Its strike is $\mathrm{N}$. $35^{\circ} \mathrm{W}$. Tht mpler sheet shows much discoloration.

Transportation, by team to railroad near by.

Prodnct: The chapel of Bowdoin College, at Iimuswick, Wal bult of the sime granite, but from another opening, referred to by (ionge I'. Merrill ss as also furnishing the stome for the First Irarish ('lumrol, in lortlant.

\section{FREEPORT.}

The Freeport quary is half a mile southeast of frecpurt station. on the Maine Centril Railhoal, on the east sile of a hillock so feet high, with motheast-southwest axis. Operator, Long \& Samders Quarries ('o., Quiney, Mass. Quarry idle since 1913.

The granite specimen D, XXYII, 127, a) is a biotite-muscovita cranite of medium-gray shade with a slight bluish tinge and rery tine, aren-grained texture, with particles ringing from 0.36 to 1.28 , ant, exreptionally, from 0.19 to 2.5 millimeters in diameter. Its minerals, in descending order of aldumlance, are potash feldspar (microcline, orthoclase), smoky quartz, solia-lime foleswir (oligoclase), black mica, and white mica. The somla-lime feldspar is considerably altered to kaolin and a white mica, and both feldspars often have intergrowths of quartz eircular in cross section. The rork contains acressory apatite. It takes a fine polish. The specific gravity was reported by F. I. Bartlett, of the Maine State assay oflice, as 2.627. It is free from pyrite.

The quarrs, first opened in $18 \$ 6$, measured in $190 \mathrm{~s}$ about 600 feet from northeast to southwest by 100 feet across, with a working face nis feet hish.

Rock structure: The granite at the northeast end of the quarry is alpred by about 5 feet of schist, and in its center the excavation, in proceeding in a direction parallel to the axis of the hill, has bisected an inclusion of this sime schist 3 feet thick and about 40 fort long. dipuing $35^{\circ} \mathrm{E}$. to a point 30 feret leelow the surface of the granite. This schist inclusion is lescribed on page 63 . (See also Pl. XV, B.) About 150 feet southeast of it is another indusion of similar material. The presence of these inclusions necussirily involves some dear work and waste. The sheets, 1 to 8 feet thick, increasing in thickness downward, dip up to $10^{\circ} \mathrm{SE}$. and $10^{\circ} \mathrm{NW}$. One set of joints, strike east, spluced 20 to 50 feet, forms the northeast wall. Another set. strike N. $75^{\circ} \mathrm{W}$., spacer 3 to 30 feet. The rift is horizontal and the grain rertical, striking east. A few knots, up to 12 inches across, of muscovite, quartz, and feldspar. No "sal."

Transportation, by cart half a mile to railroad or three-fourths mile to dock. The fine texture of the stone makes it particularly well alapted for mom ments. Among the monuments made of it are the Humbolit monmment in Chicago and the Scott monument in Pittsburgh. Pa. The front of the Maine building at the Chicago World's Fair, afterwards removed to Poland surings, Maine, and the polished tanks at Poland Springs also came from this quarry.

\section{POWNAL.}

The Pownal quary is in the southern corner of the town of Pownal, $2 \frac{1}{2}$ miles north-northeast of Yarmouth Junction on the Maine Central and Grand Trunk railroads. Cperator, Fred C. Greene, Freeport.

The granite (specimen D, XXVII, 123, a) is a biotite granite of light-gray shade and very fine, even-grained texture, most of the particles ranging from 
0.25 to 0.75 millimeter in diameter. It consists, in descending order of abuudance, of very slightly smoky quartz, potash feldspar (microcline), soda-lime tellspar (oligoclase). and hlack nica, with accessory zircon, alpatite, and magnetite. The oligoclase is much altered to a white mica, and the microcline has intergrowths of quartz, circular in cross section. The polish is inferior to that of the Freeport stone.

The ruarry, opened in 1850, measured in 1945,300 by 200 feet and averaged 3 feet in depth.

Rock structure: Flow structure at one point consists of a lamination dipf,ing $10^{\circ} \mathrm{E}$., with thin black streaks of matterl biotite scales. The sheets, 4 inclies to 4 feet 8 inches thick, dip $10^{\circ}-15^{\circ} \mathrm{SE}$. in hroud undulations. They have been tested with core drills to a depth of 60 feet and the lowest sheets found to he 6 feet thick. Vertical joints, striking $\mathrm{N}$. $50^{\circ} \mathrm{E}$., recur every $30 \mathrm{or}$ 35 feet. The rift is horizontal and the grain is vertical, striking east. A 12inch basic dike crosses the northwest half of the quarry with a N. $50^{\circ}$ E. course. A pegnatite dike, 4 inches thick, occurs at the west pnd of the quarry. There are neither knots nor rust stains nor "sap."

Trinsprertation, by cart $2 \frac{1}{2}$ miles to dock or railroad.

Product, specimens: Baker mausoleum at Woodlawn Cemetery: hotel at corner of Seventieth Street and Central Park; Van Norden Trust Building, corner of Sixtieth Street and Fifth Avenue; French monument, Calvary Cemetery. New York. This quarry has not been in operation since 1915.

\section{WESTBROOK.}

Pride's quarry is in the town of Westbrook, $3 \frac{1}{2}$ miles northeast of Westbrook (Saccarappa) and a quarter of a mile north of Prides Corners. Operator, James H. Pride, R. D., Woolford.

The granite (specimen D, XXVII, 140, a) is biotite granite of medium-gray shade with conspicuous black mica and fine, even-grained texture (particles measuring up to 0.1 inch across), consisting, in descencling order of abundance, of potash feldspar (microcline and orthoclase), smoky quartz, a little sodalime feldspar (oligoclase), and biotite with accessory apatite. The biotite scales are generally parallel.

The fualry, opened in 1S98, measured in 1905200 by 100 feet and about 6 feet in repth.

Rock structure: There is a market flow structure, dipping in places $30^{\circ}$ E. which gives the granite the appearance of a gmeiss. The sheets, 6 inches to 2 feet 6 inches thick, dip up to $5^{\circ}$. A heading on the east side strikes N. $10^{\circ}$ E. and dips $55^{\circ} \mathrm{W}$. The rift is horizontal and the grain vertical, striking east. A basic dike, 12 inches thick, striking N. $50^{\circ} \mathrm{E}$., forms the west side of the quirry. Sal from 1 to 3 inches wille in upper sheets, but none 5 feet down.

Transportation: The nearest railroad is at Westbrook, $3 \frac{1}{2}$ miles away.

Product: Curbing and bases of monuments for local demand.

FRANKLIN COUNTY.

JAY.

The Maine \& New Hampshire Granite Corporation's quarries are at North Jay.

The granite (specimen D, XXVII, 118, a) is a biotite-muscovite granite of very light gray shade ("North Jay white") and fine, even-grained texture, in which the particles range from 0.36 to 3 millimeters in diameter. It consists, in descending order of abundance, of potash feldspar (microcline and 
orthoclase), clear quartz, soda-lime feldspar (oligoclase), hack mica (biotite), and white mical (muscovite), together with accessory garnet, magnet te, and apatite. The general whiteness of this rock is due to the quart not being smoky as in nost granites, and also to the whiteness of the foldspar's, which is thus visible through the quartz. The feldspals are mostly maltereal. The following chemical analysis of this granite, male by L. 'T. Rogers, was reported by Prof. Tolm E. Wolff 84 in 1892.

\section{Anulysis of granite from quarry at North In!l.}

Silic:a $\left(\mathrm{SiO}_{2}\right)$

$71.5 !$

Titanium dioxide and $\mathrm{Fe}_{2} \mathrm{O}_{3}($ ?)

Alumina $\left(\mathrm{Al}_{2} \mathrm{O}_{3}\right)$

Ferric oxide $\left(\mathrm{Fe}_{2} \mathrm{O}_{3}\right)$

Ferrous oxide $(\mathrm{FeO})$

Lime $(\mathrm{CaO})$

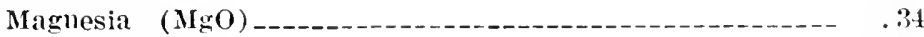

Sola $\left(\mathrm{N}_{\mathrm{il}_{2}} \mathrm{O}\right)$ - 3.39

Potash $\left(\mathrm{K}_{2} \mathrm{O}\right)$ -

Water $\left(\mathrm{H}_{2} \mathrm{O}\right)$ at red heat__._. 61

Sulphur (S)

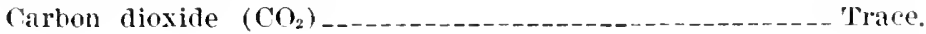

98. ais

The same analyst finds the specific gravity 2.639. A test of the compressive strength of this granite, mate for the company at the Watertown Arsenal in 1892, shows that the cube cracked at $\mathbf{1 5 . 7 2 0}$ pounds to the square inch and was destroyed at 16,310 pounds to the square inch. An earlier test of the same granite with sonewhat different results was made at that alsenal on May $6,1882 .{ }^{85}$ It does not take a very good polish owing to the abundance of mica and the large size of its plates. The "North Jay" granite was also described by M. E. Wadsworth ${ }^{80}$ in 1878.

The quarry. opened in 1872 , consists of three openings, known ats the "upper," "lower," and "boulder." The upper quarry measured in 1905 abont 425 feet from north to south by 200 feet from east to west and had an average depth of 20 feet. The lower quarry. adjacent on the west, measured 500 feet from north to south and 350 feet from east to west. with an average depth of ahout 35 feet. These openings are on the west side of a north-sonth ridge. The boulder quarry, a little north of the other two, is about 150 feet squire ar. 20 feet deep. The upper and lower quarries are separated by a mass 10 feet thick, consisting of two large aplite dikes with north-south strike.

Rock structure: In the center of the lower quarry there is a lamination in folds 20 feet broad and 3 feet high occasioned by the paralleism and abmulance of biotite plates along certain planes. Some of these plines show evidence of friction along them. There is also a north-south vertical structure associated with the dikes of aplite between the two quarries. The sheets ar 4 inches to 6 feet thick. In the upper 25 feet the sheets are thin, but helow that they become gradually thicker. In cross-section they feather out alternately, or "toe in." (See glossary, p. 471.) At the top of the hill ant at the rast side" of the unper quarry they are horizontal, but on the west side they curve over

a See U. S. Geol. Survey Nineteenth Ann. Rept.. pt. 6, continued, pp. 218, 219, 1898.

66 U. S. Geol. Survey Eighteenth Ann. Rept., pt. 5, continued, p. 961, 1897.

* Boston Soc. Nat. Hist. Proc., rol. 19, pp. 237-238, 1878. 
westward, dipping $5^{\circ}-10^{\circ}$, and possibly a little more in the lower quarry, governing the slope of the hill. At the north side of the lower quarry is a heading striking $\mathrm{N}$. $50^{\circ}-60^{\circ} \mathrm{E}$., dipping $60^{\circ}$ and also $90^{\circ}$. The courses of the various foint sets and dikes are shown in figure 41. Of joints (B) there are four discontinuous ones in a space of 50 feet in the upper quarry. The rift is horizontal, and there is no grain. The pegmatite dikes consist of milk-white potash felispar (nicrocline) and soda-lime feldspar (oligoclase), smoky quartz, biotite, and muscovite, and measure up to 2 feet 6 inches. Knots are exceptional and moisure up to 12 inches across. Ifearling (A) is covered with limonite from oxiflation of pyite. Rusty stain is noticeably absent from the sheets.

Tramsportation, by sravity track to Mraine Central Railroad, 1,300 feet distant and 300 feet down.

The product is used for monuments and buildings. Specimens: General Grant's tomb. Riverside Drive, New York: Richard Smith soldiers and sailors' memorial gateway at Fairmount Park and the Penn Mutual Life Insurance Co. Bnilding. Philadelphia; Hahnemann monument, Washington; city hall,

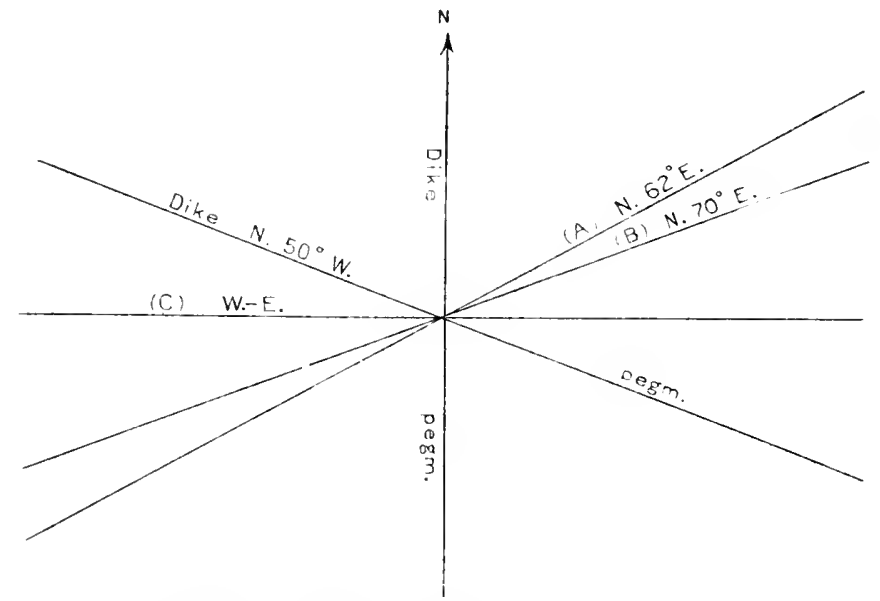

Fluure 41. - Structure at Maine \& New Hampshire Granite Corporation's quarry at North Jay, Maine.

Porthnd, Maine; Chicago is Nothwestern lailway Buildiug and Field Annex Building, Chicago: Union Trust Building, South Bend, Ind.; Exchange National Bank building. 'Tulaa, Okla.

lomgh stome, paving blorks, and crushed stone are important by-products.

\section{IIANOCK COUN'TY.}

\section{BLUEHILL.}

The White quarry, in the town of Bluehill, $1 \frac{1}{4}$ miles east of Bluehill village. Operator, leste B. I'ark (Inc.), 132S Broadway, New Iork. Idle since 1913.

The granite (npecimen D. XXVI, 36, a) is a biotite granite of medium-gray, slightly lowish color and of coarse (on the medium side) eren-grained texture. The feldspars measure as much as 0.5 inch, and some of them a little more. The rock consists, in descending order of abmdance, of potash feldspar (microcline and orthoclase), smoky quartz, soda-lime feldspar (oligoclase), and black mica (biotite), together with accessory zircon and magnetite. The feldspar is sligl:ty hluish. The contrast in shade between the polished and rough sur- 
face is markel, but the mica plates are sufliciently large ant numerous to prevent a perfect polish. Although the trxture of this stone is coarsish, it is sufficiently fine to be well allapted for fluted cohmuns and capitals. A test of its compressive strength made at the United states Arsenal at Watertown, Mass. (test 9087, 1893) gave an ultimate strength of 29,420 penuds to the square inch unter pressure applied at right angles to the rift. A similar test made by the engineering department of the sibool of Mines of Columbia University, in New lork, gave an ultimate strength of zog.es1 pounds.

The quarry, opened about 1855 , measured in 190530 ) by 350 feet and from 15 to 45 feet in deptll.

Rock structure: The striking geologic feature is the rectangular curvel joint described on page 37 and slown in Plate XIV, $B$. The sheets, 3 to 10 freet thick, dip from $10^{\circ}$ to $15^{\circ} \mathrm{W}$. and $\mathrm{SW}$. The joint courses are shown in fisure 42. Joints (A) recur every 100 feet and form a heading at right of rurved joint, as shown in Plate XIV, B. The rift is vertical, with a course $\mathrm{N}$. $50^{\circ} \mathrm{W}$., not very pronounced. There are small dikes and thick lenticular knots of very fine grained bluish-gray aplite. Dark-gray knots measure up to 10 by 4 inches. Sap

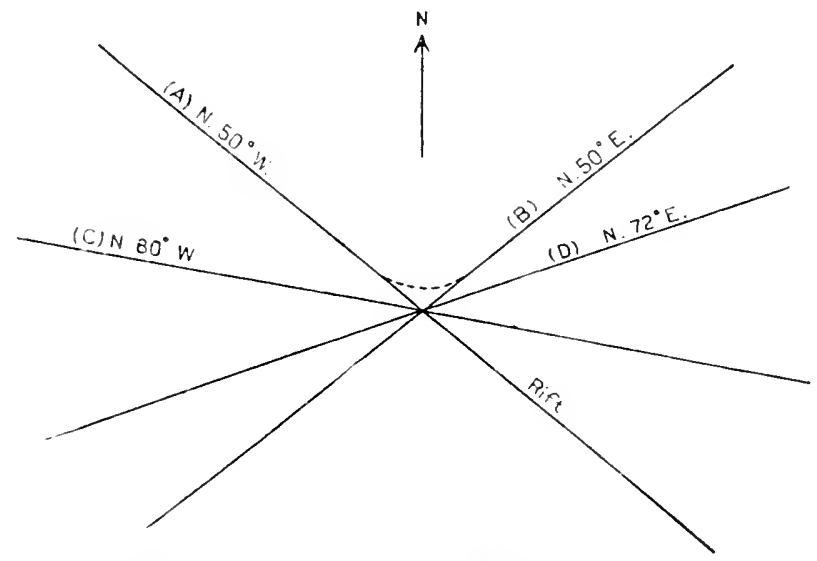

Flounw 42.-Structure at White quarry, Bluehill, Malne. The rectangular joint is shown by the dotted line.

is confined to the upper sheets, and does not exceed 2 inches in width. There are no rust spots.

Transportation, by team to docks, one-thlrd mile.

The product is used for buildings and monuments, and the waste goes into paving blocks. Specimens: Woman's Hospital, New Iolk; Mercantile Trust Co. and Caledonian Insurance Co. buildings, St. Louis; basement story of District of Columbia Municipal Building; First Day and Night Bank, Delamar and Brokaw residences, New York; chemical laboratory of Pratt Institute. Brooklyn, N. Y.; chenical laboratory of Stevens Institute of Technology, Hoboken, N. J.; fountain with large monolithic howl, Deen River, Conn.

The Chase quarries are in the town of Bluehill, 3 miles east of Bluehlll village, and nortl of Wools Point. They are no longer operated.

The granite (specimen D, XXVI, 3S, a) is a biotite granite of metlium to light-gray color and coarse evell-grained texture, the feldspar measuring up to 0.8 inch in length. It consists, in descending order of abundance, of potish feldspar (microcline and orthoclase), smoky quartz, soda-lime feldspar (oligoclase), and black mica (biotite), with accessory magnetite. The feldspars are milky 
white with a slight bluish tinge. The contrasts between the feldspar, quartz, and biotite are marked, more so than in the stone of the White quarry, because the feldspar is whiter, the quartz more snoky, and the biotite a trifle coarser. The following chenical analysis of this granite, made in 1896 by Ricketts \& Banks, of New York, is inserted here merely for reference:

Analysis of granite from Chase quarry, near Bluehill, Maine.

$\begin{array}{lr}\text { Silica }\left(\mathrm{SiO}_{2}\right) & \text { Per cent. } \\ \text { Ferrous oxide }(\mathrm{FeO}) & 73.02 \\ \text { Alumina }\left(\mathrm{Al}_{2} \mathrm{O}_{3}\right) & 2.59 \\ \text { Manganous oxide }(\mathrm{MnO}) & 16.22 \\ \text { Lime }(\mathrm{CaO}) & \text { Trace. } \\ \text { Magnesia }(\mathrm{MgO}) & 0.94 \\ \text { Potash }\left(\mathrm{K}_{2} \mathrm{O}\right) & \\ \text { Soda }\left(\mathrm{Na}_{2} \mathrm{O}\right) & \\ \text { Sulphur }(\mathrm{S}) & \\ \text { Loss and undetermined. } & \end{array}$

The same firm also made a test of this granite (test 16606,1899 ), which showed that it has an ultimate compressive strength of 23.400 pounds to the square inch.

The quarry, opened in 1872, consists of several openings on the top and eastern slopes of a hill rising 220 feet above the sea in a distance of three-fourths mile.

Rock structure: The sheets are up to 8 feet thick and are either horizontal or dip at a low angle. Vertical joints strike $\mathrm{N}$. $50^{\circ} \mathrm{W}$. and $\mathrm{N}$. $40^{\circ} \mathrm{E}$. The rift is vertical, with a north strike. There are some small dikes of aplite and dark-gray knots. Sap occurs in the upper sheets several inches thick. In one of the openings the stone has occasional light rust spots 0.5 inch in diameter, due to the oxidation of some ferruginous mineral in very minute particies.

Transportation, by cable road 1,400 feet from the main quarry to cutting shed and by locomotive track, 650 feet more, from shed to dock.

The product was used for buildings. Specimens: New York Stock Exchange, Lying-in Hospital, Manhattan Trust Building, and Grand Union Hotel, Fortysecond Street, New York; the General Thomas monument and the trimmings to the Bureau of Engraving and Printing, Washington; the League Island Dry Dock; and the post office at Harlisburg, Pa.

The Chase monumental granite: About 350 feet east of the upper opening is an area about 200 feet square, of a medium bluish-gray fine-textured, porphyritic biotite-muscovite granite (specimen D, XXVI, 39, a). The particles range from 0.07 to 1.1 millimeter in diameter, averaging about 0.37 millimeter. The isolated feldspars measure up to 0.25 inch across. The minerais, in descending order of abundance, are potash feldspar (orthoclase and microcline), smoky quartz, soda-lime felispar (oligoclase), black mica (biotite), and white mica (muscorite), with accessory magnetite. The feldspars are bluish gray. They have considerable intergrown quartz, and the rock is generally harder than the adjacent granite, which it probably traverses as a large dike. It has been quarried occasionally for local monumental use.

\section{SOUTH BROOKSVILLE.}

The Bucks Harbor quarries are at Bucks Harbor, South Brooksville. Operators, John T. Brady \& Co., 103 Park Avenue, New York.

The granite from an opening half a mile southeast of South Brooksville, (specimen D, XXVI, 46, a) is a biotite granite of light grayish-buff color with 
conspicuous black mica, and is of coarse, inclining to medium, erentgrained texture. It consists, in descending order of abundance, of a light crean-colored potash feldspar (microcline and orthoclase), smoky quartz, a milk-white soda-lime feldspar (oligoclase), and blatk mica (biotite), with accessory malynetite. The oligoclase is partly antered to kaolin and a white mica. A little pyrite was found at the quarry.

The granite from an opening one-fourth mile northeast of Sontl lirooksville (speeimen D, XXVI, 47, a) is a biotite granite of medium-gray shade, with conspicuous black mica, and coarse, even-grained texture. It consists, in descenting order of abumlance, of a very light gray potash feldspar (microcline and orthoclase), slightly smoky quartz, a lithe soda-line feldspar (oligoclase), and black mica (biotite).

Both of these granites are bright from the contrasts of their minerals.

The quarries consist chiefly of two openings, one lying half a mile somtheast of the village measured in 1905200 feet by 100 feet and 5 to 20 feet in depth; the other, one-fourth mile northeast of the village, was about 200 by 100 feet and from 5 to 10 feet deep.

Rock structure: The sheets at these quarries, 2 to $\&$ feet thick. are either horizontal or dip $10^{\circ}-15^{\circ} \mathrm{W}$. Joints at the first opening strike N. $40^{\circ} \mathrm{W}$., din $75^{\circ} \mathrm{SW}$., and recur at intervals of 15 feet or more; also NE., dipping $75^{\circ} \mathrm{S} .40^{\circ}$ W. to $90^{\circ}$. The rift is vertical, striking N. $30^{\circ} \mathrm{E}$. The sap is confined to the uppermost sheets.

Transportation: The company owns two granite wharres, whicl afford 12 feet of water at low tide.

The quarries were idle in 1917.

\section{DEDHAM.}

The Brown quary is in the town of Dedham, $1 \frac{1}{2}$ miles east of Holden station (East Holden post office) ou the Maine Central Railroad, on the northeast side of a hill 840 feet above sea level and having a northwest-southeast axis. Operator, William J. Brown, East Holden. Idle since 1913.

The sranite (specimen D, XXVI, 108, a) is a biotite granite of dark-gray matrix with light-grayish feldspars and of very coarse porphyritic texture, with some evidence of distortion and crushing of its feldspar's. These measure up to 1.5 inches in diameter, and the black mica up to 0.3 inch. The feldspars are generally twinned and in places of oval or roundish outline. The rock consists, in descending order of abundance, of potash felclspar (orthoclase and microcline), smoky quartz, soda-lime feldspar (oligoclase), and black mica (biotite), together with accessory zircon, apatite, and secondary magnetite and chlorite. The

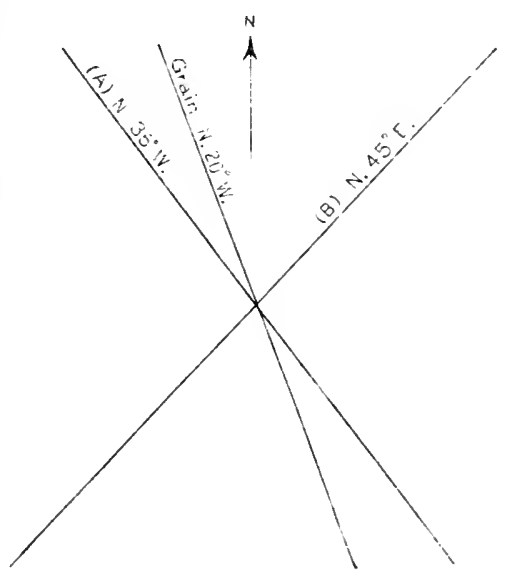

Figlae 43.- Structure at Brown quarry, Dedham, Maine. quartz contains needles of rutile(?). The orthoclase crystals contain zonally arranged quartz grains and biotite scales, and some of them are thinly rimmed with oligoclase or intergrown with it. Many small grains of quartz in the matrix indicate crushing. The oligoclase is partly altered to kaolin and a white mica. 
The rock takes a fine polish, but the durability of the polish under outdoor exposure is doubtful, owing to the large size of the mica scales.

Rock structure: The sheets, 2 to 6 feet thick, dip $15^{\circ}$ SSE. Joint courses are given in figure 43 . Joints (A) recur at intervals of 100 to 200 feet; (B) at intervals of 75 feet or more. The rift is horizontal. Aplite dikes, 1 to 4 inches thick, cross the grain at a high angle. No knots are in sight. Sap, 1 to 2 inches thick, is confined to the topmost sheet.

Transportation, by cart $1 \frac{1}{2}$ miles to cutfing shed at Holden station.

The product was used for bridge work.

\section{FRANKLIN.}

The Robertson quarry is in the town of Franklin. Operator, Harvey E. Hobertson, North Sullivan.

The granite (specimen D, XXVI, 71. a) is a biotite granite of medium-gray shade and of coarse, inclining to melium, eren-grained texture, with whitish feldspars up to 0.5 inch in diameter. Its constituents, in descending order of abundance, are potash feldspar (orthoclase and microcline), slightly smoky quartz, soda-lime feldspar (oligoclase), and black mica (biotite), with accessory magnetite and pyrite. The slight contrast between the shade of the quartz and that of the feldspar and the small size of the biotite scales rroduce a general lack of brilliancy in the rock.

The quarry, opened in 1892, measured in 1905300 feet from north to south by 300 feet from east to west and 5 to 15 feet in depth. It is drained by two siphons 800 ant 1,000 feet long.

Rock structure: The sheets, 2 to 8 feet thick, are mainly horizontal but on the west side dip $10^{\circ} \mathrm{W}$. The courses of joints and dikes are given in tigure 44 .

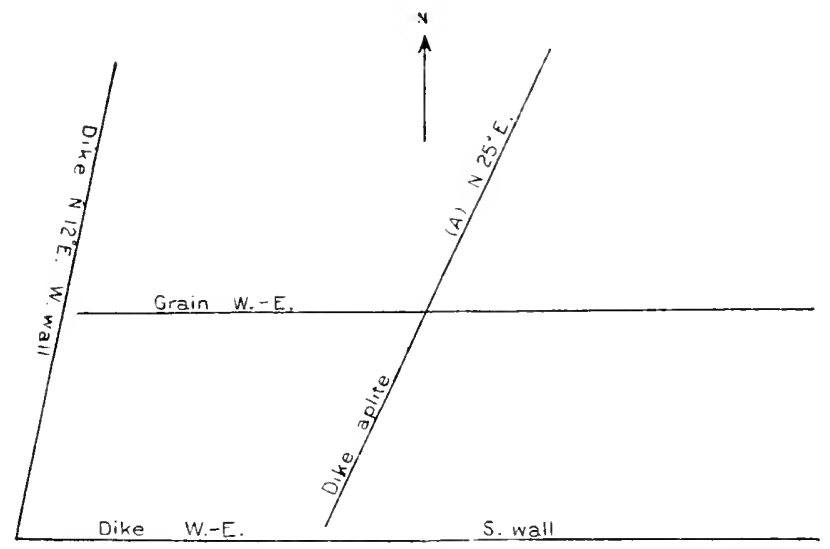

Frgitre 44.- Structure at Robertson quarry, Franklin, Maine.

Ioints (A) recul at irregular intervals. The rift is horizontal, and the grain is vertical, striking east-west. Aplite dikes are 2 to $S$ inches thick, and the granite for about a foot on each side of them is close jointed. Fnots are rather abundant and up to 2 feet across. The north-south joint face carries some pyrite. Sap is 2 to 3 inches thick along the sheets. No rust spots were detected. A 1-foot diabase dike, with its rim altered to epidote, forms the west wall of the quarry, and a $2 \frac{1}{2}$ to 3 foot dike forms the south wall. For a space of 10 feet on each side of this dike the slade of the granite has been changed to a dark gray, and the rock is filled with close joints of low dip. The microscope shows that 
the quartz particles and some of the feldspars are erosied by more or less parallel cracks, from 0.25 to 1.25 millimeters apart.

Transportation, by cart $1 \frac{3}{4}$ miles to dock in bay.

The product is used for curbing, both straight and cireular, and for paving blocks and "random" stone.

The Bragdon quary is in the town of Franklin. Grerator, L. C. Bragdon, Franklin. Inle since 1919.

The granite is a biotite granite of medium-gray shade and medium, evengrained texture like that of the Crabtree \& Havey quarry (specimen D, XXVI, 69, a), in sullivan (p. 219). Molybdenite wals found in it.

The quarry measured in 1905300 feet from north to south by 150 foet from east to west and 10 to 20 feet in depth and is drained by a siphon pipe.

Rock structure: 'The sheets, 2 to 6 feet thick, llip $10^{\circ}-15^{\circ} \mathrm{W}$. Joints strike N. $12^{\circ} \mathrm{E}$. and are spaced 150 feet. A 6-inch basic dike striking N. 12 $\mathrm{E}$. formis the west wall. Another, a foot thick, strikes almost due east.

Transiortation, by cart 2 miles to wlarf.

'The product is used for curbing (hoth straight and circular), paving blocks, and "random" stone.

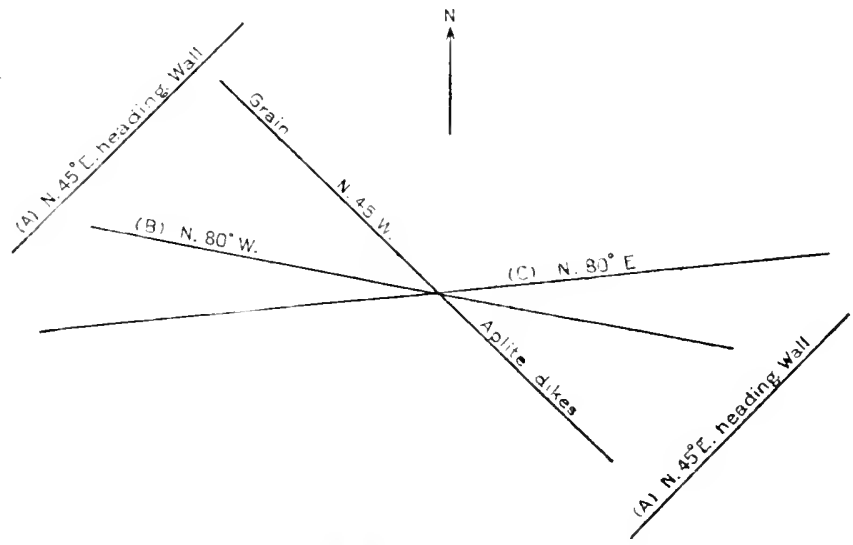

Figcre 45.-Strueture at T. M. Biaisdell quarry, East Franklin, Maine.

The T. M. Blaisdell quary is in East Franklin, 1 mile above the heat of navigation. Operator, T. M. Blaisdell, East Franklin.

The granite (specimen D, XXVI, 76, a) is a biotite granite of a medium to dark aray shade and medium even-grained texture, with felrlspars up to 0.25 inch in length. It consists, in descending orler of abundance, of potish feldspar (microcline and orthelase), slightly snoky quartz, lime-sula indspar (oligoclase 10 oligoclase-albite), black mica (biotite), together with accessory magnetite anu zircen. The effect of the slightly bluish-gray color of the feldspar and the light smokiness of the quartz is to prevent any contrast of sharle between these two minerils and also to darkent the general culor of the stone.

The quarry. opened about 1875, measured in 1905200 by 300 feet and was of varying lepth. The working face on the north was 53 feet high.

linck structure: The sheets, from 2 to 13 feet thick, dip $10^{\circ} \mathrm{NE}$. Owing to compressive strain, on the removal of load in quarrying, the bottom sheet rises laalf an inch from the underlying one. The joint courses are shown in figure 45. (A) forms a healling on the northwest and southeast sides. (C) dips in places $45^{\circ} \mathrm{N}$. The rift is horizontis, and the grain verticul, striktng 
northwest. Several parallel dikes of aplite up to 2 inches thick dip southwest at a low angle. In one 5-foot mass there are five of these. Sap is confined to the upper sheets. Black knots ul' to 8 inches across.

Transportation, by cart a few hundred feet, thence by lighter a mile to schoners.

The product is used for curbing. paving, bridges, docks, and " random."

The W. B. Blaisdell quarry is in the town of Franklin, on the southeast side of sullivan River. Operators, W. B. Blaisdell \& Co., Franklin.

The granite (specimen D, XXVI, 78, b) is a biotite granite of nedium-gray shade and medium, inclining to coarse, even-grained texture. It consists, in descending order of abundance, of potash feldspar (microcline and orthoclase), smoky quartz, soda-lime feldspar (oligoclase), and black mica (biotite), together with accessory magnetite. zircon, apatite, and serondary cpidote and chlorite. The oligoclase is partly altered to a white mica. The feldspars are grayish and are thereforc of almost the same sharle as the quartz, which deprives the rock of marked contrasts. It is a little lighter than the specimen 76, a, of the T. M. Blaistlell quirry, and is said to be a little softer. E. C:

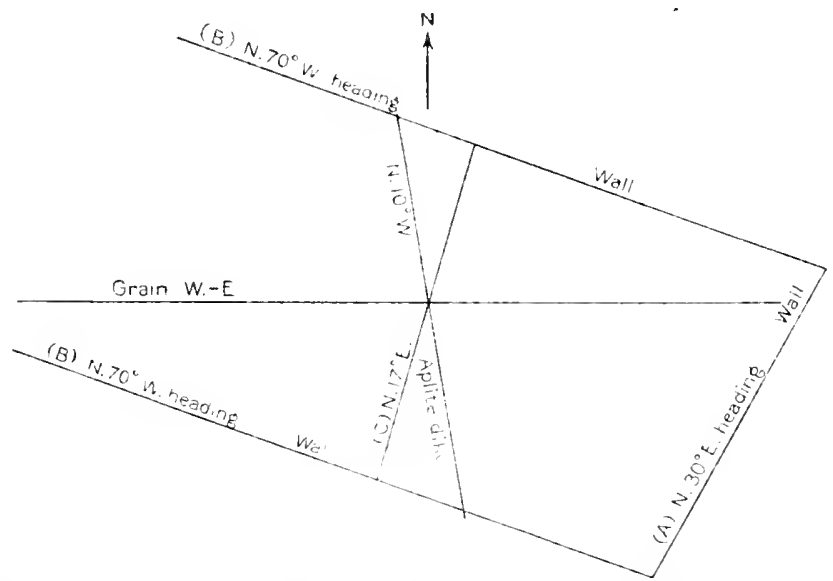

Flive 46.-Structure at W. B. Haisdell quarry, East Franklin, Maine.

Sullivan, of this Survey, has tested the granite with warm dilute acetic acid and fincls that it contains 0.15 per cent of CaO (lime), much MgO (magnesia), and 0.104 per cent of $\mathrm{CO}_{2}$ (carbon dioxide). If all the $\mathrm{CO}_{2}$ were allotted to $\mathrm{CaO}$ it would give 0.24 per cent of $\mathrm{CaCO}_{3}$ (calcium carbonate) as the content in the granite.

The quarry, opened about 1575, measured in 1905300 by 250 feet and 15 to 35 feet in depth.

Rock structure: The sheets, 6 to 7 feet thick, generally dip northwest at low angles. There is some "toeing in," owing to the overlapping of lenses. Joint and rein comses are given in figure 46 . (A) forms a heading on the east side of quarry; (B) is on the north and south sides and is coated with (alcimm eribonate (calcite), as described on page 39. The heading on the south has four joints 3 feet apart. (C) is coated with pyrite. The rift is horizontal, and the grain vertical eastward. The sap is from 1 to 3 inches thick. There are some knots up to 6 inches across.

Transportation, by "lifters" drawn by horses 1,000 feet to schooners at dock. The product is used for curbing (both straight and circular) and paving. 
The Bianchi quarry lies between Mill Pond aul Great Pond roals in West Franklin. Owner, Emerald Granite Co. (Stejhen Bianchi), 46 Cornhil, lsoston. Idle in 1921 and 1922.

The granite (specimen D, XXXVIII, "20, a). "Fincrald granito", is an al-

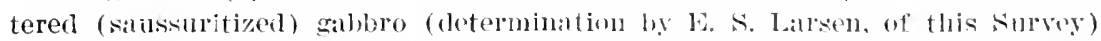
of very lark greenish-gray color. It comsists of a plagioclase foldspar near labratorite and of hornblemle aftei pyroxene with rery little pyrite. It takes a high polish. The polished face is black, irrogularly speckled with pale bluegreenish gray, and cuts almost white.

This "back granite" is very suitable for inseribed monuments.

The Bradbury quarry is in West Frmklin, neal the north eul of Grape Pond. Operators, F. Bradbury \& Sons, West Franklin.

The granite (simeimen D, XXY, 77, a) is biotite granite of dark-arasish, slightly purplish color and of very coarse, somewhat porphyritic texture, with feldspars up to an inch in diameter and black mica plates up to 0.1 inch. It "onsists, in desending orter of alundance, of a grayish-purplish potash feldspar (orthoclase and microcline), smoky quartz, yellowish-white soda-lime feldspar (basic oligoclase), and black mica (biotite). together with accessory masnetite, apatite, zircon, and secendary chlorite. Many of the grayish-pmplish potash feldspars are rimmed with the yellowish oligoclase and are also intergrown microscopically with a plagioclase feldspar and with quartz. This granite is very striking in the contrasts of its minerals. Its quartz and foldspars take a high polish, but the large biotite scales are not favorable to the durability of the polish under outdoor exposure.

The quarry is triangular in area, each side of the triangle measuring in 1905 about 75 feet, and its depth in places 15 feet, which is the height of the working face.

Rock structure: The sheets, 10 feet thick, are about horizontal. Joints striking $\mathrm{N}$. $70^{\circ} \mathrm{W}$, and dipping high recur at intervals of 5 feet or more. There are a few knots.

Transportation, by cart to railroad about 900 feet.

The product has been used for railroad culverts.

\section{LONG ISLAND (BLACK ISLAND).}

The Black IsIand quarries are in the northeastern part of Plack Island, which lies south of Mount Desert, in the town of Long Island. Operator, in 1905, Black Island Granite Co., New York.

The quarries, opened in 1892, consist of two openings. The upper one, about one-fourth mile south of the dock at the northeast comer of the island, measures 500 by 300 feet and from 10 to 40 feet in depth; the lower one, known as the "Redcliff," a little sonth of the dock, is about 100 feet square.

Specimen D, XxVI, 31, a, from the upper quarry, is a biotite granite of light pinkish-gray color and medium, inclining to coarse, even-grained texture. It consists, in descending order of abundance, of potash feldspar (uicrocline and orthoclase), smoky quartz, soda-lime feldspar (oligoclase), and rery little black mica (b:otite), together with accessory titanite and magnetite. Both feldspars are light pink. Some of the potash feldspar is rinmed with oligroclase, which in places is part altered to kaolin and a white mica. The rock presents but faint contrasts of color and, owing to the small quantity of its mica, must needs take a very fine polish.

The granite (specimen D, XXVI, 39, a), "Redcliff," of the lower quarry is a biotite granite of medium pinkish-gray color and medium, inclining to coarse, even-grained texture. It consists, in descending order of abundance, of potash feldspar (microcline and orthoclase), smoky quartz, sola-lime feldspar (oligo- 
clase), and rery little hitck mica (hiotite), together with accessory titanite, magnetite, and zircon. Foth feldspars are pinkish. The oligoclase is largely altered to kaolin amd a white mica. Its small content of mica must make this. granite surpectible of high goilisll.

Rock strurture: At the miler quary the sheets, 8 inches to 5 feet thick, are horizontal, with minur molntations. Vertical joints strike $N$. $70^{\circ} \mathrm{W}$., and recur at intervals of 100 . 200 , and 250 feet The rift is parallel to these, but feethe. Sap, 3 inches thick, is contined cutirely to the upper sheets. At the Rekliff quary the sheets. np to if feet thick, bend orer from the horizontal to $25^{\circ}$ N. and NE. Vertical juints, strike N. $77^{2}$ E., recur at intervals of 50 feet. Another set, strike $X .3 .7^{\circ}$ E. abommls at the s'des of the quarry but is scarce in the center. Joints of this strike are numerous along the north shore of the island. The ritt is vertical, with a $\mathrm{N} .77^{\circ} \mathrm{E}$. course.

The product of the uprell quarry was used for buildings, and its thin sheets for paving. That of the Redeliff quarry was used for monuments and columns. Specimen: Park Building. Brooklyu, N. Y.

The quarries are now abandoned.

\section{MOUNT DESERT.}

The Hall or McMullen quarry is in the town of Momt Desert, sutheast of the village of "IIall Quarry" and fuur-tiftlis mile north of the Robinson Momtains. Operator, Booth Bros. \& Hurricane Isle Granite Co., 208 Broadway, New York.

The granite (specinsen D, XXVI, 55, aa) is a biotite granite of general lightbuff grayish color and coarse, inclining to medium, even-grained texture. It

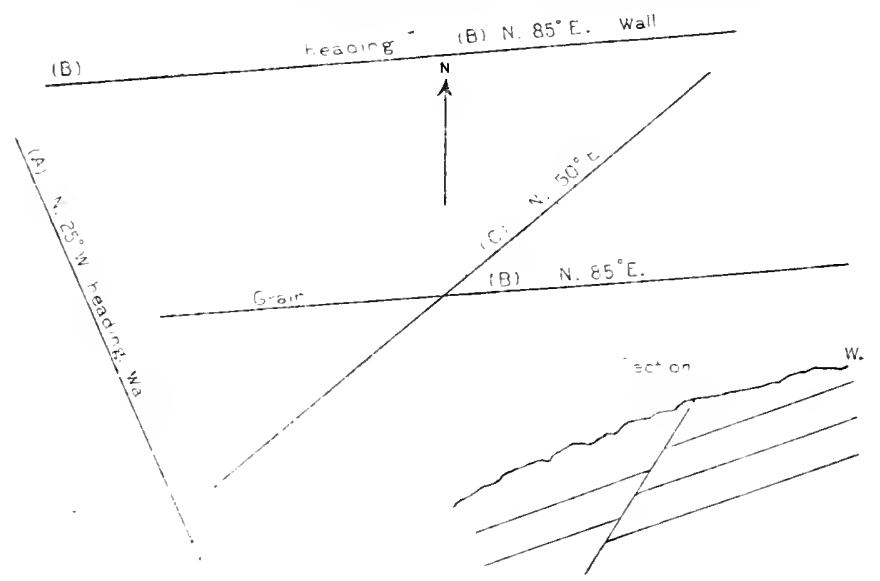

Figuke 47.-Structure at MeMullen quarry, Mount Descrt Isladd, Maine. The section shows the "toeing in" of sheets, probably by faulting along the joints.

consists, in descending order of abundance, of buff potash feldspar (orthoclase intergrown with plagioclase), smoky quartz, milk-white soda-lime feldspar (oligoclase), and black mica (biotite), together with accessory apatite and a little secondary calcite within the oligoclase. The contrasts resulting from the different colors of the four ninerals are attractive and must come out still more strongly on the polished surface. E. C. Sullivan, of this Survey, finds that it contains 0.014 per cent of $\mathrm{CO}_{2}$ (carbon dioxide) and that warm dilute acetic acirl dissolves traces, of $\mathrm{CaO}$ (lime) and $\mathrm{MgO}$ (magnesia). This per- 
centage of $\mathrm{CO}_{2}$, if all allotted to Cac. womld imply the presence of 0.03 per cent of CaCo. (calcium earbonatr). The microscope also slows the presence of a carbonate in very minute quantity.

The quarry, opened ahout 1S80, measines in 1905 250 feet from north to south ly 2no feet from ralst to west and was in fert deep at the west sicle.

Rock structure: The sleets, 2 to 12 feet thick. dip $5^{\circ}-10^{\circ}$ N.. S., and E. They are fanted alonc some of the $N .25^{\circ} \mathrm{W}$. joints, resulting in a toring in of the sheots, whide meressitates quarrying from west to east - that is. toward the hade of the faults, as shown in figure 47. The courses of the joints are shown in the sume figme. (A) forms a heading on the west. dip so W.; (B), dip. $65^{\circ}$ S.. forms a learling on the north and recurs at middle of quarry ; (C), dip $75^{\circ}-80^{\circ} \mathrm{NW}$.. forms a heading on the south and recurs at irmanlar intervals. The rift is horizontal and the grain strikes about aist. Sap along some of the sheets is 3 inches thick and exreptionally 18 inches. The granite atong joints (A) and (B) for the space of a fout is bright redrlish. (Ste P. S1.) The faces are greenish. probably from chlorite and epiolote. l'ark-gray knots measure up to 6 inches in diameter.

Transportation, by track suo feet to whatf, which is accessille to schooners of 20 feet draft.

Product specimens: United States mint. Philadelphia; basement uf New York customhouse; Bronklyn anchorage to Manhattan Brilge; and bridge over the Potomae at Washington.

The Campbell \& Macomber quary is in the town of Mount Desert, half a mile north of the top of Robinson Mountain, at its foot, and two-fifths of a mile south of IIall Quary vilage. This quarry is owned by Hale \& Hamlin, of Ellsworth. Maine, but is no longer operated.

The granite (specimell D, XXVI, 56 a), "Somes Sound pink," is a biotite granite of light pinkish-gray color and medium, inclining to coarse, even-grained texture. It consists. in descending order of abunlance, of a delicate pink potash feldspar (orthoclase, with very little microcline), smoky quart\%, milkwhite sorla-lime feldspar (olignclase). and black mica (biotite), together with aecessory magnetite, zircon, and apatite. It takes a fine polish. This stone differs from that of the Mexullen quarry in the tint of its orthoclase.

The quarry, opened about 18S0, measured in 1905150 by 200 feet by 20 feet in deptl.

Rock structure: The sleets, 2 to 6 feet thick, lip $10^{\circ}-15^{\circ}$ E. and exceptionally are thinner at the bottom than at the top of the quarry. The joints strike east, N. $12^{\circ}$ E., and N. $52^{\circ}$ E. The rift is horizontal, and the grain N. $75^{\circ}$ E. A diabase dike, $2 \frac{1}{2}$ feet wide, strikes $\mathrm{N} .20^{\circ} \mathrm{W}$. at the west side of the quarry. This is lescribed on page 52 . There are a few knots, but no sap.

Transportation, by eart 1,600 feet to wharf on Somes Somo.

Specimen buildings: Crocker residence, Darlington, N. J.; Danforth Library, Paterson, N. J.; First National Bank, Baltimore, Md.; Pbrenix National Bank, Hartford, Conn.

The Snowflake quarry is on Momut Desert, about a quarter of a mile northwest of Hall Quarry village. Operator, Allen Granite Co., Mount Desert. Quarry abandoned.

The granite (speeimen D, XXVI, 58, a) is a biotite granite of medium-cray shade and fine texture, with porphyritic pinkish feldspars up to 0.4 inch in diameter. It consists, in descending order of almulance, of pinkish rotash feldspar (orthoclase), smoky quartz, white transhcent sola-lime feluspar (oligoclase), and black mica (biotite). together with accessory magnetite. The orthoclase is intergrown with a plagioclase.

The quarry was in 1905 about 200 feet square and 5 to 10 feet deep. 
Rock structure: The sheets, 6 inches to 3 feet thick, are horizontal. Joints forming a heading on the east side strike N. $20^{\circ} \mathrm{W}$. and dip $75^{\circ} \mathrm{W}$. A diabase like, 6 to 10 inches thick, with course N. $20^{\circ} \mathrm{W}$., traverses the entire quarry.

The product is confined to paring blocks, which are carted about half a mile to the wharf.

The Allen quary, of the same concern as the Snowliake quary, lies a quarter of a mile east of it. The granite closely resembles that of the Snowflake. The sheets are 6 inches to 3 feet thick. Plate XVI, B, shows the sheets crossed by a diabase dike, which has a N. $15^{\circ} \mathrm{W}$. course and is faulted in two directions. (See p. 51.) There are geodes of pink feldspar, quartz, and epidote.

The Graves Bros. quarry is on Mount Desert, in the northern part of the village of Northeast Harbor; aduress, Northeast Harbor. This quarry is worked only occasionally, for underpinning. It is mentioned here on account of the exceptional character of the stone among Maine granites. This granite (specimen D, XXVI, 64, a) is a hornblende granite of general darkgray shade and medium even-graind texture, consisting, in descenting order of abundance, of greenish-gray and pinkish potash feldspar (orthoclase and microcline), with intergrown solithime feldspar (oligoclase-andesine), smoky quartz, and lark-green hornhlende, together with accessory magnetite, apatite, and secondary chlorite. The feldspar is largely altered to a white mica. A similar granite occurs also $1 \frac{1}{2}$ miles west-northwest of it, at the Carroll quarry, in the town of Tremont, at the south foot of Dog Mountain. (See p. 233.)

The quarry measured in 1905100 by 50 feet and 10 feet in depth. The sheets are up to 6 feet thick and dip $5^{\circ}-10^{\circ} \mathrm{W}$. There is much discoloration.

\section{STONINGTON DISTRICT.}

\section{DISTRIBUTION AND GEOLOGY OF THE QUARRIES.}

The granite industry which centers in Stonington is distribute l over an area of about 4 miles square. (See map, fig. 49.) Some of the quarries are al Deer Isle, others are south of it, on Crotch Island, so named from the inlet which divides it, and the rest are on neighboring islets.

The southern half of Crotch Islind, which measures abont 1,500 feet from north to south, shows sheet structure very clearly. (See Pl. X, B.) The sheets slope northwest and southeast at angles of $10^{\circ}, 15^{\circ}, 20^{\circ}$, and $25^{\circ}$ from its central part (140 feet above sea level), where they are horizontal. The eastwest vertical joints are conspicuons from a distance. The Goss quirry has cut into the center of the arch and also on either side of it, while the Ryan-Parker quarry (PI. XI, A) on the south is on the southeast slope of the sheets and of the hill. In the northern half of Crotch Island, at the lower quarry of the Sherwood Co., the coarse granites are in contact with a fine-textured one, which is also exploited. The contact line is vertical, but the sheets traverse both granites indifferently. The Stonington quarries embrace several varieties of granite.

\section{QUARRIES.}

The Ryan-Parker quarry is on Crotch Island, in its sontheastern part, at Thurlow Hear. (See fig. 4S.) Operator, Crotch Island Granite Co., Grand (Central Terninal, New York. Idle since 1916.

The granite (specimen D, XxVI, 20, a), "Crotch Island," is a biotite granite of lavender-tinted medium-gray color and coarse, even-grained texture. It consists, in descending order of abundance, of very light lavender-colored potash feldspar (orthoclase and microcline), smoky quartz, milk-white sodalime feldspar (oligoclase), and a little mica (biotite), rarely a plate of musco- 
vite, together with accessory magnetite, titanite, zircon, and pyrite, partly altered to limonite. The potash feldspars measure up to 1 inch, and many of them are twinned and intererown with a plagiorlase. The biotite plates do not exceed 0.1 inch across. The oligoclase is generally much altered to a white miea and kaolin and forms rims about many of the pale lavender orthoclase crystals.

E. C. Sullivan, of this Surves, determined the presence of 0.44 per cent of $\mathrm{CO}_{2}$ (carbon dioxide) and of 0.08 per cent of cao (line) and a little MgO

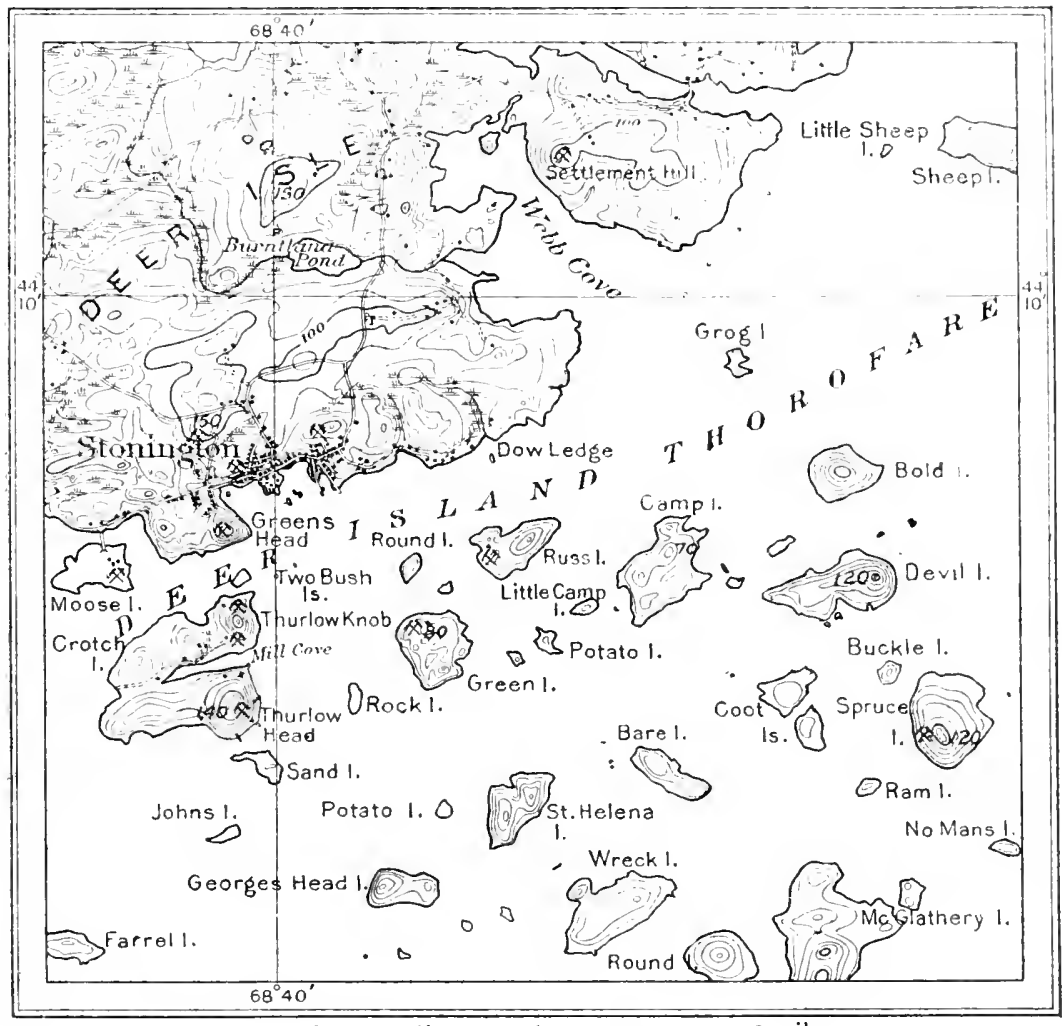

$\underbrace{0.1 / 2}_{\text {Contour interval } 20 \mathrm{feet}} \frac{1}{1}$

Figure 48.-Map showing location of quarries about Stonington, Maine. (Reduced from toporraphic map of Deer Isle quadrangle, U. S. (ieol. Survey. I

(magnesia) extractable with dilute acetic alcid. To allot all the $\mathrm{CO}$, to the CaO would give 0.10 per cent of calcium rarbonate in the granite.

This is a very handsome granite. It is coalse-textured and is therefore largely used for massive construction. Its polished surfice is attractive on account of the contrasts hetween pale lavender, white, and blark particles, and it is therefore in demand for base courses and wainscoting.

The quarry, opened about 1880, mensured in 1905 about 600 by $300 \mathrm{feet}$, and from 20 to 75 feet in lepth, averaging about 35 feet. (see Pl. XI, A.)

Rock structure: The sheets vary and increase in thickness downward and dip $20^{\circ}-25^{\circ} \mathrm{SE}$. Joint comrses are shown in figure 49 . (A) dips $80^{\circ}$ and forms 
a heading on the north, and (B) also forms one. Both (A) and (B) are infrequent. The rift is vertical and tremls N. $60^{\circ} \mathrm{W}$. Sap is 6 to 12 inches thick on either side of joint (B).

Transportation to wharves is by means of gravity on tracks 75 and 100 feet lom r.

The product is used chielly for massive construction and for buildings. specimens: P'iers of Blackwells Island Bridge and retaining wall of Riverside Irive. New York.

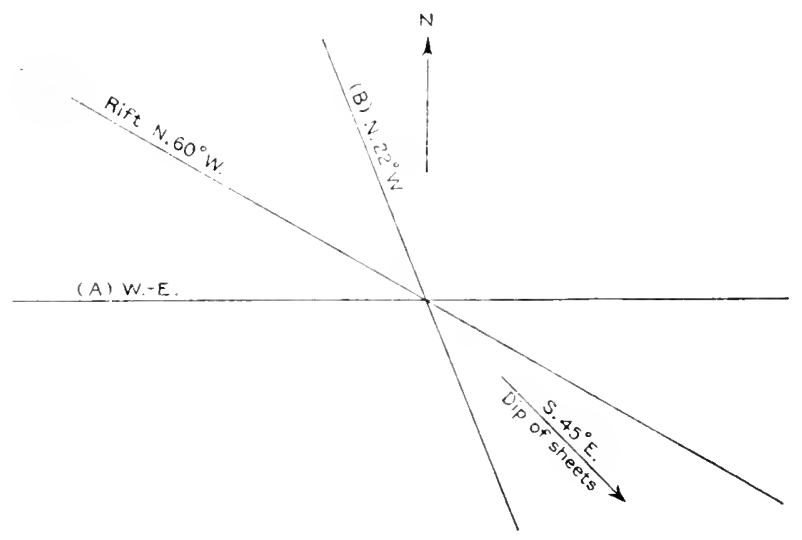

Figcre 49.-Structure at Ryan-Parker quarry, Crotch Island, Maine.

The Goss quarry is on Crotch Island, adjacent to and north of the RyanParker quarry, on Thurlow Head. (Sce fig. 48 and Pl. X, B.) Operator, John L. Goss Corporation, Stonington.

The granite is a biotite granite, inentical with that of the Ryan-Parker quarry (specimen 20, a), described on page 224.

The quarry, opened about 1872. measured in 1905 about 350 feet square, with a maximum depth of 120 feet and a minimum of 10 feet.

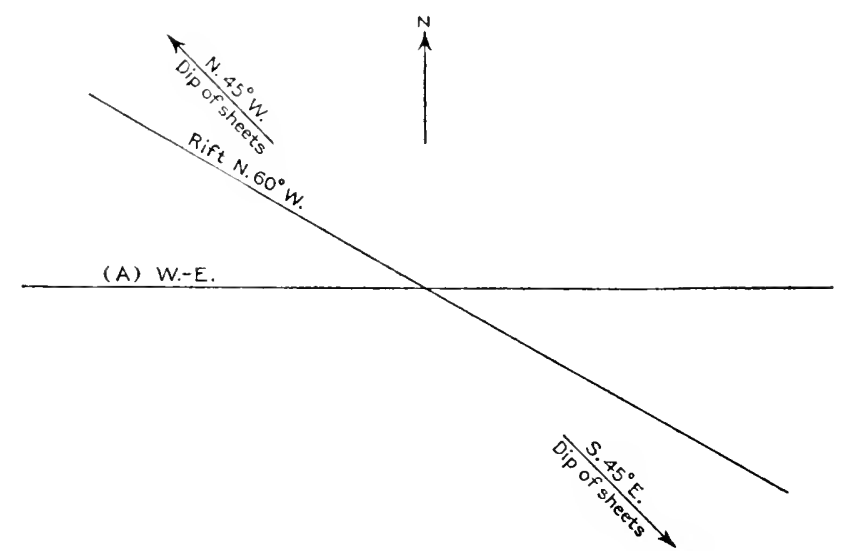

Figure 50.-Structure at Goss quarry, Crotch Island, Maine.

Rock structure: The sheets, 1 to 30 feet thick, increase rapidly in thickness downward. They are horizontal in the center of the quarry, but south of it dip up to $20^{\circ} \mathrm{SE}$. and north of it as steeply to the northwest. The joint courses and rift are shown in figure 50. Of (A) there are only two or three in the guarry. Their faces are coated with epidote. There is no sap. 
Transuortation, l,y three tracks--one 100, one 460, and one 5on feet longfrom quarry to dock; ars propelled by able engines.

The produet is used chietly for bridges amb buildings. The sllall beds aro worked juto pariner blocks.

Specimens: l'ost office. Lowell, Mass.; nulthouso, Dedham, Mass.; Merchants National Bank, New Bedtold, Mass, Larz Mnterson lipielue, Cambridge. Mass.; pieture gallery of Musteum of Finc Arts, loston; l'ilgrim Monmment, I'rovincetown, Mass.; public tibrary, Latennia, X. H.; Ninth Regiment Armory, trimmings of Lniversity Heights Bridge, Now York; Rurbioller

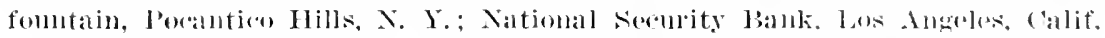

The Benveuue quary was opened ly the Benvenue dimile lo. in 19m; on

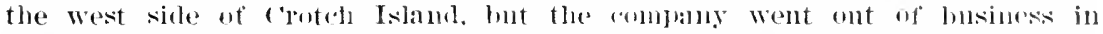
1915. The glanite is identical with that of the Ryan-Panlier and Goss quarries.

The Sherwood quarries are north of Mill Gove, Gotch Island. Operator, s. clinton sherwom, 14 Wall stroet. New York. (See fig. ts for towation of (yuarries.) Iolle since $190 \mathrm{t}$.

The granite of the lower and northern guary (specimen D, XXYl, 25, a) is a biolite-muscovite granite of light-glay shate, with a very slight buff

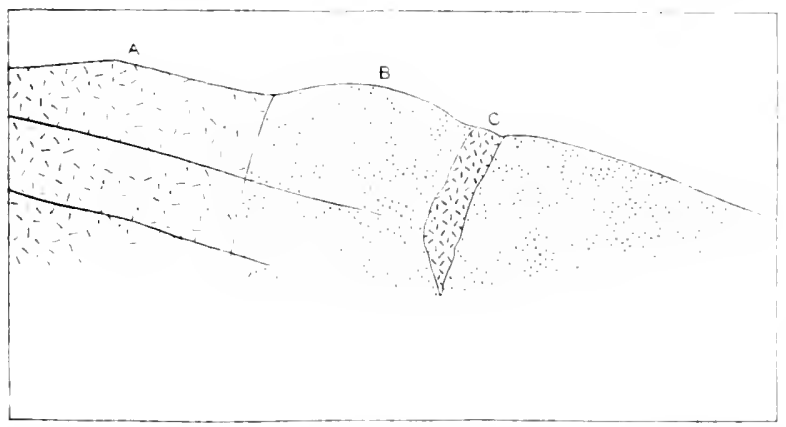

Figure 51.- Relations of fine biotite-nuscovit. granite (IB) to coarse biotite granite (A and $(C)$ and of sheet structure to both at north end of Sherwood lower quarry, croteh Island, Maine. Length, 9 feet.

tinge, anel of very fine texture. most of its particles ranging in size from 0.11 to 1.1 millimeters, the average diameter being about 0.45 millimeter. There are, however, a few quart\% particles and feldspar roystals 0.2 .5 inch arosos. ant of the latter rarely 0.5 inch in length, so that the rock las a purphyitic texture. The comstitnents, arranged in descentling order of abmulance, are

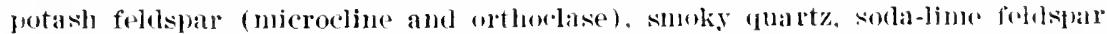
(oligoclase), black mica (biotite), and white mica (muscovite), tugether with accessory magnetite and secomtary epitote. The olignelase is largely altured to a white mical and kaolin, and all the feldspars ale in places intergown with quartz circular in cross section.

The lower quarry, opened in 1889, is triangular in area : in 1905 each sirle was 75 feet long and 40 feet deep, two of them working faces.

Rock structure: The sheets, 2 to 8 feet thick, ap $55^{\circ}-10^{\circ} \mathrm{W}$. Joints, dipping $70^{\circ}$ S. to $90^{\circ}$ and striking $\mathrm{N}$. $75^{\circ} \mathrm{K}$.e, recur at intervats of 1 to 10 fort. The rift is vertical, with strike $\mathrm{N} .60^{\circ} \mathrm{W}$., as at the south quarrips of the are. The relations of this fine granite at the morth end of the quary to low aroe 
granite of the island are slown in figme 51. The fine granite probably represents a later emption through the coarser. (See p. 34.)

Transpurtation, by track 100 feet to wharf.

Thi: duarry is worked only on special orders.

The product is used for momuments, bases, etc.

The granite of the same firm's upper quary, opened in 1890 ispecimen $D$, XXVI, : 6.1 ). is a hiotite granite of general pink sh-buff color and coarse evengraincl texture, consisting of pukish-buff potash feldspar, smoky quartz, rean-colorel soda-lime feldspar. amel black mica. The potash feldspar measures up to an inch or more in length, and the biotite scales 0.1 inch. This stome appears to be irlentical with that of the Latty quarry on freen Isle (sperimen I). XXVI, 28, a).

The upper quarry in 1905 was 200 by 100 feet and averaged about 1.5 feet in leptll.

lionk structure: The sheets, 1 to 5 feet thick, dip $5^{\circ}-10^{\circ}$ E. and W. Vertical joints strike $\mathrm{N}, 50^{\circ}-60^{\circ} \mathrm{W}$. and parallel to the rift. For a space of 50 feet across the middle of the quarry these recur at intervals of 2 to $s$ feet. Another set. less mmeroms, strike $\mathrm{N} .25^{\circ} \mathrm{W}$. and dip $60^{\circ} \mathrm{F}$. There is an irresular tapering dike of pegmatite, wh pink and white felslspar, biotite, amr muscovite. The sheets in the nper part of the quarry have "shakes" for 2 to 3 inclues from their surfare.

Tramsportation, ly rable and enghe along 900 -foot track to dock on east side of islind.

The proluct consists of random stome.

The St. Helena quarry is on St. Helena Island (see map, figr. 48) 2 miles southeast of Stonington. Operators, Benisch Bros., S95 Jamaica Avenue, Brooklyn. N. Y. Inle since 1917.

The granite is reported by the oferator as like that of the Gross quarry on I'roteh Islann, described on p. 226.

l'roluct, siecinen: Marine wreless operators' nomment, New York.

The Latty quary is in the sontheastem part of Green Island, 1 mile southpast of Stonington. (See map fig. 48.) Operator. Latty Bros. Granite Co., Stonington. Guarry abambned.

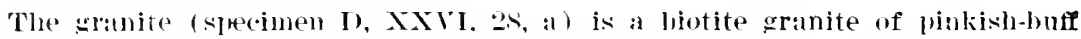
color and coalro, even-grained texture, cons'sting of a pinkish-luff potash feldspinr, smoky quat\%. cream-coloreil sodalime feldspar, and black mica. The potash forlispar measures up to an incll, and the biot te up to 0.1 .5 ineh in diancerer. The stone apuears to be idential with that of the upper quarry of the Sherworel ('o., on rerotch Island.

Rowle structure: The sheets, 6 feet to 6 feet $S$ inches thick, lip sently southeat. There ale vortical joints striking $x .45^{\circ} \mathrm{W}$.. spaced 6 to 12 feet, also forming a heading. The rilt is vertical, with eourse $\mathrm{N}$. $60^{\circ} \mathrm{W}$.

The quarry was opened in the spring of 1905.

Tramsinertation, by a 100 -foot track to wharf.

The stonington quary is on the west shore of Spruce Island, $3 \frac{1}{1}$ miles eastsontheast of Stoningtom. (See map, fig. 4S.) Quarry opened in 1905, now abandoned.

The granite (specimen D, XXVI, 27. a) is a biotite granite of pinkish-buff color and very coarse, semiporphyritic texture. It comsists of a pinkish-buff potash feldspar in crystals measuring up to 1.25 inches in diameter, smoky quartz, cream-colored soda-lime feldspar (oligoclase) in particies and crystals up to 
0.5 inch in diameter, amb black mica in seales measuring up to 0.15 inch arross. The contrasts between the two feldspars and the mica are strong. The smoky guartz is a little darker than the potash feldspar. Some of the pinkish-bulf feldspar is rimmed with the cremm-colored one.

rock structure: The sheets, 5 to 8 feet thick, dip about f10 W. Vertiall joints strike N. $45^{\circ}$ E., N. $45^{\circ}$ W., and N. $S 0^{\circ}$ li.

The Moose Island quary is in the southeastern part of Mows Island. flures-

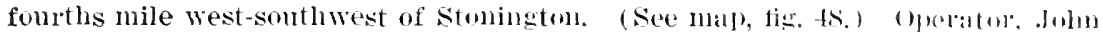
L. Goss Corporation, Stonington.

The granite is a biotite granite identioal with that of the foss and liganrarker quarries on Cloteh Island (specimen D, XXVI, 20, a), describol on liage …ㄴ.?

The quary, opened in 1573. neasured in 1905 600 by 200 teet and arriatent about 17 feet in depth.

Rock structure: The sheets, 1 to 7 feet thick, dip $5^{\circ}-10^{\circ}$ L. Vertical juints, strike $\mathrm{N} .80^{\circ}-85^{\circ} \mathrm{W}$., recm at intervals of 200 feet and form a healing mu morh side of quarry. There is no perceptible rift, and the lock does not silit well

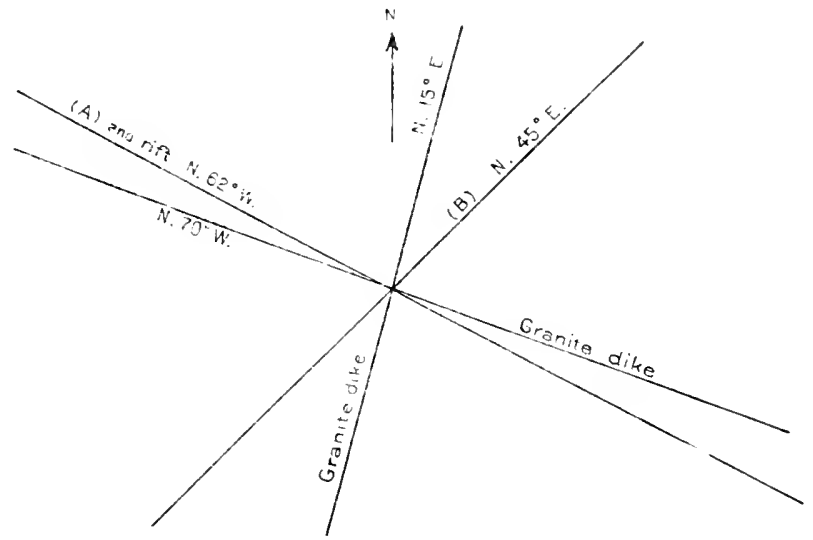

Figche 52.-Structure at Settlement quarry, on Deer Isle, near Stonington, Maine.

when frozen. The 15 -inch aplite vein, described on page 43 , has a $\mathrm{N} .80^{\circ} \mathrm{IV}$. course. Sap, 1 to 2 inches thick, is contined to the upper sheets.

Transportation, by track 200 feet to wharf.

Specimen structures: Gate house at Central I'ark and steps of Columbia University. New York; trimmings of Hampton Dormitory, Cambrigge. Mass.

The Settlement quarry is on Deer Isle, on Settlement Hill east of Webb Cove, 2 miles northeast of Stonington. (See map, fig. 48.) Owner, Roriners Granite Corporation, 271 West One lumdred and twenty-fifth Street, New York.

The granite (specimen D, XXVI, 22. a) is a biotite granite of meniun-aray. slightly lavender tint, blotched with cream white, and of coarse rexture. It consists, in descending order of abundance. of a very light lavender-colored potash feldspar (microcline and orthoclase), smoky quartz. slightly creamcolored soda-lime feldspar (oligoclase), and black mica (biotite), together with accessory magnetite, titanite, and apatite and secondary chlorite. Some of the potash feldspar is rimmed with oligoclase. The feldspars measure up to 1 inch, and the biotite plates are under 0.1 inch. The contrist between the two felispils and the mica is strong, but that between the quartz and the potasli feldspar is feeble. 
The qualry, opened in 1900, consistell in 1905 of two quarries-one near the top of the hill, why by 400 feet and 10 to 18 feet in depth; the other, on its west sirie, (jon by 60 feet and up to 14 fipet in denth.

linck strurture: The sheets, 6 inches to 16 feet thick, dip $10^{\circ}-15^{\circ} \mathrm{N}$. and $\mathrm{S}$. away from the top of the hill. Toint courses are shown in figure 52. (A) ofeurs but once: (6) recurs at intervals of 500 feet. The rift is vertical,

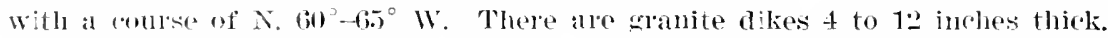
isce lestription an p. 11.) Kints ale rale and small. Pyrite ocenrs very ralely.

Transpurtation, hy locomotive and 2,500 feet of track. The distance from upuer quary to cutting shed is $1 .(6)$ feet, and from cutting shed to wharf is 600 fect.

The prohluet is used for massive construction. Specimens: Dry dock, Norfolk, Va.; balse and alproach for ald tion to bancroft Hall, United States Naval Acalemy, Annapolis, Ma.; fish pier, Boston; sea wall, Providence, R. I.; retainins wall, Riversirle I) ive (one humlred and thirty-eighth Street to end); Brooklyn and Manhattan approaches and piers to Manhattan bridge, New York. Guary now leased to Geo. A. Fuller Co., New York, and supplying part of the stome for the new courthouse in New York.

\section{SULLIVAN.}

The Crabtree \& Havey quary is in the town of Sullivan, three-fourths mile from Sullivan River. Operators, H. H. Havey \& Co., North Sullivan.

The granite (specimen $\mathrm{D}, \mathrm{XXVI}, 69, \mathrm{~b}$ ) is a biotite granite of medium-gray shade and fine to medium even-grained texture. It consists, in descending order of abundance, of milk-white potash feldspar (microcline and orthoctase), smoky quartz, wilk-white sola-lime feldspar foligoclase), and black mica (biotite), together with accessory magnetite. The stone from the lower sheets is a trifle darker than that described above, which represents the stone of the upper sheets. The difference lies in the feldspar.

The quatry, opened in 1S65, measured in 1905300 feet from north to south, 200 feet from east to west, and 10 to 50 feet in depth.

Rock structure: The sheets, 3 to 8 feet thick, dip $10^{\circ} \mathrm{W}$. and NW. In the center of the quirry they have a lenticular form (Pl. XIII, $A, B$ ). Vertical joints strike N. $80^{\circ}-85^{\circ} \mathrm{W}$, forming a healing on the north, also N. $10^{\circ}-20^{\circ}$ E., bounding the quary on the east. A diabase dike, 3 feet wide, occurs on the west side. faulted ir two paces with a displacement showing a thrust from the east. The rock contains many knots, sone of them 6 inches and a few 3 feet in diameter. Sap occurs along the sheets, but not invariably.

'Transportation, by cart three-fourths mile to wharf.

The product is used mainly for curbing and crossings. The small beds go into paving hocks.

The Stimson quarries are in Sullivan. Operator, Ernest C. Gordon, Sullivan.

The granite (specimen D, XXVI, 67. (a) is a biotite granite of mediumgray shade and fine to medium even-gratined texture, consisting, in descending order of abundance, of gray potash feldspar (orthoclase and microcline), smoky quartz, grayish soda-lime feldspar (oligoclase), and black mica (biotite), together with accessory magnetite. The biotite plates measure up to 0.15 inch across. Contrasts are slight, owing to similarity in color of quartz and feldspar.

The quarries consist of three openings, the main one of which is 200 feet square and from 15 to 30 foet leep. 
Rock structure: The sheets, 1 to 5 feet thick, are horizontal, with slight undulations. Vertical joints strike $\mathrm{N}$. $65^{\circ} \mathrm{W}$., forming headings on the north and south sidies, atso north, and are coated in places with pyrite. The rift is horizontal. A vertical dike of aplite 1 foot $\tau$ inches thick has a N. $10^{\circ}-15^{\circ} \mathrm{W}$. course. The amount of sal) is small. Fark-gray knots up to 2 inches and exceptionally 7 inches in diinneter occur.

The product is carted half a mile to a wharf.

The Dunbar quarry is $2 \frac{1}{2}$ miles northwest of sullivan village, in the town of sullivan. Operators, Inubar Fros., Sullivan.

The glanite is a biotite granite of medium-gray shade and coarse inclining to medium even-grained texture like that of the liobertson quary, in Franklin, deseribed on page 218.

The quarry, opened in 1901. measured in 1905250 by 100 feet and 4 to 8 feet in depth.

Rock structure: Sheets, 2 to 12 feet thick, unlulate with a general easterly dip of $10^{\circ}$. Vertical joints strike N. so- $85^{\circ}$ E., forming a lieading on south side of quarry, and $\mathrm{N}$. $60^{\circ} \mathrm{E}$. with a headingr; also exceptionally N. $5^{\circ}-10^{\circ} \mathrm{E}$. The rift is horizontal. A diabase dike, $S$ to 16 inches thick. has a course N. $20^{\circ}-25^{\circ}$ F. and rims of epidote, as described on page 52 . There is little or 110 sap, and knots are few.

Transportation, by cart $1 \frac{1}{4}$ miles to wharf.

'The produet is random stone, curbing, and paring.

Hooper, Havey \& Co.'s quarry is in Rorth Sullivan. Address, North Sullivan.

The granite is a biotite granite of medinm-gray shade and fine to medium even-grained texture, like that of the Crabtree \& Havey quarry (specimen D, XXVI, 69, a, described on page 230.

The quarry, opened about 1894, measured in 1905300 hy 150 fect by 15 to 20 feet in depth.

Rock structure: The sheets, 6 inches to 6 feet thick, are gently undulating and horizontal. Vertical joints strike N. $20-25^{\circ}$ E., forming the west side of quarry, and also east, forming a heading on its north side. The rift is horizontal, and the grain vertical, east-west. The rock is evidently under a compressive eastwest strain, as it tends to fracture in a north-south direction across the grain, without regard to knot holes. The knots are small.

Transportation, by cart half a mile to wharf.

The product is random stone and street material, and curbing (straight and circular), crossings, and paving blocks.

The Pettee quarry (black-granite) is three-fourths mile north of Fast Sullivan, on the roud to Tunk Pond. Owner, J. A. Pettee. East Sullivan.

This rock (specimen D, XXVI, 80, b) is a mica-quartz diorite of very dark gray shade and fine to medium texture with occasional porphyritic whitish feldspar up to 0.25 and rarely 0.5 inch. It consists, in clescending orler of abundance, of white translucent sola-lime feldsprar (oligoclase-andesine), black hornblende, opalescent quartz, black mica (biotite), and magnetite, together with accessory titanite, apatite, and pyrite. It takes a fine polish, and the contrast between polished and cut surfaces is marked. The diorite of East Sullivan is referred to by $\mathrm{W}$. O. Croshy ${ }^{87}$ in a paper on the greology of Frenchmans Bay.

The quarry, which is only 15 by 15 feet and 8 feet deer, is on the west side of a knoll 20 to 25 feet higll.

Fock structure: Vertical joints, strike N. $25^{\circ} \mathrm{W}$. and $\mathrm{N} .85^{\circ} \mathrm{W}$., recur at intervals of 1 to 5 feet. The rock splits in these directions, also horizontally. 
There are whitish bands or veins 0.5 inch thitk, consisting almost entirely of the feldsprar and guartz.

This stone is ruarried occasionally in small blocks for monuments.

The sinclatr prospect (blark-tranite) is $1 \frac{1}{2}$ miles north of last Sullivan, (1) Iferbert and Thadiens Sinclair"s (formerly Smith Bean's) farm. near charles Lowel's sawmill.

This rock (specinen T. XXYI. S2. at) is a mica-quart\% diorite of almost blark shade, with white blotehes, of medium to coarse porphyritic textrire. It

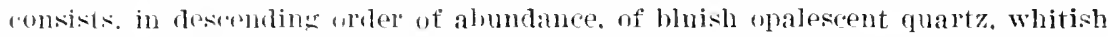
sula-lime feldspar (oliguclase-andesine), and potash feldspar (microcline and orthoclase), llack hornhlente. and black mica (biotite), together with accessory magnetite, pyrite, titanite. anel ankatite. Sune of the feldspars measme nearly an inch in length.

The ledge is exposer for a length of 51 feet north-south and a height of 20 feet. A rertiual joint strikes $\mathrm{X}$. $20^{\circ} \mathrm{W}$. An opening $10 \mathrm{by} 5$ feet and 5 feet deep was marle here in 1902.

\section{SWANS ISLAND.}

The Baid quary is on Swans Islame, east side of old harbor, not quite 1 mile east of Swans Island village and three-fourths mile sontheast of Minturn. Blerator, Matthew Iaird Contrating Co.. 433 East Ninety-second Street, New Vork. Trlle since 1917 .

The arante (specimen D, XXYI, 34, a) is a biotite granite of medium pinkishbuff color and of merlium inclining to coarse even-grained texture. It consists, in descending order of abundance, of a pinkish-buft potash feldspar (orthoclase and microcline), smoky quartz, a milk-white soda-lime feldspar (oligoclase), and black micar (biotite), together with accessory magnetite and, rarely, a litte greenish hormblende. The potash feldspars are intergrown with plagioelase and measure ul, $100.5 \mathrm{inch}$ or more, but most of the biotite is consilerably moler 0.1 inch. The stone takes a good polish, but the contrast between the polished and rough surface is fewle, owing to the smallness of the hiotite staies. The contrasts are mostly between the quartz and the feldspars. The company reprorts a test of crushing strength between 18,000 and 19,000 pounds to the square inch.

The quary, opeved in 1901, measmed in 1905500 by 250 feet, with an arerage deptlu of 15 to 18 feet.

Rock structure: The sheets. 1 to 7 feet thick, dip $15^{\circ} \mathrm{S}$. Vertical joints, striking N. $45^{\circ}$ E., recur at intervals of 50 feet; others, striking N. $80^{\circ}$ W., recur lnt twice as contimous joints. The rift is vertical north-south. Sap is confined to the shects of the upper 3 feet. No lnots or veins.

Transportation, by gravity and cable on track 1,200 feet to wharf.

The product is random, dimension, and paving stone, which go to New York, where the firm has its cutting works.

The Toothachers Cove quarry is near the end of that cove, in the western part of Swans Island, $1 \frac{1}{2}$ miles north-northwest of Swans Island village. Guarry disnsed in 1905; also in 1917.

The sranite (specinen D, XXYI, 33, a ) is a biotite granite of medium pinkishgray color and coarse, even-grained texture, with feluspars up to 0.75 inch and biotite fnlly 0.1 inch. It consists, in descenting order of abundance, of lightpink potasl feldspar (orthoclase), smoky quartz, cream-colored soda-lime feldspar (oligoclase), and black muca (biotite), together with accessory magnetite aud titanite. The orthoclase is intergrown with plagioclase. The oligoclase is altered to a white mica. The contrasts between the four minerals are marked.

The quarry in 1905 was 50 by 25 feet, with a working face 20 feet high. There are two other small openings. 


\section{TREMONT.}

The Carroll quapry is in the town of Tremont. on 1 lomut lesert Istand, at Somthwest Harbor. Operator. John Carroll, Somthwest Iitrbor.

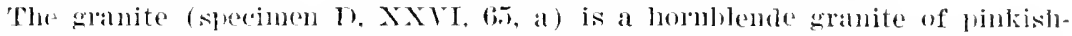
greenish metinm-grat rolol and molimm even-grained texture, consistius, in

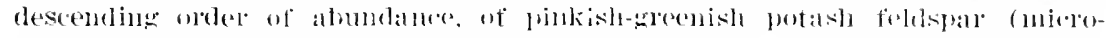

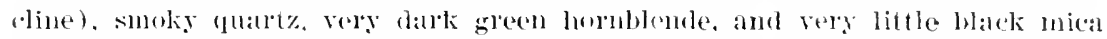
(hintito), together with acessiser magnetite and zireon and sorondalry chlorite. The niclocline is intergrown with funtz and sodatime feldspar (oligoclaseandesine) and is largoly altered to kiblin and a white mial This granite is

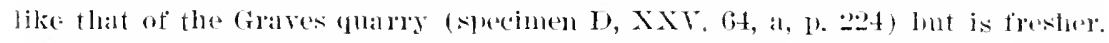

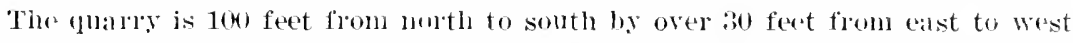
and in 1905 hatd a working face on the ast 15 fort high. The sheets a inches to 3 feret thick, are borizontal at the north end but ali $10^{\circ} \mathrm{S}$. at the sonth ent. Vertical joints strike $X .75^{\circ} E$. and $X .50^{\circ}-55^{\circ} W^{\circ}$. Knots are almulant and ale ne to 2 feet in dianmeter.

The quarly is worked only oreasionally, and the stone is nesed lomally for foundations.

\section{IENXEREC COUNTE.}

\section{HALLOWELL.}

'ine Stinchicld quary is in the town of Hallowell, $2 \frac{1}{2}$ miles northwest of the city of Hallowell, on the southern fart of Lithgow Hill, (See map, I'l. IX.) "lyeratur. Hallowell Grante Works, C. L. Paine, receiver, IIallowell.

The crante (suecinen D, XXVI, 111, a), "Hallowell," is a biotite-muscovite cranite of lightoray shade and fine texture, with porphyritic feldspars usually about 6.25 inch in diameter. It comsists, in descending order of abunlance, of slightly bhosh translucent potash feldsuar (orthoclase and microcline), smoky (light) (fiatre, sorbatime feldspar (oligoclase) of the same coler as the other, biack miea (biotite), and white mica (muscovite), together with accessory anruet, zircon, and allate. The oligoclase is usually undergoing altoration to kablin and a white nica and contains intergrowths of quart\% circular in "poss section. Extusive of the porplyritic feldspars, the general diameter of the particles ranges from 0.2 .5 to 1.0 millimeter. averaging about 0.65 . The micas are thickly disseminated. The stone talkes a fue polish and the polished face has a slight bluish tinge. A microscopic description of "Hallowell granite" will be found in Merrill's "Stomes for building and decoration," pages 63. fit.

E. C. Sullivan, of this survey, fomd that this granite contains 0.060 per (ent of $\mathrm{CO}_{2}$ (carbon dioxide) and that warm dilnte acetic acid dissolves 0.08 ler cent of CaO (lime) and a trace of MgO (magnesia). If all of this $\mathrm{CO}_{2}$ is assigned to the $\mathrm{CaO}$, the rock contains 0.14 per cent of $\mathrm{CaCO}_{3}$ (calcium carbonate). The lime extracted hy this process is in addition to that combined with silica in the soda-lime follspar. The thin sertions from the Tayntor quarry stone, which is essentially the same, show a little carbonate (see p. 235), ant the same mineral must occm also in this granite, hut in very minute quantity.

A test of the crushing strength of this granite made by Ricketts \& Banks yielrled the following results:

Flrst cube 19,260

Second cube. 
The difference in the two cubes is attributer to some imperfection in the second one.

The quarries were opened about 1826. The Stinchfield quarry measures 600 fert from northeast to southwest by 400 feet across and in 190.5 was 30 to 60 feet deen. (See Pl. XII, B.) The longfellow quarry (not in operation, but filled up to 20 feet with water), sonthwest of the Stinchfield and communicating with it, measures about 400 by 200 feet and from 50 to 70 feet in lepth. The stripping comprises up to 20 feet (increasing northwestward) of yellowish sandy clay with small boulders near the top.

Rock structure: The most striking features in these quarries are the gradual increase in the thickness of the sheets downwarl (partiy shown in Pl. XII, $B$ ), from 4 inches to $1 \mathrm{t}$ feet, and the evidence of strain afforded by the mumerous headings and joint systems shown in figure 5,3 , also the evidence of weathering afforded by the decomposition and discoloration along these headings. The sheets range from the horizontal to an inclination of $15^{\circ} \mathrm{NE}$. Many of them stop at the joints, probably owing to faulting; some taper out and ovcrlap. I'late XVII, $B$, a view of a part of the nolthwest wall of the Longfellow quarry,

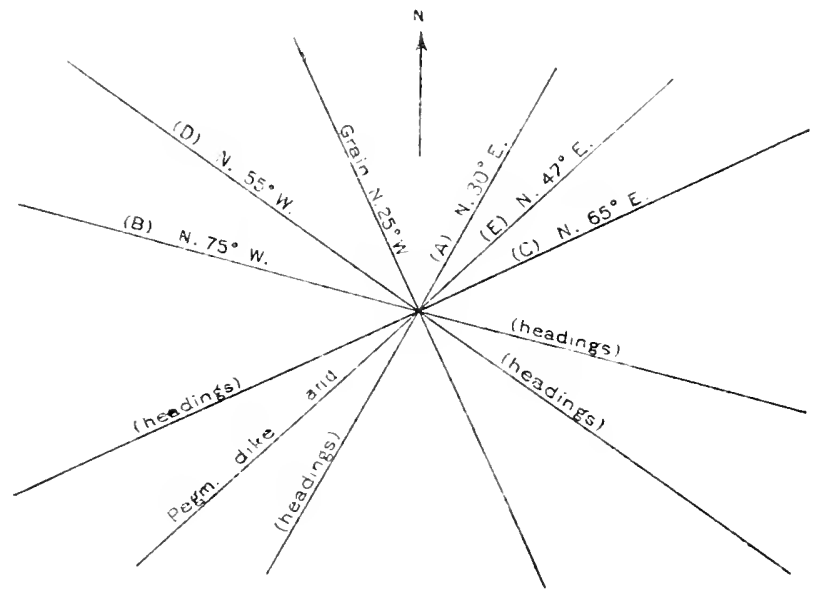

Figure 53.- Structure at Stinchfield and Longfellow quarries, near Hallowell, Maine.

shows the intersection of headings of joint systens (C) and (D). Joints (A) are spaced from 10 to 15 feet. (B) forms a heading 50 feet wirle on the southeast wall, weatheren yellow to a lepth of 50 feet from the rock surface. Joints (C) are spaced from 5 to 70 feet. In a 2 -foot heading of (C) on the southwest wall the joints recur at intervals of 2 inches to 0.5 inch and are conted with quartz cristals. Joints (D) form two headings, 10 feet wide, on the southeast wall, containing a bed of sand a foot thick and 30 feet deep or long. Joints (E) are discontinuous and grooved and polished from motion. Large areas of some of the joint planes in the Longfellow quarry are covered with frostlike crystallizations of oxides of iron and mobahy of manganese. The rift is horizontal; the arain is rertical, N. $25^{\circ} \mathrm{W}$., but feeble. A 2 -foot pegmatite dike contains milk-white oligoclase, smoky quartz, muscovite, biotite, and 1-inch garnets. Knots occur up to 0.75 inch across, exceptionally 1 by 3 inches. The sap is very marked along the joints and up to a foot thick. The concentric growth of ferruginous stain is shown in the heading photographed. 


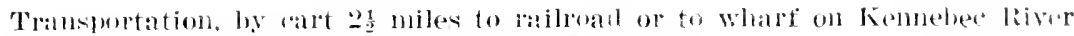
at Hallowell, accessible to schooners of 12 -foot draft.

The product is used for bubdings am sculpure. It lends itself remarkably well to delinate ornamental work and statuary, as is shown by lalate XX, a reproshetion of a photograph of a paned al the entrance to the bank of com-

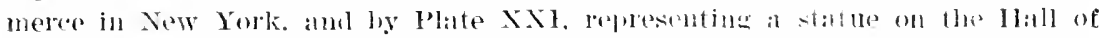

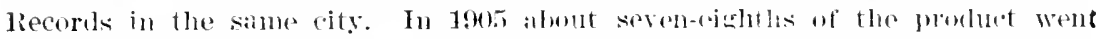
into buiting and one-eighth inte carved work. Spreciment bulelines: capitol, Albany, N. Y.; Marine National bank, buffalo, X. Y. : Jall of kerorels (indededing its statuary), Brooklyn Savings Bank, New York: Masonic 'Pmple. lisston; academic and library buildings, United states Naval Aademy, Annaludis, Mal.;

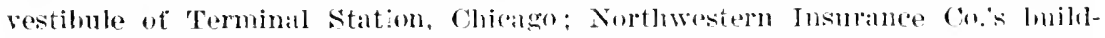
ing, Milwanke ; Savings Bank, Bangor, Maine. Specimen mommments and statnes: Statue on l'ilurim monmment, Plymoutl, Mass, national memment, Yorktown, Va.; New York State momment, Gettyshmrg, I’i.: soldiers momiment,

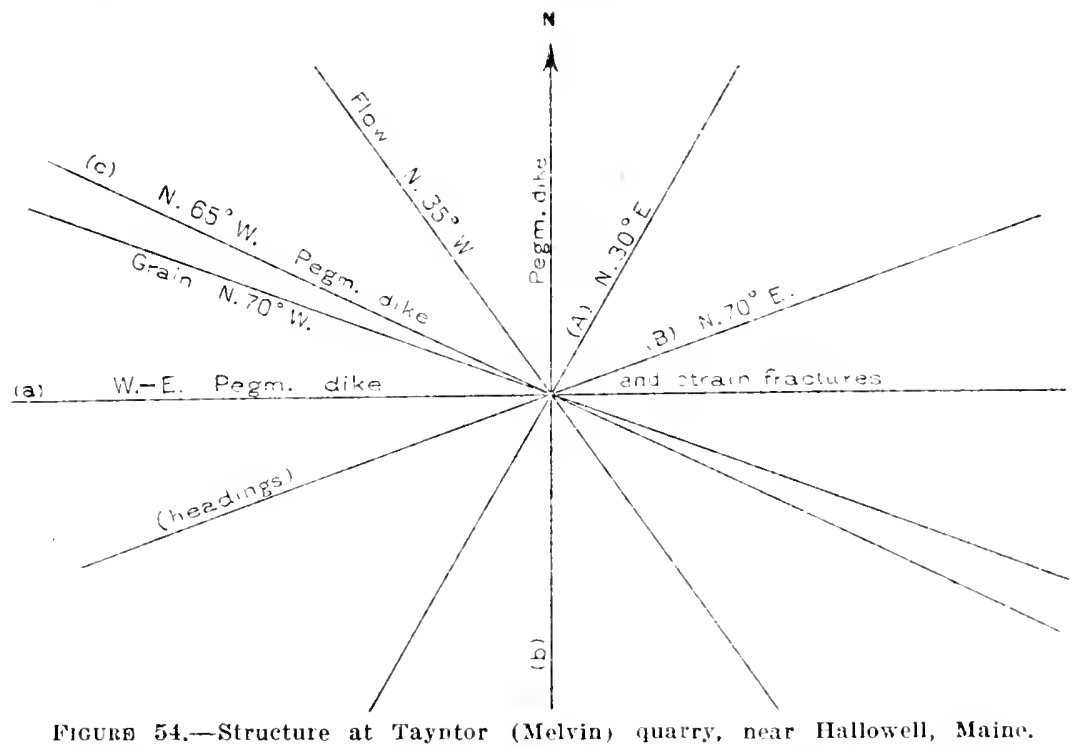

New Haven, Conn.; Richard M. Hunt monment, Central Park, New York; batIlefield monument, Trenton, N. J. In 1922 the quarry was leased to freo. A. Fuller Co. and was supplying part of the stone for the new courthouse in New York.

The Tayntor quarry (Melvin quarry) is in the town of Hallowedl, 2 miles north-nortluwest of the city of Hallowe: It is now owned hy the Ilallowell Granite Works, but has not been operated for several years.

The granite, "Hallowell," is a biotite-mustovite sranite of liglit-gray shade and fine (but porphyritic) texture, identital with that of the kongfellow and Stinchituld quarries (specimen D, XXVI, 111, a), described on pase 233. The general diameter of particles, exclusive of the porjlyyitic crystals, rimase from 0.25 to 1.25 millimeters. One of the small porblyritic oligoclase crystals measuring 2.25 millineters in diameter shows ealcite between its cleavag planes. Calcite appears also independently in plates up to $0 . \overline{5}$ millimeter across. $\mathrm{F}$. C. Sullivan, of this Survey, found that it contained 0.116 per cent of $\mathrm{CO}$ : (carbon dioxide) and that warm dilute acetic ac:d extracted 0.24 per cent of CaO (lime) and no magnesia. The $\mathrm{CO}_{2}$ found corresponds to 0.33 per eent of $\mathrm{CaCO}_{3}$ 
(calcium carbonate). The tifference in the result of the test of this and the test of the stinchield quarry stone maty not hold good of the stomes in general. The average of both tests, of $0.235 \mathrm{l}^{\mathrm{k}} \mathrm{l}$ rent for the lime carbonale of both stomes, may be noarer the truth.

The quarry, opened before 1S40. meismed in 1905520 feet $\mathrm{X}$. $30^{\circ} \mathrm{W}$. to $\mathrm{s}$. $20^{\circ}$ E. ly 275 feet across and from 10 to 40 feet in depth. The deeper part of it is 275 by 150 feet and 40 feet deep.

Rock structure: In places there is a rertical flow structure with comrse $\mathrm{X}$. $35 \mathrm{~W}$, and where it wours it is the direction of easiest fracture. The sheets measure 1 foot to 6 feet $(i$ inthes (the thicker being the lower ones), and are horizontal. The joint and dike comses are shown in tigure 54 . (A) recurs at intervals of 20 to 200 feet, and forms one leading. which does not extend beyoul a dejth of 15 feet from ther lock surfares. (13) in places dips steep north, recurs at intervals of 10 to 40 fert, and forms heidings in the northern labif of quarry. 'The rift is horizontal, and the grain rertical, N. $70^{\circ} \mathrm{W}$., but feeble. Figne at shows the courses of the promatite dikes; (a) dips $45^{\circ} \mathrm{N}$. and is 4 inches thick, (b) dips $65^{\circ} \mathrm{E}$. and is 3 inches thick, (c) dips $\mathrm{N}$. and is 3 inches thick. Iegmatite lenses 2 feet thick also occur. In the northern bart of the guary there is a batul of dark knots. from 5 to 25 feet wide, with at $\therefore$. $10^{\circ} \mathrm{F}$. comser, but the rest of the guary is free from knots. The glaciated surfaces and the sheet surfaces are free from sap except near the headings, where it extends for 6 inches from each sheet mol joint face. The granite is here under rompressive strain, for thr cores between the contiguons borings made in chameling become crushed, and on two occasions spontaneons rertical eastwest fractures 40 feet long occured through a sheet 4 feet inches thick, diagonal to two rectangulax "channels."

Transportation, by l*ail 2 miles to cutting shed at dock.

The product was used for nommental work. Specimens: General slocum monment, Gettrimm. Pal. State of Maine monmment, Andersonville, Ga.; New York State monument, Lookout Mountain (Craven House), Tenn.; soldiers' monument, Pittstield, Maine; Immlap mausolem (Corinthian style, 16 by 28 feet) and Ziegler mansoleum (Grecian Doric style, 25 by 34 feet, a fter the temple at Paestum), Woollawn Cemetery, Now York; Ceneral Miles mansolemm, Arlington, Ya.

KNUX COENTY.

MUSCLE RIDGE PLANTATION.

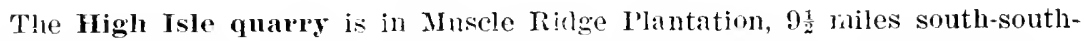
east of Rockland. Operators in 1905, William Gray \& Son, Philadelphia, Pa. Quarry now idle.

The granite (specinen $\mathrm{D}, \mathrm{XXVI}, 18$, a) is a biotite granite of slightly pinkish medium-gray color. with comspicuous black mica and of medium to coarse, even-grained texture, the feldspars measuring up to 0.5 inch and most - f the biotite scales up to $0.1 \mathrm{inch}$, but some $0.2 \mathrm{inch}$. It consists, in descending order of abundance, of a delicate pink potash feldspar (orthoclase ano microcline), smoky quartz, milk-white, very slightly bluish soda-lime feldspar (oligoclase), and black mica (biotite), together with accessory magnetite, apatite, and secondary chlorite. The oligoclase is in some places partly altered to a white mica. The contrasts between the minerals are rather marked, but the polish is not very satisfactory, owing to the large size of the biotite scales.

The following chemical analysis and determination of specific gravity were made for the firm by Prof. James F. Kerup, of Columbia University : 
Jereent.

Silica $\left(\mathrm{SiO}_{2}\right) \ldots \ldots \ldots+\ldots$

Alumina $\left(\mathrm{Al}_{2} \mathrm{O}_{4}\right) \ldots \ldots \ldots$

Ferrous oxide (FeO)

Ferric oxide $\left(\mathrm{Fe}_{2}\left(\mathrm{O}_{3}\right) \ldots \ldots\right.$

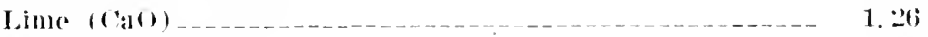

Magnesia ( $\mathrm{MgO}) \ldots 09$

Manganese $(\mathrm{M}[\mathrm{n}) \ldots \ldots$

Sulphur (S)

Sorla $\left(\mathrm{Xal}_{2} \mathrm{O}\right) \ldots$

I'otak ( $\mathrm{K}, \mathrm{O}) \ldots \ldots \ldots$

100.067

Loss on ignition, 0.55 .

Specific gravity, 2.641, equal to 16.5 .06 pounds per cubite font.

The results of three clushing tests (laboratory Nos. 1759 to 1761) on 2-inch cubes bedded with plaster of l'aris, mate at the engineering laboratory of

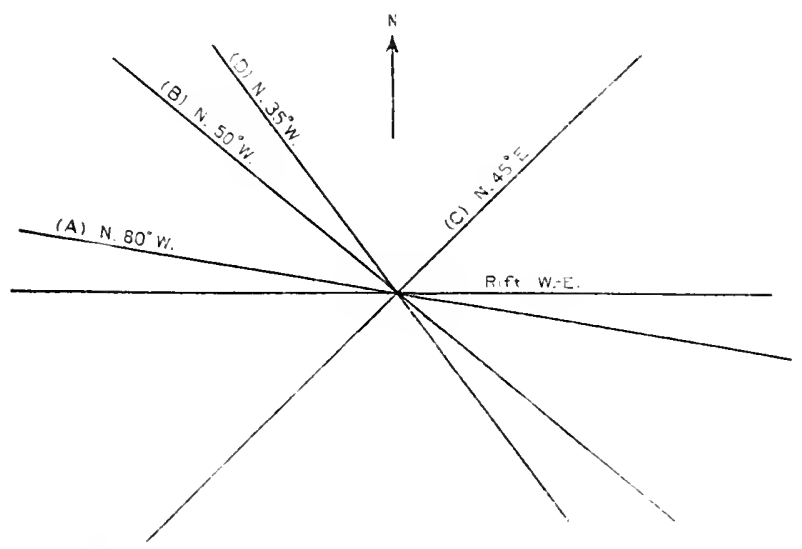

Furre 55,- Structure at High Isla quarry, Kinox County, Maine.

Columbia University for the firm. are as follows: First arack at 100,0mo to 126,300 pounds. Citimate strength in pounds per square inch, 25,850, 32.360, $32,495,33.085$.

The quarry, opened about 1S94. consists of tive openings, each about 100 fret square. with a maximum lepth of 50 feet and an average depth of about 17 feet.

Rock structure: The sheets, 2 to 14 fect thick, a re lenticular, tapering, and curve over to the northwest and southeast at low angles. (See I'. XVI, 1.) Joint coursos alle shown in figure 5.j. ( $A$ ) is mominent and forms a hearling on the south sille of the island, shown in I'late XVI, A. (B) (lips $40^{\circ} \mathrm{SF}$, occurs but occasionally, and is discontinuous. (C) also forms a heading. (ID) dips $65^{\circ} \mathrm{SW}$. and is also prominent. The rift is vertical, with east-west course. Irregular horizontal dikes of pegnatite. up to 2 inches thick, consist of the same minerals as the granite-a pink orthochase and microcline, smoky quartz, cream-rolored oligoclase, and biotite. Sap ocrurs along the sheets and joints (A) and (C), and markedly at the surface, in places up to a foot in thickness. (Fol details see p. 66 and fig. 5. ) Along some of the hualings uf $(.1)$ the wranite is weatlered to a sand at a depth of 20 feet. 
Transportation, ly gravity and track 650 feet to wharf.

The prolud was mst for huildings. Sumdry small buildings and bridge seats

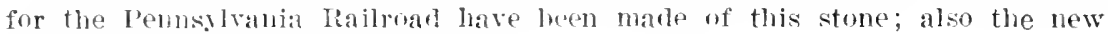
Wanamaker store in Philadelphia.

The Dix Island quaries are in Muscle Ridge Plantation, haif a mile sonthwest of High Islu. Owmel. Thomas Inyer, Two humdred and sxteenth street

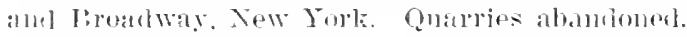

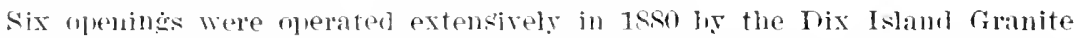
Co., which employei 1.400 men when filling large contracts. These quaries

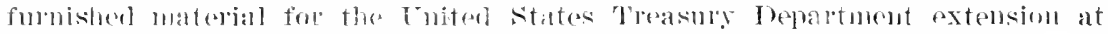
Washington, the hasement of the ('halleston ansombonse, the New Yoris and Philatelphia post offices. and the trimmines fol the New York Metropolitan Musemus of Art. Drly an oreasional block is now quarried. There is a whare with 1:2 fast of witere at ]ow tibo

The granite (specimen. П. XXVI, 1!, a) is a biotite granite of somewhat

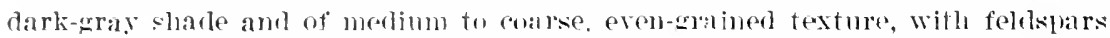
np to 0.5 inclu and many fine biotite sales larely orer 0.1 inch. It consists, in descrncling order of abmulane. of delicate pink potasl feltspar (orthoclase and microcline), smoky quart\%. a vory slightly bluish-white soda-jime foldspar (oliguclace), and black ming thintite). together with acressoly masuetite and apatite. The oligorlase is nartly altered to a white mica and rarely contains a little "an'ite. The hintite is here am! there interleaveri w:th muscovite. The chief difference hetween this and the "High Isle granite" is that in lhis the biotite scales are generally smaller and much more almulant, which darkens the shatde of the rock and huminishes the contrast between the minerals.

Lock structure: The sheets, 2 to 10 fext thick, dip $20^{\circ}-40^{\circ} \mathrm{S}$. in plares. Headings strike N. $80^{\circ}$ E. and N. $35^{\circ} \mathrm{W}$.

\section{SOUTH THOMASTON.}

The Sprucehead quarry is on Sprncehear Island, in the town of South Thonuaston, : thout 10 miles somth of Rorkland. Owuer, Bodwell Granite Co., Rockland. Quary disused since 1910

The rock (sperimen D. XXYI. 10. a), "Sprncehead," is a quartz monzonite,

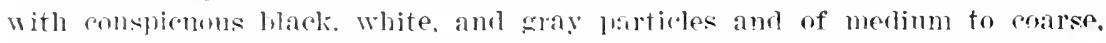
even-gatines textmre. It consists, in descending order of ahmolance, of transmcent white soda-lime feldspar (oligoclase). milk-white potash feldspar (microcline). smoky quartz, black mica (bjotite), and black hornblende, together with accesory titanite. magnetite. pyrite, zircon. apatite, and secondary epidote. Zonal structure is common in the oligoclase. The rontrasts between the brack minerals, the smoky quartz. and the felds]als are very marked.

The quarry in 1905 was about 275 feet by 250 feet and had a maximum depth of 5 s feet and an avernge rieptli of about 27 feet.

kock structure: The sheets, fiom less than a foot to 13 feet thick. iie horizontal or dip $10^{\circ}-15^{\circ} \mathrm{XW}$. and sir. intelsoeting the surface. which dijs fently southeast. The sheers are irregular in thickness, owing to the taperiur ont ot the lenses, int, in sencral, inclease in thickness downwari. .Joints arn dike. courses are shown in fisure 56 . (A) recurs frequently on the north sicke of the quarry, but two joints are 50 feet anart and have greatly facilitated the opening of the quarry. $\left(P_{0}\right)$ dips $70^{\circ} \mathrm{N}$. and traverses the entire quarry. The rift is vertical with a N. $60^{\circ}$ E. course. Knots and dikes occur. Sap is 3 Inches thick on the sheet surfaces.

$8 s$ These quarries are referred to br J. F. Wolff in Tenth Census, vol. 10. pp. 119, 120. 1858, and by G. P. Merrill in Smithsonian Inst. Ann. Rept., 1889, pt. 2, p. 416. 
Tramsportation, hy cart 300 feet to whalf.

Specimen buldings, otc.: Carnegie library. Allegheng: l'a.: post oflice and

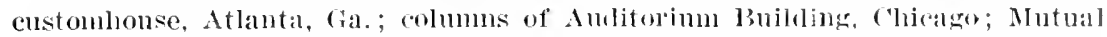
Life Insurance Co.'s buldling and National Gity Bank, New York; post oflice (exterior). Balr llarbor. Maine.

The Weskeag quarry is in the town of sonth Thomaston, 1 mile west of P'leasant Beach ame 7 miles south of looklamed. Quary disused since 1914.

The granite (specimen D, XXVI, 1+2, a) is a bintite-muscovite granite of slightly bluish medium-gray color and of medium to coarse, event-grained texture, with feldspars up to 0.5 inch and mica to 0.15 inclt. It consists, in descending oreler of abundance, of light-hluish potash feldspar (orthorbase and nicro(line). smoky quartz, bluisl or white soda-lime feldspar (oligoclase), black mica (biotite), and white mica (muscovite), together with acessory garmet, magnetite, and apatite. The oligoclase is partly altered to kaolin and a white miea. Thin secions show a marked rift. ${ }^{89}$ The stone takes a fine polish, but

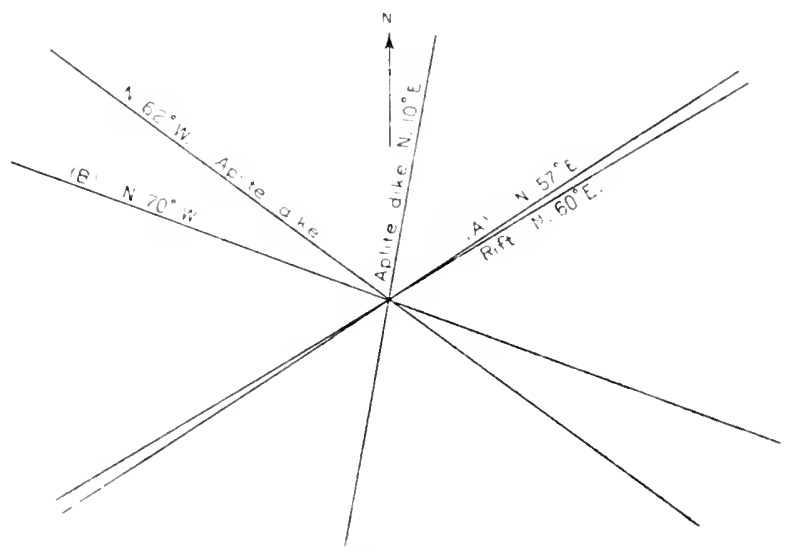

FigCre 56.-Structure at Sprucehead quarry, South Thomaston, Maine.

the abundance and size of the mica plates are not favorable to the durability of the polish under ontdoor exposure.

The quarry, reopened in 1905, covered then about an acre of ground with an average depth of 20 feet. The sheets are horizontal and tapering, lenticular. Joints strike $\mathrm{N} .80^{\circ}$ E. and dip $80^{\circ}$ S. Rift is vertical and strikes $\mathrm{N} .80^{\circ}$ E. Grain is horizontal.

Transportation, by cars and horsepower on track half a mile to wharf near Birch Point.

ST. GEORGE.

The Clark Island quarry is on Clark Island, in the town of St. George, about 12 miles south-sonthwest of Rockland. Owner, Rodgers Granite Corporation, 271 West One hundred and twenty-fifth Street, New York.

The granite (specimen D, XXVI. 12. a) is a biotite-muscovite granite of bluish, medinm-gray color and of tine to medium evell-grained texture, with feldspar up to 0.25 inch and mica under 0.1 inch. It consists, in descending order of abundance, of light-bluish potash feldspar (microcline and orthoclase), clear or very slightly smoky quarłz, light-bluish soda-lime feldspar (oligoclase), black mica (biotite), and white mica (muscovite), together with 
accessory garnet, zilcon, apatite, and secombry chlorite. The oligoclase is partly altered to a whise nica and inclucles a little carbonate. The quartz contains hairlike crystals of rntile. In general, as the quartz is so nearly clear, the bluish tint of the feldspar dominates and the contrast is mostly between it and the thickly disseminated black mica. It takes a very fine polish.

E. C. Sullivan. of this Survey, finds that it conains 0.218 per cent of $\mathrm{CO}_{2}$ (carbon dioxide), and that warm dilnte aretic aril extracts $0.2+$ per cent of CaO (lime), and mucll MgO (magnesia). Figuring the $\mathrm{CO}_{2}$ to both CaO and $\mathrm{llgO}$, this wonld give 0.43 per cent of $\mathrm{CaCO}_{3}$ (alcium carbonate) and 0.06 per cent of $\mathrm{IgCO}_{3}$ (mitgnesium carlonate). The thin section also shows carbonate.

The quarry, opened about 1870 , measured in 1905500 by 300 feet, with a maximum depth of 50 feet and an average of 25 feet.

Rock structure: The sheets, 2 to 10 feet thick, strike $\mathrm{N} .30^{\circ} \mathrm{W}$. and dip $20^{\circ}$ E. and on the east side of the quarry $20^{\circ}-30^{\circ} \mathrm{W}$. Tertical joints strike $\mathrm{N}$. $65^{\circ}-70^{\circ} \mathrm{W}$. and recm at intervals of 10 to 20 feet. The rift is rertical, with a N. $85^{\circ}$ W. course. There are two dikes of coarse pegmatite, np to 6 inches thick, one striking $\mathrm{N} .15^{\circ} \mathrm{W}$, the other $\mathrm{N} .40^{\circ} \mathrm{W}$. They consist of feldspar, quartz, muscovite, biotite, black toumaline, and red garnet. The usual sap occurs along the sheets.

Transportation, by horse power on track 900 to 1,200 feet to wharf.

specimen buildings: Post offices, Hartforrl, Conn., and Buffalo, N. Y.; Standard Oil Building, New York.

The McConchie quarry (black-granite) is in the town of St. George, about three-fourths mile north of Long Cove quarry. Quarry idle.

The rock (specimen D, XXVI, 16, a), "Crown black grani e," is a norite of very dark gray shatle and fine to medium texture, emsisting, in descending order of abundance, of an unaltered colorless to smoky feldspar coniaining both soda and lime (andesine to labradorite), hypersthene partly altered to brown hornblende, black mica (biotite) in scales np to 0.2 inch, and milnetite, together with accessory pyrite.

The quarry, opened in 1888, was in 1905 about 50 feet square and from 10 to 15 feet deep.

The stone has to be carried 10 miles to the cutting works at Sonth Thomaston. although the quarry itself is within one-fonrth mile of seaboart.

Specimen structures: Soldiers' monuments at Warren and Union, Maine.

The Long Cove quary is near both Tenants Harbor and Long Cove, in the township of St. George, abont 13 miles southwest of Rocklaud. (See Rockland toporraphic map, U. S. Geol. Survey.) Operator, Booth Bros. \& Hurricane Isle Granite Co., 208 Broadway, New York.

The granite is a biotite-ruuscovite granite of bluish medium-gray color and of fine to medinm even-grained texture like that of the clark Islan'l quarry, deseribed on page 239 . Tests of its compressive strength made by the Colmmbia School of Mines are reported by the firm to have shown an ultimate crushing strength of 22,000 pounds to the square inch, but the original report of these tests has been misplaced.

The quarry. opened about 1873 , measured in 1905 about 1.000 feet from north to south by 500 feet from east to west and from 20 to 75 feet in depth, averaging abont 40 feet. This is the only quarry in New England in which tun. neling is resorted to in the use of explosives.

Rock structure: The sheets, 6 inches to 13 feet thick, are horizontal or dip $10^{\circ}$. Joints and dike courses are shown in figure 57. (A) recurs at intervals of 2 to 30 feet, (B) dips $25^{\circ}$, (C) dips $65^{\circ}$ NE. The east end of the quarry is 
much broken up by the closeness of joints (A) and the thinness of the shcets for a considerable distance below the surface. The rift is vertical, with $N$. $80^{\circ}-90^{\circ} \mathrm{W}$. course. There is a horizontal dike of pegmatite up to 9 inches thick at the north end of the quarry ; another, divided into many parallel ones, strikes N. $70^{\circ} \mathrm{W}$. and dips $70^{\circ} \mathrm{N}$. These dikes all consist of white feldspar, quartz, muscovite, black tourmaline, and garnet. Sap is up to 18 inches thick along sheets and joints.

Transportation, by inclined track 900 feet to wharf.

The product is used chiefly for monuments and goes chiefly to Grcenwood and other cemeteries near Brooklyn, N. Y. The small bells and waste are worked into paving blocks. Specimen buildings, etc. : Post oflice, Albany, N. Y.; Bates Building, Philadelphia; and part of Saratoga monument.

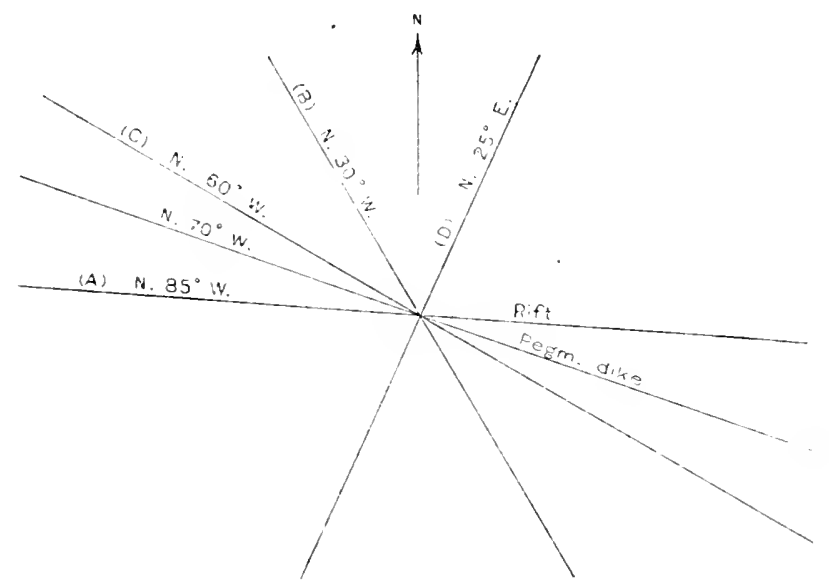

Figcre 57.-Structure at Long Cove quarry, St. George, Maine.

The Willards Point or Wildcat quarry is on Tenants Harbor, in the township of St. Gecrge, about a mile south of the Long Cove quarry. Operator, St. George Granite Co., 90 West Street, New York.

The granite is a biotite-muscovite granite like that of the Long Cove and Clark Island quarries (p. 239).

The quarry, opened before 1873, measured in 1905 about 200 by 100 feet, with an average depth of 20 feet.

Rock structure: The sheets, 1 to 3 feet thick, are nearly horizontal. There are four sets of joints-(a), strike nearly due east; (b), strike N. $55^{\circ} \mathrm{W}$.; (c), strike N. $70^{\circ}$ E.; (d), strike N. $70^{\circ} \mathrm{W}$. The rift is east-west. Permatite dikes, 6 to 12 inches thick, strike N. $30^{\circ} \mathrm{W}$. and N. $50^{\circ} \mathrm{W}$.

The quarry is only 300 feet from the dock.

Although the Rockland post office was made of this granite it is now used entirely for paving.

\section{VINALHAVEN AND HURRICANE ISLANDS.}

Vinathaven and the adjacent islands have been known collectively as the Fox Islands, and their granite as "Fox Island granite." The granite industry of these islands is distributerl over an aren about 5 miles from east to west by 4 miles from north to south. The locations of the quarries are shown on the 
map (fig. 58). Some of them are near the center of Vinalhaven Island. The Palmer quary is on the west shore; the Black and Webster quarries are on the east shore; the Sands. Marbor. and Armbrust quarries are on the south shore, near Vinalhaven village; and the P'equoit and Duschane Hill quarries lie east of the village near the cast shore. There are some minor

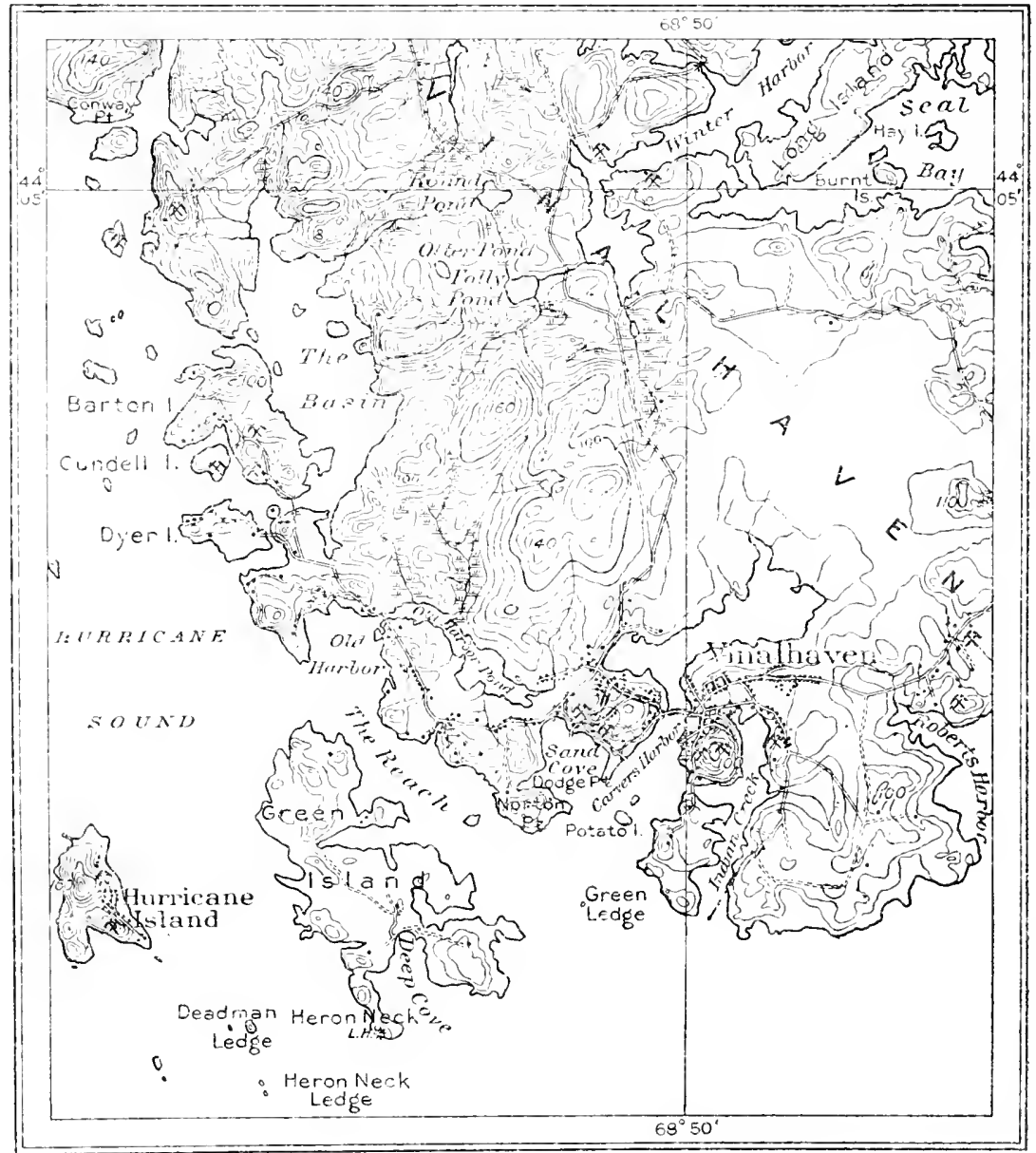

$0,1 / 2,1$ ziniles

Contour interval zofeet

FIGLRE 58.-Map slowing location of quarries on Vinalhaven and adjacent islands, known collectively as "Fox Islands," Maine. (From Vinalhaven topographic map, U. S. Geol. Survey.)

quarries ("motions") on Barton, Cundell, and Green Islands, and a large quarly on Hurricane Island. As will be seen from the descriptions, there is little difference between the coarse granites of the Hurricane Island, Sands, Harbor, Armbrust, Black, Webster, and Palmer quarries, but the granites of the Duschane Hill and Pequoit quarries are fine textured, as is also that from an abantoned opening in Vinalhaven village. 
Plate $\mathrm{X}$. A. shows the conspicums east-west jointing in the grante on Heron Neck, at the south end of Green Island. The same system of jonts recurs on Hurricane Island and at the Sands and Ambrust quarries.

The Sands quarry is in the town of Vinalnaven, at the northeast sine of the head of Saml cove. (see maps. I\%. IX and fig. 59). Operator. Bodwell (ivanite Co., Ruckland. Idle in 1922.

The granite (specimen D, XXVI. 1, b) is a biotite sranite of general pinkish-

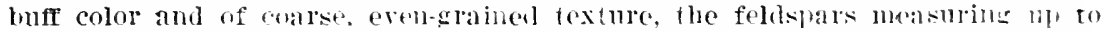
0.75 inch (rarely 1 inch) and the liotite sales up to 0.2 in h. It consists, in descending order of abmolane of a piukish-huff potash fehopar (chitely ortho-

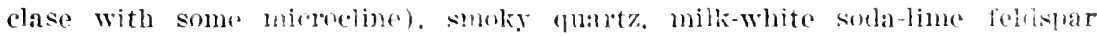
(oligoclase). and llack mica (biotite). together with accessory masuetite. zircon, and apatite. The orthodase here and there contains irregular areas of carbonate and is intergown with a plagioclase or rimmed with oligoclase. The oligoclase is party altered to kathin and a white mica. Jyrite is found by the quarrymen in rare and minte particles. and molylulenite oreurs ocracionaliy in half-ineh somles. E. C. Sullivan, of this surver, finds that this sranite com-

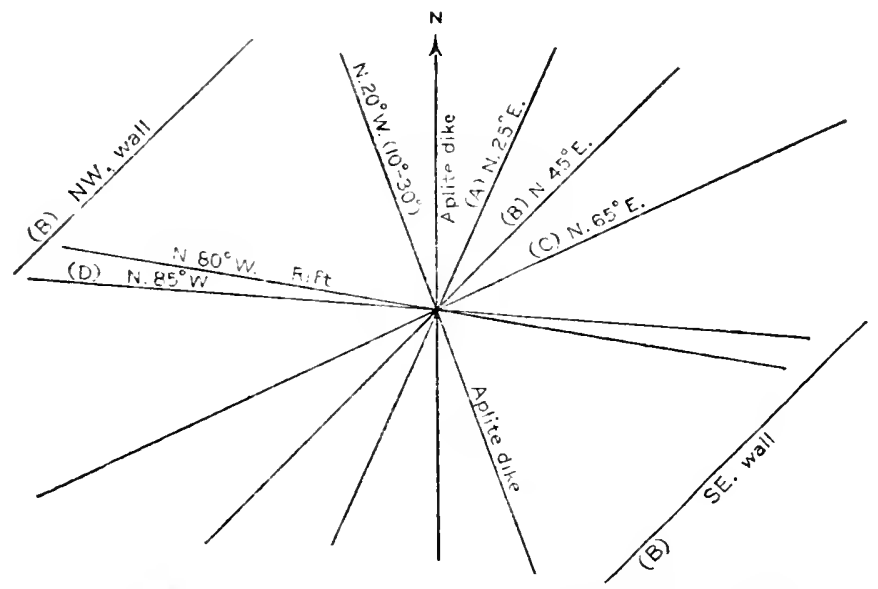

Figtre 59.-Strurture at Sands quarry, Vinalhaven, Maine.

tains 0.034 per cent of $\mathrm{CO}_{2}$ (carbon dioxide) and that warm dilute acetic aciu extracts $0.07 \mathrm{pel}^{\circ}$ cent of $\mathrm{CaO}$ (lime) and a trace of $\mathrm{MgO}$ (magnesia). This, if the $\mathrm{CO}_{2}$ is allotted to the $\mathrm{CaO}$. shows a percentage of 0.08 of $\mathrm{C}_{2 l} \mathrm{CO}$ s (calcium carbonate), the presence of which is also indicated by the microscope. The stone takes a fine polish, but the size of the mica plates does not favor the durability of the polished face under continued exposure. The contrasts of color and shade are chiefly between the two feldspars and the black mica.

The quarry, opened before 1560 , measmed in 1905 about 500 feet from northeast to sonthwest and about the same distance from northwest to sontheast, and was 20 to 75 feet deep, averaging aboat 40 feet. The exacavation has not only cut down a granite hillock but has extended below the general land level. Plate XIV, $A$, shows the south-southeast end of the quarry.

Rock structure: The sheets, 1 to 20 feet thick-grenerally. however, from 2 to 10 feet-lie flat along an east-west axis for a wilth of abont 200 feet but on either sicle curve over gently to the north and somth, with dips of $5^{\circ}, 10^{\circ}$. and $20^{\circ}$. The joint and rein courses are shown in figure 59 . Joints (B) form the northwest and southeast walls of the quarry. Joints (C) are conted in places 
with crystalline calcite to the thickness of 0.25 inch, or with hematite, chlorite, and stibite in microscopic tims. (I retemination of stilbite by W. T. Schaller, of this Survey.) The rift is reltical, with a $X .80^{\circ}$ W. course. The "hard way" or "cut off" is N. $10^{\circ}$ I. Blocks 65 anil 120 feet long have been obtained by splitting along the rift. The thickness and curvature of the sheets, the intersecting joint face, and the channeling along the "cut ofi" are shown in Plate XIV, A. Dikes of grayish aplite, described on page 43 , are 1 to 7 inches thirk. There are some dark-gray knots (see p. 59) of more biotitic granite, up to 2 feet in length and 4 inches in wiath, and some of spheroidal form, with a diameter of $2 \frac{1}{2}$ feet. Sap is 4 inches thick on either side of joints (A), (B), (D), and also along the sheet surfaces. The unbewn weathered surface about the quarry passes into a granite sand, with little or no staining by limonite.

Transuortation, by railroad 500 feet to wharf, which admits schooners and barges of 1,500 gross tons ('apacity.

The product is used for docks, bridges, piers, buildings, and monuments. The thin sheets and much of the waste are made into paving blocks 12 by 4 by 7 to 8 inches. Plate XIX, $A$, shows how the granite of this quarry lends itself to coarse sculpture. Specimen structures made exclusively of Sands quarry granite: Post Office Department building, Washington; Masonic Temple, Philadelphia; savings bank, Wilmington, Del.; board of trade building, Chicago; nost office and customhouse, Brooklyn; General Wool monument, Troy, N. X. ; Manhattan Bank, New York. The Sands quarry and the Palmer quarry together furnished all the stone for the customhouse in New York.

The Palmer or Wharf quarry is in the town of Vinalliaven, on the west side, opposite Leadbetter Island. (See map, fig. 58.) Operator, Bodwell Granite Co., liockland. Idle in 1922.

The granite (specimen D, XXVI, 2, b) is a biotite granite of general pinkishbuff color and of coarse texture, the feldspar measuring up to $0.75 \mathrm{inch}$ and the biotite scales up to 0.2 inch. It is identical with that of the Sands quarry (p. 243), except that the potash feldspar is a little more pinkish buff and the white soda-lime feldspar is of a slightly greenish tinge. The general tone of the color is "warmer." The thin section shows rarely a little hormblende.

The quarry is on the west side of a ridge 100 feet high. It measured in 1905 ahout 500 feet square, with an arerage depth of 25 feet.

Rock structure: The sheets dip $10^{\circ} \mathrm{W}$. in the front (western) part of the quarry, but gradually turn at the back or working face to $10^{\circ} \mathrm{E}$. They are 4 to 15 feet thick. About 20 feet below the top of the quarry face is a bed of granite sand, 18 inches thick, parallel to the sheets, already referred to on page 70 . The principal joints, which strike N. $80^{\circ} \mathrm{W}$. and dip $80^{\circ}$ S., form a 5 foot heading at the south end of the quarry and recur but once or twice. The rlft is vertical, striking N. $10^{\circ}$ E. Owing to the structure here, it is usual to blast by lewis holes along the grain (east-west) and then to split by plug drilling along the rift; in this way thick sheets can be split along the grain a listance of 200 feet. One block loosened measured 300 feet along the grain by 120 feet along the rift and was 15 feet thick. Dikes of aplite are rare. $A$ knot from this quarry is described in detail on page 59. Sap is up to 6 inches thick along sheet and joint surfaces. It is intense in color at the surfaces.

Transportation, by rail 700 feet to wharf, where the blocks are taken on schnoners either to the cutting sheds at the Sands quarry or directly to market.

The product is used chiefly for bridges and buildings, and the waste is made into paving blocks. This quarry, in common with the Sands quarry, furnished the material for the New York customhouse. It supplied also eight columns, 51 to 54 feet long by 6 feet in diameter, for the Cathedral of St. John the 
Divine in New York. It was intended that they should each he of one piece, but as both the direction of the rift at the quarry and arehitectural principles required that they be cut with their long axes at right angles to the rift, the strain in the great latie came upon the weakest part of the stone. However, as the first stome put into the lathe broke with a long diagonal fracture, it became evident that the chief difficulty was that the stone had been subjected to too great a torsional strain by the application of rotary power from one end onls. It therefore became necessary to make each colmun of two sections, eacil ahout 20 foet long. Plate XIX, $B$, shows the lathe with the tirst filllength column in it and three others as originally prepared for it.

Among the structures made of this granite since $190 \pi$ are the Chicago \& Northwestern Ralilual station, Chicago; State Sivings Bank, Lansing, Micls, ; West Street Building (two stories polished), United States Realty Huilding, 115 Broadway, and 97 per cent of the main piers (above foundation) of Ilell Gate Bridge, New York.

The Webster quarry is in the town of Vinalhaven, on the north shore of "Pleasant River," at the end of Winter Harbor, in the northern fart of Vinalhaven Islane. (See fig. 58.) Operators in 1905, A. M. Webster \& Co., Vinalhaven. Quarry now abandoned.

The granite is a biotite granite identical with that of the I'almer quarry. described above.

Iock structure: The sheets. 5 to 10 feet thick, dip $10^{\circ}-15^{\circ} \mathrm{N} .30^{\circ}$ E. Vertieal joints strike N. $30^{\circ} \mathrm{W}$. and N. $60^{\circ} \mathrm{E}$. The rift is vertical, with N. $30^{\circ} \mathrm{W}$. conrse. There are some knots. A spherical one is 5 feet in diameter. Sap is 3-inches thick along sheets and joints.

Trinsportation, by a graded track 200 feet to wharf admitting schooners of 300 to 350 long tons. Plate XVIII, A, shows the quarry and a schooner laden with granite.

The product, shipped in the rough. was used for buildings in New York and Boston.

The Black (Pleasant River) quarry is in the town of Vinalhaven, on the south shore of Pleasant River, at the end of Winter Harbor, in the northern part of Vinalhaven Island. Operator, Joseph S. Black, Vinalhaven. Ille since 1912.

The granite is a biotite granite, identical with that of the Palmer quarry. descrihed on page 244 .

The quarry, opened in 1S96, measured in 1905300 feet in a $\mathrm{N}$. $40^{\circ} \mathrm{W}$. direction by 200 across with a working face 45 feet high.

Rock structure: The unworked surface ahove the quarry is very free from foints, knots, and veins. The sheets, 10 to 12 feet thick. are horizontal at the working face or back of the quarry but at the front dip $10^{\circ}-15^{\circ} \mathrm{W}$. Vertical joints strike N. $20^{\circ}$ E. The rift is vertical, with course N. $40^{\circ}$ W. Kuots are from 6 inches to 2 feet 6 inches in diameter.

Transportation, by a 350 -foot track, with a grade of 10 feet. to wharf.

The product is used for building, the waste for riprap. The quarry has furnished material for the dry dock at Portsmonth, N. H., and the Rain Island Lighthouse.

The Pequoit quarry is in the town of Vinalhaven, $1 \frac{2}{4}$ m:les east-northeast of Vinathaven village, on Vinalhaven Island. (See fig. 58.) Owner, Booth Bros. \& Hurricane Isle Granite Co., 208 Broadway, New York.

The zranite (specimeil D, XXVI, 7, a) is a biotite-hornblende granite of medium-gray shale and fine, even-grained texture, with porphyritic feldspar

- Mr. Webster built his own schooners and sailed them himself, laden with his own cranite, quarried by a partner. 
u1) to 0.25 inch in length. It consists, in descenling order of abundance, of a translucent whitish jotash fehspar (inthelase, with a very little microcline), smoky quatz, a whitish sodi-line feldspar (oigoclase), black mica (biotite), aml dark hormblemle, together with aressury magnetite, titanite, and apatite. The urthoclase is here and there intergrown with a plagioclase. The orthochase i.s in places altered to kitolin amb a white mica aud inclurles oceasionally some carbonate. The porphyritic crystals are orthoclase.

The quarry, npened in 1857, consisted in 190.5 of two openings, each about 250 firet siluare and about 10 feet deepl.

link structure: The sheets, 1 to 6 feet thick, dip $10^{\circ}-15^{\circ} \mathrm{N}$. $50^{\circ}$ W. Vertical joints strike $\mathrm{N}$. $80^{\circ}$ W. and $\mathrm{N} .5^{\circ}-10^{\circ}$ F. The rift is rertical, striking $\mathbf{N}$. $3^{\circ}-10^{\circ} \mathrm{L}$.

The product is carted one-third mile to the narrows and there shipped.

The product consists entirely of paving blecks an to 14 by 4 to 5 by 6 to 7 inchesis.

The Duschane Hill quarty is in the twwn of Yinathaven, $1 \frac{1}{4}$ miles east of Vinalhaten village, on Roherts Harbor. (sce fig. 58.) Operator, Roberts Harbor Granite Co., Vinaharen.

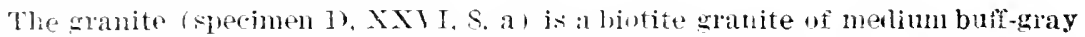
(")lor ani of fine to medium porphyritic texture, with most of the fellspar abont 0.2 incin lonf but some 0.33 or 0.5 inch lone. The rock consists, in descending orier of abuntance, of a hufï-glay fotach fehispar (orthoclase), smoky quart\%. a buti-nay soda-line feltspar (olignelase), and black mica (biotite), tognlmer with secondury dhlorite. The orthmlite is intergrowir with plagio-

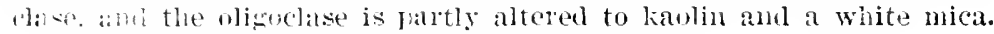

This stone is used entirely for paving blocks.

The Bodwell openings (hlack-granite) are in the town of Vinalluaren, in the diabace area west of sand Cove. Operator. Pondell Granite Co., Rocklanl. Lale in 7922 .

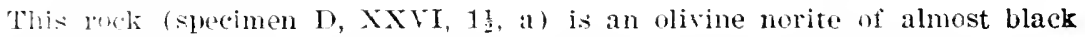
shatp ant of tine texture, consisting, in descending order of abundance, of in network of usually slenter erystals (from 1 ).37 to 1.63 nillineters in length) of mayish unaltered lime-sola fellswar labradorite to bytownite), filled whth hypersthe, greenish olivine, black nica (biotite), and nagnetite. It takes a rery tine polish aml cuts white. It is not obtainable in rery large blocks. This stome is referred to by Georwe I'. Merrill. ${ }^{\text {o }}$

The Incian Creek quary is on Indian Creek in the township of Vinalhaven, alkut h:alt a mile from Vinalharen village. (Ste tig. 5s.) Operators,

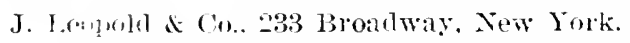

The ranite $\mathrm{i}: \mathrm{s}$ reported by lihe office of Public Roals, Department of Agriculture, as a light-gray biotite granite of melium grain, with a compressive strenth of 21,220 pounds to the siluate inch.

The unatry was opened in 1909.

The froduct is used entirely for curbing and paving.

The Armbrust quarry is in the town of Vinalinaen, between Carvers Harbor euth Indian Creek, south of Vinaharen village. Operator, Crown Hill Granile Vinks, Vinallaren.

The granite is a biotite granite similar to that oi the Sands quarry described on page $2-13$.

Thu inary cousists of numerous openings on sereral sides of a hillock 100 foet high. It has not been operated since 1907 .

-1 Tenth Census, vol, 10, p. 24. 
Rock structure: The sheets, 3 to 1.5 feet thick, are mainly horizontal but on the east side of the hill dip $10^{\circ} \mathrm{S}$. Vertical joints strike $\mathrm{N}$. $75^{\circ}-\mathrm{S} 0^{\circ} \mathrm{W}$. and N. $30^{\circ}-35^{\circ}$ E. There is no marked rift, but a rertical mass 4 feet thick, striking N. $65^{\circ} \mathrm{W}$. across the hill, has a horizontal rift and greatly facilitates quarrying, as it serves the purpose of a channel.

Transportation: The product was carted in 7 to 10 ton loars one-fourth to one-half mile to a wharf on Carrers Harbor.

The product consisted entirely of laving blocks.

The Hurricane Island quarry is in the town of Vinalhaven, in the southeastern part of Hurricane Island. (See nap, fig. 58.) Operator, IIurriane Isle Quarries Co., Rocklanil. Quarry abandoned.

The granite (specimen D, XXVI, 4, il) is a biotite granite of general pinkish. buft medinm-griy color and of conrse, even-grained texture, the reldspars measuring up to 0.75 inch and the biotite scales up to 0.2 inch. It is identical with that of the simuls quarry, desclibed on page 243. The potash feldspar is perhaps a trifle more pinkish butt than that of the Sands quarry but not quite so much so as that of the Palmer quary. These distinctions, however, are small and may not hold throughout the quarries, althomgh they characterize the typical slecimens selected for the writor hy ho superintendents of the respective quaries.

The following chemical analysis of crinite from Hurriane Islaml was made by Ricketts \& Banls, of New York, for the firm (No. 16073), and is inserted here for reference merely.

\section{Analysis of granite from Hurricane Istend.}

Silica $\left(\mathrm{SiO}_{2}\right)$

Alumina $\left(\mathrm{Al}_{2} \mathrm{O}\right.$ )

Ferrous oxide $(\mathrm{FeO})$

Lime $(\mathrm{CaO})$

Magnesia ( $\mathrm{MgO})$

Manganese oxide ( $\mathrm{InO}$ )

Soda $\left(\mathrm{Na}_{2} \mathrm{O}\right)$

Potash ( $\left.\mathrm{K}_{2} \mathrm{O}\right)$

Sulphur (S) total

Carbon dioxide $\left(\mathrm{CO}_{2}\right)$

Ioss and undetermined
70. 94

15. $6 \mathrm{~S}$

2. 29

1. 23

.19

.13

3.59

5.54

.05 None.

.37

100. 00

A compression test made by Prof. Ira H. Woolson, of the Columbia School of Mines, ${ }^{82}$ showed an ultimate crushing strength of 19,583 pounds to the square inch.

The quarly. opened about 1576 , measured in 1905500 feet along the rift ( $N$. $85^{\circ} \mathrm{W}$.) and had an average width of 150 feet. It lies on the south side of a ridge 100 feet high with a west-northwest axis. The greatest depth of working face was 105 feet and its average about 50 feet.

Rock structure: The sheets, 3 to 20 feet thick, curve over on both the north and the south side of the ridge, with a dip of not less than $10^{\circ}$. Seen from the western spur of the island, two 20-foot sheets form the upper part of the hill; beneath these. however, is a much thicker sheet, which at the east-southeast end of the hill and quarry measures fully 60 feet-too thick for economic work-

02 Day. W. C., U. S. Geol. Survey Twentieth Ann. Rept., pt. 6, continued, p. 391,1890 (test No. 1709). 
ing. These sheets are shown in Plate XII, $A$, as seen looking northwest. This abnormally thick sheet is referred to by Merrill. ${ }^{\text {b3 }}$ The sheets are traversed by three sets of joints, as shown in figure 60. (A) dips $50^{\circ}-55^{\circ} \mathrm{W}$.; (B) is vertical ; and $(\mathrm{C})$, which is diagonal to $(\mathrm{A})$ and $(\mathrm{B})$, dips $40^{\circ} \mathrm{NE}$. The rift is vertical, with N. $85^{\circ}$ E. course. The east-west system (B), which is parallel to the rift, reappeurs on Heron Neck. as shown in Plate X, A. (B) and (C) are both shown on Plate XII, A. The (B) surfaces are, in places, coated with epidote. Occasional knots occur.

Transportation, by track 100 feet to dock.

The product is used for buildings and monuments. The waste goes into paving blocks. Specimen buildings: Suffolk County courthouse, Boston; St. Louis post office and custombouse; two buildings for the Naval Academy at Annapolis. MI.

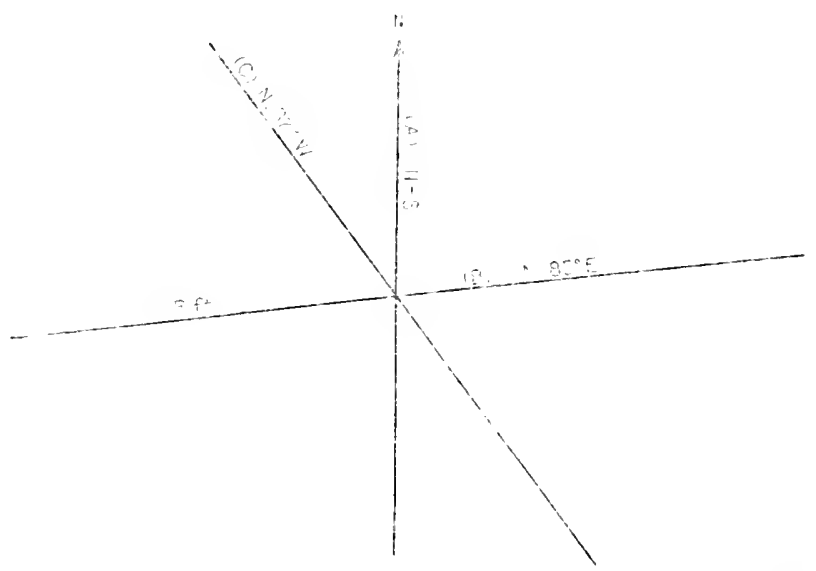

Figure 60.--Structure at Hurricane Island quarry, Knox County, Maine.

\section{LINCOLN COUNTY.}

BRISTOL.

The Round Pond quarry ("black granite") is in the town of Bristol, onefourth mile east of Round Pond village, and west of Muscongus Island. Operators, Peter Svensen \& Co., Round Pond. Quarry jule in 1916.

The rock (specimens D, XXYII, 126 a, $126 \mathrm{~b}$ ) is a quartz diorite of very darkgray and medium-gray shades and of fine, even-grained texture, with feldspars up to $0.2 \mathrm{inch}$. The darker variety consists, in descending order of abundance, of bluish-white soda-lime feldspar (oligoclase-andesine), clear quartz, black mica (biotite), potash feldspar (orthoclase and microcline), and magnetite, together with accessory titanite, zircon, and apatite and secondary calcite. The lighter variety consists of the same minerals, but with less biotite, so that it changes place with the potash feldspar in order of abundance. Both varieties take a fine polish and offer a very marked contrast between the polished and cut or hammered surface. Granite of the same shade affords no such contrast.

The quarry, opened in 1885, consists of two adjacent openings along a northwest-southeast line. The upper, or northwestern one, was in 1905100 feet square; the lower, 400 feet northwest-southeast by 100 feet across, but with a central

Smithsonian Inst. Ann. Rept., 1889, pt. 2, p. 415. 
part 37 feet wide on each side-that is, 175 feet wide. These openings ranged in depth from 10 to 65 feet.

Rock structure: Considerable scientific interest attaches to the geologic relations at this quarry, as maly be seen by the references to them on pages 48,52 . This quarry has been described by J. E. Wolff. ${ }^{24}$ The diorite underlies a mass of schist which strikes N. $15^{\circ}$ E. and is traversed by dikes and lenses of coarse pegmatite. It also includes a tongue of this schist ancl is traversed by dikes of pegmatite, aud itself in turn is traversed, as is also its negmatite, by a diabase dike. (See Pl. VIII, $B$ ). Thus the schists are older than the diorite, and the dike is later than the diorite and its pegmitite. The joint and dike courses are shown in figure 61 . The sheets, 1 to 12 feet thick, dip $10^{\circ} \mathrm{S}$. and also $10^{\circ}$ E. and are traversed by joints (A), which recur at intervals of 5 to 42 feet, and $(B)$, which recur but once or twice. There are barl headings on the northeast side of the quarry. The pegnatite dikes send out small branches. Sap. only 1 inch thick, occurs along the sheets. Knots up to 6 hy 2 inches are

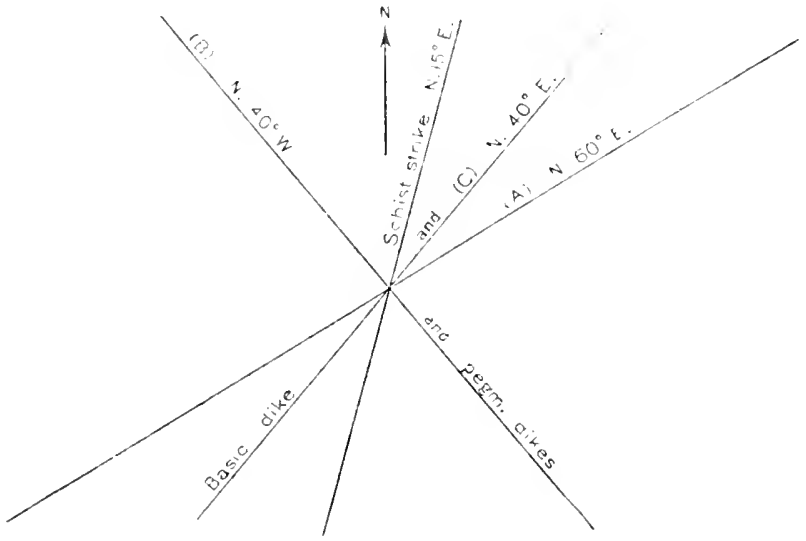

Figure 61.-Structure at Round Pond diorite quarry, Bristol, Maine.

rare. The general result of this complex structure is that it is difficult to obtain many large blocks.

Transportation, by cart about 300 feet from lower quarry and 800 to 1,000 feet from upper one to wharf in Muscongus Bay.

The product is used mostly for small monuments, which are shipped to New York without the lettering. (See Pl. XXII, $A$ ). The waste goes into paving blocks. Specimen monuments: Die of Maine monument at Andersonville, Ga. : base and die of General Sheridan monument in National Cemetery at Arlington, Va.

\section{WALDOBORO.}

The Waldoboro quarry is in the town of Waldoboro, $1 \frac{1}{2}$ miles north of Waldoboro village, on the Boston \& Maine Railroad. Operator, Booth Bros. \& Hurricane Isle Granite Co., 208 Broadway, New York. Quarry abandoned.

The granite (specimen D, XXVII, 109, a) is a muscovite-biotite granite of medium-gray sliade (a trifle darker than "Hallowell granite" and still darker than "North Jay granite") and of fine, inclining to mediull, even-grained texture, some of the feldspars measuring up to $0.25 \mathrm{inch}$, but the particles generally ranging from 0.36 to 2.56 millimeters in diameter. It consists, in

of Detals of Malne granito quarries: Teuth Census, vol. 10, p. 121, 1888. 
descending order of abundance, of a whitish translucent potash feldspar (orthoclase and microcline), smoky quart\%, whitish soda-lime feldspar (oligoclase), white mica (muscovite), and black mica (biotite), with accessory carnet. Many of the feldspars are intergrown with quartz in particles circular in cross section. Some of the mica plates are bent, indicating slight (secendary) motion. E. C. Sullivan. of this Survey, finds that this granite contains 0.045 per cent of $\mathrm{CO}_{2}$ (carbon dioxide) corresponding to a content of 0.10 per cent of $\mathrm{CaCO}_{3}$ (calcinm carbonate), ank that warm ailute acetic acid extracts from it 0.11 per cent of CaO (linre). This granite contains sporadic particles or crystals, up to 0.25 or even 0.5 inch in dianeter of a milk-white mineral, which weathers readily, becoming yellowish and powdery, and finally leaves calvities. Feorge P. Merrill, head curator of geology at the United States National Mnseum, finds it to be a feldspar lying between albite and oligoclasethat is, containing between 6 and 11 per cent of soda, therefore a little more soda than the sola-lime feldspar of the granite itself, which is 5 to 5.5 per cent-and says that the powdery material is rery near kaglin. But he does not regard his results as perfectly satisfactory, nor does he understand why such it feldspar should weather so readily. The slightly higher perentage of soda indicated does not seem to him an adequate cause for the weathering, although minerals rich in soda weather with comparative facility. Workmen report that when first decomposing this mineral protrudes beyont the granite surface.

The following analysis of the cranite was male ly ricketts \& Banks, of New York, for the firm (No, 16074), and is given merely for reference:

\section{Analysis of granite from Waldoboro quarry.}

Silica $\left(\mathrm{SiO}_{2}\right)$

Aluminal $\left(\mathrm{Al}_{2} \mathrm{O}_{3}\right)$

Ferrous oxile (FeO)

Lime ( $\mathrm{CaO})$

Magnesia $(\mathrm{MgO})$

Manganese oxide (MnO)

Soda $\left(\mathrm{Na}_{2} \mathrm{O}\right)$

Potash $\left(\mathrm{K}_{2} \mathrm{O}\right)$

Sulphur (S) total.

Carbon dioxide $\left(\mathrm{CO}_{2}\right)$
7.) 48

15. 26

1. 42

.88

.09

.10

3. 12

5. 60

Trace.

None.

100.01

A test (No. 1714) of compressive strength of "Waldoboro grinite" made by Prof. Ira H. Woolson, of the Columbia University School of Mines, ${ }^{05}$ shows a crushing strength of 23,111 pounds to the square inch.

The quarry, opened in 1860 , measured in 1905400 feet $\mathrm{X} .52^{\circ}$ E. to $\mathrm{S} .52^{\circ} \mathrm{W}$, by 140 feet across, and was 60 to 85 feet deep.

Irock structure: The geolog:c relations at this quarry are of no littie interest, as will be seen by the references to it on pages $4 S$ and 91 . The granite is in contact with the schist mass, which originally covered it and which at all the other Maine quarries, except those at Freeport and Round Pond, has been remored. On the northeast side of the quarry a mass of schist striking $\mathbf{N}$. $72^{\bullet}$ W. and dipping $45^{\circ}$ N. $28^{\circ}$ E. and also $90^{\circ}$ overlies the granite which sends small dikes into it. The contact between the two rocks as it appears at the east corner of the quarry is shown in Plate XVII, A. At the southwest end of the quarry two schist masses are partly included in the granite, and a large peg-

${ }^{20}$ Day, W. C., U. S. Geol. Survey Twentieth Ann. Rept., pt. 6, continued, p. 391, 1899. 
matie mass intervenes, as is shown ronghly in finure 16 . The sheets, 1 to 7 feet thick, lie mainly horizontal lut dip $\sigma^{3} W$. in the upper part of the quarry. The joint and dike courses are shown in tigure $6 i_{2}$. Joints (A) dip $60^{\circ}$ SE. and form both longitudinal wills of the quarry, a luading on the northwest side, and recur at intervals of 40 feet. Joints (I) (lip) $85^{\circ} \mathrm{N}$. and recur at intervals of 100 feet. The rift is horizontal and the grain vertical, with strike N. $60^{\circ} \mathrm{W}$. legmatite dike (a) is $5 \frac{1}{2}$ incines thick; dike $(b)$ is 12 inches thirk. Sall is contined to the mper sheets. Knots are very exceptional.

That the granite is under compressiv strain is shown by the closing un of the chamnels when the cores are taken out, am also by suontameous north to south fissuring.

Transportation. by art 1,800 fiet (and 129) feet down) from quarry to mill, thence by cars 19 miles to whart at Rockland. The distance from the quary to tidewater at Walloboro is only $1 \frac{1}{2}$ miles, but the water there is only 11 feet deep at high tide.

The product is used for liuildings and monuments but not for polisber work. The small sheets anl waste are used for paving and roarl ballast.

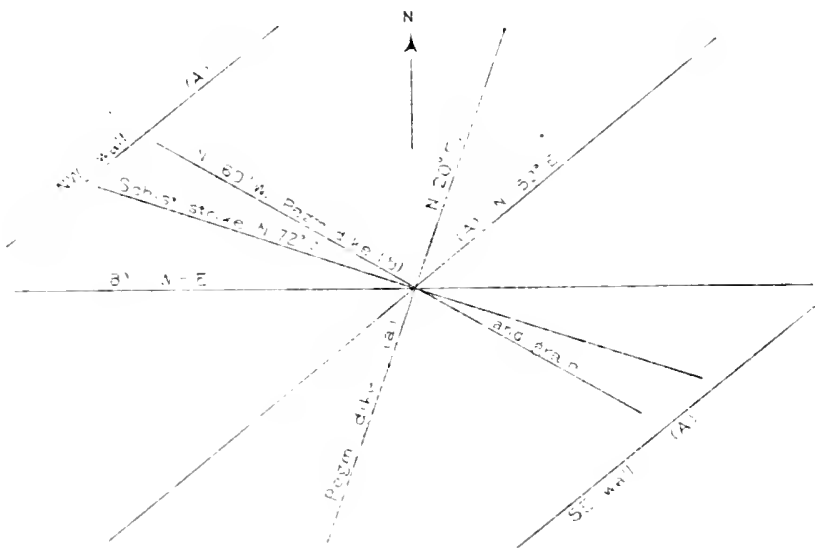

Fictes: 6z-Creneral strueture at Waldoboro quarry, Waldoboro, Maine.

Ahont 250.000 paring blocks were shipped ammally, mostly to Philadelphia. Specimen builelings: 13uffalo sarings Bank; Armory, boat house, and cadets' quarters at Inited States Naral Academy, Annapolis, Mr.; Crockett monument at Acorn Ceuctery, Rockland, Iaine: Chemical National Bank, "platfurms" for silewalk arumd schwab Buileling, and liverside Drive. New York.

This quarry was not operated in 1916.

\section{WHITEFIELD.}

Jewett's quarry ("black granite") is in the town of Whitefield, $1 \frac{1}{2}$ miles southeast of Whitefield village (Kings Mills). Quarry abandoned.

The rock (specimen D, XXVII, 113, a) is a quartz diorite of very dark aray shite with a bluish tinge, and of fine to medinm, even-grained texture and flow structure, with feldspars up to 0.25 inch in cliameter. It consists, in descendIng order of abundance, of bluish milk-white soda-lime feldspar (oligoclaseunlesine), black hornblende, quartz in amount almost if not quite equal to that of the hornblende, black mica (biotite), and accessory magnetite, titanite, zircon, apatite, and secondary epidote. The stone takes a fair polish. 
The quarry, opened in 1885 for monumental work, consists of two adjacent openings, one 50 by 25 feet, the other 60 by 30 feet. In 1905 these were 6 alid 8 leet decu, respectively.

liwck structure: The sheets, 3 to 8 feet thick, dip $25^{\circ}-30^{\circ} \mathrm{NE}$. Vertical or steep joints strike $\mathrm{N} .10^{\circ} \mathrm{W}$. and $\mathrm{N}, 42^{\circ} \mathrm{W}$. The rift is vertical, with $\mathrm{N}$. $10^{\circ} \mathrm{W}$. course, and the grain is parallel to the sineets. The sap is 3 inches thick along the joints. There is one aplite dike up to 4 inches thick. Biotite knots occur occasionally.

The quary is worked only at intervals, and the stone is used for monuments locally.

\section{OXFORD COUNTY.}

\section{FRYEBURG.}

The Eagle Gray quarry is in the town of Fryeburs, at hie northeast foot of Starks Hill, ahout $1 \frac{1}{4}$ miles south of Fryeburg village. Operator, Eagle Gray Granite Co., Fryeburg.

The grinite (specimen D, XXVII, 124, a) is a muscovite-biotite granite of medium-gray shade and of general medium, even-grained texture, with feldspar

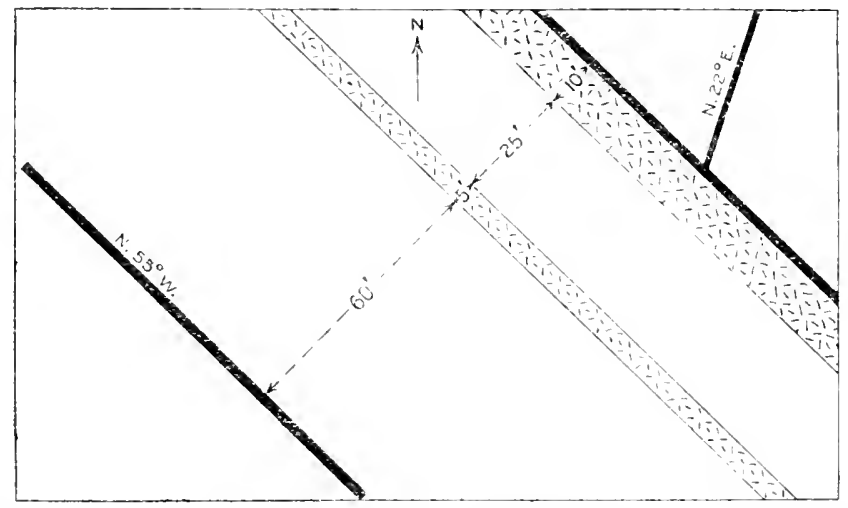

Figure 63.- Structure at Eagle Gray quarry, Fryeburg, Maine. The black bands are basic dikes, and those with a pattern are pegmatite.

0.25 inch in length and mica up to 0.2 inch. It consists, in descending order of abundance, of slightly cream-colored potash feldspar (orthoclase), smoky quartz, slightly cleam-colored sola-lime foldspar (oligoclase), white mica (muscovite), and black mica (bintite), together with accessory garnet and zircon. The contrasts are chiefly between the cream-colored feldspar and the smoky quartz and the brilliant muscovite plates. The large size of the mica plates is unfavorable to the duribility of its polisl under outdoor exposure.

The quarry, openci in 1903, was in 1905 about 150 feet square by 3 to 12 feet deep.

Rock structure: The sheets, 1 to 10 feet thick and becoming thicker southwestward, dip less than $10^{\circ} \mathrm{NE}$. There are no joints, but there are sereral pegmatite and diabase or basalt dikes, already referred to on page 52 and shown in figure 63. These generally have a northwest-southeast course. The pegmatite is very coarse, affording incomplete crystals of orthoclase 1 foot long and biotite crystals 3 inches long. Mingled with the pegmatite are irregular bands of whitish garnetiferous aplife. The absence of joints and the 
abundance of dikes are the chief obstacles here. The rift is horizontal and marked, but there is no grain. Salp, 0.5 inch thick, is confined to the top sheet.

Transportation, by cart two-fifths mile to Maine Central Railroad.

The proluet is used for buildings and for bases to monuments. Specimen builling: Granite part of the public library at Conway, N. H.

The guary was not operated in 1916.

OXFORD.

The Roy quarry is in the town of Oxforl, thres-fourths mile from oxiord viliage. Idle since 1906.

The granite (suecimen D, XXVII, 121, a) is a musevite-bietite grante of medimu cream-gray color and of medium, inclining to coarse, even-grained texture, with feldspars up to $0.4 \mathrm{inch}$ in diameter. It consists, in apploximate descending order of abundance, of a cream-colored potash feldspar (orthoclase and microcline), smoky quartz, cream-colored soda-lime feldspar (oligoclase), white mica (muscovite), and black mica (bintite), together with accessory npatite. Some of the joint plines are coater with coarse thons muserite in parallel arrangement.

Th:s quary, opened in 1898 , covers about 5 acres and has a working face 40 fect deep. It is worked only occasionally. The product is used for rough foundations and trimmings. The trimmings on the Catholic Church at Berlin, Maine, and the McGillicuddy Block at Lewiston are of this granite.

\section{WOODSTOCK.}

The Bryant Pond quarry is in the town of Woodstock, half a mile south of Bryant Pond station, on the east side of the Grand Trunk Railway. Operator, Grand Trunk Railway; address, Master of Bridges and Buildings, Grand 'irunk Railway, Montreal, Canada.

The rock (slecimen D, XXVII, 122, a) is a quartz diorite with conspicuous black particles on a bluish-white rather than a yellow-white ground, and of medium even-grained texture and flow structure, with feldspars and black minerals up to 0.3 inch in diameter (rarely 0.4). It consists, in descending order of abundance, of white translucent soda-lime feldspar (oligoclase to oligoclase-andesine). clear quartz, black mica (biotite), and b!ack hornblende, together with accessory garnet, titanite, zircon, apatite, and a little secondary epidote. Some of the feldspars are partly altered to a white mica, and some have borders radially intergrown with quartz." The clearness of the quartz and the translucent whiteness of the feldspar result in the apparent merging of the two minerals, and as the biotite and hornblende are both black the only contrast in the rock is that between black and white. There is a marked contrast between the hammered and rough surfaces, attributable to the presence of soda-lime felclspar alone. (See p. 79.) The flow structure, where marked gives the rock a gneissoid aspect.

The quarry, opened about 1864 , is $\mathbf{1 5 0}$ feet from north to south by 250 feet from east to west and from 10 to 50 feet deep. It is on the west side of a north-south ridge.

Rock structure: There is a marked flow structure, in some places horizontal and parallel to the rift but in others very irregular. The sheets, 1 to 6 feet

"Michel Lévy's "structure rermiculée." See Carte géol. France Bull. 36, vol. 5, pp. 27-28, fig. 5, 1894. 
thick, are horizontal or slightly nudulating on the quarry face, but at the west side dip $20^{\circ}-30^{\circ} \mathrm{W}$. They increase in thickness downward and at the bottom of the quarry appear to run out " "grow on "), making quarrying in that direction increasingly difleuit. A vertical joint, striking $\mathrm{N} .35^{\circ} \mathrm{L}$.. is coated with crystalline calcite and elidote. The rock alincent to it for an inch or two contains much prite and also chlorite. probably derived from the alteration of hornblende. The rift is horizontal. and the grain is vertical north-south, but disappears on the west sille. Vertical basalt or diabase dikes, witi northeasterly courses, form the north ant sonth walls of the quarry 4 feet and 22 inches thick, respectively. A 5 -incle dike oreurs 25 feet north of the south wall. A thin section of a half-inch brandilet from this dike is described on page .2. Sap is confined to the milper sheets. There are some knots.

The product is used cutirely for lindeses and stations on the Grand Trunk Railway. Specimen buildings: Vestibule, first story, and trimmings of station at Portland. Maine; station at Battle Creek. Mich.

\section{PEXOBSCUT COCNTY.}

\section{HERMON.}

The Hermon Fill quary ("black granite") is "m Hermon IIill, $5 \frac{1}{2}$ miles northwest of Bangor. Owner, Dr. II. F. Hanson, Bangor.

This black grante (specimen D. XXVI. 100, c) is an altered diabase porphyry of dark-green color and fine trine. with norphritic crystals of black hornblende up to 0.75 inch in diameter. The rock consists, in descending order of ahmilance, of hornblende. cilcite, a much altered feldspar (plagioclase), and magnetite. together with secondary actinnite, fibous serpentine, and chlorite. It contains sufhcient caleite (calein carbonate) to make it effervesce with cold dilute hydrochlorite acid. It talies a very tine polish and cuts very light. but the presence of the calcite exposes it to attack by the carbonic acid of the atmosphere. It is therefore more sultable fur indon work. Ora W. Knight," State assayer of Maine, reports that it contains a very small anount of platinum which is very irregularly and unevenly distributed.

Rock structure: The outcrop is about 200 feet from northeast to southwest by 40 to 50 feet across and occurs in a chioritic quartzose shale striking $\mathrm{X}$. $45^{\circ} \mathrm{F}$. In places, however, there intervenes a granite porphyry containing crystils of orthoclase largely altered to muscovite. chlorite, and biotite. The sheets, from 6 incles to 6 feet thick, dip $30^{\circ} \mathrm{S} .60^{\circ} \mathrm{E}$. Vertical joints strike $\mathrm{N}$. $60^{\circ} \mathrm{W}$., furming a healing on the northeast, and recur at 20 -foot intervals, also striking N. $20^{\circ} \mathrm{W}$. and spaced from $2 \frac{1}{2}$ to 8 feet. Both show marks of slippage. There is also a diagonal set striking N. $45^{\circ} \mathrm{W}$. and dipping $45^{\circ} \mathrm{SW}$, recurring irregularly. The rift seems to be parallel to the sleets. Sap occurs along the joints. There are quartz veins parallel to the sheets and rift.

Transportation, by cart 1 mile to Maine Northern Seaport Railroad or $5 \frac{1}{2}$ miles to Bangor.

The quarry is worked only occasionally.

The product is used for dies, memorial tablets. and wainscoting. Specimen monmments: Die on soldier's' monument at Hermon; about 20 dies in Nount Hope and in Mount Pleasant cemeteries at Bangor; dies at cemetery at Springtield; cornerstone of Catholic Church at Orono; keystone, ete., at Lord Hall, University of Maine. 
PISCATAQUIS COUNTY.

GUILFORD.

The Queen City quarry is $3 \frac{1}{2}$ miles from Foxcroft, in Guilford Township. Last orelator, Queen City Granite Co., 13angor. Quary idle in 1918.

The granite (specimen D, XVII, 107, a) is a biotite-muscovite granite of light-gray shade and melium to coarse, even-grained texture, with feldspars up to 0.5 inch in dianneter and biotite scales up to 0.15 inch. It consists, in descending order of abundance, of very slightly bluish-white potash feldspar (nicro(line), smoky quartz, a whitish soda-lime feldspar (oligoclase), black mica (biotite), and much less white mica (muscovite), together with accessory magnetite. The oligoclase is partly altercd to a white mica. As the feldspars are of similar color and the muscovite is present in small amount the contrasts are between the feldspar, smoky quartz, and biotite, and they are marked.

The quarry measured in 1905100 by 50 feet, with a maximum depth of 70 feet, averaging about 35 .

The stone was used for building. The trimmings of a brick building erected in 1899 for the Bangor Theological Seminary and those of the Stetson Block at Bangor are made of it.

The Brawn quarry is 1 mile distant from the Queen City, in the same township. Operator, H. A. Brown, Foxeroft. The granite resembles that of the Queen City quarry. guarry temporarily idle in 1918.

\section{SOMERSET COUNTY.}

\section{hartiand.}

The Hartland quarry is in the town of Hartland, near Hartland village, on the Sebasticook \& Moosehead Railroad. The quarry, prior to 1905, had been operated by Joseph H. Baker. l'roperty reported as owned by the Linn estate.

The rock (specimen D, XXVII, 141, a, collected by Dr. George Otis Smith), is a quartz diorite with conspicuous black particles on a more bluish than yellowish-white ground, of medium to coarse, even-grained texture with flow stricture. It consists, in descending order of abundance, of a translucent milk-white soda-lime feldspar (oligoclase), very slightly smoky quartz, black mica (biotite), black hornblende, and accessory titanite and magnetite. Some of the feldspars are cloudy from incipient alteration.

\section{NORRIDGEWOCK.}

The Dodlin quarry is in the town of Norridgewock, on the northeast side of Dodlin Hill, $2 \frac{1}{2}$ miles south of Norridgewock village, and has a northnortheasterly axis and a height of 350 feet above the general level and of 650 feet above the sea. Although this quarry is now disused, it is described becanse of its geologic interest.

The rock (specimens D. XXYII, 116, a, 116, b) is a quartz monzonite of two shades. Specimen 116, a, is a general medium gray with conspicuous black particles on a white ground; and specimen 116, b, is a general light gray with much finer black particles on a ground of mixcl white and gray. Both rocks have a like texture, medinm inclining to fine, with porplyyritic crystals of white feldspar up to 0.5 inch. In the darker rock $(116$, a) the biotite scales measure up to 0.1 inch; in the lighter rock they rarely attain 0.05 inch. Both varieties consist, in lescending order of abundance, of a slightly bluisl milk-white soda feldspar (oligoclase) and, in equal or sighitly less amount, a 
whitish potash feldspar (microeline); qua!tz, almost clear in the darker rock $(116, a)$ and light smoky in the lighter one $(116, b)$; and black mica (biotite) (considerable in 116, a, but much less in $116, \mathrm{~b}$ ), with accessory magnetite, titanite, zircon, and lyrite, a: secondary epdote and white micas. Some of the feldspars are radially intergrown with quartz.

The quarry, opened about 1855, measured in 1905400 feet from north-northwest to south-southeast by 250 feet across, with an average depth of 30 feet.

Rock structure: There is a vertical northeast-southwest flow structure indicated by the dividing line between the rark and light granite (shown in fig. 64), and also in the light and dark banding of some of the lower sheets. The sheets, 2 inches to 16 feet thick, dip about $5^{\circ} \mathrm{E}$. In the southern part of the quarry they are up to 2 feet thick, but in the northern part 2 to 16 feet. The joints are parallel to the $110 \mathrm{w}$ and spaced 200 fert. From the relation of the thickness of the sheets to the joint spaces, both in this quarry and in two adjacent openings, it apnears that in piaces thin sheets, in others thick sheets, continue downward in alternating vertical zones, and that thin sheets are also likely to occur on both sides of the vertical joints for a few feet. These exceptional relations are probally the to vertical faulting. A small borizontal

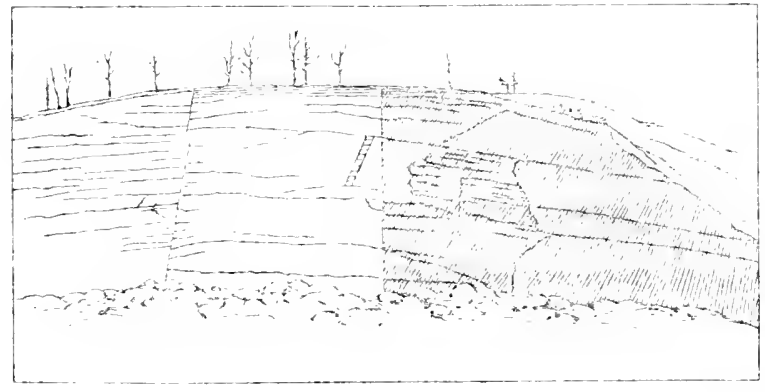

Frgure 64.-Diagrammatic sketch showing junction of light and medlum-gray granites (quartz monzonites) and the lateral change in thickness of sheets at the Dodlin quarrs, near Norridgewock, Maine. displacement in a vertical flowage band is evidently due to faulting at right angles to the other. The rift is horizontal, at right angles to the flow. The grain is vertical and parallel to flow and jo:nting. "Shake" strueture occurs along the sheets near headings. (See p. 39.)

The product nas used mainly for buildings. Specimens: Post office, Muskegon, Mich.; Merrill Library, Norwood, Mass.; Cathol 'c Church, Lewiston, Maine; courthouse, Bangor, Maine; insane asylum (annex), Augusta, Miaine.

The Lawton quarry is in the town of Norridgewock, on the northwest side of Dodlin Hill, $2 \frac{1}{2}$ miles sonth-southwest of Norridgewock. Operator, F. S. Lawton, Norridgewock. Idle since 1917.

The rock is a quartz monzonite of medium-grily and light-gray shade and medium and porphyritic texture, identieal with that of the Dodlin quarry.

The quarry, opened before 1845 , consisted in 1905 of two openings measuring 200 by 100 and 300 by 200 feet and 5 to 10 feet deep.

Rock structure: The same flow strueture occurs as at the Dodlin quarry, on the other side of the hill. The sheets, up to 5 feet th:ck, average 3 to 4 feet and roll over the hill with a dip of $10^{\circ}$ both north and south. Between some of the ordinary sheets there are unusual ones, 0.5 inch thick, which in large slabs are flexible. Whether this was in part due to incipient disintegration was not determined. The lentieular form of the sheets gives them the appearance of being very irregular in thickness. Vertical joints, strike $\mathrm{N}$. $60^{\circ}-65^{\circ}$ E., recur at intervals of 10 to 50 feet. The rift is horizontal, and the 


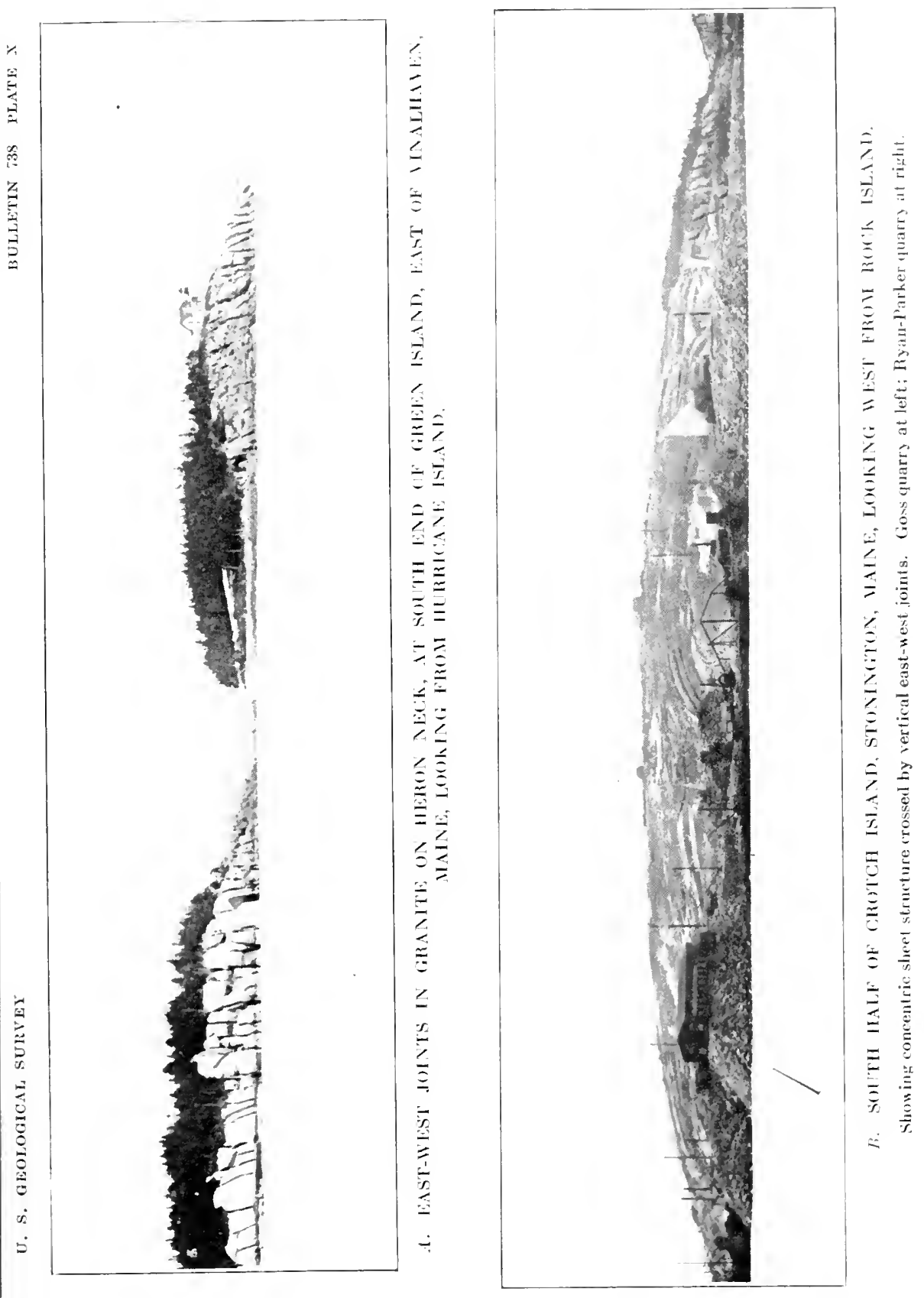




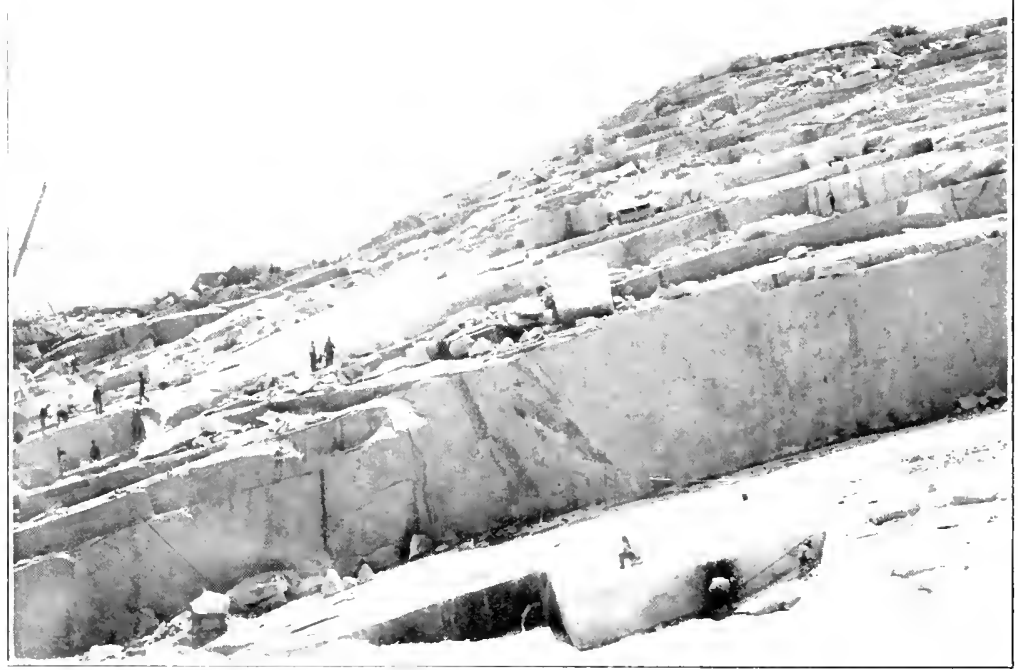

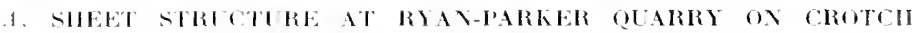
ISLA \I, IIE IE, I,WKING SUTIIWEST.

The lower sheet in 25 feret thick and is split along the: rift.

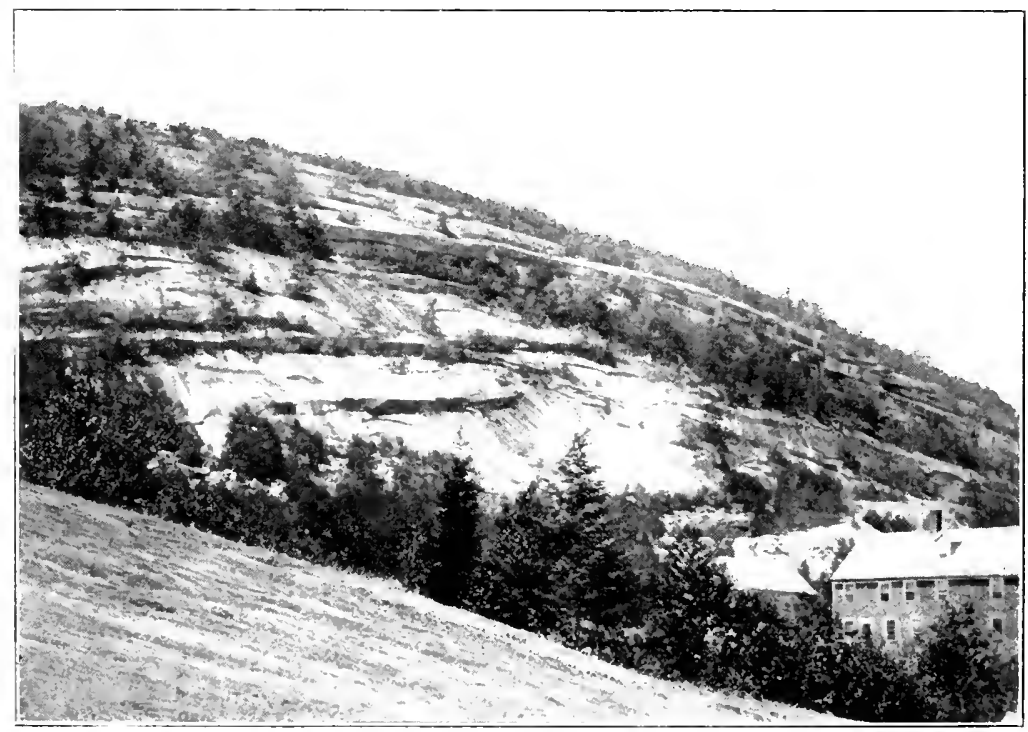

B. EAST SIDE OF WOSUITO WOINTAIN, FRANGFORT, WAINE, IOOKING NORTHWEST.

Shon iny sh+et and dom" structure, also trosion of slerets. 


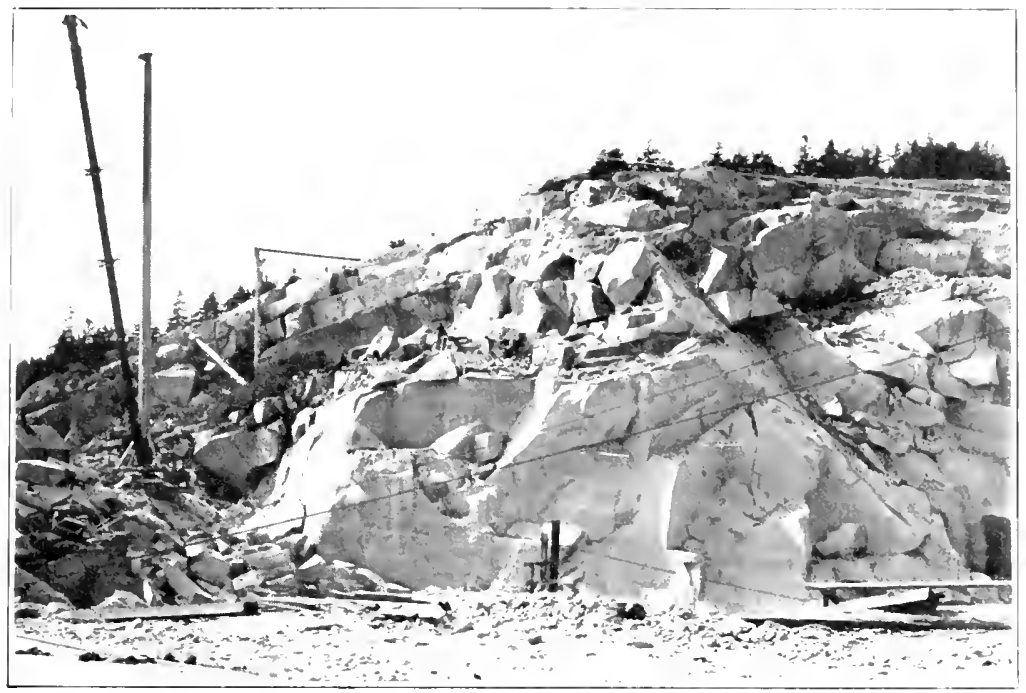

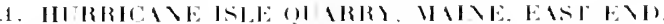

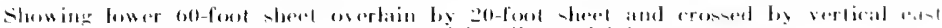
wave joint and bi diazonal joint.

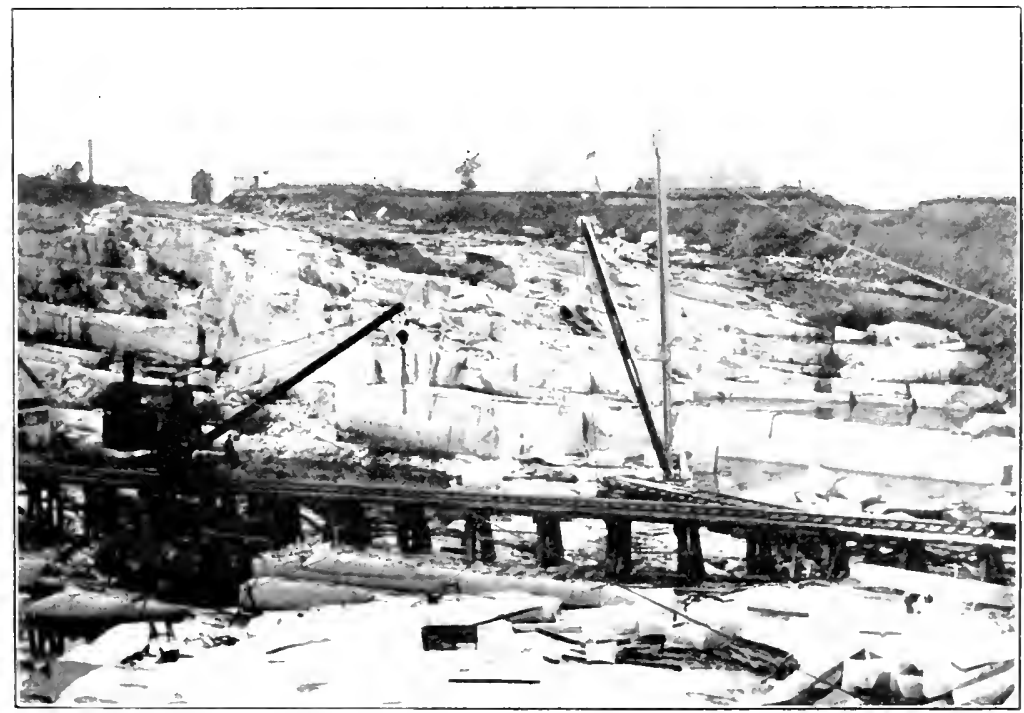

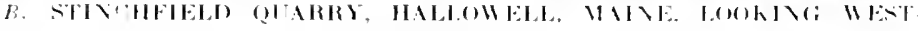
VORTIII FET.
}

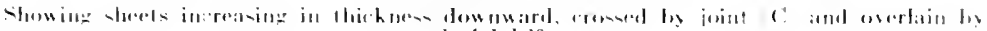
elaceial trifl. 


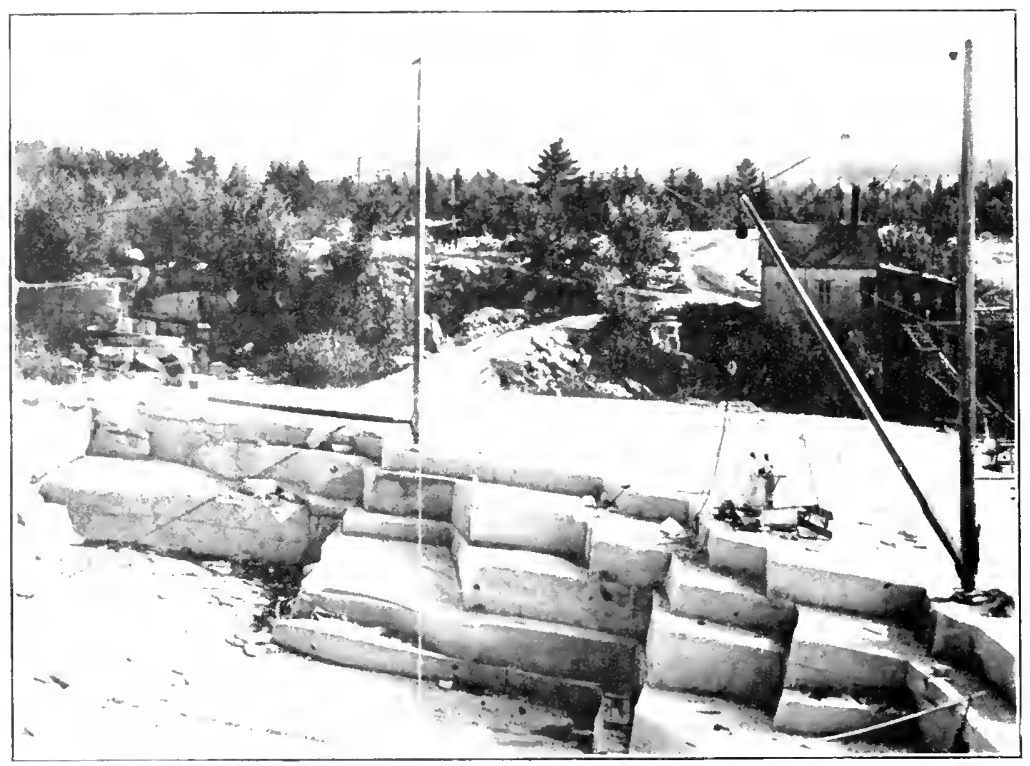

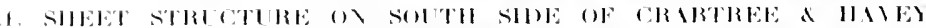

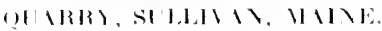

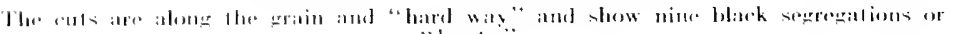
"hnibli."

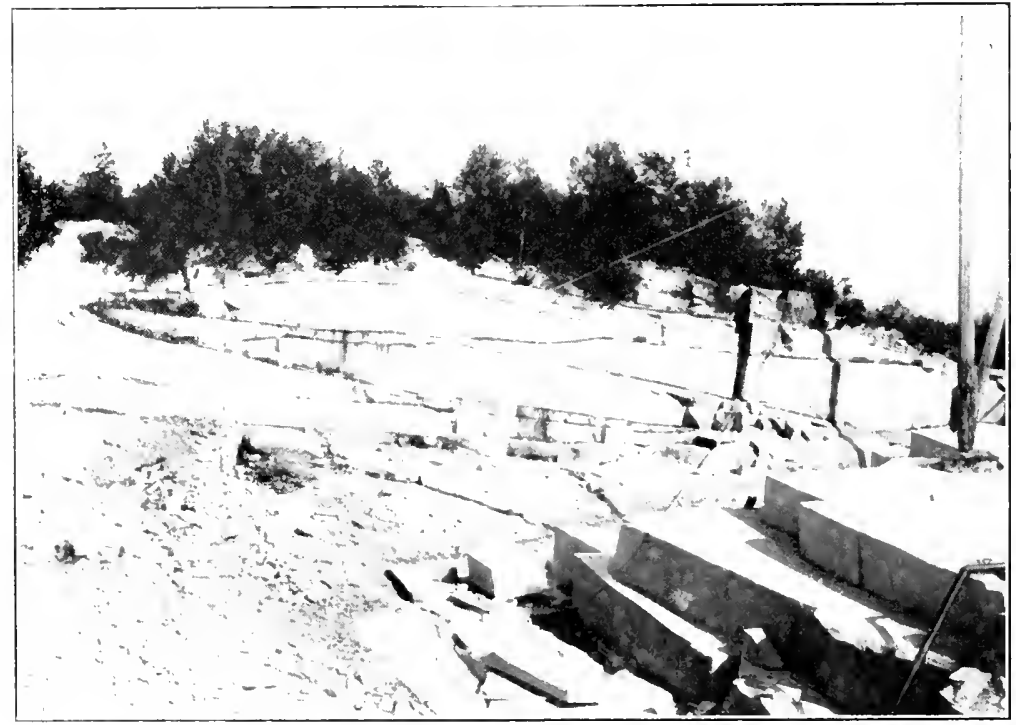

R. EAST WALL, OF CRARTREE \& IIVEY QUARRY, SHOWING LENTICULAR FOHW OH SIJEETS IN I ERTICAL CROSS SECTION ON A JOINT FACE.

The lorm of these sheets accomnts lor the irremlarity of thickness shown in $A$. 


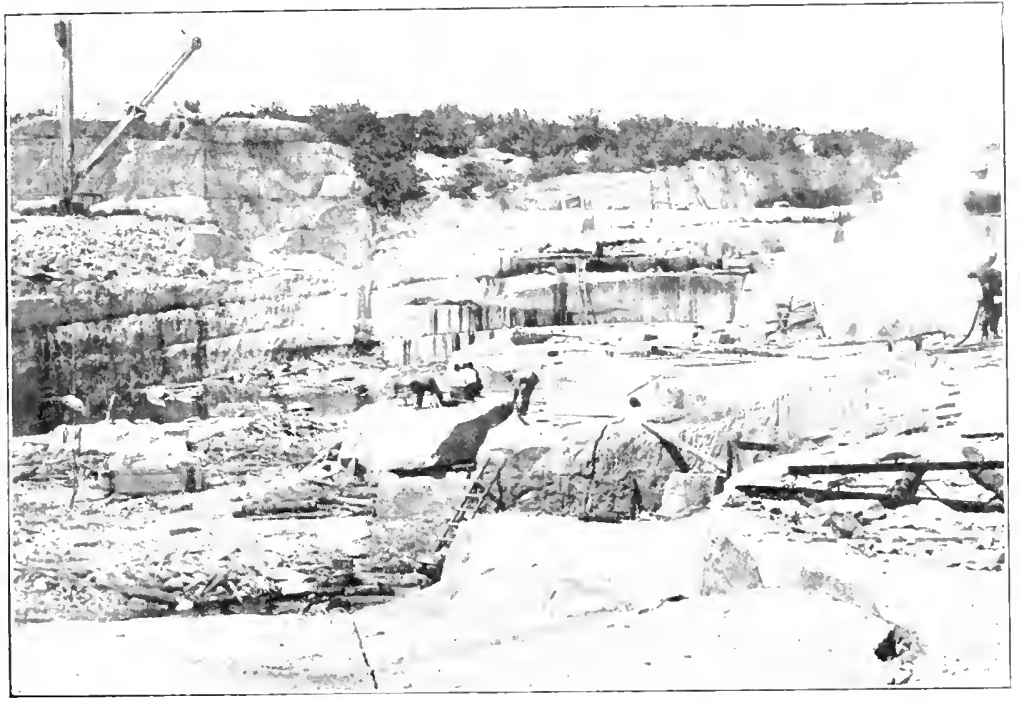

A. SANDS QUARRY, VINALHAVEN, MAIE, LOOKING

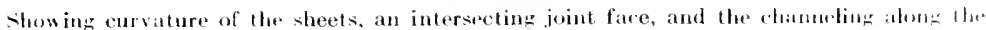
"hard way," or $>10^{\circ} \mathrm{E}$.

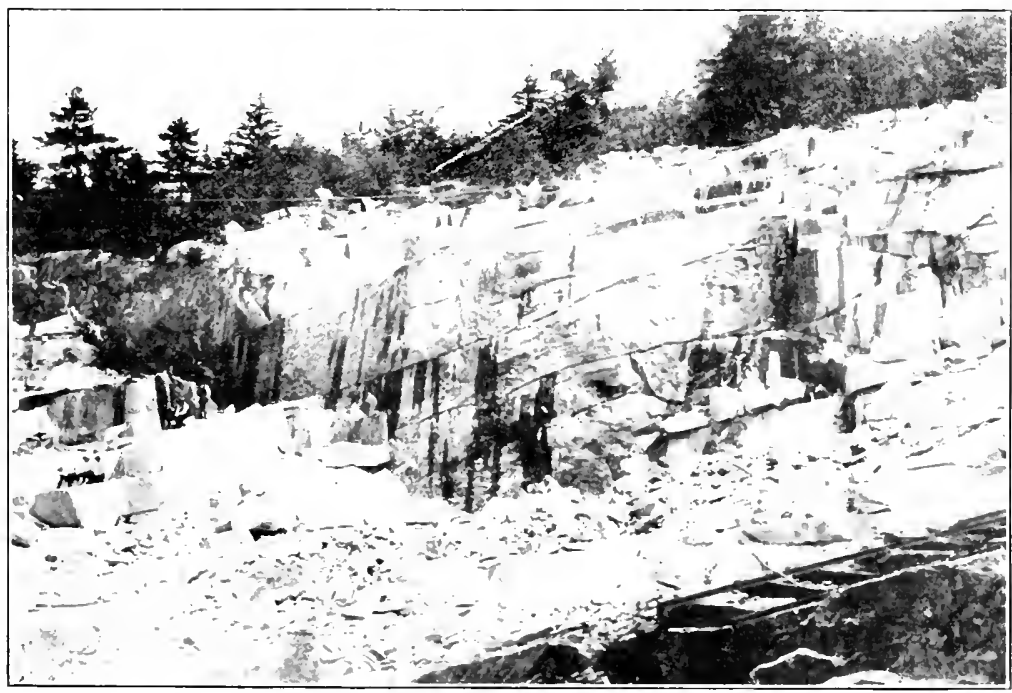

B. WHITE QUARRY, BLUEHILL, VAIVE, LOCKIVF; Y. $10^{\circ} W$.

Showing lenticular sheets crossed by a vertical joint curving from \. $50=11$. 10 \. $511=1$.

The black vertical streaks are underweround water istuing from betwent the shents. 


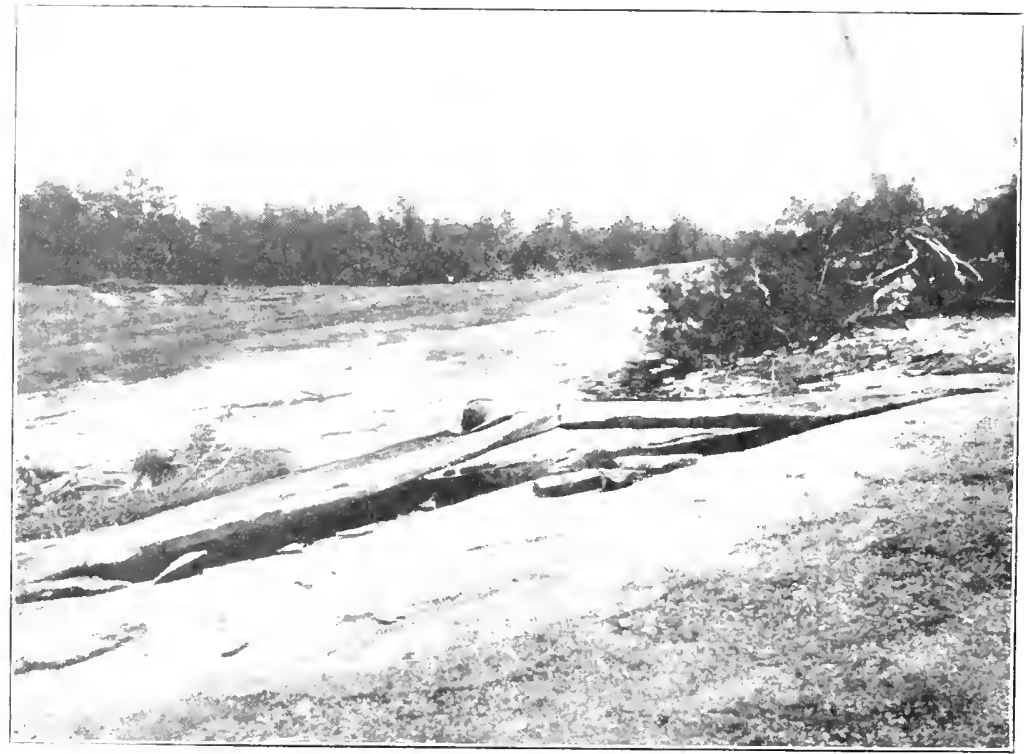

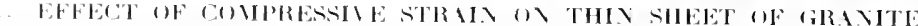

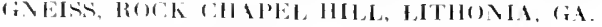

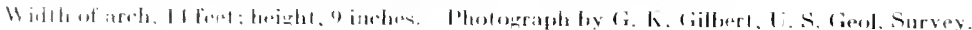

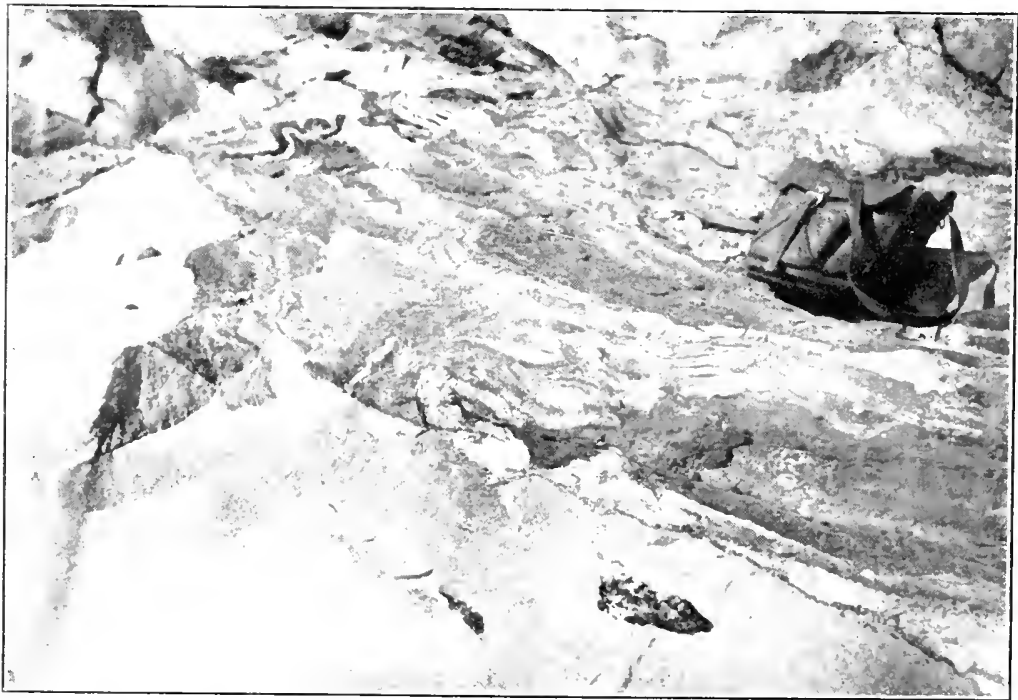

R. HMER EDGE OF SCIIST IVALISION IV GRIVITE IT OITARY IN FRELIORT, IIIDE.

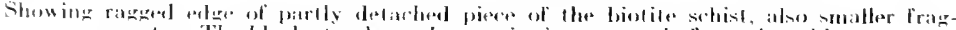

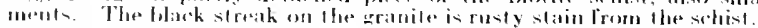




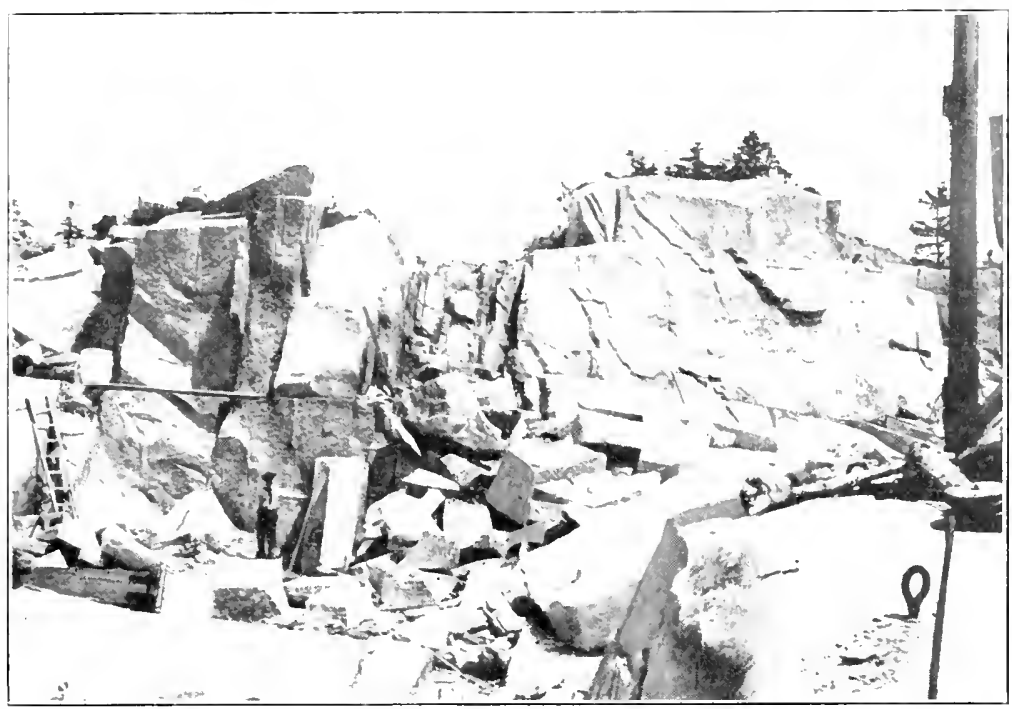

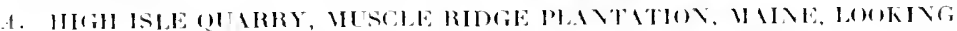
EAST.

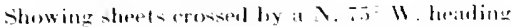

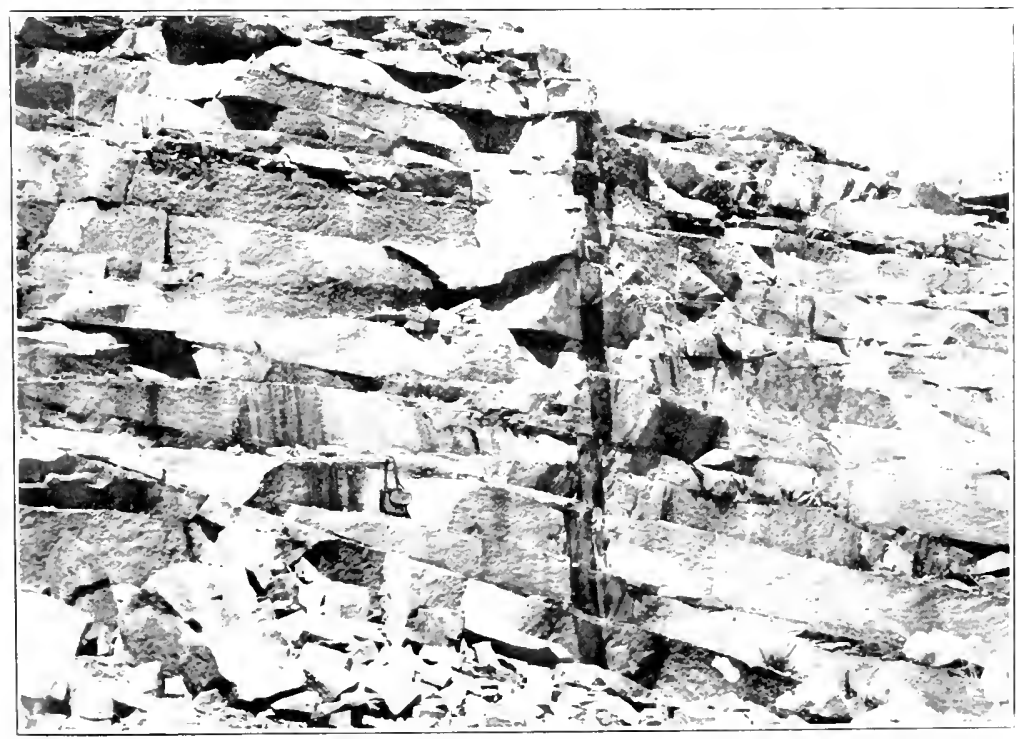

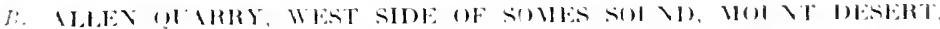

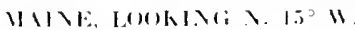

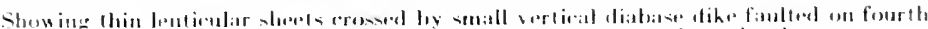

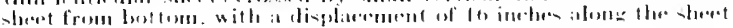




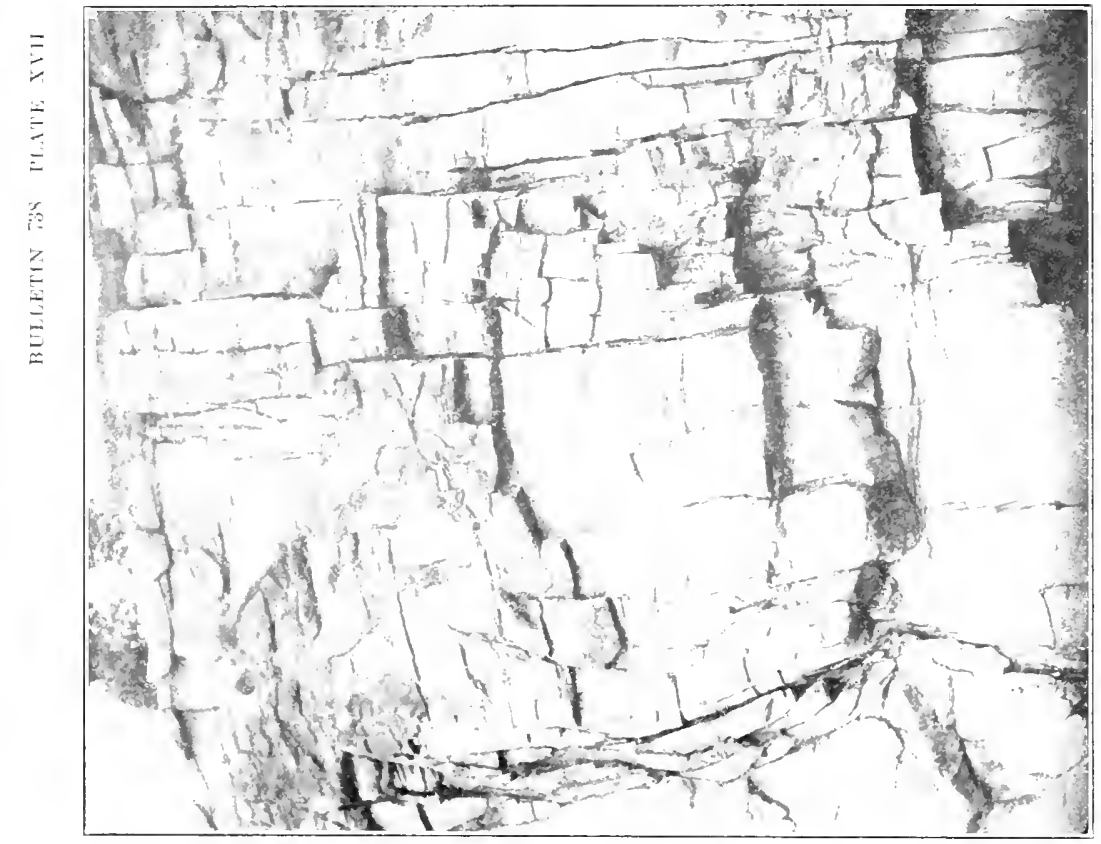

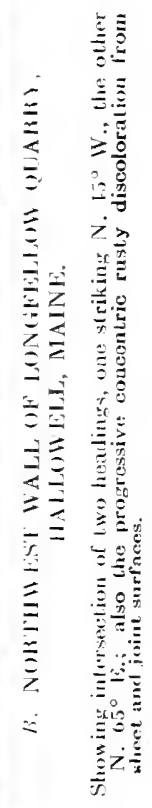

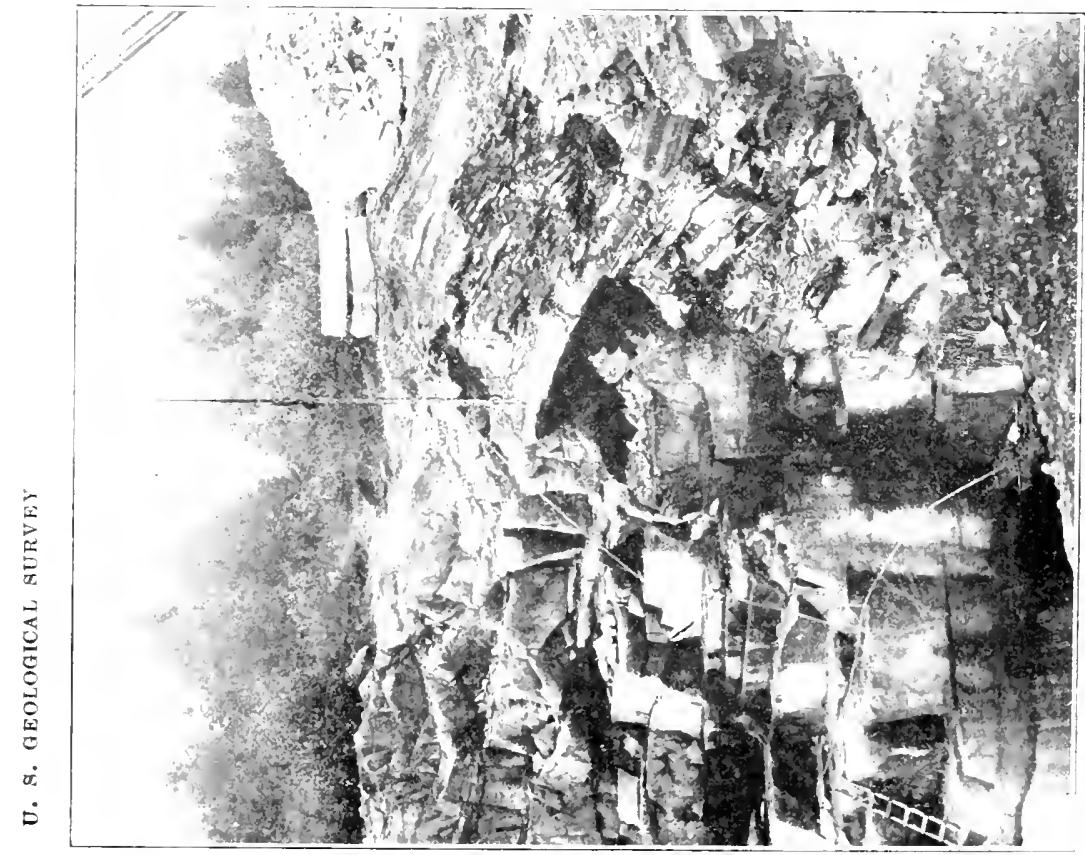

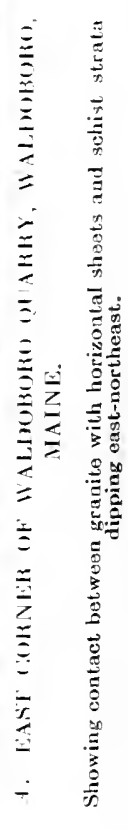




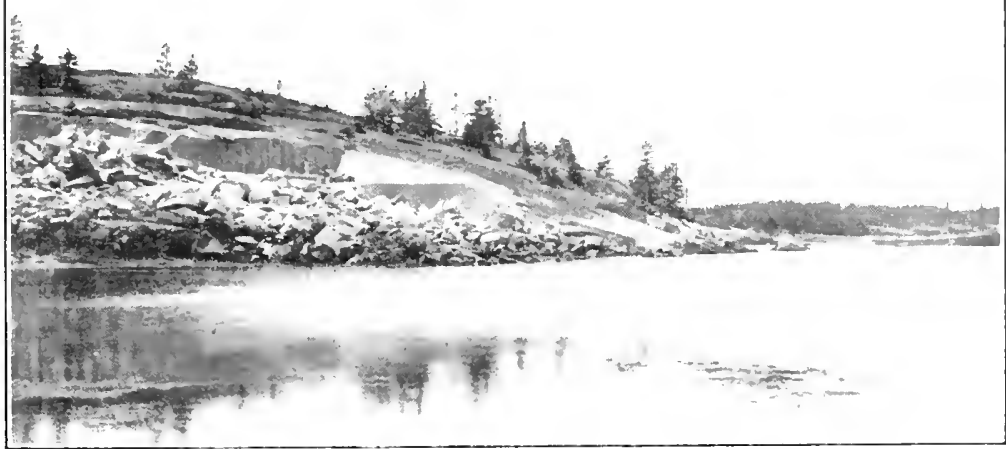

A. WEBSTER QUARRY, ON PLEASANT RIVER AT END OF WITER IIARBOL, VINALIAVEN, MANE, LOOKIVR WEST.

A typical tidewater quarry. Granite-laden shlooner at right. Pholongaph by Merrithen.

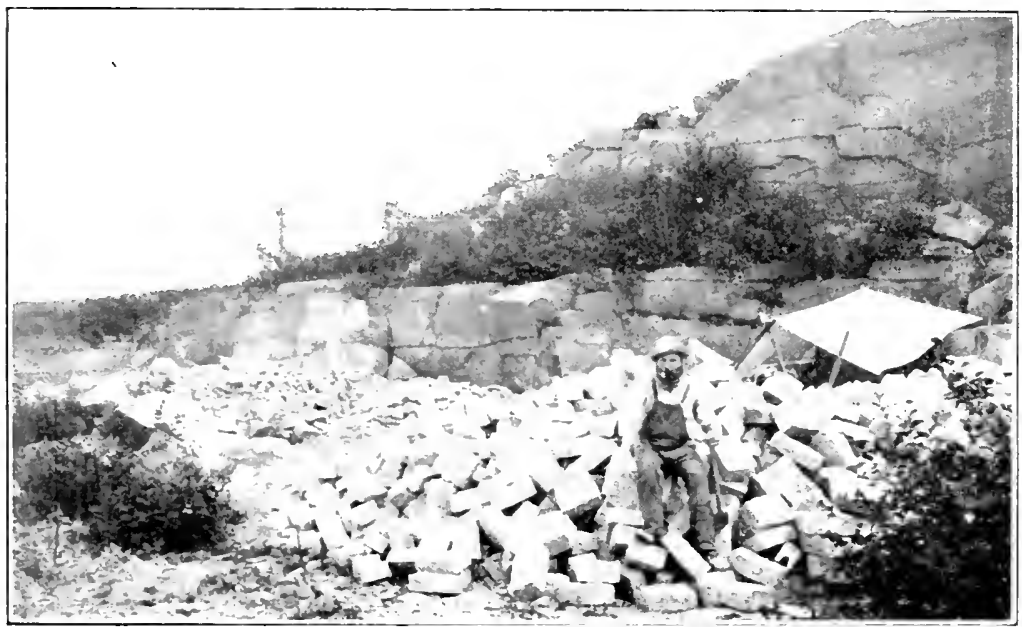

B. A TYPICAL MAINE PAIIXG-BLOCK QLARRY, CALLED A "MOTIOX."

()ierated by one man provilad with a tent, rarely with very small haml derrick. Phutograph by lierritlen. 


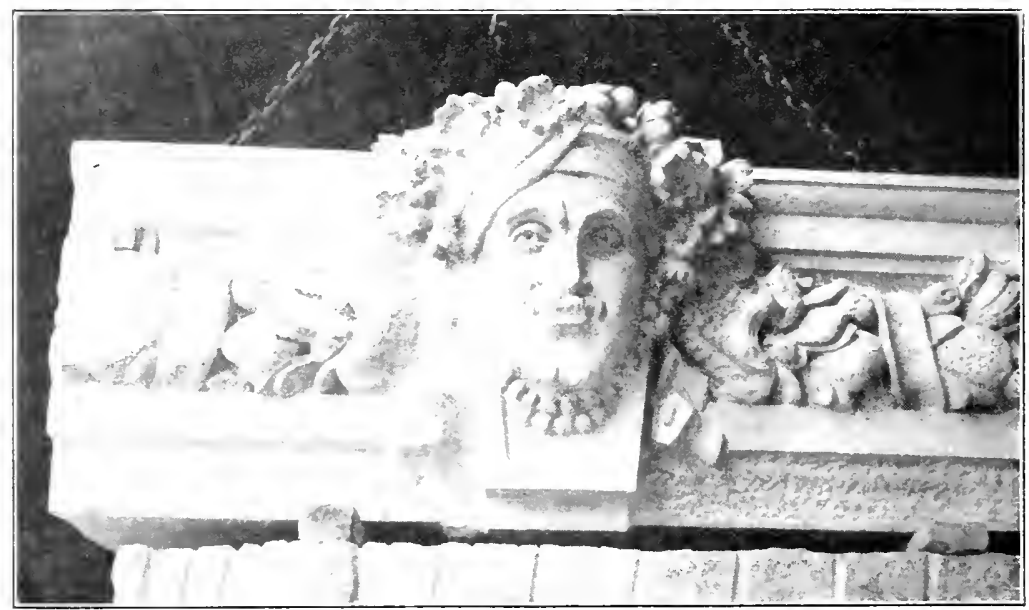

I. I.IVTEL FOR VEW YORK CLSTOMHOUSE.

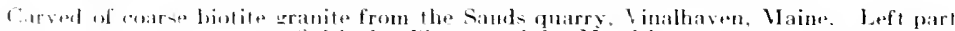
unfinisherd. Photonrath by Vîerrithew.

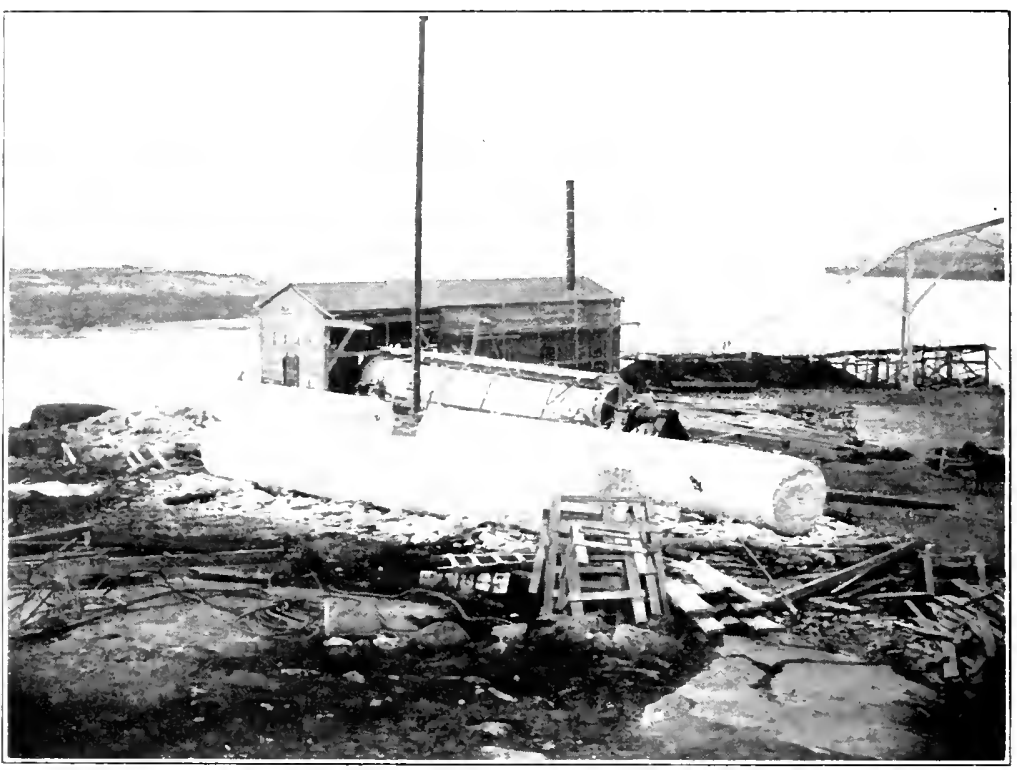

R. MONOLITIIC COLT UNS FOR TIIE CITIIEDRAL OF ST. JOIIN TIIE DIIINE AT \EW YORK.

Coarse biotite granite from lialmer quarry. Vinathaven, llaine. Length, 51 feet 6 inches: diameter, 6 tioej. Gne column in lathe. 


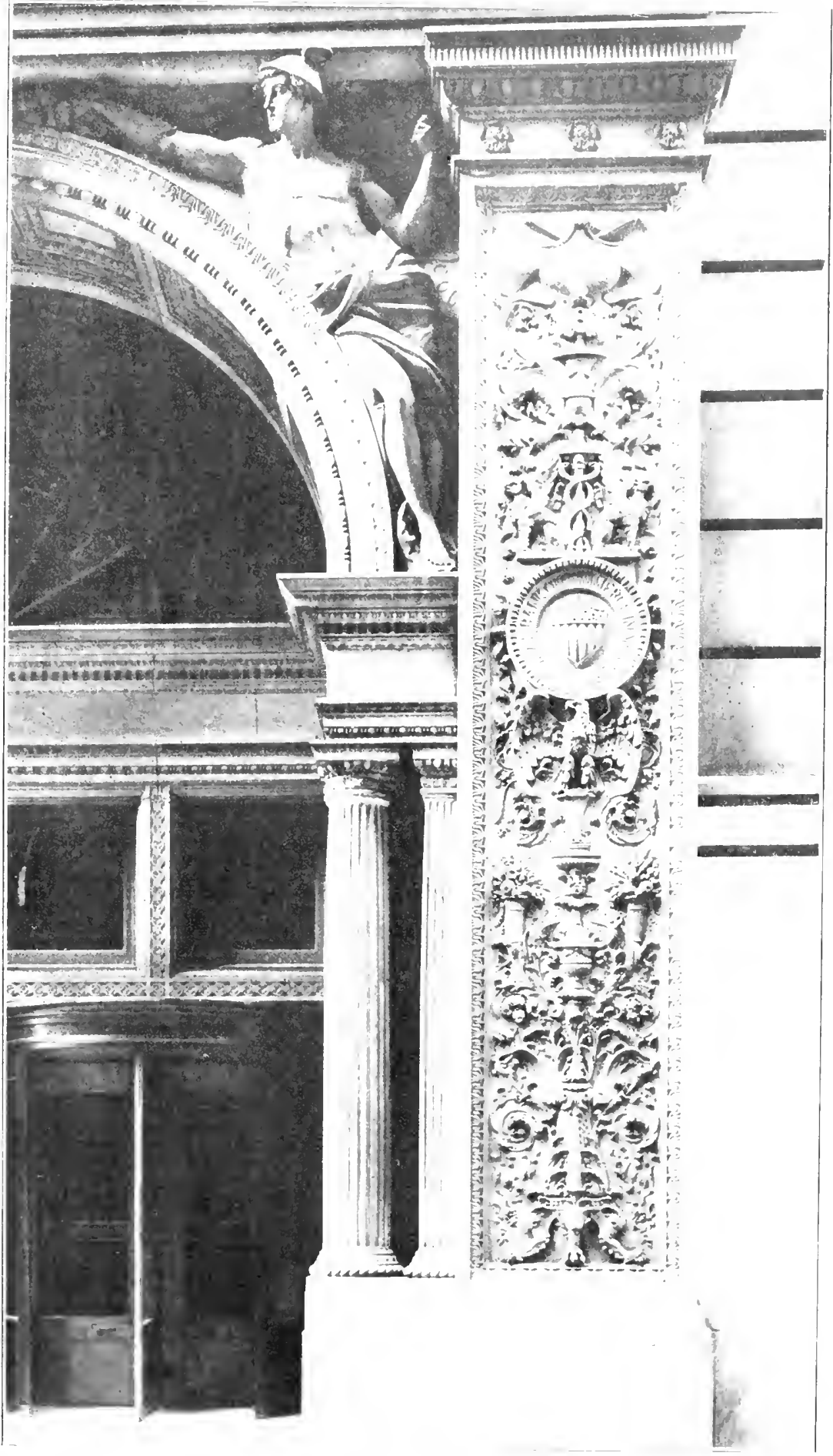

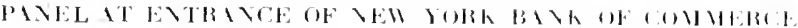




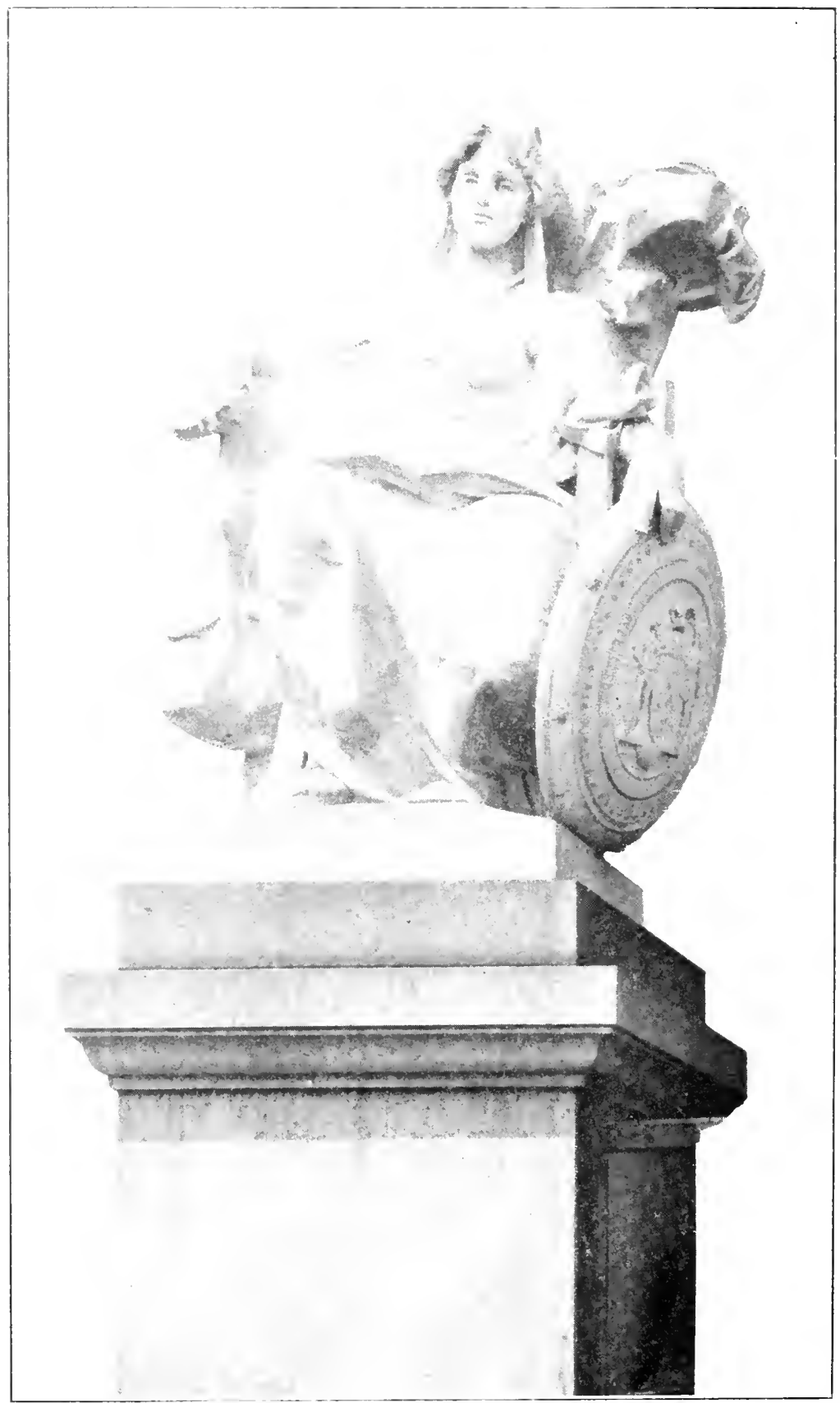

STATUE AT HALL OF RECORDS, NEW YORK.

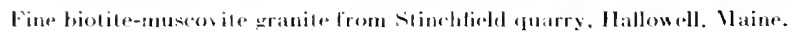



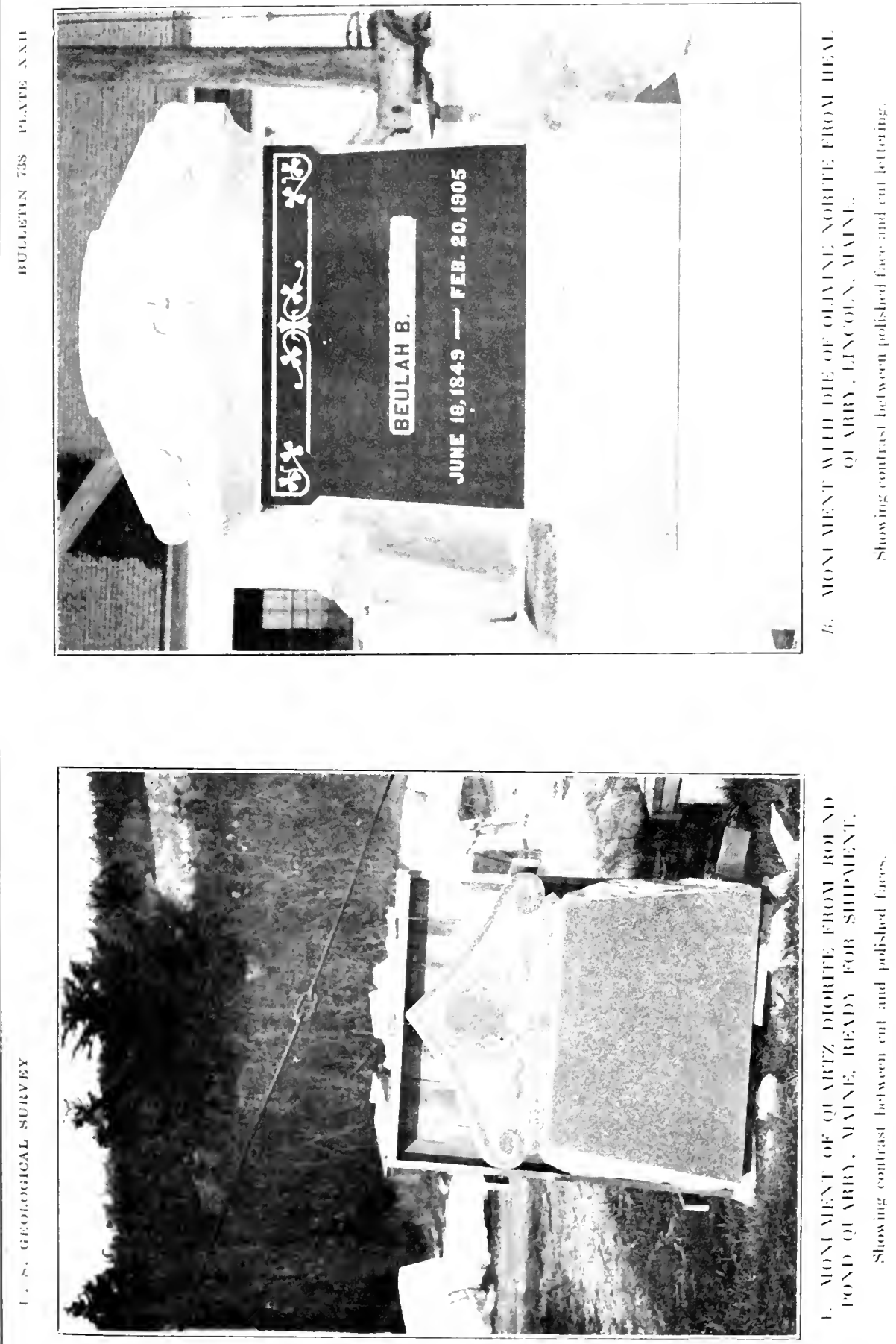

grain vertical, with rourse N. $60^{\circ}$ E. Kinots, buth light nud dark, are rare. Sap occurs along the sleets up to 6 inches in thickness. A 6-inch dike of white aplite strikes $\mathrm{N} .80^{\circ}$ W.. glaciated with the granite at the surface (specimen

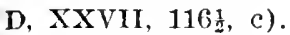

Transportation, by cart 3 miles to railroad at Norliolgewock.

The product is used for buildings, bridges, and momments to supply local demands. Specimen: Town bridge at Bingham, Maine.

The Taglor quary is in the town of Norrilgewock, on Dodlin Hill, about one-fourth mile north of the Lawton quarry. Operators, D. E. Taylor \& Son, Norrilgewock. Telle since 1916.

The granite (silecimen. D. XXVII, 117, a) is a biotite-muscovite granite of light-gray shadr and very fine, even-grained texture. The particles range from 0.11 to 1.1 millimeters, exceptionally 2.19 millimeters, anr average about 0.50 millineter. 'They consist, in descending order of ahundance, of a sliglitly bluish milk-white potash feldspar (microcline and orthoclase), dear quartz, sodalime feldspar (oligoclase), black nica (biotite), and very little white mica (muscovito), togetler with accessory magnetite and apatite.

This is a small opening, from which stone is ohtained occasionally for monumental purposes.

\section{WALDO COUNTY.}

\section{FRANKFORT.}

The Mosquito Mountain quarry is in the town of Frankfort, on top of Mosquito Mountain, 2 miles S. $10^{\circ}$ E. of Frankfort village. This mounta in is a granite dome rising 545 feet above tidewater, close by, with a steep east face shown in Plate XI, B. Operator, 1905, Hayward Pierce, Frankfort. Quarry not operated since 1912 and now abandonel.

The granite (specimen D, XXVI, 52, a) is a hornblende-biotite granite of general medium-gray shade and of porphyritic texture, with milk-white feldspar crystals from 0.5 inch to 1.5 inches in diameter in a gray matrix of mediun texture, with black minerals up to 0.1 inch. It consists, in descending order of abundance, of milk-white potash feldspar (orthoclase and microcline), smoky quartz. milk-white soda-line feldspar (oligoclase), black hornblende, and black mica (biotite), together with accessory titanite, magnetite, and apatite, and a little secondary chlorite, epidote, and carbonate (calcite or dolomite). The porphyritic feldspars are generally twins. E. C. Sullivan, of the United States Geological Survey, finds that this granite contains 0.1 per cent of $\mathrm{CO}_{2}$ (carbon dioxide) and that warm dilute acetic acid extracts 0.07 per cent of $\mathrm{CaO}$ (lime) and a trace of $\mathrm{MgO}$ (magnesia). Figuring the $\mathrm{CO}_{2}$ to both $\mathrm{CaO}$ and $\mathrm{MgO}$ this would give 0.13 per cent of $\mathrm{CaCO}_{3}$ (calcium carbonate) and 0.08 per cent of $\mathrm{MgCO}_{3}$ (magnesium carbonate). The microscope also shows carbonate.

A test of the compressive strength made of this glanite in connection with its use for the U. S. dry tocks at Kittery, Maine, reported by the owner of the quarrs, gives it an ultimate crushing strength of 32,635 pounds to the square inch.

The quarry was opened before 1837 on the east side of the mountain. The iater opening on the top measured in 19051,000 by 500 feet, with a maximum depth of 25 feet.

Rock structure: The sheets, 6 inches to 15 feet thick, dip gently northwest and east from the summit of the dome, and below, on the east side, thy dip $45^{\circ}$, as shown in Plate XI, $B$. Some of the upper slicets taner out at the sidos. 
(See, further, p. 31.) Vertical joint and dike courses are shown in figure 65. The rift is horizontal, and the grain is vertical, with strike N. $80^{\circ}-85^{\circ} \mathrm{W}$. Some of the joint surfaces are coated with secondary chlorite and pyrite. A dike of quartz monzonite, 10 feet thick, dips $40^{\circ}$ E. (See p. 41.) There are branching dikes of aplite from 1 to 3 feet thick. At the south end of the quarry a diabase dike $\tau$ feet thick crosses from east to west. (See p. 52.) Somewhat abundant knots up to a foot in diameter and of circular or elliptical cross section occur. Sap is up to a foot thick in the upper sheets but absent lower down.

Transportation, by about 7,000 fect of track and gravity cars from quarry to cutting shed and wharf on Marsh River (South Branch Stream), which admits schooners of 14-foot draft.

The product was used for bridges and buildings, and the small sheets and waste for paring. Specimens: Post oftice at Iynn, Mass., and part of that at Chicago, Ill.; New York Central Railroad bridge across Harlem River.

The Mount Waldo quarry is in the town of Frankfort, on the north spur of Mount Waldo, 660 feet above sea lerel, one-third mile southwest of Frankfort village. The geographic relations of Mosquito Mountain and Mount Waldo

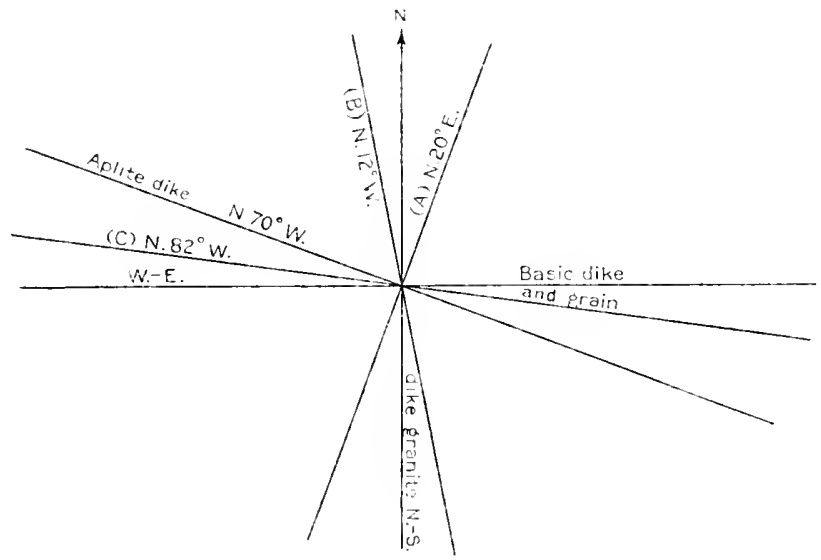

Figlre 65. - Structure at the Mosquito Mountain quary, Frankfort, Maine.

to Penobscot River are shown on the U. S. Geological Survey's Bucksport topograplic map. This quarry was operated by the Mount Walelo Granite Works, Frankfort, hat has been ille since 1914 .

The granite (specimen D, XXVI, 53, a) is a biotite granite of medium-gray shade and fine even-grained texture, with feldspar up to 0.2 inch and biotite scales up to 0.1 inch. The finer particles range from 0.36 to 1.46 millimeters in diameter. It consists, in descending order of abundance, of gray potash feldspar (orthoclase and microcline), smoky quartz, gray soda-lime feldspar (oligoclase), and black mica (biotite), together with accessory magnetite, titanite, and secondary chlorite. The oligoclase is partly altered to kaolin and a white mica. A coarser and lighter granite (specimen $53, \mathrm{~b}$ ) from this quarry is a biotite granite of light-gray shade and medium, inclining to fine, even-grained texture, with feldspars up to 0.3 inch and biotite scales up to 0.1 inch, consisting, in descending order of abundance, of white potash feldspar (orthoclase and microcline), smoky quartz, white soda-lime feldspar (oligoclase), and black mica (biotite), together with accessory magnetite, titanite, and secondary chlorite. The oligoclase is partly altered to kaolin and a white mica. This 
variety is in places coirsely porphyritic. Conrge l'. Merrill gefers th the two "Mount Wallo granites." A test of the compressive strengtl of inomit waldo granite, made at the Cuited States arsenal at Watertown, Mass., in $1900,{ }^{19}$ yichled the following results" with "-incli cubes:

\section{Text of Mount Waido granite.}

No. of test.
$\ldots$

The quarry, opened before 1851, measured in 1905 soo feet flom nirth to south by 400 feet from east to west and from 10 to 30 foet in depth.

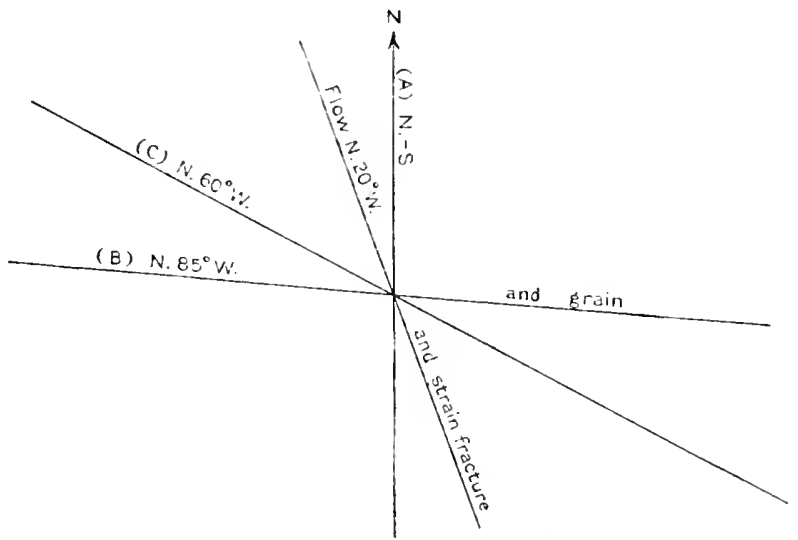

Figcre 66.-Structure at the Mount Waldo quarry, Frankfort, Maine.

Rock strueture: There is a rerticul dike of the coarser and lighter andmite (specimen 53, b) 200 feet or nore wide. having a course $x$. 200 W. with the darker granite (smecimen 53, a) on both sides of it, the rolations indicating vertical flow structire. The longer axes of many of the fellapals lie

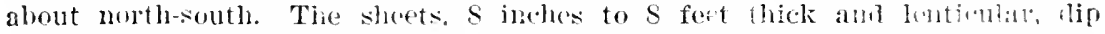

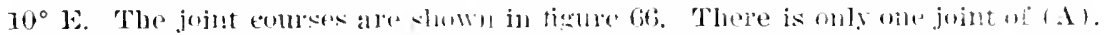
(B) recurs at intervals of 40 fet: $(6)$ at intervals of 20 to 40 feet al megle. The rift is horizontal, and the grain vertical. striking $\mathrm{X}$. 850 W. The wranite is under complessive strain from east-mutleast to west-soluthwest. cansing north-nothwest to sonth-sontheast vertical fissures the entire lenst? of the quarry. This fissuring las occurret in summer time and lass been accumpanierl by an explosive noise. The slerets are rery fre from sall. knots are exceptional, but ond nar the junction of the fine and medium stanites

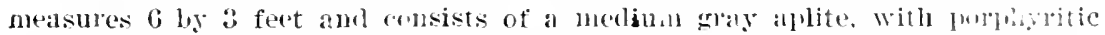

wollection of huiling and ornamental stones in the Conited Stats National Masum: Smithsonian Inst. Ann. Rrpt., 14s!, pt, 2, p. 415.

${ }^{93}$ Reilly, J. W., Ordbance liejt., Trsts of Metal, ete., 1900, p. 119, 1941. 
whitish twinned feldspars up to 0.75 inch in length and biotite scales up to $0.05 \mathrm{inch}$.

Transportation, by two gradeil tracks, each 1,200 feet long, operated by zravity from the quarry part way down the hill to the power house, thence by at cable roal (Roebling engine) $1 \frac{1}{4}$ miles to the wharf, which is accessible t: sclingilers of 15 -feet draft.

Tho product is used for buildings. The small sheets and waste are made into javing blucks. Specinen buillings: Milwankee, Clevelamo, Indianajolis, and Jersey city post offices; Ihiladelphia Mint; new municipal building, New York; l'ulblic library, St. Louis; post office, Bangor, Maine.

\section{LINCOLN.}

The Lincolnville quarry is in the town of Lincolin, near the north end of I, lae Mreminticook. Onelator, W. E. Dornan, East Union.

The granite (specimen D, XXVI, 50, a) is a muscovite-biotie granite of liglu-gry slade and fine, indining to nedinm, even-graned texture, with feld-

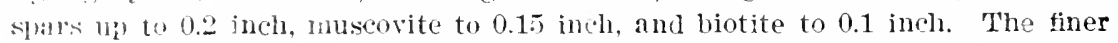
partictes range from 0.18 to 1.83 milhmeters in d'ameter. The rock consists, in ioserending onder of albundance, of slightly bluish-white potash feldspar writecluse and microcline), smoky duatr, whitish soda-lime feldspar (oligo(clase), white mica (muscorite), and black mica (biot te), together with accessory anatite. The oligorlace is muth altererl to kaolin. The foldspars generally are intergrown with fuartz in particles that are cireular in cross stetion. The stome takes a fair polish with a blush tinge, but the size of the muscov te pates is against the great durability of the polsh under ontuonr exposture.

The quatry oprened about 1855 , moasured in $1905100 \mathrm{by} 50$ foet and was 29 feet deep.

Irock structure: The sheets, 6 to 15 feet thick, dip $25^{\circ} \mathrm{S}$. Tertical joints, strike N. $69^{\circ}-65^{\circ}$ W. reeur at intervals of 8,14 , ant 23 feet; also a sincle joint, strlke N. $60^{\circ}-65^{\circ}$ E. Another one strikes $\mathrm{N} .60^{\circ} \mathrm{W}$. and dils $60^{\circ}$ SLE. The r:ft is vert cul, with strike $\mathrm{X} .60^{\circ}-65^{\circ} \mathrm{W}$. Sall is faint anıl 4 to 8 inches thick along ille sheets. Knots, up to 8 by 0.5 inch, are rare.

Transportation, by art i miles to elec ric railroad. thence 8 miles ty Mane (emtral Railroad.

The product is used localiy almost entirely for momments. Specimen: Trinumings to Carlters Block, Thoekport, Maine.

The Heal quary ("black granite") is in the town of Lincoln, about 2 miles fron the brifge over the outlet to Tilden lonl and about 32 miles from the shore lentibcot bay. Operator, A. s. Heal, Belfast. Quary abanloned.

rliss rock is an olivine norite of alnost black shate, with glistening surfaces, and o: medium texture. The polished surfaces show a brilliant dark olivegremish minerin. Uner the microscope this rock consists of incerlacing slender erystals of a trans? ucent lime-soma feldspar (labradorite, with 10 to 14 per cont of lime), the suaces between which have been filled with the following mincals, in descending arder of abundanc: (iremish hypersthene (see p. 94), black hornblende, greenish olivine, black mica (biotite), and magnet te, with acosiony pyrite and secombary chlorite and serpentine. The stone takes a hrilliant polsh and under sunlight shows the greenish hypersthene. The ham. mered or cut surface is very light, as shown in Plate XXII, $B$.

The quarry, opened in 1903, measured in 190530 by 40 feet and about 10 feet in dep'l. It is worked only occasionally. The stone has to be carted 7 miles to Belfast to be cut.. It is used for dies and tablets for local demand and is admirably adapted for these purposes. 


\section{SEARSFORT.}

The Bog Hill quarry is in the town of Searsport, on Monnt libhaim (Bog Hill), about 5 miles north-northwest of Seansurt village and a miles tast of Swanville.

The granite (specimen $D$, XXVI, n. a) is a biotite granite uf ligliteray shade and polvluritic text!re, with foldspars up to 1.5 inches in diameter, in a gromdmass of melium texture, with biolite scales un to 0.2 inch. It romsists, in fescenting orler of ahmulanee, of a whitish potash fellspar forthocluse alld microcline), smoky quartz, whitish sola-lime feldspar (oligoclaso). and black mica (biotite), together with alecessory magnetite, titanitr, zireom, apatite and secondary chlorite and epidote. The porphyritic orthoclase crystals. genterally twimes? are intergrown with oligodase and quartz. Some have a zonal situcture indicated by inclusions of quartz and oligoclase. The oligoclase is frartly altered to kaolin and a white mica.

The quary is 200 feet from north to south by 50 feet from east to west and averages ahout 5 feet in depth.

Rock structure: The sheets, 1 to 4 feet thick, dip $10^{\circ} \mathrm{S} .30^{\circ} \mathrm{F}$., and are crossed by steep joints striking $\mathrm{N}$. $75^{\circ} \mathrm{W}$., forming hearlings at the soith side, and one in the center. Some black knots up to 2 inches across; also pyrite crystals on the joint faces.

This stone has been used for monuments and buildings in Belfast and for paving blorks, but the quarry is abundoned. The product had to he carted 5 miles to Searsport.

\section{SWANVILIE.}

The Oak Hill quarry is in the town of Swanville, on Oak Mill, about 6 miles north-northwest of Belfast. Quarry ahandoned.

The sranite (specimen D, XXYI, 49, a ) is a biotite granite of slightly hhuish dark-gray colol and fine even-grained texture, with particles rangins generally from 0.25 to 1 millimeter in diameter ant an occasional feldspar up to 2.5 millimeters or 0.1 inch. It consists. in descending order of abundance, of slightly hluish-white potash feldspar (microcline anc orthoclase), smoky quartz, slirhity bluish-white soda-lime feldspar (oligoclase), and black mica (biotite). The feldspars are intergrown with quartz and the oligoclase is here and there partly altered to a white mica. The stone takes a very fine polish, to the durability of which the fineness of the mica contributes.

The quarry, opened about 1872 , consists of several openings, the largest of which is 175 by 100 feet, with a working face 60 feet high.

Rock structure: The sheets, 1 to 4 feet thick, dip $10^{\circ} \mathrm{W}$. Vertical or steep joints, strike $\mathrm{N} .80^{\circ} \mathrm{W}$., recur at intervals of 10 and 20 feet and form headings on the north sirle. Sap 2 inches thick occurs along the shects. There are sone knots up to 2 inches across.

Transportation. hy cart one-fourth mile to a siding from Sargents Crossing on the Maine Central Railroad.

The product is well allapted to monumental uses. The stone is the darkest of the fine-texturerl granites of the State (compare Freeport, p. 211; Pownal, n. 211: and Sherwool, p. 227) and is finer textured than the hlue sranite of Westerly, R. I. This quarry was formerly leased to the New England rranite Co.. of Westerly. 


\section{WASHINGTHN COL NTY.}

\section{ADDISON.}

Plif Pleatsant River quarry "Blark slante", is in the town of Adlison at I malutille, on the east sile of l'leasunt liver l'ay. Operator, l'leasant River Granite ('o.. Alalison. Iolle in 1921 and 19\%.).

This rock ispecimen I, XXVI, a:3, a) is an lypersthene-olivine gabbro of ahmost black sharle anc of medium ophitic textme, with black particles up to half an inch and slender whtish crystals. The polished surface is jet-black mottled w th a little white. Encler the microscone this rock comsists, in descending onier of abmulanece, of slenter whitish tramslatrent crystals of a feldsial with hoth limt and sola, andesine-haralorite) intricately interlicen. tha slatow between which are filled with a dark-brownish diallage (see 1. (1). hatk mical (liotite), a little hypersthene, ant greenish olivine, together witl stomblay mannet te, a white mica, and calcite. The diallage is altered along its elges to homblemele. The stone takxs a very fine jolish, and the hammeres or cut surlace is almost white. It is rererred to by George P.

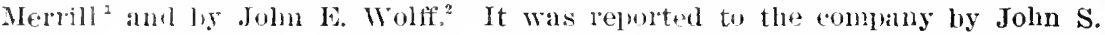
Newhery in octohei, 1890 , as withstantling a pressme of 2,410 pounds to the square inch. Its weight is given hy the firm as $18 t$ prounds to the cubic foot.

The quary, opened about 1885 , in 1905 measured 75 by 50 feet with a working fare alont 50 feet high. It is on the south side of an east-west ridge 70 feet hirh, the myler 5 to 10 feet of which consists of morainal sand and boulders.

limk struture: The sheets, 3 to 17 feet thick. undulate from the horizontal to

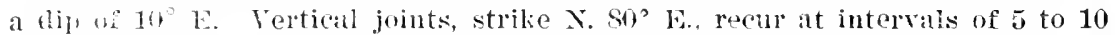
feet am form a healling on the south; a set striking $\mathrm{Y}$. $35^{\circ} \mathrm{W}$. recurs at intervals of 20 to $; 0$ fett, forming a heading on the west. 'There are also several irrogular fractures. The rift is vertical east-west, and the grain is horizontal. There are 10 feet of stained and fractured rock at the top, but sap is usually hartly an inch in thickness. Dikes of whtish quartz monzonite, describei un latge 61 of Bulletin 313, are 1 to 14 inches thick. Tlere is also a more or less horizontill light and dark banding, due to alternating changes in the amomit of feldspar.

Transpertation, hy cart on a track 300 feet from quary to mill and 300 feet thence to wharf on Pleasant River Bay.

The product is used for monuments and interior decorations. The dimensions of the blocks are limited by the spacing of the joints and sheets. The usual sizes shipped measure 2 feet 6 inches by 2 feet 6 inches by 1 foot and also 3 to 6 feet by 1 foot by 1 foot. The largest block shipped measured 6 feet by 4 feet 6 inches by 4 feet 6 inches.

Specimen work: Pase of wainscoting in the city hall at Philadelphia; tallet with Welsh inscription in Waslington Monument, Washington, D. C.; Dillurth mumument, Moristown, N. J.; Zeller momument, Lewisburg, Pa.; Center monument, Greewood Cenetery, Brooklyu, N. Y.; mantlepiece in public library at Machias, Maine; memorial to Architect French in New York.

The Thornberg quarry ("black granite") is in the town of Addison, 3 miles south of Arldison village. Operator in 1905, A. M. Thoruberg, Addison; quarry not operated in $\mathbf{1 9 1 6 .}$

1 Tenth Census, vol. 10, p. $24,1884$.

${ }^{2}$ Idem, p. 116.

3 Newhery's report will be found in U. S. Geol. Survey Eighteenth Ann. Rept., pt. 5, rontinued, p. $961,1897$. 
The rock (specimens D, XXVI, 94, a and 94, aa) is a hypersthene gabbro of almost black shade and of medium ophitic textme. Thre are two varistiesa dark one, which is externaly jlentical with that from the Pleasant River quarry, and a lighter one, in which the white mottling due to the feldspar is a little more abmotant. Lnder the microseope this stone is generally irentical with that of the Pleasant Rivel quary, except that in this one the feldspar is labradorite and there is no olivine. This, however, may not be clatracteristic of the rock as a whole. A little accessory lyrite and apatite and a cond-sized particle of secondary epidote were also fumd in the "Thornburs" gibliro. The stone takes a very fine polish, and the hammerell or cut sulfires are almost white.

The Black Diamond quarry ("black granite") is in the town of Addison, on Yoho Bay. Operator, Maine Black Diamond Granite Co.

The rock (specimen D, XXVI, 91, a), known as "Indian BIack Diamond granite," is a hypersthene gabbro of very dark gray shate, with slight brownish tinge, and of fine to medium ophitic texture, consisting, in descendins order of ahundance, of a whitish solatlime feldspar (andesine) in not greatly elongated (rystals, brownish diallawe (party altered to hormblende), black mica (biotite). a little hypersthene, and (liatt\%, together with arcessory magnetite. Where most exposed the ledge has turned a little brownish and weathered spheroidally. A polished block, reported as from this quarry and shown to the writer in a stonecutter's yard at Quincy, Mass., hat hecome pitted from exposure, but monuments erectert 20 years or more ago in New York City are reported to be in goml condition.

The quarry in 1902 was 200 leet square and from 10 to 20 feet deep. It has a track 600 feet long to a wharf which admits schooners of 11 feet draft. The older part of the quarry has been worked down to sea level, but a large supply of stone lies to the east in a rising ridge.

Rock structure: The sheets, 3 to $\&$ feet thick, are horizontal or dip $20^{\circ} \mathrm{N}$, Vertical joints, strike $\mathrm{N} .80^{\circ} \mathrm{E}$., recur at intervals of 5 to 20 feet, and a set striking N. $30^{\circ} \mathrm{W}$. recurs at intervals of 2 to 10 feet. There is rarely a set striking N. $45^{\circ}-50^{\circ} \mathrm{W}$.

\section{BAILEYVILLE.}

The Hall quarry ("black glanite") is in the town of Baileyville, at the north elge of Meddybemps Lake, 5 miles southwest of Baring, on the Washington County Railroad, about 7 miles soutbwest of Calais. Operator in 1905, F. H. Hall, Calais. The quarry is no longer operated.

The rock (specimens D, XXVI, 98, b, d) is a norite of brilliant luster, very dark gray shade withont any yellowish tinge and of coarse texture and marked rift, with jet-black particles up to 0.5 inch in dianeter in a network of translncent whitish feldspar. Under the microscope it consists, in descending order of abundance, of elongated transparent crystals of feldspar (with both soda and lime, andesine-labradorite) interlacel. but parallel in the flow and rift direction, with the intervening spaces filled with hynersthene (partly altered to brown holnblende), magnctite, and black mica (hiotite), together with accessory calcite and a white mica derived from the partial alteration of a few of the feldspars. The hypersthene and hornblende constitute the conspicuous black particles seen with the unaided eye. In the lighter bands of the rock the feldspar largely crowds out the hypersthene. The content of magnetite is so great that large blocks of the rock deflect the magnetic needle. Mr. Hall stated that the stone endures the fire and water test very well; that its compressive strength, as determined by the Watertown Arsenal testing machine, is 22,500 pounds to the square inch, and that an assay by Carmichael, of Boston, 
shows it to contain a small percentage of gold. The papers that give formal evidence of these results, having, unfortunately, been misnaced, can not be cited here. The stone takes a high polish, and the hammered and cut surface is almost white. It is very tough but silifs with filcility along the rift.

The quary, opened in 1302, consists of two adjacent openings on the northeast side of a northest-sontheast rilge over one-fourth mile long and about so feet high. These openings measure 60 by 25 feet and 35 feet in depth and 50 by 20 feet and 20 feet in repth, respectively.

Rock structure: The ulper 8 feet of the working fiace is traversed by lightgray more feldspathic bands 0.25 to 2 inches thick, constituting a flow structure parallel to the sheets, which are from 1 to 6 feet thick and dip alout $15^{\circ} \mathrm{SW}$. Vertical joints strike northeast-southwest, cross the ridge at intervals of 6 inches to 7 fiet, and form a heading in the smaller northwesterly opening. The rift is parallel to the sheets. The structure along this ridge is umusually farorable for quarryins.

Transportation, by cart 5 miles to raring, on the Wasington Connty Railroad.

Specimen montiments: A monmment prected by Stephen A. Lovejoy at Melrose Cemetery, Melrose, Mass.

The Tarbox quarry ("black granite") is in the town of Baileyville, about 900 feet nortleast of the Hall quarry, described above, at the north edge of Meddybemps Lake, 5 miles southwest of Baring, on the Washington County Railroad, and about 7 miles southwest of Calais. Operator, Redbeach Granite Co., Rerbeach.

This rock is a norite identical with that of the Hall quarry. It appears to belong to an outcrop northeast of and parallel to the ridge referred to.

\section{CAIAIS.}

Garduer"s prospect ("black granje") is in the town of Calais, on St. Croix River, 6 miles south of Calais, north of road to Redbeach. Owner. Lorenzo Gardner, Calais.

This rock (specimen D, XXVI, 100, a) is a quartz diorite of very dark gray (not bluish) slade and fine, even-glained texture, consisting, in descending order of abundance, of a whitish soda-lime feldspar (andesine) considerably altered to a white mica, hornblende partly altered to chlorite, quartz, black mica (biotite), and magnetite, together with accessory titanite, pyrite, and apatite and secondary calcite. It takes a high polish, and the hammered and cut surfaces are very light. The stone is suitable for monumental work. Dr. George Otis Smith, who visited the Girriner prospects in 1903, states that "pink granite oceurs intrusive in the dioritic rock in such a manner that both kinds of stone could be quarried from the same opening." One part of the dioritic rock he found in thin section to be in reality a diabase.

The Mingo-Bailey quarry ("black granite") is in the town of Calais, about 6 miles south of Calais, on the southwest side of the road to Tiedbeach, on the north side of an east-west ridge, near top. Operators, Mingo, Bailey \& Co., Redbeach.

The rock (specimen D, XXVI, 103, a) a norite, 1s almost black with a slight greenish tinge and of fine to medium even-srained ophitic texture. It consists, in descending order of abundance, of a whitish soda-lime feldspar (andesine) considerably altered to a white mica, hypersthene (some of it partly or entirely altered to fibrous actinolite), magnetite, aud black mica (biotite), with accessory pyrite. The stone takes a fine polish and affords a very light hamnered or cut surface. 
The quarry measured 50 by 15 fret and up to 20 feet in depth in 1905 'The sherts are about 10 feet thick. Vertical joints. strike about east to west, rocur at intervals of 1 to 3 feet.

The quarry is worked only oceasionally, and the stones are carted to the company's cutting shed, near Redbeach, on st. Croix River.

The Beaver Lake quarry ("black crmite") is in the town of Calais, near the nortl end of Beaver lake, 4 miles west of Red Ijeach village. Operator, Maine lied Granite Co.. Beal Leach. Quarry idle.

The rock (specimcin D, NXVI, 96, g) is a mica-quartz diorite of gencril darkgray shade (black mottled with white and gray) and of coarse to medium porphyritic texture, with feldsuars up to 0.5 inch in diameter. It consists, in descending order of abundance, of a grayish feldspar containing hoth soda and lume (andesinc-labradurite), hlack hornblende, blark mica thiotite), matnetite. and a little quart\%, together with accessory pyrite. calcite. and apatite. I'ne feldspar is partly altered to kaolin and a white mical, prodneing the milliy-iwhte parts of the feldsinas seen in the polished specimen, and some of the holnlitencle is fibrous. The stone takes a high lulish and when hammererl or cut hats a very light surface.

The quarry, opened in 1885 , measured in 1905250 feet from north-northeast to soutl-sonthwest by 75 feet arross and had a working face on the fast 30 feet in height.

lincis structure: The sleets, 6 inches to 7 teet 6 inches thick, dip $15^{\circ} \mathrm{W}$. and are lenticular. The unper 10 fcet of the face consists of shatterial surfaces rock and includes a bed $i$ foot thick of sand, due to interstitial weathering. The conises of joints and dikes are shown in figure $6 \pi$. (A) recurs at intervals of 2 to 10 feet. (B) at interrals oi 10 feet, (C) still less frequently. There are also ir regular joints, which

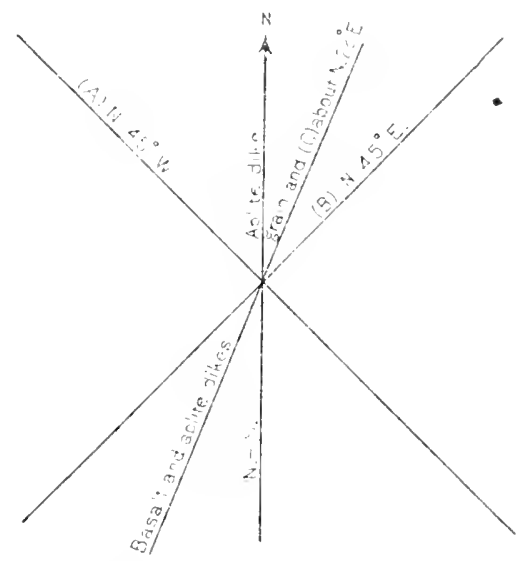

Figun 67.- Structure at the Beaver Lake diorite quarry, Calais, Maine. break the rock up into irregular blocks.

A dike of pinkish aplite, 4 to 8 feet thick, runs the entire length of the quarry on the west. A 1-inch dike of white aplite dips $15^{\circ} \mathrm{S}$. Similar dikes recur at frequent intervals. Some strike north and curve. A dike of olivine basalt ocfurs also on the west sile or front of the quirry and is crossed by branches from the large dike of pinkish aplite. The rift is horizontal and the grain verticul, striking north-northeast. Thus, altogether, the structure and injections are complex and render the quarrying of large blocks difficult. Notwithstancling this, blocks of 9 by 9 feet hy 20 inches have been obtained, and one 12 by 32 by 6 feet was in sight in 1905 .

Transportation involves cartage of 4 miles to the company's cutting mill at Rel Beach and a further cartage of one-fuurth mile to a what on st. Croix River.

The product is used entirely for monuments, of which the soldiers' monument at Calais is a specinen.

The Shattuck Monntain quarry is in the town of Calais. 3 miles westsouthwest of Red Bearh rillaye, on Shattuck Mountain. Mperator, Maine Red Granite Co., Red Beach. Quary idle. 
The granite (specimen D, XXVI, 104, b), "Shattuck Mountain," is a biotite grinite of dark redhish to greenish-gray color and medium to coarse, evengrained texture, with feldspars up to 0.5 inch and sparsely disseminated biotite under 0.1 inch. It consists, in descending order of abmdance, of a reddish potash feklspar (orthoclase), smoky quartz, greenish sola-lime feldspar (oligoclase), and black mica (biotite), together with accessory magnetite, apatite, and secondary chlorite. The oligoclase is here and there partly altered to a white mica. The smallness and sparseness of the micas are favorable to the durability of its polish.

The quarry, opened in 1890 , consister in 1905 of three openings on the south side of an east-west ridge. The principal opening measured 50 by 25 feet and from 10 to 20 feet in depth.

Rock structure: The sheets, 5 to 7 feet thick. are horizontal or dip south at a small angle. Joints, strike N. $25^{\circ}$ E., dip $60^{\circ}$ NNW., recur at intervals of 10 to 22 feet and form headings on the north and south sires of the quarry. Another set, strike N. $40^{\circ} \mathrm{W}$., dip $65^{\circ} \mathrm{W}$., forms a heating on the east side and recurs in midclle of quarry. The heading of the first set on the north is about 6 feet thick an: 1 inciudes a bed of clayey sand $S$ inches thick. It lias three sets of subjoints, one striking N. $40^{\circ}$ E., dipping $55^{\circ}$ ste, spaced 2 to 12 inehes; another striking $\mathrm{N}$. $50^{\circ} \mathrm{W}$, rertical, spaced 6 inches to 2 feet; and another striking $\mathrm{N}$. $90^{\circ} \mathrm{C}$, vertical, siaced 4 to 12 inches. The rock has no rift. The weathering of this granite has been referred to on page 70 .

Transportation, by cart 3 miles to Red Beach, on St. Croix River.

The product is used for ormanental and mommental work. Specimens: Four fiuted columns 22 by 3 feet, in the courthouse at Marquette, Mich.

The Mingo-Bailey quarry is in the town of Calais. $1 \frac{1}{2}$ miles north-northwest of Red Beach. Operators, Mingo, Bailey \& Co., Red Beach. Quarry abaulonetl.

The granite (specimen D, XXVI, 102, b) is a biotite granite of dark-reddish color speckled with pale greenish and of medium, even-grained texture, with feldspars up to 0.4 inch and sparse biotite under 0.1 inch. It consists, in descending or!er of abundance, of a dark-pinkish potash feldspar (orthoclase), very smoky quartz, a pale yellowish to greenish soda-lime feldspar (oligoclase) considerably altered to a white mica. black mica (hiotite). and accessory magnetite and zircon. The rock takes a ligh polish that exhiluits marked contrasts between the two feldspars ard the smoky quartz. The smallness and sparseness of the biotite scales favor the durability of the polish. The stone is of a lighter red than that of the Shattuck Mountain quarry, but is darker than that of the Maine Red Granite Co.'s "old quarry."

The quarry is 25 feet square by 8 feet deep.

Transportation, by cart $1 \frac{1}{2}$ miles to wharf at Red Beach.

The product is used entirely for monuments.

The Maine Red Granite Co.'s quarry is in the town of Calais. three-fourths mile west of Red Beach. Operator, Maine Red Granite Co., Red Beach. Quarry iolle.

The granite (specimen D, XXVI, 97 , a) is a biotite granite of general brightpinkish-gray color and medium, even-grained texture, with feldspars up to 0.4 inch and sparse biotite scales under 0.1 inch. It consists, in descending order of abundance, of a pinkish potash feldspar (orthoclase), smoky quartz, cream-colored soda-lime feldspar (oligoclase), and black mica (biotite), together with accessory magnetite and zircon. The oligoclase is partly altered to kaolin and a white mica. The stone takes a high polish, the durability of which is favored by the sparseness and smallness of the mica scales. In weathering about the quarries the feldspars whiten from increasing kaoliniza- 
tion. Tho contrasts are chielly betwen the two feldspars and the smoky quartz. This tyo of "rorl grinite" is the brightest of those occurring in Maine.

The quary consists of two ofrenings, nue known as the "old fuary," opened in 1876 , and a new one arljacent to it. The new one was in 1905 about 150 feet square by 20 to in feet deep.

Rock structure: The sheets, 6 inches to 5 feet thick, dip $10^{\circ}-30^{\circ}$ SE. Joints, strike N. $80^{\circ} W$. d p steep morth, rexur alt intervals of 1 to 5 feet. Wthers, strike X. $40^{\circ}$ F.. dip $80^{\circ}$ SE., recur at intervals of a inches to 5 feet. The falces of this set are coated with calcite and (phidote. There is no rilt whateror. It is ovident from the frequent reeulpence of both sets of joints and the small range in thickness of the sheets that the conditions ale not favorible for quarrying latre blocks. John F. Wolfe " refers to the structure of "Redbeach granite."

Transportation, by eart, three-fourths mile to whari on St. Croix River. The company's cutting and jolishing works are one-fourth mile west of red Beach.

The product is used entirely for momumental and ornamental work.

The Red Beach Granite Co.'s quarry is in the town of calais, on Cooks Mountain, $S$ miles southeast of Calais, about 1,000 feet southwest of road to

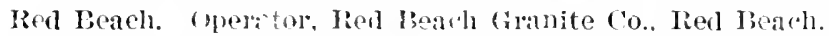

The granite is a bictite granite of general bright pinkish-gray rolor and medium eren-grained texture like that of the Maine Red Granite Co.'s quarry near Iied Beuch, described on page 266, and of the Bodwell Granite Co.'s abandoned quarry on Cooks Mountain.

The quary, opened in 1895 , is $50 \mathrm{by} 25$ feet and from 5 to 20 feet deep. The sleets, up to 5 feet thick, dip north at a low angle. Vertical joints strike N. $80^{\circ}-90^{\circ} \mathrm{F}$. forming numerous headings. There is no rift.

Transportation, by eart over half a mile to wharf on St. Croix River at Red Beach.

The product is used for buillings and monmments. Specimens: Red granite in two ecrner wings of the American Museum of Natural History, in New York; pedestal to General Grant's monument at Galena, Ill.

\section{JONESBORO.}

The Fish quarry is in the town of Jonesbore, 1 mile northwest of Jonesboro village. Owner, N. W. Fish, Jonesboro.

The granite (specimen D, XXVI, 3T, b) is a biotite granite of lavender medium-gray color and medium, even-grained texture, with feldspars generally up to 0.4 inch (exceptionally 0.5 inch) and sparsely disseminated biotite up to 0.1 inch. It censists, in descending order of abundance, of a pale lavendercolored potash feldspar (orthoclase), smoky quartz, milk-white soda-lime feldspar (oligoclase), and a little black mica (biotite), together with accessory magnetite and secondary epidote, zoisite, and calcite. The feldspars are considerably altered to white micas, and the biotite is also largely altered to chlorite. This stone resembles that of the Goss and Ryan-Parker quarries of Crotch Island (p. 224) in the lavender tint of its orthoclase, but its texture is finer. Their resemblance may be found to be still greater in lower and fresher sheets.

The quarry, a small opening about 300 feet northwest of Mr. Fish's house, has been worked only occasionally. The sheets are up to 5 feet thick and lie horizontal.

The Bodwell-Jonesboro quarry is in the town of Jonesboro, 2 miles east of Jonesboro village. Operator, Borlwell Granite Co., Rockland.

The granite (specimen D, XXVI, $86, \mathrm{~h}$ ), " Joneshoro red," is a biotite granite of general medium pinkish-gray color and of coarse, inclining to medium, even- 
grained texture. with biotite sparsely disseminated and up to 0.05 inch in dianeter. It consists, in descending ordel of abundance, of pinkish potasl feldspar (orthochase), smoky quartz, cream-colored sola-lime feldspar (oligoclase), and a little black mica (biotite), together with accessory magnetite and secondary white mica, kaolin, and ehlorite. The orthorlase is intergrown with plagioclase, and the oligoclase is here and there largely altered to a white mica and kaolin and the biotite to chlorite. The contrasts are chiefly between the two feldspars and the smoky quartz. The stone takes a fine polish, the durability of which is faroren by the smallness of the biotite scales.

The quarry, opened about 1875 , measures about 700 feet $\mathrm{N}$. $80^{\circ}$ E.-S. $80^{\circ}$ W. by 200 feet from north to sonth, and has a depth of 10 to 33 feet. Its area is irregular, as shown in figure 68. Its drainge requires occasional pumping.

Rock structure: This quarry shows a greater variety of dike courses than any wher of the Maine quaries. The sheets, 6 inches to 5 feet thick, are horizontal, with slight unclulations. The joint and dike courses are shown in figure 68. (A) recurs on the north and sonth sifes of the quarly and in the middle, and forms a heading on the sonth; (B) forms a heading on the northwest side;

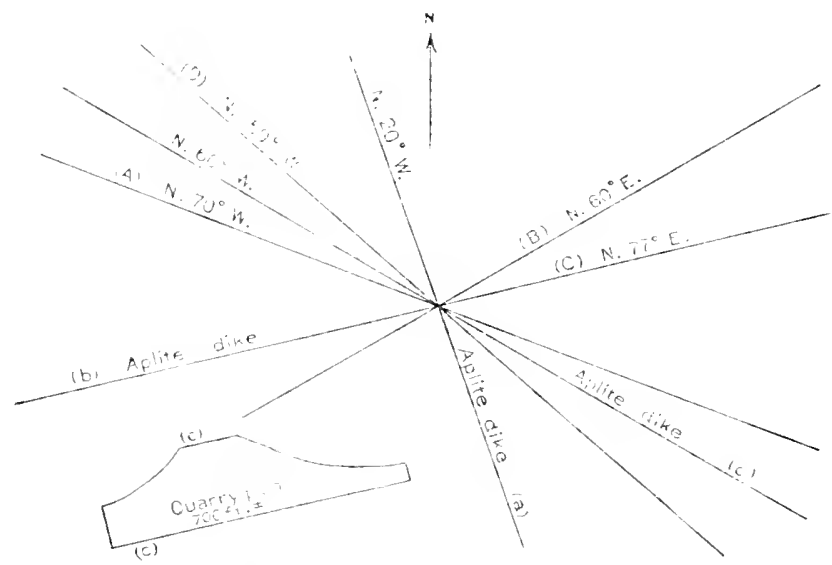

Figdre 68,-General plan and structure at the Bodwell quarry, Jonesboro, Maine.

(C) appears on the south wall, intersecting the heading; (D) dips steeply south, and also intersects the south wall. The rift is vertical, with strike $\mathrm{N}$. $70^{\circ} \mathrm{W}$. There are two dikes of reddish aplite $(a)$, one 6 feet thick, another 4 feet thick; a third $(b)$, also reddish, is 3 to 6 feet thick; a grayish aplite dike (c), 1 to $1 \frac{1}{2}$ inches thick, can be traced from 200 to 300 feet, eutting all the other dikes. Thin sections of $(a)$ are described on page 44. Knots occur up to 12 by 8 inches, but rarely. There are geodes and short veins, containing quartz, epitlote, and calcite. (See p. 62.) The sheet surfaces are in places coated with epidote from the alteration of feldspar. John E. Wolff " has referred to the "Jonesboro red granite" and some of its peculiarities.

Transportation, by cart 1 mile to wharf on Englishmans Bay. The stone is shipped to Vinalhaven for finishing.

The quarry is not in operation for want of demand for granite of this color, but it is in good operating condition.

The product has been used for buildings. Specimens: Custombouse and post office, Buffalo, N. Y.; Methodist Book Concern Building; Havemeyer residence,

b Tenth Census, vol. 10, p. 116, 1888. 
Fifth Avenue and Sixty-sixth Street, New York; customhouse and post office, Fall River, Mass.; Western Savings Bank Builling, Ihiladelphia; and (since 1905) National lank of Commerce, Kinsas City, with two 2-story froits with carred and polished surfices; Dimock family mausoleum (Egyptian style), New I,ondon, Conn.

The Booth Bros. Jonesboro quarry, in the town of Jonesboro, is 11 mites east of Joneshoro village. Operator, Bonth liros. \& Hurrieane Isle Granite Co., 20s liroatway, New York.

The granite (sivecimen D, XXVI, 85, b), "Jonesburo ret," is a hiotite granite of general medium pinkish-gray color and coarse, incliuing to a medium, evengrained texture, with slarsely disseminated biotite up to 0.05 inch in dianneter. It consists, in descending order of abundance, of a pinkish potash fellspar (ortloclase), a litle less pink than that of specimen S6, h, from the Rodwell quarry, smoly quartz, cream-colored sola-lime feldspar (oligoclase), and black mica. (biotite), together with accessory magnetite and secondary white micas. zoieite, and chlorite. The orthoclase is here and there intergrown with a plagioclase. The oligoclase is largely altered to a white mica and kaolin, and the biotite to chlorite. The contrasts are between the two fellspars and the smoky quartz. The stone takes a high polish, the durability of which is favored by the suallness of the hiotite plates. Its general color is not quite so piukish as that of the rooiwell quarry.

The fullowing chemical analysis of this graute was made hy licketts \& Banks, of New York (No. 10072), and is yiven hore merely for the purpose of reference:

\section{Ainalysis of granite from Joneshoro quarry.}

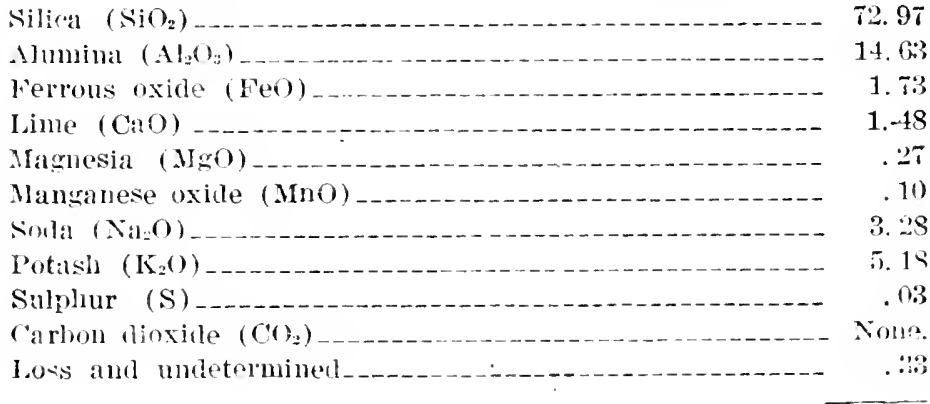

100.00

The quary is of triangular arra, abont $10 \mathrm{by}$ is hy 75 feet and 30 feet deep. Rock structure: The slieets, 5 to 10 feet thick and lenticular, lie horizontal or dip $5^{\circ} \mathrm{XW}$. or $5^{\circ} \mathrm{SIC}$. A vertical joint, strike N. $60^{\circ} \mathrm{W}$, forms the wall on the sontluwest. A set striking N. $35^{\circ}-50^{\circ} \mathrm{F}$. forms beadings on the northwest and sontheast and recurs at intervals of $5,10,20$, and 70 feet. Its faces are coated with lematite. The rift is vertical, with strike $\mathrm{N} .60^{\circ} \mathrm{W}$. The grain is horizontal. Knots are small and infrequent. Sap up to 3 inches th:ck is connred to headings. The structural conditions are unfarorable for quarrying liare blocks.

Transportation, along a track one-third mile to wharf on Englishmans Bay.

The quarry is not in operation.

The product has been used for building. 


\section{JONESPORT.}

The Minerva Cove quary is in the town of Ismfsprt wi the north sige of Head Harbor Island, about $3 \frac{3}{2}$ miles sontleast of Jonespert. Quarry no longer operated.

The granile (specimens I, XXYI. S8, a. and Ss. Ju is a bontits granite which in the lower sheets is of general dark reddish-gray colow. With beth a pinkinh and a greenish feldspar, but in the mprer sheets has a white instead of a

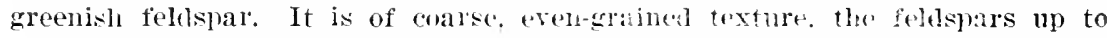
an inch in length and the biotite up to 0.2 inch. It consists. in descendin

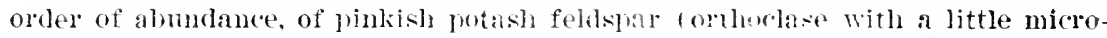
cline), smoky quartz. dull greenish or milk-white sotia-lime felrspar (oligoclase) and black mica (biotite) in compieum flakes, togetlier with aecessory magne'ite. lyrite, titanite, and apatite. The ortloclase. senerally in twins is intergrewn with plagioclase. The oligodase is largely altered to white mica and kaolin, paiticularly in the nuper sheets. where it has fascel from green to white. The quartz is clow?y from the presence of multudes of irregular bubbles, the largest of whirh measure 0.01 mill:me er, ol about 0.0004 inch in length. It is also traversed by irregulor fissures containing sericite. Some of the pinkish ortholase is rimmed with white or greenish ohimolase or completely envelops a greenish oligoclase crystal. The contrasts are feeble in the granite of the lower sherts, owing to the darkness of the oligoclase and quartz, but are marked in that of the upuer sheets. the four minerals all differin: in shade.

The qualy consists of five (1) eniuss- 11) $1(4)$ hy 25 and 14 feet deep; (2) 50 by 25 and 40 feet deep: (3) 300 by 70 and 35 feet deep : 44 triangnlar, 100 by 150 by 75 feet deep, with working lace 3.5 feet high; 1.31 ind by 25 and 20 feet deep.

Rock struciure: The sheets at the mper upening. 2 to 22 feet thick but nsually 5 to 15 feet, dip $10^{\circ}$ NE. Vertical joints striking N. $10^{\circ}$ E. or nortl form a heading on the east and recur at intervais of 5 to 10 feet. Another set strikes east and dins $60^{\circ} \mathrm{s.}$. and one which nlay belong to it strikes $\mathrm{N} .80^{\circ} \mathrm{W}$. and dips $90^{\circ}$. The rift is horizontal; the grain vertical, striking north. Dikes of aplite up to an inch thick have $\mathrm{X}$. $60^{\circ} \mathrm{E}$. courses.

Transportation, by cart 700 fect and 50 fert down grade from upper open. ing to wharf. From the opening at the whirf stones are loaded hy derricks directly on schnoners.

The product was used for huildings. Specimens: Colorado Building, at Fonrteeth and $G$ Streets, Washington; Statr armory. Providence, R. I.; power holise of the Metropolitan Street Railway (Intermban), Ninety-fifth to Ninetysixth Streets and First Avenue to Hudson River. New York.

The Hardwood Island quarry is in the town of Jomespurt, on Harlwood Islant, which lies $3 \frac{2}{2}$ miles sonthwes of Joheprot village. Operator, Rockport Granite Co., Rockiont, Mass.

The granite (specimen I, XXVI, 90, a ?. "sinese-a-bec red." is a biotite granite of general dark reddish-gray color, with a white and a pinkish feldspar, and of coarse, even-grained texture, like that of specimen \&s. a, from Head Harbor IsJant, described above, but with an occasional isolated feldspar.

The Rosiwal method was allubed to a slecinen of this smante with a polished face 5 by 3 inches. The size of mesh was 0.9 inch: total length of lines, 10.20 inches. Owing to the irregular massing of the foldspar in the specimen a second test was mace with the short set of lines shifted onefourth inch, and the long set adjusted accordingly. The results of both tests were averaged for the final estimate. 
Sizes and percentages of minerals in granite from Marduood Islam, as determined by the Rosical method.

\begin{tabular}{|c|c|c|c|c|}
\hline Mincral. & lirst test. & Second & \multicolumn{2}{|c|}{ Averages. } \\
\hline 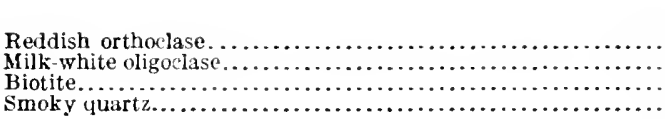 & $\begin{array}{r}\text { Inches. } \\
10.12 \\
8.00 \\
1.72 \\
20.36\end{array}$ & $\begin{array}{r}\text { Inches. } \\
12.46 \\
8.2 .1 \\
1.54 \\
17.96\end{array}$ & $\begin{array}{r}\text { Inches. } \\
11.29 \\
8.12 \\
1.63 \\
19.16\end{array}$ & $\begin{array}{r}\text { Per ecnt. } \\
23.85 \\
22.45 \\
4.05 \\
44.65\end{array}$ \\
\hline & 40.20 & 40.20 & 40.20 & 100.00 \\
\hline
\end{tabular}

Percentage of both feldspars, 51.30 .

This granite takes a fme polish, in which the contlists between the pinkish and white feldspars and the black mica stand out on the hackgromal of smoky quartz. Some of the pinkish feldspars are bordered hy the white. The large size (usually 0.1 inch) of the hotite scales is against the durability of the polish under long-continued outilour exposure.

The quarry measured in 1905150 by 60 feet and 15 feet in depth, but its bottom was between tide levels. There is no stripling.

Iiock structure: The sheets, 2 to 10 feet thick, are horizontal but in places curve seaward. Joints, strike N. $75^{\circ} \mathrm{W}$., dip $65^{\circ} \mathrm{S}$., recur only at rare intervals. Others, strike $N .45^{\circ}$ W. and rertical, recur at intervals of 18 feet and over. The rift is vertical, with strike $\mathrm{N} .10^{\circ} \mathrm{E}$. Dikes of aplite up to 6 inches thick strilie N. $25^{\circ} \mathrm{W}$.

Transportation. by lifting the blocks onto the wharf, which is 125 feet from the quarry.

The product is used for buildings. Specimens: Wainscoting and stairway in main entrance to Suffolk County Courthouse, Boston; the American Baptist Publication Society Building, Philadelphia; 25 columns in the Catholic Cathedral in Newark, N. J.; Germania Life Insurance Puilding, New York; Miami Hotel, Dayton, Ohio; Cuyahoga Hotel. Cleveland, Ohio; Old State Tational Bank, Evansville, Ind.; (ity haths, Kansas City, Mo.

\section{MARSHFIELD.}

The Marshfield quary is in the town of Marshfield, 3 miles north of Machias. Operators, Butler \& Berry, Machias.

The granite (specimen $\mathrm{D}, \mathrm{XXVI}, \mathrm{S4} . \mathrm{h}$ ) is a biotite granite of medium pinkishgray color and of medium to fine, even-grained texture, with feldspars from 0.1 to 0.4 inch and sparsely dissenninated biotite under 0.1 inch in diameter. It consists, in clescending order of abundance, of pinkish potash feldspar (orthoclase). smoky squartz, trean-colored soda-lime feldspar (oligoclase), and a little black mica (biotite), together with accessory magnctite, titanite, and zircon and secondary kaolin, white nicas, and chlorite. The orthoclase is intergrown with plagioclase, the oligoclase is much altered to kaolin and a white mica, and the biotite is partly chloritized. Molybdenite occurs here and thre. The grinite is slightly less pinkish than that from the quarry of Booth Jiros. at Joneshoro (specimen 85, b). The contrasts are also reduced by the greater fineness of the particles. It takes a fine polish, tle durability of which is farored by the sparseness and smallness of the biotite scales.

The quarry, olened about 1594, measured in 1905200 by 150 feet and 2 to 10 feet in depth. 
Rock structure: The sheets, 1 to 8 feet thick, dip irregularly up to $10^{\circ} \mathrm{SW}$. and NIV. Vertical joints, strike N. $55^{\circ}$ K., form headings on the north and south sirles. Another set, strike N. $60^{\circ} W^{\circ}$, dip $70^{\circ}$ SW. to $90^{\circ}$, forms headincs near the east sicle and recurs at intervals of 10 to 50 fect. A third and diagmal set, strike No. $85^{\circ} \mathrm{F}$, dip $55^{\circ} \mathrm{N}$., recurs irregularly. There is some "toeing in " of sheets, probably owing to faulting along the set of joints striking N. $55^{\circ} \mathrm{L}$. The faces of the second set are conted witl epidote, and those of the third with pyrite. The rift is horizontal. There are geodes (up to 6 inches thick) of orthoclase and oligoclase, smoky quartz, amethyst, and pyrite filled with calcite, epirloie. and chlorite. Sap is 2 inches thick in the upper sheets only.

'Trinsportation, by cart 3 miles to railroad or wharf at Machias.

The product is used for monuments and buildings. Specimens: Basement front and steps of E. S. Draper residence, Beacon Street, Boston; also monuments for Bostou and for local demand.

\section{MILLBRIDGE.}

The Millbridge quarry is in the town of Millbrilge, near Millbridge village, in the southwestern part of Washington County. Operators, Swanton \& Wallace, Millbridge. Quary abandomerl.

The granite (specimen D, XXVII, 143, a) is a biotite granite of medium buff color and of nedimm, even-grained texture, with feldspars up to 0.3 inch rexceptionaly 0.5 inch) and biotite seales under 0.1 inch. It consists, in descending order of abundince, of a bufi-colored potash feldspar (orthoclase), smoky quartz, very slightly greenish-white soda-lime feldspar (oligoclase), and black mica (biotite), together with accessory magnetite and apatite. The quartz his numerous rery irregular bubbles up to 0.028 millimeter in length. The orthoclase is intergrown with a plagioclase. Granulation ("crush borders") occurs along the contacts of the feldspars with one another. The stone takes a high polish, the durability of which is favored by the smallness of the biotite scales.

Some tests of a Millbridge granite, quarried at White Rock Mountain by S. L. Treat \& Co., were made in 159.5 by the United States Ordnance Department at the Watertown Arsenal. ${ }^{6}$ These give it a shearing strength of 2,820 pounds, a transverse strength of 2,069 pounds, and a compressive strength of 19,917 pounds to the square inch.

The Millbridge quary was not visited by the writer, and the firm failed to reply to questions as to dimensions of quarry and product.

\section{YORK COUNTY.}

ALFRED.

The Bennett quarry is in the town of Alfred, 1 mile southwest of Alfred village, south ot the Portland \& Rochester Railroad, at the north foot of a 480-foot hill. Operator's in 1905, Bennett Bros, Alfred. Quarry no longer operated.

The rock (specimen D, XXVII, 153, a) is a quartz diorite of slightly greenish dark-gray color, with conspicuous black mica, and of medium, even-grained texture, with feldspars up to 0.25 inch and biotite scales under 0.2 inch. It consists, in descending order of abundance, of a grayish soda-lime feldspar

- Tests of metals, etc., for 1895 , pp. 319, 325, 344, 409, 1896. 
(oligoelase), black mica (biotite), quartz (smoky or milky), dark hornhlende and magnetite, with accessory titanite, zireon, apatite, and secondary epidote and a white miea. The oligoclase is often in goot-sized twins and is intergrown with orthoclase and quartz and generally cloudy and altered by a white mica. The only contrast in this stone is that between the gray of the feldspar and quartz and the black of the miea. After one or two years' exposure the feldspar loses its slightly bluish tinge and assumes a greenish one, which is attributed to the oxidation of its ferrous oxide. (See further p. 76.)

The quarry, opened prior to 1875 , measured, in 1905,60 by 150 feet and up to 30 feet in depth.

Roek structure: The sheets, un to 12 feet thick, and inclined, are crossed by vertical joints, strike N. $70^{\circ}$ E., recurring at intervals of 10 feet and forming a heading $S$ feet wide in center of quarry. Another set, also vertical, strike $N$. $20^{\circ}-25^{\circ} \mathrm{W}$., recurs at intervals of 20 fcet. The rift is horizontal, and the grain vertical, with strike N. $70^{\circ} \mathrm{E}$. The sip is 2 inches thick along the sheets. A rertical bed of sand, 6 inches thick, lies in the central heading.

Transportation, by cart 1 mile to Alfred railroad station.

The product was used for eurbing and buildings. Specimen: Parsons Memorial Library, Alfred village.

\section{BERWICK.}

The Spence \& Coombs quarry ("black granite") is in the town of Berwick, $1 \frac{1}{2}$ miles southeast of North Berwick village and station. Operators, Perry Bros., Concord, N. H.

This rock (specimen D, XXVII, 139, a) is a gabbro of very dark olivebrownish color and medium ophitie texture, consisting. in descending order of abundance, of longitudinal crystals of grayish olive-brownish lime-soda feldspar (labradorite) between which are particles of diallage, black micil (biotite), magnetite, and a little pyrite, together with secondary hornblende, analcite, zoisite, and calcite. The freshly quarried stone becomes somewhat brownish on exposure. It takes a high polish, and the cut or hammered surface is light gray.

The quarry consists of two openings, in 1905 about 25 feet square by 5 to 10 feet deep.

Rock structure: The sheets, 6 to 8 feet thick, lie nearly horizontal and are crossed by vertical joints striking $\mathrm{N} .25^{\circ}-30^{\circ} \mathrm{W}$. and by another set striking N. $45^{\circ}$ E. and dipping $65^{\circ} \mathrm{SE}$. and recurring at intervals of 6 to 20 feet.

The quarry is worked only occasionally, and the stone is used entirely for monuments.

The Miniutti quarry ("black granite") is in North Berwick, in the township of Berwick. Operators, Miniutti Bros. \& Co., Concord, N. H. Idle in 1922.

The granite (specimen D, XXXVIII, 27, a) "North Berwick blaek granite," is a gabbro of very dark olive-greenish color and ophitic medium texture, with feldspars up to 0.4 inch. It consists, in descending order of abundance, of olive-brownish lime-soda feldspar (labradorite), diallage, hornblende, biotite, nlagnetite, quartz, and very little pyrite. Secondary minerals are the hornblende, zoisite, chlorite, ealcite. It takes a high polish, and the polished face has an extremely dark olive color and shows in oblique light many grains of magnetite. The cut or hammerer face is light gray.

The quarry was opened about 1912.

The stone is used for inscribed monuments.

105709-23-19 
BIDDEFORD.

The Ricker quarry is in Biddeford city, at 19 Granite Street. Operator, George H. Yates, Biddeford.

The granite (specimen D, XXVII, 129, a) is a biotite granite of general lightgray shade with conspicuous smoky quartz and slightly bluish-white feldspar, and of coarse, even-grained texture, with feldspars up to 0.75 inch and biotite under 0.2 inch. It consists, in descending order of abundance, of a slightly bluish milk-white potash feldspar (microcline and orthoclase), dark smoky quartz, milk-white soda-lime feldspar (oligoclase), and black mica (biotite), together with accessory nagnetite, zircon, and apatite and secondary white mica and kaolin, derived from the alteration of the oligoclase. The contrasts in this granite are unusually brilliant. They are between the white of the feldspars, the gray of the very vitreous quartz, and the black of the mica. The stone takes a fine polish, but the largeness of the biotite scales does not favor its durability under exposure to the weather.

The quarry, opened in 1865, was in 1905100 by 50 feet and from 5 to 25 feet deep.

Rock structure: The sheets, up to 12 feet thick, are crossed by joints, strike N. $50^{\circ}$ E., dip $55^{\circ} \mathrm{NW}$., which recur at intervals of 2 to $20 \mathrm{feet}$, and by a set striking N. $45^{\circ} \mathrm{W}$. and dipping $60^{\circ} \mathrm{S}$. W., which recur at intervals of 2 to 10 feet and over.

Transportation, by cart 1 mile to railroad.

The product is used for monuments, etc.

The Gowen Emmons quarry is in Biddeford eity, at 17 Granite Street. Operator, Frank Morin, Biddeford.

The granite (specimen D, XXYII, 128, a) is a biotite granite of general lightgray shade, with conspicuous smoky quartz and slightly bluish-white feldspar,

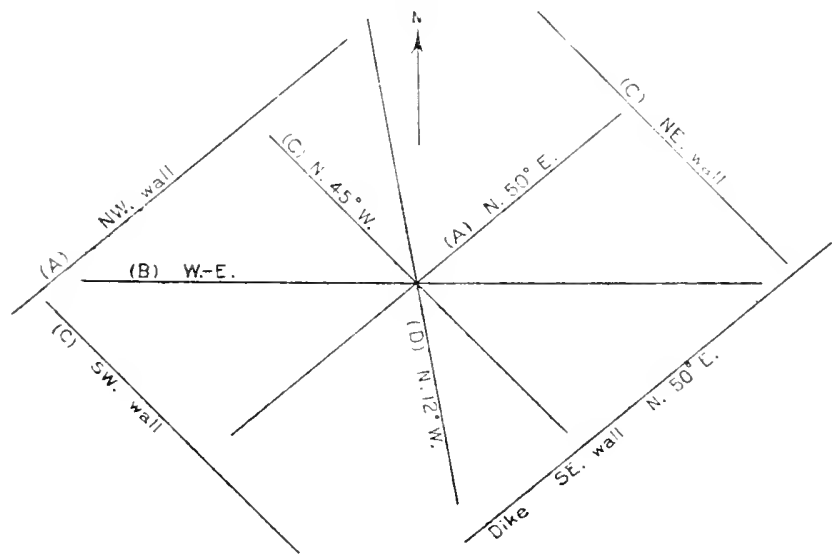

Figure 69.-Structure at the Gowen Emmons quarrp, Biddeford, Maine.

and of coarse, even-grained texture, with feldspars up to 0.75 inch and biotite under 0.2 inch. It is identical with that of the Ricker quarry (specimen 129, a), described above. In the sheets nearer the surface the feldspar is slightly grayish or greenish, diminishing the contrasts.

The quarry, opened about 1865, consisted in 1905 of two openings, an old one 200 feet from northeast to southwest, 100 feet across, and from 30 to 70 feet deep, and a new one 250 feet from northeast to southwest, 200 f $: 2 \cdots 0$ s, and 10 to 60 feet deep. 
Rock structure: The sheets, 1 to 12 feet 6 inches thick, increasing in thickness downward, undulate horizontally. The joint courses are shown in ficure 69. (A), dip $55^{\circ} \mathrm{NW}$, recurs at intervals of 2 to 20 feet; (B), dip $70^{\circ}$ S., occurs exceptionally; (C), dip $60^{\circ} \mathrm{SW}$., forms the northeast and southeast walls and recurs at intervals of 2 to 10 feet or more; $(D)$, dip $65^{\circ} \mathrm{l}$, oceurs axceptionally. The rift is rertical, N. $60^{\circ} \mathrm{W}$; the grain is horizontal. On the southeast wall there is a basic dike up to 1 foot thick and nearly rarallel to joints (A). Black knots occur up to 6 inches across. Sap is 6 inches thick on both sides of upper sheets but diminishes below.

Transportation, by cart 1 mile to railroad.

The product is used for buildings and monments. Specimens: Hospital, Dover, N. II.; Lincoln Monument, Springfield, Ill.

The Wormwood quarry is in the town of Biddeford, 1젼 miles southwest of Biddeford city, in West Biddeford. Operators, Ira T. Wormwood \& Sons, Biddeford. Idle since 1916.

The granite (specimen D, XXVII, 130, a) is a biotite granite of general medium pinkish-buff color and of coarse, even-grained texture, with foldspars up to 0.75 inch and biotite up to 0.15 inch. It consists, in descending order of abundance, of a pinkish-buff potash feldspar (microcline and orthoclase), dark smoky quartz, cream-white soda-lime feldspar (oligoclase), black mica (biotite), and a very little muscovite, together with accessory magnctite and secondary epidote, chlorite, baolin, and white micas. The oligoclase is considerably altererl to kaolin, a white nica, and epidote, and the biotite to chlorite. The contrasts in this stone are chiefly between the pinkish-buft and white feldspars and the smoky quartz, to which the black mica adds another element. As some of the potash feldspars are more pink and others more huff, it has in all five colors and shades.

The quarry is 40 by 20 feet and 6 to $S$ feet deep.

Rock structure: The sheets, 7 feet thick (increasing to 15 feet lower down the hill), are crossed by vertical or steep joints, strike N. $80^{\circ}-85^{\circ} \mathrm{W}$., which recur at intervals of 20 feet, and others strike N. $40^{\circ}$ E. which recul at intervals of 35 feet with headings. Sap is 1 to 2 inches thick along the top sheet, but 4 inches along the headings. A bunch of knots up to $S$ inches thick and of egg-shaped outline was noticed.

Transportation, by cart 1 mile to railroad siding.

The product is used for buildings. Specimen: Trimmings on St. Joseph's Church, Biddeford. (Material for the dry dock at Charlestown, Mass., was quarried at an old adjacent opening.)

The Andrews quarries are in the town of Biddeford, about $1 \frac{1}{2}$ miles southeast of Biddeford city and half a mile south of Saco liver. Operator, George Willett Andrews, Biddeford. Quarry abandoned.

The granite (specimen D, XXVII, 133, a) is a biotite granite of general lightgray color, with conspicuous black mica, and of coarse. even-grained texture, with feldspars up to 0.75 inch and biotite up to 0.2 inch. It consists, in descending order of abundance, of a translucent bluish-white potash feldspar (microcline and orthoclase), light smoky quartz, milk-white soda-lime feldspar (oligoclase), and black mica (biotite), together with accessory magnetite, titinite, zircon, and apatite and secondary kaolin and a white mica derived from the alteration of the oligoclase. The feldpsars are considerably intergrown with quartz, some circular in cross section. The contrasts are between the feldspars, quartz, and mica. The feldspar is more bluish than that of the Ricker and Gowan Emmons quarries. 
The quarries, opened in 1862 and again in 1895, consist of six small openings of various dimensions, only one of which-a "boulder quarry"-was worked in 1905.

Rock structure: The rift is horizontal, and the grain vertical, striking northwest-southeast, but the difference between them is not marked. The jointing perwits the quarrying of blocks up to 25 feet square. Sap is 2 inches thick. Knots in some of the openings are up to 3 and even 10 feet long.

Transportation, by cart half a mile to Saco River, or 2 miles to railroad at Biddeford.

The product is used for buildings, monuments, etc. Specimens: Tribune Building, New York; General Dix monument, Fort Monroe, Va.; foundation and trimmings of Watson \& Miller Building, Portland, Maine. This quarry has furnished granite for the Delaware and Saco River breakwaters and curbing for Dover and Rochester, N. H.

\section{HOLLIS.}

The Bear Hill quarry is in the town of Hollis, on Bear Hill, 1 mile westsouthwest of Bradbury station (Hollis Center), on the Portland \& Rochester Railroad. Operator in 1905, E. M. Bradbury, Hollis Center. Quarry disused.

The granite (specimen D, XXVII, 136, a) is a biotite-muscovite granite of medium to light gray shade with a slight greenish tinge, evenly spangled with black and white mica, and of medium, inclining to fine, even-grained texture, with feldspar up to 0.3 inch and mica up to 0.1 inch. It consists, in descending order of abundance, of a grayish potash feldspar (orthoclase and microcline), glightly smoky quartz, grayish soda-lime feldspar (oligoclase), black and white mica (biotite and muscovite), with accessory apatite and a secondary white mica, As the quartz is about of the same shade as the feldspar, the only contrast is between the gray ground and the micas.

The quarry, reopened in 1901 (begun in 1855), consists of an older opening of irregular shape, from which about 700 cubic yards have been quarried and an acre stripped, and a later opening 50 feet square and 5 to 10 feet deep.

Rock structure: The sheets are lenticular, up to 6 feet thick, and horizontal. Vertical joints, strike $\mathrm{N}$. $55^{\circ} \mathrm{W}$., form a heading on the southwest; other joints, strike $\mathrm{N} .30^{\circ}-35^{\circ} \mathrm{E}$, recur at intervals of 30 feet or more. The rift (horizontal) is marked, and the grain is vertical, striking east. Pegmatite dikes, up to 6 feet thick, strike N. $10^{\circ}-20^{\circ} \mathrm{W}$., recur at intervals of 30 feet or more and in places branch. They consist of quartz, feldspar, biotite, and muscovite. A basic dike, 1 to 12 inches thick, with a course N. $30^{\circ}$ E., traverses the entire quarry, crossing the pegmatite dikes. The sap is marked on the upper sheet and also along the joints and up to 6 inches thick.

Transportation, by cart one-fourth mile to railroad.

The quarry produced stone for the foundation of a pulp mill (Bar Mills) and for a dam on Saco River.

\section{KENNEBUNKPORT.}

The Day quarry is in the town of Kennebunkport, 3 miles southwest of Biddeford. Operators, A. H. Day \& Co., Bidileforl. Idle since 1913.

The granite (specimen D. XXVII, 131, a) is a biotite-muscovite granite of medium-gray shade, with conspicuous black mica, and of coarse, even-grained texture, with feldspars up to an inch across and biotite scales up to 0.2 inclu. It consists, in descending order of abundance, of a gray, in places very slightly buff-pinkish, potash feldsnar (microcline and orthoclase), very smoky quartz, milk-white soda-lime feldspar (oligoclase), black mica (biotite), with a little white mica (muscovite). The contrasts in this granite are marked. 
The quarrs, opened about 1899 , was in 1905 50 feet square and 25 to 30 feet deep.

Rock structure: The sheets, 4 to 14 foet thick, dip $10^{\circ}$ E. .Toints, strike north, dip $60^{\circ} \mathrm{W}$., form a heading on the west and lecur at intervals of 30 feet or more. One striking northwest dips $80^{\circ} \mathrm{SW}$; another strikes N. $80^{\circ} \mathrm{E}$., and still another strikes northeast and dips $40^{\circ}$ SE. This is a "houlder quarry." The rift is horizontal, and the grain N. $70^{\circ}-75^{\circ} \mathrm{W}$., but they are not marked. Sap, 2 to 3 inches thick, oceurs along the joints.

Transportation by cart 1 mile to railroad siding.

The product is used for bridge work, and some of it wis used in the dry dock at Kittery, Me.. and some for bridges on the Iuston \& Maine Railroad.

The Ross quarry is in the town of Kemphunkport, 31 miles southwest of Biddefort. Operators in 1905, Ellis \& Buswell, Woburn, Mass. Quarry no longer operated.

The gramite (specimen D, XXVII, 132, a) is a biotite granite of general light-gray shade, with translucent milky-white feldspars, dark, smoky quartz, and black mica, and of coarse, even-grained texture, with feldsyars up to 1 inch across and hiotite scales under 0.2 inch. It is similar to that of the Ricker and Gowan Emmons quarries, described on page 274.

The quarry, opened in 1887 , was in 1905 about 200 feet square and 35 feet deep.

Rock structure: This is a trpical "boulder quarry." with irregular joints, as shown in figure 70 . The sheets, 14 to 22 feet thick, are

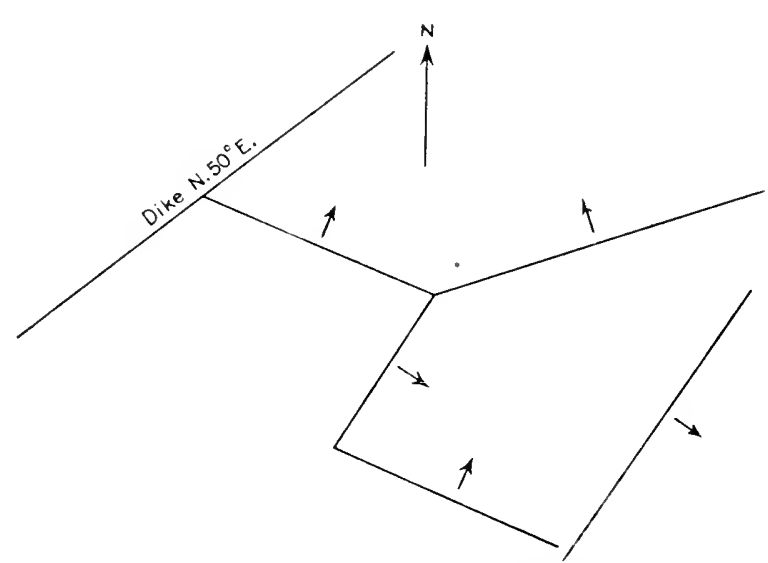

Figure 70.-Approximate structure at Ross (Ellis \& Buswell) "bouider quarry," Kennebunkport, Maine. The small arrows show the direction of dip of joints.

horizontal or dip $30^{\circ}$ E., but irregularly. A basic dike, 10 inches thick, forms the northwest side of the quarry and is said to continue for one-fourth mile N. $50^{\circ}$ E. The joints run in four directions, none of them at right angles to another and none of them vertical. Sap is 3 to 6 inches thick along the sheets. Knots up to 6 inches thick are not abundant.

Transportation, by cart one-third mile to siding on Boston \& Maine Railroad.

The product was used mostly for bridge work. Specimen structures: Gateway at Hope Cenletery, Kennebunk, Maine (except the balls on the posts) ; Renwick tomb, cemetery near Kittery, Naine; railroad bridge, Haverhill, Mass.

\section{WELLS.}

The Lord quarry is in the town of Wells, about 1 mile east-northeast of Wells Depot on the Boston \& Maine Railroad (eastern division), near a school house at a road fork. Operator, Granville IV. Lord, Wells Depot. Idle since 1915.

The granite (specimen D, XXVII, 138, a) is a biotite granite of light pinkishgray color, with sparse conspicuous biotite, and of medium to coarse, evengrained texture, with feldspars up to 0.5 inch and biotite scales up to 0.2 inch. 
It consists, in descending order of abundance, of a delicate pink potash feldspar (microcline and orthoclase), with slightly smoky quartz, cream-white sodalime feldspar (oligoclase), and black mica (biotite), together with accessory magnetite and zircon and secondary white mica and chlorite. The potash feldspars are both intergrown with plagioclase. The oligoclase is intergrown with quartz in particles circular in cross section and is partly altered to a white mica and the biotite to chlorite

The stone takes a good polish, but the large size of the biotite scales is not favorable to the durability of the polish in outdoor exposure. The contrasts are chiefly between the grayish-pinkish ground and the black mica.

The openings are small. The sheets, 1 to 3 feet thick, are horizontal. Vertical joints strike N. $10^{\circ}$ E. and N. $70^{\circ} \mathrm{W}$. The rift is horizontal. Sap is 2 inches thick along the sheets.

\section{MASSACHUSETTS.}

\section{DISTRIBUTION OF GRANITE-QUARRYING CENTERS..}

The chief commercial granites of Massachusetts are in the counties of Essex (Rockport, Peabody, Middlesex (Graniteville, Westford), Norfolk (Quincy), Bristol (Fall River, New Bedford), and Worcester (Milford, Uxbridge). The location of the quarrying centers and isolated quarries is shown in Plate XXIII. The areal extent and probable geologic age of the granites will be found on the recently published geologic map of the State. ${ }^{7}$

A brief reference to the geology will preface the quarry descriptions of each granite center. The counties will be taken up, as in the other States, in alphabetic order. Some counties have only one or two quarries.

\section{THE QUARRIES, THEIR GRANITE AND FINISHED PRODUCT.}

\section{BERKSHIRE COUNTY.}

The quarries in Berkshire County are in the towns of Becket and Otis. These towns are on the southern continuation of the Green Mountain range in the east-central part of the county. The range attains thereabouts elevations of 1,750 and $1,8+5$ feet, but is deeply cut by south-southeasterly valleys, through which flow branches of Westfield River, and by minor north-south and eastwest tributary hollows.

\section{GEOLOGIC RELATIONS.}

The geology of the region has been described by Emerson. 8 There is a large area of Becket granite gueiss, in places, however, with very slight gneissic structure. This is regarded as of Archean age, although similar fine-grained greisses in the same range in Vermont are probably Algonkian. At the quarry in Becket the granite is in contact with an overlying mass of black schistose quartz-mica diorite containing both potash and soda-lime feldspar, and along

${ }^{7}$ Emerson, B. K., Geology of Massachusetts and Rhode Island: U. S. Geol. Survey Bull. 597, pl. 10, 1917.

Idem, pl. 10, pp. 153, 154, 1917 . 


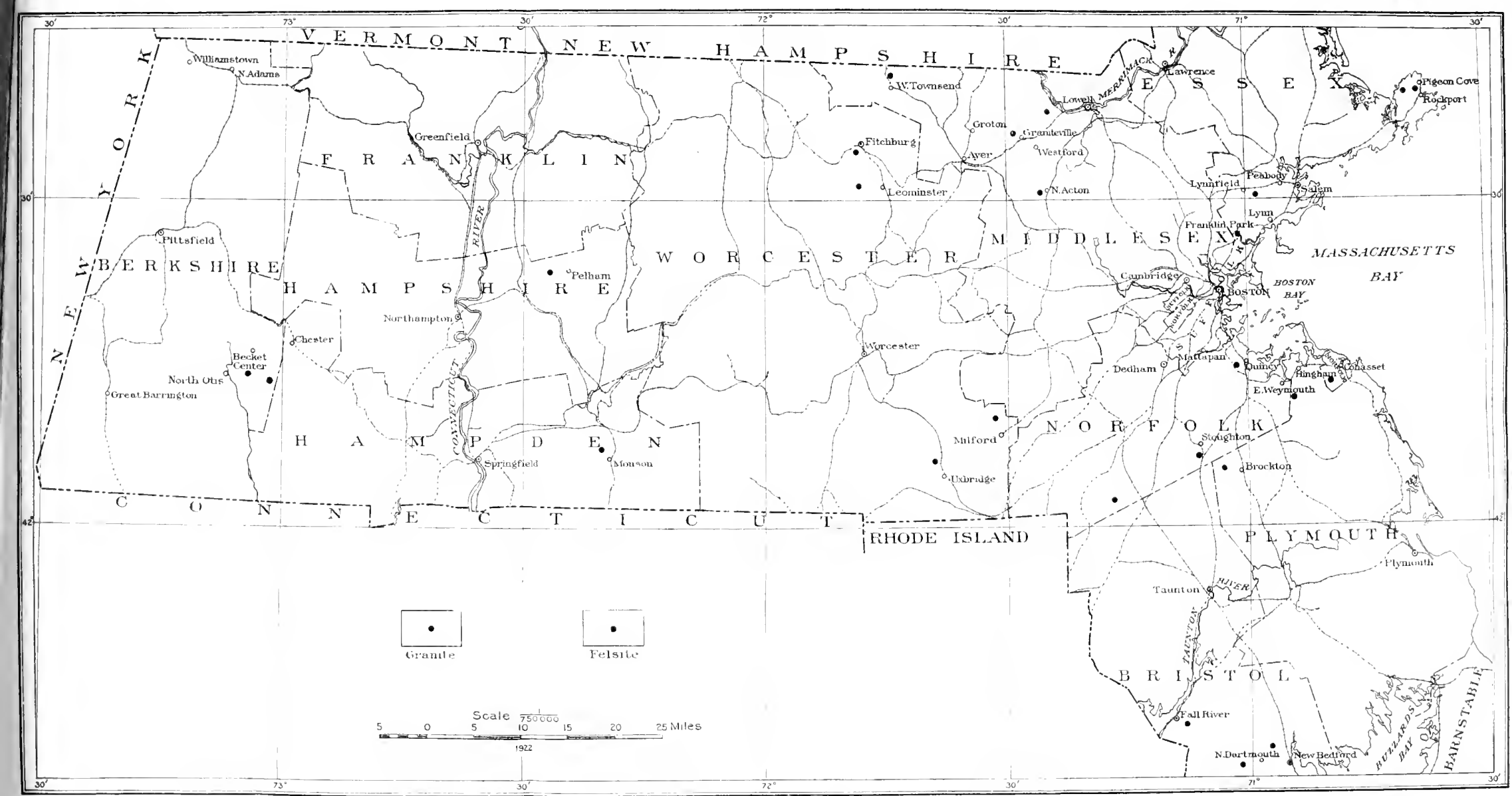



the contact the granite has a banded flow structure. Emerson regarls this rock (Lee quartz diorite) "as a contact zone of the Becket granite gneiss and to have originated by differentiation in place." The field observations indicate either the inclusion of a large mass of the cliorite scliist by the granite or else an intrusion of the granite in all overlying cliorite schist. At the quarry in Otis, besides the Becket granite gneiss, plicated schist a few feet thick, of uncertain age, is exposed.

\section{BECKET.}

The Hudson \& Chester quarry is in the town of Becket, 1 mile west of longitude $73^{\circ}$ and latitude $42^{\circ} 15^{\prime}, 1,400$ feet above sea level, 23 miles southwest of Chester, on the Boston \& Albany Railroatl. (See Becket and Chesterfield topographic maps, U. S. Geol. Survey.) Operator, Chester Granite Quarries Co., Chester.

The granite (specimens D, XXIX, $91 \mathrm{f}, \mathrm{g}, \mathrm{k}$ ), "Chester dark" and "Chester light," is a muscovite-biotite granite of medium inclining to dark bluish-gray to medium bluish-gray color and of fine texture, with feldspars up to 0.15 inch and mica in very fine particles. The texture of this granite is neither exactly gneissoid, porphyritic, nor even grained. In thin section the coarser particles of quartz and feldspar are seen to lie in a somewhat micaceous matrix of very fine texture, and there is not a little granulation about the feldspars. The average diameter of the particles of this matrix, estimated by the Rosiwal method, is less than 0.005 inch, which is finer than in the finest Westerly granite (p. 407), although the stone as a whole is coarser texture than that. Its constituents, in descending order of abundance, are light bluish-gray potash feldspar (microcline, rarely orthoclase); slightly bluish quartz, with sheets of cavities (up to 0.02 millimeter in diameter) in two rectangular directions with brightly polarizing rift and grain cracks parallel to them; light bluishgray soda-lime feldspar (oligoclase-albite); white mica (muscovite); and black mica (biotite). The only difference between the dark and light varieties is in the percentage of the black mica. Accessory: Titanite, pyrite, ilmenite, allanite, fluorite, apatite, and zircon. Secondary: Muscovite, carbonate, and epidote (as rim about allanite). The amount of titanite is relatively large.

Kemp ${ }^{9}$ has described this granite.

An estimate of the mineral percentages in this granite, by the application of the Rosiwal method to a camera lucida drawing of a thin section enlarged $\mathbf{3 7}$ diameters, with a mesh of 1.2 inch and a total linear length of 25.85 inches, yields the following results :

Estimated mineral percentages in granite from Becket, Mass.

Quartz

49. 35

Potash feldspar (orthoclase 17.05, microcline 11.50)

28. 55

Soda-lime feldspar (oligoclase-albite)

15. 37

Mica (muscovite, 4.10 , biotite, 2.47)

6. 57

Titanite

.16

100.00

- Kemp, J. F., On the granite quarried at Chester, Mass.: New York Acad. Sci. Trans.. vol. 11, for 1s91-92, pp. 129-130. 
The following analysis, by Prof. L. M. Dennis, of Cornell University, is quoted by Kemp in the paper referred to:

Analysis of granite from Becket, Mass.

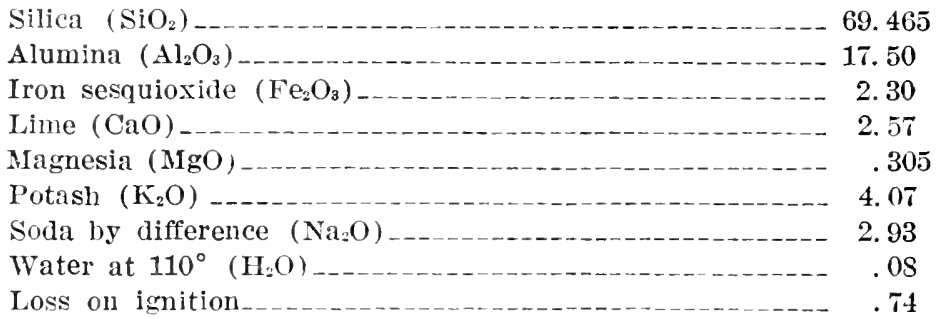

99.960

Specific gravity 2.684 to 2.688 .

George Steiger, clemist, of this survey, fiuds that this granite contains 0.53 per cent of $\mathrm{CaO}$ (lime), soluble in hot dilute acetic acid, which indicates a content of 0.94 per cent of $\mathrm{CaCO}_{3}$ (calcium carbonate), the presence of which is also shown by the microscope and by a slight effervescence with muriaticacid test.

Kemp states that a cube of this stone was tested at Columbia University by boiling in dilute muriatic acid ( 1 part of $\mathrm{HCl}$ of specific gravity 1.20 to 20 parts of $\mathrm{H}_{2} \mathrm{O}$ ) for five hours, when it was found to have lost 0.59 per cent in weight. Another boiled for the same length of time in dilute sulphuric acid (1 part of $\mathrm{H}_{2} \mathrm{SO}_{4}$ of specific gravity 1.84 to 20 parts of $\mathrm{H}_{2} \mathrm{O}$ ) gave a loss of 0.48 per cent.

Absorption and crushing tests, made at the same time and place, yielded the following results: Four cubes of specific gravities 2.688, 2.687, 2.684, and 2.688, after three weeks' soaking, absorbed $0.0021,0.0021,0.00224$, and 0.0026 per cent. The crushing test was applied to five cubes, which showed a crushing strength ranging from 25,350 to 28,841 pounds to the square inch.

The stone takes a fair polish and hammers somewhat light. The fineness of the particles precludes any marked contrast. The feldspar and quartz appear light gray, and the mica black, producing a fine mottling.

The quarry, opened in 1886, measured in 1906 about 600 feet east to west by 100 feet across and from 50 to 100 in depth.

Rock structure: The sheets are normally lenticular and horizontal, 6 inches to 30 feet thick, becoming thicker downward; but there is some irregularity in this increase in different parts of the quarry. There are two sets of joints. Those of set (a) strike N. $10^{\circ}$ E., dip $30^{\circ}-35^{\circ} \mathrm{W}$., and are spaced 18 inches to 20 feet. They are intermittent and have a thin coat of discoloration, the microscopic character of which is described on page 83 . Those of set (b) strike N. $80^{\circ} \mathrm{W}$., are vertical, and are spaced $\mathbf{1 0}$ to 25 feet, exceptionally curved so as to dip as low as $55^{\circ} \mathrm{W}$. On the north side a mass of fine-grained heavy, hard black schist, 40 feet thick, overlies the granite. It is traversed by horizontal and vertical quartz veins, the latter taking their rise at the contact with granite and tapering upward. Emerson ${ }^{10}$ in one of his earlier papers on the locality represents this mass as also overlain by the granite at one end, but that part had probably been quarrled away before the writer's visit in 1906. A thin section of this rock, crossing also a tortuous white veinlet, is

${ }^{10}$ U. S. Geol. Survey Bull. 159, fig. 16, p. $75,1899$. 
found to consist, in descending order of abundance, of quartz, with sheets of cavities and lift cracks parallel to them polarizing brightly, black mica, potash feldspar (microcline), soda-lime feldspar (oligoclase), muscovite. and hornblende. Accessory: Ilmenite, titanite, pyrite, apatite, and zircon. Secondary: Epidote, carbonate, and limonite. The white veinlets are mainly quartz and soda-lime fellspar. This rock thus appears to be a quartz-nica diorite schist, but with putash feldspar apparently exceeding the sola-line feldspar. It is an eruptive rock made schistose by pressure before the intrusion of the granite and probably formed part of the original cover into which granite was intruded. That the granite is the later rock is evident because of the marked flow structure, which, for a space of 2 feet below the diorite suhist, runs parallel to the contact surface, as has been observed in some New Hampshire quarries (p. 14). This flow structure consists of parallel white bunds from 0.1 to 0.3 inch wide, recurring at intervals of 1 inch. The gray granite between these light bands is darker than that beyond then. A thin section of one of these bands shows it to consist of quartz and feldspar, the quartz with many sheets of cavities up to 0.03 inch and with rift cracks parallel to them. In the darker bands biotite, epidote, titanite, and muscovite are very abundant. At the northeast corner the flowage bands have very sinuous courses, the rock taking on the appearance of a true gneiss. On the west side the flow structure, shown by a band of lighter granite 2 feet thick, strikes N. $55^{\circ}$ E. and dips $40^{\circ}$ SE. At the northwest corner, several feet below the granite surface, is an inclusion, 10 by 8 feet, of coarse garnetiferous muscovite-biotite gneiss with accessory magnetite, apatite, and zircon. It is a very different rock from either the granite or the diorite schist and was evidently broken off from some vverlying or adjacent formation during the granite intrusion and inclosed by the molten matter.

The rift is reported as dipping about $20^{\circ} \mathrm{W}$. and the grain as vertical, with a N. $10^{\circ}$ E. course.

At the northwest corner there is a pegmatite dike (feldspar and quartz, coarse) up to 2 feet thick, with a northwest course. In thin section the feldspar is seen to be orthoclase, with fissures from 0.37 to 1.85 millimeters wide, filled with fragments of microcline and quartz and stringers of white mica. It has evidently been subjected to pressure and some metamorphism.

Rusty stain along the sheet surfaces is 3 to 12 inches thick.

Transportation, by Chester \& Becket Railroad, a branch of the Boston \& Albany, which connects the quarry through Walker Brook hollow with the main line at Chester, a distance of $3 \frac{1}{2}$ miles. The rough stone is shipped direct from the quarry; the rest is taken to the cutting shed at Chester and reshipped there. The granite thus comes to be known as "Chester granite," although the quarry is in Becket.

The product is in regular demand for monuments in Pennsylvania, New York, and Michigan. Specimens: Dr. Hoover monument, Chambersburg, Pa.; McCormack monument, Pittsburgh, Pa.; W. A. Harder monument, Hudson, N. Y.

\section{OTIS.}

The Newall quarry is in the town of Otis, about 2 miles west-sonthwest of the Hudson \& Chester quarry and a mile north of Church Hill, 1,760 feet above sea level, about 3 miles northeast of otis village. The opening is a little south of the highway from Lee and on the south side of the Lee-Huntington trolley line, with which it is connected by a siding.

The granite (specimens D, XXXIX, 234, a, b, c) is a biotite-inuscovite granite of medium gray shade and of fine, inclining to mellum texture. with feldspar 
up to 0.2 inch. It consists, in descending order of abundance, of milk-white potash feldspar (mostly microcline with some orthoclase), pale : moky quartz, a little soda-lime feldspar (oligoclase to oligoclase-albite), black mica (biotite), and white mica (muscorite). Accessory: Pyrite, ilmenite, titanite, apatite, zircon. Secondary : Carbonate. Slight effervescence with muriatic-acid test. The stone is not identical with that of the Hulson \& Chester quarry.

The quarry, opened in 1917 by Joseph Newall \& Co., of Westerly, R. I., measures about 95 by 150 by 100 feet in area and from 2 to 15 feet in depth.

Rock structure: The sheets, 4 inches to 2 feet thick, are thin in the upper $\&$ feet. There are two sets of joints-(a), strike N. $10^{\circ}-40^{\circ} \mathrm{W}$., spaced 18 to 20 feet; (b), strike N. $70^{\circ}$ E., spaced $S$ to 100 feet. Flow structure strikes about north and is steeply inclined, marked by fine darker bands with whitish borders and a total width up to 0.5 inch. Dikes of pegmatite, 0.25 to 2 inches thick, have $\mathrm{N} .80^{\circ} \mathrm{E}$. and $\mathrm{N} .30^{\circ} \mathrm{W}$. courses. The rift is vertical, east-west, and the grain presumably north-south. From 100 to 200 feet east of the opening is an outcrop of plicated schist with strike N. $20^{\circ} \mathrm{W}$.

The stone was used for monuments. On July 30, 1918, the quarry was idle, but in 1920 it had been reopened.

\section{BRISTOL COUNTY.}

\section{GEOLOGIC RELATIONS.}

The granites of Fall River and New Bedford, although very different, are both in a large granite area in the southeastern part of the State designated on Emerson's map in Bulletin 597 as "Dedham granodiorite (chloritic biotite granodiorite)" and are regarded as possibly of Devonian age.

\section{FALI RIVER.}

Tle Beattie \& Wilcox quarry is in the city of Fall River, near Watuppa

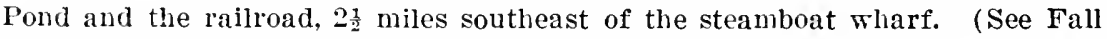
River topographic map, U. S. Geol. Survey.) Owner, David Beattie, Fall River. Quarry not in operation.

The granite is of two colors. One (specimen D, XXX, 116, a), "Fall River pink," is a gneissoid biotite granite of medium pinkish-gray color, with black spots, and of gneissoid, coarse, inclining to medium texture, with feldspars up to 0.5 inch and mica up to 0.4 inch. Its constituents, in descending order of abundance, are pinkish microperthite (potash feldspar, orthoclase and microcline, minutely intergrown with soda-lime feldspar); milky quartz, granulated (particles mostly under 0.5 millimeter), with some cavities in sheets; milkwhite soda-lime feldspar (oligoclase-albite), a little micacized and epidotized; biotite (black mica), mostly chloritized; and a little bleached biotite or muscovite. Accessory : Garnet and titanite. Secondary : Epidote, usually about the biotite, a white mica, chlorite, very little carbonate, and hematite stain. Some of the second feldspar has bent lamellae. No effervescence with muriaticacid test.

The rock of the other color (specimen D, XXX, 116, b), "Fall River gray," is a gneissoid biotite granite of light buff-gray color, with inconspicuous black spots, and of gneissoid, medium, inclining to coarse texture, with feldspars up to 0.4 inch and mica up to 0.3 inch. Its constituents are the same as in the "pink," except that the microperthite is pale buff to pinkish, the second feldspar is light greenish, and the granulated quartz is clear and colorless, its particles measuring up to 0.75 millimeter. Among the secondary minerals is a little limonite stain. No carbonate detected nor effervescence. 
These granites have in places flowage lands in which one band contains many more than the average of hiotite spots, and the next contains many less and is also finer grained than the general mass, resembling an aplite.

These are very suitable granites for massive structures. The pink has more mineral contrasts than the other.

The quary, opened in 1893 , measured in 1910 about $400 \mathrm{by} 200$ feet and 10 to 40 feet leep.

liock structure: The sheets 1 is inches to 16 feet thick, undulate horizontally, Joint courses. etc., are shown in figure 71 . Set (A), dip steeply N. $7^{\circ} \mathrm{W}$. , spaced 50 feet, forms the west-sonthwest wall and a heading 20 feet wide 50 feet east of it. Set (B), vertical, spaced 20 to 200 feet. The flowage lands described dip stceply S. $30^{\circ} \mathrm{W}$. Shear zones dip $65^{\circ} \mathrm{NW}$, are up to an inch in widtl, and are spaced 2 to 3 feet. 'The extrenely fine, roughly parallel meandering planes of dark schistose material within the zones are fratures flled in their willer parts with cpilote, carbonate, and muscovite. Veililets of quartz cross the feldspars, about which there is some gramulation. The lamellae of the sola-lime fetispars are much bent, and some are even minutely plicated. The rift is horizontal. and the grain dips about like the joints of set (A). A black, extremely fine-grained basaltic dike, described on page 56 , is 6 inches to 4 feet thick and weathers :pheroialally. The "sap" is 1 to 8 inches thick on sheet surfaces.

The product met local demands mostly. Specimens: Armory, city library, Flint mills, Fall liver; Ban'gan Chapel, in cemetery, Iawtucket, R. I.; "stone bridge" to Aquidneck Island and naval training station, Newport, R. I.

The Beattie quarry is in Fall River, $1 \frac{1}{2}$ miles west of the steamboat wharf. Operator, William H. Beattie, 33 North Quarry Street, Fall River. Idle in 1920.

The granite is of two colors. One (specimen D, XXX, 117, a), "Fall River

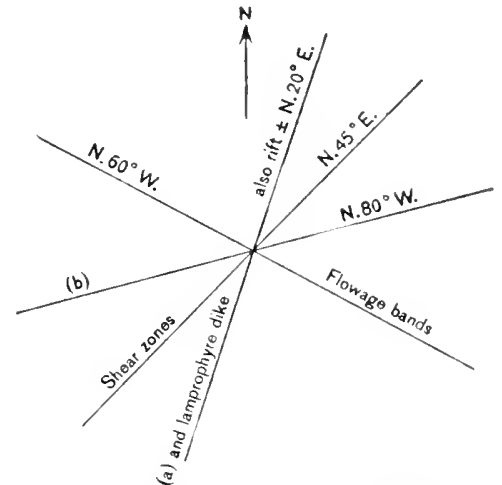

Figure 71.-Structure at Beattie

Wilcox quarry, Fall River, Mass. pink," is a gneissoirl biotite grunite of light pinksh-gray color, with black spots, and of slightly gucissoid, coarse texture, with feldspars and mica up to $0 . e^{2}$ inch, the mica exceptionally reaching 0.6 inch. Its constituents, in descending order of abundance, are pinkish microperthite (potash feldspar, microcline and orthoclase, some of it epidotizer, minutely intermown with soda-lime feldspar); clear colorless quart\%. granulated, with particles mostly under 0.5 incl, and with carities, some in sheets, and rutile needles: and greenish to milk-white soda-lime feldspar (oligoclase-albite), micacized and epidoti\%ed. some of its particles with bent lamellae. Accessory: Allanile, zircon, rutile. Secnndary: Fibrons muscovite stringers, another white mica, eridote, carbonate. It effervesces with murjatic-acir test.

The rock of the otlee color (specimen D, XXX, 117. b), "Fall River gras", is a gneissoid bintite granite of light-gray shade with concpicuous b]ck and greenish spots, and of slightly gneissoifl, eoarse, inclining to nedium texture. Its constituents, in descending order of abundance, are translucent grayish microperthite (potash feldspar, orthoclase and microcline, minutely intergrown with soda-lime feldspar): faintly purplish milky, quartz, granulated, with particles under 0.5 inch and with cavities; gras to pale creenish. not translucent soda-lime fellspar (olieoclase-albite), micacized and epidotized; biotite 
(black mica), some chloritized, generally with epidote: and a ittle bleached biotite or muscovite. Accessory: Allanite, garnet, and magnetite. Secondary : Carhonate, a white mica, epidote, chlorite. and hematite stain.

These granites are very similar to those of the Beattie \& Wilcox quarry, but they differ in that the pink is of lighter hue, and the gray has more marked mineral contrasts. Both pink and gray are attractive stones, well adapted for massive structures,

The quarry, opened before 1S65, measured in 1910900 by 700 feet and from 20 to 60 feet deep.

Rock structure: The sheets, 8 inches to $S$ feet thick, are horizontal or dip $5^{\circ}-10^{\circ} \mathrm{SE}$. Joint and dike ceurses are shown in figure 72 . Joint set (A) forms a heading 30 feet wide through the center of the quarry and is spaced 20 to 125 feet, with slickensided sericite-coated clese joints parallel to it (specimen $\mathrm{D}, \mathrm{XXX}, 117, \mathrm{c})$. Set (B), vertical, forms the sonth wall and is spaced about 40 feet. Set (C), vertical, forms a heading 50 feet wide diagonally through the quarry. The rift is horizontal, and the grain scarcely perceptible. A 3-inch pegmatite dike containing much quartz dins $43^{\circ} \mathrm{N} .55^{\circ} \mathrm{W}$. and has shear zones along it with small micaceous or chloritic masses. An aplite dike is 4 inches

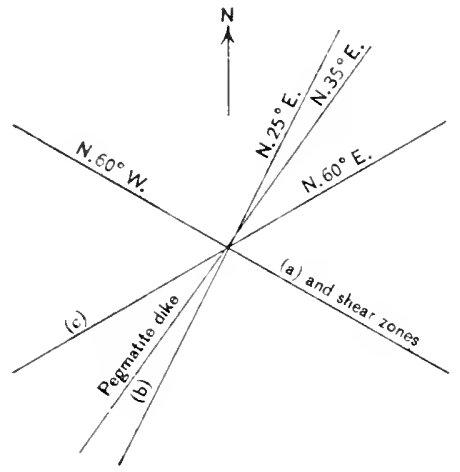

Flgure 72.-Structure at Beattie quarry, Fall River, Mass.

thick. Dark segregations measure up to $\mathbf{3}$ inches across. Limonite stain is up to 6 inches thick on sheet surfaces.

Transportation, by cart $1 \frac{1}{2}$ miles to railroad or wharf.

The product is used mostly for buildings and wharves. The waste goes into curbing, paring, and crushed stone. Specimens: Sagamore Manufacturing Co.'s mill, wharves of Fall liver Iron Works, Bristol County jail, Fall River; Bristol County courthouse (except trimmings), Taunton, Mass.; Naval War College building, Nenport, R. I.

The Savoie quarry is on Savoie Avenue,

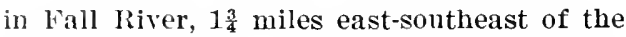
steamboat whart. Operator, Carey Quarry \& Construction Co., Savoie Avenue, Fall River.

The granite is a gneissoid biotite granite of light-gray shade with conspicuous black and greenish spots, and of coarse inclining to medium texture, closely resembling the "gray" of the Benttie quarry.

The quarry, epened in 1895, measured in 1910200 feet by 100 feet and 30 to 40 feet deep.

Rock structure: The sheets, 2 to 6 feet thick, are horizontal. There are four sets of joints. Set (a), vertical, strike N. $60^{\circ} \mathrm{W}$. forms a heading on the north wall. Set (b), steep to vertical, strike N. $10^{\circ}-20^{\circ} \mathrm{W}$, forms the east and west walls and a heading 20 feet wile at the south end and is spaced 5 to 60 feet. Set (c), strike NE., dip $30^{\circ} \mathrm{NW}$., only two, 12 feet apart. Set (d), diagonal, strike N. $20^{\circ}$ E., dip $65^{\circ} \mathrm{S}$. $70^{\circ}$ E., spaced 5 to 40 feet. The rift is horizontal, and the grain vertical, with north-south course. A dark brownishgray apl:te dike, 6 inches to 2 feet thick (specimen $\mathrm{D}, \mathrm{XXX}, 118, \mathrm{~b}$ ), strikes east-west. There is also a pinkish apilite dike 10 feet wide (specimen 118, a.) Both these aplites are described on page 44. Quartz veins and shear zones strike N. $60^{\circ}$ E. and dip $50^{\circ}$ N. $30^{\circ}$ W. There is no "sap" away from headings,

Transportation, by cart $2 \frac{1}{4}$ miles to dock or rail. 
The product is used for bulllings, curbing, and paving, and its market is mostly lueal. Specimens: City library, Maple Street School (trimmings), Fall liver.

The Sears quarry is in Fall River, about $1 \frac{1}{4}$ miles east of the steamboat wharf. Operator, C. H. Sears, Fall River. Guary abandoned.

The granite is a gneissoil biotite granite of light-gray shade with conspicuous black and greenish spots, and of coarse, inclining to medium texture, like the "gray" of the Deittie quarry (p. 283).

The quarry, opened in 159:, measured in 1910125 by 75 feet and 20 feet deep.

Rock structure: The sheets, 1 to $S$ feet thick, undulate. There are two sets of joints. (Set $(a)$, about east-west, forms the north wall and a hearling 15 feet wide through the center of the quarry and is spaced 2 to 20 feet. Set (b), nearly north-sonth, forms the west wall and is spaced 10 to 20 feet but in places crosses one sheet only. The rift is horizontal and the grain vertical. north-south, but scarcely perceptible. There is little "sap" away from headings.

Transportation, by cart.

The proluct was used for loeal buildings. Specimen: Lower story of Textile School, Fall River.

The Stinziano quary is at the corner of Locust and Oak Grove avenues, Fall River. Operator, Fall River Granite \& Quarry Co., Fall River.

The granite is essentially like that of the other Fall River quarries.

The product is dressed stone for buildings and pedestals, also paving and foundations.

The Ross quarry is at the head of Barlow Street, near Watuppa Pond, in Fall River, 23 miles about southeast of the steamboat wharf. (See topographic map of Fall River quadrangle, U. S. Geol. Survey.) No longer operated.

The granite (specimen D, XXX, 119, a), "Fall River, Barlow Street," is a gneissoid biotite granite of medium bluish-gray color and of medium texture, with feldspars up to 0.3 inch and mica up to 0.1 inch. Its constituents, in descending order of abundance, are pinkish cloudy microperthite (potash feldspar, orthoclase and microeline, minutely intergrown with soda feldspar); (clear colorless quartz, granulated, with particles nearly all under 0.5 millimeter; clear colorless to pale-greenish soda feldspar (albite), micacized and epidotized; and biotite (black mica), some of it chloritized, associated with epidote and a little muscovite or bleached biotite. Accessory: Garnet. Secondary: Muscovite in stringers, also a white mica in the albite, epidote, carbonate, and chlorite. No effervescence with muriatic-acid test.

As will be noticed from the description, this stone differs from the other Fall Iiver gray granites in the absence of the large black micas. The second feldspar here is pure albite. The mineral contrasts are feeble.

'The quarry, opened before 1901, measured in 1910125 feet square and 30 feet deep.

Rock structure: The sherts, 1 to 5 feet thick on the east side, are lacking ou the west side. There is only one joint, striking east-west and forming the south wall. The upper sheets are hadly discolored.

The product was curbing, flagging, and paving.

NEW REDFORD.

The Sullivan quaries are near Rocklale, in the township of New Berlforl, 2 miles northwest of the city. (See New Bedford tojographic mal, U. S. Geol. Survey, and Pl. XXIII.) Operator, Sullivan Granite \& Construction Co., New Beiforl. 
The granite (specimens D, XXX, 121, a, pinkish, and b, less pinkish), "New Bedford," is a biotite-muscovite granite gneiss of light pinkish-gray color and of slightly gneissoid, coarse inclining to medium texturc, with feldspars up to 0.5 inch and mica up to 0.1 inch. Its constituents, in descending order of abundance, are light-pinkish potash feldspar (microcline), some of it slightly kaolinized; medium smoky quartz with cavities and black particles in parallel sheets; milky soda-lime feldspar (oligoclase-albite); biotite (black mica), some of it chloritized; and muscovite (white mica). Accessory: Garnet, magnetite, fluorite, apatite, aud zircon. Secondary : Kaolin, epidote, chlorite, and limonite. No carbonate or pyrite detected. No effervescence with muriatic-acid test.

This is an attractive and substantial building stone. Its mineral contrasts are a little more marked than those of the "Dartmouth granite." The absence or scarcity of pyrite and carbonate is in its favor.

The quarries comprise two openings. The main one, begun about 1860 , was in 1910600 by 150 feet and from 50 to 75 feet deep. The other, about 300 feet farther south, formerly known as the Denault guary, was about 250 by 150 feet and from 50 to 70 feet deep.

Rock structure: Dike, joint, and grain courses are shown in figure 4 (p. 55). The sheets in the main quarry are 10 to 25 feet thick, hut for a space of 5 or 6 feet on either side of the dikes there are sheets 3 to 15 inches thick, which were evidently formed after the dikes and largely in consequence of then. There are two sets of joints. Set (a), coated with epidote, is vertical and spaced 50 feet. Set (b), confincel to the Denault quarry, dins $55^{\circ} \mathrm{E}$., is spaced 2 to 30 feet. with a heading at east wall and another 10 to 18 feet wide near it. The rift is horizontal. The likes have been described on pages 55-56. There is one each on the north, south, and west walls, through the center, and another of pegmatite near the west wall. The amount of rusty stain is small.

Transportation, by cart 2 or 3 miles to New Berford.

The product is used for local buildings and streets. Specimens: Armory, public library (90 per cent, the rest being from Fall River quarries). St. James and St. John Roman Catholic churches, anel trimmings to most of the cotton mills, New Bedford.

\section{DARTMOUTH.}

The Dartmouth quarry is in Dartmouth Township, three-fourtbs of a mile east of Westport Mills and $8 \frac{1}{4}$ miles southeast of the Fall River steamboat wharf. (See Fall River topographic map, U. S. Geol. Survey, and Pl. XXIII.) Operator, New Bedford \& Dartmouth Granite Co., New Bedford.

The granite (specimen D, XXX, 122, a), "Dartmouth," is a gneissoid biotitemuscovite granite of rery light buff-gray color and of rery slightly gneissoid, medium, inclining to coarse texture, with feldspars up to 0.5 inch and mica up to 0.1 inch. Its constituents, in descending order of abundance, are transhucent cream-colored microperthite (potash feldspar, microcline, minutely intergrown with lime-soda feldspar, oligoclase-albite, and somewhat kaolinized); pale, smoky quartz, with cavities, in sheets; clear to translucent soda-lime feldspar (oligoclase-albite), but little kaolinized; and muscovite (white mica) and biotite (black mica) in about equal amounts. Accessory: Garnet. Secondary: Kaolin and carbonate. Very little effervescence with muriatic-acid test. This is a serviceable constructional stone of feeble mineral contrasts.

The quarry, opened in 1903, was in 1910 about 150 by 100 feet and 30 feet deep, with a working face 45 feet high on the west.

Rock structure: The sheets, 1 to 12 feet thick, are about horizontal. The joints, all discontinuous, are of three sets- $(a)$, strike N. $75^{\circ} \mathrm{E}$., dip $75^{\circ} \mathrm{S} .15^{\circ}$ E., on north and south walls only; $(b)$, strike north, dip $50^{\circ}$ E., spaced 3 to 10 
feet; forms the west wall; $(c)$, strike N. $25^{\circ} \mathrm{W}$, dip $65^{\circ} \mathrm{N} .65^{\circ}$ E., one only. The rift is horizontal and the grain vertical, with $\mathrm{N} .60^{\circ} \mathrm{E}$. course. There are small pegmatite and smoky quartz dikes with N. $60^{\circ} \mathrm{W}$. courses. Rusty stain is ap to 3 inches thick on sheet surfaces, diminishing at the bottom of the quarry.

The product is used for local buildings, curbing, and paring. Specimen: Trimmings on Lunds Corner schoolhouse, New Bedford.

\section{ESSEX COUNTY.}

\section{PEABODY-LYNNFIELD DISTRICT.}

GEOLOGIC RELATIONS.

The granites of the Peabody-Lyunfield district are in a granite area designated on the geologic map of the State ${ }^{11}$ in Bulletin 597 as "Quincy granite (soda-rich riebeckite granite)."

The granite is an olive-greenish lornblende-augite granite resembling the riebeckite-aegirite granite of Quincy, but its black silicates contain very little soda. Washington ${ }^{12}$ refers to the stone in these words:

"The rocks belonging to this class were first noticed by Wadsworth in 1885 and were later described more in detail by Sears. Rosenbusch has expressed the opinion that these are related to the akerite type of syenites, a keen observation which my study of the rocks fully confirms. These rocks are found chiefly in the eastern part of Essex County, in Essex, Beverly. Manchester, Gloucester, and on Cape Ann. * * * The color even of the freshest specimens is greenish, which varies in shade from a dark greenish black to a light shade of greenish gray."

In common with the green granite of Redstone, N. H., described on page 168, that of Peabody and Lxnnfield contains considerable allanite, to the oxidation of which the green color is partly due. (See further p. 7t.)

QUARRIES.

The Linehan quarry is in Peaborly Township, on a knoll one-fourth mile east of Bartholomew Pond, about 3 miles west-southwest of Peaborly. (See Salem topographic map, U. S. Geol. Survey and PI. XXIII.) Operator. John Dubie, Peabody. Quarry abandoned.

The granite (specimen D, $\mathrm{XXX}, 128$, a), "Peabolly green," is a hornblendeaugite granite of very dark olive-greenish color and of eren-grained, coarse texture, with feldspars up to 0.7 inch and black silicates up to 0.2 inch. Its constituents, in descending order of abundance, are dark olive-greenish micropertlite (potash feldspar, orthoclase, minutely intergrown with plagioclase, probably soda feldspar, kaolinized and with crush borders) ; rery dark greenish smoky quartz, with cavities in sheets intersecting, some at right angles, and with cracks filled with limonite stain; green hornblende; and augite intergrown with or passing into the hornblende. Accessory: Magnetite, allanite, rather plentiful zircon, and apatite needles. Secondary: Kaolin, limonite stain, and carbonate. Slight effervescence with muriatic-acid test.

This granite differs from the green of the Robin Rock quarry (p. 2S9) only in its more rellowish tinge. When first quarried it is grayish, but within a week it becomes yellowish green.

12 Emerson, B. K., op. cit., pp. 189, 189.

12 Washington, H. S., The petrographieal province of Essex County, Mass. : Jour. Geology, vol. 6, p. 787, 1898. See also Sears, J. H., The physical geography, geology, mineralogy, and paleontology of Essex County, Mass., pp. 178, 190, Salem, Mass., 1905. 
The quarry, opened in 1900, measured in 1910250 feet east and west by 80 and 100 feet across and 20 to 40 feet deep.

Rock structure: The sheets, 8 to 16 feet thick, are lenticular and horizontal. There are two sets of joints- $(a)$, vertical, strike $N .15^{\circ}$ E., on east and west walls only, 250 feet aljart; $(b)$, "rift joints," diagonal, strike $\mathrm{N}$. $70^{\circ}$ E., dip $65^{\circ}$ S. $20^{\circ}$ E., coated black with hornblende, ${ }^{13}$ also. with calcite up to 0.12 inch thick, spaced 30 to 60 feet. The rift, which is marked, is parallel to set $(b)$; the grain is at right angles to it, and the hardway horizontal. Darkuray knots are 0.5 inch to 12 inches across. The stain forms a dark-brown surface on the sheets, with an inch of pale granite below it; in places, how. ever, the brown part is an inch thick and the pale granite 2 inches. The joints are also discolored in this way.

Transportation, by cart, an average of 3 miles.

The product is used for street work and trimmings. Specimen: Trimmings on addition to Mercantile Bank, Salem.

The Caron quarry is in Peabody Township, about a quarter of a mile south-southeast of the town farm on Lynnfield Street. (See Salem topographic map, U. S. Geol. Survey, Operators, M. Caron \& Sons, 32 Perkins Street, Salem. Quarry abandoned.

The granite, "Peabody green," is a hornblende-augite granite of very dark olive-greenish color and of even-grained, coarse texture like that of the Linehari quarry, described on page 287.

The quarry, opened in 1898, measured in $191075 \mathrm{by} 30$ feet and from 10 to 30 feet deep.

Rock structure: This is a "boulder quarry" yielding blocks 18 feet thick. There are two sets of joints- $(a)$, strike N. $77^{\circ}$ E., dip $60^{\circ}$ S. $13^{\circ}$ E., spaced 10 to 20 feet; $(b)$, strike N. $40^{\circ}$ E., dip $50^{\circ}$ N. $50^{\circ}$ W., spaced over 30 feet. The rift is parallel to set $(a)$ and the grain dips $70^{\circ}$ about west. The "sap" is up to 3 inches thick on masses below the surface, half of it being brown.

Transportation, by cart.

The product is used for trimmings and curbing. Specimens: Trimmings on hotel at corner of Mill and Washington Streets, and on store at comer of Derby and Dinell Streets, Salem.

The Den quarry is on the Peabody and Lynn town line, about $2 \frac{3}{4}$ miles north-northwest of Lynn station. (See Boston Bay topographic map, U. S. Geol. Survey.) Operator, C. E. Mulge, Lynn. Idle since 1912.

The granite ( specimens D, XXX, 126, a. b), "Peabody green," is a hornblendeaugite granite of dark to very dark olive-greenish color. When first quarried the feldspars are less greenish and lighter and the general color corresponds, but this soon changes. Its texture is even grained, course, with feldspars up to 0.7 inch and black silicates up to 0.4 inch. Its constituents, in descending order of abundance, are medium but soon becoming dark greenish-gray microperthite (potash feldspar (orthoclase), minutely intergrown with soda feldspur (albite), much kaolinized, with crush borders and with cracks filled with limonite stain) ; very dark yellow-greenish smoky quartz, with cavities in sheets, some intersecting at right angles, and with cracks parallel to them and filled with limonite stain; black hornblende (green in section), with inclusions of allanite; and black augite (green in section). intergrown with or passing into the hormblende, also with inclusions of allanite. Accessory : Magnetite, allanite, zircon, apatite, and rery little biotite. Secondary: Limonite stain proceeding from the allanite and augite and following the boundaries of particles and

${ }^{13}$ These black-coated joints signify metamorphism after the jointing. See p. 82 . 
cracks, kaolin. a brown and also a blue hornblende (n)obably ritbeckite) in fiblous crystals growing out of the augite surfaces into quartz and feldspars, and carbonate. Slight efferresence with muriatic-acid test.

This stone is reported as taking a good polish, whinh might be expexterl from its lack of mica.

The quarry, opened about 1905 , measured in 1910 about 100 ferst suluare and 20 to 60 feet deep.

Rock structure: The sheets, 16 to over 30 feet thick, dip $20^{\circ} \mathrm{S} .55^{\circ} \mathrm{F}$. There are four sets of joints- $(a)$, discontinuous, strike $x .5^{\circ}$ E., dip $75^{\circ}$ r., forms a heading on east wall, spaced 30 to 40 feet; $(b)$, vertical, strike east, forms a leading 100 feet wide on east wall, spaced 25 to 40 feet: $(c)$, strike $\mathrm{N} .40^{\circ} \mathrm{W}$., dip $47^{\circ} \mathrm{S} .50^{\circ} \mathrm{W}$., one onls; $(d)$, vertical, strike N. $30^{\circ} \mathrm{W}$., one only. The rift dips steeply S. $60^{\circ} \mathrm{W}$, and the grain, which is almost as pronouncel as the rift, is horizontal. Very dark gray segregations (knots) are up to 0.5 inch, exceptionally 2 feet across. A thin section of one of these knots (specinen $D$, XXx, 126, d) shows a groundmass of particles of microperthite and plagioclase (probably albite) from 0.1 to 0.3 millimeter in diameter, with thickly disseminated particles of augite from 0.02 to 0.37 millimeter, and minute grains of magnetite. At the edge is a large porphyritic microperthite, a crystal of zircon, and a particle of augite associated with a blue hornblende, biotite, magnetite, and zircon.

The feldspars on the sheet surfaces are generally much kaolinized. The rusty stain (specimen $\mathrm{D}, \mathrm{XXX}, 126, \mathrm{c}$ ) is up to an inch thick, and tlue palegreen band below it from 2 to 4 inclies. A top sheet, 12 feet thick and 100 by 40 feet in area, is all discolored.

Transportation, by cart.

The product is used for base courses, steps, curbing, crossings, caps, and parIng. The rusty faces are used for base courses. Specimens: Starr Parsols Monument, in Pine Grove Cemetery, and sap-faced base course of dwelling at corner of Wave and Ocean streets, Lyinn.

The Robin Rock quarry is in Lynnfield Township, four-fifths of a mile south-southeast of South Lynnfield station. (See Lawrence topographic map, U. S. Geol. Survey.) This quarry was operated by the late Arthur L. Kallenberg. of Lynnfield, and may be operated again by his son.

The granite (specimen D, XXX, 127, a), "Robin Rock green," is a hornblende-augite granite of very dark greenish color and of coarse, even-grained texture, with feldspars up to 0.6 inch and black silicates up to 0.4 inch. Its constituents, in descending order of abundance, are dark-blue or greenish-gray microperthite (potash feldspar, orthoclase, minutely intergrown with soda feldspar, albite, and kaolinized) ; very dark, slightly greenish smoky quartz, with cavities in sheets intersecting at right angles; black (under the microscope greenish) hornblende with inclusions of allanite; very little separate soda feldspar (albite); and black (under the microscope greenish) augite. Accessory : Magnetite, allanite, pyrite, zircon, and a little biotite. Secontlary : Kaolin and limonite stain. No effervescence with muriatic-acid test.

Another variety (specimen D, XXX, 127, b). "Robin Rock gray," is also a hornblende-augite granite but of dark-gray shade, speckled with black, and of coarse, even-grained texture, with feldspars up to 0.7 inch and black silicates up to 0.3 inch. Its constituents appear to be the same as those of the other rariets, but, as shown by efferrescence with acid test, carbonate is present. The microperthite is dark gray in the hand specimen but shows some limonite- 
stained faces. Angite is intergrown with hornblencle or passes into it. Apatite appears among the accessory minerals. and zircon is rather plentlful. 'Ihis stone probably becomes somewhat greenish on continued exposure.

This stone appears well when fine pointed.

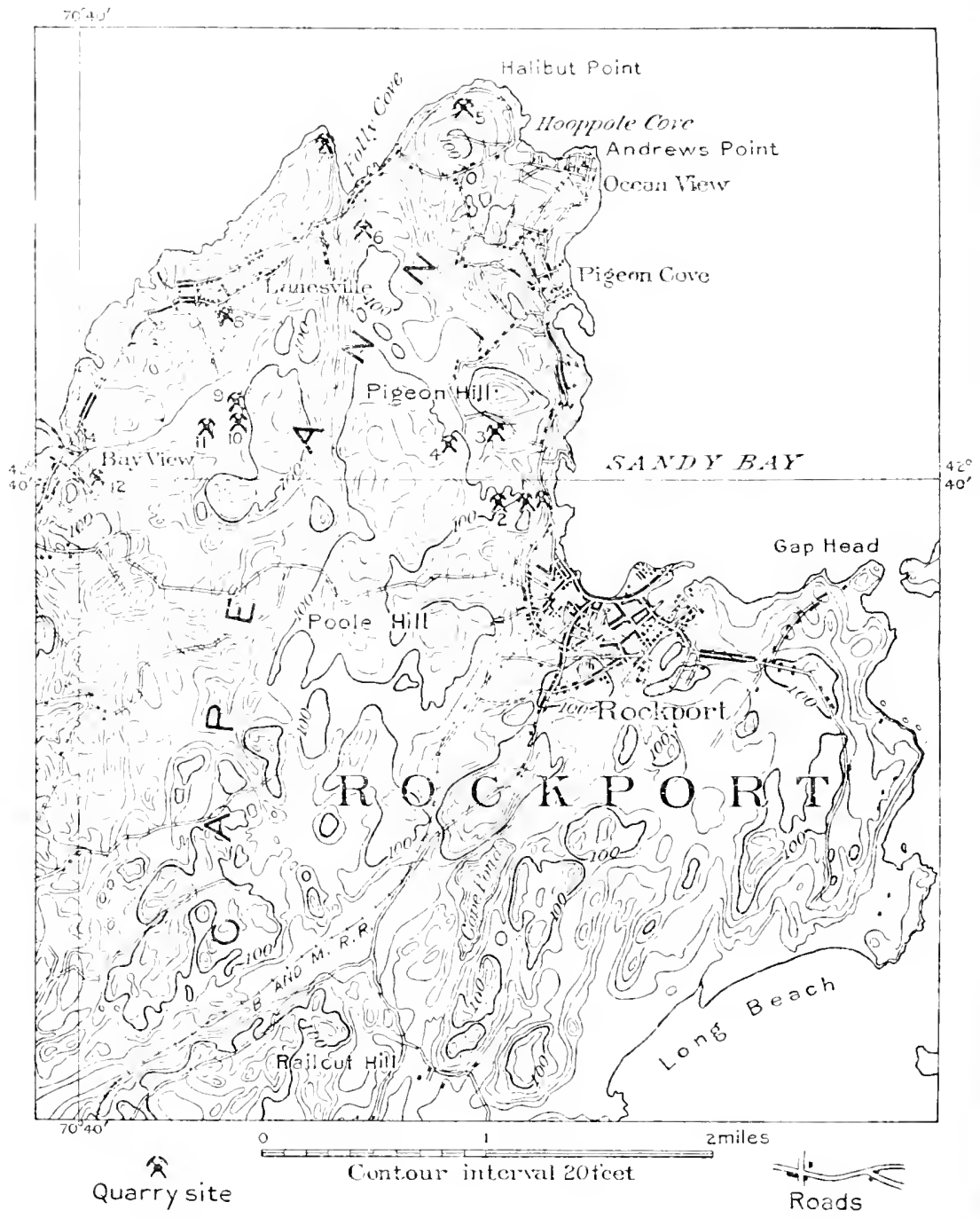

Figure 73.-Map of part of Cape Ann, Mass., showing the location of Rockport granite quarries. 1, Flat Ledge quarry; 2, upper pit, Rockport Granite Co.; 3, lower Pigeon Hill quarry; 4, upper Pigeon Hill quarry; 5, Babson Farm quarry; 6, Nickerson quarry; 7 , Breakwater quarry ; 8, Canney quarry; 9, Devils Rock quarry; 10, Cheves Green Granite quarry; 11, Blood Ledge quarry ; 12, deep pit, Rockport Granite Co.

There are several openings, some of which are a century old. The one worked in 1910 was triangular in area, 75 feet on a side and 5 to 25 feet deep.

Rock structure: The sheets, 18 inches to 6 feet thick, dip $10^{\circ} \mathrm{E}$. There is only one set of joints, vertical, strike N. $80^{\circ} \mathrm{W}$., spaced 3 to 12 feet, with a 
heading 15 feet wide on the north side. The rift is vertical, witl east-west course, and the grain vertical, north-south. "Knots" measur ul to 6 inches. The stain on sheet surfaces is yellowish for an inch, then for 2 inches the stone is pale.

Transportation, by cart 4 to 6 miles to Wakefield and Realing.

The product was used for buildings, foumbations, sills, steps. and curbing.

\section{ROCKPORT.}

\section{TOPOGRAPIIY.}

The township of korkport ocempies the eastern and northorn fint of that insular mass on the Atlantic coast commonly known as Cape Ann. (Ser Glowester topographic map. I. S. Geological Survey.) It is a rogion of low, roundish or oval granitic or sambly hillocks. none exceeling 180 feet in height. and of marshes and bonlder-strewn sand flats. The most conspicuous of these hillocks is Pigeon Hill, about a mile north of Rockport village, which is remarded as a drumlin. The quarries are in the northern part of the cape, seattered alonis the shore or within three-quarters of a mile of it, from Rockport to Bay View. (See fig. 73.)

\section{GEOT.OGIC RELATIOXS.}

The physiography and geology of Cape Ann have been interestingly described by Shaler and Tarr.

The entire cape is represented in Shaler's map ${ }^{14}$ as made up of slanite, but traversed at very close intervals by diabase dikes and at a few points by quartz porphyry dikes. According to Sears's geologic map of Essex County, hormblende granite covers Halibut Point, Rockport, and the area half a mile east of Bay View; but a quarter of a mile east of Bay View there is a small area of " angite syenite." 15

Emerson ${ }^{10}$ on the geologic man of the State shows the cape as a part of a large area of "Quincy granite" (soda-r'ich ricbeckite-bearing granite hut with a small area of Beverly syenite just north of Pigeon Cove and another about Lanesville, neither of which, however, is quarried.

The geologic age of the granite is regarded as Carboniferous. The hasic dikes may be Triassic. They range from 0.5 inch to 40 feet in wirlth.

\section{"ROCKPORT GRANITE."}

The more recent scientific accounts of "Rockport granite" are those of Wadsworth, ${ }^{17}$ Merrill, ${ }^{18}$ Washington, ${ }^{10}$ Sears, ${ }^{20}$ and Clapp. ${ }^{21}$ Cooke, ${ }^{22}$ Clarke, ${ }^{23}$ anıl

${ }^{14}$ Shajer, N. S.. The geology of Cape Ann, Mass. : U. S. Geol. Survey Ninth Inn. Rept., pp. 529-611, pl, 77, 1889 .

15 Sears, J. H., The physical geography, geology, mineralogy, and paleontology of Essex County, Mass., Salem, Essex Institute, 1905.

${ }^{10}$ U. S. Geol. Survey Bull. 597, pl. 10, pp. 188, 189, 197, 1917.

${ }_{17}$ Wadsworth, M. E., Notes on the petrography of Quincy and Rockport: Boston Soc. Nat. Hist. Proc., rol. 19, 1881.

${ }^{18}$ Merrill, G. P., Smithsonian Inst. Rept. for 18s5, pt. 2, p. 419, 1889.

19 Washington, H. S., The petrographical province of Essex Connty, Mass.: Jour. Geology, vol. 6, pp. $790-796,1898$.

20 Sears, J. H., op. cit., pp. 150-153.

${ }^{21}$ Clapp, C. H., Igneous rocks of Essex County, Mass., 1910; Geology of the igneous rocks of Essex County, Mass.: U. S. Geol. Surrey Bull. 704, 1921.

22 Cooke, J. P., On cryoplyllite, a new mineral species of the mica family with some associated minerals in the granite of Rockport, Mass.: Am. Jour. Sci., 2d ser., rol. 43, pp. 217-230, 1867; On danalite from liockport: Idem, 2d ser., rol. 42, p. 73, 1866.

${ }^{23}$ Clarke, F. W., On cryophyllite from Rockport: Idem, $3 \mathrm{~d}^{\mathrm{ser}}$, vol. 32, p. $358,18 s 0$. 
Pentieli an:l Forbes ${ }^{2}$ have describel certain new or unusual minerals in

"Rockport granite."

The following epitomizes the descriptions of rough and polished specimens an! thin sections of this granite from all the quarries as given in the succeeding pages. Analyses, mineral percentages, and results of physical tests follow the deseription.

"Rockport granite" is of two sorts. The more abundant, knowu commercially as "gray granite," is a hornblende granite of medium-gray shade (in places with slight greenish or bluish tinge) spotted with black. Its texture is medium to coarse and even grained, with feldspars up to 0.3 or 0.5 inch aud hornblende up to 0.2 inch. Its constituents, iu descending order of abundance, are a light-gray potash feldspar (orthoclase with or without microcline) of a slightly greenish or bluish or buff tinge, generally twinned and minutely intergrown with soda-lime feldspar (albite to oligoclase-albite), more or less kaolin. ized; smoky quartz with abundant cavities (many with liquid and vacuoles), from 0.0043 millimeter or less to 0.02 millimeter in diameter, mostly in sheets: hlack hornblende, in places with a little bluish-black riebeckite (p. 317) : very little separate soda-lime feldspar like that described above; and very little black mica (biotite or lepidomelane).$^{25}$ Accessory: Magnetite, pyrite, allanite, fluorite, zircon, apatite. Secondary: Hematite, limonite, kaolin, some black hornblende, calcite.

Estimates of the mineral percentages by the Rosiwal method yieid these results: Feldspar, 55.50 to 59.60 , average 57.97 ; quartz, 33.88 to 38.90 . a verage, 35.82 ; hornblende and mica, 5.60 to 7.26 , average, 6.20 .

"Rockport granite" is said to be "hard." These estimates show quartz averaging 35.83 per cent, or if the green of Bay View, given beyond, is averaged with the gray, 34.85 per cent, whereas the average amount of quartz in five tests of Quincy granite is 30.60 per cent (p. 318), in "Conway" red granites 28.62 per cent (p. 166), and in the "Redstone granite" of Westerly, R. I. (p. $413), 29.8$ i per cent. This extra 6 per cent of quartz may be sufficient to account for the hardness.

H. S. Washington ${ }^{28}$ gives the following analysis of "Rockport granite":

\section{Analusis of "Rockport granite."}

[H. S. Washington, analyst.]

Silica $\left(\mathrm{SiO}_{2}\right)$

77. 61

Titanium dioxide $\left(\mathrm{TiO}_{2}\right)$

Alumina $\left(\mathrm{Al}_{2} \mathrm{O}_{3}\right)$

11. 94

Iron sesquioxide $\left(\mathrm{Fe}_{2} \mathrm{O}_{3}\right)$

Iron oxide $(\mathrm{FeO})$

.87

Manganese oxide $(\mathrm{MnO})$

Trace.

Magnesia $(\mathrm{MgO})$

Trace.

Lime ( $\mathrm{CaO})$

.31

Soda $\left(\mathrm{Na}_{2} \mathrm{O}\right)$

3. 80

24 Penfield, S. L., and Forbes, E. H., Fayalite from Rockport, Mass., etc.: Am. Jour. Sci., 4th ser., vol. 1, pp. 129-131, 1896.

${ }_{25}$ H. S. Washington (op. cit., p. 793) reports two varieties of biotite, one very pale green, probably cryophyllite of Cooke, the other darker greenish gray, lepidomelane (annite). F. W. Clarke (op. cit.) shows that several varieties of biotite occur.

${ }^{20}$ Op. cit., p. 793 . On p. 794 he gives these estimates of the mineral percentages, based partly on the analysis and partly on microscopic observation: Feldspar 50.2 per cent, quartz 35.5 per cent, hornblende and two blotites 3.8 per cent, accessory minerals 0.5 per cent. The figure for quartz agrees very closely with that obtained by the Rosiwal method. 
Potash $\left(\mathrm{K}_{2} \mathrm{O}\right)$

4.98

Water $\left(\mathrm{H}_{2} \mathrm{O}\right)$ 'Irace.

Water $\left(\mathrm{H}_{2} \mathrm{O}\right)$ at $110^{\circ}+$ ignition

.23

100.54

Specific gravity 2.618 at $18^{\circ} \mathrm{C}$.

Messrs. Steiger and Sullivan, chemists, of this Survey, hind that this granite contains from 0.14 to 0.20 per cent of $\mathrm{CaO}$ (lime) soluble in hot tilute acetic acid, which indicates the presence of 0.25 to 0.35 per cent of $\mathrm{CaC}()_{3}$ ( (ailcium carlomate calcite). (see pl. 294, 296.)

Because the black silicate is almost entirety hornhlencle the stone takes a very high polish. The contrasts of shade between the gray fellspar, suloky quartz, and black hornblende are much more marked on the polished than on the rough face.

The other variety of "Rockport granite," known as "green granite," is also a hornblende granite but of somewhat dark olive color spotted with black. Its texture is medium to coarse. even grained, with feldspars ul to 0.3 and 0.5 Inch and hornblende up to 0.2 inch. Its constituents, in descending order of abundance, are nedium olive-gray feldspars. like those of the gray variety, slightly yellow-greenish smoky quartz, black hornblende and biotite (black mica), together with accessory magnetite, zircon, and allanite, and secondary kaolin. limonite. and calcite. The feldspar varies in the same particle from an olive-green to a scarcely greenish milk-white. Limonitic stain is visible in the rift and other cracks of both feldspar and quartz. This stain seems to originate in particles of allanite and masnetite, in the biotite and hornblende, and partly in minute ferruginous particles in the feldspars. Quarrymen state that this stone. which when first quarried is a dark gray, becomes greenish after an exposure of three or four hours to rain. It is also stated that the green granite loses some of its color on continued exposure about the quarry. Specimens of this slightly faded green granite show that. while the feldspars have lost a little of their greenness, that color is preserved in the quartz.

An estimate of the mineral percentages in this granite hy the Rosiwal method yielis the following results: Feldspars, 58.45 ; quartz, 31.95 ; lornhlende, 9.60 .

This granite takes as high a polish as the gray, but its contrasts are less marked.

Besides these granites there is near Bay View a dark brownish-gray riebeckite-aegirite-biotite granite, which has only been prospected and is lescrihed on 1:ate 302. aml also near Pigeon Cove a beantiful diabase polplyry, as ret little worked, described on page 303 . The bright rust-colored "sap" referred to on page $6 \tau$ is unnsually abundant in some of the Rockport quarries. This brightly discolered granite has been used by architects in the hasements of several private residences on the Cape. The offices of the Rockport Granite Co. and the Rockport Carnegie Library are made of it. In both huillings the fresh gray granite has been used for trimmings. The resulting contrast is ploasing.

\section{GEOLOGY OF ROCKPORT QUAREIES.}

The conspicuous feature of the Rockport quaries is the large number of basic dikes which traverse them. Some of these are shown in plate XXVII, $A, B$. Their courses are given in the quarry descriptions. One attains a thickness of 18 feet. The dike matter was erupted through deeply parted joints. Contemporaneous with the dikes was the irregular-shaped injeetion de- 
scribed on page 54 and shown in Plate XXVII, $B$, and figure 3 . The faulting of the large dike in the same quary shows that a crustal movement affected the region after the crystallization of the dike material. The injection of molten matter into cold granite was not withont effect, for the stone on either side of these dikes is likely to be darkened. (See p. 57.)

The pegmatite dikes contain some bright-green feldspar (amazon stone). A 4-inch dike of aplite is borlered by pegmatite 1 to 2 inches thick.

Segregations (knots) are not uncommon in "Rockport granite," but at Halibut l'oint, the extreme north end of the cape, in the Babson Farm quarry, there is one of unusual chinicter. It is $S$ by 4 by $2 \frac{1}{2}$ feet and consists mainly of feldspar and quartz. (See further \%. 60.)

Although some of the data obtained from the quarrymen as to rift and grain appear to be incorrect, owing to their confounding rift and grain or else to inaccurate observation, the course of the rift appears to be east-west and generally vertical and the grain horizontal. Rift and grain cracks can be detected in the quartz areas of polished surfaces.

Sheet structure is generally imperfect, owing eitber to the shortening of the lenses by increase in the curvature of the fractures or to the low-dipping joints which intersect them, or else to incomplete development. In some places the "toe-nail structure" enhances the difliculties.

The joints at the 11 quarries in operation in 1906 have the following courses: About north, N. $\because 5^{\circ}$ E., N. $30^{\circ}-40^{\circ}$ E., N. $60^{\circ}-75^{\circ}$ E.; about east, N. $15^{\circ}-20^{\circ} \mathrm{W}$, N. $30^{\circ}-45^{\circ} \mathrm{W}$., and $\mathrm{N} .55^{\circ}-70^{\circ} \mathrm{W}$. The courses noted at the largest number of quarries were $\mathrm{N} .30^{\circ}-40^{\circ}$ E., N. $30^{\circ}-40^{\circ} \mathrm{W}$., $\mathrm{N} 60^{\circ}-75^{\circ}$ E., and east.

At the upper Pigeon Hill quarry a compressive strain in all lateral directions results in undulating fractures and binds the chisels in channeling.

\section{QUARRIES.}

The Flat Ledge quarry is half a mile north-northwest of Rockport and 80 feet west of Sandy Bay. (See fig. 73.) Operator, Rockport Granite Co., Rockport.

The granite (specimens D, XXVIII, 24, a, f), "Rockport light gray," is a hornblende granite of medium gray, slightly bluish-green color with inconspicuous black spots. In large masses its general color is bluish gray. Its texture is medium to coarse, even grained, with feldspars up to 0.5 inch and homblende to 0.2 inch. Its constituents, in descending order of abundance, are a light-gray, slightly blue-greenish potash feldspar (orthoclase, some of it twimed and microcline), minutely intergrown with soda-lime feldspar and somewhat kaolinized; very smoky quartz; black hornblende; and very little separate sola-lime feldspar (oligoclase-albite); together with accessory magnetite, molybdenite, purple fluorite, and zircon and secondary kaolin and calcite.

George Steiger, a chemist of this Survey, finds that it contains 0.20 per (ent of $\mathrm{CaO}$ (lime) soluble in hot dilute acteic acid. which indicates the presence of 0.35 per cent of $\mathrm{CaCO}_{3}$ (calcium carbonate, calcite).

The stone takes a very high polish and hammers somewbat light.

The quarry, opened about 155.5, neasures abont 1,100 fect from northwest to sontheast by 1,000 feet across and 125 feet in depth.

Rock structure: The sheets, 6 inches to 30 feet thick, are horizontal in the southern part, dip $25^{\circ} \mathrm{NW}$. on the east side, and dip about $20^{\circ} \mathrm{S}$. in the center. One set of joints, strike N. $15^{\circ} \mathrm{W}$., (dip $65^{\circ} \mathrm{WSW}$., is spaced 8 to 15 feet. Another set, strike N. $60^{\circ} \mathrm{WV}$. dip $S 0^{\circ} \mathrm{NNE}$., is spaced 2 to 25 feet. The rift is reported as dipping $20^{\circ}$ about south, and the grain as vertical, with a $\mathbf{N}$. $15^{\circ}-20^{\circ}$ E. course. A medium-grainel pegmatite dike, 5 feet thick, strike $N$. 
$30^{\circ} \mathrm{W}$., dip $25^{\circ} \mathrm{E}$., consists of potash felıspar (microcline and orthoclase), smoky quartz, soda-lime feldspar (oligoclase to andesine), garnet, and zircon. A coarse-grained dike, not examined microscopically, consists of a crean-colored feldspar, in places bright green, smoky quartz, black and pussibly other varieties of mica, and gamets. Basie dikes strike N. $10^{\circ}$ li., N. $15^{\circ} \mathrm{W}$., and N. $60^{\circ}$

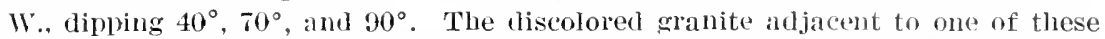
was examined and has heen deseribed on page 58. Rusty stain, 0.25 to 2 inches thick, is rers abmdant and bright, particularly along the joint faces. (See 1)]. $67-69$.

Transportation, by an 800 -foot track to entting shed and wharf.

Product of this and other Rockport quarries of this company yielding gray granite-specimens: Fox Hill briuge, Lymn; courthouse, Worcester; Y. M. C. A. Building and customhouse, Boston; Masonic Temple, Champaign, Cook Connty IIospital, Chicago; Tyler monument, Richmond, Va.

The "Upper pit" of the Rockport Granite Co. lies west-southwest of the Flat Ledge quarry, about half a mile northwest of Rockport. (See fig. 73.) Operator, Rockport Granite Co., Rockport.

The granite, "Rockport light gray," is a hornblende granite identical with that of the Flat Leflge quarry.

An estimate of the mineral percentage in this stone, made by the Rosiwal method, with half-inch mesh and total hinear length of 20 inches, yielded the following results: Feldspars, 55.50; quartz, 39.90 ; hornblende, 5.60.

The quarry measures about 625 feet from northwest to southeast by 325 feet across; an intermediate opening, 150 by 125 feet, averages 100 feet in depth.

Rock structure: The sheets, 4 to 35 feet thick, dip $20^{\circ}$ about east. One set of joints, strike N. $30^{\circ} \mathrm{E}$., dip $50^{\circ} \mathrm{W}$., is spaced down to 10 feet; another, strike about $\mathrm{N}$. $30^{\circ} \mathrm{W}$., dip $30^{\circ}-50^{\circ} \mathrm{E}$., is spaced town to 5 feet. A third set, in the intermediate opening, strike N. $70^{\circ}$ F., dip steeply south-sontheast, is spaced 10 to 25 feet. A fourth set, "blind seams," strike east, dip $50^{\circ}$ S., recurs at very irregular intervals and is unstained. The rift is reported as striking $\mathrm{N}$. $80^{\circ} \mathrm{W}$. and dipping $75^{\circ}-80^{\circ} \mathrm{S}$. The grain is probably like that in the Flat Ledge quarry. There are four basic dikes on the east and west sides, striking N. $15^{\circ} \mathrm{W}$. and dipping $70^{\circ} \mathrm{E}$., and an S-foot dike in the smaller opening striking N. $70^{\circ} \mathrm{W}$. and dipping steeply north-northeast. A dike of aplite, 4 inches wide, with a border of pegmatite 1 to 2 inches thick with bright-green feldspar, strike N. $55^{\circ}$ E. Gray knots measure up to 12 inches.

Transportation, by track 1,500 feet to wharf.

In 1906 this quarry was furnishing part of the granite for the piers and tower of the Cambridge-Boston bridge over Charles River, and also for the anchorage of Manhattan Bridge No. 3 on the New York side.

The lower Pigeon Hill quarry is at the south foot of Pigeon Hill, one-third mile west of the shore and 1 mile north-northwest of Rockport. (See fig. 73.) Operator, Rockport Granite Co., Rockport.

The granite (specimens D, XXVIII, 34, a, b), "Roekport light gray," is a hornblende granite of medium-aray, slightly bluish-green color, and inconspicuous black spots. Its texture is medium to coarse and even grained. In texture, general color, and constituents this stone appears to be identical with that of the Flat Ledge and "upper pit" of the Rockport Granite Co. The only discernible difference is that the Pigeon Hill stone shows less quartz and a slightly lighter shade in the feldspar. The thin sections also slow the presence along with the black hornblencle of a little blue-black riebeckite (soda bornblende) and a little biotite (black mica). Allanite, apatite, and 
pyrite annear also among the accessories. There is some secondary brown hornblende filling microscopic cracks in the feldsnar, also a little secondary hematite and limonite stain. Some cavities of irregular outline in the quartz measure up to 0.02 millimeter; others, of oval or roundish form with liquid and racuoles, measure up to 0.0043 millimeter.

An estimate of the mineral percentages in this granite, made by the Rosiwal method, with half-inch mesh and a total linear length of 30 inches, yields the following results: Feldspars, 58.86; quartz, 33.S8; hornblende, 7.26.

A chemical analysis of this stone, by H. S. Washington, is given on page 292. E. C. Sullivan, a chemist of this Survey, finds that it contains 0.14 per cent of CaO (lime) soluble in hot dilute acetic acid, which indicates a content of 0.25 per cent of $\mathrm{CaCO}_{3}$ (ealcium carbonate, calcite).

The following lata as to this granite were obtained by tests made at the United States Arsenal at Watertown, Mass., in 1894 from stone quarried during the previous month:

Compressive strength: Tests 6S71. 6S72, 6870 (cubes about 4 inches square). First crack at $79,000,56.000$, and 94,000 pounds; ultimate compressive strength,

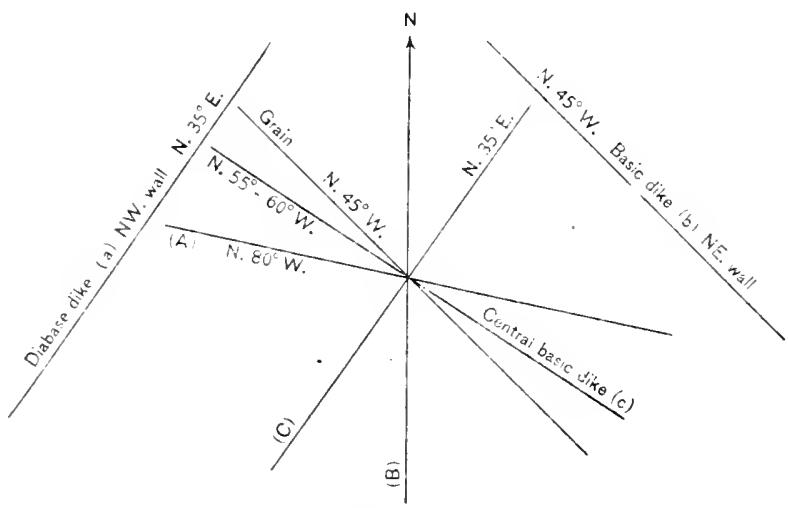

Flgtre 74.-Structure at lower Pigeon Hill quarry, Rockport, Mass.

$20,716,20,522$, and 17,772 pounds to the square inch. Direction of rift and grain in cubes not given.

Commessive elastic strength: The block tested measured 24 by 4.01 by 6.06 inches; weight, 54.5 pounds; weight per cubic foot, 161.5 pounds; sectional area, 24.3 inches square. Pressure applied endwise. Under a pressure of 1,000 pounds to the square iuch, the compression in a gaged length of 20 inches was 0.0031 inch ; under 2,000 pounds, from 0.0063 to 0.0078 inch ; under 4,000 pounds, from 0.0116 to 0.0129 inch; under 6,000 pounds, from 0.0162 to 0.0175 inch: under 8,000 pounds, from 0.0208 to 0.0209 inch; under 10,000 pounds, from 0.0253 to 0.0258 inch; and under 12,000 pounds, 0.0297 inch.

Shearing strength: Dimensions of block, 12 by 6 by 4 inches; distance apart of supports, 6 inches; width of plunger, 5 inches. Tests, 6879, 6880. First tension fractures midway between supports at 45,400 aud 38,600 pounds. Shearing fractures developed later near edge of one support. Shearing strength, 2,047 and 1,052 pounds to the square inch of shearing area.

Transverse strength: Dimensions of block, length, 24 inches; width, 6 inches; breadth, 4 inches (decimals omitted) ; length between end supports, 19 inches; tests, 6SS2, 6SS3; ultimate strength, 12,320 and 12,480 pounds to the square 
inch, equaling a modulus of rupture of 2,404 and 2.416 , respectively. This was computed by the formula

$$
\mathrm{R}=\frac{3 \mathrm{pl}}{2 \mathrm{~b} \times 1^{2}}
$$

The granite talies a very high polish and hammers rather light.

The quarry, opened about 1871, measured in 1906 about 625 feet on the northeast side and 700 feet on the southwest side by 450 to 500 feet across and from 40 to 80 feet in tepth.

Rock structure: The sheets, 6 to 10 feet thick, dip about $10^{\circ} \mathrm{NI}$. in the northern part of the quarry but $10^{\circ}-30^{\circ} \mathrm{SE}$. in the southeastern fart. The joint and dike courses are shown in figure 74 . Set (A), dip $75^{\circ}$ N., spacerl 3 to 10 feet, abounds in the southern part. (B), dip $55^{\circ} \mathrm{W}$., exceptionally $55^{\circ}$ E., spaced 2 to 20 feet. In the southwestern part the closeness of these joints precludes the quarrying of large hlocks. (C), dip steeply west. The rift is reported as horizontal but feeble, and the grain as vertical with northwest course. Dike $(a), 10$ to 12 inches thick, dip $65^{\circ} \mathrm{W}$, forming west sirle of quarry, is a fine-grained diabase consisting of soda-lime feldspar (anclesine). hornblence from alteration of augite, magnetite, and black micis. Dike $(b), 18$ inches thick. dip $75^{\circ} \mathrm{SW}$, forms the north wall. Dike $(c), 12$ inches thick, (lip $75^{\circ}$ WSW., crosses the center of quarry. Knots measure up to $10 \mathrm{by} 7$ inches, and rusty stain up to 6 inches on sheet surfaces.

Transportation, by horsep wer and an inclined trick one-thirt mile to wharf.

The product goes chiefly into buildings but partly into paring and riprap for breakwater use. Specimens : High School, Charlestown, Mass., entire; Bradfort Nemorial Chapel, Gloncester.

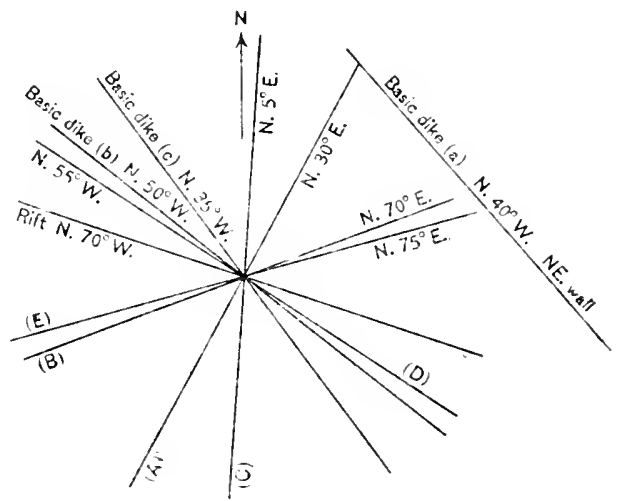

Figene 75.-Structure at upper Pigeon Hill quarry, Rockport, Mass.

Mass.; Chelsea riaduct over Boston \& Maine Railroad at Mystic Wharf, Mass.; Union National Bank, Pittsburgh, Pa.

The upper Pigeon Hill quarry is about a mile northwest of Rockport and one-third mile southwest of Pigeon Hill. (See fig. 73.) Operator, Rockport Granite Co., Rockport.

The granite is a hornblende granite of medium-gray, slightly bluish-rrcen color, with inconspicuous black spots. Its texture is medium to coarse and even grained. It is identical in composition with the stone of the lower quarry.

The quarry, opened about 1876 , measured in 1906 about 800 feet in a $\mathrm{N} .35^{\circ} \mathrm{F}$. direction by 450 feet $\mathrm{N}$. $65^{\circ} \mathrm{W}$. and from 50 to 100 feet in deptl.

Rock structure: The sheets, 4 inches to 12 feet thick, dip mainly west up to $10^{\circ}$. Thin sheets are confined to the upper 20 feet. The sheet structure is generally regular, as shown in Plate XXVII, $A$. Joint and dike courses are giveu in figure 75 . Set (A), vertical, spaced 7 to 50 feet. (B), dip $20^{\circ} \mathrm{S}$. spaced 50 feet; its low inclination confuses the sheet structure in places. (C), dip $55^{\circ}$ W., spaced 10 to 50 feet. (D), exceptional and intermittent, dip $75^{\circ}$ NE. (E), also exceptional, dip $75^{\circ} \mathrm{SSE}$. The rift is reported as vertical, 
with N. $70^{\circ} \mathrm{W}$. course, and the grain as horizontal. There are three or more basic dikes from 12 to 15 inches thick: Dike ( $a$ ) forms the northeast wall; $(b)$ about 350 feet from (a), dips $80^{\circ} \mathrm{NE}$.; $(c) 300$ feet southwest of $(a)$, is vertical. The intersection of the sheets by the central dike is well shown in Plate XXviI, $A$. Knots are reported as generally not over 2 feet, but rarely up to 10 by 5 feet. Rusty stain is from 0.5 to 12 inch thick.

Transportation, by inelined track half a mile to wharf.

The product is used largely in construction. Some of it was used in the towre on the southeast corner of the Cambridge and Boston bridge over Charles River.

The Coalford Swamp quarry is near Pigeon Cove. Operator, J. Leonard Johnson, Pigeon Core.

The granite is essentially identical with that of the Pigeon Hill quarries.

The product is rough and hammered granite and paving.

The Babson Farm quarry is at the north end of the cape, near Halibut

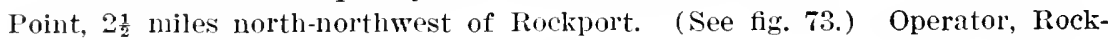
port Granite Co., Rockport.

The granite (sperimen 1', XXVIII, 25, d) is a hornblende granite of somewhat dark greenish-gray color. It is markedly darker than the granite of the Flat Ledge and ligeon Hill quarries. Its texture is medium to coarse, even grained, with feluspars up to 0.5 inch and homblende up to 0.3 inch. Its constituents, in descending order of ahundance, are medium greenish-gray potash feldspar (orthoclase), intergrown with soda-lime feldspar and in places much kaolinized; very smoky quartz, with parallel sheets of eavities and abounding in prismatic grayish crystals up to 0.02 millimeter; black hornblende; and very little separate sola-lime feldspar (oilgoelase-albite). Accessory: Magnetite, zircon. and apatite. Seeondary: Kaolin, limonite, hematite, and chlorite, the last in eracks and isolated particles within the feldspar, also along the boundaries of particles. To the chlorite and the limonite the feldspar owes its greenish tinge.

The quary, opened about 1897, measures about 350 feet in a northeasterly direction by 150 feet across and from 40 to 50 feet in depth.

Rock structure: Sheet structure is normal. The sheets, 4 inches to 15 feet thick, increasing in thickness downward, are horizontal or dip $10^{\circ} \mathrm{NW}$. There are four sets of joints-(a), strike N. $40^{\circ}$ E., dip $75^{\circ}$ SE. or $90^{\circ}$, spaced 10 to 40 feet, forms the northwest and southeast walls; (b), strike N. $4^{\circ}$ W., dip $45^{\circ}-50^{\circ} \mathrm{SW}$., spaced 100 to 200 feet; (c), strike N. $65^{\circ} \mathrm{W}$., vertical, forms the northeast and southwest walls; (d), strike N. $\$ 0^{\circ}$ E., vertical, forms a short heading near the north corner and recurs at rare intervals. The rift is reported as marked and vertical, with $\mathrm{N} .50^{\circ} \mathrm{E}$. course, and the grain as horizontal. A segregation of uncommon composition, $S$ by 4 by $2 \frac{1}{2}$ feet, in this quarry is described on page 60. There is some pyrite on the joint faces. Rusty stain is 1 to 6 inches thick along the sheet surfaces.

Transportation, by cart one-fourth mile to wharf, which affords 30 feet of water at low tide.

The Nickerson quarries are one-fourth mile southeast of Folly Cove and 2 miles N. $30^{\circ} \mathrm{W}$. of Rockport. (See fig. 73.) Operator, W. E. Nickerson, Ianesville. Idle since 1912 .

The granite, like specimen D, XXVIII, 29, a, from the Devils Rock quarry, lescribed on page 299 , is a hornblende granite of medium-gray slightly buff color and weak contrasts.

The main quarry, opened in 1896, is triangular and measured in 1906 about 350 feet N. $40^{\circ}$ W. hy 350 feet east and 400 feet N. $40^{\circ}$ E. and up to 25 feet in depth. The other opening measured about 100 by 60 feet and 60 feet in depth. 
Rock structure: The sheets, 9 inches to 6 feet thitk, mondate horizontally. There are four sets of joints-(a). stribe nearly east, vertical, spaced 10 to 100 feet; (b), strike N. $40^{\circ}$ L., exceptional: (c) in the smaller pit, strike rertical, spaced 10 to 20 feet; (d), in the smaller pit, strike N. $30^{\circ} \mathrm{W}$, dip $70^{\circ}$ E., spaced from 10 feet up. The rift is reporterl as reltiral, with east-west course, and the grain as horizontal. A vertical dialbase dike, 6 feet thick, weathering spheroidally, strikes N. $40^{\circ} \mathrm{W}$. and forms the northeast wall of the main quarry. Another east of the quarry has a like comse. Kinots are reported as not over 1 foot in diameter. Kusty stain is 2 inches thick on lower sheets and 9 inches on the npper ones.

Transportation, by cart one-half mile to Ianesville wharf.

The product consists largely of paving stone, with some "random" stone. The tuarry was not operited in 1916.

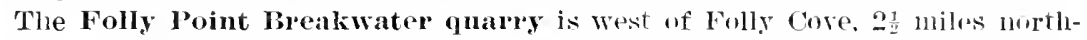
west of Rockport. (See fig. 73.) Operator, Coast \& Lakes Contracting Corporation, 41 Broad street, New York. Irlle since 1915.

The granite is a gray hornblente granite, which. because of the use to which it was being put, was not specially examined.

The quarry, opened in 1905. measured in 1906 about 250 feet in a westnorthwesterly direction hy 100 foet across and from 5 to 30 feet in depth.

Sheet structure is scarcely perceptible, hut the interserting joints and hearings are so numerous as to facilitate quarrying for the purpose in view.

Transportation, by track 300 feet to wharf.

The product in 1906 was riprap for the Rockport breakwater. The average weight of each block was 4,000 pounds and the minimum 200 pounds.

The Butman Arenue quarry is on Butman Arenue, Lanesville. Operator, Cape Ann Granite Corporation, Lanesville.

The quarry was opened in 1906.

The granite is used for buildings, sea walls, bridges, breakwaters, and paring.

The Devils Rock quarry is about half a mile southeast of Lanesville and about $1 \frac{3}{1}$ miles $\mathrm{N} .55^{\circ} \mathrm{W}$. of Rockport. (See fig. 73.) Inlle since 1917.

The granite (specimen D, XXVIII, 29, a) is a horublende granite of general medium gray, not bluish shade and of medium to coarse. even-grained texture, with feldspars up to 0.4 inch and black hornblende np to 0.3 inch. It consists, in descending orcler of abumlance, of light-gray potash feldspar (microcline and orthoclase), from slightly greenish to cream-colored, minutely intercrown with soda-lime feldspar (albite to oligoclasealbite) and somewhat kaolinized: very smoky quartz with cavities; and black hormblente. Accessory : Magnetite, pyrite, zircon, and allanite. Secondary: Kaolin.

'The quarrs, opened in 1576. measured in 1906 about 400 by 200 fcet and averaged about 50 feet in depth.

Rock structure: The sheets, 1 to 18 feet thick, dip $10^{\circ} \mathrm{N}$. There are three sets of joints-(a), strike N. $25^{\circ}$ E., dip $70^{\circ}$ E. to $90^{\circ}$, spaced 3 to 90 feet, forms a beading on the west side; (b), strike N. $70^{\circ}$ W., dip $45^{\circ}$ to steeply north, spaced from 1 to 50 and 100 feet, forms a heading on the south sicle and the wall on the north; (c), diagonal, strike N. $25^{\circ}$ E., dip about $65^{\circ}$ NW., spaced 20 feet at the south end, does not recur. The rift is reporterl as good. vertical, and with east-west course. There is a 6 -inch basic dike on the east sicle. Gray knots are reported up to 14 by 6 inches. Rusty stain is 1 to 6 inclies thick.

Transportation, by cart 1 mile to Lanesville wharf, which affords 13 feet of water at high tide. 
The product is used for building and paving. In 1906 this quarry furnished rock for the naval dry dock at Kittery, Maine.

The Cheves Green Granite quarry is about 250 feet south of the Devils lonk quarry and $1 \frac{3}{4}$ miles N. $60^{\circ}$ W. of Rockport. (See fig. 73.) Quarry idle since 1917.

The granite (specimen D, XXVIII, 30. a), "green granite," is a hornblende granite of somewhat dark olive color, spotted with black, and of medium to coarse, even-grained texture, with feldspars up to 0.5 inch and hornblende up to 0.3 inch. When first quarried the yellowish-green tint is scarcely percentible, but after a few hour's' exposure to rain it becomes marked. Its constituents, in descending order of abundance, are a medium olive-gray potash feldspar (orthoclase and microcline, much of it twinned), minutely intergrown with soda-lime feldspar (many of the feldspars are much kaolinized and contain minute particles, possibly of an oxide of iron); very smoky quartz with cavities and black particles; some separate soda-lime feldspar (albite to oliqoclase-albite); and black hormblende. Accessory: Magnetite. allanite (most of it within hornhlende particles), and zircon. Secondary: Calcite and limonite stain, some of it proceeding radially from allanite particles, also in cracks and along boundaries of particles.

The contrast in this stone, owing to the dark shade of the quartz, is mostly between the feldspar and the combined quartz and hornblende.

The quarry is somewhat triangular in outline, measuring about 200 feet $\mathrm{N}$. $70^{\circ} \mathrm{W}$. by 100 to 200 fect arross. and in 1906 was 30 to 90 feet deep.

liock structure: The sheets are up to 35 feet thick. The joints correspond to sets (a) and (b) of the Devils Leck murry, and the rift is said to be as in that quarry but less marker.

The Blood Ledge quary is three-fifths mile east-moriheast of Pay View and 2 miles N. $62^{\circ} \mathrm{W}$. of Rockport. (See fiw. 73.) Operator, Rockport Granite Co., Rockport.

The granite (specimens D, XXVIII, 2s, b. e), "Rockport sea-green," is a hornblende granite of general somewhat dark olive color, with black spots, and of medium to coarse, even-grained texture, with feldspar up to 0.5 inch and hornblende up to 0.2 inch. Its constituents, in descending order of abun(lance, are a more or less kaolinized medium olive-gray potash feldspar (orthoclase and microcline, mostly twimned), minutely intergrown with soda-lime feldspar (albite to oligoclase-albite); very smoky quartz with cavities and black particles; black hornblende; and rarely a little biotite. Accessory: Magnetite, allanite, zircon. Secondary: Kaolin, chlorite, limonite stain. This stain occurs in meandering cracks in both felclspar and quartz and along the boundaries of particles, and also radiates flom allanite particles, which are one of the primary causes of the yellowish-green tint of the granite. Part of this quary yields a gray granite like that of the "Deep Pit" (p. 301). The "green granite" described above when first quarried is dark gras, but after wetting becomes in three to four hours olive green. After continued exposure about the quarry the green tint becomes less marked.

An estimate of the mineral percentages in this stone, obtained by the Rosiwal method, with a mesh of 0.7 inch and a total linear length of 16.8 inches, yields the following results: Feldspar, 58.45; quartz, 31.95 ; hornblende, 9.60.

This stone takes a very high polish and hammers rather light. Some particles of feldspar vary on the polished face from an olive-green to a scarcely greenish milk-white. The contrasts between the three minerals are more marked on the polished face. This granite is well adapted for indoor decorative use. 
The quarry, opened about 1868, formed in 1906 an inequilateral quadrangle, the longest side of which measured about tho feet, and which is bisected by a basic dike and contains an unexcarated central mass upon which the derrick stands, as shown in figure 76 . Its depth is about 150 feet below the general surface, from whicli, however, 50 feet had already heen quarriel away.

Rock structure: The sheets, 10 to 30 feet thick, dip $15^{\circ} \mathrm{W}$. There are four sets of joints, whose courses are given in figure $76-(\mathrm{A})$, dip $55^{\circ} \mathrm{li}$., spalced 3 to 30 feet, forms the west wall; (B), exceptional, dip $50^{\circ} \mathrm{W}$.; (C), dip $30^{\circ}$ N.; (D), dip $90^{\circ}$ or steeply south, forms the short south wall and recurs intersecting the north wall. The rift is reported as rertical, with a $\mathrm{N} .85^{\circ} \mathrm{W}^{\circ}$. course, and the grain as also vertical and about north-south. The stone is said to split most readily from the ends of the blocks, both along rift and grain. The basic dike, shown in figure 76 , is 2 feet thick and dips $70^{\circ} \mathrm{sW}$. Dark knots a few inches in diameter were collected, but they are reported as occurring up to the size of half a barrel. linsty stain is up to 3 inches thick on slieet faces.

Transportation, by a locomotive and track about 1 mile to wharf at Bay View.

The product is userl for buildings, monuments, locks. amel paving. Specimens: Ot gray granite, the first story (outside) of Suffolk County courthouse, Boston; six polished columns and two pilasters in the Madison Square Presbyterian Church, New York. Of the polished green granite, Hamilton Club house. Chicago;

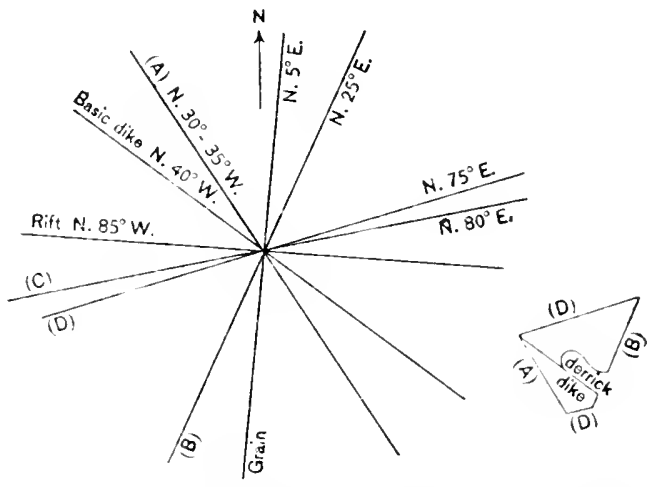

Figtre 76.-Structure and plan of Blood Ledge (1uarry, Rockport, Mass.

O. D. Barnes Building, Wichita, Kans,; National State Bank, Newark, N. J.; Woolworth Building, New York. Of the "bush-hammered" green granite. post offices at Elkhart, Ind., and Deadwood, S. Dak.; Syndicate Building, Minneapolis, Minn.; Brooks Bros.' Building, New York.

The "Deep or Old Pit" is about one-fifth mile from tidewater at Bay View, on the west side of the cape, $2 \frac{1}{4}$ miles N. $73^{\circ} \mathrm{W}$. of Rockport. (See fig. 73.) Operator, Rockport Granite Co., Rockport.

The granite (specimens D, XXVIII, 27, a, b), "Bay View gray," is a hornbende granite of medium-gray shade (lighter than 25, d, Babson quarry, p. 298, and darker than 24, a. 34, a, and 29, a, Flat Ledge, Pigeon Hill, and Cheres quarries, pp. 294, 295, 300), with a slight cream and greenish tinge, spotted with black. Its texture is medim, even grained, with feldspars up to 0.4 inch and hornblende up to 0.3 inch. Its constituents, in descending order of abundance, are a cream-colored and pale-greenish, more or less kaolinized potash feldspar (orthoclase and microcline, mostly twinned), minutely intergrown with soda-line feldspar; very smoky quartz with cavities; a little separate soda-lime feldspar (oligoclase-albite), and black hornblende. Accessory: Magnetite, zilcon, and allanite. Secondary: Kaolin, chlorite, calcite, and hematite and limonite stain. The colors of feldspar are evidently due to the chlorite and limonite. 
An estimate of the mineral percentages in this granite, by the Rosiwal method, with half-inch mesh and total linear length of 20 inches, yields the following results: Feldspar, 50.60: quartz, 34.70: hornblende, 5.70.

This sranite takes a very high polish. In the rough its contrasts are less marked than those of the Flat Ledge and Pigeon Hill stone. and the color of the feldspar is different. but the contrasts are more marlied on the polished face, owing to the lighter tinge of the felclspar.

The quarry, opened about 1848 , measures about 800 feet $\mathrm{N}$. $20^{\circ} \mathrm{W}$., by 500 feet across, but owing to a recess its actual area is about 750 by 500 feet. Its depth is about 200 feet. A diagonal view of this quarry is given in Plate XXYiI, $B$, and a rough plan of it in figure $7 \pi$.

lock structure: Sheet structure is hardly perceptible but at the south end seems to $d l_{1} 20^{\circ}$ E. and at the northeast corner to undulate horizontally. In the absence of sheets horizontal chamneling has to be resorted to. Steeply downward-curving partings, "toenails," are conspicuous in the central part. Joint and dike courses are shown in figure 77.

There are four sets of joints-(A), rertical; (B), rlip $60^{\circ}$ E.; (C), dip $55^{\circ}$ $\mathrm{NE}$; (D), rertical. The rift is reported as vortical, with $\mathrm{N} .85^{\circ} \mathrm{W}$. course, and

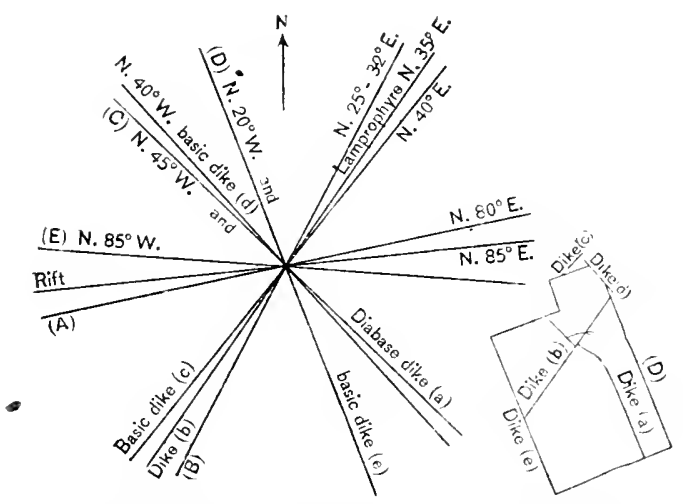

Figure 77.-Structure and plan of Deep Pit quarry, near Bay View, Rockport, Mass. the rrain as horizontal. The stone is said to split readily from the top. There are five lasic dikes. The central one, (a), hornblende diabase of sula-lime feldspar (andesine) micasized, augite, hornblende, magnetite, and black mica (lintite), from 12 to 18 feet thick and dipping $55^{\circ}-60^{\circ} \mathrm{NE}$. crosses the quarry diagonally, but with marked curvature, N. $\because 0^{\circ}-45^{\circ} \mathrm{W}$.. and is also faulted along dike $(b)$ with a lateral displacement of about 15 feet. Both of these dikes and the fault are shown in Plate XXVI, $B$. Dike (b), a lamprophyre consisting of soda-lime feldspar (andesine) altered to white mica, zoisite, and epidote, also with hornblende, augite, and magnetite, is 18 inches thick and dips $55^{\circ}$ WNW. Dikes $(c),(d)$, and $(e)$ are rertical. In the northern part a small branching and curved basic dike intersects and branches off from dike (a). The relations of these dikes are shown in figure 77 . In about the center of the quarry at a depth of 125 feet is an irregular mass of injected hornblende diabase, more fully described on page 54 and also shown in figure 3 , which is probably connected more or less remotely with dike (a). Rusty stain along sheet surfaces is up to 6 inches thick.

Transportation, by track half a mile to wharf at Bay View, which affords $15 \frac{1}{2}$ feet of water at low tide.

Specimen structures: Boston and Baltimore post offices.

The Bay View dark-granite prospect is between the Blood Ledge quarry and the "Deep Pit" near Bay View, and was opened by the Rockport Granite Co., of Rockport. It may be in the small area of augite syenite shown on Sears's geologic map of Essex County. ${ }^{27}$

${ }^{27}$ Sears, J. II., The physical geography, geology, mineralogy, and paleontology of Essex County, Mass. Salem Essex Inst., 1905. 
The granite (specimens $\mathrm{D}, \mathrm{XXVIII}, 2 \mathrm{~S} \frac{1}{2}, \mathrm{a}, \mathrm{h}$ ) is a rieleckite-acgirite-liotite granite of dark brownish-gray color and medinm to coarse. exch-Lraned texture, with feldspars up to 0.5 inch in diameter. It consists, in descending order of abundance, of a brownish-gray potash foldepar (orthochase and microcline), somewhat kaolinized, mostly in twins and minutely intergrown with sorla-lime feldspar; slightly smoky quartz; brownish-gray sola-lime feldspar (abite to oligoclase-albite) ; blue-black liebeckite (soda-hornblende) ; wreen-black acgirite (soda-augite); and black mica. Accessory: Magnetite, allanite, zircon, fluorite, and apatlte; the first three are somewhat abundant. Secondalry caldote is present in small amomt, and a little limonitestain occurs to which the feldsiars owe their brownish tinge. They also contain minute particles of all the black silicates.

This rock takes a very high polish and hammers rather light. The quartz and feldspar being of about one shade, the only contrist on the polished face is between these and the black silicates. On the rough face the contrast is slight.

The Pigeon Cove porphyry quarry is on a dike of alteresl diabase porphyry. 18 feet wide, represented by Shaler ${ }^{28}$ and Tarr as exposed for hilf a mile on the hillock west of Pigeon Cove, with a N. $21^{\circ} \mathrm{W}$. course, also as reappearing in Rockport three-fourths mile west of Gap Head with a N. $9^{\circ}$ W. course. Washington ${ }^{20}$ refers to this dike as cutting the quarry pit at Pigeon Cove and describes it microscopically as a labradorite porphyry. Operator's, Fuller, Foley \& Co., West Quincy, Mass.

This diabase porphyry (specimens D, XXIX, 89, a, b), "Rocliport porphyry," has a very tark green or black fine-grained groundmass, with porphyritic felespars of medium greenish-gray color, from 0.2 to 4.42 inches in length by about 0.78 inch in width. Many of the crytals are from 1 to 2 inches long. Their striation shows plainly. Plate XXY, $B$, shows the general character of the rock. The sromdmass consists of these minerals, in descending order of abundance: Lime-sola feldspar (andesine-labralurite), partly micacized; angite, largely altered to a green hornblende; and chlorite, biotite (black mica), magnetite, apatite. and rarely a little secondary calcite.

This rock takes a very high polish, and the contrast between the black groundmass and the large pale-greenish crystals is most striking.

Product specimens: Four polished disks, 5 inches thick and 2 feet 6 inches in diameter (made in two halves), embedded in the Roman pavement abont the Bethesda Fountain, also a band around its central drain plate, on "The Terrace" at end of "The Mall" in Central Park, New York. The texture of this porphyry is sliown in Plate XXY, $B$.

\section{HAMPDEN COUNTY.}

\section{MONSON.}

According to Emerson, ${ }^{30}$ the gneiss of Monson forms a narrow north-south strip which. with a short interruption, extends from the New Hampshire border to the Connecticut horder. It is called Monson granodiorite and is regarded as of late Carboniferous or post-Carboniferous age. The parallel banding of the rock is attributed to segregation of the biotite during flowage.

${ }^{29}$ Shaler, N. S., The geology of Cape Ann, Mass. : U. S. Geol. Survery Ninth Anu. Rept., p. $609, \mathrm{pl} .77,1889$.

* Washington. H. S., The petrographical province of Essex County, Mass.: Jour. Geology, vol. 7, p. 290, 1899.

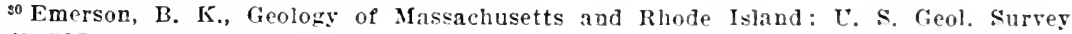
Bull. 597, p. 241 , pl. $10,1917$. 
The FIynt quarries are in Monson Township on the southwest side of Bun-

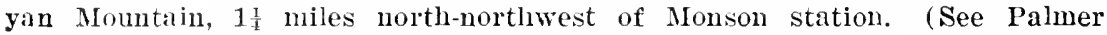
topographic mal, U. s. Geol. survey, and Plate XXIII.) Operator, William N. Flynt Granite Co., Monson.

The granite (specimens D, XXX, 90, a, b, c), Monson (darker variety, used for faces of buildings), is a quartz-nica cliorite gneiss (granodiorite) of dark to very lark glay shade and fine to very fine elongated (unplicated) gneissose texture, with feldspars and mica up to 0.2 inch but mostly under 0.1 inch. Its constituents, in lescending order of abundance, are clear colorless quartz with cavities; bluish transhucent to milk-white soda-lime feldspar ${ }^{31}$; and biotite (black mica). Accessory : Magnetite (fourth in order of abundance), garnet, zircon, apatite, and allanite. Secondary: Epidote (fifth in order of abundance) and chlorite. No effervescence with muriatic-acid test. No pyrite on the polished face.

A light to medium gray rariety (specimen 90, c) with fine bands of dark gray has the same composition as the rock described above but less biotite. This stock is used for curbing, foundations, etc.

The following analysis of it was made by W. F. Hillebrand ${ }^{32}$ :

Analysis of quartz-mica diorite from Flynt quarry, Monson, Mass.

Silica $\left(\mathrm{SiO}_{2}\right.$

Alumina $\left(\mathrm{Al}_{2} \mathrm{O}_{3}\right)$

Iron sesquioxide $\left(\mathrm{Fe}_{2} \mathrm{O}_{3}\right)$

Iron oxide $(\mathrm{FeO})$

Magnesia (MgO)

Lime $(\mathrm{CaO})$

Soda $\left(\mathrm{Na}_{2} \mathrm{O}\right)$

Potash $\left(\mathrm{K}_{2} \mathrm{O}\right)$

Water $\left(\mathrm{H}_{2} \mathrm{O}\right.$ at $\left.105^{\circ}\right)$

Combined water $\left(\mathrm{H}_{2} \mathrm{O}\right.$ above $\left.105^{\circ}\right)$.

Titanium dioxide $\left(\mathrm{TiO}_{2}\right)$

Carbou dioxide $\left(\mathrm{CO}_{2}\right)$

Phosphoric acid $\left(\mathrm{P}_{2} \mathrm{O}_{3}\right)$

Manganese oxide (MnO)

Barium oxide ( $\mathrm{BaO}$ )
65.02

18. 37

1. 21

2. 06

1. 49

6. 20

3. 96

.64

.09

.42

.33

None.

.14

.09

Trace.

100.92

Merrill ${ }^{33}$ states that a test of this gneiss showed a crushing strength of 15,390 pounds to the square inch with the pressure applied at right angles to the foliation, and 12,720 pounds with the pressure applied in the direction of the foliation.

The fine and eren foliation of this gneiss renders it more suitable for some purposes and less for others than a true granite. The absence of pyrite in its composition is in its favor as a building stone. Its foliatiou prevents its taking a high polish.

The first opening was made in 1824 by United States agents for the construction of the armory at Springfield, Mass. The quarry in operation in 1910 was about 350 by 150 feet and from 20 to 30 feet deep.

${ }^{31}$ In describing thlu sections of this rock in U. S. Geol. Survey Bull. 470, the writer mistook the grating twinning of plagioclase for microcline and so determined the rock as a biotite-quartz monzonlte.

32 U. S. Geol. Survey Bull. 419, p. 22, analysis 1, 1910.

"s Merrill, G. P., Stones for building and decoration, p. 406, New York, 1891. 
Rock structure: The sheets, 6 inches to 10 feet thick, mostly 2 to 5 feet, dip $5^{\circ}-20^{\circ} \mathrm{W}$. The ouly joints are parallel to the foliation and are spaced 10.50 , and 90 feet. The gneiss foliation stlikes N. $10^{\circ}$ E. and tips $75^{\circ} \mathrm{N} .80^{\circ} \mathrm{W}$. The rock is of light, medium, and dark gray colors in alternating hands of very different wirlths. Some are not over 0.25 inch wide; others 2 or 3 feet. These bands are free from plications, but one was found doubled over on itself vertically for the space of a foot. Each band as seen on the sheet surface also varies greatly in width. Some foliation faces are chloritie. The rift corresponds to the foliation and the grain is horizontal. A few pegmat.te bands up to 3 inches thick occur. There is no rusty stain.

The Monson quarries have long been referred to as affording evidence of compressive strain, ${ }^{34}$ but although the rock is still under a north-south strain, fracturing attended with explosive sounds no longer occurs.

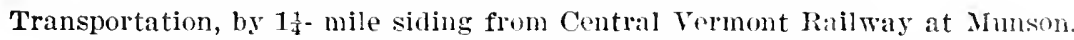

The product is used for buildings, bridges, and monuments; the seconds for curbing, foundations, and crushed stone for concrete. Specimens: Iloritio Iyon Library, Monson; Walker Hall, Amherst College, Mass.; Church of St. Francis Xavier on Sixteenth Street, Isabella Home on One hundred and nineteenth Street, Munn Monument, Woodlawn Cemetery, New York ; Roman Catholic Church and rectory, West New Rochelle, N. Y.; residence of Charles La Dow, Thurlow Terrace, Albany, N. Y.; Congregational Church and Doane buildings, Rockville, Conn.; fountain at Weatogue, Conn.; Hall Memorial Chapel, Watertown, Conn.; high school, East Orange, N. J.; Park Avenue Methodist Church, Chicago.

\section{HAMPSHIRE COUNTY.}

\section{PELHAN.}

The granite at Pelham is in a lenticular area designated on the map of Bulletin 597 "Pelham granite (gray biotitic gneissoid granite)" and shown as extending from Northfield to Belchertown with a maximum wilth of 8 miles. Its age is regarded by Enerson as late Carboniferous or post-Carboniferous, and its banding is attributed to segregation in flowage.

The Ward quarry is in Pelham Township, 2 miles northeast of West Pelham and about 4 miles east-northeast of Amherst. (See Belchertown topographic: map, U. S. Geol. Survey, and Pl. XXIII.) Operator, E. P. Bartlett, Amherst. Idle since 1908 .

The granite (specimens $\mathrm{D}, \mathrm{XXX}, 91, \mathrm{a}, \mathrm{b}, \mathrm{c}$ ), Pelham, is a biotite granite gneiss of general dark bluish-gray color and rery fine elongated (unplicated) gneissic texture, with feldspars and mica under 0.1 inch. It is finely banded. the bands being mostly not over 0.04 inch wide and of very dark gray alternating with white. There are fine-grained white bands without blark mica (specimen $c$ ). There are also lenses of quartz and feldspar up to 0.3 inch wide and several lnches long. containing black mica crystals uj to 0.3 inch in diameter, lying transverse to the foliation (specimen b). Its constituents, in descending order of abundance, are clear to translucent bluish potash feldspar (microcline and orthoclase); very pale smoky quartz; biotite (black mica) with a little muscovite; and very little milk-white plagioclase feldspar, kaolinIzed. Accessory: Magnetite, titanite, zircon, allanite, apatite. Secondary: Kaolin, epidote, carbonate, chlorite. No effervescence with muriatic-acid test."

as See Niles, W. II., Some interesting phenomena observed in quarrying: Boston Soc. Nat. Hist. Proc., vol. 14, pp. 80-87, 1872 ; vol. 16, pp. $41-43,1874$; also Emerson, B. K., Geology of Old Hampshire County, Mass.: U. S. Geol. Survey Mon. 29, pp. 64-65, 1898.

so Emerson's description of the stone will be found on pl. 248-249 of Bulletin 597.

$105700-23-21$ 
An nualysis of this prmeiss male ly Gorge steiger, a chemist of this Survey, mbws:

Andysix of biotite granite unciss from Peltam, llass."

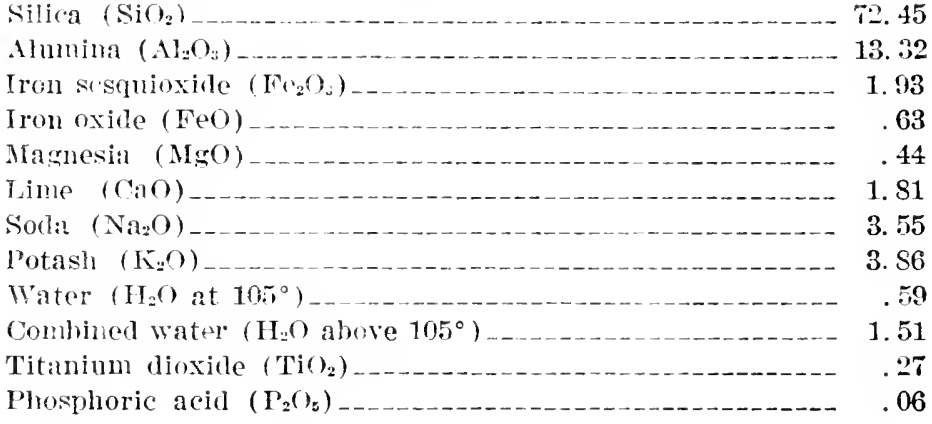

100. 42

In comparing this analysis with that of the Monson granodiorite (p. 304) it will be noticed that this has higher percentages of silica and potash and lower of alumina. iron oxides, magnesia, and lime. The microscopic descriptions of the two rocks show that the Monson granoliorite contains much more soda-lime feldspar than the I'elham stone.

The Pelham granite resenbles that of Monson in appearance, and its economic uses and value are similar. The shade of the Pelham stone is a trifle lighter than that of the best dark granite of the Monson quarry.

The quary, olened before 1862 and now worked irrigularly, measures about 200 feet in a northwest direction and has a working face 25 feet high on the northeast.

Rock structure: The sheets. 6 inches to 2 feet thick, are parallel to the gneiss foliation, which strikes $\mathrm{N}$. $S 0^{\circ} \mathrm{W}$. and dips in undulations $5^{\circ}-13^{\circ} \mathrm{N} \cdot 10^{\circ} \mathrm{E}$. The sheet surfaces are slickensited. with strise striking $\mathrm{N} .10^{\circ} \mathrm{E}$. There are no joints. The rift is parallel to the foliation, and the grain is probably vertical, with N. $10^{\circ}$ E. course. Pegmatite dikes of liglit feldspar, smoky quartz, and biotite up to an inch thick dip $50^{\circ}-60^{\circ}$ about north. Lenses of smoky quartz, up to 30 feet long ant to 6 inches thick, lie in the foliation, and porphyritic feldspar lenses up to $3 \mathrm{l}, \mathrm{y} 2$ incles are strung along in the foliation, forming in places, with biotite and quartz, pegmatitic bands un to 2 inches thick. One such lens contains black hornblende masses 2 inches by 1 inch.

Tiransportation, by cart about 4 miles to Amherst.

The product is used for local builtings. Specimens: Old gymnasium and basement story of geological and zoological building at Amherst College.

\section{MIDDLESEX COUNTY.}

GEOLOGIC RELATIOIS.

The quarries in Acton ar: in an ar"a designated on the map of Bulletin 597 "igneous gneiss of undetermined age (including schist)." Those in Groton and Westford are in an area designated "Ayer granite (coarse porphyritic biotite muscovite granite)" and are regarded by Enerson ${ }^{20}$ as of a late Carboniferous or post-Carboniferous age. The quarry in Townsend is in an area designated

so U. S. Geol. Survey Bull. 419, p. 22, analysis L, 1910.

¿. U. Geol. Survey Bull. 587, pp. 218, 223-225. 
"Fitchburer granite (white muscovite-biotite sranite)," a descrint on that hardly fits the granite quarried in Townend and also across the state line

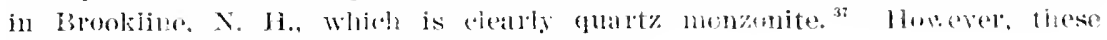

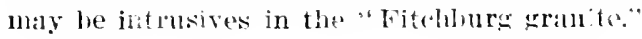

\section{ACrON.}

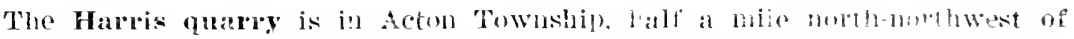

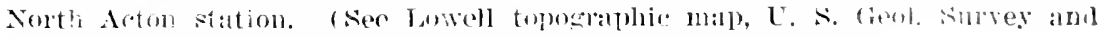
Pl. XXIII, Oierator, North Acton Quarry Co, North Acton.

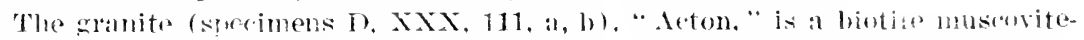

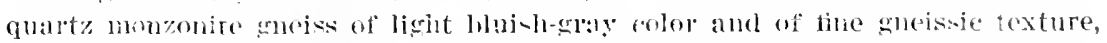

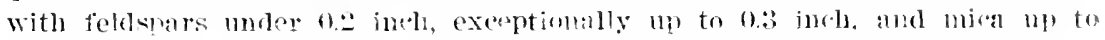
0.1 inch. Its constituents. in rescendisg molel of almudance, are milliwhite

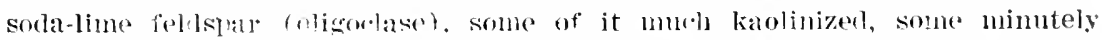

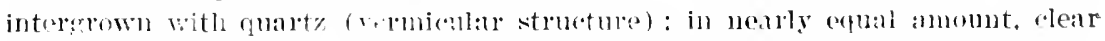

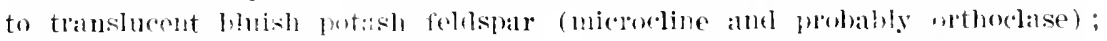
clear colorless quatto struined, with rutile neelies am some cavities; biotite (black mira). stmu of it moritizel ; and museorite (white mical). Aecessory : Magnetite, rathel plentiful, alratits, rutilr, zircon. Secondary: Kanlin,

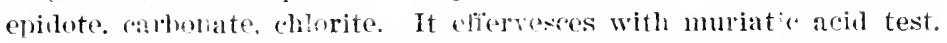

This is a bright stme of sullicient compeness to show the mincral rontrasts, the color's leeing blatk atu white.

The quilry. apened in 1855, moisured in 1910200 by 100 feet and from 10 to :3 feet diere.

Rock structure: Tlere are traces of shects from 6 inches to 3 feet thick, but blokks 12 ffet thick can be obtilinel. This is a "bouldel quarry." There are two sets of joints-- $(a)$, strike $\mathrm{N}$. $75^{\circ}$ E., dip $75^{\circ}$ S. $15^{\circ}$ E., slickensided and conted with epidote, one only, forming the north wall; $(b)$, strike $\mathrm{N}$. $35^{\circ} \mathrm{W}$, dip $45^{\circ}$ S. $55^{\circ}$ W. to $90^{\circ}$, spaced 5 to 50 feet. The rift is about

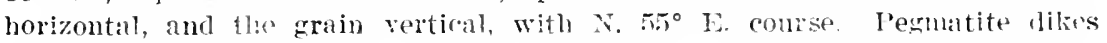
up to 5 incles thick have a $X .30^{\circ} \mathrm{i}$. comrse. Rust stain is up to a foot thick on the nuter masses.

Transportation, by cart to North Acton station, half a mile.

The product is used for buildings, monuments, and curbing. Sipromens: James Wotheriee monument, Woodlawn Cemetery Acton; Samuel Guilford monument. Nount Hope Cemetery : and Dunlop monument, Sleepy Hollow Cemetery, West Acton.

Quarry not operater in 1916.

The McCarthy quarry is in Acton Towiship, alyont half a mile northwest of North Acton station, at the top of a small knoll. (See Lowell topogripluice map. U. S. Geol. Survey, and Pl. XXIII.) Operator, Thomas MeCarthy, North Acton. Inle since 1916.

The granite (specimen D. XXX, 112, a), "Acton fine," is a biotite-muscoritequartz monzonite of light to medinm bluish-glay color and of fine to very fine, obscurely gneissoid texture, with feldspiars under 0.2 inch and mica up to 0.1 inch, but mostly unfler 0.05 inch. Its constitnents, in descending onder of abundance, are translucent to milk-white sola-lime feldspar (oligoclasc-andesine), slightly kaolinized; in nearly equal amount, clear bluish potash feldspar. (microcline and probably orthoclase) ; clear colorless quartz, strines, in places granulated and with carities; biotite (black mica); and muscovite (white mica), also stringers of secondary fibrous muscovite. Accessory : Magnetite,

"Idem, pp. 232, 233. 
apatite, and zireon. Secondary: Ep:dlote, carbcnate, muscovite, and kaolin. No effervescence with muriatic-acid test.

This is a fine-grained stone withont mineral contrasts and is suitable for fine work.

The quarry, opened in 1890, measured in 1910150 by 80 feet and 20 feet reep.

Rock structure: The sheets, 6 to 16 inches thick, are horizontal or dip $10^{\circ} \mathrm{NH}$. There are no joints. The rift is horizontal, and the grain rertical, with northeast course. A pegmatite dik 2 feet thick is parallel to the grain. On the sontheast, northwest, and southwest sides the granite is in ecntact with a quirtzmira diorite. On the northwest side, 6 feet from the contact, there is an inchusion of this disrite gneiss. 'There is no rusty stain.

Transportation, by cart about three-fourths of a mile to North Acton station.

The product is used for buildings, monuments, and curbing. Specimens: Schoolhouse back of a mill on Maynard estate, Maynard.

GROTON.

The Rafierty quarry is in Groton Township, 4 miles east-southeast of Groton village and $1 \frac{1}{2}$ miles northwest of West Graniteville staticn. (See Gro ton and Lowell topographic maps, U. S. Geol. Survey, and Pl. XXIII.) Operator, Groton Granite Co., 10 Faneuil Hall Square, Boston. Idle in 1920.

The granite (specimens D. XXX, 100, c, d), "Groton," is a muscovite-biotite granite gneiss of light to medium gray shade and of medium, inclining to coarse gneissic, slightly porphyritic texture, with feldspars up to 0.5 inch and mica up to 0.1 inch. Its constituents appear to be identical with those of specimens 93, a, b, c, from the H. E. Fletcher quarry on Oak Hill, in Westford (p. 309). It effervesces with muriatic-acid test.

This stone, like the granite sneisses of Westford, is devoid of mineral contrasts. It is well adapted for base courses and all work requiring much greater transverse strength in one direction than in the other and for curbing.

The quarry, begnin in a small way in 1860 , but reopened in 1910 , was then 50 feet square, and its west side was 30 feet higher than the east side.

Rock structure: The sheets, 2 to 6 feet thick, dip $20^{\circ} \mathrm{N}$. $35^{\circ}$ E. One steep joint at the west side strikes $N$. $75^{\circ} \mathrm{E}$. The gneiss foliation is vertical, with N. $30^{\circ}$ F. strike. The rift is horizontal, and the grain corresponds to the foliation, the face of which is more micaceous than the rift face. There is a 30 -foot inclusion of porphyritic biotite granite gneiss (described on p. 63), also two smaller ones. A pegmatite dike up to 6 inches thick crosses the gneiss and the inclusion, as do also small dikes of aplite gneiss with oligoclase-albite. No stain below the surface sheet.

Transportation, by cart $1 \frac{1}{2}$ miles to siding near West Graniteville station.

The Shaker quarry is in Groton Township, on an 80-foot hillock threefourths mile north-northwest of Littleton station and 4 miles southeast of Groton village. (See Groton topographic map, U. S. Geol. Survey.) Operator, H. N. Fletcher, Graniteville.

The grante (srecimen D, XXX, 106, a.), "Groton," is a muscovite-biotite granite gueiss of medium bluish-gray color and slightly porphyritle, medium, inclining to fine gneissic texture, with feldspars up to 0.3 inch. Its constituents, in descending order of abundance, are translucent bluish potash feludspar (microcline and orthoclase); light smoky quartz with rutile needles and cavities, granulated, with particles under 0.37 millimeter; milk-white soda-lime feldspar (near oligoclase-albite), kaolinized and micacized; muscovite (white mica), and biotite (black mica), some of it chloritized. There are also some fibrous muscovite stringers. Accessory: Garnet, apatite. Sec- 
ondary: Katolin, two white micas, epdote, chlorite. No effervescence with muriatic aciol test.

This strne is like the other gneisses of Groton and Westford but wore buisil and of uniform color, without mineral contrasts.

Tle quarry in 1910 was of triangular form, 100 feet on a side and 10 to 25 feet irel.

The shcets, 6 inches to 3 fcet thicis. unciulate.

The prouluct has ben lised for buildings.

WESTFCRD.

The active ruarries of Westford are in two groups. One is on Oali Hill, an irregular mass of knolls rising to a heiglit of 200 feet above Merrimack Iiver, in the northern part of the township. All but one of this group have their granite landings at Woods Corners (Slah City), on both Merrimack River and a siding of the Boston \& Maine Railroal, 4 miles roughly west of Lowell. The other groul is on Snake Mealow Hill, 100 to 160 feet above the nearest railrond, in the southwestern part of the township. This group has its outlet at the Graniteville and West Graniteville stations, not a mile away and about 9 miles west-southwest of Lowell. (See Pl. XXIII.)

The H. E. Fletcher quarry is on the southeastern part of Oak Hill, in Westford Township, $1 \frac{1}{4}$ miles northwest of West Chelmsford station. (See Lowell topographic map. U. S. Geol. Survey.) Operator, H. E. Fletcher Co., West Chelmsford.

The granite (specimens D, XXX, 93, a, b, c), "Oak Hill," is a muscovitebiotite granite gneiss of very light, slightly bluish-gray color on the rift face lut light gray on the grain face. and of medium gneissic, slightly porphyritic texture, with fellspars up to 0.3 inch and micas up to 0.2 inch. Its constituents, in descenting order of abundance, are translucent bluish potash feldspar (microcline and orthoclase), slightly kaolinized; milk-white sola-lime foldspar, (oligoclase), much kaolinized and with some white mica; clear colorless quartz, finely granulaterl, with particles to 0.5 millimeter but mostly under 0.35 millimeter, and with rutile needles and some cavities; muscovite (white mica); biotite (black mica), some of it chloritized: and stringers of fibrous muscovite. Accessory: Apatite. Secondary: Kaolin, white mica. carbonate, cpidote, chlorite. Very slight effervescence with nuriatic-acid test.

This gneiss is very well adapted for base courses and all wolk requiring much greater transierse strength in one direction than in another. It is devoid of mineral contrasts. The absence or greater scarcity of pyrite and magnctite is favorable to the durability of its color.

The quarry, opened about 1880, measured in 1910 about 700 feet in a norineast direction by 500 feet across and from 30 to 40 feet in depth. Since then its area las been extended without increasing its flenth.

Rock structure: The sheets, 8 inches to 12 feet thick, molulate horizontally. There are three sets of joints- (a) strike N. $30^{\circ}-40^{\circ}$ E., curving to $\mathrm{N}$. $\pi \mathrm{s}^{\circ} \mathrm{F}$., - $\operatorname{dip} 70^{\circ} \mathrm{N} .55^{\circ} \mathrm{W}$. to $90^{\circ}$, and forms a hearling on the southerist wall; (b) strike $\mathrm{N}$. $30^{\circ} \mathrm{W}$, dip $60^{\circ}$ N. $60^{\circ}$ E., on soutluwest wall; (c) strilie N. $50^{\circ} \mathrm{W}$. dip $65^{\circ} \mathrm{N} .40^{\circ} \mathrm{W}$. spaced 300 feet and over. The gneiss foliation strikes $\mathrm{N}$.

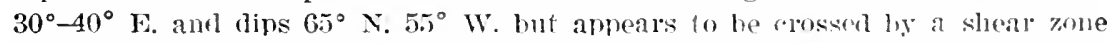
dipping $65^{\circ}$ about southeast. The relations of the foliations alr obscure. The rift is horizontal, and the grain rertical. with N. $40^{\circ}$ V. course, parallel to the foliation, which shows more mica than the rift face. An aplite dike, 11 inches thick, bordered with half an inch of pegmatite on eithel sille. has an adst-west course. Pegmatite dikes are up to 8 inches thick. Where the granite is 
permatitic the mita is in erystals np to 0.4 inches across. (Specimen D, XXX, 98, c.) The anmult of linon te stain is insignificant. Mr. Fletcher finds a compressive strain which relieves itself by :n expansion amolnting to an inch In 100 feet.

The fine stock produced is used for bnildings, and the coarse pegmatitic rock for bridges, paving, curbing; the wate is crusher for concrete. Specimens: East and west wings of Massachusetts Capitol; First National Bank, Boston: granite for the Frick Mansion at Prides Crossing, near Beverly; base course and steps of courthouse, Lowell, Mass.; soldiers' momment. Plaistow, N. H. ; 20 stories (sixth to twenty-fith) of Bankers' 'Trust Co. Builung, Wall and Nassau strects, XuW York; strps, bise course, and approacles of post office and United States comrthouse, New Orleans.

The Mevill quary is near the north ent of (ak Hill, in Westford Township, 6 miles west of Lowell. (See Lowell topographic map, U. S. Geol. Survey.) This quarrs was operated in $1910 \mathrm{by} \mathrm{F}$. A. Mallory but is now dislised.

The granite, "Oak Hill," is a muscovite-biotite granite gneiss of very light gray shade and of medium meissic, slighty proplytitic texture identical with that wi the H. Whetcher quas'r. duscribed on patge 309.

The quarry, opened about 1830, measured in 1910700 to 1,000 feet in a northeasterly direction by 500 feet across and 40 feet leep.

Rock structure: The sheets, 6 inches to 8 fect thick, tlip $10^{\circ}$ NL. but are intersected on the east wall by exceptional secondary sheets 10 to $: 0$ feet thick, dinlins $20^{\circ}$ N. $47^{\circ}$ E. (See p. 36.) There is but one set of joints, striking $\mathrm{N}$. $75^{\circ} \mathrm{E}$. and spaced on the average 50 feet. The gneiss foliation strikes $\mathrm{N} .40^{\circ} \mathrm{E}$. The rift is horizontal, and the grain vertical, with $\mathrm{N} .35^{\circ} \mathrm{E}$. course. The stone splits better along the foliation than along the grain. There are dikes of pegmatite and aplite with blinck tourmaline. The aplite, consisting of potash feldspars, fuartz with rutile and cavities, oi goclasealbite, apatite needles, callonate, and epidote, but no mica, has bands of black tourmaline 0.4 inch apart and 0.2 inch wide. An inciusion, 2 by 18 inches, of fine hanled biotite gneiss was noticed.

Transportation, by cart about 2 miles to Woods Corners siding.

The product was used mostly for curbing aud paving.

The Peterson quarry is on Gak Hill, in Westold Township, a little over half a mile about north-northwest of the H. W. Fletcher quary. Operator, Peterson Bros., West Chelmsford.

The grinite (specimens D, $X X X, 94, a, b)$ is similar to that of the $H . F$. Fletcher quarry, described on page 309 , but a little coarser.

The quarry, opened in 1509 , was in 1910200 feet square and 15 to 30 feet deep.

Rock structure: The sheets, 8 inches to 6 feet thick, dip $5^{\circ}-10^{\circ}$ SE. There are two sets of joints-(a), strike N. $15^{\circ}-30^{\circ}$ L., dip steep to $90^{\circ}$, spaced 10 to 75 rest: (1) . strike N. $65^{\circ} \mathrm{W}$. dip $60^{\circ} \mathrm{S} .25^{\circ} \mathrm{W}$. also N. $25^{\circ}$ E. The gneiss foliation strikes N. $40^{\circ}$ E. and dips $70^{\circ} \mathrm{S} .50^{\circ}$ E. The rift is horizontal, and the grain rertical, with $\mathrm{N} .2 \tau^{\circ}$ E. course. Pegmatite dikes up to a foot thick have a $\mathrm{N} .60^{\circ} \mathrm{W}$. comse. Rusty stain up to 6 inches thick is contined mostly. to the thin sheets. There is a compressive strain in the grain direction.

Transportation, by cart 3 miles to Wools Corners siding.

'The product is used for trimmings, steps, sills, and curbing. Specimens: Trimmings on Massachusetts Mills, East Merrimac Street, Lowell.

The Perley Carkin quarry adjoins the Peterson quarry on the northeast. Operitor, Perley A. Carkin, North Chelmsford.

The granite is identical with that of the Peterson quarry.

'The quarry, opened in 1905 , was in 1910400 by 200 feet and 15 to 34 feet deep. 
Rock structure: The slueets, 1 foot to 8 feet $t$ inches thick, are about horizon tal. The only joints strike N. $15^{\circ}-30^{\circ}$ E., are verticil or steep, and a re spacel 30 to 140 feet. Foliation, rift, and grain are the same as in the Leterson quarty The amount of stain is small.

Transportation, by cart $1 \frac{3}{4}$ miles to Wools Corners siding.

The product is used for curbing, paving, and trimming.

The C. W. Carkin quarry is nearly a quarter of a mile east of the Perley Carkin quarly. Operator, C. W. Garkin, North Chelmsford.

The srinite is identical with that of the Peterson quarry.

The quarry was in 1910200 by 60 feet and 10 to 15 feet leep.

lock structure: The sheets, 6 inches to 4 feet thick, are lorizontal. Two joints, one on eitler side of the quarry, strike N. $30^{\circ}$ E. Foliation, rift, and grain are the same as in the I'eterson quarry.

The product is used for curbing, paving, and trimming.

The Cartwright quarry is on Oak Hill, in Westford 'Township, ahout a mile north-northwest of the H. E. Fletcher quarry and nearly half a mile southeast of the Mrerrill quirry. Operator, George A. Morris, North Chelmsford.

The granite is identical with that of the quaries above mentioned.

In 1910 the quarry was 50 feet squire and 5 to 10 feet deep. The sheets are 5 to 10 feet thick.

The product is used for curbing.

The H. N. Fletcher quarries are on the top and south side of snake Mearlow Hill, in Westfold Township, about half a mile north-northwest of Graniteville station. See Lowell topographic map, U. S. Geol. Surrey, and Pl. XXIII.) Operator, H. N. Fletcher, Graniteville.

The granite (specimen D, XXX, 101, a), "Graniteville," is a nuscovite-biotit'-quartz monzonite gneiss of very light gray shade and of gneissic, medium, Inclining to fine, slightly porphyritic texture, with feldspars up to 0.3 inch but mostly not over 0.2 inch and micas up to 0.2 inch. Its constituents, in deserndins orter of abundance, are milk-white soda-lime feldspar (olicroclase-albite), generally kaolinized anci micacized, some with bent laminae; clear colnrless qualt\%. ermulated, with particles mosty not over 0.25 millimeter, and with rutile noedles; translueent liluish potash feldspar (microcline and orthoclase); muscorite (white mica) and stringers of fibrous muscovite; and biotite (black mica), sune of it chloritized. Accessory: Garnet. Secondary : Kaol'n, white micas, epidote, carbonate. The quartz forms a matrix of fine particles in which the felderars lie. Some effervescence with muriaticacid test.

The gneiss in places is coarsely porphyritic (specimen D, XXX, 101, b), of mellimm-ing color with dark bluish-gray feldspars up to an inch square and even 2 inches by 0.75 inch. The matrix has foldspars up to 0.2 inch and micas up to 0.1 inch. The feldspars are microperthite-potash fellspar (microcline), minutely intergrown with soda-lime feldspar (oligoclase-albite).

Some of the foliation faces of the gnejes carry muscovite crystals (specimen D, XXX. 102, a).

The stone of these quarries is generally lighter than that of the Oalk Hill quatries lut possesses the same general character and qualities.

The north quarry, opened in 1906, was in 1910250 feet square but had an unexearated part 50 by 125 feet on one sile.

Rock structure: The sheets, 1 to 6 feet thick, molulate horizontally. There are five sets of joints- $(a)$, strike N. $70^{\circ} \mathrm{I}$., dip $45^{\circ} \mathrm{S} .20^{\circ} \mathrm{E}$., spaced 20 feet; $(b)$, strilie N. $10^{\circ} \mathrm{W}$., forms a hearling 70 feet wirle beyond the east wall; $(c)$, strike $\mathrm{N}$. $20^{\circ}$ W., dip steep to $90^{\circ}$, spacer 8 feet; (d), vertical, strike N. $10^{\circ} \mathrm{F}$; $(c)$, strike N. $30^{\circ}-40^{\circ}$ E. dip $70^{\circ} \mathrm{N} .55^{\circ} \mathrm{W}$. to $90^{\circ}$, spaced 50 feet and over, forms the east wall. The rift is horizontal and 
the grain vertical, with $\mathrm{N} .30^{\circ} \mathrm{E}$. course. The foliation is plicated, with a strike of $\mathrm{N} .40^{\circ} \mathrm{E}$. Pegmatite lenses occur.

The south quarry, opened in 1860 , was in 1910200 by 150 feet and 10 to 40 fect leep. The slieets, rift, and grain are the same as in the north quarry. Where are two sets of joints- $(a)$, vertical, strike N. $35^{\circ}$ E., spaced 4 to 10 feet; (b), verticul, strike N. $75^{\circ} \mathrm{W}$., spaced 3 to 6 feet.

Transwortation, by cart half a mile to Graniteville station.

The fromet is used mostly in curbing and paving.

The Palmu: quarries are on the north side of Snake Meadow Hill, in Westford Township. (Sce topographic map. U. S. Geol. Surves, Lowell.) Operators, Lewis P. Palmer \& Sons, Graniteville.

The granite of the upper quarry (specimens D. XXX, 92, b, c), "Graniteville," is a mediun-gray quartz monzonite of gneissic, slightly porphyritic, medium inclining to fine texture, with feldspar up to 0.3 inch and micas up to 0.2 inch, rarely 0.3 inch. The stone of the lower quarry is reported as a little coarser than this. The constituents, in descending order of abundance, are grayish soda-lime feldspar, kaolinized and micacized; in about equal amomt, bluish-gray potash feldspar (microcline and orthoclase), intergrown with quartz that is circular in cross section: light smoky quartz. finely granulated, with particles up to 0.25 (rarely 0.37 ) millineter, and with rutile needles and cavities; muscovite (white mica), some with prisn fuces, also fibrous muscovite stringers; and biotite (black mica), some of it chloritized. Accessory: Magnetite, apatite. Secondary: Epidote, carbonate, kaolin. white micas. It effervesces slightly with muriatic-acid test.

This stone structurally resembles that of the Oak Hill quarries, but its color is a little darker and its mineral composition slightly.different. It is much darker than the gneiss of the H. N. Fletcher quarry.

The upper quarry was in 1910 about 300 by 215 feet and 20 to 40 feet deep. The lower quarry, 600 feet east of the upper, was about 200 by 100 feet and 15 feet deep.

Rock structure: The sheets in the upper quarry are 1 to 5 feet thick and dip $10^{\circ}$ about northeast; in the lower quarry they are 2 to 7 feet thick and about horizontal. There are four sets of joints- $(a)$, strike N. $20^{\circ}$ E., dip $75^{\circ} \mathrm{N}$. $70^{\circ} \mathrm{W}$., forms the west walls; $(b)$, vertical, strilie N. $35^{\circ} \mathrm{W}$., spaced 50 feet; (c), strike about east, d p $70^{\circ} \mathrm{N}$. to $90^{\circ}$, forms the north and south wills; $(d)$. vertical, strike $N .10^{\circ} \mathrm{W}$., forms a 20 -foot heading. The gueiss foliation strikes N. $45^{\circ}-60^{\circ}$ E. and dips $75^{\circ}$ SSE. to $90^{\circ}$. The rift is horizontal, and the grain vertical, with northeast course like the fol ation. The grain face is thus more micaceous than the rift face. There is a 12inch dike of alternating bands of aplite and pegmatite with a N. $20^{\circ}$ E. course A fine-grained inclusion of biotite schist or gneiss with zoisite from this quarry has been described on page 63 . Rusty stain is up to 3 inches thick on sheet surfaces.

Transportation, by cart three-fourths mile to Graniteville station.

The product is used for building, curbing, and paving.

The Conture quarry lies on the west side of Snake Meadow Hill, in Westford Township. It is now idle.

The granite is like that of the Palmer quarries, described above.

The quarry, opened in 1906 , was, in $1910,150 \mathrm{by} 100$ feet and 12 feet deep.

Rock structure: The sheets, 2 to 12 feet thick, are horizontal. There are three sets of joints- $(a)$, vertical, strike N. $10^{\circ} \mathrm{W}$., spaced 3 to 12 feet; $(b)$, strike N. $30^{\circ}$ L., dip $70^{\circ}$ S. $60^{\circ}$ E., and also N. $60^{\circ} \mathrm{IV}$; $($ c $)$, strike N. $80^{\circ}$ E.. spaced 10 to 20 feet, coated with epidote and quartz crystals and slickensided, 
crosses the quarry lengthwise in the center. Iift, grain, and foliation are as in the other quarries of this hill.

Transportation, by cart about thrce-fourths mile to Graniterilie station.

The product is used for curbing.

The Wright quarry is on the east sicle of sinke ilealow Hill, in Westford Township. Operator, Charles L. Couture, Granitevills.

The granite is the same as that of the Palmer quarries (p. 812).

The quarry, opened in 1880, Was in 1910300 by 150 feet and 15 to 23 feet deep.

liock structure: The sheets, 6 inches to 3 fect thick, are horizontal. Tlicre are three sets of joints-(a), vertical, strike $N .10^{\circ} \mathrm{W}$., forms a healling on the east wall; (b). strike N. $10^{\circ} \mathrm{K}$., one neal west wall, one in coiter, and possibly others concealed hy waste; $(c)$, steer, strike N. $45^{\circ}$ N., forms the west wall. The gneiss foliation strikes $\mathrm{N}$. $50^{\circ} \mathrm{E}$. l'egmatite and aplite dikes up to a foot thick have northerly courses.

The product is used for curbing.

The Hildreth quarry lies south of the Couture quarry, on the west side of the hill, in Westford Township. Operator, H. V. Hildreth, Westford. Ille in 1922.

The granite is like that of the Palmer quarries (p. 312).

The quarry, opened about 1845 , was in 1910300 by 150 feet and 10 to 40 feet deep.

Rock structure: The sheets, 1 to 13 feet thick, dip at a low angle to the north. There are two sets of joints- $(a)$, vertical or steep, strike $N$. $10^{\circ}$ E., spaced 150 feet, forms east and west walls; (b), discontinuous, strike N. $50^{\circ}$ E., dip $60^{\circ}$ N. $40^{\circ}$ W., spaced 2 to 10 feet, forms a heading on the east wall. Rift, glain, and foliation are as at the other quarries of this hill. Rusty stain is up to 4 inches thick on sheet surfaces.

The product is used for building and curbing.

Other quarries on Oak Hill in Westford are the Prescott quary, operator, Arthur Decarteret, of Tyngsboro; and the Barker Lot quarry, operator. Thomas Le Masurier, of North Chelmsford.

\section{TOWNSEND.}

The Barker Hill quarry is on the sonthwest side of Barker Hill, about 200

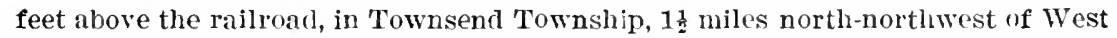
Townsend station and about $1 \frac{1}{4}$ miles north of West Townsend village. (See Groton topographic map ,U. S. Geol. Survey, and Pl. XXIII.) Operator, Duncan Rusk, West Townsend.

The granite (specimen D, Xxx, 113, b). "West Townsend white," is a biotite-quartz monzonite of very light, faintly buff-gray color and of evengrained medium inclining to fine texture, with feldspars under 0.3 inch, rurely over 0.4 inch, and mica up to 0.1 inch. Its constituents, in descending order of abundance, are colorless clear to translucent potash feldspar (microcline), muclı kaolinized and intererrow with quartz that is circular in cross section; in nearly equal amount, milk-white to faint pinkish soda-lime feldspar (oligoclascalbite), somowhat mieacized; light smoky quartz with cavities in sheets; biotite (black miea); and a little muscovite or bleached biotite. Accessory: Magnetite (plentiful), apatite, zircon, and rutile(?) needles in chlorite. Sccondary: Chlorite after biotite, carbrnate, a white miea, and hematite stain from the magnetite. The polished face shows magnetite. It effervesces with muriaticacid test.

A pinkish variety (specimens D, XXX, 113, a, d, e), "West Townsend red," is of light medium pinkish-gray color and of the same texture and composition 
as the "white," but the thin section shows pyrite and what is possibly altered allanite, with radiating cracks filled with hematite staln.

This is a constructional and monumental granite of slightiy coarser texture than the monumental granite of South Brookline, N. H. and probably of the same geologic age. South Brookline is only 4.4 miles east-northeast of this quarry. (Siee Groton topographic map and p. 192.) The stone takes a good polish.

The quarry, opened in 1907 , measured in 1910225 by 150 fret and 5 to 15 feet in dejth.

Rock structure: The sheets, 1 to 5 feet thick, are about horizontal. There are no joints. The rift is horizontal and the grain vertical, with $\mathrm{N}$. $80^{\circ} \mathrm{W}$. course. A pegmatite dike up to 4 feet thick has a $\mathrm{N}$. $55^{\circ} \mathrm{W}$. conise. There are also lenses of pegmatite. The inclusion of biotite or diorite gneiss referred to on paine 63 came from below the quary. Rusty stain is up to 6 inches thick.

Transportation, by cart one-third mile to railroad.

The prouluct is used mostly for buildings but partly for monuments. Specimens: Entire front of Thames National Iank, Norwich, Conn.; trimmings to Alvirne Memorial Chapel, IIndson. N. H., post office, Nashua, N. H., and Thompson Memorial Chapel, Williams College, Williamstown, Mass.

\section{NORFOLK COUNTY.}

The quarres in Wrentham, Stoughton, and Cohasset are in two large areas designated on the map of Bulletin 597 "Dedham glanodiorite (ehloritic biotite granodiorite)" and described by Emerson on pages 175-177 of that bulletin.

\section{WRENTHAM.}

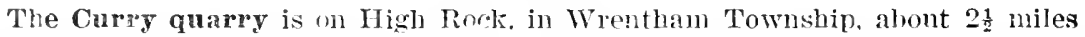
east-southeast of Wrentham station. (See Franklin topographic map, U. S. Geol. Survey, and Pl. XXIII.) Operator, High Rock Granite Co., Foxhoro.

The granite (specimen D, XXX, 115, a), "Wrentham," is a hornblende granite of light-gray shade and of even-grained medium, inclining to coarse texture, with feldspars up to 0.5 inch and mica up to 0.1 inch. Its constituents, in descending order of abundance, are very light gray to pale cream-colored microperthite (potash feldspar, microcline ancl orthoclase, somewhat kaolinized. minutely intermrown with soda-lime feldspar): medium smoky quartz with abundant cavities in sheets; clear colorless to milk-white striated soda-lime feldspar (oligoclase-andesine), much kaolinized, also micacized and epidotized, tn some crystals from within outward; and hornblende associated with epidote. Accessory: Magnetite. Secondary: Kaolin, a white mica, epidote, carbonate. Very slight effervescence with muriatic-acid test.

This is an attractive stone with marked mineral contrasts and is suitable for substantial structures. The quarry, opened in 1884, was in 1910 about 150 feet square and 25 to 35 feet deep.

Rock structure: The sheets, 4 to 16 feet thick (one a foot thick), are horizontal or dip $15^{\circ}$ E. or IV. and are likely to have 2 inches of decomposed granite between them. One set of joints, vertical, strike N. $10^{\circ}$ E., spaced 2 to 100 feet, is coated with epirlote. Another set, strike N. $60^{\circ}$ E., dip $70^{\circ} \mathrm{N} .30^{\circ} \mathrm{W}$., forms headings of very close joints in the upper 10 feet of the rock. (See p. 38.) An obscure flow structure dips about $55^{\circ} \mathrm{N}$. The rift is horizontal and the grain vertical, with N. $80^{\circ} \mathrm{W}$. course. Knots are 1 to 6 inches in diameter. Rusty stain is 2 feet thick on the top sheet.

Transportation, by cart to local customers.

The product is used for building, curbing, and monuments. 
The Messer quarry is in the township of Stmulitur, l! miles south of Stoughton Center, on Washington Street. Operators, Messer Bros., Brockton.

'ilue zrmite, "Stoughtom," is a liotite or hornblende wranite of general

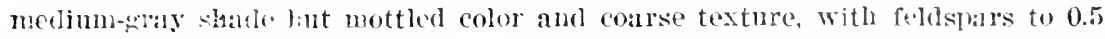
inch and lark silicate to 0.1 inch. Its cumstituents in descending orler of ubundance are light pink potash feldspar (microcline and orthoclase); incdium smoky, iaintly amethystine quartz wilh cavities in sheets; pale-green to mllkwhite soda-lime feldspar (oligoclase-albite), much kaolinized ancl micacized; chlorite and epidote (after biotite or hormblende). Accessory : Pyrite, manetite. Secondary: Kaolin. chlorite, epidote, limonite, a white mica ancite. Slight effervescence with muriatic-acid test.

The fresh rough face of this granite affords pleasant eontrasts of color which are more marked on the nolished face, but are too delicate to endure outdoor exposure.

The product is used for trimmings and tombs. Specinens: Trimmings on public library and Sampson Building, Brockton, and on Oakes Ames resinence, Sharon; recciving tomb, Catholic cemetery. Stoughton.

\section{COHASSET.}

The Tiffany quarry is in the township of Cohasset. on Beechwond Avemue, about 2 miles sonthwest of Cohasset Station. Operator. Louis C. Tiffany, 46 West Twenty-third Street. New York.

The sranite (specimens D, XXXVII, 2S ; a, rough ; b, polished). "Colnasset." is a biotite or hornhlende granito of general medium-gray shade but mottled color and coarse texture, with feldspars to 0.5 inch and dark silicate to 0.2 inch.

Its constituents, in descending order of abundance, are ninkish potash feldspar (orthoclase, some of it minutely intergrown with a plagioclase): pale pea-green to ream-colored sela-lime feldspar (alhite to olisoclase-alhite). much kaolinizel. micacized, and some of it epidotized; medium smoky quartz, faintly amethystine. with cavities in slueets: chlorite and epirlote (after hiotite or hornblende). Accessory: Magnetite. Secondary: Chlorite. epidote, kaolin, sericite, another white mica, calcite. Rift and grain cracks are marked.

The polished face is very attractive and by its varicts of color well adapted for interior decoration.

The product is used entirely for monumental and memorial purnoses and interior church work.

QUINCY, MILTON, AND BRAINTREE.

. TOPOGRAPHY.

There is a conspicuous range of low hills south of Boston. known as the Blue Hills, which curves from Great Blue Hill, 11 miles south-southwest of the city, to Forbes Hill, $7 \frac{1}{2}$ miles south-southeast of it. and whose tops lie hetween the 150 and 640 foot levels. (See Boston and Dedham tonographic mans, U. S. Geol. Survey.) The Quiney granite district lies at about the northeast end of this range, in the townships of Quincy, Milton, and Braintree, Norfolk County. Some of the quarries are on the North Commons from athout half a mile west-southrest to a wile west of Quincy Center; other's are in West Quincy from $1 \frac{1}{2}$ to 2 miles about west-southwest of the Center; two are in Milton, some 3 miles west of the Center: and one is in Braintree. Quarry locations are shown 
on the map (Pl. XXIV). The reader will find some interesting historical matter on the Quincy quarries in a chapter on the early history of the granite industry in New England by George P. Merrill, ${ }^{38}$

\section{GEOLOGIC RELATIONS.}

The geology of the vicinity of Quincy and Boston is very complex and difficult and has long been under investigation and discussion by several resident and other geologists. ${ }^{39}$

The granite of Quincy was part of a great deeply buried mass of molten granitic material of various kindis, which was intruded in Carboniferous time into a considerable mass of orellying slates, etc., of middle Cambrian and possibly later age. which in places were entirely remored by subsequent erosion. That these slates were originally marine clayey sediments of middle Cambrian time is shown by the presence of fossil crustaceans typical of the middle Cambrian in some of them in the town of Braintree. After a long interval a large part of the region hecame again submerged during the Carboniferous period, and the adrancing sea formed new sadiments, but there was an interval of glaciation and the formation of till with pebules from the exposed igneous and sedimentary rocks of Cambrian or post-Cambrian time.

This submergence continued until the conglomerate was overlain by a considerable accumulation of clayey sediments. During the post-Carboniferous crustal movement, which affected a large part of the continent, these clays became slate and were powerfully foltled; basic dikes were also intruded into the granite and the overlying heds. The colrugation and elevation of the surface in post-Carthoniferous time exposed the Carboniferous beds to erosion, so that portions of the granite surface which had been covered ly them again became exposed. In Triassic time more hasic dilies forced their way through fissures in the granite. Events in this region were further complicated by the occurrence of eruptions of very siliceous rocks at various points and times.

On the geologic unap of the State in Bulletin 597 the quarries of the Quincy district are in a lenticular area, about 10 miles from east to west by half a mile to $2 \frac{1}{2}$ miles from north to south, of "Quincy granite (soda-rich riebeckitebearing granite)," which in the text is regarded as of Carboniferous age. Lying within this area are several small areas of Braintree slate, of middle Cambrian age.

QUINCY GRANITE.

The following faragraphs epitomize the writer's descriptions of rough and polished specimens and thin sections of granite from all the quarries as given

${ }^{39}$ Smithsonian Inst. Rejt.. 1SST-St, pt. 2, pll. 28T-2xs.

30 Crosby, W. O., Genctic and structuril relations of the impous rocks of the lower Neponset Valley, Mass. : Ain. Geologist, rol. 36, pp. 39-41, 1905. Emerson, B, K., and l'erry, I. II., The gren schists and associated granites and porphyries of Rhode Island: U. S. Geol. Survey Rull. 311, n. 51, 1907. Crosby, W. O., The Bluebills complex: Boston Soc. Nat. Hist. Occasional Papers, No. 4, pt. 3, 1900 (includes Prof. Florence Bascom's work on the volcanic and plutonic rocks of the Boston basin). Mansfleld, G. R., The origin and structure of the Roxbury conglomerate: IIarvard Coll. Mus. Comp. Zoology Bull., rol. 49 (Gcol. ser., rol. 8, No. 4), pp. 161, 259, pl. 6, 7, 1906. Loughlin, G. F., structural relutions biween the giriney sranite and adjacent sedimentary formations: Am. Jour. Sci., 4th ser., vol. 32. P. 117, 1911. Sayles, R. W., The Squintum tillite: Harvard Coll. Mus. Comp. Zoology Bull., vol. 56, No. 2, pp. 141-175, 1914. Lahee, F. A. Late Paleozoic glaciation in the Boston Basin, Mass.: Am. Jour. Sci., 4th ser., vol. 37, p. 316, 1914. Emerson, B. K., Geology of Massachusetts and Rhode Island: U. S. Geol. Surver Bull. 597, pl. 10, pp. 186-191, 1917. 
farther on. 'The more recent scientific aceounts of this granite are by Warlsworth, ${ }^{40}$ Merrill, White, Washillenton, ${ }^{43}$ and Warren.,

Quncy granite is a riebeckite-aegirite sranite. ineberite and aresirite are varieties of amphibole and pyroxene, respectively, both rich in soda ( $S$ to 10 per cent) and in iron sesquioxile (abont ' 28 , 1 re cent) but poor in almmina, magnesia, and lime. The general color of the fresh normal wan te rantes from a medium gray or bluish or greenish or morpish grag to a rely darts bluish gray, all with black spots which, on cluser inswertion, ale seen to be lolue-luack or green-black or a mixtme of both. Its texture is medium to condrse and cren grained, with feluspints up to 0.4 and 0.5 inch and the black silicates up to 0.3 and 0.4 inch. Its constituents, in descending order of abundance, alle lliese: (1) A medium to dark buish or greenish to bhish grag feldspar (orthochase, much of it twinned), always with minutely intergown solatine feldspar (alb.te to oligoclase-albite). It is aplarenty more or less darkened by a varying number of extremely minute particles of a black mineral, which are not absolutely distinguishable from opaque particles of kaolin, and is always slightly tinted by minute particles of grass-green aegirite and whitened by partial kalolinization or black streaked by clusters of radiating fibrous crystals of dark-brown hornblende. The fresh feldspar always contains crystals of blue-brownish riebeckite from 0.01 to 1.0 millimeter long by up to 0.01 millimeter in width. These crystals, and also the aegirite, are in many specimens arranged in two rectangulat directions, one that of the twimning plane, the other that of the internown solatime foldspar. In some sections (p. 327) the feldspars were found crossed by rift and grain cracks filled or overlain by minute crystals of riebeckite, thus evidently of secondary origin like those on joint planes described on page 82 . (2) Medium to dark smoky quartz, some of it with a slight bluish tince. It contains cavities (many with liquicl and movilble vacuoles) arranged in streaks and sheets and measuring from 0.0028 to 0.02 millimeter in length. This quart also incloses minute black particles and in places hairlike erystals, presmnahly of rotile, more rarely minute crystals of ricbeckite, one measuring $0.175 \mathrm{hy} 0.004 \mathrm{t}$ millineter. (3). A little limesoda feldspar (abite to oligoclise-ilbite). (4) Riebeckite (blue-black in hand specimen but Prussian blue and brownish gray in thin section) and aegirite (green-black in hand specimen but light green to emerald-green in thin section), both minerals in many specimens intermpn. The aegirite may surround riebeckite, or these relations mis be reversed. In some specincus richockite in slender crystals appears like a secondary growth on aegirite. In others the aegirite appears as filling spaces between the other minerils. Lasal sections of It appear as if corroded. All of the riebeckite can not be secondary, because it appears in minute crystals within the quartz and forms the center of large crystals of aegirite. Nor can all the aegirite be secondary, hecause crystals of it also occur within quartz particles and also surrounded by radiating crystals of riebeckite. (See p. 327.) The aegirite is likely to contain particles of magnetite and carbonate.

so Wadsworth, M. E., Notes on the petrography of Quincy and Rockport: Roston Soc. Nat. Hist. Proc., vol. 19. pp. 309-3i6, 1881.

"Merrill, G. P. The collection of building and orramental stoncs in the Unitcd States National Museum: Smlthsonian Inst. Kept. for 1885-86, pt. 2, pp. 403, 418.

White, T. G., A contribution to the petrography of the Boston Basin: Foston SocNat. Hist. Proc., vol. 28, pp. 128-132, 1897.

s Washington, H. S., Sölvsbergite and tinguaite from Essex County, Mass. : Am. Jour. Bci., 4th ser., rol. 6, p. 181. 1898.

uWarren, C. H., Petrology of the alkali-granites and porphyries of Quincy and the Blue Huls, Mass. : Am. Acad. Arts Sci. Proc., vol. 49, No. 5, pp. 203-330, 1913. 
The andsirg m merals are imenite, magnetife (probably), pyrite (very rare), zirom in lonbly terminated crystals. fluorite, titanite, and the minute black particles in quartz. The secondary minerals are kolin. yollow-brown

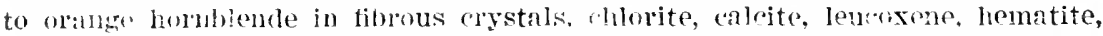
limonite (associated with zireon amd regirite), and part of the riebeckite. One of the iltered granites (Sartori quarry) contains spherulites which polarize like zircon. Another one (Savo quarry) is cut by a reinlet of secondary epionte, quatr, and calcite.

Fstimates of the mineral percentages by the losiwal method sield the following figures for the "melium," "dark," and " extra dark:"

\section{Lstimuted mineral percentages in Quincy granite.}

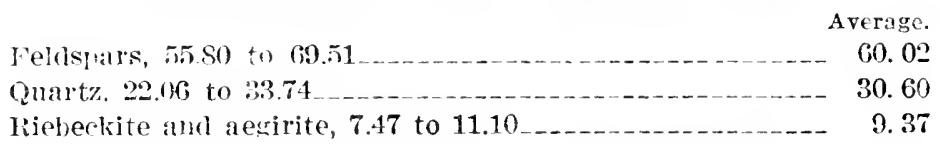

of course tle microsconic particles of the soda-iron silicates are not inchled In these ligures.

The following andysis of Quincy grante hy Henry s. Washington ${ }^{40}$ was published in 1895:

Analysis of rieteclitc-acgirite granite from the Hardwick quarry, Quincy, Mass.

Silica isio..

Titanium dioxide $\left(\mathrm{TiO}_{2}\right)$

Aluminar $\left(\mathrm{Al}_{2} \mathrm{O}_{3}\right)$

Iron sesquioxile $\left(\mathrm{F}_{2}: \mathrm{O}_{3}\right)$

Tron oxile (FeO)

Manganese widle $(\mathrm{MnO})$

Magnesia $(\mathrm{MgO})$

Lime $\left(\mathrm{Cil}_{\mathrm{i}} \mathrm{O}\right)$

Soda $\left(\mathrm{Na}_{2} \mathrm{O}\right)$

Potash $\left(\mathrm{K}_{2} \mathrm{O}\right)$

Water above $110^{\circ}\left(\mathrm{H}_{2} \mathrm{O}\right)$
73. 93

12. 29

2. 91

1. 55

Trace.

.04

.31

4. 66

4. 63

.41

100.91

Specific gravity 2.642 at $22^{\circ} \mathrm{C}$.

Two later analyses of the sume granite, but from the Hitcheock and the Reinhator quarries, by C. H. Warren ${ }^{46}$ differ but little from the above."

4 See Am. Jour. Sci., th ser., vol. 6, p. 181, 1898; also Jour. Geology, vol. 6, p. 793, 1888.

${ }^{40}$ Op. cit., p. 227.

\7 Fог anilyses and optical features of riebeckite and aegirite see Rosenbusch, H.. Mikroskoplsche Physiographie der Minerallen und Gesteine, 4th ed., vol. 1, pt. 2. pp. 213, 244, 1905; for discussion as to their origin see Murgoci, G, M., On the genesis of riebeckite and riebeckite rocks: Am. Jour. Sci., 4th ser., vol. 20, pp. 133-145, 1905 ; and Cross, Whitntan, on some secondary minerals of the amphibole and pyroxene group: Am. Jour. Sci., 2d ser., vol. 39, pp. 359-370, 1890. Murgoci (op. cit., p. 138) sums np the views on the origin of these two minerals thus: "Some petrologists have considered the aegirite as a transfomation product of rinbeckite, and others bave taken the riebeckite for a secondary product of aeqirite. Most petrolocists state, however, that riebeckite and aegirite are irimary in their rocks." On the next page in a footnote he adds: "The best argument for the primary existence of the aegirite is its occurrence in the same rock, with little thln needles of riebeckite, whlch fould not resist even the slowest and -ightest action of transformation." 
general way and classified on page 59. They have been exhaustively treated by Warren in the work rited.

Rift in the Quincy quarries is reporterl as generally vertical or nearly so, with a course from N. $65^{\circ} \mathrm{W}$. to due west, and the grain as vertical or nearly so and about north to south. The rrain is generally feeble. Rift courses of north, $\mathrm{N} .10^{\circ} \mathrm{E}$, anc $\mathrm{N} .30^{\circ} \mathrm{W}$, are reported at a few quarries, and at three the gra $n$ is reporter as horizontal. At the Swingle quarry, which is crossed by a diagonal heading striking north, the rift is reported to be north-south on the west sicle of that heading but east-west on its east side. The angle of inclination of both rift and grain is reported as subject to modifications. some of which are probably only local; others are due to general physical principles. At the Reinhalter quarry the rift is vertical below but not quite vertical near the surface. Mr. Cashman staterl that in lis quarry the grain is $90^{\circ}$ when the sheet is split from the top, but if split from the side it is steeply inclined. Mr. Galvin reporter that the grain is horizontal when the drilling is done from east to west, but dips $20^{\circ}$ when it is lone from north to south. The degree of dip of rift and grain is affected by gravity-that is, it is proportioned to the weight of the block on one side or the other of the fracture. Two foremen find that when the sheets are inclined the dip of the rift swerves from the vertical. At the Field \& Wild quarry rift and grain are reported as varying greatly in different blocks. The subject of rift will be found more fully discussed on page 15, and its apparent relation to the sheets of fluidal cavities is explained on page 17.

The crushing of cores between drill holes made in channelling shows that the Quincy granite mass is now unler compressive strains from the north and south and the east and west. This strain in some quarries appears to increase with their depth. At one quarry not only are north-sonth chamels closed by it, but diagonal subjoints are started from the channels.

Sheet structure in Quincy is regular in places, as at the Dell Hitchcock quarry (PI. XXV, A), where it consists of lenses with an undulating course usually parallel to the rock surace and increasing in thickness downward. But it is more commoniy obscure and irregular owing to the shortening and thickening of the lenses, which results in "houlder quaries." Sheet structure extented in 1906 to a repth of 150 feet from the rock surface at the Ballou quarry on the North Commons and to a dejth of 175 fcet in the Reinhalter quarry in West Quincy, but in 1917 it rearhod a depth of 250 feet. The inclination of the sheets is in places as high as $15^{\circ}$, and their thickness ranges from 6 inches to 27 fect. They are rarely intersected by sharp curving joints or partings known as "toenails." The oligin of sheet structure has been fully discussed on pages 26-36. In quarrying it is safe to count on a gradual increase in the thickness of the sheets downward. If for a space thin sheets recur they may be expected to give way to thicker ones below. The quarry adjacent to the Dell Hitchcock is reported to have been abandoned because of the appearance of thin sheets below and the assumption that they would not be succeeded by thicker ones. At the Reinhalter quarry, which in 1906 was 225 feet (leep, the lowest sheet was over 45 feet thick. Mr. J. S. Sivingle reports that his quarries have now reached a depth of about 250 feet without reaching the limit of sheet structure.

The general character of the jointing can be inferred from the quarry diagrams (figs. 71-74). The principal joint sets are: (a), striking N. $60^{\circ}-85^{\circ} \mathrm{W}$. to N. $83^{\circ}$ F., and its complementary set (b), north to N. $20^{\circ}$ E.; a single set (c), striking N. $10^{\circ}-30^{\circ} \mathrm{W}$.; and (d), striking N. $25^{\circ}-55^{\circ} \mathrm{W}$., with its complementary set (e), N. $45^{\circ}-50^{\circ} \mathrm{W}$. A noticeable feature in some of the deeper quarries is the vertical discontinuity of the headings. Some of the 


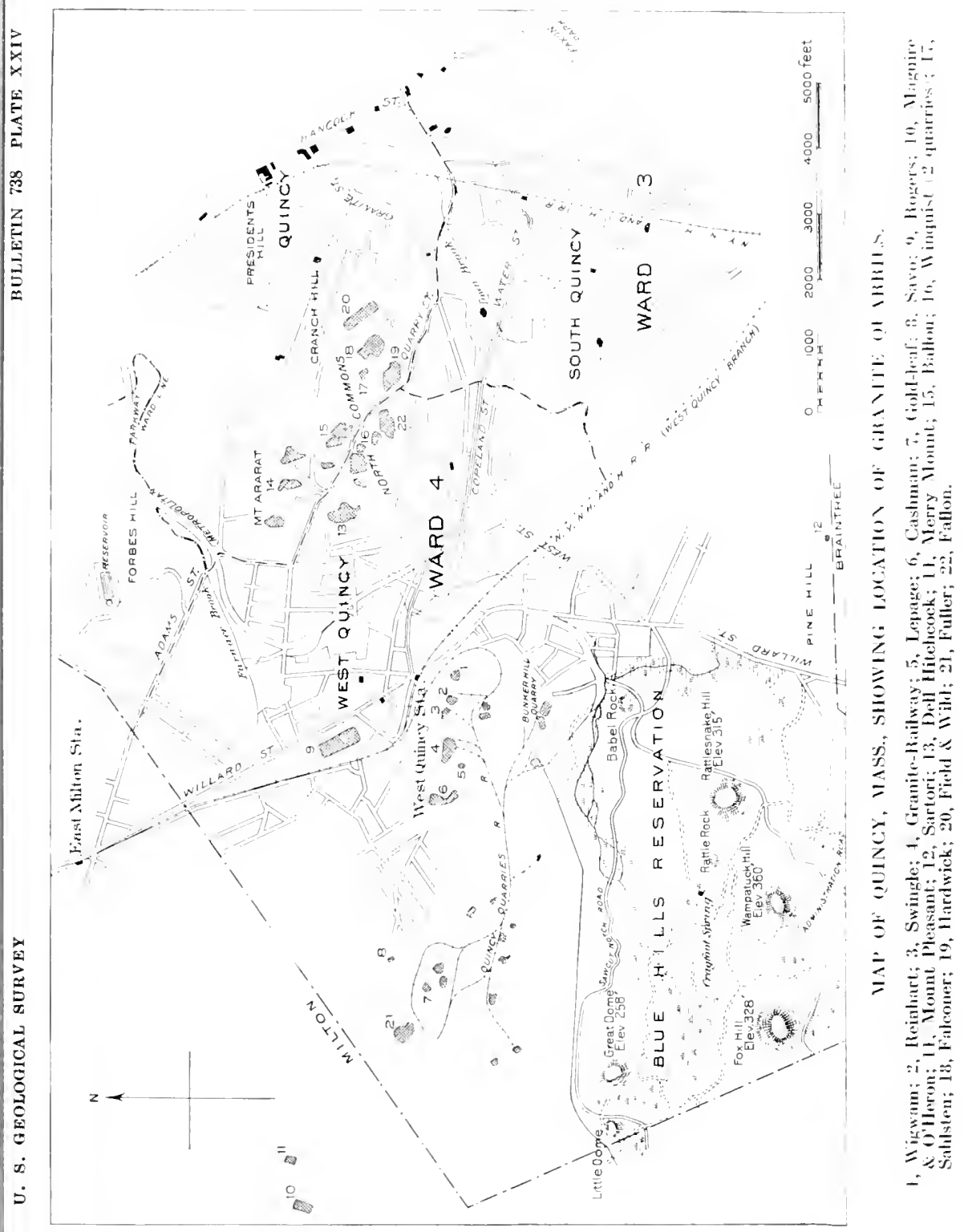



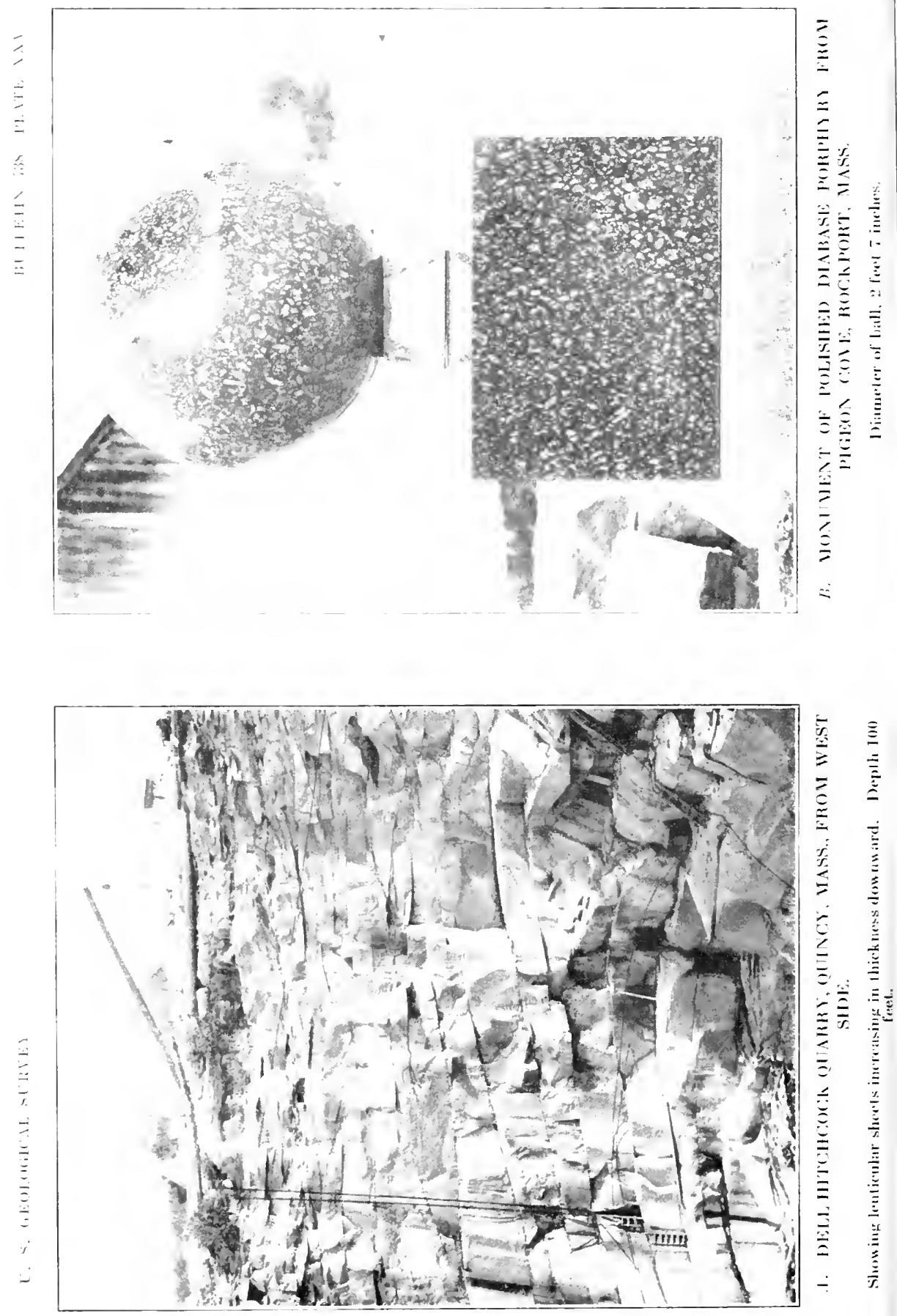


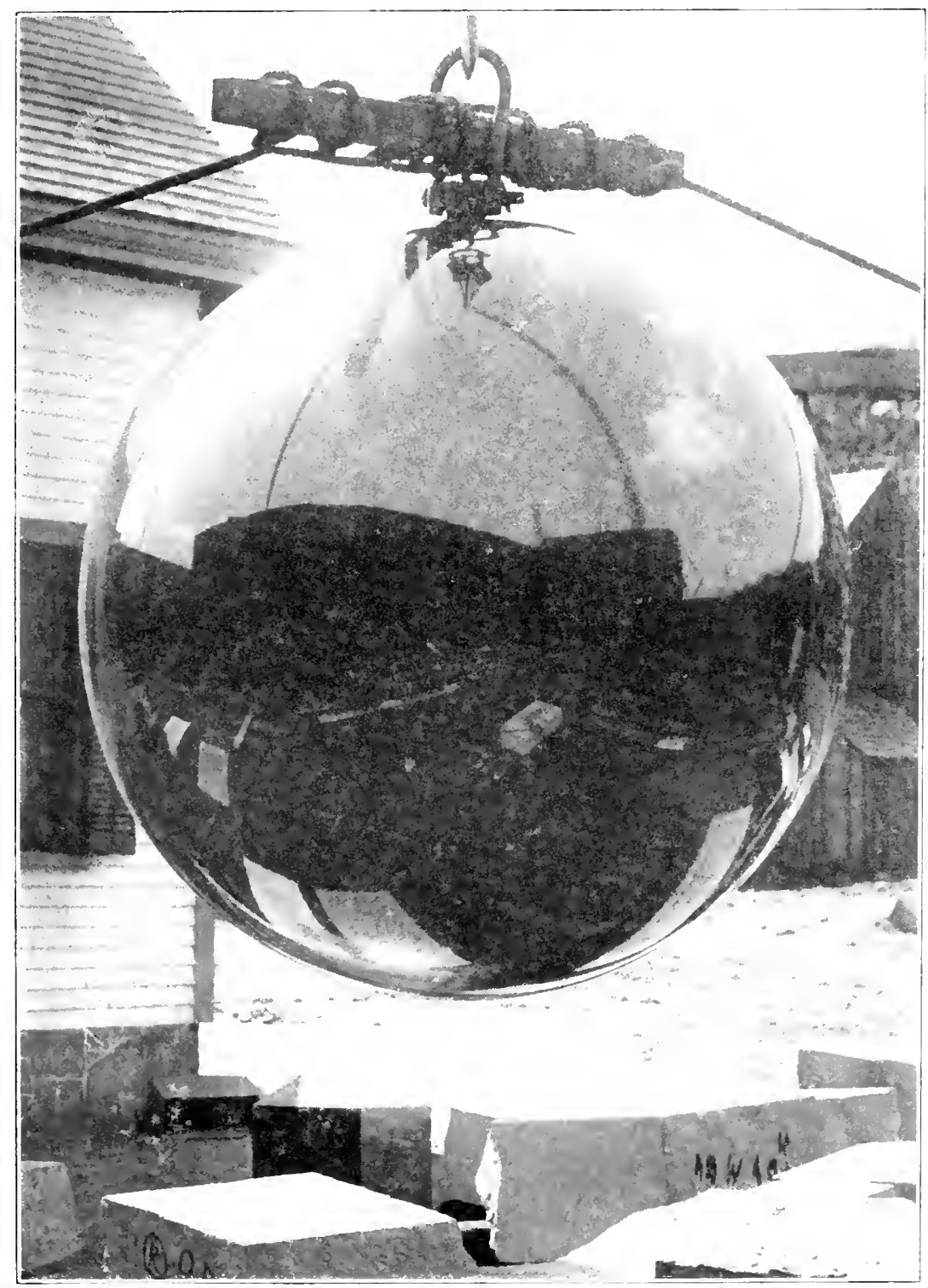

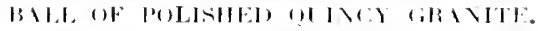

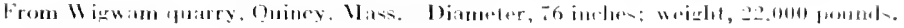




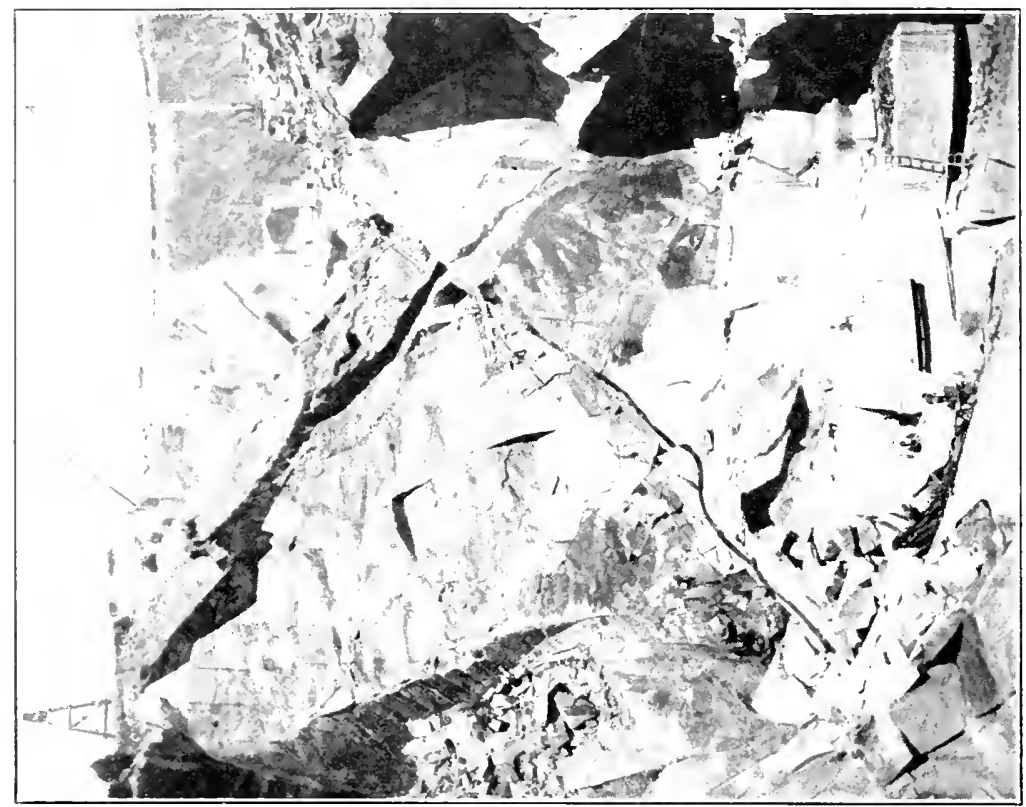

\begin{tabular}{ll}
\hline & \\
$\vdots$ &
\end{tabular}
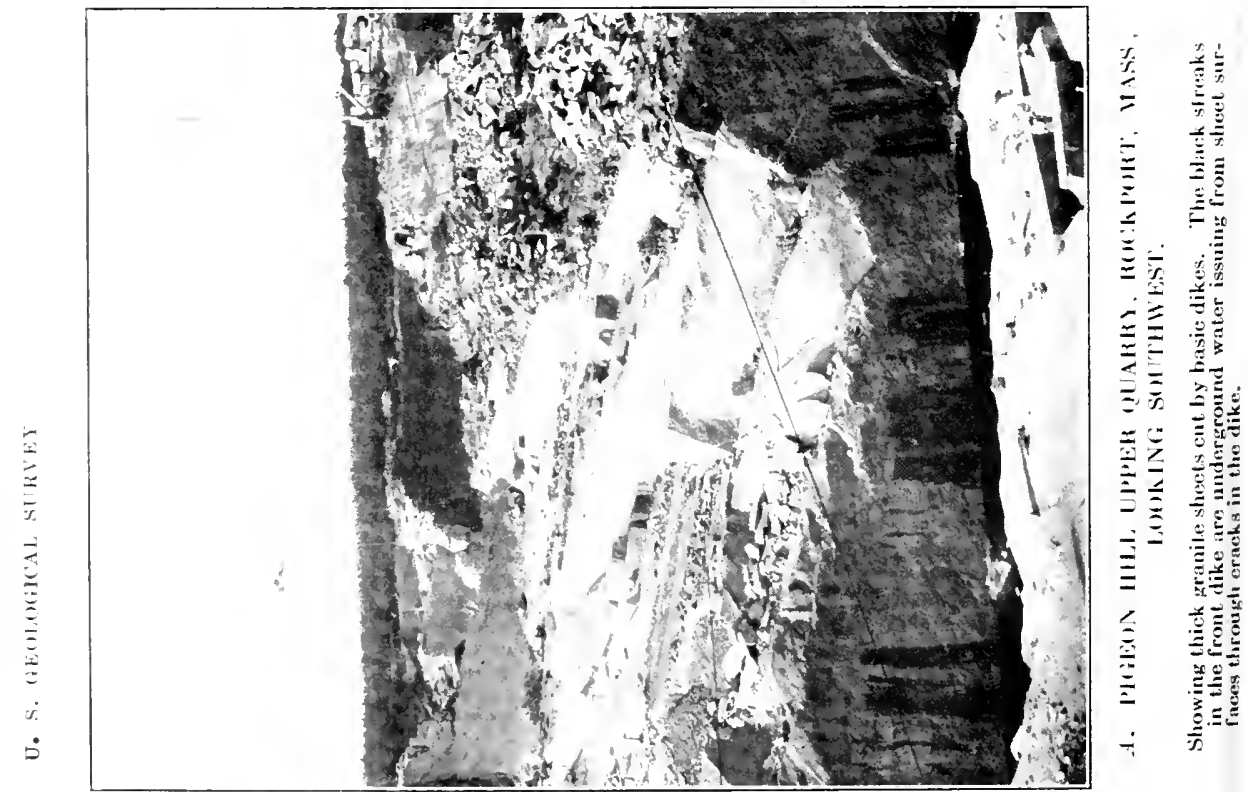
bottom ones disapponr upward within 100 feet of the surface; others which occur at the surface disappear below. Some of the joints are also intermittent. The possibility of a bad heading dying out below is as encouraging to the quarryman as the possibility of the appearance of a new one below is discouraging. This discontinuity in the joints and headings reflects the comples character of the stresses to which the region was exposed.

The remarkable black joint coatings of riebeckite have been described on page 82 . At one of the Milton quarries this appears on the sheet surfaces also, and the adjacent granite is lighter in shade.

From these summaries on the granite and on its geology is exposed at the quarries the following inferences may be drawn: The riebeckite-aegirite granite of Quincy had aegirite as one of its original constituents and riebeckite as another, but some of the riebeckite is clealy secondary. as shown by its occurrence in lift cracks and on sheet and joint faces. The formation of this mineral on these faces indicates that the granite after acquiring its sleet and joint structure was sulyected to metamorphism, probably that which accompanier the post-Carboniferous crustal movement. The source of this secondary riebeekite may well have been the aegirite itself. The hematite-spotted granite ("orei" "), the pink mranite, and the greenish-brown granite (described on 1p. $79,331,335$ ), while evilently due to the alteration of the aegirite particles to magnetite, hematite, green horublende, biotite, and chlorite, owe these minoral changes partly to processes of deep-seated alteration and partly to regional metamorphism, and the pea-green variety is due to the dissemination of fine prisms and grains of aegirite in its feldspars. In the dull-reddish granite of Braintree (p. 335) the aegirite and riebeckite seem to have been decomposed and the feldspars kaolinized and reddened by secondary hematite. The latest change was the brownish iron staining along sheet and joint suriaces, which is attributable to percolnting surface water oxidizing the magnetite and sodairon silicates and possibly also adding flesh supplies of iron sesquioxide obtained from deposits once overlying the granite.

QUARRIES.

The Dell Hitchcock quarry is on the North Commons, south of Quarry Street. (See intap, Pl. XXIV, No. 13.) Operator, Quincy Quarries Co., Quiney. The granite (specimen D, XXVIII, 67, d), "dark Quincy," is a riebeckiteaegirite granite of somewhat dark and slightly bluish-gray color with black spots. Its texture is medium to coarse, even grained, with feldspar up to 0.5 incis and black silicates usually not over 0.3 but occasionally 0.5 inch. Its constituents, in deaconding order of abundance, are a melium bluish and greenish gray potash felispai (orthociase), usually twinned, minutely intergrown with soda-lime feldspar and inclosing minute crystais we riebeckite and grains of aegirite and in places somewhat kaolinized; smoky quartz with cavities (some with liquid and vacuoles) and black particles in streaks or sheets; a little separate soda-lime feldspar (albite to oligoclose-albite); aegirite. much of it intergrown with riebeckite. Accessory: Magnetite, zircon. fluorite. Secondary: Kaolin, calcite, brown fibrous hornblende, and chlorite in rift cracks in feldspar.

The contrast in the rough stone is entirely between the black silicates and the combined quartz and feldspar.

A specimen (D, XXVIII, 67, c) of the "light Quincy" is more of a nedium gray with a slight greenish tinge. Its general composition is the same as that of the "dark Quincy," with probably more kaolin and aegirite in the feldspars. The contrasts are more marked.

$105709-23-22$ 
The quarry, opened before 1826 , is about 500 feet N. $25^{\circ}$ E. by 500 feet $N .65^{\circ}$ W. and in 1906 was 100 feet deep. (See Pl. XXV, A).

Rock structure: The sheets, 6 inches to 12 feet thick. are lenticular, undulating horizontally. As shown in the plate the upper 30 feet consists of very thin sheets which, owing to their thinness and rustiness, are valueless. Joints (a) strike $\mathrm{N}$. $70^{\circ} \mathrm{W}$, dip $90^{\circ}$, and are spaced irregularly, but nowhere completely cross the quarry. A set with similar strike, but dipling $30^{\circ}-35^{\circ} \mathrm{NNE}$., is represented. Joints (c) strike N. $20^{\circ} \mathrm{W}$., dip $90^{\circ}$, and are spaced 14 to 30 and 400 feet. At the bottom there are short intermittent joints dipping eist and in other directions, which are coated with ricbeckite and thus have blue black

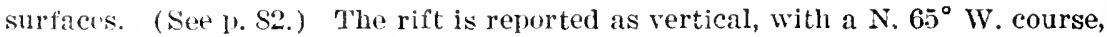
and the feeb'e grain as at right angles to it and vertical. A dark bluish-gray knot $(67$, e) contains porphyritic crystals of aeririte, as describerl under group 1 on page 59. There are also some of group 3 . The boundaries between the "light" and "dark" granite are not well defined. Rusty discoloration is 2 to 18 inches thick. Where it is only "2 ipches there is a zone of incipient stain several inches thick.

Transportation, by cart three-fourths mile to railroad and about a mile to local cutting sheds.

Specimen: Three bases and die of the Jefferson monument at Louisvile, Ky.

The Merry Mount quarry is on the North Commons, north of Quarly Street. (See map, I'l. XXIV, No. 14.) Operator, Merry Mount Granite Co., Quineg. Idle since 1914.

The granite (specimen D, XXIX, 86, a), "dark medium Quincy," is a riebeckite-aegirite granite of somewhat dark, slightly purplish-gray color, slightly darker than that of 67 , d. The texture is medium to coarse, even grained, with felouspar up to 0.5 inch and black silicates up to 0.3 inch. Its constituents, in descending order of abundance, are a medium and dark or slightly greenishgray potash feldspar (orthoclase, generally twinned), always minutely intergrown with soda-lime feldspar (albite to oligoclase-albite), in places somewhat kaolinized and inclosing riebeckite crystals up to 0.094 by 0.0094 millimeter and minute grains of aegirite; also hematite stain; smoky quartz with streaks or sheets of cavities and minute black particles; a little separate sodalime feldspar (oligoclase-andesine); blue-black riebeckite and green-biack aegirite, either separate or Intergrown. Accessory: Zircon (abundant in crystals up to 0.47 millimeter), fluorite. Secondary : Kaolin, limonite, hematite.

The purplish tinge of this granite is evidently due to hematite in the feldspar. The contrast in the rough stone is entirely between the biack silicates and the general gray of the quartz and feldspar.

E. C. Sullivan, chemist, of this Suryez, extracted 0.11 per cent of $\mathrm{CaO}$ (lime) from this granite $\mathrm{y}$ means of hot dilute acetic acid, which indicates the presence of 0.19 per cent of $\mathrm{CaCO}_{3}$ (calcium carabonate, calcitc). The thin sections also show calcite.

A specimen of "medium Quincy" (D, XXIX, 86, b) is a trifle lighter in color and has a slightly greenish tinge. Its texture and constituents are the same, except that the feldspar borders on light gray and hematite stain is absent. The quartz is darker than much of the feldspar.

The quarry, opened in 1S56, measured in 1906 about 300 feet from north to south by 200 across and from 130 to 150 feet in depth.

Rock structure: On the west wall is a 5-foot dike of lamprophyre, described on page 53 , which strikes $N .10^{\circ} \mathrm{E}$. The sheets are lenticular in all directions and mainly horizontal, 1 to 16 feet thick. They thicken downward, but with thin sheets at intervals, to a depth of 40 feet. Joints (b) strike N. $10^{\circ}$ E., dip $90^{\circ}$ or steep west, are spaced 5 to 20 feet, and form a heading near the 
dike. One diagonal joint (d) strikes N. $50^{\circ} \mathrm{E}$. and dips $70^{\circ} \mathrm{NW}$. The rift is reported as striking $\mathrm{N} .10^{\circ} \mathrm{E}$. and vertical or dipping steeply west, and the grain as east, dipping steeply north. In indivilual blocks the rift is considerably affected by gravity. Knots, both lark and light, are 1 to 6 inches across. but some are reported as 2 feet 6 inches in two diameters. Rusty stain on sheet surfaces is 1 to 6 inches thick.

Transportation, by cant 1 unile to railroad or cutting sherl.

The product consists chiefly of the "dark medium." Specimen: Barney mansolenm at Springfield.

The Ballon quarry is on the North Commons. north of Quarry Street. (See map. Pl. XXIV. No. 15.) Operator, John C. Ballou, West Quincy.

The sranite (snecimen D, XXIX, So, a). "dark Quiney witl mimute red dots," is a riebeckite-aegirite granite of dark, sligrlitly purplish-gray color, with spalse inconspicuous reddish stains. Its shade is slightly darker than that of S6. a (Merry Mount " (lark medium"). Its textmle is medium to coarse, even grainel, witl feldspars up to $0.5 \mathrm{inch}$ and black silicates to $0.3 \mathrm{inch}$. Its constituents, in descending order of abundance, are a dark-gray potash feldspar (orthoclase), twinned, minutely intergrown with soda-lime feldspar, in places somewhat kaolinized, rarely witl hematite stain along its cleavage planes, and inclosing grains of aegirite and crystals of riebeckite up to 0.114 millimeter long: smoky quartz of very slight bluish tinge, with abundant cavities up to 0.0094 and exceptionally 0.037 millimeter in diameter, in streaks or sheets intersecting one anoiner at all añgles, aña with very minute black particles; the (unurtz incloses a riebeckite crystal $0.17 \mathrm{~S}$ by 0.0047 millimeter; a little sejarate sola-lime feldspar (albite to oligoclase-albite); and finally riebeckite, some of it intergrown with aegirite, the latter containing magnetite and carbonate. Accessory : Zircon. mannetite. Secondary: Kaolin, hematite, limonite (about the giron), calcite.

Wie contrast is confined to that between the black silicates am the dalk oray of the feldsuar and quartz with its faint reddish spots.

Genrese sireizer, enemist, of this Survey, extracted 0.28 per cent of CaO (lime) from this stone by means of lot dilute acetic acid, which indicates a content of 0.5 per cent of $\mathrm{CaCO}_{3}$ (calcimm carbonate, calcite). The thin sections also slow calcite.

The quarry, opened before 1856 , measured in 1906 about 200 feet from north to south by 100 feet across, but with a recess on the south wall 16 by 18 feet. Its depth was 150 feet.

liock structure: An interesting cylindrical pegnatite dike. a section of which is exposel at the botton of the quariy. has been described on page 49 . The sheets, 8 inches to 20 feet thick, increasing in thicknoss downwarl, are lenticnlar, irregular, and dip both north and south. The sheet strneture extends at least to a defth of 150 feet from the rock surface, bow which there is no partinc for 16 fret. Joints (a) strike about $\mathrm{N} .80^{\circ} \mathrm{W}$., dip $70^{\circ} \mathrm{N}$., are spaced 3 to 30 feet, form a short lieading in about the center and one on the northeast sirle. Joints (b) strike nearly north, diij $: 10^{\circ}$ and steeply west. form headings at east and west walls, one, 100 feet from west wall, and another (30 to 40 feet widle) 75 feet west of east end. Toints (c), striking $\mathrm{N} .10^{\circ}-30^{\circ}$ W.. form a heading at the northwest romer at the fullry. Tlue rift is reported as about north, and the grain as east. hoth vertical. Stain is up to 3 inches wide along the joint faces but is scarcely present on shect surfaces.

Transportation, by car 1 mile to railroat.

The pribuct is used mainly for monuments, and the inferior stock for paring. Specimen structure: Masonic Builuing, Philadelphia. 
The Winquist quarries are on the North Commons south of Quarry Street. (See map, Pl. XxIV, No. 16 and opening west of it.) Operator, Common Quarry Co. (Carl G. Winquist), Quincy.

The granite of the Baker opening (No. 16), alone operated in 1906, "extra light," is a ribeckite-aegirite granite of light pea-greenish color and medium to coarse trxture. It is iflentical in composition with that of the iepage quarry (specimen D, XXVIII, 76, a), described on page 330. It owes its green color to the abundance of minute grains and erystals of aegirite in the feldspar. The quart\% is amethystine, not smoky. The contrast is chiefly between the black silieates and the feldspar, but there is also some between the purple tinge of the quartz and the light green of the feldspar.

This stone was used entirely for building and hammered work.

The granite of the MeDonald opening (west of No. 16) consists of light and dark "medium" and "dark" Quiney and is used for monuments, etc.

The Baker opening measures about 300 by 250 feet and 125 feet in depth; the MeDonald opening about $200 \mathrm{by} 150$ and 100 in depth.

Rock structure (Baker opening): There is a basic dike 6 feet thick, along the south side, dipping steeply south; a like one a little north of the north wali dips sterply north. The sheets, 2 to 22 feet thick, dip low north. Joints are few. Joints (a) strike nearly eist, steep, form north and south walls only. Joints (b) strike nearly north, form east and west walls only ; one diagonal (e), strike norihwest, dips $45^{\circ} \mathrm{SW}$. Rusty stain is up to 6 inches thick on sheet surfaces.

Transportation, by cart 1 mile to railroad.

The Fallon quarry is on the North ('on!mons, on the south side of Quarry Street, west of the Hardwick quary. (See map, I'l. XXIV). Operators, Johr: Fallon \& Sons, West Quincy. Idle since 1916.

The granite is "dark medium Quincy."

The quarry measures about 600 by 100 feet and 100 feet in depth.

Roci structure: In this quarry a cyliudrical dike of pegmatite, like that at the Ballou quarry, was discovered a few years ago. (Soo lanelis hy livarrom and Palache, cited on page 49.)

Specimen product: Pilgrim Monument (excluding statue), Plymouth.

The Hardwick quarry is on the North Commons opposite the corner of Quarry anl smith streets. (See map, Pl. XXIV, No. 19.) Operators, C. H. Hardwick \& Co., Quincy.

Ti:e granite (wrocimen D, XXIX, 79, d), "medium," is a riebeckite-aegirite granite of dark, slightly purplish gray color, a trine uarker than 86 , a (the "dark medium " of Merry Mount quarry) and a little darker and more purplish than 67, d (the "dark" of Dell Hitehrock quarry). It is of medium, evengrained texture, with feldspars and black silieates up to 0.4 inch. Its coiistituents, in descending order of abundance, are a medium and dark, slightly purplish-gray potash feldspar (orthoclase), usually twinned, always with minutely intergrown soda-lime feldspar and exceptionally with quartz also; in places it is somewhat kaolinized, contains minute aegirites and crystals of riebeckite from 0.0094 to 0.066 millimeter long up to 0.0094 millimeter wide: light smoky quartz with intersecting streaks or sheets of eavities from less thas 0.0043 to 0.02 millimeter long, also with very minute black particles; riebeckite and aegirite, the latter with black nonmetallic particles (limonite?) ; a little soda-lime feldspar (albite to oligoclase-albite.) Accessory: Magnetite. Secondary: Kaolin, brownish-yellow fibrous hornblende on riebeckite, limonite (?).

The contrast is largely between the black silicates and the gray of the quartz and feldspar. 
The "light" of the same quarry (specimen I, XXIX, 79, f) is a similar granite of medium gray, inclining to dark shade without bluish or greenish or purplish tinge, with bluchlack and rery dark green spots, and of medium texture, with feldspar ant rieheckite up to 0.4 inch. Its constituents are identical with those of the "medimm" alreary deseribed, except that the feldspar is in places stained with hematite, in others with limonite, proceding from limonite associated with zireon. and that the angirite appears to he slightly altered. There is some lencoxene aljacent to imenite. The acorite contains not a little magnetite. Fluolite is among the accessory minerals.

The contrast between the black silinates and the ofler minerals in the "light" is greater than in the "medium," becaluse the feldspars are lighter.

The "dark" (specimen 79. e) is darker than the "mesliun" and of the same shade as the "dark" of the Granite Railway quarry (68, b), page 329 , but of marked purplish tinge. Its texture is medium to coarse.

An analysis of a granite from this quarry is given on page 318 .

The quarry, first opened in a small way in 1790 , but first operated by the Hardwick family in 1848, neasured in 1906 about 300 feet east and west by 150 feet across, and has now reached a depth of 150 feet.

Rock structure: The sheets, 8 inches to 20 feet thick, usually increasing in thickness downward, but in places thin to a lepth of 50 feet, are lenticular and horizontil. Joints (a) strike N. $80^{\circ}-85^{\circ} \mathrm{W}$., dip $55^{\circ}-65^{\circ} \mathrm{N}$., spaced 10 , 30 , and 60 feet, form a heading on the west wall. Joints (c) strike N. $30^{\circ} \mathrm{W}$., dip $70^{\circ} \mathrm{SW}$., spaced 5, 25, and 150 feet, form a hearling 30 feet wide in east half of quarry. These joints are intermittent. The rift is reported as vertical, with a course about $\mathrm{N} .30^{\circ} \mathrm{WV}$. and the grain as horizontal. The boundary between the "medium" and the "light" is irregular. Within the hearlings the stone has a marker purphish tint from hematite stain. There are rows of riebeckite particles up to $0.5 \mathrm{inch}$ wide with a $\mathrm{N}$. $85^{\circ} \mathrm{W}$. course and a dip of $55^{\circ} \mathrm{S}$. There are also quartz veinlets with a N. $20^{\circ} \mathrm{W}$. course, less than 0.1 inch thick, which in places give way to black silicates. In thin section this black part consists chiefly of quarty, aegirite, and magnetite, with a little zircon (in doubly terminated lyramids), purple fluorite, and carbonate. Aplitic knots of group 1, described on page 59, are up to 3 feet by 4 inches. Light-gray knots of group 2, with porphyritic feldspar, occur also. Rusty stain along the sheet surfaces is from three-fourths inch to 6 inches thick.

Transportation, by cart 1 mile to railroal and varying distances to local cutting sheds.

The product is chiefly the "medium" but includes some "dark" and "light," the last used for hases and hammered work. Specimens: Addition to Gore Hall at Harvard University, erected in 1870 ; customlouse at New Orleans; Lewis Cass monument at Detroit, Mich.; a 5 -foot polished ball in Fairmount Cemetery, Newark. N. J. The firm supplies rough stock to concerns that finish it.

The Galvin quary is on the North Commons, between the Falconer and the Hardwick quarries. (Sce map. Pl. XXIV.) It is now abantoned.

The granite is a riebchite-aegirite granite of dark or medim gray color.

liock structure: There are pegmiltite quartz veins at intervals of 2 to 10 feet, striking $\times 25^{\circ} \mathrm{W}$. and dipping $50^{\circ} \mathrm{S}$. $65^{\circ} \mathrm{W}$. These reins, up to 1 inch thick, occury the center of belts of light granite 10 inches wicle and are crossed by vertical subjoints striking about north and not over 1 foot long. (See p. 40.)

The product is carted to local eutters.

The Falconer quarry (formerly McKenzie \& Pattison) is on the North Commons. (See map, PJ. XXIV, No. 18.) Operators, Falconer \& Co., Quincy. This has on its northwest side quartz veins, like those of the Galvin quarry, 
striking $\mathrm{N} .50^{\circ} \mathrm{W}$. anet dipping $50^{\circ} \mathrm{s} .40^{\circ} \mathrm{W}$. forming the center of bauds of whitish and brownish discoloration.

The guarry is 400 by 250 feet and 100 leet deep.

The product is used for tombs and cemetery monuments.

The Field \& Wild quarry is on the North Commons between the fatconer quarry and Cranch street. (See maj, Pl. XXIV, No. 20.) It is now abancloned.

The slanite, "lark," "medium," and "light," is a riebeckte-alegirite glanite of dark and neelium sray shates.

The quary, mened about 1940, measured in 1906 about 600 feet from northwest to sontheast by 150 feet acioss and from 75 to 100 feet in depth.

linck structure: The rock surface on the northeast side dips steeply east, with sheets from 1 to 3 feet thick paraltel to it. Some thin sheets occur also in the upper 20 feet on the southwest s.de. Juints (b), strike N. $15^{\circ}$ H., dip $90^{\circ}$ or steel, slaced 10 to 50 feet, occur at the northwest end only; joints (c), strike N. $15^{\circ} \mathrm{W}$, dip $80^{\circ}$ E., spacel 1 to 8 feet; joints $(d)$, strike N. $45^{\circ}$ E., dip $70^{\circ}$ $85^{\circ} \mathrm{N} .45^{\circ} \mathrm{W}$., slatced 20 to 50 feet; (e), strike about N. $45^{\circ}$ W., dip $30^{\circ}-50^{\circ} \mathrm{S}$. $45^{\circ}$ W. spaced 2 to s feet. Some intermittent joints are coated with riebeckite. The ritt is siall to vary greatly in direction both in the quarry and in different blocks. Numerous quartz reins like those at the Galvin and Falconer quarries strike about N. $45^{\circ} \mathrm{W}$., dip $45^{\circ} \mathrm{S} .45^{\circ} \mathrm{W}$., spaced 2 to 25 feet. They are mostly crossed by subjoints 1 foot long, parallel to joints (c), an inch or two apart. Some of them have a central fracture. In places they are only 0.02 inch thick. A thin section of one shows quartz crowded with cav ties in intersecting streaks, crystals of ilmenite (mohal)ly), and carbonate. The hand specimen shows fluorite along the elgre of the vein. The feldspars adjacent to the vein are traversed by tibrous nunscovite, also kaolinized, stained with limonite, and otherwise altered. (See p. 77.) Knots up to more than 6 inches, some of them of group 2 (p. 59), with porphyritic feldspars, occur.

The Wigwam quary is on Willard Street, 570 feet south of West Quincy Station. (see map, Pl. XXIV, No. 1.) This quarry was operated in 1906 by Badger Bros., but is now abanklonet.

The slanite, chiefly "dark" and "extra dark," with some "medium" and "hight," is a ritheckite-aegin'ite granite of dark, very dark, or medium bluishgray color and of medium to coarse, even-grained texture. Its constituent minel'als are similar to those of specimens D, XXVIII, 68, b ("lark"), and D, XXIX, 78, a ("extra dark"), described on pages $327,329$.

A polished specimen (D, XXVII, 73, a) of the "medium" shows the feldspars ranging from a dark gray to a greenish medium gray, and cream-colored in spots owing to kaolinization. The contrasts between the black silicates, the grayish quartz and feldspars, and the cream-colored parts of the feldspars are marked and give the stone a mottled appearance.

An estimate of the mineral percentages made by applying the Rosiwal method to this specimen, with a mesh of 0.6 inch and total linear length of 20.4 inches, yields these figures: Feldspars, 69.51; quartz, 8.43; riebeckite and aegirite, 22.06 .

The quarry, opened between 1920 and 1830, measured, in 1906, about 250 feet in a N. $65^{\circ} \mathrm{W}$. direction, by 100 feet across, and from 100 to 160 feet in depth.

Rock structure: The sheets at the surface, on the north and west sides, 1 to 3 feet thick, dip $50^{\circ} \mathrm{NE}$. On the south and east sides there are traces of sheet structure in the upper 40 feet but none below that. Joints (a), strike N. $83^{\circ} \mathrm{E}$. and vertical, are spaced 6 to 20 feet. Joints (b), strike N. $10^{\circ}$ E. and vertical, are spaced 3 to 18 feet and form the southwest wall. Owing to its irregular sheets and the spacing of the joints this is technically a "boulder quarry." The rift was reported as vertical, with an east-west course on the south side, 
but on the north as dipping steeply north, and the grain as vertical north to south. Black knots are reported up to 6 by 2 feet. Greenish and mudly yellow knot of group 3, page 59, measure up to 1 foot in length by a few inches in width. Reddish and greenish spots ("oreī," p. 7S) occur in the upper 30 feet.

The product consisted chiefly of the "dark" and "extra dark" for monuments. Specimens: Polished columns in monument to So'omon Willard, architect of Bunker Hill Monument, in Hall Cemetery, West Quincy; polished columns in New Orieans customhouse; polished ball, 6 feet 6 inches in diameter, in cemetery at rock Island, Ill., a photograph of which is reproduced in Plate XXVI.

The Reinhalter quarry is 570 reet south-southwest of West Quincy station. (See map, Pl. XXIV, No. 2.) Operator, J. S. Swingle, Quiney.

The granite (specimen D, XXIX. 7S, a). "extra dark," is a riebeckite-aegirite granite of very dark bluish-gray color and of medium to coarse, even-grained texture, with feldspars up to 0.5 inch and black silicates up to 0.3 inch. Its constituents, in descending order of abundance, are a dark and medium gray potash feldspar (orthoclase), mostly twinned, minutely intergrown with sorlallime feldspar, darkened probably by a black mineral in very minute particles; it incloses minute erystals of riebeckite and grains of aegirIte: smoky quartz with intersecting streaks and sheets of cavities, very minute black particles and isolated crystals of aegirite; blue-black riebeckite and green-black acririte, in places intergrown; a little separate soda-line feluspar (albite to oligoclase-ablite.) Arcessory: Zircon (rather abundant), ilmenite, and pyrite. Cracks in orthoclase and quartz, intersecting at right angles, probably rift and grain cracks, contain or are crossed

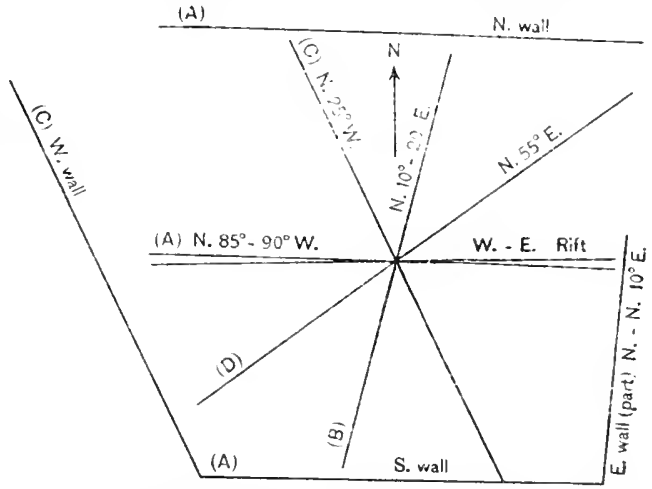

Finitit 7S.- Stmeture at Reinhalter quarry, West Quincy, Mass.

by secondary minute erystals of rebeckite. The feldspar is much darker on either side of these cracks. Secondary : Lencoxene and part of the rioheckite.

The "medium" of this quarry is a dark. very slightly greenish-gray stone of the same texture. Its shade is like the "medium" of the Hardwick quarry (p. 324). but its tint is different. It is darker than the "dark" of the Dell Hitchcock quarry but differs from that also in tint.

The quarry, opened before 1871 , measures 200 by 150 feet on one side and 200 feet on the other and 250 feet in depth.

Rock structure: The sheets, 14 inches to 20 fect thick, extend down 250 feet from the rock surface. At a point on the east side, 150 feet down, they dip east. On the south side, 175 feet down, they strike N. $85^{\circ} \mathrm{W}$. and dip $25^{\circ}-35^{\circ} \mathrm{s}$. Below that there is a sheet 55 feet thick. Toint and rift courses are shown in figure 78. Joints (A) dip $90^{\circ}$, form the nortl and south walls, and recur at intervals of 10 and 35 feet. At 35 feet from the north wall they form a 10 -foot heading which extends from a point 100 feet below the surface to the bottom. Joints (B) are vertical, form the east wall, are intermittent, and are spaced $s$ ) and 60 to 70 feet. The east wall is intersected by a wide heading striking $\mathrm{N}$. $20^{\circ}$ E. and dipping steeply east. Joints (C) dip $90^{\circ}$ and form the west wall. 
Joints (D) are vertical and exceptional. In about the center of the top of the north wall is a 25 -foot heading, which at a point 50 feet down disappears behind it. The heading (A) has "dark" and "medium" granite on its south side and "extra dilrk" on its north silfe. The sheets at a point 175 feet down are intersected by several convex southward-curving partings, "toenails." The rift is reported as $90^{\circ}$ below, but not quite $90^{\circ}$ near the surface, and the grain as horizontal. Black knots are usually but a few inches in diameter, but some 2 feet by 1 foot 6 inches are reported. Gray knots are from 0.5 to 8 inches. Rusty stain meisures up to 3 inches on joint faces, but down to $0.5 \mathrm{inch}$ on sheet faces near the bottom.

Transportation, by a siding at the quarry, by cart one-fourth mile to cutting shed, and a shorter distance from shed to railroal.

The product consists of " extra dark," "dark," and " medium," but most of it is "extra dark." It is used for monuments and columns. The largest block obtained weighed 50 tons.

The Swingle quarry is about 600 feet southwest of West Quincy station and adjoins the Reinhalter quarry on the west. (See map, Pl. XXIV, No. 3.) Operator, J. S. Swingle, Quincy.

The granite (specimen D, XXVIII, 72, a), "extra dark," is a riebeckiteaegirite granite of very dark bluish-gray color and of medium to coarse, even-

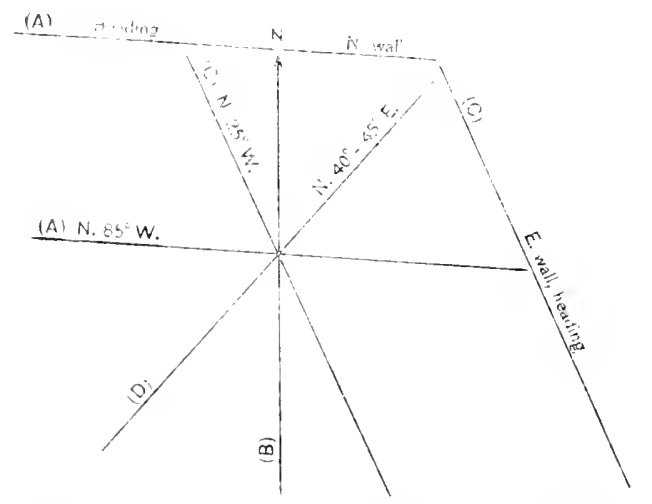

Higure 79.-Structure at Swingle quarry, West Quincy, Mass. grained texture, with feldspars up to 0.5 inch and black silicates up to 0.3 inch. Its constituents are like those of the stone in the adjacent Reinhalter quarry (specimen 78 , a).

The contrast in the polished stone is confined to that between the black silicates and the dark gray of the other minerals.

An estimate of the mineral percentages in specimen $72, a$, by the Rosiwal method, with a mesh of 0.5 inch and a total linear length of 20 inches, yields these results: Feldspars, 56; quartz, 33.50; riebeckite and aegirite, 10.50 .

The quarry, opened about 1846, measures abont 200 feet from north to south, by 175 feet across and 250 feet in depth.

Rock structure: Irregular horizontal sheets are apparent only to a deptb of 100 feet, below which joints and headings predominate. This is a boulder quarry and its management is difficult. Joint and rift courses are shown in figure 79. (A), rertical or dip $75^{\circ} \mathrm{S}$., form a heading on the north wall and are spaced 10 to 30 feet. (C), vertical, form a heading on the east, 30 feet wide, which separates this from the Reinhalter quarry. (D), diagonal, form a heading on the west wall dipping $75^{\circ}$ SE. and another extending from east to south wall. They are spaced 2 to 10 feet and some dip $90^{\circ}$. (B), also diagonal, dip $70^{\circ}$ E., form a heading intersecting the south wall and another at the northwest corner. The rift is reported as vertical with a north-south course west of heading (C), but with an east-west course east of it. This anomaly may be due to faulting. Knots, green or black, are reported as measuring from 6 inches to 2 feet in diameter. Rusty stain is from 0.5 to 2 inches thick on sheet surfaces at the bottom. 
Transportation. by railroad siling for ont of town shipments but by ant about 1 mile to local dealers.

The product is used mostly for monumonts. Shimments labe bern male to Connecticut, Rhude Island, New Hampshire, Mane, New York, New Jersey, Pennsylvania, Delaware, Ohio, Indiana, Illinois, Miøligan. W'sconsin, and

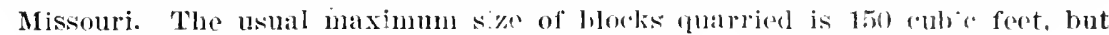
blocks 40 by 6 by 8 teet are obtainalule.

The Berry quarry has also been operated by J. S. Swingle simes 1914.

The Granite Railway quarry derives its name from a ll mit we laifroad constructed in 1S26 to bring the granite for the Bunker Hill Monment from a neigluboring onening to tidewater at Nemonset liver. The guarry now workerl is about 1,050 feet west-southwest of West quincy station. (Soe map, Pl. XXIV, No. 4.) Operator, Granice Railiary Co., Quncy.

The granite (specimens, D, XXVIII, 68, h, h), "Quiney dark-lbue railway," is a riebeckite-aegirite granite of dark blu'sh-gray color and medimm to coarse, even-grained texture, with feldspars uj, to 0.5 inch and hlack silicates up to 0.3 inch. Its constituent $\mathrm{s}$, in descending order of abundance, a re a dark bluish to greenish gray, black-streaked potash feldspar (orthoclase), in twins, mimutely intergrown with soda-lime feldspar, apparently darkened by microscopic black particles and also somewhat kaolinized, containing blue-brownish crystals of riebeckite down to 0.009 millimeter long, also irregular particles of green aegirite and some. slender ones up to 0.37 millimeter long arranged either along the twinning plane or the plane of intergiowth with the soda-hime feldspar; the black streaks are due to elusters of radiating fibrous crys als of a brown hornblende; smoky quartz with intersecting streaks or sheets of cavities, from less than 0.0028 to 0.0055 millimeter, also with aboundant microscopic black particles; hue-black riebeckite and green-black aegirite, largely intergrown; basal sections of the aegirite appear corroded; separate soda-line feldspar (albite to oligoclase-albite) in very small amount. Accessory: Ilmenie, zircon in doubly terminated pyramicls, alatite. Secondary: Kaolin, lencoxene, hematite and limonite stain (rare), bown hormblende, and, as shown by test, calcite.

The contrast between the smoky shade of the quartz and the slightly blush to greenish gray of the feldspar is small. It lies mainly between these and the black silicates.

An estimate of the mineral percentages by the Rosiwal methor yiclis the following results, with a mesh of 0.4 inch and a total linear length of 71.2 inches: Feldspars, 58.79; quartz, 33.74; riebeckite and aegirite, 7.47. Of course the last figure does not include the mieroscopic particles of the two black silicates.

E. C. Sullivan, a chemist of this Survey, extracted 0.13 per cont of Car) (lime) from this granite by means of hot dilute acetic acid, which indicates the presence of 0.25 per pent of $\mathrm{CaCO}_{3}$ (calcium carbonate, calcite).

The "extra dark" of the same quarry (specimen D, XXVIII, 68, c) is darker than 68 , b, but a trifle lighter than the "extra dark" of the Swingle quarry. The feldspar seems to be darkened by more brown horublende and more abundant other black particles. There is also a dark orange-colored hornblende. The minute riebeckite crystals and long, slender aegirite particles are both arranged with reference to the twinning of the feldspars. An aegirite particle ( 0.2 by 0.14 millimeter) coated with radiating crystals of riebeckite (up to 0.09 millimeter long) occurs within a quartz area. Purple fluorite is mingled with the reibeckite.

The quarry, opened in 1826, is roughly T-shaped, the top of the $\mathrm{T}$ measuring about 800 feet N. $75^{\circ}$ W. by 450 feet N. $10^{\circ}$ E. and the stem being about 
250 by 20 feet. Its depth ranged in 1906 from 50 to 70 feet, but 30 feet of rock had been removed from the present edre of the quarry. In 1906 a mass about 100 feet square, rising 30 to 40 feet above the elge and devoid of sheet structure, projected into the quarry west of the stem of the $T$.

Rock structure: A 15-foot diabase dike dipping $60^{\circ}$ NNE., with a greenish rim a foot thick on its underside, bounds the quarry on the southwest. (See p. 52.) The granite under the dike has three sets of joints, one dipping about $50^{\circ}$ in the opposite direction, one parallel to the dike, and a third striking $\mathbf{N}$. $22^{\circ}$ E. with the dip of the dike. In places the sheets are regular, in other places they are short lenses, and in others they are altogether absent. This is a boulder quarry. The courses of dike, joints, and rift are shown in figure 80 . Joints (A), dip $55^{\circ} \mathrm{SW}$, form a heading on the northeast, and are spaced 1 to 12 feet; $(B)$, vertical, form the east and west walls and are spaced irregularly up to 300 feet; (C), diagonal and dipping $70^{\circ} \mathrm{W}$., form a heading at the west angle of the $T$ in the projecting mass; ( $D$ ), diasonal, dip about $55^{\circ}$ E., coated with ricbeckite and hence called "black seams" (see p. \$2), occur intermittently on the south side of the quarry. The rift is reported as vertical, with a $\mathrm{N}$. $80^{\circ} \mathrm{W}$. course, and the grain as also vertical at right angles to it, but feeble.

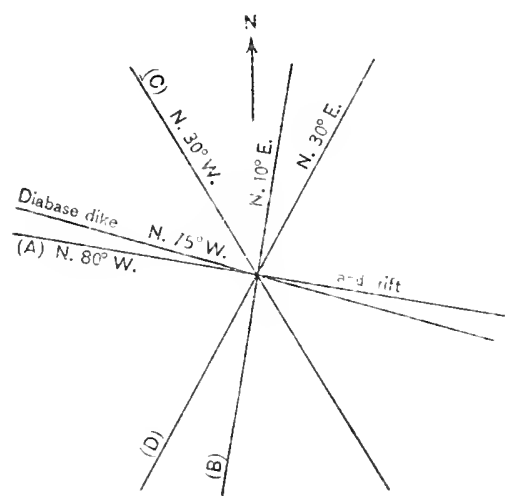

FiGIRE 80.-Structure at Granite Railway quarry, West Quincy, Mass. In the westein jallt of the top of the $T$ there is a mass of hematitic and chloritic sranite ("oreï") extending 30 feet llown from the surface. This is described fully on page 78. Knots of latrk-arlay shatle measure up to 12 by 6 inchles. lousty stain is from 3 to 12 im.lies thick on joint and sheet faces in the dheper part of the quarry.

This ("mplny onerates another quarry,

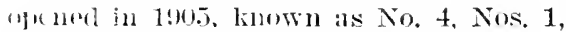
2 . aml is be ng clesignations of parts of the last qualry. No. 4 lies west of the swingle qually and measured in 1906 ahout 2(n) feet N. $15^{\circ}$ E. by 75 to 100 feet cast and is from 15 to 40 leep. The sherets, fi inches to 8 feet thick, are horizontal or dip north with the hill surface. The Bunker Hill fuary, which furnisherl stone for the Bunker Hill Monument, lies about 1,800 feet soutl of No. $t$, hut is now idle. (See map, Pl. XXIII.)

Transpoltation, by siding to New York, New Haven \& Hartford lailroad.

The product is used mostly for mommenis and polished building fronts. Specimens: Bunker Hill Momument; a polished monmment 23 feet high to W. C. Whitney, former Secretary of the Nary, at Woodlawn Cemetery, New York. The waste is used for cellar stone, riprap, and paving.

The Lepage quary is between the Granite Railway and the Cashman quarries. (See map, I'. XXIV. No. 5.) It has now heen abandoned.

The granite (specimen D, XXVII, 76, a). "extra light," is a riebeckite-aegirite granite of light pea-greenish color and medium to coarse, even-grained texture, with feldspars up to 0.5 inch and black silicates to 0.4 inch. Its constituents, in descending order of abundance, are a licht pea-green potash feldspar (orthoclase, mostly twinned), minutely intergrown with soda-lime feldspar, somewhat kaolinized and contains more fine grains of aegirite than the gray granites of the region, hut contains far fewer minute crystals of riebeckite; the aegirite is likely to be parallel to the twinning plane of the orthoclase or the plane of intergrowth of the two feldspars; amethystine 
quartz, showing effects of strain and containing interserting streaks and sheets of cavities. also minute black particles; blueblack riebeckite and grcen-black aegirite, in places intergrown; sodalime feldspar (albite to oligoelase-albite). Accessory : Ziron, pyrite, tluorite. Secombary: Kaolin. carbonate, limonite, slenter crystals of urange-yellow hornblencle radiating from aegirite particles.

As pointed out on page 77 , the peculiar color of this granite and its feldspar seems to be due to the abundance of fine grains of areririte and to the alsence or alteration of the minute riebeckite crystals. Kaolinization has also light-

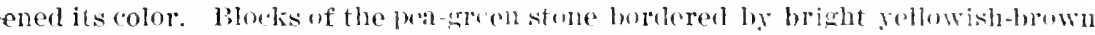
stain afford striking contrasts (sperimen D. XXVIII, 76, b). It takes a poor polish and is used only for bridges, cubing. paving. ete. On the north side of the quary there is some " dark" adaptod to monmental work.

The quary, opened in 1005. massured in 1906 about 100 fect north to south by 60 to 80 feet across and from 30 to 45 feet deep.

Rock structure: The sleets, 1 to 5 feet thick, lip $10^{\circ} \mathrm{S}$. Joints (a), strike N. $80^{\circ}-85^{\circ} \mathrm{W}$., dip $70^{\circ}-80^{\circ} \mathrm{N}$., form the sonth wall, spaced 4 to 10 feet; (h), strilie $\mathrm{N}$. $15^{\circ} \mathrm{K}$., lip $90^{\circ}$ and $30^{\circ} \mathrm{E}$., form the west wall and a heading on the east wall. spaced 3 to 10 feet. The rift is reported as $91^{\circ}$, with an eastwest course. and the grain as vertical, north-south.

The Cashman quarry is ahont 1,800 feret west of the West guincy station. (See map. Pl. XXIY. No. 6.) It is now abaudoned.

The granite. "extra dark," "medimm," and "extra light." is a riebeckiteaegirite granite of very dark or medium bluish-gray or of light pea-greenish color, and of medium to coarse. evrn-grained texture. Its constituents correspond to those of the several varieties of Quiney granite as described on pages 77,319 .

The quarry, opened ahout 1876 , is of irregular area owing to several offsets or projecting parts on the nortle, east. and west sides. It was in 1906. roughly, about 350 feet north to south by 225 feet across and from 70 to 100 feet deep.

Rork structure: The sleets. 1 to 5 feet thick, are lenticular and ftat on the south sicle, but dip north at the north. Joints (a) strike about east, dib steep north or south, form a hearling on the north side, and are spaced 10 to 75 feet. Joints (b) strike about north, dip $99^{\circ}$, form headings on east side and 35 feet mest of it. and are spaced 10 to 30 fret. The rift was reported as vertical, about east-west, but in places steep north or south. When split from the side, the rift in these places is vertical. The grain is said to dip stepply. with north-south course. A workman stated that the rift in the "extra light" was superior to that in the dark stone, and the blocks in sight showed smooth rift breaks. The "extra licht" oceurs at both north and south ends of the quarry, and the dark in the center. Near a hearling at southeast corner the granite is hematitic ("oreï"). (See p. 78.) Rusty stain is from 1 to 3 ind hes thick on botb light and dark stone.

Transportation, by cart 2 miles.

The product is monumental and brilse work. Specimen structures: Arch bridge across Furnace Brook Parkway, West Quincy; five bridges between South Braintree and Whitman, on the Plymouth division of the New York, New Haven \& Hartford Railroad.

The Savo quarry is about four-fifths mile west-northwest of Wrst Quincy station. (See map, Pl. XXIV. No. S.) It is now abanlonerl.

The granite (specimen $\mathrm{D}, \mathrm{XXIX}, \mathrm{st}$, a) is an altererl reberkiti-aegirite granite of pinkish medium-gray color and medium to coarse, even-srained texture, with feldspars up to 0.5 inch and wreenish silicates up to 0.2 inch. Its constituents are, in descending order of abundance, light-pinkish, not transparent potash feldspar (orthoclase), twinned, with minutely intergrown soda- 
lime feldsuar, considerably kaolinized but containing no riebeckite; its pinkish color must be attributed to hematite. arising either from the oxidation of FeO in the feldspar or of magnetite in the other jarticles; smoky quartz with intersecting streaks or sheets of cavities and minute black particles; riebeckite and alemir te altered to quartz, magnetite. carbonate, epidote and in some cases (liborite; a litile sola-lime feldspar (oligoclase-andesine). Accessory: Zircon (ratler large), fluorite. Secondary: Kanlin, carbonate, magnetite (some in (rystals), chlorite, hematite. (See further on this granite p. 78.) The pink tint farles somewhat on exposure.

The quarry, openerl in 1905 , measured then about 135 feet $\mathrm{N} .55^{\circ} \mathrm{W}$. by 50 feet across and 40 feet in depth.

Rock structure: The sheets, 1 to 8 feet thick, dip $45^{\circ}$ N. $25^{\circ}$ E. Joints (a) strike N. $70^{\circ} \mathrm{W}$, dip abont $60^{\circ} \mathrm{N} .20^{\circ}$ E. and S. $20^{\circ} \mathrm{W}$.; (c) strike N. $30^{\circ}$ $W^{\prime}$., dip $90^{\circ}$ and steeply west. The pink granite occupies the south half of the quarry and the pea-green the north half. The rift is reported as vertical, north-south, and the grain as horizontal. Rusty stain is 8 to 12 inches thick.

Transportation, by cart $1 \frac{1}{2}$ miles to West Quincy.

The Gold-leaf quarry is 4,500 feet $\mathrm{N}$. $80^{\circ} \mathrm{W}$. of the West Quincy station. (See map, Pl. XXIV, No. T.) Operator, Quincy Quarries Co., Quincy. Quarry not operated in $1917-18$.

The granite (sprecimens D, XXVIII, 71, a. b), "gold-leaf Quincy," is a riebeckite-aegirite granite of medium bluish green-gray color (a trifle lighter than 67, c, the "light" of Dell Hitcheock quarry), speckled with black and yellow-brown. Its texture is medium to coarse, even-gramed, with feldspars up to 0.5 inch, black silicates to 0.3 inch, and yellow-brown stains to 0.5 inch, but the quirtz areis are finely granular. Its constitutents, in descending order of abundance, are medium bluish green-gray potash feldspar (orthoclase), twinned, minutely intergrown with soda-lime feldspar, in places granulated, somewhat kaolinized, and containing many minute crystals of riebeckite and fine grains of aegirite, to both of which the feldspar owes its peculiar color ; quartz, clear to light smoky, almost witlout cavaties, all granulated in particles mostly under 1 millimeter, rarely 2 millimeters in diameter; blue-black riebeckite and green-black aegirite, in places associated with limonite (and hematite?) ; sodi-lime feldspar (abite and probably oligoclase-albite) in small amount. Fluorite is accessory. Secondary limonite occurs in irregular areas, mostly not related to the particles of black silicate, and this produces the yellow-brown stains.

An estimate of the mineral percentages by the Irosiwal method, with a mesh of 0.5 inch and a total linear lengtl of 74 inches, yields these figures: Feldspars, 67.37; quartz, 23.01; riebeckite and aegirite, 9.62. As compared with the percentages in other Quincy granites these approxinate those of the Wigwam quarry stone. This is the lightest of the Quincy monumental granites. The contrasts between the light bluish-green of the feldspar and the black particles and the yellow-brown stains are marked. The minute particles of gramulated quartz reflect the light and, as it were, spangle the surface, and where the limonite stain coinciles with the quartz areas the yellow-brown spots are the more conspicuous, hence the trade name "gold-leaf." It takes a high polish, but as small pits are likely to appear in the quartz owing to the dropping out of minute quartz particles, it seems better adapted to indoor ornamentation.

The quarry in 1906 was about 125 feet square and from 20 to over 50 feet in depth.

Rock structure: Joints (a) strike N. $80^{\circ}$ W., dip vertical and steeply north, form the north wall, spaced about 50 feet; (c) strike N. $10^{\circ} \mathrm{W}$., dip $30^{\circ} \mathbf{E}$.p 
form three headings in the east half and are spaced 4 to 15 feet. These apparently serve as sheets. Fine-grained gray knots of group 1 (p. 59) are 6 inches in diameter.

Transportation, by sidings connected with Granite branch of New York, New Haven \& Hartford Ra:Iroad, as shown in Plate XXIV.

Product: The last building of any importance made from this stone is that of the Carnegie Institute at Pittsburgh, Pa.

The Rogers quarry is at the north foot of the Blue Hills, 1,500 feet northwest of West Quincy station, on Willard Street. (See map. Pl. XXIV, No. 9.) Operator, Quiney Quarries Co., Quincy.

The granite (specimen I, XXVII, 70, d), "extra dark," is a riebeckitealegirite granite of very lark lmrplish-gray eolor and of medium to coarse texture, with felkspars up to 0.5 inch and black silieates up to 0.3 inch. Its constituents are like those of the Reinhalter and the Granite Railway "extra lark" wlanite, deseribed on pages 327,329 . The feldspars have more whitish kalolinized strealis, hence the general shade is slightly lighter than that of ti,e cranites referred to $(78$, a. and 68 , e), and minute liematitic stains aecount for its more purplish hue. This quarry also yields the "dark."

The quarly, opened in 1S32, moisured in 1906 about 600 feet from north to south by 175 feet aeross and from 40 to 150 feet in repth.

Rock structure: The sheets a.- sirut and thick lenses, which render the structioir vosempe and irregular. (The structure is given in fig. 12 of $\mathrm{U}$. S. Geol. Survo Bull. 354. 1908.) Joints (A) dip $90^{\circ}$ or steeply north and are spaced 10 to 20 feet. (IB) d p steeply east, form headings on east and west walls, and are spaced 10 to 20 feet. (C) dip $50^{\circ} \mathrm{E}$., form a heading at the northwest eorner, the faces of which are coated with riebeckite, and are spaced 6 inches to 4 feet. (See on these black joints, p. 82.) This heading interaccis a nealing of (B). (D), diagonal, dip $40^{\circ} \mathrm{S} .45^{\circ} \mathrm{W}$, are spaced 2 to 20 feet. At the south end several faces dipping $30^{\circ}-60^{\circ} \mathrm{N}$. may belong to (A).

The $r$ ft is reported as vertical, with east-west course, and the grain as alon rerile:ul, fit riant angles, but feeble.

A basic dike, 2 feet thick, at the norin end dips $65^{\circ} \mathrm{N}$. Fine-grained aplitie

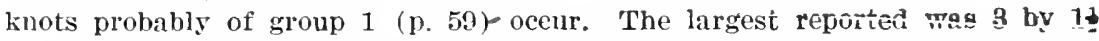
feet. Irusty stain is 1 to 12 inches thick. In places all the granite to a depth of 30 feet is somewhat stained, but in other's good stone occurs at the top. At the south end, west side, the granite upon exposure discolors readily to a medium, slightly olive-gray. Specimen D, XXVIII, 70, b, describe on page 78, had been exposed three years at a point 30 feet down. In thin section the stain is seen to proceed from particles of riebeckite and aegirite.

Transportation, by siding from New York, New Haven \& Hartforl Railroad.

The produet is used for monuments and the waste for road material, etc.

The Mount Pleasant quarry is at the northwest tuot of the Blue Hills, in Miiion Township, on Iyman Road, off Pleasant Street. (See map, Pl. XXIV, No. 11.) The quurry was operated in 1906, but is now abandoned.

The granite (specimen D, XXIX, $\delta \overline{5}$, a), "dark Quiney," is a riebeckiteaegirite granite of dark bluish-gray color, a trifle lighter than 68 , b ("dark-blue laikwas") and with a more bluish tinge. Its texture is medium to coarse, evengrained, with feldspars up to 0.5 inch and black silieates to 0.3 inch. Its constituents, in descending order of abundanee, are a medium to dark bluishgray potash feldspar (orthoclase, mostly twinned), minutely intergrown with sola-lime feldspar, in places somewhat kaolinized, with unusually abundant minute erystals of riebeckite and some particles of aegirite, also minute orange-colored hornblende erystals; quartz, dark snoky, with very slight bluish tinge, containing $m$ nute carities and black particles in intersecting streaks 
and sheets; blue-black riebeckite and green-black aegirite, in part intergrown; soda-line feldspar (albite and probably oligoclase-albite) in very small amount. Accossory : Hluorite, allinite. Secondary : Kaolin, calcite, limonite, and probably the orange-colored homblende.

The hlueness of this stone is rlearly due to the abundant riebeckite crystals in the foldspals. This comes out on the polishod face. (See specimen 88, a, which is identicall but from the adjoining quarry, described below.)

George steiger. chemist, of this survey, extracted from this granite by means of hot dilute acetic acid $0.15 \mathrm{~g}$ er cent of caO (lime). which indicates a content of 0.26 per rent of $\mathrm{CaCO}_{3}$ (calcite). Thin sections also show calcite.

The quarry, opened in 1901, meastired in 1906 ahout 125 by 100 feet and 100 fect in deptli.

liock structure: The sheets, 5 to 27 feet thick, are horizontal and turn to dip gently east. Sone of the sheet surfaces on the west side are coated with riebeckite. (Ste p. S2.) Joints (b), strike N. $10^{\circ}$ E., dip $90^{\circ}$ and steeply east, form the east wall, spaced 5 to 11 feet; (a), strike N. $60^{\circ} \mathrm{W}$.. form a heading on the sonth sile, spaced 2 to 15 feet; (e), diagonal, strike about northwest, form a heading near the west wall, which has a darli-bluish stone northeast of it but interior light stone southwest of it. Black riebeckite-coated joint and sheet faces abound in this part. The rift is reported as vertical, with a nearly N. $10^{\circ}$ 1. coure. Buty staln is up to 2 inches thick on the lower sheets.

Transportation, by cart $2 \frac{1}{4}$ miles to railroad at West Quinc: 2.2 miles to cutting sheds at Quincy.

The chirf product was used for monments.

The Maguire \& O'Heron quarry is at the northwest foot of the Blne Hills, in Milton Township, about Sou feet southwest of the Mount Pleasant quarry, off I'leasant street. (See map, Pl. XXIT, No. 10.) The quarry was operated in 1906 , but is now abandoned.

The granite (specimen I, XXIX, Ss, al), "dark Quincy," is a riebeckiteaegirite granite of dark hluish-gray color like that of the adjoining Mount Pleasant quarry (specinen S5, a). Its texture and constituents ب!le a!so identical.

The pohisiter race orings ont the marked bluish tinge of the feldspars, which are streaked with whitish kaolinized parts and contrast somewhat with the smoky quartz, but mich more with the black silicates. This stone differs from the "dark-blue railway" (specimen D, XXVIII, 68, h, p. 329) by its slightly more bluish tinge, which is due to the greater abundance of microscopic riebeckite crystals in the feldspars.

An estimate of the mineral percentages by the Rosiwal method, with a mesh of 0.5 inch and a totul linear length of 20 inches, yields these figmres: Feldspars, 55.80; quartz, 33.10; riebeckite and aegirite (excluding microscopie particles), 11.10 .

The (quary, opened in a small way about 1882 but in a larger way in 1901 , neastured in 1906 about 250 feet N. $35^{\circ}$ E. by 75 to 150 feet across and 70 feet in dejth.

Rock structure: The sheets, 3 to 15 feet thick, dip up to $20^{\circ}$ SW. Joints (b), strike north, dil steeply east, form a 50 -foot heading on the southwest wall, spaced 3 to 20 feet; (c), strike N. $20^{\circ}-25^{\circ} \mathrm{W}$., dip $75^{\circ}$ ENE., form a heading in the mild!le of the south end; (d), strike $\mathrm{X} .35^{\circ} \mathrm{K}$., dip $90^{\circ}$ to sterp west, form the east and west walls, slaced 3 to 100 feet. The rift is reported as nearly vertical, with a north strike, and the grain as horizontal. Quartz veins, 1 to 3 inches thick, dipping $30^{\circ} \mathrm{SE}$. and inclosed in belts of whitish discoloration, recur at intervals of 3 to 18 feet. (See Ip. 325-326.) Rusty stain 3 to 18 inches thick on the lower sheets. 
'The product was used mostly for monuments and the waste for cellar stone. specimen monments: Brabley momment. ['urly sitation, N. Y. : monmment to Samuel Neilson, at loughkepsie, N. Y. : Long monument at Mansfield, ohio; ['atterson momment at Ashlame, l'al.: Merehan momument at St. Joseph's Cemetery, Buston; and Mead Ghapel, hake Walcabue. N. Y.

The Sartori quarry is on l'ine lI:H, on the soldheist side of the l3lue IIills,

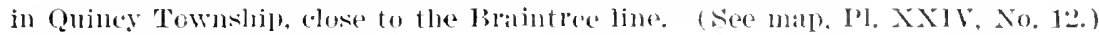
It is now abandoned.

The granite (specimen D, XXIX, 8., a) is an altered riebeckite-achirite granite of very dark, dull greenish to brownish gray color, almost without con trasts, and of medium to coarse, even-graned texture, with feldspars up to 0.5 inch and altered back silicates up to 0.3 inch. Its constituents, in descending order ot abundance, are a lark greenish to brownish gray, nearly oparye potash feldspar (orthoclase), twimmed, some of which is minutely inter wrown with soda-lime feldspar, mostly much kablinized and in places mucl micacized, and here and there stained with hematite (no ategirite or riebeckite crystals were detected in it) : smoky quaria, in places pinkish from hematite strin, with intersecting streaks or sheets of arvitios and minute black particles; riebeckite and aegirite particles rompletely altered to masses of greenish biotite, magnetite (mostly octahedral). Cabbualte, and quartz with some (hlorite or delessite; rery little sodalime feldspar (oligoclase). Accessory: Magnetite, zircon, allanite, fluorite. There are also hownish halls (spherulites) of radiatinc fibrous crystals. 0.02 to 0.1 millimeter in diameter, some of which polarize like zircon. Secondary: Biotite, a white mica, cañóñate, chlorite or delessite, hematite, magnetite.

'inis ginite differs hy its gleenish-brownish color from all the other Quney granites, although mieroscopically it approaches the pinkish of the Savo quarry (p. 331), but it differs from that by the different alterations of its feldspars and black silicates.

The quarry measured in 190650 by 30 feet am 15 to 20 feet in depth.

The product had been found adipted only to hases, curbing, and paving.

The Stacy quarry is in Lruintree Tumshiv iust beyond the Quiney line, about a mile south ô Gutney station. Operntor, J. Siày, South Quincy.

The granite (specimen D, XXXVII, 23. a), "red Braintree," is (probably) an altered riebeckite-aegirite granite. It is of dull medium redlish-gray color with weak contrasts and of cuarse, (wen-uramed texture, with feldspars up to $0.5 \mathrm{inch}$. Its constituents, in descemling order of alumelance, are dull pinkish medimm-gray artholase and microlerthite, mulh kablinized; medium smoky quartz with fluidal cavities; am very little placrioclase. No ofher si-

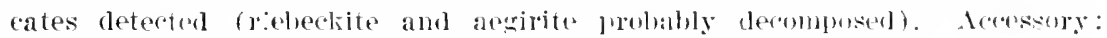
Magnetite in culses and octahedrit, write. Secombary: Kablin, calromate, hematite, limonite sta:n.

The fually was opened in 1915 and is small.

The product is useif for monmments.

PITMUTTI COISTH.

The wranites of l'lymouth county ewrel very small areas and ar uot shown on the geologie map of the Staite in rulletin stit.

BROCKTON.

The Brockton Heights quarry was on learl Street, Brockton Heights, about $2 \frac{1}{2}$ miles west of Brockton station in the same township. (See Dorlham topographic map, U. S. Geol. Survey.) 
This quarry was abandoned in 1914 and the property cut up into house lots. The granite is lescribed because of its exceptional character.

The granite (specimen D, XXX, 130, a), is a biotite-hormblende (or altered augite-holublende) granite of light greenish-gray color with large pink spots and matrix of medium texture (feldspars up to 0.3 inch and mica up to 0.2 inch) and with porphyritic light-pink feldspars up to 0.8 inch. The constituents of the matrix. in descending orler of abundance, are milk-white to greenish soda felispar (albite), much micacized; clear colorless to slightly milky quartz with cavities in sheets; chlorite, probably after biotite (possibly after augite); a little microperthite (potash feldspar, microcline, minutely intergrown with sodil felıspar, albite. kiolinized, with epiclote and zoisite in microscopic particles): and yellow hornblende in fibrous radiating crystals. The large pink crystals are also microperthite and contain sparse groups of yellow hornblende crystals. Accessory : Magnetite, titanite. Secondary : Epidote, zoisite, plentiful carbonate, chlorite, a white mica, kaolin, quartz. There are veinlets of carbonate, epidote, and quartz. Ffferesces with muriatic-acid test.

Sheet and joint structure were foum to be defective, and there was no perceptible rift or grain.

Specimen of product: Mattapan station on New York, New Haven \& Hartford Railroad.

\section{HINGHAM.}

The Hingham seam-face quarries are in Hingham Twwnship, $3 \frac{1}{2}$ miles S, $15^{\circ} \mathrm{W}$. of Hingham station and about thrce-fourths mite foutheast of Lovell Cornels. (See Abington topographic map, U. S. Geol. Survey and Pl. XXIII.) Operator, Plymouth Quarries, Inc., 6 Besten Street, Boston.

The granite (specimens D. XXX, 124, a, b), "Hingham," is an aplite of light, slightly greenish-gray color and of fine, slightly porphyritic texture, with feldspars up to 0.2 inch. Its constituents, in descending order of abundance, are milk-white soda-lime feldspar (oligoclase-albite), much kaolinized and micacized and a little epidotized, the alteration proceeding from within the crystals outward; clear colorless quartz, with cavities, rare particles of smoky quartz up to 0.1 inch; pale-greenish potash feldspar (microine), a iitite lavininized; very little biotite, and nore of chlorite after biotite, both in small particiey and sparse. Accessory: Pyrite, plentiful, and magnetite. Secondary: Kaolin, a white mica, chlorite, and epidote, mostly about the chlorite. No effervescence with muriatic-acid test.

The following analysis of the fresh aplite made in 1900 by F. J. Moore and given in a report made to the company by W. O. Crosby and G. F. Loughlin is published here for reference:

Analysis of aplite from Hingham, Mass.

Silica $\left(\mathrm{SiO}_{2}\right)$

Alumina $\left(\mathrm{Al}_{2} \mathrm{O}_{3}\right)$

14. 45

Ferrous oxide ( $\mathrm{FeO})$

1. 44

Ferric oxide $\left(\mathrm{Fe}_{2} \mathrm{O}_{3}\right)$

Potash $\left(\mathrm{K}_{2} \mathrm{O}\right)$

Soda $\left(\mathrm{Na}_{2} \mathrm{O}\right)$

4. 36

Lime $(\mathrm{CaO})$

4. 74

Magnesia $(\mathrm{MgO})$

1. 03

Sulphur (S) Trace.

Water (loss on ignition) 
The 0.02 per cent of sulphur is equivalent to about 0.04 per cent of pyrite. Traces of manganese and phosphoric acid were noted.

The same report gives the following additional determinations made by A. A. Blanchard in 1910:

Water below $110^{\circ} \mathrm{C}$

Water above $110^{\circ} \mathrm{C}$

Carbon dioxide $\left(\mathrm{CO}_{2}\right)$

Total pyrite $\left(\mathrm{FeS}_{2}\right)$

Material soluble in water

Material soluble in carbonic acid

Tests made at the Watertown Arsenal in 1910 on specimens of the fresh aplite show a crushing strength ranging from 32,900 to 39,800 pounds to the square inch. Tests of the transverse breaking strength of the fresh aplite made for the company by Crosby and Loughlin gave these results:

Results of tests of breaking strength of aplite from Hingham, Mass.

\begin{tabular}{|c|c|c|c|c|}
\hline $\begin{array}{l}\text { Number } \\
\text { of tests. }\end{array}$ & $\begin{array}{c}\text { Size of } \\
\text { beams } \\
\text { (inches). }\end{array}$ & $\begin{array}{c}\text { Span } \\
\text { (inches). }\end{array}$ & $\begin{array}{l}\text { Mavimum load } \\
\text { (pounds). }\end{array}$ & $\begin{array}{c}\text { Transverse } \\
\text { breaking } \\
\text { strength } \\
\text { (pounds per } \\
\text { square inch). }\end{array}$ \\
\hline $\begin{array}{l}4 \\
4 \\
2\end{array}$ & $\begin{array}{l}3 \text { by } 6 \\
4 \text { by } 8 \\
4 \text { by } 8\end{array}$ & $\begin{array}{l}12 \\
12 \\
19\end{array}$ & $\begin{array}{l}10,090-22,310 \\
20,610-49,420 \\
16,820-17,700\end{array}$ & $\begin{array}{l}3,320-3,770 \\
2,950-3,470 \\
3,400-3,660\end{array}$ \\
\hline \multicolumn{4}{|c|}{ General average $. . . \ldots \ldots \ldots \ldots \ldots \ldots . . . .}$. & 3,440 \\
\hline
\end{tabular}

In comparison with these results two Watertown Arsenal tests of "Rockport granite," 4 by 8 inch beams and 19-inch span, show transverse breaking strengths of 2,404 to 2,416 pounds; and one of Milford (Mass.) granite, 1,745 pounds.

Tests of porosity and absorption made for the company by Crosby and Loughlin on four 3 -inch cubes of the rusty aplite show from 0.285 to 0.371 per cent, or 0.04 to 0.55 gram per square inch of surface. In these tests the cubes were first dried at $110^{\circ} \mathrm{C}$. for 24 hour's, weighed, soaked for 49 hours in distilled water, the first two hours in hoiling water, and then weighed again after removing excess water. Similar tests with two 4 -inch cubes of the fresh aplite, which, however, were soaked for six weeks instead of two days, showed only 0.00 .2 gram per square inch of surface.

The specific gravity of the fresh aplite was found by the same persons to be 2.637, which corresponds to a weight of 164.8 pounds to the culbic foot.

The quarries, begun many ycars ago for rough-faced stone hut only in 1891 for seam-faced stone, comprise three onenings. The largest (No. 1) was in 1910 150 feet square and 25 to 45 feet deep. No. 3, 600 feet S. $80^{\circ}$ F. of No. 1, was 75 by 30 feet and 10 to 20 feet deep.

Rock structure: At the largest opening the sheets, very imperfectly developed and 4 inches to 6 feet thick, dip $5^{\circ}-20^{\circ} \mathrm{NW}$. There are five sets of joints- $(a)$, vertical, strike $\mathrm{N} .25^{\circ}$ E., forms a wide heading with joint spaces 2 inches to 2 feet 6 inches; (b), strike $X .257^{\circ} W$, dip stcep $N .65^{\circ}$ E. spaced 10 to 30 feet; $(c)$, strike N. $55^{\circ}$ W., dip $70^{\circ}$ N. $35^{\circ}$ E., only two 2 feet apart; $(d)$. strike $\mathrm{N} .30^{\circ} \mathrm{W}$., diagonal to quarry, dip stcep S. $60^{\circ} \mathrm{W}$., one only ; $(c)$, strike N. $77^{\circ} \mathrm{W}$., dip steep N. $13^{\circ} \mathrm{F}$., forms the north and south walls.

105709-23-23 
At opening No. 3 there are no sheets whatever. Joint $(a)$ forms a heading with spacing 8 inches to 3 feet; $(b)$ dips $75^{\circ} \mathrm{S} .65^{\circ} \mathrm{W}$. to $90^{\circ}$ and is spaced 10 to 30 feet ; $(r)$ dips $40^{\circ} \mathrm{S} .35^{\circ} \mathrm{W}$.

All these sheet and joint faces are more or less stained with linonite from 0.06 to 2 inches thick, lue to the oxidation of the somewhat plentiful pyrite. There are gravich knots up to 0.5 inch. rarely 2 by 10 inches.

Owiur to the harlness of the granite, the soluty rif sleets, the sumerabundanee of joints and hoadings, and the prevalence of " sap" these would be very discomragine quarries to work for ordinary pmposes, but in suplying the demand for rusty seam-faced stone their petrographic and stuctural features are turned to good accomnt. Blocks, 4 to 15 inches thick with a seam face, are used either as trimmings or for the main exterior, ant the rough-faced unstained stone is used as trimmings. (See p. 293.) The following quotation concerns this phase of the granite industry : ${ }^{48}$

"To the ordinary uses to which granite is put there must be added the somewhat recent demind for the sap portions for decorative ashlar work and rustic masonry. The quarries which possess sap rock of the desirable colors are earning a new and adventitions revenue. In fact, the increasing demand for seam-faced granite and other rocks has led to the opening of several granite quarries which produce only stock of this kint. The demand for seam-face granite is steadily increasing; its introduction is becoming more general, and its artistic merits are wantina better appreciation."

Transportation, by cart 2 miles to East Weymouth station or $\mathbf{1 6}$ miles direct to Boston.

Product: The intersection of some of the joints and sheets makes it pos sible to obtain a regular supply of rusty seam-faced stones with angles $90^{\circ}$ or $120^{\circ}$. The reat cusching strength of tisis aplite has brought it into remand for kerstone for tumnel arches.

It has been furthermore proposed to transform "healings" and "sap," the ordinary obstacles to sunite quarrying, into "things of beaty" by carving bas-reliefs of leaves and garlands on the iron-stained joint faces. This is done by cutting away the rusty part, usually from 0.125 to 0.25 inch thick, so that the leaves in brown project on a light-grayish ground. Blocks thus worked can be utilized in ormamental bands on exteriors.

Specimen edifices: Harkness Nemorial Quarlangle. Yale University. New Haven. Conn.; Bates College Chapel, Lewiston. Maine; First Baptist Church, Braintrce, Mass.; State Armory, Arlams, Mass: Faith Church, Springfield, Mass; W. O. Briggs resilence, Detroit, Mich.; art building, Vassar College, Poughkeensie, N. Y.; Trinity Church, Syracuse, N. Y.; B'Nai Jeshurun Synagogue, Nerw York City; Church of the Covenant, Wilmington, N. C.; Calvary Eniscopal Church, I'roviclence. I. I.

The Miller seam-face quary is in Hincham Township about $2 \frac{1}{4}$ miles south-southeast of East Weyniouth station and 1 mile east-southeast of Lovell Cormers. (See Abington topographic map, U. S. Geol. Survey.) Operator, J. E. L. Miller, Last Weymonth.

The granite (specimen D, XXX, $125 \mathrm{~h}$ ), "Weymouth," is an aplite identical with that of the quarries last described and evilently belongs to the same mass. In thin section the biotite appears less altered to chlorite.

The quarry, opened in 1901, is triangular in area, 100 feet on two sides and 125 feet on the other, and in 1910 was 30 to 45 fect deep.

${ }^{4}$ Whittle. C. I., The building and road stones of Massachusetts: Mineral Industry, vol. 7., for 1898, New York and London, p. 638, 1899. 
Rock structure: There are no sheets, but three sets of joints- $(a)$, strike $N$ $25^{\circ}$ E., forms healings with joint splates of 2 inches to 3 feet; (b), vertical strike N. $25^{\circ}$ W., spaced 10 to 25 feet; $\left(r^{2}\right)$, stlike N. $65^{\circ}$ E., dip $40^{\circ} \mathrm{S}$. $25^{\circ}$ E. A diabase dike 18 inches thick strikes about east.

The prodnct, used mostly for seam-faced work, is carted to East Weymouth. Speriuens: Gateway, Albany Rural Cemetery; Congregational Chureh. Wollaston; Episcopal Churches, Hingham. IJolyoke, ant Brookline; Baptist Church. Prockton; Unitarian Church. Winchester; Methodist Episopal ('hurch, Dorcilester, Mass.; city hridge, Waterbury. Comn.: Episopel Church. Newport, R. I.

The IIamilton Seam Face quarry, recently opened, is in Ilinglinn Township. Operator. Hanilton Seam Fare Granite Co. 45 Cormhill, Boston.

l'roduct, specimen edifices: St. Vincent Ferrel Church, Sixty-sixtls Street and Lexington Arenue, New York City: Presbyterian Church. Grenshure Pa.

SUFFOLA COUNTY.

REVERE.

The felsite porphyry of Revere is in an area designated "Mattalun volcanic complex (flows. tuffs, breccias, and dikes)" on the geologic map of the State in Bulletin 507. and these rocks are all regarded as of early Carboniferous age.

Although felsite porphyry is not a wranite, it is a related igneous rock of almost identical chenical composition. The purplish-hrown felsite porphyry of Black Ann Hill, in Revere, las heen found to be very valuable for concrete construction. Tests made by the engineer of the Boston Transit Commission show that heams of 30 -inch span. made with broken stone and the felsite dust flow the crusher (presumably with 1 -inch screenings), have an arerage breaking stiength 15.74 per cent hicher than that of beams made with the same broken stone and sand. The superiority of folsite dust to sand for concrete is probably due to the fact that the aurularity of the vitreous fruments is greater than that of water-rolled quartz and feldspar wains.

The Black Ann Hill quarry is at the solutheast foot of IBlack Amb Hill. in North Revere, that part of Revere Township which lies between the townships of Malden and Sangus. (See Bosten topographic maI, U. S. (reol. Surrey.) Operators. H. \& D. Furnett. Frankiin Park.

The rock (specimen D, XXXII, 13, a). "Revere," is a rhyolitic felsite porphyry ${ }^{49}$ of rery dark purplish-gray color and of dense, aplateridy homogeneous texture, with very minute whitish reins and close joint faces coated with

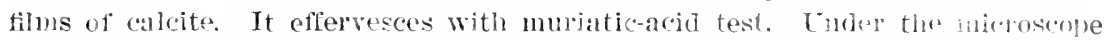
it shows a fluirlal spherulitic banded texture, with porplyritic erystals of orthoclase (?), albite, and oligoclase: also particles of quartz and late scales of biotite and chlorite. Accessory: Magnetite. zircon. Veinlets of quartz and carbonate fault the feldspars. Secondary: White micas, epidote, carbonate. quartz, chlorite.

The quary has an east-west working fiace to to 700 feet high and 200 feet long.

A trap or diabase dike crosses the felsite, from east to west, tapering ont.

Transportation, by cart one-fourth mile to siding on Sangus lirancli of IBoston \& Maine Railroad.

The product is used for roads and concrete matrial, amrl the s-incil screenings and dust are sought for use in concrete in the place of sand. This quarry sup-

- Determination by Whitman Cross, of the U. S. Geological Survey. 
plied orer 61.000 tons of crushed felsite for the construction of the East Boston tomnel and 21,000 tens to the United States Engineer Corps in $189 \mathrm{~S}$ for the construction of the battery at Fort Heath. in Winthrop. 'The dust was also used in $190 \mathrm{~S}$ in the concrete of two large schoolhouses. three fire-engine stations, two city stables, the hospital, and the armery in Chelsea.

H. A. Carson, chief engineer of the Boston Transit Commission. had the relative value of the dust of this felsite (with s-inch screenings) and of sand, for concrete, tested in beams of 30 -inch span, with these results:

Test of felsite dust and sand for concrete. ${ }^{a}$

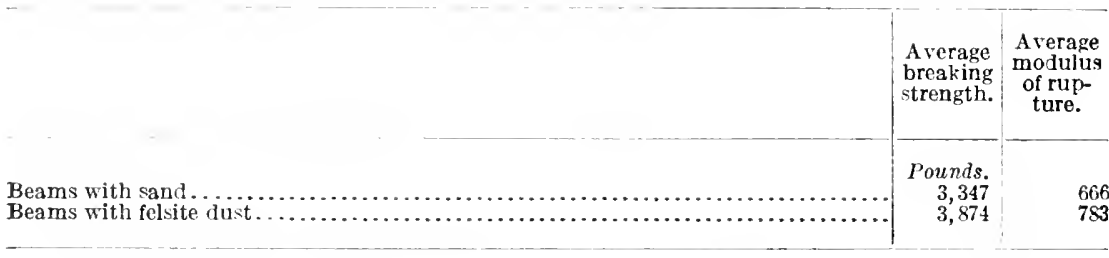

a See Boston Transit Comm. Seventh Ann. Rept., A, p. 41, Cong. 15, 1901.

IYNN.

Although the Sheehan quarry is in the town of Lynn, in Essex County, it is in the silme geologic area as the Black Ann Hill quarry and is therefore mentioned here. Opfintor, John W. Sheehan, 5S5 Western Avenue, lynn.

The reck appears to be identical with the dark purplish rhyolitic felsite porphyry of the Black Ann Hill quarry.

It is crushed for concrete and roads and used in blocks for foundations.

\section{WORCESTER COUNTY.}

\section{MILFORD GRANITE DISTRICT.}

TOPOGRAPHY.

Milford lies $16 \frac{1}{2}$ miles southeast of the city of Worcester. (See map, Pl. XXIII.) It is a region of low hillocks with north-northeast and northwest trends. The situation of the quarries is shown in figure 81 . They lie between $\mathrm{N} \cdot 10^{\circ} \mathrm{W}$. and N. $45^{\circ} \mathrm{E}$. of Milford. Two are just over the line in Ifopkinton (Middlesex County). All are between the 300 and 500 foot levels.

GEOLOGIC RELATIONS.

The granite of Milford has been described by Emerson and Perry, ${ }^{51}$ and recently by Emerson, ${ }^{52}$ who writes:

"The Milford granite occupies a large area extending from Westboro and Southboro, Mass., to Cranston, R. I., and a sillall area west of the principal one, chiefly in Grafton, Mass. * * * The Milford granite is intruded into the Northbridge granite gneiss and into the supposed Algonkian rocks and is overlain by the Carboniferons Bellingham conglomerate of the Woonsocket area.

B1 Emerson, I. K., and Ierry, J. H., The green schists and associated granites and perphyries of Rhode Island: U. S. Geol. Survey Bull. 311, pl. 1, 1907.

52 Emerson, B. K., Geology of Massachusetts and Rhode Island: U. S. Geol. Survey Bull. 597, pp. 165, 166, 1917. 
So far as the formation itself is concerned. there seem to be no relations by which to determine its age nore closely, but it is apparently of the same age as the Dedham granoliorite and it is therefore regarderl as prohably Devonian.

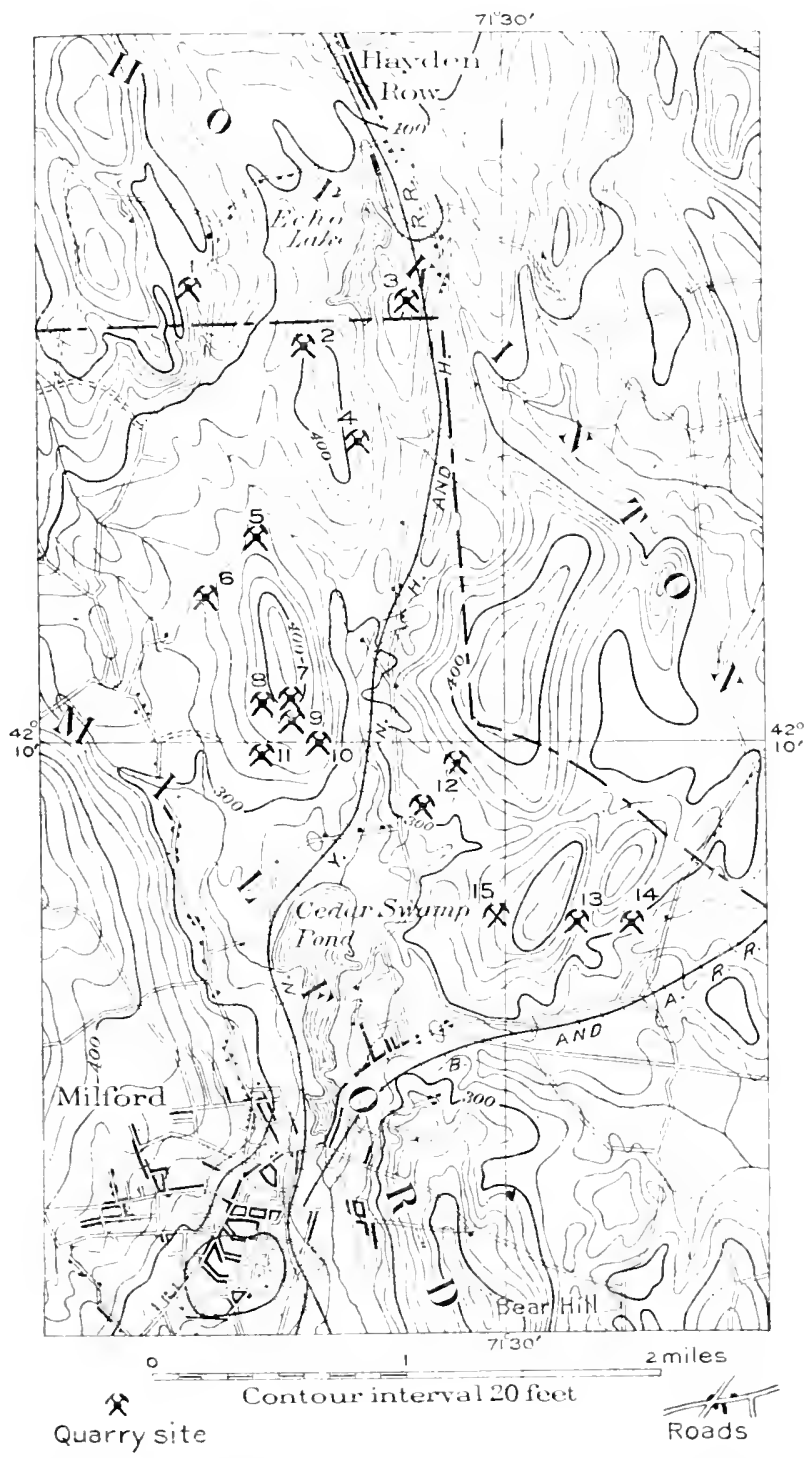

Figtre 81, - Map of Milford, Mass, showing Iocation of granite quarries, 1, Maguire: 2. Echo Iake: $\therefore$. Ilopkinton; 4, Cuttine: $\pi$, IIassaclusetts t'ink; 6 , North Milford; 7, No. 8, Webb: \&, No. 7, Webb: 9, No. ․, Welib; 10, No. 3. Webb: 11, No. 4, Webb; 12. Bay State; $1:$, East; 14. Noreross; 15 , No. 5, Wobb. New Iay state quarry a little northeast of No. 12 .

"There is generally around the granite a dark hornblendic border, supposed to be a contact phase of the granite manma, which is described below as the Ironstone quartz diorite." 
On the maly of Bulletin int the grantw of this district appears uncer the des'guation "Niltorl granite (biotite granite with blue quartz)."

\section{" MH.FOH GHANITE."}

The folkwing elitomizes the descriptions of rough and polished specimens and thin sections of granit: given beyond. Analyses and tests are also summarized. Milforl granite is a biotite granite. Its general color ranges from a light gray or light pinkish-wray to a metium, slightly pinkish or pinkish and greenislegray, but always with spots rich in black mica from 0.2 to 0.5 inch across and in some cases tapering out to an inch in length.

Its texture ranges from medium to coarse, not porphyritic; but, owing primarily to a marked thow structure and secondarily to compression, there is some alinement of pirticles, wiving the stome a slightly gnessoid appearance. The follspar, quartz, and biotite are each likely to form continuous lenticular areas up to an inch in length. On the polished face the quartz is seen to be finely granular. The general appearance of the stone varies according to the relation of the direction of the cut face to that of the flow structurt. Wherever the plates of black $\mathrm{m}$ cal, which lie with their major axes in the plane of the flow structure, coincide with the face of the stone, it will slow innch larger black spots than where the face intersects that plane at right angles.

Its constituent minerals, in descending order of abumelance, are (1) a more or less delicate pink, rarely cream-colored potash feldspar (orthocluse and microclin(s), minutely intergrown with soda-lime fellwpar and in places somewhat kaolinized; (2) faintly blue quartz fractured into particles up to $\mathbf{1 . 7 5}$ millimeters, in some specimens not over 0.75 millimeter, showing some arrangement of cavities in sheets and in places with hairlike crystals presumably of rutile; (3) a slight yellowish-green to milli-white, rarely clear striated soda-lime feldspar (albite to oligoclase-albite), which, where not clear, abounds in minute crystals and particles of pidote an 1 zoisite, seales of white mica, and some chlorite and kilolin; (4) biotite (black mica), some of it chloritized and associated with enidote. Accossory: Garnet, pyrite, magnetite, ilmenite, zircon, allanite, (usually rimmed wilh epidote), apatite. Secondary: Kaolin, white mica, epidote, zoisite, calcite (usually in the sola-lime feldspars), titanite (about probable ilmenite in biotite), hematite. There is some radiate intergrowth of quartz and felelspar.

The color of the stone is governed mainly by its feldspars, pink from the lotish and green from the soda-lime feldspar. These are but rery shightly modified by the rale-bluish tinge of the quartz.

The somewhat gneissoid arrangement of the minerals, giving the fellspar and quartz particles uncertain boundaries in the direction of the flow. prevents the accurate application of the Rosiwal method, which provides that no one particie should be crossed more than once by lines parallel. A specimen from quary No. S of the Webb Pink Granite Co., in which there is little if any flow structure, contained the following percentages: Feldspar, 55.91; quartz, 35.66 ; biotite, 8.43 .

Five tests on three specimens of the more gneissoid granite showe:l the following ranges: Feldspar, 49.92-70.83; quartz 23.04-41.08; biotite, 4.72-11.29. These variations are due partly to the very different proportion of biotite on the different faces of the rock, as already explained.

Three analyses of this granite, made by L. P. Kinnicutt and R. H. Richards, are giron under the respective quarries. They show these extremes: 
Extremes of analysis of Milford granite.

Silica $\left(\mathrm{SiO}_{2}\right)$

Alumina $\left(\mathrm{Al}_{2} \mathrm{O}_{3}\right)$

Iron oxide ( $\mathrm{FeO}$ )

Iron sesquioxile $\left(\mathrm{Fe}_{2} \mathrm{O}_{3}\right)$

Manganese oxide $(\mathrm{MnO})$

Lime $(\mathrm{CaO})$

Magnesia (MgO)

Potash $\left(\mathrm{K}_{2} \mathrm{O}\right)$

Soda $\left(\mathrm{Na}_{2} \mathrm{O}\right)$
72. 02-77.08

12. $54-14.43$

$.52-.95$

$.00-1.25$

$.24-\quad .33$

$75-1.18$

Trace- .01

4. $99-5.41$

3.64 .55

The following analysis of the granite from one of the Noreross Bros. quarries was made by Prof. C. F. Chandler, of Columbia University. ${ }^{83}$

Analysis of Milford granite.

Silica $\left(\mathrm{SiO}_{2}\right)$ 76. 07

Alumina $\left(\mathrm{Al}_{2} \mathrm{O}_{3}\right)$

12. 67

Iron sesquioxide $\left(\mathrm{Fe}_{2} \mathrm{O}_{3}\right)_{-}$

2. 00

Manganese oxide $(\mathrm{MnO})$

.03

Lime ( $\mathrm{CaO})$

.85

Magnesia $(\mathrm{MgO})$

.10

Potash $\left(\mathrm{K}_{2} \mathrm{O}\right)$

4. 71

Sola $\left(\mathrm{Na}_{2} \mathrm{O}\right)$

3. 37

99. 80

E. U. Sullivan, a chemist of this survey, extracted, by means of hot dilute acetic acid, 0.06 per cent of CaO (lime) from an average slecimen from the Cutting quarry. This line was thus present in the form of $\mathrm{CaCO}_{3}$ or calcite (calcium carbonate) to the extent of 0.107 per cent, its presence being shown in these sections. It probably was formed from the decomposition of the lime-sodal feldspar.

Six crushing tests made at the United States Arsenal at Watertown, Mass., show an ultimate strength of 20,000 to 29,200 pounds to the square inch.

Those sections of the stone in which mica is least abundant take a good polish, but the others are not likely to preserve their polish in prolonged outdoor exposure. The scarcity of pyrite and magnetite on the polished face is very noticeible. Unfortunately the delicate pink of this granite atter a few years' exposure becomes buff-colored, as may be observed in the Pennsylvania Railroad station in New York. This is rery probably due to the passing of the hematite $\left(\mathrm{Fe}_{2} \mathrm{O}_{3}\right)$ of the potash feldspar into limonite $\left(\mathrm{Fe}_{4} \mathrm{O}_{2} \mathrm{H}_{6}\right)$.

\section{GEOLOGY OF MILFORD QUARRIES.}

The diorite schist dikes that traverse this granite have already been described on page 56, and the probable connection between the development of schistosity in these dikes and the stress which granulated the quartz of the granite has been pointed out. There are also dikes of aplite from 0.5 inch to 4 feet thick, some of it a quartz monzonite in composition, and dikes of porphyritic granite with N. $10^{\circ}$ and $35^{\circ}$ E. and N. $20^{\circ} \mathrm{W}$. courses. Some of these contain elliptical biotitic segregations (or inclusions?).

The flow structure strikes $\mathrm{N} .10^{\circ}, 35^{\circ}, 40^{\circ}, 45^{\circ} \mathrm{W}$. and $\mathrm{N}$. $77^{\circ}$ E. and dips $40^{\circ} \mathrm{E}$. to $90^{\circ}$ or in places is nearly horizontal.

53 Day, W. C., U. S. Geol. Survey Ann. Rept., pt. 6, continued, p. 221, 1898. 
There are inclusions of biotite gneiss or mica diorite from a few inches to 2 feet thick, showing that this rock overlay or adjoined the granite at the time of its intrusion.

The rift is reported as everywhere horizontal and the grain as vertical with a N. $40^{\circ}$ E. to an east-west direction. Rift and plane of flow structure are in places nearly parallel.

Sheets, 6 inches to 18 feet thick, are generally irregular or undulate horizontally with inclinations up to $20^{\circ}$.

As will be seen from the quarry diagrams, there is a wide range in the joint courses. They are north, N. $10^{\circ}, 20^{\circ}-25^{\circ}, 45^{\circ}, 50^{\circ}, 60^{\circ}$ E., and N. $60^{\circ}, 70^{\circ}$, $80^{\circ} \mathrm{W}$. Those occurring at the largest number of quarries are north to N. $10^{\circ}$ E., N. $45^{\circ}-60^{\circ}$ E., and N. $55^{\circ}-70^{\circ}$ W. The filling of a parted joint with calcite probably derived from once overlying calcareous rocks has been noted on page 83 .

\section{QUARRIES.}

The Cutting quarry is in Milford Township. 3 miles N. $5^{\circ}$ E. of Milford and half a mile south of Echo Lake (fig. 81). Quarry idle.

The granite (specimens D, XXVIII, 13, a, b, c), “Milford pink" is a biotite granite of a very slightly pink-tinted light-gray color and conspicuous black spots. Its texture is somewhat gneissoid, medium to coarse, with particles up about 0.5 inch. In faces cut parallel to the plane of flow structure the black spots measure fully 0.5 inch, but when cut in the traverse direction about 0.3 inch. The quartz areas are always granular, the particles up to 1 millimeter in diameter and exceptionally 1.5 millimeters. The rock consists of the following minerals, in desceuding order of abundance: A very delicate pink potash feldspar (orthoclase and microcline, both with minutely intergrown soda-lime feldspar); quartz with minute cavities arranged in sheets, appearing colorless in isolated particles but in the aggregate having a very pale bluish tinge; a milk-white to pale-greenish striated lime-soda feldspar (albite to oligoclasealbite), usually crowded with particles and crystals of epirlote and zoisite from 0.0094 to 0.076 millimeter in length; biotite (black mica), some of it altered to chlorite and associated with epidote. Both feldspars are somewhat kaolinized, particularly the soda lime. Accessory: Garnet, rare pyrite and magnetite, titanite, zircon, allanite crystals up to 1 millimeter long coated with epidote, apatite. Secondary: Kaolin, epidote, zoisite, chlorite, calcite, hematite.

An estimate of the mineral percentages with half-inch mesh and total linear length of 45.5 inches yields: Feldspars. 65.67 ; quartz, 23.04 ; biotite, 11.29.

The following analysis was mare by Lennard P. Kinnicut, of the Worcester Polytechnic Institute, in 1898 , and is given here for reference.

Analysis of granite from Cutting quarry, Milford, Mass.

Silica $\left(\mathrm{SiO}_{2}\right)$ 77. 08

Alumin: $\left(\mathrm{Al}_{2} \mathrm{O}_{3}\right)$

Iron oxide ( $\mathrm{FeO})$

Lime ( $\mathrm{CaO}$ )

Magnesia $(\mathrm{MgO})$

Potash $\left(\mathrm{K}_{2} \mathrm{O}\right)$.

Soda $\left(\mathrm{Na}_{2} \mathrm{O}\right)$

E. C. Sullivan, a chemist of this Survey; extracted 0.06 per cent of CaO (lime) from this granite by hot dilute acetic acid. This indicates the pres- 
ence of 0.107 per cent of $\mathrm{CaCO}_{3}$ (calcium arbonate) or anleite, the presence of which is shown in thin sections.

Two tests made at the Uniter states alsenal at Watertown. Mass., in 1898, give it an ultimate strength of 25.252 and 27,226 pomnls to the siluare inch.

The quarry, opened before 1859 , measured in 1906 about 500 feet in a northnorthwest direction by 150 feet ealst-west and 20 to 30 feet in depth.

Rock st:ucture: The sheets, 6 inches to 18 feet thick, are horizontal but irregular in places. The rift is reported as hor:zontal and the gritin as vertical.

The peculiar mica dorite schist dike on the west side is desrribed on page 56. Aplite dikes are 5 inches to 2 feet thick. The courses of joints, flow structure, dikes, and gain are shown in figure 82 .

Heading (A) dips $70^{\circ}$ E. and joint (B), only at the north end, dips $65^{\circ}$ s. ste. Bands of more biotitic granite with groups of black elliptical schistose linots or inclusions inclicate the direction of flow. In this section these slow particles all under 0.1 incl, mostly biotite, next a plagioclase much alterer to epidote and zoisite, and lastly quartz. Gamets in roundish grains are also present. Rusty stain along the sheets is 6 to 12 inches thick.

Transportation, by siding from the New York. New Haven \& Hartford Railroad and track from quary to cutting shed.

The product is used mainly for buildings. Specimen structures: Bank building. Newton, Mass. ; street-railway depot at Georgetown, D. C. ; New York State monument on Lookout Mountain. Chattanooga, Tenn., cons sting of a shaft 6 feet in diameter and 50 feet high made in sec-

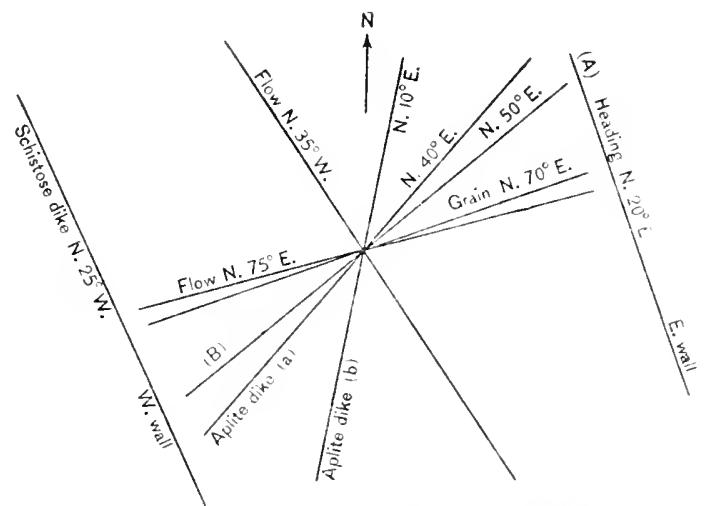

Figure 82.-Structure at Cutting quarry, Milford, Mass. tions; part of the base and all the lantern for the Pennsylrania Railroal terminal station at New York.

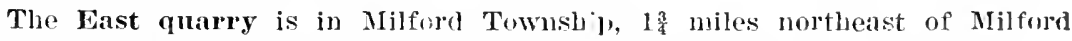
(fig. 81). Operator, Milford Pink-Victoria White Granite Co., Milford.

The granite (specimens D, XXVIII, 14, r, e, g, h), "Milford pink," is a biotite grante of light pinkish-gray color with more or less conspicuous black spots. The general color is more pinkish than that of the Cutting quarry stone. Its texture is somewhat gneissoid, medium to coarse. Feldspar and mica measure up to 0.5 inch, but the feldspar individuals merge into lenses an inch long. as do also the quartz and biotite. The length and width of the biotite spots in any surface depends upon whether that surface is parallel to the plane of the flow structure or to its sirle, or crosses it. The quartz a reas are always granular, with particles up to $\mathbf{1 . 7 5}$ millimeters across. The rock consists of these minerals in descending order of abundance: A light-pink potash feldspar (microcline and orthoclase) with some intergrown sola-lime feldspar, slightly kaolinized; quartz (with m nute carities ar:anged in sleets), which in the aggregate has a very pale bluish tinge; a milk-white to light-greenish striated soda-lime feldspar (albite to oligoclase-albite), partly kaolinized and crowded with minute particles and crystals of epidote and zoisite. with a few 
scales of white mica and rarely calcite; biotite (black mica), some of it chloritizel, rarely containing ilmenite, with a rim of leucoxene. Accessory: Garnet, apatite, magnetite and pyrite (rare), ilmenite, zircon, allanite (up to 0.6 millimeter), rimmed with epidote. Secondary : Kaolin, a white mica, epidote zois te, leucoxene, chlorite, calcite. The merging of the particles by the gneissoid structure vitiates somewhat the application of the Rusiwal method of estimating the mineral percentages, and the great variation in the amount of biotite on different specimens also affects the results. Four tests on two specimens with meshes 0.5 inch and a total linear length of 29.8 inches yielded these results :

Estimated mineral percentages in gneissoid granite from Last quarry, Milford, Mass.

Feldspar

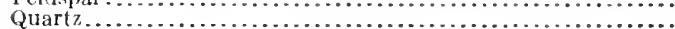

Biotite.

\begin{tabular}{r|r|r|r}
49.92 & 58.47 & 68.22 & 70.83 \\
41.08 & 35.08 & 25.92 & 24.45 \\
9.00 & 6.45 & 4.86 & 4.72 \\
\hline 100.00 & 100.00 & 100.00 & 100.00 \\
\hline & & &
\end{tabular}

The following analysis of this granite, made for the company by Prof. R. H. Richards at the Massachusetts Institute of Technology, is given here for reference :

Analysis of granite from the Fast quarry, Milford, Mass.

Silica $\left(\mathrm{SiO}_{2}\right)$

Alumina $\left(\mathrm{Al}_{2} \mathrm{O}_{3}\right)$

Iron oxide $(\mathrm{FeO})$

Iron sesquioxide $\left(\mathrm{Fe}_{2} \mathrm{O}_{3}\right)$

Manganous oxide $(\mathrm{MnO})$

Lime (CaO)

Magnesia ( $\mathrm{MgO})$

Potash $\left(\mathrm{K}_{2} \mathrm{O}\right)$

Soda $\left(\mathrm{Na}_{2} \mathrm{O}\right)$

Loss in ignition
72.02

14. 43

.89

1. 25

.33

1. 18

Trace.

5. 41

5. 85

.35

The durability of the polished face on outdoor exposure will vary according to the size and number of the biotite particles.

The quarry in 1906 measured about 100 feet from north to south by 300 feet across and 40 to 80 feet deep.

Rock structure: The chief feature is a rertical granite dike 4 feet thick crossing the quarry diagonally. It is a biotite granite of medium to dark greenish to gray color with pinkish spots. Its texture is fine to medium, with porphyritic feldspars up to 0.6 inch and exceptionally to 1.3 inches in length. The matrix consists largely of greenish soda-lime feldspar (oligoclasealbite), partly kaolinized and epidotized; a slightly bluish granular quartz, the colors of these two minerals giving the rock a general bluish-green tinge; and biotite (black mica). The large pink crystals are potash feldspar (orthoclase with minutely intergrown soda-lime feldspar, also microcline). There is also some potash feldspar in the groundmass. Accessory: Garnet. apatite (fairly abundant), zircon, allanite. Secondary : Kaolin, muscovite, chlorite, epidote, zoisite, calcite. This dike contains black segregations (inclusions?), mainly of biotite with slightly bluish quartz and epidote. The granite has a flow structure marked by darker bands striking N. $10^{\circ} \mathrm{W}$. and lipping $40^{\circ} \mathrm{E}$. 
The granite also contains irreguar inclusions, from 1 to 2 feet in diameter. of a dark-gray and black banded, very tine srained, sontewhat schistose mica diorite (quartz, biotite. and plagioclase, with pyrite, magnctite, and epidote). The rift is reported as horizontal, and the grain as rertical. The sheets, 1 to 15 feet thick, dip $10^{\circ}-15^{\circ}$ SSW. The courses of dike, flow. wrain, and joints are shown in figure S3. Joints (A), dip $80^{\circ}$ E., recur at intervals of 100 to 200 feet; (B), dip $45^{\circ}-50^{\circ} \mathrm{SSW}$., spaced 3 feet and orer; (C), dip $45^{\circ} \mathrm{N}$; (D), one only. dip $60^{\circ} \mathrm{NW}$; (E), dip $45^{\circ} \mathrm{W}$., slickensided horizontally. The face of (A) on the west wall is coated with a mass of minutely brecciated granite 1 ? inches thick, cemented with calcite, chlorite, fibrous muscovite, and limonite. Rusty stain along the sheets is from 6 inches to 2 feet thick.

Transportaton, by siding from Boston \& Albany Railroad.

The product is used mainly for buildings. Specimens: Hanover National Bank, New York; Boston Public Library; public library, Columbus, Ohio. In

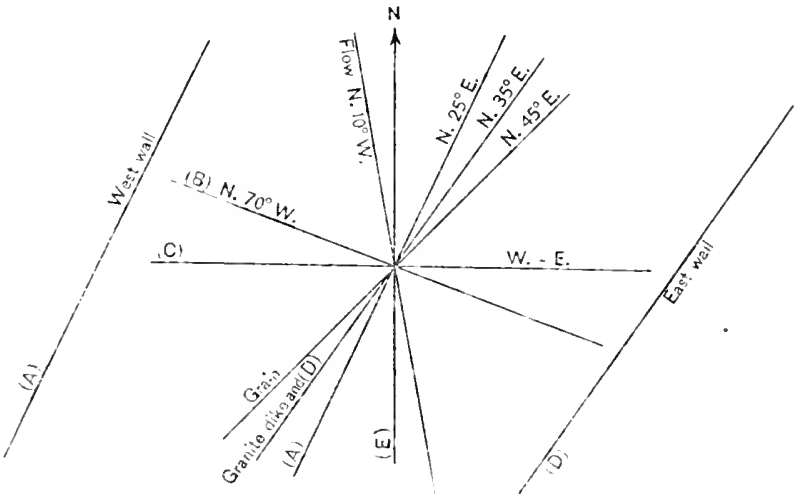

Flqere 83.-Structure at East quarry, Milford, Mass.

1906 this quarry was furnishing part of the stone for the basement of the National Museum at Washington and part of that for the Pennsylvania Railroad terminal at New York.

The Bay State quarries are in Milford Township, $1 \frac{3}{4}$ and 2 miles north-northeast of Milford. (See fig. 81.) Operator, Pink Granite Co, of Milford, Milford.

The granite (specimens D, XXVIII, 16, a, b), "Milford pink," is a biotite granite of light pinkish-gray color, like that of the Cutting quarry (p. 344) but with more conspicuous greenish feldspars and much smaller spots of black mica. Its texture is medium to coarse, even-grained, with very little if any gneissnoid structure. The feldspars measure up to 0.5 inch, the black mical to 0.3 , rarely 0.4 inch, and the quartz is granular. Its constituents, in descending order of abundance, are a delicate pink potash feldspar (orthoclase and microcline, both inclosing large particles of soda-lime feldslar); quartz with some cavities in sheets, clear, not bluish; a milk-white to light-greenish sodalime feldspar (albite to oligoclase-albite), partly kaolinized and epidotized. also with some white mica and calcite; biotite (black mica), some of it chloritized. Accessory : Garnet, magnetite, pyrite. Secondary: Kaolin, a white mica, epidote, zoisite, calcite.

A partial analysis, leaving out potash and soda, made for the company by Prof. R. H. Richards, of the Massachusetts Institute of Technology, is given here for reference: 
I'arlial analysis of granite from West quarry, MIilford, Mass.

Silica $\left(\mathrm{SiO}_{2}\right)_{-1}$

Alumina $\left(\mathrm{Al}_{2} \mathrm{O}_{3}\right)$

Iron oxide ( $\mathrm{FeO})$

Irom sesquioxide $\left(\mathrm{Fe}_{2} \mathrm{O}_{3}\right)$

1.14

Manganese oxide ( $\mathrm{MnO}$ )

Lime $(\mathrm{CaO})$

Magnesia ( $\mathrm{MgO})$

Loss on ignition

The old "West" quarry, opened about 1887, measured in 1906 about $300 \mathrm{by}$ 175 feet and 40 feet in depth. A new quarry was opened in 1915 a little northeast of it.

Rock structure at West quarry: There are on the east side conspicuous vertical dikes of medium-gray fine-grained quartz monzonite, 0.5 inch to 2 feet thick, strike N. $20^{\circ} \mathrm{W}$., occurring at intervals of 20 to 100 feet. This consists of clear potash feldspar and clondy light-gray soda-lime feldspar in almost equal amounts, the latter kaolinized, micaized, and altered to epidote and zoisite; quartz, with hairlike crystals of rutile and cavities; biotite, some of it altered to chlorite. Accessory: Garnet, etc. Secondary: Kaolin, a white mica, epidote, zoisite, chlorite, calcite. There are two schist dikes already described on page 56 . One on the north wall, 2 feet thick, strikes $\mathrm{N} .65^{\circ}-70^{\circ} \mathrm{W}$. and dips $65^{\circ}$ NNE.; another, farther south, 20 inches thick, strikes about northwest and is vertical. The sheets, 2 to 15 feet thick, are nearly horizontal at the north end of the quarry but dip $15^{\circ}-20^{\circ}$ at the sonth end. The sheets become irregular at the bottom. Vertical joints, strike north to N. $10^{\circ}$ E., spaced 10 to 100 feet, form a heading on west $s^{\circ}$ de. One at the north end strikes N. $60^{\circ} \mathrm{W}$. and dips curving $45^{\circ}-50^{\circ} \mathrm{SW}$.

Transportation, by track one-half mile to New York, New Haven \& Hartford Railroad.

Product, specimens: John Hancock Insurance Co. Building, Federal Street, Boston; Amherst College Library, Amherst, Mass.; Chamber of Commerce, liochester. N. Y. ; customhouse, Wilmington. N. C. ; E. T. Stotesbury residence, Chestnut Street, and Pliza Hotel, South Broad Street, Philadelphia; part of halscment of National Museum and approaches to Lincoln Memorial, Washington.

The Norcross quarry is in Milforr Township, nearly 2 miles northeast of Milford and about one-fourth mile east of the East quarry. (See fig. 81.) Operators, Dodds Bros., Milford. Idle since 1905.

The granite (specimen D, XXVIII, 15, a) "Milford pink," is a biotite granite of light pinkish-gray color with more or less conspicuous black spots. The general color is like that of the granite in the East quarry, described on page 345 , but is marked by light blood-reddish stains not over 0.25 inch across and an inch or two apart. Its texture is like that of the granite in the East inarry. The quartz grains measure up to 1.1 millimeters. Its constituents are also the sane, but with the addition of red henratitic stains, which originate presumably in the oxidation of magnetite particles.

The quarry measured in 1906175 feet from northeast to southwest by 100 feet across and about 70 feet in depth.

Rock structure: The sheets, up to 15 feet thick, have a low north dip. Joints strike about northeast, dip over $50^{\circ} \mathrm{NW}$., form the northwest and south- 
tast walls. Another set with a similar strike dips $30^{\circ}-45^{\circ} \mathrm{SE}$., aud is spared $\therefore$ to 10 feet. A third set strikes about north or diasonally to quilry and nerears on the southwest wall. The rift is reiported as better than at some of the other Miliord quarries. Rusty stain is up 102 feet thick.

The Massachusetts Pink quarry is in M lforl Township, 22 miles north of Milford, at the north end of a low north-south ridge. (See fir. 81.) Idle since 1914.

The granite (specimen D, Xxvil, 21, b), "Milford piuk," is a biotite granite of a very slightly pink-tinted light-gray color with conspicuous black spots. Its texture is somewliat gurissoid, medium to coarse; in other resperts and in mineral conposition it closely resembles the stome of the rutting quar'y, described on page 344 .

The quarry, opened in 1902, was in 1906300 feet from east to west by $2(0)$ fect across and from 10 to 35 feet deep.

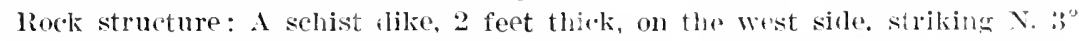
W. and dipping $55^{\circ}$ E., las already been mentioned on page 56 . The sheets, 4 to 25 feet thick, dip low east. There are three sets of joints-(a), strike N. $35^{\circ}$ W., dip $65^{\circ}$ E., spraced 100 feet; (b), strike N. $55^{\circ}-60^{\circ}$ E., (lip) $90^{\circ}$, spaced 30 feet: (c). strike $\mathrm{N} .55^{\circ} \mathrm{W}$, rlip $40^{\circ} \mathrm{W}$. The rift is reported as borizontal, and the grain as vertical from east to west. lusty stain is up to 3 inches thick on the lower sheets.

Transportation, by cart 3 wriles to futting shed at New York, New llaven \& Hartford Iailitoal track.

The product is used for buildings. bridges, and mausolemus. Snecimens: Bridge over Bromx River, Bronx Park, New York; Rochester Safe Deposit \& Trust Co. Bu.lding, Rochester, N. Y.; Bloomingdale nansileum. Greenwood Cemetery, N. Y.; McKinley national memorial, Canton, Ohio.

The Hopkinton quarry is in Hopkinton, Middlesex County, a mile south of Hayden liow and about 33 miles north-northeast of Milforl. (See fig. 81.) Irle since 1914.

The granite (specimen D, XxVIII, 22, a) is a biotite granite of medium, slightly pinkish gray color with fine black specks. Its texture is eren-grained, medium, with feldspars generally up to 0.4 inch and mica to 0.2 inch. It is thus pinker and finer grained than that of the Massachusetts Pink quarry. Its constituent minerals, in descending order of abundance, are a pinkish potash feldspar (orthoclase and microcline), inclosing particles of soda-lime feldspar and slightly knolinized; faintly rose-colored granular quartz in particles up to 1.37 millimeters; a grasish or greenish-gray sola-lime feldspar (albite to oligoclase-albite), a little kaolinized and epidotized, with some white mica; biotite (black mica), some of its chloritized. Accessory: Garnet, magnetite, apatite, zircon, allanite (bordered with epidote). Secondary: Kaolin, epidote, zoisite, chlorite, a white mica.

The quarry in 1906 was 50 feet square and 2.5 feet deep.

Product: The Bishop mausoleum, Sleepy Hollow Cemetery, Tarrytown, N. Y.

The Maguire quarry is in Hopkinton, half a mile west of Echo take and 33 miles N. $5^{\circ} \mathrm{W}$. of Milford. (See fig. 81.) Quarry idle.

The granite is a hiotite granite of a rery slightly pink-tinted light-gray color with conspicuous black spots. In texture and constituents it is reported as corresponding to the stone of the Cutting quarry, described on page $3+4$.

The quarry, opened in 1906 , measured then $300 \mathrm{by} 100$ feet and up to $15 \mathrm{finl}$ in depth.

The sheets are reported as dipping about $20^{\circ} \mathrm{NE}$. 
Transportation, by cart 1 mile to cutting shed on ralilroad siding.

The Echo Lake quarry is in Milford Townshp near the Hopkinton line and Echo Lake, $3 \frac{1}{2}$ miles N. $5^{\circ}$ E. of Milford. (Ste fig. S1.) Quary idle.

The granite is a biotite granite of slightly pink tinted light-gray color, reported as a little more pinkish than that of the Cutting quarry, described on page 344

The quarry, opened in 1906, measured then 60 by 40 feet and up to 20 feet in depth.

The sheets are reported as dipping about $20^{\circ}$ W., but irregular. A "soft heading "- that is, a schist dike like that at the Cutting quarry, described on page 56 -is reported as forming the west side of the quarry, with a northnorthwest strike.

Transportation, by cart 1 mile to cutting shed on railroad siding.

The Sorth Milford quapy is in Milford Township, $2 \frac{1}{2}$ miles about $\mathrm{N} .7^{\circ} \mathrm{W}$. of Milford and one-third mile sonthwest of the Massachusetts Pink quarry. (See fig. 81.) Operator, North Milford Granite Co., Milford. Idle since 1908.

The granite is a biotite granite of very slightly pink-tinted light-gray color with conspicuous black spots. In texture and constituents it is identical with the stone of the Cutting quarry, described on page 344 .

The quarry, opened in 1905, was in 1906100 feet square and averaged $\mathbf{5}$ feet in depth.

Rock structure: Owing to the irregularity of sheets this is a "boulder quarry." Vertical joints strike N. $80^{\circ}$ E. and N. $25^{\circ}$ E. The rift is reported as horizontal and the grain as vertical, with N. $80^{\circ}$ E. course.

Transportation, by cart $2 \frac{1}{2}$ miles to New York, New Haven \& Hartford and Boston \& Albany railroads.

The product is used for construction. Specimens: The granite part of Redmond Bank Building, 31 Pine Street, and trimmings for tenements of Homes Suburban Co., One hundred and fifty-sixth Street, New York; trimmings for residence of Hennen Jennings, northeast corner of Massachusetts Arenue and Sheridan Circle, Washington. Quarry not operated in 1916.

The Carroll quarry is in Milford Townsh p, 13 miles north of Milford and half a mile north-northwest of Cerlar Swamp Pond. (See fig. 81.) Operator, Webb Pink Granite Co., 40 Crescent Street, Worcester. (Quarry designated Tos. 4 and 5 by the company.) Now idle.

The granite (specimen D, XXVIII, 18, b) is a biotite granite of light-gray shade with conspicuous black spots. This is the whitest of the Milford granites. Its texture is somewluat gneissoid, medium to coarse, with feldspars and mica up to 0.5 inch across and with finely granular quartz. Its constituents, in descending order of abundance, are cream-colored to palest-pink potash feldspar (orthoclase and microcline), with minutely intergrown soda-lime feldspar and slightly kaolinized; clear, not bluish quartz in grains up to 0.5 millimeter, and with cavities some of which are in sheets; clear to cloudy, some very pale greenish sola-lime feldspar (albite to oligoclase-albite), not a little kaolinized and epidotized; biotite (black mica), some of it chloritized. Accessory: Garnets (minute and usually in rows), apatite, fluorite, allanite (rimmed with epilote), zircon. Magnetite and pyrite not observed. Secondary: Kaolin, epidote, zoisite, chlorite, calcite, white mica.

The following analysis of this granite, made for the company by Robert $\mathrm{C}$. Sweetzer, of the Worcester Polytechnic Institute, in 1905, is given here for reference : 
Analysis of granite from the Carroll quarry. Milford, Mass.

Silica $\left(\mathrm{SiO}_{2}\right)$
Alumina $\left(\mathrm{Al}_{2} \mathrm{O}_{3}\right)$
Iron oxide $(\mathrm{FeO})$
Lime $(\mathrm{CaO})$
Magnesia $(\mathrm{IgO})$
Potash $\left(\mathrm{K}_{2} \mathrm{O}\right)$
Soda $\left(\mathrm{Na}_{2} \mathrm{O}\right)$
Water $\left(\mathrm{H}_{2} \mathrm{O}\right)$

Specific gravity 2.633.

The quarry, opened in 1905 , measured in 1906 about 500 by 200 feet ancl up to 30 feet in depth.

Rock structure: The sheets, 6 inches to 15 feet thick, undulate horizontally. The rift is reported as horizontal, and the grain as vertical, with $\mathrm{N} .65^{\circ} \mathrm{E}$. course. Joints (a), strike N. $60^{\circ} \mathrm{W}$., dip $90^{\circ}$, spaced 10 to 60 feet; (b), strike N. $20^{\circ} \mathrm{E}$, dip $90^{\circ}$. form headings at the northwest and southeast sides and in the middle; (c), strike N. $80^{\circ} \mathrm{W}$.. dip $45^{\circ} \mathrm{S}$, one in the middle and another 25 feet east of it. Rusty stain is 2 inches thick on sheet surfaces.

The product of this quarry is combined with that of the next.

The Webb quarries Nos. 6 and 8 are in Milford Township, 2 miles north of Milford. (See fig. 81.) Operator, Webb Pink Granite Co., 40 Crescent Street, Worcester. Quarry idle.

The granite (specimens D, XXVIII, 17, a, b), "Milford pink" is a biotite granite of medium pinkish and gremish-gray color, with bick spots which are not as conspicuous as those of the stone in the Carroll aud Cutting quarries. Its texture is even-grained, medium, with feldspars up to 0.4 inch and mica up to 0.2 inch in diameter and finely granular quartz. Its constituents. in descending order of abundance, are a delicate pink potash feldspar (orthoclase and microcline), minutely intergrown with soda-lime feldspar and with quartz and more or less kaolinized; a very faintly bluish finely granulan quiltz with cavities some of which are in sheets; a yellow-greenish to clear sodi-lime feldspar (albite to oligoclase-albite), generally krolinized and epirotized also with some scales of white mica and chlorite: biotite (black mica). Accessory: Magnetite, apatite, zilcon. Secondary: Kaolin, epidote, zoisite, clllorite. a white mica.

An estimate of the mineral percentages by the Rosiwal method with $\frac{1}{2}$-iuch mesh and total linear length of 46.5 inches yields these results: Feldsliar, 55.91 ; quartz, 35.66 ; biotite, 8.43 .

W. T. Schaller, chemist, of this survey, extracted from an arerage specimen of this granite, by means of hot dilute acetic acid, 0.04 per cent of CaO (lime). which indicates the presence of 0.07 per cent of $\mathrm{CaCO}_{3}$ (ealcium callumate. calcite). This lime is of course irrespective of that combined with silica in the oligoclase feldspar and epidote.

The stone takes a fair polish, but the mica particles are sufficiently large to detract from the durability of the polish in prolonged outdoor exposure.

The quarry, opened in 1905, measured in 1906 abont 250 by 200 feei and up to 30 feet in depth.

Rock structure: A flow structure, shown by biotitic streaks, strikes N. $40^{\circ}$ W. and dips $50^{\circ} \mathrm{NE}$. The sheets, 5 to 12 feet thick, are horizontal in irregular undulations. Joints (a), strike N. $40^{\circ}$ W., dip $90^{\circ}$, spaced 3 to 10 feet; (b), 
strike N. $15^{\circ}$ E., dip $75^{\circ}$ E., recur at an interval of 8 and one of 50 feet. The rift is reported as hoimontal, and the gra $n$ as vertical, with an east-wost course.

Transportation from these quarries, by tracks 3,750 feet to sidings of New York, New Haven \& Hartford Ra lroad.

Product, specinens from all this company"s quarries except the next: Union Station, Baltimore; courthouse and municipal building, Wilmington, Del.; Commercial National Bank, Chicago; Cuyahoga courthouse, Cleveland, Ohio; John Hancock Builuling No. 2, boston; new post office, New York.

The Webb No. 10 quarry is in Milford Township, two-thirds mile east of the northern part of Celar Swamp Pond. (See fig. S1.) Operator, Webb Pink Granite Co., 40 Creseent Street, Worcester. Idle since 1917.

The granite, "Milford pink," is reported as resembling in color that of the East quarry, described on page 345 , but with a somewhat finer texture, the botite spots being more sparse and less elongated so as to have pracically the tame appearance on rift, grain, and hardway faces.

The quarry is about $300 \mathrm{by} 100$ feet, with a working face of 30 feet, part above and part below the ground level.

Product: This quarry supplied the granite for the Freer Art Collections Building of the Smithsonian Institution, Washington.

\section{UXBRIDGE.}

The Uxbridge quarries are 8 miles southwest of Milford and nearly 15 miles south-southeast of Worcester. (See map, Pl. XXIII.)

The granite of Uxbridge is in an area about $17 \frac{1}{2}$ by $10 \mathrm{~m}$.les designated on the map of Bulletin 597 " Northbridge granite gneiss (porphyritic granite largely (rushed to gneiss)" and referred doubtfully to the Archean. (See pp. 155, 156 of that bulletin.)

The Blanchard quarries are in Uxbr:dge Township, about $1 \frac{1}{2}$ miles westnorthwest of Uxhrifge s'ation and $1^{\frac{3}{4}} \mathrm{~m}$ les south-southeast of Whitinsville. (See Blackstone topographic map, U. S. Geol. Survey.) Operator, Blanehard Bros. Granite Co., Linwood.

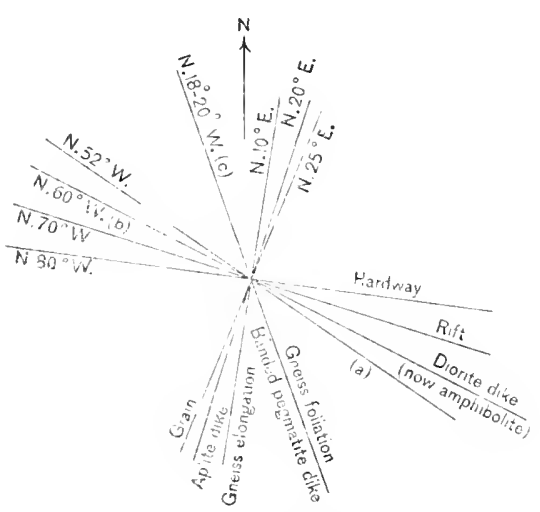

IFiguBe 84.-Structure at Blanchard quar. ries, Uxbridge, Mass.

The granite (specimens D, XXX, 114, d, e), "Uxbridge," is a biotite granite gneiss of light to medium gray shate (light gray on rift face and medium gray on hard-way face) and of medium porphyritic, elongated gneissic texture, with feldspars up to 0.4 inch (exceptionally 0.5 inch) and laminae of quartz and mica up to 0.1 inch wide, alternating with laminae of feldspar up to 0.3 inch wide. Its constituents, in descending order of abundance, are light-buff potash feldspar (mierocline and orthoclase), slightly micacized; light smoky quartz. with cavities in laralke and rectangular sheets; milkwhite solli-lime feldspar (oligoelase); biotite (black miea); and a little muswite or bleacher biotite. Accessory: Magnetite, apatite, purple fluorite. Secmdary: Carbonate, epidote, kaolin, muscovite. Effervesees slightly with muriatic-acid test.

This gneiss resembles that of Sterling, Comn., and is a useful constructiona! stone. 
The quarries, begmn in 1864, consist of two openings. The larger in 1910 measured 300 by 200 feet and 20 to 50 feet feen. and the sulluler, triangular in area, 100 feet on a side and 60 feet deep in the center.

Rock structure: Is sheet structure is absent this is a "boulder quarry." The courses of the joints, foliation, etc., are shown in figure 84 . Joint set (A), dip $77^{\circ}$ S. $3 S^{\circ}$ W., spacert 5 to 40 feet; (13), dip $30^{\circ} \mathrm{N}$. $45^{\circ}-60^{\circ}$ E., spaced 3 to 20 feet; (C), dip $55^{\circ} \mathrm{S}$. $72^{\circ} \mathrm{W}$., spaced 10 to 60 feet. The foliation dips $35^{\circ} \mathrm{N}$. $70^{\circ} \mathrm{E}$. The rift $\operatorname{dips} 10^{\circ}-15^{\circ} \mathrm{N} .20^{\circ} \mathrm{E}$., and the grain and hard way are rertical. Aplite dikes are 2 inches to 3 feet thek. Pegmatite dikes of handed qualtz and feldspar (described on P. 51) parallel to joints (C) are up to 3 feet thick, and an amphibolite dike (described on p. 54) parallel to joints ( $B$ ) is 6 to 18 inches thick. The amount of sap varies greatly. Some blocks are free from it, some are all stained, on others it is a foot thick.

Transportation, by private siding to New York, New Haven d Ifatford Railroarl, $1 \frac{1}{2}$ miles.

\section{LEOMINSTER.}

The Leavitt quarry is in Leminster Township, 2 miles west of that village and about 400 feet above it. (Sce Fitchburg topogriphic nap), U. S. Geol. Survey, and I'l. XxilI.) It was last merated in 1916 by L. F. liumase, of Leominister, but is mow disused.

The grante (specimen $\mathrm{L}, \mathrm{XXX}, 110, a)$, "Leom.nister," is a mica diorite of dark bluish-gray colol (between "Balle dark" and "Quincy extrat dark") and of very tine, even-grained texture, with linticles moler 0.1 inch. Its constituents, in descending order of abundance, are lisht-grayish sorla-lime feldspar (oligoclase-amlesine); botite (black mita), with lalre nuscurite or bleached biotite; and very light smoky quartz. Accessory: Titanite (fourth in order of abundance), plentiful apatite needles, zircon crystals in strings, also branching, and prrite. Secondary: Carbonate, chlorite. It effervesces with muriatic-acid test.

This is a handsome fine-grained dark stone, suitable for monuments or buildings. It ought to hammer light.

The quarry, opened in 1570, measuret in 1910300 fect north and south by 200 feet across and 5 to 30 feet deep.

Rock structure: The sheets, 6 inches to 5 feet thick, but mostly under 18 inches, dip $20^{\circ} \mathrm{E}$. There are two sets of joints-(a), vertical, strike N. $80^{\circ}$ E., forms the sonth wall; (b), vertical, strike N. $5^{\circ}$ E., dip steeply east to $90^{\circ}$, forms the east and west walls. The rift is parallel to the sheets, and the grain vertical north to south. The quarry is crossed diagonally by a large ramifying dike of banded aplite and pegmatite, lescribed on page 45, a horizontal section of which is shown in figure 2. Minor dikes of aplite and also of pegmatite intersect the main dike. One 4 feet 6 inches thick is on the west wall. The diorite also has here and there white feldspar "knots" up to 1.5 inches across.

Transportation, by cart $2 \frac{1}{4}$ miles to Leominister station.

The product was used for buildings, trimmings, cubing, flagging, and foumdations. Specimens: Haws Menorial Chapel. Eielereen Cemetery ; trimmines to Mayo and Jones blocks, Leominister; trimmings to Acre School, Clinton, Miss.

\section{FITCHBURG.}

On the geologic map of Pulletin 597 the granite of Rollstone Itill, a a mile west of Fitchburg station, is in an area extending from the vicinity of Worcester

5 Tluis hill takes its name from a glacial boulder. 10 by 8 feet, of porphyritic cranite with 3 -inch feldspars, resting on its summit.

$105709-23-24$ 
to and beyond the New Hampshire line, designated "Fitchburg granite (white nuscovite-hiotite granite)" and regarded by Emerson as of late Carboniferous or post-Carboniferous age. ${ }^{85}$

The McCaulif quarry is on the west sille of Rollstone Hill in Fitchburg, a mile a little south of west of the boston \& Maine Railroad station. (See Fitchurg topographic map. U. S. Geol. Surver, and Pl. XxIII.) Operator, I3. F. McGaulift Quarry Co. (Inc.), Fitehburg.

The granite (specimen D, XXX, 107, a) is a muscovite-biotite granite gneiss of light to medium bluish-gray color and of gneissic medium texture, with feldspar's up to 0.3 inch and mieas up to 0.2 inch. Its constituents, in descending order of abundance, are clear to translucent bluish potash feldspar (microcline and orthoclase); light smoky quartz, finely granulated (particles under 0.37 millimeter), with rutile neelles and cavities; milk-white soda-lime feldspar (oligoclase-albite), kaolinized and micacized; muscovite (white mica) and fibrous muscovite in stringers: and biotite (black mica), some of it chloritized. Accessory: Garnet, apatite. Secondary: Kaolin, white mica, epidote, chlorite. No efferrescence with muriatic acid test.

This is a constructional granite gneiss of bright mineral contrasts.

The quarry, opened about 1865, is triangular in area, measuring in 1910 ahout 450 feet on its north sirle and 175 feet on its east side, which are the working faces, and 10 to 20 feet deep.

Rock structure: The sheets, 1 to 8 feet thick, horizontal at the northeast corner of the quarry, dip away radially to an angle of $15^{\circ}$ in its lower part. There are four sets of joints- $(a)$, strike N. $75^{\circ} \mathrm{W}$. to N. $75^{\circ}$ E., dip $65^{\circ}$ about south, spaced 3 to 20 feet, forms the north wall, and the joints are tight and ferruginous; $(b)$, vertical, strike N. $5^{\circ} \mathrm{W}$., only a few; $(c)$, strike N. $60^{\circ}$ E., dip $75^{\circ}$ S. $30^{\circ}$ F., spacel 12 feet and over, few and loose; $(d)$, strike, N. $20^{\circ}$ W., dip $45^{\circ} \mathrm{S} .70^{\circ} \mathrm{W}$., three only, 20 to 150 feet apart. The gneiss foliation strikes N. $10^{\circ} \mathrm{E}$. and $\operatorname{dips} 55^{\circ} \mathrm{N} .80^{\circ} \mathrm{W}$. The rift is horizontal and the grain vertical, with N. $80^{\circ}$ F. course. There are a number of pegmatite dikes up to 4 inches thick, with black tourmaline dipping $45^{\circ}$ about north and spaced 15 feet and over. Some of these dikes neander and combine. One is faulted along a N. $20^{\circ}$ E. plame. Another has a 0.5 inch central hand of smoky quartz and borders of feldsirar and tourmaline. The stone is generally sound exeept near the main joints and for 2 or 3 inches along sheet surfaces.

Transportation, by cart one-eighth mile to railroad siding.

The best of the product is used for base courses, the seconds for eurbing and paring, and the waste for concrete. Specimen: First story of high sehool, Fitehburg.

The Litchfield quarry is on the southwest sille of Rollstone II:Il in Fitchburg, nearly a mile west-southwest of the Boston \& Maine Railroad station. (See Fitchburg topographic map, U. S. Geol. Survey, and Pl. XXIII.) Operator, B. F. MeCauliff, Fitehburg.

The granite is ilentical with that of the McCauliff quarry.

The quarry, opened in 1875 , is triangular in area, 700 feet in a northerly direction by 200 feet and 75 feet.

Rock structure: The sheets, 6 inches to 6 feet, some 15 _ feet thick, curve gently westward from the top of the hill. There is but one set of joints, strike N. $70^{\circ}$ E., dip $45^{\circ}$ S. $20^{\circ}$ E.. two only, 50 feet apart, discontinuous. Foliation, rift, and grain are as at the McCauliff quarry. Pegmatite dikes up to 6 inches dip $50^{\circ} \mathrm{NE}$; at the southeast end is one, 2 feet thick, of smoky quartz, feldspar, muscovite, and black tourmaline. Some of these dikes

${ }^{55}$ Sre Bull. 597, pp. 231-233, and on the minerals of Rollstone IIill, p. 237. 
are very micaceous, becoming the "sand seams" of quarrymen. The "sap" is 6 inches thick on the top sheets.

The product is used for dimension stone, curbing, and paving. The smallest size from the crusher is used for graveling roofs. Specimens: Wallace Way, steps and buttresses to high school, and most of the stone in Episcopal Church chapel, Fitchburg.

The Godbeer quarry is on the northeast side of Rollstone IIIll, in Fitchburg, about three-fourths mile west of the Boston \& Maine Railroad station. Quarry no longer operated. Last operator, Henry Godbeer. Fitchborg.

The gr:nite is identical with that of the McCauliff quarry.

The quarry in 1910 measured 250 feet in a northeast direction by 200 feet aeross and 5 to 10 feet deep.

Rock structure: The sleets, 1 to 8 feet thick, dip $20^{\circ}$ NE. Their variation in thickness is due to incomplete formation. There are three sets of joints(a), vertical, strike N. $40^{\circ}-60^{\circ}$ E., spaced 10 to 20 feet, has rusty faces; $(b)$, strike N. $80^{\circ}$ E., dip $55^{\circ}$ S. $10^{\circ}$ E., few ; $(c)$, strike N. $60^{\circ}$ W., dip $40^{\circ}$ S. $40^{\circ}$ W., few.

Transportation, by cart half a mile to railroad siding.

The product was used for building and curbing. Specimen: Third story of Moran Building, Fitchburg.

\section{CONNECTICUT.}

\section{GEOLOGIC RELATIONS. ${ }^{55 a}$}

By II. E. Gregory.

OUTLINE OF GEOLOGIC IIISTORY OF CONNECTICUT.

Whether the area now occupied by Connecticut was land or sea at the heginning of geologic time is unknown. It is probable, however, that some of the gneisses and schists antedate the appearance of life on the earth. Unfortunately no fossils have been found in the older roks of the State, and all that can be said with assurance regarding the age of these formations is that they were in existence long prior to Triassic time. Pre-Cambrian time is believed to be represented by the Becket gneiss, which ontcrops over wide areas in northern Litchfield County. This rock is, however, so profomndly changed that it is impossible to determine with accuracy the original from which the present complex mass was derived. The limestone and marbles of Canaan and Danbury were probably deposited in Cambro-Ordovician time, and the material forming these ro $\mathrm{ks}$ is believed to have been furnished by high land masces located east of the Rhode Island border-lands which long ago disappeared.

553 The section: on the geologic history of Connecticut, the distribution of its granites and gneisses, and the nature and age of its granitic intrusions are reproduced from IJ. S. Geol. Survey Bull. 484. 
The geologic history of the immensely long time represented by the Silurian, Devonian, and Calboniferons ages has not yet been completely deciphered. Whether rocks belonging to these ages exist in western Connecticut is unknown, but the metamorphosed equivalents of Carboniferous sediments are represented in the eastern part of the State. Though much doubt exists regarding the Paleozoi sedimentary record, there is abundant eridence for the statement that at frequent intervals during these ages igneous intrusions oc urred. Masses of igneous rock, which occur as minute dikes and sheets, may be consideierl as remnants of larger masses, which were poured out on the surface or bidden beneath the overlying strata.

Moreover, an examination of the schists and gneisses of the State reveals the fact that all rocks older than the Triassic sandstone have been involved in movements within the earth's crust and have accordingly been so mnch metamorphosed as to destroy all fossils which they may have contained and to modify the rocks themselves beyond recognition. The dates when these far-reaching changes took place are believed to coincide with the mountain-making epochs marking the close of Ordorician and of Carboniferous time. The extent of these changes and their fundamental character are revealed by a study of the metamorphic rocks of the State.

These rocks are chiefly schists and sneisses, and accordingly have structures incticating that they have been profoundly changed from their original sedimentury or imneous chalacter. The original component minerals have been rearlanged, stretched, and drawn out in lines; new minerals have been prodnced; farts have been fused and recristallized. Instead of horizontal layers or uniform igneous misses. we find twisted and broken rock with layers, bands, and riblun structures in every conceivable position. Moreover, this tangle of structure is further complicated by the presence of dikes, seams, and veins which have made their way into the rock at different stages of its history. In looking at this confused mass of rock which forms the Connecticut crystallines it seems apparent that it has taken part in manifold changes which went on in the earth's crust for ages. ${ }^{56}$

The monntains and plateaus of Carboniferous time were worn down during Triassic time, and the materials of which they were composed have gone to make the sandstone of central Connecticut. The amount of rock removed from Connecticut prior to Triassic time may lue judged from the appearance of the rock immediately underlying the Mesozoic strata. The structure of the schists which form the floor of the Triassic is such as can be produced only at depths a mile or possibly sereral miles below the earth's surface. We may be reasonably sure, therefore, that mountains of folded strata once occupied Connecticut and that the granites and gneisses and schists which we see are but the stumps of lofty land masses "rivaling the Alps in height and ruggedness." 
1)uring the formation of the conglomerates, sandsiones, and shales-a time proved by dinosalur and fish remains to be Triasiclava was poured out over central Connecticut and possibly orer the entire State. Remains of these flows of basalt now staml as a riclge seratrating the valleys of Farmington and Conneticut rivers. During Cretaceous time the highlands were lowered and the entire surface was rehleed practically to a plain sioping from northwest to southeast, and the Cretaceous sediments now exhibital on Long Island probably atso covered sonthern ('onnecticut. 'This plain (peneplain) formed during (retaceous time was uplifter during early Tertiary time, and the streams were thereby given wereater eroding power and began at once to deepen and widen their valleys. Continued crosion during the millions of years comprehended in Tertiary time resulted in giving to Connecticut the lalder features of valley and hill, highland and lowland, which exist at the present time.

During the Pleistocene ("glacial") epoch the surface features of Connecticut were again remodeled. The more prominent erosion forms of Tertiary time remained. but the details of the scenery were completely changer. Hills were rounded off, valleys were filled, and the entire State was covered with a mantle of glacial débris. Drainage lines were rearranged and the lakes, swamps, and bogs so tharacteristic of the State were formed. Decomposed rock and "rotten rock" were largely removed from the ledges, learing fresh rock near" the surface. This last-mentioned result of glaciation is of interest to quarrymen, as the expense and dificulty of procuring commercial stone have thereby been greatly lessened.

DISTRIBUTION OF GRANITE AND GNEISSES IN CONNECTICLT.

The areas of granite gneiss in Connecticut are shown on the map forming Plate XXVIII. The true granites occur in masses so small that they are not shown on this map. In fact, unchanged granite occupies probably less than one-half of 1 per cent of the 4,990 square miles of the State. It will be noticed that the granite gneisses occur either as long, narrow bands, as illustrated by the Glastonbury and Monson gneisses, in larger areas of irregular outline like the Sterling and Berket gneisses, or in rock masses surrounded entirely by schist, as at Bristol and Collinsville. As all of the granite gneisses of the State are adapted for use as structural material, and some of them also for road metal, and as those who are interested in the quarry industry may wish to examine these various types of granite gneiss, the following brief description is given of the more important formations. ${ }^{57}$

${ }^{87}$ Abstracted from Connecticut Geol. and Nat. Ilist. Survey Rull. 7, pp. 33-38. 
Becket gneiss.- Is light gray in color, of firm texture, and has a mirorm banded structure. In many places the rock is highly quartzose and gramular. The formation inclutes many reins of quartz and pegmatite. supposed to be of pre-Cambrian aye.

I'rospet porphyritic gneiss.-Is light gray in color. The gneissoil appearance is grouluced ly bands of granular quartz and feluspar interbedinel with layers

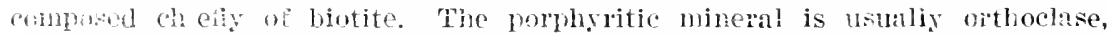
white or gink in color, rarying from one-sixteenth snch to 3 inches in length. Tho rok is hedever! to have been a cranite porphyry intruded into the lIartlind schist.

Bristul aranite gneiss.-Typical rock is light gray, with gneisso d structure more or less teveloned by the presence of layers of biotite; more schistose lavers contain muscovite. An evenly banded hornblende gneiss uccupies part of the area. Gamet is nearly everywere present and in places rises to the rank of a principal mineral. The rock was originally a mass of granite and diorite intruded into Hartland schist.

Collinswille granite gneiss.-Two types appear intermingled without order, a light gray, heary-bedded rock, grading into massive granite, and a very dark gray to black variety, which grades by imperceptible stages into evenly banded hornblenle gnciss. The rock consists of feldspar, largely orthoclase, quartz in irregular grains, and biotite. Was originally granite and diorite intruded into Hartland schist.

Brookfield diorite.-Is usually massive, but show's also muessold and even schistose phases. Both light and dark types are present, the former containing much quartz, and in extreme cases no dark mineral except biotite. The dark variety shows an almost complete absence of quartz, and in its place dark hornblende. It is an imeous mass intruled into the quartzite and schists of this region.

Danbury granodiorite gneiss.-The rock presents two important facies-a biotite granite and a diorite in which hornhlende becomes an important constituent and quartz is less prominent. There are gradations between the two types. It is prevailingly porphyritic, with pink or white phenocrysts of feldspar, is igncous in origin, and was intruded prior to the time when metamorphic action converted igneous and sedimentary rocks alike into gneisses and schists.

Thomaston granite gneiss.--Rock varies in structure from an almost massive granite to a rock with distinctly schistose phases. It is of igneous origin, as shown by the fact that it often occurs as dikes, and fragments of other rocks are included in it.

Glastonbury granite gneiss.-Two types-a granite biotite gneiss or a biotite granite, in a narrow band along the eastern borler, and a darker, well foliated gneiss, with biotite, hornblende, and epidote, in the remainder of the area. Both massive and schistose phases sometimes become augen gneiss. Believed to be of igneous origin.

Monson granite gneiss.-Where typically exposed, the rock is a fine-grained, dark-gray, uniform biotite-hornblende gneiss, marked at short intervals by parallel seams of quartz, and with bauds of biotite and hornblende. It is believed to be of igneous origin.

Eastford granite gneiss.- In general, a light or dark gray gneiss, fine grained, or in places even porphyritic. The composition and texture show the rock to be of igneous origin.

Sterling granite gneiss.-The rock is pink or gray in tone, and is made up of two distinct types-a porphyritic gneiss with an abundance of biotite along foliation planes, and an aplite or granite gneiss practically free from mica. 
The porphyritic type is always highly gueissoid and the phenocrysts of pink feldspar are drawn out into lenticular forms. Where phenocrysts are absent the rock shades into a nomal granite, which is intermediate between the two above-mentioned types. The aphtic ape is forohbly a later intrusion than the porphyritic and normal types. Origin, igneous.

Willimantic gnciss.-In general, the rock is coarse gratred and often porphyrtic in structure, usually considerably crumpled and folled. There are two varieties, the light and the dark. The light variety consists of quartz, feldspar, ancl biotite, in the proportions of a normal granite. The rark variety contains a relatively smaller amount of feldspar and quartz, with a larger anount of biotite and some hornblende. Origin, igneous.

Canterbury granite gneiss.-The formation consists essentially of a muscovite-biotite gneiss, varying in texture from a fine, even-grained rock to a porphyry with feldspars a quarter eí an inch or so in length. Netamorphism has prodnced irregular wary bunds of biotite separated by flattened layers of quartz and feldspar. Origin, igneous.

Maromas granite gneiss.--It is in some places massive, but usually well foliated. Composition is that of a normal granite. (See Sterling granite gneiss.) This rock is eruptive and is intruded into the Bolton schist.

Haddam granite gneiss.-It is a light-colored, rather fine-grained, granitic aggregate of quart\% and feldspar, through which are seattered small isolated flakes of biotite. In the outcrops the rock is a moderately thick-bedded gneiss. Origin, igneous.

Branford granite gnciss.-The rock is a medium-grained granite with a banded structure, consisting very largely of white feldspar. In the feldspars are embedded small round quartz grains, and biotite is also present in about equal amount. Small reddish garnets commonly occur, but may fail entirely. The rock has a pronounced tendency to weather, with a brownish stain on the cleavage surfaces of the feldspar. Origin, igneous.

stony creek anite gnciss.--See Sterling granite gneiss.

Lyme granite gneiss.-See Sterling granite gneiss.

New London granite greiss.- See Sterling granite gneiss.

Mamacoke gneiss.-The rocks occupying the larger areas of this formation are decidedly gneissic, sometimes containing much biotite, and nore rarely hornblende, and are frequently grmitic in apheinruce. The tylucal rock is uniformly medium grained, light to dark gray in color, and consists of white feldspar and quartz, with brilliant black mica, and sometimes small amounts of hornblende and garnet. The dark minerals constitute about one-third of the rock, but the range in both directions is considerable, in one case giving rise to a biotite gneiss, in the otber a granitic one. Origin, igneous.

\section{NATURE AND AGE OF THE GRANITIC INTRUSIONS OF CONNECTICUT.}

The stages of the process whereby the granite masses of Connecticut have attained their present form are not altogether understood. It is, however, certain, as stated above, that the granites and granite gneisses have been revealed by the removal of overlying material; and if we assume erosion to have proceeded much farther and an additional thousand feet or so to have been removed from the rocks of the State we should find that, instead of the limited areas of 
granite gneiss and the few patches of granite now exposed, large areas of granite surrounded by gneisses and schists would exist.

There are several ways in which molten rock may find its way into strata already existing. It may be actually forced into other rocks in such a way as to crowd them apart or to lift them bodily. On the other hand, the molten mass which later becomes granite may work its way quietly into the surrounding rock, melting and assimilating the overlying strata. This is believed to be the method of intrusion by which the Connecticut granites were formed, and a mass like the Stony Creck granite gneiss or the Sterling granite gneiss is to be considered as merely surface portions of igneous intrusions which extend to great depth. It is quite likely, as previously stated, that some of these granite areas represent deep-seated portions of volcanoes from which at one time granitic lavas were poured out over the State. If such lava flows ever existed all traces of them have been removed by the erosion of thousands of feet of rock.

The Bristol and Collinsville granite gneisses represent another type of intrusion. In both these localities the Hoosac ("Hartland") schist is seen to lap up orer the granitic rock, and the gneiss exposed shows evidence of being near the top of the original igneous mass.

It is generally supposed that the granites, and particularly the granite gneisses of Connecticut, date from the earliest geologic agesthat, in fact, they represent "parts of the original earth's crust," and this popular view coincides with the opinion expressed by geologists who have not studied the occurrence of these rocks in detail; but there is little to justify this view of the great age of most of the granitic rocks. With the possible exception of the Becket gneiss, no gneisses in Connecticut are regarded as of pre-Cambrian age, and the fact that the Sterling granite greiss cuts metamorphosed Carboniferous sediments make it unnecessiry to ascribe a date earlier than the Carboniferous for most of the intrusives in the eastern part of the State.

The last of the great earth morements that gave the structure to the metamorphic rocks of Connecticut occurred, presumably, at the close of Carboniferous time, and though the structure of some of the granite gneisses indicates that they have been subjected to more than one series of earth movements, the structure of others may be explained on the theory that they have passed through only one period of metamorphism. For example, the gneissoid character of the Sterling granite gneiss is believed to date from post-Carboniferous time. If this hypothesis is correct, the igneous gneisses are, in part at least, younger than the schists with which they are associated. The granites which are little or not at all metamorphosed are probably of two periods, the first coincident with the movements which produced the gneissoid and schistose structure in the rocks, 


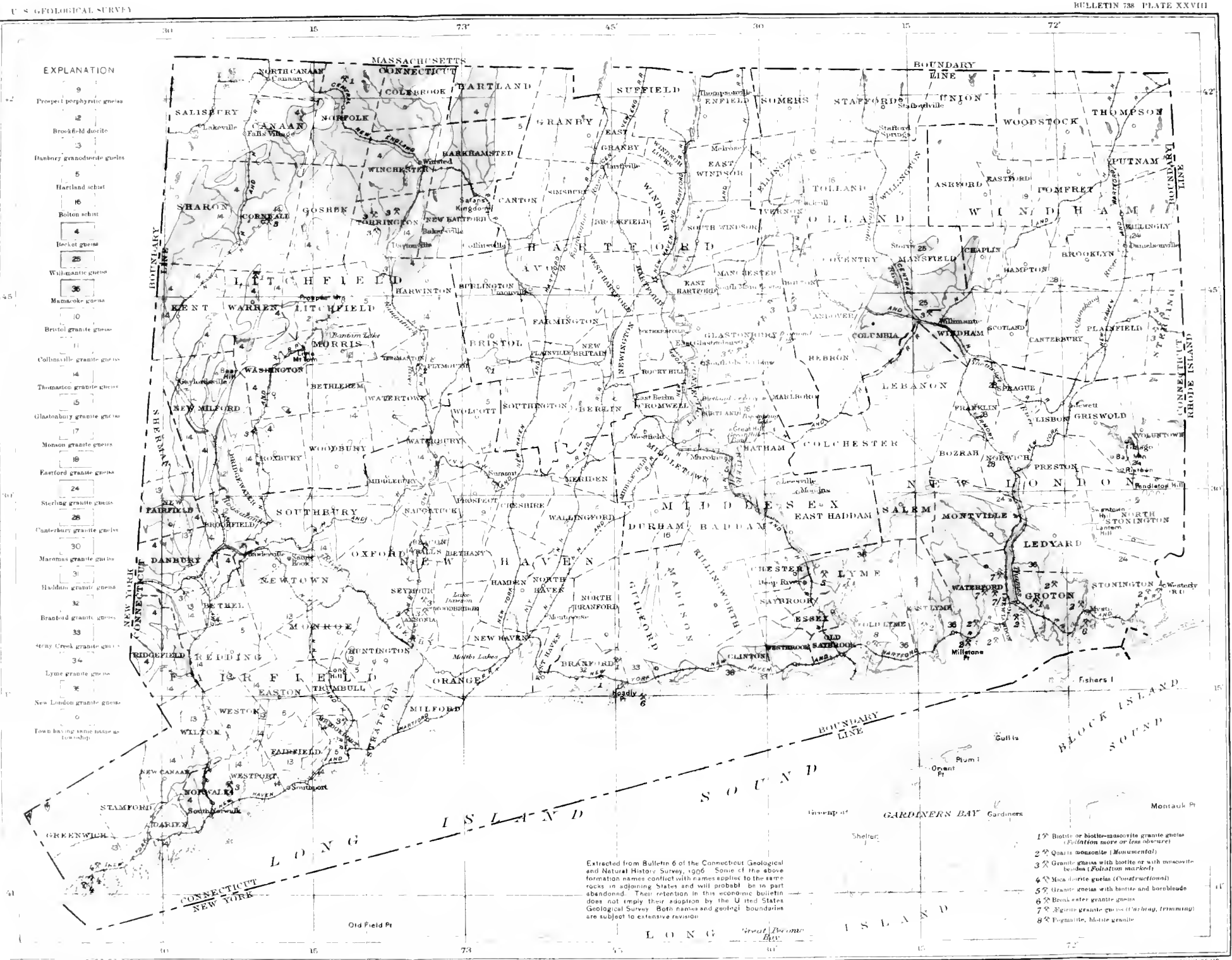

PRELIMINARY GEOLOGIC ANI ECONOMIC MAP OH CONNECTICUT 
$=$ 
and the seconcl at some later date. 'This sctond date of intrusion is proved by the fact that the massive granites have not been subjeeted to the pressure which produced the gneisses and that they eut into and through the granite gneisses. Occasionally, moreover, framents of gneiss are included in the granite itself. The descriptions of Stony Creek granite gneiss and Westerly granite (1)p. 37\%, 406, and 415) make this relationship clear. The relative are of the varions granites and gneisses may be stated as follows: 'The granite unpisses intruded into the ancient sediments are the oldest. The less metamorphosed granites come next; the pegmatites were formed at the same time as the granites or at a slightly later date, and dikes of granite were intruded after most of the pegmatites were formed. For instance, part of the granite quarried at Westerly is intrusive in pegmatites, granite, and granite gneiss alike and appears to be the latest formed rock in southeastern Connecticut.

\section{GRANITE QUARRIES OF CONNECTICUT.}

The locations of the quarries are shown on the geologic map (Pl. XXVIII) by symbols.

\section{FAIRFIELD COUNTY.}

\section{BRIDGEPORT.}

The Burlison or Parsons quary is in Bridgeport Township, on the Trumbull Road, about 750 feet south of the Trumbull line and about $3 \frac{1}{2} \mathrm{miles}$ northnortheast of the Bridgeport railroad station. Owner, C. Lewis Bill, Park Gardens, Bridgeport. Quarry disused since 1913, but not abandoned.

The granite (specimen D, $\mathrm{XXX}, 40$ a) is a muscovite-biotite granite gneiss of medium bluish-gray color and fine-graine! gneissic texture, with finely laminated, unplicated foliation, its particles being under 0.2 inch. Its constituents, in descending order of abundance, are transheent bluish potash feldspar (mierocline and orthoclase), clear colorless quartz, translucent bluish sola-lime feldspar (oligoclase-andesine), muscovite (white mica), and biotite (black mica). Accessory : Zircon, apatite. Secondary: White mica and calcite, bnt not enough to effervesee witl muriatic-acid test.

Owing to its foliaceous texture the stone looks very different on its rift, wrain, and hardway sides, and the muscovite gives its rift face a brilliant sheen.

The quarry measured in 1908 abont $100 \mathrm{by} 50$ feet and 25 to 30 feet in depth.

Rock structure: The gneiss foliation strikes N. $30^{\circ} \mathrm{E}$. and is rertical. The sheets, 6 inches to 3 feet thick, dip $25^{\circ} \mathrm{NL}$. and are in places horizontal. There are three sets of joints-(a), strike N. $50^{\circ} \mathrm{W}$., dip $40^{\circ}-50^{\circ} \mathrm{NE}$., spacel 3 to 40 feet; (b), strike N. $55^{\circ} \mathrm{W}$, dip $60^{\circ} \mathrm{SW}$., forms a headine at the north-nortlieast wall, one 50 feet south of it, and a thirl at the south-southwest wall; (c). strike about north, dip steep east, forms a heading on west side. Tho rift seems to correspond to the foliation ( $\mathrm{N} .30^{\circ} \mathrm{E}$., vertical), the grain to be horizontal. and the hardway vertical, N. $50^{\circ} \mathrm{W}$. Pegmatite occurs parallel to the foliation.

Transportation, by cart.

The product was used for cellars, walls, and trimmings, for which its even foliation well adopts it. Specimen: Trimmings of Bridgeport railway station. 


\section{DANBURY.}

The Treadwell prospect is in I)antury Township, $1_{4}^{3}$ nin les north-northwest of the Danbury railroad station, on a ridge east of the Padanaram road, on the farm of Stephen B. Treadwell.

The gran:te is an unevenly banded fine-grained dark to medium pinkish gray biotite gneiss. It consists of pinkish and milk-white feldspar, smoky quartz, ant? black mica.

Stone has been quarried for underpinning, off and on for years, from small openings 250 and 500 feet east of the house.

Rock structure: The gneiss foliation strikes N. $45^{\circ}-55^{\circ} \mathrm{W}$. and $\operatorname{dips} 50^{\circ}$ NE. to $30^{\circ}$. It is injected with pegmatite. The ledges are probably extensive, thit concealed by a thin cover of gravel and clay.

\section{GREENWICH.}

The Voorhis quarry is in Greenwich Township at the head of Byram Harbor, a mile southwest of the Greenwich railroad station. (See map, fig. 85.) Quarry abandoned sine 1908 .

The "Greenwich" blue-black granite (specimen D, XXX, 43, a) is a mica diorite gneiss of extremely dark bluish-gray color (darker than "Quincy extra

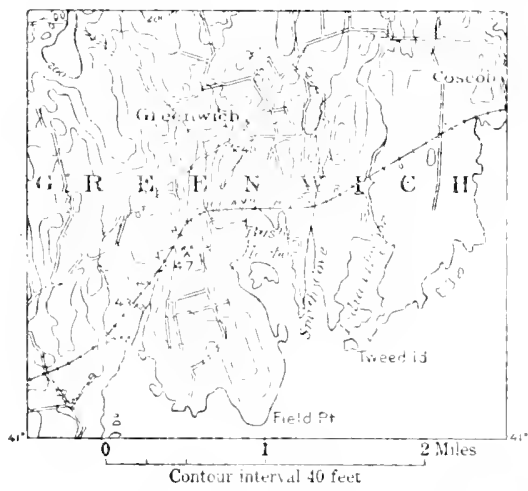

FlgURE 85.-Map of part of Greenwich, Conu., showing location of granite (diorite gneiss) quarries. 42, Ritch; 43 , Voorhis: 47, Christiano, Oak Ridge; 48 , Christiano, Hamilton Avenue. dark") and of coarse porply ritic gneissic lextu e. with feldspars, mostly twins, forming lenses up to 2 by 0.4 inch, but mostly not over 1 by 0.3 inch, :nd kown to 0.3 by 0.1 inch. The long ixes of these lenses are parallel to the rok foliation and the plane between the twin crystals is nearly so. The "wstiturnts of the rork, named in descencling order of abundlance, are medium translucent bluish-gray sodalime feldspar (andesine. with possibly olinglase-antestre). some in large twins, a little micacized and kaolinired: hiotite (black mica) ; clear colorless potash feldspar (m crocline); (lear colorless quartz; and green hornblende. Accessory: Pyrite, titanite, allitite, allanite, zircon; the three first in some abundance. Secondary: Epilote, kaolin, a white mica, calcite. The rock efferresces slightly with muriaticacid test.

Tiro tests of the ultimate transverse strength of this granite made at the United States arsenal at Watertown, Mass., in November, 1896, on pieces 15 inches long between supports, yielded these results:

\section{Results of transverse tests of "Greenwich" blue-black granite and Quincy granile.}

\begin{tabular}{|c|c|c|c|c|c|}
\hline & Test No. & Breadth. & Depth. & $\begin{array}{l}\text { Breaking } \\
\text { welght. }\end{array}$ & $\begin{array}{l}\text { Modulus of } \\
\text { rupture. }\end{array}$ \\
\hline 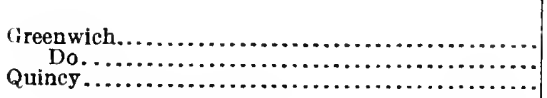 & $\begin{array}{l}9762 \\
9763 \\
9765\end{array}$ & $\begin{array}{r}\text { Inches. } \\
1.01 \\
1.02 \\
1.01\end{array}$ & $\begin{array}{r}\text { Inches. } \\
1.02 \\
1.02 \\
1.02\end{array}$ & $\begin{array}{r}\text { Pounds. } \\
152 \\
177 \\
177\end{array}$ & $\begin{array}{r}\text { Pounds. } \\
\text { a } 3,257 \\
\text { a } 3,757 \\
2,164\end{array}$ \\
\hline
\end{tabular}

a A verage modulus of rupture of Greenwich granite, 3,507 pounds. 
The rock is excedlingly tongh under the hammer. It is dark yet brilliant, and the contrasts between its black mica anl bluish-gray feldspars are very marked and pleasing. Its apmarent texture and shade differ on its three sides. The side parallel to the foliation, showing hardly any feldspar, is black; the sitle at right angles to the foliation and parallel to the long axes of the lenses shows the felds [ar most conspicumsly ; and the side transverse to those axes shows the light and dark minerals more exenly mixed. A structure built of the stone set on the elige of its foliation would be almost black. Its appearance wonlel ditfer somewhat afereling as the grain face or the harchay face, were alone exposed, and if the stmes were laid promiscuously, without regard in texture, the effect would be still different.

The quary, olmol hefore $18 \% 3$, measured in $190 \mathrm{~s}$ about 500 feet from morth to south by 200 feet across and 50 feet in depth.

linck structure: The gueiss foliation strikes N. $150^{\circ}-20^{\circ}$ l. and is rertical. The sheots, 1 to 35 feet thisk, strike $\mathrm{N}$. $80^{\circ} \mathrm{W}$., tip $20^{\circ}$ S., and are mostly separated by small aplito dikes. One sot of jo:nts only ; strike N. $65^{\circ} \mathrm{W}$.. dip vertical or very steep and slickensided. The rift is reported as parallel to the foliation: the grain as vertioal, with $\mathrm{N}$. $80^{\circ} \mathrm{W}$. course; and the hardway horizontal. Small dikes of aplite (described on n. 44) run parallel to the foliation and also unclulate horizontally.

Transportation, by cart 500 foet to a wharf almitting schooners of $6 \frac{1}{2}$ feet draft at high tiale.

The product was used for buildings and massive structures. and the waste for riprap. Specinens: Fort Schuyler, Throgs Neck, Long Island Sound; I'hysicians' quarters at south end of Blackwells Island, East River; Episcopal Church. Port Washington, Long Island; residence of C. J. Osborn, Mamaroneck, N. Y.; wall about Trinity Cemetery, One inundred and fifty-third Street and Broadway, New York City.

The Ritch quary is in Greenwich Township, on the west side of Lyram Harbor, $1 \frac{1}{4}$ miles southwest of Greenwich railroad station. (See map, fig. 85, p. 362.) Operators, W. \& S. Ritch, Port Chester, N. Y. Quarry abandoned.

The granite (specimens D, XXX, 42, a, b), "Greenwich" blue-black granite, is a mica diorite gneiss of extremely dark bluish-gray color and coarse porphyritic gneissic texture identical with that of the Voorhis quarry, described above.

The quarry in 1908 was ahout 200 feet souare. with working faces $15-40$ feet high on the north, south, and west.

Rock structure: The sneiss foliation strikes $\mathrm{N} .20^{\circ} \mathrm{E}$. and dips $90^{\circ}$. The sheets, 2 to 3 feet thick and generally separater by thin aplite dikes, dip $25^{\circ} \mathrm{W}$. There are two sets of joints- $(a)$, strike $\mathrm{N}, 80^{\circ} \mathrm{W}$, vertical, spacei 2 to 10 feet, forms the north and south walls and two hearlings near the center; $(b)$, strike N. $15^{\circ}-20^{\circ} \mathrm{W}$., vertical, spaced 10 feet or more. The rift is reporterl as parallel to the foliation, the grain vertical with $\mathrm{N} .80^{\circ} \mathrm{W}$. course, and the hardway horizontal. Pegmatite dikes, mostly of feldspar, the largest 16 inches thick, meander vertically along the foliation. Dikes of aplite, 0.25 inch to 2 inches thick (specimen D, XXX, 42, c), are of medium bluish-gray color and very fine texture with particles under 0.1 inch. (See for details p. 44.) This aplite differs from the gneiss only in its poverty of mica and richness of quartz. Rusty stain is an inch thick on sheet and joint faces.

Transportation, by cart 500 feet to wharf admitting schooners of 7 feet draft at high tide.

The product is used for buildings and street work and the waste for riprap. Specimens: Catholic churches in Flushing and Mamaroneck, N. Y., and Stam. 
fort, Conn.; Catlolic cathedral and bishol, house at intersection of randerbilt, Lafayette, Clemont, and Green avenues, Brooklyn.

The Christiano Oak Ridge quarry is in Gerenweln Townshi] at the north end of the ridge between Bush and Byam harbors, about three-fifths m'? westsouthwest of the dreenwich railroat station. (Nee fig. Sir.) Operator, Joseph christiano, Greenwich. Quarry abandoned.

The granite (specinen D. XXX, 47, a). " (rrenwicl " blue-black granite, is an extremely dark bluish-gray mica diorte sneiss. identical with that of the Vorin:s quary, ducribed on page 362. "xcept that it has a little angite besides the hornblende.

The quarry, opened in 1901, measured in 1908 about $175 \mathrm{by} 150$ feet and from 10 to 20 feet deep.

Rock structure: The meiss foliation strikes N. $15^{\circ}-20^{\circ}$ E. and dips $90^{\circ}$. The sheets, 2 to 10 feet thick, are horizontal or dip very low east. There are four sets of joints- $(a)$, strike N. $75^{\circ} \mathrm{W}$., vertical, spaced $1-10$ feet $;(b)$, strike $\mathrm{N}$. $20^{\circ}$ E., vertical or stee]) west, spaced 3-10 leet, coinciding with the small aplite dikes; $(c)$, strike N. $30^{\circ}$ W., rertical (exceptional), spaced as low as 5 feet; (d) (one only), strike N. $85^{\circ}$ W., dip $55^{\circ}$ about nortl. Pegmatite dikes, in beadlike lenses up to 8 inches thick, are either parallel to the foliation or branch from it. The numerous aplitic dikes, from 0.25 to 3 inches thick, strike with the foliation but have plications from 1 to 6 feet across. This aplite (specimen $D, X X X, 47, b$ ) is of very light gray color and very fine texture, and is almost illentical with specimen 42, c, from the Ritch quarry, described on jage 44.

Transportation, by cart.

The product is used for buildings, and the waste is crushed for roads. Specimen buildings: Catholic Church, Bruce Memorial gate (Bruce Park, Greenwich Avenue and Steamboat Road), and residence of Charles Hirshhorn North Street, Greenwich.

The Christiano Hamilton Avenue quarry is in Greenwich Township, half a mile northwest of the Greenwich railroad station. (See fig. 85, p. 362.) Operator, Joseph Christiano, Greenwich. Quarry abandoned.

The granite (specimen D, XXX, 48, a), "Greenwich" blue-black granite, is a mica diorite gneiss of extremely dark bluish-gray color identical with that of the Voorlis quarry, described on page 362 .

The quarry. opened in 1873, measured in 1908 about 60 by 30 feet and from 10 to 20 feet deep.

Rock structure: The gneiss foliation strikes N. $15^{\circ}$ E. and is about rertical. Sheets are hardly developed. There are two sets of joints-(a), strike N. $45^{\circ}$ W., vertical, spaced 8 to 15 feet; (b), loose, strike $N .15^{\circ}$ E., vertical, spaced 10 feet. The rift is reported as paralle to the foliation, the grain at right angles to it and rertical, and the hard way horizontal.

Transportation, by cart.

The product is used for buildings. Specimens: Residences of George $\mathbf{E}$. Weed, Rockside Park, and of James McCutcheon, Belle Haven Park, Greenwich.

\section{NORWALK.}

The Hall quarry (formerly known as the Bates cnarry) is in Norwalk Township, about $1 \frac{1}{2}$ miles northeast of the Norwalk railroad station. Operator, Irving Hall, Norwalk.

The granite (specimen $\mathrm{D}, \mathrm{XXX}, 44, \mathrm{a}$ ) is a muscovite-biotite granite gneiss of light warm-gray color and of gneissic medium inclining to fine texture, with feldspars and mica to 0.25 inch. It is brightly spangled with mica on its 
foliation face. Its constituents, named in descending order of abundance, are light rream-colorel potash feldspar (microcline), but little liaolinized; pale smoky quạtz, with cavities in sheets; milk-white sola-lime feldspar (oligoclase albite), much kaolinized. micacized, and with calcite; muscovite (white mica); and biotite (black mica). Accessory: Garnet, apatite. Secondary: Kaolin, a white mica, calcite, some in veinlets. Effervesces freely in places with muriatic-acid test.

The quary in 1908 was about 50 feet square and from 20 to 30 feet deep.

Rock structure: The sneiss foliation dips $5^{\circ}$ to $20^{\circ}$ NW. The sheets, 1 to 4 feet thick, parallel to the foliation, are but imperfectly developel. There are two sets of joints-(a), strike N. $40^{\circ}$ E., rertical, forms the nurth wall; (b), strike northwest, vertical, spaced 2 to 8 feet, forms the east and west walls and a heading 8 feet wide near the north wall. Sone of the joints of this heading have been parted 0.25 to 2 inches and filled with quartz. Both sets of joints ale slickensided. The rift is along the foliation.

Transportation, by cart.

The product is used for walls, undelpinning, steps, etc. The quarry is worked only occasionally.

\section{H.IRTFORD COLNTY.}

BRISTOL.

The Dunn quarry is on Divinity Street, in Bristol, abont a mile westsonthwst of the enter of the horoush. Quary no longer operated.

The iranite (specimen D. XXX, 62, a, "Bristol granite gneiss," No. 10 of the State preliminary (reolog (c map) is a garnetiferous quartz monzonite gneiss of limht, including to medium bluish-gray color and of gneissic banded fine texture, with feldspars up to 0.2 inch, mica to 0.1 inch, and garnets to 0.08 inch. It has wary bands and lenses of light and dark and relldsh color, the l'glit bands up to 0.5 inch in width. the dark to 0.3 inch, and the redtlish to 0.1 inch. Its constituents, in descending order of abundince, are clear to whitish soda-lime felrepar (albite). some of it sl ghtly kaolinized; cher bluish quartz, with cavities in sheets; a little potash feldspar (orthoclase) : biotite (black mica). some of it chloritized. Accessory : Gamets (fourth or fifth in order of abundance), magnetite, apatite. Secondary : Kaolin, chlorite, limonite.

This is a hard, serviceable, ant attractive stone.

The quarry consists of two openings, one abolit $100 \mathrm{by}$ bo feet and 5 to 10 feet deen, the other 50 feet square, harely opened in 1909.

Rock structure: The mneiss foliation strikes east and dips steeply south. The sheets, 3 to 8 feet thick, are irregular. There are three sets of joints(a), strike about north, with headings 12 feet wire: (b). strike about east: (c), diagonal. The spacing of joints in the smaller opening admits the quarying of blocks 10 feet square by 3 to 5 feet. The rift in both olvenings is across the foliation.

Transportation, by cart 1 mile to railroad.

The product was used for foundations and buildings. "Brightwood," Mrs. W. A. Mckay's mansion on West Street, in Bristol, was built of this granite, but some of it came from another now disused quarry, and some from the site of the mansion itself.

The Seymour Street quarry, in Pristol. is operated occasionally by the Pierson Engineering \& Coustruction Co., Bristol.

The granite is like that of the Dunn quarry; the opening is small and irregular. 


\section{GLASTONBURY.}

The Glastonbury quarries, as shown on the map (fig. 86 ), are scattered along a $\mathrm{s}$. $49^{\circ} \mathrm{W}$. riuge, the northern pat of which is now known as Minnechaug Mountain, called also locally Birch Mountain, and the southern part of which goes by the name of Eightmile $H$ il. The gneiss foliation at the quarries strikes $\mathrm{N} .45^{\circ}-80^{\circ}$ E., areliging about N. $60^{\circ}$ E., ant thus differs but little from the trend of the ridge. The strike at the Curtis cuarry, how. crer, is about north. The Peterson quarry, in Bolton, Tolland County (p. 399), is on the northeastern continuation of the same ridge. The strike there is N. $10^{\circ} \mathrm{E}$.

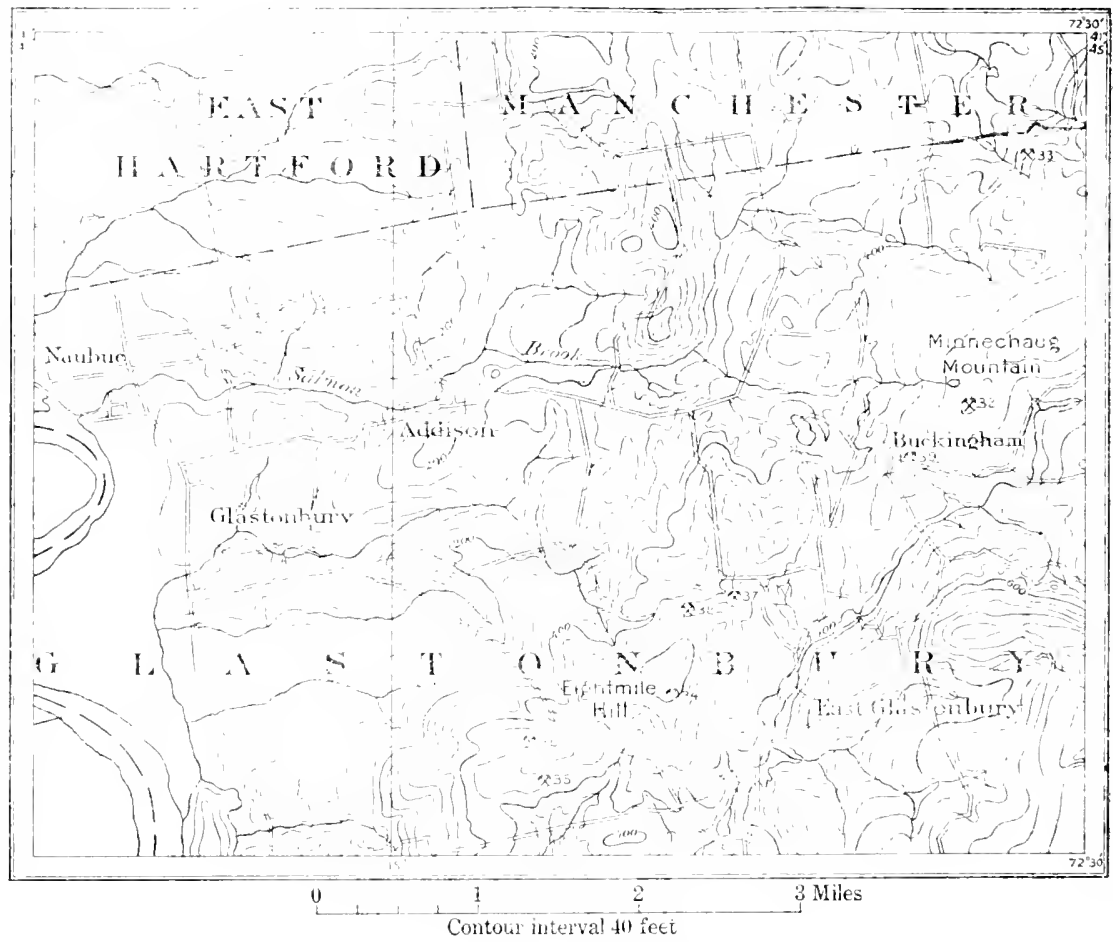

Figure 86. - Map of Glastonbury, Conn,, showing location of granite gneiss quarries. :3, corhin ; :3, Gorman ; 34, Lanjelson ; 35, Belden; :36, Curtis; 37 , Brooks ; 38, Slater ; 39, Flastombury Granite Weriss.

The rock at these quarries is a more or less obscurely porphyritic biotite granite gneiss, with feeble nineral contrasts and a markerl foliation, but its textule and shade vary slightly at different quarries. It is designated on the State preliminary geologic map "Glastonbury granite gneiss, No. 15." The Glastonbury quarries have long supplied curbing and crosswalks to the city of Hartiorel, for which the foliation of the stone admirably adants it.

The Corbin quarry is in Glastonbury, at the top of Birch Mountain, 5 miles east-northeast of Glastonbury village. (See fig. 86.) Operator, A. S. Freeburg, Hartford.

The granite (specimen $\mathrm{D}, \mathrm{XXX}, 32, \mathrm{a}$ ) is a biotite granite gneiss of mediumgray shade and of fine gneissic texture, with porphyritic feldspars up to 0.3 inch, and matrix with particles under 0.05 inch. In places it has minute brown- 
leldspars are intergown with quartz circular in cross section. No effervescence with muriatic-acid test.

This stme is less weathered than that of the last two quarries, and therefore barder. It has been used for buillings, steps, etc.

The Danielson quarry is in Glastonbury Township, on the south side of the tol) of Fightmile Hill, $3 \frac{1}{2}$ mile's southeast of Glastonbury village. (See fig. S6.) It is now disused.

The grinite (specinen I), XXX, 34, a) is a biotite granite gneiss of dark, inclining to medium brownish-gray color and of fine narked gneissic texture, with porphyritic feldspars to 0.3 inch in a matrix with particles under 0.1 inch, in thin section mostly letween 0.11 and 0.94 mill:metrr. Its constituents, in descending order of abmolance, are pale-buff to pinkish potash feldspar (nicrocline and orthodlase), somewhat kaolinized; medium smoky quartz showing effects of strain and with some cavities in sheets; grayish translucent sorla-lims follspar (oligrolase). slightly kaolinized; and biotite (black mica). Accessory : Epirlote (fifth in order of abundance), apatite, magnetite, allanite. Secomlany: kaolin, l monite. hematite (stain). No effervescence with muriatic-acid test.

The quarry measured, in 1908, about 60 by 35 feet and 10 feet deep.

Rock structure: Gnejss foliation and rift strike N. $55^{\circ}$ F. and dip $25^{\circ} \mathrm{N}$. The sheets, 1 to 2 feet thick, are also parallel to these. There is one joint on the north sirie, striking $\mathrm{N}$. $70^{\circ} \mathrm{w}$. Vert.cal pegmatite dikes, 3 to 6 inches thick, strike N. $S 0^{\circ}$ W. Some of smoky quartz up to 4 inches thick.

Transportation, by cart 10 miles to Hartford.

The product was used for curbing and steps.

The Belden quarry is in Glastonbury Township, on Eightmile Hill, 0.3 mile south of the Ifartford turnpike and 3 miles southeast of Glastonbury village. (Sce fig. S6.) Operator, H. T. Iingner, East Glastonbury.

The granite (specimen D, XXX, 35, a) is a b:otite granite gneiss of medium buff-gray color (a trifle lighter than "Concord guanite") and of ine gneissic texture, with feldspars to 0.2 inch and nica, in aggregates, un to $0.5 \mathrm{inch}$, conspicuous along the foliation. Iorphyritc texture not apparent. Its constituents, in lescending orler of abundance, are crean-colored potash feldspar (microcline and orthoclase), somewhat kaolinized; pale smoky quartz, some of it in long laminae 0.2S millimeter wide; whitish soda-lime feldspar (oligoclase), somewhat kaolinized; biotite (black mica) ; and a little muscovite or bleached biotite. Accessory : Garnet (fiftl in order of abundance), ep.dote, magnetite, allanite. Secondary: Kaolin, limonite stain, calcite. No effervescence witr muriatic-acid test.

The quarry consists of several openings, some of which were made in 1863. The one worked in 1908 measured $50 \mathrm{by} 40$ feet and 20 feet deep.

Iiock structure: Gneiss foliation and rift strike northeast and dip $10^{\circ}$ to $20^{\circ}$ NW. The sheets, 6 inches to 5 feet thick, are parallel to these. There are two sets of joints-(a), strike N. $20^{\circ}$ E., vertical, forms the north wall; (b), strike N. $65^{\circ}$ W., vertical, forms the east and west walls and recurs in center, discontinuous. The grain is reported as vertical, with north-south course. Pegmatite dikes are up to 6 inches thick. Some smoky quartz veins or lenses.

Transportation, by cart 10 miles to Hartford.

The product is chietly used for curbing and crosswalks, and smaller blocks for paring. Blocks $1 \frac{1}{2}$ to 2 incles thick are prepared for lining tubes at feldspar-crushing works instead of the oak timber formerly used for that purpose.

The Brooks quarry is in Glastonbury Township, on the northeast side of

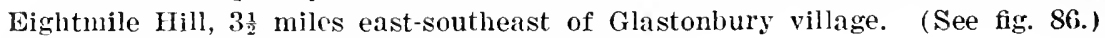
Operator, Henry R. Brooks, R. D., Glastonbury. 
The granite is a biotite granite gnelss of medium-gray shade and fine gneissic porphyritic texture, identical in composition with that of the Corbin quarry, described on page 366 , and with the same minute brown spots, due to allanite.

The quarry, opened in 1889, measured in 1908 about 400 feet from east to west by 150 feet across at one end and 50 feet at the other, and from 5 to 60 feet deep.

Rock structure: The gneiss foliation and rift strike N. $70^{\circ}$ E. and dip $25^{\circ}$ $\mathrm{N} .20^{\circ} \mathrm{W}$. The sheets, 1 to 6 feet thick, are parallel to these. There are two sets of joints-(a), strike N. $75^{\circ}$ E., dip steep S. $15^{\circ}$ E., spaced 10 to 20 feet; (b), strike $\mathrm{N} .35^{\circ} \mathrm{W}$., vertical, spaced 20 feet. The grain is vertical, north to south, but the stone breaks with equal facility along the hard way. Four vertical pegmatite dikes, the largest 10 inches thick, strike $N .77^{\circ} W$. and are 10 feet or more apart. This pegmatite (specimen D, XXX, 3T, b) consists of cream-colored feldspar and smoky quartz, with sparse minute garnets and rare scales of biotite and muscovite.

Transportation, by cart 10 miles to IIartford, or $5 \frac{1}{2}$ miles to rail at South Manchester, or 5 miles to wharf at Naubuc (Glastonbury landing), on the Connecticut.

The product is used for curbing and building.

Specimens: Curbing and steps, Cheney Park, South Manchester, and trimmings on Methodist Cluurch at Windsor.

The Slater quarry is in Glastonbury Township, one-fourth mile west-southwest of the Brooks quarry and about $3 \frac{3}{4}$ miles southeast of Glastonbury village. (See fig. S6.) Quarry now disused.

The granite is a biotite granite gneiss, identical with that of the Corbin quarry described on page 366 .

The quarry was in 190820 feet square and 15 feet deep.

Rock structure: Gneiss foliation and rift strike N. $55^{\circ}$ E. aud dip $30^{\circ} \mathrm{N}$. $35^{\circ} \mathrm{W}$. The sheets, 2 to 4 feet thick, are parallel to these. There are two sets of Joints-(a), strike northeast, dip $40^{\circ} \mathrm{SE}$., spaced 15 feet; (b) strike nortluwest, vertical, one only. The grain is vertical, north to soutl, but the rock breaks equally well along the hard way. Four-inch pegmatite dikes strike N. $70^{\circ} \mathrm{W}$. A 12 -inch vertical dike strikes $N .10^{\circ}$ E., carries muscovite in plates up to 5 inches square and 4 inches thick, about 6 inches apart, the rest of the dike being mostly feldspar.

The product was used for curbing, crosswalks, and steps.

\section{LITCHFIELD COUNTY.}

CORNWALL.

The Benedict quarry is in Cornwall Township, on the north side of White Rock, three-fourths mile east of Cornwill rillage. Owner, Trusten H. Benedict. Quarry disused.

The granite (specimens D, XXX, 60, a, b, c), is a biotite-muscovite granite gnelss of medium bluislı-gray color and of medium, inclining to fine gnelssic texture, with feldspars to 0.3 inch and mica to 0.1 inch; also with lare porphyritic clear feldspars, the largest 0.4 inch. Its constituents, in descending order of abundance, are clear bluish potash feldspar (microcline and orthoclase), intergrown with quartz that is circulal in cross section; clear colorless quartz; translucent to milk-white soda-lime feldspar (oligoclase), somewhat kaolinized and with calcite; biotite (black mica); and muscorite (wlite mica).

$105709-23-25$ 
Accessory: Illmenite (probably) surrounded by titanite, apatite, allanite, zircon. Secondary: Calcite, epidote, kaolin, a white mica. There is a little minute rermicular intergrowth of quartz and feldspar and some granulation of the feldspars. Slight effervescence with muriatic-acid test.

This is a bright-bluish foliaceous stone, without marked minelal contrasts.

The quarry is 75 feet square by 10 to 15 feet deep.

Rock structure: Gneiss foliation and rift strike N. $50^{\circ}$ E. and are vertical. The sheets, 2 to 4 feet thick, dip low northwest. There are two sets of joints(a), strike N. $60^{\circ}-75^{\circ} \mathrm{W}$, vertical, spaced 20 to $25 \mathrm{feet}$, forms a heading on the soutl wall; (b), strike N. $10^{\circ}$ E., vertical, spaced 15 feet. The grain is vertical, with northwest course. Pugmatite dikes up to 2 inches thick strike N. $15^{\circ} \mathrm{E}$. Between the quarry and the cemetery on the north side of the road a similar gneiss is in contact with, or contains an inclusion of, a fine-grained biotite gneiss with particles up to 1 millimeter, consisting of quartz, biotite, microcline, and oligoclase-andesine, with accessory apatite, titanite, zircon, and striking N. $10^{\circ}-$ $20^{\circ} \mathrm{E}$.

Transportation, by cart $4 \frac{1}{2}$ miles to rail at Cornwall Bridge.

The product was used for trimmings, for which its foliation and color well adapt it.

\section{LITCHFIELD.}

The Mascetti quarry, $2 \frac{1}{2}$ miles south of Torrington, is in the townshlp of Litchfield, three-fourths mile northwest of East Litchfield village, on the west side and south end of a knoll rising 480 feet abuve the village. Operators, Mascetti \& Holley, Torrington. Idle since 1918.

The granite (specimen $\mathrm{D}, \mathrm{XXX}, 53, \mathrm{a}$ ) is a muscovite-biotite granite gneiss of medium, inclining to light bluisll-gray color and of fine gneissic texture, with feldspars uncier 0.2 inch and mica mostly under 0.1 inch. Its constituents, named in descending order of abundance, are clear bluish potash feldspar (nicrocine); light smoky quartz with cavities; milk-white soda-lime ieldspar (oligoclase), somewhat kaolinized and intergrown with quartz, circular in cross section; muscovite (white mica); and biotite (black mica) in smaller flakes, some of it chloritized. Accessory : Garnet (sixth in order of abundance), tourmaline, apatite, zircon. Secondary : Kaolin. calcite, chlorite. The rock effervesces slightly with muriatic-acid test.

This rock is brilliant, with muscovite on its foliation face.

The quarry, opened about 1903, was in 1908 about 200 feet long, with a working face 50 feet high on the east.

Rock structure: Gneiss foliation and rift strike N. $20^{\circ}$ I. and dip $20^{\circ}$. The sheets, 2 to 4 feet thick, dip $20^{\circ}$ to $50^{\circ} \mathrm{NW}$. One set of joints only, strike N. $5^{\circ}$ E., dip $65^{\circ}$ E., spaced 3 to 20 feet and over. Pegmatite dikes, with black tourmaline and bordered with aplite, 1 to 2 feet thick, meander vertically with a N. $15^{\circ}$ E. course. Others up to an inch thick are parallel to the foliation.

Transportation, hy cart $1 \frac{3}{4}$ miles to East Litchfield, or $2 \frac{1}{2}$ miles to Torrington.

The product is used for curbing and steps, for which it is well adapted.

\section{NORFOLK.}

The Crissey quarry is in Norfolk Township, on the southeast sitle of Bald Mountain, $2 \frac{7}{8}$ miles north-northwest of the village of Norfolk. Owner, R. I. Crissey, Norfolk.

The granite (specimen D. Xxx, 61, a, b,) is a biotite-muscovite granite gneiss of medlium, very slightly greenish gray color and of even-grained, fine, ohscurely gneissic texture, with feldspars under 0.2 inch and mica under 0.1 
inch. Its constituents, in descending order of ahundance, are clear colorless potash feldspar (microcline and orthoclase) : clear colorless quartz, with wous cavities in sheets; milk-white soda-lime feldsuar (oligoclase), mostly kaolinized, micacized, and with calcite; biotite (black nica), some of it chloritized; and muscovite (white nica). Accesory: Magnetite, allatite, allanite (limmed with epidote), zircon. Secondary: Kiolin, calcite, a white miea, epirlote, limonite stain. There is some feldspar granulation and also vernicular intergrowth of quartz and feldspar.

The stone effervesces with muriatic-acid test. R. C. Wells, a chenist of this Survey, finds that it contains 0.36 per (ent of Ca() (line). Solnhie in warm dilute (10 per cent) acetic acid, which indicates a content of U.6t per cent of $\mathrm{CaCO}_{3}$ (calcium carbonate, calcite).

This is a bright, fine-grained gray granitc, without mineral contrasts and without contrasts of tint between cut and polished faces.

The quarry, opened before 1850 , consists of four excavations, the highest and largest of which measures about 150 feet from southeast to northwest and has a working face 50 feet high on the northeast.

Rock structure: The sheets, 6 inches to 5 feet thick (some reported as 7 feet but now covered), dip $10^{\circ} \mathrm{NW}$. ind are normal. There are two sets of foints-(a), strike N. $80^{\circ}$ E., dip steep south to $90^{\circ}$, forms the northwest and southeast walls; (b), strike N. $20^{\circ}$ E., vertical, discontinuous, spaced 5 feet or more. The rift is reported as about horizontal, but the rock splits soutleast-northwest.

Transportation, by cart 1 mile to Central New England Railway.

The product was used for buildings, monuments, and coping. Specimens: Chapel of Congregational Church and the railroad station at Norfolk; Egbert T. Butler and Anson Gaylord monuments, Norfolk Center Cemetery.

This quarr, originally opened for coping for the Hoosac Tunnel, in Massachusetts, was closed in 1893 , owing to a difficulty with the railroad as to freight rates.

\section{ROXBURY.}

The Rockside quarry is in Roxbury Township, on the east side of Mine Hill, four-fifths mile north of Roxbury station. Although this quarry is disused it is described on account of its geologic interest and its former economie importance.

The granite (specimen $\mathrm{D}, \mathrm{XXX}, 5 \overline{7}$, a) is a muscovite-biotite granite gneiss of medium bluish-gray color and of fine-grained, even, unplicated gneissic texture, with particles under 0.2 inch and conspicuous white mica along its foliation..$^{50}$ In thin section the particles, aside from muscovite, range from 0.11 to about 2 millimeters. Its constituents, in descending order of abundance, are translucent bluish potash feldspar (mostly microcline witl some orthoclase), slightly kaolinized; clear colorless quartz with cavities in sheets, one conspicuous set with cracks parallel to it, another less abundant at right angles to the first; muscovite (white mica); whitish soda-lime feldspar (oligoclase); the stone of an upper opening shows oligoclase to oligoclase-andesine), somewhat kaolinized and micacized; and biotite (black mica). Accessory: Apatite (rather abundant), zircon. Secondary: Kaolin, one or two white micas, calcite. No effervescence with muriatic-acid test.

* W. H. Hobbs regards the muscovite as secondary and formed at the time of the foliation. He also describes the feldspar as crushed and granulated. See Rlce, W. N.a and Gregry, H. E., Connecticut Geol. and Nat. Hist. Survey Bull. 6, p. 110. 
The quarry, opened in 1890, measured in 1908 about 800 feet from northeast +2 southwest by 275 feet across, with a working face on the northwest side 35 to 75 feet high.

Rock structure: The gueiss foliation dips gently southeast on the outer east side of the quarry but $15^{\circ} \mathrm{S}$. $20^{\circ} \mathrm{W}$. at the working face, tending to become horizontal within the hill. The sheets, 4 inches to 18 feet thick, correspond to the foliation. The upper 30 feet of the working face consists of thin sheets. There are two sets of joints. Set (a), strike northwest, vertical, forms a headIng at the southwest wall; a nother, 6 to 8 feet wicle, is 200 feet northeast of that wall; and another, 3 feet wide, is 300 feet farther northeast. The rock left unquarried about these two headings is about 50 feet wide. These joints are spaced 2 to 20 fect. Set (b), strike northeast, dips $7^{\circ}$ NW., one 50 feet below the rock surface, another 25 feet lower. The rift corresponds to the foliation. The grain is reported as striking N. $35^{\circ}$ E. and dipping $85^{\circ} \mathrm{S} .55^{\circ}$ E., and the hardway as rertical, with $N$. $55^{\circ} \mathrm{W}$. course. There are white aplitic dikes, from 0.12 to $\mathrm{S}$ inches thick, almost parallel to the foliation. These are very quartzose, without biotite, and with rare muscovite. Some of this aplite is very light gray to white and of even-grained, very fine granitic texture, with feldspar antl light smoky quartz under 0.1 inch and the finer particles between 0.05 and 0.56 millimeter. It efferresces with muriatic-acid test. Some of these dikes have oligoclase-albite and microcline in about equal parts. Smoky quartz veins, the largest 0.25 inch thick, run parallel to them. Others have a gneissic texture and show a little muscovite, evidently secondary and forming "membranes covering the foliation planes," as described by Hobbs. The main gneiss is also crossed by dikes of rose-colored aplite up to 4 feet thick, dipping like the joints of set (b). One of these consists chiefly of oligoclase-andesine with crush borders, smoky to amethystine quartz, a little microcline, and rare muscovite but no biotite, in places with microscopic garnets. All its particles are under 0.1 inch. One of the smaller dikes contains microcline, quartz, a little albite, garnet, muscovite. apatite, named in descending order of abundance. Its feldspars are under 0.05 inch and its quartz particles up to 0.2 inch.

Within three of the headings are the mineral veins described on page $\mathbf{7 5}$, evidently all related to the larger siderite vein which was formerly mined on the hill and to which it owes its name. Away from the headings the gneiss has little if any rusty stain.

Transportation, by siding to Litchfield branch of New York, New Haven \& Hartford Railroad.

The product was used for buildings and railroad bridges, and the waste blocks, with aplite or other blemishes, for retaining walls. The stone was in demand because of its color and low price. Specimens: Four rock-faced houses, corner Serenty-second Street and Tenth Avenue, and the retaining wall of the New York Central \& Hudson River Railroad, Sixty-seventh to Seventy-second Streets, New York. This wall is 1,350 feet long, 58 feet high; base 21 feet wide on Serentr-second Street.

\section{THOMASTON.}

The Plymonth quarry is in Thomaston Townslip, about $1 \frac{1}{2}$ miles south of Thomaston village and nearly half a mile north of Reynolds Bridge. Operator, Plymouth Granite Co., Thomaston.

The granite (specimen $\mathrm{D}, \mathrm{XXX}, 54$, a) is a quartz monzonite of medium bluish-gray color and of even-grained, fine granitic texture, with feldspars and mica up to 0.1 inch. Its constituents, in descending order of abundance, are light smoky quartz, with hairlike crystals of rutlle and cavities in sheets; 
translucent bluish soda-lime feldspar (oligo(lase), some of it micacizerl and kaolinized; clear colorless potash feldspar (microcline and orthoclase); biotite (black mica); and muscovite (white mica). Both feldspars are intergrown with quartz more or less circular in cross section. Accessory : Apatite, rutile. Secondary: Kaolin, a white mica. No effervescence with muriatic-acid test.

This is a bright fine-grained monumental granite which is without mineral contrasts but which euts and hammers light. Newberry, ${ }^{\infty 0}$ in 1884 , referred to the adaptation of this stone to monumental work.

The quarry measured in 1908 about 200 feet from north to south by 50 feet across, with a working face 20 to 40 feet high on the east.

Rock structure: The granite is capped by 10 to 20 feet of quartz monzonite gneiss, gray or consisting of white feldspar and quartz bands, 0.2 to 0.3 incb wide, alternating with black bands of biotite less than 0.05 inch wide. The constituents of this gneiss, in lescending order of abundance, are light smoky quartz with cavities, milk-white oligoclase, whitish orthoclase, biotite, and a little muscovite or bleached biotite. Accessory: Magnetite, apatite, titanite. Secondary: Kaolin, a white mica. This gneiss is intricately plicated. In places Its foliation is abruptly intersected by the granite. The boundary between the two rocks is very irregular, and pegmatite occurs along part of it. A tapering inclusion of the gneiss, 10 feet by 14 inches or more long and 3 feet wide, occurs 8 feet below the contact. The sheets, 6 inches to 3 feet thick, dip gently west but are less regular in the gneiss capping. There are two sets of joints-(a), strike N. $35^{\circ}$ E., vertical, spaced 8 to 30 feet, continuing into the gneiss; (b), strike N. $80^{\circ} \mathrm{W}$., vertical, spaced 3 to 10 feet or over.

Transportation. by very short siding to New York, New Haven \& Hartford Railroad.

The product is used for monuments.

\section{TORRINGTON}

The Costello quarry is in Torrington Township, $2 \frac{1}{2}$ miles northwest of Torrington and 550 feet above it. Operator, Edward M. Costello, R. D. 1, Torrington. Idle since 1916.

The granite (specimen $\mathrm{D}, \mathrm{XXX}, 50, \mathrm{a}$ ) is a muscovite-biotite granite gneiss of medium faintly buff gray color and of fine, very gneissic texture, with feldspars under $0.2 \mathrm{inch}$, but with larger micas conspicuous on the foliation face and with sparse garnets to $0.2 \mathrm{inch}$. Its constituents, in descending order of abundance, are cream-colored potash feldspar (microcline), intergrown with quartz that is more or less circular in cross section; light smoky quartz with cavities in sheets; cream-colored sodi-lime feldspar (oligoclase-albite to albite) ; muscovite (white mica); and biotite (black mica). Accessory: Garnet, apatite. Secondary: Limonite.

The quarry, opened in 1898, measured in 1908 about 250 feet in it $\mathbf{N}$. $60^{\circ} \mathbf{E}$. direction by 50 feet across and 25 feet in depth.

Rock structure: The foliation strikes N. $50^{\circ}$ E. and dips $55^{\circ} \mathrm{N} .40^{\circ} \mathrm{W}$. The sheets, from 8 to 12 feet thick (exceptionally, near the surface, 1 foot thick), are horizontal or inclined to $30^{\circ} \mathrm{NNW}$. There are two sets of joints-(a), strike N. $30^{\circ}$ E., dip $30^{\circ}-70^{\circ}$ N. $60^{\circ}$ W., spaced 8 to 10 feet: (b), strike N. $20^{\circ} \mathrm{W}$., dip $70^{\circ}$ ․ $70^{\circ} \mathrm{E}$, spaced over 100 feet. forms al heading at the west end. The rift curlesponcls to the foliation, and there is little clifference between the grain and the hard way. Carnetiferous pegmatite dikes are up.to 2 inches thick. There is little or no rusty stain on shect surfaces. 
Transportation, by cart 3 miles to Torrington or 11 miles to Winsted.

The product is used for building, trimming, and curbing. Specimens: Parish house of Third Congregational Church, Torrington; Winsted Hosiery Co.'s office. Winsted; trimmings on public library, Winsted; trimmings on factories of Standard Manufacturing Co. and Union Hardware Co., Torrington.

The Michiel quarry is in Torrington Township, more than a nile west of Torrington and 340 feet above it. Operators, John de Michiel \& Bros., Torrington. Iclle in 1922.

The granite (specimen D, XXX, 52) is a muscorite-biotite granite gneiss of medium, inclining to dark bluish-gray color and of medium, very gneissic texture, with feldspar to 0.4 inch and large micas, which are very conspicuous on the foliation faces. Its constituents, in descending order of abundance, are translucent bluish potash feldspar (microcline and orthoclase); light smoky quartz with cavities in sheets and cracks parallel thereto, the sheets of cavities passing uninterruptedly from one particle to the next; a little milk-white sodalime feldspar (oligoclase). somewhat kaolinized; muscovite (white mica); and biotite (black mica). Accessory: Garnet, apatite, zircon. Secondary: Kaolin. Poth feldspars are intergrown with quartz that is more oj less circular in cross section. No effervescence with muriatic-acid test.

The quarry, opened in 1901, was in 1908 about 150 feet square and 15 to 30 feet deep.

Rock structure: The gneiss foliation is vertical, with $\mathrm{N} .35^{\circ} \mathrm{E}$. course. The sheets, 1 to 14 feet thick, are horizontal in the center of the quarry, curving over gently on the sides. There are two sets of joints-(a), strike northwest, dip vertical or steep southwest, spaced about 20 feet; (b), strike N. $20^{\circ}$ E., dip steep N. $70^{\circ} \mathrm{W}$., suaced 50 feet. The rift corresponds to the foliation, and the grain and hard waly are reported as equally pronounced.

The product is used mainly for buildings; some for trimming and curbing. Specimens: Methodist Church, Winsted; Italian Catholic Church, Torrington; L. Ripley residence, Litchfield; trimmings on Litchfield library and on the State armory, Meriden.

The Torrington Borough quarry is in Torrington Township, about 11 miles north-northwest of Torrington and several hundred feet above it. Owned and operated by the borough of Torrington. Quarry abandoned.

The granite (specimen D, XXX, 51, a) is a biotite granite gneiss of general dark-gray shade, finely banded with black, and very fine to fine schistose texture, with feldspars under 0.1 inch. Its constituents, nameil in descending order of abundance, are medium-gray potash feldspar (microcline and possibly orthoclase); medium smoky quartz, with cavities in sheets; light-gray sodalime feldspar (oligroclase), mostly kaolinized and micacized; biotite (black mica); and a little muscovite. Accessory: Pyrite, apatite, zircon. Secondary: Kaolin, a white mica, calcite.

Associated with this gneiss is a mica diorite gneiss (specimen D, XXX, 51, b), a heavy black rock of fine schistose texture. Its constituents, in descending order of abundance, are biotite (black mica); smoky quartz, with cavities in sheets; green hormblende; soda-lime feldspar (andesine), with accessory pyrite (fifth in order of abundance) ; apatite; and secondary calcite.

Both biotite gneiss and diorite gneiss are crossed by meandering dikelets from under 1 inch to 6 inches thick of a quartz monzonite gneiss (specimen $\mathbf{D}$, $\mathrm{XXX}, 51 \mathrm{c})$ of medium bluish-gray color and fine gneissic texture, with feldspar under 0.1 inch and very fine micas. Its constituents, in descending order of abundance, are light smoky quartz with cavities in sheets and cracks parallel thereto; milk-white soda-lime feldspar (oligoclase-andesine), some of it kaolinized, micacized, and with calcite; blulsh potash feldspar 
(orthoclase), slightly kaolinized; biotite (black mica); and a little muscorite or bleached biotite.

The quarry measured in 1908 about 400 feet from northeast to southwest, with a working face from 30 to 65 feet on the northwest.

Rock structure: The foliation of the main gneisses strlkes N. $35^{\circ}-40^{\circ}$ E. and dips $45^{\circ}-60^{\circ} \mathrm{W}$. As stated, they are cut by a network of meanlering grayish veinlets of quartz monzonite (specimen $c$ ), but they are also crossed by severil dikes of pegmatite from 3 to 20 feet thick, the largest and central one of which contains two inclusions of the gneiss measuring 5 by 10 and 2 to 1 by 10 feet. This pegmatite (specimen D, $\mathrm{XXX}, 51$, e) is of medium pinlishgray color and of very coarse texture, with large feldspars and quartz particles up to 0.5 inch. Its constituents are reddish microcline and orthoclase, but slightly altered; anethystine quartz with cavities in parallel sheets and cracks parallel and at right angles thereto; a little oligoclase, much micacized and kaolinized; muscovite; and biotite. There are crush borders about the feldspars. There are two sets of joints-(a), strike nortleast, verticul, forms a heading near the outside of quarry; (b), strike N. $70^{\circ} \mathrm{W}$., dip $55^{\circ}$ and $30^{\circ}$ S. $20^{\circ}$ W., spaced 3,30 , and 100 feet. Both sets are sllckensided.

The product is used entirely for macadamizing roads in the borough of Torrington. As little as possible of the pegmatite is used, and that is mixed with the gneisses.

\section{WARREN.}

The Comstock prospect is in Warren Township, a mile north-northeast of Warren village and 21 miles east of North Kent. Owner, Reuben Tree Voss, 26 Franklin Street, New York.

The granite (specimen $\mathrm{D}, \mathrm{XXX}, 59, \mathrm{a}$ ) is a biotite granite of medium-gray shade and of medium, inclining to fine texture, with feldspars up to 0.2 and 0.3 inch and mica to 0.2 inch. Its constituents, in descending order of abundance, are clear colorless potash feldspar (microcline); pale smoky quartz, with some cavities in sheets; milk-white soda-lime feldspar (oligoclase), a little kaollnized; biotite (black mica); and a little muscovite or bleached biotite. Secondary: Kaolin, limonite. Both feldspars are intergrown with quartz circular in cross section or in vermicular form. No effervescence with muriatic-acid test. The specimen, coming from a long-exposed upper sheet, hardly does justice to the stone.

The opening, made a number of years ago, is 100 feet square and 5 feet deep.

Rock structure: The sheets, 6 to 14 inches thick, are horizontal. There is a 12-inch pegmatite dike on one side. The exposed surfaces are speckled with limonite stain.

Transportation, by cart 3 miles to North Kent, on New York, New Haven \& Hartford Railroad.

\section{MIDDLESEX COUNTY.}

\section{MIDDLETOWN.}

The Benvenue quarries are in Middletown Township, about $4 \frac{1}{2}$ miles eastsoutheast of the Middletown railroad station, on the mass south of the bend in Connecticut River and from 200 to 350 feet above it. The nearest railroad stations are Benvenue and Maromas, $1 \frac{1}{2}$ miles from the openings. Last operator, Benvenue Granite Co., 41 Park Row, New York. Although these quarries are abandoned they are described on account of their scientific interest.

The granite (specimen D, XXX, 29, a, Maromas granite gneiss, No. 30, of the State preliminary geologic map) is a biotite-hornblende granite gneiss of 
dark bluish-gray color and of fine-grained gneissic texture, with porphyritic feldspars up to 0.3 inch and mica up to 0.1 inch. Its constituents, in descending $0 r^{\circ} \mathrm{der}$ of abundance, are translucent bluish potash feldspar (microcline and orthoclise); clear colorless quartz, showing effects of strain and with cavities in sheets; milk-white soda-lime feldspar (oligoclase) somewhat kaolinized; biotite (black mica); and hornblende. Accessory: Pyrite, magnetite, titanite, apatite, allanite, zircon. Secondary: Kaolin, epidote. No effervesence with muriatic-acid test. ${ }^{61}$

This is a bright, somewhat foliaceous bluish-gray stone, with strong mineral contrasts.

The Beuvenue quarry, about a mile southeast of Benvenue station, half a mile southwest of Maromas, and 200 feet above the river, measures about 400 feet from north to south by 200 feet across and is from 10 to 60 feet deep. The upper quarry, three-fourths of a mile south-southeast of Benvenue station and 350 feet above the river, measures about 300 feet from east to west by $\mathbf{7 5}$ feet across, with a working face on the south 40 to over 60 feet high.

Rock structure: At both quarries the gneiss foliation strikes northwest and dips $15^{\circ} \mathrm{SF}$. The elongation of the gneiss is in a N. $65^{\circ}$ E. direction. The sheets, 6 inches to 6 feet thick, dip $10^{\circ}-20^{\circ} \mathrm{E}$. There are two sets of joints-(a), strike N. $10^{\circ}$ E., dip steep, spaced 5 to 20 feet, forms a 10 -foot heading on the west side; (b), discontinuous, strike east, dip steep, spaced 5 to 20 feet, forms a 10 -foot heading 100 feet from the east end. The rift corresponds to the foliation; the grain is vertical, east-west, and the hardway vertical, north-south. Dikes of white to rose-colored aplite, 1 to 12 inches thick, strike N. $80^{\circ}-90^{\circ} \mathrm{W}$., also $\mathrm{N} .35^{\circ} \mathrm{W}$. Its particles, less than 1 millimeter, consist of quartz, orthoclase and microcline, oligoclase, and scarce biotite, with accessory pyrite, titanite, and allanite. There are pegmatite dikes of smoky quartz bordered with alternating streaks of oligoclase with microcline and hornblende, up to 3 inches thick, striking $N .75^{\circ}$ E. There are also dark-gray elliptical segregations from 2 inches to 3 feet long by 0.5 to 8 inches wide, tapering in the direction of the gneiss foliation. The minerals of these segregations, in descending order of abundance, are microcline with orthoclase, quartz, biotite, oligoclase, hornblende, with accessory apatite, titanite, and zircon.

These quarries were abandoned on account of their overbundance of joints, knots, and dikes.

\section{NEW HAVEN COUNTY.}

\section{ANSONIA.}

The Potter quarry is in Ansonia, about three-fourths mile north-northeast of the center of the village. Operator, William Potter, Ansonia. Idle since 1915.

The granite (specimen D, $\mathrm{XXX}, 45, \mathrm{a}$ ) is a muscovite-biotite granite gneiss of medium bluish-gray color, brightly spangled with mica on the foliation faces, and of fine-grained, unplicated, finely gneissic texture, with feldspars not over 0.2 and mostly under $0.1 \mathrm{inch}$, but with mica to $0.5 \mathrm{inch}$. Its coustituents, in descending order of abundance, are clear bluish potash feldspar (microline and less orthoclase) ; clear colorless quartz, with cavities in sheets ; translucent bluish soda-lime feldspar (oligoclase), slightly kaolinized; muscovite (white mica); and biotite (black mica). Accessory: Apatite, garnet. Secondary: Kaolin. calcite. Efferresces with muriatic-acid test.

${ }^{61}$ For a description of the gneiss of this quarry and its structure see Westgate, I. G., A granite gueiss in central Connecticut: Jour. Geology, vol. 7, pp. 638-654, 1899. 
The stone glistens brightly with mica on its foliation face, but its other two sides are bluish gray without contrasts. Its foliation adapts it for all uses requiring long flat stones.

The quarry, opened about 1890, measured in $190 \mathrm{~S}$ about 200 by 150 feet and 10 to 50 feet deep, with a working face on the northwest 50 feet high.

Rock structure: Foliation and rift strike N. $35^{\circ}$ E. and dip $45^{\circ} \mathrm{S} .55^{\circ}$ E. The sheets, 6 inches to 4 feet thick and normal, nearly coincide with the foliation. There are three sets of joints-(a), strike north, vertical, spaced 10 to 30 feet, forms a heading at the west wall, one (20 feet wide) 40 feet from the northeast wall, and another at that wall; (b), strike east-west, vertical, and discontinuous vertically, spaced rery irregularly, 3 to 5 feet or more; (c) strike N. $75^{\circ}$ E., dip $30^{\circ}$ N. $15^{\circ}$ W., discontinuous vertically, occurs at rare intervals. There are several pegmatite dikes up to a foot thick. A vertical dike striking N. $15^{\circ}-22^{\circ}$ W. crosses the entire quarry. A group of such dikes, 2 feet wide, has a like course. The pegmatite consists of quartz, feldspar, muscovite, and black tourmaline. Rusty stain is up to 6 inches thick on the lower sheet surfaces.

Transportation, by cart to Ansonia.

The product is used for curbing, crosswalks, steps, and coping, mostly for local demands. The Holbrook quarry in Seymour is on the same belt of rock.

\section{BRANFORD.}

The Norcross quarry is in Branford Township, about 11 miles north of Stony Creek village. (See fig. S7.) Operator, Milford Pink-Victoria White Granite Co., Milford, Mass.

The granite (specimens D, XXxx, 93, a, rubbed; b, c, polished; g, rough; Stony Creek granite gneiss, No. 33 of the State preliminary geologic map), "Branford red granite," is a biotite granite gneiss of medium, reddish-rrlas color and of very variable but mostly from medium to coarse. not polphyritic, gneissoid texture, with feldspars from 0.1 to 0.3 and even 0.8 inch and mica to 0.2 and 0.3 inch. Its constituents, in descending order of abundance, are reddish potash feldspar (microcline, some intergrown with plagioclase, and less orthoclase), somewhat kaolinized, some micacized, and some bent; medium smoky or smoky amethystine quartz, showing effects of strain and with cavities in streaks and sheets; milk-white or greenish-white to cream-colored sodalime feldspar (oligoclase to oligoclase-andesine), kaolinized and micacized and witl more or less calcite; biotite (black mica), some of it chloritizerl; and a little muscovite or bleached biotite. Accessoly: Magnetite, pyrite, apatite, zircond. Secondary: Kaolin, whito nicas. calcite, epirlote. zoisite, chlorite, limonite. Both feldspars are intergrown with quartz more or less circular in cross section. The stone effervesces with muriatic-acid test.

A specimen of the finer parts (D, XXIX, 93, j) shows fellspar up to 0.1 inch ani constituents identical with those given above. A specimen of the extra coarse (pegmatitic) parts (D. XXXrX, 93, e) shows feldspars up to 1 and 1.5 inches. Its constituents are the same as of the others, but the microcline is more clominant and the rock therefore a little more pinkish.

$A$ compression test made at the United States arsenal at Watertown, Mass. (No. 6763 ), gives this granite an ultimate compressive strength of 22,447 pounds to the square incl,, rift and grain directions not recorded. Gillmore gire its specitic gravity as 165.4 and its ratio of absorption as $1.201{ }^{\circ}$

62 Gillmore, Q. A., Report on compressire strength, efe., of various linds of building stone from different sections of the United States, etc.. Engineer Iept., U. S. Army, p. 12,1874 . 
The following analysis was made for the firm by Leonard P. Kinnicutt at the Worcester Polytechnic Institute in 1890:

Analysis of biotite granite gneiss from Stony Creek.

Silica $\left(\mathrm{SiO}_{2}\right)$

72. 73

Alumina $\left(\mathrm{Al}_{2} \mathrm{O}_{3}\right)$ and iron oxide $(\mathrm{FeO})$

16.95

Lime $(\mathrm{CaO})$

Magnesia ( $\mathrm{MgO})$ Trace.

Potash $\left(\mathrm{K}_{2} \mathrm{O}\right)$

Soda $\left(\mathrm{Na}_{2} \mathrm{O}\right)$

Loss and undetermined

The marked feature of this rock is its very irregular texture, which is due in part to pegmatitic injection, in part to flow structure, and in part probably

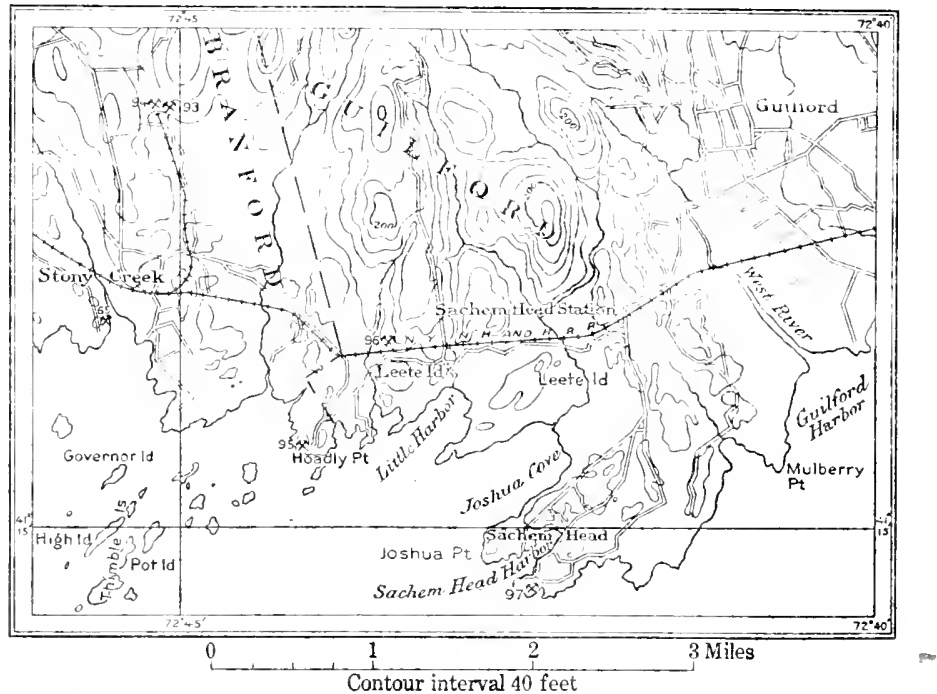

Flguki 87.-Map of Branford and Guilford, Conn., showing location of granite quarries. 65, Brooklyn; 9., Norcross; 94, Stony Creek; 95, Hoadley Neck; 96, Leete Island; 97. Sachem Head.

to snessic foliation. These irregularities are shown in the polished slab illustrated in Plate XXX, A. In places the rock is a flow gneiss; iu others a pegmatite; in others it approaches an aplite in fineness. It is a brilliant stone. Its mineral contrasts lie chiefly between the reddish and whitish feldspars, but these are not everywhere distributed in their normal proportions. It takes a fair polish. The polished face shows some maguetite, some mica, and a little pyrite, and is therefore less suitable for outdoor than indoor use. That its strength and attractive color have more than counterbalanced its irregularity of texture is indicated by the inportant structures in which it has been used.

The quarry, begun in 1887. consists of a lower opening and an upper one 100 feet north of it. The lower one measured in 1908 about 450 feet north to south by 200 feet across and 15 to 65 feet deep; the upper one, about 500 feet north to south by 100 feet across and 15 to 40 feet deep. 
Rock structure: The sheets, 2 to 25 feet thick, are horizontal or inclined $10^{\circ}-20^{\circ} \mathrm{SE}^{\mathrm{cz}}$ There are two sets of joints- $(\mathrm{a})$, strike cist, vertical ur steer, spaced 5 to 75 feet, in upper quarly contined to the sonther'n 100 foet of the quarry, where their spacing is 5 to 20 feet; (b), strilie N. $10^{\circ}$ L. anul $N .5^{\circ}-15^{\circ}$ $W$, vertical, forms a 5 -foot heading on the east side of the lower charry and, extending through the upper one, is spaced 10 to 40 fiet. The $110 \mathrm{w}$ structure, consisting of more or less biotitic or nonbiotitic hands, strikes $N$. $76^{\circ} W^{\circ}$. am $\operatorname{dips} 35^{\circ}-55^{\circ}$ N. $20^{\circ}$ E. to rertical. A slight greissic foliation is prohubly also present, hut is obscured by the flow structure and the permatite. 'Traces of that foliation appear under the microscope in the strained quartz, bent feldspars, and veinlets of secondary muscovite. The rift is reported as horizontal in the upper quarry and dipping $3^{\circ}-5^{\circ} \mathrm{W}$. in the lower, and the gralin as vertical, with $\mathrm{N} .20^{\circ}-30^{\circ} \mathrm{W}$. course. A few inches of "shake structure" occur along the sheet surfaces. Botin knots and inclusions occur. A microscopic description of a knot, from the neighboring guarry of the Stony Creek Red Granite Co., is given on page 380 . Inclusions range from 2 to 1 foot and under to 8 by 3 by 1 foot. One of these (specimen D, XXIX, 93, h) is a black schistose rock with particles under 0.1 inch and consists, in descending orker of abundance, of hornblende, andesine, biotite with muscovite, quart\% and accessory titanite, magnetite, or ilmenite. It is a quartz-mica diorite gneiss. A nedium-gray gneissoid inclusion (specimen D, XXK, 93, (i), with particles under 0.1 inch, consists, in like order, of oligoclase-andesine, quartz, ant biotite, with accessory zircon, and thus is a mica diorite gneiss. Still others ( with oligoclase, quartz, and biotite and accessory pyrite, magnetite, alpatite. titanite, and zircon. The coarser feldspars are zonally arranged about some of the inclusions--that is, they have a pegmatitic border. One inclusion is rimmed with biotite.

Transportation, by siding to New York, New Haren \& Hartford Railroarl, as shown in figure 87.

The product is used mostly for buildings and bridges and some for monuments. Specimens: South Terminal Station, Boston; Bessemer Building, Pittsburgh; Newherry Library and Republic Monument, Chicago; Connecticut River Bridge (arches and coping), Hartford; polished columns ( 43 feet 1, 6 feet 2 inches at buse) of Battle Monument. West Point; olelisk (45 feet long) at Locks Park, Saulte Ste. Marie, American side (see Pl. XXX, $B$ ) ; Eincoln menorial. Hodgenville, hy; General Staff College am Me.lillan fomtain Washington; pedestals of Sheridan monument, New York, and of Hooker monument, statehouse grounds, Boston.

The Stony Creek quarry is in Branford Townstip, about 1$\}$ miles nortl of Stony Creek village, less than one-fourth mile west-northwest of the Norcross quarry and on the opposite (east) side of the same rilge. (See fig. 87.) Operator, Stony Creek Red Granite Co., Stony Creek. Ille since 1915.

The granite (specimens D, XXIX, 94, a, e, rough and polisher!, Siony Creek granite gneiss, No. 33 of the State preliminary geologric map), "Stony Creek rea granite," is a blotite granite gneiss of melium to coarse, not porpliyritic texture. The stoue is identical with that of the Norcross quarry, describer above, except that in the average specimen submitted the potash feldspars are more reldish and the sola-lime feldspars are a greenish-gray, instead of whitish or cream-colored, having evidently retained more of their original color. The effect is to diminish the contrast between the feldspars. The sections also show

os A view of the sheet structure bere is given in a paper by Prof. J. F. Kemp, (iranites of southern Rhode Island and Connecticut [etc.]: Geol, Soc. Amerlca Bull., vol. 10, pp. $361-382,1899$. 
velnlets of secondary muscovite and calcite in the feldspars and of muscovite in the quartz.

The stone effervesces with muriatic-acid test. R. C. Wells, a chemist of this Survey, finds that it contains 0.25 per cent of llme ( $\mathrm{CaO})$, soluble in warm dilute 10 per cent acetic acid, which indicates a content of 0.445 per cent of $\mathrm{CaCO}_{3}$ (calcium carbonate, calcite).

The quarry, opened about 1876 , consisted in 1908 of two openings, an eastern one measuring about 200 feet in a north-northwest direction by 35 to 50 feet across, with a working face on the east, and a western opening measuring about 400 feet in a north-northwest direction by 75 feet across and from 10 to 30 feet in depth, with a working face on the west. This western opening is about 300 feet south of the other, but on the east side of a ridge about 80 feet high and 300 feet west of that which separates the eastern opening from the Norcross quarry.

Rock structure: The sheets, 2 to 12 feet thick, dip $15^{\circ}$ WSW. There are two sets of joints-(a), strike N. $60^{\circ}-70^{\circ}$ E., dip $50^{\circ}-70^{\circ} \mathrm{NNW}$., spaced 10 , 15, 70, and 200 feet; (b), strike N. $30^{\circ}-35^{\circ} \mathrm{W}$, vertical, spaced 5 to 40 feet, forms a heading, 5 to 10 feet wide, on the working face of the western opening. There is a marked flow structure, consisting of biotitic planes or bands striking N. $65^{\circ} \mathrm{E}$. and dipping $60^{\circ}-65^{\circ} \mathrm{NNW}$. The rift is reported as horizontal, and the grain as vertical with a course N. $35^{\circ} \mathrm{W}$. Some of the pegmatite feldspars measure up to 1.5 inches. Some irregular lenses of chloritic quartz are up to 12 inches across. A dark-gray fine-grained knot consists, in descending order of abundance, of microcline and oligoclase in almost equal amounts, biotite, and a little quartz, together with accessory magnetite, apatite, zircon. Rusty stain is up to 8 inches thick on sheet surfaces.

Transportation, by siding to New York, New Haven \& Hartford Railroad.

The product is used mostly for buildings. Specimens: Grand Central Terminal Station, Belleve Hospital, Kent Hall and Philosophy Building of Columbia University; Lord \& Taylor Building, New York; Erie County Sarings Bank, Buffalo, N. Y. ; Rossia Insurance Building. Hartford ; First National Bank, New Haven, Comn.; Guardian Trust \& Savings Building, Clereland, Ohio; Baron von Steuben monument. Washington.

The Opie quarry is in Branford Township, on the road from Stony Creek to North Branford. about a mile north of Stony Creek station. Operator, C. J. Opie, Stony Creek. Idle since 1915.

The gianite, "light pink," is a biotite granite of medium pinkish-gray color and of medium texture, with feldspars up to 0.4 inch and biotite under 0.1 inch. The gneissoid or pegmatitic character of outcrop not determined.

It consists. in descending order of abundance, of pinkish potash feldspar (microcline and orthoclase) ; pale smoky quartz; whitish to cream-colored sodalime feldspar (oligoclase-albite), much kaolinized and micacized; biotite; chlorite; and muscovite. Accessory: Magnetite, pyrite. Secondary: Chlorite, kaolin. a white mica, epidote, calcite. Slight effervescence with muriatic-acid test.

It takes a very fair polish.

This quarry was opened in 1916, but is not now in operation.

The Brooklyn quarry, no longer worked, is on the point west of Stony Creek vilage, in Branford. (See fig. 87.) It was visited by Freeman Ward, then of the faculty of the Sheffield Scientific School, Yale University, who contributes the following observations:

"There are a series of oncnings, extonding 600 or 750 feet about parallel with the shore line, which have not been worked for 20 or 25 sears or nore. 
"The sheets range from the horizontal to a dip of $15^{\circ}$. There are six sets of joints-(a), strike N. $19^{\circ}$ W.; (b), strike N. $49^{\circ} \mathrm{W}$.; (c), strike N. $64^{\circ}-69^{\circ}$ W.; (d), strike N. $79^{\circ}$ W.; all dip $75^{\circ}-85^{\circ}$ N.; (e), strike N. $86^{\circ}$ E., dips $50^{\circ}-55^{\circ}$ N.; (f), less conspicuous, strike N. $71^{\circ}$ E., dip $50^{\circ}-55^{\circ}$ S. $19^{\circ}$ E. Inclusions of a biotite and of a horublencle gneiss measure up to 36 by 12 feet, but some are thin and slablike. Perhaps some of the biotitic streaks are elongated inclusions. All the inclusions, especially the large ones, are likely to be well injected witl granite, and some of them have segregations of garnets. Pegmatite does not occur in definite dikes but in irregular streaks which have no distinct boundaries and grade imperceptibly into the surrounding granite. This pegmatite las generally the appearance of the typical Stony Creek granite but may be coarser, the maximum size of its feldspars being 3 inches."

The unpegmatized granite (specimen D, XXX, 65, a. Stony Creek granite gneiss, No. 33, of the State preliminary geologic map, collected by Mr. Ward but examined by the writer) is a biotite granite gneiss of somewhat dark reddish-gray color and of even-grained melium texture, with feldspar to 0.3 inch and mica to $0.05 \mathrm{inch}$. Its constituents, in descending order of abundance. are pale-reddish potash feldspar (microcline anıl orthoclase), slightly kaolinized; medium smoky quartz, strained and with eavities in sheets; slightly greenish soda-lime feldspar (oligoclase to oligoclase-andesine), more or less micacized and kaolinized; biotite (black mica), some of it chloritized; and a little muscovite or bleached biotite. Accessory: Garnet (fifth in order of abundance), lyrite, zircon. Secondary: Kaolin, a white mica, calcite, chlorite. The stone efferresces with muriatic-acid test.

The Hoadly Neck quarries are in the town of Branford, at the end of Hoadly Point. (See fig. 87.) Operator, estate of Joln Beattie, Peter and Jolnn Beattie, jr., executor's, Leete Island.

The granite (specimens D, XXIX, 95, c, d, from West quarry, Stony Creek granite gneiss, No. 33 of the State preliminary geologic map), "Hoadly Neck West quarry grinite" is a biotite granite gneiss of general medium, inclining to dark reddish-gray color, and of coarse to very coarse banded, plicated gneissic porphyritic texture, consisting of reddisl-gray or whitish lenses and bands alternating with or horlered by thin sheets of black mica and with some thin bands of smoky quartz. The lenses, which are distorted feldspar clystals, com. monly twins, measure up to 3 inches in length and 1 inch in width, and the mica bands 0.1 to 0.2 inch. The texture as seen in hand specimens is shown in Plate XXXI, A. The foliation is coarsely plicated, the plications up to 10 inches in width, and these are in places faulted, as shown in figure 19 (p. 94). The constituents of this biotite granite gueiss, in descending order of abundance, are reddish potash feldspar (microcline, somewhat kaclinized. with some orthoclase); medium smoky quartz, with cavities in sheets; whitish sola-lime feldspar (oligoclase), intergrown with quartz more or less circular in cross section or in rermicular form and generally much micasized; biotite (black mica), some chloritized; and a little green hornblende. Accessory: Garnet, pyrite, zircon. apatite. Secondary: A white mica, kaolin, limonite about pyrite calcite. The stone effervesces slightly with muriatic-acid test.

This stone has marked mineral contrists and striking textural features, as shown in the plate. It is a coarse constructional granite gneiss of warm cray tint.

The stone of the East quarly (specimens D, XXIX, 95, l, In) lacks the coarsely banded porphyritic texture of the other. Its colo: is medium redaish gray, and its texture is gneissic, even grained medium, inclining to fine, with 
fellswars up to 0.3 inch and mica under 0.1 inch. Its constituents are the same as the others, but a thin section shows the light feldspar as oligoclase-albite.

The quarry, opened in 1867, consists of two openings-the West quarry, in 1908 abont 1,500 feet east to west by 800 feet across, with a working face from 30 to 70 feet above sea level, and the East quarry, about 2,000 feet long and curving from west to east by 400 feet across, with working face like the other.

Rock structure: In the West quarry there is a plicated gneissic foliation about horizontal, faulted in places with displacement of a few inches. The sheets of that quarry, 2 to $S$ feet thick, are horizontal or dip $10^{\circ} \mathrm{NE}$. Those of the East quarry, 6 inches to 2 feet thick, turn from the horizontal to dip $10^{\circ}$ E. There are three sets of foints in the West quarry-(a), strike N. $80^{\circ} \mathrm{W}$., vertical, forms a heading at east end, one 5 to $S$ feet wide through the center, spaced 5 to 150 feet; (b), strike about northeast, vertical, spaced 40 to 200 feet; (c), strike N. $20^{\circ}$ W., vertical, spaced 10 feet or more. There are two other sets in the East quarry- $(d)$, strike N. $15^{\circ}$ E., dip $77^{\circ}$ E., spaced 5 to 10 feet or more; (e), strike N. $60^{\circ}$ W., vertical, spaced 5 to 10 feet, forms occasional small beadings. The rlft is reported as horizontal. and the grain as vertical, with $N .65^{\circ}$ E. course at the West quarry and $N .75^{\circ}$ E. at the East quarry, but the difference in their fissility appears to be slight. Pegmatite dikes (specimen, 95, a), 1 to 3 feet thick, strike N. $20^{\circ}-45^{\circ}$ E. They consist of the same miuerals as the gneiss, but in extra coarse particles. There are dikes or bands of fine biotite granite gneiss up to 4 inches thick. Some of these in the West quarry are parallel to the foliation and have been plicated with it, as shown in figure 19. This rock is of medium pinkish-gray color and of very fine to fine gneissic banded texture, with feldspars up to 0.1 lnch, The bands of the coarse gneiss are reddish or light and lark gray or black, from 0.05 to 0.4 inch wide, and result from the distribution of the various minerals in parallel laminae. The constituents of this fine gneiss are identlcal with those of the coarse rock. Allanite is among its accessories. In the East quarry there are dark bands of mica diorite gueiss (specimen $\mathrm{D}, \mathrm{XXIX}, 95, \mathrm{k}$ ) up to 2 feet thick, strike N. $62^{\circ}$ E., dip $75^{\circ}$ N. $28^{\circ}$ W., consisting in descending order of abundance, of biotite, oligoclise-andesine, green hornblende, and quartz. These are either inclusions elongated in the direction of the flow or more probably altered basic dikes.

Transportation, either by siding to New York, New Haven \& Hartford Railroad at Leete Island station or by water. There are seven docks near the quarrles with 8 feet of water at low tide.

The product is used for massive bridge work, buildings, and monument perlestals. Specimens: Anchorage of Suspension 13ridge. Niagara; anchorage of lirst Prookiyn Bridge; approaches and abutments of Madison Avenue Brldge, Harlem River; piers and abutment of Connecticut River Bridge, Hartford; pedlestal of statue of Liberty, Xew York Harbor: of Gen. Anderson monument, Fort Sumter, S. C.; of soldiers and sailors' monument, Riverside Drive, New York. A polished slab of the West quarry stone, 6 by 3 feet. exposed for 20 years at a house near the quarries has stond exposure well, notwithstanding the coarseness of its mica.

\section{GUILFORD.}

The Leete Island quarry is in Guilford Township, abont 350 feet northnortheast of Lepte Island station on the New York. New Haven \& Hartford Rililroad. (See fig. 87.) Operator, Estate of John Beattie, Peter and John Beattie, jr., executors, Leete Island.

The sranite (specimen D, XXIX, 96, a, Stony Creek granite gneiss, No. 33 of the state preliminary geologic map), Iecte IsIand granite, is a biotite 
granite of medium reddish-gray color and of granitic or obscurely gnelsalc, even-grained medium texture, with reldspars up to 0.25 inch and mica to 0.21 inch. Its constituents, in descending orler of abundance, are reddish potash feldspar (microcline and orthoclase, the latter intergrown with soda-lime feldspar), generally fresh; medium smoky quartz with cavities in sheets; cream-colored soda-lime feldspar (oligoclase-albite), micacized, kaolinized, and with calcite; biotite (black mica), some of it chloritized; and a little muscovite or bleached blotite. The microcline is intergrown with guartz more or less circular in cross section. There are crush borlers ahout some of the feldspars, and reinlets of muscovite. Accessory: Magnetite. zircon. Secondary: Kaolin, white micas, calcite, chlorite. It effervesces with muriatic-aciol test.

This stone resembles that of the Norcross and Stony Creek quarries (pp. $377,379)$, but its texture is finer and more regular. Yet it contains here and there some pegmatitic streaks with feldspar up to 2 inches across. Whatever apparent gneissic texture it has is due minly to flow structure.

The quarry is on the southwest side of a knoll and measures about 650 feet from southeast to northwest by 50 to 150 feet across, with a working face on the northeast about 60 feet high.

Rock structure: The sheets, 1 to 6 feet thick, are arched, being level in the center of the hill and lipping to $20^{\circ} \mathrm{W}$. on its west side and $10^{\circ} \mathrm{E}$. on its east side. There is but one set of joints, strike about east, vertical, spaced 5 to 100 feet. There are black knots (specimen $96, \mathrm{~b}$ ) up to 1 by 4 feet, of very irregular outline, of fine-grained black quartz-mica diorite gneiss, consisting (in usual order) of oligoclase, quartz, and biotite, with much magnetlte and accessory apatite, and zircon.

Transportation, by siding to adjoining station.

Product: The quarry has not been worked recently, because of the cheaper transportation by water afforded by the location of the firm's other quarries.

The Sachem Head quarry is in Guilford Township, on Sachem Head, on the south side of Great or Sachem Head Harbor. (See fir. ST.) Operator. Cuast \& Ialies Contracting Corporation, 25 Broad street, New York. Abandonerl in 1914.

The granite (specimens D, XXIX, 97, a, b, c, d, Stony Creck granite gnleiss, No. 33 of the State preliminary geologic map), Sachem Head granite, is a biotite granite gneiss of medium, more or less reddish gray color and of variably gneissic texture, ranging from medium, inclining to fine, even grained, with feldspar to 0.3 inch, to porphyritic, with a matrix of the same charactel containing isolated reddish-buff feldspars up to 0.7 inch, and also with pegmatitic streaks with feldspars up to 1 inch. The mica is mostly under 0.1 inch, and the jegmatitic portions up to 0.2 inch. The constituents of th's rock. in descending order of abundance, are reddish-buff po ash felıspar (microcline and some orthoclase), but slightly kaolinized; medium smoky quariz with cavites in sheets and some cracks ronghly parallel thereto; striated milk-white solalime feldspar (oligoclase-albite), mole or less micacized and with calcite; biotite (black mica), some of it chloritized; and very little muscovite or bleached biotite. Accessory: Magnetite, apatic, zircon. Seconlary: One or two white micas, kaolin, calcite, hematite, chlorite, epidote. Veinlets of muscovite :mel also of calcite. Both feldspars are intercrown with quartz, more or less circular in cross section. The stone efferresces with muriatic-acid test.

Gillmore gave the specific gravity of this granite as 163.7 and its latio of absorption as $1.162 .^{\text {ot }}$

es Gllmore, Q. A., Report on compressive strength, r.t., of various kinds of building stone from different sections of the United States, etc., Engineer Dept., I. S. Army, p. 12,1874 . 
This is a brilliant granite, with greater variations of shade, color, and texture than those of the granite of the Norcross and Stony Creek quarries. The prevalence of "shake structure" has probably prevented its use in buildings and also facilitated its exploitation for other purposes.

The quarry, opened before 1893 , has a working face on the east about 1,000 feet long and from 25 to 50 feet high, averaging about 35 feet, which in the course of excavation had in 1907 receded from 450 to 500 feet. $^{\text {es }}$

Rock structure: A flow structure or gneiss foliation strikes $\mathrm{N} .70^{\circ}$ E. and curves vertically. The sheeis, 3 to 8 feet thick, are horizontal. There is also a coarse horizontal shake structure spaced 0.5 to 3 inches and even 6 inches. In places these minor sheets are 6 inches thick over the whole face. There are two sets of joints-(a), strike N. $70^{\circ}$ E., vertical, spaced 200 to 500 feet; (b), one only, strike N. $40^{\circ}-45^{\circ}$ E., dip $80^{\circ}$. Rusiy stain is a foot wide along the sheet surfaces.

Transportation, by a system of tracks which, starting near the working face, converge at the dock where the barges are moored.

Product: Material for the Point Judith (R. I.) and New Haven breakwaters was supplied from this quariy. The quarry has not been operated since 1913 .

\section{SEYMOUR.}

The Holbrook quarry is in Seymour Township, a mile east of Naugatuck River, near the Ansonia line. Operator, Ansunia Quarry Co., Ansonia. Idle in 1920.

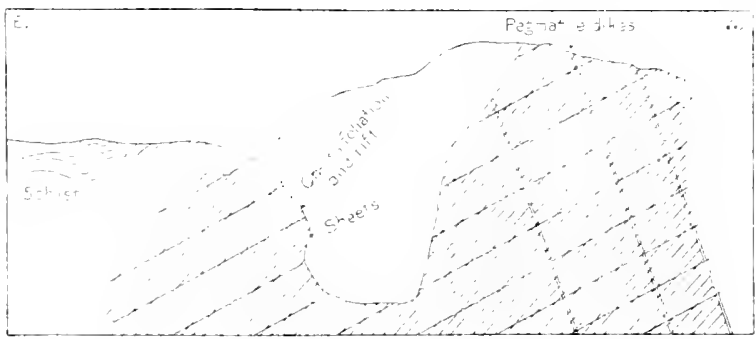

Figure 88.-Section of Holbrook quarry, Seymour, Conn. Sheet structure less regular than drawn.

The granite (specimens D, XXX, 46, a, b) is a muscorite-biotite granite gneiss of marked medium bluish-gray color, spangled with mica on the foliation face, and of fine-grained, slightly plicated, finely gneissic texture, with feldspars not over 0.2 inch and mostly under 0.1

inch but with mica to 0.5 inch. Its constituents, in descending order of abundance, are clear bluish potash feldspar (microcline and less orthoclase) ; clear colorless quartz; translucent bluish soda-lime feldspar (oligoclase), slightly kaolinized; muscovite (white mica), and biotite (black mica). Secondary: Kaolin. No efferrescence with muriatic-acid test.

The granite is identical in composition with that of the Potter quarry, in Ansonia (p. 376), which lies three-fourths mile south, but this is more markedly bluish. The stone glistens brightly on its foliation face, but its other two sides afford no contrasts. Its foliation adapts it well for all uses requiring long flat stones.

The quarry, opened about 1877 , measured, in 1908, about 300 feet from southwest to northeast by 150 feet across and from 50 to 70 feet in depth.

Rock structure: The gneiss foliation strikes N. $25^{\circ}-30^{\circ}$ E. and dips $47^{\circ} \mathrm{S}$. $65^{\circ} \mathrm{E}$. The sheets, 2 to 5 feet thick, incompletely developed, dip $25^{\circ}-30^{\circ} \mathrm{E}$. There are three sets of joints-(a), strike N. $75^{\circ}$ W., vertical, spaced 2 to 30 feet, forms a heading at the south wall and a heading 10 feet wide 75 feet

60 See U. S. Geol. Survey Bull. 484, pl. 5, 1911, for a view of the working face of thls quarry. 
north of it; (b), strike N. $25^{\circ}$ E., dip $45^{\circ}-75^{\circ}$ S. $65^{\circ}$ E. and vertical, spaced 3 to 10 and 30 feet, forms the west wall, and at south end undulates like sheets; (c), undulating, strike N. $30^{\circ}$ E., dip $30^{\circ}$ N. $60^{\circ}$ W.; one at east side. The rift coincides with gneiss foliation, and the grain with the same strike dips $25^{\circ} \mathrm{W}$. On the east the gneiss is in contact with an overlying mass of biotite-quartz feidspar schist. (See fig. 88.) This schist (specimens D, XXX. 46, c, d) is more or less intensely plicated. In thin section it consists, in descending order of abundance, of quartz, biotite, microcline with orthoclase, pyrite, and garnet. It is probably of igneous origin. Pegmatite (of feldspar, smoky quartz, muscovite, and black tourmaline) appears in numerous dikes from 6 inches to 2 feet thick. Of a set striking $\mathrm{N} .10^{\circ}-15^{\circ} \mathrm{W}$., there are five spaced 15 to 20 feet. Another set of three striking N. $35^{\circ} \mathrm{E}$. is spaced 10 to 18 feet. There is very little stain.

Transportation, by cart $1 \frac{1}{2}$ miles to railroad at Ansonia.

The product is used for curbing, circulars, marking and bltching posts, crosswalks, trimmings, and concrete for local demands. Specimens: Trimmings on Fountain Hose Fire Co. Bullding, Ansonia, and on St. Francis Parochial School, Naugatuck.

\section{NEW LONDON COUNTY.}

\section{GROTON.}

The Salter quarry is in Groton Township, on Thames River, three-fifths mile south-southeast of the Groton ferry landing. Operators, John Salter \& Son, Groton.

The granite (specimen D, XXX, 4, a, Westerly granite of Rice and Gregory's Manual of geology of Connecticut), "Groton," is a quartz monzonite of medium, slightly greenish gray color, and of even-grained, fine granitic texture, with feldspars and slender micas up to 0.15 inch but mostly not over 0.1 inch. Its constituents, in descending order of abundance, are light-gray soda-lime feldspar (oligoclase), mostly kaolinized and micacized and with calcite; light smoky quartz with hairlike crystals of rutile; medium, slightly greenish gray potash feldspar (microline, slightly kaolinized, with orthoclase) ; biotite (black mica) some of it chlorltized; and a little muscovite or bleached biotite. Accessory : Magnetite, apatite, allanlte. Secondary : A white mica, kaolin, calcite, limonite, chlorite.

An estimate of the mineral percentages by the Rosiwal method, applied to a camera-lucida enlargement ( 25 diameters) of a thin section, yields these results with a mesh of 0.7 inch and total linear length of 43.4 inches: Sodalime feldspar (oligoclase), 41.25; quartz, 38,00; potash feldspar (microcline and ortloclase), 16.35; black mica (biotite), 2.80 ; magnetite, 1.60 . The average diameter of the particles calculated from the same measurements is 0.0235 inch.

The stone effervesces with muriatic-acid test. R. C. Wells, a chemist of this Survey, finds that it contains 0.18 per cent of CaO (lime) soluble in warm dilute (10 per cent) acetic acid, which indicates a content of 0.32 per cent of $\mathrm{CaCO}_{3}$ (calcium carbonate, calcite).

This is a monumental granite closely related to the blue granites of Westerly, R. I., but of about half as fine a texture. (See p. 406.) The floral carving reproduced in Plate XXXIII, $B$, shows its adlaptation to sculpture. As in quartz monzonites generally, the contrast between its polished and cut face is marked. Minute particles of magnetite and pyrite appear on the polished face.

The quarry, opened about 1835, measured in 1908 about 550 fert in a nortleast direction by 50 to 100 feet across and from 20 to 30 feet in depth. 
Rock structure: The granite forms an apparent dike, 12 feet thick, dipping about $20^{\circ} \mathrm{E}$. between two masses of gray and black diorite gneiss (specimen $\mathbf{D}$, $\mathrm{XXX}, 4, \mathrm{~b}$, New London granite gneiss, No. 35, of the State preliminary geologic map), with a foliation striking N. $65^{\circ}$ W. and dipping $75^{\circ}$ N. $25^{\circ}$ E., which is injected with pegniatite. This gneiss consists of quartz, oligoclase, microcline, and hornblende, named in the usual order. The granite sheets are short, lenticular, 2 to 12 feet thick, and dip $20^{\circ} \mathrm{SW}$. The sheets in the gueiss eapping, which is 10 to 20 feet thick, are 6 inches to 5 feet thick and dip $15^{\circ} \mathrm{S}$. There are no Joints. The rift is reported as dipping about $10^{\circ} \mathrm{NE}$, and the grain as vertical, with $\mathrm{N}$. $70^{\circ} \mathrm{E}$. course. Niles ${ }^{\circ}$ in 1876 reported evidences of compressive strain at this quarry.

Transportation, by cart to wharf or rail at Groton.

The product is mostly monumental stone and some for trimmings. The gneiss is sold for breakwater use. Specimens: Monument to Col. William Ledyard (killed in battle of Groton Heights, 1781) in Ledyard Cemetery. Groton ; monument to first four founders of Stonington at Wequetequock burying ground, Stonington; Edward Newman obelisk, Woodlawn Cemetery, New York; Rev. Byron A. Woods sarcophagus, Forest Hill Cemetery, Philadelphia; Charles Tyler statue, Druid Hill Ridge Cemetery, Baltimore; Kennard Celtic cross, Kensico Cemetery, Valhalla, N. Y., shown in Plate XXXIII, $B$.

The McIntosh quarry is in Groton Township, on Broad Street extension, a mlle northeast of Groton village, on the E. W. Crouch farm.

The granite (specimen D, XXX, 2, a, Mamacoke gneiss, No. 36 of the State preliminary geologic map) is a biotite granite gneiss of general medium pinkishgray color and of gneissic banded texture, with pinkish and grayish bands from 0.5 to 0.3 inch wide. Its particles are fine, with feldspars up to 0.2 inch. Its constituents, in descending order of abundance, are light-pink potash feldspar (microcline. somewhat kaolinized), intergrown with quartz more or less circular in cross section; light smoky quartz; milk-white soda-lime feldspar (oligoclase to oligoclase-anclesine), mostly much kaolinized and micacized and with calcite; biotite (black mica), much chloritized; and a little muscovite or bleached biotite. Accessory: Magnetite, pyrite, garnets, tourmaline, zircon. Secondary: A white mica, kaolin, chlorite, calcite. A band of quartz and microcline is 1.12 millimeters wide. The stone effervesces with muriatic-acid test.

This Is an attractive stone, on account of its delicate color and banded texture.

Rock structure: The gneiss foliation is vertical, with about east to west course. The rift is transverse to the foliation. Both rift and grain fractures are smoother thau those along the follation.

The Eckerlein quarry is in the township of Groton. about half a mile eastsoutheast of Center Groton, nearm the top of a north-south ridge. Operator, Rolert Eckerlein, R. D. 1, Groton. Idle since 1913.

The granite (specimen $\mathrm{D}, \mathrm{XXX}, 13$, a, related to Westerly granite), "Center Groton granite," is a quartz monzonite of medium, inclining to dark greenishgray color and of even-grained, fine granitic texture, with feldspars and slender micas up to 0.1 incls. Its constituents, in descending order of abundance, are greenish-gray sola-lime feldspar (oligoclase), micacized and kaolinized and with calcite; light smoky quartz, with hairlike crystals of rutile and cavities in sheets, with cracks parallel thereto; slightly buff-gray potash feldspar (microcline and orthoclase), some of the microcline kaolinized and micacized in center and also intergrown with quartz more or less circular in cross section; biotite

o Niles, W. H., The geological agency of lateral pressure exhibited by certain movements of rocks: Boston Soc. Nat. Hist, Proc., vol. 18, p. 279, 1875-76. 
(black mica), mostly chloritized and with needles, probably of rutile; and some muscovite or bleached biotite. Accessory : Magnetite, apatite, allanite, rutile. Secondary: Kaolin, white micas, calcite.

Some of the granite (specimen D, XXX, 13, b) is of medium-gray shade and warm tint, with texture and constituents like those of the other. The potash feldspar is, however, faintly pinkish, and the soda-lime foldspar (oligoclase to oligoclase-andesine) is milk-white. Zircon is accessory. Both rocks effervesce witl muriatic-acid test.

An cstimate of the mineral percentages male by applying the Rosiwal method to a camera-lucida enlargement (25 diameters) of a thin section yielts these results with a mesh of 0.8 inch and a total linear length of 45.7 inches: Sodalime feldspar (oligoclase), 35.18; quartz, 29.90; potash feldspar (microline and orthoclase), 29.67; black mica (biotite). 4.16; magnetite, 1.09 . The arerage diameter of the particles calculated from the same measurements is 0.0256 inch.

These are fine-grained monumental granites, about half as fine as "Blue Westerly" but of different color. (See p. 406.)

Like other quartz monzonites, these cut and lammer light, the cut or hammered face aftording not a little contrast of shade to the frolished face, which is darker than the rough face.

The quarry, opened in 1S55, measured in 1908 about 150 by 100 feet and 25 to 40 feet in deptl.

Rock structure: The darlier granite (specimen 19, a), is 10 feet thick and overlies the lighter (specimen 13. b). The sheets, 22 inches to 13 feet thick, dip gently east and south. There are two sets of joints-(a), strike N. $15^{\circ} \mathrm{W}$., dip $65^{\circ}$ E.. spaced 5 to 50 feet; (b), strike N. $80^{\circ}$ E., vertical, one only in center. The rift is reported as striking north and dipping sicep east, and the grain as east-west, with steep south dip. Both are equally marked. A 4-foot pegmatite dike, with feldspars up to 12 inches and muscovite to 6 inches, strikes $N, 10^{\circ} \mathrm{W}$. Rusty stain is 2 to 4 inches thick on sheet surfaces.

The Kopp quarry is in Groton Township. about half a mile somtheast of Center Groton and one-fomth mile S. $30^{\circ} \mathrm{W}$. of the Everlein quarry operators, J. K. Kopp \& Sons, New London, Quarry abamdonerl.

The granite (snecimen D. XXX, 12. a, related to Westerly crainite) is a quartz monzonite of medium, faintly greenish gray color and of even-grined. fine to vory fine granitic texture. with feldspars and mica to 0.05 inch.

This is a monumental granite of finer texture tlan that of the Ecker]ein quarry, more nearly like that of "blue Westerly" (see p. 406), and of shade 1ntermediate between specimens a and b of the Eckerlein quarry.

The quarry was opened in 1890.

The stone is used for momments and ants light.

The McGaughey quarry is in Gritin Townslip. in the village of Mystic, half a mile northwest of Mystic station. Oporatol. William R. Moraughey, Mystic. Idle in 1922.

The granite (specimens D. XXX. 20, a, b, related to Westury ylute), "Iystic granite," is a quartz monzonite of merlim, inclining to dark, faintly greenish-gray color, and of even-glatsed. Hine granitic textme. With foldspels and mica under 0.2 inch. Its constituents. in desenfing order of alumlance. are

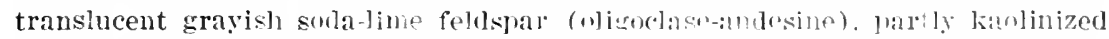
and micaized; medinm snoky quartz with lairlike crystals uf rutilu alud cavities in sheets; clear colorless to faintly pinkish potash foldspar rmiclocline and orthoclase), intergrown with quartz mope or less rircular in cross section; biotite (black mica), some of it chloritized; and a little nuswerite or bleached biotitc. Accessory: Magnetice, psrite, apatite, allanite, zircon, purple fluorite. 
Secondary : Kaolin, a white mica, calcite, chlorite. It effervesces with muriatlc acid test.

This is a monumental granite, almost as fine as "blue Westeriy" but with more abundant black mica and thus of darker shade. It cuts light gray and polishes dark gray. The polish is fair but shows pyrite and magnetite. The stone is reported as "very hard."

The quarry, opened before 1827 , measured in 1908 about 100 feet from east to west by 35 feet across, with a 50-foot working face (cliff) on the south.

Rock structure: The granite forms an apparent dike, 25 feet thick, underlain by a coarse biotite granite gneiss (specimen $\mathrm{D}, \mathrm{XXX}, 20$, d, Mamacoke gneiss, No. 26 of the State preliminary geologic map) and dipping gently south into the base of the cliff and also overlain near its top by a similar gneiss. The sheets, 6 inches to 5 feet thick, but mostly under 13 inches, are about horizontal. The foliation of the gneiss dips steep north or vertical. The only set of joints strikes N. $40^{\circ}$ E., dips $65^{\circ} \mathrm{S} .50^{\circ} \mathrm{E}$., forms a 10 -foot heading in middle, and is siacer 5 to 30 feet. A rertical "blind seam," striking N. $60^{\circ}$ E., proves to be a veinlet of a zeolite. (See p. 75.) A vertical pegmatite dike strikes $\mathrm{N}$. $30^{\circ} \mathrm{W}$. There are also dikes of pegmatite and aplite in the gneiss. An inclusion of the gneiss, 4 by $2 \frac{1}{2}$ feet, lies in about the center of the granite mass.

Transportation, by cart to New York, New Haven \& Hartford Railroad.

The product is used for monuments.

\section{EAST IYME.}

The Malnati quarry is in East Lyme Township, 2 miles northwest of Niantic station and 160 feet above it. Operators, A. Malnati \& Co., 76 Liberty Strcet, Quincy, Mass.

The granite (specimen D, XXX, 7, a, rough; e, polished and hammered, related to Westerly granite), "golden-pink Niantic," is a quartz monzonite of medium pinkish-gray color and of even-grained, fine granitic texture, with Peldspars and mica up to 0.1 inch. Its constituents, in descending order of abundance, are light smoky quartz, with hairlike crystals of rutile and with few cavities; translncent pinkish to milk-white soda-lime feldspar (ollgoclase), considerably kaolinized, micacized, and with calcite; clear colorless to translucent white potash feldspar (microcline and a little orthoclase); biotite (black mica), some of it chloritized; and a little muscovite or bleached biotite. Both feldspars are intergrown with quartz more or less circular in cross section. Accessory: Magnetite, apatite. Secondary: Hematite from magnetite, kaolin, a white mica, caicite.

A somewhat darker granite (specimen D, XXX, 7, b), "golden-pink dark," from the same quarry, is of medium, inclining to dark pinkish-gray color and of the same texture and composition as the other, but the quartz is more smoky (section shows cavities in sheets), the oligoclase is more altered and darker, and zircon appears. Both granites effervesce with muriatic-acid test.

An estimate of the mineral percentages by the Rosiwal method, applied to a camera-lucida enlargement (25 diameters) of a thin section, yields these results with a mesh of 1.5 inches and total linear length of 27 inches: Quartz, 35.41; soda-lime feldspar (oligoclase), 32.74; potash feldspar (microcline and ortloclase), 29.48 ; black mica (biotite), 1.93 ; magnetite, 0.44 . The arerage diameter of the particles, calculated from the same measurements, is $\mathbf{0 . 0 2 7 5}$ inch.

These granites are reddish monumental granites of about half the grade of fineness of "blue Westerly." Owing to streaks which are said to appear 
on large polished faces, the stone is used chiefly for rough and hammered or carved work hut is admirably adapted for inscriptions, the light pinktshgray hammered face contrasting strongly with the redlish-brown polished face (specimen 7 , e).

The quarry, opened in 1900, measured in 1908 about 250 feet from east to west by 65 feet across and 75 feet in depth.

Rock structure: The granite occurs in a dikelike mass, 40 fect thick, dipping about $20^{\circ}$, between a lower and an upper mass of gneiss. which has a foliation striking N. $30^{\circ}$ E. and dippins $50^{\circ} \mathrm{S} .60^{\circ}$ W. This (Mamacole granite gneiss. No. 36 of the State preliminary geologic map) is a biotite granite gneiss of medium, slightly pinkish gray color and of medium gneissic texture. Its quartz is light smoky with cavities in sheets; its felispars are light-pink nicrocline and orthoclase and milk-white oligoclase. The overlying mass is 20 feet thick and is more altered and weathered, its feldspars having largely passed into crystalline kaolin, making the rock very friable. The granite sheets, 3 to 10 feet thick, are short, irregular lenses. There are two sets of joints-(a), strike N. $5^{\circ}-10^{\circ} \mathrm{W}$, vertical, spaced 3 to 15 feet; (b), strike east, rertical, spaced 3 to 15 feet. The rift is reported as north-south and the grain as east-west, both vertical and of like fissility. Rusty stain is 2 to 4 inches thick on sheet surfaces.

Transportation, by cart over 2 miles to Niantic.

The product is used for monuments, which are finished at Quincy, Mass.

The Carlson quarry is in East Lyme Township, about 2 miles northwest of Niantic station and about 600 feet southwest of the Malnati quarry. Operator, William Sieverts, Niantic, Conn.

The granite, "golden-pink," is a quartz monzonite of medium pinkish-gray color and of even-grained, very fine granitic texture, identical in composition and qualities with that of the Malnati quarry, described above.

The quarry, opened in 1900 , measured in 1908 about 125 by 75 feet and 10 to 30 feet in depth.

Rock structure: The granite occurs in a dikelike mass, 40 feet thick, dipping about $30^{\circ} \mathrm{S}$. between masses of biotite granite gneiss jdentical with that at the Malnati quarry. The foliation of the overlying gneiss, which is 20 feet thick, strikes N. $80^{\circ} \mathrm{W}$. and dips $25^{\circ}-30^{\circ} \mathrm{N}$. $10^{\circ} \mathrm{E}$. The granite sheets, up to 10 feet thick, are short shelly lenses with irregular dip. There are two sets of joints-(a), strike N. $40^{\circ}-55^{\circ}$ E., curving vertically, spaced 5 to 12 feet; (b), strike about north, vertical, forms a heading at east side and one or two at west side.

Transportation, by cart 2 miles to Niantic.

The product is used for monuments.

LYME.

The Joshua Rock quarry is in Lyme Townshlp at Joshua Rock. on the eas? shore of Connecticut River, 2 miles north of Essex Wharf. It is abandoned.

The granite (specimens D, XXX, 17, a, b. Lyme granite gneiss, No. 34, of the State preliminary geologic map), variegated granite, is an aegirite granite gneiss of general melinm, inclining to dark, slightly purplish gray color with fine redolish, pinkish, greenish, and black hands, also cherry-red spots. Its texture is fine gneissic, banded with feldspar and black silicate under 0.2 inch. Its constituents, in descending order of abumdance, are clear colorless to dense pinkish potash feldspar (microcline), more or less kaolinizod and cuarsely intergrown with guart\%; light smoky (fuartz with cavities in theets and cracks parallel thereto; milk-white soda-lime feldspar (oligoclase-albite) more or less kaolinized; and black aegirite (green in thin section). Acces- 
sory: Magnettte (or ilmenite), titanite, yellow colophonite (lime-iron garnet), these three in some abundance, zircon, allanite. Secondary: Hematite and IImonite stain, calcite, kaolin. No effervescence with muriatic acid test. The banding is due to the rarying abundance or absence of aegirite or the preponderance of quartz or feldspar in parallel planes. The quartz and feldspar are stained cherry-red from hematite, either evenly in bands or else in irregularly disseminated spots.

The quarry is on the west side of a cliff 60 feet high, which is the working face.

Rock structure: The gneiss foliation strikes N. $75^{\circ}-80^{\circ} \mathrm{W}$. and dips $45^{\circ}$ N. $10^{\circ}-15^{\circ} \mathrm{E}$. There are passages of biotite and other black silicates (dikes or knots?) 1 to 3 feet thick (specimen D, XXX, 17, c). Vertical joints strike north.

The Selden Neck quapries are in Lyue Township, on Selden Neck, on the east shore of Connecticut River, opposite Deep River station. Owner, A. W. Parker Co., 361 Fulton Street. New York. Quarries abandoned.

The granite (specimens I. XXX, 15, a. b. Mamacoke gneiss, No. 36, of the State preliminary geologic map) is a hornblende-biotite granite gneiss of medium, inclining to dark reddisb-gray color streaked with black, and of fine gneissie texture, with lenses and laminae of black silicates 0.1 to 0.2 inch apart and with feldspar particles under 0.1 inch. Its constituents, in descendtng order of abundance, are reddish-gray potash feldspar (orthoclase and less microcline); light smoky quartz, with cavities in sheets; a little reddish-gray soda-lime feldspar (oligoclase); greenish hornblende; and biotite (black mica). Accessory: Apatite, zircon. Secondary: Hematite, limonite, kaolin, calcite. Both feldspars are somewhat kaolinized. The stone effervesces slightly with muriatic-acid test.

This is a fine-grained reddish constructional granite with conspicuous bright black streaks and lenses but without other mineral contrasts.

There are two quarries-a southern one east-southeast of Deep Rirer station. and a northern one east of it. The former measures about $250 \mathrm{by} 40$ feet. with a working face on the east. The other, about one-fourth mile west-northwest of it. measures about 200 feet from east to west. with a working face on the north 60 feet high.

Rock structure: At the south quarry the gneiss foliation strikes N. $80^{\circ}-85^{\circ}$ E. and dips $20^{\circ}-25^{\circ} \mathrm{N} .5^{\circ}-10^{\circ} \mathrm{W}$. The sheets, 1 to 3 feet thick, dip with the foliation. There are four sets of joints-(a), strike N. $70^{\circ}$ E., dip $75^{\circ} \mathrm{S} .20^{\circ} \mathrm{E}$., suaced 2 to 5 feet; (b). strike north, vertical, spaced 2 to 5 feet; (c), strike N. $40^{\circ} \mathrm{E}$, vertical; (d), strike N. $75^{\circ}-80^{\circ} \mathrm{W}$, dip $30^{\circ} \mathrm{S} .10^{\circ}-15^{\circ} \mathrm{W}$. At the northern opening the gneiss foliation strikes N. $75^{\circ}$ E. and $\operatorname{dips} 25^{\circ} \mathrm{N} .15^{\circ} \mathrm{W}$. The sheets, 2 to 6 feet thick, dip with the foliation. There are two sets of joints-(a), strike N. $50^{\circ}$ E., vertical; (b), N. $10^{\circ}$ E., vertical or steep east, forming an 8-foot wide heading at east edge of quarry. Pegmatite dikes, 1 inch to 2 feet thick, dip low northeast. The rift at both quarries is parallel to the long axes of the lenses and at right angles to the gneiss foliation. The grain is parallel to that foliation, and the hard way is transverse to it and to the lenses.

\section{OLD LYME.}

The MacCurdy quarry is in Old Lyme Township, on Duck River, between Lyme village and the Iyme and Blackhall station. Owner in 1908, Mrs. Evelyn MacCurdy Salisbury, 237 Church Street, New Haven, Although this little quarry has not been worked for many years, it is described on account of the attractIveness of its stone. 
The granite (specimens D, XXX, 49, b, c, l, the last being a polisherl cube with edges 3.5 inches), "MacCurdy granite," is a pegmatite with the composition of a biotite granite. Its general color is medium pinkish to reddish gray spotted with black. Its texture is very coarse porphyritic, with feldspars up to 1.5 inches (exceptionally to 4.5 inches) and mica mostly under 0.5 inch (exceptionally up to $1 \mathrm{inch}$ ). Its constituents, in descending order of abundance. are pinkish to reddish potash feldspar (orthoclase and microcline, both minutely intergrown with oligoclase), somewhat micacized; light to medium smoky quartz with cavities in parallel or intersecting sheets; lignlit pinkish to cream-colored and milk-white, rarely clear striated soda-lime feldivall (oligoclase). generally micacized; and biotite (black mica), some of it chloritized. Accessory: Magnetite, pyrite, apatite (considerable), and zircon. Secondary: White micas, calcite, hematite, chlorite. ${ }^{\text {a }}$

The stone elfelvesces with muriatic-acid test. li. (. Wells, a chemist of this Survey, finds that it contains 0.46 per cent of CaO (lime) soluble in warm dilute 10 per cent acetic acid, which indicates a content of 0.82 per cent of $\mathrm{CaCO}_{3}$ (calcium carbonate, calcite), the presence of which is also shown in the section.

W. P. Blake, in in 1880 , determined the specific gravity of the reddish feldspar as 2.580 and that of the granite as 2.643 , and the weight of a cubic foot of it as 165.2 pounds, or 12.106 cubic feet to 2,000 pounds.

The contrasts between its minerals, the cleavage planes of the large porphyritic feldspars retlecting the light, the iridescence of some of the feldspars, and the attractiveness of its general color make this an unusual rock. The polished face brings out the colors still more strongly. It is well adapted in the rough for monumental use and, when polished, for internal decorations. Between 1871 and 1881 this pegmatite was examined more or less thoroughly by James D. Dana, A. Daubrée, Des Cloiseaux, G. W. Hawes, W. P. Blake, C. U. Shepard, and specimens of it were exhibited at the expositions of Philadelphia, 1876, and Paris, 1878. Newberry ${ }^{\text {ss }}$ referred to it in his Tenth Census report on building stones.

The quarry measures about 50 by 30 feet and from 5 to 10 feet in depth, but some rock was probably quarried above the present surface.

Rock structure: Several dikes of the pegmatite, 15 to 22 feet thick, have penetrated a mass of banded gneiss parallel to its foliation, which strikes $\mathrm{N}$. $50^{\circ}-60^{\circ}$ E. and $\operatorname{dips} 40^{\circ}-45^{\circ} \mathrm{N}, 30^{\circ}$ E. At one point the pegmatite apparently crosses the foliation of the gneiss horizontally. The gneiss (specimen D, XXX, 49 , a, Lyme granite gneiss, No. 34 of the State preliminary geologic map) is a biotitic quartz monzonite sneiss of medium, inclining to dark gray color, with fine bands of various grays, and of fine mneissic texture, with particles under 0.2 inch and bands from 0.1 to 0.3 inch. The constituents of the bands crossed by one thin section are, in the usual order, quariz with cavities in many parallel sheets, with rift cracks para!lel ther io, some of them filled with fibrous muscuvite, also with a set of sparser and finer cracks at right angles to the first set (the rift coincides with the foliation of the rock), oligoclase, orthoclase, and biotite.

Transportation. by cart about half a mile to New York, New IIaven \& Hartfort Railroad.

e7 This granite was first examined microscopically by Des Cloiseanx, who reararded the feldspar intergrown with the microcline as albite. See Am. Jour. Sci., 3d ser., vol. 20, p. 335,1880 .

Tenth Census, vol. 10, p. $321,1884$. 
Product: The Channing Memorial Church, with its steeple, at Newport, R. I., was built of this stone in 1881. The trimmings, however, were of light and dark gray granite.

\section{STONINGTON.}

The Masons Island quarry is in Stonington 'Township, at the northwest end of Masons Island, on Pine Ifill. Operators, E. S. Belden \& Sons, Hartford. Quarry abandoned.

The granite (specimen D, XXX, 21, a, Mamacoke gneiss, No. 36, of the State prelininary geologic map) is a quartz monzonite flow gneiss of banded light and dalk gray shade. Its texture is evell grained, fine, banded, with feldspars under 0.2 inch and mica under 0.1 inch. Its constitutents, in descending order of abundance, are pale smoky quartz, with cavities in sheets; milk-white sodalime feldspar (oligoclase. probably), some of it micacized; clear colorless potash feldspar (microcline, probably a little orthoclase also); and biotite (black mica). Accessory: Magnetite, garnet, allanite, zircon.

The quarry, opened in 1850, measured in 1908 about 200 feet from east to west, with a working face 30 to 60 feet high on the north.

Rock structure: The rock appears to be a granite with flowage bands caused by the different distribution of the biotite in parallel bands. The banding dips low west. There are lenses of coarse pegmatite (white and pink feldspar and biotite) parallel to the bands. There are also dikes of this pegmatite, some vertical, some dipping southeast or northwest. ${ }^{.9}$ The sheets, 6 inches to 4 feet thick, are horizontal. One joint only, strike about east-west.

Transportation, by track 450 feet to dock on Mystic Harbor.

The product is used entirely for riprap for breakwater construction.

The New Anguilla quarry is in Stonington Township, a mile east of Anguilla Creek, and $1 \frac{1}{2}$ miles west-northwest of the station at Westerly, $\mathbf{R}$. $\mathbf{I}$. Operator, Morrison Granite Co. (Inc.), Westerly, R. I. Idle since 1913.

The granite (specimen D, XXX, 19, b), “New Anguilla," is a quartz monzonite of medium, slightly bluish gray color and of even-grained, fine granitic texture, with feldspars under 0.1 inch and mica under 0.05 inch. Its constituents, in descending order of abundance, are light smoky quartz with cavities; milkwhite soda-lime feldspar (oligoclase), much kaolinized, micacized, and with calcite; in about equal amount slightly bluish-gray potash feldspar (microcline and orthoclase), intergrown with quartz, more or less circular in cross section; biotite (black mica), some of it chloritized; and a little muscovite or bleached biotite. Accessory: Titanite, apatite, magnetite, pyrite, zircon. Secondary : Kaolin, a white mica, calcite. The stone effervesces with muriatic-acid test.

This is a monumental granite resembling "blue Westerly" (p. 406) in color and texture. Like other quartz monzonites, it cuts and hanmers light.

The stone from another opening (specimen D, XXX, 19, c) is of light-buff, inclining to medium-glay color and of evell-grained, medium texture, with feldspars up to 0.25 inch and mica under 0.1 inch. It consists of cream-colored feldspar, medium smoky quartz, and black mica. It effervesces with muriaticacid test. This is hardly suitable for monumental use.

The quarry, opened in 1908, measured about 100 feet from east to west by 30 feet across and averaged 4 feet in depth. Another opening 500 feet south was 40 by 20 feet and 5 to 8 feet deep.

Rock structure: The bluish-gray quartz monzonite has a capping of gneiss 3 to 5 feet thick. This (specimen D, XXX, 19, a), probably Putnam gneiss of

${ }^{60} J$. F. Kemp described this pegmatite in his Granites of soutbern Rbode Island and Connecticut: Geol. Soc. America Bull., vol. 10, pp. 373, 374, 1899. 
Rice and Gregory, ${ }^{70}$ is a biotite granite gneiss of medium gray shade, finely banded with dark gray, and of fine to very fine unplicated gneissic texture, with feldspars under 0.1 inch and miea uncler 0.05 inch. Its constituents, in the usual order, are microcline, quartz, oligoelase, and biotite, with accessory magnetite, apatite, zireon, allanite. The foliation strikes nearly east and is vertical. The contact between granite and gneiss is in places very jagged or bordered with 12 inches of pegmatite and aplite, which also penetrate the gneiss. The sheets, exposed in 1908, were 6 inches to 5 feet thick. There are three sets of joints- $(a)$, strike east, vertical; $(b)$, strike north, vertical and discontinuous; $(c)$ (one only), strike N. $60^{\circ} \mathrm{W}$., dip $55^{\circ} \mathrm{S}$. $30^{\circ} \mathrm{W}$. The rilt is reported as horizontal, and the grain and hard way as equally fissile. The flow structure dips $25^{\circ} \mathrm{S}$. At the south opening a dike or band of the quartz monzinite, 10 feet wide, has the medium-grained granite, described on page 392, on both sides of it. Flow structure dips $50^{\circ}-70^{\circ} \mathrm{S}$.

Transportation, by cart 2 miles to Westerly, R. I.

The blue-gray quartz monzonite is used for monuments.

The Murray quarry is in the village of Pawcatuck, in Stonington Township, about three-fourths mile northwest of Westerly station. Quarry no longer operated.

The granite (specimen D, XXX, 18, a, Sterling granite, No. 24 of the State preliminary geologic map), "red Westerly," is a biotite granite of dark, inclining to medium reddish-gray color and of even-grained granitic medium, inclining to coarse texture, with feldspar up to 0.4 inch (exceptionally 0.5 inch) and mica to 0.2 inch, but mostly under 0.1 inch. Its constituents, in descending order of abundance, are reddish potash feldspar (microcline and orthoclase), slightly kaolinized; amethystine smoky quartz, with cavities in sheets; cream-colored striated soda-lime feldspar (oligoclase to oligoclasealbite), much kaolinized and micacized, in places stained red from hematite; biotite (black mica), some of it chloritized; and a little muscovite or bleached biotite. Accessory: Magnetite, pyrite, apatite, allanite, zircon. Secondary: White micas, kaolin, chlorite, calcite, limonite from allanite, hematite from magnetite. Marked effervescence with murlatic-acid test.

This is a brilliant constructional granite of attractive tint. Its mineral contrasts are between its black mica and pink and cream-colored feldspar. The stone is illentical with that of the Redstone quarry at Westerly, $R$. I. (See p. 412.)

Another biotite granite (specimen D, XXX, 18, b) from the sime quarry is of dark, inclining to medium, slightly reddish-gray color. It is a little darker and less redilish than the stone described above. Its texture is even-grained medium, with fellspar to 0.3 inch and mica to 0.1 inch. Its constituents are iike those of the other, but the sorla-lime feldspar is of greenish-gray color. The effect of this and of the finer texture of the stone is to darken its general shade.

The quarries, opened abont 1859, are two-a northern one, measuring in 1908 about 150 by 75 feet, with a to-foot working face on the west, and a southern one, separated from the other by a 50-foot mass and consisting of two 50-foot square openings, one east of the other.

Rock structure: The sheets, 2 to 10 feet thick, dip gently north and, at the south end, west. There are three sets of joints-(a), strike N. $60^{\circ}$ E., dip $65^{\circ}$, spaced 4 to 20 feet and over; (b), strike N. $82^{\circ}$ E., vertical, rerldish, coated with epidote, spaced 2 to 20 feet; (c), strike N. $25^{\circ}$ E. Flow structure

to Manual of the geology of Connecticut: Connecticut (icol. and Nat. IIist. Survey Bull. 6, p. 132, 1906. 
and grain strike east; the former dips $60^{\circ}$. The rift is reported as horizontal. Pegmatite dikes (specimen D, XXX, 18, c) up to 6 inches thick strike N. $60^{\circ}$ W. The unquarried mass between the two quarries and about 10 feet of the south end of the northern quarry consist of the finer darker granite (specimen b), which constitutes a dike or band.

Transportation, by cart 1 mile to railroad at Westerly, R. I.

The product of the main quarry (specimen a) was used for building and trimming; that of the smaller (b) for monuments.

\section{WATERFORD.}

The Scott quarry is in Waterford Township, 3 miles north of New London, on Bolles Hill, about half a mile south of Quaker Hill village. Quarry abandoned.

The granite (specimen D $\times x x, 9$, b), Mamacoke gneiss, No. 36 of the State preliminiry geologic map) is an aegirite granite gneiss of medium pinkish to purplish gray color and of very fine, sliglitly gneissic, in places banded texture, with feldsuar under 0.1 inch (rarely to 0.15 inch) and black silicate under 0.05 inch. Its constituents, named in descending order of abundance, are grayish to pinkish potash feldspar (microcline and orthoclase), intergrown with soda-lime feldspar (oligoclase-albite) and somewhat kaolinized; light smoky quartz with cavities in sheets; a little separate soda-lime feldspar of the same kind; black aegirite (green in thin section). Accessory: Magnetite, titanite. Secondary: Kaolin, hematite stain. No effervescence with muriatic-acid test.

A specimen (D, XXX, 9, a) of a part witl alternating black, gray, and reddish plicated bands from 0.1 to 0.3 inch wide shows the same minerals with zircon, but the soda-lime feldspar is abite or oligoclase-albite and all separate. Some of the bands are largely quartz, others largely feldspar, still others mainly aegirite.

The quarry, opened in 1898, measured in 1908150 feet along the highway by 50 feet from it and averaged 5 feet in depth, with a working face 20 feet high at the back.

Rock structure: The sheets, 1 to 4 feet thick, are about horizontal. Two sets of joints occur at rare intervals-(a), strike N. $10^{\circ} \mathrm{W} ., \operatorname{dip} 60^{\circ} \mathrm{W}$.; (b), strike N. $65^{\circ}$ E., vertical. The gneiss foliation strikes N. $10^{\circ} \mathrm{W}$. and N. $20^{\circ}$ E. and dips east. At one point this is sharply plicated along the strike. The rift is reported as vertical east to west and the grain as vertical north to south. Dikes or lenses of pegmatite and aplite up to 2 feet thick run with the foliation.

The product is underpinning, curbing, trimmings, steps, and paving. The quarry is worked only occasionally.

The Millstone quarry is in Waterford Township, on Millstone Point, 5 miles southwest of New London. (See fig. 89.) Operator, Henry Gardiner, Millstone.

The granite (specimens D, XXX, 6, a, b, k, polished, d, e, rough, related to Westerly granite of Rice and Gregory), "Millstone granite," is a quartz monzonite between medium and dark grily, smoky, and of even-grained granitic, fine texture, with feldspars up to 0.2 inch but mostly under 0.1 inch and mica to 0.1 inch. Its constituents, named in descending order of abundance, are whitish to buff striated soda-line feldspar (oligoclase-albite), much of it kaolinized and micacized and intergrown with quartz circular in cross section; translucent gray potash feldspar (microcline and a little orthoclase), little altered; medium smoky quartz, with some cavities in sheets; biotite (black 
mica), some of it chloritized; and very little muscovite or bleached biotite. Accessory: Magnetite (fifth in abundance), allanite (sixth in abundance), pyrite, apatite, zircon. Secondary: Kaolin, a white mica, limonite from allanite, calcite, chlorite.

An estimate of the mineral percentages by the Rosiwal method, applied to a camera-lucida enlargement (25 diameters) of a thin section, yields these results with a mesh of 1.7 inches and total linear length of 40.8 inches: Soda-lime feldspar (oligoclase-albite), 34.22; potash feldspar (microcline and orthoclase), 31.81; quartz, 25.54; black miea (biotite), 7.21 ; magnetite, 0.93 ;

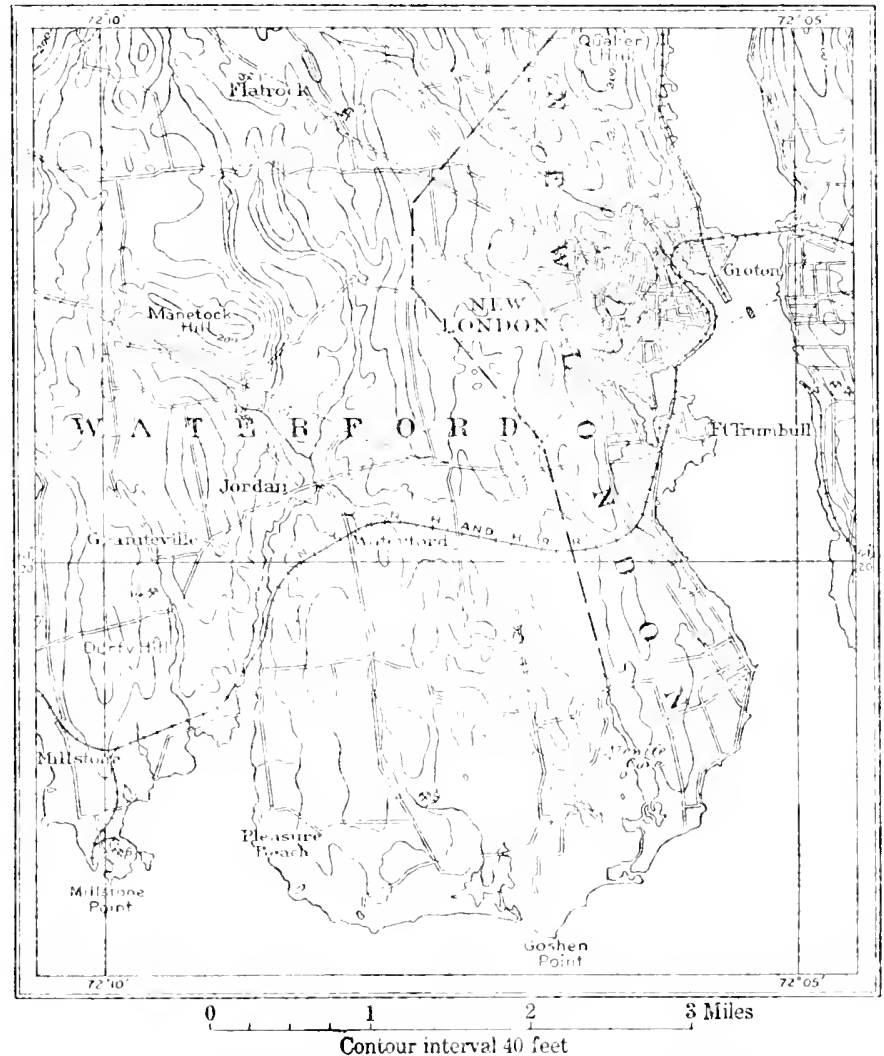

Figure 89.-Map of southern part of Waterford, Conn., showing location of granlte quarrles. 1. Flat Kock; 3, Goos ; 5, Waterford ; 6, Millstone ; 14, Somers.

allanite, 0.29. The average diameter of the particles calculated from the same measurements is 0.0354 inch.

This granite effervesces somewhat frecly with cold dilute muriatic acid. R. C. Wells, a chemist of this Survey, finds that it contalns 0.31 per cent of $\mathrm{CaO}$ (lime), soluble in warm dilute (10 per cent) acetic acid, which indicates a content of 0.55 per cent of $\mathrm{CaCO}_{3}$ (calcium carbonate, calcite). Calcite is also shown by the microscope.

A transverse test (No. 9764) made at the United States arsenal at Watertown, Mass., in 1896, on a piece of this granite 18 inches Iong by 1.02 by 1.02 inches and with 15 inches between end supports, gave a molulus of rupture of 2,029 pounds, the piece breaking under 138 pounds. 
This is a brilliant, somewhat fine-grained smoky monumental aud inscriptional granite without mineral contrasts except on close inspection. Its texture Is about one-third as fine as that of the coarser "blue Westerly" granite (New England Granite Works quarry, 0.0112 inch).

It takes a high polish, but the polished

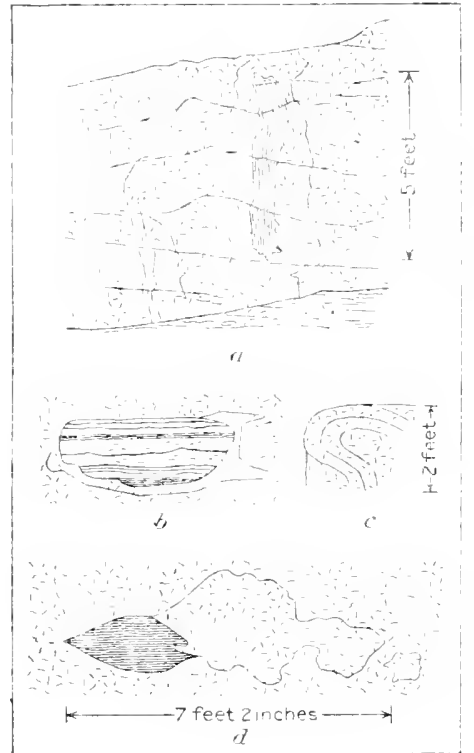

Figure 90. - Details at Millstone quarry, Waterford, Conn. $a$, Vertical section of pegmatite dike in quartz monzonite, with inclusions of biotite gneiss (after a photograph by E. F. Burchard, U. S. Geol. Survey) ; $b$, horizontal section of jnclusion of biotite gneiss, 20 by 8.5 inches, partly surrounded with pegmatite, in quartz mcuzonite; $c$, vertical section of tortuous flow structure, consisting of biotite sheets; $d$, horizontal section of inclusion of gneiss associated with very coarse pegmatite in quartz monzonite. face shows magnetite and some pyrite. It hammers and cuts medium gray, thus afforling a marked contrast of shade to the polished face, which is dark sray. ${ }^{71}$

A pinkish variety (specimen D, XXX, 6, i), "Millstone pink," no longer quarried, is a quartz monzonite of medium, inclining to dark, slightly pinkish gray color, with unevenly distributed cherry-red stains. Its texture is a trifle coarser. the feldspars and mica mostly under 0.15 inch. Its composition is identical with that of the other but includes secondary hematite, which causes the cherry-red spots.

The quarry, opened in 1830, measured in 1908 about 800 feet in a N. $40^{\circ} \mathrm{W}$. direction and had a width varying from about 150 to 300 feet, owing to two embayments on the northeast wall, and a depth of 50 to 150 feet. ${ }^{\text {ia }}$

Rock structure: The relations of granite and gueiss here have been described on page 89. The gneiss (specimen $\mathrm{D}, \mathbf{x x x}$, 6, f, Mamacoke sneiss, No. 36 of the State preliminary geologic map) appears to be a black and white banded biotite granite gneiss of fine to medium texture. The granite sheets, lenticular, normal, and mostly 2 to $S$ feet thick, but 6 to 12 inches in the upper 20 feet of the southeast end and 6 inches to 2 feet in the upper 15 feet of the central northeast side, dip $20^{\circ} \mathrm{N}$. $65^{\circ} \mathrm{E}$. There are two sets of joints-(a). strike N. $40^{\circ} \mathrm{W}$., vertical, forming parts of the northeast and southwest walls and a 30-foot heading at the north-northwest corner. spaced 6 inches to 33 feet but mostly 3 to 10 feet; (b), strike north to N. $10^{\circ} \mathrm{E}$, steep, occurs at greater aud irregular intervals. A little sea vater enters the quirry at the bottom through some of these joints. Flow structure, indicated by biotitic bands, strikes $\mathrm{N} .45^{\circ}-60^{\circ} \mathrm{W}$. and dips $30^{\circ} \mathrm{sW}$., but near the northwest end of the quary the bands are tortuous, doubling over on themselves, as shown in figure $90, c$. A block in the storage yard with a concentric structure of this kind probably formed part of a turn in one of these granite

${ }^{7} \mathrm{~J}$. S. Newberry in 1884 described it as " a dark-gray granite of fine, homogeneous texture, showing strong contrast of color between polished and dessed surfaces." Tenth Census U. S., vol. 10 , p. $321,1884$.

${ }^{71}$ See Kemp, J. F., op. cit., pl. 36, fig. 2, for a rlew of the quarry as it appearea beiwe 1888 and 1898 . 
currents. The rift is reported as dipping $5^{\circ}-10^{\circ} \mathrm{N} .80^{\circ}$ E., and the grain as vertical, with N. $65^{\circ}$ E. course. Pegmatite and aplite dikes dip $30^{\circ}$ at intervals of 3 to 10 feet. One with large biotite crystals strikes $\mathrm{N}$. $55^{\circ} \mathrm{E}$. There are many inclusions. Some have been described on page 62 and are shown in figure 90. Rusty stain is about 2 inches thick on sheet surfaces. Niles, ${ }^{72}$ in 1876 , mentioned the crushing of channel cores and cramping of drills at this quarry by northeast-southwest compression.

Transportation, by siding 1 mile to New York, New Haven \& Hartforl Railroad at Millstone station and also by slort siding to dock, which admits vesgels of 12-foot draft at low tide.

The product is used for monuments and buildings, and the waste for breakwater riprap, road, and concrete material. Specimens: Saratoga Monument, interior, entrance, ancl all but upper 10 feet of exterior; also a polished inscribed tablet of the Millstone pink; base, pedestal, and cap of Barnum monument, Bridgeport; George W. Childs mausoleum, Philadelphia.

The Somers prospect is in Waterford Township, $2 \frac{1}{2}$ miles west-soutliwest of New London, on the east side of Durfy Hill, near Graniteville. (See fig. 89.) This is a small opening, made in $\mathbf{1 9 0 2 .}$

The granite (specimen $\mathrm{D}, \mathrm{XXX}, 14, \mathrm{~b}$, related to Westerly granite of Rice and (regory) is a quartz monzonite of medium, inclining to dark buff-gray color and of even-grained granitic fine texture, with feldspar mostly under 0.1 luch but up to 0.2 inch and mica mostly uncler 0.05 inch but up to 0.1 inch. This rock is overlain by a few feet of similar but pinkish granite (specimen $D$, XXX, 14, a). Both effervesce slightly with muriatic-acid test.

'Tlis granite is finer textured than that of the Millstone quarry, and specime'll $14, \mathrm{~b}$, is a little lighter in color. Specimens taken from upper $S$ feet.

liock structure: The sheets are irregular, 1 to 8 feet thick, dipping $30^{\circ} \mathrm{E}$. Joints (a), strike nearly east, vertical, spaced 9 to 20 feet; (b), strike north, dil) west, discontinuous, one only. There is some pegmatite.

The Waterford quarry is in Waterford Township, $3 \frac{1}{2}$ miles south-southwest of Niw Lonrlon, 23 miles south of Waterford station, and a mile east of Pleasure Beach. (See fig. 89.) Operator, Booth Bros. \& Hurricane Isle Granite Co., $20 S$ Broadway, New York.

'The granite (specimens D, XXX, 5, a, b, rough, d, polished and hammered, related to Westerly granite of Rice and Gregory), "Connecticut white," is a quartz monzonite of medium buff-gray color and of even-grained granitic, fine texture, with feldspar up to 0.2 inch, rarely $0.3 \mathrm{inch}$, but mostly under 0.1 inch, and slender micas up to 0.15 inch, rarely 0.2 inch. but mostly not orer 0.1 inch. 'The long axes of the micas are parallel to the rift. Its constituents, in descending order of abundance, are milk-white soda-llme feldspar (oligoclase-andesine), kaolinized and micacized; cream-colored potash feldspar (microcline and a little orthoclase), slightly kaolinized and intergrown with quartz more or less circular in cross section; light smoky quartz, with hairlike crystals of rutile, rare cavities in sheets, and some rift cracks parallel thereto; biotite (black mica), some of it chloritized; and very little muscovite or bleacher biotite. Accessory : Magnetite (fifth in order of abundance), apatite, zircon, allanite; no mrite detected. Secondary: A white mica, kaolin, calcite, chlorite, limonite.

An estimate of the mineral percentages by the Rosiwal method applied to a camera-luciua enlargement (25 diameters) of a thin section yields these results with a mesh of 1 inch and a totul linear length of 27 inches: Soda-lime feldspar (oligoclase-andesine), 33.63 ; potash feldspar (microcline and little orthoclase),

72 Niles, W. H., The geological agency of lateral pressure cxhibited by certain movements of rocks: Boston Soc. Nat. Hist. I'roc., rol. 18, for $1875-76$, p. 279. 
32.29; quartz, 29.92 ; black mica (biotite), 3.65 ; magnetite, 0.51 . The average diameter of the particles, calculated from the same measurements, is 0.0206 inch.

The stone effervesces with muriatic-acid test. R. C. Wells, a chemist of this Survey, finds that it contains 0.29 per cent of $\mathrm{CaO}$ (lime), soluble in warm dilute (10 per cent) acetic acid, which indicates a content of 0.51 per cent of $\mathrm{CaCO}_{3}$ (calcium carbonate, calcite) ; calcite is also shown by the microscope.

The following analysis (No. 12757) of this granite, made for the company by Ricketts \& Banks, of New York, is given here for reference:

\section{Analysis of quartz monzonite from Waterford quarry.}

Silica $\left(\mathrm{SiO}_{2}\right)$

Alumina $\left(\mathrm{Al}_{2} \mathrm{O}_{3}\right)$

Iron oxide $(\mathrm{FeO})$

Lime $(\mathrm{CaO})$

Magnesia ( $\mathrm{MgO})$

Potash $\left(\mathrm{K}_{2} \mathrm{O}\right)$

Soda $\left(\mathrm{Na}_{2} \mathrm{O}\right)$

Sulphur (S)
68. 11

14.28

2. 63

1. 86

.68

5. 46

6. 57

.34

99.93

Ira H. Woolson, E. M., of Columbia University, made two compression tests on cubes of 2 -inch edges in 1896, with these results (rift and grain directions not noted):

\begin{tabular}{|c|c|c|c|}
\hline Test No. & $\begin{array}{c}\text { First } \\
\text { crack. }\end{array}$ & $\begin{array}{c}\text { Maximum } \\
\text { stress. }\end{array}$ & $\begin{array}{c}\text { Ultimate } \\
\text { strength. }\end{array}$ \\
\hline & & & Pounds per \\
& & Pounds. & Pounds. \\
$1575 \ldots .$. & 65,000 & 93,100 & 23,510 \\
$1576 . .$. & 92,000 & 97,600 & 23,921 \\
\hline
\end{tabular}

This is a very fine-graded monumental and inscriptional granite of buff to mediun-gray tint without mineral contrasts. It is finer and lighter than the "Millstone granite" and about half as fine as "blue Westerly" which averages 0.0099 inch per particle. (See p. 406.)

It takes a high polish. The polished face shows a little magnetite and is of medium inclining to dark gray shade; the hammered face is a light gray, to which the stone owes its trade name. This property of hammering and cutting light it possesses in common with "Westerly," "Groton," "Millstone," and other quartz monzonites. Its adaptation, to fine architectural and sculptural work is shown in Plates XXXII and XXXIII, $A$, and its lightness when hammered in Plate XXXII.

The quarry, opened about 1878, measured in 1908 about 600 feet from eust to west by 150 feet across at the east end and 250 feet at the west end and from 75 to 125 feet in depth.

Rock structure: The granite occurs in two dikelike masses, 30 and 40 feet thick, as described in detail on page 89 , and shown in figures 13 and 14 . There are three sets of joints-(A), vertical, spaced 3 to 20 feet; (B), vertical or steep west, spaced 3 to 50 feet: (C), dip $50^{\circ}-75^{\circ}$ NW., spaced 2 to 75 feet. (See fig. 91.) The rift dips $10^{\circ} \mathrm{S}$. $15^{\circ} \mathrm{E}$, with the long axes of the biotite scales, the grain dips $75^{\circ} \mathrm{N} .15^{\circ} \mathrm{W}$, and the hard way is vertical. Joint, rift, and grain courses are shown in figure 91 . In splitting along the rift the granite is reported as breaking more readily from the west side than from the north. Biotitic knots up to 6 inches in diameter are rare. Inclusions of the gneiss, 3 
inches across and 2 by 3 feet, occur $2 \frac{1}{2}$ and 6 feet above the contact of the upper granite dike underlying gneiss. The granite surface tends to weather spheroidally. (See p. 72 and Pl. XXIX, B.) Rusty stain is 2 to 6 inches thick on sheet surfaces.

Transportation, by cart 1 mile to dock at Pleasure Beach, which admits vessels of 9 feet draft at low tide, or 2 miles to New York, New Haren \& Ifart. ford Railroad at Waterforl station.

The product is used mostly for monuments.

Specimens: Soldiers' monument, Whitinsville, Mass,, shown in Plates XXXII and XXXIII, $A$; Chelsea Savings Bank, Norwich, Conn.; Littlefield shaft, Swan Point Cemetery, Providence, R. I.; Hoy mausoleum, Mount Moriah Cemetery, Philadelphia; City Denosit Bank, Pittsburgh, Pa.; Clark residence (basement), Riverside Drive, and Dudley Celtic cross, Woodlawn Cemetery, New York; soldiers and sailors' memorial (Cyrus E. Dallin, sculptor), Syracuse, N. Y.; Alexander Hamilton memortal (Bela Pratt, sculptor), Grant Park, Chicago.

\section{TOLLAND COUNTY.}

\section{BOLTON.}

The Petersen quarry is in Bolton Township, in the northeastern part of Minnehausch or Birch Mountain, about 2 miles soutluwest of Bolton village and $1_{4}^{3}$ miles southeast of Highland Park post oflice, in Manchester. The quarry is not in operation.

The granite (specimens $\mathrm{D}, \mathrm{XXX}, 31$. a, b, Glastonbury granite gneiss, No. 15 of the State preliminary geologic map) is a biotite cranite gneiss of medium. slightly bluish-gray color, with conspicuous broitl black streaks on the foliation face, and of medium-grained unplicated, very gneissic texture, with porphyritic lenticular feldspar up to 0.2 and 0.4 inch long. The quartz is in lamellae up to 0.1 inch thick and the mica to 0.04 inch. The stone looks rery different on its rift, grain, and lard-way sides. Its constituents, in descending order of abundance, are translucent blnish potash feldspar (microcline and orthoclase), somewhat kaolinized; light smoky quartz, strained and with cavities in parallel sheets and cracks pirallel to or coinciding therewith; milk-white soda-lime feldspar (oligoclase to oligoclase-andesine); and biotite (black mica). Accessory: Garnet, pyrite. Secondary : A white mica, kaolin. Botl feldspars are intergrown with quartz more or less circular in cross section. The stone does not effervesce with muriatic-acid test.

The quarry is a small opening, made in 1908 .

Rock structure: The sheets, 3 feet thick, dip gently east, The gneiss foliation strikes $\mathrm{N} .10^{\circ} \mathrm{E}$. and is vertical. The rift is parallel to it, the grain horizontal, and the hard way vertical, east-west. An 18-inch aplite dike runs parallel to the foliation. This (specimen $\mathrm{D}, \mathrm{XXX}, 31, \mathrm{c}$ ) is of mellium bluishgray color and of fine, slightly gueissic texture. Its constituents, in the usual order, are smoky quartz; bluish microcline, with orthoclase; milk-white sodalime feldspar; and a little sparse biotite and pyrite. Its quartz and feldspar particles are mostly from 0.11 to 0.33 millineter, with some porphyritic ones 0.54 to 0.84 millimeter. 
The contrasts in this stone are more marked than in any of the gneisses of Glastonbury described on pages 366-369.

The stone was used for underpinning and cellar stone and is well adapted to sllls.

\section{WINDHAM COUNTY.}

\section{STERIING.}

The Oneco quarry is in Sterling Township, 1 mile southrest of Oneco village, near the Rhode Island line. (See Pl. XXVIII.) It is now disused.

The granite (specimen D, XXX, 22, a, Sterling granite gneiss, No. 24 of the State preliminary geologic map) is a biotite granite gneiss of medium, inclining to dark, slightly bluish-gray color and of fine-grained unplicated gneissic texture, with porphyritic feldspars up to 0.2 and 0.4 inch and mica in fine parallel streaks 0.1 to 0.2 inch apart. Its constituents, in descending order of abundance, are bluish potash feldspar (microcline intergrown with quartz more or less circular in cross section, also orthoclase), somewhat kaolinized; light smoky quartz, with cavities in parallel sheets and cracks parallel thereto; a little milk-white soda-lime feldspar (oligoclase), some of it kaolinized and micacized; and biotite (black mica). Accessory: Titanite (fifth in order of abundance), magnetite (or ilmenite), garnet, apatite, allanite, zircon. Secondary: Kaolin, white mica. No effervescence with muriatic-acid test.

The quarry, opened about 1868, measured in 1908 about 500 feet from nortlwest to southeast by 400 feet across and 35 feet in depth.

Rock structure: The gneiss foliation strikes N. $10^{\circ}-25^{\circ} \mathrm{W}$. ancl is vertical. The sheets, up to 5 feet thick, dip $5^{\circ}-10^{\circ} \mathrm{SW}$. and NW. Joints $(a)$, strike $\mathrm{N}$. $80^{\circ}-85^{\circ}$ E., vertical, spaced 10 feet and much more; $(b)$, "blind seams" with quartz and pegmatite dikelets, strike N. $30^{\circ} \mathrm{WV}$., dip $50^{\circ}$ E., spaced 3 to 10 feet. Biotitic surfaces (flow structure?) strike N. $30^{\circ}$ W., and dip $50^{\circ}$ N. $60^{\circ}$ E. The rirt is reported as parallel to the gneiss foliation, and the grain is vertical, east to west, feeble. There are pegmatite lenses of smoky quartz and pink feldspar, with purple fluorite and epilote crystals. Dikes of whitish aplite up to 4 inches thick strike N. $50^{\circ}$ W. (See microscopic description under Marriott quarry, below.)

Transportation, by siding to Central New England Railway.

The product was used for building, curbing, and paving, and the waste for crushed stone.

The Marriott quarry is in Sterling Township, 1 mile southwest of Oneco station and one-fourth mile east of the Oneco quarry. Operators, R. B. Marriott \& Sons. Oneco.

The granite (specimens D, XXX, 23, a, b, Sterling granite gneiss, No. 24 of the State preliminary geologic map), "Oneco," is a biotite granite gneiss of medium, inclining to dark bluish-gray color and of fine-grained unplicated gneissic texture, with porphyritic feldspar up to 0.2 and 0.4 inch and mica in fine parallel streaks 0.1 to 0.2 inch apart. Its constituents are identical with those of the Oneco quarry stone, but the section shows secondary calcite, and the stone effervesces slightly with muriatic-acid test.

Thls granite gneiss is well adapted by its foliation for curbing and trimmings. It has a marked bluish tint and looks well hammered on the grain and hard-way sides.

The quarry, first opened in 1881, reopened in 1903, measured in 1908 about 200 by 150 feet and 15 feet in depth.

Rock structure: The gneiss foliation strikes north to N. $15^{\circ} \mathrm{W}$. and is vertical. The sleets, 1 to 7 feet thick, dip $5^{\circ} \mathrm{E}$. There are two sets of joints- $(a)$, strike 


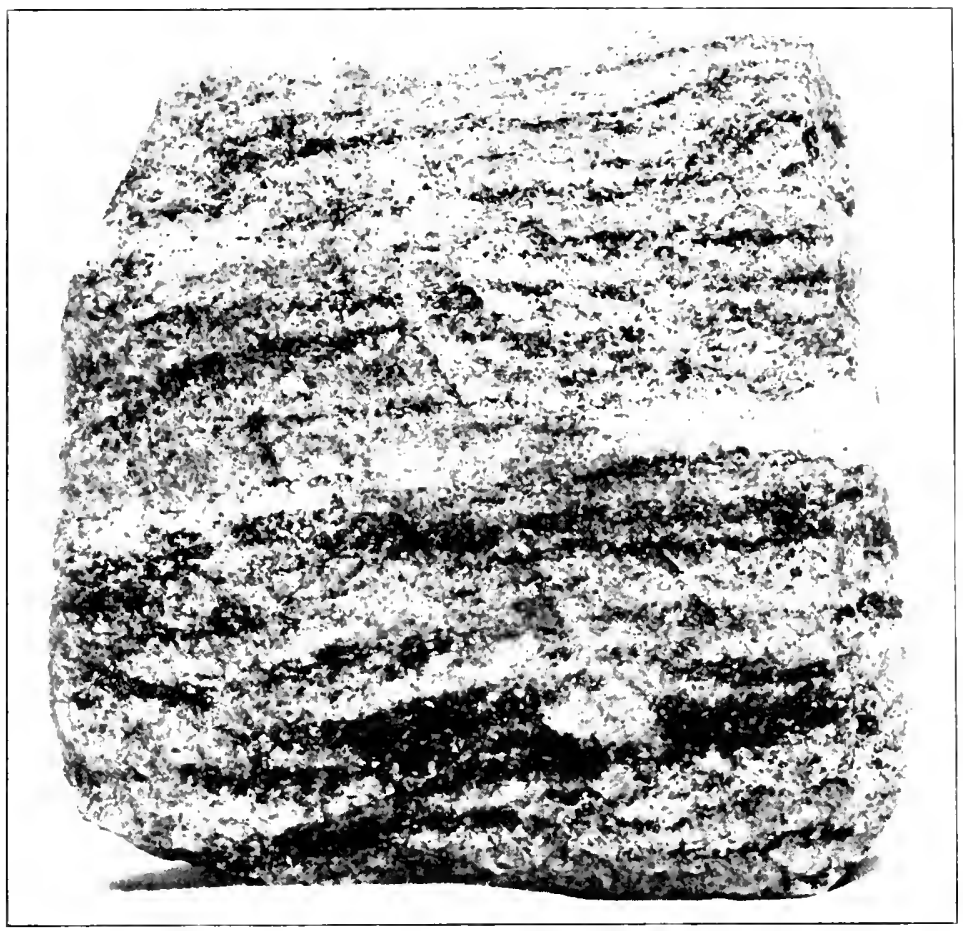

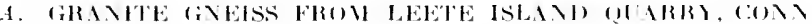

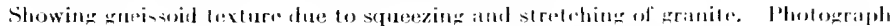
by II. E. Grepory.

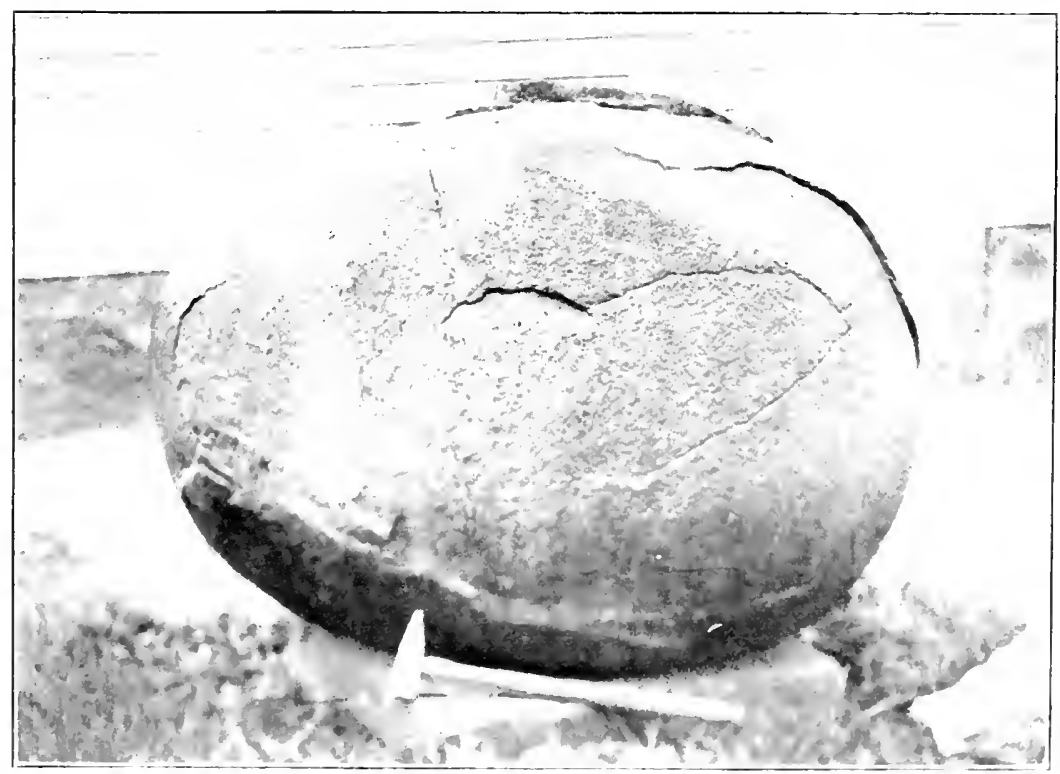

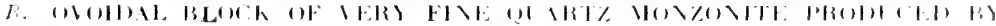
IETHERII; (ili, I. R. 1 . 


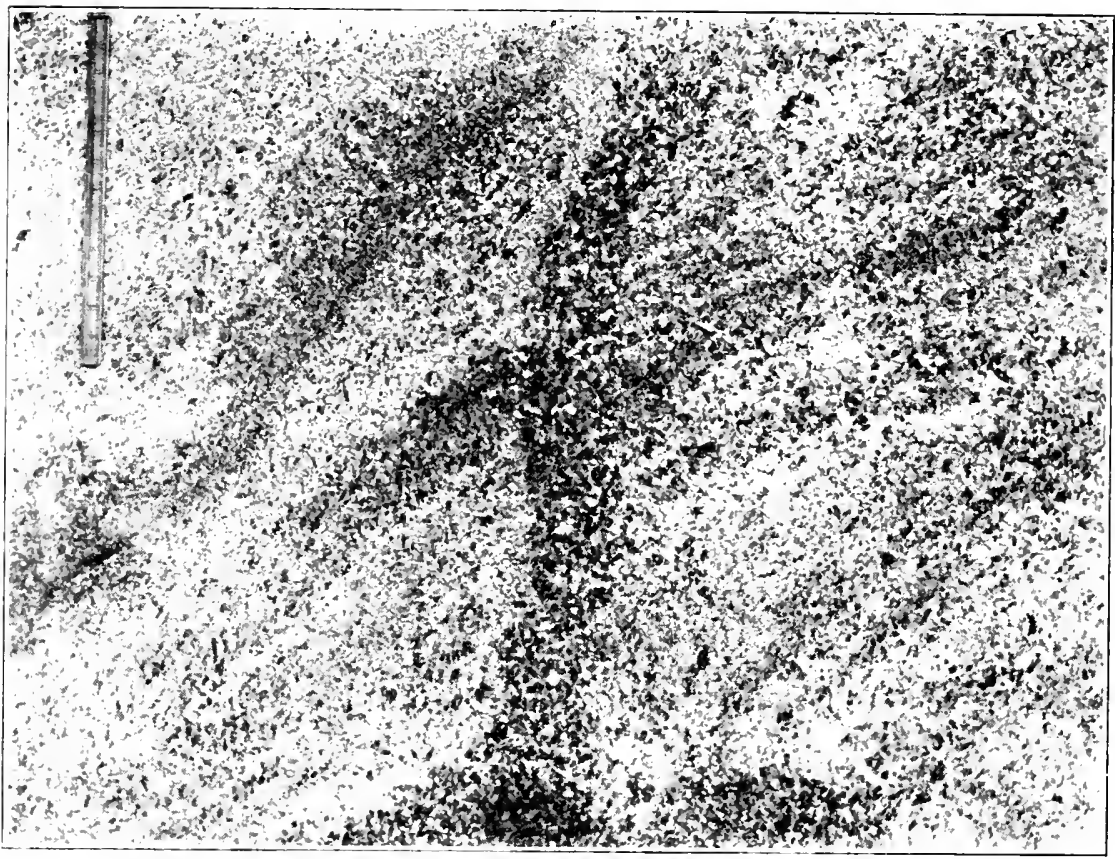

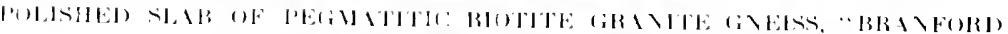

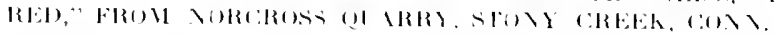

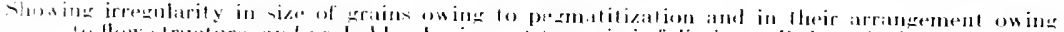

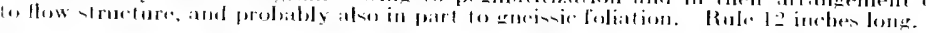

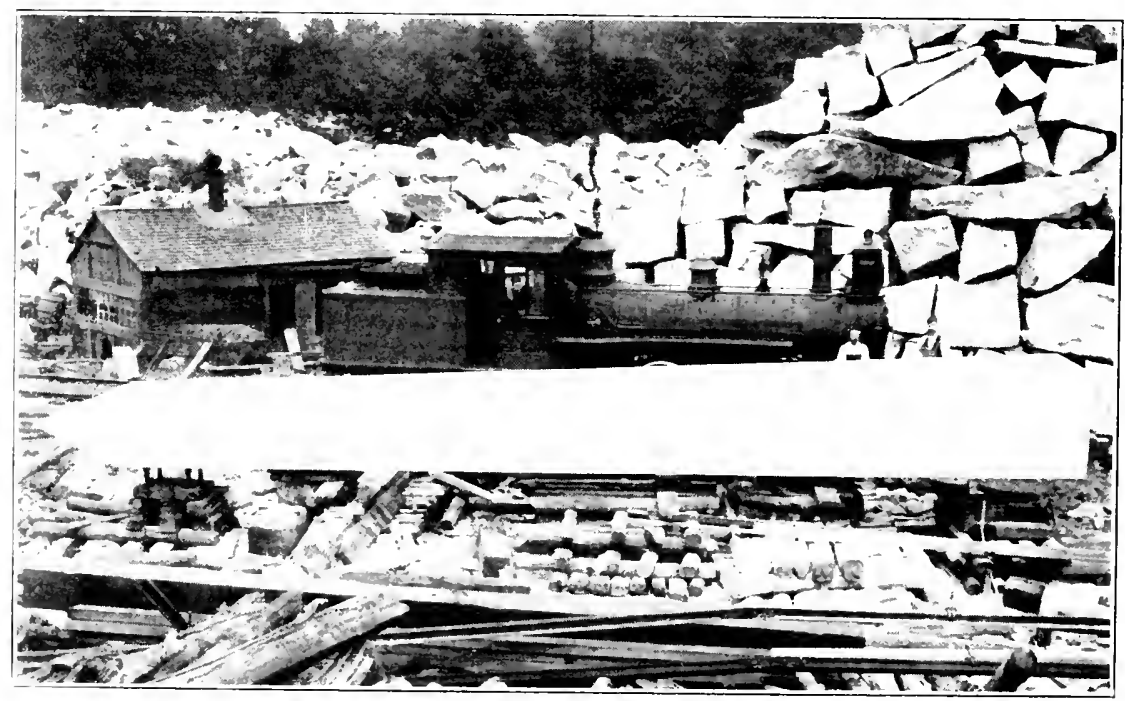

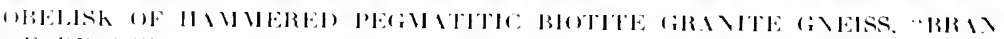

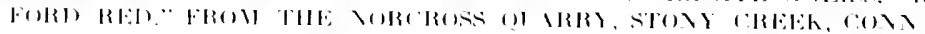




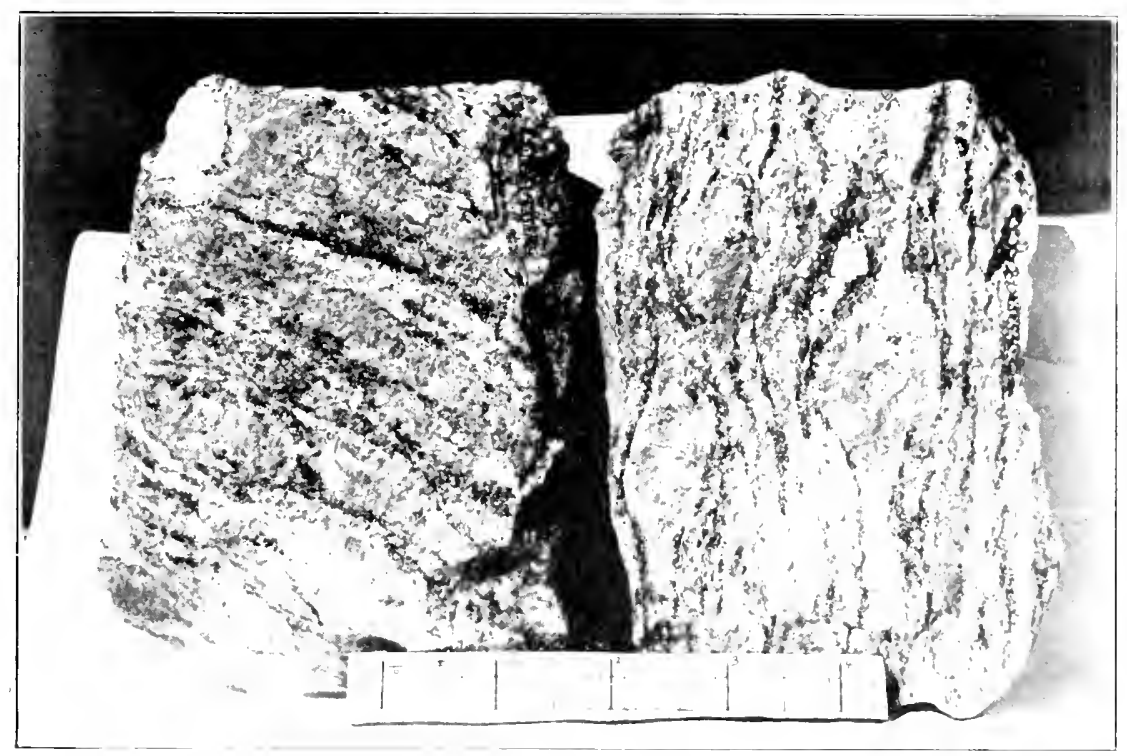

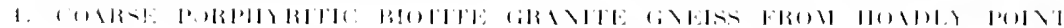

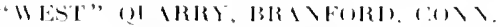

mint and quart\% in binl l.

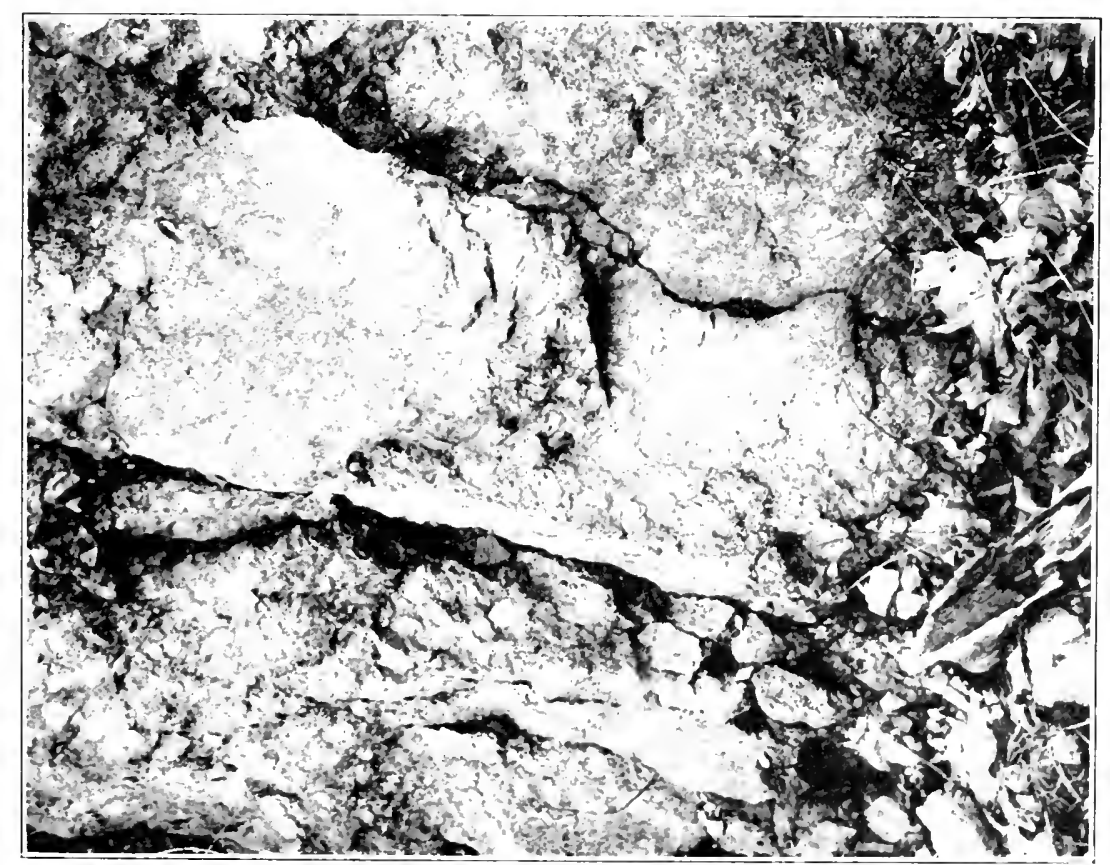

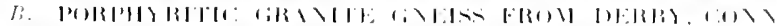




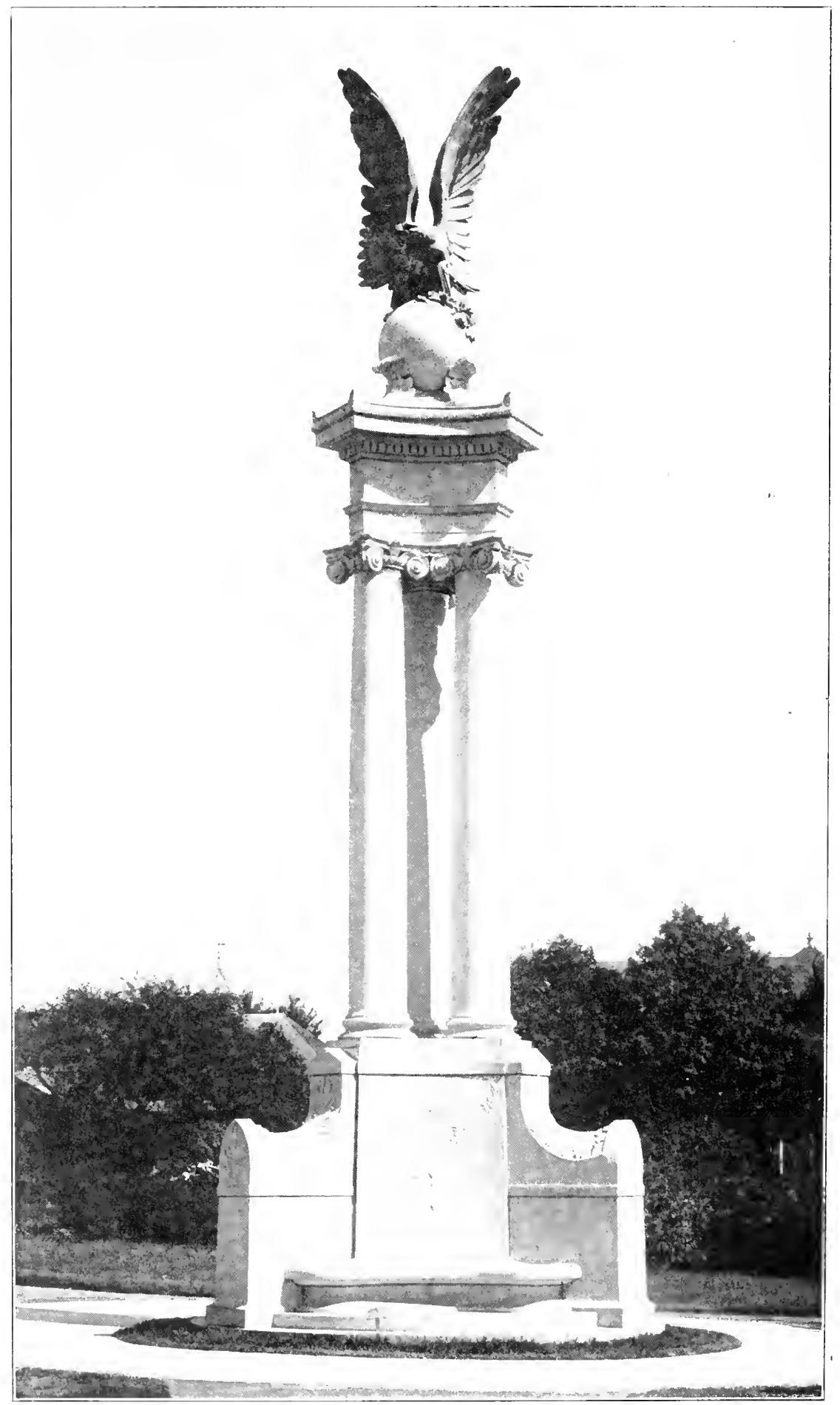

SULDIERS AND SILURS MONUMENT AT WIITINSULLE, MASS.

Made of ham nare I bif-gray tine quart\% moazonite lroin Booth quarry at Waterford, Comn. A. b. F. II: nlit, antit. II. L. Wacteil sculptor. Ifeight to to of ball, 30 fret. Eagle of bronze. 


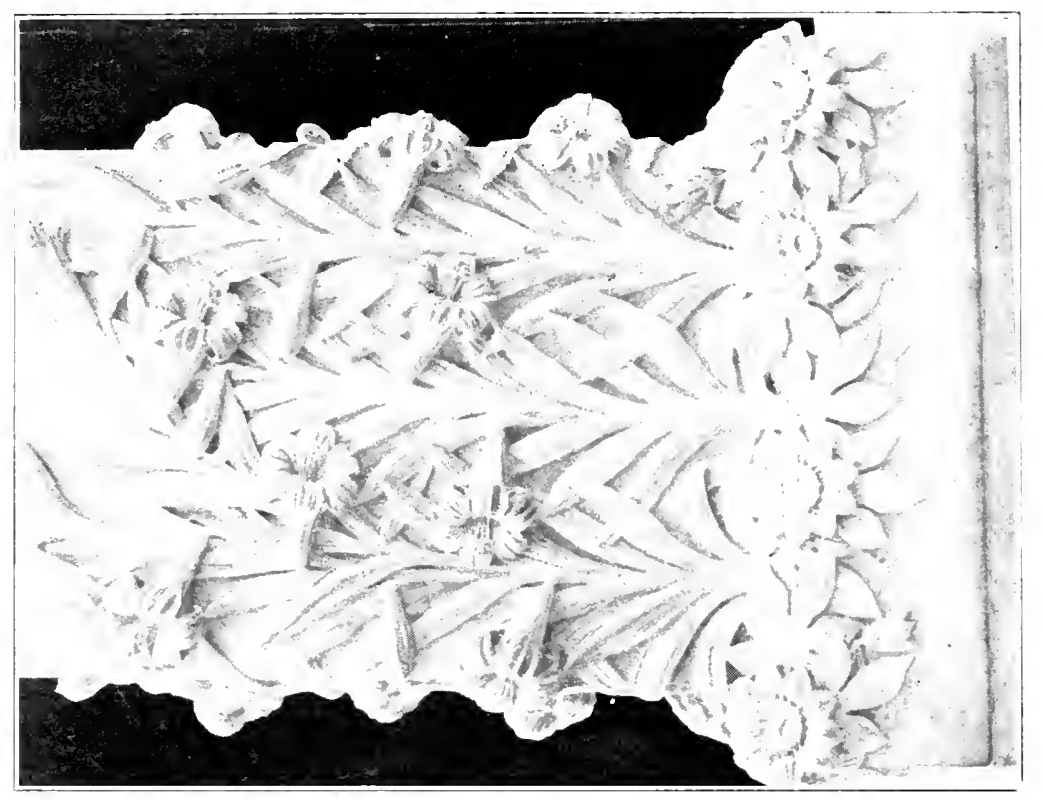

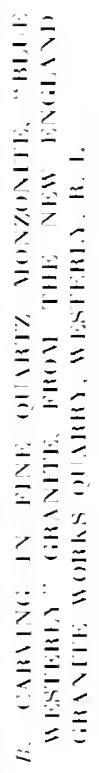

Q⿻

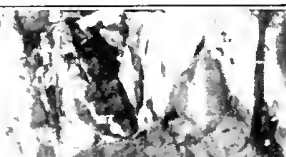

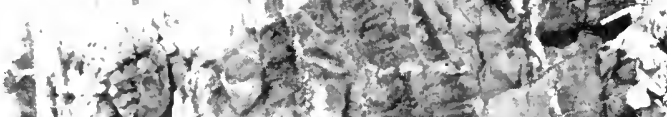

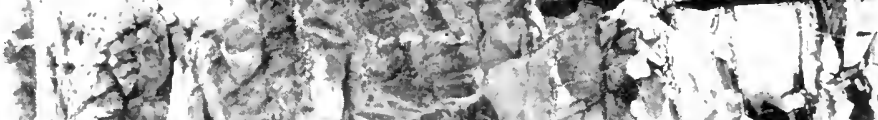

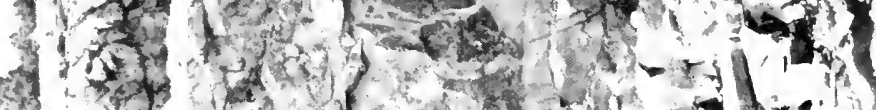

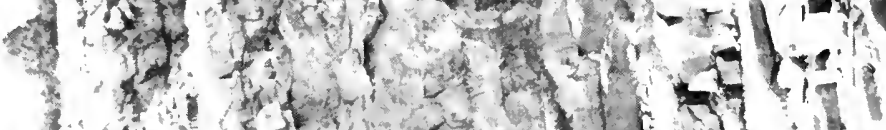

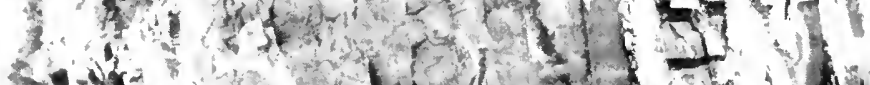

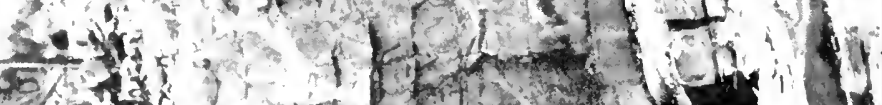

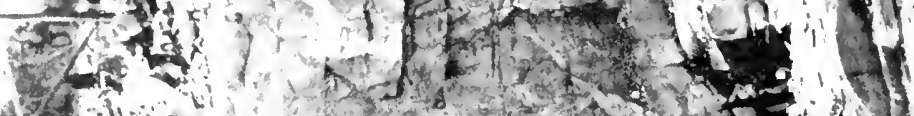

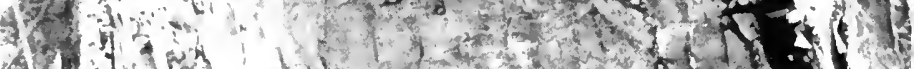

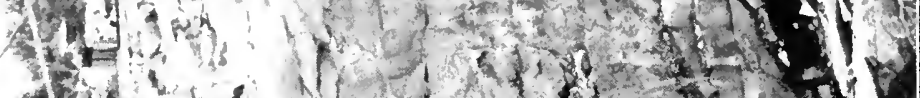
1.

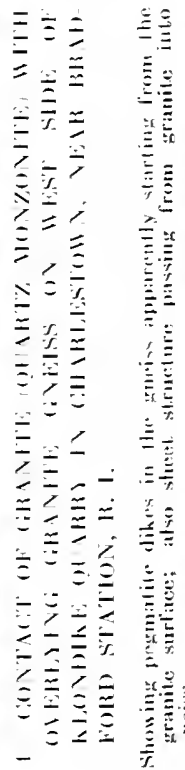


N. $65^{\circ}$ E., vertical, spaced 3 to 30 feet, forms the south wall; $(b)$, strike north, vertical, forms east and west walls, and one on either side. The rift coincides with the foliation; the grain is horizontal, and the hard way vertical, east to west. The stone breaks somewhat readily along the hard way. There are dikes of aplite up to a foot thick, striking nortluwest. A small one of these has a central band of ilmenite 0.3 inch thick. The aplite (specimen D, XXX, 23, c), like that of the Oneco quarry, is of light cream-color and very fint texture, with particles under 0.1 inch. In a thin section they range from 0.05 to $1.12 \mathrm{milli}$ meters. Its constituents, in descending order of abundance, are clear colorless quartz with cavities, microcline with ortloclase, oligoclase, minute and sparse biotite, with accessory ilmenite, garnet, and apatite. There is a 6-inch dike of smoky quartz with feldsuathic border on the west side; also lenses of pegnat1te with smoliy quartz.

Transportation, by cart $1 \frac{1}{6}$ miles to Oneco station.

The product is used for curbing, building, trimmings, chimney caps, and paving, which is sent to Providence. Specimens: Cranske Mill addition at Broosup, Conn.

The Bennett quarries are in Sterling Township, three-fourtlis mile east of Sterling station and about $1 \frac{1}{4}$ miles west of the Rhode Island line. Operator, Nelson A. Bennett, Sterling. Idle since 1914.

The granite (specimens D, XXX, 24, a, d, e, Sterling granite gneiss, No. 24 of the State preliminary geologic map) is a biotite granite gneiss of general light pinkislı-gray color, with conspicuous black streaks on the foliation face, and of fine-grained, obscurely plicated, gneissic, much elongated porphyritic texture. It is marked by long, tapering parallel lenses from 0.1 to 0.3 inch wide consisting of quartz or feldspar or mica. The rock has rery different aspects on its rift, grain, and hard-way faces. The rift or foliation face (specimen a) shows the lenses of black mica, pink feldspar, and smoky quartz. Along the grain (specimen a, smallest side), which is vertical to the foliation but parallel to the lenses, the mica is in very thin streaks, while along the hard way (speeimen e), which is at right angles to the lenses, the rock is mottled with pink, gray, and black. The feldspar particles are up to 0.2 inch. The constituents, in descending order of abundance, are light-pinkish potash feldspar (microcline and orthoclase), slightly kaolinized; light smoky quartz, with cavities in irregular sheets; cream-colored soda-lime feldspar (oligoclase-albite), somewhat kaolinized; biotite (black mica); and very little hornblende. Accessory: Allanite, apatite, zircon. Secondary: CaIcite, kaolin. Slight effervescence with muriatic-acid test.

A more pinkish granite (specimen 25 , a), from a point about $1 \frac{1}{2}$ miles northnortheast of Sterling station, a little north of Quaduck Brook, is of identical texture and composition. but the feldspars are more pinkish and more altered, the oligoclase-albite being much kaolinized and carrying calcite.

These stones are well adapted for the manufacture of paving blocks on account of their marked rift and grain and their smooth fracture along the hard way. The contrasts of shade and color in the fresh rock and its foliation make it suitable and attractive for other uses.

The quarry, if such it can be called, is part of a boulder train about $1 \frac{1}{2}$ miles from north to south by one-half a mile in width, consisting of boulders of one gneiss, which range from 5 to 30 feet in diameter and correspond to the underlying gneiss of the region. Indeed, a few of the quarried "boulders" are the weathered tops of ledges. The quarry there is, in the quarrymen's sense, a "boulder quarry." 
Rock structure: A ledge of the gneiss, 30 feft high, shows the gneiss foliation, striking north and dipping $55^{\circ}-70^{\circ} \mathrm{W}$. Sheets 2 to 5 feet thick dip $25^{\circ} \mathrm{N} .70^{\circ} \mathrm{W}$., and vertical joints strike east and are spaced 1 to 10 feet. The rift coincides with the foliation, and the grain is at right angles to it but parallel to the lenses. Slight discoloration extends 10 inches from the surface.

Transportation, by cart to a 200 -foot siding one-quarter mile east of Sterling station.

The product is usel for curbing, sills, caps. steps, buttresses, underpinning, and paving. The paving, which is the chief product, tinds a market in Providence. The operator pays a royalty to the landowners on the boulders he splits up.

The Sterling quarry, an abandoned quarry three-fifths mile east-southeast of Sterling station, in the same township, is of interest because of the texture of its stone.

The granite (specimen D, XXX, 26 a) is a biotite granite gneiss of medlum, inclining to dark bluish-gray color and of fine gneissic texture, with fine matrix (particles under 0.2 inch) and porphrritic feldspars up to 0.5 inch. Its const tuents are the same as those of the Bemett boulders, but the potash feldspar is bluish, the quartz clear and colorless, and the oligoclase milk-white to buff or faintly pinkish. The porphyritic texture is less obscured by elongation, and the biotite, while in paralel arrangement, is evenly distributed, as is also the quartz. Titanite is among the accessory minerals. This gneiss evidently originated in the sanie granite as that of the Bennett bonlders but is less metamorphic-that is, its minera!s have not heen redistributed to the same extent, nor have its feldspars been subsequently so greatly altered.

Rock structure: The gneiss foliation strikes north and dips $70^{\circ} \mathrm{W}$. to $90^{\circ}$, and the sheets are from 6 inches to 3 feet thick.

\section{WINDHAM.}

The Larrabe quarry is in Windinam Township, three-fourths mile northwest of the Wilimantic railroad station. Operator, Charles Larrabee, jr., R. D. 2, Willimantic. Idle since 1915.

The granite (specimens D, XXX, 27, a, b, d, Willimantic gneiss, No. 25, of the State preliminary geologic map) is a biotite granite gneiss of interbanded medium and very dark glay shades, with a few pinkish hands of muscovite gneiss and some of pinkish pegmatite. Its texture is fine-grained gneissic, with an unplicaterl lamination and particles under $0.1 \mathrm{inch}$, the feldspars in the pegmatite bands up to 0.3 inch. The consituents of the medium-gray bands, in descending order of abundance, are transincent potash fedspar (microcline, partly kalinized, and orthoclase); light smoky quartz with some cavities; whitish soda-lime feldspar (oligoclase or oligoclase-andesine), some of it kaolinized and micacized and with (alcite, also intergrown with quartz more or less circular in cross section; biotite (black mica), some of it chloritized; and a little musco-

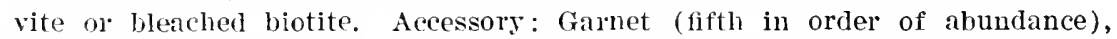
magnetite, pyrite, apatite, zircon, titanite. Secondary: Kaolin, a white mica, calcite, chlorite. Much quartz is in lenses $0.2 S$ by 2.24 millimeters. There are many fine particies of quartz and feldspar between the larger ones. In some specimens garnets are so abundant as to make minute pinkish bands. No effervescence with muriatic-acid test.

A thin section of a pinkish (not pegmatitic or garnetiferous) band shows the same potash feldspar, pinkish and much kaolinized, light smoky quartz, much altered oligoclase-andesine, anı murcovite instean of hiotite, witl allanite 
among the accessories. This is a muscovite gneiss. The very dark bands are due to more abundant biottte.

The quarry, opened about 1878, measured in 1908 about 300 feet from east to west by 150 feet across and 40 feet in depth.

Rock structure: The gneiss foliation strikes east and dips $10^{\circ} \mathrm{S}$. The sheets, 6 to 12 inches thick, coincide with the foliation. There are three sets of joints(a), strike N. $40^{\circ}$ E., vertical, spuced 2 to 8 feet, coated with quart\%; (b) strike N. $5^{\circ}$ E., vertical; (c), strike N. $80^{\circ} \mathrm{W}$., vertical, spaced 20 foret. The rift coincirles with the foliation, but the grain is vertical, north to south, and difficult, and the hard way more so. Iegmatite and smoky quirtz veins up to 2 feet thick concide with the foliation and some with joints (b) an (c). Some smill pegmatite dikes carry a little apatite.

Transportation, by cart three-fourths mile to Willimantic.

The product is used for curbing, crosswalks, steps, and flagging, for which its uniformly straight foliation and its great toughness in transverse directious well adapt it.

\section{HHODE ISLAND.}

The granite industry of Rhode Island centers at Westerly. Some of the quarries are near Westerly; others near Bradford station in the same township, and some in Charlestown. Westerly is at the extreme western edge of the State. 5 miles north-northeast of Watch Hill. on the Atlantic shore, and Niantic is $4 \frac{1}{2}$ miles east-northeast of Westerly. (See Stonington aud Charlestown topographic maps, L. S. Geol. Survey, and fig. 92.)

\section{WASHINGTON COUNTY.}

\section{WESTERLY AND CHARLESTOWN.}

\section{TOPOGPAPHY.}

Some of the Westerly quarries are on an east-west ridge about a mile northeast of the eity. This ridge attains an eleration of 200 feet nbove sea revel, or 160 feet above the city. Others are about a mile southeast of Westeriy on the 130-foot level. and one lies a mile east of it on the 100 -foot level. The quarries formerly known as "The Niantie" lie from a mile sonth-southeast to $1 \frac{3}{4}$ miles sontheast of Tiradford station, some being in the town of Westerly. and one in the town of Charlestown. (See fig. 92.)

\section{GEOLOGIC REIATIONS.}

The granites of Westerly and Charlestown have been briefly describert by Merrill, ${ }^{73}$ by Kemp ${ }^{74}$ and by Rice and Gregory, ${ }^{75}$ and in Gregory and Robinson's geologic mal of Connectieut, ${ }^{76}$ reprofuced in Plate XXVIII, the granite gneiss area into which the Westerly granites were intruded in the artjacent parts of Connecticut is shown.

7 Merrill, G. 1'., Report of building stones: 'Tenth Census, vol. 10, p. 20, 1885.

is Kemp. J. F., Granites of southern lhorle Ishand and Counecticut, with obserrations on Atlantic coast granites in general; Geol. Suc. America Bull., vol. 10, pp. 361-382, especially p1. 365-370, 375, 376, and pl. $25,1599$.

is Rice, W. N., and Gregory, H. E., Manual of the geology of Connecticut: Connerticut State Geol. and Nat. Hist. Survey Bull. 6, pp. 115, 136, 152, 154, 155, 1906.

"6 Gregory, I1. E., and Robinson, H. H., I'reliminary grological map of Connectlcut, Sterlin: granite gneiss (24), also the accompanying Outline of the geology of the state: Connecticut State Geol. and Nat. Hist. Surpey Bull. 7, p. 36, 1907. 
According to these geologists, the "pink" and "blue" fine-grained Westerly granites were intruded as dikes in a molten siate into certain older granite gneisses (Sterling granite gneiss), which form extensive parts of the surface

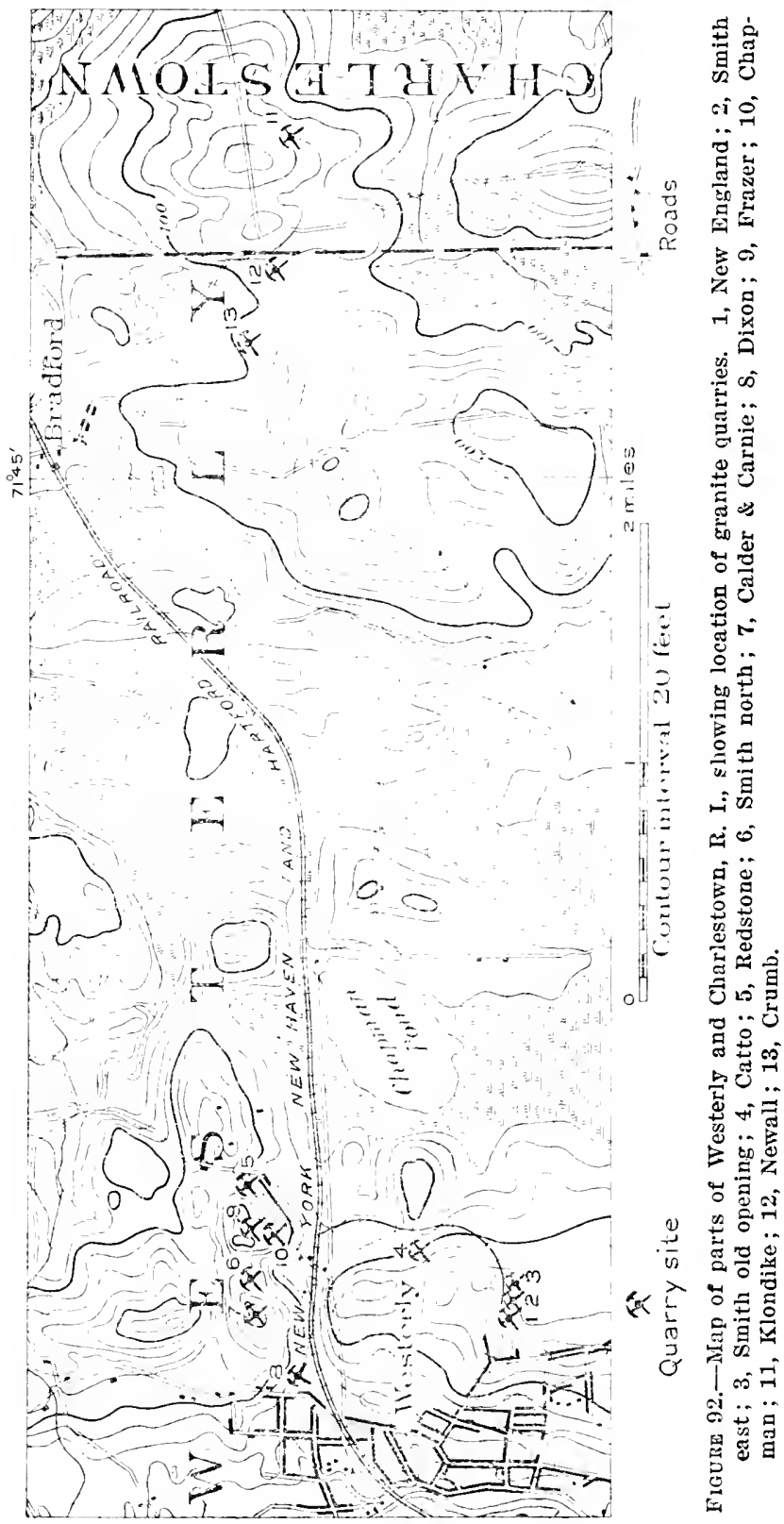

along the Atlantic shore. The medium-grained reddish granite of the Redstone quarry, northeast of Westerly, and the very coarse gneisses exposed at the other quarries all belong to this granite gneiss formation. These granite 
gneisses were originally granites which had likewise been intruded into an earlier overlying gneiss, a metamorposed sedimentary rock (Putnam gneiss, etc.), of which no remnants are reyorted as occurring at Westerly. Prior to the intrusion of the Westerly granite these older granites had been subjected to an amount of lateral compression sufficient to crush, elongate, rearrange. and recrystalize their particles and thus change them into gneiss. The amount of this change is not always uniform. At sonre time prior to the intrusion of the Wresterly granite the granite gneiss was traversed by pegmatite dikes.

The Westerly granites themselves were later also traversed by peginatite dikes and still later by basic dikes. These dikes are probably of Triassic age, as are the tral) ridges of New Haven and the Connecticut Valley. Thus the Westerly region bears records of at least five periods of igneous activity.

In the geologic map of Massachusetts and Rhode Island compiled by Emerson" the Sterling granite gueiss area extends from Westerly eastward to Narragansett Hier and northward along the Connecticut border to the latitude of Pawtucket. ${ }^{78}$

GEOLOGY OF WESTERLY AND CIIARLESTOWN QUARRIES.

That the fine pink granite is of later date than the coarser red cranite (Sterling granite gneiss) is clear from their relations at the Redstone, Smith north, and Calder \& Carnie quarries. That the red granite itself is older than a banded biotite gneiss follows from its containing inclusions of it. Northeast of Westerly the pink granite was intruded into the red granite, but at the Smith and Catto quarries (fig. 18) it or its associated fine blue granite was intruded into a finely banded biotite gneiss not unlike that in the red granite, and at the Flondike, Newell, and Crumb quarries, near Bradford station (Pl. XXXIY, $A$, and fig. 93), it was intruded into a porphyritic biotite gneiss which may be simply a more gneissic phase of a coarser Sterling granite gneiss than that exposed at the Redstone and Dixon quarries. But the finely banded gneiss of the other quarries and of the inclusions resembles the inclusions in the "Redstone granite" and differs from that granite itself both by the absence of microcline and by the predominance of oligoclase or of oligoclase-andesine to andesine, so as to indicate that these finely banded gneisses belong to another formation. possibly to the Putnam gneiss of Connecticut geologists. At the Smith quarry the strike of the banded biotite gneiss is N. $35^{\circ} \mathrm{W}$.

The fine Westerly granites appear in dikelike masses from 50 to 150 feet thick, striking N. $75^{\circ}-90^{\circ} \mathrm{WV}$. and dipping $30^{\circ}-45^{\circ}$ about south. At the Smith quarry they are underlain by a parallel mass of aplitic granite of similar character, carrying also inclusions of finely banded biotite gneiss. At the Klondike quarry the granite has a how structure striking N. $10^{\circ}-20^{\circ} \mathrm{W}$., intersecting the course of the alparent dike. It is uncertain whether these are granite dikes or protuberances from a broad intrusive mass which have become exposed by the erosion of the thimner parts of the overlying gneiss.

The phenomena at the quarries indicate the following as the probilile order of geologic events about Westerly: (1) A finely banded biotite gneiss forms the surface; (2) intrusion by the red granite of the hill northeast of Westerly with a northeasterly flow structure, and also by the gray granite near Bradford station; (3) metamorphism of the red and gray granite converting it

77 See U. S. Geol. Survey Bull. 597, pl. 10, p. 230, 1916.

${ }^{75}$ See also Loughlin, G. F., Intrusive granites and associated sediments in south. western Rhode Island: Am. Jour. Sci., 4th ser., vol. 29, pp. 447-457, 1910 ; The gabbrow and assoclated rocks at I'reston, Conn.: U. S. Geol. Surrey Bull. 492, 1912. 
into a porphyritic gneiss (Sterling granite gneiss); (4) intrusion of the fine granites of Westerly and Charlestown, in some places into the earlier banded biotite gneiss, in others into the more or less aitered Sterling granite gneiss; (5) pegmatite and aplite dikes traverse both the westerly granites and the Sterling granite gneiss, though some of the latter are connected with the intrusion of the finer granite; (6) a diabase dike, probably Triassic, traverses both the Westerly and the sterling granite and the pegmatite dikes in the latter at the Redstone quarry.

The chief joint course in the fine granites is N. $10^{\circ}-25^{\circ}$ E., but the following also oceur: N. $35^{\circ}-10^{\circ}$ E., N. $50^{\circ}-60^{\circ}$ E., N. $10^{\circ}-22^{\circ}$ W., N. $455^{\circ}-55^{\circ}$ W. In the older red granite the courses are $\mathrm{X} .35^{\circ}-15 \mathrm{E}$. and $\mathrm{X} .60^{\circ} \mathrm{W}$. The rift in the fine granite is reported as either horizontal or inclined $10^{\circ} \mathrm{N}$. or S., and the grain as either vertical or $75^{\circ} \mathrm{N}$, with an east-west or N. $65^{\circ} \mathrm{W}$. or $\mathrm{N}$. $70^{\circ} \mathrm{E}$. course, in one instance with a dip of $45^{\circ} \mathrm{S}$. 20-W., in another with a scarcely perceptible dip. The rift in the coarser granite is reported as dipping $20^{\circ} \mathrm{E}$. or IV. A compressive strain is reported as being from north and south, east and west, and northeast and southwest.

WESTERLY GRANITEN.

The following summarizes the more retailed descriptions of specimens and thin sactions, from both Westerly and "Niantic" (Charlestown) quarries, given on pages $408-414$.

"Westerly pink," sometimes called "Westerly statuary" granite is a quartz monzonite of more or less pinkish or buff medium-gray color, ant of very fine, even-srainer texture, with slender feldspars not over 0.1 inch long and slender micas not over 0.15 inch long. Its constituents, in descending order of abundance, are pale smoky quartz; clear colorless to milk-white soda-lime feldspar (oligoclase-abite to oligoclase); in nearly equal amount. slightly pinkish or cream-colored potash feldspar (microcline and orthoclase); and black mica. Magnetite and pyrite are among the accessory minerals, and calcite is anong the secondars.

"Blue Westerly" granite is a quartz monzonite of more or less bluish medium-gray color, with fine black particles, and of fine, even-grained texture, with feldspars up to 0.1 or 0.2 inch and mica to 0.1 or 0.15 inch long. Its constituents, in descending orler of abundance, are clear to milk-white, pinkish, or cream-colored soda-lime feldspar (oligoclase-albite to oligoclase) : more or less transparent bluish or greenish potash feldspar (microcline and orthoclase); and black mica. Magnetite and pyrite are among the accessory minerals, and calcite is among the scondary.

"Red Westerly" granite is a biotite granite of redaish-gray color speckled with black and of even-grained merlium, inelining to coarse texture, with feldspars under 0.4 inch, excentionally 0.5 inch, and mica up to 0.2 inch long. Its constituents, in descending order of abundance, are reddish potash feldspar (microcline and orthoclase); smoky quartz; cream-colored striated soda-lime feldspar (oligoclase-albite); and black mica. Both feldspars are in places stained red from hematite, resulting from the oxidation of manetite particles, which with pyrite is among its accessory minerils. Secondary calcite.

Estimates of the mineral percentages in the pink granite, obtained by applying the Rosiwal method to camera lucida drawings of parts of two thin sections enlarged 40 diameters, yield the following results, with mesh of 1 and 1.4 Inches and total linear lengths of 40 and 33.6 inches. 
Estimated mineral percentages in "Westerly pink" granite.

\begin{tabular}{|c|c|}
\hline Quartz__-_-_-_-_- & 36.09 \\
\hline Oligoclase-albite to oligoclase (soda-lime feldspar) & 30.63 \\
\hline Microcline and orthoclase (potash feldspar) & 28.44 \\
\hline Biotite (black mica) & 3.59 \\
\hline White mica & .50 \\
\hline 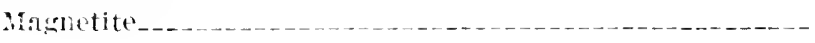 & .75 \\
\hline
\end{tabular}

The average diameter of the particles, obtained by the same measurements, 1s 0.17 .5 millineter, or 0.0069 inch. Measurements of the larger particles in four thin sections of this cranite, made with the micrometer, give the followling figures: Microrline and orthorbase 0.50 to 0.95 millimeter, oligoclase 0.56 to 1.122 millimeters, hintite 0.39 to 0.56 millimeter, white mica 0.168 to 0.392 millimetr r, quartz 0.50 to 1.122 millimeters, magnetite 0.112 to 0.224 millimeter. The feldspars, quarty, and biotite in their coarser partieles thus range from 0.39 to 1.122 millimeters, or 0.015 to 0.0439 inch.

Two estimates of the mineril percentiges in "Westerly blue" granite (pp. $409,416)$, made in the same way, average:

Estimated mineral perecntages in "Westerly blue" granite.

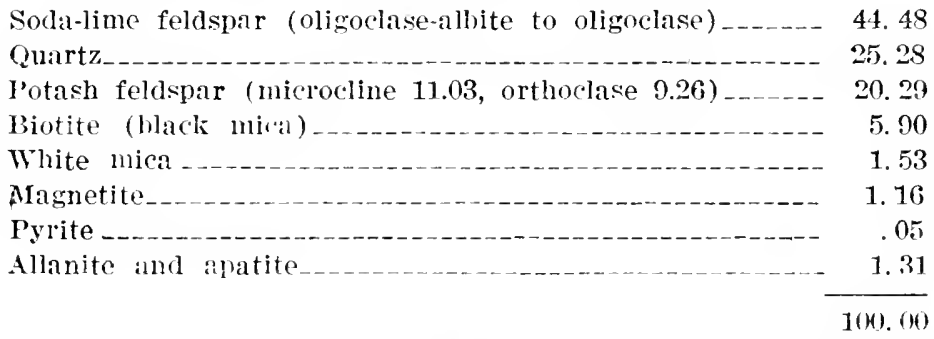

The average diameter of the particles ohtained by the application of the same method to three "Westerly blue" granites, is 0.0099 inch, or about 50 per cent larger than that of the statuary.

An estimate of the mineral percentages in "red Westerly" granite will be found on page 413 .

Kemp " gives two analyses of Westerly granite made by $\mathbf{F}$. W. Love, then of Cornell University, which are repeated here for reference.

Analyses of Westerly granites.

\begin{tabular}{|c|c|c|}
\hline & $\begin{array}{c}\text { Gray } \\
\text { granite. }\end{array}$ & $\begin{array}{c}\text { Red } \\
\text { granite. }\end{array}$ \\
\hline \multirow[t]{2}{*}{ 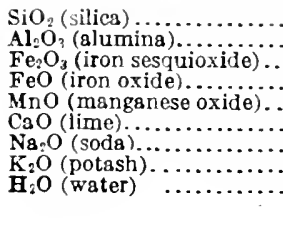 } & $\begin{array}{c}71.64 \\
15.66 \\
2.34 \\
\text { Trace. } \\
2.70 \\
1.578 \\
5.60 \\
.482\end{array}$ & $\begin{array}{r}73.05 \\
14.53 \\
2.96 \\
\text { Trace. } \\
2.06 \\
1.72 \\
5.39 \\
.29\end{array}$ \\
\hline & 100.00 & 100.00 \\
\hline
\end{tabular}

Temp, J. F., Granites of southern Rhode Island and Connecticut, with obserrations on Atlantic coast granites in general: Geol. Soc. America Bull., vol. 10, p. 375, 1899. 
Kemp gives 2.654 as the specific gravity of the gray analyzed.

Messrs. Sullivan and Schaller, chemists, of this Survey, find that five specimens of Westerly granites contain the following percentages of CaO (lime) soluble in hot dilute acetic acid, which indicate the presence of the percentages of $\mathrm{CaCO}_{3}$ (calcium carbonate) shown in the second column. All these granites effervesce slightly with muriatic-acid test.

Lime and calcium carbonate in Westerly granite.

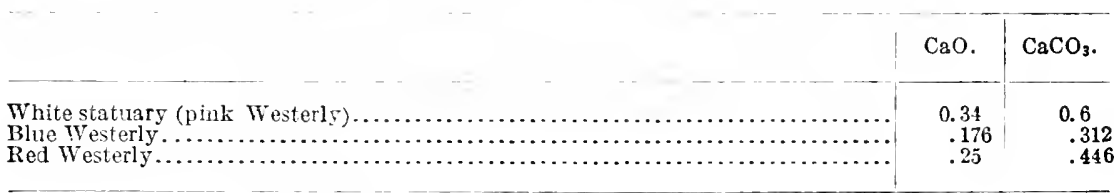

The "pink" (really buff to slightly pinkish gray) and the "blue" (really bluisl gray) Westerly granites are strictly monumental granites, but the former has been called a statuary granite, as it lends itself to the most delicate carvings. The fineness of its texture becomes more apparent in comparing it with that of statuary marbles. As compared with European marbles its texture is between that of "Carrara ordinary" and "Laas statuary" of Tyrol. As com. pared with American marbles it corresponds to the dolomite of Lee, Mass., and the "Brandon Italian" of Vermont. On the table of grades of marble texture it falls in grade 4, medium. It takes a high polish, and its hammered surface is light, offering, as quartz monzonites generally do, a marked contrast of shade to the polisherl surface.

Although "blue Westerly" granite (marble, grade 5, coarse) is 50 per cent coarser in texture than the "pink Westerly," it lends itself well to monumental and sculptural work, as is shown by Plate XXXIV, $B$. Its polish is not quite so high as that of the "pink," owing to the larger size of its mica scales, but its contrast of shade is equally strong.

"Red Westerly" granite is used only for construction.

$$
\text { QUARRIES. }
$$

The New Fngland quarry is 0.9 mile southeast of the Westerly station and 100 feet above it. (See fig. 92.) Operator, New England Granite Works, Westerly.

The granite is of two varieties. One (specimens D, XXVIII, 1, f, i), " pink Westerly," is a quartz monzonite of very slightly pinkish medium-gray color, and of very fine, even-grained texture, with rery slender feldspars not over 0.1 inch long and slender mica scales rarely 0.1 or 0.15 inch long. The arerage diameter of all its particles, including the magnetite, as determined by the Rosiwal method, is 0.0069 inch, or 0.175 millimeter, as given on page 407 . Its constituents, in descending order of abundance are pale smoky quartz with hairlike crystals of rutile and a few cavities; clear colorless to milk-white soda-lime feldspar (oligoclase-albite to oligoclase), partly kaolinized and nicacized ; in almost equal amount, slightly pinkish or cream-colored potash feldspar (microcline and orthoclase), some of it intergrown with quartz circular in cross section; biotite (black mica), some of it chloritized and interleaved with white mica or else partly bleached; some separate nuscovite may be present also. Accessory: Magnetite (ilmenite?), titanite, pyrite, allanite, apatite, zircon, rutile. Secondary: Kaolin, one or two white micas, chlorite, carbonate.

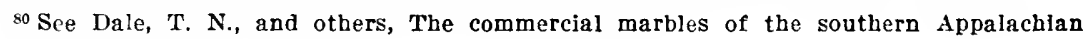
region: U. S. Geol. Survey Bull. - (in preparation). 
Estimates of mineral percentages in this stone have been given on page 407 .

W. T. Schaller, chemist, of this Survey, finds that it contains 0.34 per cent of $\mathrm{CaO}$ (lime) soluble in hot dilute acetic acid, which indicates a content of 0.6 per cent $\mathrm{CaCO}_{3}$ (calcium carbonate). The presence of calcite is shown by the microscope and by a slight effervescence with muriatic-acid test.

A compression test made for the firm at the United States arsenal at Watertown, Mass., in 1907 , with a cube of about 2 -inch face, gave this granite an ultimate compressive strength of 39.750 pounds to the square inch (direction of rift or grain with reference to pressure not noted).

The sculptural qualites of this stone have already been dwelt upon. The polished face shows minute particles of magnetite and a few of pyrite. It hammers light gray, and the contrast between this and the shade of the polished face is somewhat marked.

The second rariety (specimens D, XXVIIII, l, c, cc), "blue Westerly," is a quartz monzonite of very slightly bluish medium-gray color with fine black particles. Its texture is even grained, fine, with feldspars up to 0.2 inch and mica to 0.15 inch. Its constituents, in descending order of abundance, are: Clear to milk-white or pinkish soda-lime feldspar (oligoclase-albite to oligoclase), much of it kaolinized and micacized; pale smoky quartz with a few needle-like crystals, probably of rutile, and with cavities in sheets; clear to blue-greenish and grayish potash feldspar (orthoclase and microcline), intergrown with quartz, circular in cross section, and slightly micacized; biotite (black mica), some of it chloritized, and with needle-like crystals of rutile (?) ; and muscovite or bleached biotite. Accessory: Magnetite (ilmenite?), pyrite, apatite, allanite, zircon, rutile. Secondary: Kaolin, two white micas, chlorite, carbonate, rarely hematite and epidote.

An estimate of the mineral percentages, obtained by applying the liosiwal method to a camera lucida drawing of part of a thin section enlarged 40 diameters, yields the following results with a mesh of 1.7 inches, and total linear length of 42 inches:

Estimated mineral percentages in "blue Westcrly" granite from the quarry of the New England Granite Works.

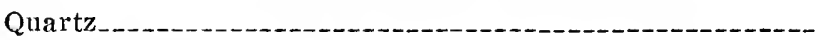

Soda-lime feldspar (oligoclase-albite to oligoclase)

Potash feldspar (microcline 4.14, orthoclase 10.5)

Biotite (black mica)

White mica

Magnetite

Allanite
21. 15

52.64

14. 65

5.52

3.05

1. 71

1. 28

100. 00

No great value need to be attached to the figures for allanite, as a shifting of the mesh would bave thrown it out altogether.

The average diameter of the particles obtined by the same methou is 0.0112 inch.

E. C. Sullivan, a chemist of this Surrey, finds that this stone contains 0.20 per cent of $\mathrm{CaO}$ (lime), soluble in hot dilnte acetic acil, which indicates $a$ content of 0.35 per cent of $\mathrm{CaCO}_{3}$ (calcium carbonate). The presence of ealcite is also shown by the microscope and by a very slight effervescence with muriatic-acid test.

A compression test made for the firm at the United States arsenal at Watertown, Mass., in 1907, with a cube of about 2-inch face, gave it an ultimate com- 
pressive strength of 31,970 pounds to the square inch (direction of rift or grain with reference to pressure not noted).

This stone takes a high polish, but the mica scales, being a little larger than in the "pink," show more on the surface. The polished face shows not a little magnetite in fine particles, with rare grains of pyrite. The combination of a slightly bluish with a slightly pinkish feldspar, both in fine particles, results in a peculiar gray in the polished face. The hammered face is light gray and in contrast to the shade of the polishel surface.

The quarry, opened about 1860 , measured in 1906 about $3 \%$ feet in a westnorthwest direction by 200 fect across and from 40 to 80 feet in depth. Within 20 feet west-northwest of it is another opening of about the same size, to be united with the main opening, so as to cobain a working face 600 fect long.

Rock structure: The sheets, 6 inches to 12 feet thick, are horizontal but somewhat irregular, owing to "growing on." There are two sets of joints-(a), strike N. $15^{\circ}-25^{\circ} \mathrm{E}$, vertical, spaced 8 inches to 30 feet, forms a heading 15 to 20 feet wide on the west sile, separating it from the older excation, and another, 5 to 10 feet wide, on the east side, which divides this from the adjacent Smith quarry; (b), strike N. $50^{\circ}-55^{\circ} \mathrm{W}$., rertiral, spaced 18 inches to 30 feet. The rift is reported as hol'zontal, and the srain as rertical, with $\mathrm{N} .65^{\circ} \mathrm{W}$. course. There is a 2 -inch permatite dike striking $\mathbf{N} .37^{\circ}$ E., consisting of pink potash feldspar, amethystine quartz, and muscovite; the feldspar is partly altered to light-green epidote. Pegmatite dikes also traverse the heading on the west side. Rusty stain is 1 to 7 inches thick on the shect surfaces. There is much kaolinization of feldspar and limonite stain adjacent to the pegmatite dikes. On the south-southwest wail the slanite is in contact with a southward inclined overhanging mass of dark biotite gneiss with a vertical foliation. This is also crossed by pegmatite dikes. The line of contact vetween granite and gneiss is jagged in places. The relations on the north wall are now largely concealed hy dumps, but their character is woll exposed in the adjoining Smith quarry, as described on page 411. The structural relations of the pinkish-gray and bluish-gray granite to each other are not clear. At one point on the southsouthwest wall the former seems to underlie the latter, and there seem to be also lateral changes in the color of both near the dike which are possibly caused by it. The width of the granite from nortil-northeast to south-southwest, at right angles to the dip, does not exceed 150 feet.

Transportation, by siding to New York, New Haven \& Hartford Railroad.

Nearly all of the product is used in monumental work, the rest in buildings, and the waste for paving, particularly small blocks for electric roads. Specimen monuments of the "blue": National monument, Gettysburg, Pa.; Antietam monument, Maryland; Perkins monunent, Akron, Ohio; Skinner and Ware monuments, Denver, Colo.; of the "pink": Horne monument, with a 7-foot 6-inch figure, Homewood cemetery, Pittsburgh, Pa.; Whiton monument, Greenwood cemetery, Brooklyn, N. $X$. Plate XXXIV, $B$, shows lilies and passion flowers on the base of a cross of the "blue" stone. Specimen buildings of the "blue": Connecticut Mutual Insurance Building, Hartford; Branford House, Groton, Conn.; Mutual Life Insurance Building, Philadelphia; Williamsburg Savings Bank, Brooklyn, N. Y.

The Smith quarry adjoins on the east the one just described and is about 0.9 mile southeast of Westerly station and 100 feet above it. (See flg. 92.) Operator, Smith Granite Co., Westerly.

The granite consists of the Identical two varietles, "Westerly pink" and "Westerly blue," already described under the New England quarry. Both are quartz monzonites-the pink a slightly pinkish medium-gray of even- 
grained, very fine texture; the blue a slightly bluish nerlium-gray of evengrained, fine texture. (For full descrintions see pp. 408-409.)

The quarry, first opened in 1846, consists of two openings. The "New East quarry," separated from the New England quarry only by a heading measured in 1906250 feet east-southeast by 200 feet across and 65 feet deen; the other, older one, contiguous to the last on the east, was about 400 feet east-southeast hy 125 feet across and 150 feet deep.

Rock structure: The sheets in the upper 25 feet are from 2 inches to 2 feet thick, and below that fromi 9 inches to 5 feet thick, and all horizontal. There is only one set of joints, strike N. $20^{\circ}-22^{\circ}$ E., spaced 100 to 300 feet, forms a 50 -foot heading between the two openings and a 5 to 10 foot heading between the western opening and the New England quarry. The rift is reported as horizontal, and the grain as vertical, with a N. $65^{\circ} \mathrm{W}$. course. On the southsoutluwest the granite is overlain by a mass of dark-gray banded hiotite-hornblende gneiss of somewhat fine texture, which strikes N. $30^{\circ} \mathrm{V}$. and dips $45^{\circ}$ SSW. The rock contains much soda-lime foldspar (oligoclase-andesine to andesine) but no microcline. On the north-northeast the granite is apparently underlain at $45^{\circ}$ by a mass of cranite (quartz monzonite) of more or less pinkish-gray color and of somewhat fine texture with a variable amount of black mica. so as in places to resemble an aplite. It is also marked in places by dark-brownish stains, 0.25 inch in diameter and an inch or so apart, which are due to the alteration of allanite particles into hematite and limonite. This rock contains many angular inclusions, large and small, of a somewhat finely banded biotite gneiss, which itself contains lenses and dikes of pegmatite parallel to its schistosity and evidently formed hefore the intrusion of the quartz monzonite. The foreman stated that the "blue granite" at the bottom of the larger opening contained an inclusion 10 feet in diameter like the inclusions of gneiss above described. In this opening about 40 feet of " pink" intervenes between the overlying gneiss and the "blue," but in the smaller opening these relations are reversed. The entire width of the mass of "blue" and "pink" appears to be 80 to 100 feet, measurerl at right angles to its inclination. The heading which separates the two openings is much broken by subjoints parallel to it. For a thickness of 8 feet on the west it is altered to a dull greenish-reddish color. In thin section this shows the feldspars kaolinized, micacized, and chloritized, most of the biotite bleached, the magnetite passing into hematite and the pyrite into limonite. As its soda-lime feldspar is oligoclase-andesine, differing from that of the adjacent granite, this heading may he a transverse granite dike. These structural data were obtained in 1906 .

Transportation, by sidine to New York, New Haven \& Hartford Railroad, but paving stones are carted one-third mile to wharf on Pawcatuck River.

The product is nearly all used for monuments; the waste goes into paving blocks of various sizes. Specimen monuments: Equestrian statue of WashIngton erected by the United Order of American Mechanics at Allegheny, Pa.; Roger Williams monument at Roger Williams Park, Providence, R. I.; First Massachusetts Volunteer Infantry monument, Gettysburg, Pa.; Ohio State inommment. Vicksburg. Miss.; sollier's monument, Jewett City, Conn.; of the "pink," C. A. Roebling monument, 'Trenton, N. J.

The Calder \& Carnie quarry is 0.9 mile $\mathrm{N}$. $50^{\circ} \mathrm{E}$. from the Westerly station, and 160 fect above it, on the western hump of the ridge north of the railroad. (See fig. 92.) Operator, Smalley Pink \& Red Westerly Co., Westerly.

The granite (specimen D, XXVIII, 8, a), "Westerly pink," is a quartz monzonlte of medium pinkish-buff gray color, more pinkish than any of the other fine Westerly granites except specimen I, e, from the rock next to the peg- 
matite dike in the New England quarry. Its texture is even grained, very fine, with feldspars not over 0.1 inch and mica still less. Its constituents are the same as those of the fine stone from the Smith north quarry, but with a little more hematite stain. The thin section shows carbonate, and the stone efferresces slightly with muriatic-acid test. The quarry also yields the " red" constructional granite described on this page.

The quarry, first opened in 1882, measured in 1906 about 400 by 250 feet and 90 feet deep.

The sheets, 6 inches to $S$ feet thick, are horizontal and irregular. There are two sets of joints-(a), strike N. $20^{\circ} \mathrm{W}$., dip $45^{\circ} \mathrm{S} .70^{\circ} \mathrm{W}$., spaced 2 to 8 feet, discontinuous, forms a beading 10 feet wide in the center, and one of these joints lias subjoints striking $\mathrm{N} .30^{\circ} \mathrm{W}$., one-half to 1 inch apart; (b), strike N. $35^{\circ}-40^{\circ}$ E., dip $S 0^{\circ}$ N. $37^{\circ}$ W., aud $90^{\circ}$, spaced 2 to $S$ feet. The rift is reported as dipping north at a low angle, and the grain as striking N. $70^{\circ} \mathrm{E}$. and dipping $45^{\circ}$ E. $20^{\circ} \mathrm{W}$. The fine granite occur's here as a dike dipping $45^{\circ}$ S. and 50 feet thick, with the medium-grained "red" on both sides of it. It also contains pegmatite rikes parallel to its course. Some fine veins in the fiow direction are described on page 22. Along joints (a) the granite is much reddened for 1 to 2 inches. In this reddish zone the feldspars are much kaolinized and micacized, the biotite is chloritized, epidote occurs, and ths magnetite is altered to hematite, which has reddened the feldspars. Rusty stain is up to $4 \frac{3}{4}$ inches thick on sheet surfaces.

Transportation, by cart three-fourths mile to siding of New York, New Haven \& Hartford Railroad.

The product is used for monuments and buildings.

The Catto quarry is about a mile east-southeast of Westerly station, 60 feet above it, and half a mile northesst of the Smith and New England quarries. (See fig. 18.) It is now abandoned.

The granite (specimen D, XXVIII, 9, a), "blue Westerly," is a quartz monzonite of very slightly bluish medium-gray color with fine black particles. It is a trifle more bluish than that of the New England quarry. Its texture is fine, with feldspar and mica up to $0.1 \mathrm{inch}$, the former exceptionally 0.16 inch. It is thus a trifle finer than specimens 1, c, cc (p. 409), but its constituents are the same.

The quarry, opened before 1886, measured in 1906 about 350 feet east-west by 200 feet across and from 75 to 100 feet in depth.

Rock structure: The sheets, 6 inches to 10 feet thick, dip north at a low angle. But one set of joints strike N. $22^{\circ} \mathrm{W}$., vertical, spaced 3 to 50 feet, and discontinuous below. The rift is reported as horizontal and the grain as scarcely perceptible. The east face of quarrs shows the relations of the granite to overlying banded gneiss.

The Redstone quarry is less than $1 \frac{1}{2}$ miles east-northeast of Westerly station, at the east foot of an east-west ridge, one-fourth mile north of the New York, New Haven \& Hartford Railroad. (Sce fig. 92.) Operator, New England Granite Works, Westerly.

The chief granite of this quarry (specimens D, XXYIII, 2, b, h), "red Westerly," is a biotite granite of medium reddish-gray color speckled with black. Its textnre is even grained, medium, inclining to coarse, with feldspars under 0.4 inch, exceptionally $0.5 \mathrm{inch}$, and mica up to 0.2 inch. Its constituents, in descending order of abundance, are reddish potash feldspar (nicrocline and orthoclase), some of it slightly micacized, intergrown wtih quartz in vermicular structure, in places also with soda-lime feldspar; smoky quartz with hairlike crystals, probably of rutile, also with cavities in sheets with rift cracks parallel to them; cream-colored striated soda-lime feldspar (oligoclase-albite), kaolin- 
lzed and micacized, and intergrown with quartz like the other; and biotite (black mica), some of it bleached. Accessory: Magnetite, pyrite, apatite, zircon, rutile. Secondary: Kaolin, two white micas, hematite stain from magnetite particles, in places reddening both feldspars, calcite.

An estimate of the mineral nercentages by the Rosiwal method yields the following results with a mesh of one-half inch and total linear length of $33 \frac{1}{2}$ inches: Potash feldspar (microcline and orthoclase), 35.40; quartz, 29.87; soda-lime feldspar (oligoclase-albite), 2S.35; biotite (black mica), 6.74.

An analysis of this granite by Love has been given on page 407 .

W. T. Schaller, chemist, of this Survey, finds that it contains 0.25 per cent of $\mathrm{CaO}$ (lime) soluble in hot dilute acetic acid, which indicates a content of 0.446 per cent of $\mathrm{CaCO}_{3}$ (calcium carbonate), the presence of which is shown by the microscope and also by a slight effervescence with muriatic-acid test.

A compression test made for the firm at the United States arsenal at Watertown, Mass., in 1907, with a cube of about 2-inch face, showed the first crack with 106,000 pounds and final fracture with 113,000 pounds, indicating an ultimate compressive strength of 28,540 pounds to the square inch (direction of rift of grain with reference to pressure not noted).

The contrasts between the colors of the two feldspars come out strongly on the polished face, which shows considerable magnetite and some pyrite. The size of the mica plates is not favorable to the durability of the polish in longcontinued outdoor exposure. It is a constructional granite of warm tint.

The quarry, opened in 1880 , measured in 1906 about 850 feet from north to south by 250 feet across, with a working face 100 feet high on the west.

Rock structure: The sheets, 1 to 20 feet thick, are somewhat irregular. In the upper part most of them dip $10^{\circ}$ about west-northwest and a few ale horizontal, but lower down all are horizontal. At the south end the sheets are intersected by sliarply curved partings ("toenails"). There are inclusions of finely banded biotite gneiss resembling the capping at the Smith and Catto quarries. The rift is reported as horizontal and the grain as fairly defined and vertical, with a N. $20^{\circ}$ E. course. There is but one set of joints. strike N. $35^{\circ}$ E., dip $70^{\circ}$ S. $35^{\circ}$ E. to $90^{\circ}$, spaced 15 to 50 feet, forms a heading in the center of the quarry and a heading at the extreme north end which is 40 feet wide. A dike 5 to 19 feet thick runs the whole length of the quarry, with a dip of $10^{\circ} \mathrm{S}$., consisting of alternating reddish aplite and coarse pegmatite (reddish feldspar, smoky quartz, and biotite), some of the surfaces of which are coated with iridescent drusy hematite. Beneath this almost horizontal dike is a mass of unknown extent of fine pinkish quartz monzonite like that at the Smith and New England quarries described on page 406. This reaches the surface at the north and south ends of the quarry. The ovoidal mass shown in Plate XXIX, B, and described on page 73 , came from the 40 -foot heading which crosses this quartz monzonite at the north end of the quarry. Small basic dikes are described on page 56. Rust stain on the sheet surfaces is up to 3 , rarely 4. inches thick. A thin section of it shows both feldspars stained with limonite. It follows irregular cracks in the microcline and the quartz, as well as the boundaries between them. It proceels in some cases clearly from the larger grains of magnetite and from biotite scales.

Transportation, by siding to New York, New Haven \& Hartford Railroad.

The product is used entirely for buildings. Specimens: Southern Pacific Building, Houston, Tex.; Tuberculosis Hospital, New Haven, Conn.; town hall and courthouse, Westerly, R. I.; Elks' Memorial, Buffalo, N. Y. ; American Exchange, American Tract Society, and Travelers Insurance Co. Buildings, New York Clty. 
The Smith North quarry is a mile N. $60^{\circ}$ E. of the Westerly station, 120 feet above it, in a saddle on the east-west ridge north of the railroad. (See fig. 92.) Operator, Smith Granite Co., Westerly.

The granite is of two solts- "red Westerly," a medium-grained biotite granite of medium reduish gray color identical with that of the Redstone quarry (specimens D, XXVIII, 2, b, ll), described on page 412, and "pink Westerly" (specimen D, XXVIII, 4, a), a quartz nonzonite of medium buff-gray color and of very fine, even-gritined texture, with feldspars mostly up to 0.057 inch, exceptionally 0.1 inch, and mica to 0.025 ,exceptionally $0.15 \mathrm{inch}$. It is identical in composition with the "pink Westerly" described on page 408, but is of more pinkish tint.

The quarry, opened before 1892, measured in 1906 about 200 feet from east to west by 150 feet across, with a working face 75 feet high on the west and 25 feet on the east.

Rock structure: The sheets, 6 inches to 10 feet thick, are lenticular but very irregular and without uniform dip. The only set of joints strikes N. $10^{\circ}$ E., vertical or learly so, spaced 20 to 40 feet. The rift is reported as dipping $10^{\circ} \mathrm{S}$. and the grain $75^{\circ} \mathrm{X}$. Sixty feet of the fine granite overlies the "red," the plane of their contact dipping $40^{\circ}-50^{\circ}$ about south. At the top of the wolking face a lesmatite dike 10 feet thick dips $45^{\circ} S$. Rusty stain is only 2 inches thick on sheet faces.

Transportation, by cart one-fourth mile to New York, New Haven \& Hartford Railroad.

Product: The "red" is used for buildings and the "pink" for monuments.

The Dixon quary is about half a mile nortleast of the Festery siation at the west foot of the ast-west riklge north of the railroal. (see fig. 92.) It is now abandonerl.

The granite (specimen D, XXVIII, 7 , a) is a biotite granite of medium buff-gray color with tine black particles. Its texture is medium, inclining to coarse, with feldspars up to 0.4 inch, exceptionally 0.5 inch, and mica to 0.15 inch. Its constituents, in descending orler of abundance, are pinkish-gray potash fuldspar (nicrocline and orthoclase), slightly kaolinized and intergrown with quartz and solla-linte feldspar; smoky quartz with cavities; greenish-gray striated soda-lime fehlspar (oligoclase-alnite). some of it nuch micacized and kaolinized; and biotite (black mica), some of it chloritized. Accessory: Magnetite, pyrite, apatite, allanite, zircon. Secondary: Kaolin, two white micas, chlorite, limonite, liematite, carbonate.

This is a constructional granite which is closely related to the "red" of the Redstone quarry but in which the potash feldspars are less reddish and the soda-lime feldspars are greenish instead of cream-colored.

The quary consisted in 1906 of three openings-one 150 by 100 feet and 20 to 40 feet deep, one 100 by 75 feet and 40 feet deep, and one 100 by 50 feet and 10 to 30 feet deep.

Rock structure: The sheets, 6 inches to 6 feet thick, are generally horizontal. There are two sets of joints-(a), strike N. $45^{\circ}$ E. vertical, spaced 50 to 100 feet, forms several headings; (b), strike N. $60^{\circ} \mathrm{W}$. vertical, spaced 50 feet and over, less numerous than (a).

Although the stone is adapted for buildings, only crushed stone was being produced in 1906.

The Chapman quarry is near the foot of the rilge. (See fig. 92.) It is abandoned, but is nentioned here becanse of its geologic features.

A joint face forming the west wall and working face strikes $\mathrm{N}$. $10^{\circ} \mathrm{W}$. It is intersected at intervals of 1 to 3 feet by vertical joints striking N. $50^{\circ} \mathbf{E}$. At the top is an inclusion of biotite gneiss 10 feet in diameter. Dipping $10^{\circ} \mathrm{s}$. 
atross this face is a pegmatite dike about a foot thick. Between 20 and 30 feet below it is an aplite dike a few inches thick with like dip. The sheets are only 1 to 3 feet thick. and the joint intervals are too short to make quarrying protitable. The granite is the fine-textured pinkish-gray quartz monzonite already described.

The Klondike quary is in Chiarlestown, 13 miles southenst of liradford station and $5:$ miles east of Westerly station. (See fig. 92.) Operator, Sullivan Granite Co., Westerly.

The granite (specimens D, XXVIII, 11, c, g), "blue-white Westerly," is a quartz monzonite of medium bluish-gray color with very fine black particles. Its texture is fine, with feldspars up to 0.1 , exceptionally $0.2 \mathrm{inch}$, and mica to 0.05 , exceptionally 0.1 inch. Its constituents, in descending order of abundance, are rlear to milk-white or eream-colored striated soda-lime feldspar (oligoclase), partly kaolinized and micacized (in some crystals the altered part is central ; in others it forms a zone with unaltered feldspar within and without it); slightly smoky quintz with hairlike erystals, probably of rutile, and very few cavities; more or less tramslarent bluish potash feldspar microcline and orthodase, the first intersrown with quartz); and biotite (black mica), some of it chloritizer. Accessory: Magnetite, titanite, pyrite rare, apatite, allanite, zircon, rutile. Secondary: Kaolin, a white mica, carlonate.

E. C. Sullivan, a chemist of this Survey, finds that this granite contains 0.18 per cent of $\mathrm{CaO}$ (lime) soluble in lot dilute acetic acil, which indicates a ('ontent of 0.32 per cent of $\mathrm{CaCO}_{3}$ (calcium carbonate), the presence of which is also shown by the microscole and hy a slight effervescence in muriatic-acid test.

A compression test made for the firm at the United States arsenal at Watertown, Mass., in $190 \bar{\tau}$, with a cube of ahout 2 -inch face, showed the first crack with 107,000 pounds and final fracture with 118,000 pounds, showing an ultimate compressive strength of 29,500 pounds to the square inch (direction of rift or grain with reference to pressure not stated).

This is a monumental granite of fine texture and bluish tint. Its texture Is a little finer than that of the "blue" of the New England quarry and about the same as that of the stone from the Newall quarry (p. 416). It is more bluish than the former, not containing any pinkish feldspar, and, its mica particles heing finer, it takes a higher polish. The polished face shows magnetite in fine particles, but scarcely any pyrite. There is a considerable contrast of shate between the hammered and polished faces.

The quarry, opened in 1897, measured in 1906 about 600 feet from east to west by 100 feet across and from 75 to 100 feet deep. (See Pl. XXXIV, A.) On the south sitle the stripping of drift increases from 5 feet in thickness at the west wall to 35 feet at the east wall, owing to the inclination of the rock surface.

Rock structure: The sheets, 1 to 8 feet tlick, dip generally $5^{\circ} \mathrm{S}$. There is but one set of joints, which strike N. $25^{\circ} \mathrm{E}$., dip $70^{\circ} \mathrm{W}$., spaced 5 to 50 feet. The rift is reported as horizontal, lut feeble. A flow stucture, shown by streaks of black mica, strikes N. $15^{\circ} \mathrm{W}$. and dips west. There is a dike of aplite striking $\mathrm{N} .25^{\circ} \mathrm{E}$. dipping $70^{\circ} \mathrm{W}$. The structural relations are shown in figure 98 and Plate XXXIV. A.

since the diagram of figure 93 was made lle process of axcation is reported to have shown in 1909 a narmwing of the grante dike below, but it may widen aga in farther down. 
The problem presented by the structure here is whether this belt of granite $\mathbf{7 5}$ feet thick is simply a dike of indefinite depth or a minor protuberance in the undulating surface of a wille granitic intrusion which became exposed by the erosion of the overlying gneiss where it was thinnest. The gneiss (specimen $D$, XXVIII, 11, a) is of a rery dark gray shade and fine to medium texture, but with poiphyritic feldspars from 0.5 to $1 \frac{1}{2}$ inches in diameter, consisting of a light pinkisly-buff potash feldspr (microcline and orthoclase), rimmed with milk-white soda-liwe feldspar (oliwolase-andesine). The groundmass consists of the same potash feldspar, smoky quartz, the same soda-lime feldspar, and biotite. The granite is crossed at irregular intervals by pinkish and pyritiferous "streaks," veinlets from 0.1 to 0.4 inch wide, with a centril thread of epidote. 'Their course is parallel to the joints. In thin section the sola-lime feldspars of these veinlets ar" much kaolinized and micacized. Rusty stain along sheets is 1 to 6 inches thick. Some joint faces are coated with a thin film of calcite; others with epidote from the alteration of feldspar.

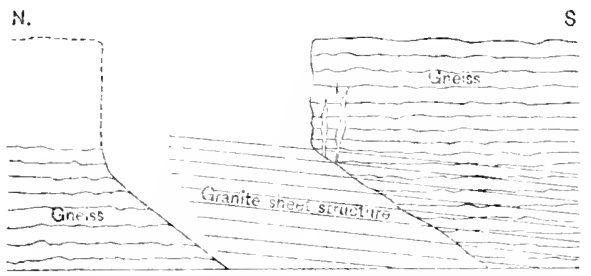

Figure 93. - Approximate structure at the Klondike quarry, in Charlestown, R. I. (See further on P. 415.)
Transportation, by cart $2 \frac{1}{2}$ miles to New York, New Haven \& Hartford Railroad.

'The product is used entirely for monuments.

'The NewalI quarry is in the town of Westerly just west of the Charlestown line, $5 \frac{1}{4}$ niles about east of Westerly station, and $1 \frac{1}{4}$ miles southeast of Bradford station. (See fig. 92.) Operator, Sullivan Granite Co., Westerly.

The granite (specimens D, XXYII, 6, a, c), "blue Westerly," is a quartz monzonite of medium bluish-gray color, with very fine black particies. Its texture is eveu grained, fine, with feldspars and mica up to 0.1 inch. Its constituents, in descending order of abundance, are clear to milk-white striated soda-lime feldspar (oligoclase), somewhat kaolinized and micacized; pale smoky quartz, with few hairlike crystals, probably of rutile, and cavities; clear bluish to translucent potash feldspar (orthoclase and microcline), intergrown with quartz and slightly kaolinizerl; and biotite (black mica), some of it chloritized. Accessory: Magnetite, pyrite, allanite, zircon, rutile. Secondary : Kaolin, a white mica, carbonate.

An estimate of the mineral percentages, obtained by applying the Rosiwal method to a camera lucida drawing of part of a thin section enlarged 40 diameters, yields the following results with a 2 -inch mesh and a total linear length of 38 inches.

Estimated mineral percentages in "blue Westerly" granite from the Newall quarry, near Westerly, R. I.

Soda-lime feldspar (oligoclase)

Quartz

Potash feldspars (microcline 17.91, orthoclase 8.00) 25.91

Biotite (black mica)

Magnetite

Pyrite 
Much weight should not he attached to the fisures for alatite and allanite, for the mesh could have been shifted to avoid intersecting these particles, but their sum can be safely regarded as standing for the more abundant accessory minerals next to magnetite and pyrite. The average dianeter of all the particles obtained by the same measurements is 0.0057 inch.

IV. T. Schaller, chemist, of this survey, fints that it contains 0.15 per cent of CuO (lime) soluble in dilute acetie acid, which indicates a content of 0.26 per cent of $\mathrm{CaCO}_{3}$ (calcimm carbonate), the mesence of̈ which is also shown by the microscope and by a slight efferrescence with muriatic-aeid test.

This is a fine-grained monmental granite susceptible of high polish and fine carving. It is of the same texture as the stone of the Klondike quarry and a little finer than the blue of the New England and Smith quarries. Its shate is a trifle darker than that of the granite from the Kondike quarry. The polished face shows many minute particles of magnetite and a few of pyrite. There is a marked contrast between the hammered and polished faces.

The quarry, opened in 1853 , measured in 1906400 to 450 feet from east to west by 250 feet across and from 50 to 100 feet in depth.

Rock structure: The sheets, 1 to 9 feet thick, are horizontal at the east end, (iip $10^{\circ}-15^{\circ} \mathrm{W}$. at the west end and $1.5^{\circ} \mathrm{s}$. at the bottom. There are two sets of joints-(a), strike N. $25^{\circ}$ E., dip $75^{\circ}$ EsE, spateed 5 to $200 \mathrm{feet}$; (b), strike N. $45^{\circ} \mathrm{W}$. rertical, exceptional. The rift is reported as dipping $20^{\circ}$ about east, but in places west, and the grain as striking east and vertical. The granite orcurs in a dikelike mass about 100 feet thick, dipping $45^{\circ} \mathrm{S}$. and both underlain and overlain by "white horse," which here is a light pinkish-gray biotite gneiss consisting of light-pinkish potash feldspar (microcline) in elongated crystals, smoky quartz, elear to milk-white oligoclase, and biotite. The foliation of this gneiss appears to strike about east and to dip with the surface $45^{\circ} \mathrm{S}$. A pegmatite borker separates granite from gneiss. Minute brownish veins traverse the gneiss. Rusty stain is up to 14 inches thick on sheet surfaces, and ferruginous water exudes from between them 25 to 50 feet down the quarry.

Transportation, by cart $1 \frac{1}{4}$ miles to New York, New Haven \& Hartford Railroad at Niantic, and thence $4 \frac{1}{2}$ miles by rail to cutting shed at W'esterly.

The prodnct is used exciusively for monmments. Specimens: Sirrophagus monument to Senator Sherman, Mansfield, Ohio; obelisk to Gen. Lew Wallace, Crawfordsville, Ind.; W. L. Elkins and P. A. B. Widener mausoleums, Central Laurel Hill, Philadelphia; monument to J. D. P'utnam erected by Fourteenth Wisconsin Regiment on the battle field of Shiloh; reproduction of the elaborate Celtic cross of St. Martin in the island of Iona, erected by Mrs. MeNeil in Rosedale Cemetery, Los Angeles, Calif.; T. M. Newall monument at Westeriy, which has a delicate bas-relief of an entire poply plant and a butterfly (ciesign copyrighted).

The Crumb quarry is in Westerly, 1 mile S. 32 $2^{\circ}$. of Bralford station, and 5 miles about east of Wester!y station. 1sere tig. 93.) (Juratur, sulliran Granite Co., Westerly.

The granite, "blue Westerly," is a quartz monzonite of medium bluish-gray color, with rery fine black particles, and even-raincd, fine texture, identical with that of the Newall quarry, described on page 416 .

The quarry, opened in 1857 , measured in 1906 about 400 feet from east to west by 125 feet across and 40 feet in depth.

Rock structure: The sheets, 6 inches to 8 feet thick, are umluliting horizontal. There are two sets of joints-(a), strike N. $25^{\circ} \mathrm{E}$, dip, $50^{\circ}-70^{\circ}$ WSW., spaced 10 to 150 feet, forms a heading across the center; (b), strike N. $60^{\circ}$ E., vertical, ex. 
ceptional and discontinuous. The rift is reported as horizontal, but with a "run" dipping low east, and the grain as vertical, east-west. The granite oceurs in a dikelike mass, apparently continuous with that of the Newall quarry, about 850 feet east-southeast of it. It is about 100 feet thick and is underlain on the north by a gneiss, "white horse," with a foliation and surface dipping $20^{\circ}$ $40^{\circ} \mathrm{S}$. This gneiss (specimen D, XXVIII, 12, b) is a light pinkish-gray biotite gneiss identical with that of the Newall quarry (p. 417). The light-pinkish feldspars (orthoclase and microcline) are in elongated lenses from 0.2 to 0.3 inch wille. The biotite is fine and sparse. Although the schistosity of the stone may be great enough to impair its strength, its contrasts of color are very attractive. The granite is crossed by a 1-inch pegmatite dike dipping $45^{\circ} \mathrm{E}$. Rusty stain is 10 to 15 inches thick along sheet surfaces. The faces of joints (a) are in places bright reddish and thinly coated with radiating pearly crystals of a silicate, stilbite (?).

Transportation, by cart $1 \frac{1}{4}$ miles to railroad at Niantic.

The product is used for monuments, which are made mostly in Quiney, Mass. Specimens: Alexander Thompson and Oliver Hazard Cooper monuments, Swan Point Cemetery, Providence; Ihode Island monument, Andersonville, Ga.

\section{ADAPTABILITY OF NEW ENGLAND GRANITES.}

A cursory glance at the paragraphs on "Product" in the foregoing quarry descriptions will suffice to show the great variety of adaptations of New England granites. Some, by their many joints and in places "shake structure," together with their situation at tidewater, supply irregular blocks of all sizes at low cost for breakwater construction. Others, by their marked rift and grain, lend themselves to the manufacture of paving blocks. Still others, by their even gneissic texture, are equally well adapted for curbing, crossings, and sills. Then come the coarse thick-sheeted granites useful in the construction of massive edifices, bridges, and their approaches and anchorages or retaining walls. Here belong also those coarse granites occurring in such thick sheets and with such sparseness of joints as to furnish large monolithic columns. Besides all these are the numerous granites suitable for ordinary buildings and monuments and offering to the architect a great variety of color, tint, and shade-pinkish, greenish, pale lavender, buff, cream-colored, bluish grays, many shades of gray, besides white, almost as white as white marble, and black (Norwich) suitable for sooty atmospheres.

These granites also include a wide range of texture. (See Pls. XXX, A, and XXXI, A, showing two of the coarse-textured ones.) Some granites by the fineness of their texture are adapted to delicate sculpture. Statuary, flowers, and intricate conventional designs can be carred in granite. Others by the height of their polish, the size of their porphyritic crystals and the colors, tints, and shades of their feldspars, quartz, and mica are adapted to interior decoration. Some of the quartz monzonites and the so-called black granites are specially useful as inscribed tablets or dies on account of the contrast between their polished and cut surfaces. 
Finally there are the rust-colored granites and aplites (Rockport and Hingham, Mass.), affording, when used in connection with normal granites, unique contrasts of color; also the aplite of Hingham, of unusual compressive strength, sought after for keystones.

It would be difficult to name a use for granite which can not be supplied by some of the quarries described in this bulletin, and as to colors the only ones lacking in New England are the deep purple and deep reddish, which must be sought in Wisconsin or Scotland or Norway. Some reddish granites occur also in Minnesota, Missouri, Texas, and Oklahoma.

Among the notable structures and public monuments built of New England granite are the Library of Congress, Union Station, Post Office (including interior polished columns), National Museum, and Freer Art Collection Building, Washington; Hall of Records, customhouse, post office, Bank of Commerce, Bankers 'Trust Co. Building, pedestal of Statue of Liberty, columns of Cathedral of St. John the Divine, New York; soldicrs and sailor's memorial, Syracuse, N. Y.; Cook County courthouse, Alexander Hamilton memorial, Grant Park, Chicagro; State capitol, Madison, Wis.; Northwestern Mutual Life Insurance Building, Milwaukee, Wis.; Museum of Fine Arts, Minneapolis, Minn.: McKinley national memorial (including sarcophagi), Canton, Ohio; Lincoln memorial, Hodgenville, Ky.; State capitol, Harrisburg, Pa.; national monument, Gettysburg, Pa.; Pilgrim monument, Provincetown, Mass.; Bunker IIll Monument, Charlestown, Mass.; soldiers and sailor's' monument, Whitinsville, Mass.; State library and ('onnecticut River Bridge, Hartford. Conn.

\section{ECONOMIC CLASSIFICATION OF NEW ENGLAND GRANITES.}

The granites of New England in respect to their general uses may be divided into nine classes- $(\mathrm{A})$ constructional. used for buildings, bridges, retaining walls, pedestals; (B) monumental, used for monuments, and requiring finer texture than those of class $a$; (C) s:ulptural, used for delicate carving and statues, also for monuments; (D) inscriptional, adapted to inscriptions legible at a distance; (E) polish, susceptible of high polish; (F) rusty-faced, for buildings requiring special contrasts of color: (G) curbing and trimming. adapted by their gneissic texture for curbing, trimming. and sills; (H) breakwater, easily quarried and situated at tidewater, and thus adapted to the construction of breakwaters: (I) paring. suitable by their rift and grain for the manufacture of paving blocks. As the waste of some constructional and monmental granites is also used for paringr. any enumeration of paving-stone quarries would be misleadling. The quarries on the Maine coast and on Cape Ann, Mass., are the chief producers of paving blocks. 
In the first of the following tables all the granites described in this bulletin, except a few unimportant prospects and hopeless quarries, are classified in the nine classes named. The locality, quarry name, trade name, color or tint and shade, texture, and scientific name of each granite are given in separate columns, together with a page reference to the description of stone and quarry. The localities are given by States in alphabetic order, but in each State the order is that of the quarry descriptions. The table gives all the granites but not all the quarries in which they occur.

In order to facilitate the search for granite of a particular color or shade all the granites of classes $a, b, c$, and $f$ have been classified according to their dominant colors and shades, without reference to their uses, in Table 2. The designations of color or tint and shade make 17 groups-1, white; 2 , black; 3 , gray with strong contrasts, white dominant: 1 , black and white, strong contrasts, black dominant; 5, gray, porphyritic; 6, gray with weak contrasts, light, medium, dark; 7 , gray, light, medium, dark, tinted bluish, greenish, buff ; 8, lavender tinted; 9 , reddish gray, light, medium, dark; 10, pinkish gray, light, medium, dark, bright; 11, pinkish to light gray or light buff-gray, with large black spots; 12 , pinkish-reddish buff; 13 . buff ; 14 , cream-colored; 15 , greenish, pea or olive; 16 , mottled; 17 , rust-colored. 


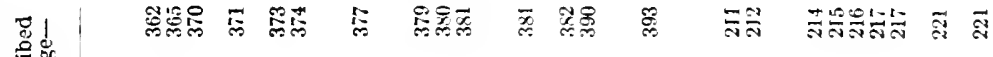
苋范
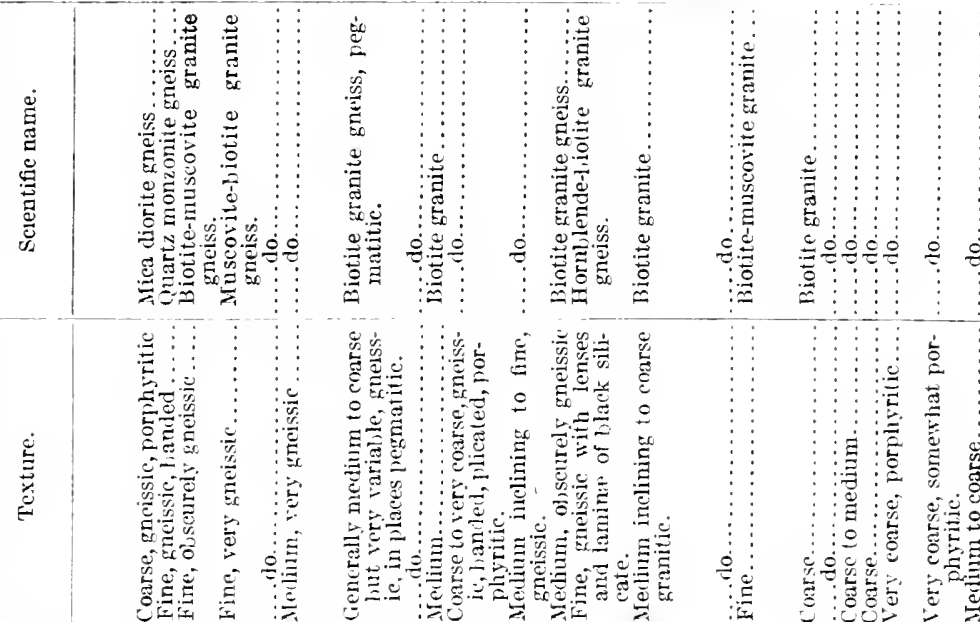

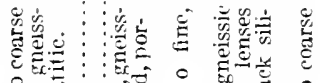


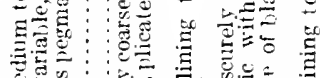

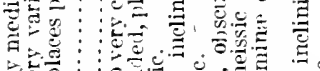
the

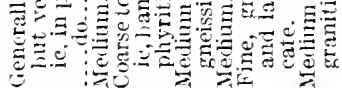

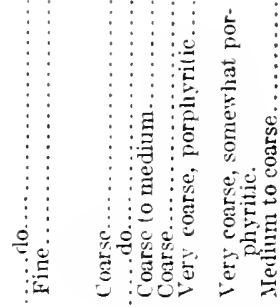

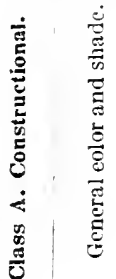
鼠离

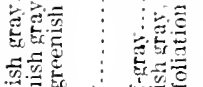
(

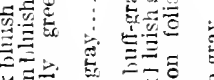

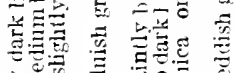

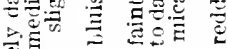

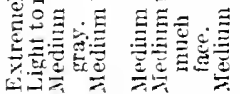

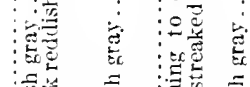

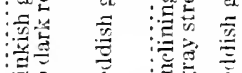
产言

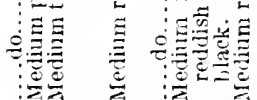

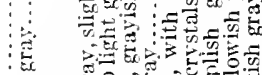
t5.

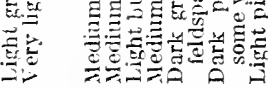

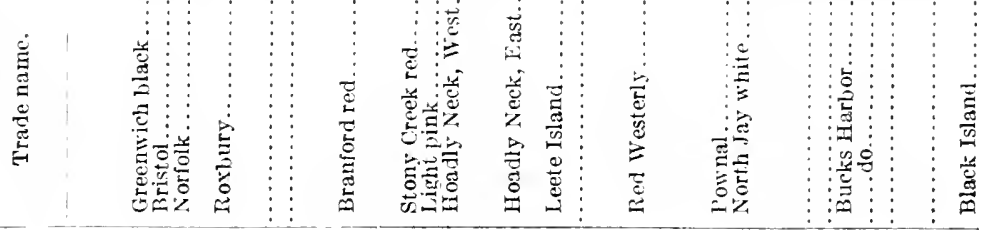

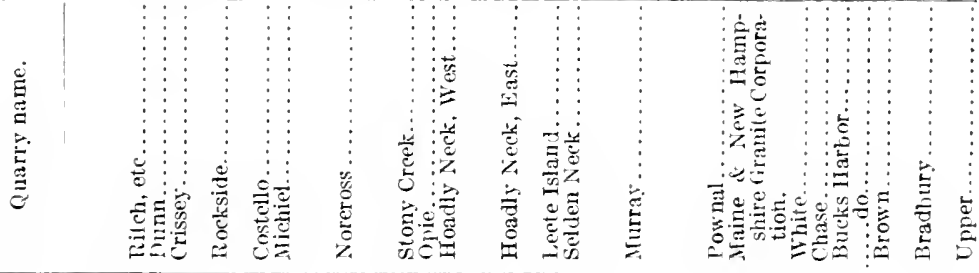

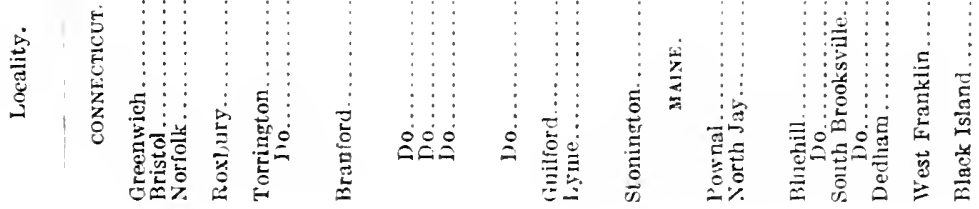




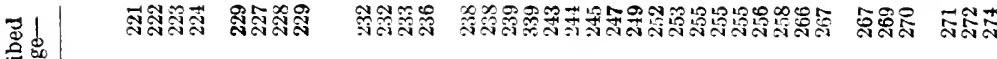
跑莒 คัํํㅇ

రే
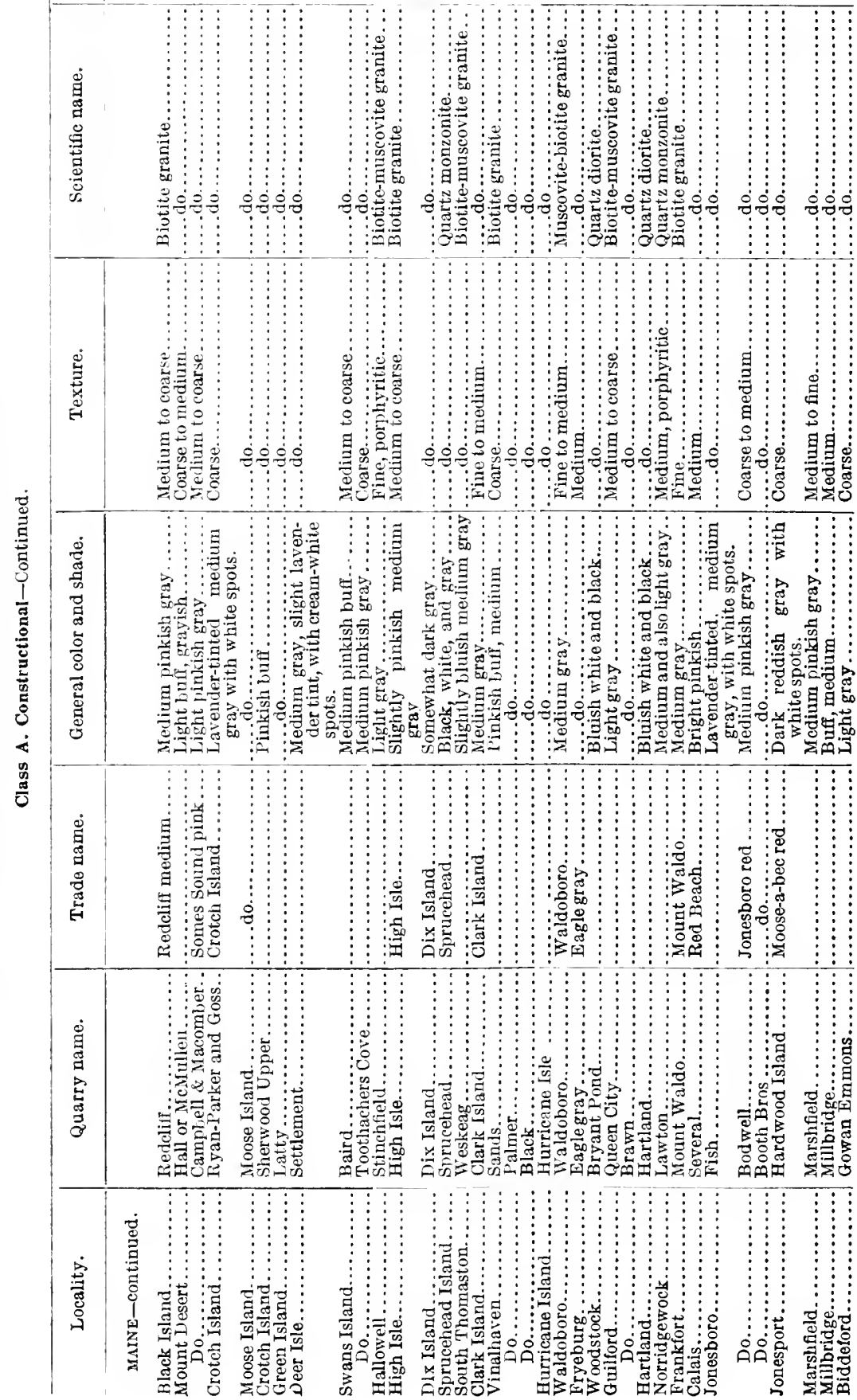


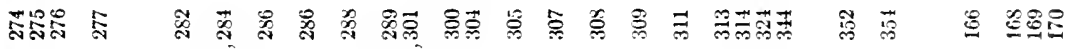
箈薄

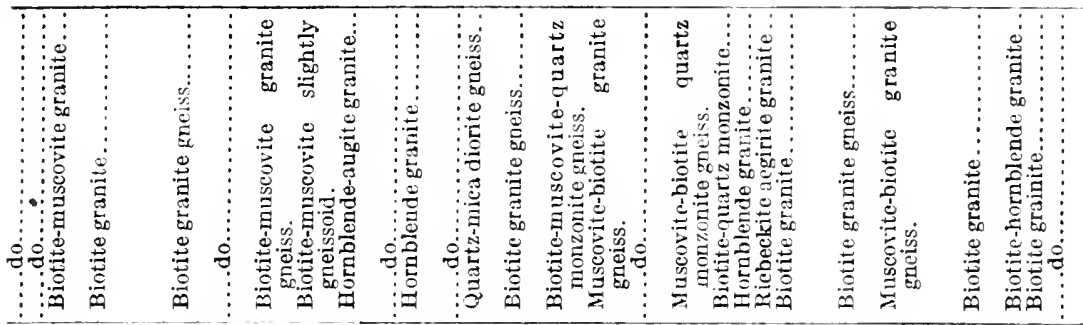

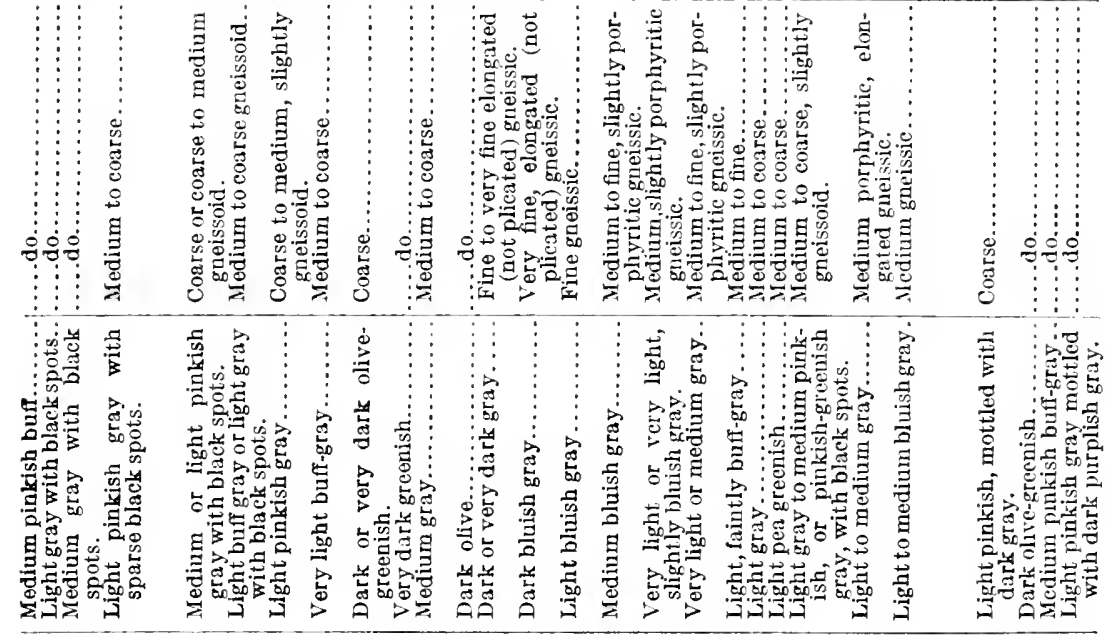

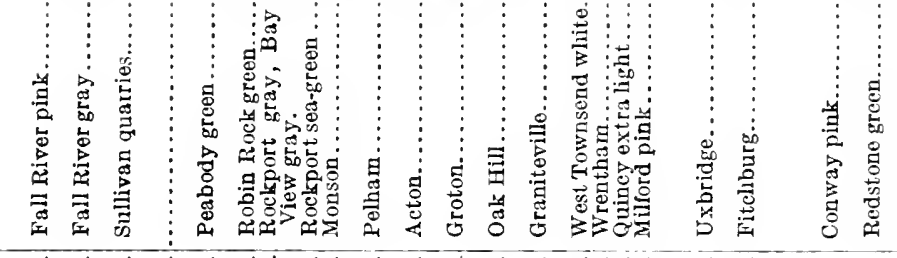

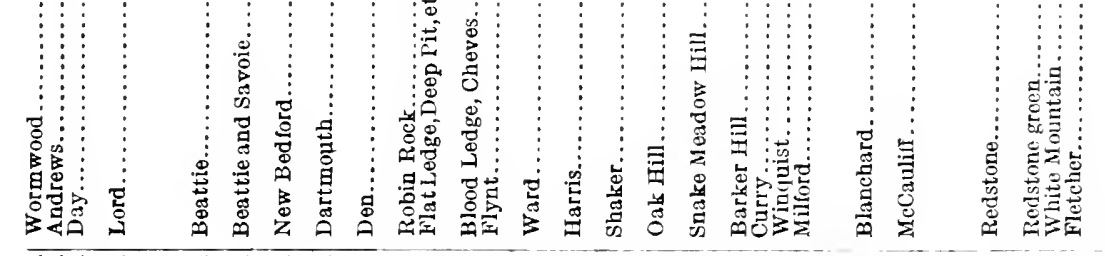

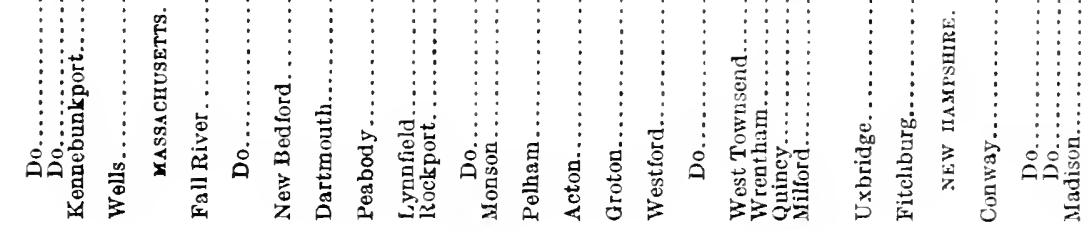




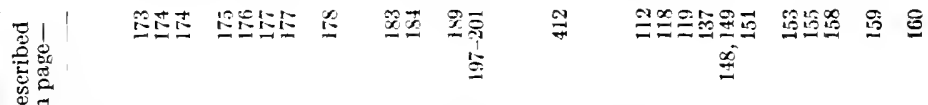

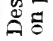

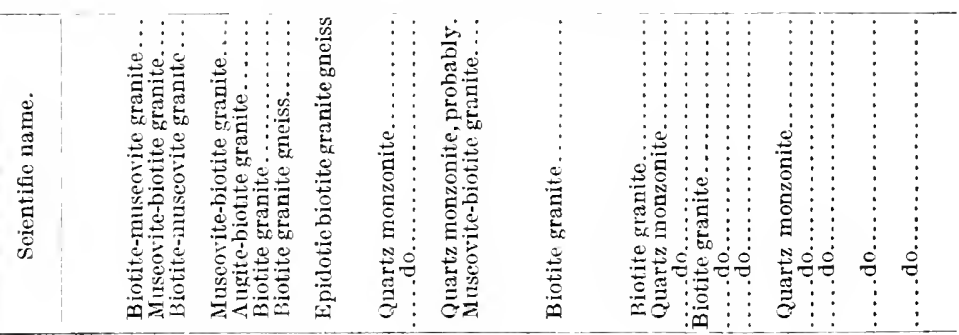



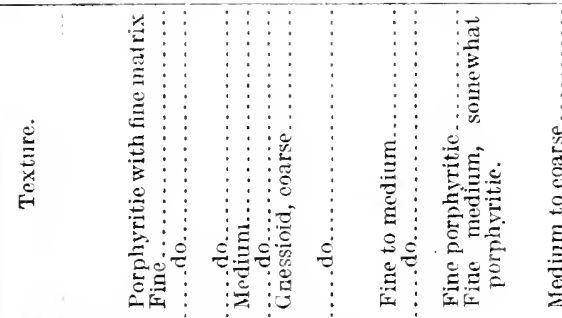

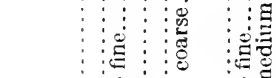

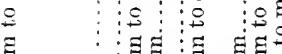

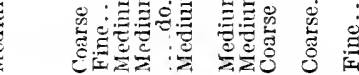

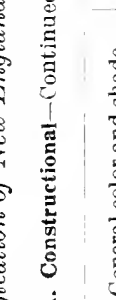

妾它

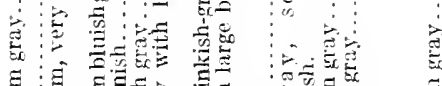

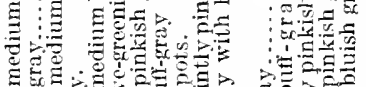

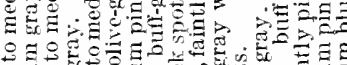

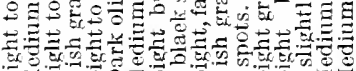

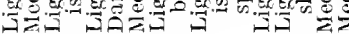

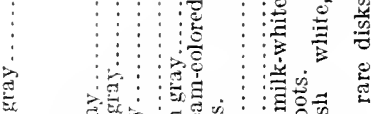

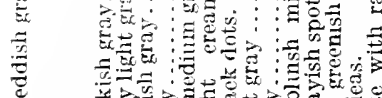

焉

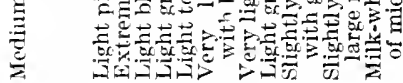

氙

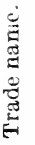

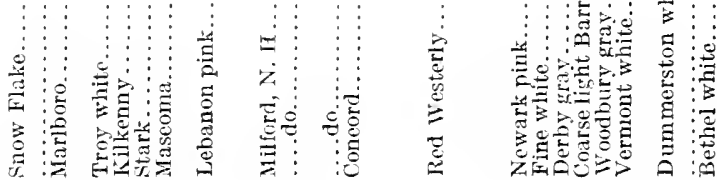

营

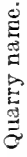

:

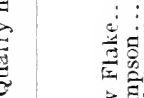

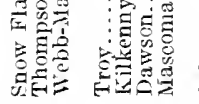

它

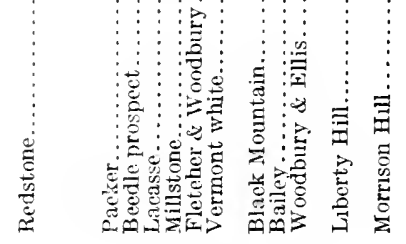
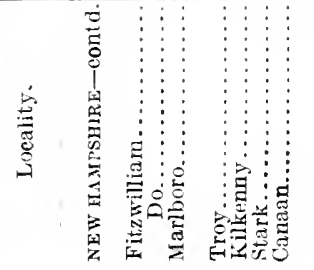

ताA है। 


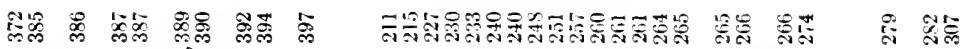
悹

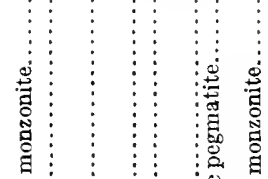

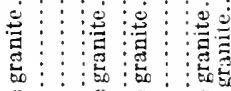

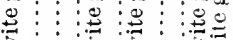

$\stackrel{\varrho}{\varrho}$

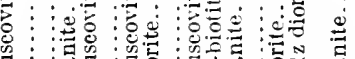

范

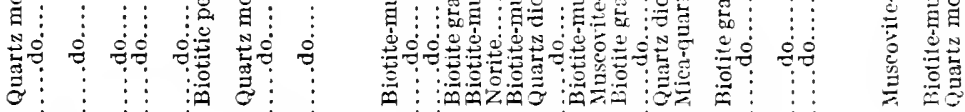

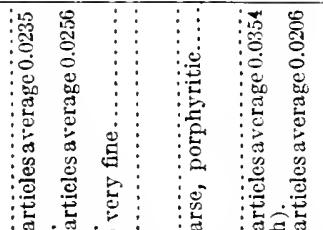

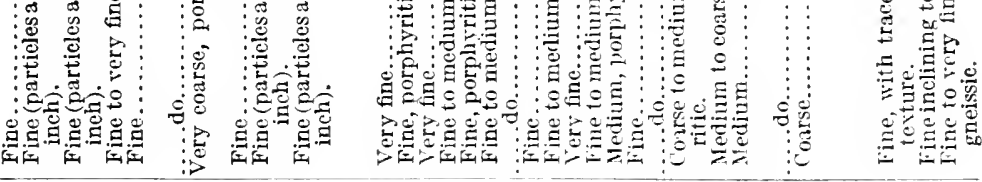

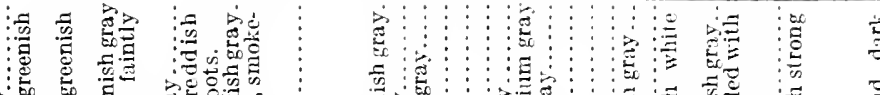

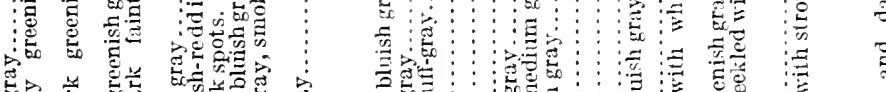

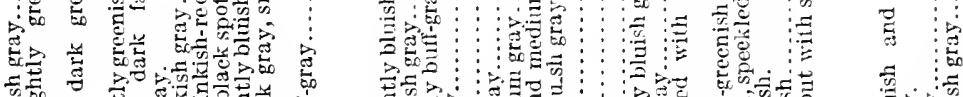

总

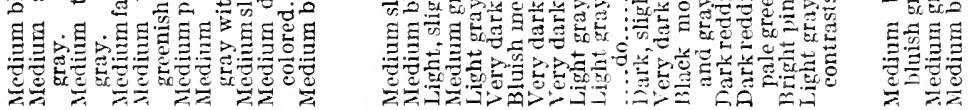

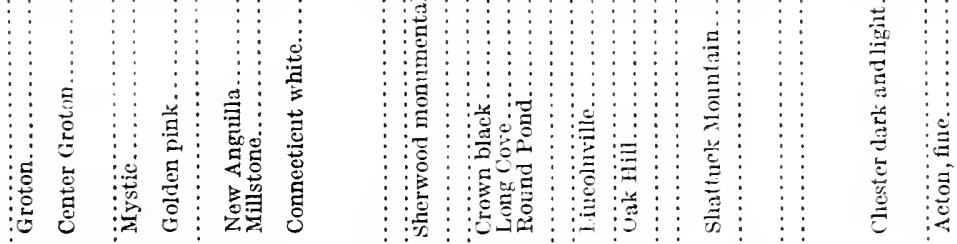

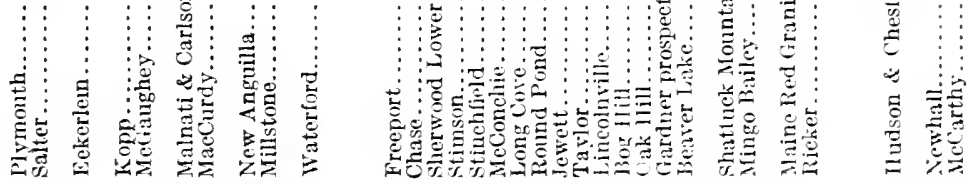

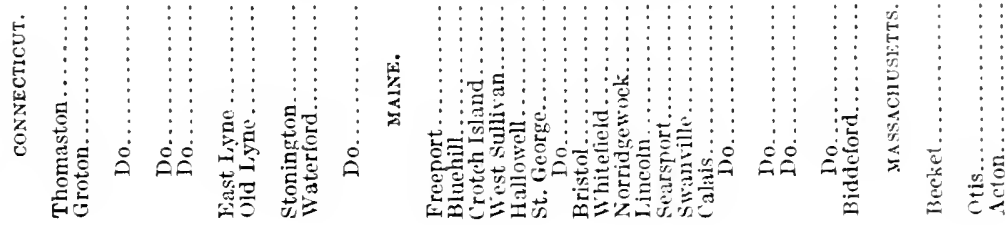




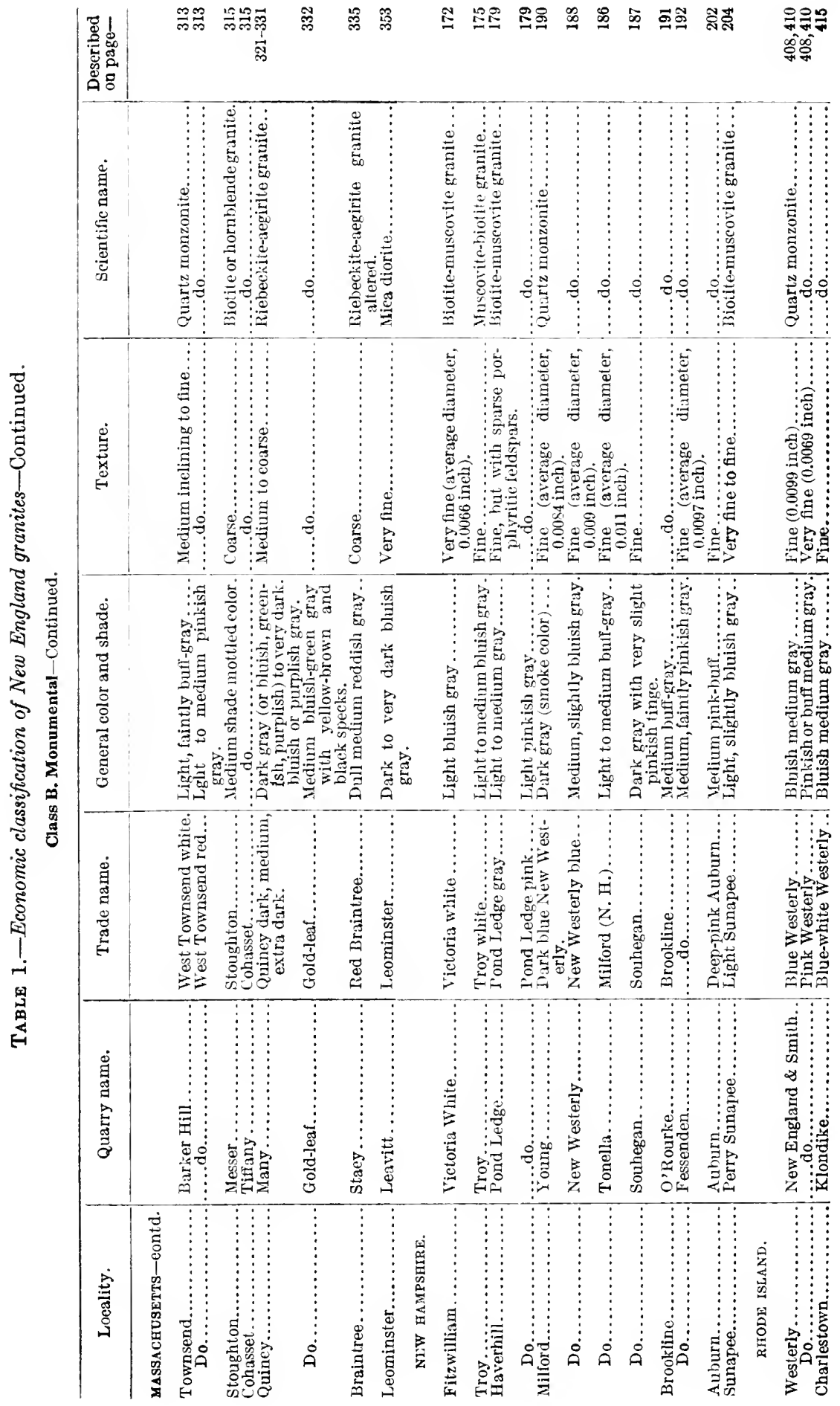




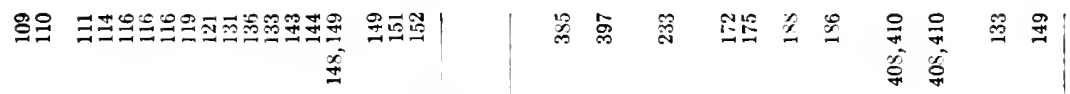

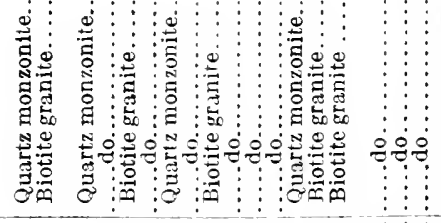

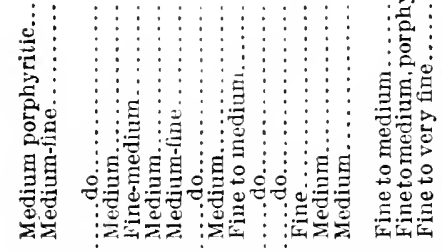

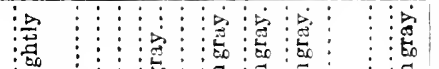

结

司更

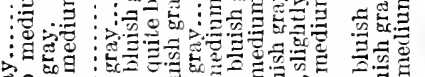

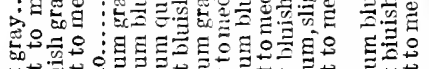

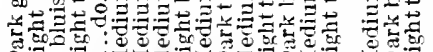

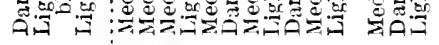
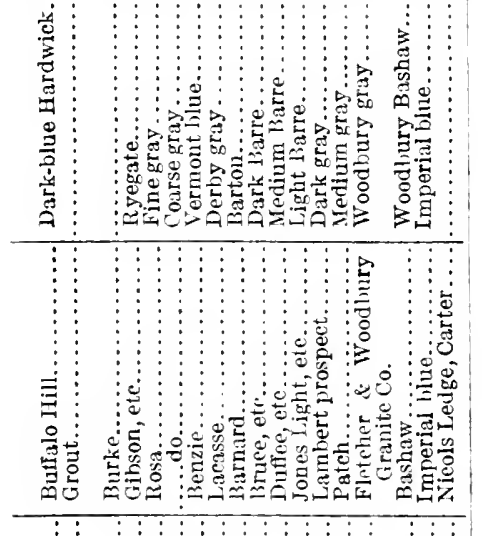

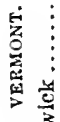

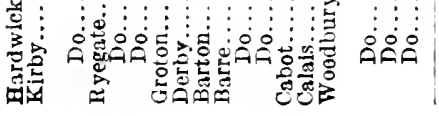
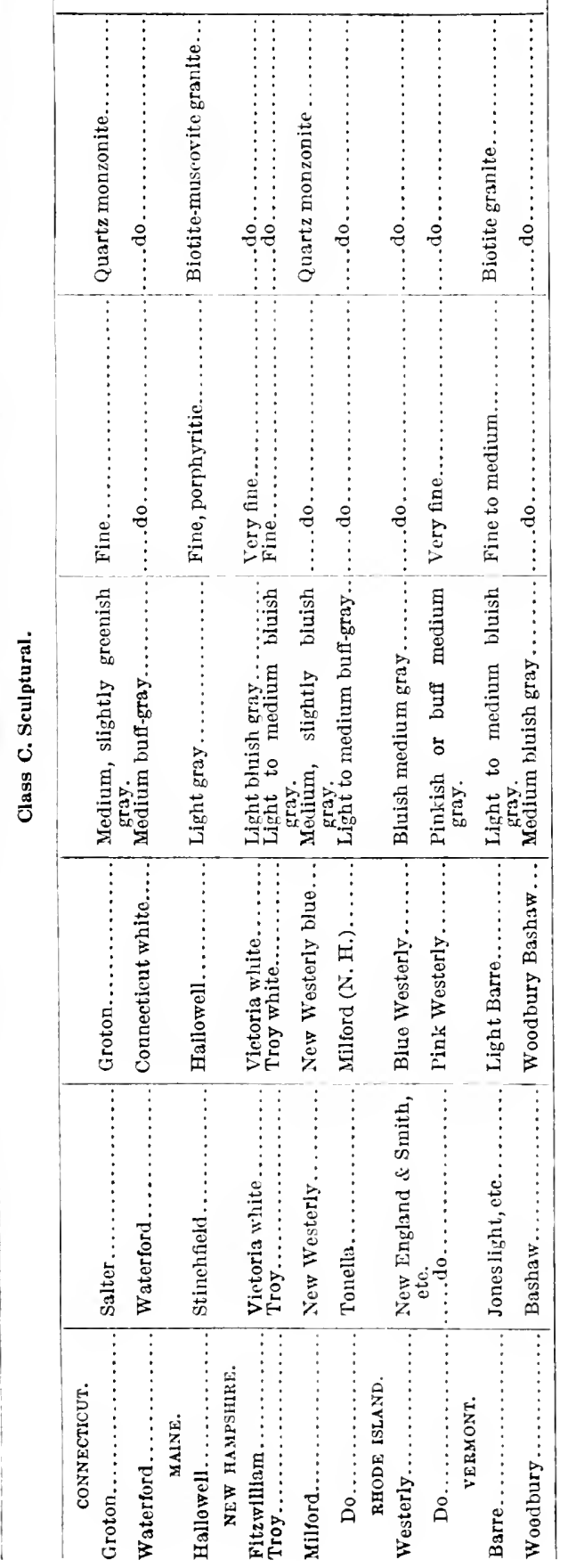


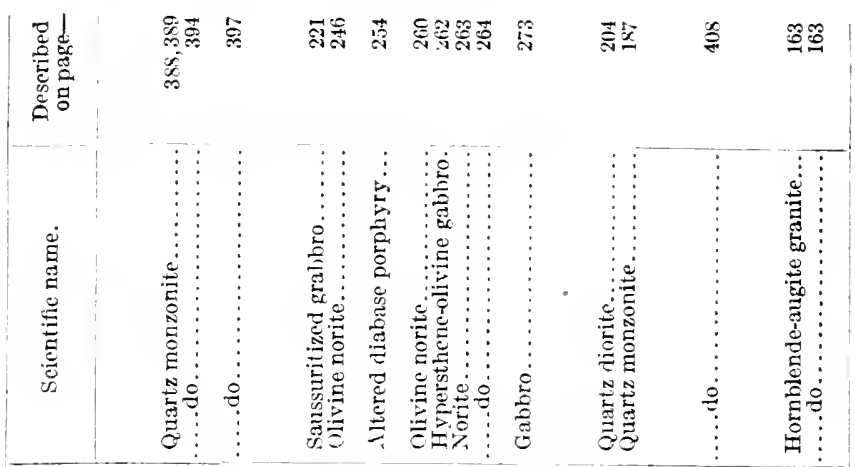



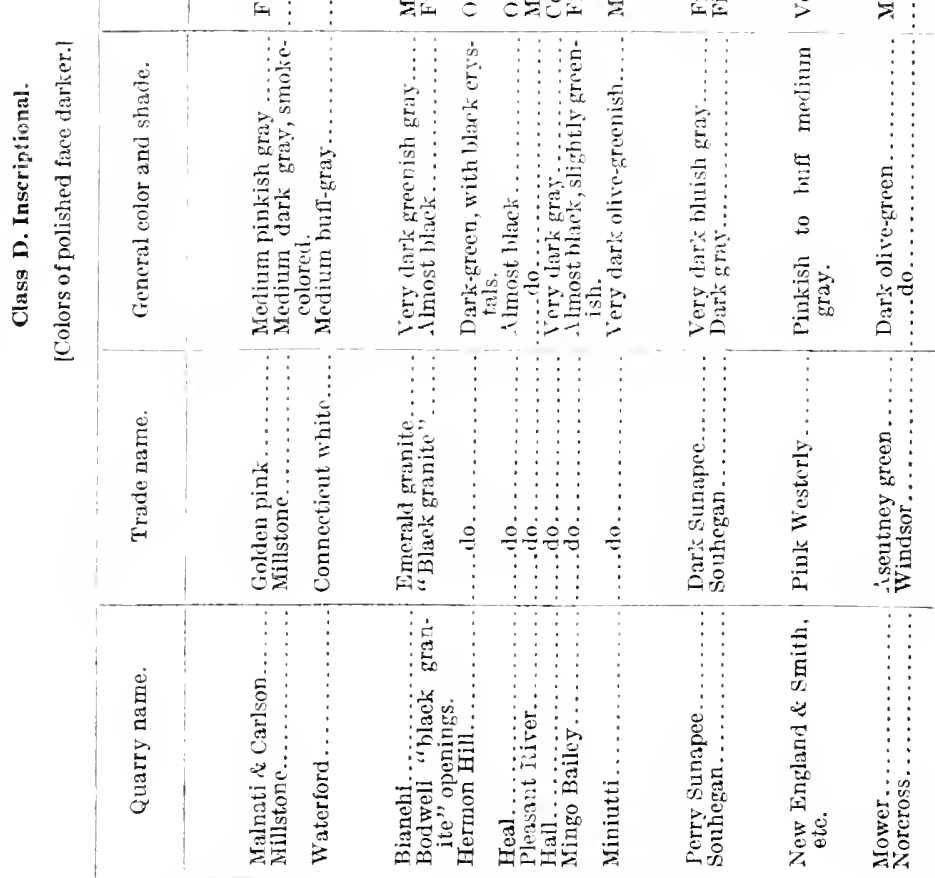

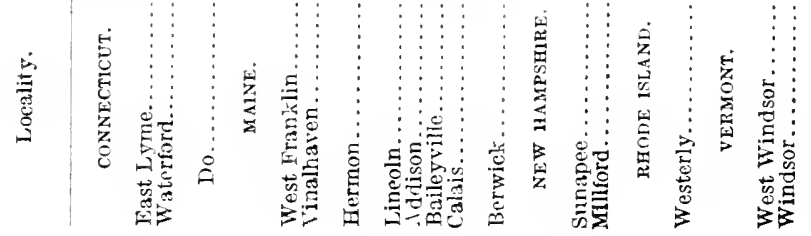




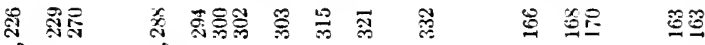 茳}

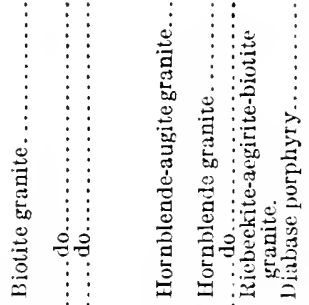

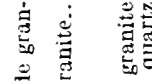

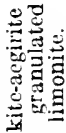

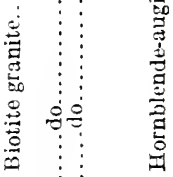

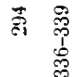

焉号

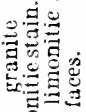

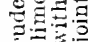

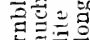

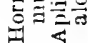

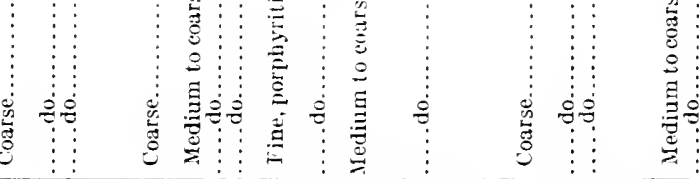

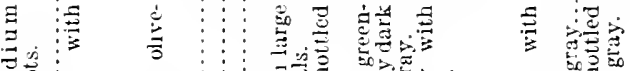

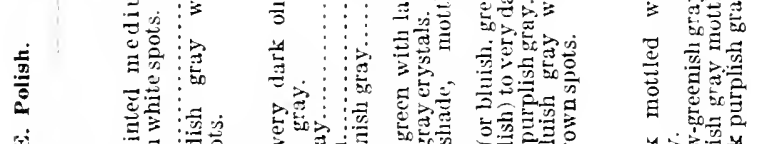

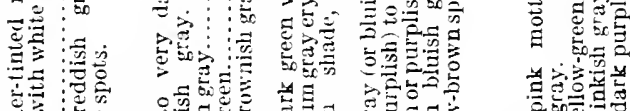

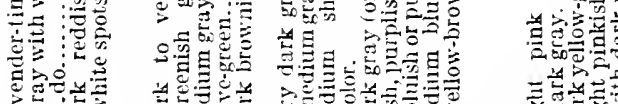

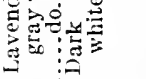

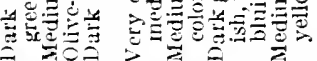

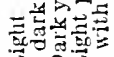

焉:

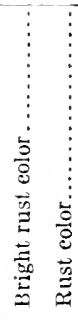

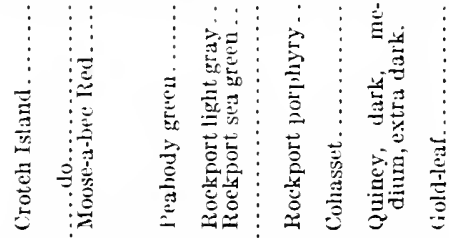

离

產

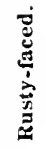

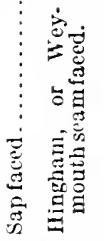

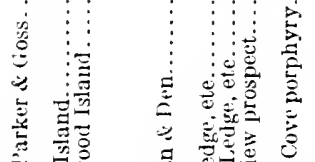

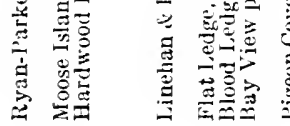

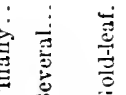

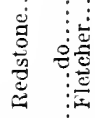

额

要

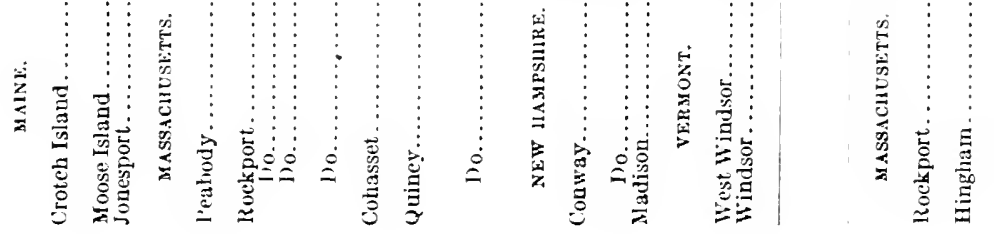




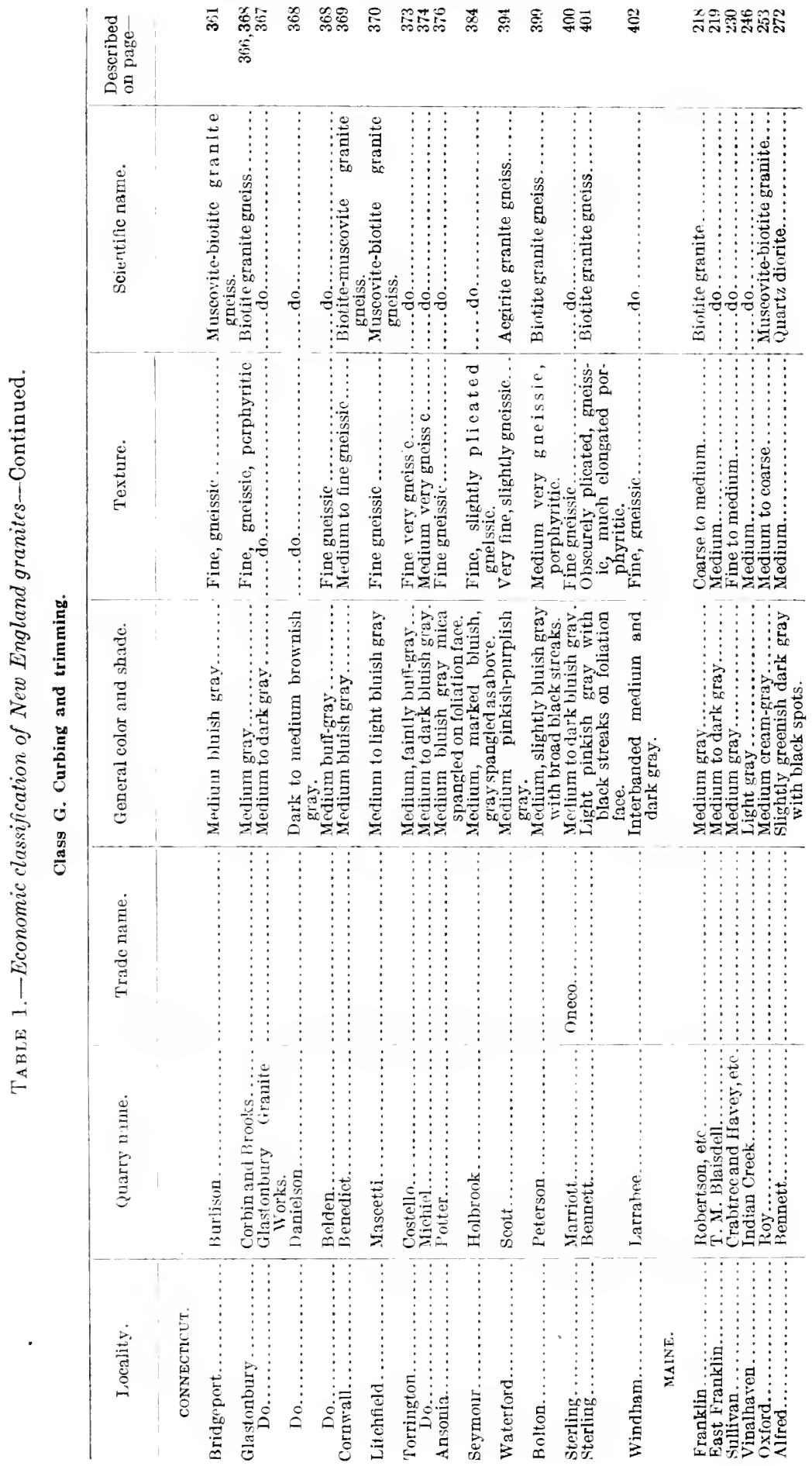




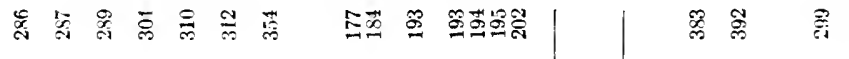

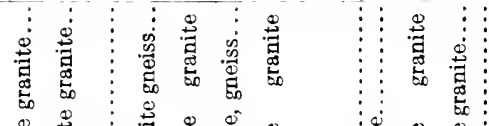

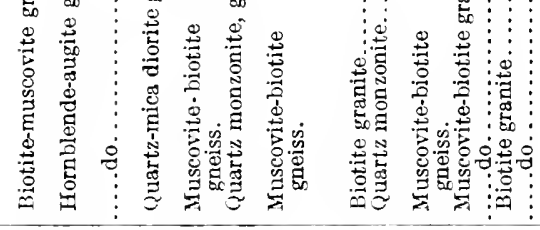

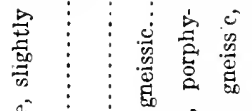

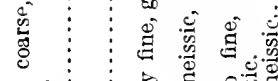

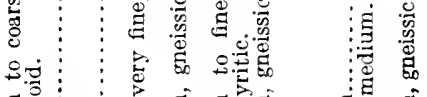

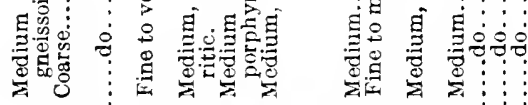

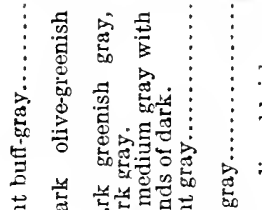

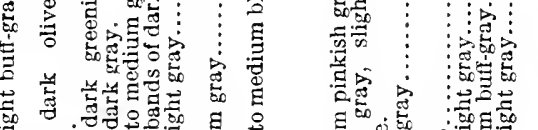

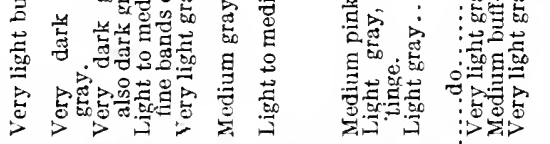

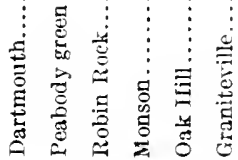

活空

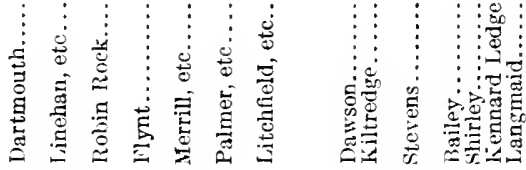

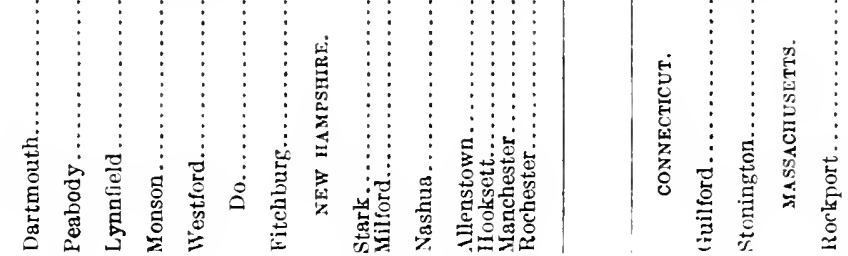

$\vdots$

$\therefore$

若 晜

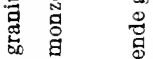

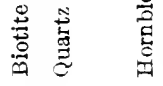

窟

๑ี

$\therefore .0$

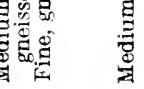




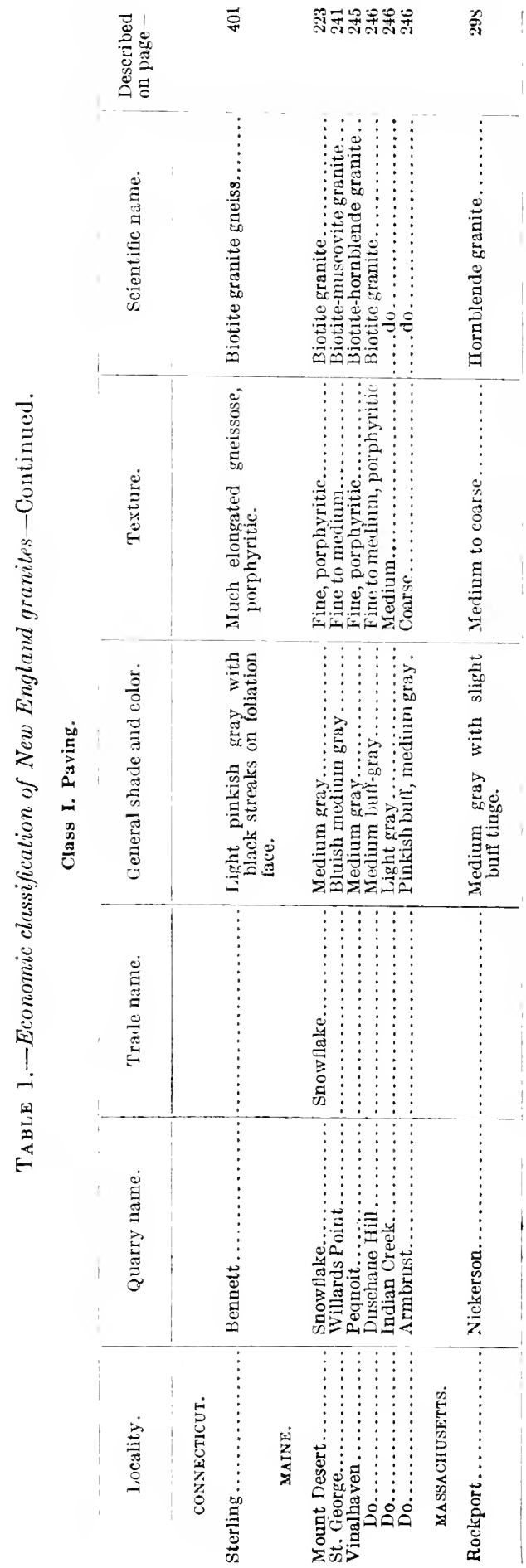


TaBLe 2.-The constructional, monumental, sculptural, and rusty-faccd granitcs of New England grouped by dominant colors and shades.

$$
\text { Group 1. White. }
$$

Vermont.-Bethel, Plymouth, Randolph.

CONNECTICUT.-Norwich.

$$
\text { Group 2. Black. }
$$

Group 3. Gray with strong contrasts, whitc or gray dominant.

Marne.-Biddeford: Ricker, Gowan Emmons, Andrews quarries. Kennebunkport: Day quarry. Bluehill: Chase quarry. South Thomaston: Weskeag quarry. Guilford: Queen City quarry. South Brooksville: Bucks Harbor quarries.

Massachusetts.-Wrentham: Curry quarry. Rockport: Devils Rock quarry. VERMONT.-Delby: Lacasse quarry.

Group 4. Black and white, strong contrasts, black dominant.

Marne.-Sprucehead Island: Sprucehead quarry. Hartland: Hartland quarry. Woodstock : Bryant Pond quarry.

Group 5. Gray, porphyritic.

MaIne-Hallowell: Stinchfield quarry. Norrldgewock: Lawton quarry. Frankfort: Mount Waldo. Searsport: Mount Ephraim (Bog Hill) quarry. Bluehill: Chase monumental quarry. Dedham: Brown quarry. West Franklin : Bradbury quarry.

MASSACHUSETTS.-Groton: Shaker quarry. Westford: Oak Hill and Snake Meadow Hill quarries. Uxbridge: Blanchard quarries.

New Hampshrre.-Fitzwilliam: Snowflake quarry. Harerhill: Pond-ledge quarry.

VERMONT.-Hardwick: Buffalo Hill quarry. Woodbury : Drenan and Imperial Blue quarries.

Group 6. Gray with weak contrasts, light, medium, dark.

Connecticut.-Waterford: Millstone quarry, medium and dark

MarNe.-Pownal : Pownal quarry, light. Jay : Maine \& New Hampshire Granite Corporation quarry, very light. Sullivan: Stimson quarry, medium. Muscle Ridge Plantation: Dix Island quarry, dark. Bristol: Round Pond quarry, dark and medium. Waldoboro: Waldoboro quarry, medium. Norridgewock: Taylor quarry, light.

New Hampshire.-Milford: Tonella old quarry, light.

Vermont.-Kirby: Burke quarry, light to medium. Ryegate: Rosa quarry, fine gray. Barton: Owen aplite prospect, dark.

Group \%. Gray, light, medium, dark (tinted bluish, greenish, buff).

Connecticut.-Bristol : Dumn quilry, light to medium bluish. Norfolk: Crissey quarry, medium greenish. Roxbury: Rockside quarry, medium bluish. Torrington: Costello quarry, medium buff ; Michiel quarry, medium to dark bluish. Thomaston: Plymouth quarry, medium bluish. Croton: Salter quarry, etc., medium greenish. Stoningtou: New Anguilla quarry, medium bluish. Waterford: Waterford quarry, medium buff. 
Maine-Freeport: Medium bluish. Bluehill: White quarry, medium bluish. South Brooksville: Bucks Harbor quarres, light buff. Mount Desert: Hall quarry, light buff. Crotch Island: Sherwood lower quarry, light buff. South Thomaston: Weskeag quarry, bluish medium. St. George: Long Cove quary, bluish medium. Whitefield: Jewett quarry, very dark bluish. Swanville: Oak Hill quarry, dark bluish.

Massachusetrs.-Becket: Hudson \& Chester quarry, medium bluish. Dartmouth: Yery light buff. Pelham: Dark bluish. Acton: MeCarthy quarry, medium bluish. Townshend: Barker Ilili, light buff. Quincy: Dark to very dark bluish, greenish or purplish. Leominster: Dark bluish.

New Hayrshine.-Fitzwilliam: Victoria White quarry, light bluish. Marlboro: Light to medium bluish. Troy: Light to medium bluish. Concord: Various quarries, medium bluish. Milford: New Westerly quarry, medium bluish. Tonella: (King) quarry, medium buff. Brookline: O'Rourke quarry, medium buff. Sunapee: Perry quarry, light bluish.

Rhode Island.--Westerly: Various quarries, medium bluish. Charlestown: Klondike quarry, medium bluish.

Vermont,-Kirby: Grout quarry, light to medium bluish. Ryegate: Rosa quarry, (coarse) medium bluish. Groton: Benzie quarry, medium bluish. Derby : Lacasse quarry, light bluish. Barre: Various quarries, light, medium, dark bluish. Cabot: Bluish, Calais: Patch quarry. medium bluish. Woodbury: Bashaw, Imperial Blue, and Nicols Ledge Carter quarries, bluish, medium, dark. light to medium.

\section{Group S. Lavender-tinted.}

Maine.-Crotch Island: Ryan-Parker, Goss, and Benvenue quarries. Moose Island: Moose Island quarry. Jonesboro: Fish quarry.

Group 9, Reddish gruy, light, medium, dark.

Consectict T. Branford: Norcoses and Stony Creek quarries, medium. Hoadly Neck: Medlum to dark. Guilford: Leete Island quarry, medium. Lyme: Seirlem Neck quarry, medium to dark. Stoninston: Inrray quarry, medium. Old Lyme: IIacCurdy quarry, mediun.

Massichtsetts.-Praintree: Stary quarry, meqlimn.

RHIODE IsLANm. Westerly: Redstoue quarry, etc., medium.

Group 10. Pinkish gray, light, medium, dark, bright.

Connecticut,--Brandford: Opie quarry, merlinm. East Lyme: Malnati \& Carlson quarries, medium.

Malne.-Black Island: Light and merlium. Mount Desert: Campbell \& Macomber quary, light. Swans Island: Toothachers Core quarry, medium. High Isle: Medium. Calais: Several quarries, bright. Joneshoro: Bodwell \& Booth Bros. quarries, medium. Marshfield: Medium. Wells: Lord quarry, light.

MassachusetTs.-New Bedfold: Sullivan quarries, light. Townshend: Barker Hill quarry, light to medium.

New Hamphine.-Conway: Redstone quarry, light with large dark-gray and small black spots. Madison: Fletcher quarry, light, mottled with dark purplish gray. Milford: Carlton quarry, medium; Souhegan quarry, dark. Brookline: Fessenden quarry, faintly pinkish.

Rhode Island.-Westerly: New England, Smith, and other quarries, medium. Vermont.-Newark: Packer quarry, light. 
Group 11. Pinkish to light gray or light buff-gray with large black spots.

Massiciusetts.-Milford: Various quarries. Fall River: Beattie, Savoie, and other quarries.

NEw HAMpshirf.-Canaan: Mascoma quarry. Lebanon: Lebanon quarry.

\section{Group 12. Pinkish to reddish buff.}

MaINE.-Crotch Island: Sherwood Upper quarry. Green Island (Stonington): Jatty quarry. Swans Island: Baird quarry. Vinalhaven: Sands, Palmer, and Black quarries. Hurricane Island: Hurricane Island quarry. Biddeford: Wormwood quarry.

\section{Group 13. Buff.}

Manne.-Millbridge: Millbridge quarry.

Group 14. Cream-colored.

Vensont-Woodbury: Vermont White quary, very light cream-colored.

Group 15. Greenish, pea, or olive tint.

MASSAChusetTs.-Peabody: Den quarry, dark to very dark olive-greenish. Lynnfield; Robin Rock quarry, very dark greenish. Rockport: Bloodledge and Cheves quarries, dark olive-greenish. Quincy: Lepage, Winquist \& Cashman quarries, light pea-greenish.

New Hampshine.-Conway: Redstone green quarry, dark olive-greenish. Kilkenny : Kilkenny quarry, dark olive-greenish.

Group 16. Mottled.

Connecticut.-Lyme: Joshua Rock quarry, general purplish gray with fine reddish, pinkish, areenish, and black bands, also cherry-redhish spots.

Massachusfits.-Stoughton: Messer quarry, mottled pink, pea-green and medium gray. Colasset: Tiffany (uarry, mottled pink, pea-green, cream-color, medium gray, and black (very tark green).

Croup 1\%. Rust-colored.

Massachusettis. Rockport: Flat Ledge quary, bricht rust color. Hingham: Hingham, Miller, and Hamilton quarries, rust co.or.

\section{GEOLOGIC FACTORS IN GRANITE QUARRYING.}

The problems confronting the granite quarryman alunt to open a quarry are many. Their solution requires not only practical experience in granite quarrying and somndness of juclgment but also a little knowledge of geology and mathematics.

It is first of all assumed that suitable specimens representing the average quality of the fresh rock have been procured and subjected either by the United States Bureau of Standards or else by competent persons provided with the necessary machines and instruments to the tests enumerated on pages 99-103 in order that the quality of the stone may be determined apart from all commercial considerations. 
The next step is a careful exploration of the granite surface, if necessary by stripping in trenches, to determine the areal extent of the stone of the quality tested, the spacing of the joints, the number and location of headings, dikes, veins, and the quantity of knots. A sufficient amount of vertical exploration should be done, if necessary by core drining, to determine the thickness of the sheets, width of sap, course and quality of rift and grain, and also, if possible, the direction of the flow of the granite.

That the quarryman needs to have at least a rudimentary knowledge of geology is shown by the danger of his confounding, for want of it, igneous and sedimentary rocks. As granite issued from below, the supply of the granite of any given area is exhaustless in the direction of the source of its flow. A granite mass can never be penetrated in quarrying except in a direction transverse to that of its flowage. Quarymen have been known to imagine that granite occurs in "pockets," like outliers of a sedimentary rock left by the erosion of the rest of the bed. This error" arises from their having quarried across the flow of a granite dike instead of toward its source. But as the channel through which the granite flowed may narrow or widen it is well to determine by diamond drilling whether the narrowing is to prove great enough to enhance the cost of quarrying.

With these geologic preliminaries as to the area, quality, structure, and source of the granite disposed of, there remain the purely technologic problems as to the selection of quarry site, location of dumps, the drainage, water supply, transportation, the use of explosives, and method of splitting, and the machinery for hoisting, drilling, and transporting, none of which lie within the province of this bulletin.

\section{THE PRODUCTION OF GRANITE IN THE NEW ENGLAND STATES.}

By A. 'T. Coons.

\section{HISTORICAL REVIEW. 81}

PERIOD BEFORE THE CIYL WAR.

The stone industry in New England began in colonial times with the use of boulders and cobbles. The splitting of dimension stone from boulders was a crude operation. The stone for King's Chapel, built in 1749-1754 and considered an architectural masterpiece at the time, was obtained by dropping heavy iron balls upon heated boulders and hammering the split stone into shape. Split stone was used mainly in the construction of wharves, foundations, and wells, and cobbles were used for street paving. The sources of supply were

81 Adapted from text by G. F. Loughlin, forming a chapter in the "History of the mineral industries," compiled by E. W. Parker for the Carnegie Institution. 
within reasonable distance for transportation by water or by teams of oxen. About the beginning of the nineteenth century considerable granite was conveyed to Boston from Quiney, Mass., by ox teams and from Chelmsford (now Westford), Mass., by canal. Quarrying from the ledge hegan in Quincy in 1825 to supply stone for the Bunker Hill Monument, and with the introduction of quarry implements and the "plug and feathers" or "wedge and half-rounds" method of splitting stone, the industry developed rapidly.

The first quarries of more than local importance were convenient to water transportation, on the coasts of Massachusetts and Maine. The rapid growth of American commerce, with the resulting requirements for harbor improvements and coast protection. rreated a strong demand for granite in the construction of jetties. sea walls, wharres, and forts. 'This demand was supplied at first fiom quarries at Quincy and Cape Ann, Mass., and later from quarries in Rhode Island and Connecticut also. During the century that has elapsed since the opening of the first ledge quarry at Quiney other uses have been developed to so great an extent and the requirements for sea walls and similar construetion work have been so well supplied that granite for such work now constitutes only a small part of the total output.

The use of granite for architectural work also grew rapidly during the second quarter of the nineteenth century, and many buildings in the larger cities on the Atlantic coast were erected of granite from the coast of New England. - The Quincy granite, owing, no doubt, to its reputation gained as the stone used in Bunker Hill Monument, to its favorable position near tidewater, and to the nore advanced methods of quarrying it, was probably the leading building granite during this period, although other granites along the coast of Maine and Massachusetts were finding an equally extensive range of markets. Inland granites of New England, now well known, were supplying mostly local demands, which included a few important buildings, such as the State capitols of New Hampshire and Vermont. Toward the middle of the century the construction of railroads, by furnishing transportation, began to give these granites more extensive markets.

Granite paving blocks were introduced into Boston in 1840 , into Philadelphia in 1848, and into New York about 1850 and soon became one of the principal granite products. The blocks first used were consider"ably larger than the modern blocks, their surfaces measuring a square foot or more in area; but experience soon resulted in the adoption of blocks essentially like those used to-day. ${ }^{82}$

\footnotetext{
82 Brayley, A. W., History of the granite industry in New England, vol. 1, pp. 167-170.
} Boston, 1913 . 
Granite flagstones, principally from Quincy and Rockport, Mass., were probably introduced before the Civil IVar, and flagstones from granite quarries along the coast of Maine were probably used in Boston and other cities along the Atlantic coast not long a fterward.

Granite was only occasionally used as a monmmental stone until after 1860 , but by 1880 its desirability for this use had become generally appreciated.

The avalable data on production of stone for the early years of the industry are very incomplete and represent only the leading quarries and possibly also the cutting plants. Much stone produced for local use and rough construction work, such as walls, piers, and docks, was probably not included in the figures of production. The report of the Eighth Census, for 1860, gives only the total value of all kinds of stone produced in the New England States. 'The value of the output of Connecticut $(\$ 532,704)$ was mostly for sandstone, and that of Massachusetts $(\$ 289,626)$ included granite, marble $(\$ 122,496)$, and "pudding stone." Granite produced in Maine in that year was valued at $\$ 295,280$, in New Hampshire at $\$ 23,540$, and in Rhode Island at $\$ 6,800$, but none was reported from Vermont. The granite industry in Maine and Massachusetts was then considered very prosperons.

\section{PERIOD SINCE THE CIVIL WAR.}

BUILDING STONE.

There are no data a vailable fo show the effect of the Civil War upon the granite industry of New England, and none of much value to show the size and growth of the industry before 1880. The figures compiled by the Ninth Census, ${ }^{83}$ for 1870 , suggest a substantial increase in the total value of output of the leading quarries compared with the period before the Civil War, but the comparison is obscured by the fact that prices were relatively high in 1870. During the 25 or 30 years after the Civil War the granites that were the most prominent before the war still led in production. The darkerred granites of Maine, the dark bluish-gray granite of Quiney, Mass., and the lighter-gray granites of Rockport, Mass., Hallowell, Maine, and Concord, N. H., were prominent among building stones. The lighter-pink coarse-grained granites had been regarded with less favor by some because of their coarser texture and because their minerals lacked sufficient contrast in color, especially for monumental work. ${ }^{84}$ Gradually, lowever, and probably owing in large part to the growing popularity of the buff and gray limestone from

${ }^{83}$ Ninth Census, vol. 3 , p. 749, 1872.

Merrill, G. P., Stones for building and decoration, p. 61, 1903. 
Indiana, tastes changed in faror of the lighter-colored building stones, and from 1895 to 1900 the pale-pink granites, particularly those of the l'enobseot Bay district, Maine, and Milford, Mass., became prominent. Some of the darker-colored granites fonnd a growing demand as monmental stone.

From 186.5 to 1890 the principal granite products were building, paring, and monumental stome. Crushed stone for water-bound macarlam was gaining recognition, though its output was insignificant compared with that of to-tay.

The general increase in the industry in 1889 as compared with 1880 is striking (see table, p. 443) but does not imply a steady growth. Sales of stone in genoral wore thought to have decreased in 1883 owing to a marked preference for brick construction, and they decreased again in 188t owing to a general industrial decline. In 1885, howerer, both the output of granite and its popularity for ornamental and decorative use showed a gain, whereas prices, owing to increasing competition, declined. From then until 1890 the industry was prosperous. This half decade was the first of two conspicuously prosperous periods for the building-stone industry since annual statistical information has been arailable.

This period of prosperity was followed by a decline in the demand for buildings and by the panic of 1903, when the output of structural stone and clay products decreased greatly. The output of stone as a whole continued to diminish until 1896, when the total value of all building stone sold was estimated at $\$ 10,000,000$. The production of Portland cement was then beginning to increase rapidly, but the demand for buildings, after five years of curtailment, had now become so great that all structural materials found ready markets, and their production increased until 1902. After two years of decrease the sales of building stone as a whole increased mtil 1906, which marks the end of the second prosperous period of the industry. After a marled decline in $190 \mathrm{r}$ and 1908 sales of granite for building fluctuated with a slight net gain until 1913, in spite of keen competition with lower-priced building materials for both rough construction and higher grades of architectural work. The effect of this competition has been gradual restriction of granite to the more costly buildings.

The drastic curtailment in high-class building during the war period 1914-191s was to be expected, and since then the high costs of production and transportation together with labor troubles have delayed revival of the building-stone industry. There is, however, another shortage of buildings, and with industry in general becoming stabilized the demand for building granite may be expected to increase. 


\section{GRANITE FOR OTHER USES.}

Monumental stone-As already stated, the use of granite for monumental stone had attained considerable prominence by 1880 . Since then the production of monumental granite has made such districts as Barre, Vt., Quincy, Mass., and Westerly, R. I., famous throughout the country. The output was on the whole steady (see fig. 95, p. 442) lintil the war period, when the abnormal prosperity of some industries and the increased demand for memorials caused a marked increase, whereas the output of other granite products greatly decreased. The severe depression that followed the war, however, greatly reduced the demand for monumental stone, and curtailment of output has been continued by labor troubles, which have led producers of monumental granite in particular as -well as several producers of granite of other classes to adopt what is practically the open shop.

Paving stone.-The demand for paving stone appears to have continued steadily except in periods of general depression until about 1895, when keen competition began with other materials that had certain advantages over granite blocks as then prepared and laid. The years 1909-1911 marked a high point in both the quantity and value of granite paring blocks sold from New England quarries, as well as from all quarries in the United States. This period was followed by a slight decline and by a second high point in 1913-14. The expected decline during the war period lasted until 1919, when, owing to renewal of street improvement in cities that had the heaviest traftic, the paring-block output began to increase. It declined again in 1920 , but increased in 1921, when the value of the paving blocks sold was the largest ever recorded. There is no question regarding the greater resistance to wear of granite paving blocks as compared with competing materials, and the latest improved methods of preparing and laying them produce smooth road surfaces that will maintain their smoothmess so long as the foundation upon which the blocks rest withstands the weight of traffic. As cheaper pavements are proving satisfactory for light to rather heavy traffic, the growth of the granite paving-block industry is expected to keep pace with that of extremely heavy city traffic.

Crushed stone.-The demand for crushed stone began late in the nineteenth century with the introduction of water-bound macadam roads. The use of crushed stone in concrete for foundations and buildings began about 1900, and its effect on the building-stone industry was soon noticeable. By 1907 the value of the crushed stone sold exceeded the combined values of the building and monumental stone. The quarries of the New England States were among the first to supply crushed stone, but most of this material was basalt. Few of the New England quarries that supply building and monumental 
granite furnish crushed stone in any quantity. Massachusetts is the largest producer, and the greater part of the output comes from quarries especially operated and equipped for turning out this product. The production of crushed granite from the New England quarries, except for yearly fluctuations due to the effect of business conditions on the demand, showed a general moderate increase from 1896 to 1915 , when the unusual conditions caused by the war brought about a rapid decline, and in 1918 the output was less than in any other year since 1902. A small increase in 1919 was followed by decreases in 1920 and 1921, but production in each of these years exceeded that of 1918 . At present water-bound macadam is being superseded by asphaltic and cement-concrete parements, in which gravel is used as well as crushed stone for the aggregate. Specially prepared crushed granite is finding considerable faror in terrazzo work for floors and in the better elass of concrete exterior construction. In this work the color of the stone, as well as its durability, is of importance.

Conclusion.-The development of several products from one quarry and the finding of uses for what has heretofore been waste are indications of the present trend of the industry. 'The diversification of the granite industry and increased competition of all its products with other materials has resulted in gradual elimination of companies not properly equipped and financed to meet the present exacting requirements. The industry has adranced in the last century from one of primitive methods to one requiring elaborate and expensive equipment. A comparison of the years 1902 and 1919 in the cerisus table (p. 443) shows that although the number of quarries and employees greatly decreased, the output did not change in proportion.

The production since 1896 is shown in the accompanying diagrams (figs. 94-96).

\section{STATISTICS OF PRODUCTION.}

The figures of production for the different States given in the accompanying tables are compiled from the records of the United States Geological Surrey and for the years prior to 1882 from the reports of the Bureau of the Census. The Survey figures are totals of reports from the quarrymen. The values given are values f. o. b. at point of shipment and are based on the way the quarryman sells his stone. If the stone is cut by the producer, the value of the dressed stone is used. At Barre, Vt., and Quincy, Mass., most of the stone is sold in the rough by the producers to mills and manufacturing plants in the vicinity. The stone quarried at Rockport and Milford, Mass., Woodbury, Vt., Westerly, R. I., Stony Creek and Waterford, 
('oun., North Jay, Maine, and Redstone, Concord, and Milford, N. H., is sold largely as dressed stone.

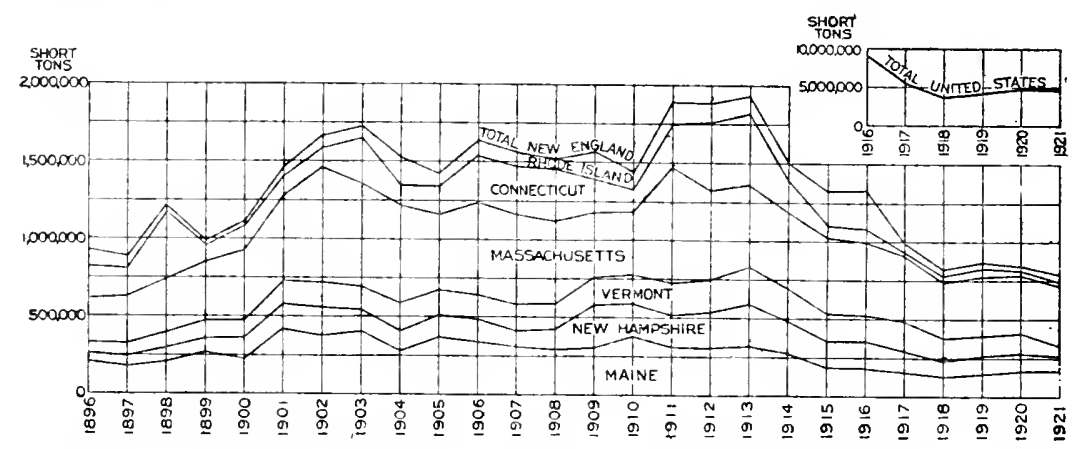

Figure 94.-Granite produced in New England, 1896-1921, and in the United States, 1916-1921.

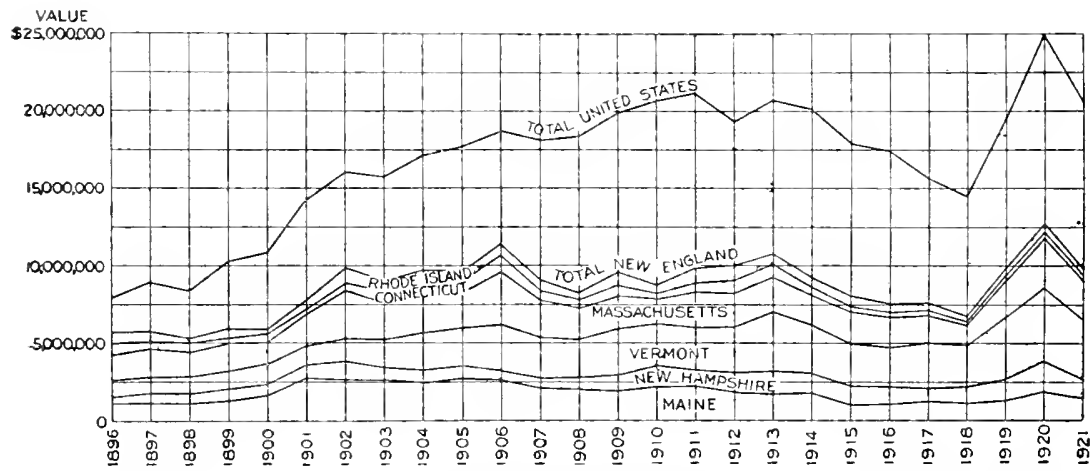

Figure 95.-Value of granite produced in New England and in the United States, 1896-1921.

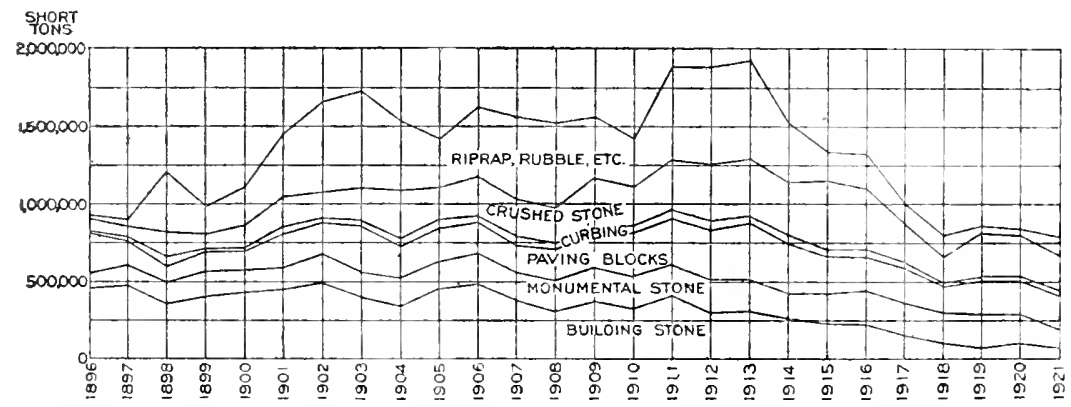

Frgure 96.-Granite of different classes produced in New Engiand, 1896-1921. The space between two adjacent curves shows the production of the class specified, and the upper curve indicates total production.

In preparing the diagrams (figs. 94-96) the available figures for quantity were used, and such estimates as were necessary were based on the knowledge that average values did not vary greatly for the different products between the years 1891 and 1916. 


\section{PRODUCTION BY CENSUS YEARS.}

Approximate annual statistics of stone production began to be collected in 1850 , but no separate figures of the different granite products were compiled until 1889. The following table, compiled from reports of the Bureau of the Census and the United States Geological Survey, reflects the condition of the granite industry in New England in the different census years:

Granite produced in the Vew England States in 1880, 1889, 1902, 1909, and 1919.

\begin{tabular}{|c|c|c|c|c|c|}
\hline & 1880 & 1889 & 1902 & 1909 & 1919 \\
\hline \multicolumn{6}{|l|}{ Maine: } \\
\hline Number of quarries................ & 68 & 153 & 110 & & 44 \\
\hline Average number of wage earners.. . & 4,687 & 3,737 & 2,832 & 2,132 & 747 \\
\hline Acreage of quarry land ............. & (......... & $\cdots \cdots \cdots \cdots$ & $\ldots \ldots \ldots \cdots \cdots$ & & \\
\hline $\begin{array}{l}\text { Production-- } \\
\text { Approximate quantity, short tons.. }\end{array}$ & 183,000 & 563,000 & 378,000 & 300000 & 149.820 \\
\hline 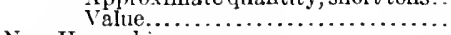 & $\$ 1,175,286$ & $\$ 2,225,839$ & $\$ 2,659,450$ & $\$ 1,939,524$ & $\$ 1,274,474$ \\
\hline \multicolumn{6}{|l|}{ New Hampshire: } \\
\hline Number of quarries................ & 39 & 78 & 51 & 40 & 24 \\
\hline A verage number of wage earuers.. & 513 & 1,253 & 1,219 & 1,305 & 589 \\
\hline Acreage of quarry land ............. & & & ........ & 5,947 & 4,688 \\
\hline \multicolumn{6}{|l|}{ Production -} \\
\hline Approximate quantity, short tons.. & 159,400 & 240,000 & 178,000 & 270,000 & 104,690 \\
\hline \multicolumn{6}{|l|}{ Vermont: } \\
\hline Number of quarries.... & 12 & 53 & 74 & 53 & 29 \\
\hline A verage number of wage earner & 105 & 961 & 1,505 & 2,035 & 1,062 \\
\hline Acreage of quarry land......... & & & & 1,986 & 1,987 \\
\hline \multicolumn{6}{|l|}{ Production- } \\
\hline 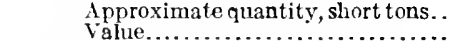 & 16,000 & 90,000 & 167,000 & 186,000 & 133,627 \\
\hline \multicolumn{6}{|l|}{ Massachusetts: } \\
\hline Number of quarries............... & 92 & 151 & $a 115$ & & 45 \\
\hline A verage number of wage earners... & 2,246 & 3,333 & a 2,700 & 2,278 & 1,034 \\
\hline Acreage of guarry land...$\ldots \ldots \ldots$. & & . & $\cdots$ & 2,914 & 3,384 \\
\hline \multicolumn{6}{|l|}{ Production- } \\
\hline Value.............. & $\$ 1,329,315$ & $\$ 2,503,503$ & $\$ 3,080,857$ & $\$ 2,164,619$ & $\$ 2,477,938$ \\
\hline \multicolumn{6}{|l|}{ Connecticut: } \\
\hline Number of quarries................... & 32 & 53 & a 35 & 38 & 14 \\
\hline $\begin{array}{l}\text { A verage number of wage earners......... } \\
\text { Acreage of Guarry land............... }\end{array}$ & 872 & 1,630 & a 800 & 868 & 92 \\
\hline \multicolumn{6}{|l|}{ Production - - } \\
\hline Approximate quantity, short tons.. & 213,000 & 322,000 & 131,000 & 223,000 & 52,730 \\
\hline $\begin{array}{l}\text { Value..... } \\
\text { Rhode Island: }\end{array}$ & $\$ 407,225$ & $\$ 1,061,202$ & $\$ 524,629$ & $\$ 610,514$ & 8205,124 \\
\hline \multicolumn{6}{|l|}{ Rhode Island: } \\
\hline Average number of wage e & 760 & 1,195 & 638 & 675 & 262 \\
\hline Acreage of quarry land... & & & & 500 & 433 \\
\hline \multicolumn{6}{|l|}{ Production- } \\
\hline Approximate quantity, short tons.. & 114,000 & 242,000 & 60,000 & 169,000 & 40,503 \\
\hline \multicolumn{6}{|l|}{ Total New England: } \\
\hline Number of quarries............... & 260 & 525 & 404 & 324 & 166 \\
\hline A verage number of wage earners. . & 9,183 & 12,109 & 9,694 & 9,293 & 3,786 \\
\hline $\begin{array}{l}\text { Acreage of quarry land } \ldots \ldots \ldots \ldots \ldots \ldots \\
\text { Production- }\end{array}$ & ........... & Production- & $\ldots \ldots \ldots$. & 15,423 & 12,918 \\
\hline Approximate quantity, short tons.. & $1,073,400$ & $2,262,000$ & $1,656,000$ & $1,563,000$ & 865,130 \\
\hline 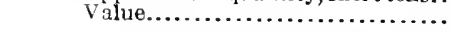 & $\$ 3,897,567$ & $\$ 8,031,161$ & $\$ 9,717,079$ & $\$ 9,674,915$ & $\$ 9,859,344$ \\
\hline
\end{tabular}

a The Bureau of tho Census gives for Massachusetts 204 quarries and 3,395 wage earners and for Connecticut 49 quarries and 943 wage earners. These figures include basalt quarries, which are here deducted according to United States Geclogical Survey records. The number of wage earners is estimated.

\section{PRODUCTION BY STATES.}

MAINE.

The quarry industry in Maine was of considerable magnitude from about 1876 to 1911 but has decreased about 50 per cent in the last 10 rears. The quarries started as a result of the usual local demand, but 
their nearness to tidewater furnished a splendid outlet for the stone, and although New York and vicinity has been the largest market, it has been shipped to all the eastern coast cities and also by rail to Chicago, St. Louis, Atlanta, Albany, and many other interior cities. The chief use for Maine granite until recently has been for bridges, piers, buttresses, and all kinds of heavy masonry, as well as public buildings and residences. Paving blocks formerly ranked second in output, but in 1921 the amount of stone that was cut into paving block was more than twice as much as all the other stone quarried. In 1911 the the tomnage for paring blocks was about one-half as much as for the other products. About 3 per cent more blocks were produced in 1921 than in 1911 , so that although the paving-block business in the State has held its own in competition with the different linds of paring materials, the demand for all other constructional granite, including curbing and a negligible amount of monumental stone, has sufiered keenly from the competition of stone from other States, but chiefly from the use of concrete for buildings and foundations.

The report of the Tenth Census (1880) shows that some of the quarries in operation at that time had been opened at the dates indicated below.

Cumberland County:

Brunswick, 1836.

Pownal, 1860-1872.

Franklin County :

Chesterville, 1845.

North .Jay, 1872-1876.

Hancock County :

West Sullivan, 1840-1876.

Deer Isle, 1870-1877.

Mount Desert, 1871.

East Blue Hill, 1872-1879.

Franklin, 1879.

Kennebec County :

Hallowell, 1800.

Augusta, 1856-1877.
Knox County :

Spruce Head, 1836.

Vinalhaven, 1850-1S79.

Dix Island, 1851.

South Thomaston, 1859-1878.

Hurricane Isle, 1870.

St. George, 1874.

Lincoln County :

Waldoboro, 1830 .

Round Pond, 1877.

Wallo County :

Frankfort (Mount Waldo), 1853.

Lincolnville, 1876.

York County, Bidleford, 1860-1868.

These dates show the beginning of the granite industry in the state but until 1860 activity in the quarries was only local, and it was not until about 1870 that they became well known.

The granite quarries operated in Maine during 1921, as known to the Tnited States Geological Survey, were as follows: 
Granite quarries operated in Maine in 1921.

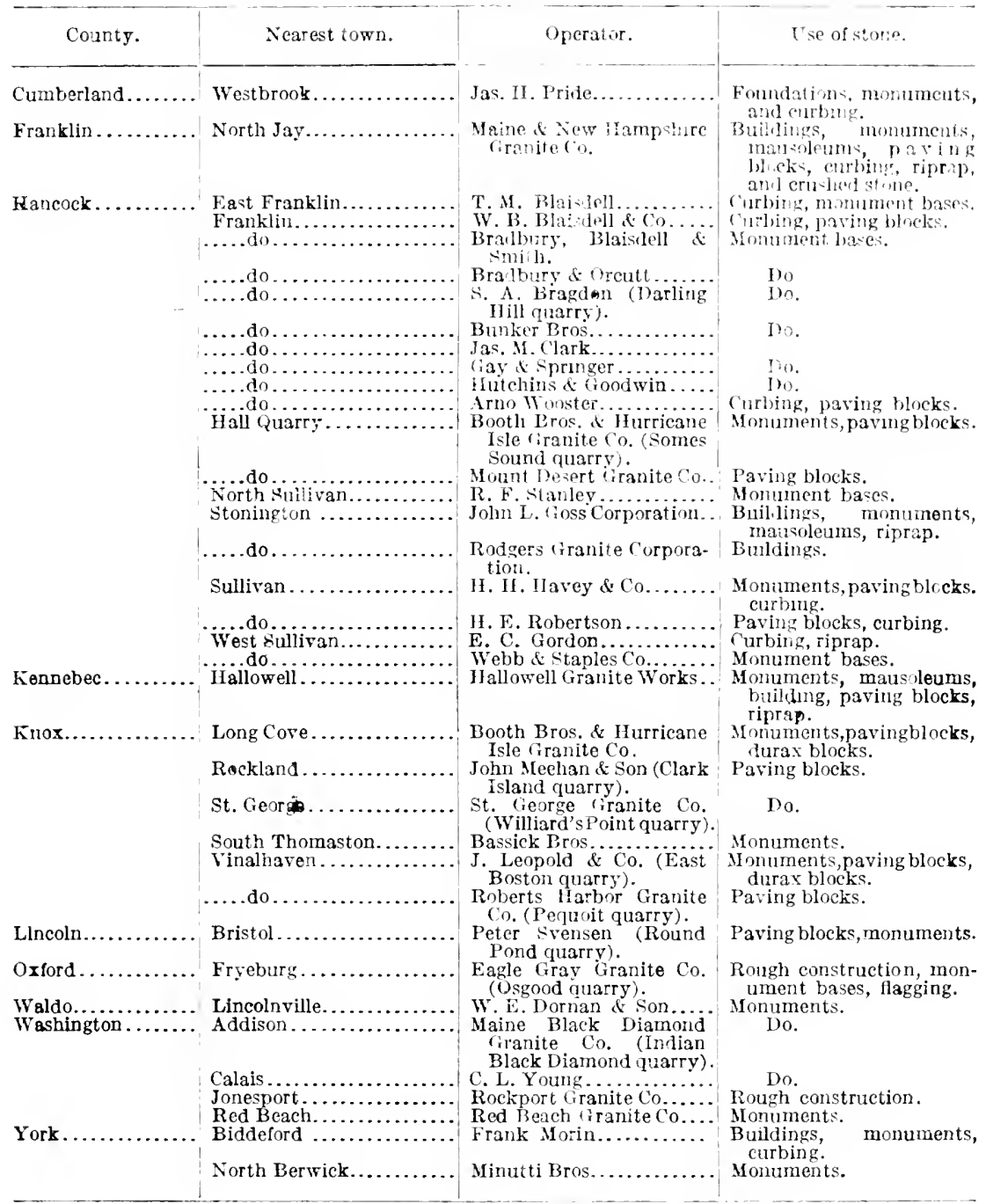

The Geological Survey is also informed that plans are under way by the George A. Fuller Co., New York City, to operate quarries at Hallowell and Stonington (Deer Isle) in order to quarry stone for the courthouse in New York City, for which this company has the building contract. 


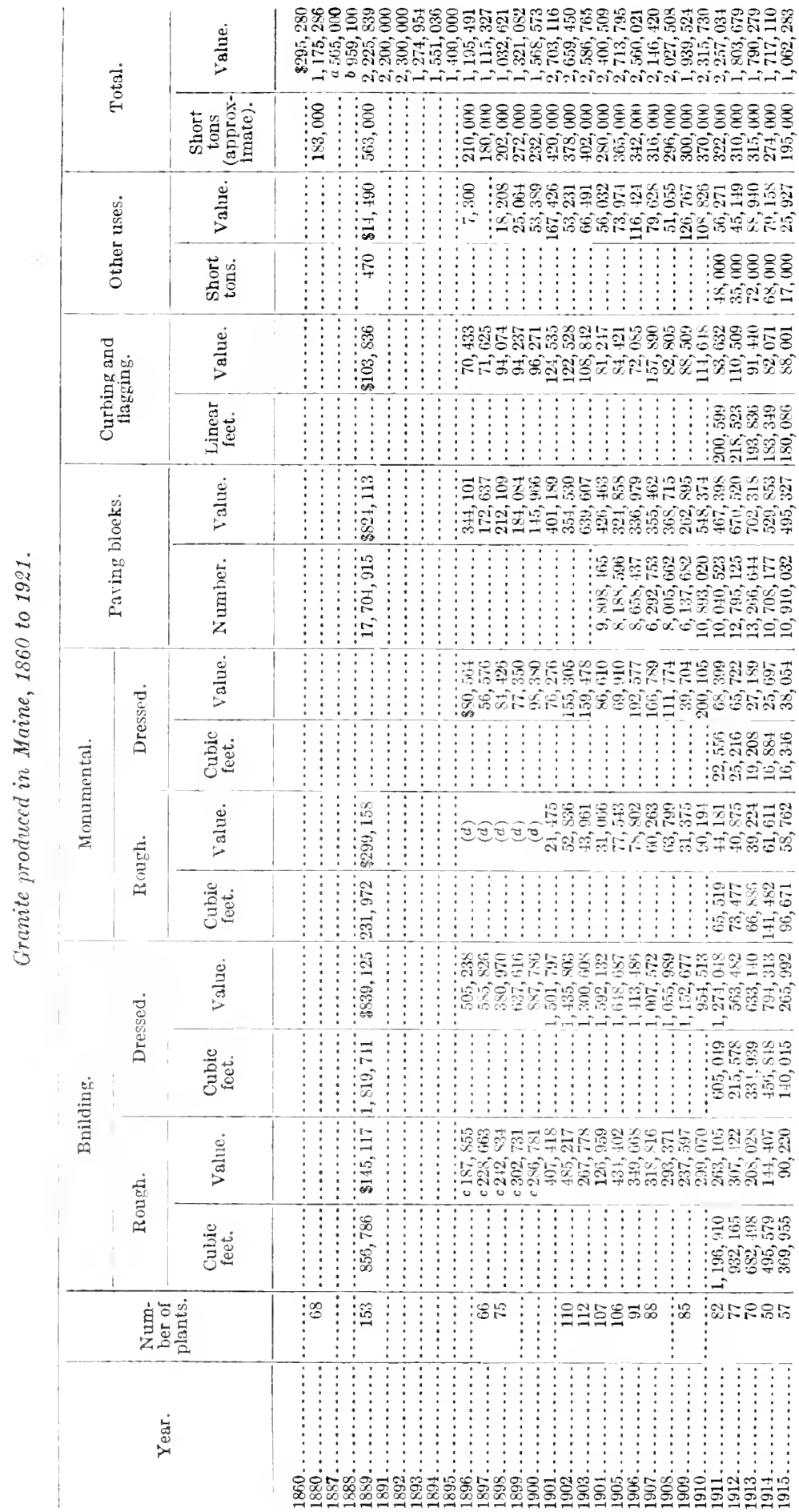




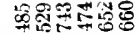

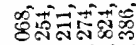

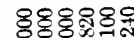

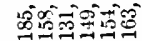

象

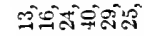

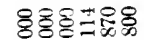

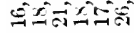

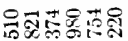

कीजिए

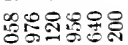

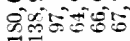

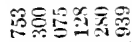

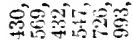

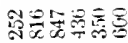

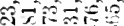

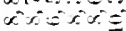

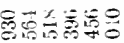

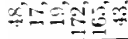

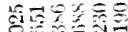

cirin

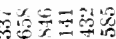
-

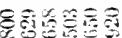
วิำ

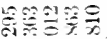

Fीำ

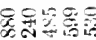

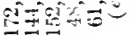

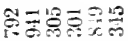

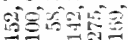

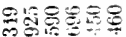

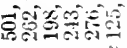

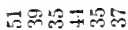

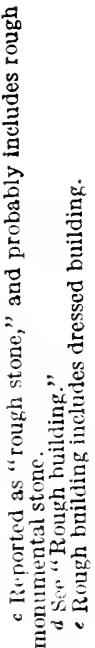

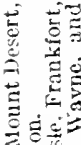
. 色 D. 政 o 的政 50 政 解

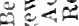
比 붕 들. . 政 影彭融 


\section{NEW HAMPSHIRE.}

New Lampshire, notwithstanding its nickname "Granite State," usually ranks below Massachusetts, Maine, and Vermont in cuantity of granite produced, but in 1921 it made a larger output than Vermont. Recorls show that stone from boulders at Concord was used in 1812 for the construction of the New Hampshire State prison and in 1816 to 1819 for the construction of the statehouse, but it was in 1840 that the ledges of the famous Rattlesnake Hill were first opened. Few quarries, however, were operated until after 1860. At Milford quarries were opened in 1813, and stone was drawn by oxen to neighboring towns in 1833 ; but it was not until after 1851, when railroad transportation was available, that stone was shipped any distance. Quarries were opened at Marlboro in 1812, at Nashua in 1822, at Fitzwilliam in 1860-1879, and at Allentown in 1876. Granite from New Hampshire, like that from Vermont, has been sold only to a small extent for crushed stone and riprap work. The demand for the product, chiefly as building and monumental stone and paving blocks, has therefore not shown the sharp changes indicated for the other States.

In 1921 granite was produced at the following localities in the State :

Granite quarries operated in New Hampshire in 1921.

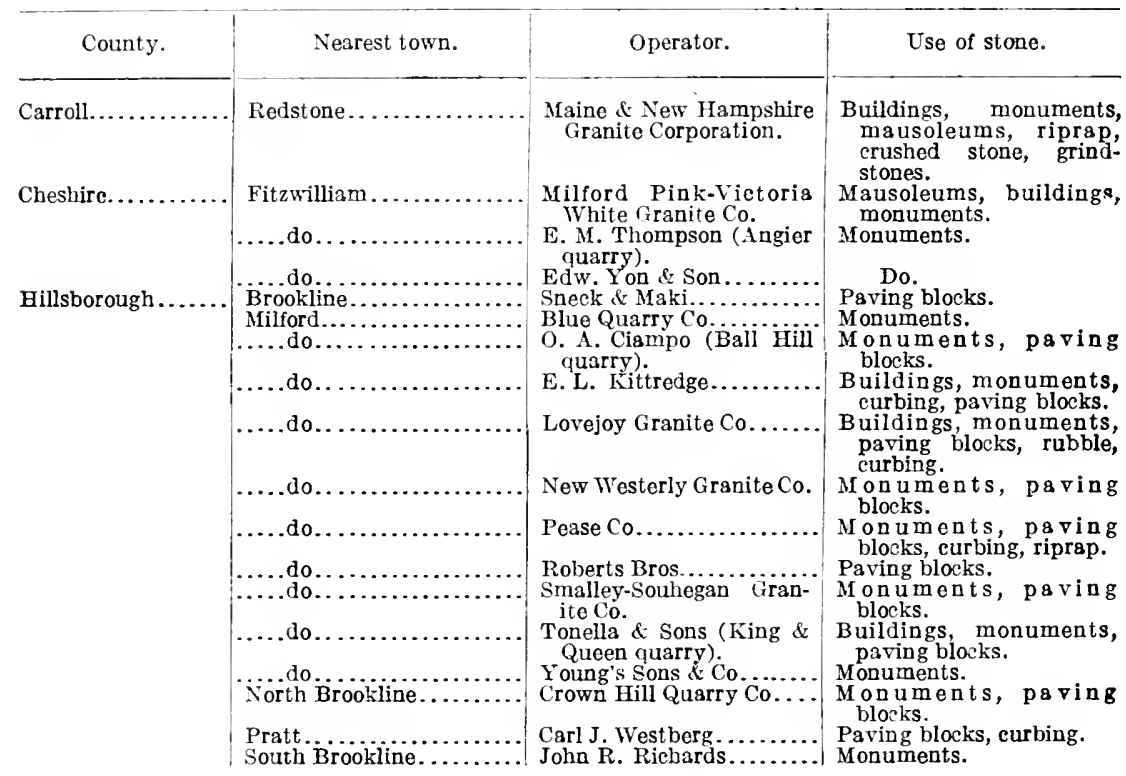


Granite quarries operated in New Hampshire in 1921-Continued.

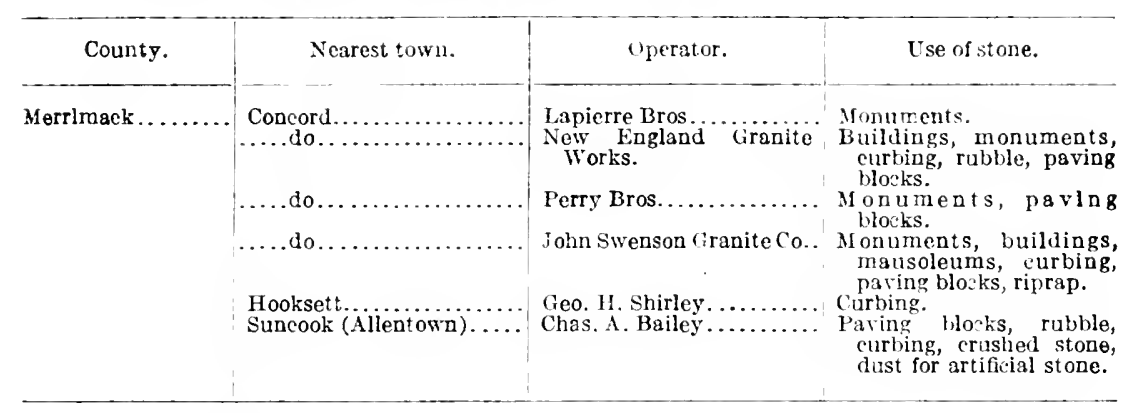

$105709-23-30$ 


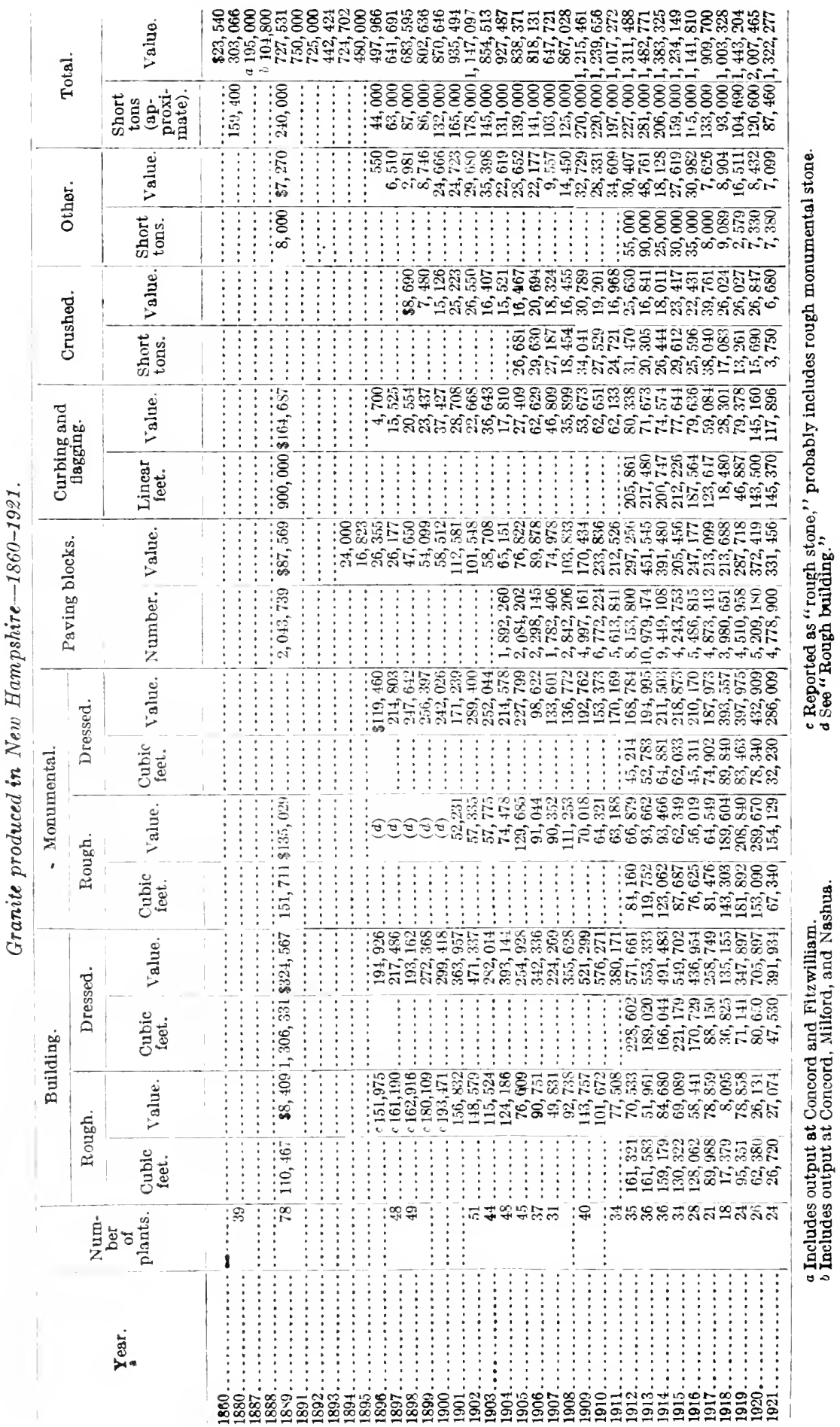


VERMONT.

Records show that stone from the vieinity of Barre, Vt., was used to build houses as early as 1814. In 1804 millstones were furnished to Canadian and New Engiand mills, and in 1893) stone was drawn from Harre to Montpelier to build the State appitol, which has recently been enlarged by stone from the same quarries. The report of the Wighth Census (1860) does not record any granite production from Vermont, but the report of the Tenth Census (1880) shows that quarries were opened at Barre as early as 1835 and 1840 and at Ryegate in 1850 . The first factor in the rise of Vermont to prominence in the granite industry was the extension in 1875 of the Central Vermont Railway to Barre. In 1888 a railroad was built to the quarries, saving laanling that had bern mostly done by ox teams. In 1880 the census report showed a production from Vermont of 187,140 cubic feet of granite, with a value of $\$ 59,675$. In 188 t the barre quarries produced 800,000 cubic feet of stone, valued at $\$ 225,000$, and in 1858 stone vilued it $\$ 276,000$ was produced at Barre and \$3,000 at Woolbury. The Eleventh Census (1889) showed 53 quarries in operation and an output of more than $1,000.000$ cubic feet. The largest number of quarries at Barre were opened between 1882 and 1890.

The 1)ummerston quarries were developed in 1875. In Caledonia county cunaries at Hardwick and South Ryegate were openerl between 1850 and 1555 , but the principal development here also took place after the builling of a railroad in 1896 . The Williamstown quarries were developed in 1859: the Bethel quarries in 1902 (qu:1rries were opened here in 1868); the Woodbury quarries in 1880): and the Mount Ascutney quarries in 1906. The other quarries in the State are smaller and less known and have not har much influencer on the total prouluction. Barre has become the largest renter for monumental stone in the comtry if not in the world. Little of the stone quarried is milled or dressed by the quarrymen. most of it being sold in rough blocks to manufacturers for dressing. The magnitude of the entire granite business in 1917 and 1918 in the Barre district is shown in the following tabular statement furnished by Athol R. Bell, secretary of the Barre Quarries \& Mannfarturers Association, and published in the report on stone in Mineral Resonrces of the United States. 1918. The district inclurles liarre. Williamstown, East Barre. Montpelier, West Berlin, Northfield, and Waterbury. The years 1917 and 1918 are taken as representing more normal years than 1920 and 1921. 
Estimated output of monumental granite in the Barre district in Vermont in $1917-18 .^{a}$

\begin{tabular}{|c|c|c|}
\hline & 1917 & 1918 \\
\hline 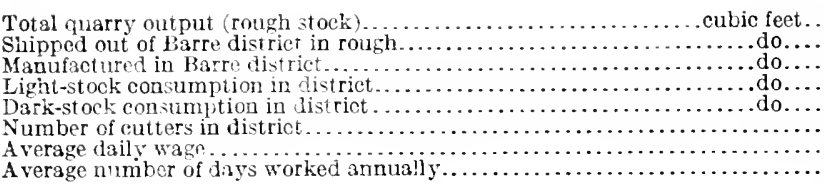 & $\begin{array}{r}1,560,000 \\
260,000 \\
1,300,000 \\
800,000 \\
500,000 \\
2,550 \\
\$ 5.00 \\
280\end{array}$ & $\begin{array}{r}1,654,800 \\
248,222 \\
1,406,578 \\
879,111 \\
527,467 \\
1,500 \\
\$ 5.60 \\
260\end{array}$ \\
\hline \multirow[t]{2}{*}{ 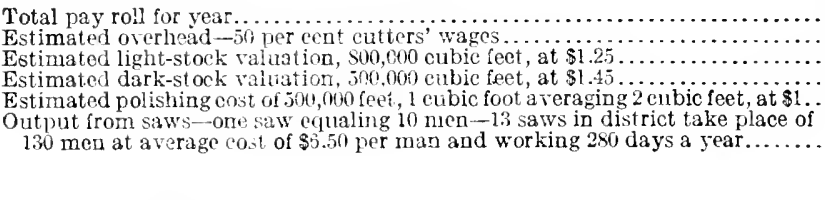 } & $\begin{array}{r}\$ 3,570,000 \\
1,785,000 \\
1,000,000 \\
725,000 \\
1,000,000 \\
236,000\end{array}$ & 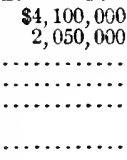 \\
\hline & $8,316,000$ & \\
\hline
\end{tabular}

a These estimates do not include production by other machinery, such as lathes and sand-blast machines, nor do they include valuation of rough stock shipped outside of the Barre district.

Mr. Bell states that 56 quarries were operated during 1918. Regarding industrial conditions in 1918, he says:

The Barre granite industry in 1918 was naturally subject to a good many of the proscriptions which necessity imposed upon nonessential industries. Our members, while realizing that the loss to them would be measurably irreparable, patriotically cooperated with the Government in sending men, many of them skilled pneumatic-tool operators, to the shipyards. In addition there was the prevailing shortage of unskilled labor at the quarries, and of course many men were with the colors.

The alduous winter of 1917-18 cut down the number of working days to 260 , the average being 280 . Yet the steady introduction of labor-saving machinery partially closed up the gap caused by the decimation of man power in the industry, prolonged suspensions due to extreme weather and fuel orders, and the inevitable shortage of cars.

The stone quarried at Woodbury, which is the center next in importance to Barre, is largely milled and dressed by the producer, as is the Dummerston stone. The accompanying tables and diagrams show the present depressed condition in the Vermont granite industry. 'The total output in 1921 was less than it was 32 years ago, with half as many guarries in operation, but the value of the product was over six times as great. The producers in 1921 were as follows:

Granite quarries operated in Vermont in 1921.

\begin{tabular}{|c|c|}
\hline County. & Nearest town. \\
\hline Caledonia........... & 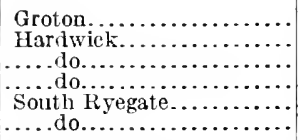 \\
\hline $\begin{array}{l}\text { Orange } . . . . \ldots \ldots \ldots \\
\text { Orleans............. }\end{array}$ & 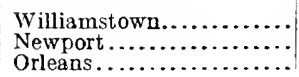 \\
\hline
\end{tabular}

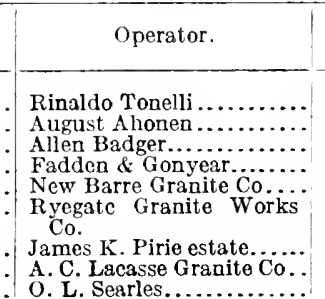

Use of stone.

Monuments.

Do.

Do.

Do.

Do.

Buildings, monuments.

Monuments.

Do.

Do. 
Granite quarries operated in Vermont in 19?1-Continued.

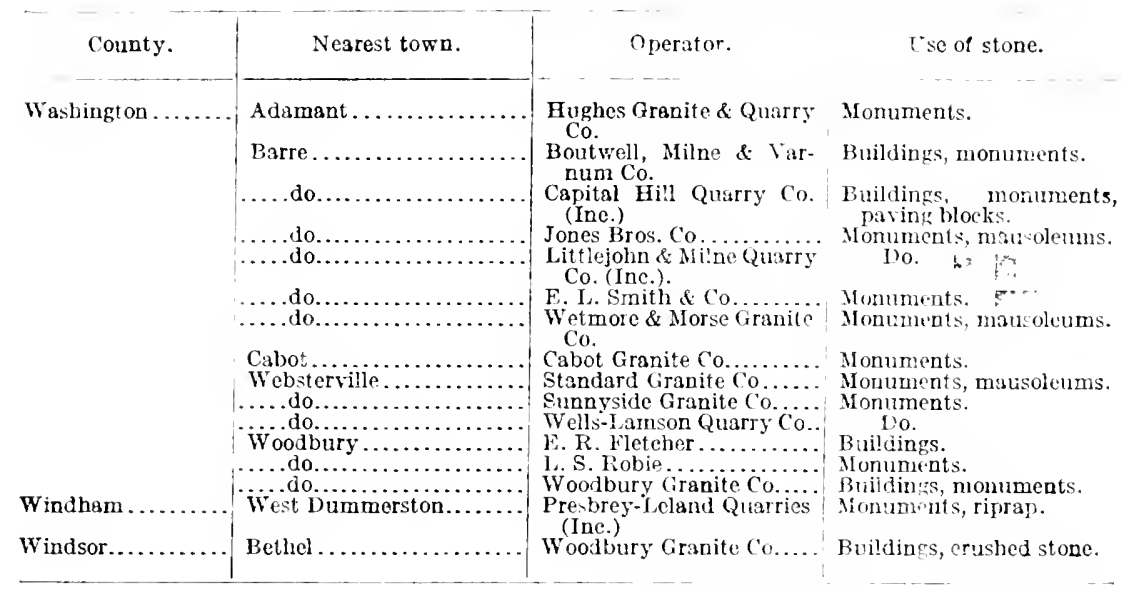




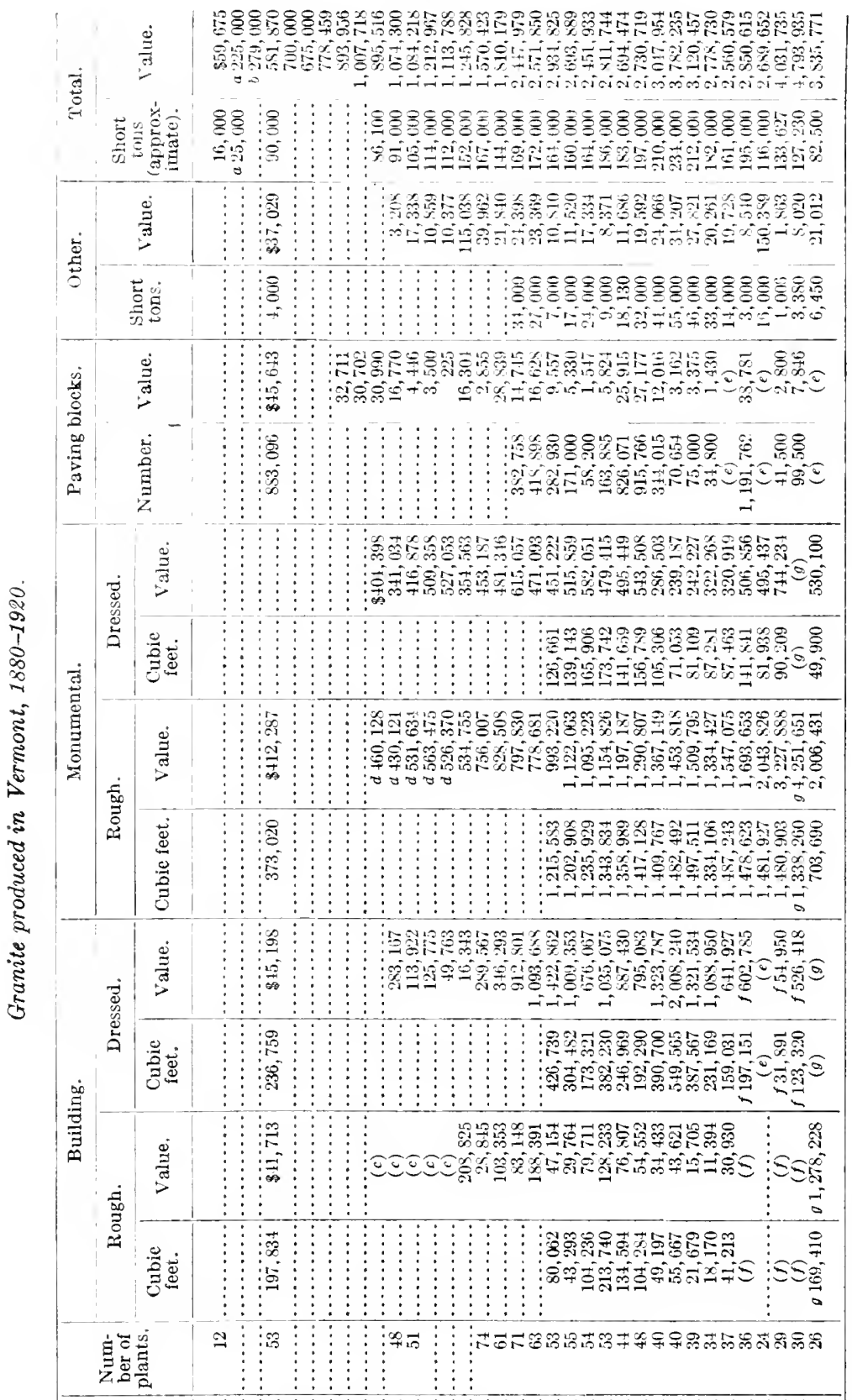


MASSACHUSETTS.

Massachusetts has always been the largest producer of granite among the New England States, but on account of the large amount of low-priced products-paving blocks, curbing, crushed stone, breakwater stone, jetty stone, riprap, and other rough construction materials-supplied from the quarries, it has at times been execeded in total value of output by Maine, and since 1906 by Vermont.

As previously stated, the real granite industry of this State began with the opening of the Quincy quarries in $182 t$ and the building of the Bunker Hill Monument and the railway or tramway from the quarries to tidewater. The development of quarry methods from quarying and handling by hand power to the hand derrick, the application of steam to hoists, drills, pumps, etc., followed by the use of compressed air and finally electricity in both quarry and shop has been a direct result of this at that time enormous enterprise. The quarries at Quincy have been in continuous operation since they were opened. In 1837, according to Doctor Pattee's History of Quincy, the output of the Quincy quarries was 64,590 tons of stone, valued at $\$ 248,737$, and there were 533 employees. In 1845 there were 526 employees, and the value of the output was $\$ 324,500$. In 1865 ten quarries produced $\$ 271,880$ worth of stone and employed 306 men. The production at Quincy for 1887, 1888, and 1916-21 has been as follows, according to reports to the United States Geological Survey :

Granite produced at Quincy, Mass., 18s\%, 1889, and 1916-1921.

\begin{tabular}{|c|c|c|c|}
\hline Year. & $\begin{array}{l}\text { Number } \\
\text { of plants. }\end{array}$ & $\begin{array}{l}\text { Short tons } \\
\text { (approxi- } \\
\text { mate). }\end{array}$ & Value. \\
\hline 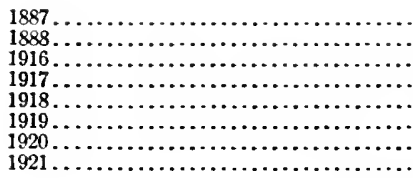 & $\begin{array}{r}10 \\
10 \\
5 \\
8 \\
8 \\
6\end{array}$ & $\begin{array}{l}62,000 \\
29,000 \\
26,000 \\
32,000 \\
27,000 \\
14,000\end{array}$ & $\begin{array}{r}8520,000 \\
500,000 \\
460,263 \\
398,196 \\
336,843 \\
614,005 \\
674,233 \\
311,178\end{array}$ \\
\hline
\end{tabular}

Stone was also quarried at an early date at the Chelmsford quarries. but the quarries on Cape Ann-at Gloucester, Rockport, Lanesville, and Pigeon Cove-were operated soon after the Quiney quarries and from their admirable location for transportation have furnished, besides high-grade monumental and building stone, an enormous quantity of stone for river and harbor work and street work.

According to the report of the Tenth Census, quarries in operation in 1880 were opened in Massachusetts at the places and dates which are given on page 456 . 


\section{Berkshire County :}

Chester (Becket), 1878-1880.

\section{Bristol County :}

New Bedford, 1860.

Fall River, 1810-1873.

\section{Essex County :}

Rockport, 1830-1870.

Lawrence, 1817.

Gloucester, 1851-1878.

Hampden County :

Monson, 1839.

\section{Middlesex County :}

Graniteville, 1860.

Lowell, 1876.

Westford (Chelmsford), $\quad \mathbf{1 8 4 5}-$ 1880.

Norfolk County :

Quincy and West Quincy, 18101879.

\section{Norcester County :}

Fitchlourg, 1S31-1876.

Milford, 1869.

Leominster, 1872.

Quarries in operation in Massachusetts in 1921.

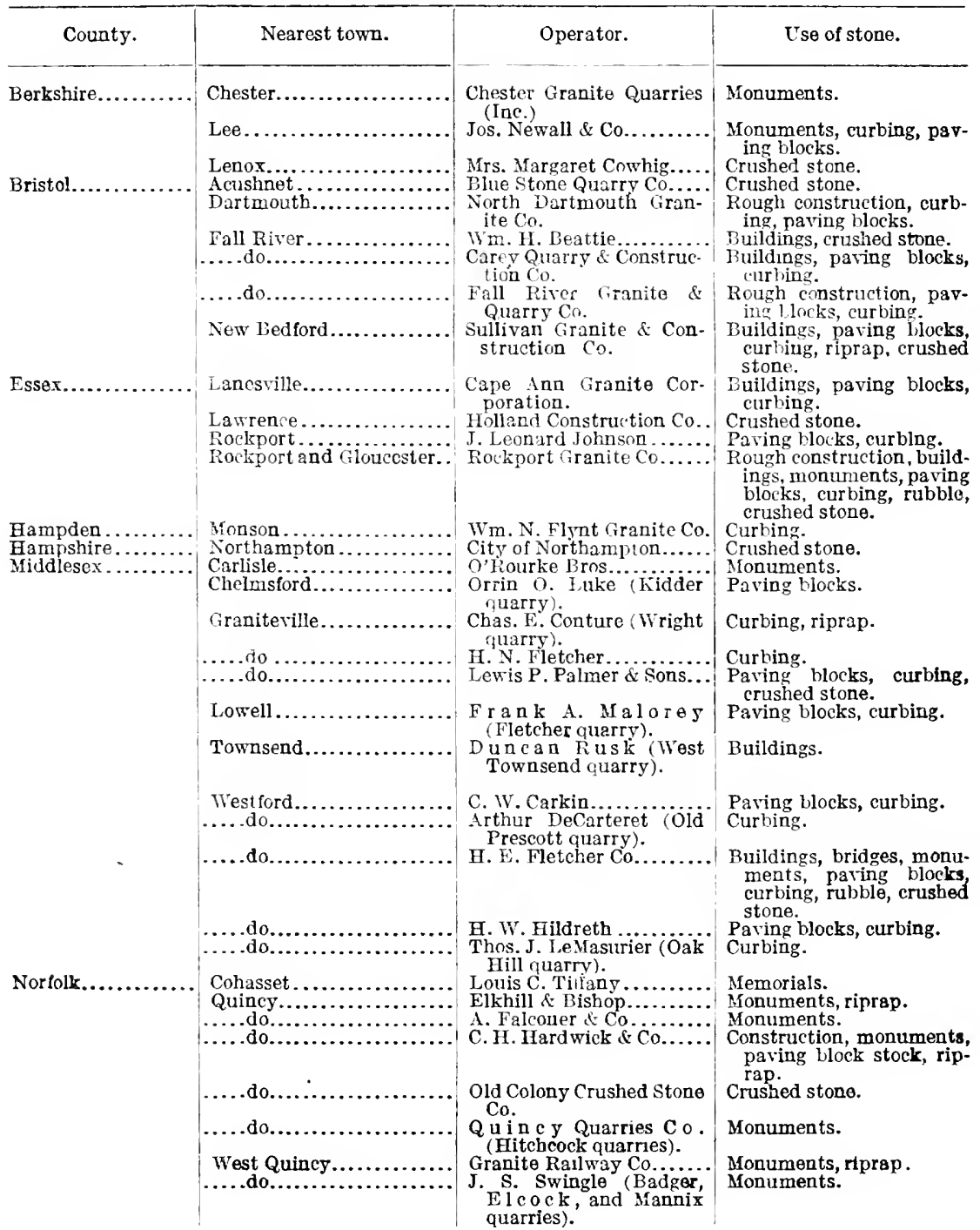


Quarrics in operation in Massachusetts in 19?1-Continued.

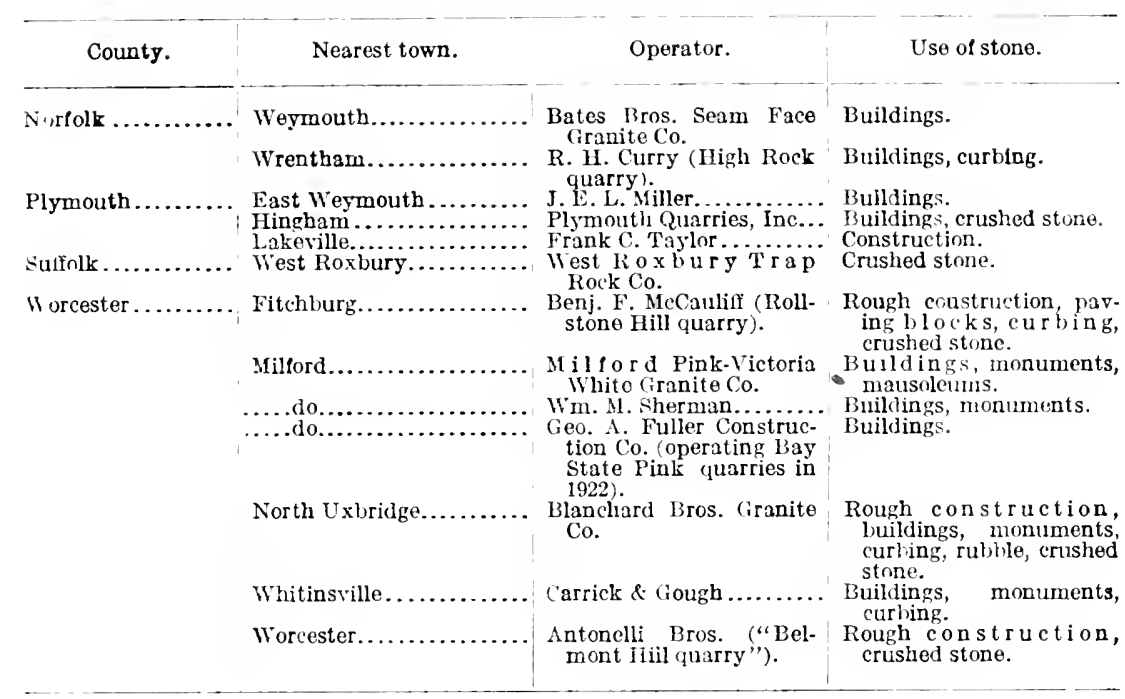




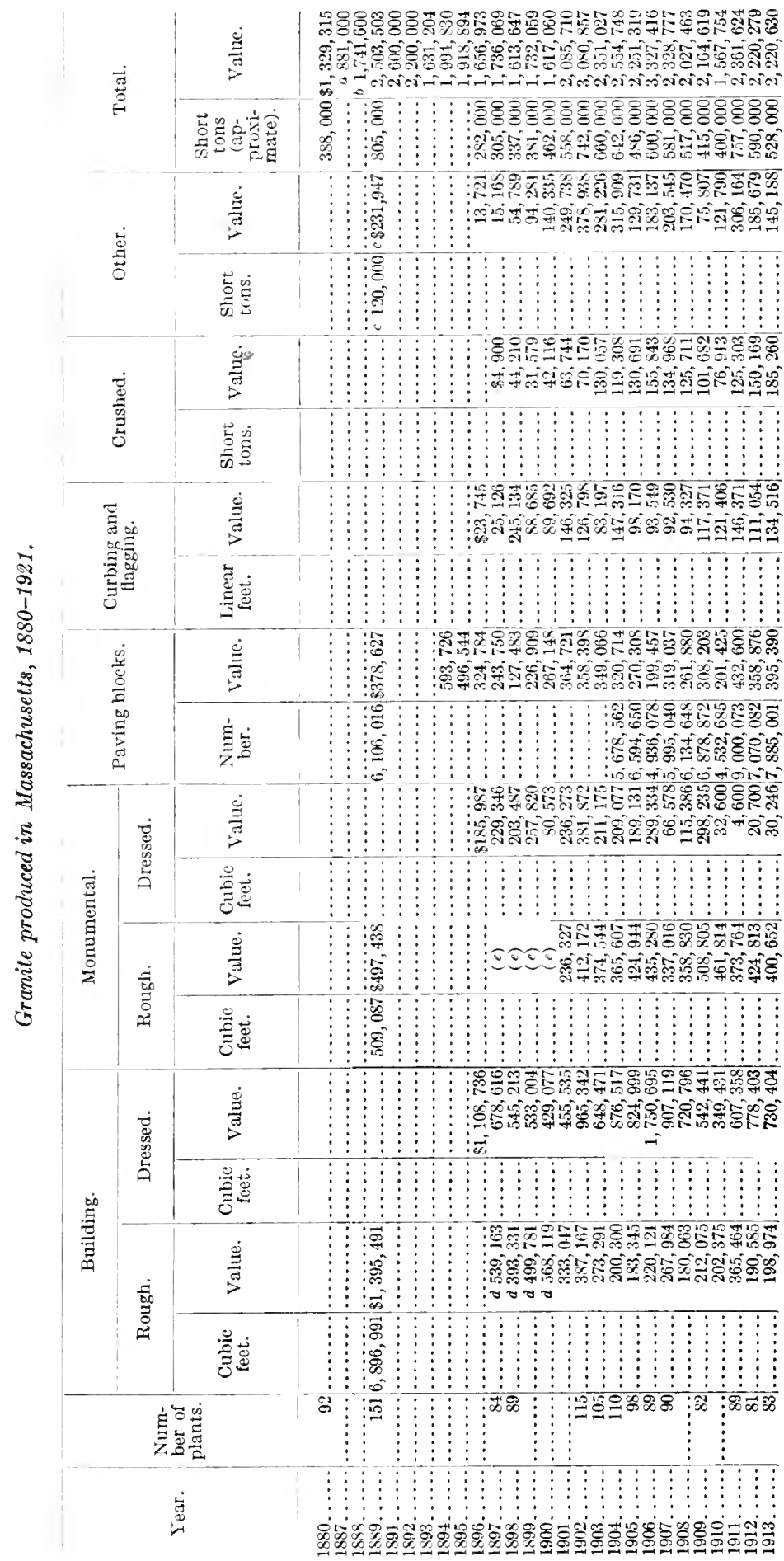




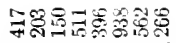
केते

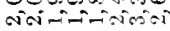

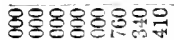

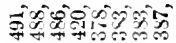

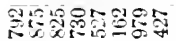

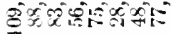

:

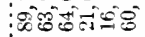

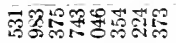

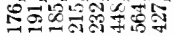

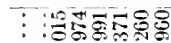

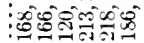

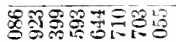

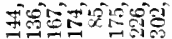
: :

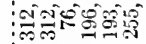

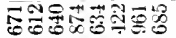

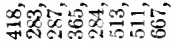

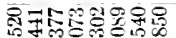

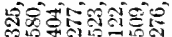

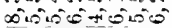

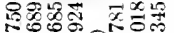
तing

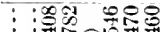
$00-50$

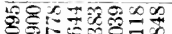

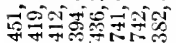

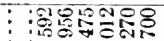

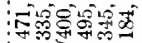

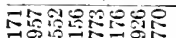

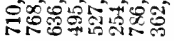

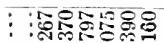

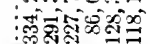

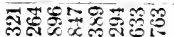
कै0

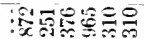

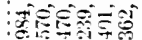

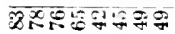




\section{CONNECTICUT.}

The granite industry in Connecticut has declined relatively more than in any other State in New England. In the five years 19171921 the output decreased 65 per cent, and the production for 1921 was about one-thirtieth of that in 1889. In 1889 there were 49 quarries in operation; in 1921, 11 . Much of the Connecticut granite has been used for small work, such as copings, sills, lintels, steps, foundation:, cross walls, eurbings, and sidewalks. and the use of concrete for work of this class has closed practically all the small quarries in the State. No granite quaries have been operated in this State for extensive riprap, breakwater, or jetty work in recent years, and this has also contributed to the decrease in output. The most important operations in 1921 were at Stony Creek, Waterford, Niantic, and buildings and monumental stone were the chief products.

The activity of quarries in Connecticut in early years is shown by the report of the Tenth Census (1880), which gave the following dates of opening of quarries in operation at that time:

\section{Fairfield County:}

Greenwich, 1830-1S50.

Iridgeport, 1873.

Hartford County :

Glaston!ury, 1850.

Litchfield County :

Thomaston, 1855.

Mindesex County :

Hadtam, 1800.

Middletown, 1830.

New Haren County :

Ansonia, 1818.

Leete Island, 1870.

Stony Creek, 1878.

\section{New London County :}

Niantic, 1832.

Waterford, 1835.

Groton, 1840-1869.

Lyme, 1875-1876.

Windham County :

East Killingly, 1842.

Sterling, 1855-1877.

Oneco, 1868.

Willimantic, 1877.

Granite quarries in operation in Connecticut in 1921.

\begin{tabular}{|c|c|c|c|}
\hline Counts. & Nearest town. & Operator. & Use of stone. \\
\hline $\begin{array}{l}\text { Fairfield... } \\
\text { Hartford.. }\end{array}$ & Bridgeport...... & Burns Co ........................ & Crushed stone. \\
\hline Hartford. & Glastonbury.. & $\begin{array}{l}\text { Glastonbury Granite Works } \\
\text { (Inc.) }\end{array}$ & $\begin{array}{l}\text { Rough construction, curb- } \\
\text { ing. }\end{array}$ \\
\hline $\begin{array}{l}\text { Litch field ........... } \\
\text { New ilaven....... }\end{array}$ & $\begin{array}{l}\text { Thomaston.... } \\
\text { Stony Creek... }\end{array}$ & $\begin{array}{l}\text { Plymouth Granite Co........ } \\
\text { Millford Pink-Victoria White } \\
\text { franite Co. }\end{array}$ & $\begin{array}{l}\text { Buildings. } \\
\text { Buildings, monuments, } \\
\text { mausoleums, }\end{array}$ \\
\hline & Millstone... & Genry Gardiner.............. & $\begin{array}{l}\text { Monuments, riprap, pav- } \\
\text { ing blocks. }\end{array}$ \\
\hline New London....... & Waterford.... & $\begin{array}{l}\text { Booth Bros. \& Hurricane Isle } \\
\text { Grantite Co. }\end{array}$ & $\begin{array}{l}\text { Buildings, monuments, } \\
\text { paving blocks, riprap. }\end{array}$ \\
\hline Windham. & 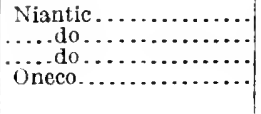 & 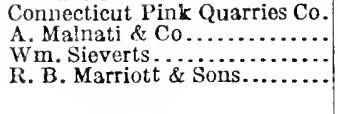 & $\begin{array}{l}\text { Monuments. } \\
\text { Do. } \\
\text { Do. } \\
\text { Buildings, curbing, paving } \\
\text { blocks. }\end{array}$ \\
\hline
\end{tabular}




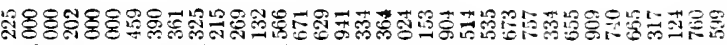

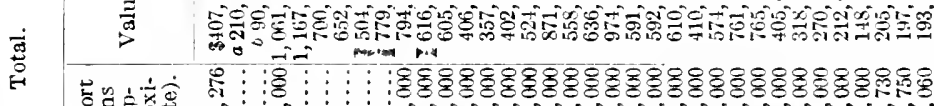

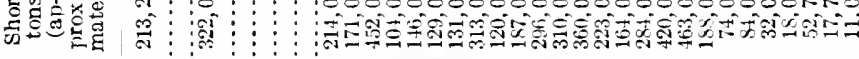

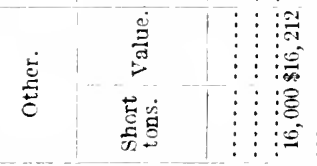

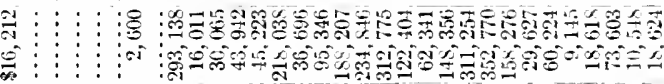

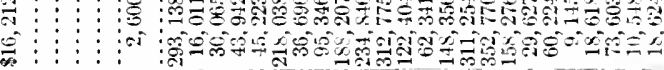

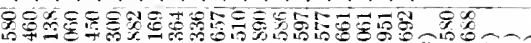

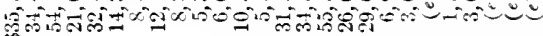

僖

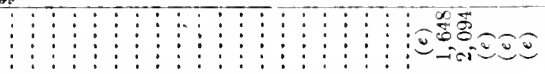

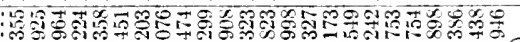

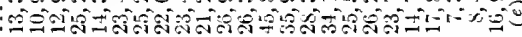

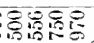

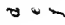

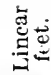

:

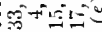

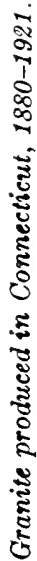

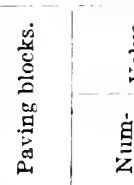

峞

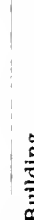

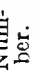

(8)

:

变

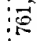

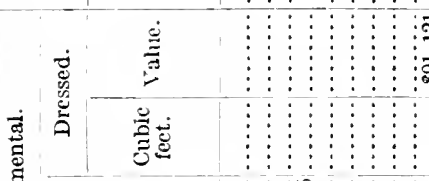

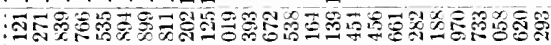

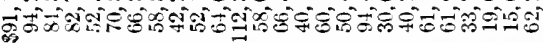

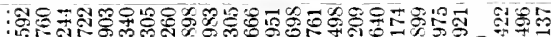
月ी

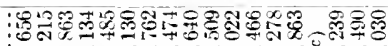

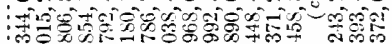

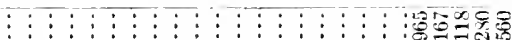
$=E^{-10} \operatorname{cis} i s^{\circ}$

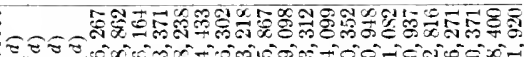

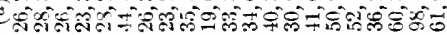

हो हैं

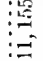

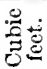

$\underbrace{0}$

ن

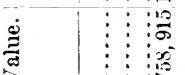

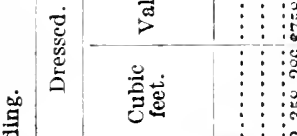

$\begin{array}{ll:l}\stackrel{g}{\Xi} & \vdots \\ \stackrel{5}{\rightarrow} & 1\end{array}$

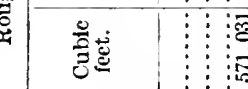

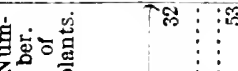

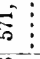

;

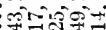

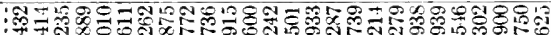

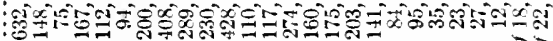

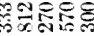

जon-i-

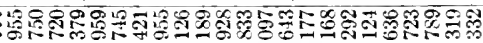

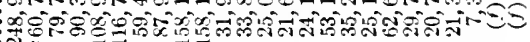

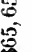

:

$8 \mathrm{sin}=5$

治觉

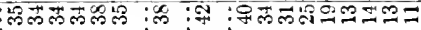


RHODE ISLAND.

The granite industry of Rhode Island center's around Westerly, Washington County. Quarries were opened in this district as early as 1843, according to the report of the Tenth Census (1880), but it was after 1850 before the industry was fairly begun. In Providence County a quarry at Diamond Hill was opened in 1840, and one at Cranston in 1820. A quary was opened at Newport, Newport County, in 1855 .

There were 35 operators of quarries in 1889, and but 6 in 1921, aside from producers of crushed stone. The chicf product of the Westerly quarries is monumental stone, and for this reason there was not so large a decrease in output in the five years 1917-1921 as was shown by the States where building stone is a considerable factor. A number of quarries have combined during the last few years.

Operators of granite quarries at Westerly, Washington County, R. I., in 1921.

\begin{tabular}{|c|c|}
\hline Firm name. & İse. \\
\hline 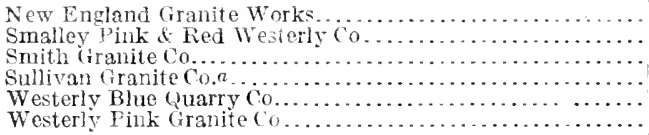 & $\begin{array}{l}\text { Buildings, monuments, mausoienms. } \\
\text { Monuments, paving blocks, rubble. } \\
\text { Do. } \\
\text { Monuments. } \\
\text { Monuments, paving block. } \\
\text { Monuments. }\end{array}$ \\
\hline
\end{tabular}

a Operates the Crumb, Llondike, Joseph Nerall d ( 'o. (Dalbeattie), and John B. Sullivan quarries.

The operators of quarries for crushed stone were as follows:

Bristol County :

L. H. Callan, Bristol.

Newport County :

Peckham Bros. Co., Middletown (conglomerate. "putdingstone").

City of Newport, Newport.

J. K. Sullivan, Newport.

J. F. Sullivan, Newport.

Providence County:

Central Falls Stone Co., Central Falls (sanustone).

Jos. McCormick, East Providence (sundstone or "bluestone").

Thomas J. Quinn, Ashton (granite).

Iron Stone Trap Rock Co., Woonsocket (cumberlandite, an ilmentitemagnetite rock). 


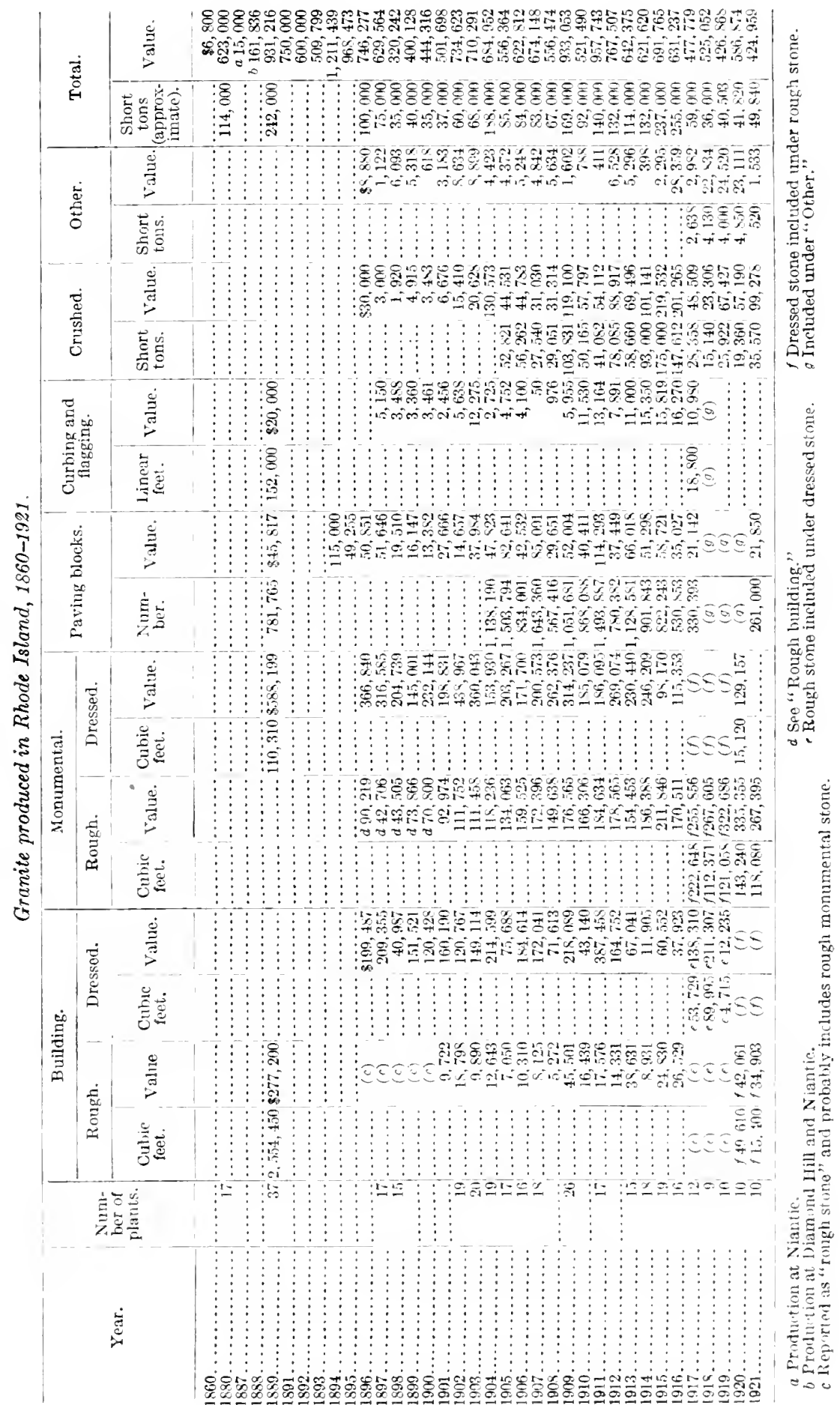




\section{BIBLIOGRAPHY OF ECONOMIC GEOLOGY OF GRANITE.}

[Including physical tests and geometrical analyses of granite and statistics of granite production in the United States.]

Anderson, Thor, Sveriges Granitindustri, Stockholm, 1911.

Anonymous, The structural and industrial materials of California: California

State Min. Bureau Bull. 3S, pp. 23-60, 1906.

… Die Steinbriicle Sachsens, Granit: Der Steinbruch, Jahrg. 7, pp. 83-90, 1912.

The granite quarries of Lake Maggiore: Gior. genio civile, abstract in Inst. Civil Eng. Proc., 1912, also in Quarry, vol. 18, p. 51, February, 1913.

- The Demitz-Thumitz granite quarries near Bautzen: Ver. deutsche Ingenieuren Zeitschr., 1911-12.

BAKER, IR. T., Building and ornamental stones of Australia: Tech. education series No. 15, Government of New South Wales, 1909. Includes 11 colored plates of polished specimens ( $S$ granites, 2 trachytes, 1 porphyry).

Bowles, Oliver, The structural and ornamental stones of Minnesota: U. S. Geol. Survey Bull, 663, pn. 50-149, 1918.

Brayley, A. W., History of the granite industry of New England, Boston, 1913. Buckley, E. B., Building and ornamental stones of Wisconsin: Wisconsin Geol. and Nat. Hist. Survey Bull. 4, granite, pp. 88-100, 107-115, 121-160; tests, pp. 46-74, 358-415, 1898.

Buckley, E. B., and Buthler, H. A., The quarrying industry of Missouri: Missouri Bur. Geology and Mines, 2d ser., vol. 2, granite, pp. 60-S5, 1904.

Clark, W. B., and Mathews, E. B., Report on the physical features of Maryland, together with an account of the exhibits of Maryland mineral resources by the Maryland Geological Survey: Maryland Geol. Survey Special Pnb., vol. 6. granites, pp. 115, 144, 173-177, pl. 8, fig. 1, pl. 12, 1906.

Coons, A. T., The stone industry in 1904: U. S. Geol. Survey Mineral Resources, 1904, granite, pp. 17-32, 1905. (See also Mineral Resources for 1905-1921.)

DALE, T. N. The granites of Maine, with an introduction by George Otis Snith: U. S. Geol. Survey Bull. 313, 1907.

- The chief commercial granites of Massachusetts, New Hampshire, and Rhode Island: U. S. Geol. Survey Bull. 354. 1908.

- The granites of Vermont: U. S. Geol. Survey Bull. 404, 1909.

Supplementary note on the granites of New Hampshire: U. S. Geol. Survey Bull. 430, pp. 346-372, 1910.

- Supplementary note on the granites of Massachusetts: U. S. Geol. Survey Bull. 470, pp. 240-288, 1911.

Dale, T. N., and Gregory, H. E., The granites of Connecticut: U. S. Geol. Survey Bull. 484, 1911.

Darton, N. H., Economic geology of Richmond, Va., and vicinity: U. S. Geol.

Survey Bull. 4S3, 1915.

DAX, W. C., Stone: U. S. Geol. Survey Mineral Resources, 1899 and prior years.

Frentzel, Alexander, Das Passauer Granitmassiv : Geogn. Jahreshefte, Jahrg.

24, pp. 33-192, Munich, 1911 [1912].

GÄBERT, C., Die technisch nutzbaren Gesteine des Königreichs Sachsen: Der Steinbruch, Jahrg. 7, pp. 72-82, 1912

Gillarone, Q. A., Report on the compressive strength, specific gravity, and ratio of absorption of various kinds of building stones from different sections of the United States tested at Fort Tompkins, Staten Island, N. Y., Engineer Department, U. S. Army, 1874. 
Ḧ̈векL, D., Die Gneiss (Granit) Industrie ron Albersweiler in der Rheinpfal\%: Der Steinbruch, Jalng. 8, pp. 300-302, 1913.

Hakris, G. F., Granite and our granite industries, London, 1888.

Henstrom, Heraran, On the natural building and ornamental stones of Sweden: Sveriges Geol. Undersökning, ser. C., No. 209, 1908.

IERmann, O. Steinbruchindustrie und Steinbruchgeologie, Berlin, 1899.

'Technische Verwerthung der Lausitzer Granite: Zeitschr. prakt. Geologie, 1895 , pp. 433-444.

- Gesteine fur Architektur und Skulptur ( $2 d$ edition of Anhang to "Steinbruchindustrie u. Steinbruchgeologie"), granite, porphyry, and diorite, pp. 8-35, 1914.

HisschwaLd, J., Die Prüfung der natürlichen Bausteine auf ihre Wetterbeständigkeit, Berlin, 1908. Abstract in Zeitschr. prakt. Geologie, vol. 16, JulySejt. and Nov., 1908.

Holarquist, P. J., Studien über dje Grauite von Schweden: Geol. Inst. Upsala Bull. 7, pp. 77-269 (22 tables and 40 tigs), 1906.

Hull, EDWARD, A treatise on the building and ornamental stones of Great Britain and foreign countries, London, 1872.

Humphrey, R. L., Fire-resistive properties of various building wateriuls: U.S. Geol. Survey Bull. 370, pp. 69-72, 1909.

Hunter, J. F., The Aberdeen granite quarry near Gumnison, Colo.: U. S. Geol. Survey Bull. 540, pp. 359-362, 1914.

Julien, A. A., Building stones; elements of strength in their constitution and structure: Franklin Inst., Jour., Pa., vol. 147, pp. 257-142, 1899.

Comparison of methods of graphic analysis of rocks: Geol. Soc. America Bull., vol. 14, pp. 460-468, 1903.

KaISER, ErIch, Die Verwitterung der Gesteine, besonders der Bausteine, 30 pp.: Handbuch der Steinindustrie, vol. 1, Berlin, 1915.

Lewis, J. V., Building stones of New Jersey: New Jersey State Geologist Ann. Rept. for 1908.

Lor.D, E. C. E. Examination and classification of rocks for road building, including the physical properties of rocks with reference to their mineral composition and structure: U. S. Dept. Agr. Office Public Roads Bull. 31, Physical properties of granite for road making, Table 2, 1907.

I.UxDBonM, HJALMAR [summary of his papers on granite aud granite quarryIng in Europe, by William C. Day]: U. S. Geol. Survey Mineral Resources, 1893, pp. 578-582, 1894.

Mailerot, A., Granites of the eastern townships of Quebec: Camilia Geol. Survey Summary Rept. 1913, pp. 217, 218, 1914.

Matriews, E. B., The granite quarries of Maryland: Marylaud Geul. Survey. vol. 2, pp. 136-160, 1898.

Mathews, S. W., The granite industry of Maine: Maine Bur. Inilustrial and Labor Statistics Sixteenth Ann. Rept., pp. $7-51,1902$.

McCourt, W. E., Fire tests of some New York building stones: New York State Mus. Bull. 100, granite and gneiss, pp. 13, 16-19, 26-27, 29-32; pls. $1-3,9-11,14-17.1906$.

- The fire-resisting qualities of some New Jersey buileling stones: New Jersey State Geologist Ann. Rept.. 1906. Granites and gneisses, np. 26;-2S. Marril., ( $r$. P., On the collection of Maine building stones in the United States Nitional Museum: U. S. Nat. Mus. Proc.. vol. 6. pp. 165-183. $18 S 3$.

- Collection of building and ornamental stones in the United States National Museun: Smithsonian Inst. Ann. Rept., 1886. pt. 2. 1859.

10500. 23-_- :11 
Merbilt, G. P., Physical, chemical, and economic properties of building stones:

Maryland Geol. Survey, vol. 2, pp. 47-123, 1898.

- Stones for building and decoration, 3d ed., New York, 1903.

Stone (granite): Twelfth Census, Mines and quarries (1902), 1905.

NEWBERrY, J. S., Report on bullding stones of the United States and statistics of the quarry industry: Tenth Census, vol. 10, pp. 318-324, 1884 .

OxAAL, JoHN, Der. huite granit i Sogn, Geologisk optraeden og tekniske egengkaper (English summary) : Norges geol. Undersögelse Aarbok, 1913, 1.

- Norsk Granit (English summary) : Norges geol. Undersögelse No. 76, Kristiania, 1916.

PaIge, Sidner, Mineral resources of the Llano-Burnet region, Tex.: U. S. Geol. Survey Bull. 450, 1911.

PARKS, W. A., Report on the building and ornamental stones of Canada, vol. 2, Maritime provinces: Canada Dept. Mines (No. 203), New Brunswick and Nova Scotia granites and black granites, pp. 107-152, 1914.

__ Idem, vol. 3, Province of Quebec. (No. 279.) Granites, gneisses, and black granites, pp. 139-191, 1914.

- Idem, vol. 5, Province of British Columbia, pp. 65-124, 186-192, 1917.

Perkins, G. H., Report on the marble, slate, and granite industries of Vermont, granite, pp. 51-68, 1898.

- Report of State geologist on the mineral resources of Vermont, 18991900, granite, pp. $57-77,1900$.

- Report of State geologist on the mineral industries and geology of certain areas of Vermont, 1903-4, granite, pp. 23-44, 1904.

- Report of State geologist on the mineral industries and geology of certain areas of Vermont, 1907-8, granite, pp. 32-46, 1908.

Reusch, HaNs, Granite industrien red Idefjorlen, etc.: Norges geol. Undersögelse Aarbog, 1891.

Rich, GEorge, The granite industry of New England: New England Magazine, February, p. 742, 1892.

RichakDSON, C. H., and Conway, E. F., The terranes of Irasburg, Vt.: Vermont State Geologist Eighth Rept., granite, pp. 155, 156, pl. 54, with granite areas, 1912.

IRıEs, Heinnich, Economie geology, 4th ed., New York, 1916.

Rirber, C. C., Norges granit industrl: Norgeg geol. Undersögelse No. 12: Aarbog for 1893, with English summary.

Losiwal, Atgust, Ueber geometrische Gesteinsanalysen; ein einfacher Weg zur ziffermässigen Feststellung des Quantitätsverhältnisses der Mineralbestandtheile cemengter Gesteine: K.-k. geol. Reichsanstalt Verh., vol. 32, pp. 143-175, 1898 .

-_. Ueber einige neue Ergebnisse der technischen Untersuchung von Steinbaumaterialien; eine neue Methode zur Erlangung zahlenmässiger Werte fiil die "Frische" und den "Verwitterungsgrad" der Gestcine: K.-k. geol. Reichsinstalt Verh., vol. 33, pp. 204-225. 1899.

_.__ Ueber weitere Ergebnisse der technischen Untersuchnng zur Erlangung zahlenmässiger Werte für die "Zähigkeit" der Gesteine: K.-k. geol. Relchsanstalt Verll.. pl). 234-246, 1902.

Schmor. - - Natiulliche Bausteine (vol. 76 , Bibliographie der gesammiten Technik), Hannover, 1908.

Schuint, ALbеiт, Die Granitgewinnung im Fichtelgebirge, ihre Geschichte und Rechtsverhältnisse: Der Steinbruch, Jalırg. 5, pp. 294-296, 310-311, 344-345. 1010 . 
TARK, R. S., Eronomic geology of the United Staltes, with briefer mentinn of foreign mineral products, $2 \mathrm{~d}$ ed., New York, 1895.

TARR, W. A., A study of the effects of heat on Missouri granites: Missouri Univ. Bull., vol. 15, No. 27, September, 1914.

Warson, T. L., Granites of the southeastern Atlantic States: U. S. Geol. Surrey Bull. 426, 1910.

Mineral resources of Virginia, Builling and ornamental stones, etc. (grantes of Pielmont region), Virginia Jamestown Exposition Commission, 1907.

Watson, T. I., and Laney, F. B., with the collaboration of G. I. Merrill, The building and ornamental stones of North Carolina: North Carolina Geol. Survey Bull. 2, 1906.

Weidman, Samuei, The greology of north-central Wisconsin: Wisconsin Geol. and Nat. Hist. Survey Bull. 16, granite quarries. pp. 636-640; analyses of granite from central and southern Wisconsin, p. 340; from northern Michigan and northern Minnesota, p. 341 ; disintegrated granite for country roads, p. 643, Madison, 1907.

Williams, I. A., The comparative accuracy of the methods for determining the percentages of the several components of an igneous rock: Am. Geologist, vol. 35, January, 1905.

Wolff, J. li., Details regarding quarries (granite): Tenth Census, vol. 10, 1888.

See also the successive renorts of the tests of metals and other materials for incustr'al purposes made at Watertown Arsenal, published by the United States War Department.

The German periodicals named below also give results of tests of granite:

Mitteilungen der technischen Versuchsanstalten zu Berlin.

Mitteilungen der Anstalt zur Prüfung von Baumaterialien am Polytechnikum in Zurich.

Mitteilungen aus dem mechanisch-technischęn Laboratorium der Königlichen technischen Hochschule in Mïnchen.

The substance of the papers by Merrill in rol. 10 of the United States Tenth Census, 1S88, and in the Proceedings of the U. S. Nat:onal Museum, vol. 6, 1883, has reappenred in more molern form in his other works.

\section{GLOSSARY OF SCIENTIFIC AND QUARRY TERMS.}

Accessory minemals in granite are original constituents of the rock, found only in small, often only in microscopic quantity.

Acidic. A term applied to rocks in which silicic acid (silica) or quartz prerominates.

Alrasite. An opaque black mineral (silicate), brown in thin section, one of the prima:y less commor: accessory constituents of iranite, which contains from 12 to 17 elements, inchuling 6 of the rarer ones. For analyses see Dana. I. S.. System of mineralogy, 6th ed., pp. 522-526, 1892.

INTICLixe. A term applied to granite sheets or sedimentary berts thit form an arch.

Arrte. Fine-grained granite, generally oceurring in dikes and containing little mica and a high percentage of silica.

BAsrc. A term applied to rocks in which the iron-matnesia minerals and feldspars witl lime and soda predominate, such as diabise or basalts.

BLAck Hniss. Term used hy quarrymen to denote a dark hiotite gneiss in contact with the granite. 
Blind seams. Quarrymen's term for incipient joints.

Bonluer quarix. One in whilh the joints are either so close or so irregular that no very large blocks of stone can be quarried.

Channel. A narrow artificial incision across a mass of rock, which, in a granite sheet, is made either by a series of contiguous drill holes or by blasting a series of holes arranged in zigzag order.

Cleavage, when applied to a mineral, designates a structmre consequent upon the geometric arrangement of its molecules at the time of its crystaliliza. tion.

Close-Jointed. A term applied to rock containing joints that are very near together.

Crocus. A term used in some quarries to denote gneiss or any other rock in contact with granite.

Crush Border. A microscopie gramular structure sometimes characterizing aujacent feldspar particles in granite in consequence of their laving been crushed together during or subsequent to their crystallization.

CUT-OFF. Quarrymen's term for the direction along which the granite must be channeled, because it will not split. Same as "hard way."

Dendrites. Plantlike crystallization of iron or manganese oxides on the sur faces of fissures in any rock or mineral. Frost crystals on window panes are of like character.

Drke. A mass of granite, diabase, basalt, or other rock which has been erupted through a narrow fissure.

Dimension stone. A term apllied to stones that are quarried of required dimensions.

DrP. The inclination from the horizon, given in terms of degrees, of a sheet, joint, heading, dike, or other structural plane in a rock.

DrifT. Sand and boulders deposited by the continental glacier.

Drumin. Oval hillock of clay and boulders formed beneath the ice sheet of the glacial epoch.

Enosron. The wearing away of portions of a rock by such natural agencies as stream or ice action.

Exfoliation. The peeling of a rock surface in sheets owing to changes of temperature or to other causes.

FAcling. The slipiage of a rock mass or masses along a watural fracture.

Flow structume. The parallel arrangement of the minerals in granite or other igneous rock in the direction of its flowage during its intrusion.

GEODE. A rock cavity lined with crystals. Geodes in granite are attributed to steam or gas bubbles.

GraIN in granite is practically the direction in which the stone splits "next easiest," the "rift" being that in which it splits most readily.

Grout. A term applied to the waste material of all sizes obtained in quarrying stone.

Grow-on. Quarrymen's term to designate the place where the sheet structure dies out, or the place where two sheets appear to grow onto one another.

HARD wAY. The direction at right angles to both rift and grain in which granite rloes not split readily. (See Cut-off.)

HEADING. A collection of close joints.

Heading seam. See Joints.

Hematite. An oxide of iron $\left(\mathrm{Fe}_{2} \mathrm{O}_{3}\right)$, which, when scratched or powdered, gives a cherry-red color.

IGNEOUS. A term applied to rocks that have originated in a molten condition. 
Jornts. More or less steeply inclined fractures which cross the grante sheets and which are attributed to various stresses.

KAoLIN. A hydrous silicate of alumina derived from the alteration of feldspar. Kaolinization. The process by which a feldspar passes into kaolin.

KNots. A term applied by quarrymen to dark-gray or black objects, more or less oval or circular in cross section, which are segregations of black unica or hornblende formed in the granite while in a molten state. English quarrymen call them "heathen."

KNox hore. A circular drill hole with two opposite vertical grooves whlch direct the explosive power of the blast.

IEw IS HoLf. An opening made by drilling two or three holes near together and chiseling out the intervening rock.

L.imonite. A hydrous oxide of iron $\left(2 \mathrm{Fe}_{2} \mathrm{O}_{3}, 3 \mathrm{H}_{2} \mathrm{O}\right)$; a hydrated hematite, which. when scratched or powdered, gives a brownish rust color.

MATR1x. The general mass of a rock which has isolated crystals; sometimes called groundmass.

Metamorphism. The process, partly physical, partly chemical, by which a rock is altered in the molecular structure of its constituent minerals and in their arrangement. Metamolphism may be regional, due to crustal compression, or contact, due to the intrusion of seflimentary rock by an igneous rock.

Mindineter. French decinal linear measure, the thousandth part of a meter or the tenth nart of a centimeter. It is equivalent to nearly 0.04 inch, the meter being $39 \frac{10}{27}$ inches.

Monolith. A colmm or monument of one stone.

Motron. A term userl in granite regions to designate small paving-block quarries.

Opfitic. A term applied to microscopic lock texture to designate a mass of longish interlacing crystals, the spaces between which have been filled with minerals of later crystallization.

Oneï. A term applied in the Quincy quarries to Quincy granite which has heen rendered valueless by the alteration of its aegirite particles.

Pegmatrte. A very coarse granite occurring in irregular dikes or lenses in granites and some other rocks.

Phenocryst. A term applied to isolated crystals visible to the unalded eye and lying in the mass of a rock of igneous origin.

Plagloctase. A term applied to all those feldspars that are not potash feldspars.

Pleg AND fenthers. A quarrymen's term. The plug is a wedge, and the feathers are two short pieces of half-round iron whose curved sides fit the drill hole while their flat silles receive the plug. By drixing the plugs in a series of holes a stune may be broken.

Polarized right. Light whose vibrations, unlike those of ordinary lisht. which are in all directions, are in only one plane. Polarized light is used in the microscopic study of rocks.

Porphyritic. A term applied to rock texture to designate the presence of isolated crystals in a general mass (matrix or groundmass) of finer material.

Pscudomonir. Signifies false form and designates a crystal in which, owing to various chenical changes, the oriminal mineral has been more or less replaced by others. The form of the crystal no longer corresponds to the mineral. 
QUartz monzonite. Technical designation for a granite in which the percentages of soda-line feldsinar and of potash feldspar are nearly the same or in which the former exceels the latter. In ordinary granites the amount of suda-lime feldspar is relatively small.

Baniom STONE. A term applied by quarrymen to quarried blocks of any dimensions. (See definition of dimension stone.)

RiFT. A quarrymen's term to designate an obscure microscopic cleavage in granite which greatly facilitates quarrying.

Run. A term used by quarrymen in connection with "rift," appareutly to denote the course of the deflection of the rift due to gravity, strain, or other not yet understood cause. In southern and western quarries the grain is called the run.

SALT HORSE. Quarryman's term for aplite or other useless rock.

SAND sEams. Quariy term for more or less minute veins or dikes of muscovite (white nica) with some quartz, in cases also with feldspar.

Sand strearss. Same as sand seams.

SAP. Quarrymen's term for ferruginous discoloration along sheet or jolnt surfaces. .

ScHist. A rock made up of flattish particles arranged in rough parallelism, some or all of which have crystallized under pressure.

Schistosity. The quality of being like a schist.

SEAM. Quarrymen's term for joint.

Secondary minerals. Minerals whose presence is due to the alteration of the original minerals.

Sedimentary. A term designating those rocks that consist of particles deposited under water.

Shgregation. The scientific term for "knot," a collection of material separated from other material. A vein of segregation is one formed by the filling of a fissure with mineral matter originating in the surrounding rock.

Sericite. A more or less fibrous form of muscovite (potash mica), often resulting from the alteration of feldspar.

Sнakes. Quarrymen's term to designate a somewhat minute close-joint structure, which forms along the sheet surface as a result of weathering.

ShEET QUARRY. A quarry in which the granite lies in sheets. crossed by widespaced steep joints.

Suickensides. The polished and grooved faces of a joint or bed caused by motion and friction.

Strain sheEt. Quarrymen's tern for granite sheets produced by present compressive strain.

Stratified. A term applied to rock consisting of oliginally horizontal beds or strata.

Strike. The direction at right angles to the inclination of a plane of bedding, a sheet, or joint, etc.

Stripping. The material (sand, clay, soil, etc.) overlying a rock of economic value, which must be removed before quarrying.

Specific GRavity. The weight of a rock or mineral compared to that of a body of distilled water of the same bulk.

Subjornt. Minor joints diverging from or parallel to the regular joints.

Syncline. A geologic term for the trough part of a wavelike sheet or bed of rock.

Til.L. A mixture of clay and boulders deposited by glaciers. 
Trumte. Special name for the material of the till. The evidence that the clay and pebbles or boulders are of glacial origin is in the parallel striation of the pebbles or boulders owing to their having been rubbed against a rock while fixed in the moving ice.

Toeing In. Quarrymen's term for the wedging in of the end of a granite sheet under an overhanging joint, probably in consequence of the faulting of the sheets along the joint. It is also applied to the overlapping of lenticular sleets.

"Toenalls." Curved joints intersecting the sheet structure, in most places striking with the sheets, in some differing from them in strike $45^{\circ}$ or more. Twin crystals. Two adjacent crystals which have formed with the poles of their main axes in opposite or different directions.

Weathering. The decomposition of a rock owing to the action of the weather. White hoRse. Term used by quarrymen to denote a light-colored gneiss, aplite, or pegmatite.

Wollastonity. A mineral cunsisting of silicil 51.7 per cent and lime 48.3 per cent $\left(\mathrm{CaSiO}_{3}\right)$. It commonly results from the metamorphism of calcareous rock or marble where in contact with an igneous rock. 



\section{INDEX.}

A.

102 , 157,172

Acknowledgments for aid. $307-308$

Acton, Mass., quarries in

418-419

Adaptability of the granites

$262-263$

Addison. Inine, quarries in

features of
granjte for capitol at. $\quad 235$ $\begin{aligned} \text { Albany, } N \text {. Y.. granje for capitol at } & 235 \\ \text { granite for post office at__.. } & \mathbf{2 4 1}\end{aligned}$

Arlington National Cometery. Va., granite for monuments in $\ldots \ldots \ldots \ldots$.

Alfred, Mainc, granite of Allegheny. Pa., granite for Carnegle Library at ........... granite for equestrian statue of

Washington at

Alien quarr. Mount lesert. Matne. features of .........

plato slowing.............

Allentown. Pa., granite for Irehlgh County courthouse at

granite for post office at_... 173 sllenstown, N. II., granite of _._ 143-1!4

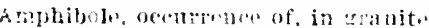
Aralysis, clominal testing of cranite by

Analysis of aplite from Hingham, Mass._.

biotite granite gneiss from rellham. Mass.

from Stony Creek, Conn. granite from Barre, Vt. ..._ 125, 139

Becket, Miss._._._._... 280

Bethel, Vt............. 157

Concord, ‥ 11......... 199

lligh Islo quarry. Maine_ 236-237

IIurricano Island. Maine-_ 247

Jonesboro, Maint__._.... 299

Milford, Mass..._._._._. 343 ,

344. 346, 347-345, 350-3.11

North .Jay, Maine_..._. 213

Redstone, N. II._._._. 166-167,

$168-169$

Rockport, Mass.......... 292-293

Troy, N. II............ $17 \overline{5}$

WaIdoboro, Maine____ 250

Westerly, R. I. ....... 407

Windsor, Vt..._..... 16:-163 quarto-mica cliorito from Monson, llass. .........

quartz monzonite from Water. ford, Conn..........
Analyses of granite, extreues of .. 7-9

Anderson quarry, Barre, Vt., description of

Andersonville, Ga., granite for monuments at _... 236. $24: 4,4 \mathrm{~s}$

Andrews quarries, Biddeford, Maine, product of _._._. $27 \overline{5}-276$

Intolia, Ind.e granite lor soldiers and sailors' nonument at _...................

Annapolis, IId.e granite for U. S. Xilval Acutamy at_... $2: 30$, $235,248,251$

Arsonia, Conn., granite of _..._- $376-377$

Armbrust quarry, Vinalhaven, Maine, features of _....... $246-247$

Atlanta, Ga., granite for post oflice and custombouse at _- 239

Auburn quarry, Auburi, N. 11., product of

13.

Rabson Farm quary, Rockport. Mass., description of -

Bailey prospects, Dummerston, Vt.. product of

Bailey quarry, Allenstown. N. II.. rescription of_._._. 193-194

Railey quarry, Barie, vt., deseri]). tion of .......... 132

Baileyville, Maine, quarries at_-_- 263-264

Baird quarry, Swaus Island, Maine, product of

liail of polished Quiney granita, plate showing -...-..-

Ballou quarry, Quincy, Mass., description of _._.

Inugor. Maine, granite for courtlouse at ..........

lank of Commerce. New York, pinel at entrance of, plate showing _._._.......

Binrelay quarry, Barre, Vt., product of _...................

larker Hill quiry, Townsend. Mass. froducts of _...... 313-314

Barker Lot quarry, Westfold, Mass., locition of

Barnard quariy, liarton, lit., prodnct of _................

liarre. Vt., carvod sranite from. plates showing_..... 160 contact phonomena at ......... sti-by frinite artil ju and alljoining, geology of $12 \%-123,125-123$ quarries of ........... 128-143 topography of ....... 121-122 
Page.

Batre, Vt., granite of ....... 123-12: uranite of, earved pxerara of. plate showing -.

map of, showing location of Erinite ynaritis.....

Rarre Franite \& Quarry Co., quarry of _................

Marre Medium quary, Barre, Vt., description of _.......

balton. Vt., granite of _...............

lay stite quarriss, Milford, Mass., product of__._._. $347-348$

Bay View clark-granite prospect, Rockpolt, Mass., rock of _... 302-303

Rear Hill quarry, Hollis, Maine, product of _........

Heattie \& Wilcox quarry. Fall River, Mass, description of__ 282-283

Buttie quarry, Fall River, Mass, description of -..._ 283-285

Buver Iako quarry, Calais, Maine, description of

265

recket, Mass., granite of _-___-_ 279-281

Reeket gneiss, deseription of _.... 358

Refdle's prospect. Randoiph, Vt., granite of _-_...- $118-119$

Relden quarry, Glastoubury, Conn.. product of _._._.

Benedict quarly, Cornwall. Conn., product of _._. $369-370$

Bennett quarries, Sterling, Conn., profluet of _.____ 401-402

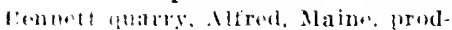
uct of _.

Renrenue quarries, Middletown, (') 11. descliption of - $375-376$

Benrenue quarry, Crotch Island, Maine, product of -..-

Penzle quarry, Groton, Vt., description of _........ 116-118

Herry quarry, Quincy, Mass, operation of .

Berwick, Malne, quarries in_.._._. 329

lethel, rt., arverl grinitr from, plates showing ..... 160

contact phenomena at 84-85 granite of, grology of $155-156$ nature of 156-157 quarries of _..._.

lianchi quarry, West Franklin. Maine, desicription of _ 2al

Bibliography of economic geology of granite _........ $\$ 6.1-467$

Biddeford, Maine, quarries in_-_- 274-276

Bilack Ann Hill guarry, levere, Mass., produet of $\ldots 339-340$

Black Dlamond quarry, Addison, Maine, profluet of _..-

"Black granites," composition of _- 94-95 localities of origin of physieal properties of rocks known is _..._. texture o
Black Island quarries, Long Island. Maine, produets of - 221-222

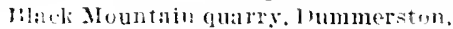
Vt., plate showing ... 160

products of _._._._._. $153-154$

Black quarry, Vinalhiven, Maine, featnres of _.......

Hlaisdell. T. M., quarry, East Franklin, Maine, deseription of _.

Blalsdell, W. R., quacry, Franklin, Maine, description of -

Blanchard quarries, Uxbridge, Mass. description of _____ $\mathbf{3 5 2 - 3 5 3}$

Blood I, dere quil]ry, Rorkport, Mass. description of _... $300-301$

Bluehill, Maine, quarries in_._._. 214-216

White quarry at, plate showing - 256 Bodwell-Joneshoro fuary, Jonesboro, Maine, description of

$267-269$

lodwell openings. Vinalharen, Maine.

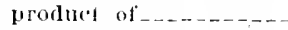

Bodwell quarry, Manchester, N. H., product of _._._._. 194-195

log lllll quarry, Searsport, Maíne, product of _.........

loise, Idaho, granite for State eapitol at

I’olton, Conn., granite of _._._- 399-400 Books treating of economic geology of grinuite___._._. $464-46 \%$

granite and its constituent minerals _........

Bwoth Bros. Jonesboro quarry, Jonesboro, Maille, product of - - -

Boston, Mass., granite for Atlantle Avenue Bridge at_---

granite for Bunker Hill Monument at city hall at__..._._. 200 Gen. Hooker monument at_ $\mathbf{3 7 9}$ navs yard at_....... 170, 275 State capitol at_._._._. 310 Sufrolk Connty courthouse at _..._....... 248, 271

loulwell quarry, Barre, Vt., description of _._._ 128-129

liradhury quarry, West Franklin, Maine, proluet of _-_-

Branford. Conn., granite gneiss from, plate showing

quarries in $\ldots . . .637-382$

Branford granite gneiss, deseription of

"Irranford Red" eranite. hammered and polished, plates showing _..._._.

Hinw quarry, Gullford, Maine, features of

Breakwater granites, table of _... 431 Bridgeport, Conn., granite of _..... 361 Bristol, Conn., quarries in ...... 365 Rristol, Maine, granite of _... 248-249 
Page.

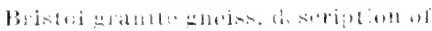

Brockton lleights yulry, Brockton, Mass, product of - 335-33ti

Brookticla diorite, deselilution of _. 35

Brookline. N. 11., 4ualeries of___ 191-19\%

Brooklyn, N. S., Ëratuile fur post of fice aud custuminuse at

granite for Irisun-ship mattyrs monnumbl at

Brooklyn qualel, liranford, Cotus., frectipliun of _... $380-381$

lirooks quarry, (ilistumbuly, Conn., findures of _-_ _ $36 \times-369$

Hrown quariy, Iballa:m, Maine, prodnet of $\ldots \ldots+218$

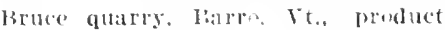

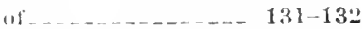

Brunswick, Matur, eranite of $\ldots \ldots 210-211$

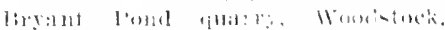

Miline, product of - $253-254$

Bucks llarbor guirries, Sulh Blocksville, Mfine, products of _..... 216-217

Buffalo, N. Y., granite for post office a116 customhouse at - 240, 268s

IBufiato IIill guarry, IIardwiek, It.. proluct of $\ldots \ldots \ldots \ldots 109-110$

Huilding. Nee Construction.

Bujlings and momuments constuctal ot tluc granitos_...

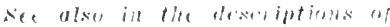
quarites.

Burke quarry, Kirby, Vt., proluct uf _........ 111-112

Burlison quarry, Bridgeport, Conn.. product of

361

Burgs, Robert, statu, plate showingButman Arenue quarly, Lavesville. Mass., frations of

299

C.

Cabot, Vt., granite of $143-144$

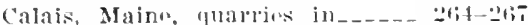

Calais, Vt., quarrios in_....... 144-145

Calcite, influence of, ill granite....

Calciun carbonato, tosting griuite for

Caller d Carnic quars, Westerly, R. I. Afereriptlon of - 411-412

Cabulen, N. J.. erranite ror county courthouse at at -

Campbell \& Macomber quarry, Mount Frosert Maino, probur

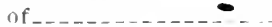

Catto quary, Westerly, R. I., rentures of

Canaan, N. II., granite of ____ 177-178 Canterlury eranito suniss, lescrip lion of ...................

Canton quarry, Parro, Vt.. fea tures of _..........

Canton, Ohio, granite for MeKinley

national memorial a 1 - $163,34 ?$

Cape Aun. SeP Rockpolt. Mass.

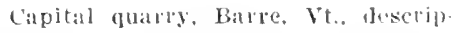
iion oi.

Puge.

falkin, (? W.. gualy, Westord, Iissi, fentules of

tarkin, 1"rley, guarry, Westoril, Miss., fostures of . \$10-311

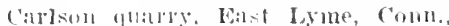
foidures of _..

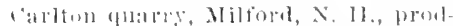
IICts of _ _..... $189-190$

(aron qualry. l'taboly", Miss., feat1110 of .

Carroll guarry, Milfurd, Mass., prod. uct of $\ldots \ldots \ldots \ldots-351$

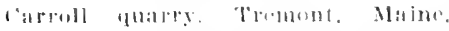

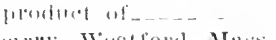

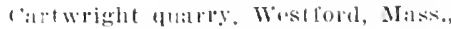
fitatures af $\ldots-\ldots+\ldots$

("alvings in granite, plates showing_..... 160, 256;. 400, 401

Cashman gualry, Quiney, Mass., product of $\ldots \ldots \ldots \ldots$

Cathedral of sit. John the Divine, Now York, columns for

columns for, plat, showing-_- 256

Chamblel, C. F., analy'sis by _.... 343

Chapman qual'y, Wresterly, IR. I. feitulise of ..... $\ldots$ 4J4-415

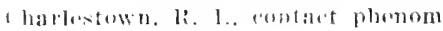
1'llil at .

graulte of _...

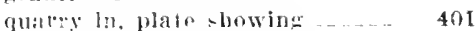
ser al*o Wisterly. L. I.

Chattiuooga, Tenn., granite for State numuments at $\ldots-\ldots 134,345$

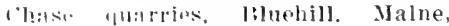
1) Chemical conposithon of granite _.. 7-9 See also Analysis of rranite.

Cheres Green Granite quarry, Rock port, Mass., prorluet of

Chicago, Ill., granjto for Alezander Iranilon momorial at

granite for Cook rounty, court-

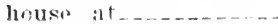

Cook County llospital at -

IJumboldt monument at . -

Mckinley Momorial at _.

Newberry Jihrary at ...-

Ropublic Monumint it _..

300

399

150

295

211

200

379

$\$ 7.9$

Christiano Hamilton Avenue quarry, Gerenwixh, cente. do. saription of

Christiano oilk Ridge duary, Gireoll wirll, romn. deserip. tiıा औf _..........

C'lark Island qualry. St. ritorge

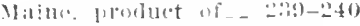

Ciark tjualriss, bummerstom, Vt., poullots of _. . . 151-155

("ascitication, ("onnmic, of wranites $13-14$ soientific, of grinites_. _ _ 13 
clevelaud, Ohio, granite for city hall granite for Cuyahoga county courthouse at_......

Coalford Swamp quarry, Rockport, Mass., feutures of

Coarse, use of term

Coarseness. Sce Texture.

Cohasset, Mass., granite of.

Cohesiveness of granite

collinsville zrallite gniss, lescrip tiun of

Colors of the granites._._._. $5,6,10$ influence of feletspars on_- $75-79,81$

table showing ..._._._. 420,433-435 S'ce also shade.

Columbus, Ohio, granite for public library at

Comstock prospect, Warren, Comu.. product oí_.......

Concord, N. HI., granite of, description of _.

granite of, geology of _._._ 195_196

quarrles in, descriptions of - 197-202 location of _......... 195

Connecticut, breakwater granites of +31

constructional grinites of

curbing and trimming granites of

distribution of grinlite and gneisses in _..._. $357-359$

geologic history of _._._._. $355-35 i$

geologic map of, showing location of granite quar. ries._._.

sranitic intrusions in, nilime and age of _._._. $359-361$

lnscriptional granites of _.... 428

monumental granites of $\ldots \ldots+425$

paving granite of _._._... $\$ 32$

production of granite in _.. 4 'j0-461

quarries in, dates of opening of 460

descriptions of

operated in 1921_._._. 460

sculptural granites of _...... 427

Consolidated qu: rry, Barre, Vt., deseription of

C'onstituents of granite_........

Sce also Analysis of granite.

Construction, fluctuation in the use of grinite for..._. $438-439$

Constructional granites, table of _- 421-424

Contacts with invaded rocks, petrographic phenomena at $84-89$

plates showing

structural phenomena at ..... $89-93$

whele eximined_........... 84

Conway, N. Il., granite for public library at

quarries of, descriptions of -- 166-170 genlogy of . locations of__________ 164-165

Cooling, rapid, of granitic magma_- 3-4 coons. Miss Altha T.. The production of granitw in the Now England Statrs__- 2, 4:6-463
Corbin quarry, Glastonbury, Conn., product of _._._. $366-367$

Cornwall, Conn., granite of _._. 369-370

Costello quarry, Torrington, Coun..

product of _.____ 373-374

Conture quary, Westford, Mass., features of _._._._ 312-313

Crabtree \& Elavey quarry. Sullivan. Maine, description of 230

plates showing__._._._._... 256

Crawfordsvillo, Ind., granite for Grin. Lew Wallace obelisk at_............

Crissey quarry, Norfolk, Conn., produet of _...

Cross, C. W., cited _._. 23

Cross, Whitman, cited____._. 138

Croteh Island, Maine, description of $\mathbf{3 1}$ granite bels on, plates showing $\mathbf{2 5 6}$

Crumb quary. Wosterly, li. r, produet of _._._._. $417-418$

Crushed granite, changes in demand for

Cuba, glanite for monmment to General Gomez in_..... 164

Curbing and trimming granite, table of _._.

Curry quarry, Wrentham, Mass., product of

Cutting quarry, Milford, Mass., deseription of _._._. $344-345$

D.

Danbury, Coun., granite of _......Danbury granodiorite gneiss, deseription of

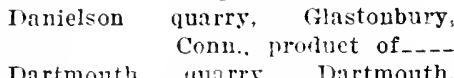

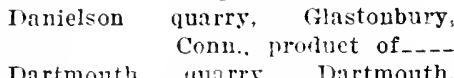

Dartmouth tuarry. Dartmouth. Mass., product of _- 286-28T

Dawson quarry. Stark. N. H., produet of

Day, William C., analysis by_-_-- 139

Day quarry, Kennebunkport, Maine, product of_........ 276-277

Dayton, Ohio, zranite for post office

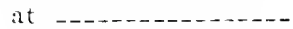

200

Deadwood, S. Dak., granite for post offirp at__._..........

Decatur. Ill., granite for post office at $\ldots \ldots \ldots$...............

Decomposition of glanite, causes

- and rate of._._._- 6, 70-72

Dedham, Maine, granite of _._._ 217-218

Deep Pit quarry, Rockport, Mass., description oî_-__- 301-302

reep River, Conn., granite for foun-

tain : it

Definition of granite........-

Definitions of geologic and quarrying terms -

Den quarry, Lynn and Peabody, Mass., description of_ 288-299

Dennis, L. M., analysis by_....280

Derby, Conn., granite gneiss from, plate showing 
Paze

Derby, Vt., granite of _._. licvils Rork quarry, Lanesville, Miass, description of _-__-_ $299-300$

viabase porphyry, monument of, plate showing --_----

Dtkes, uplite, occurreuce and features of

basice influence of, on grinite $-5 \bar{i}-5$, occurrence and features of - 51-56 basic schistose, occurrence and features of cutting granite gneiss, plate showing-_-_--_-_---

cutting sheets of granite, plates showing_-_-_-_-_-- 256,321

cylinärical_....._._.

fluldal cavities in_._._._... 22

granite, occurrence and features of _._._._._._._._. 41-42 pegmatite, groups of _._._.- 73-74 occurrence and features of _ 46-50 pegmatitic quartz, occurrence and features of _-_._- 50-51 Diorite, quartz, dikes in, plate show-

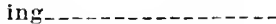

Discoloration, test of granite for Dix Island quarries, Muscle Ridge Plantation, Maine, de. scription of

bixon quarry, Westerly, R., I., product of -........

Nodlin quarry, Norridgewock, Maine, description of

Domes, cause of

Double-shcet structure, plate showing

Irover, N. H., granite for hospital at Lrenan quarries, Woodbury, Vt., product of ...........

loffee quarry, Barre, Vt., product of

Iummerston, Vt., quarrit's of _-_ 153-155

Dunbar quarry, Sullivan, Maine, features of

Uumn quarrs, Eristol. Conn.. produet of .................

Duscbane fill quarry, Vinalhaven, Maine, product of

F.

Eagle Gray quarry, Fryeburg, Malne. description of _._._. 252-253

Wast Iyme, conn., quarries in _- $388-389$

East Orange, N. J., granite for high school at ...........

East quarry, Milford, Mass.. discription of _._.

Eastford granite gneiss, description of _.....................

Weho Iake quarry, Milford, Mass., featules of .........

Eckerlein quarry, Groton, Conn., product of _._._. $386-3.37$

Economic classification of the grani:ps
Ligypt, woatlering of anclent granite monuments in .... 72

Elustiuty of granite_._. 11

Elkhart, Ind., granite for post oflice at _... 301

Ellis quarry, Betbel, Vt., description of

Emerson, B. K., cited_..__._. 340-341

Emerson quarry, Fitzwilliam, N. H., features of

Emmons, Gowen, quarry, Biddeford, Majne, description of _..-

Empire dark quarry. Barre, vt., description of

Empire Light (iranite quarry, Barry, Vt., description of _..- 140

Expansibility of granite._. 12 test for

\section{F.}

Falconer quarry, Quincy, Mass., features of

Fall River, Mass., granite for custombouse and post office at__._.

quarries in

Fillon quarry, Quincy, Mass, features of _._. 324

Faults, occurrence of

Feldspar, colors of, original and secondary _..._._. $75-79$

klnds of, in granite____.

Felsite, test of, in concrete... 340

Folsite porphyry. nature and use of. 339

Fessinden quars. Brookline, N. II., product of ._..... 192-193

Ficld \& Wild quarry, quincy, Mass., description of _._._. 326

Fine, use of term $\ldots \ldots \ldots 2,9$

Fire tests of granite_............ 13, 102

Fish quarry, Jonesboro, Maine, product of _._._. 267

Fitchburg, Mass., quarries in___- 353-355

Fitzwilliam district, N. H., geologic relations of _........ 171

quarries of Flat Ledge quarry, Rockport, Mass., product of _...... 294 29.5

Fletcher, II. E., quarry, Westford, Mass., products of _- $309-310$

Fletcher, II. N., quarrles, Westford, Mass., product of - _ 311-312

Flitrher quarry, Madison, N. H.. product of _._._... 170-171

Fletcher quarry, Woodbury, Vt., deseription of _..... $148-149$

plate showing............ 160 Flexibllity of granite Fluirls, occurrence of, in granite gnelss _.

necurlence of, in small dikes or velns

relation of, to rift and grain- 17-21 secondary Inclusions of _.... 22-24 
Page.

Flynt quarries, Monson, Mass., pro ducts of _....... 304-305

Folly Point Breakwater quarry, Rockport, Mass., features of

Fort sumter, S. C., granite for Gen. Anderson monument at

Fox Islands. Maine, quarries on-- 241-248

Fox quarry, Concord, $\mathrm{N}$. H., description of _..._._. 200-201

Fractures, contemporary, occurrence of -

Frankfort, Ky., granite for State capitol at..........

150

Frankfort, Maine, granite beds at, plate showing _._._. $\quad 256$

quarries in

Franklin, Maine, quarries in_-__ 218-221

Franklin, Mass, gravite for Thayer library at_........

Frazer quarry, liyegate, Vt., description of _..._._. 115-116

Frupport quarry, Freeport, Maine, description of .......

plate showing

Fryeburg, Maine, granite of _-- 252-253

\section{G.}

Galveston, Tex.. granite for Early Settless' monuwent at.

Galvin quarry, Quincy, Mass., features of _........

Gardner's prospect. Calais, Maine. products of _.....-

Gases in minerals of granite..... Geodes, occurrence and features of Geology, application of, to quarrying granite _..... $435-436$

Gettysburg, 1'a., uranite for monunuents at $-235,236,410,411$

Gibson quarry, Ryerate, Vt., product of _........... 11:-115

Gilbert, G. K., on sheet structure-- 29-30 Glastonbury grinite gneiss, description of _...........

Glastonbury Granite Works quarries. Glastonbury, Conn. product of _.........

Glastonbury, Coun.
product of

(ilossiry of scientific and quarry terms _........ $467-471$

Gneiss, classes of _.............

See also Granite gneiss.

Godbeer quarry. Fitchlorg. Mass., features of

Gold, occurrence of, in Maine granite _....... 263-264

Gold-leap quarry, Quincy, Mass., product of _..._._. 332-333

forman quarry, Glastonbury. Conn.. product of _..... $36 \bar{T}-36 \mathrm{~s}$

Goss quarry, Crotcil Island, Maime. description of - - - 226-2.27

fraln, relation of, to fluidal carities $17-21$
Grauite, orbicular, plate showing--

rocks classed as..........

Granite gneiss, contact of granite with, plates showing 161,400

fluidal carities in _._._._._. 21-22

in connecticut, distribution and

rarieties of _._._- 357-359

obelisk of, plate showing _._._ 400

plates showing._._._._._. 400

plicated testure in

polished slab of, plate showing- 400

Granite Railway quarry, Concord, N. II. See Upper Swenson quarry.

Granite Railway quarry, Quincy, Mass., description of - 329-330

Grant quarry, Brunswick, Maine, description of _..._._. 210-211

Graves liros. quarry, Mount Desert, Maine, product of ...-

Green Island, Maine, joint structure on, plate showing _._. 256

Greenwich, Conn., quarries in_._. 362-364 Gregory, H. E. cited________- 46-47 froluric relations of the granites of Connecticut _._._ 355-361

Groton, Conn., monument of granite from, plate showing -- $\quad \mathbf{4 0 0}$

quarries in . Groton, Mass., quarries in _._._. 308-309 Groton, Vt., granite of _..._-_ 116-118 Grout quarry, Kirby, Vt., description of _............ 110-111 Guilford, Conn., quarries in _... 382-384 Guilford, Maine, quarries in ..... 255

\section{H.}

IIaddam granite gneiss, description of _......-

Ilall quarry, Baileyvilie, Maine, prod. uet of _._._._._. 263-264

IIall ullary. Mubut itstrt, Maine. sec McMullen quarry.

IIall quarry, Norwalk, Conn., product of _._.

Hallowell, Maine, carred granite from, plates showling.-

Innafellow quarry at, plate showing _.......... 256

quarries at _._.

Stinchfield quarry at, plate showing_._._._.....

llamilton Seam Face quarry, Hingham, Mass., features of 339

"liard way," direction of IIariness of gianite _........... 12

test for

Hardwood Island quarry. Jonesport, Iaine, product of $--270-271$ Iardwick, Vt., granite of _-_ 108-110 Ilardwick quarry, Quincy, Mass., description of _._. $324-325$

Iarris quarry, Acton, Mass., product of 307 
Page.

Herrtsburg, Pa., granlte for post office at

granite for State capitol at liartford, Conn., granito for ('onnecticut liver bridge it _._.

granite for State library and city hall at_.......

Is rtiand quarry, Hartland, Maine, granite of .......

Haverhill, Mass., granite for bridges at

granite for Dudley Porter fountain at .............

Haverhlll, N. H., quarrles in

Headings, intersection of, plate showing -...--

cicurrence of

-hrets cut hy, plites showing-

Heal quarry, Lincoln, Maine, product of ...........

Heat tests. See Fire tests.

llell Gate Bridge, New York, granite for

Iienneterry quarry, Concord, N. H., product of

11. ran llitl quarry. IIermon, Maine. product of

159

255

184

171

$\mathbf{2 5} 6$

38

$\because 56$

260

245

202

254

Herrmann, O., on sheet structure_- $28-29$

IIth Isle quarry, Muscle Ridge Plantation, Maine, description of

$236-238$

plate showing

Hildith quarry, Westford, Mass., fentures of

IIIletirant, W. $l_{\text {., analyses by }}$ 162 $16 \because, 304$

Hinghan, Mass., quarries in $--336-339$
History of the granite industry_- $436-441$

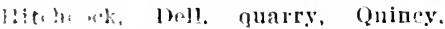

Mass., description of _321-322

Ifouddly Neck quarries, Branford. Conn., description of_381-382

Hoibrork quarry, Seymour, Conn.. description of __._. $384-385$

Inllis, Maine, granite of 276 Honllis quarry, Concord, N. II. Sep Lower Swenson quarry.

Hoksett, N. II, granite of ...... Hownr. llavey \& Co.. quarry of, North Sullivan, Maine

Hewac Tunnel, Mass., granite for.Ilonkintun quarry, Iopkinton, Mass., product of .........

Hurlson \& Chester quarry, liecket,

Mass, proluct of _- $279-281$

llurriate Island quarry, Vinal haven, Mainc, plate showing _.......... 256

product and structure of _... . $247-248$

I.

Ineferial Blue quarry, Woodbury, $\mathrm{Vt}$., product of
Inclusions, oceurrence and features of _.

India, artificial sheeting of granite in

Indian Creek quarry, Vinallaven, Maine, features of ...-

Iuscriptional granites, table of ....

Jutrusiun. lacelition of overlying strata by

Italian quarry, Ryegate, Vt., descoip. tion of ...................

Ithaca, N. Y., granite for post office at__................

J.

Jamestown, Va., granite for nonument at............

Jefferson City, Mo., granite for State capitol at -

Jowett's quarry, Whitefield, Maine. product of _..._. 251-252

Jolnts, coatings on faces of _... $81-84$ groups and causes of ....... $37-38$ sce also Jleadings and Subjoints.

Jones Dark quarry, Williamstown, Vt., description of ...-

Jones Iight quarry, Barre, Vt., features and product of _ 133-135

Jonesboro, Maine, quaries in _. _ 247--26! Jonesport, Maine, quaries in _._ 270-271 Joshua Rock quarry, Iyme, Conn., product of ........ 389-390)

K.

Kansas City, Mo., granite for city baths at_....... 271

Kemp, James F., analysis by _-__ 236-237 Kennard Ledge quarry, Manchester, N. II., product of _..--

Kennebunkport, Maine, quarries in _........... $276-277$

Kilkenny quarry, Kilkenny, N. II., produet of _...... 176-177

Kinnicutt, reonard $r$., absorption tests by $\ldots \ldots 157,172,17 \%$

analyses by _.......... 175, 344, 378

Klrby, Vt., granite of _....... 110-112

Kittredge quarry, Milford, $\therefore$. 11 , product of _........ 154

Klondlke quarr., Charlestown, R. I., description of $\ldots \ldots \ldots$ 415-41;

"Knots." See Segregations.

Kopp quarry, Groton, Conn., features of

\section{L.}

Lacasse quarry. Derly, Vt., prod lict of _... 119-120

Iake Sllore quary, Calais, Vt., product of _._...... 145

lambert's prospect, cabot, vt., product of -

Langmail quarry, Rochester, N. II., product of ...... 202-20s 
Larrabee quarr, Windhan, Cons.. product oi _...... 402-403

Latty quarry, Green lsland, Minine. product of _........

228

I.awton quary, Norridewock, Maine. description of _._._- 256-257

Luifue 1sland, Philadelphia, I'a., granite for diy dock it

Leavitt quarry, Leominster, Mass.,

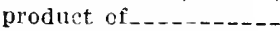

Lbanon quarry, Lbanon, N. II., product of _._._. 178-179

Lete Island quarry, Guilford, Coun., product of _... _. $382-383$

protuct of, plate showing___._ 400

Leominster, Mass., granite of -_-_ 353

Lepage quarry, Quines, Mass., prodllet of

Liberty Hill quarry, Rochester, Vt., product of _.

lime carbouate, testing granite for

Lincoln, Maine, calved quanite from, plate showing

Lincoln, Nebr., grauite for post office at__._._._.

Lincolnville quarry, Lincolu, Maine,

Linehan quarry, I'eabody, Mass, product of

Litchfield, Comn., granite at_._._-370

Litchfield quarry, Fitchburg, Mass., features of _-_._-_ :351-:35.

lithonia, Ga., effect of cumpressive strain at, plate showing -

Long Cove quarly, st. George, Haine, description of $240-241$

Long Island, Maine, quilries in-- 221-222

Longfollow quarry, Hallowell, Maine, features of ..............

plat: shuwing-_._...-._-...--

234

256

lorif quarry, Wells, Maine, prodlict of

Louisville, Ky., granite for Jefferson monument at.......

Love, F. W., analyses by-_..-

I, vejoy quarly, Milford, N. H., description of

Lewell, Mass, gravile for city hall at -......

Lowrer sirenson fratry. Concerce,

N. li., description of Lyme, Conn., quarites in_._... 389-390 Lyun, Mass., felsite porpinyry of_-_ $\mathbf{3} 40$

$$
\text { II. }
$$

Mecartby guarry, Acton, Mass., product of:-_._._. $307-308$

MeCauliff quarry, Fitchburg, Mass, product of́_.......

McCouchie quarry, st. George, Maine, product of----

MacCurdy quarry, Old Lyme, Conn., product of _._._. 390-392

MeDonald \& Cutter quarry, Barre, Vt., desiription of .....
MeGaughey quarry, Groton, Conn., proiluet of _._._- 3St-3Ss

McIntosh quarry, Groton, Conn., product of ........ 386

McKenua, Charles I., analysis by-- 157 MeMullen cuars, Mount Desert. Iaine. description of $222-223$

Madison, N. II., srunite of _-_ 170-171

Madison, Wis., granite for State capitol at_.--..-

Magnetite, large content of, in wranite of Bail'yille. Iaine

Miaguire luarrs, Hopkinton, Mass., features of _._._- 349-350

Masuire \& O'Ilowon quary, Milton, Mass., product of _- $334-335$

Maine, constructional granites of $421-423$

curbing and trimming granites of -...... 430

granite in, distribution of _- 103,205 geologic history and relations of _._._._._. 207-209

iuscriptional granites of _-_-- 428 map of southern part of, showing distribution of granitic rocks and clialrivis_............

monumental granites of _-_..- 425 paving rranites of polish granites of _-__-_._.- 429 production of granite in _._. $443-447$ quarries in, dates of opening of $\mathbf{4 4 4}$ descriptions of _._._._- 205-278 distribution of _..-_.- $209-210$ uperated in $19: 1 \ldots \ldots+45$

matrils of "blitck rranite" in, distribution of

sculptural granite of slocet structure in granites of - 31-32 Maine \& New Hampshice Granite Cornoration, quarries of, at North Jay, Maine _..._... 212-214

Maine lit d finite Co., quarry of, at Calais, Maine_-- 266-267

Maluati quarry, East Lyme, Conn., product of _...-_- 388-389

Mamacole gnciss, description of _.. $\quad 359$

Manchester, $\Sigma$. H., quarries of _- 194-195

Miln, rowosic, of Connecticut showing location of granite quarlies_........--

360

Malp of Barre, Vt., showing location of "aranite qaarries _........

Masmathusette. Nhwing location of incinite quarries_-_

Quiney, Mass., showing location of granite quarries._.

southern part of Mine, showing distribution of franitic rocks and guarries_._......... 
Iage.

Map of Vermons and New llominen showille locatier if

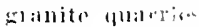

Maromas granite gncise. deseril tion of .............

Marquette, Nich., granite tw retil holse at .

Marr \& tiordon quarry, laarfe it?

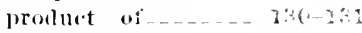

Mariott quarry, Ster]ing. (sil, f y.re

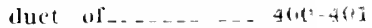

Marshtield quariy, Marshtiold Xiaint nroluet of _...... $271-272$

Maseetti fuarry, Litelitida. Coun product of

Malscoma qualry, rillatit. $>11$. prolluct of

Masoms Island quarry. Steringerte. Coun., frature et

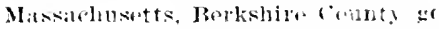
ology of the framts in

brokwater granito of ..... $4: i 1$

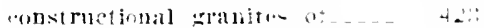
curbing and trinmin: Elature of

Essex County. mature wionta in ............

mip of, skowing locatiul o: granite quario.... 278

monumental granites of _... 4 ic 6 -42fi paving granite of ........ 482 jolish graniles of .......... 420 production of granit, ir . . $45.4-45 \%$ quarries in, dites of enwhing of

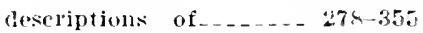
distribution of ........ I03. $27 \mathrm{~s}$ nperated in $1921 \ldots \ldots \ldots+45(i-457$

rusty-faced granites of _..... 429 Massalunsetts Pluk quarly, Milfoje Mass., prodnc: of -.. Medinm, use of term

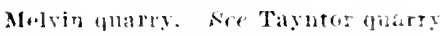
Merrill, G. I'., eited_.._......... Merrill quarry, Westford, Mass, fest. tures of ..........

MT.ry Mrount quarry. Quincy. Mass. description of . . _- $32 z_{2}-223$

Messer guarry, Stoughton. Mass product of .........

Mica, black (biotjte), influerice of as a constiturist of qranite............

white (muscovite), influpree of as a constitueut of granite..............

Michiel quarry, Torrington, Cont product of _....... 47

Middletown, crenn., granite of _ stimate Milforl, N. II., contact plencoutua at _..............
Milforl dietrict. Mass., granite of soroluey of $840342,: 243-344$

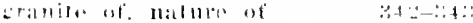
qualries in _. topergrably of $\ldots \ldots t o$

Milfort district, $X$. 11., granill w. de:sription of $\quad 1<2-18.3$

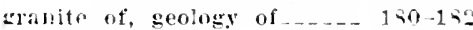
gluarries ot _........... 1-3-191 ropography of _........... 150

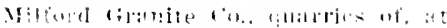

Milforl, N. $11 \ldots \ldots$ js?

fuilry of. piate showing _._. 151

Milluridge guarry, Mlillbridse, Main". product of ....... 27:

Millor seaun-face quarry. IIingham. Mass., product of $-3: 33-3.39$

Millsture quarry. Barre, Vt.. prod. uet of _............

Millstone quarry, Waterford, Conn. description of _... $391-3:+$

Milue \& Wyli, quarry, Barere, lt. prosluet of ........ 12!t-3 34

Milne quary, Barre, Vit., deserip,

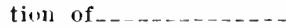

Miswalier. Wis. granite for post oflice at $\ldots \ldots$........

Mineral composition of granite...

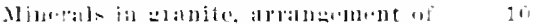
coatings of, on juint faces_._-8i-8t forms of .... kimel and proportions of, test for $\ldots \ldots \ldots+20 \mathrm{~m}$

Minerva Cove quarry, Jonesport. Maine, profuct of -

Ifingo-Bailey quarries, Calais. Maine, fratures of _.. 26, 265,253

Miniuti quarry, Berwick, Maine, product of _.........

Mirulafulis. Minu., granite for Mu. seum of Fine Arts at 151

\$4 Mencon. Mass.. quarries in

2 Monson granite gneiss, description of

Momment of quartz diorite, plate showing _._._._._.

with die of olivine norite, plate showing

Morumental granite, changes in do. mand for

table of

Morizonite, white quartz, plate showing carving in

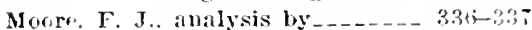
Mone Ielard quarry, Maine, features of

Morrisun qualty. livente. Vt., d, scription of

Menquito Mountaln, Frankfort, Maine, description of .

Mosquito Momntain quarcy, Frank fort. Maime, descriptinn

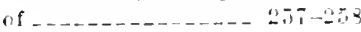




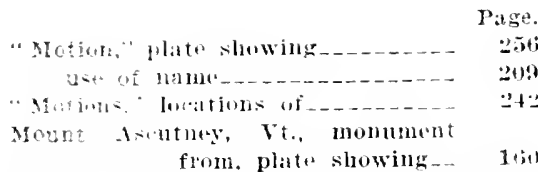

Page.

256

$20 !$

$\because 2$

Moniti Lo-fert, Maine, quarries on_ 222-224

Iount Pleisiant quilry, Milton.

Masis. product of _-_ $3333-334$

Mrint Waldo quary, Frankfort,

llaine rleneription of .. 31. $25+-260$

Mawee fuarry, Wimlsor, Vt.. description of ........

Mersy quatry. Stonington, ('omu, firoduct of

Musele liblus Plantation, Maine. quarries in _...... 236-238

Muscovite, veins of

Muskcon, Mith., sranite for post offiet at

\section{N.}

Nosbua. X. H.. granite for post ofice at $\ldots \ldots+\ldots$

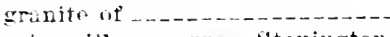

Now Anguilla quarry, Stonington, Conn.. description of $392-393$

Yw Pedfurd, Mass, dikes in Sulli-

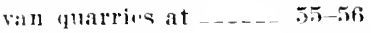

Eaniti for industrial monnment at ........ 173

quarries in _._.

Niw England Granite Works quarry, concold, N. II., protuet of

Nen England quarry, Westerly, R. I., products of _._._. $408-410$

Now Ilampsbire, const ructional gran. ite of _......... $423-424$

surling and trimming granites of _.........

inscriptional granites of .....monumental granites of ...... polish granites of

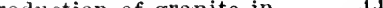
purries in descriptions of $16+205$ distribution of _._._._. 1113,164 map showing locatlon of __- 108 operated in $1921 \ldots \ldots+49-449$ sculptural granite of (1)

N

Nic

New York, aranite for American Mu-

Page.

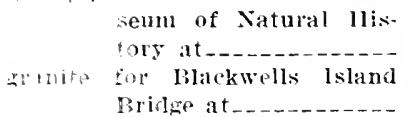

toridge in Bronx Park at.-

Eronklyn Bridge at

Solumbia Lniversity at_-- 164.

"ustomhouse at _._._._. $\mathbf{2 4}$

Fort Schuyler at

firateral frant's tomb at _.. 214

discolomation of _....

I.an of IRecorrls at _._._. 235

Hell Gate Bridge at .... 245

Manhittan Fridge at_-__ 173, $2: 23,2: 30,295$

manivipal building at _... 260

new post office at

perdistal of Statue of Libe.ty at

phasians' quarters, Blackwills lsiand, at____- 363

Fublie Library at__._._. 176

retaining wall of liverside I)rive at

soldiers and sailors' monument at 382

Stock Exchange at

Wonmats IIospital at____ 215

Hall of Records at, plate showing statue on_...... 256

poroliyry for fountain in Cential Park at_.....-

Newall quary. this, Mass., description of ...

Newall ynare, Westerly, R. I., prodnet of ....

Newark, N. I., zrimite for city hall at $\ldots \ldots+172$

Newark, Vt., granite of _.__ $112-113$

Newport, R. I., granite for briclue at $\quad 283$

granite for Naval War College

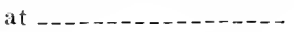

Niagara Fulls, N. Y., granite for Suspension Bridge at

Niantic quarries. See Westerly, K. I., and Charlestown, R. I.

Nichols Ledge Carter quarry, Woodbury, Vt.. product of $-152-153$

Nickerson quarries, Rockport, Mass., features of -_-__- 299-299

$41:$

338 manite for Sale University at

Now Orleans, La.. granite for customhouse at ......-

granite for post office at__-_._-

Nin Westerly quarry, Milford, N. 11. product of _-_-_-_ 188-189

Nit York. liank of Commerce in. plate slowing panel at intrince of

anstumbonse at, plate showing lintel for
327

310
Noreross quarry, Branford, Conn., description of ____ 377-379

Noreross quarly. Milford, Mass., features of

Noreross quarry, Windsor, Vt., deseription of

Norfolk, Conn., granite of _._- 370-371

Norfolk, Va., granite for dry dock at $\quad 230$

Norridgewock, Malne, quarries in - 255-257

North Jay, Maine, granite of ___ 212-214

North Milford quarry, Milford, Mass., product of -...- 
Northern Ganite Co., quarying by

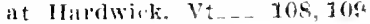
Norwalle, conn., granite of _... $264-305$

\section{o.}

Oak llill quarry. Swanvilit. Nataz proluet of _...... 261

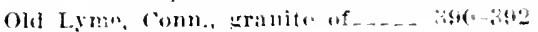

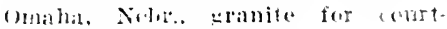

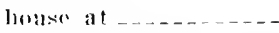
149

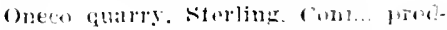
uet of . . . . . . .

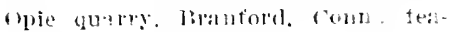
tures of ...........

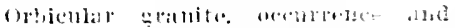
features of . . . . tik ti

Orisin of wrante.......

orourke suarry. Brooklibe $x$ il product of ...... $181-3: 19$

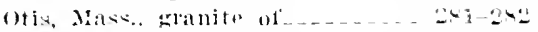

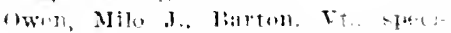

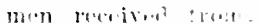

Txast, Juln, (itmit.

(iti

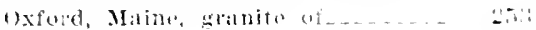

\section{IP.}

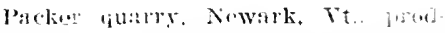
urt of . . . . . $11: 118$

I'alm"r guturies. Westemml, Mars periluct of

Lalmer quarry, Vinalhaver. Maste, deseription of .... 24-24-4i

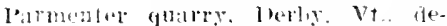
scription of _. $1: 0-1 \pm 1$

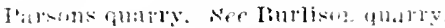

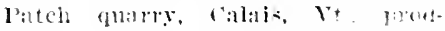
ulet of

Paterson, X. I., gianite for Tral. forth Liliraly it _...

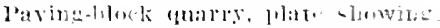
203

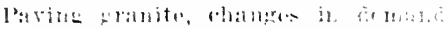
for

introfluetion of

tillile of

Pequoit quarry, Vimalhavi. Misiso product of ...... $45-246$

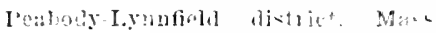
Hiture of grasith ah- 26

4

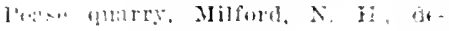
scription of _..... $184-185$

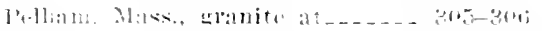

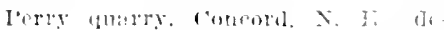
sepiption of _...

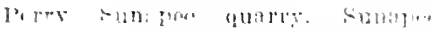
న. II. products of $28-205$

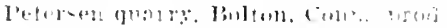

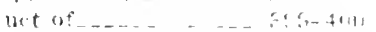

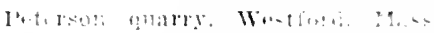
foitlolies of

lettee quarry. East Sullivat, M.

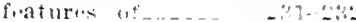

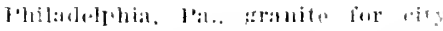
lisill at

Pisge.

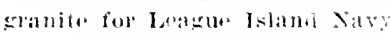
Yard at

soldiers and sillers wato way, in lin limowily I':irk at ...

Cuited States Mint at _. 2.2.? 2tin

Pismon cove porpliyry anarry, Rock port, Mass.. product of _.

$30:$

Pigeon llill quarries. lower ame up ler, Rockport, Mis:.. deseriptions of ... 234-2!n

Pirio gualry. Williamstown. Vt. description of ... 1+1-14:

Pitsilurelt, Pa., granite for Carmerio Institute :11_... 17 $33: 3$

wante for eity amd county buildiner at ....... 3!n

Scote momursent in_._.

Platimu, oceurmone of, in $11: 1 \mathrm{~m}$, Eratite $\ldots$.

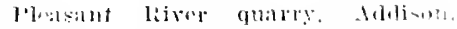
Inine, product of

l'leasant liver guarly. Vinalhatera Naine. Ser l:1 a el:

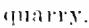

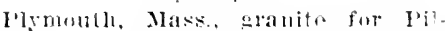

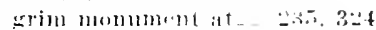

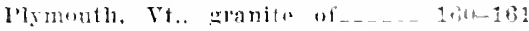
l'lemouth quarry, Thomastoly, athe

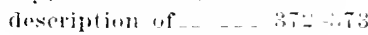

Foint Judith, R. I., granit for horti water at .......... $3 a-1$

Folinh, test of glanite for $\ldots \ldots \ldots$ I (M)

Polinh granites, table of

Fond Ledgu quarrios, Haverhill, $x$

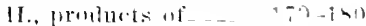

I'orenity of glanitu. _ _...

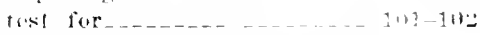

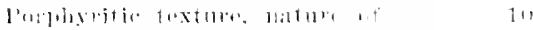

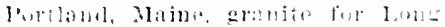

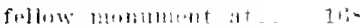

I'ortsmumih, N. 11.. sranite for wats?

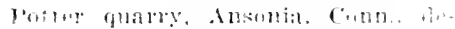
seription of $35-307$

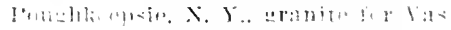
sal rollos at

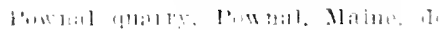

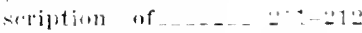

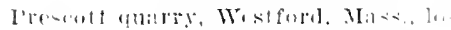
(at $\mathrm{i}+1 \mathrm{l}$ af .......

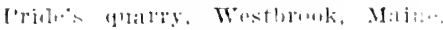

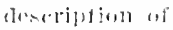

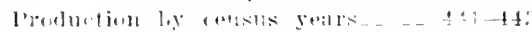

lor stiats $1+13-11 ; 3$

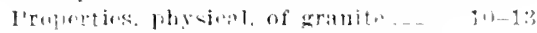

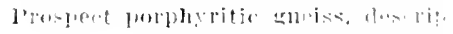
tion of

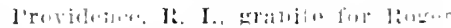

Whitams mommont an $\$ 11$

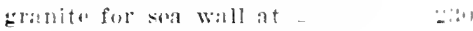
citate armory at 
Frublications on economic geolugy of

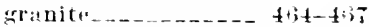

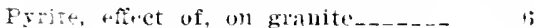
Fyroxene oceurence ot, in granite.

\section{Q.}

turether history of $43 i-4+1$ usi- ri geolusy in i:35- $1: 34$ 4cartz in sranite, colors of _.... int:uence of

trature of

\$)

Guastz momzonite, monmments of, plates showing _... 4114), flld

wroklal block of, plate showing

Qun City guary. Ginilford, Miants. product of ........

Gusics. Mass., beginnings of quarying at ......

folished granite from, plate showing _..........

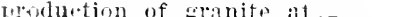

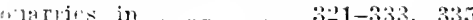

map showing location of _ $: 30$

quarly at, plate showins_-_ $3: 0$

Quidy grisite. geology of - $316,319-321$ lature and composition of _ $316-313$

F lisher bill of, plate showiner-

fil? granite area, topography of -....

\section{R.}

Enfory qualy, filoton, Miss., 1.rofuet of ..........

Eistruds eranite

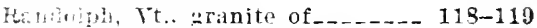

Far Sinch firate Co., quarry of, Calais, Maine_._.-- 26 $\vec{i}$

F. 1-1, ye, Y. Il., fluidal carities in granite of _._-_- $1 \bar{\tau}-19,19$ Etrdote green quary, conway, X. H., product of _- 163-169 Eubitre pink quarry, Conway, ‥ IT. product of $-140 ;-165$ fanter. rianly. Westerly, R. I., pioduct of _...... $412-413$

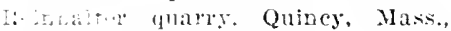
description of _.. : :2:-9-3:3

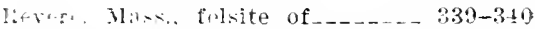

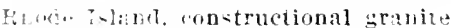

$$
\text { of }
$$

is -ripitional dranite of́-....$4 \div 3$ risumintial wranites of _... tye I.roclution of arimite in $\ldots+462-463$ quartios in, doseriptions of $-10 \%-413$ li-tribution of _..... 10:3, 103

sulptural manites of _..... 4 -

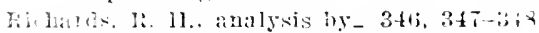

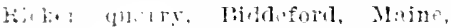

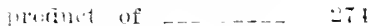

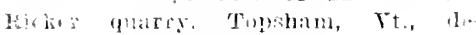
stription of _.......

If: kitte \& Manks, analyses by $247,250,240,394$
But in franits, definition of -

crevions observations on

Exiltion of, to filuilal cavities - 17-21

Rift iteriotile, nature and production of - 1 -

Ixif litlery. 'ireenwich, Conn., description of -_._. $363-364$

Keblita Harry, Franklin, Maine, destription of .... 218-219

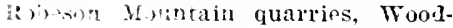
bury, Vt., description ind product of $36,142-151$ Iivis in quarry, Lyunfield, Mass., products of _- $289-291$ Roblumer. Eronklin C., analyses isy _- _ _ $166-167,168-169$

Rochestse, Y H, rranite of _...- 202-203 Rochesfer, rt., granite of _.____ 159-160 Rokport, Masi, tikes in quarries

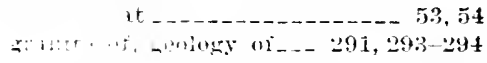

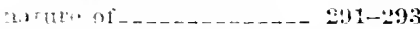

monnent trom, plate showing $\quad 320$

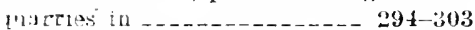

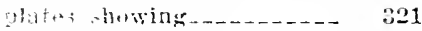

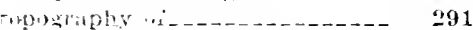

R.leport ritanite Co., Upper pit of 295

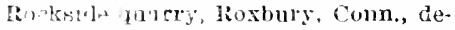
serigtion of -

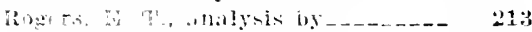

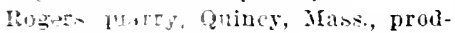
set of _......... 333

Rosq J'itry. Ryegate, Vt., product of

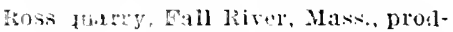
ict if 1 .

Ross quary, Kennetunkpart, Maine, iescription of ........

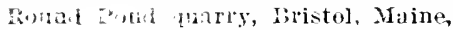
aried sranite from, blate showing ....... 256

lexcription of .

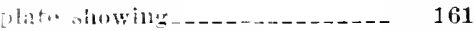

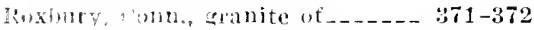

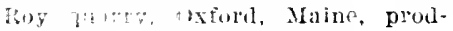
let ot-....... 253

Rigur thlia, ve stain, rusty.

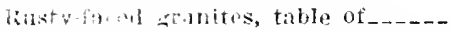

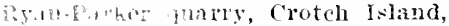

Jiant, deseription of $22 \div-226$

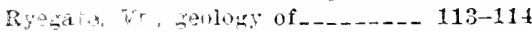
rinuite if _............ $114-116$

\section{$\therefore$}

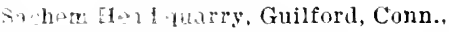
eroluct of

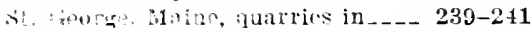

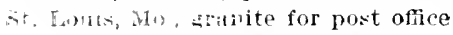
unil ilstomhouse at _._ $\quad 248$

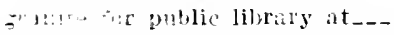
260

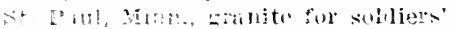
uremorial at .......

sialte fluty, froton, Conn., prod11.t if 
Sands quarry, Yinalliaven, Maine, description of _- - 2 243-244

plate showing-.._-

"Sap" granita. usw of _._. saratoga, N. Y., granite for mowu. ment at _........

Sartorl quarry, Quiney, Mass., produet of ............

sault Ste. Marie, Mi.h., granite for obelisk at _..........

saro quarry, Quincy, Mass., product of _- $\ldots+\ldots 31-332$

Savoie quarry, Fall River, Mass, features of _._._._. 294 29.5

Schlst, contact of granite with, plate showing _._..........

included in granite, plate showing

injector with sranite, plate slowing

Scope of the riport portand

scott quarry, Waterford, Conn., product of .........

Sculptural granites, table of

Seam-faced granite, quarries producing _...

use of 338

Sears quarry, Fall River, Mass., features of -

Searsport, Maine, granite of -_-_-Segregations, acidic, cccurrence and features of

basic, occurrence and features of -

Sulden Neck quarries, Lyme, Conn., produet of

settlement quarry, Deer Isle, Maine, description of -...- 229-230

Seymour, Conn., granite of _-_-_ 381-385

seymour street quarry, Bristol, conn., features of _.-_

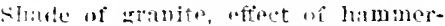
ing on

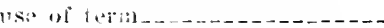

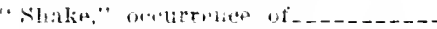

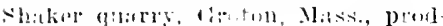
$11 \div 1$ 1,i - _...

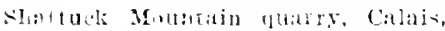

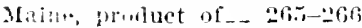

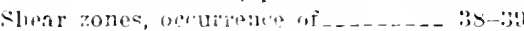

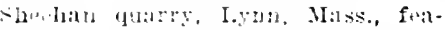

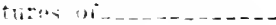

Sitcls, thin, formal by rompressive sliti:i, plate showin:

Sincman \& Yalwalls, analysis of gramitis by

199

Sherwol quarrits, rootell Island. Maine. Ineription of $2 \pm 7-2: 29$

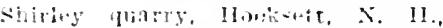

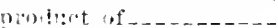

sincluer bupupt, Wast sullivan, Milinn. prouluet of $\mathrm{f}_{-\ldots}$ s!ater quariy, tantombury, conn.,

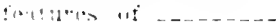

Smith, fiestere Otis, The occurrence of “ranite in Maine - 205-200

Smitl lawer quirry, Birre, Vt., description of .........

Sinth North quäry, Westerly, R. I. feitures of f

Smith quary, Westerly, le. I., des.ription of _..... 410-411

smitl leprer quary, Is:arr. Vt. product of _._._._- 135-1365

Snow Flake guarry, Fitzwilliam, N. H., product of _... 173 Snowflake quarry, Mount lesert, Naine, probuet of -2 223-224 Somers prosprect. Waterford, comn., fritures of ....... 397

Sullogan quarry, Milford, N. H., profluct of _._._. 187-189

sinth Frooksille, Maine, quarries it _ _ _

South Thomaston, Maine, quarries jn _.

Specifie gravity, determination of, as a test for granite _- 102

Spectacle Pond quarry, Sunapee,

N. II., produet of

Spence \& Coombs quarry, Berwick, Maine, product of

Springfield, Ill., granite for Lincoln monument at........

Springfield, Mass., granite for United States armory at

Sprucehead quarry, South Thomaston, Maine, description of _-_-_-_-_-_ 238-239

Stacy quarry, Braintree, Mass., product of

Stain, rusty, occurrence and causes of -

rusty, removal of tist of granite for...... 9

Stark, $X$ II.. granite of _._._. 177

Striger, frorge, analysis by__... 306 Strphen \& Gerard quary, Parre. rt., description of $-132-133$

Sterling, Comn., quarries in _... _ 400 - 10 ' Sterling granite gnciss, description of _-

Sterling quarry, sterling, comn. i)oduet of $\ldots \ldots+\ldots$ 402 Stevens guarry, Nashu:1, N. II., deseliption of .......

Stinson qualrirs. Sullivan, Maine. features $01 \ldots \ldots \ldots-2: 30-231$

Stinchfield quarty, Hallownl, Maitie. product of _. _ 2:33-2.24, 235

structure in _._.

Stinziano quarry, Fall River, Misss., feitures of ........ 28.j

Stoniugton, conn., quarries in _._ $392-394$ Stonington district, Malme, geolngic relations of the grituite in_._. quarries in, descriptious of - $221-230$ distribution of 
Stonington quarry, Spruce Island, Inine. prorluct of $-228-22 n$

stony Cresk, Conn., polished and hammered granite gueiss from, plates showing _............

stony Creck quarry, Branford, Conm., product of $-379-380$

Stoughton, Mass., granjte of

Strin, compressive, effect of, on rranite, plate showing _...

compressive, fractures caused liy _-

"strain sherts," use of llame_-_- 34 straiton quarry. Barre, Vt., description of _._._._._. 140-141

strenpth, compressive, transverse. ami tensile, tests of sranite for ..........

strunture of granite._._._-_._- 14-41

dome, plates showing_...... 256

duuble-sheet, cause of _...... 36

flow, indirations of _._._._._ 14-15

11:is of term ........ 5

gnejsir, nature and cause of $-65-66$ use of term ............

joint, plates showing _..... $25 t$ linticular, plates showing--- 256. 320

"onion," ritlsts of _ _ _._. $32-30$; sheet, rauses of__._._. 24-31, 52-36 observations on, in New England_... 32 plates showing _....... 160, 256 previous observations on_- 26-30 Suljoints, nature and occurlence of - $39-40$ Sullivan, Maine, quarries in_... 230-232 Sullivan quarries, New Bufora, Mass., product of - 285-246 Snnapere, N. 11., qualries in .... 203-205 Sulngide quary. Barre, Vt., operation of . . . . .......

Swans Island, Maine, quarries on.. Swamville, Maine, granite of ..... 261

Swretzer, Iolwert C., analysis by- 350-35I

swerion quarriıs. Concorl, \. HI., deseriptions of _._. 199-200

Swingle quarry, Quiney, Mass, deseription of _..._._. $328-329$

Sycile, polivhed and cut, plate showing-_-_._-_.-- -

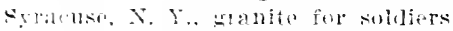
and sailors' memorial at

T.

Tarbox quarry, Iaaleyville, Maine, features of

Tassin, Wirt, cited__._.....

'Jaylui quarry, Norridswock, Maine, product of

Tayntor qunry, llallowell, Maine, description of _._._. 235-236

Terms used in geology and quarrying ............ $467+47$
Tests of gianite

I'age.

rixtuie of granite.

plicated sneissic

99-10:

9-10

Thomaston, Comp oriulite of $372-373$

Thomalston granite rreriss, deseription of

Thompson quawr. Fitzwilliam. N. H. produrt uí.........

Throrubeg quarry. Adlison, Maine, product of _-_._- 262-26.3

Tirlwater. gititry an, plate showing _........... 250

Tifian quarry cibascet. Mass., pirntare of

Toledn, Ohju, wranito tur Fort Meigs moirument at......-

Tulella King quarry. Yilforl. N. H. products of _._._. 186-187

Tonella old quarry, Milford, N. H., description of _-_ 185-1 8 ;

Touthachers core quarry Swans I-1:ard. Majne, features of

Topham, Vt., sranite of Torrington Borough quary, Torringtoin. Comn. description ot_.... _........ 37

374-375

Townerend. Nass. manice of _._- 313-314

Trealwell prosient. Imbonry. Coun., fratures of

lyeatment, counomice of the eranites. urler of _... 103-104

Tremont. Inine. fromite of -

l'renton, N. J.. granite for battlefield nomumurit at -..----

Troy, N. Y. grauite for post offerat

Troy quarer, Troy. X. H.. produit of

$175-17 t$

\section{l.}

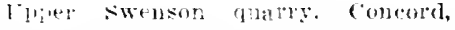
․ 11. frowluet of _. 192-200

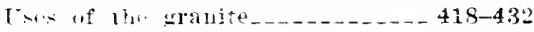

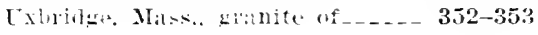

\section{r.}

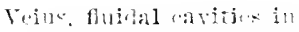

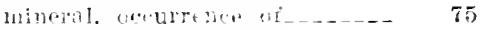
22 muserite. aceurrenes w._.

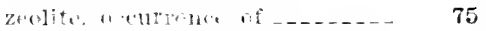

Virmust. construtionsl granites of $\quad 4: 4$ irrante railroads oí_....... 108 grianitos at, geologic hirtory

of _.

gevborie relation of _ _ 105-107 inceriptional sranites of ...... 428 monumentil Granites of ..... 427 pelish erranites of._._...... 429 produrtiol of :raubie in____ 451-45t quarrits in. de ariptions of _- 108-164 distribution of __ 102, 10-1-105 m.1p slowing location of .. 105 operater in $1921 \ldots \ldots+45: 453$ scuiptiral grautio of _...... $4: 5$ 
Vernont White ifuitery, Wuolloury, Vr. procluet of .....Yickshurs, Miss, yranite tor monunents in iational military park at _- 151.200, 411

Victoriat Whitw fuarry, Fitzwillam. N. 11., protuct of - $172-173$

Vinalhaven, Maine, arved granito from. Wlate showing --

monolithic eolumus from, plate showing-_.........

pavinubluck quarry at, plate showing _._.

quarries in _........ 211-248

Vitrcousness of eranite-_._._. $12-13$

Voorhis quary, direnwield, Comin, prointert of _... $362-363$

W.

Witloboro, Maine, contact phenomenia at

Waldoboro quary, Waldohoro, Maine, plite showing

product and strueture of _. $240-251$ Ward, Fremali, dited___._. _ 3.60-:81 Ward quarry, l'ilham, Mass, prod-

Warren, Cenn., entanite of Washington, Henry s., analyses log _.

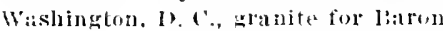
von steulen monument at ...........

granito for bridgu ovel I'otomac River at ..........

Freer Art Collections Building at _...........

General sherman monument at__._._._._._._._. 149

General staff College at_-

General Thomas montunent at_... 216

llahnwman wonument at $\quad 214$

Library of Congress at 1 - 176. 134

Lincoln Memorial at_... 348

Medillall fountain at_.. $37 !$

Municipal Building at_-_ 215

National Museum at _._ 347,345

New National Museum at ${ }_{-} \quad 15$ !

post office at__._._. 159,169

l'ost Office Dipartment building at .........

Senate Office livililing at ..

Waterbury, Conn., granite for bridge at

Waterford, conn., contart phenomena at _..._._. $89-90$

granite momunint from, plates showing _._....... 400

quarries in

Waterford quarry, Waterford, Conn., deseription of _._. : :397-:399

Watson, T. I., analyses by_..... o Weathering of granite, effects of, plate showing .......
Weathering of granite, ovoidal Page, prerecess and rile of Wob Fitzwilliam quarry, Fitzwilliam, N. Il., description of $f$

Webh Marlbero quarly. Marlloro, N. 11., desiription of

Wols quarries Nos. 7, s, and 10, Milfort, Mass., product of

Webluer quarries. Woodisury, Vt., procluets of

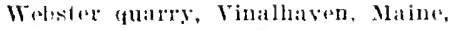
features of

plate showing ........ 25;

Woight of sranite _..._._.

determination of _......... 102

Wolls, Moline, granild of _.. $277-278$

Wells-Iamson quarry, Barre, Vt., profuct of _..._. $138-13$ !)

Wiskeag quarry. Senth 'lhomaston, Maine, profuct of ... 239

West Point, X. Y., erranito for Jatthe Nonument at

Westbrowk, Nitine, Eranite of .... 212

Wistrory, R. I., arvel "blu" Westerly" granite from, plate showing_._._._. $40 \mathrm{I}$

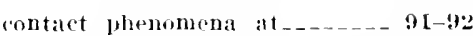
granite of, geology of _._. $403-406$ nature and eomposition of _............ $406-10 \mathrm{~s}$ quarries in___._.-405-415, 416-418 quartz monzonite from, plate showing_-.._..... 400

topograpliy of

Westiord, Mass., quarries ln _._ 309-313 Wetmore \& Morse quarry, Barre, Vt., description of

Wharff quarry. Sce Palmer quarry. White Mountain quarry, Conway, N. IJ., product of _.._ 169-170

White quarry, Bluehill, Maine, deseription of _._._. 214-215

Whitefield, Maine, granite of _-_- 251-252 Whitinsville, Mass., soldiers and sailors' monument at, granite for._._...-.

399

soldiers and sailors' monument at, plates showing ....

Whitney, .J. D., rited Whittli, C. I., cited............. Wirhita, Kans., granite for soldier. amel sailors' nemorial at__._._...........

Wigwam quarry, Quiney, Mass., produet of _...

Wildbur quarry. Harre. Vt., description of _._._._.

$14:$

Wildent quarry. sce Willarls I'oint quarty.

Willards Point quarry. St. Georg", Maine, features of 
Willinantic gneiss, description of -

Wilmington, Del., granite for courthouse and municipal building at _........

wilmington, N. C.. pranite for customlouse at

Windham, romu, granite of $402-403$

Windsor, Vt.. granite of, description of _.... granite of, geology of _... 161-162 quarries of _-__-__-__-__- 163-164

Winquist quilries, Quincy, Mass., product of _..._. 324

Woodbury, Vt., "arved granite from, plate showing _......-

contact phenomena at 160 granites of quarries of $\ldots \ldots \ldots \ldots$ 148-153 topography of
Page.

(1)

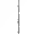

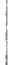
Page.
Wordbury quary, Bethel, vt., de-
seription of

Wrodstock, Main', granite of _-_ 253-254 Wormwood quarry, Biddeford. Maine, product of

Wenthan. Mass., granite of́..._- 314 Wright quarry, Westford, Mass., features of .......-

i.

313

Ion quarry, Fitzwilliam, $\mathrm{X}$. H., features of

York, l'a.. granite for State suldiers' monument at $\mathrm{t}_{-\ldots} \ldots$

Yorlitown, Va., granite for national monument at_....... 23\%

Young quarry, Milford N. H., produet of

\%.

Zolite, reins of 



SOUTHEASTERN MASSACHUSETTS UNIVERSITY

TN970.D15

The commercial granites of New England

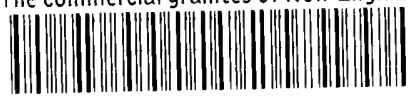

з ㄱㄹㄹ 00103 5754

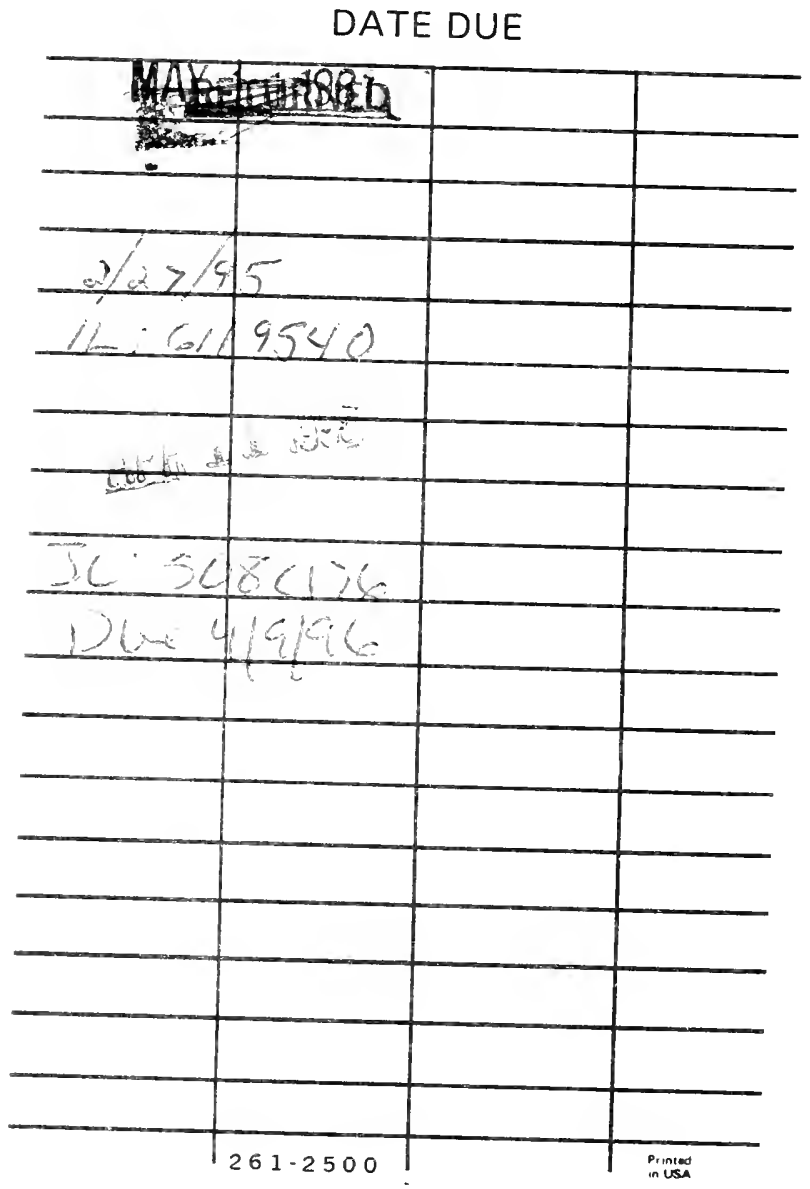




$$
\begin{array}{ll}
\text { TN970 } & \\
D 15 & \times 38947
\end{array}
$$


